UNIVERSIDADE DE SÃO PAULO

INSTITUTO DE GEOCIÊNCIAS

\title{
MICROMORFOLOGIA DE SÍTIOS CONCHEIROS DA AMÉRICA DO SUL: ARQUEOESTRATIGRAFIA E PROCESSOS DE FORMAÇÃO DE SAMBAQUIS (SANTA CATARINA, BRASIL) E CONCHEROS (TERRA DO FOGO, ARGENTINA)
}

\author{
Ximena Suarez Villagran \\ Orientador: Prof. Dr. Paulo C. F. Giannini \\ Co-orientador: Prof. Dr. Jordi Estevez Escalera
}

TESE DE DOUTORAMENTO

Programa de Pós-Graduação em Geoquímica e Geotectônica

Em convênio de dupla-titulação com a Universidad Autónoma de Barcelona, Programa de Doctorado en Arqueología Prehistórica 


\section{Agradecimentos}

Agradeço à Fundação de Amparo à Pesquisa do Estado de São Paulo (FAPESP, processo 08/ 51264-0) e CNPq (processo142532/2008-9) pela ajuda na realização desta tese. Ao meu querido orientador Prof. Paulo C.F. Giannini, quem modelou a minha transformação em cientista. Ao Prof. Paulo DeBlasis, por ter me dado a grande oportunidade de ingressar no mundo dos sambaquis. Aos professores do Museu de Arqueologia e Etnologia da USP (MAE/USP) que me apoiaram nas minhas pesquisas de mestrado e doutorado: Marisa Afonso, Levy Figuti, Astolfo Araujo, Eduardo Neves, Fabíola Silva e Verônica Wesolowski. À Prof. Madu Gaspar (MN/UFRJ) e Prof. Jose Maria Lopez Mazz (UdelaR) pelo continuo apoio e confiança no meu trabalho.

Devo agradecer a diversos pesquisadores que colaboraram com bibliografias e comentários: Julieta Gomes Otero (CONICET), Florencia Borella (UNICEN), Cristian Favier Dubois (UNICEN), Walter Neves (IB/USP), Manuel Arroyo-Kalin (UCL), Jose Iriarte (University of Exeter), Sergio Netto (UNISUL) e Myrian Alvarez (CONICET).

Agradeço o apoio dos laboratórios de sedimentologia (Labsed), petrografia sedimentar (Labpetro), microscopia eletrônica de varredura (MEV), tratamento de amostras (LTA) e laminação do Instituto de Geociências (IGc/USP). Especial agradecimento aos técnicos Isaac Sayeg, Elaine, José Paulo e Paulinho. Agradeço ao laboratório de isótopos estáveis (CENA/USP) e ao serviço de microscopia (UAB).

Ao meu co-orientador de tese pela Universitat Autónoma de Barcelona, Prof. Jordi Estevez e aos colegas da UAB e Departamento de Arqueologia e Antropologia da Institució Milá i Fontanals (CSIC/ Barcelona): Assumpció Vila, Marco Madella, Andrea Balbo, Débora Zurro, Juan Jose Ibañez, Xavier Terradas, Ignacio Clemente, David Ortega, Manuela Perez e Ivan Briz. Aos bons amigos que deixei na Espanha Joana Boix, Ivana Dragicevic, Ivan Armenteroz, Laura Caruso, Diana Gomes de la Rua, Eva Benitez, André Colonese e Ester Verdún.

A Danilo Assunção e Kiristen Bright pela colaboração no trabalho de campo. A Profa. Rosa Maria Poch (UdL) pela imensa ajuda na análise micromorfológica. Ao Prof. Marco Marquez (UNC), Prof. Luis C.R. Pessenda (CENA/USP), Profa. Deisi Farias (UNISUL) e Prof. Andres Zarankin (UFMG). A Luciana Scherer, Gina Bianchini, Tiago Atorre e Josiane Millani Lopez. A Tobias pelas distrações nos finalmentes.

Aos meus amigos! Paula Nishida, Célia Boayadjian, Milene Fornari, Paula Amaral, Daniela Klokler, Lucelene Martins, Mirian Forancelli, Patricia Fisher, Gislaine da Costa Fernandez, Jordana Zampelli, Elisangela Morais, Camila Agostini, Caroline Borges, Camila Constatino, Vanessa Pestana, Sara Nomura, André Sawakuchi, Adriano Ferreira, Daniel Rodrigues, Glória Garcia, Paula Sucerquia, Johanna Mendez. E as minhas irmãs do Uruguai Maria Jose Malet, Daniela Perez, Ana Díaz, Tatiana Bulla, Magella Tiscornia e Lorena Laporta.

Finalmente, o maior gracias à minha linda familia. 


\section{Resumo}

O estudo de oito sambaquis do litoral sul do Estado de Santa Catarina e de um concheiro da Terra do Fogo permitiu entender a dinâmica dos processos de formação de diferentes tipos de concheiros. No caso dos sambaquis catarinenses, o objetivo principal foi compreender os processos de formação culturais (atividades humanas) e naturais (tafonômicos) e suas mudanças ao longo do tempo, a partir da análise estratigráfica de sítios cuja cronologia envolve todo o período de ocupação humana pré-histórica da região (c. 7400-1000 anos AP). No caso fueguino, realizou-se o estudo micro-estratigráfico de um concheiro etno-histórico, para servir como modelo interpretativo na formulação de hipóteses sobre a formação dos concheiros. Os métodos utilizados para caracterização dos sedimentos arqueológicos incluíram: granulometria, zooarqueologia, isotopia de $\mathrm{C}$ e $\mathrm{N}\left(\delta^{13} \mathrm{C}\right.$ e $\left.\delta^{15} \mathrm{~N}\right)$, micromorfologia e microscopia eletrônica de varredura. Utilizou-se também a analogia experimental com fogueiras acesas em diversos contextos conhecidos e queima controlada de moluscos.

Três tipos de sambaquis foram analisados: quatro de padrão estratigráfico conchífero; dois de núcleo arenoso; e dois em montículo ictiológico. A formação do primeiro e terceiro tipos seguiu um padrão recorrente e contínuo que envolve retrabalhamento de elementos depositados e queimados em local diferente do final. Estes elementos incluem resíduos alimentares, como conchas, restos de peixe (ossos e tecidos) e material vegetais (carvões e plantas de ciclo fotossintético $\mathrm{C}_{3}$ ), assim como componentes terrígenos relacionados com o substrato sedimentar nos arredores do sambaqui e com sedimentos provenientes dos bancos de moluscos explorados. Os sambaquis de núcleo arenoso representam ocupações efêmeras, mas planejadas. A sua formação envolveu levantamento de montículos de areia e/ou aproveitamento de dunas eólicas, com posterior deposição de moluscos e resíduos de fogueiras.

Desta análise, extraem-se duas implicações substanciais: 1) o hábito de retrabalhamento de resíduos pode ter incluído a destruição dos locais de moradia, nunca achados até o momento, associados aos grandes sambaquis; 2) a correspondência entre o processo de formação identificado nos montículos ictiológicos e nos sambaquis conchíferos sugere continuidade na atividade deposicional, apesar da mudança de matéria prima (substituição das conchas por restos de peixe) e da adoção da tecnologia cerâmica em tempos recentes.

O concheiro etno-histórico analisado para comparação geo-etnoarqueológica foi formado a partir de ocupações domésticas, recorrentes durante pelo menos um século. A análise do anel de conchas periférico possibilitou caracterizar micromorfologicamente os episódios de deposição massiva de conchas, pisoteamento e abandono do sítio. A análise das fogueiras localizadas na área central do concheiro permitiu identificar estruturas de combustão de temperatura alta e moderada (superior e inferior a $500^{\circ} \mathrm{C}$, respectivamente). A comparação das microfácies do concheiro fueguino com as microfácies identificadas nos sambaquis catarinenses mostra diferentes trajetórias pré-deposicionais, relacionadas, no primeiro caso, com a deposição imediata e secundária de detritos de alimentação nos arredores do local de moradia, e, no caso dos sambaquis, com a sucessão intrincada de ações de deposição, queima e transporte, associada à formação de depósitos terciários. Estas observações corroboram a maior complexidade no processo de formação dos sambaquis.

Palavras-chave: Geoarqueologia; micromorfologia; Santa Catarina; Terra do Fogo; sambaquis; concheiros; estratigrafia. 


\title{
Micromorphoogy of South American shell sites: archaeostratigraphy and formation processes of sambaquis (Santa Catarina, Brazil) and concheros (Tierra del Fuego, Argentina)
}

\begin{abstract}
To understand site formation processes in shell sites, eight sambaquis (shell mounds) from the southern coast of Santa Catarina and one shell midden (conchero) from Tierra del Fuego were studied. For the sambaquis of Santa Catarina, the aim was to understand the cultural and natural formation processes (human activities and taphonomy) and the way they changed through time through the whole period of prehistoric human occupation in the region (c. 74001000 years BP). In Tierra del Fuego, the micro-stratgraphic study of an ethnohistoric shell midden was done to serve as model for hypothesis on formation processes of shell sites. The methods used for characterization of archaeological sediments included: grain-size analyses, zooarchaeology, $\mathrm{C}$ and $\mathrm{N}$ isotopy $\left(\delta^{13} \mathrm{C}\right.$ e $\left.\delta^{15} \mathrm{~N}\right)$, micromorphology and scanning electron microscopy. Experimental archaeology was done using different hearths lit on known contexts and by controlled burning of mollusk shell.

Three types of sambaquis were analyzed: four shell mounds; two sand mounds; and two fish mounds. Formation of the first and third group followed a recurrent and continuous pattern of reworking of items, accumulated and burnt in a different location than the final. These items included food refuse, like shell, fish remains (bone and tissue) and plant material (charcoal and residues of $\mathrm{C}_{3}$ plants), as well as terrigenous components from the sedimentary substrate of the surroundings of the site and from the explored shell beds. Sand mounds are ephemeral but planned occupations. Their formation involved rising of a sand mound and/or occupation over sand dunes, with deposition of shells and plant remains on top.

Two substantial implications are extracted from this analyses: 1) the reworking of food residues may be destructing the remains of daily occupations associated with the large sambaquis, that have never been found to this moment; 2) the correspondence of formation process in shell mounds and fish mounds suggests continuity in the depositional activities, besides the change in material (substitution of shell by fish remains) and adoption of ceramic technology in recent times.

The ethnohistorical site analyzed for geo-ethnoarchaeological comparison was formed by recurrent domestic occupations that lasted for a century. Analyses of the peripheral shell ring allowed the micromorphological characterization of episodes of massive shell deposition, trampling and site abandonment. Analyses of hearths located in the central habitation area showed micromorphological indicators of high temperature and moderate temperature combustion structures (over and under $500^{\circ} \mathrm{C}$, respectivley). Comparison of microfacies from the fueguian shell midden and microfacies from the sambaquis shows different pre-depositional trajectories. In the first case, deposition is related with the immediate and secondary discard of food refuse around the living space. In the second case, formation is related with an intricate succession of deposition, burning and transport of items that resulted in a tertiary deposit. These observations corroborate the great complexity in the formation processes of sambaquis.
\end{abstract}

Key-words: Geoarchaeology; micromorphology; Santa Catarina; Tierra del Fuego; shell mounds; shell middens; stratigraphy. 


\section{Micromorfología de concheros sudamericanos: arqueoestratigrafía y procesos de formación de sambaquís (Santa Catarina, Brasil) y concheros (Tierra del Fuego, Argentina)}

\section{Resumen}

El estudio de ocho sambaquís del litoral sur del Estado de Santa Catarina y de un conchero de Tierra del Fuego permitió entender los procesos de formación de diferentes tipos de concheros. En el caso de los sambaquís, el objetivo fue comprender los procesos de formación culturales (actividades humanas) y naturales (tafonómicos) y sus cambios a lo largo del tiempo, a partir del análisis estratigráfico de sitios cuya cronología abarca todo el período de ocupación humana prehistórica de la región (c. 7400-1000 años AP). En el caso fueguino se realizó el estudio micro-estratigráfico de un conchero etnohistórico, para servir como modelo interpretativo en la formulación de hipótesis sobre la formación de los concheros. Los métodos utilizados para caracterización de sedimentos arqueológicos incluyeron: granulometría, zooarqueología, isotopía de $\mathrm{C}$ y $\mathrm{N}(\delta 13 \mathrm{C}$ e $\delta 15 \mathrm{~N})$, micromocrfología y microscopia electrónica de barrido. Se utilizo también la analogía experimental, con fogones prendidos en diversos contextos conocidos, y quema controlada de moluscos.

Tres tipos de sambaquís fueron analizados: cuatro sitios de patrón estratigráfico conchífero; dos de núcleo arenoso; y dos montículos ictiológicos. La formación del primer y tercer grupo siguió un patrón recurrente y continuo de retrabajamiento de elementos depositados y quemados en local diferente del final. Estos elementos incluyen residuos alimenticios, como conchas, restos de pescado (huesos y tejidos) y componentes vegetales (carbones y restos de plantas C3), así como componentes terrígenos relacionados con el substrato de las inmediaciones del sambaquí y sedimentos provenientes de los bancos de moluscos explotados. Los sambaquís de núcleo arenoso representan ocupaciones efímeras, pero planeadas. Su formación envolvió el levantamiento de montículos de arena y/o aprovechamiento de dunas eólicas, con posterior depositación de moluscos y residuos vegetales.

De este análisis se extraen dos implicaciones substanciales: 1) el habito de retrabajamiento de residuos puede ser el agente de destrucción de las áreas de habitación asociadas a los grandes sambaquís, nunca encontradas hasta el momento; 2) la correspondencia en el proceso de formación de montículos ictiológicos y sambaquís conchíferos sugiere continuidad en la actividad depositacional, a pesar del cambio en el material (substitución de las conchas por restos de pescado) y adopción de la tecnología cerámica en tiempos recientes.

El conchero etnohistórico analizado para comparación geo-etnoarqueológica se formó a partir de ocupaciones domésticas recurrentes. El análisis del anillo de conchas periférico ceracterizó micromorfológicamente a los episodios de depositación de conchas, pisoteo y abandono del sitio. El análisis de los fogones del área central del conchero identifico estructuras de combustión de temperatura alta y moderada (superior e inferior a $500^{\circ} \mathrm{C}$, respectivamente). La comparación entre las microfacies del conchero fueguino y de los sambaquís muestra diferentes trayectorias pre-depositacionales. En el primer caso, relacionadas con la depositación inmediata y secundaria de detritos de alimentación alrededor del área de habitación y, en el segundo caso, con una intrincada sucesión de acciones de depositacion, quema y transporte asociada a la formación de depósitos terciarios. Estas observaciones corroboran la mayor complejidad del proceso de formación de sambaquís.

Palabras clave: Geoarqueología; micromorfología; Santa Catarina; Tierra del Fuego; sambaquís; concheros; estratigrafía. 


\section{ÍNDICE}

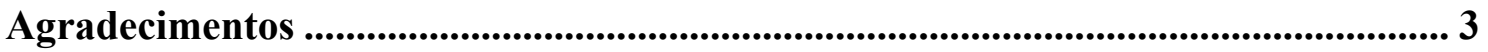

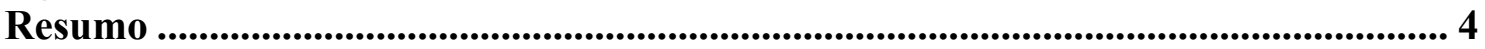

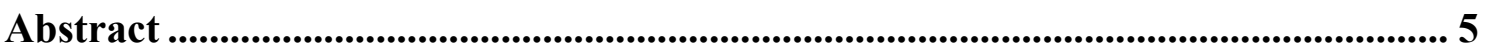

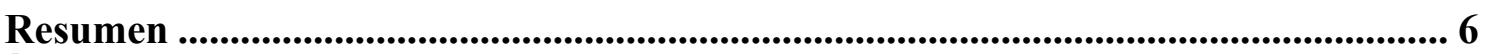

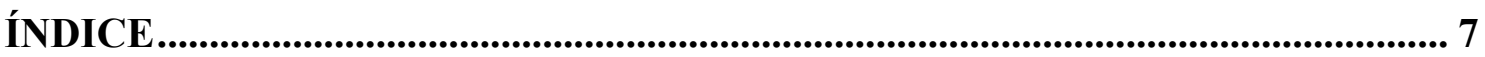

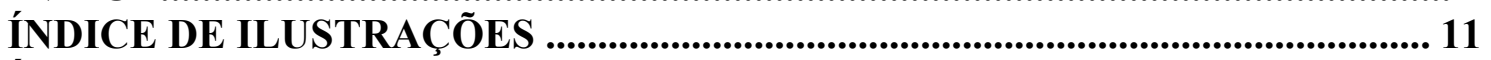

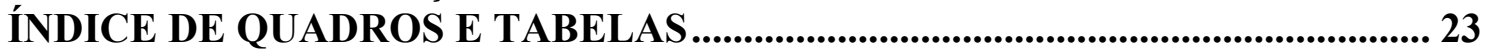

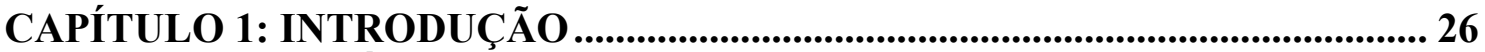

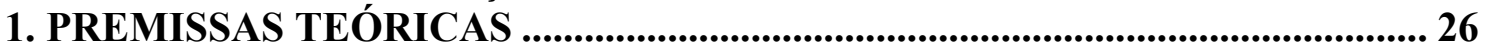

2. GEOARQUEOLOGIA DE CONCHEIROS ........................................................ 29

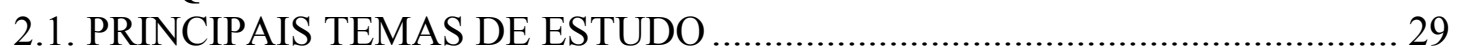

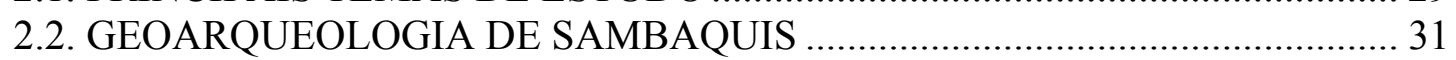

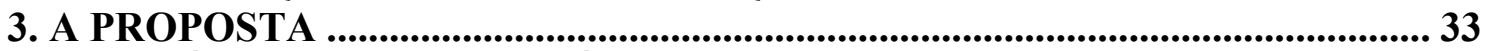

3.1. ANÁLISE DE ARQUEOFÁCIES ............................................................. 34

3.2. CONSTRUÇÃO DE MODELOS INTERPRETATIVOS …............................. 35

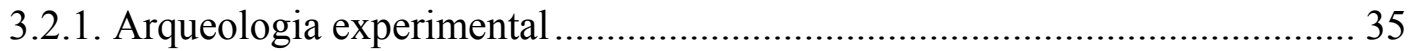

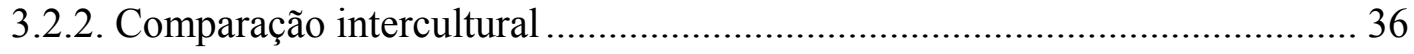

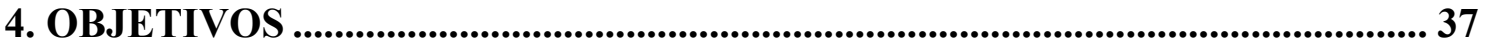

CAPÍTULO 2: CONCHEIROS E SAMBAQUIS ...................................................... 38

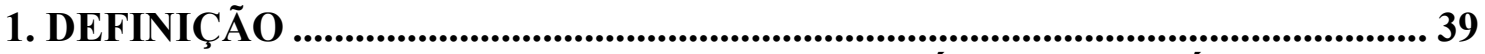

2. CONCHEIROS DO HOLOCENO INICIAL E MÉDIO DA AMÉRICA DO SUL

3. SAMBAQUIS DO LITORAL BRASILEIRO 40

3.1. A OCUPAÇAO SAMBAQUIEIRA DA COSTA …......................................... 45

3.2. MODELO DE POVOAMENTO DA COSTA BRASILEIRA ........................... 47

3.3. AS CULTURAS MARÍTIMAS DO LITORAL BRASILEIRO ......................... 48

3.4. O COLAPSO DA CULTURA SAMBAQUIEIRA …....................................... 51

3.5. SAMBAQUIEIROS DO LITORAL E GRUPOS CERAMISTAS DO

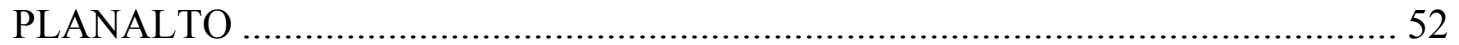

3.5.1. Os sítios costeiros com cerâmica Taquara/Itararé....................................... 54

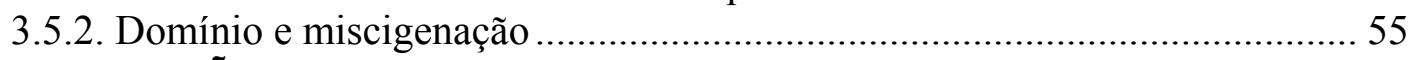

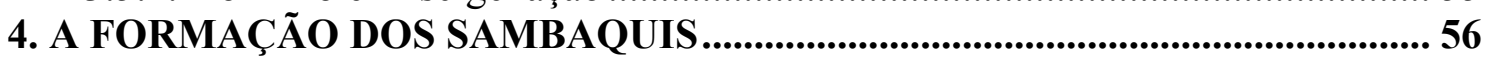

4.1. MODELOS DE CONSTRUÇÃO ................................................................. 57

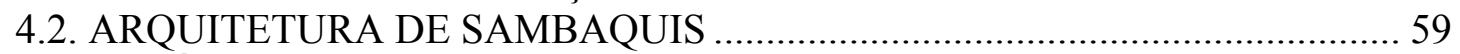

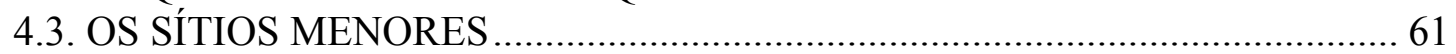

5. CASO DE ESTUDO COMPARATIVO: CONCHEIROS ETNO-HISTÓRICOS

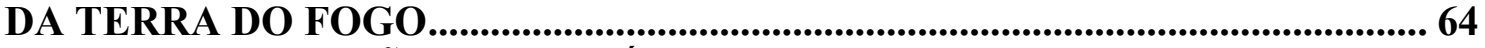

5.1. A INFORMAÇÃO ETNOGRÁFICA SOBRE OS YAMANA …........................6 66

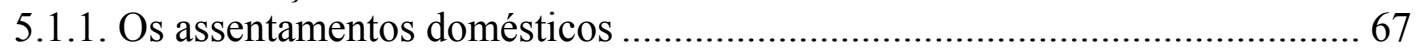

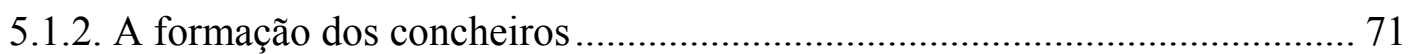

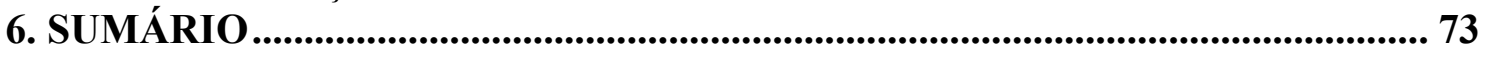

CAPÍTULO 3: SAMBAQUIS DO LITORAL SUL CATARINENSE ................... 75

1. INTRODUÇÃO ........................................................................................................ 75

2. UMA PAISAGEM HISTÓRICA ................................................................. 79 


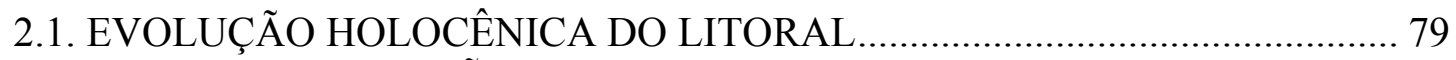

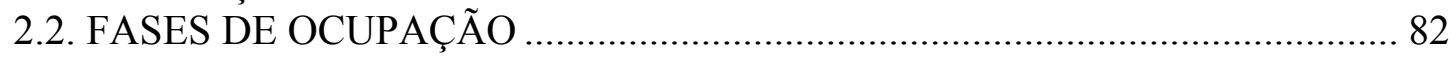

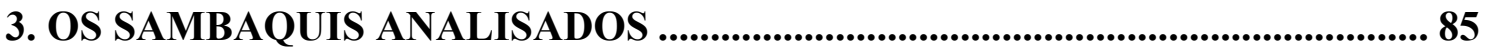

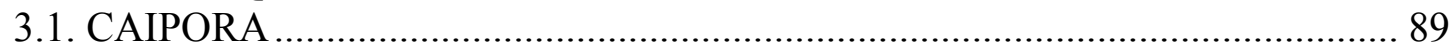

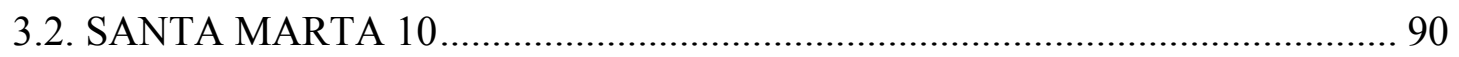

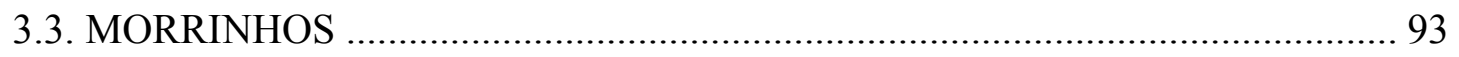

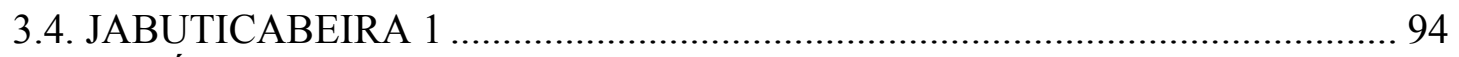

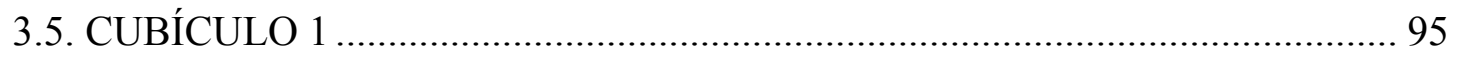

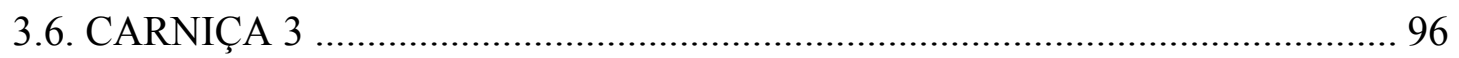

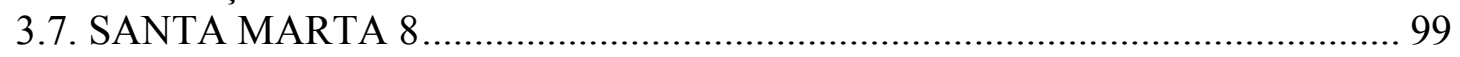

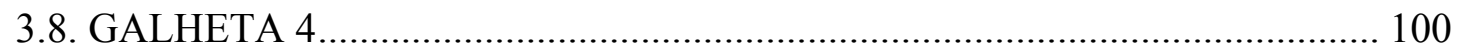

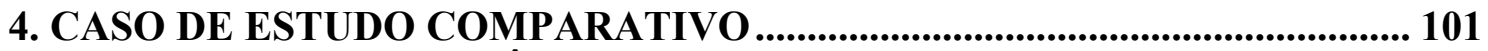

4.1. EVOLUÇÃO HOLOCÊNICA DO CANAL BEAGLE …............................... 103

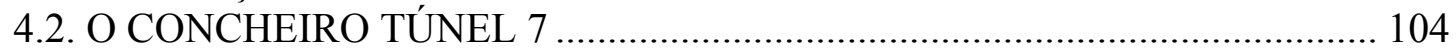

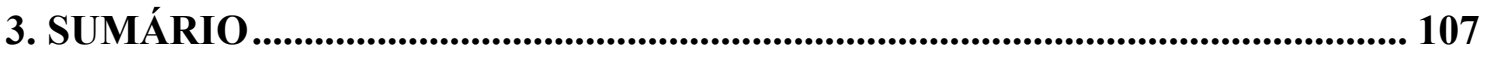

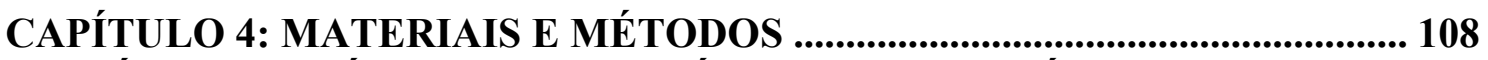

1. ANÁLISE DE FÁCIES E MICROFÁCIES ARQUEOLÓGICAS..................... 108

1.1. FUNDAMENTOS DA ANÁLISE DE ARQUEOFÁCIES ............................... 108

1.1.1. Descrição, caracterização e interpretação ................................................. 110

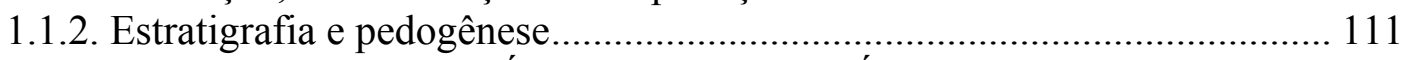

1.2. FUNDAMENTOS DA ANÁLISE DE MICROFÁCIES ................................ 113

1.2.1. Arqueofácies e microfácies arqueológicas ............................................ 114

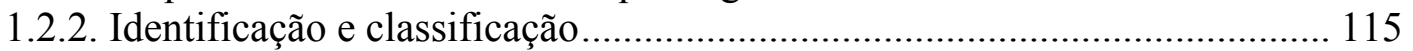

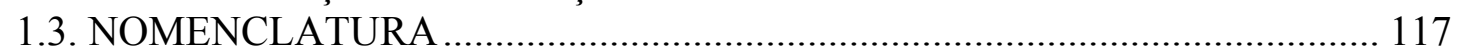

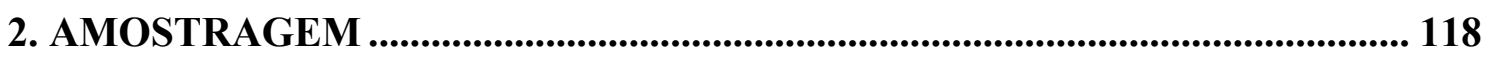

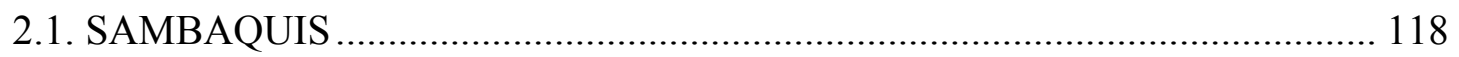

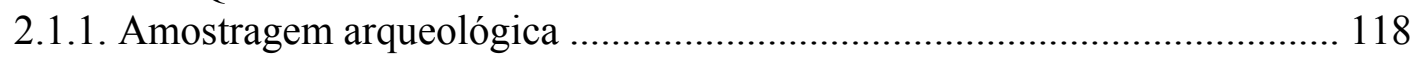

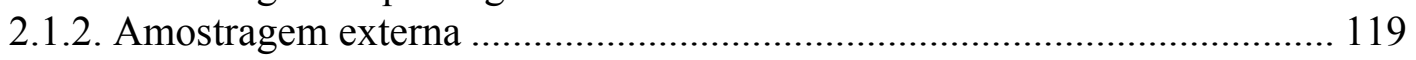

2.1.3. Experimental ...................................................................................... 121

2.2. CASO DE ESTUDO COMPARATIVO: CONCHEIRO TÚNEL 7 ................ 123

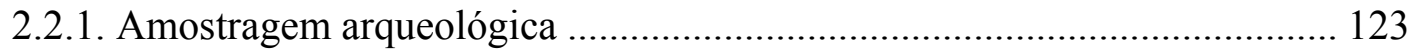

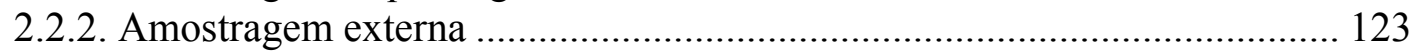

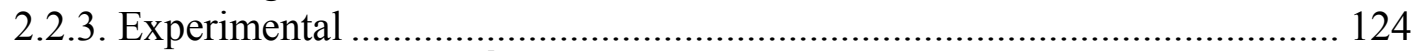

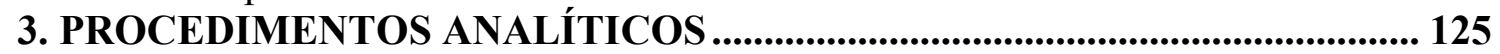

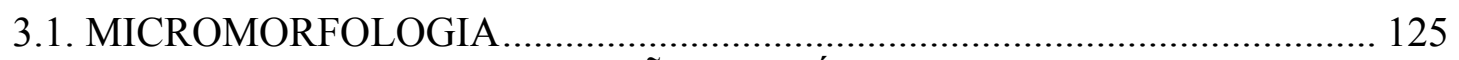

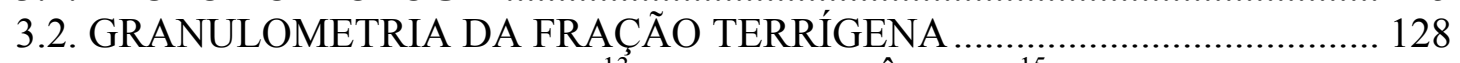

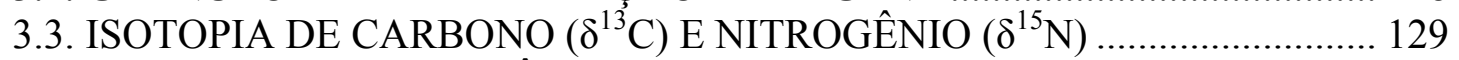

3.4. MICROSCOPIA ELETRÔNICA DE VARREDURA ..................................... 131

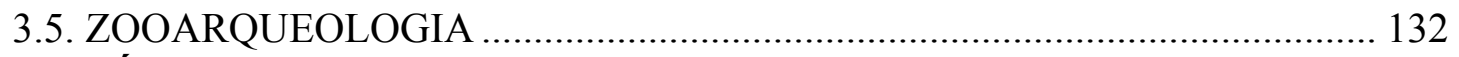

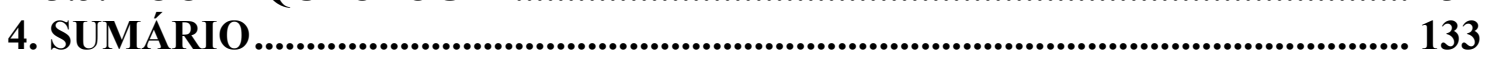

CAPÍTULO 5: GEOARQUEOLOGIA DE SAMBAQUIS DO LITORAL SUL DE SANTA CATARINA E CONCHEIRO ETNOHISTÓRICO DA TERRA DO

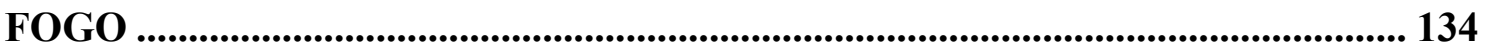

1. COLEÇÃO DE REFERÊNCIA EXPERIMENTAL ..................................... 135

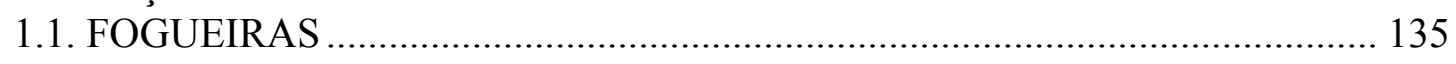

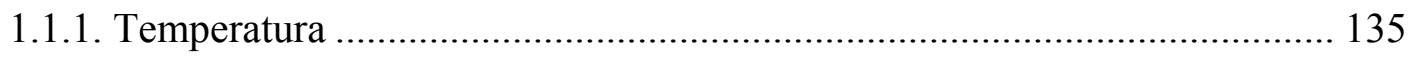

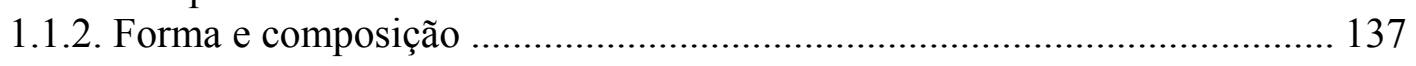


1.1.3. Alteração do substrato e preservação ......................................................... 140

1.1.4. Micromorfologia de fogueira sobre substrato conchífero ........................... 141

1.2. QUEIMA CONTROLADA DE ANOMALOCARDIA BRASILIANA........... 143

2. SAMBAQUIS DO LITORAL CATARINENSE .................................................... 148

2.1. PADRÃO ESTRATIGRÁFICO CONCHÍFERO.......................................... 149

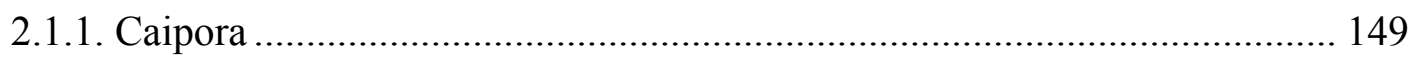

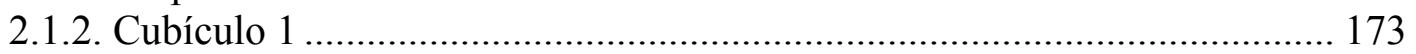

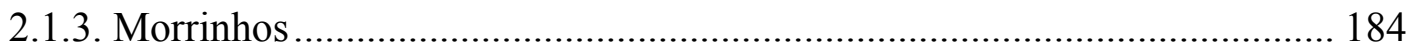

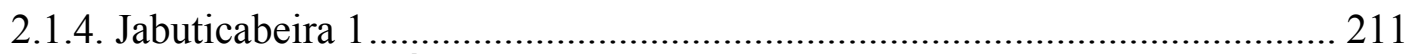

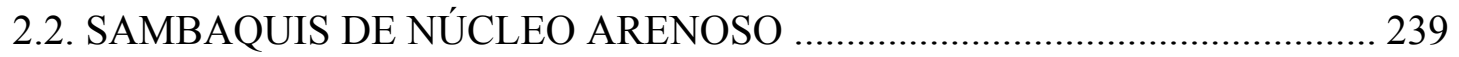

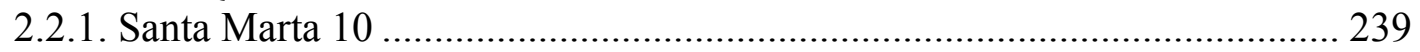

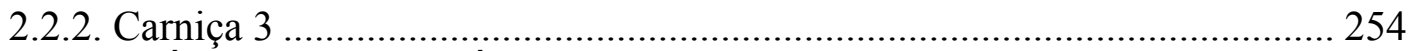

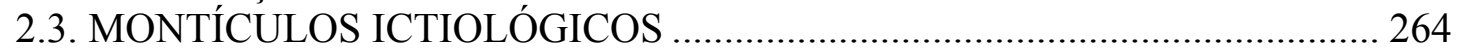

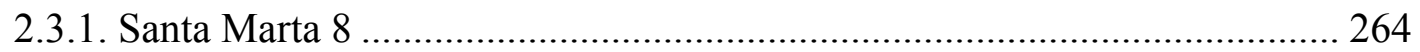

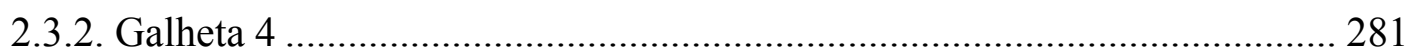

3. GEOARQUEOLOGIA DE UM CONCHEIRO ETNO-HISTÓRICO NA

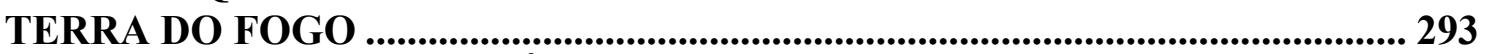

3.1. COLEÇÃO DE REFERÊNCIA EXPERIMENTAL ........................................ 293

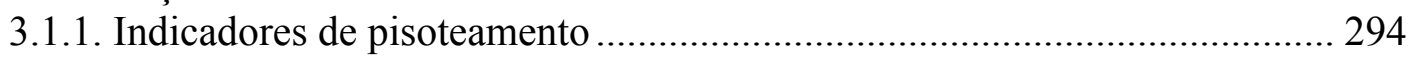

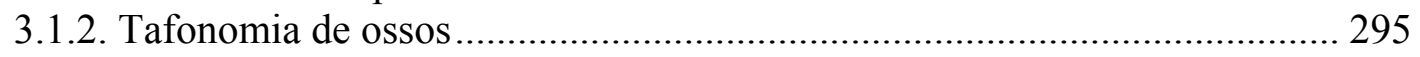

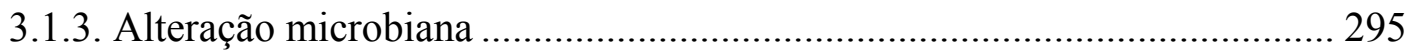

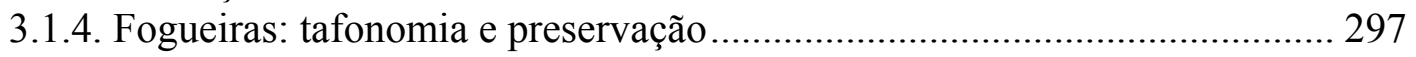

3.1.5. Queima controlada de Mytilus edulis ......................................................... 300

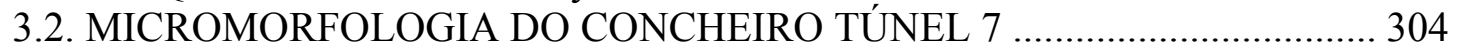

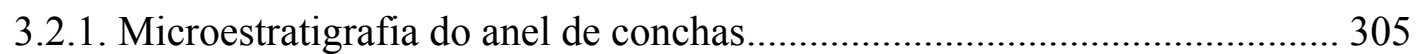

3.2.2. Micromorfologia da área central de habitação .......................................... 314

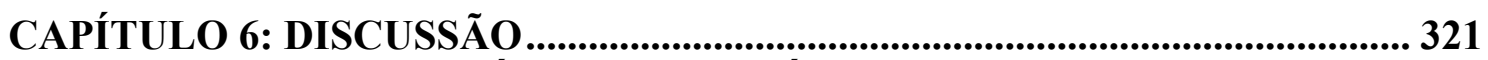

1. PADRÃO ESTRATIGRÁFICO CONCHÍFERO .......................................... 321

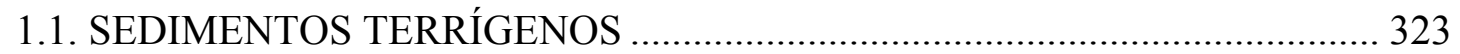

1.1.1. Proveniência das areias terrígenas............................................................. 324

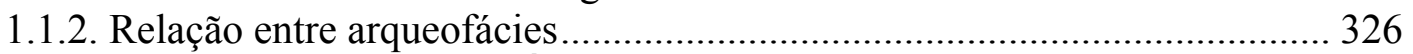

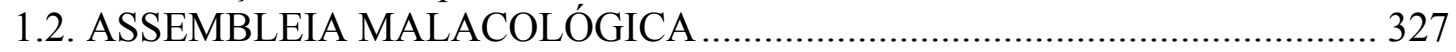

1.2.1. Relação entre espécies predominantes ..................................................... 330

1.2.2. Disponibilidade de espécies: comparação com concheiros naturais ........... 332

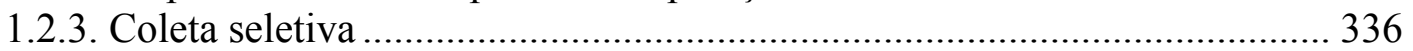

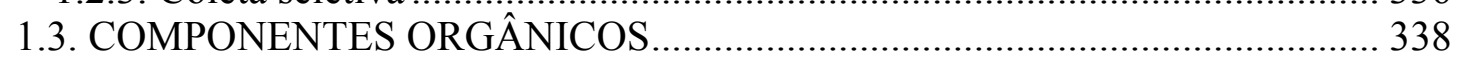

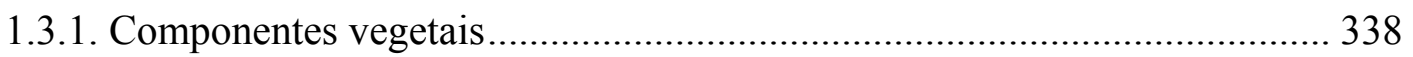

1.3.2 Resíduos de origem animal ............................................................... 342

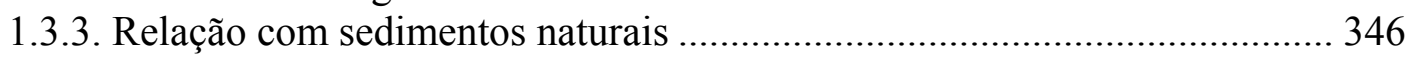

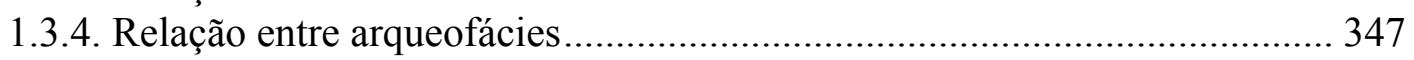

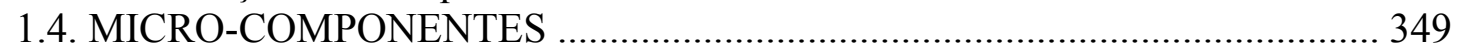

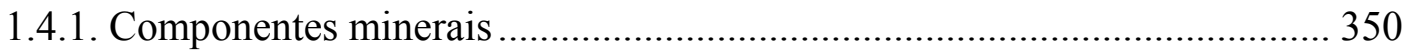

1.4.2. Componentes biológicos principais: conchas e ossos ............................. 352

1.4.3. Componentes biológicos secundários ..................................................... 356

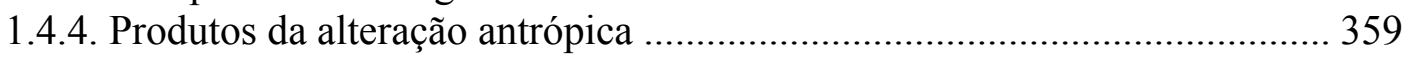

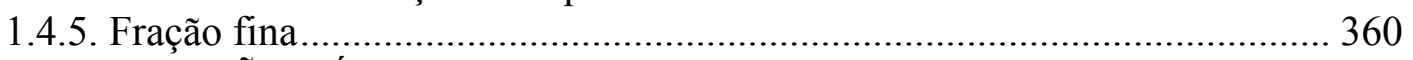

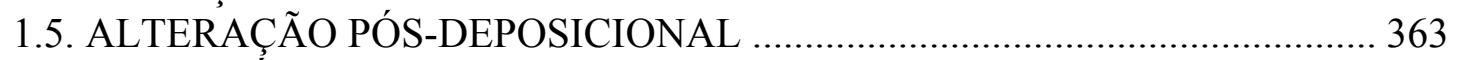

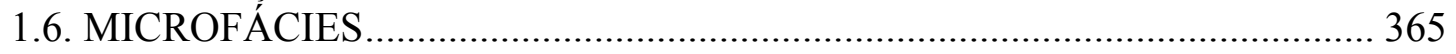


1.6.1. Recorrência de microfácies intra e inter-sítio ............................................... 367

1.6.3. Microfácies tipo B: retrabalhamento de fogueiras .................................. 372

1.6.4. Microfácies tipo C: agregados de lama de depósitos paleolagunares ......... 374

1.7. FORMAÇÃO DE SAMBAQUIS CONCHÍFEROS …....................................... 376

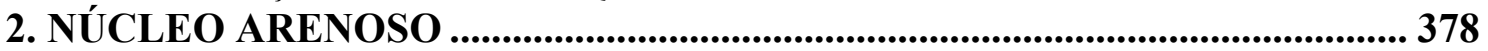

2.1. SEDIMENTOS TERRÍGENOS …….............................................. 379

2.2. ASSEMBLEIA MALACOLÓGICA …...................................................... 380

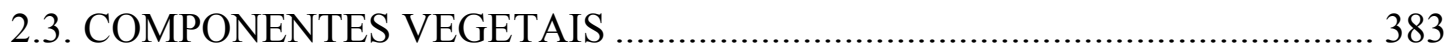

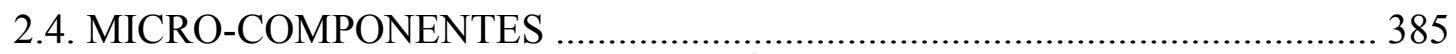

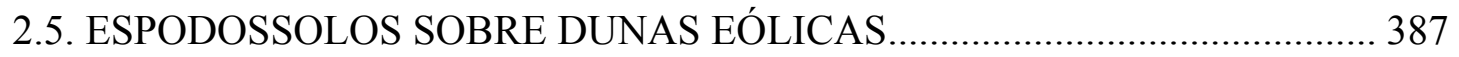

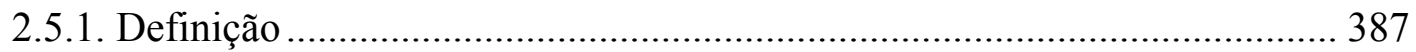

2.5.2. Formação de espodossolos em sambaquis de núcleo arenoso .................. 388

2.5.3. Microcarvões e formação de horizontes espódicos.................................. 390

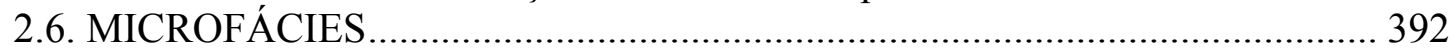

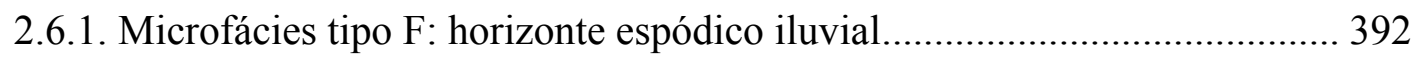

2.6.2. Microfácies tipo G: horizonte espódico em matriz de conchas e areia....... 393

2.6.3. Microfácies tipo H: duna eólica .................................................................. 394

2.7. FORMAÇÃO DE SAMBAQUIS DE NÚCLEO ARENOSO .......................... 394

3. MONTÍCULOS ICTIOLÓGICOS .................................................................... 396

3.1. SEDIMENTOS TERRÍGENOS ……................................................ 397

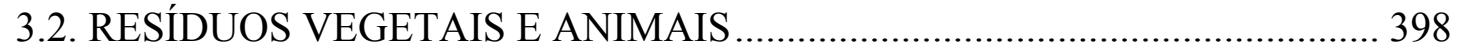

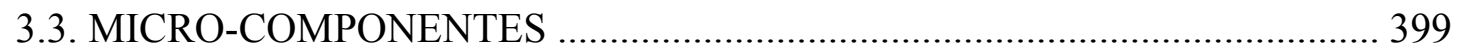

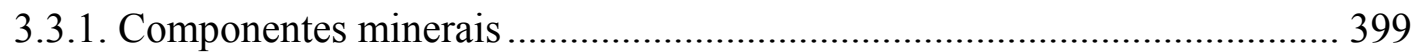

3.3.2. Componentes biológicos, biominerais e produtos da alteração antrópica .. 400

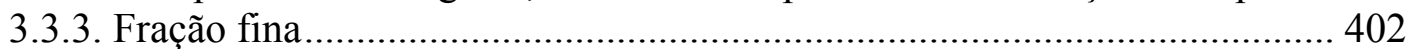

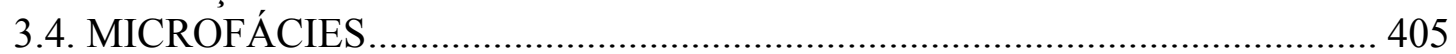

3.4.1. Microfácies tipo I: retrabalhamento de resíduos com predomínio de ossos 405

3.4.2. Microfácies tipo J: ocupação sobre depósito arenoso ................................ 407

3.4.3. Microfácies tipo K: substrato arenoso......................................................... 407

3.4.4. Microfácies tipo L: horizonte espódico em matriz de ossos e areia............ 408

3.5. FORMAÇÃO DE MONTÍCULOS ICTIOLÓGICOS ..................................... 410

4. CONCHEIRO ETNOHISTÓRICO NA TERRA DO FOGO ............................ 412

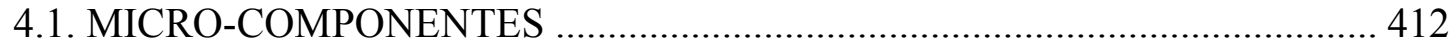

4.2. TAFONOMIA DE CONCHEIROS EM CLIMA FRIO................................... 413

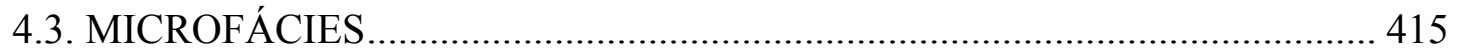

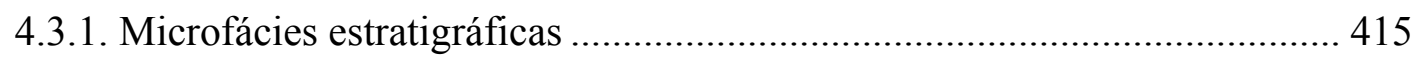

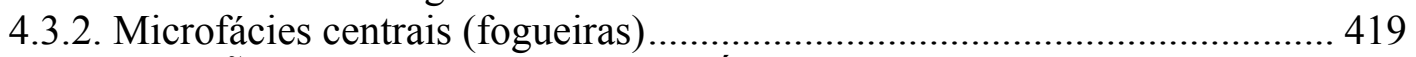

4.4. FORMAÇÃO DO CONCHEIRO DOMÉSTICO ......................................... 422

5. ANALOGIA GEO-ETNOARQUEOLÓGICA .............................................. 424

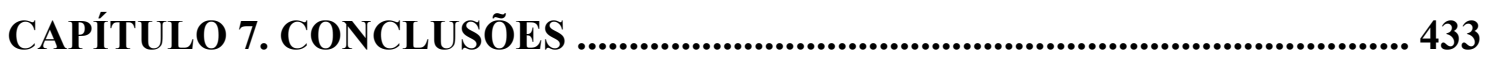

1. COMEÇO E AUGE DOS SAMBAQUIS ............................................................ 434

2. COLAPSO E SURGIMENTO DA UMA NOVA ORDEM ............................... 437

REFERÊNCIAS BIBLIOGRÁFICAS .................................................................. 440

ANEXO 1: Figuras e tabelas complementares ..................................................... 475

ANEXO 2: Publicações, prêmios, participação em eventos ...................................... 490 


\section{ÍNDICE DE ILUSTRAÇõES}

Figura 2.1. Mapa da América do sul com localização dos concheiros/sambaquis mais antigos, e sítios datados da transição Pleistoceno/Holoceno com evidências do uso de recursos aquáticos. As duas flechas indicam possíveis rotas migratórias de colonização das áreas litorâneas do continente. . .43

Figura 2.2. Fotografias etnográficas dos Yamana que habitaram as costas do Canal Beagle: A) costa do Canal Beagle, com localização de três cabanas Yamana (indicadas com uma flecha), em fotografia tomada por Greten Motsny; B) cabana Yamana fotografiada pela Mission Scientifique Du Cap Horn em 1882-1883; note-se a acumulação de conchas que conduz à entrada da cabana; C) família Yamana fora da residência (Mission Scientifique Du Cap Horn em 1882-1883); D) Mulher Yamana sentada sobre um concheiro (Mission Scientifique Du Cap Horn em 1882-1883); E) cabana Yamana coberta pela neve com menina e cachorro, fotografia tomada por Greten Motsny; F) canoas nas águas do Canal Beagle (Mission Scientifique Du Cap Horn em 1882-1883).

Figura 3.1. Sambaquis do litoral sul catarinense: A) mapa de localização da área de estudo; B) sambaqui Garopaba do Sul, o maior sambaqui que existe atualmente na região; C) sambaqui do Ipoã; D) sambaquis de Encantada; E) sambaqui de Jabuticabeira 2; F) retirada de sepultamento humano do sambaqui Garopaba do Sul (B, D e E: fotografias de Paulo Giannini; F: fotografia de Armando Coimbra). .78

Figura 3.2. Sistemas deposicionais costeiros do litoral centro-sul de Santa Catarina, identificados por Giannini $(1993,2002)$ (modificado de Giannini \& Santos 1994).

Figura 3.3. Fases de ocupação do litoral sul catarinense definidas por Giannini et al. (2010) em base em um conjunto de 129 datações ${ }^{14} \mathrm{C}$ de 48 sambaquis prospectados e datados pelo projeto Sambaquis $e$ Paisagem.

Figura 3.4. Imagem de satélite com a localização e vista aérea dos oito sambaquis estudados: Caipora, Santa Marta 10, Morrinhos, Jabuticabeira 1, Cubículo 1, Carniça 3, Santa Marta 8 e Galheta 4. A linha ponteada na imagem central indica a divisória entre os setor interno e externo segundo Giannini et al. (2010)

Figura 3.5. Vista do entorno de localização do sítio Caipora (superior esquerda), desde o topo do sítio, em primeiro plano, até a planície lagunar, ao fundo, com seção vertical analisada (superior direita), de direção NW-SE. Sítio Santa Marta 10, em contexto de paleodunas eólicas das gerações 1, 2 e 3 (inferior esquerda) e vista da seção analisada, de sul a norte, com área de escavação do anel de conchas (inferior direita).

Figura 3.6. Vista do entorno de localização do sítio Morrinhos (superior esquerda), com trincheira trabalhada à direita da foto e seção estudada (superior direita), de direção N-S. Seção inferior de Jabuticabeira (inferior esquerda), de norte a sul, e seção estudada no nível superior (inferior direita), de direção SE-NW.....

Figura 3.7. Vista do entorno de localização do sítio Cubículo (superior esquerda), vendo-se o sambaqui na direita da foto e a planície lagunar na esquerda, com seção vertical analisada (superior direita), de direção S-N. Vista do sítio Carniça 3 (inferior esquerda) e seção estudada, com bloco amostrado para micromorfologia (inferior direita), de direção NE-SW.

Figura 3.8. Vista da região de Santa Marta, a partir do sítio Santa Marta 8, com vista do sítio coberto por vegetação densa. Vista da Ponta da Galheta a partir da praia da Galheta, setor norte, com indicação da localização do sítio Galheta 4 (flecha amarela) e seção estudada, de direção NW-SE. 98 
Figura 3.9. Concheiros etno-históricos da Terra do Fogo: A) Mapa de localização da área de estudo, no litoral norte do Canal Beagle. B) Vista do Canal Beagle, a partir da escavação do concheiro Túnel 7. C) Vista do sítio Túnel 7 durante o outono. D) Concheiro Túnel 7 observado desde a morena glacial sobre o qual acha-se parcialmente assentado, de oeste para leste. E) Escavação no concheiro Lanashuaia, localizado embaixo da estrutura branca de cobertura. F) Depressões no terreno, indicativas da localização de antigos concheiros na Baía Cambaceres (B, D, E e F: fotografias de Jordi Estevez e Assumpció Vila; C: fotografia de Myrian Alvarez) 102

Figura 3.10. Sul da Patagônia e Terra do Fogo, com localização dos campos de gelo modernos, seus limites máximos de extensão durante o último máximo glacial (UMG, $20 \mathrm{kA}$ ) e o alcance das morenas no final do período glacial (Pleistoceno tardio). Adaptado de Coronato et al. (1999: 79) e McCulloch et al. (2005: 358).

Figura 3.11. Concheiro Túnel 7: A) Vista do sítio, com área escavada embaixo da estrutura de cobertura branca. B) Escavação do concheiro, com localização das duas colunas de amostragem no anel de conchas e delimitação da área central de coupação (linha ponteada). C) Topografia segundo Orquera \& Piana (1995). Na topografia, as quadras delimitam a área do sítio escavado. Quadras I a IV correspondem ao componente moderno, e VII a XI, ao componente antigo. 106

Figura 5.1. Gráfico e tabela com as temperaturas atingidas no centro de combustão e no substrato (a $5 \mathrm{~cm}$ da superfície), durante uma hora de queima, em duas fogueiras experimentais (sobre paleoduna eólica e sobre depósito de retrabalhamento de sambaqui). 136

Figura 5.2. Fotografias das duas fogueiras experimentais: A) fogueira sobre paleoduna eólica, com indicação da temperatura atingida a 60 minutos do inicio da queima; B) fogueira sobre depósito de retrabalhamento de sambaqui, com indicação da temperatura atingida a 45 minutos do inicio da queima; C) fogueira sobre paleoduna eólica, apagada, com indicação da temperatura do substrato, quatro horas depois do apagado o fogo; D) fogueira sobre depósito de retrabalhamento de sambaqui, apagada, com indiicação das temperaturas do substrato e a diferentes profundidades, 12 horas depois de apagado o fogo.

Figura 5.3. Fogueira sobre paleoduna eólica: A) esquema de alteração do substrato produzido por fogueiras em forma de bacia, como a realizada, nesta pesquisa, sobre areia dunar (modificado de March, 1996); as setas brancas indicam a trajetória do calor no inicio do fogo (esquema superior) e algumas horas depois, enquanto as setas prets indicam a trajetória do calor subaéreo; B) duas cabeças de peixe queimadas na fogueira; C) conchas de Anomalocardia brasiliana, após retiradas da fogueira; D) configuração da fogueira após apagada. Note-se o escurecimento do perímetro da bacia onde foi acesa a fogueira, como previsto no modelo de March (1996). 138

Figura 5.4. Fogueira sobre depósito de retrabalhamento do sambaqui Cabeçuda: A) esquema de alteração do substrato produzido por fogueiras planas (modificado de March, 1996); as setas brancas indicam a trajetória do calor sob a perspectiva horizontal da fogueira (esquema superior) e em seção vertical (esquema inferior); B) fogueira plana sobre o sambaqui, apagada; C) seção de alteração térmica; D) detalhe da alteração do substrato, em que se vê camada lenticular decimétrica de cinzas sobre lâmina milimétrica de material carbonizado. Notem-se os formatos horizontal e vertical da fogueira plana, coincidentes com o previsto no modelo de March (1996).

Figura 5.5. Fotomicrografias de seção delgada coletada na periferia da fogueira acesa sobre substrato conchífero (depósito de retrabalhamento do sambaqui Cabeçuda): (A, B) massa basal composta por grãos de quartzo, fragmentos de osso queimados e carbonizados e fragmentos de concha, a PPL e XPL; C, D) detalhe da fração fina composta por fragmentos de osso queimado na fração silte entre áreas de micrita carbonática, a PPL e XPL; E) concha com sinais de alteração térmica (coloração cinza escuro e fissuras 
internas) em matriz micrítica associada a cinzas de madeira, a PPL. F) carvão em processo de transformação para cinza, a PPL.

Figura 5.6. Alteração de Anomalocardia brasiliana a temperaturas de $200^{\circ} \mathrm{C}$ e $300^{\circ} \mathrm{C}$ : A1) concha queimada a $200^{\circ} \mathrm{C}$, com preservação do perióstraco; A2) borda enegrecida da face interna da valva; A3) detalhe da superfície queimada da face externa da valva; A4-5) fotomicrografias da valva queimada, com camadas de crescimento, a PPL e XPL; B1) concha queimada a $300^{\circ} \mathrm{C}$; B2) borda enegrecida e superfície escurecida da face interior da valva; B3) fotomicrografia da superfície da valva, com perióstraco preservado; B4-5) detalhe do perióstraco ainda aderido à valva.

Figura 5.7. Alteração de Anomalocardia brasiliana a $400^{\circ} \mathrm{C}$ e $500^{\circ} \mathrm{C}$ : A1) concha queimada a $400^{\circ} \mathrm{C}$, com preservação do perióstraco; A2) borda carbonizada da face interna da valva e superfície enegrecida; A3) fotomicrografia da concha queimada, com perióstraco ainda preservado; A4) fotomicrografia da valva escurecida; 5) detalhe do perióstraco queimado; B1) concha queimada a $500^{\circ} \mathrm{C}$; B2) borda acinzentada e superfície esbranquiçada da face interna da valva; B3) fotomicrografia da superfície cor marrom escuro; B4) fotomicrografia da valva queimada, com escurecimento pronunciado na face interna; B5) detalhe do perióstraco, ainda aderido à valva. 146

Figura 5.8. Alteração de Anomalocardia brasiliana a $600^{\circ} \mathrm{C}$ e $700^{\circ} \mathrm{C}$ : A1) concha queimada a $600^{\circ} \mathrm{C}$; A2) borda acinzentada da face interna da valva; A3) fotomicrografia da concha queimada enegrecida, sem perióstraco, com fissuras longitudinais e transversais; A4-5) fotomicrografia da valva escurecida a PPL e XPL. B1) concha quemada a $700^{\circ} \mathrm{C}$; B2) borda acinzentada da face interna da valva; B3) fotomicrografia da concha queimada, preta a cinza escuro; B4-5) fotomicrografia da valva a PPL e XPL...

Figura 5.9. Alteração de Anomalocardia brasiliana a $800^{\circ} \mathrm{C}$ : A1) concha queimada a $800^{\circ} \mathrm{C}$, tão fragilizada que não se manteve inteira; A2) valva calcinada; A3) fotomicrografia da valva calcinada, de cor cinza, com pseudo-vacúolos; A4-5) fotomicrografia da valva calcinada, a PPL e XPL 148

Figura 5.10. Seção vertical estudada do sítio Caipora; A) localização dos pontos de amostragem e descrição das arqueofácies identificadas; B) seção transversal esquemática (sem escala) da área de localização do sítio. 151

Figura 5.11. Amostragem externa ao sítio Caipora: A) localização do ponto de amostragem; B) entorno de localização do sítio com afloramento granítico localizado a SE do sambaqui; C) descrição das fácies identificadas; D) trincheira amostrada com localização das fácies. 152

Figura 5.12. Histogramas da distribuição granulométrica para a Fácies A do ponto de amostragem externo ao sambaqui Caipora e da AF 1 do mesmo sambaqui. Note-se o domínio dos pelíticos na Fácies A e das frações grânulo, areia muito grossa e areia fina na AF 1

Figura 5.13. Fotomicrografias à lupa estereoscópica dos grãos retidos nas malhas de 1,0 $\mathrm{mm}$ e $0,5 \mathrm{~mm}$ da arqueofacies 1 do sítio Caipora. Note-se a presença de ossos (o), conchas (ch), fragmentos líticos (fl) e quartzo (q).

Figura 5.14. Análises isotópicas $\left(\delta^{13} \mathrm{C}\right.$ e $\delta^{15} \mathrm{~N}$ e razão $\left.\mathrm{C} / \mathrm{N}\right)$ de duas amostras provenientes da $\mathrm{AF} 1$ do sítio Caipora, e uma amostra da Fácies A da trincheira aberta em área externa ao sítio: A) gráfico de valores de $\delta^{13} \mathrm{C}$ e razão $\mathrm{C} / \mathrm{N}$ com intervalos definidos para plantas de ciclo fotossintético $\mathrm{C} 3$ e algas, segundo parâmetros de Boutton (1996), Lamb et al. (2006), Meyers (1997), De Niro e Epstein (1978), De Niro e Hastrof (1985) e Sifeddine et al. (2004); B) gráfico dos valores de $\delta^{15} \mathrm{~N}$ e $\delta^{13} \mathrm{C}$ com intervalos definidos para plantas de ciclo fotossintético C3 e animais marinhos, segundo parâmetros definidos por Ben-David et al. (1998), Commisso \& Nelson (2006), Fogg et al. (1998), Morris et al. (2005) e De Niro (1987)....154

Figura 5.15. Desenho esquemático das cinco seções delgadas analisadas no sítio Caipora, com localização do bloco de amostragem na sucessão vertical e identificação de microfácies na lâmina. 156 
Figura 5.16. Gráficos com porcentagens dos diferentes componentes microscópicos das $\mathrm{mF} 2,3,4 \mathrm{e}$ horizonte de solo superficial (Hz A) do sítio Caipora: A) freqüências de componentes da fração grossa; B) relação de porcentagens de poros, fração grossa e fração fina. Note-se a diminuição da porosidade e aumento da fração fina no horizonte superficial.

Figura 5.17. Fotomicrografias de moluscos encontrados no sítio Caipora: A) gastrópode; B) fragmentos de concha de craca; C) bivalve indeterminado; D) fragmentos de ostra, identificados pela fibrosidade longitudinal da concha; E, F) concha queimada a temperatura maior que $600^{\circ} \mathrm{C}$, a PPL e XPL

Figura 5.18. Fotomicrografias de ossos queimados no sítio Caipora: A, B) ossos queimados, reconhecidos respectivamente por bordas avermelhadas, a PPL, e birrefringência baixa, a XPL; C, D) vértebras de peixe, freqüentemente encontradas e facilmente identificáveis em seção delgada, a PPL e XPL. 166

Figura 5.19. Fotomicrografias da $\mathrm{mF}$ 3: A) seção vertical esquemática com localização da amostra para micromorfologia; B) massa basal composta por fragmentos de concha, osso, e grãos minerais, PPL; C, D) microestrutura de microagregados intergranulares interligados, composta por mistura de argilominerais com micrita secundária, a PPL e XPL; E, F) detalhe da micromassa, com finos fragmentos de osso queimado e agregados de microcarvões no interior, a PPL e XPL

Figura 5.20. Fotomicrografias da $\mathrm{mF}$ 4: A) seção vertical esquemática com localização da amostra para micromorfologia; B) massa basal composta por fragmentos de concha, conchas queimadas, ossos, e grãos minerais, PPL; C, D) microestrutura de microagregados integranulares interligados, composta por mistura de argilominerais com micrita secundária a PPL e XPL; E, F) detalhe da micromassa, com fragmentos de osso queimado, concha e grãos de quartzo, a PPL e XPL

Figura 5.21. Fotomicografias de espinhos de equinoide encontrados na $\mathrm{mF} 4 \mathrm{~b}$ do sítio Caipora, a PPL $(\mathrm{A}, \mathrm{C})$ e XPL $(\mathrm{B}, \mathrm{D})$.

Figura 5.22. Feições pedológicas do sítio Caipora: A, B) revestimentos de micrita e argilominerais impuros, a PPL e XPL; C, D) enchimentos de micrita límpida, a PPL e XPL. Os enchimentos caracterizam-se por ocuparem a totalidade do poro ou vazio em que infiltram, enquanto os revetimentos cobrem apenas as paredes dos poros e/ou a superfície dos componentes da fração grossa.

Figura 5.23. Fotomicrografias da transição entre $\mathrm{mF} 4$ e horizonte de solo na superfície da seção vertical analisada: A) seção vertical esquemática com localização da amostra para micromorfologia; B) massa basal composta principalmente por grãos de quartzo, feldspato e fragmentos líticos, com presença subordinada de conchas e ossos no horizonte A superficial, PPL; C, D) transição entre o horizonte de solo, sem conchas, e a $\mathrm{mF} 4$, com fragmentos de conchas e maior porosidade, a PPL e XPL; E, F) detalhe da massa basal da $\mathrm{mF} 4$, com fragmentos de concha de diverso tamanho, a PPL e XPL

Figura 5.24. Seção vertical estudada do sítio Cubículo 1: A) localização dos pontos de amostragem e descrição das arqueofácies identificadas; B) seção transversal esquemática (sem escala) da área de localização do sítio. 175

Figura 5.25. Amostragem externa ao sítio Cubículo 1: A) localização do ponto de coleta; B) entorno de localização; C) descrição das fácies identificadas; D) trincheira amostrada, com posição das fácies......176

Figura 5.26. Histogramas da distribuição granulométrica para as Fácies A e B do ponto de amostragem externa ao sambaqui Cubículo 1, e da AF 5 do mesmo sambaqui. Note-se o domínio de grânulos e pelíticos nas Fácies A e B, respectivamente, e a distribuição bimodal na AF 5.

Figura 5.27. Fotomicrografias à lupa estereoscópica dos grãos retidos nas malhas de $1,0 \mathrm{~mm}$ e $0,5 \mathrm{~mm}$ da AF 5 do sítio Cubículo 1. Note-se presença de ossos (o), conchas (ch), carvão (cr) e quartzo (q)... 177 
5.28. Análises isotópicas $\left(\delta^{13} \mathrm{C}\right.$ e $\delta^{15} \mathrm{~N}$ e razão $\left.\mathrm{C} / \mathrm{N}\right)$ de amostra proveniente da $\mathrm{AF} 5$ do sítio Cubículo 1, e de amostras das Fácies A e B da trincheira aberta em área externa ao sítio: A) gráfico de valores de $\delta^{13} \mathrm{C} e$ razão $\mathrm{C} / \mathrm{N}$ com intervalos definidos para plantas de ciclo fotossintético $\mathrm{C} 3$ e algas; $\mathrm{B}$ ) gráfico dos valores de $\delta^{15} \mathrm{~N}$ e $\delta^{13} \mathrm{C}$ com intervalos definidos para plantas de ciclo fotossintético $\mathrm{C} 3 \mathrm{e}$ animais marinhos. .... 178

Figura 5.29. Desenho esquemático da seção delgada analisada no sítio Cubículo 1, com localização do bloco de amostragem na sucessão vertical e identificação de microfácies na lâmina.

Figura 5.30. Gráficos com porcentagens dos diferentes componentes microscópicos da $\mathrm{mF} 9$ e do horizonte de solo superficial (Hz A) do sítio Cubículo 1: A) frequências de componentes da fração grossa; B) relação entre as porcentagens de poros, fração grossa e fração fina. Note-se o aumento da porosidade e da fração fina no horizonte superficial. 179

Figura 5.31. Fotomicrografias da mF 9 e mF HzA do sítio Cubículo 1: A) seção vertical esquemática com localização da amostra para micromorfologia; B) massa basal do horizonte superficial (mF HzA) com maior freqüência de raízes e poucas conchas em relação a $\mathrm{mF} 9$, PPL; C, D) massa basal da $\mathrm{mF} 9 \mathrm{com}$ microestrutura de grumos coesivos e fragmentos de concha e ossos, PPL e XPL; E, F) detalhe da micromassa composta por argilominerais e MO, com fragmentos de osso e carvão, PPL e XPL. 183

Figura 5.32. Fotomicrografias de elementos encontrados no sítio Cubículo: A, B) concha queimada e fragmento de osso com sinais de dissolução, PPL e XPL; C, D) fragmento de concha de Ostrea sp., PPL e XPL; E) excrementos elipsóides no horizonte de solo superficial, PPL; F) fragmentos de concha, concha queimada (fragmentos pretos) e ossos na $\mathrm{mF}$ 9, PPL. 184

Figura 5.33. Seção vertical estudada do sítio Morrinhos: A) localização dos pontos de amostragem e descrição das arqueofácies identificadas; B) seção transversal esquemática (sem escala) da área de localização do sítio. 187

Figura 5.34. Gráficos das distribuições granulométricas e parâmetros estatísticos para o sítio Morrinhos e amostragem em sedimentos naturais das proximidades: A) histogramas da distribuição granulométrica para as AF 2, 3 e 4 do sambaqui Morrinhos; note-se o domínio da fração areia média, fina e muito fina para as $\mathrm{AF} 2,3$ e 4, respectivamente; B) diagramas em caixa (boxplot) dos parâmetros estatísticos diâmetro médio, desvio padrão e assimetria para o conjunto de amostras do sítio Morrinhos e amostras deltaicas (DL) e paleolagunares (PL) do testemunho TB2 (Nascimento, 2010) coletado a aproximadamente $2 \mathrm{~km}$ do sambaqui. 188

Figura 5.35. Fotomicrografias à lupa estereoscópica dos grãos retidos nas malhas de $1,0 \mathrm{~mm}$ e $0,5 \mathrm{~mm}$ das arqueofacies 2, 3 e 4 do sítio Morrinhos. Note-se a presença de ossos (o), conchas (ch), carvão (cr) e quartzo (q).

Figura 5.36. Análises isotópicas $\left(\delta^{13} \mathrm{C}\right.$ e $\delta^{15} \mathrm{~N}$ e razão $\left.\mathrm{C} / \mathrm{N}\right)$ de amostras provenientes das $\mathrm{AF} 2$ e 4 do sítio Morrinhos: A) gráfico de valores de $\delta^{13} \mathrm{C}$ e razão $\mathrm{C} / \mathrm{N}$ com intervalos definidos para plantas de ciclo fotossintético $\mathrm{C} 3$ e algas; B) gráfico dos valores de $\delta^{15} \mathrm{~N}$ e $\delta^{13} \mathrm{C}$ com intervalos definidos para plantas de ciclo fotossintético $\mathrm{C} 3$ e animais marinhos. 190

Figura 5.37. Desenho esquemático das quatro seções delgadas analisadas no sítio Morrinhos, com localização do bloco de amostragem na sucessão vertical e identificação de microfácies na lâmina. = significa equivalência entre microfácies identificadas em lâminas diferentes; + significa microfácies que envolve atributos de microfácies diferentes identificadas em outras lâminas. 191

Figura 5.38. Gráficos com porcentagens dos diferentes componentes microscópicos das microfácies identificadas nas AF $3(\mathrm{mF}$ 3a.1, 3a.2 e 3b) e 4 ( $\mathrm{mf} 4 \mathrm{a} .1$, 4a.2, 4a.3 e 4b) do sítio Morrinhos: A) freqüências de componentes da fração grossa; B) relação entre as porcentagens de poros, fração grossa e fração fina. 
Figura 5.39. Fotomicrografias da $\mathrm{mF} 3$, amostra 3a, do sítio Morrinhos: A) seção vertical esquemática com localização da amostra para micromorfologia; B) massa basal da $\mathrm{mF}$ 3a.1, formada principalmente por conchas de distribuição sub-horizontal e fragmentos de osso, PPL; C, D) detalhe da massa basal da $\mathrm{mF} 3 \mathrm{a} .1$, com fragmentos de concha e osso em meio a micromassa fosfática com áreas de concentração de micrita associada à dissolução das conchas, PPL e XPL; E, F) massa basal da mf 3a.2, com grãos de quartzo e feldspato em micromassa de argilominerais, com diatomáceas, PPL e XPL

Figura 5.40. Fotomicrografias da micromassa da $\mathrm{mF}$ 3a.1: A, B) fragmento de osso com sinais de dissolução e revestimento de micrita, PPL e XPL. C, D) fragmentos de osso, em micromassa fosfática de baixa birrefringência, PPL e XPL

Figura 5.41. Fotomicrografias da $\mathrm{mF}$ 3, amostra 3b, do sítio Morrinhos: A) seção vertical esquemática com localização da amostra para micromorfologia; B) massa basal composta por fragmentos de concha e ossos, com alguns indivíduos queimados, com microestrutura de microagregados intergranulares e presença de raízes frescas, PPL; C, D) área de concentração de conchas e ossos queimados, carvão e cinzas sobre concha de molusco sem evidências de queima, PPL, XPL; E, F) micromassa composta por micrita com argilominerais, fosfatos e microcarvões entre finos fragmentos de osso queimado, PPL e XPL 205

Figura 5.42. Fotomicrografias de cinzas de madeira identificadas na seção delgada 3a do sítio Morrinhos: A, B) área de concentração de cinzas entre restos de tecido silicificado, com concentração de fragmentos de osso queimados na porção superior em meio a micromassa de argila rubefacta, PPL e XPL; C, D) concentração de cinzas rubefactas, PPL e XPL

Figura 5.43. Fotomicrografias da $\mathrm{mF} 4$, amostra 4a, do sítio Morrinhos; A) seção vertical esquemática, com localização da amostra para micromorfologia; B) porção da seção delgada com as três microfácies identificadas, PPL; C) concentração de conchas queimadas a temperatura superior a $600^{\circ} \mathrm{C}$ na $\mathrm{mF} 4 \mathrm{a} .1$, PPL; D) massa basal da $\mathrm{mF}$ 4a.2 com microestrutura de grãos de quartzo e feldspato revestidos interligados, com alguns fragmentos de concha, PPL; E) detalhe da $\mathrm{mF} 4 \mathrm{a} .2$ com micromassa composta por argilominerais, PPL; F) agregado milimétrico de lama que caracteriza à mF 4a.3, PPL. 207

Figura 5.44. Fotomicrografias de elementos de destaque na $\mathrm{mF}$ 4a.1: A) agregado de argila rubefacta associado a conchas queimadas a diferentes temperaturas de, pelo menos, duas espécies de moluscos, PPL; B) concha queimada a $800^{\circ} \mathrm{C}$ em micromassa composta por cinzas e argila rubefacta, PPL; C) escória vítrea, PPL; D) concha com fragmentos de perióstraco carbonizado, alguns já separados da valva e outros ainda aderidos, PPL. 208

Figura 5.45. Restos de tecidos silicificados na $\mathrm{mF}$ 4a.1: A-C) intercalação entre células alongadas e arredondadas, PPL; D) detalhe dos tecidos vegetais observados, PPL. 208

Figura 5.46. Componentes inorgânicos de origem biológica dentro dos agregados de lama da mF 4a.3: A, B) gastrópode, PPL; C, D) espécie de diatomácea encontrada com maior freqüência nos agregados de lama (Paralia sulcata), PPL 209

Figura 5.47. Fotomicrografias da $\mathrm{mF} 4$, amostra 4b, do sítio Morrinhos: A) seção vertical esquemática com localização da amostra para micromorfologia; B) agregado de lama, PPL; C, D) massa basal com fragmentos de concha e ossos com sinais de queima, em microestrutura esponjosa com microagregados intergranulares interligados, PPL e XPL; E, F) detalhe da micromassa formada por micrita com argilominerais, nódulos órticos de óxi-hidróxido de ferro e enchimentos de micrita, PPL e XPL 210

Figura 5.48. Feições pedológicas do sítio Morrinhos: A) revestimento pendular de micrita, PPL; B) Revestimento contínuo, não laminado de microespato redor de um vazio, PPL; C, D) enchimento denso incompleto de micrita proveniente da dissolução e precipitação do carbonato de cálcio das conchas, PPL e 
XPL; E) revestimento de espato, PPL; F) nódulo órtico de óxi-hidróxido de ferro em agregado de lama, PPL

Figura 5.49. Seções verticais estudadas do sítio Jabuticabeira 1, com localização dos pontos de amostragem e descrição das arqueofácies identificadas.

Figura 5.50. Gráficos das distribuições granulométricas e parâmetros estatísticos para o sítio Jabuticabeira 1 e amostragem em sedimentos naturais das proximidades: A) histogramas da distribuição granulométrica para as $\mathrm{AF} 1,2,3,4,5,6,7$ e 9 do sambaqui Jabuticabeira 1. Note-se o domínio da fração areia média para as arqueofácies analisadas na seção inferior (AF 1 a AF 5) e aumento progressivo da fração areia fina no topo da seção inferior (AF 6) e na seção superior (AF 7 e AF 9); B) diagramas em caixa (boxplot) das estatísticas diâmetro médio, desvio padrão e assimetria para o conjunto de amostras do sítio Jabuticabeira 1 e amostras paleolagunares (PL) das sondagens realizadas nas proximidades do sambaqui Jabuticabeira 2 (Villagran, 2010) localizado a pouco mais de $2 \mathrm{~km}$ de Jabuticabeira 1 215

Figura 5.51. Fotomicrografias à lupa estereoscópica dos grãos retidos nas malhas de $1,0 \mathrm{~mm}$ e $0,5 \mathrm{~mm}$ das arqueofacies 1, 2, 3, 4, 5, 6, 7 e 9 do sítio Jabuticabeira 1. Note-se a presença de ossos (o), conchas (ch), carvão (cr), grãos de quartzo (q) e fragmentos de osso carbonizado (oc).

Figura 5.52. Análises isotópicas $\left(\delta^{13} \mathrm{C}\right.$ e $\delta^{15} \mathrm{~N}$ e razão $\left.\mathrm{C} / \mathrm{N}\right)$ de amostras provenientes das $\mathrm{AF} 1,2,3,4,5$, 6 e 7 do sítio Jabuticabeira 1: A) gráfico de valores de $\delta^{13} \mathrm{C}$ e razão $\mathrm{C} / \mathrm{N}$ com intervalos definidos para plantas de ciclo fotossintético $\mathrm{C} 3$ e algas; B) gráfico dos valores de $\delta^{15} \mathrm{~N}$ e $\delta^{13} \mathrm{C}$, com intervalos definidos para plantas de ciclo fotossintético $\mathrm{C} 3$ e animais marinhos.

Figura 5.54. Gráficos com porcentagens dos diferentes componentes microscópicos das microfácies identificadas nas AF 5 ( $\mathrm{mF} 5), 6(\mathrm{mF}$ 6), 7 ( $\mathrm{mF} 7.1,7.2,7.3$ e 7.4), 8 (mF 8) e 9 (mF 9) do sítio Jabuticabeira 1: A) freqüências de componentes da fração grossa; B) relação entre as porcentagens de poros, fração grossa e fração fina.

Figura 5.53. Desenho esquemático das cinco seções delgadas analisadas no sítio Jabuticabeira 1, com localização do bloco de amostragem na sucessão vertical inferior (esquerda) e superior (direita) e identificação de microfácies na lâmina.

Figura 5.55. Fotomicrografias da $\mathrm{mF} 5$, amostras 5 e 5/6, do sítio Jabuticabeira 1: A) seção vertical esquemática, com localização da amostra para micromorfologia; B) massa basal da $\mathrm{mF} 5$ formada por conchas de distribuição sub-horizontal com alguns fragmentos de osso e carvão, PPL; C) agregado milimétrico de argilomineral, PPL; D) agregado de argilominerais associado à face côncava de concha de Anomalocardia brasiliana; E, F) micromassa de grãos revestidos interligados, PPL e XPL

Figura 5.56. Fotomicrografias de elementos de componentes da fração grossa da mF 5 (PPL): A) escória vítrea; B) concentração de diatomáceas da espécie Paralia sulcata em agregado de argilominerais; C) gastrópode; D) fragmento de osso, com sinais de dissolução.

Figura 5.57. Fotomicrografias da $\mathrm{mF} 6$, amostra 5/6, do sítio Jabuticabeira 1: A) seção vertical esquemática com localização da amostra para micromorfologia; B) massa basal formada por fragmentos de concha, osso e grãos de quartzo em microestrutura de microagregados intergranulares, PPL; C, D) detalhe da micromassa composta por argilominerais, MO e fosfatos, com inclusões de fragmentos de osso na fração silte, PPL e XPL. .234

Figura 5.58. Fotomicrografias da $\mathrm{mF} 7$ do sítio Jabuticabeira 1: A) seção vertical esquemática com localização da amostra para micromorfologia; B) massa basal da $\mathrm{mF} 7.1$, formada por agregados de argilominerais rubefactos e carbonizados com camada de conchas queimadas a temperaturas maiores que $600^{\circ} \mathrm{C}$, PPL; C) detalhe de agregado de argila rubefacta, PPL; D) massa basal da $\mathrm{mF} 7.2$, formada por fragmentos de concha de distribuição horizontal entre microagregados intergranulares, PPL; E) massa 
basal da $\mathrm{mF}$ 7.3, composta por argilominerais com micrita e MO em microestrutura de grânulos coesivos, PPL; F) massa basal da mF 7.4 formada por agregados centimétricos de argilominerais, PPL.

Figura 5.59. Fotomicrografias de elementos de destaque na $\mathrm{mF}$ 7.1: A, B) agregado de argila rubefacta, PPL e XPL; C) agregado de argila queimada com gastrópode, PPL; D) interior de agregado de argila queimada com diatomáceas da espécie Paralia sulcata; E) concha queimada a temperatura superior a $700^{\circ} \mathrm{C}, \mathrm{PPL} ; \mathrm{F}$ ) detalhe de concha queimada a temperatura superior a $800^{\circ} \mathrm{C}$, com concentração de espato associada a degradação da concha calcinada, PPL 236

Figura 5.60. Fotomicrografias de elementos de destaque nas $\mathrm{mF} 7.3$ e 7.4: A) gastrópodes na $\mathrm{mF}$ 7.3, PPL; B) concha queimada a temperatura superior a $600^{\circ} \mathrm{C}$ na $\mathrm{mF} 7.3$, PPL; C) agregado de argila da $\mathrm{mF}$ 7.4, com diatomácea de espécie Triceratum flavus, PPL; D) concentração de diatomáceas das espécies Paralia sulcata, Actinoptycus vulgaris e Coscinodiscus sp., na mF 7.3, PPL; E, F) grão de argila glauconítica em agregado de argilominerais da mF 7.4, PPL e XPL. 237

Figura 5.61. Fotomicrografias da $\mathrm{mF} 8$ do sítio Jabuticabeira 1: A) seção vertical esquemática com localização da amostra para micromorfologia; B) massa basal da $\mathrm{mF} 8$, formada por fragmentos de concha com distribuição aleatória; C, D) micromassa formada por argilominerais e micrita, PPL e XPL.

Figura 5.62. Fotomicrografias da $\mathrm{mF} 9$ do sítio Jabuticabeira 1: A) seção vertical esquemática com localização da amostra para micromorfologia; B) massa basal da $\mathrm{mF} 9$ formada por fragmentos de concha de distribuição horizontal com agregados milimétricos de argilominerais, PPL; C, D) micromassa formada por argilominerais e micrita, com agregados de argilominerais, PPL e XPL 238

Figura 5.63. Seção vertical estudada do sítio Santa Marta 10: A) localização dos pontos de amostragem e descrição das arqueofácies identificadas; B) seção transversal esquemática (sem escala) da área de localização do sítio.

Figura 5.64. Amostragem externa ao sítio Santa Marta 10: A) localização do ponto de amostragem; B) entorno de localização; C) descrição das fácies identificadas; D) trincheira amostrada com localização das fácies. 242

Figura 5.65. Gráficos das distribuições granulométricas e estatísticas descritivas para o sítio Santa Marta 10 e amostras de sedimentos naturais das proximidades: A) histogramas da distribuição granulométrica para as Fácies A e B identificadas no sítio Santa Marta 10 e Fácies B2 do ponto de amostragem externa ao sambaqui; note-se o domínio da fração areia fina em todas as amostras; B) diagramas em caixa (boxplot) das estatísticas diâmetro médio, desvio padrão e assimetria para amostra da Fácies B do sítio Santa Marta 10 (SM10), das Fácies A e B2 da amostragem externa (SM10*) e das amostras da geração de dunas eólicas 2 (G2) tomadas de Giannini et al. (2007), Giannini (1993), Martinho (2004) e Sawakuchi (2003)

Figura 5.66. Análises isotópicas $\left(\delta^{13} \mathrm{C}\right.$ e $\delta^{15} \mathrm{~N}$ e razão $\left.\mathrm{C} / \mathrm{N}\right)$ de amostras provenientes das Fácies $\mathrm{B}$ e $\mathrm{B} 2$ do sítio Santa Marta 10: A) gráfico de valores de $\delta^{13} \mathrm{C}$ e razão $\mathrm{C} / \mathrm{N}$ com intervalos definidos para plantas de ciclo fotossintético $\mathrm{C} 3$ e algas; B) gráfico dos valores de $\delta^{15} \mathrm{~N}$ e $\delta^{13} \mathrm{C}$, com intervalos definidos para plantas de ciclo fotossintético $\mathrm{C} 3$ e animais marinhos.

Figura 5.67. Seções delgadas analisadas no sítio Santa Marta 10 (amotras SM 10 A e SM 10 A/B) e fora do sítio (SM 10 B2), com localização dos blocos de amostragem na sucessão vertical e identificação de microfácies na lâmina. 245

Figura 5.68. Gráficos com porcentagens dos diferentes componentes microscópicos das microfácies identificadas nas Fácies A (mF A), B (mF B), A2 (mF A2) e B2 (mF B2) do sítio Santa Marta 10: A) 
freqüências de componentes da fração grossa; B) relação entre as porcentagens de poros, fração grossa e fração fina.

Figura 5.69. Fotomicrografias de grãos minerais no sítio Santa Marta 10: A, B) mineral opaco e mineral pesado anisotrópico, PPL e XPL; C, D) clasto de argila. Pelas suas propriedades ópticas, como coloração esverdeada (PPL) e cor de interferência laranja os clastos de argila poderiam ser esmectita ou glauconita.

Figura 5.70. Fotomicrografias da $\mathrm{mF}$ A do sítio Santa Marta 10: A) seção vertical esquemática, com localização da amostra para micromorfologia; B) massa basal composta por grãos de quartzo, feldspato, minerais pesados e opacos, PPL; C, D) detalhe dos revestimentos delgados de MO ao redor dos grãos minerais, PPL e XPL.

Figura 5.71. Fotomicrografias da $\mathrm{mF} \mathrm{B}$ do sítio Santa Marta 10: A) seção vertical esquemática, com localização da amostra para micromorfologia; B) massa basal composta por grãos de quartzo, feldspato, minerais pesados e opacos, PPL; C, D) microestrutura de grãos revestidos, PPL e XPL; E, F) detalhe dos revestimentos de $\mathrm{MO}$ ao redor dos grãos da fração grossa, PPL

Figura 5.72. Fotomicrografias da $\mathrm{mF}$ B2 nas proximidades do sítio Santa Marta 10: A, B) massa basal composta por grãos simples e interligados, PPL e XPL; C-F) detalhe dos revestimentos de argila microlaminada, PPL e XPL. .254

Figura 5.73. Seção vertical estudada do sítio Carniça 3: A) localização dos pontos de amostragem e descrição das arqueofácies identificadas; B) seção transversal esquemática (sem escala) da área de localização do sítio. 255

Figura 5.74. Gráficos das distribuições granulométricas e parâmetros estatísticos para o sítio Carniça 3 e amostragem em sedimentos naturais das proximidades: A) histogramas da distribuição granulométrica para as Fácies A e B identificadas no sítio Carniça 3; os dados referentes à AF A foram tomados de Tanaka (2007); note-se o domínio da fração areia fina na AF 1 e de areia muito fina na AF 2; B) diagramas em caixa (boxplot) das estatísticas diâmetro médio, desvio padrão e assimetria para AF 2 de Carniça 3 (CR3), dunas de geração 2 (G3) e amostras de cordões litorâneos (CL) tomados de Tanaka (2007). .256

Figura 5.75. Fotomicrografias à lupa estereoscópica de grãos retidos nas malhas de 1,0 mm e 0,5 mm, da arqueofacies 2 do sítio Carniça 3. Note-se a presença de ossos (o), conchas (ch), carvão (cr) e dente de miraguaia (d). 257

Figura 5.76. Análises isotópicas $\left(\delta^{13} \mathrm{C}\right.$ e $\delta^{15} \mathrm{~N}$ e razão $\left.\mathrm{C} / \mathrm{N}\right)$ de amostra proveniente da $\mathrm{AF} 2$ do sítio Carniça 3: A) gráfico de valores de $\delta^{13} \mathrm{C}$ e razão $\mathrm{C} / \mathrm{N}$ com intervalos definidos para plantas de ciclo fotossintético $\mathrm{C} 3$ e algas; B) gráfico dos valores de $\delta^{15} \mathrm{~N}$ e $\delta^{13} \mathrm{C}$ com intervalos definidos para plantas de ciclo fotossintético $\mathrm{C} 3$ e animais marinhos. 258

Figura 5.77. Desenho esquemático da seção delgada analisada no sítio Carniça 3, com localização do bloco de amostragem na sucessão vertical e identificação de microfácies na lâmina. 259

Figura 5.78. Gráficos com porcentagens dos diferentes componentes microscópicos da mF 2 do sítio Carniça 3: A) freqüências de componentes da fração grossa; B) relação entre as porcentagens de poros, fração grossa e fração fina.

Figura 5.79. Fotomicrografias da $\mathrm{mF} 2$ do sítio Carniça: A) seção vertical esquemática, com localização da amostra para micromorfologia; B) massa basal composta por conchas de Anomalocardia brasiliana inteiras com distribuição (trama/ arranjo) sub-horizontal, PPL; C, D) massa basal com conchas inteiras e 
fragmentadas, a PPL e XPL; E, F) micromassa composta por agregados de MO polimórfica em forma de pellets, a PPL e XPL.

Figura 5.80. Fotomigrografias de elementos de interesse na $\mathrm{mF} 2$ do sítio Carniça 3: A) fragmento de osso com sinais de queima; B, C) conchas com bioerosão; D) excrementos elipsóides de ácaros dentro de raiz, PPL.

Figura 5.81. Seção vertical estudada do sítio Santa Marta 8: A) localização dos pontos de amostragem e descrição das arqueofácies identificadas; B) seção transversal esquemática (sem escala) da área de localização do sítio. .265

Figura 5.82. Amostragem externa ao sítio Santa Marta 8: A) localização do ponto de amostragem; B) entorno de localização; C) descrição das fácies identificadas; D) trincheira amostrada com localização das fácies. 266

Figura 5.83. Histogramas da distribuição granulométrica para as AF 1, 2 e 3 do sítio Santa Marta 8 e Fácies A e B identificadas na trincheira de amostragem externa ao sítio. Note-se o domínio da fração areia fina em todas as amostras. .267

Figura 5.84. Fotomicrografias à lupa estereoscópica de grãos retidos nas malhas de $1,0 \mathrm{~mm}$ e 0,5 mm, da arqueofacies 1, 2 e 3 do sítio Santa Marta 8 e Fácies B da trincheira aberta em área externa ao sítio. Notese a presença de ossos (o), osso carbonizado (or), e osso calcinado (oc) e dente (d). 268

Figura 5.85. Análises isotópicas $\left(\delta^{13} \mathrm{C}\right.$ e $\left.\delta^{15} \mathrm{~N}\right)$ e razão $\mathrm{C} / \mathrm{N}$ de amostras provenientes das $\mathrm{AF} 2$ e 3 do sítio Santa Marta 8 e Fácies B da amostragem extra-sítio: A) gráfico de valores de $\delta^{13} \mathrm{C}$ e razão $\mathrm{C} / \mathrm{N}$ com intervalos definidos para plantas de ciclo fotossintético C3 e algas; B) gráfico dos valores de $\delta^{15} \mathrm{~N}$ e $\delta^{13} \mathrm{C}$ com intervalos definidos para plantas de ciclo fotossintético $\mathrm{C} 3$ e animais marinhos. 269

Figura 5.86. Seções delgadas analisadas no sítio Santa Marta 8, com localização do bloco de amostragem na sucessão vertical e identificação de microfácies na lâmina. 270

Figura 5.87. Gráficos com porcentagens dos diferentes componentes microscópicos das $\mathrm{mF} 1$, 2, 3a e 3b do sítio Santa Marta 8. A) freqüências de componentes da fração grossa; B) relação entre as porcentagens de poros, fração grossa e fração fina.

Figura 5.88. Fotomicrografias das $\mathrm{mF} 1$ e 2 do sítio Santa Marta 8: A) seção vertical esquemática, com localização da amostra para micromorfologia; B) contato entre a $\mathrm{mF}$ 1, inferior, e a $\mathrm{mF} 2$, superior, PPL; C) massa basal da $\mathrm{mF} 1$ composta por grãos de quartzo, PPL; D) microestrutura de grãos interligados da $\mathrm{mF}$ 1, formada por micromassa de argilominerais com micro-fragmentos de osso e microcarvão, PPL; E) massa basal da $\mathrm{mF} 2$ formada por ossos, fragmentados e inteiros, carvão e grãos de quartzo, PPL; F) microestrutura da $\mathrm{mF} 2$ formada por microagregados intergranulares e grãos revestidos, PPL....

Figura 5.89. Fotomicrografias de elementos de interesse na mF 2 do sítio Santa Marta 8: A) agregado de argilominerais com diatomáceas, PPL; B) concentração de espículas de esponja e diatomáceas, PPL; C) agregado de escória vítrea, PPL; D) micromassa transparente com microcarvão e micro-fragmentos de osso, PPL; E, F) revestimentos impuros, micro-laminados, PPL.

Figura 5.90. Fotomicrografias da $\mathrm{mF} 3$ do sítio Santa Marta 8: A) seção vertical esquemática, com localização das amostras para micromorfologia; B, C) massa basal composta por bolsões de fragmentos de osso milimétricos, carvão e grãos de quartzo, PPL; D) áreas com microestrutura de microagregados intergranulares, PPL; E, F) detalhe da micromassa formada por micro-fragmentos de osso, agregados de fosfato secundário e microcarvão, PPL. 279 
Figura 5.91. Fotomicrografias de fragmentos de osso na $\mathrm{mF} 3 \mathrm{com}$ birrefringência baixa, de primeira ordem, a PPL (A, C) e XPL (B, D)

Figura 5.92. Fotomicrografias de partículas silicosas na $\mathrm{mF} 2$ e 3: A) detalhe de agregado de espículas de esponja e diatomáceas na $\mathrm{mF} 2$, PPL; B) diatomáceas e fitólitos entre fragmentos de osso de peixe na $\mathrm{mF}$ 2, PPL; C) detalhe de B, com frústula da diatomácea Coscinodiscus excentricus; D) fitólito alongado na $\mathrm{mF} 3$, com sinais de derretimento, PPL.

Figura 5.93. Seção vertical estudada do sítio Galheta 4: A) localização dos pontos de amostragem e descrição das arqueofácies identificadas; B) seção transversal esquemática (sem escala) da área de localização do sítio. .283

Figura 5.94. Gráficos das distribuições granulométricas e parâmetros estatísticos para o sítio Galheta 4 e amostragem em sedimentos naturais das proximidades: A) histogramas da distribuição granulométrica para as Fácies A, B e AF 1; note-se o domínio da fração areia muito fina na Fácies A e areia fina na AF 1 e Fácies B; B) diagramas em caixa (boxplot) das estatísticas diâmetro médio, desvio padrão e assimetria para AF 1 do sítio Galheta 4 (GA4), Fácies A (GA4*) e geração de dunas eólicas 1 (G1), 2 (G2), 3 (G3) e 4 (G4) tomadas de Giannini et al., (2007), Giannini (1993), Martinho (2004) e Sawakuchi (2003).......284

Figura 5.95. Fotomicrografias à lupa estereoscópica de grãos retidos nas malhas de $1,0 \mathrm{~mm}$ e 0,5 mm, da arqueofacies 1 do sítio Galheta 4. Note-se a presença de ossos (o), osso carbonizado (Os.car. = or) e osso calcinado (Os.cal. $=$ oc). .285

Figura 5. 96. Análises isotópicas $\left(\delta^{13} \mathrm{C}\right.$ e $\delta^{15} \mathrm{~N}$ e razão $\left.\mathrm{C} / \mathrm{N}\right)$ de amostras provenientes da $\mathrm{AF} 1$ e Fácies $\mathrm{B}$ do sítio Galheta 4: A) gráfico de valores de $\delta^{13} \mathrm{C}$ e razão $\mathrm{C} / \mathrm{N}$ com intervalos definidos para plantas de ciclo fotossintético $\mathrm{C} 3$ e algas; B) Gráfico dos valores de $\delta^{15} \mathrm{~N}$ e $\delta^{13} \mathrm{C}$ com intervalos definidos para plantas de ciclo fotossintético $\mathrm{C} 3$ e animais marinhos. 286

Figura 5.97. Desenho esquemático das seções delgadas analisadas no sítio Galheta 4, com localização dos blocos de amostragem na sucessão vertical e identificação de microfácies nas lâminas. 287

Figura 5.98. Gráficos com porcentagens dos diferentes componentes microscópicos da $\mathrm{mF} 1$ do sítio Galheta 4: A) frequências de componentes da fração grossa; B) relação entre as porcentagens de poros, fração grossa e fração fina.

Figura 5.99. Fotomicrografias da $\mathrm{mF} 1$ do sítio Galheta 4: A) seção vertical esquemática, com localização da amostra para micromorfologia; B) massa basal composta por grãos de areia quartzosa e fragmentos de osso queimado, PPL; C, D) micromassa composta por MO monomórfica, PPL e XPL; E) detalhe da micromassa com inclusões de fragmentos de osso, PPL; F) revestimento de MO monomórfica ao redor de grão de quartzo, PPL. 291

Figura 5.100. Fotomicrografias de elementos identificados na $\mathrm{mF} 1$ do sítio Galhera 4: A) revestimento de MO monomórfica ao redor de escória vítrea, PPL; B, C) fitólito PPL; D) revestimento de MO monomórfica com inclusões de finos fragmentos de osso ao redor de fragmento de osso, PPL. 292

Figura 5.101. Fotomicrografias da coleção de referência experimental: A) microfácies superior da amostra do caminho de animais, com agregados lenticulares, PPL; B) microfácies intermediária do caminho de animais, com detalhe da concentração de esporas de fungos (e); C) praia de seixos próxima aos concheiros, notando-se o predomínio de ossos de mamífero marinho, com detalhe de ósteons dissolvidos, PPL; D) praia de seixos com fragmentos de concha de coloração diversa, PPL; E) serrapilheira sob a floresta de Nothofagus sp., em que se nota concentração de excrementos de ácaros dentro de tecido de madeira, PPL; F) camada de substâncias húmicas (camada H) sob a floresta, com agregados de matéria orgânica decomposta, PPL 
Figura 5.102. Fotomicrografias das três fogueiras experimentais estudadas na Terra do Fogo: A) camada milimétrica de cinzas e resíduos vegetais oxidados na fogueira sobre o prado, PPL; B) fogueira na praia, com fragmentos de osso de mamífero marinho queimados, PPL; C) fogueira no acampamento dos arqueólogos, formada por cinzas, carvão e argila rubefacta, PPL; D) agregados de POCC. .298

Figura 5.103. Alteração de Mytilus edulis a $200^{\circ} \mathrm{C}$ e $300^{\circ} \mathrm{C}$ : A1) concha queimada a $200^{\circ} \mathrm{C}$ com superfície avermelhada; A2-4) fotomicrografias das camada interna e externa ainda preservadas, com escurecimento das bordas, PPL e XPL; A5) detalhe de perióstraco preservado; B1) concha queimada a $200^{\circ} \mathrm{C}$; B2-5) fotomicrografias da concha queimada; note-se camada interna avermelhada e com fissuras incipientes, PPL e XPL 301

Figura 5.104. Alteração de Mytilus edulis a $400^{\circ} \mathrm{C}$ e $500^{\circ} \mathrm{C}$ : A1) concha queimada a $400^{\circ} \mathrm{C}$, com coloração acinzentada; A2-5) fotomicrografias da concha queimada com formação de fissuras longitudinais, escurecimento e coloração avermelhada da camada interna e mudança no tamanho dos cristais da calcita que compõe a camada exterior, PPL e XPL; B1) concha queimada a $500^{\circ} \mathrm{C}$ de coloração acinzentada e alta fragilidade; B2-5) fotomicrografias mostrando separação completa da valva interna e externa e múltiplas fissuras longitudinais e transversais à superfície da valva, PPL e XPL.......302

Figura 5.105. Alteração de Mytilus edulis a $700^{\circ} \mathrm{C}$ e $800^{\circ} \mathrm{C}$ : A1) concha queimada a $600^{\circ} \mathrm{C}$, com coloração acinzentada; A2-5) fotomicrografias da concha queimada de coloração castanho escuro a preta (PPL) e manchas escuras a XPL, com fissuras na camada interior e calcita fibrosa na camada exterior da valva; B1) concha queimada a $800^{\circ} \mathrm{C}$, com cor branca; B2-5) valva completamente deformada de coloração preta (PPL) com pseudo-vacuólos. .303

Figura 5.106. Macro e microestratigrafia do concheiro Túnel 7: A) sucessão vertical esquemática, a partir de informações disponíveis em Orquera (1996), com localização das duas colunas de amostragem para micromorfologia (C11 e C12); B) microfácies identificadas na C11 e C12, com correlação entre as sucessões estratigráficas de cada coluna. Note-se correspondência da unidade B35. .308

Figura 5.107. Fotomicrografias de elementos encontrados no concheiro Túnel 7: A) concha com perióstraco preservado, acompanhada de micromassa de agregados mamilares pretos, PPL; B) fragmento de osso intemperizado, identificado graças à seção delgada de referência coletada da praia de seixos, PPL; C) detalhe de agregados em blocos angulares que caracterizam à $\mathrm{mF} 2$, com cristais aciculares de calcita na micromassa, PPL e XPL; D) mesmo agregado de C, a XPL; E, F) fragmento de concha com cristais aciculares de calcita que se desprendem, PPL e XPL 311

Figura 5.108. Fotomicrografias das seções delgadas 2B e 3B da coluna 12 do sítio Túnel 7 (PPL): A) desenho esquemático da seção delgada $2 \mathrm{~B} ; \mathrm{B}$ ) $\mathrm{mF} 1$, com fragmentos de concha (c) e fragmentos líticos (fl); C) $\mathrm{mF} 2$, com blocos angulosos de argila organomineral com finos fragmentos de concha e osso; D) $\mathrm{mF} 3$, com fragmentos de concha de espécie indeterminada e fragmentos de concha de gastrópode (g); E) desenho esquemático da seção delgada $3 \mathrm{~B} ; \mathrm{F}$ ) $\mathrm{mF} 4$, formada por conchas de espécie indeterminada, conchas de mexilhão (m) e fragmentos líticos de distribuição horizontal e empacotamento fechado.......312

Figura 5.109. Fotomicrografias das seções delgadas 4B, 5B e 6B da coluna 12 do sítio Túnel 7 (PPL): A) desenho esquemático da seção delgada 4B; B) $\mathrm{mF}$ com conchas de mexilhão $(\mathrm{m})$ inteiras; $\mathrm{C}$ ) desenho esquemático da seção delgada $5 \mathrm{~B}$; D) $\mathrm{mF} 4$, com conchas de mexilhão e carvão (cr) de distribuição horizontal; E) desenho esquemático da seção delgada $6 \mathrm{~B}$; F) $\mathrm{mF} 3$ com conchas de mexilhão fragmentadas in situ, fragmentos líticos (fl) e concha queimada (cq). 313

Figura 5.110. Fotomicrografias das seções delgadas 7B e 8B da coluna 12 do sítio Túnel 7 (PPL): A) desenho esquemático da seção delgada $7 \mathrm{~B}$; B) $\mathrm{mF} 3$, com conchas inteiras de mexilhão $(\mathrm{m})$ e conchas fragmentadas in situ; C) detalhe de bloco anguloso da $\mathrm{mF} 2$ com fragmento de osso no interior (o); $\mathrm{D}) \mathrm{mF}$ 
5, composta por camada de seixos (fl); E) desenho esquemático da seção delgada 8B; F) $\mathrm{mF} 4$, composta por conchas de mexilhão de distribuição horizontal e empacotamento fechado.

Figura 5.111. Seção esquemática, sem escala, do sítio Túnel 7, com localização das cinco fogueiras estudadas (AC4, 5, 6, 8 e 10) e desenho esquemático das seções delgadas de cada fogueira, com identificação de microfácies.

Figura 5.112. Fotomicrografias da $\mathrm{mF} 7$ (AC4, 5 e 6): A) seção vertical esquemática, com localização das fogueiras amostradas para micromorfologia; B) micromassa da $\mathrm{AC} \mathrm{4}$, composta por fragmentos de concha queimados com grânulos soltos de microcarvão, PPL; C) micromassa da AC5 composta por fragmentos de concha queimados e carvão, entre grânulos finos de microcarvão, PPL; D) revestimento pendente de calcita na AC 6, PPL; E, F) parte da micromassa da AC 6 formada por cinzas e argila rubefacta, PPL e XPL

Figura 5.113. Fotomicrografias da mF 8 (AC 8 e 10): A) seção vertical esquemática, com localização das fogueiras amostradas para micromorfologia; B, C) massa basal da AC8, com microestrutura em câmara com conchas e ossos queimados, fragmentos líticos e vazios em canal e em câmara, PPL; D) massa basal da $\mathrm{AC10}$, com microestrutura em câmera e fração grossa composta por conchas queimadas e fragmentos líticos, PPL; E, F) micromassa da AC8, formada por cinzas e argila rubefacta, PPL e XPL. 320

Figura 6.1. Mapa da área de estudo, com localização dos concheiros naturais identificados por Hurt (1974), Caruso Jr. (1995), Fornari (2010) e Nascimento (2011). .335

Figura 6.2. Análises isotópicas $\left(\delta^{13} \mathrm{C}\right.$ e $\delta^{15} \mathrm{~N}$ e razão $\left.\mathrm{C} / \mathrm{N}\right)$ de amostras provenientes dos oito sambaquis analisados nesta tese e de trincheiras de amostragem externas a cinco deles: Caipora, Cubículo 1, Galheta 4, Santa Marta 8 e Santa Marta 10: A) gráfico de valores de $\delta^{13} \mathrm{C}$ e razão C/N para amostras coletadas em sambaquis conchíferos, com intervalos definidos para plantas de ciclo fotossintético $\mathrm{C}_{3}, \mathrm{C}_{4}$ e algas; $\mathrm{B}$ ) gráfico dos valores de $\delta^{15} \mathrm{~N}$ e $\delta^{13} \mathrm{C}$ para amostras coletadas em sambaquis conchíferos, com intervalos definidos para plantas de ciclo fotossintético $\mathrm{C}_{3}, \mathrm{C}_{4}$, animais marinhos e animais terrestres; C) gráfico de valores de $\delta^{13} \mathrm{C}$ e razão $\mathrm{C} / \mathrm{N}$ para todas as amostras analisadas nesta tese, com intervalos definidos para plantas de ciclo fotossintético $\mathrm{C}_{3}$ e algas; D) gráfico dos valores de $\delta^{15} \mathrm{~N}$ e $\delta^{13} \mathrm{C}$ para todas as amostras analisadas nesta tese, com intervalos definidos para plantas de ciclo fotossintético $\mathrm{C}_{3}$ e animais marinhos; E) gráfico de valores de $\delta^{13} \mathrm{C}$ e razão $\mathrm{C} / \mathrm{N}$ com intervalos definidos para plantas de ciclo fotossintético $\mathrm{C}_{3}$, $\mathrm{C}_{4} \mathrm{e}$ algas para amostras provenientes dos oito sambaquis analisados nesta tese e amostras de testemunhos coletados por Amaral (2008), Amaral et al. (2012) e Nascimento (2011) em fácies lagunares e deltaicas da região de estudo; F) gráfico dos valores de $\delta^{15} \mathrm{~N}$ e $\delta^{13} \mathrm{C}$ com intervalos definidos para plantas de ciclo fotossintético $\mathrm{C}_{3}, \mathrm{C}_{4}$ e animais marinhos. 341

Figura 6.3. Gráfico dos valores de $\delta^{13} \mathrm{C}$ e $\delta^{15} \mathrm{~N}$ de amostras provenientes dos quatro sambaquis conchíferos analisados, com intervalos de referência para plantas de ciclo fotossintético $\mathrm{C}_{3}$, moluscos, peixes de água doce, peixes marinhos e mamíferos marinhos. .342

Figura 6.4. Gráfico de componentes principais para 23 seções delgadas dos quatro sambaquis conchíferos analisados. .369

Figura 6.5. Concheiros do Canal Beagle: A) perfil do sítio Túnel 1 (Orquera \& Piana 1999: 33); B) perfil de um concheiro na Ilha Navarino (Handbook of South American Indians, volume 1, 1945: 28); C) perfil estratigráfico do sítio Túnel 7; D) concheiros anelares na Baía Cambaceres; E) sítio Kurakani (Orquera \& Piana 1999: 25); E) concheiros da Ilha Navarino (Handbook of South American Indians, volume 1, 1945: 27). 


\section{ÍNDICE DE QUADROS E TABELAS}

Quadro 3.1. Sambaquis do litoral sul de Santa Catarina estudados neste trabalho. As idades e setores de loclaização foram tomados de Giannini et al. (2010). 88 Quadro 3.2. Informações sobre contexto geológico-geomorfológico, coordenadas UTM e cronologia do concheiro etno-histórico Túnel 7 estudado neste trabalho.................................................................. 105 Quadro 4.1 Amostragem experimental em fogueiras e queima controlada de moluscos para atuar como referência na identificação de fogueiras in situ e de resíduos queimados remanejados nos sambaquis... 122 Quadro 4.2. Amostragem experimental em fogueiras e queima controlada de moluscos para atuar como referência na identificação de fogueiras in situ e resíduos queimados remanejados em concheiros do Canal Beagle. 125 Quadro 4.3. Síntese das diferentes análises realizadas por sítio arqueológico, na amostragem externa aos sítios e na amostragem experimental (fogueiras e queima controlada de moluscos). TdF: Terra do Fogo; SC: Santa Catarina. 133

Quadro 5.1. Descrição das alterações térmicas observadas nas conchas de Anomalocardia brasiliana, queimadas na mufla a temperaturas de 200 a $800^{\circ} \mathrm{C}$...................................................................... 144

Tabela 5.1. Descrição micromorfológica do sambaqui Caipora.......................................................... 157

Tabela 5.2. Componentes minerais e orgânicos da fração grossa da amostra CA 2-3............................ 159

Tabela 5.3. Componentes minerais e orgânicos da fração grossa da amostra CA 3..............................160

Tabela 5.4. Componentes minerais e orgânicos da fração grossa da amostra CA 4a............................161

Tabela 5.5. Componentes minerais e orgânicos da fração grossa da amostra CA 4b.............................162

Tabela 5.6. Componentes minerais e orgânicos da fração grossa da amostra CA HA-4........................163

Tabela 5.7. Descrição micromorfológica do sambaqui Cubículo 1......................................................180

Tabela 5.8. Componentes minerais e orgânicos da fração grossa da amostra CB1-9.............................181

Tabela 5.9. Descrição micromorfológica do sambaqui Morrinhos......................................................193

Tabela 5.10. Componentes minerais e orgânicos da fração grossa da amostra MO-3a..........................195

Tabela 5.11. Componentes minerais e orgânicos da fração grossa da amostra MO-3b..........................196

Tabela 5.12. Componentes minerais e orgânicos da fração grossa da amostra MO-4a.......................... 197

Tabela 5.13. Componentes minerais e orgânicos da fração grossa da amostra MO-4b........................198

Tabela 5.14. Descrição micromorfológica do sambaqui Jabuticabeira 1. ............................................2221

Tabela 5.15. Componentes minerais e orgânicos da fração grossa da amostra JB1-5 ...........................224

Tabela 5.16. Componentes minerais e orgânicos da fração grossa da amostra JB1-5/6.......................225

Tabela 5.17. Componentes minerais e orgânicos da fração grossa da amostra JB1-7 .........................226

Tabela 5.18. Componentes minerais e orgânicos da fração grossa da amostra JB1-8...........................228

Tabela 5.19. Componentes minerais e orgânicos da fração grossa da amostra JB1-9...........................228

Tabela 5.20. Descrição micromorfológica do sambaqui Santa Marta 10 ............................................246

Tabela 5.21. Componentes minerais e orgânicos da fração grossa da amostra SM10 A/B..................247

Tabela 5.22. Componentes minerais e orgânicos da fração grossa da amostra SM10 B.......................248

Tabela 5.23. Componentes minerais e orgânicos da fração grossa da amostra SM10 B2 .....................249

Tabela 5.24. Descrição micromorfológica do sambaqui Carniça 3 .....................................................260

Tabela 5.25. Componentes minerais e orgânicos da fração grossa da amostra CR 32 .........................261

Tabela 5.26. Descrição micromorfológica do sítio Santa Marta 8......................................................2271

Tabela 5.27. Componentes minerais e orgânicos da fração grossa da amostra SM8-1/2 .......................272

Tabela 5.28. Componentes minerais e orgânicos da fração grossa da amostra SM8-3a.........................273

Tabela 5.29. Componentes minerais e orgânicos da fração grossa da amostra SM8-3b. ......................2273

Tabela 5.30 . Descrição micromorfológica do sítio Galheta 4. .........................................................28

Tabela 5.31. Componentes minerais e orgânicos da fração grossa da amostra GA4-1.........................289

Tabela. 5.32. Componentes minerais e orgânicos da fração grossa da amostra GA4-A/1 .....................289

Quadro 5.2. Alterações microscópicas de valvas de Mytilus edulis, queimadas de 200 a $800{ }^{\circ}$ C...........304

Tabela 5.33. Descrição micromorfológica da coluna de amostragem do sítio Túnel 7..........................309

Tabela 5.34. Descrição micromorfológica das fogueiras (AC) identificadas na área central de Tunel 7. 317 Quadro 6.1. Espécies de moluscos identificadas nos sambaquis Caipora, Cubículo 1, Morrinhos e Jabuticabeira 1, com descrição do substrato e ambiente onde a espécie vive. Dados de vermetídeos e cirripídeos tomados de Laborel and Laborel-Deguen (1996). Demais moluscos tomados de Rios (1985).

328

Quadro 6.2. Distribuição de espécies de moluscos nos sítios Caipora, Cubículo 1, Morrinhos e Jabuticabeira $1 . \cdots=$ espécie dominante $(50-70 \%) ; \cdots=$ espécie freqüente $(10-50 \%) ; \cdot \bullet=$ poucos 
indivíduos ou fragmentos $(1-10 \%) ; \cdot=$ ocasionais $(<1 \%)$. As espécies identificadas em negrito são aquelas que vivem aderidas a substrato rochoso em mar aberto.....................................................329

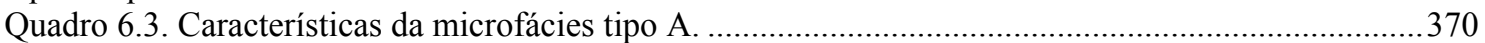

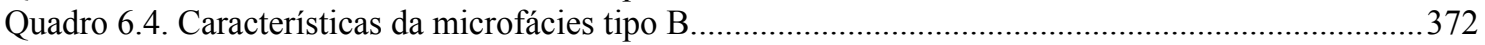

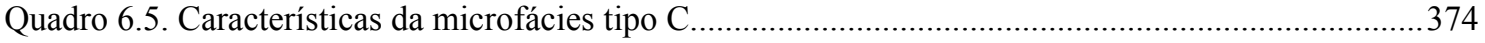

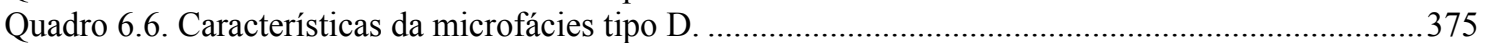

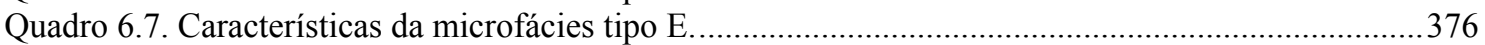

Quadro 6.8. Espécies de moluscos identificadas nos sambaquis Santa Marta 10 e carniça 3, com descrição do substrato e ambiente onde a espécie vive. Dados sobre vermetídeos e cirripídeos tomados de Laborel and Laborel-Deguen (1996). Demais moluscos tomados de Rios (1985).

Quadro 6.9. Distribuição de espécies de moluscos nos sítios Santa Marta 10 e Carniça 3. •••• = espécie dominante $(50-70 \%) ; \cdots=$ espécie frequente $(10-50 \%) ; \bullet=$ poucos indivíduos ou fragmentos $(1-10 \%) ; \bullet$ $=$ ocasionais $(<1 \%)$.

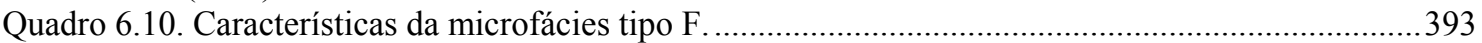

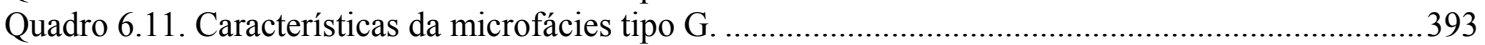

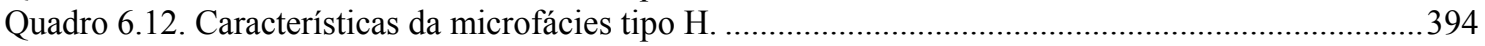

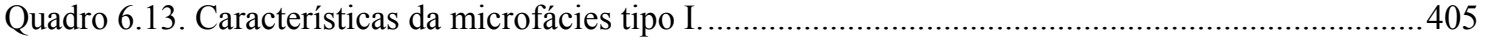

Quadro 6.14. Características da microfácies tipo J..........................................................................407

Quadro 6.15. Características da microfácies tipo K. .......................................................................408

Quadro 6.16. Características da microfácies tipo L............................................................................409

Quadro 6.17. Características da microfácies 1, 2 e 3 da C12 no concheiro Túnel 7............................416

Quadro 6.18. Características da microfácies 4 e 5 da C12 no concheiro Túnel 7. ................................418

Quadro 6.19. Características da microfácies 7 e 8 na área central do concheiro Túnel 7......................420 


\section{CAPÍTULO 1: INTRODUÇÃO}

\section{PREMISSAS TEÓRICAS}

Este trabalho fundamenta-se no diálogo contínuo entre arqueologia e geociências, voltado principalmente à interpretação cultural, a ser construída a partir da articulação entre teorias ou programas de pesquisa arqueológica e teorias e métodos das geociências. Os sambaquis ou concheiros, objeto de estudo desta tese, são definidos como sítios monticulares construídos, já que resultam da ação humana de transporte massivo de partículas, deposição em local específico e ocupação reiterada desse local, independente da função atribuída à esta ocupação.

Sítios monticulares construídos podem incluir: 1) acumulações de resíduos associados a ocupações domésticas, como, por exemplo, os numerosos middens situados atrás das cabanas, nas aldeias circulares dos Kuikuro no Alto Xingu (Heckenberger, 1996; Schmidt and Heckenberger, 2009); 2) estruturas em terra de até 2 metros de altura, a exemplo dos montículos funerários e áreas entaipadas associados à tradição Taquara/ Itararé (Beber, 2004; Iriarte et al., 2008); e 3) estruturas maiores em terra, de dezenas de metros de cumprimento, como plataformas cerimoniais, de residência, cultivo etc., como as que existem em diversas áreas da Amazônia central até a Ilha do Marajó (Erickson, 2000, 2008; Erickson \& Balée, 2006; Schaan, 2008, 2010).

Frequentemente, a função de acúmulo residual é utilizada como argumento contra a visão dos sítios de menor tamanho como construções ou produtos intencionais. Por exemplo, no caso de assentamentos domésticos, a formação de montículos como resultado da acumulação de resíduos é concebida como produto acidental e não como projeto construtivo. No entanto, a intencionalidade na formação destes depósitos é manifesta, já que, independente de seu uso ou função, resultam da ação humana deliberada de acumulação de materiais em local selecionado, e não de agentes naturais ou desconhecidos. Todos estes depósitos, sejam grandes lixões sejam plataformas cerimoniais, são decorrência material da organização social do espaço e representam construções dentro de sistemas culturalmente específicos. 
A isto vincula-se outra premissa importante neste estudo: a concepção dos sedimentos arqueológicos em sítios monticulares construídos, a exemplo dos sambaquis, como produto humano e fonte de informações sobre a dinâmica cultural. Estes sedimentos transformam-se em cultura material por terem sido deliberadamente produzidos por um grupo com significados e finalidades próprios. Esta visão deriva da abordagem de estudo de antropossolos, ou solos formados e caracterizados pelos efeitos da influência humana (Eidt, 1984; French, 2003; Limbrey, 1975; Woods, 2003), e de sedimentos (Butzer, 1989; Hassan, 1978; Stein and Farrand, 1985; Stein, 1985, 1987) como parte do registro arqueológico. O estudo dos sedimentos arqueológicos, especialmente em sítios construídos, é equiparável e complementar à análise artefatual.

A abordagem geoarqueológica proposta não se alinha com a perspectiva adaptacionista e naturalizadora, frequentemente usada na geoarquelogia de concheiros e no estudo de sítios costeiros do Holoceno inferior (ver Bailey \& Flemming, 2008; Bicho, 1994; Erlandson, 1994; Erlandson, 2001; Fa, 2008; Kennett, 2005; Orquera et al., 2011; Piana \& Orquera, 2009). O adaptacionismo concebe a unilateralidade da relação entre meio ambiente e cultura e vê aos grupos humanos como em processo constante de adaptação às alterações impostas pela natureza (Gnecco, 2003), enquanto a perspectiva naturalizadora concebe os grupos caçador-coletores como em constante procura da maximização do gasto energético (Ingold, 2000, 2002). Sob esta visão, os grupos humanos definiriam o sistema de assentamento, densidade populacional, estratégia de subsistência, entre outros, a partir da necessidade de obter o maior rendimento das características e das eventuais mudanças do meio físico que ocupam.

Neste trabalho, os humanos são considerados agentes de transformação e parte ativa na dinâmica das paisagens, entendidas como produto histórico da dialética entre natureza e cultura (Balée, 1988; Balée \& Erickson, 2006; Balée, 2006). O enfoque da ecologia histórica, cada vez mais crescente na arqueologia da América do Sul, e especialmente na da Amazônia (Arroyo-Kalin, 2008, 2010; Balée, 1994; Denevan, 1992; Erickson \& Balée, 2006; Heckenberger et al., 2003; Neves \& Petersen, 2006; Schaan, 2010), traz uma mudança fundamental na antropologia de caçador-coletores e revela a complexa dinâmica de interação e co-evolução entre os humanos e os sistemas naturais.

À visão antropocêntrica segundo a qual humanos e processos naturais atuariam como forças conjuntas na formação das paisagens, articulam-se, neste trabalho, as 
considerações feitas a partir da arqueologia da paisagem sobre o valor simbólico e o significado sociopolítico dos ambientes construídos (Criado-Boado, 1989, 1993, 1999; Ingold, 1993). Os sambaquis do litoral sul de Santa Catarina (Brasil), objeto de estudo deste trabalho, associam-se a transformações profundas de ordem social, onde gerações de indivíduos eram agrupadas para. A construção destes sítios, e de sambaquis de menor escala, envolve modificações do meio físico a partir da criação de estruturas que, na sua forma atual e no seu significado pretérito, projetam o passado e incorporam atividades que são essencialmente cíclicas (ver Stewart et al., 2004). Estes sítios serão utilizados para contar a história do grupo envolvido na sua formação e da paisagem que eles modelam e integram.

$\mathrm{Na}$ análise aqui proposta, seguem-se as linhas de interpretação avançadas por Estevez et al. (1998) Estevez (2002), Gassiot \& Estevez (2002), Fiore \& Zangrando (2006) e Zangrando (2009) para os concheiros fueguinos, e Gaspar ${ }^{1}$ (2004), Gaspar et al. (2007) e Klokler (2001, 2008), para os sambaquis catarinenses. Em termos gerais, estes autores, desde a análise de diferentes componentes do registro arqueológico (fauna, artefatos líticos e ósseos) e de marcos teóricos diversos, questionam a visão normativa entre mudanças ambientais e processos de câmbio social, e disponibilidade de recursos e estratégia de subsistência. Neste sentido, fatores ideológicos, simbólicos e pressões ou conflitos sociais (intra e intergrupo), são considerados agentes fundamentais nas mudanças observadas no registro arqueológico.

Em resumo, as premissas teóricas que nortearão esta tese incluem: 1) o uso dos sedimentos arqueológicos como instrumento de interpretação arqueológica; 2) a visão dialética dos humanos e o entorno físico que ocupam, com a paisagem como produto histórico e recipiente de significados sociais; 3) a importância dos fatores ideológicos nos processos de mudança em caçador-coletores.

\footnotetext{
${ }^{1} \mathrm{Na}$ arqueologia de sambaquis, a tese de Gaspar (1991) iniciou a visão destes concheiros como artefatos, construído pelos indivíduos que o ocuparam a partir da deposição deliberada de materiais, resultado de ações pertinentes ao sistema sócio-cultural sambaquieiro (Gaspar 1991: 85).
} 


\section{GEOARQUEOLOGIA DE CONCHEIROS}

Pela sua composição rica em restos faunísticos, principalmente malacológicos, os sítios concheiros são tradicionalmente utilizados para reconstituir as atividades de subsistência do grupo e as adaptações ecológicas a ambientes costeiros (Andrus \& Crowe, 2000; Bicho, 1994; Bird, 2002; Claasen, 1986a, 1986b; Erlandson, 1988, 1994; Jerardino et al., 1992; D. Kennett, 2005; De Masi, 2001; Milner et al. 2007; Reitz, 1988; Stiner et al., 2003; Waselkov, 1987). A ubiquidade cronológica e geográfica dos concheiros serve para estudar a evolução das ocupações costeiras e o desenvolvimento das primeiras economias marítimas, assim como para afirmar a importância das áreas litorâneas no desenvolvimento cultural de caçador-coletores (Erlandson, 2001; Erlandson et al., 2008; Fa, 2008; Jones et al., 2002; Mannino \& Thomas, 2002; Rick et al., 2005; Sandweiss, 2003; Waselkov, 1987; Yesner, 1980)

No entanto, a complexidade estratigráfica e composicional e os múltiplos significados e processos associados à formação destes sítios abrem um leque maior de estudos não exclusivamente focados na subsistência e adaptação. Por exemplo, estudos recentes chamaram a atenção sobre o valor ritual da fauna recuperada em alguns concheiros e no uso do próprio concheiro como área cerimonial (Bird and Bliege Bird, 1997, 2000; Claassen, 1991, 1996, 1998; DeBlasis et al., 2007; Klokler, 2008; Lightfoot and Cerrato, 1988; Luby and Gruber, 1999; Luby, 2004; Russo, 2004). A seguir, apresentam-se os principais temas de estudo em geoarqueologia de concheiros e uma breve revisão dos trabalhos geoarqueológicos realizados na arqueologia de sambaquis.

\subsection{PRINCIPAIS TEMAS DE ESTUDO}

$\mathrm{Na}$ geoarqueologia de concheiros, o foco das análises, em geral, tem envolvido o estudo da assembleia de moluscos como evidência da evolução geológica de áreas costeiras e ribeirinhas. Os fatores ambientais, que influenciam o tipo e a disponibilidade 
de recursos malacológicos, foram o principal objeto de estudo, em oposição aos fatores comportamentais de manejo e descarte de resíduos que, ao longo ou curto prazo, acabam formando o concheiro.

Em termos gerais, a geoarqueologia de concheiros envolve seis temáticas fundamentais: 1) variações no nível relativo do mar (NRM) e sua influência na localização dos depósitos e na exploração de recursos (Bailey \& Craighead, 2003; Cannon, 2000; Emery \& Edwards, 1966; Erlandson, 1988 b; Fa, 2008; Fedje \& Christensen, 1999; Miller et al., 1995; Sandweiss, 2003); 2) dinâmica e geomorfologia costeira, evolução sedimentar e ocupação humana (Bailey \& Flemming, 2008; Bicho \& Haws, 2008; Fa, 2008; Mason, 1993; Whittacker \& Stein, 1992); 3) reconstrução paleoambiental, mediante articulação de informações produzidas a partir da análise de moluscos provenientes de concheiros com dados geológicos, botânicos, isotópicos, etc. (Cortez-Sanchez et al., 2008; Fa, 2008; Morey \& Crothers, 1998; Sandweiss, 1996, 2003; Van der Schriek et al., 2007, 2008); 4) métodos para distinguir entre concheiros naturais e antrópicos (Attenbrow, 1992; Bailey, 1977; Henderson et al., 2002; Rosendahl et al., 2007; Rowland, 1994; Stone, 1995; Sullivan \& Connor, 1993); 5) datação de conchas carbonáticas para construir cronologias de ocupação (Bateman et al., 2008; Deo et al., 2004; Erlandson \& Rick, 2002); 6) métodos de estudo estratigráfico e processos de formação de sítio (Arnold et al., 1997; Chadwick \& Madsen, 2000; Dalan et al., 1992; Morey et al., 2002; Stein, 1992 a- c, 1996; Stein et al., 1992).

Dos seis grandes temas expostos, este trabalho concentra-se no último da lista. Estudos pioneiros sobre arqueoestratigrafia de concheiros foram conduzidos por Julie Stein desde a década de 1980. Os trabalhos da autora estabeleceram um marco de referência para o estudo de concheiros no mundo. A sua contribuição mais importante refere-se ao estabelecimento de um método de estudo estratigráfico que contempla a caracterização dos sedimentos que compõem os concheiros, mediante ensaios laboratoriais, e interpretação dos processos de formação dos sítios ${ }^{2}$ (Morey et al., 2002; Stein, 1992a- c, 1996; Stein et al., 1992).

Apesar dos trabalhos de Julie Stein, o uso da geoarqueologia na escala de sítio é o tema de menor produção bibliográfica. Provavelmente, isto se relaciona ao fato da

\footnotetext{
${ }^{2}$ A autora propôs também um método para determinação de taxas de acumulação/crescimento de concheiros, a partir de datações ${ }^{14} \mathrm{C}$ de carvão recuperado em áreas escavadas (Stein, 2003).
} 
zooarqueologia, em vista da própria composição dos concheiros, ser considerada mais adequada na caracterização e estudo estratigráfico-temporal deste tipo de sítio. Análises faunísticas têm-se mostrado frequentemente suficientes para a interpretação de mudanças em estratégias de subsistência e exploração dos recursos. Quando os resultados da zooarqueologia são articulados com estudos geoarqueológicos, estes são realizados não na escala de sítio, mas na de paisagem, a partir da combinação de diversas análises faunísticas (taxonômicas, esclerocronológicas, isotópicas etc.) com dados geológicos, botânicos etc., voltados à reconstrução do panorama de evolução ecológico-geográfica e sua interação com as comunidades humanas.

Este trabalho adota uma abordagem geoarqueológica para o estudo de sambaquis na escala de sítio a partir da análise padronizada das sucessões verticais, com o objetivo de explorar os fatores comportamentais envolvidos na construção dos sambaquis e suas mudanças ao longo do tempo. Contribui-se ao desenvolvimento de estudos estratigráficos em concheiros e testa-se o uso de técnicas de análise sedimentar (granulometria, isotopia, micromorfologia e microscopia eletrônica de varredura), combinadas com dados zooarqueológicos, na completa caracterização dos sítios.

\subsection{GEOARQUEOLOGIA DE SAMBAQUIS}

No Brasil, trabalhos de caráter geoarqueológico em sambaquis aparecem desde a primeira metade do século XX. Segundo Afonso (2008), as pesquisas de Leonardos (1938) sobre artificialidade dos sambaquis e os trabalhos de Duarte (1968), Emperaire \& Laming-Emperaire (1956a, 1956b), nos sambaquis da costa do Paraná e São Paulo, constituem abordagens implicitamente geoarqueológicas. A estes autores, deve somarse o trabalho de Biocca et al. (1947), sobre análises químicas e bacteriológicas em sedimentos de três sambaquis na Ilha de Santo Amaro (SP), a proposta de Guerra (1950) sobre a diferenciação entre terraços e sambaquis. Também cabe mencionar os trabalhos de Castro Faria na região de Laguna (SC) que, segundo Lima (1999), foi pioneiro na aliança entre arqueologia e geomorfologia (Castro Faria, 1952, 1959). Posteriormente, a pesquisa de Hurt (1974), em sambaquis do litoral sul de Santa Catarina, e os trabalhos interdisciplinares de Kneip (Kneip et al., 1975), nos sambaquis do Rio de Janeiro, 
também vêm representar abordagens pioneiras no estudo de sambaquis ancorado nas geociências.

Outros trabalhos também podem ser considerados implicitamente geoarqueológicos, apesar de estarem vinculados à produção de conhecimento na área das geociências e não terem por objetivo o estudo da pré-história. Exemplo disso são as numerosas publicações sobre o uso da localização dos sambaquis e sua cronologia como indicadores de paleoníveis de mar (Bigarella, 1965, 1976; Fairbridge, 1976; Martin \& Suguio, 1976a, 1976b; Martin et al., 1986; Suguio et al., 1976, 1992; Suguio, 1993).

Pesquisas geoarqueológicas relacionadas com flutuações do NRM e localização de sambaquis foram realizadas em várias áreas do Brasil, nos últimos 10 anos, seguindo, basicamente, os mesmos lineamentos dos trabalhos realizados desde a década de 1950, tanto na arqueologia (Emperaire \& Laming-Emperaire, 1956 b; Hurt \& Blasi, 1960; Hurt, 1974; Laming, 1960; Laming-Emperaire, 1975), como nas geociências (Bigarella, 1965, 1976; Fairbridge, 1976; Martin \& Suguio, 1976a, 1976b; Martin et al., 1986; Suguio et al., 1976, 1992; Suguio, 1993). Todos estes trabalhos partem da premissa, frequentemente implícita, de que a evolução espacial na ocupação do território por parte dos sambaquieiros está diretamente relacionada com a configuração da paisagem, resultado das oscilações do NRM durante o Holoceno. Estes trabalhos foram realizados no litoral de regiões como: norte da Bahia (Amâncio \& Dominguez, 2003; Santana, 2007; Santana et al., 2003); Rio de Janeiro, nos sambaquis da Ilha do Cabo Frio (Tenório et al., 2005) e complexo lagunar de Saquarema (Barbosa, 2007); sul de São Paulo (Calippo, 2004, 2010); sul do Paraná e norte de Santa Catarina (Oliveira, 2000); centro-sul de Santa Catarina (Kneip, 2004); e norte do Rio Grande do Sul (Kern, 1982; Perreti, 2009).

As pesquisas geoarqueológicas na escala do sítio, em geral, focaram no desenvolvimento de métodos não invasivos para delimitação dos sambaquis e no estudo dos processos de formação de sítio. Métodos geofísicos foram utilizados para identificar a verdadeira extensão de sambaquis e reconhecer feições especificas no seu interior (fogueiras, concentração de artefatos líticos, entre outros) no Rio de Janeiro (Mello, 2001), em sambaquis fluviais de São Paulo (Gomes, 2003; Schimmel et al., 2002), e no litoral sul de Santa Catarina (Rodrigues, 2009; Rodrigues et al., 2009; Santos et al., 2009). 
Trabalhos geoarqueológicos sobre formação de concheiros foram desenvolvidos por Afonso \& DeBlasis (1994) e Afonso (1999), no sambaqui Espinheiros II (Joinville), e por Amenomori (2001, 2005), nos sítios Mar Virado, Couves I e Montão de Trigo, situados em ilhas do litoral norte de São Paulo. Um completo estudo pedológico foi realizado por Corrêa (2007) em sambaquis da Região dos Lagos (RJ), com aplicação de técnicas pouco usuais na arqueologia de sambaquis, como micromorfologia, e microscopia eletrônica de varredura. Apesar de não declaradamente geoarqueológico, este estudo contribuiu com informações que permitem a caracterização dos sambaquis como arqueo-antropossolos (sensu Kampf and Kern, 2005).

Recentemente, o trabalho de Brochier (2009) sobre modelos geoarqueológicos para detecção de sítios soterrados, trouxe importantes questionamentos quanto ao potencial de preservação de sítios costeiros em geral. Os trabalhos de Giannini et al. (2005), Villagran (2008) e Villagran et al. (2009a), no sítio Jabuticabeira 2, litoral centro-sul de Santa Catarina, apesar de focalizarem um único sítio, oferecem métodos de análise e modelos interpretativos que podem ser utilizados em outros concheiros, independentemente do contexto geográfico e cronológico de localização (química de sedimentos, micromorfologia, análise de fácies, arquitetura deposicional, entre outros).

O método de análise proposto para Jabuticabeira 2 será expandido, nesta tese, a outros sambaquis da região, com a finalidade de testar e refinar o método de estudo estratigráfico de sambaquis, padronizar a abordagem e habilitar a comparação inter e intra-sítio.

\section{A PROPOSTA}

Neste trabalho a geoarqueologia será utilizada para estudar os processos de formação de sambaquis na escala de sítio, com aplicação de um método estratigráfico, denominado análise de arqueofácies (Villagran 2008; Villagran et al. 2009), que permitirá a comparação entre diferentes tipos de sambaquis de diversa cronologia. Esta abordagem permitirá avaliar o desenvolvimento da ocupação humana da área de estudo, suas mudanças ao longo do tempo, e sua relação com a evolução dos sistemas naturais do Holoceno. Na construção de modelos interpretativos, será utilizada a analogia 
experimental e a comparação com um contexto arqueológico submoderno etnograficamente conhecido.

\subsection{ANÁLISE DE ARQUEOFÁCIES}

A análise de arqueofácies, método de estudo estratigráfico desenvolvido na interface entre arqueologia e geociências (Villagran 2008; Villagran et al. 2009a), será aplicada ao estudo de oito sambaquis do litoral sul do Estado de Santa Catarina. Este método aponta à identificação de produtos de deposição antrópicos nas sucessões verticais para interpretar a atividade, ou sucessão de atividades, associadas a formação e evolução dos sítios. As três etapas fundamentais da análise de arqueofácies são: 1) identificação de fácies arqueológicas em campo (segundo lista de atributos deposicionais); 2) caracterização, em laboratório, das propriedades de cada fácies (com ênfase na análise micromorfológica); 3) e interpretação das fácies e seu arranjo espacial com base em modelos de arqueofácies (construídos a partir de analogia arqueológica intecultural e experimental). A meta desta pesquisa será utilizar a informação produzida pela análise de arqueofácies para estudar a formação dos sítios e a evolução da ocupação sambaquieira na região durante o Holoceno.

A verticalidade dos processos de deposição antrópicos, a partir da relação entre arqueofácies em uma sucessão estratigráfica, além de oferecer uma visão cronológicoevolutiva dos processos de formação, mostra permanências ou mudanças na dinâmica de formação dos sítios. A horizontalidade dos processos de deposição antrópicos, através da relação inter-sítio entre fácies arqueológicas de uma mesma região, permite construir o panorama de ocupação a partir de práticas de diferente escala e natureza (domésticas, rituais ou uma fusão de ambas) que participaram na construção do espaço. A verticalidade e horizontalidade no estudo das sucessões estratigráficas outorgam dinamismo e significado aos processos de deposição antrópicos, no tempo e espaço.

A caracterização dos sedimentos arqueológicos, segundo o método proposto, prioriza a análise micromorfológica. A observação na escala microscópica permite conhecer a história deposicional e pós-deposicional dos sítios construídos a partir da configuração atual dos sedimentos. A análise micromorfológica será complementada 
com outros ensaios que ajudem a explorar o seu potencial interpretativo. Análises granulométricas, razão de isótopos de carbono e nitrogênio $\left(\delta^{13} \mathrm{C}\right.$ e $\left.\delta^{15} \mathrm{~N}\right)$ da matéria orgânica dos sedimentos arqueológicos e naturais, composição química multi-elemental e dados micromorfológicos e de química pontual via microscopia eletrônica de varredura serão empregados na completa caracterização das fácies naturais e arqueofácies sob estudo.

\subsection{CONSTRUÇÃO DE MODELOS INTERPRETATIVOS}

A explicação das sucessões estratigráficas, após a fase de caracterização das arqueofácies, realiza-se a partir da construção de modelos interpretativos. O importante não é unicamente estabelecer as propriedades de cada arqueofácies, mas conhecer a relação destas com as características composicionais e tafonômicas das outras fácies que compõem a mesma sucessão vertical ou mesmo das identificadas em sítios próximos da região. Na construção de modelos que expliquem os atributos observados nas sucessões estratigráficas, utilizam-se analogias, mediante confronto com casos similares na literatura, uso de abordagens experimentais e comparações interculturais.

\subsubsection{Arqueologia experimental}

Neste trabalho, a arqueologia experimental será empregada para estudar os produtos materiais de processos atuais conhecidos e interpretar a potencial ação desses processos no passado, a partir de produtos com atributos semelhantes observados no registro arqueológico. Especificamente, a arqueologia experimental será utilizada para aprofundar a identificação de estruturas de combustão in situ ou resíduos de queima retrabalhados, a partir de fogueiras experimentais e queima controlada de moluscos.

Esta abordagem baseia-se no atualismo como método de inferência de eventos passados por analogia com processos observados no presente (Rudwick, 1976). No entanto, o atualismo aqui mencionado não se refere a comportamentos nem leis sociais e 
culturais, mas restringe-se a processos naturais, ainda que estes possam em parte surgir de interferência humana.

\subsubsection{Comparação intercultural}

A analogia também será utilizada entre dois contextos arqueológicos: os sambaquis de Santa Catarina e um concheiro etno-histórico da Terra do Fogo (Argentina). Esta estratégia será aplicada como auxílio na formulação de hipóteses sobre o comportamento humano e o significado dos vestígios materiais que dele resultam, apesar das diferenças étnicas, cronológicas e geográficas das duas culturas em estudo. O sítio utilizado para comparação é um concheiro do período histórico construído por grupos caçador-coletores etnograficamente conhecidos: os Yamana. A possibilidade de correlacionar a formação do sítio arqueológico com os relatos sobre a vida cotidiana dos Yamana, inexistente para os grupos construtores de sambaquis, permite outorgar significado social ao registro arqueológico, sempre através da avaliação crítica dos fatores condicionantes de cada registro (arqueológico e etnográfico) ${ }^{3}$.

Os argumentos de relevância que vão permitir a correspondência analógica estão fundamentados na teoria dos processos de formação de sítio (Schiffer 1972, 1983, 1987) e referem-se ao processo de formação cultural que se encontra por trás dos dois contextos a serem estudados: o descarte e a construção de concheiros. No entanto, vale esclarecer que a analogia será realizada, numa primeira instância, sobre o processo de construção dos concheiros e sambaquis enquanto ação mecânica sujeita a modificações físico-químicas, e não quanto ao significado deste processo. O significado do processo será analisado numa ultima instância interpretativa, após a avaliação das semelhanças e diferenças entre ambas as culturas de caçador-coletores associadas à formação de concheiros. O significado do descarte não é equivalente de uma cultura a outra (Hodder

\footnotetext{
${ }^{3}$ Estudos etnoarqueológicos realizados nos concheiros históricos do Canal Beagle demonstram o viés e a subjetividade do registro etnográfico que também é passível de mudar ao longo do tempo. Isto significa que a analogia etnográfica direta unicamente pode ser utilizada no estágio de formulação de hipóteses, mas não na construção de explicações sobre o comportamento social pré-histórico a partir da comparação do registro arqueológico com o etnográfico (Estevez \& Vila 2007; Vila et al. 2007).
} 
1982b) e, portanto, será estudado no seu contexto cultural específico, como possível fator condicionante dos atributos observados.

\section{OBJETIVOS}

O objetivo geral desta pesquisa é compreender detalhadamente os processos de formação culturais (atividades humanas) e naturais (tafonômicos) de sambaquis e suas mudanças ao longo do tempo, mediante o estudo, na escala meso e microscópica, de oito sambaquis localizados no litoral sul catarinense, cuja cronologia envolve todo o período de ocupação humana pré-histórica da região. Deste modo, propõe-se aprofundar os conhecimentos sobre configuração da paisagem e formação dos sambaquis em diferentes momentos da história dos grupos humanos que habitaram o litoral catarinense, desde a sua chegada até o abandono do projeto construtivo com conchas.

A estratégia de abordagem proposta é a de explorar a análise de arqueofácies como ferramenta padronizada para o estudo dos processos de formação de sambaquis, com ênfase na micromorfologia, como técnica primordial na caracterização de fácies deposicionais antrópicas, e na arqueologia experimental e comparação intercultural, como auxiliares na construção de modelos interpretativos. Assim, aspira-se ao uso da análise de arqueofácies como ferramenta no estudo dos processos de formação de sítios concheiros em geral. 


\section{CAPÍTULO 2: CONCHEIROS E SAMBAQUIS}

As informações agrupadas neste capítulo apresentam uma visão geral dos principais tópicos a serem tratados na tese. Começa-se pela definição dos sítios concheiros e os diferentes contextos e cronologias que estes sítios apresentam na América do Sul. Das cronologias mais antigas, passa-se à realidade brasileira e ao objeto de estudo desta tese: os sambaquis. Por ser um dos objetivos deste trabalho a avaliação das mudanças, ao longo do tempo, na formação dos sambaquis catarinenses, discute-e a chegada das culturas marítimas ao litoral brasileiro, os diferentes tipos de sítio associados a esta cultura e as causas do colapso da acumulação social de conchas. $\mathrm{O}$ processo de colapso relaciona-se frequentemente à chegada ao litoral de grupos ceramistas do planalto. Esta migração é interpretada a partir de sítios costeiros com cerâmica interiorana. Como dentro do conjunto amostral desta tese incluem-se, além dos sambaquis, sítios costeiros com cerâmica, apresenta-se brevemente uma explicação alternativa sobre a relação entre ambos os grupos que será retomada na conclusão.

As teorias e modelos vigentes sobre formação de sambaquis são apresentados, com as propostas desenvolvidas em sítios de Rio de Janeiro, São Paulo, Paraná e Santa Catarina, que enfatizam na relação centro-periferia para explicar a formação dos montículos de conchas (formação dos concheiros como resultado do descarte de resíduos ao redor do local de moradia). A visão interpretativa sobre a formação dos sítios enuncia-se na arquitetura de sambaquis, que define os sítios como objetos que outorgam significado ao ambiente construído, através da conspicuidade das estruturas, o simbolismo funerário, a multifuncionalidade e a recorrência na ocupação.

Por último, introduzem-se as particularidades do caso de estudo comparativo que será utilizado como complemento na construção de modelos interpretativos para sambaquis: os concheiros etno-históricos do Canal Beagle (Terra do Fogo, Argentina). Estes sítios estão associados a grupos etnograficamente conhecidos, que foram extensamente descritos pelos cronistas dos séculos XIX e XX. As crônicas provêm de informações detalhadas sobre o processo de formação dos concheiros fueguinos e do cotidiano das culturas litorâneas. 


\section{DEFINIÇÃo}

A palavra concheiro, neste trabalho, define um tipo de depósito arqueológico que possui como características comuns: 1) composição essencialmente malacológica; 2) origem vinculada à deposição antrópica, independente de sua localização geográfica e cronologia. Estes depósitos podem apresentar-se como sítios específicos, com ou sem estratificação, compostos na sua totalidade por mais de $30 \%$ de conchas, ou como estratos discretos na sucessão estratigráfica de sítios maiores. No Brasil, estes depósitos são popularmente chamados de "sambaquis", enquanto no resto da América do Sul são referidos como concheros ou conchales.

Os concheiros mais antigos que se conhecem datam do Pleistoceno, com idade de até $250 \mathrm{kA}$, e localizam-se em áreas costeiras da África e Europa ${ }^{4}$. Na América, os concheiros mais antigos são datados da transição Pleistoceno-Holoceno e estão localizados na costa pacifica (Cannon, 2000; DeFrance et al., 2001, 2009; Erlandson, 2007; Keefer, 1998; Rick et al., 2001; Sandweiss, 2003). A frequência de concheiros aumenta consideravelmente durante o Holoceno, quando aparecem em áreas costeiras dos cinco continentes. Atualmente grupos na Nova Zelândia, Austrália e África, ainda incluem a formação de concheiros como remanescente material na paisagem (Bird, 2002; Bird \& Bliege Bird, 1997, 2000; Bowlder, 1976; Lasiak, 1991; Meehan, 1982; Moss, 1993).

\footnotetext{
${ }^{4}$ No norte africano, costa do estreito de Gibraltar, foram encontradas evidências do consumo de moluscos no abrigo Banzu, desde 250 até $70 \mathrm{kA}$ (Ramos et al., 2008). O concheiro mais antigo, com idade máxima de ca. 164 kA, está no sítio PP13B no litoral da África do Sul (Marean et al., 2007), onde se encontraram as primeiras evidências do uso de moluscos na dieta do Homo sapiens. Na Itália, a gruta dei Moscerini, habitada por populações neandertais, apresentou evidências da exploração de moluscos desde $110 \mathrm{kA}$ (Stiner et al., 1999). No continente asiático, no sudeste e ilhas da Melanésia, evidências do consumo de moluscos aparecem associadas à chegada dos primeiros Homo sapiens na região, desde $45 \mathrm{kA}$ (Szabó and Amesbury, 2011). Cabe destacar que em todos estes casos, os concheiros referidos são camadas discretas na estratigrafia de sítios em cavernas. Os concheiros a céu aberto mais antigos localizam-se na África do Sul, Sea Harvest e Hoedjies Punt, datados entre 60-70 kA (Volman, 1978).
} 


\section{CONCHEIROS DO HOLOCENO INICIAL E MÉDIO DA AMÉRICA DO SUL}

Os sítios concheiros estão entre as manifestações mais antigas de ocupações litorâneas com economias marítimas nas Américas. No litoral pacífico dos Estados Unidos (Califórnia), existem concheiros a céu aberto e em caverna com idades máximas de até 12 kA (sítios Daisy Cave e Cardwell Bluffs, respectivamente) (Erlandson, 2007; Erlandson et al., 2008; Rick et al., 2001). No Canadá, o concheiro EITa-18 tem cronologia semelhante, datado em 11,6-11,2 kA (Cannon, 2000). Na América do Sul, costa sul do Peru, o concheiro estratificado Ring Site é o mais antigo do continente, datado em 11,2 kA (Sandweiss, 2003). No entanto, as evidências de economias marítimas antecedem estas ocupações em até dois mil anos. Tal é o caso do sítio Arlington Springs, na Califórnia (ilha de Santa Rosa), datado em 13,1 kA (Johnson et al., 2007), o sítio Monte Verde, na costa sul do Chile, datado em 14,6 kA (Dillehay, 1999) e o sítio Quebrada Jaguay, na costa central do Peru, com idade máxima de 13 kA (Sandweiss 2003) (Figura 2.1).

As evidências de ocupações costeiras anteriores ao inicio do Holoceno são usadas para reforçar a hipótese de uma via litorânea de chegada dos primeiros grupos humanos às Américas durante o Pleistoceno (entre 20 e $15 \mathrm{kA}$ ) através da borda do Pacífico (Beck \& Jones, 2010; Dixon, 2001; Erlandson \& Braje, 2011; Erlandson, 2001, 2002, 2007; Erlandson et al., 2007; Fagundes et al., 2008; Fladmark, 1979; González-José et al., 2008; Heusser, 1960; Hubbe et al., 2011; Mandryk et al., 2001; Pitblado, 2011). Uma vez na América do Sul, a migração costeira teria seguido uma rota atlântica e outra pacífica de colonização, com ingresso ao interior do continente pelos vales fluviais que desembocavam no oceano (Dixon, 2001; Hubbe et al., 2011; Miotti \& Salemme, 2004; Miotti, 2003; Neves et al., 2003) (Figura 2.1).

Da suposta rota atlântica, as ocupações litorâneas mais antigas do Brasil podem ser remanentes (ver tópico 3.2.). Os sambaquis mais antigos do litoral brasileiro localizam-se nos estados de São Paulo e Rio de Janeiro. Estes correspondem, respectivamente, aos sambaquis Cambriu Grande, datado em 7,8 kA (Calippo, 2004), e o sambaqui do Algodão, datado em 8,7 kA (Lima et al., 2002 b). No estado de Santa Catarina, o sambaqui mais antigo, o sítio Caipora, está localizado a aproximadamente 
$20 \mathrm{~km}$ da atual linha de costa e foi datado em 7,4 kA (Giannini et al., 2010) (Figura 2.1).

Sambaquis mais antigos ainda se encontram em áreas interioranas associadas a contextos fluviais no estado de São Paulo e na Amazônia. O sítio Capelinha ${ }^{5}$, de pouco mais de 10.000 anos cal. AP é o sambaqui fluvial ${ }^{6}$ mais antigo do vale do rio Ribeira de Iguape (São Paulo) (Neves et al., 2005), enquanto o sambaqui Taperinha é o sambaqui fluvial mais antigo da Amazônia, com cerca de 8000 anos cal. AP (Roosevelt, 1991) (Figura 2.1).

Os concheiros mais austrais do litoral brasileiro encontram-se no Rio Grande do Sul. A sul, com exceção do sítio La Esmeralda, no litoral leste do Uruguai (datado de 3200 anos AP) (Bracco, 1999; Lopez Mazz et al., 1996), sítios concheiros só voltam a se encontrar no trecho no litoral atlântico compreendido entre o sul da província de Buenos Aires e a Terra do Fogo, inclusive. Baixas frequências de restos malacológicos existem em sítios do litoral das províncias de Buenos Aires e La Pampa, mas nenhum destes sítios corresponde a concheiros (Bonomo \& Aguirre, 2009) tais como definidos neste trabalho ${ }^{7}$.

Após os sítios do litoral do Peru e do litoral brasileiro, as cronologias mais antigas para sítios concheiros aparecem na Patagônia argentina, na região do Golfo de São Matias $^{8}$ (Borella \& Favier Dubois, 2008; Favier Dubois et al., 2009; Gomez Otero, 2006; Zubimendi, 2007) e na Patagônia chilena (Flores \& Lira, 2006; Jerardino et al., 1992; Legoupil, 2005; Rivas et al., 1999; San Roman et al., 2009). No litoral atlântico, a ausência de sítios anteriores com traços de adaptações costeiras é associada ao aumento do NRM durante o Holoceno, que teria deixado embaixo da água aqueles sítios localizados próximos às antigas margens ou paleo-desembocaduras dos rios Paraná, Uruguai, Colorado, Negro, Chubut, Deseado, Santa Cruz e Chico, na plataforma

\footnotetext{
${ }^{5} \mathrm{O}$ sítio Capelinha, o mais antigo do litoral sudeste, seria na verdade um sítio raso a céu aberto onde predominam as conchas (DeBlasis, 1988) e não um montículo malacológico estratificado. As particularidades deste sítio também incluem a existência de pelo menos dois componentes ocupacionais (Penin, 2005) e a presença de um indivíduo de morfologia craniana paleoamericana, associado aos indivíduos da região de Lagoa Santa (Neves et al., 2005; Neves \& Okumura, 2005).

${ }^{6}$ A denominação de sambaqui fluvial vincula-se à localização do concheiro nas proximidades de rios e ao conteúdo malacológico no qual predomina a presença de espécies de moluscos terrestres, como Megalobulimus sp. ou Strophocelius sp. (Leonardos, 1938).

${ }^{7}$ Segundo Bonomo \& Aguirre (2009), estes moluscos teriam sido coletados dos cordões litorâneos e a sua presença nos sítios estaria associada a motivos simbólicos e ornamentais, e não ao seu aproveitamento como recurso alimentício ou matéria prima construtiva.

${ }^{8}$ O sítio Arroyo Verde 1, datado de ca. 7750 anos AP, é o concheiro mais antigo da Patagônia (Gomez Otero, 2006)
} 
continental agora submersa (Gomez Otero, 2006; Gomez Otero et al., 1998; Miotti \& Salemme, 2004; Miotti, 2003; Salemme \& Miotti, 2008) (Figura 2.1).

No extremo mais austral do continente, as primeiras evidências do uso de recursos marinhos também antecedem à aparição de concheiros. O sítio Tres Arroyos, datado em ca. $11 \mathrm{kA}$, é a ocupação humana mais antiga da região com restos de moluscos e lobo marinho, apesar de estar fundamentalmente associado a grupos dedicados à caça de mamíferos terrestres (guanaco) e de espécies já extintas (cavalo americano, preguiça gigante, entre outros) (Massone, 1987, 1996). Os concheiros apresentam cronologias levemente mais modernas que os sítios do Brasil e Argentina ${ }^{9}$. Ocampo \& Rivas (2000) dataram um nível de concheiro no litoral sul do Canal Beagle (sítio 136 Áridos Guerrico) localizado a $8 \mathrm{~m}$ sobre o nível do mar, porém próximo à praia, em ca. 7200 anos cal. AP (datação em concha, ca. 6800 AP idade convencional). No litoral norte do Canal Beagle, populações de caçador-coletores construíram o concheiro mais antigo da região, o sítio Túnel I, datado em ca. 6400 anos AP (Orquera et al., 2011) ${ }^{10}$ (Figura 2.1).

\footnotetext{
${ }^{9}$ Os concheiros são posteriores à separação da Terra do Fogo da Patagônia continental, que aconteceu há 8 kA (Clapperton et al., 1995; Coronato et al., 1999; Rabassa et al., 2000).

${ }^{10} \mathrm{O}$ sítio Túnel I também possui um componente pré-concheiro, de ca. 6700 AP, com evidências da exploração de recursos continentais (guanaco) e sem indícios do uso de recursos aquáticos (Orquera and Piana, 1999; Piana and Orquera, 2009).
} 


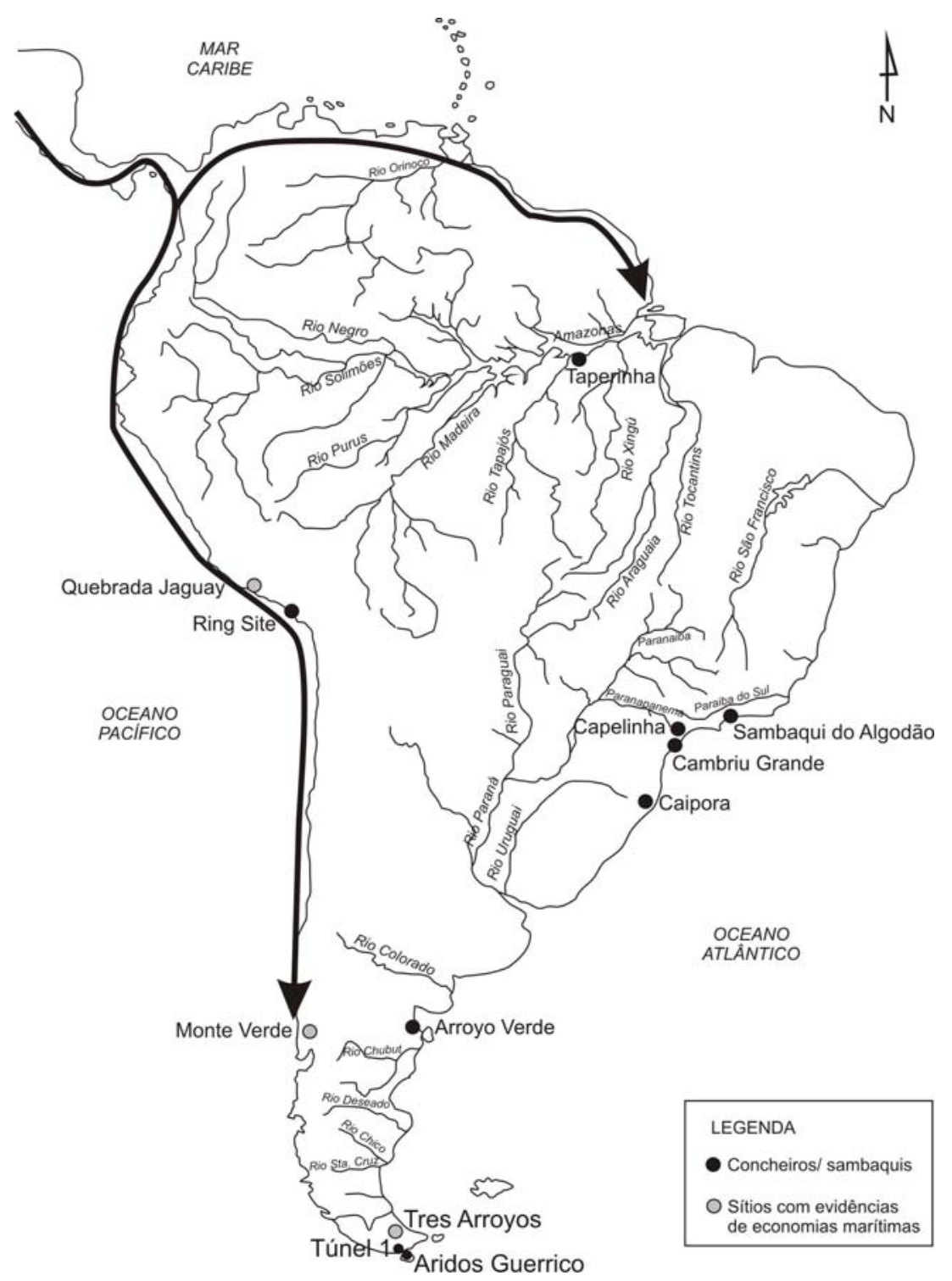

Figura 2.1. Mapa da América do sul com localização dos concheiros/sambaquis mais antigos, e sítios datados da transição Pleistoceno/Holoceno com evidências do uso de recursos aquáticos. As duas flechas indicam possíveis rotas migratórias de colonização das áreas litorâneas do continente.

\section{SAMBAQUIS DO LITORAL BRASILEIRO}

A palavra "sambaqui" está etimologicamente relacionada a duas palavras de origem tupi: "tambá", que significa moluscos, e "qui”, que significa monte (LamingEmperaire, 1975; Prous, 1992). Serrano (1938) menciona que cada autor dá uma interpretação diferente para o vocábulo sambaqui. Por exemplo, Capanema propõe que o término deriva de "hambá-qû̂", molusco esparzido, enquanto Baptista Caetano o 
associa a "h'ambá-kyp", que significa lixo de molusco. Hure, por outro lado, sugere que a palavra resulta da conjunção de "taba" e "quig", que significaria "é aqui a aldeia" (Serrano, 1938).

Independente da sua origem, o termo sambaqui é utilizado desde o século XVI para referir-se aos concheiros antrópicos que se localizam ao longo da costa brasileira (Mendonça de Souza, 1991), desde o Rio Grande do Sul até a Bahia, e do Maranhão ao Pará (Gaspar, 1998). Os sambaquis são frequentemente estratificados, mas não exclusivamente, compostos principalmente por carapaças de moluscos, fragmentos de osso, carvão e sedimentos terrígenos. Em alguns casos, contêm estruturas de habitação11, assim como vários sepultamentos humanos no seu interior, o que levou a sua interpretação como espaços multifuncionais (Gaspar, 1991).

Apesar de estes sítios mostrarem certa diversidade regional, quanto a tamanho, forma e composição, a cultura material dos grupos sambaquieiros permanece constante ao longo da faixa costeira, caracterizada, em termos gerais, por tecnologia lítica e óssea polida (DeBlasis et al., 1998; Tenório, 2004). Da mesma maneira, as práticas de subsistência não apresentam grandes mudanças ao longo do litoral e mostram dependência no consumo de peixes, junto com a exploração de moluscos, vegetais e alguns mamíferos terrestres e marinhos (Bandeira, 1992; Castilho, 2005; Figuti, 1992; Klokler, 2008; Scheel-Ybert et al., 2003; Wesolowski et al., 2007).

A associação entre área de moradia, descarte de alimentos e sepultamentos humanos em sambaquis levou a considerar estes grupos costeiros como único sistema ou unidade cultural ${ }^{12}$, chegado ao litoral por volta de $10.000 \mathrm{AP}$, de grande expansão ao longo da costa brasileira, embora com desenvolvimentos regionais específicos (Gaspar, 1991, 1998, 2000; Tenório, 2004).

As diferenças morfológicas, composicionais e inclusive artefatuais, observadas por trás da aparente homogeneidade dos sambaquis, também foram propostas como evidência de uma multiplicidade de sistemas socioculturais que, vindos do interior em tempos remotos, se expandiram ao longo da costa (Lima, 1991, 1999). Neste sentido, estudos bioantropológicos mostram a homogeneidade genética entre os indivíduos

\footnotetext{
${ }^{11}$ Estruturas de habitação em sambaquis são identificadas a partir da associação entre marcas de poste, superfícies compactadas, estruturas de combustão e artefatos (Gaspar 1991).

${ }^{12}$ A unidade cultural entre os grupos construtores de sambaquis tinha sido sugerida, inicialmente, por Serrano (1946), e posteriormente por Prous (1974), este último a partir do estudo tipológico das esculturas zoomórficas em pedra achadas em vários sambaquis do litoral sul.
} 
sepultados em sambaquis e a diferença entre eles e os esqueletos achados em sítios do interior, inclusive da região de Lagoa Santa, com existência de microdiferenciações regionais na costa (Alvim et al., 1975; Mendonça de Souza, 1995; Neves, 1988; Okumura, 2007; Prous, 1992). Estudos isotópicos recentes, realizados em sambaquieiros do litoral paulista, também identificaram microdiferenciações na costa, explicadas como produto do desenvolvimento local de grupos que, chegados do interior ou do litoral, habitaram a plataforma continental hoje submersa ${ }^{13}$ (Calippo, 2010).

\subsection{A OCUPAÇAO SAMBAQUIEIRA DA COSTA}

Os registros sobre ocupação sambaquieira são mais numerosos nos estados de Santa Catarina (região de Laguna, Florianópolis e Joinville), Paraná (baías de Paranaguá e Guaratuba), São Paulo (Cananéia-Iguape e Santos) e Rio de Janeiro (baía de Guanabara e Região dos Lagos), onde as pesquisas são igualmente mais abundantes. No litoral nordeste e equatorial, a presença de sambaquis é considerável, principalmente nos estados de Pará e Maranhão (Bandeira, 2008; Simões, 1975). Atualmente, propõe-se que teriam existido dois blocos maiores, embora não exclusivos, de desenvolvimento da cultura sambaquieira: 1) Rio de Janeiro, onde os sítios são de mediano porte (até $5 \mathrm{~m}$ de altura) com associação entre áreas de habitação e locais de sepultamento (Barbosa, 2001, 2007; Gaspar, 1991); 2) Santa Catarina, onde os sítios são frequentemente monumentais (mais de $5 \mathrm{~m}$ de altura), com maior quantidade de sepultamentos humanos e presença de zoólitos ${ }^{14}$ (Fish et al., 2000; Gaspar et al., 2008; Gaspar, 1998). Alguns autores propõem que estas duas áreas corresponderiam a dois prováveis eixos, norte e sul respectivamente, de povoamento do litoral brasileiro desde o interior. O local de origem desta leva migratória estaria localizado entre o norte do Estado de Paraná e sul de São Paulo, segundo Neves (1988), ou entre o norte do Estado de Santa Catarina e o sul do Paraná, segundo Oliveira (2000).

\footnotetext{
${ }^{13}$ A hipótese de existência de sambaquis na plataforma continental atlântica que se acha atualmente embaixo das águas oceânicas já tinha sido proposta por Laming (1960) no estudo sobre os sambaquis dos estados de São Paulo e Paraná, assim como por Beltrão \& Kneip (1967) para os sambaquis mais antigos do litoral do Rio de Janeiro, que se encontram hoje total ou parcialmente submersos.

${ }^{14}$ Figuras zoomorfas de pedra polida recuperados em vários sambaquis do litoral meridional do Brasil (e até em sítios no Uruguai).
} 
Estudos craniométricos realizados por Okumura (2007), em sambaquis do litoral do Rio de Janeiro, São Paulo, Paraná e Santa Catarina, reforçaram a hipótese de Schmitz (1981), verificada por Neves (1988), do desenvolvimento de duas populações costeiras, uma ao norte e outra ao sul do Estado de Paraná. Os mesmos ensaios mostram ausência de afinidade genética entre os grupos costeiros (sambaquis) e interioranos (sítios Umbú, Itararé e Tupiguarani) ${ }^{15}$, o que refutaria a origem interiorana das populações costeiras.

Esta constatação respalda a hipótese dos grupos sambaquieiros do litoral atlântico como entidade independente, que não guardaria relação evolutiva, genética nem cultural, com os grupos do planalto. Os sambaquieiros sim estão vinculados com as populações ribeirinhas que exploraram igualmente moluscos, porém terrestres, no começo do Holoceno. Segundo pesquisas recentes, os grupos associados à formação dos sambaquis fluviais do vale do Ribeira de Iguape, apesar de subsistirem de espécies faunísticas e vegetais da Mata Atlântica ${ }^{16}$ e não litorâneas (ver Alves, 2008 e Plens, 2007, para análises zooarqueológicas em sambaquis fluviais), apresentam associação genética (Neves and Okumura, 2005; Okumura, 2007) e cultural com os grupos costeiros.

A relação entre sambaquis litorâneos e fluviais foi explicada por Collet \& Prous (1977) como resultado de intrusões sazonais dos grupos litorâneos até o interior. Uma explicação semelhante foi dada por Barreto (1988), a partir da análise do sistema de assentamento de sambaquis fluviais. A autora propõe que a presença humana no interior do vale do rio Ribeira de Iguape estaria ligada à ocupação prévia do litoral, na região paleoestuarina do vale, e não do planalto. Segundo Barreto (1988), os sambaquis fluviais do Vale do Ribeira apresentam mais vinculação com os sambaquis litorâneos, em termos de tecnologia lítica, óssea, padrão de assentamento e práticas funerárias (com associação entre local de residência e deposição dos mortos) de que com qualquer sítio do interior, inclusive com aqueles que apresentam evidências do consumo de moluscos.

Lima (1999) concorda em colocar a ocupação do Vale do Ribeira como resultado de intrusões oportunistas até o interior de grupos eficientemente adaptados à vida no

\footnotetext{
${ }^{15}$ Os dados craniométricos que trabalha Okumura (2007), a pesar de receber algumas críticas quanto à sua suscetibilidade a variação por fatores ambientais (Churchill, 1996; Lieberman, 2000), são considerados diagnósticos da relação genética entre populações (Sparks and Jantz, 2002).

${ }^{16}$ Bioma que se estende ao longo do litoral atlântico do Brasil e inclui a Floresta Ombrófila Densa, Floresta Ombrófila Mista, Floresta Ombrófila Aberta, Floresta Estacional Semidecidual, Floresta Estacional Decidual, Manguezais e Restingas (www.ibge.gov.br).
} 
litoral. Estas intrusões teriam seguido os vales fluviais que cortam a serra do Mar e atuam como portais naturais que facilitam o deslocamento entre a costa e o interior (Lima, 1999; Lima \& Lopez Mazz, 1999). Uma hipótese semelhante foi proposta por Calippo (2010), que também defende a relação entre sambaquis fluviais e litorâneos do Estado de São Paulo, com uma possível origem comum vinculada à ocupação dos paleovales fluviais e paleoplanícies litorâneas do Pleistoceno. Esta relação original teria desembocado, ao longo do tempo, em uma diferenciação entre os grupos que permaneceram no ambiente fluvial e os que se especializaram no ambiente litorâneo.

\subsection{MODELO DE POVOAMENTO DA COSTA BRASILEIRA}

Contrário ao esperado nos modelos de Neves (1988) e Oliveira (2000), os sambaquis antigos, do início do Holoceno, não se encontram no litoral paranaense, onde a data mais recuada alcança os 6500 anos AP (Garcia 1979 em Brochier, 2009), mas sim nos estados de São Paulo, Rio de Janeiro e Santa Catarina. No entanto, apesar de terem sido prospectados mais de 300 sambaquis no litoral do Paraná, somente 13 possuem datação (Brochier 2009). Assim, as cronologias disponíveis ainda não são

suficientes para contradizer os modelos hipotéticos de povoamento do litoral. Ao mesmo tempo, as pesquisas sobre sambaquis na plataforma continental submersa (ver Calippo 2010), ou sobre sítios soterrados por depósitos holocênicos (ver Brochier 2009), podem ainda trazer ocorrências mais antigas que corroborem, ou refutem, os modelos de dispersão existentes.

A ausência de afinidade biológica demonstrada para indivíduos do interior (sítios com cronologias de 6000 a 1700 anos AP) e litoral (sambaquis), junto com a similaridade entre sambaquis fluviais e litorâneos do Estado de São Paulo (Okumura 2007), afasta a necessidade de explicar o povoamento da costa através de corredores naturais que quebram a barreira imposta pela serra do Mar. De fato, deslocamentos desde a costa até o interior foram propostos para explicar a ocupação do interior norteamericano através dos rios que desembocam no Pacífico (Fix, 2005; Kelly, 2003), assim como para o povoamento da Patagônia a partir de populações que ocuparam, no 
Pleistoceno, as costas pacífica e atlântica da América do Sul (Miotti 2003; Miotti \& Salemme 2004).

Vários indícios já apontam à possível existência de uma antiga via de chegada e ocupação da costa brasileira, de origem exclusivamente litorânea, como, por exemplo: 1) a falta de relações genéticas entre indivíduos do interior e litoral; 2) e o vinculo genético e cultural entre os grupos litorâneos e aqueles que ocuparam um dos corredores mais importantes de comunicação entre o planalto e litoral (os sambaquis fluviais do vale do Ribeira de Iguape). Somado a isso, a lacuna de datas recuadas para o estado do Paraná (suposta via de entrada do interior à costa), apesar de ser potencialmente uma ausência metodológica, como mencionado antes, atualmente apoia a via litorânea de migração. Esta via litorânea poderia estar vinculada com a rota atlântica de colonização da América do Sul (Hubbe et al., 2011; Neves et al., 2003; Rothhammer \& Dillehay, 2009). Os seus remanentes estariam hoje submersos devido ao aumento do NRM durante o Pleistoceno e Holoceno (ver modelo de paleolinhas de costa com áreas potenciais de localização de sambaquis antigos em Calippo 2010). As culturas marítimas que já se encontravam na América há pelo menos $13 \mathrm{kA}$ podem estar relacionadas com os grupos que, no Holoceno inferior e médio, dedicavam-se a exploração intensiva dos recursos costeiros e deixaram os sambaquis que caracterizam o litoral do Brasil.

\subsection{AS CULTURAS MARÍTIMAS DO LITORAL BRASILEIRO}

A arqueologia de sambaquis tem mais de cem anos de vida. Nos últimos vinte anos, as pesquisas concentraram-se em três tipos de estudos (Villagran 2010): 1) sistêmico-funcionais, de influência processual, com foco na investigação de padrão de assentamento, função dos sítios, práticas de subsistência e organização social, entre outros; 2) trabalhos especializados sobre componentes particulares dos sítios, que incluem os estudos bioantropológicos em esqueletos sepultados em sambaquis e os trabalhos da arqueobotânica (antracologia e análise de restos vegetais no cálculo dentário); 3) e trabalhos de influência pós-moderna, que apontam a aspectos simbólicos 
do ritual funerário associado à formação de alguns sambaquis e à percepção da paisagem litorânea por parte dos seus habitantes.

As pesquisas pertencentes ao primeiro grupo produziram informações de base que permitiram caracterizar os grupos costeiros quanto a seu padrão de assentamento, dieta e acervo artefatual. $\mathrm{O}$ assentamento teria sido preferencial em franjas do litoral que incluíram a formação de estuários, baías e sistemas de lagunas costeiras durante sua evolução no Holoceno ${ }^{17}$ (Ab'Saber, 1984; Calippo, 2010; DeBlasis et al., 1998; Figuti, 1993; Fish et al., 2000; Gaspar, 1991; Lima and Lopez Mazz, 1999; Lima, 1999; Prous, 1992). A distribuição dos sítios formaria grupamentos ao redor dos grandes corpos de água, fonte dos recursos alimentícios (Barbosa, 2007; Gaspar, 1991; Kneip, 2004). A ocupação dos sambaquis teria sido continua, sem táticas sazonais de mobilidade ${ }^{18}$, com sítios que serviam de local de residência contínua e outros que eram ocupados como acampamento temporário (De Masi, 1999, 2001). Apesar do volume de moluscos acumulados nos sambaquis, os peixes seriam a principal fonte de proteína para estas populações (Bandeira, 1992; Figuti \& Klokler, 1996; Figuti, 1992, 1993; Klokler, 2001, 2008; De Masi, 1999, 2001), com consumo complementar de espécies vegetais (Boyadjian 2007; Scheel-Ybert et al. 2003, 2009a; Wesolowski 2000; Wesolowski et al. 2007) e consumo ocasional de mamíferos marinhos (focas, golfinhos e baleias) ${ }^{19}$ (Castilho, 2005; Castilho \& Simões-Lopes, 2008; Klokler, 2008; Prous, 1992).

Os conjuntos artefatuais recuperados em sambaquis, como arpões e redes de pesca, confirmam a dependência dos recursos aquáticos ${ }^{20}$ (DeBlasis et al., 1998; Prous,

\footnotetext{
17 Os contextos aquático-costeiros caracterizam-se por grande biodiversidade e disponibilidade de recursos ao longo do ano. Esta perspectiva é utilizada para explicar a ausência de sambaquis em alguns estados do Nordeste brasileiro, como Sergipe. Segundo Amâncio e Dominguez (2003), as características fisiográficas e ecossistemas associados a esta porção da costa brasileira não teriam oferecido contexto propício para o desenvolvimento da cultura sambaquieira, pela impossibilidade geológica de desenvolvimento de sistemas lagunares costeiros. Calippo (2010) oferece uma explicação semelhante para justificar a ausência de sambaquis nos estados de Piauí, Ceará, Rio Grande do Norte, Paraíba e Pernambuco, onde a plataforma continental é estreita e impede a formação de sistemas estuarinos e lagunares. No entanto, sambaquis existem sob dunas eólicas em estados do sul e sudeste e cabe pensar na sua existência sob dunas eólicas nos estados de Piauí, por exemplo, Ceará ou Rio Grande do Norte.

${ }^{18}$ Para os sambaquis fluviais ou concheiros localizados no vale do Ribeira de Iguape, Barreto (1988) mostrou igualmente evidências da permanência ininterrupta do grupo nos sítios, tanto no inverno quanto no verão.

19 Os mamíferos marinhos menores podiam ter sido capturados ocasionalmente nas redes de pesca, enquanto que as baleias encalhavam na praia e eram provavelmente forrageadas in situ (Castilho and Simões-Lopes, 2008).

${ }^{20}$ Associados à tecnologia lítica polida que se encontra em sambaquis, estão os sítios denominados de "estações ou oficinas líticas", lugares onde acontecia a preparação dos instrumentos (Rohr 1984), também chamados de "amoladores polidores fixos" por Tenório (2003). Estes locais aparecem na forma de pequenas bacias (de 20 a $40 \mathrm{~cm}$ de comprimento) em afloramentos rochosos sobre ou próximos ao litoral.
} 
1992; Tiburtius, 1996). A existência de embarcações para deslocamento e pesca foi proposta por Gaspar (1991) e inferida de maneira indireta em vários trabalhos posteriores. As inferências baseiam-se na existência de sambaquis em ilhas, paleoilhas hoje ancorados à terra firme por tômbolos, ou em morros testemunho do embasamento cristalino que antigamente se achavam em meio a grandes corpos de água atualmente assoreados (Amenomori, 2005; Calippo, 2010; Giannini et al., 2010; Nishida, 2001; Prous, 1992; Tenorio, 2003).

Dentro do segundo grupo de pesquisas, estudos bioantropológicos confirmaram a prática cotidiana de pesca e mergulho através de marcadores osteológicos específicos, tanto em homens quanto mulheres (Alvim \& Seyfreth, 1968; Mendonça de Souza, 1995; Neves, 1988; Okumura \& Eggers, 2005; Rodrigues-Carvalho, 2003), junto com evidências de sedentarismo e alta densidade populacional (Alvim \& Gomes, 1989; Mendonça de Souza, 1995; Neves \& Wesolowski, 2002; Okumura \& Eggers, 2005).

Quanto aos padrões de residência, os estudos bioantropológicos mostram duas realidades opostas. Alvim observou uma maior variabilidade em esqueletos femininos, e interpretou esta constatação como evidência de exogâmia com residência patrilocal (casamento fora do grupo e residência do casal na casa do pai do homem). Já o trabalho de Neves (1988) oferece uma interpretação oposta ao basear-se na observação de maior homogeneidade entre os esqueletos de mulheres que de homens. Isto leva o autor a concluir pela existência de um padrão de residência matrilocal entre os sambaquieiros (residência do casal na casa da família da mulher), que reflete a importância das mulheres na sociedade. Prous (1992) coloca esta divergência como sinal dos vários padrões de exogâmia que existiram no litoral. Recentemente, Hubbe et al. (2009) corroboraram a proposta de Neves (1998) a partir de uma amostragem mais extensa que inclui tanto sambaquis, como sítios com cerâmica Taquara/Itararé nos estados de Paraná e Santa Catarina, incluindo também um caso no Rio Grande do Sul.

O terceiro grupo de pesquisas mostra a influência dos ambientes costeiros e seus recursos no ritual e simbolismo funerário dos grupos litorâneos (Gaspar, 2000, 2004; Gaspar et al., 2007; Klokler, 2008). Dentre estes trabalhos, destaca-se uma nova linha de pesquisa que se refere a estudos de gênero. $O$ estudo pioneiro foi realizado por Escórcio \& Gaspar (2010) a partir da análise do mobiliário funerário em homens e mulheres sepultados em sambaquis do litoral do Rio de Janeiro. As autoras indicam a ausência de divisões rígidas entre os gêneros e grande variabilidade nas frequências de 
tipos artefatuais associados a cada gênero. Neste sentido, cabe ressaltar a alta ocorrência de lesões ósseas observada em mulheres enterradas no sambaqui Zé Espinho, litoral do Rio de Janeiro, interpretada como indicador de violência doméstica ou sequestro (Rodrigues-Carvalho et al., 2009).

Estas informações permitem definir os grupos sambaquieiros como culturas marítimas, como estabelecido por Calippo (2010) a partir das propostas de Muckelroy (1978), Adams (2002) e Diegues (2004). Na antropologia marítima ${ }^{21}$, defende-se o particularismo dos pescadores, possuidores de práticas sociais, culturais, rituais e simbólicas construídas a partir da relação profunda com o mar (Diegues 2004). A relação dos sambaquieiros com as fontes de recursos aquáticos (mar, lagunas, estuários) iria além da exploração dos seus componentes bióticos para subsistência do grupo. A exploração dos ambientes litorâneos comportaria uma visão específica do mundo, desenvolvida a partir do vínculo e da "apropriação" não exclusivamente econômica, mas também política, social e simbólica do meio físico e suas particularidades.

\subsection{O COLAPSO DA CULTURA SAMBAQUIEIRA}

Os processos que conduziram ao fim da cultura sambaquieira compreendem uma combinação de fatores ambientais e culturais. Entre os fatores ambientais, propõem-se: o impacto que teve nos bancos de moluscos a mudança na salinidade dos corpos de águas devido às flutuações do nível relativo do mar no Holoceno (Barbosa, 2007; Calippo, 2010; Gaspar et al., 2008; Hurt, 1974); e a predação antrópica dos moluscos, que teria provocado a completa exaustão deste recurso (Hurt 1974; Lima 1999). Os fatores culturais referem-se à migração até o litoral dos grupos ceramistas do tronco linguístico Jê, vindos do planalto há aproximadamente 1500-1000 anos atrás, o que teria provocado a completa desestabilização do sistema sociocultural dos sambaquieiros e posto fim ao projeto de acumulação social de conchas (Barbosa, 2007; Beck, 1972; DeBlasis et al., 2007; Gaspar, 1991; Gaspar et al., 2007, 2008; Hurt, 1974; Lima, 1999;

\footnotetext{
21 "A antropologia Marítima é, hoje um campo de pesquisa especializado de estudo etnológico sobre comunidades que vivem do mar, principalmente da pesca" (Diegues 2004: 53).
} 
Neves, 1988; Schmitz et al., 1993) de modo aparentemente violento e conflituoso (Lessa, 2005; Lessa \& Scherer, 2008).

A relação entre os grupos litorâneos e interioranos pode observar-se nos sítios costeiros com cerâmica Taquara/Itararé2 ${ }^{22}$, definidos nesta tese com "sítios mistos". Estes sítios, datados entre 1500 e 500 AP, apresentam ritual funerário e conteúdo faunístico e artefatual semelhantes aos da cultura sambaquieira, juntamente com cerâmica Taquara/Itararé (por exemplo, camada superficial dos sambaquis Enseada I e Forte Marechal Luz, e sítios Praia das Laranjeiras II, Tapera, Base Aérea e Armação do $\mathrm{Sul}^{23}$ ) (Beck, 1971, 1972; Bryan, 1961; Rohr, 1984; Schmitz et al., 1992, 1993).

Alguns autores propõem que os grupos ceramistas interioranos, possivelmente assimilados com os antigos habitantes da costa, incorporaram parte das práticas e costumes dos sambaquieiros (Schmitz, 1996; Schmitz et al., 1993), e tornaram-se os novos habitantes do litoral até a massiva migração pelo Atlântico dos grupos Tupiguarani. Nesta tese, oferece-se uma visão alternativa do processo de contato entre grupos do interior e do litoral (ver tópico 3.5.3)

\subsection{SAMBAQUIEIROS DO LITORAL E GRUPOS CERAMISTAS DO PLANALTO}

No litoral norte e nordeste do Brasil, as culturas sambaquieiras desenvolveram tecnologias cerâmicas conhecidas como tradição Mina, cuja data máxima é de aproximadamente 5500 anos AP (Bandeira, 2008; Gaspar, 1995; Silva, 2000). No litoral centro-sul e sudeste, estes grupos nunca teriam desenvolvido tecnologias de fabricação de cerâmica. Os únicos vestígios cerâmicos que se recuperam em sambaquis aparecem nos estratos superiores dos montículos e são associados à chegada ao litoral de grupos ceramistas do tronco linguístico Jê, vindos do planalto aproximadamente 1500 a 1000 anos atrás (Beck, 1972; Bryan, 1961; Chmyz, 1976; Deblasis et al., 1998; Gaspar et al., 2008; Lima, 1999; Rohr, 1972, 1984; Schmitz et al., 1993). Alguns autores mencionam

\footnotetext{
22 A cerâmica Taquara/Itararé caracteriza os grupos Jê meridionais (Brochado, 1984; Noelli, 2000; Schmitz, 1988). Estes ceramistas pertencem ao tronco lingüístico Macro-Jê e teriam chegado ao Brasil meridional há pelo menos 3000 anos, desde o planalto central brasileiro (Noelli, 2000; Urban, 1992).

${ }^{23}$ Os indivíduos do sambaqui Forte Marechal Luz são anatomicamente diferentes dos sambaquieiros (Prous 1992), já os indivíduos enterrados em Praia da Laranjeiras II, Tapera, Base Aérea e Armação do Sul não apresenta diferenças morfológicas com os sambaquieiros (Okumura 2007).
} 
a existência de recipientes de argila não cozida, escavadas nas camadas de conchas dos sambaquis, anteriores à aparição de cerâmicas do planalto (Beck, 1972; Bryan, 1961; De Masi, 2001).

Redes de intercâmbio entre planalto e litoral existiram desde antes da influência massiva dos ceramistas de tradição Taquara/Itararé, em Santa Catarina, Paraná e São Paulo (este último com menor frequência de ocorrências), ou tradição Una, no Rio de Janeiro, e posteriormente tradição Tupiguarani em todo o litoral. No Rio de Janeiro, por exemplo, fragmentos de cerâmica Una foram recuperados em sambaquis antes da influência massiva dos Jê. No sambaqui do Moa, encontrou-se cerâmica num nível estratigráfico datado em ca. 3600 anos AP (Kneip, 1994) e na camada superficial do sambaqui da Pontinha, datada em ca. 1790 anos AP (Crancio \& Kneip, 1994) ${ }^{24}$.

Valvas de molusco, dentes de tubarão e restos faunísticos de espécies marinhas recuperaram-se em diversos sítios do interior. Indústria lítica típica do planalto também foi achada em sítios costeiros, como bolas mamilares, pedras geométricas e diversas matérias primas líticas que não afloram no litoral (Barreto, 1988; Batista da Silva et al., 1990; Beck, 1971, 1972; Chmyz, 1976; Dias, 1987; Dias \& Carvalho, 1980; Piazza \& A Prous, 1979; Prous, 1992; Reis, 1980; Schmitz, 1984; Tiburtius et al., 1950). Zoólitos também foram achados em sítios do planalto (Mentz Ribeiro et al., 1977; Prous, 1992; Schmitz, 1984). Outra evidência de contato pretérito entre planalto e litoral está representada pelo achado de grânulos de amido de araucária no cálculo dentário de indivíduos sepultados em sambaquis (Wesolowski et al., 2007).

Segundo o estudo realizado por Okumura (2007), o vínculo interior-litoral teria ficado limitado, durante milênios, a trocas de materiais, contatos sociais e políticos, mas não genéticos, já que análises bioantropológicas mostram não ter existido intercâmbio de indivíduos entre ambas as regiões.

\footnotetext{
${ }^{24}$ Da mesma maneira, dois fragmentos de cerâmica com tempero de concha, típico da região amazônica, foram recuperados em camada de ca. 3200 anos no sambaqui Corondó (Carvalho, 1987).
} 


\subsubsection{Os sítios costeiros com cerâmica Taquara/Itararé}

No Estado de Santa Catarina (e também Paraná ${ }^{25}$ ) existem acampamentos litorâneos com restos de cerâmica de tradição Taquara/Itararé, aqui denominados de "sítios mistos". Estes sítios foram tradicionalmente associados à chegada dos grupos ceramistas que, uma vez na costa, teriam adotado estratégias de captação de recursos que incluíam a pesca e coleta de moluscos (Bandeira, 1999; Batista da Silva et al., 1990; Beck, 1972; Chmyz, 1976; Fossari, 2004; Rohr, 1972b; Schmitz, 1996, 1999c; Schmitz et al., 1993; Uchôa, 1981). A interpretação baseia-se na diferença morfológica e composicional entre sítios mistos e sambaquis, junto com a presença de cerâmica e maior diversidade na indústria óssea que se observa em alguns sítios mistos. No entanto, estudos recentes indicam um panorama algo distinto.

Wesolowski (2000), a partir de análise de marcadores osteológicos, observa padrão típico de grupos caçador-coletores tanto em indivíduos sepultados em sambaquis como em sítios mistos do litoral norte de Santa Catarina. Existiria uma continuidade na dieta dos habitantes da costa, sem adoção da horticultura quando da chegada da tecnologia cerâmica. Isto leva a autora a construir duas hipóteses: 1) que os grupos que ocuparam os sítios mistos não guardariam relação com os grupos do planalto; 2) que os grupos do planalto, horticultores, abandonaram esta prática ao chegar ao litoral.

Análises craniométricas realizadas por Okumura (2007) reafirmam o proposto por Neves (1988) sobre afinidade genética entre indivíduos sepultados em sítios mistos e sambaquis da ilha de Santa Catarina. Os mesmos estudos mostram semelhanças entre séries ceramistas e sambaquis do litoral norte e sul do estado. Já no litoral norte e sul de Santa Catarina, a continuidade genética não é tão clara e a associação entre indivíduos sepultados em sambaquis e sítios mistos é variável (Okumura 2007).

As análises isotópicas realizadas por Bastos (2009) em indivíduos sepultados nos níveis pré-cerâmicos e cerâmicos do sambaqui Forte Marechal Luz (ilha de São Francisco do Sul, SC) indicaram que, do conjunto de 32 indivíduos analisados, unicamente três não eram locais. Dois destes indivíduos alóctones estavam enterrados

\footnotetext{
${ }^{25}$ No estado de Paraná, Rauth (1963) reporta a existência de um sambaqui, o sítio Ilha das Cobras (Baía de Paranaguá) de $70 \mathrm{~cm}$ de altura e $30 \mathrm{~m}$ de cumprimento, com cerâmica Itararé até $20 \mathrm{~cm}$ de profundidade. No sambaqui Ilha das Pedras (Baía de Antonina), Beber (2004) menciona a existência de uma camada preta no topo do sambaqui de 3,5 m de altura, com cerâmica Itararé e Tupiguarani.
} 
no nível cerâmico do sambaqui, e um no nível pré-cerâmico. Os três possuem a mesma procedência interiorana. Estas análises também mostraram leves mudanças no padrão alimentar dos indivíduos enterrados no nível cerâmico do sítio, que Bastos (2009) interpreta como resultado de maior deslocamento até o interior em busca de recursos.

No sítio misto praia da Tapera (ilha de Santa Catarina), frequentemente associado a grupos Itararé (Batista da Silva et al. 1990; Fossari 2004; Schmitz et al. 1993), estudos sobre marcadores de estresse realizados por Scherer et al. (2006) indicam a prática de atividades vinculadas à captação de recursos marinhos (natação, remo, arremesso de redes etc.). Estes mesmos indicadores foram amplamente identificados entre sambaquieiros de Santa Catarina e Rio de Janeiro (ver Mendonça de Souza 1995; Rodrigues-Carvalho 2003).

As evidências indicam continuidade entre os indivíduos sepultados em sambaquis e sítios mistos e apontam a confirmar a primeira das hipóteses propostas por Wesolowski (2000). Assim como observado para os acampamentos litorâneos sem cerâmica, os sítios mistos teriam sido produzidos pela mesma população costeira e não por migrantes ceramistas do interior que velozmente desenvolveram uma vida marítima, como já mencionado por Prous (1992).

\subsubsection{Domínio e miscigenação}

Existem duas diferenças maiores entre sambaquis e sítios mistos: a primeira refere-se ao padrão de residência pós-marital observado em cada tipo de sítio; a segunda, às marcas de violência detectadas nos indivíduos enterrados em sítios mistos.

Hubbe et al. (2009) identificaram que, em vários sítios mistos, entre os quais se incluem o da Tapera e Forte Marechal Luz, discutidos anteriormente, o padrão de residência é patrilocal, em oposição ao padrão matrilocal observado em sambaquis. $O$ novo padrão de residência pode ser interpretado como resultado da chegada de novas populações. No entanto, entre os Jê meridionais do período histórico (Xokleng e Kaigang) menciona-se padrão de residência matrilocal (Urban 1978) e também bilateral (Santos, 1973), este último relacionado à reestruturação, produto das pressões exercidas pela sociedade nacional, como salienta Santos (1973). Portanto, Jê e sambaquieiros podem possuir o mesmo padrão de residência. 
Em indivíduos sepultados em sítios mistos de Santa Catarina detecta-se um aumento nas marcas de violência (Lessa 2005; Lessa \& Scherer 2008). No entanto, estes indivíduos apresentam as mesmas marcas osteológicas de atividade e a mesma dieta que os ocupantes dos sambaquis (Bastos, 2009; Okumura, 2007; Scherer et al., 2006; Wesolowski, 2000).

A mudança observada no padrão de residência é infinitamente mais significativa que a adoção da cerâmica, já que influi em vários aspectos da organização social, política e econômica do grupo. Isto significa que, apesar de predominar a continuidade genética e cultural entre ocupações cerâmicas no litoral e sambaquis, a influência interiorana há 1500-1000 anos foi mais complexa que a simples transmissão de uma inovação tecnológica como a cerâmica. Tal influência teria envolvido mudanças radicas na organização social, intercâmbio de indivíduos, assim como aumento na violência inter e intra-grupal (como mostrado por Lessa, 2005, e Lessa \& Scherer, 2008).

Nesta tese, a partir de uma revisão das pesquisas mais recentes sobre ocupação do planalto e do litoral (principalmente no Estado de Santa Catarina), propõe-se que o crescimento populacional e o poderio alcançado pelas populações do planalto, há 1500 anos, provocou um aumento nas redes de interação entre planalto e litoral (ver Prous 1992). O domínio dos Jê sobre os sambaquieiros, que provocou uma intensa reestruturação e transformação do sistema sociocultural das comunidades litorâneas (ver Gaspar et al. 2007), pode ser uma resposta à pressão exercida pelos Guaranis sobre as populações interioranas (ver Noelli 1999, 2004). Assim, seriam estes indivíduos miscigenados no último milênio, sob o domínio da influência interiorana, os que encontraram os guaranis na costa, e não os descendentes de uma suposta leva migratória de grupos do planalto que se adaptaram rapidamente à vida litorânea há 1500-1000 anos.

\section{A FORMAÇÃO DOS SAMBAQUIS}

Desde o abandono do debate inicial sobre o caráter antrópico ou natural dos sambaquis, a intencionalidade na formação dos sítios tomou o papel principal nas 
discussões científicas. Na década de 1990, vários autores postularam que os sambaquis podem ser considerados como artefatos, por terem sido deliberadamente construídos pelo grupo (Afonso and DeBlasis, 1994; Figuti and Klokler, 1996; Gaspar and DeBlasis, 1992; Gaspar, 1991).

Atualmente considera-se que as conchas que constituem a matriz dos sambaquis teriam sido utilizadas, na sua maioria, como elemento construtivo ${ }^{26}$ que outorga volume às estruturas, utilizadas tanto como local de habitação como de deposição dos mortos (Afonso \& DeBlasis, 1994; Figuti \& Klokler, 1996; Gaspar, 1991, 2004; Gaspar et al., 1994; Gaspar \& DeBlasis, 1992; Klokler, 2001, 2008). A escolha dos locais de coleta das conchas nem sempre estaria associada à proximidade do recurso, senão a preferências culturalmente determinadas (Calippo 2010).

Nos tópicos a seguir, discute-se a construção dos sambaquis como ação mecânica e como elemento simbólico. Apresentam-se os primeiros modelos sobre o processo de formação dos sambaquis como resultado da acumulação de resíduos na periferia de cabanas, do levantamento de plataformas etc. Posteriormente, apresenta-se a arquitetura de sambaquis, como ação simbólica de construção da paisagem a partir da acumulação de conchas. Além dos grandes sítios monumentais, existem sítios menores, tradicionalmente tomados como evidência de intensificação da pesca entre os grupos da costa. No entanto, pesquisas recentes indicam contemporaneidade e concomitância na ocupação de sítios de ambos os portes.

\subsection{MODELOS DE CONSTRUÇÃO}

Diversas hipóteses e modelos foram propostos para explicar o processo de construção dos sambaquis. Em todos os modelos, predomina a visão dicotômica centro vs. periferia como estrutura subjacente à ordenação do espaço nos sítios (Barbosa, 1999; Gaspar et al., 1994). Um deles, elaborado por Tiburtius (1966) a partir de observações realizadas no sítio Conquista 9, perto de Joinville, postula a formação de um anel de detritos periférico sem estratificação interna, que circunda uma área central

\footnotetext{
${ }^{26}$ Ab'Saber \& Bernard (1953) tinham mencionado o uso do berbigão (Anomalocardia brasiliana) como possível material de entulho nos sambaquis de Cananéia, utilizado para completar e aplainar a superfície de cada camada.
} 
caracterizada por uma sucessão de camadas horizontais de ocupação. Uma área de menor altura no anel foi interpretada pelo autor como porta de saída da área central de ocupação. $\mathrm{O}$ mesmo padrão de anel periférico foi observado no sítio Mar Casado, no litoral de São Paulo (Guidon, 1964) e proposto por Laming-Emperaire (1975) como modelo geral de formação de todos os sambaquis. No sambaqui Araújo II, Estado do Paraná, Orssich (1977) igualmente propõe a ocupação cotidiana do centro, onde observa maior concentração de fogueiras, camadas de cinzas e buracos de estaca, com descarte de conchas e demais resíduos até as laterais do sambaqui. Esta dinâmica resultaria na formação de diques ao redor das áreas de habitação que, frequentemente, deviam ser aplainados para obter uma nova superfície de ocupação.

O modelo elaborado por Gaspar \& DeBlasis (1992) segue as diretrizes propostas por Tiburtius (1966) e Orssich (1977) sobre a formação do dique de detritos ou anel de conchas periférico. Os autores propõem o crescimento do sambaqui a partir da construção prévia de uma plataforma, sobre a qual acontecia a acumulação progressiva de restos alimentares depositados na periferia da área central de habitação. $O$ anel de detritos seria eventualmente terraplenado para formar uma nova plataforma aplainada sobre a qual se estabeleceria uma nova área de habitação.

No sambaqui Ilhote do Leste, Tenório et al. (2008) interpretam a mesma oposição centro/periferia a partir da observação de camadas mais espessas na área central do sambaqui. Na porção central do sítio, também se acharam fogueiras cercadas por seixos, interpretados pelas autoras como indicador do local de habitação, além de camadas mais finas com bolsões de conchas esparsos. Resíduos de lascamento foram encontrados unicamente na área periférica. Os autores também interpretam o habito de limpeza e varrido da área de habitação.

No sambaqui Ilha da Boa Vista 4 (Rio de Janeiro), Barbosa (2001) identificou dois espaços principais e subordinados no sambaqui. A proposta da autora, apesar de continuar com a oposição centro vs. periferia, não segue o padrão de anel periférico dos trabalhos anteriores. Um dos espaços identificados está formado por uma área central de ocupação, com maior concentração de artefatos ósseos e malacológicos, etapas de fabricação de artefatos, restos faunísticos, botânicos e humanos. Nesta área, agrupavamse montículos, de 5 a $10 \mathrm{~m}$ de diâmetro, do lado de áreas de habitação (identificadas por pisos de argila). O outro espaço identificado é a periferia, caracterizada por maior ocorrência de refugo de lascamento de quartzo. 
Outro formato de sítio e modelo de crescimento foi proposto por Hurt \& Blasi (1960) para explicar a formação do sambaqui de Macedo, no Paraná. Segundo os autores, os sambaquieiros construíam um monte de conchas sobre o qual habitavam. No entanto, a moradia não teria envolvido cabanas, já que não foram identificados buracos de estaca neste sambaqui, unicamente fogueiras e extensas camadas de cinza e carvão, tomadas como evidência de habitação em supostos abrigos de galhos. O sambaqui estaria assim formado por um conjunto de montículos-habitação arranjados em torno de um espaço central ou praça ${ }^{27}$. Um modelo de formação diferente foi também proposto por Bryan (1993) para o sítio Forte Marechal Luz, na ilha de São Francisco do Sul (SC). Este sambaqui ter-se-ia desenvolvido a partir da ocupação de um degrau natural (possível terraço marinho) e da acumulação subsequente de detritos no sopé do terraço.

\subsection{ARQUITETURA DE SAMBAQUIS}

A arquitetura de sambaquis refere-se tanto ao processo mecânico quanto ao significado da construção dos sítios. O sambaqui, como elemento arquitetônico, é transmissor de significados e expressa os princípios de ordem e classificação que regem o funcionamento da sociedade (ver Fletcher, 1989; Parker Pearson and Richards, 1994). Por isso, a arquitetura de sambaquis discute-se separadamente dos modelos elaborados para explicar a sequência construtiva dos sambaquis como ação mecânica.

O sambaqui com informações mais detalhadas sobre sua arquitetura é o Jabuticabeira 2, localizado no litoral sul de Santa Catarina. Composto por duas camadas estratificadas de espessura métrica (conchífera na base e ictiológica no topo), este sambaqui ofereceu as seguintes informações e interpretações: 1) a construção do sítio seguiu um padrão de levantamento de pequenos montículos funerários, que se superpõem no tempo e no espaço (Bendazzoli, 2007; DeBlasis et al., 1998; Fish et al., 2000; Karl, 2000; Klokler, 2001, 2008; Nishida, 2007); 2) os sepultamentos humanos eram acompanhados por resíduos de festins celebrados em honra aos mortos (Klokler 2001, 2008); 3) a queima de materiais vegetais e faunísticos foi uma prática recorrente

\footnotetext{
${ }^{27}$ As interpretações de Hurt \& Blasi (1960) sobre as estruturas de habitação no sambaqui do Macedo baseiam-se, em grande medida, em comparações com observações etnográficas dos índios Seta (ou Xeta) que ocupam a serra dos Dourados, no Paraná.
} 
(Bianchini, 2008; Klokler, 2008; Nishida, 2007; Villagran, 2008; Villagran et al., 2009, 2010) e algumas espécies vegetais podem ter sido queimadas graças a suas características aromáticas, vinculadas com atividades rituais no sambaqui (Bianchini et al., 2007); 4) os materiais que compõem tanto a camada conchífera como a ictiológica representam uma somatória de episódios de queima, acumulação e descarte de resíduos alimentares para construção dos montículos funerários, através de um processo que expressa a ritualização dos elementos descartados em contexto doméstico ou cerimonial (Villagran, 2008, 2010; Villagran et al., 2009; Villagran et al., 2009a; Villagran et al., 2010).

A partir dos trabalhos desenvolvidos no sítio Jabuticabeira 2 (Santa Catarina), o ritual funerário passou a ser considerado eixo do crescimento dos sambaquis conchíferos e monumentais. Porém, as características funcionais de outros sambaquis e seu significado podem exibir variações intra-sítio ${ }^{28}$ e inter-sítio que merecem estudos mais aprofundados. Principalmente no que refere à categorização dos sambaquis monumentais como espaço exclusivo de funérea ritual, como tinha sido proposto por Wiener (1875) e por Duarte (1968) para os sambaquis com sepultamentos. As evidências de estruturas de habitação em numerosos sambaquis com corpos humanos desde a ilha de Santa Catarina até Rio de Janeiro indicam que ritual e cotidiano de fato teriam ocupado o mesmo espaço físico e simbólico, tanto no sambaqui, como elemento arquitetônico, como nos sambaquieiros, como sistema cultural.

No litoral sul de Santa Catarina, onde não existem evidências claras de áreas de habitação, nem no sambaqui ${ }^{29}$ nem nas suas imediações, a reunião entre o mundo dos mortos e dos vivos poderia ter sido a norma (ver Wesolowsky 2000 para o litoral norte do estado). Jabuticabeira 2 é claramente um sítio funerário (ver Klokler, 2008), mas a sua construção envolveu o remanejamento de resíduos domésticos, para dar volume à estrutura, assim como de restos de festins, para cobrir os corpos. O hábito de acumular e queimar resíduos para posterior deposição no sambaqui, na construção dos montículos funerários, pode ter destruído as evidências dos locais de moradia onde acontecia a

\footnotetext{
${ }^{28}$ Já Gaspar (1991) questionou a suposta homogeneidade horizontal dos sambaquis que tinha conduzido, nas décadas de 70 e 80, à identificação de tradições, fases e subfases dentre os sambaquis do Rio de Janeiro por diversos autores, que basearam a sua tipologia em diferentes áreas escavadas do mesmo sítio. ${ }^{29}$ Castro Faria (1959) menciona evidências da ocupação do sambaqui Cabeçuda como área de habitação, junto com local de sepultamento dos mortos. Hurt (1974) relata o achado de quatro fundos de habitação delimitados por buracos de poste no sítio de Caieira.
} 
acumulação prévia à deposição no sambaqui (Villagran 2008, 2010; Villagran et al. 2009a, 2009b).

\subsection{OS SÍTIOS MENORES}

As evidências de ocupação humana pré-histórica no litoral sul e sudeste do Brasil não se restringem aos sambaquis que até hoje caracterizam a paisagem costeira. Contemporâneo aos sambaquis existe outro tipo de sítio, denominado na bibliografia de "acampamento litorâneo" 30 , formado por acumulações rasas (de menos de $1 \mathrm{~m}$ de altura) e superfície variável (de 200 até $2000 \mathrm{~m}^{2}$ ) de sedimentos finos, frequentemente referidos como "terra preta", ossos de peixe e escasso, senão nulo, conteúdo de conchas de moluscos. As conchas, quando presentes, acontecem na forma de bolsões ou lentes de extensão limitada. Em alguns casos, apresentam cerâmica de tradição Taquara/Itararé e correspondem aos sítios mistos discutidos no tópico 3.5.2.

Este tipo de depósito pode acontecer seja como sítio isolado, seja superposto a sambaquis (Lima 1999; Prous 1992). Encontra-se desde o Rio de Janeiro até o Rio Grande do Sul. No Rio de Janeiro, foram associados à tradição Itaipu ${ }^{31}$ (Dias, 1976; Mendonça de Souza, 1991). Em São Paulo, encontram-se nas ilhas e apresentam associação entre área de moradia e sepultamento dos mortos (Amenomori, 2005; Nishida, 2001). No Paraná, as informações são escassas, mas Bigarella (1950) menciona a existência de duas jazidas paleoetnográficas em terreno de manguezal e de um sambaqui com camada de terra preta acima. Em Santa Catarina os acampamentos litorâneos são abundantes, especialmente na ilha de Santa Catarina e no litoral norte do estado. Apresentam vastas áreas habitacionais, identificadas a partir da associação entre estruturas de combustão (de grande tamanho e rodeadas de seixos), buracos de estaca,

\footnotetext{
${ }^{30}$ Estes sítios também podem ser referidos com o nome de paradero (Serrano), sítio paleoetnográfico (Rohr; Tiburtius), sítios rasos (Chmyz), sambaquis sujos (Garcia; Laming \& Emperaire), acampamentos conchíferos (Prous \& Piazza), concheiros (Barreto) e mesmo como sambaquis (Beck) (Prous 1992). A inerente conotação funcional do termo acampamento, que dá a idéia de ocupação esporádica e de curta duração, pode ser enganosa para se referir às amplas e complexas estruturas habitacionais e funerárias que caracterizam estes depósitos. Neste sentido, Prous (2006) adota a denominação de "sítio de pesca e coleta não construído" para referir-se aos antigos acampamentos litorâneos, embora tal terminologia adicione mais contradições ao termo ao negar a sua construção em oposição à construção dos sambaquis.

${ }^{31}$ Este esquema classificatório apresenta numerosas falhas e encontra-se atualmente em desuso Segundo Gaspar (1991), existem mais semelhanças que diferenças entre os sítios e conjuntos artefatuais da tradição Itaipu e da tradição Macaé, associada aos construtores de sambaquis.
} 
pisos de argila compactada, "fornos polinésios" e artefatual lítico e ósseo. Grandes concentrações de sepultamentos humanos são igualmente comuns (Beck, 1971, 1972; Prous, 1992; Rohr, 1984).

Por serem compostos primordialmente de restos de peixe, os acampamentos litorâneos foram tradicionalmente interpretados como produto de uma mudança na dieta das populações costeiras. Esta mudança teria envolvido a substituição da coleta de moluscos pelo desenvolvimento de pesca especializada, motivada por câmbios ambientais e/ou super-exploração dos bancos de moluscos (Beck, 1972; Lima, 1991, 1999; Mendonça de Souza, 1995; Rohr, 1984; Schmitz et al., 1988; Schmitz et al., 1993). Na mesma linha interpretativa, a nova estratégia de subsistência indicaria a transformação dos coletores de moluscos em grupos mais sedentários, com economia de pesca e organização de tipo tribal (Lima, 1999).

No entanto, estudos zooarqueológicos (Bandeira, 1992; Figuti, 1992; Nishida, 2001, 2007) e isotópicos (De Masi 1999, 2001) demonstraram que a pesca foi a atividade econômica principal tanto em sambaquis como em acampamentos litorâneos, e o consumo de peixe a fonte básica de proteína entre todos os grupos costeiros.

Outro argumento utilizado para admitir a dicotomia sambaqui vs. acampamento era que os acampamentos se encontram sobre dunas e em praias de mar aberto, afastadas das áreas lagunares, local de preferência para a construção de sambaquis (Dias, 1976; Lima, 1999). No entanto, esta aparente diferença na distribuição geográfica pode resultar de um viés de observação e/ou preservação, isto é, a baixa visibilidade dos sítios superficiais e sua suscetibilidade ao preenchimento sedimentar característico das porções do litoral brasileiro submetidas ao efeito das variações do NRM no Holoceno (Brochier, 2009; Giannini et al., 2010). De fato, existem informações sobre sítios sepultados por sedimentos holocênicos no litoral do Paraná ${ }^{32}$. Estes achados permitem cogitar a possibilidade, aventada por Giannini et al. (2010), de sítios assemelháveis aos acampamentos litorâneos terem existido também em áreas mais afastadas da atual linha de costa, associados a sambaquis conchíferos. Pela escassa altura e alta vulnerabilidade

\footnotetext{
${ }^{32}$ No litoral do Paraná, Bigarella encontrou um sítio soterrado por sedimentos holocênicos a pouco mais de $1 \mathrm{~km}$ do sambaqui Matinhos, datado em $2750 \pm 250$ anos AP (Chmyz et al., 2003). Em contexto similar, foi achado outro sítio, nas proximidades de Paranaguá, sobre uma camada compacta, de cor marrom a preta, entre camadas arenosas com estratificações paralelas e cruzadas na barreira pleistocênica (Chmyz, 1975).
} 
dos sítios rasos, se comparados com os grandes e resistentes sambaquis, o seu registro pode ter sido destruído ou estar obliterado pela evolução geológica do litoral.

Nem sequer a cronologia dos sítios pode ser utilizada como argumento favorável à separação entre acampamentos e sambaquis, já que frequentemente se trata de sítios contemporâneos $^{33}$. Além disso, estudos craniométricos mostraram afinidade genética entre os indivíduos sepultados nos acampamentos das ilhas paulistas e nos sambaquis do litoral continental do estado, mesmo padrão observado entre acampamentos na ilha de Santa Catarina e sambaquis continentais (Okumura, 2007). No Estado de São Paulo, a afinidade biológica teria se transformado, com o tempo, em estratégias de subsistência diferenciadas para ocupações em sambaquis e acampamentos, como demonstrado por Calippo (2010) a partir de análises isotópicas.

As evidências parecem confirmar a hipótese de Gaspar (1991) da existência de uma única unidade sócio-cultural na costa, com variações regionais. A associação entre áreas de moradia, descarte de alimentos e enterramento dos mortos que se observa em sambaquis e acampamentos litorâneos, junto com a similaridade nas indústrias líticas, ósseas e malacológicas e afinidade biológica nos indivíduos sepultados em ambos os tipos de sítio, sugere que sambaquis e acampamentos foram produzidos por uma mesma população e que se tratava de realidades coetâneas.

\footnotetext{
${ }^{33}$ O sítio Pântano do Sul, na ilha de Santa Catarina, é um sambaqui que apresenta continuidade lateral com acampamento com sepultamentos e tem idade máxima de $4460 \pm 110$ anos AP (Schmitz \& Bittencourt, 1996b). Também na ilha de Santa Catarina, o sítio Armação do Sul, acampamento précerâmico, foi datado em $2670 \pm 90$ (Schmitz et al., 1992). O sítio Mar Virado, na ilha do mesmo nome no litoral norte de São Paulo, data de $2640 \pm 70$ anos AP (2480-2140 anos cal. AP) (Nishida, 2001). No Rio de Janeiro o sítio Ilha dos Macacos, na margem da laguna de Saquarema, foi datado em $2160 \pm 40$ anos AP (Barbosa, 2007).
} 


\section{CASO DE ESTUDO COMPARATIVO: CONCHEIROS ETNO- HISTÓRICOS DA TERRA DO FOGO}

Concheiros com cronologias que vão dos 6400 anos AP até o período do contato com os europeus caracterizam as costas do Canal Beagle (Terra do Fogo, Argentina). Estes sítios associam-se a populações canoeiras especializadas na exploração de recursos marítimos $^{34}$ (Miotti and Salemme, 2004; Orquera and Piana, 1996 a, 1999 a; Orquera, 2005; Piana and Orquera, 2009; Salemme and Miotti, 2008). Os concheiros fueguinos são rasos, poucos superam o metro de altura, e são geralmente estratificados. Costumam apresentar forma de anel com depressão central, embora também existam concheiros em forma de domo e meia-lua (Orquera and Piana, 1996 a, b, 1992, 1999 a, 2000; Piana and Orquera, 2009; Zangrando et al., 2009) ${ }^{35}$. Em todos os sítios, existem evidências de consumo de pinípedes (lobo marinho) (ver Schiavini, 1993), com exploração complementar de recursos terrestres (guanaco), aves marinhas (pinguim, cormoran e petrel), peixes e moluscos (mexilhão), além de restos de cetáceos.

De acordo com as crônicas etnográficas, no momento de chegada dos europeus (séculos XVII-XVIII) a Terra do Fogo estava ocupada por quatro grupos étnicos principais: Ona ou Selknam; Yahgan ou Yamana; Alakaluf ou Kaweshkar; e Haush ou Manneken ${ }^{36}$. Os Selknam habitavam a região norte da ilha e subsistiam da caça de guanacos das estepes e exploração complementar do litoral. Os Alakaluf habitavam as ilhas ocidentais do arquipélago fueguino e compartilhavam com os Yamana o estilo de vida essencialmente marítimo, apesar de manter diferenças linguísticas. Os Haush

\footnotetext{
${ }^{34}$ Segundo Orquera \& Piana (1999, 2006, 2009), o elemento tecnológico mais destacável desta cultura litorânea foram os arpões com ponta separável, que permitiam a caça de animais a distância, provavelmente desde canoas. Segundo os autores, as culturas marítimas do canal Beagle só se desenvolveram quando a floresta de Nothofagus sp. colonizou a região há 6000-5500 anos AP. Com as matérias primas lenhosas construíram-se as canoas e fabricavam-se os arpões.

${ }^{35}$ Concheiros monticulares, de maior expressão horizontal, aparecem no arquipélago chileno. Na ilha de Chiloé, por exemplo, existem concheiros com até $3 \mathrm{~m}$ de altura e $50 \mathrm{~m}$ de extensão (Legoupil, 2005); inluem, na região de Arica, norte do Chile, concheiros de até $10 \mathrm{~m}$ de altura associados à cultura Chincorro, conhecida por representar as evidências mais antigas de mumificação intencional no mundo (Arriaza et al., 2001).

${ }^{36}$ A subdivisão em grupos étnicos é atualmente questionável. É possível que, por um lado, esses quatro grupos lingüísticos existissem, embora com variantes dialetais dentro de cada um; por outro lado, havia grande permeabillidade e transferência de pessoas entre as diferentes agrupações mencionadas. Estudos cranionmétricos indicaram o vínculo genético entre os Alakaluf, Selknam e Yamana (Cocilovo \& Di Rienzo 1985), com diferenças morfológicas evidentes entre eles no momento da chegada dos europeus à região (Varela et al., 1996).
} 
habitavam a porção sudeste da ilha e teriam subsistido a partir da exploração combinada de espécies terrestres e marítimas. (Bridges, 1885, 1893; Gusinde, 1982, 1986; Hyades and Deniker, 1891; Lothrop, 1928; Martial, 2005).

Os Yamana, que ocupavam as costas do Canal Beagle e ilhas menores do arquipélago chileno e cabo de Hornos, eram grupos canoeiros (ver tópico 5.1) cuja vida e subsistência estava voltada à exploração de recursos aquáticos (mamíferos marinhos, peixes, moluscos e aves), com consumo complementar de guanaco (Estevez and Martinez, 1997; Estevez et al., 1996, 2001; Juan-Muns, 1992; Mameli, 2000). A formação de concheiros era parte da dinâmica de ocupação dos Yamana até tempos históricos. Muitos dos cronistas que visitaram a região associaram estas acumulações de valvas de moluscos com o local de moradia dos indígenas (Bridges, 1975; Darwin, 1839; Spears, 1895; Spegazzini, 1882; Wilkes, 1844).

Os concheiros associados aos grupos yamana estudam-se, desde 1986, sob uma perspectiva que visa confrontar a informação etnográfica com a informação recuperada das escavações arqueológicas ${ }^{37}$ (Estevez and Vila, 1998). O objetivo maior do grupo de pesquisa é estudar os fenômenos sociais a partir do registro arqueológico (Estevez and Vila, 2007; Vila et al., 2006; Vila et al., 2007). Nesta abordagem, etnoarqueologia é entendida como instrumento de desenvolvimento de teoria e método com base na contrastação de métodos e teorias arqueológicas e etnográfico-antropológicas ${ }^{38}$ (Briz, 2004; Estevez and Vila, 1996; Estevez et al., 1998).

Partindo da base de que as atividades humanas se organizam no tempo e no espaço e que seus produtos (o registro arqueológico como resto da atividade social) também são organizados, os concheiros foram escavados em extensão seguindo um método microestratigráfico específico para este tipo de sítio (Estevez \& Vila 2007; Orquera \& Piana 1992; Vila et al. 2007, 2010). Esta estratégia visa mostrar a heterogeneidade dos concheiros para que, a partir do estudo da sua variabilidade interna,

\footnotetext{
37 Terra do Fogo representa um contexto propício para tal finalidade, já que existem documentações etnográficas completas sobre as populações indígenas que ocupavam o território no momento de contato com os europeus, assim como sítios arqueológicos antigos (Estevez and Vila, 2007; Estevez et al., 1998; Estevez, 2009; Vila et al., 2007).

${ }^{38} \mathrm{O}$ primeiro sítio escavado sob a perspectiva etnoarqueológica foi o concheiro Túnel 7, seguido dos sítios Alashawaia e Lanashuaia, todos associados aos grupos Yamana (Estevez and Vila, 1998; Alvarez et al., 2009; Estevez et al., 2001; Piana et al., 2000). Além destes sítios, foram escavados sítios rituais e funerários (Estancia Remolino e Mischiwen III) e sítios domésticos e rituais associados aos grupos Selknam, no litoral norte da Terra do Fogo (sítios Ewan 1 e 2) (Bogdanovic et al., 2009; Camarós et al., 2009; Caruso et al., 2009; Estevez and Vila, 2007; Mansur et al., 2007; Vila et al., 2006 a, 2007, 2004).
} 
entenda-se o sistema econômico e social que produziu o sítio (Estevez 2009; Vila et al. 2010).

Com o auxilio das informações etnográficas disponíveis e da abordagem etnoarqueológica referida, será estudado um concheiro yamana utilizando a mesma abordagem proposta para sambaquis. A possibilidade de estender o método proposto a um contexto no qual o registro sedimentar possa ser relacionado com informações de primeira mão sobre a cotidianidade dos grupos, sempre considerando o viés do registro etnográfico, permite aprofundar a formulação de hipóteses sobre o significado dos processos de deposição antrópicos vinculados com a formação dos concheiros.

\subsection{A INFORMAÇ̃̃O ETNOGRÁFICA SOBRE OS YAMANA}

Os grupos canoeiros do Canal Beagle organizavam-se em famílias nucleares ou em grupos de duas a três famílias que viviam e se deslocavam conjuntamente (Fitz-Roy, 1839; Gusinde, 1951, 1986 a; Lothrop, 1928; Lovisato, 1884; Martial, 2005; Spegazzini, 1882; Wilkes, 1844). A cabana, os alimentos capturados e a canoa eram propriedade da família ou grupo, enquanto o território, seus recursos e as cabanas cerimoniais (enquanto durasse a cerimônia) eram bens comunitários (Gusinde 1986).

Os grupos yamana eram nômades e permaneciam por curtos períodos de tempo, de dias e até semanas, em cada local de acampamento (Fitz-Roy, 1839; Darwin, 1839; Despard, 1863; Hyades \& Deniker, 1891; Martial, 2005; Lothrop, 1928; Gusinde, 1986). Unicamente eventos excepcionais, como o encalhamento de uma baleia na costa ou a realização de cerimônias (chiejaus ou kina) $)^{39}$, motivavam períodos mais prolongados de permanência num local (Gusinde 1986).

\footnotetext{
${ }^{39}$ Chiejaus e Kina referem aos dois tipos de cerimônias realizadas pelos Yamana, a primeira incluía homens e mulheres jovens, enquanto a segunda era somente realizada entre os homens jovens. Durante estas cerimônias, ensinava-se aos jovens o comportamento moral e se lhes instruíam as tradições e tarefas que realizariam quando adultos. As cerimônias reuniam vários grupos (formados por um conjunto de famílias nucleares), celebravam-se em cabanas espacialmente confeccionadas para tal finalidade e duravam até dois meses, ou até que a comida, freqüentemente proveniente de uma baleia encalhada, acabasse (Chapman, 1997).
} 
Os deslocamentos estavam igualmente favorecidos pela posse de canoas (Figura $2.3 \mathrm{~F}$ ), que lhes permitiam navegar longas distâncias até lugares inacessíveis por terra ${ }^{40}$ (Orquera \& Piana 1999b). Por esse motivo, os acampamentos freqüentemente se localizavam na costa (Figura 2.2 A) (Gusinde 1986; Hyades \& Deniker 1891; Lovisato 1884; Martial 2005; Wilkes 1844). No entanto, existem relatos que mencionam a existência de acampamentos yamana longe da costa, em áreas protegidas na beira da floresta (Gusinde 1986; Spegazzini 1882).

Um atributo chamativo das canoas yamana era o transporte de pequenos fogos e brasas que seriam desembarcados no local escolhido para o próximo acampamento. Para isso, construía-se uma pequena plataforma no chão central da canoa com seixos, terra argilosa, areia, conchas moídas e grama compactada (Bridges 1975; Gusinde 1986; Forster 1777; Hyades \& Deniker 1891; Lothrop 1928; Lovisato 1884; Martial 2005; Wilkes 1844). No final do século XIX, as canoas de córtex dos Yamana foram substituídas por canoas monóxilas (feitas com um tronco de árvore) (Gusinde 1986).

Apesar de cobrirem-se com capas de couro de animais para protegerem-se do frio, os Yamana frequentemente andavam nus e/ou cobertos com um pequeno encobre-sexo de couro ou uma pequena capa (Bridges, 1975; Darwin, 1839; Despard, 1863; Fitz-Roy, 1839; Gusinde, 1951, 1986 b; Hyades \& Deniker, 1891; Lothrop, 1928; Lovisato, 1884; Martial, 2005; Wilkes, 1844).

\subsubsection{Os assentamentos domésticos}

A alta mobilidade dos Yamana fazia com que as choças que construíam fossem precárias e pouco duradouras. Elas eram ocupadas por uma ou até três famílias e podiam ser de dois tipos: em forma de domo, de aproximadamente 2,5 $\mathrm{m}$ de diâmetro e 1,7 $\mathrm{m}$ de altura; ou cônicas, com cerca de $3 \mathrm{~m}$ de diâmetro e $2 \mathrm{~m}$ de altura (Orquera \& Piana 1999b). As cabanas possuíam estrutura de madeira e/ou troncos, coberta com folhas, grama, algas, terra, córtex de árvore e couros de animais (Figura $2.2 \mathrm{~B}, \mathrm{C}, \mathrm{E}$ ) (Bridges 1987; Darwin 1839; Despard 1863; Fitz-Roy 1839; Gusinde 1986, 1951;

\footnotetext{
${ }^{40}$ Apesar de a construção e o concerto da canoas serem atividades realizadas pelos homens do grupo, sua condução, guia e remada eram realizada pelas mulheres (Bridges 1987; Despard 1863; Fitz-Roy 1839; Gusinde 1986, 1951; Hyades \& Deniker 1891; Lovisato 1884; Martial 2005; Spears 1895; Weddell 1825; Wilkes 1844).
} 
Hyades \& Deniker 1891; Martial 2005; Lothrop 1928; Lovisato 1884; Spegazzini 1882; Wilkes 1844).

Em ambos os tipos de residência era sempre mantida uma fogueira central como meio de aquecimento (Gusinde 1986, 1951; Hyades \& Deniker 1891; Lovisato 1884; Martial 2005; Wilker 1844), e também algumas fogueiras periféricas para aquecer aos indivíduos que ficassem fora da área central (especialmente as crianças) (Hyades \& Deniker 1891; Martial 2005) e, inclusive, fora da cabana (Gusinde 1986). As fogueiras eram acesas sobre seixos (Lovisato 1884), incluindo conchas (Bridges 1987).

Dentro da cabana, aconteciam todas as atividades cotidianas: dormia-se, comia-se, os homens confeccionavam artefatos em pedra, concha e osso, e as mulheres fabricavam cestos, colares, artefatos em couro, preparavam a comida, limpavam e cuidavam do fogo (Haydes \& Deniker 1891). Apesar de que as gentes yamana costumavam jogar os restos de alimento no fogo, conservavam a carne do lado de fora da cabana (Gusinde 1986). Os métodos utilizados para preparação dos alimentos envolviam o aquecimento diretamente no fogo ou acima das brasas e cinzas ${ }^{41}$ (Bridges, 1885, 1987; Gusinde, 1986 a; Hyades, 1887). A prática de cozimento, especialmente de carne, sobre pedras quentes aquecidas com fogo foi também mencionada por alguns cronistas (Stambuk, 1986), ou colocação direta do animal sobre as brasas (Gusinde 1986). Segundo a maioria dos cronistas, os moluscos eram jogados diretamente ao fogo ou às brasas e cinzas para abrirem-se as valvas e extrair-se a carne ${ }^{42}$ (Fitz-Roy 1839; Gusinde 1986; Martial 2005; Wilkes 1844).

O abandono de uma cabana não envolvia sua destruição intencional (Fitz-Roy 1839; Gusinde 1986; Hyades \& Deniker 1891; Martial 2005), já que freqüentemente a cabana podia ser re-ocupada pelo mesmo grupo familiar ou outro diferente. Em contraste às cabanas de uso doméstico, aquelas construídas para a realização de cerimônias eram propriedade de toda a comunidade e, após a finalização da cerimônia, eram abandonadas e deixadas a deteriorar. As cabanas cerimoniais também diferiam dos assentamentos domésticos em dimensões, já que deviam albergar a vários indivíduos em pé, pelo que podiam chegar a alcançar até $12 \mathrm{~m}$ de comprimento, 3,5 $\mathrm{m}$ de largura e 2,5 m de altura (Gusinde 1986).

\footnotetext{
${ }^{41} \mathrm{O}$ termo utilizado pelos Yamana para se referir à ação de cozinhas sobre as brasas ou cinzas era pushana (Bridges 1933), enquanto o termo pukwia (Bridges 1987) ou puku (Hyades \& Deniker 1891) era usado para se referir a ação de cozinhar em geral.

${ }^{42}$ A palavra köpuku (Bridges 1987) referia ao cozimento dos moluscos.
} 
Nos relatos de vários cronistas, menciona-se que cada cabana ocupada por uma ou várias famílias yamana era acompanhada de um monte de conchas e outros resíduos (Bridges 1975; Despard 1863; Gusinde 1986; Lovisato 1884; Martial 2005; Spears 1895; Spegazzini 1882; Wilkes 1844). Fala-se do fato desta acumulação de detritos ter função de proteção dos fortes ventos do litoral (Bridges 1975; Gusinde 1986; Martial 2005). Os relatos dos cronistas também sempre localizam os conchales ou concheiros ao longo da costa, em enseadas, áreas protegidas do vento e também em locais expostos à ação das ondas, mas nunca no interior (Gusinde 1986; Lovisato 1884). 

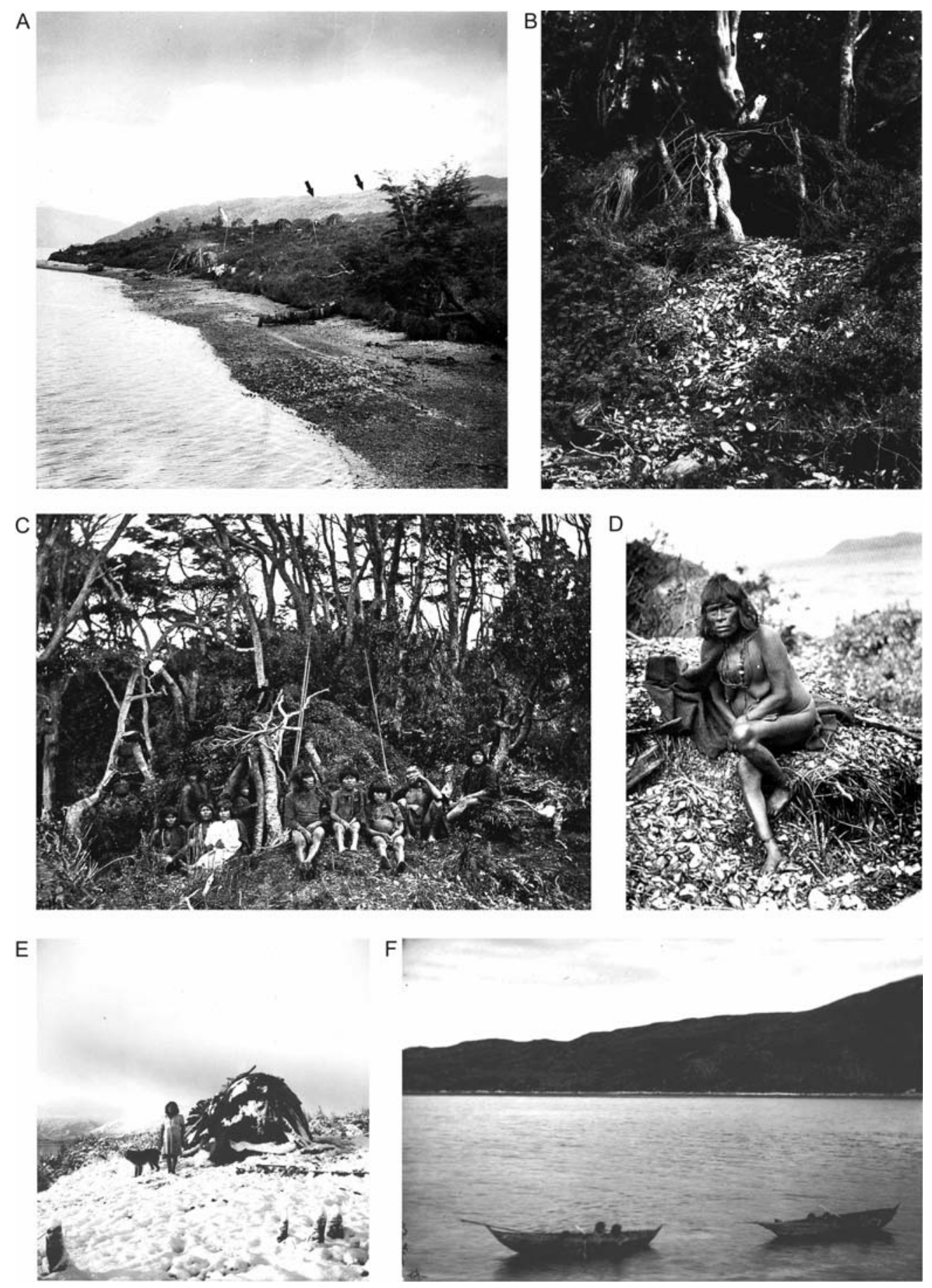

Figura 2.2. Fotografias etnográficas dos Yamana que habitaram as costas do Canal Beagle: A) costa do Canal Beagle, com localização de três cabanas Yamana (indicadas com uma flecha), em fotografia tomada por Greten Motsny; B) cabana Yamana fotografiada pela Mission Scientifique Du Cap Horn em 1882-1883; note-se a acumulação de conchas que conduz à entrada da cabana; C) família Yamana fora da residência (Mission Scientifique Du Cap Horn em 1882-1883); D) Mulher Yamana sentada sobre um concheiro (Mission Scientifique Du Cap Horn em 1882-1883); E) cabana Yamana coberta pela neve com menina e cachorro, fotografia tomada por Greten Motsny; F) canoas nas águas do Canal Beagle (Mission Scientifique Du Cap Horn em 1882-1883). 


\subsubsection{A formação dos concheiros}

Segundo Orquera \& Piana (1999b), o primeiro autor a associar os concheiros que se distribuem ao longo da costa do Canal Beagle com a moradia dos indígenas da região foi Darwin (1839), e os que relacionaram diretamente o material que compõe os concheiros com resíduos de cozinha, especificamente, foram Despard (1863), Spegazzini (1882) e Lothrop (1928). A forma e a localização dos concheiros em relação à cabana de moradia variam segundo os cronistas. Alguns mencionam que a cabana construía-se acima do concheiro (Gusinde 1986; Lovisato 1884); outros, que os concheiros eram pequenos montículos ao lado da entrada da cabana (Martial 2005; Spears 1895; Wilkes 1844); e outros ainda, que se tratava de terraplenos que circundavam a área ocupada pela cabana (Bridges 1975; Despard 1863). As dimensões dos concheiros também variam de acordo com os autores. Fala-se de montículos de até 4,5 m de diâmetro e 3,5 m de altura (Bridges 1975; Gusinde 1986; Lovisato 1884). Gusinde (1986) menciona que a reocupação dos concheiros, pela mesma família ou por outras gerações, fazia com que as suas dimensões aumentassem ano a ano (Figura 2.2 B, D).

A formação dos concheiros é citada como resultado da superposição de estratos compostos dos resíduos alimentícios que eram jogados fora de área de moradia, com predomínio de mexilhão, entre outros bivalves e gastrópodes, e alguns ossos de animais. O próprio Gusinde (1986), ao narrar os achados em concheiros antigos, especifica que todos os restos faunísticos que se recuperam nesses concheiros correspondem ás mesmas espécies das quais os grupos yamana se alimentam atualmente, o que serve para corroborar sua filiação étnica.

A observação dos concheiros antigos também ofereceu descrições de alterações tafonômicas nos concheiros da região. A formação de concreções carbonáticas é mencionada por Gusinde (1986) e Lothrop (1929), ao referirem-se à presença de "capas de brecha" (com 5 a $35 \mathrm{~cm}$ de espessura) próximo à base dos concheiros e até em estratos superiores. Todas as fontes etnográficas mencionam a importância que o consumo de moluscos tinha entre as populações yamana (Orquera \& Piana, 1999 b; Orquera, 1999), especialmente da espécie Mytilus edulis (Linneaus) (popularmente conhecido como mejillón, em Espanhol, ou mexilhão, em Português), muito freqüente nas costas do Canal Beagle. Estimativas realizadas por Segers (1908), que trabalhou 
como médico em Ushuaia entre 1886 e 1889, indicam um consumo médio diária 8 a 10 $\mathrm{kg}$ de Mytilus por indivíduo yamana.

Esta visão levou a interpretar que tanto a localização da área de residência, como a grande mobilidade dos grupos, estavam motivados pela continua procura de novos bancos de moluscos após o esgotamento daqueles já explorados (Lovisato 1884; Martial 2005; Wilkes 1844). No entanto, outros autores sugerem que não seria o esgotamento em si que motivaria o deslocamento, senão a intenção de impedir a sobre-exploração dos bancos (Steager, 1965). Segundo Gusinde (1986), a presença de bancos de moluscos não teria sido definitiva na escolha do local de acampamento e muitas vezes os grupos yamana podiam percorrer grandes distâncias em busca de moluscos.

Apesar da maioria dos cronistas relatarem o papel primordial dos moluscos na alimentação das populações costeiras, a exploração deste recurso devia ter atuado como complemento na dieta e/ou como recurso de fácil captura em tempos de escassez (Orquera 1999; Orquera \& Piana 1999b, 2001). Além disso, tanto o material faunístico recuperado dos concheiros do período histórico, associados às populações yamana, como as análises isotópicas realizadas em ossos de indígenas da região, apontam ao consumo primordial de mamíferos marinhos e guanaco (Estevez et al., 2001; Mameli and Estevez, 2004; Orquera \& Piana, 2000; Orquera, 1999; Panarello et al., 2006; Yesner et al., 2003).

A grande maioria dos cronistas relata que a coleta de moluscos era exclusivamente realizada pelas mulheres do grupo, acompanhadas às vezes pelas crianças (Fitz-Roy, 1839; Gusinde, 1986 b; Hyades \& Deniker, 1891; Hyades, 1885, 1887; Martial, 2005; Spears, 1895; Weddell, 1825).

Enterramentos humanos em concheiros não eram frequentes entre os grupos yamana, apesar de que alguns cronistas falam desta prática. Segundo Hyades \& Deniker (1891), o defunto era enterrado no concheiro na entrada da cabana; já Martial (2005) descreve que o defunto ea enterrado onde finalizava o montículo de conchas. E, de acordo com Koppers (1997), somente as crianças eram enterradas nos concheiros.

No geral, os grupos yamana praticavam a cremação dos corpos na cabana ou no interior da floresta, nunca sobre a praia (Bridges, 1975, 1886; Despard, 1863; Gusinde, 1986 a; Hyades \& Deniker, 1891; Lovisato, 1884; Spegazzini, 1882), mas este costume não teria perdurado após o contato com os europeus (Orquera \& Piana 1999b). Como afirmaram Lovisato (1884) e Koppers (1997), antigamente todos os corpos eram 
cremados; o hábito de enterrá-los em fossas de pequena profundidade teria começado somente após a chegada dos missioneiros anglicanos. No entanto, também existem relatos que mencionam a prática do enterramento de indivíduos adultos, mulheres e crianças na própria cabana de moradia, no concheiro, fora da área de residência, em pequenas ilhas, em cavernas, ou em bancos de areia (Bridges 1886; Despard 1863; FitzRoy 1839; Gusinde 1951, 1986; Martial 2005; Lothrop 1928; Lovisato 1884; Spegazzini 1882).

No entanto, na Terra do Fogo e ilhas do arquipélago do Cabo de Hornos as evidências arqueologias mostram sepultamentos humanos em concheiros e em afloramentos rochosos próximos a $\operatorname{concheiros}^{43}$ (Alvarez et al., 2008; Piana et al., 2006). Na síntese realizada por Piana et al. (2006), mencionam-se achados de sepultamentos humanos em concheiros na Ilha Navarino (Spencer 1951; Ocampo et al. 2001 em Piana et al. 2006), nas ilhas Wollaston e Bayly (Cabo de Hornos) (Legoupil, 1993), em três concheiros no Canal Beagle (sítios Shamakush I, Shamakush X e Acatushún), assim como dois enterramentos em abrigo rochoso que estavam cobertos por camada de conchas. Em todos os casos trata-se de enterramentos em posição primária. A estes casos soma-se o esqueleto de uma criança achado no sítio Ajej I (Piana et al., 2007, 2000, 2008; Piana \& Vazquez, 2009) e os o esqueleto recuperado no sítio Harberton (Piana and Vazquez, 2008; Vila, comunicação pessoal). Na costa noroeste e nordeste da ilha, foram achados sepultamentos em 2 concheiros rasos compostos de Mytilus edulis: o sítio Marazzi 1 (6170 \pm 50$)$, no litoral da Baía Inútil que contém uma cremação parcial; e Laguna Arcillosa 2 (5508 \pm 48$)$ na costa Atlântica (Morello et al. 2012; Salemme \& Bujalesky 2000; Salemme et al. 2007).

\section{SUMÁRIO}

Sítios concheiros, a exemplo dos sambaquis brasileiros, aparecem desde o Pleistoceno Superior. Nas Américas, as economias marítimas surgem durante a

\footnotetext{
${ }^{43} \mathrm{Na}$ ilha de Chiloé também se recuperaram ossos humanos de um concheiro (sítio Yaldad 2) datado de ca. 5900 anos AP (Legoupil, 2005).
} 
transição Pleistoceno-Holoceno e incluem, dentre os seus remanentes, concheiros rasos, a céu aberto e em cavernas, localizados no litoral pacifico do continente. No Brasil, os primeiros sambaquis aparecem há cerca de 10.000 anos em áreas interioranas dos estados de São Paulo e Amazônia. No litoral atlântico, as ocupações mais antigas não ultrapassam os 8000 anos AP e encontram-se nos estados de Rio de Janeiro, São Paulo e Santa Catarina.

Os grupos associados aos sambaquis brasileiros eram, desde o primeiro momento de ocupação do litoral até o abandono da prática social de acumulação de conchas, culturas marítimas. A evidência arqueológica mostra que estes grupos possuíam práticas sociais, culturais, rituais e simbólicas, elaboradas a partir da relação profunda com os ambientes aquáticos (mar, estuários e lagoas). Além dos grandes sambaquis de composição essencialmente conchífera, outros tipos de sítios estão associados às culturas litorâneas. Tradicionalmente concebidos como resultado de mudanças nas estratégias de subsistência, estes sítios, de menores dimensões e conteúdo malacológico desprezível, integravam o sistema de assentamento sambaquieiro.

Vários modelos foram propostos para explicar o crescimento dos sambaquis, a partir de exemplos que se fundamentam na dicotomia entre área central de ocupação e área periférica de descarte de resíduos. Nestes modelos, explica-se a ação mecânica, produto da organização social do espaço, que ao longo do tempo teria resultado na configuração atual dos sítios. A arquitetura de sambaquis, pelo contrário, deriva da interpretação dos processos de formação dos sambaquis como elementos que simbolizam e determinam a percepção do ambiente pelas comunidades litorâneas.

$\mathrm{Na}$ construção de modelos interpretativos que ajudem a explicar as sucessões verticais nos sambaquis, será utilizada a analogia arqueológica intercultural com um grupo conhecido etnograficamente. Os grupos yamana da Terra do Fogo formavam concheiros nos assentamentos domésticos, na forma de anel periférico à área central de moradia. A partir de uma perspectiva etnoarqueológica que examine as informações etnográficas em contraste com o registro arqueológico, propõe-se estudar um concheiro yamana com os mesmos métodos utilizados para sambaquis. A correspondência nos métodos aplicados a ambos os tipos de sítio habilitará a comparação intercultural e o uso de informações derivadas da análise do concheiro etno-histórico na formulação de hipótese sobre o significado da construção dos sambaquis. 


\section{CAPÍTULO 3: SAMBAQUIS DO LITORAL SUL CATARINENSE}

\section{INTRODUÇÃO}

No litoral do Estado de Santa Catarina, onde se encontram os sambaquis mais volumosos do Brasil, as características da ocupação sambaquieira não foram homogêneas. Por exemplo, na costa norte (região de Joinville) e centro do estado (ilha de Santa Catarina), os sítios são menores, com alturas que não ultrapassam $5 \mathrm{~m}$, e apresentam associação entre áreas de moradia e de sepultamento (Afonso \& DeBlasis, 1994; De Masi, 1999, 2001; Schmitz \& Bittencourt, 1996). Já no litoral sul, área de estudo desta pesquisa, destaca-se a conspicuidade dos sítios, com dimensões que atingem atualmente os $30 \mathrm{~m}$ de altura e $500 \mathrm{~m}$ de cumprimento, bem como a alta freqüência de sepultamentos humanos (Beck, 1971; Carvalho \& Seyfreth, 1971; DeBlasis et al., 1998; Fish et al., 2000; Hurt, 1974) (Figura 3.1).

Porém, dentro da própria área de localização dos sítios monumentais, existe uma variedade de sítios menores (menos de $5 \mathrm{~m}$ de altura), também categorizadas como sambaquis, que receberam menos atenção nas pesquisas. Estes sítios pequenos estão sendo recentemente revalorizados como satélites aos sambaquis monumentais e com funções específicas, embora ainda não completamente elucidadas (Assunçao, 2010; Klokler et al., 2011; Peixoto, 2008).

Um caso que merece ser mencionado é o do sambaqui Encantada 3, cujo reduzido tamanho (menos de $1,5 \mathrm{~m}$ de altura) e estratigrafia composta por núcleo arenoso e camada superficial de conchas com sedimentos pretos (Klokler et al., 2011; Peixoto, 2008) teriam conduzido, no esquema tradicional, à sua colocação na categoria de acampamento litorâneo ${ }^{44}$ (ver Capítulo 2, tópico 4.3). No entanto, a sua datação recuada, de 5265-4835 anos cal. AP (Giannini et al. 2010) e a localização nas

\footnotetext{
${ }^{44}$ Sítios rasos sem cerâmica, formados por camadas pretas de areia com conchas, aparecem também no litoral central do Rio Grande do Sul. Estes sítios são freqüentemente interpretados como assentamentos ceramistas Tupiguarani (Rogge, 2006), apesar de muitas vezes não conterem nenhum resto cerâmico nem datação que confirme a associação étnica. Estes sítios poderiam ser semelhantes, em forma e composição, ao Encantada 3, no litoral sul de Santa Catarina, apesar de serem mais recentes. Um dos sítios rasos do Rio Grande do Sul apresenta uma ocupação pré-cerâmica que foi datada em $2170 \pm 70$ AP (Rogge 2006).
} 
proximidades de sambaquis maiores permitem integrá-lo ao sistema sambaquieiro de ocupação da costa (ver Peixoto 2008).

Segundo Kneip (2004) e DeBlasis et al. (2007), as lagunas costeiras que caracterizam a região funcionaram como epicentro da distribuição dos sambaquis e provavelmente atuaram como referência essencial no assentamento das comunidades. A escolha do local de implantação dos sambaquis estaria influenciada pela visibilidade aos grandes corpos de água, que atuavam como fonte de recursos protéicos (peixes) e de matéria prima construtiva (conchas).

No estudo realizado por Giannini et al. (2010), identificou-se a clara preferência destas comunidades em se estabelecer em locais secos e protegidos das inundações periódicas $^{45}$. Entre estes locais de assentamento, incluíam-se, além das margens lagunares, pontais rochosos (de mar aberto e entre a planície lagunar), paleodunas eólicas e paleotômbolos de retrobarreira (que se desenvolvem à retaguarda dos pontões rochosos). Pela demonstrada preferência de estabelecimento dos sambaquis em locais secos, os autores respaldam a hipótese de que o crescimento vertical dos sítios não estaria guiado pela elevação de uma plataforma para proteção da ação destrutiva das águas, como pode ter acontecido em outras áreas litorâneas, senão como estratégia de construção da paisagem (DeBlasis et al. 2007; Fish et al. 2000; Gaspar 1998, 2004).

Pesquisas arqueológicas na área de estudo desta tese focalizaram na localização de sambaquis e no estabelecimento de cronologias de ocupação, a partir de amostras datadas do topo e da base dos montículos ${ }^{46}$. A robusta cronologia construída mostrou que a ocupação da área teria começado em cerca de 7500 AP e perdurado por aproximadamente 6000 anos (DeBlasis et al. 2007; Giannini et al. 2010).

Giannini et al. (2010) advertem para o fato de que as cronologias de ocupação devem ser tomadas como evidência parcial, por três motivos: 1) sítios mais antigos, anteriores ao máximo transgressivo (atingido na região entre 5700-5100 anos AP, segundo Angulo et al., 1999, 2006), podem ter sido afogados pelo mar ou laguna e

\footnotetext{
${ }^{45}$ Guerra (1953) estabelecia que a ocupação acontecia em zonas emersas e locais protegidos das águas.

${ }^{46}$ As pesquisas recentes sobre sambaquis do litoral sul do estado de Santa Catarina incluem o "Projeto Arqueológico do Camacho" (FAPESP processo 97/03831-6, Wenner-Gren Foundation, Heinz Foundation, University of Arizona, Museu Nacional UFRJ e CNPq), o auxílio à pesquisa "Processos formativos nos sambaquis do Camacho, SC: padrões funerários e atividades cotidianas" (FAPESP, processo 03/02059-0) e o projeto temático "Sambaquis e paisagem: modelando a inter-relação entre processos formativos culturais e naturais no litoral sul de Santa Catarina" (FAPESP, processo 04/11038-0); este último coordenado pelos Profs. Drs. Paulo DeBlasis (Museu de Arqueologia e Etnologia MAE/USP), Madu Gaspar (Museu Nacional MN/UFRJ) e Paulo C.F. Giannini (Instituto de Geociências IGc/USP).
} 
posteriormente recobertos pelo assoreamento da região após a descida do NRM; 2) pela intensa mineração que os sambaquis sofreram durante as décadas de 1950 e 60, o nível superior atual do sambaqui, tomado como data final da sua formação, pode representar um momento intermediário na sua formação, exposto pela atividade mineradora; 3) no caso dos sambaquis maiores, a sua formação a partir da disposição de pequenos montículos concomitantes e justapostos sugere que amostras da base do sítio podem não representar o início da formação do sambaqui como um todo, e sim desse montículo particular.

No litoral sul de Santa Catarina, poucos sítios foram escavados e o único sambaqui que foi objeto de escavações parciais, mas sistemáticas, foi o Jabuticabeira 2. Os estudos multidisciplinares realizados neste sambaqui permitiram interpretar $\mathrm{o}$ processo e significado da sua formação (Bendazzoli, 2007; DeBlasis et al., 1998; Fish et al., 2000; Karl, 2000; Klokler, 2001, 2008; Nishida, 2007; Villagran, 2008, 2010; Villagran et al., 2010) (ver capítulo 2, tópico 5.2), assim como inferir sobre dieta, patologias e relações genéticas entre os indivíduos nele sepultados (Bartolomucci, 2006; Boyadjian, 2007; Filippini and Eggers, 2005; Filippini, 2004; Klokler, 2001, 2008; Nishida, 2007; Okumura and Eggers, 2005; Petronilho, 2005; Storto et al., 1999). 

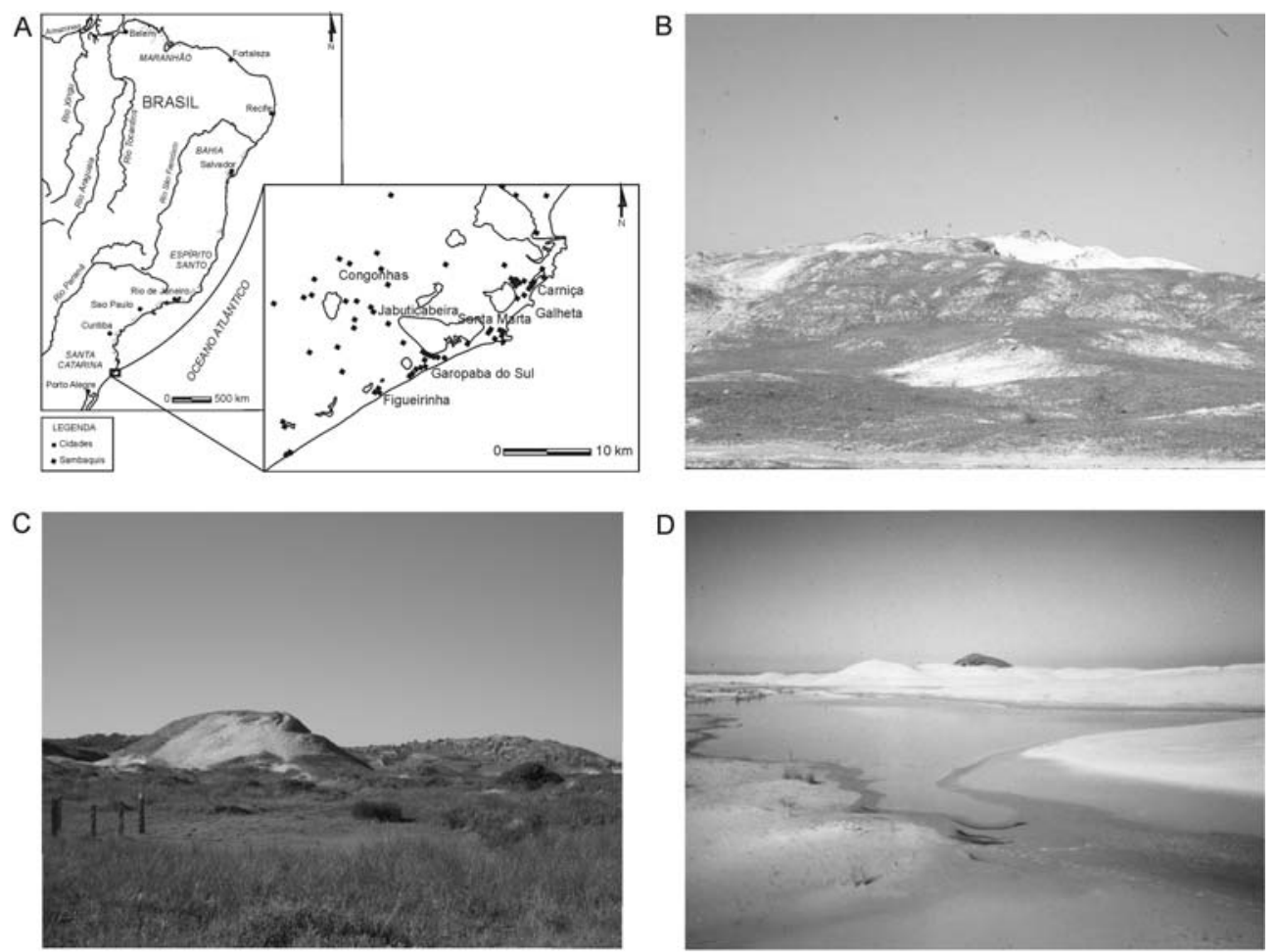

E
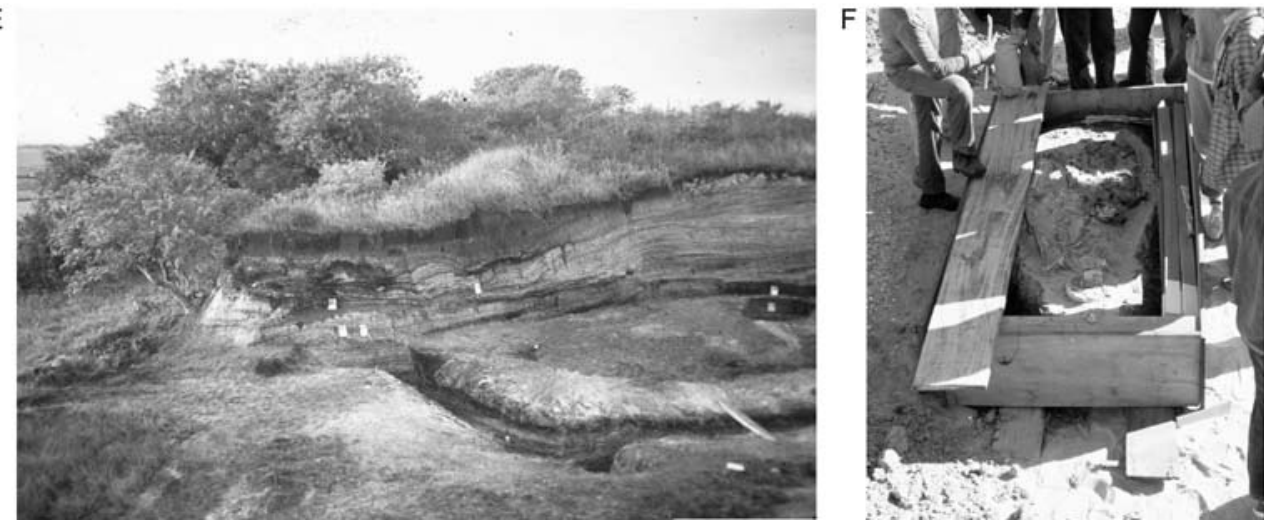

Figura 3.1. Sambaquis do litoral sul catarinense: A) mapa de localização da área de estudo; B) sambaqui Garopaba do Sul, o maior sambaqui que existe atualmente na região; C) sambaqui do Ipoã; D) sambaquis de Encantada; E) sambaqui de Jabuticabeira 2; F) retirada de sepultamento humano do sambaqui Garopaba do Sul (B, D e E: fotografias de Paulo Giannini; F: fotografia de Armando Coimbra). 


\section{UMA PAISAGEM HISTÓRICA}

A evolução geológica do litoral catarinense durante o Holoceno teve uma influência marcante, porém não determinante, nas mudanças observadas no registro arqueológico quanto à escolha do local de levantamento dos sítios. A preferência por assentamentos próximos às margens lagunares, fonte de recursos protéicos e matéria prima construtiva, foi constante durante os quase 6000 anos de ocupação da área. Para entender detalhadamente a relação entre evolução geológica e ocupação humana apresenta-se, nos tópicos a seguir, o modelo de evolução holocênica da área de estudo e as quatro fases de ocupação humana, identificadas a partir da datações de topo e base de 48 sambaquis da região.

\subsection{EVOLUÇÃO HOLOCÊNICA DO LITORAL}

A área de estudo deste trabalho abrange parte dos municípios de Laguna e Jaguaruna. Esta faixa do litoral centro-sul catarinense, no trecho que vai desde Jaguaruna até Garopaba, apresenta quatro grandes sistemas deposicionais quaternários definidos por Giannini (1993, 2002) como: lagunar, barra-barreira, planície costeira e eólico $^{47}$ (Figura 3.2). O sistema lagunar holocênico envolve as lagunas Mirim, Imaruí, Santo Antônio, Santa Marta, Camacho e Garopaba do Sul, todas intercomunicáveis entre si e com o mar, assim como um conjunto de lagos residuais de antigas lagunas. Este sistema foi produto da ação de dois processos mais ou menos simultâneos, resultantes das mudanças no NRM, cujo máximo na região data de mais de 5700 anos AP (Angulo et al., 1999, 2006). Estes processos consistem no crescimento de uma barreira arenosa, com isolamento parcial dos corpos de água à retaguarda, e no afogamento de vales de dissecação previamente escavados em terraços marinhos

\footnotetext{
${ }^{47}$ Segundo (Hesp et al., 2009), existiriam apenas dois sistemas deposicionais holocênicos na região: planícies de cordões; e barreiras holocênicas que inclui tanto ás lagunas como os depósitos eólicos. No entanto, Tanaka et al. (Tanaka et al., 2009) ressaltam que lagunas e depósitos eólicos não estão exclusivamente relacionados ao sistema barreira e seriam, portanto, sistemas deposicionais independentes.
} 
pleistocênicos. Tal distinção permite a diferenciação entre dois tipos de associações de fácies lagunares, a "baía-laguna" (Santa Marta, Camacho e Garopaba do Sul) e a "valelaguna" (Garopaba, Ibiraquera, Mirim e Imaruí), respectivamente (Giannini 1993, 2002).

A baía-laguna constitui a baía receptora principal do delta do rio Tubarão, o qual, por volta de 5000 anos atrás, ingressou na antiga baía lagunar e ramificou-se em sete distributários principais. A progradação do delta provocou a fragmentação da baía lagunar em lagos e lagunas menores, em cujas margens ergueram-se grande parte dos sambaquis que ainda se preservam na região (Nascimento, 2010). A porção vale-laguna do sistema lagunar envolve as lagoas a norte da Passagem da Barra (Santo Antônio, Imaruí e Mirim) e os atuais vales de inundação dos rios Sangão e Riachinho. O estudo sedimentológico e micropaleontológico de amostras provenientes dos rios Sangão e Riachinho indicam que a desconexão final da laguna com o oceano ocorreu entre ca. 2700-2300 anos AP (Amaral, 2008; Amaral et al., 2012).

O sistema barra-barreira (Giannini 1993, 2002), ou simplesmente barreira (Giannini et al. 2007), com mais de $20 \mathrm{~km}$ de comprimento e até $2 \mathrm{~km}$ de largura, constitui-se de sedimentos arenosos holocênicos depositados sob a ação das ondas, que isolaram atrás de si o complexo de lagunas anteriormente mencionado. Este sistema estende-se de Jaguaruna até Laguna. No sistema retrobarreria adjacente, foram identificadas três fases evolutivas: fase 1, anterior ao máximo transgressivo holocênico, com predomínio da dinâmica sedimentar marinha; fase 2, entre cerca de 5500 e 3000 anos AP, caracterizada pelo progressivo declínio do NRM, aporte sedimentar terrestre e redução da influência das águas marinhas; e fase 3, de 3000 AP até o presente, com o fechamento da desembocadura lagunar e formação de áreas de marismas e pântanos sobre a margem da retrobarreira (Fornari, 2010).

O sistema planície costeira, que apresenta na região pelo menos duas gerações, uma pleistocênica e outra holocênica, diferencia-se por não estar associado geneticamente a corpos lagunares adjacentes e por poder apresentar alinhamentos de cordões litorâneos (Giannini 1993, 2002). Exemplo disso são os cordões litorâneos que ocorrem na planície do Ji, imediatamente a norte de Laguna (Giannini 1993, 2002; Tanaka, 2010). Cordões regressivos ocorrem também dentro do sistema lagunar, na região situada entre as desembocaduras das lagunas de Santa Marta e Santo Antônio, local conhecido como planície de Campos Verdes (Giannini 1993). Estes cordões, de 
posição transversal à atual linha de costa, representam o crescimento progradacional da planície sentido NW. Este crescimento teria sido a partir do paleopontal lagunar situado na margem NE da laguna de Santa Marta, pela ação de ondas na região de paleodesembocadura lagunar (Tanaka, 2007, 2010; Tanaka et al., 2009).

O sistema eólico, o de maior extensão, superpõe-se aos sistemas barreira, planície costeira e lagunar e divide-se em quatro gerações de depósitos eólicos denominadas gerações 1, 2, 3 e 4, em ordem de idade decrescente. A geração eólica 1 é seguramente pré-último máximo glacial e, pelo menos em parte, anterior a última máxima inundação do Pleistoceno, a 2 é essencialmente anterior à máxima inundação holocênica, a 3 foi formada quase inteiramente nos últimos três milênios e a 4 corresponde às dunas ativas 48 (Giannini, 1993, 2002; Giannini et al., 2007; Giannini \& Suguio, 1994; Martinho, 2004; Sawakuchi, 2003).

O estudo polínico realizado por Amaral (2008) e Amaral et al. (2012) em testemunhos coletados da região de Jaguaruna indicou que, pelo menos nos últimos 4000 anos, o clima era semelhante ao atual, sem registro de mudanças na vegetação. Desde o Holoceno Médio-Tardío, a região apresenta vegetação aberta com predomínio de Poaceae, do tipo característico de áreas de pântano e margem lagunar, e vegetação arbórea/arbustiva de mata de restinga (Amaral, 2008; Amaral et al., 2012). Estudos isotópicos na matéria orgânica em amostras de região, comparados com modelos propostos para outras áreas do Estado de Santa Catarina (Cruz et al., 2006; Wang et al., 2006), indicam a mudança de condições mais secas no começo do Holoceno, até condições mais úmidas no Holoceno Médio, até o momento atual, com dois períodos maiores de aumento da paleoprecipitação (Amaral, 2008; Amaral et al., 2012; Nascimento, 2010).

\footnotetext{
${ }^{48}$ Giannini et al. $(2007,2001)$ e Sawakuchi (2003) agruparam as gerações eólicas em duas seqüências deposicionais: uma mais antiga (seqüência $\mathrm{A}$ ) compreendendo a geração eólica 1, e outra mais recente (seqüência B) abrangendo as gerações eólicas 2, 3 e 4. Este agrupamento é reforçado por datações pelo método da luminescência (Sawakuchi, 2003; Giannini et al., 2007).
} 


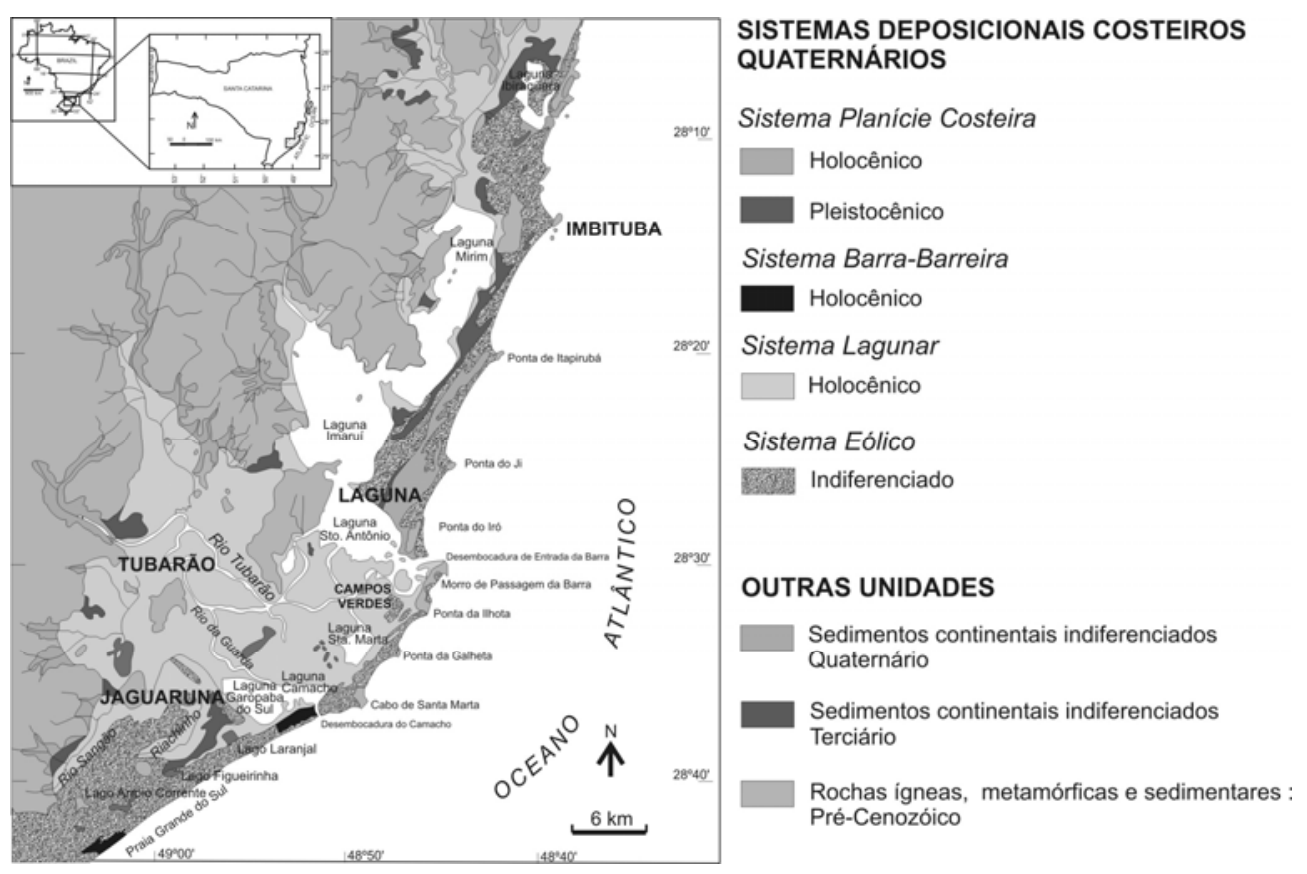

Figura 3.2. Sistemas deposicionais costeiros do litoral centro-sul de Santa Catarina, identificados por Giannini (1993, 2002) (modificado de Giannini \& Santos 1994).

\subsection{FASES DE OCUPAÇÃO}

Segundo Giannini et al. (2010), os sambaquis do litoral sul de Sana Catarina distribuem-se em dois compartimentos geográficos principais: 1) setor interno, ou deltaico, associado às bordas e morros-testemunho do delta lagunar do rio Tubarão, onde aparecem os sítios mais antigos; 2) e setor externo, ou litorâneo, associado aos pontões costeiros e à barreira arenosa holocênica e respectiva margem lagunar retrobarreira, onde aparecem os sítios associados à fase final da cultura sambaquieira. Por sua vez, os sambaquis da área de estudo apresentam três padrões estratigráficos: 1) padrão conchífero, formado por interestratificação de lâminas conchíferas centimétricas a decimétricas e lâminas mais delgadas de sedimentos pretos; 2) sambaquis de núcleo quarzto-arenoso, de formato monticular, maciço, coberto por camada decimétrca de areia com conchas rica em matéria orgânica; 3) e montículos ictiológicos (sensu Villagran et al. 2010), formados por misturas maciças ou mal estratificadas de areia com ossos de peixe, carvão, conchas ocasionais e, em alguns casos, fragmentos cerâmicos (Giannini et al. 2010). Estes sítios são agrupados na categoria sambaquis apesar de 
serem, na realidade, sítios mistos, como aqueles descritos no Capítulo 2, tópicos 3.4 e 3.5.1.

Em termos gerais, os sambaquis mais antigos apresentam padrão estratigráfico de tipo conchífero e localizam-se no setor interno, ou deltaico. Estes sítios são, atualmente, os mais afastados da linha de costa. No setor externo, ou litorâneo, existe a maior concentração de sítios, porém, estes são posteriores ao máximo transgressivo na região, atingido há cerca de 5700 anos AP (Angulo et al., 1999, 2006). Os sambaquis de núcleo arenoso e os montículos ictiológicos são exclusivos do setor externo, embora contemporâneos, em muitos casos, a sambaquis de padrão estratigráfico conchífero do setor interno.

No litoral sul de Santa Catarina 48 sambaquis foram datados por ${ }^{14} \mathrm{C}$. Destes sítios, 28 possuem apenas uma datação, enquanto os 20 restantes têm idades máximas, tomadas de amostras localizadas próximas à base dos sítios, e idades mínimas, tomadas do topo do montículo. Giannini et al. (2010) analisaram a distribuição de frequências de sambaquis no litoral sul catarinense quanto à cronologia de início da deposição, usando unicamente as idades máximas em sambaquis com mais de uma datação ${ }^{49}$. O histograma da distribuição de freqüências de idades por sambaqui permitiu identificar quatro marcos cronológicos importantes de formação de sambaquis, que definem, a partir da correlação das idades com a configuração peleogeográfica da área de estudo, quatro fases maiores de ocupação: Fase 1, de 7500 a 5500 anos cal AP; Fase 2, de 5500 a 4000 anos cal AP; Fase 3, de 4000 a 1700 anos cal AP; e Fase 4, de 1700 anos cal AP até o presente (Figura 3.3).

Na Fase 1 (7500-5500 anos cal AP), que inclui os sítios mais antigos, anteriores e contemporâneos ao máximo transgressivo, a região estava coberta de água na forma de uma paleobaía cujo limite alcançava a encosta da serra que bordeja o atual delta do rio Tubarão. No pé da serra e a poucos metros da paleolinha de costa, localizavam-se os primeiros sambaquis de padrão estratigráfico conchífero, assim como em morros testemunhos do embasamento pré-cenozoico em meio à paleobaía. Existe um único sítio com núcleo arenoso contemporâneo ao máximo transgressivo no setor externo, o sítio Santa Marta 10, localizado sobre costão rochoso em campo de dunas eólicas. O

\footnotetext{
${ }^{49}$ Todas datações ${ }^{14} \mathrm{C}$ foram calibradas para variação isotópica do carbono atmosférico ao longo do tempo no Hemisfério Sul pelo programa CALIB 6.0 (Stuiver and Reimer, 1993), com protocolo SHCal04 (McCormac et al., 2004). As 42 datações realizadas em conchas carbonáticas foram calibradas para correção do efeito reservatório com uso do protocolo Marine 04 (Hughen et al., 2004).
} 
isolamento deste sítio, sem conexão emersa com o continente, como também acontece com sítios localizados em morros testemunhos em meio á paleobaía, evidencia a existência de embarcações desde os registros mais antigos de ocupação humana.

Durante a Fase 2 (5500-4000 anos cal AP), posterior ao máximo transgressivo, intensifica-se o levantamento de sambaquis, tanto conchíferos como de núcleo arenoso, no setor externo. $\mathrm{O}$ assentamento humano no setor externo esteve favorecido pelo surgimento de terrenos propícios para ocupação, a partir da formação da barreira arenosa, de paleotômbolos à retaguarda dos costões rochosos e do campo de cordões litorâneos da região de Campos Verdes. No setor interno, o assoreamento da região produzido pela retirada das águas e descenso do NRM após 5700 anos AP, levou à formação do sistema lagunar e provocou o deslocamento dos pontos escolhidos para construção dos sambaquis até as margens da paleolaguna.

Na Fase 3 (4000-1700 anos cal AP), registra-se a o auge da ocupação sambaquieira, com incremento notório da quantidade de sítios, principalmente de padrão estratigráfico conchífero, mas também de sambaquis de núcleo arenoso. Nesta fase, destaca-se o incremento na concentração de sítios nos arredores do morro das Congonhas, no setor interno, e à retaguarda do Cabo de Santa Marta e região de Campos Verdes, no setor externo.

Os últimos 1700 anos estão representados pela Fase 4, caracterizada pela ocupação exclusiva do setor externo e pelo surgimento de sítios de padrão estratigráfíco de tipo montículo ictiológico, que inclui também a camada areno-lamosa preta do topo do sambaqui Jabuticabeira 2. Este último momento de ocupação relaciona-se com a suposta chegada dos grupos interioranos de tronco lingüístico Jê até o litoral, como evidenciaria a presença de cerâmica Taquara/Itararé nos sítio Santa Marta 8, Galheta 4 e Costão do Ilhote. No entanto, durante esta fase sítios de padrão conchífero ainda permaneciam ativos, como indicam as datações mínimas dos sambaquis Cabeçuda, Morrote e Caieira, assim como sítios de núcleo arenoso, como o sambaqui Lagoa dos Bichos 2 e Santa Marta 5, todos estes no setor externo. 

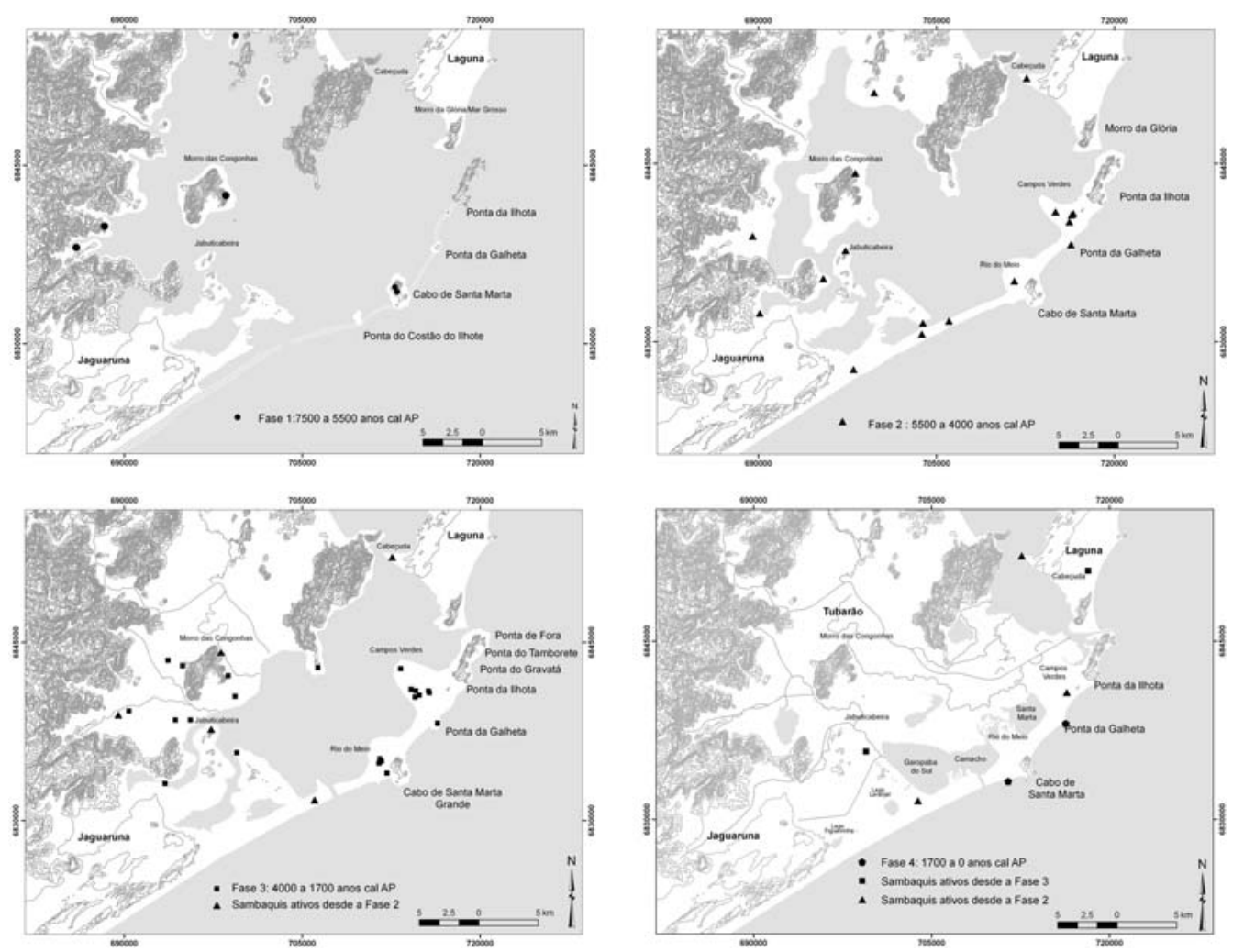

Figura 3.3. Fases de ocupação do litoral sul catarinense definidas por Giannini et al. (2010) em base em um conjunto de 129 datações ${ }^{14} \mathrm{C}$ de 48 sambaquis prospectados e datados pelo projeto Sambaquis $e$ Paisagem.

\section{OS SAMBAQUIS ANALISADOS}

Os sambaquis do litoral sul de Santa Catarina escolhidos para este estudo foram selecionados seguindo os critérios de diversidade estratigráfica, contexto geomorfológico de localização e diversidade cronológica propostos na classificação de Giannini et al. (2010). Estes critérios apontaram abranger as quatro fases de ocupação sambaquieira, assim como a diversidade de padrões estratigráficos e contextos geomorfológicos de localização de sambaquis na região.

Foram selecionados oito sambaquis para este estudo. Do conjunto de sítios, dois sambaquis representam a ocupação do setor interno e externo durante a Fase 1, os sítios Caipora e Santa Marta 10, de padrão estratigráfico conchífero e núcleo arenoso, respectivamente. Da Fase 2, foram analisados dois sambaquis, um no setor interno, o sítio Morrinhos, e outro no setor externo, representado pela porção inferior do sambaqui 
Jabuticabeira 1. Da Fase 3, escolheu-se um sítio no setor interno, o sambaqui Cubículo1, e dois no setor externo, o sítio Carniça 3 e a porção superior de Jabuticabeira 1. A Fase 4, final da ocupação da área, esta representada pelos sítios Santa Marta 8 e Galheta 4, ambos no setor externo (Figura 3.4). No Quadro 3.1, apresentam-se as informações sobre coordenadas UTM, contexto geológico de localização e idade calibrada dos oito sambaquis estudados. 

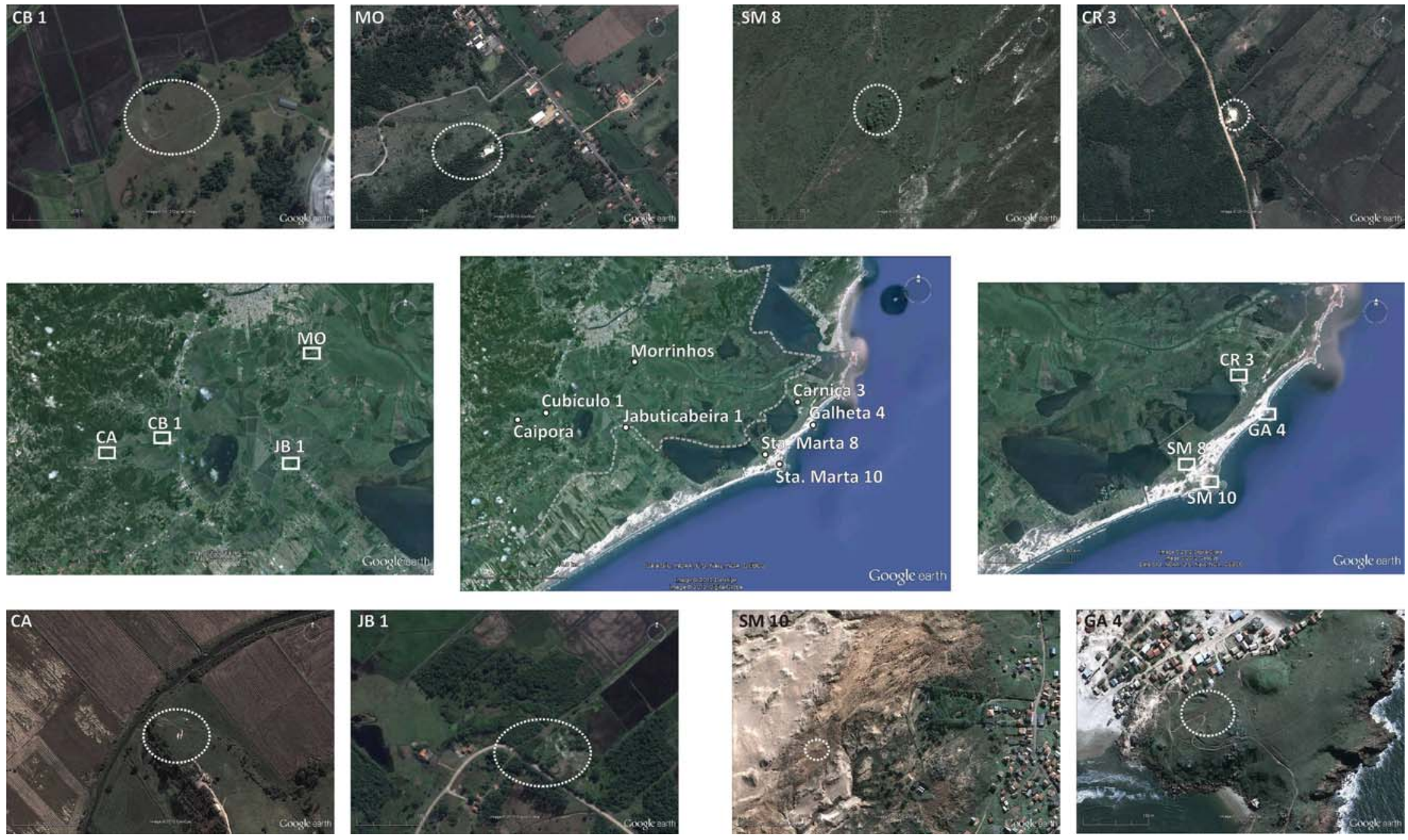

Figura 3.4. Imagem de satélite com a localização e vista aérea dos oito sambaquis estudados: Caipora, Santa Marta 10, Morrinhos, Jabuticabeira 1, Cubículo 1, Carniça 3, Santa Marta 8 e Galheta 4. A linha ponteada na imagem central indica a divisória entre os setor interno e externo segundo Giannini et al. (2010). 
Quadro 3.1. Sambaquis do litoral sul de Santa Catarina estudados neste trabalho. As idades e setores de loclaização foram tomados de Giannini et al. (2010).

\begin{tabular}{|c|c|c|c|c|c|c|}
\hline Sítio & Setor & $\begin{array}{l}\text { Contexto geológico- } \\
\text { geomorfológico }\end{array}$ & $\begin{array}{l}\text { Coord. } \\
\text { UTM }\end{array}$ & Fase & Idade ${ }^{14} \mathrm{C}$ & $\begin{array}{l}\text { Idade } \\
\text { calibrada }^{50}\end{array}$ \\
\hline Caipora & Interno & $\begin{array}{l}\text { Sobre embasamento } \\
\text { granitóide que } \\
\text { bordeja a oeste o } \\
\text { delta do rio Tubarão }\end{array}$ & $\begin{array}{l}685972 / \\
6838795\end{array}$ & 1 & $\begin{array}{l}6590 \pm 60 \\
(\text { Beta } \\
234199) ; \\
5410 \pm 60 \\
(\text { Beta } \\
234198)\end{array}$ & $\begin{array}{l}7570-7320 / \\
6280-5950 \\
\text { anos cal. AP }\end{array}$ \\
\hline Santa Marta 10 & Externo & $\begin{array}{l}\text { Sobre dunas de } \\
\text { geração eólica } 2 \text {, } \\
\text { empoleiradas no } \\
\text { embasamento pré- } \\
\text { cenozóico }\end{array}$ & $\begin{array}{l}713010 / \\
6834345\end{array}$ & 1 & $\begin{array}{l}5240 \pm 70 \\
(\text { Beta } \\
248571)\end{array}$ & $\begin{array}{l}6180-5750 \\
\text { anos cal. AP }\end{array}$ \\
\hline Morrinhos & Interno & $\begin{array}{l}\text { Na base da face norte } \\
\text { do morro das } \\
\text { Congonhas, } \\
\text { testemunho granítico } \\
\text { em meio ao delta do } \\
\text { rio Tubarão }\end{array}$ & $\begin{array}{l}698169 / \\
6844181\end{array}$ & $2 / 3$ & $\begin{array}{l}4480 \pm 60 \\
(\text { Beta } \\
209714) ; \\
3230 \pm 70 \\
(\text { Beta } \\
209713)\end{array}$ & $\begin{array}{l}5290-4860 / \\
3570-3220 \\
\text { anos cal. AP }\end{array}$ \\
\hline Jabuticabeira 1 & $\underset{51}{\text { Externo }}$ & $\begin{array}{l}\text { Sobre morrote } \\
\text { testemunho na } \\
\text { paleobaía lagunar no } \\
\text { bairro da } \\
\text { Jabuticabeira }\end{array}$ & $\begin{array}{l}697334 / \\
6837666\end{array}$ & $2 / 3$ & $\begin{array}{l}4185 \pm 90 \\
(A z 10639) \\
2430 \pm 125 \\
(A z 10642)\end{array}$ & $\begin{array}{l}4850-4430 / \\
2750-2130 \\
\text { anos cal AP }\end{array}$ \\
\hline Cubículo 1 & Interno & $\begin{array}{l}\text { Em pé de encosta } \\
\text { coluvionar, no limite } \\
\text { oeste do delta do rio } \\
\text { Tubarão }\end{array}$ & $\begin{array}{l}689508 / \\
6838876\end{array}$ & 3 & $\begin{array}{l}3500 \pm 50 \\
(\text { Beta } \\
248575)\end{array}$ & $\begin{array}{l}4078-3716 / \\
3845-3568 \\
\text { anos cal. AP }\end{array}$ \\
\hline Carniça 3 & Externo & $\begin{array}{l}\text { Em paleopontal } \\
\text { lagunar na região de } \\
\text { Campos Verdes }\end{array}$ & $\begin{array}{l}714519 / \\
6840380\end{array}$ & 3 & $\begin{array}{l}3360 \pm 50 \\
(\text { Beta } \\
248567)\end{array}$ & $\begin{array}{l}3810-3360 \\
\text { anos cal. AP }\end{array}$ \\
\hline Santa Marta 8 & Externo & $\begin{array}{l}\text { No paleotômbolo à } \\
\text { retaguarda do Cabo } \\
\text { de Santa Marta }\end{array}$ & $\begin{array}{l}711563 / \\
6835181\end{array}$ & 4 & $\begin{array}{l}1710 \pm 40 \\
(\text { Beta } \\
253668)\end{array}$ & $\begin{array}{l}\text { 1691-1416 } \\
\text { anos cal. AP }\end{array}$ \\
\hline Galheta 4 & Externo & $\begin{array}{l}\text { Sobre a ponta da } \\
\text { Galheta }\end{array}$ & $\begin{array}{l}716313 / \\
6838045\end{array}$ & 4 & $\begin{array}{l}980 \pm 40 \\
(\text { Beta } \\
211734)\end{array}$ & $\begin{array}{l}\text { 927-763 anos } \\
\text { cal. AP }\end{array}$ \\
\hline
\end{tabular}

${ }^{50}$ Calibração realizada a 2 sigma com programa CALIB 6.0 (Stuiver and Reimer, 1993) e protocolo SHCal04 (McCormac et al., 2004) tomadas de Giannini et al. (2010).

${ }^{51}$ A rigor, o sítio Jabuticabeira I pode pertencer igualmente ao setor interno, já que se encontra a vários quilômetros da costa e sobre morro testemunho do embasamento cristalino. No entanto, foi colocado no setor externo por estar localizado na margem sudoeste da laguna Garopaba do Sul. 


\subsection{CAIPORA}

O sítio Caipora foi escolhido por ser o sambaqui mais antigo da área de estudo, datado de 7570-7320 anos cal. AP, na base, e 6280-5950 no topo. Pertencente à Fase 1 de ocupação ${ }^{52}$ (7500-5500 anos cal AP), este sambaqui tem $25 \mathrm{~m}$ de cumprimento, 20 $\mathrm{m}$ de largura e $3 \mathrm{~m}$ de altura (Assunção 2010), está localizado no setor interno (Giannini et al. 2010) sobre embasamento granitóide e possui boa visibilidade da planície paleolagunar que se encontra ao norte e nordeste (Figura 3.5). Na época em que o sítio era ativo, esta planície correspondia à grande paleobaía que caracterizava a região após à máxima transgressão holocênica (Giannini 1993, 2002; Fornari 2010). A presença de um forno de cal imediatamente ao lado do sítio, no seu contato com o depósito paleolagunar, é indicador da exploração que o sambaqui sofreu no passado recente. Ao mesmo tempo, o sítio é atravessado por uma pequena estrada, de uns $2 \mathrm{~m}$ de largura, que desemboca próxima ao forno de cal anteriormente mencionado. Assim, parece lógico pensar que nem sua forma e extensão, hoje, nem sua estratigrafia atual refletem completamente a condição do sítio pós-abandono.

$\mathrm{Na}$ seção vertical estudada, localizada a nordeste do sítio, o sítio apresenta constituição essencialmente conchífera, com fragmentos de rocha. Possui pelo menos um sepultamento humano na base da seção. Análises faunísticas realizadas por Ferraz (2010) mostram que, além do componente terrígeno ( $\sim 25 \%$ do volume total), a assembléia faunística deste sambaqui é dominada por Ostrea sp. ( 42\%), seguida de Anomalocardia brasiliana (Gmelin, 1971) ( 13\%) e outros bivalves e gastrópodes, com somente $0,4 \%$ de ossos.

\footnotetext{
52 Os sambaquis da Fase 1, ocorrem sobre terrenos elevados, sobre o embasamento cristalino précenozoico ou sobre paleodunas eólicas de geração 1 ou 2, pré-máxima inundação holocênica (Giannini et al. 2010).
} 


\subsection{SANTA MARTA 10}

O sítio Santa Marta 10 é o mais antigo da região de Santa Marta e um dos mais antigos da área de estudo. Do setor externo, é o único sítio que pertence à Fase 1 de ocupação (5500-4000 anos cal AP), junto com o sítio Santa Marta 9 (Giannini et al. 2010). Apesar da sua antiguidade, trata-se de um sambaqui pequeno, com cerca de $10 \mathrm{~m}$ de cumprimento, $10 \mathrm{~m}$ de largura e 0,2 $\mathrm{m}$ de altura (Assunçao, 2010).

Tanto sua forma como composição destoam das características gerais dos sambaquis estudados neste trabalho. Nele se observa um bolsão de conchas que se estende em forma de anel, datado em 6180-5750 anos cal. AP (Figura 3.5) inserido em camada de areia lamosa preta sobre núcleo arenoso. No esquema tradicional, este sítio teria sido definido como acampamento litorâneo (ver Capítulo 2, tópico 4.3).

Durante o período de formação do sítio, a ponta de Santa Marta estava isolada, sem comunicação permanente com o continente, o que sugere a chegada dos sambaquieiros até o local com ajuda de embarcações (Kneip 2004; Giannini et al. 2010). O sítio localiza-se sobre paleodunas de geração eólica 2, empoleiradas no embasamento pré-cenozóico (Giannini 1993, Giannini et al. 2007). Na área de implantação, observaram-se afloramentos de paleodunas da geração eólica 1 (compactas e vermelhas), 2 (acima da geração 1, com bandas de impregnação e coloração amarela cinzenta) e 3 (amarelas, com bandas de impregnação muito tênues) (Giannini 1993; Giannini et al. 2007; Martinho \& Giannini 2001a, 2001b; Sawakuchi 2003).

Assunção (2010) identificou nas proximidades do sambaqui Santa Marta 10, assim como nos sambaquis Santa Marta 1, 3 e 9, um extenso sítio lítico a céu aberto, denominado Morro do Céu. Este sítio contém artefatos líticos lascados e polidos em quartzo, quartzito, granito, arenito e basalto, que são constantemente soterrados e descobertos pelo processo de deflação eólica. Uma situação semelhante foi observada no sítio Lagoa dos Bichos 2 (Peixoto, 2008) onde se acharam artefatos líticos dispersos ao redor do sambaqui ${ }^{53}$.

\footnotetext{
${ }^{53} \mathrm{O}$ intenso desgaste relatado em artefatos recuperados destes contextos (Assunçao, 2010; Peixoto, 2008) pode ser em parte resposta à erosão eólica (Rick, 2002), o que dificulta a análise funcional efetuada macroscopicamente.
} 

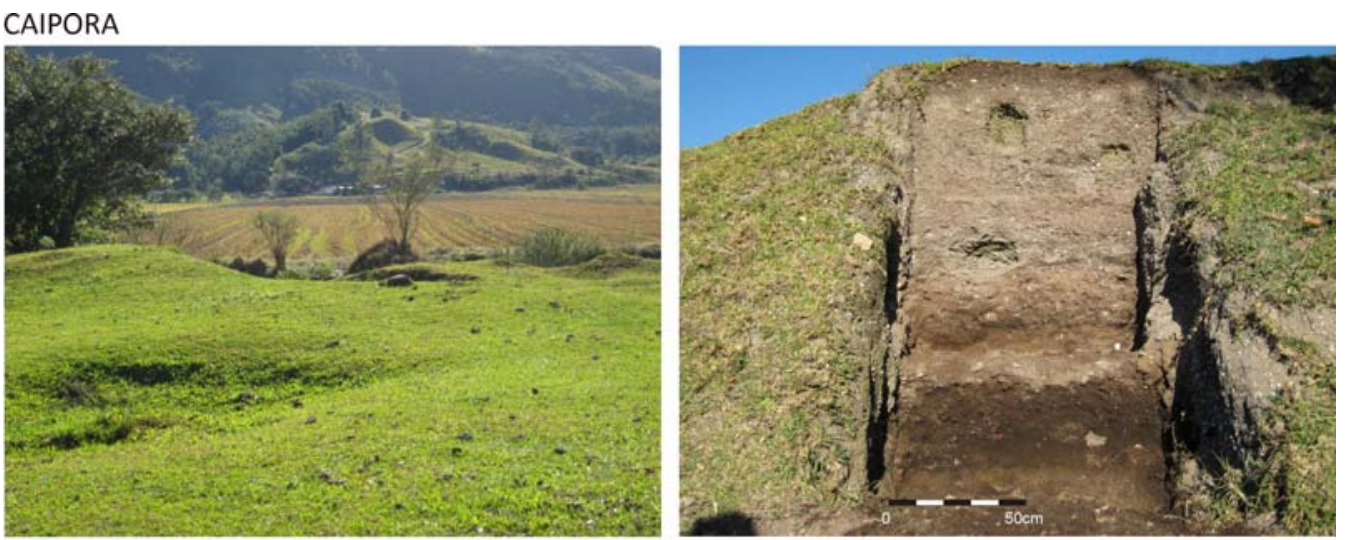

SANTA MARTA 10
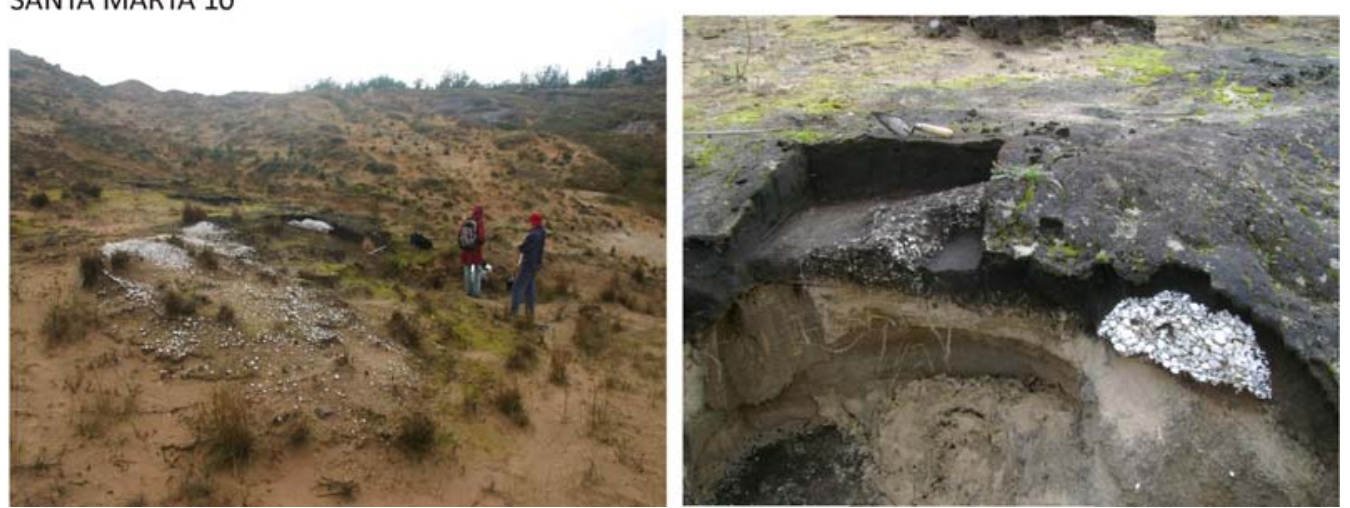

Figura 3.5. Vista do entorno de localização do sítio Caipora (superior esquerda), desde o topo do sítio, em primeiro plano, até a planície lagunar, ao fundo, com seção vertical analisada (superior direita), de direção NW-SE. Sítio Santa Marta 10, em contexto de paleodunas eólicas das gerações 1, 2 e 3 (inferior esquerda) e vista da seção analisada, de sul a norte, com área de escavação do anel de conchas (inferior direita). 

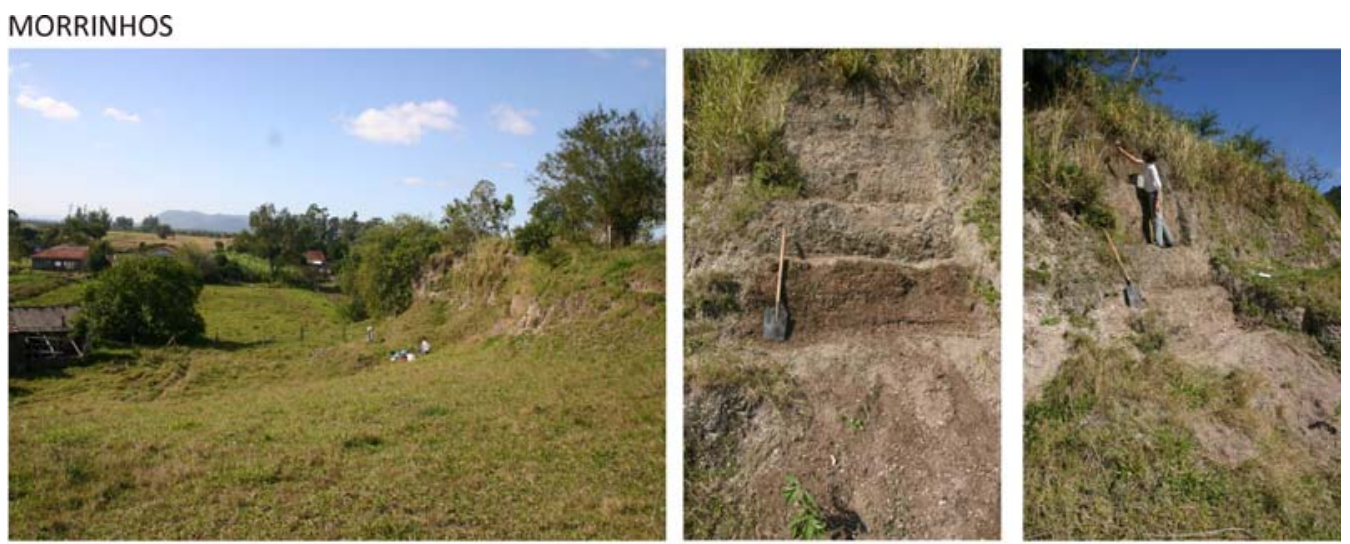

JABUTICABEIRA 1
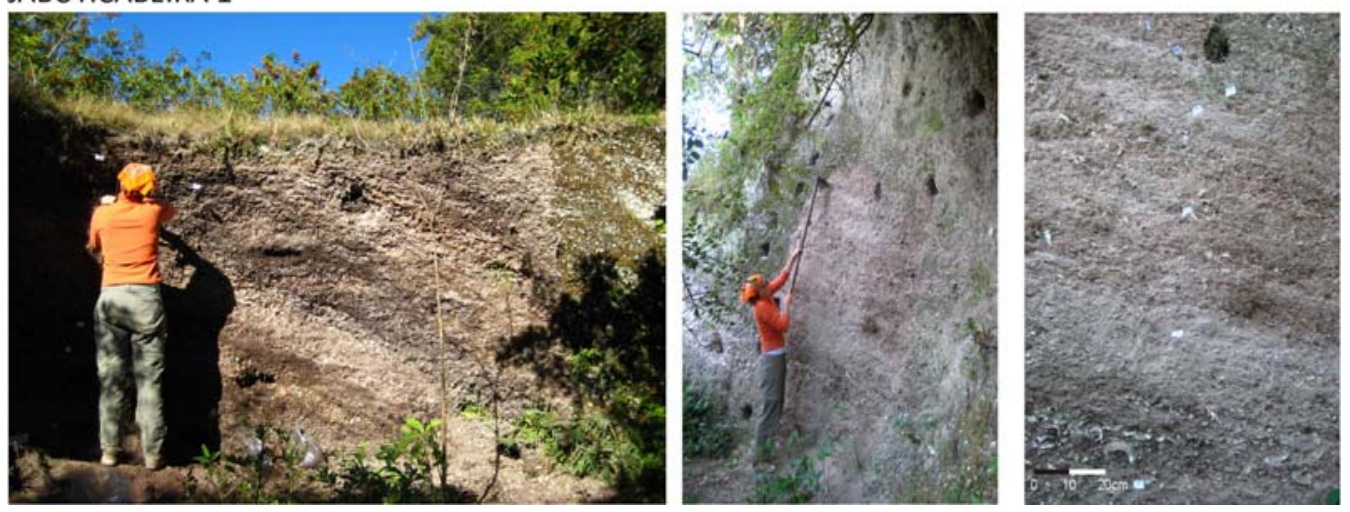

Figura 3.6. Vista do entorno de localização do sítio Morrinhos (superior esquerda), com trincheira trabalhada à direita da foto e seção estudada (superior direita), de direção N-S. Seção inferior de Jabuticabeira (inferior esquerda), de norte a sul, e seção estudada no nível superior (inferior direita), de direção SE-NW. 


\subsection{MORRINHOS}

O sítio Morrinhos, datado entre 5290-4860 anos cal. AP, na base, e 3570-3220 anos cal. AP, no topo atual, pertence às Fases 2 e 3 de ocupação da área de estudo (5500-4000 anos cal AP e 4000-1700 anos cal AP, respectivamente), momento em que se observa o deslocamento da distribuição dos sítios em direção ao sistema lagunar ${ }^{54}$ (Giannini et al. 2010; Kneip 2004).

Trata-se de um sambaqui de $130 \mathrm{~m}$ de cumprimento, $100 \mathrm{~m}$ de largura e $10 \mathrm{~m}$ de altura (Assunção 2010) localizado na face norte do morro das Congonhas, no setor interno ou deltaico (Giannini et al. 2010). Este sítio conta com seção de aproximadamente $20 \mathrm{~m}$, acompanhando a borda do testemunho cristalino, previamente exposta para finalidades de exploração mineral. No local escolhido para estudo, a seção está composta por quatro grandes degraus de $80,65,100$ e $100 \mathrm{~cm}$ de altura e aproximadamente $1 \mathrm{~m}$ de largura (Figura 3.6). No total, a seção trabalhada tem $3,45 \mathrm{~m}$ de altura, mas o seu ponto mais alto não alcança o topo atual do sambaqui, que se encontra a aproximadamente $1 \mathrm{~m}$ acima da superfície do último degrau.

A cobertura vegetal no topo do sambaqui é de floresta densa, como a que caracteriza a totalidade do morro das Congonhas. Um solo profundo desenvolve-se na superfície do sítio. Sua estratigrafia é essencialmente conchífera, monótona e repetitiva, apesar da grande altura do depósito.

\footnotetext{
${ }^{54}$ A ocupação do setor externo, sobre substrato do sistema barreira e lagunar, intensifica-se na fase 2 (5500-4000 anos cal AP) (Giannini et al. 2010).
} 


\subsection{JABUTICABEIRA 1}

O sítio Jabuticabeira 1, datado entre 4850-4430 anos cal. AP, na base, e 27502130 anos cal AP, próximo ao topo atual, encontra-se parcialmente assentado sobre morrote testemunho do embasamento cristalino na paleobaía lagunar, e sobre paleodunas da geração 2. Apresenta $400 \mathrm{~m}$ de cumprimento, $150 \mathrm{~m}$ de largura e $7 \mathrm{~m}$ de altura (Assunção 2010). Este sambaqui localiza-se no limite entee os setores interno e externo e sua deposição abrange tanto a fase 2 (5500-4000 anos cal AP) como a fase 3 (4000-1700) de ocupação da região. A fase 3 é identificada como momento de auge dos sambaquis de padrão estratigráfico conchífero (Giannini et al. 2010).

A formação deste sambaqui precede ao sítio mais conhecido da região, o Jabuticabeira 2. Durante o inicio da ocupação do local, o sítio encontrava-se localizado sobre um istmo arenoso fixado no morrote testemunho. Os dois sambaquis de Jabuticabeira foram contemporâneos por mais de mil anos, sendo o Jabuticabeira 1 abandonado quando a margem da paleobaía lagunar ainda se encontrava próxima. Porém, pelos mesmos motivos explicados para os sítios descritos anteriormente, a intensa exploração sofrida impede considerar a sua data mínima disponível como indicador do momento final de ocupação. Conforme Bocchi \& Liberatore (1968), na década de 1960 este sambaqui tinha $15 \mathrm{~m}$ de altura e estava em franca exploração clandestina pelos proprietários do terreno. Ainda de acordo com esses autores, até aquela data $50 \%$ do volume original do sítio já haviam sido explorados. Segundo Rohr (1984), em 1983 restavam apenas 5\% do volume total do sambaqui. Atualmente, ao sudeste do sítio, existe uma plantação de milho que atinge parte da área ocupada pelo sambaqui, sinal de que ele continua sendo alterado.

Duas seções foram estudadas (Figura 3.6), uma delas numa trincheira inferior no centro do sítio, cuja base atinge o contato com o granito subjacente, e a outra numa trincheira superior a oeste, a poucos metros da anterior. O topo desta seção, a julgar pela grande compactação e fragmentação dos componentes, parece tratar-se de resíduo de moinha. A seção superior está totalmente concrecionada e não alcança a superfície atual do sítio, que se encontra a aproximadamente $1 \mathrm{~m}$ do topo do perfil. Em ambos as seções, a interdigitação de lentes na estratigrafia permite inferir a constituição do sítio por grandes montículos que se desenvolvem de maneira sincrônica e, muitas vezes, superposta. 
Análises faunísticas efetuadas por Ferraz (2010) nas mesmas seções que serão trabalhadas neste estudo mostraram o predomínio de Anomalocardia brasiliana ( $66 \%$ ), seguido de Ostrea sp ( 20\%), Thais haemastoma ( 5\%), mariscos $(\sim 4 \%)$ e ossos de peixe $(\sim 1,5 \%)$. Pelo menos dois sepultamentos humanos foram encontrados por mesmo autor nas seções verticais analisadas, um deles próximo à base da trincheira inferior e outro a cerca de $50 \mathrm{~cm}$ acima da base da trincheira superior. No entanto, descrições de Bocchi \& Liberatore (1968) confirmam a existência de maior número de sepultamentos no sítio, assim como de estruturas de combustão e diversos artefatos líticos (machados, pontas de flecha).

\subsection{CUBÍCULO 1}

O sítio Cubículo 1 localiza-se a nordeste do sítio Caipora, em pé da encosta coluvionar do Ilhote do Cubículo, também no setor interno (Giannini et al. 2010). Destaca pela sua grande extensão atual, com $550 \mathrm{~m}$ de cumprimento, $150 \mathrm{~m}$ de largura e $8 \mathrm{~m}$ de altura (Assunção 2010). Amostras coletadas da base e do topo do sambaqui indicam deposição rápida, que teria começado cerca de 3800 anos cal. AP e finalizado há aproximadamente 3600 anos cal. AP. O sítio Cubículo 1 pertence à fase 3 de ocupação $^{55}$ (4000-1700 anos cal AP) (Giannini et al. 2010). No entanto, este sítio também mostra claras evidências de exploração e alteração modernas. Ele encontra-se atravessado por duas estradas, que o dividem em quatro porções; além disso, uma plantação de milho existe a sudoeste e uma grande cratera foi aberta próximo a atual porção central do sítio, onde se localiza o corte estudado. Estas alterações são indicadores indiscutíveis da devastação que ainda sofre o sambaqui. Portanto, a curta cronologia disponível entre as amostras de base e topo não é necessariamente representativa do tempo total de formação do sítio.

A seção estudada, localizada na parte norte do sambaqui, permite observar a geometria monticular das camadas conchíferas que o compõem (Figura 3.7). Neste sítio, a exemplo do sambaqui Caipora, destaca-se a alta concentração de valvas de Ostrea sp.,

\footnotetext{
${ }^{55}$ Nesta fase, observa-se uma tendência de deslocamento dos pólos de ocupação tanto no setor interno quanto externo. No setor interno, aumenta a ocupação nas imediações do morro das Congonhas e, no setor externo, tem-se incremento da ocupação no centro e nordeste da franja litorânea.
} 
com menor freqüência de Anomalocardia brasiliana. As camadas são pouco compactas e altamente friáveis, com concentração de sepultamentos humanos visível nas seções. A sua proximidade com a atual planície paleolagunar, e a idade máxima disponível indicam que, desde o início, o sítio teria estado próximo à beira da baía-laguna.

\subsection{CARNIÇA 3}

O sítio Carniça 3, com $40 \mathrm{~m}$ de cumprimento, $30 \mathrm{~m}$ de largura e $5 \mathrm{~m}$ de altura (Assunção 2010) possui uma única datação, de 3810-3360 anos cal. AP, proveniente de amostra de Anomalocardia brasiliana coletada no topo. Trata-se de típico sambaqui do setor externo, localizado em paleopontal lagunar (Figura 3.7) e pertencente à fase 3 de ocupação (4000-1700 anos cal AP), momento em que já estava em formação a planície de cordões litorâneos da região de Campos Verdes (Tanaka et al. 2009; Giannini et al. 2010). A planície de Campos Verdes está formada por feixes de cordões litorâneos, dispostos de maneira transversal à costa atual superpostos, em parte, por paleodunas de geração 3 (posteriores à máxima inundação holocênica). A SW, limita-se por uma faixa arenosa correspondente a um paleopontal cuja presença favoreceu o acumulo sedimentar e formação dos cordões (Giannini 1993; Tanaka 2007; Tanaka et al. 2009). Sobre o paleopontal, encontram-se localizados quatro sambaquis (Carniça 1, 2, 3 e 4) (Hurt 1974), enquanto nos cordões encontram-se outros três (Carniça 5, 6 e 7) (Assunçao, 2010).

Sua estratigrafia relativamente simples, composta por camada lamosa preta com conchas sobre núcleo arenoso, é característica comum a vários dos sítios da região de Campos Verdes e Santa Marta, assim como ao Encantada 3, localizado a sudeste da margem atual da laguna Garopaba do Sul. Segundo Rohr (1984), em 1975 o sítio ainda encontrava-se intacto, apesar de estar localizado próximo às caieiras. A altura atual do sambaqui possui uma diferença de apenas $1 \mathrm{~m}$ em relação à suas dimensões relatadas por Rohr (1984) para a década de 1970. Este sítio salvou-se da exploração intensiva pelo seu escasso valor econômico, relacionado com a alta quantidade de areia misturada com as conchas. 
Tanaka (2007) e Tanaka et al. (2009) ressaltam que tanto a ausência de estruturas sedimentares internas indicativas de deposição eólica na porção arenosa, quanto a forma e altura do depósito, incompatíveis com as de dunas eólicas existentes na região, sugerem origem antrópica para o núcleo arenoso deste sambaqui. As areias utilizadas para levantamento do montículo teriam sido coletadas de sedimentos de cordões litorâneos e/ou depósitos eólicos próximos, como constatado por Tanaka (2007) e Tanaka et al. (2009) a partir de análises granulométricas comparação. Quanto à matéria orgânica que compõe a camada lamosa superior, análises isotópicas de $\delta^{13} \mathrm{C}$ e razão $\mathrm{C} / \mathrm{N}$ realizadas por Menezes (2009) mostraram uma possível relação genética com a matéria orgânica dos depósitos lagunares da região.
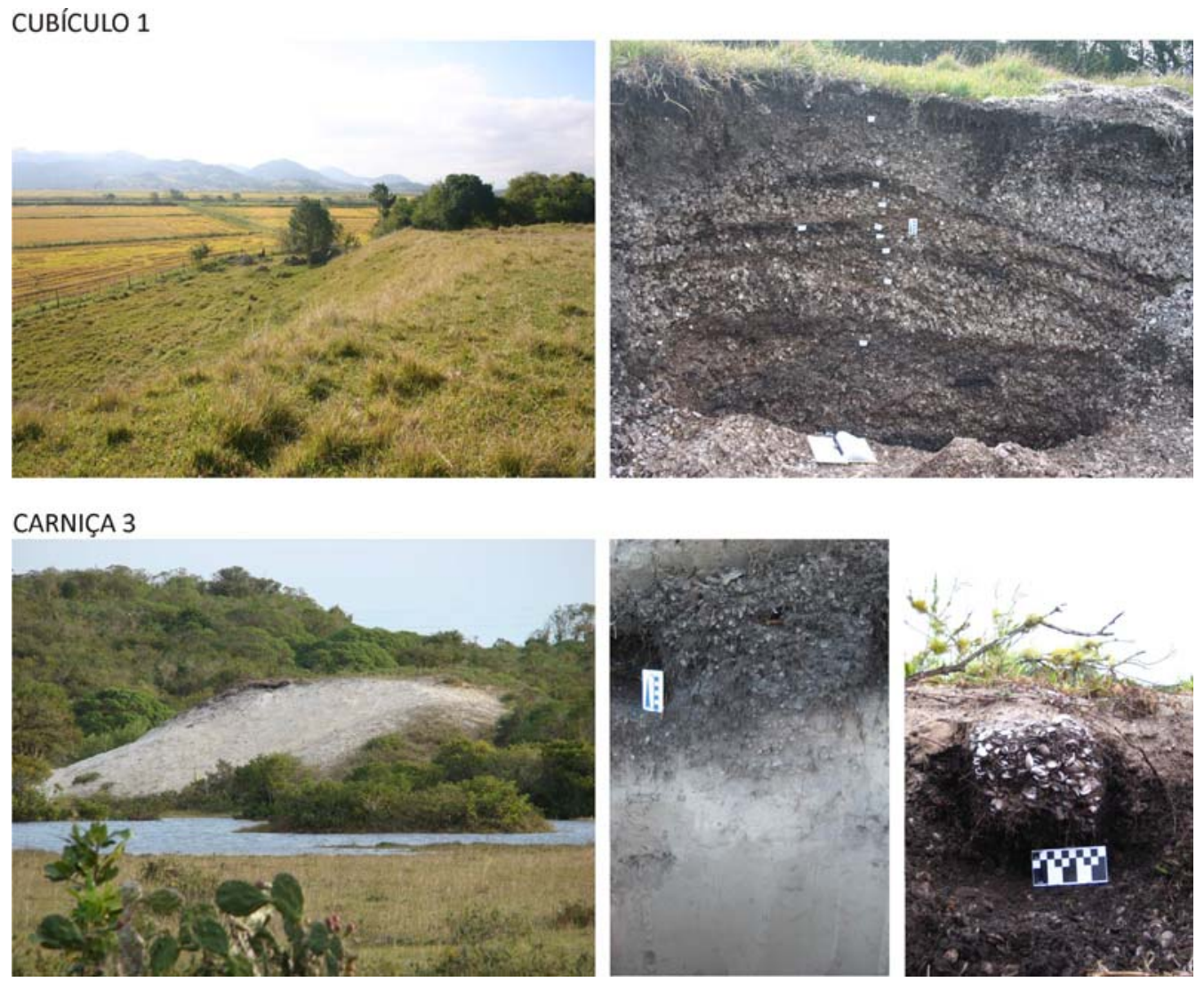

Figura 3.7. Vista do entorno de localização do sítio Cubículo (superior esquerda), vendo-se o sambaqui na direita da foto e a planície lagunar na esquerda, com seção vertical analisada (superior direita), de direção S-N. Vista do sítio Carniça 3 (inferior esquerda) e seção estudada, com bloco amostrado para micromorfologia (inferior direita), de direção NE-SW. 

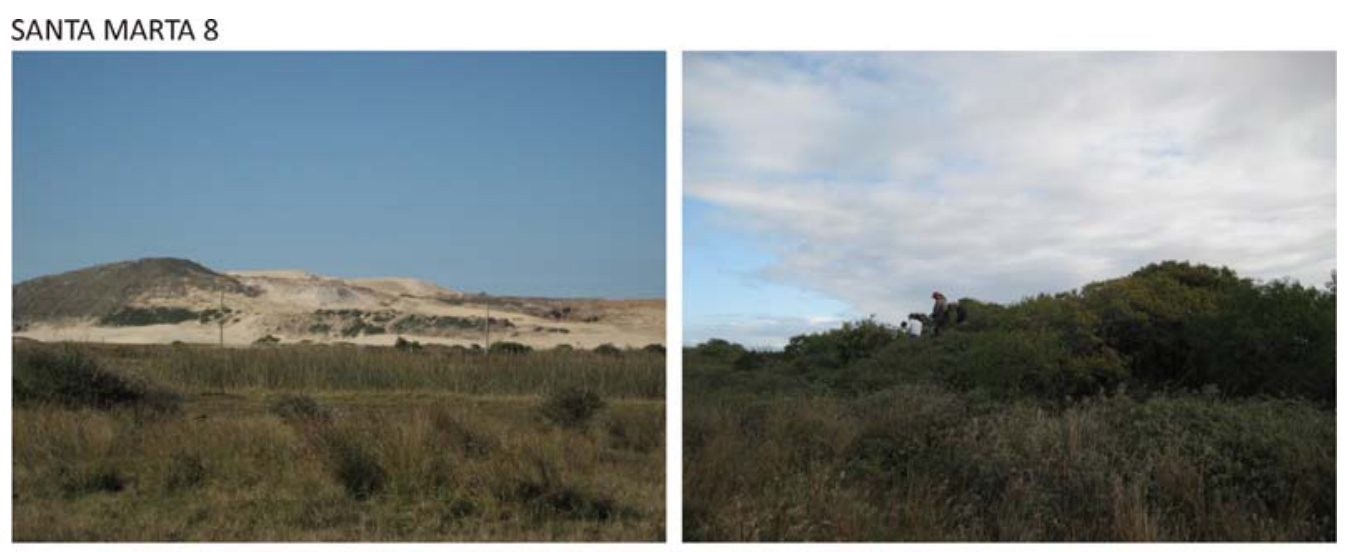

\section{GALHETA 4}

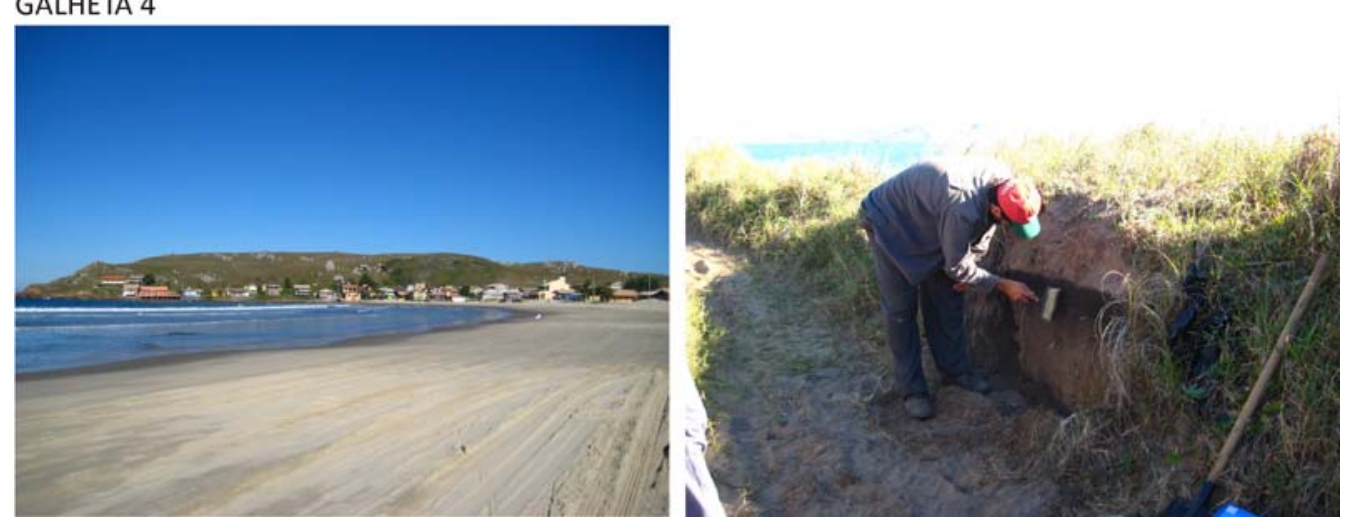

Figura 3.8. Vista da região de Santa Marta, a partir do sítio Santa Marta 8, com vista do sítio coberto por vegetação densa. Vista da Ponta da Galheta a partir da praia da Galheta, setor norte, com indicação da localização do sítio Galheta 4 (flecha amarela) e seção estudada, de direção NW-SE. 


\subsection{SANTA MARTA 8}

O sítio Santa Marta 8 encontra-se localizado no paleotômbolo à retaguarda da ponta de Santa Marta, a aproximadamente $820 \mathrm{~m}$ da atual margem da laguna de Camacho. Foi caracterizado pelos pesquisadores do projeto Sambaquis e Paisagem como sítio Jê, devido à presença de cerâmica de tradição Taquara/Itararé, tanto em superfície como em subsuperfície. Uma única idade é disponível para este sítio, que corresponde a um sepultamento humano próximo à base, datado em 1691-1416 anos cal. AP. Trata-se de um sítio misto, como definido no Capítulo 2, tópico 3.4.1, e que possui a datação mais antiga da região dentre os associados à presença dos grupos do planalto. Sua idade e padrão estratigráfico permitiram definir o início da última fase de ocupação da área de estudo, a fase 4 (1700-0 anos cal AP), caracterizada pela aparição de sítios unicamente no setor externo (Giannini et al. 2010).

A composição do sítio Santa Marta 8, à base de ossos de peixe, areias terrígenas e carvão, lembra a camada preta superior que caracteriza o sítio Jabuticabeira 2 (Villagran 2008). A única diferença reside na ausência da intercalação entre camadas de materiais completamente queimados e camadas de restos intemperizados, observada no Jabuticabeira 2. No Santa Marta 8, estes materiais parecem estar mais intensamente misturados, sem acamamento diferencial. Na área de localização do sítio, no paleotômbolo à retaguarda da ponta de Santa Marta (Figura 3.8), foram mapeados mais três sambaquis de padrão estratigráfico conchífero e núcleo arenoso, facilmente visíveis deste local (Santa Marta 5, 6 e 7).

Segundo Assunção (2010), parte deste sítio teria sido explorada para construção de uma estrada que se encontra atualmente em desuso, por ter sido coberta pela sedimentação eólica. 


\subsection{GALHETA 4}

O sítio Galheta 4 localiza-se na ponta da Galheta, setor externo, entre os sambaquis Galheta 1 e 2 . Apresenta $30 \mathrm{~m}$ de cumprimento, $30 \mathrm{~m}$ de largura e $10 \mathrm{~m}$ de altura (Assunçao, 2010). É atribuído à ocupação Jê, em vista da presença de cerâmica de tradição Taquara/Itararé e de corpos com marcas de queima, associada à prática da cremação (DeBlasis \& Farias, 2007). Não seria um sambaqui, propriamente dito, mas um sítio misto (ver Capítulo 2, tópico 3.4.1). Pertence à fase 4 de ocupação segundo Giannini et al. (2010) e representa, dentro da linha cronológica estudada nesta tese, o momento final da ocupação pré-colonial da costa (Figura 3.8).

Foram recuperados durante as escavações neste sítio nove sepultamentos humanos, um dos quais foi datado em 927-763 anos cal. AP. Três destes nove sepultamentos encontraram-se nas proximidades da seção vertical estudada: dois a aproximadamente 1,5 m de distância a noroeste da seção e um cerca de $3 \mathrm{~m}$ a sudeste. Todos os sepultamentos apareceram em camada de areia lamosa preta, localizada a partir de 40-50 cm de profundidade, com 20-30 $\mathrm{cm}$ de espessura.

$\mathrm{Na}$ escavação do sítio, observaram-se também grandes concentrações de fauna associada aos sepultamentos (peixes, aves, moluscos e mamíferos marinhos e terrestres), assim como artefatos líticos (polido e lascado) e ósseos (em osso de ave), além de fragmentos cerâmicos. Artefatos líticos polidos foram encontrados igualmente em áreas distantes dos sepultamentos, a profundidades de 30 até $60 \mathrm{~cm}$ (DeBlasis \& Farias, 2007).

Segundo DeBlasis \& Farias (2007), a função do sítio teria sido essencialmente cerimonial, relacionada com a celebração de rituais funerários e festins, com fogueiras acesas nas proximidades dos enterramentos e deposição massiva de fauna (freqüentemente articulada) sobre os corpos. Com base nas datações disponíveis para os sambaquis e sítios de associação Jê que se encontraram na ponta da Galheta, Assunção (2010) propõe que o local seria um complexo arqueológico de ocupação recorrente durante milhares de anos. $\mathrm{O}$ autor interpreta que a escolha de implantação de cemitérios em área elevada e de grande visibilidade, com baixo potencial como local de residência dada a grande distância a fontes de água doce, responde a motivos simbólicos. Seguindo 
esse raciocínio, postula que a implantação em tempos tardios de um cemitério Jê, fora dos sambaquis que já existiam no local, representaria uma estratégia de domínio territorial dos novos grupos que se instalaram na região.

\section{CASO DE ESTUDO COMPARATIVO}

Com o objetivo de comparar as análises realizadas em sambaquis com concheiros que estivessem etnograficamente documentados na América do Sul, escolheu-se um concheiro submoderno localizado no litoral norte do Canal Beagle (Terra do Fogo, Argentina). Este concheiro etno-histórico foi adstrito aos grupos yamana (Orquera \& Piana, 1996a; Orquera \& Piana, 1999a; Estevez \& Vila, 2006; Estevez et al., 2001), canoeiros de recente desaparição na região (entre os séculos XVIII-XIX).

A associação do concheiro com um grupo conhecido, a partir das crônicas e relatos etnográficos, transforma o sítio em objeto de estudo etnoarqueológico. Esta associação permite que as informações registradas nas crônicas, coletadas a partir da observação direta destas sociedades então ativas, possam ser contrastadas e complementadas com os dados recuperados na escavação arqueológica. 

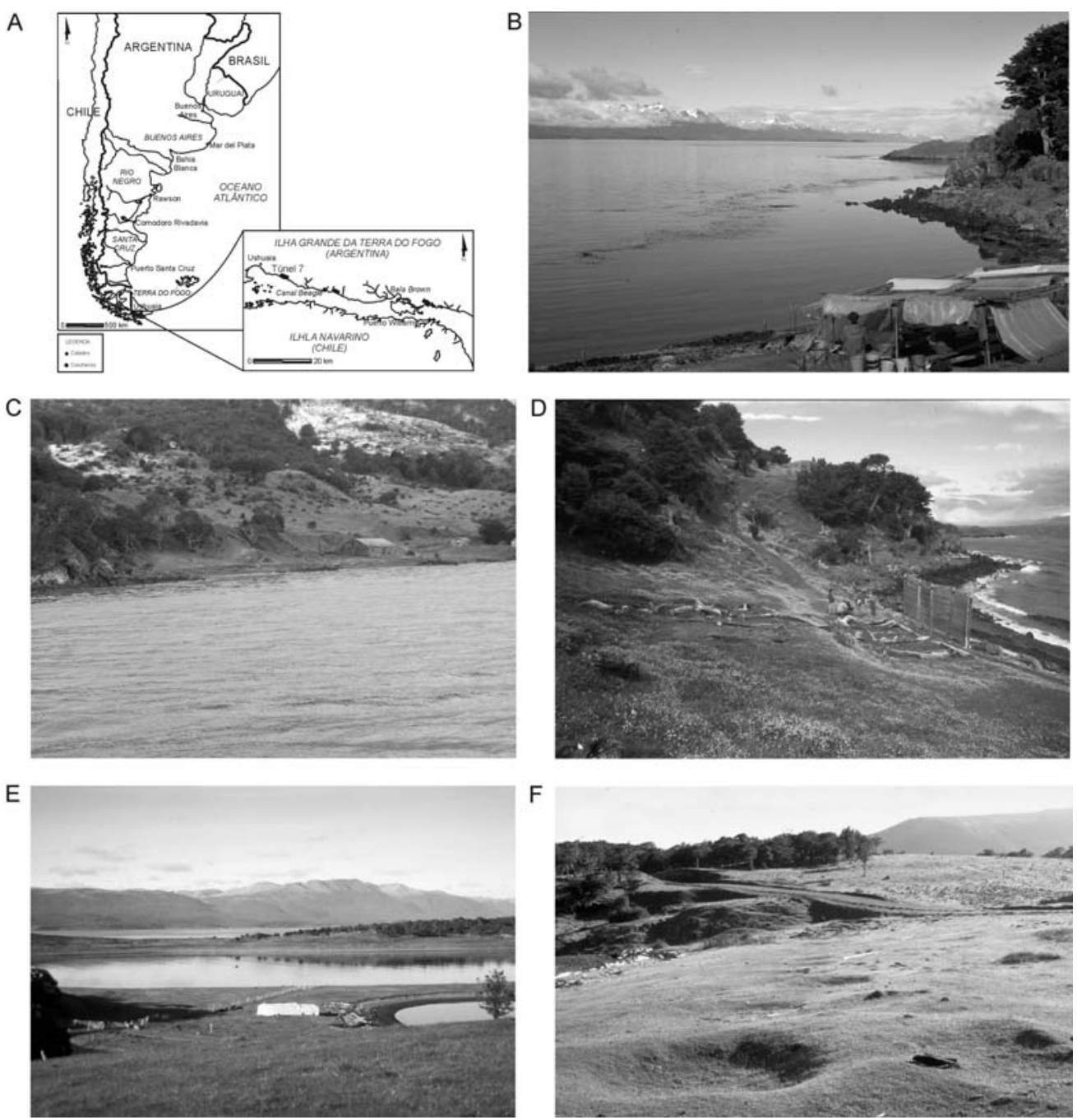

Figura 3.9. Concheiros etno-históricos da Terra do Fogo: A) Mapa de localização da área de estudo, no litoral norte do Canal Beagle. B) Vista do Canal Beagle, a partir da escavação do concheiro Túnel 7. C) Vista do sítio Túnel 7 durante o outono. D) Concheiro Túnel 7 observado desde a morena glacial sobre o qual acha-se parcialmente assentado, de oeste para leste. E) Escavação no concheiro Lanashuaia, localizado embaixo da estrutura branca de cobertura. F) Depressões no terreno, indicativas da localização de antigos concheiros na Baía Cambaceres (B, D, E e F: fotografias de Jordi Estevez e Assumpció Vila; C: fotografia de Myrian Alvarez). 


\subsection{EVOLUÇÃO HOLOCÊNICA DO CANAL BEAGLE}

O Canal Beagle (Terra do Fogo, Argentina) tem aproximadamente $200 \mathrm{~km}$ de comprimento e divide a ilha Grande de Terra do Fogo, ao norte, da ilha Navarino e ilhas menores, ao sul. Consiste num vale glacial afogado que une o oceano Atlântico com o Pacífico. A costa do canal é rochosa e caracteriza-se pela presença de pequenas baías com praias de seixos (Rabassa et al., 2000).

Após o final das glaciações pleistocênicas, no Holoceno inicial (há 9.4 kA), um grande lago glacial ocupava o Canal Beagle, cujas águas alcançaram os $30 \mathrm{~m}$ sobre o atual nível do mar. Pouco antes dos $8.2 \mathrm{kA}$ o canal se abriu e, progressivamente, as águas marinhas passaram a substituir as lacustres. Por volta de $8 \mathrm{kA}$, o ambiente marinho já tinha se estabelecido completamente no canal (Rabassa et al., 1986) (Figura $3.10)$.

No litoral norte do Canal Beagle, existe um sistema de paleopraias suspensas, ou terraços marinhos do Holoceno, que se estendem sub-paralelamente à atual linha de costa. A mais antiga destas paleopraias, datada em ca. 6000 anos AP, localiza-se a $10 \mathrm{~m}$ acima do nível do mar atual, enquanto a mais recente (posterior a 3000 anos AP) possui cota de 1,3 a $3 \mathrm{~m}$. A variação do NRM responsável pela formação destes terraços teria envolvido tanto soerguimento tectônico, para os terraços mais recentes, como reajuste glácio-isostático, para os mais antigos (Bujalesky et al., 2004; Gordillo et al., 1992, 1993; Isla and Bujalesky, 2000; Rabassa et al., 2000).

A cronologia e a magnitude da máxima transgressão marinha holocênica no Canal Beagle ainda é tema de discussão. Segundo Porter et al. (1984), o máximo NRM na Terra do Fogo teria alcançado 3,5 m cerca de 7000 anos AP. Morner $(1987,1991)$ indica que o nível máximo do mar teria sido apenas 0,5 a 1,0 m mais alto entre $9000 \mathrm{e}$ 4000 anos AP, enquanto Rabassa et al. (2000) mencionam evidências de alturas máximas de $8 \mathrm{~m}$ a $12 \mathrm{~m}$ em 6000 anos AP.

Gordillo et al. (1992, 1993) indicaram que a diminuição do NRM desde o Holoceno Médio é concomitante à estabilidade na permanência da floresta de Nothofagus sp. e do clima frio e úmido, com pequenas variações relacionadas a eventos de avanço e retrocesso neoglaciais (Candel et al., 2009; Coronato et al., 1999; Markgraf, 1993). 


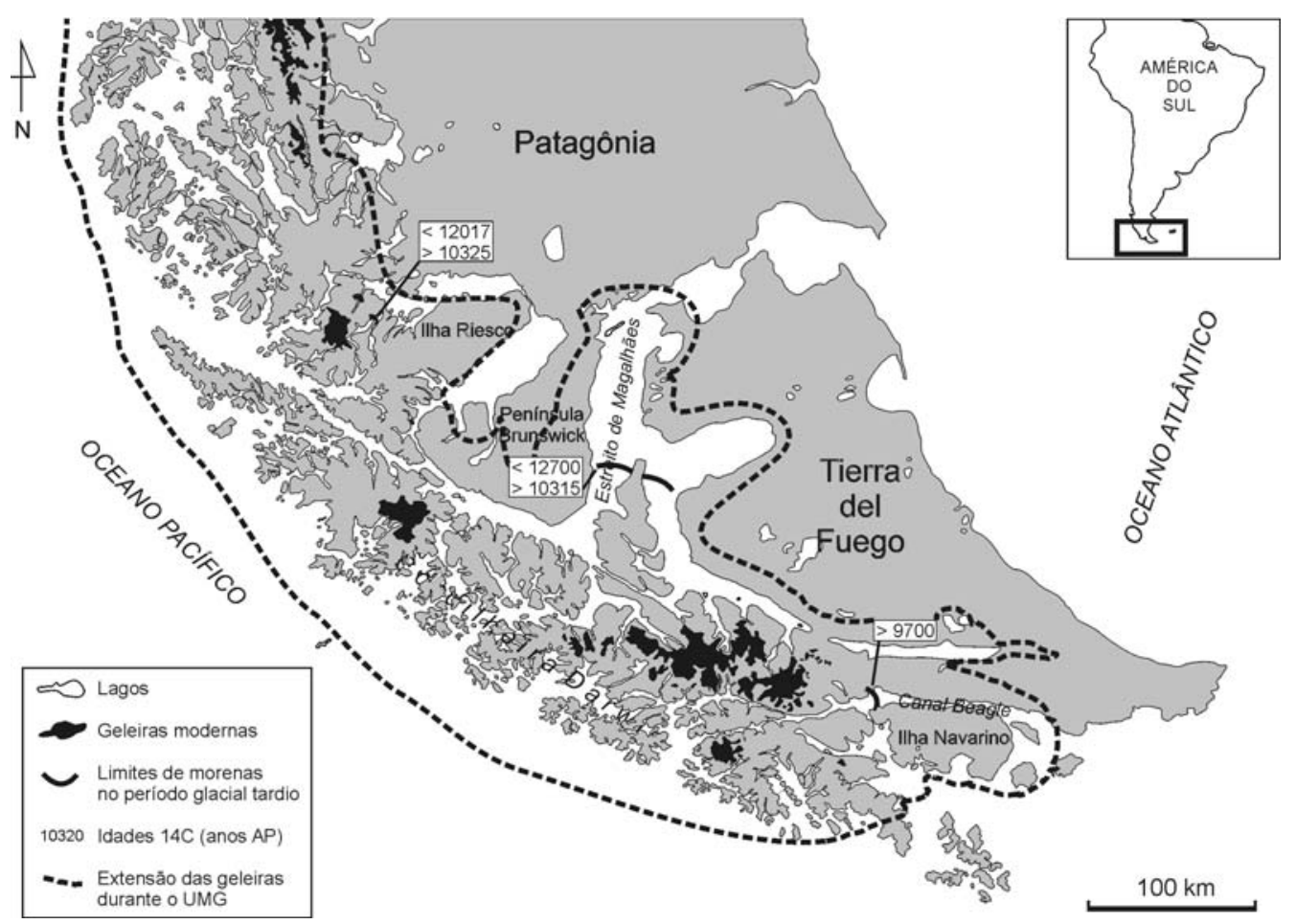

Figura 3.10. Sul da Patagônia e Terra do Fogo, com localização dos campos de gelo modernos, seus limites máximos de extensão durante o último máximo glacial (UMG, $20 \mathrm{kA}$ ) e o alcance das morenas no final do período glacial (Pleistoceno tardio). Adaptado de Coronato et al. (1999: 79) e McCulloch et al. (2005: 358).

\subsection{O CONCHEIRO TÚNEL 7}

O sítio Túnel 7 esta localizado no litoral norte do Canal Beagle, a $20 \mathrm{~km}$ da cidade de Ushuaia (capital da Terra do Fogo), no sopé de uma morena glacial de forma semilunar sobre a praia de seixos (Figura $3.11 \mathrm{~A}, \mathrm{C}$ ). De formato anelar, com 30-60 cm de altura, o concheiro representa o remanente de uma ocupação doméstica, com 100 a 200 anos de antiguidade (Estevez et al. 2006). Este sítio foi escavado e estudado desde a década de 1990 sob uma perspectiva que enfatiza a organização espacial das atividades associadas com sua formação (Balbo et al., 2010; Briz et al., 2005; Estevez et al., 2001; Estevez \& Vila, 1998, 2006, 2007; Orquera, 1996; Orquera \& Piana, 1992, 1996a, 1996b, 1999, 2000, 2001; Piqué, 1999, 2006; Vila et al., 2010, 2007, 2004; Zurro et al., 2009) (Figura 3.11 B). No Quadro 3.2, apresentam-se as coordenadas UTM, contexto geológico de localização e idade calibrada do concheiro Túnel 7. 
Quadro 3.2. Informações sobre contexto geológico-geomorfológico, coordenadas UTM e cronologia do concheiro etno-histórico Túnel 7 estudado neste trabalho.

\begin{tabular}{llll}
\hline Localização & Contexto geológico-geomorfológico & $\begin{array}{l}\text { Coordenadas } \\
\text { UTM }\end{array}$ & Cronologia \\
\hline Canal & Sobre praia de seixos no pé de morena glacial a & $554388 /$ & $1835-1898$ anos \\
Beagle & poucos metros da atual linha de costa & 3924868 & DC
\end{tabular}

A área escavada do concheiro, localizado na porção mais próxima da praia atual, ofereceu data histórica por dendrocronologia. Adjacente à área escavada, existe uma concheiro mais antigo, datado em ca. 2000 e 1300 anos AP, que apoia também sobre terraço marinho mais elevado (Piana \& Orquea 1996). Nesta tese, refere-se especificamente a seção vertical na área central do componente moderno do sítio, onde se focalizaram os trabalhos de escavação.

O método de escavação utilizado envolveu a retirada cuidadosa de cada unidade estratigráfica identificada, tanto em planta como em seção vertical, sem uso de níveis de escavação artificiais (a cada $5 \mathrm{~cm}$, por exemplo). O objetivo deste método foi coletar a maior quantidade de informação possível da escavação do sítio ${ }^{56}$ já que, em concheiros, as unidades de deposição estão em tese bem preservadas, sempre que não tiverem sido objeto de processos pós-deposicionais maiores, como bioturbações por mesofauna ou escavação moderna da estrutura, entre outros (Orquera \& Piana 1992, 1996b).

A estratigrafia do sítio caracteriza-se por apresentar interestratificação de lâminas conchíferas centimétricas e lâminas delgadas de sedimentos pretos e areias. Como descrito nas crônicas etnográficas, na área central encontrou-se a estrutura remanente de uma cabana de moradia, identificada por marcas de poste e pelo "efeito parede" na distribuição dos artefatos. A análise de superposição de estruturas de combustão evidenciou a existência de, pelo menos, dez ocupações sucessivas neste local (Estevez \& Vila 2006). As estruturas de combustão correspondem aos momentos de ocupação do sítio, nos quais sempre era mantida uma fogueira central junto com fogueiras secundárias na periferia, e às vezes fora, da cabana. As lâminas centimétricas de sedimentos finos e pretos que geralmente recobrem as estruturas de combustão,

\footnotetext{
${ }^{56}$ Segundo este modelo, unidades discretas de deposição podem identificar-se em sítios concheiros através da percepção, na escavação, de superfícies de diferente resistência estrutural (sedimentos mais ou menos fáceis de retirar durante a escavação por decapagem) e finas lentes de sedimento terrígeno preto entre as camadas.
} 
foram tomadas como evidência de abandono do local, que se daria após visitas temporais ao sítio (Estevez \& Vila 2006).

A recorrência do uso do local foi responsável pela formação do anel de conchas circundante, pela ação de descarte e varrido de resíduos alimentícios fora da cabana. Em cada visita ao sítio, construíram-se cabanas praticamente sobre o mesmo lugar, aproveitando a concavidade deixada pela acumulação anelar de conchas (Estevez \& Vila 2006). Segundo Verdún (2006, 2010), existia uma intencionalidade na deposição das conchas ao redor da cabana, relacionada com a vontade de construir uma estrutura de proteção.
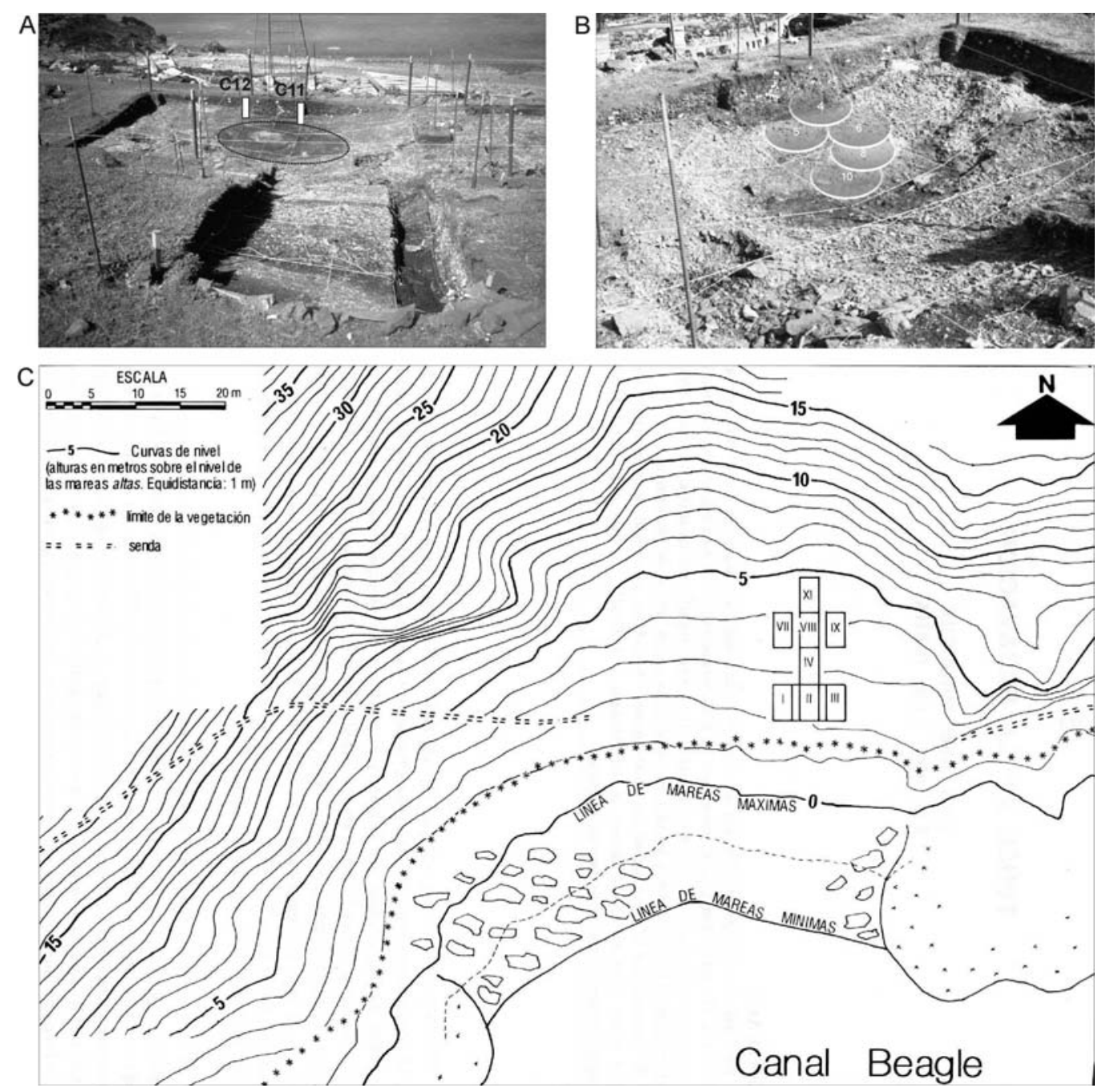

Figura 3.11. Concheiro Túnel 7: A) Vista do sítio, com área escavada embaixo da estrutura de cobertura branca. B) Escavação do concheiro, com localização das duas colunas de amostragem no anel de conchas e delimitação da área central de coupação (linha ponteada). C) Topografia segundo Orquera \& Piana (1995). Na topografia, as quadras delimitam a área do sítio escavado. Quadras I a IV correspondem ao componente moderno, e VII a XI, ao componente antigo. 


\section{SUMÁRIO}

Neste capítulo, apresentou-se a área de estudo desta tese, no litoral sul catarinense, junto com a proposta de Giannini et al. (2010) sobre as quatro fases de ocupação sambaquieira da região e as informações introdutórias sobre os oito sambaquis escolhidos para análise. Apresentou-se, também, a área de estudo no litoral do Canal Beagle (Terra do Fogo), com breve revisão da evolução holocênica do canal e descrição do concheiro etno-histórico que será usado como estudo de caso comparativo.

Das informações aqui apresentadas sobre sambaquis de Santa Catarina extraem-se algumas das problemáticas que serão exploradas neste trabalho. Estas temáticas incluem: a relação entre o processo de formação dos sambaquis e a paleogeografia do local de implantação dos sítios, com uso dos sedimentos arqueológicos como registro das mudanças paleoambientais; o significado da mudança deposicional possivelmente associada à chegada dos grupos Jê ao litoral, e caracterizada pelo aparecimento de sítios mistos e ictio-montículos (sensu Villagran et al., 2010); a função dos sambaquis de menores dimensões e com estratigrafia caracterizada por núcleo arenoso e camada superficial preta, que frequentemente aparecem como estruturas satélite dos sambaquis maiores (ver Assunçao, 2010; Peixoto, 2008); o detalhamento da sucessão de atividades associadas à formação dos sítios; os indicadores sobre proveniência do material construtivo que corroborem o uso de conchas como matéria prima para a elevação das estruturas, como demonstrado por Figuti (1992), e não unicamente como elemento alimentício; e a tafonomia de sambaquis em clima subtropical úmido. No caso do concheiro fueguino, do qual se possui um controle maior sobre a dinâmica cultural envolvida na sua configuração, as temáticas de interesse incluem, entre outras: detalhamento da análise intra-sítio, com identificação, a partir do registro arqueossedimentar, de áreas de atividade dentro do espaço delimitado pelo concheiro; correlação entre os relatos etnográficos e o registro arqueossedimentar, para elaboração de modelos geoarqueológicos que permitam interpretações comportamentais em contextos onde não há disponibilidade de relatos etnográficos; tafonomia de concheiros em climas frios. 


\section{CAPÍTULO 4: MATERIAIS E MÉTODOS}

A proposta metodológica deste trabalho é essencialmente estratigráfica, ou seja, visa entender os processos de formação dos sambaquis, a partir da avaliação das sucessões verticais em seções expostas. Tanto nos sambaquis catarinenses como no concheiro fueguino utilizado como estudo de caso comparativo, o método de análise e interpretação que será aplicado, incluindo etapas de campo e de laboratório, será a análise de fácies arqueológicas, ou arqueofácies, desenvolvida por Villagran (2008, 2010) e Villagran et al. (2009a). Este método foi elaborado com base em propostas de Orquera \& Piana (1992), Stein (1992) e Courty (2001).

\section{ANÁLISE DE FÁCIES E MICROFÁCIES ARQUEOLÓGICAS}

A análise de fácies arqueológicas é um método de estudo estratigráfico que contempla tanto a descrição como a interpretação das sucessões verticais em sítios onde existe recorrência tempo-espacial de unidades arqueológicas. Este método representa uma adaptação da análise de fácies desenvolvida na sedimentologia moderna (Anderton, 1985; Walker, 1983) e foi inspirado nas propostas de Stein (1992) e Courty (2001) na arqueologia. O objetivo é estudar os processos de formação, culturais e naturais, em depósitos arqueológicos estratificados.

\subsection{FUNDAMENTOS DA ANÁLISE DE ARQUEOFÁCIES}

A análise de arqueofácies foi desenhada para aplicação em depósitos arqueológicos construídos, como concheiros ou montículos de terra. Estes depósitos são 
resultado do trabalho humano de acumulação e/ou transporte e deposição massiva de partículas, naturais e artefatuais, em local específico. $\mathrm{Na}$ formação de concheiros estratificados, existe um padrão de processos deposicionais recorrentes, relativos à deposição antrópica de materiais. Esses processos são definidos como processos deposicionais antrópicos que, dentro da dinâmica construtiva de cada sítio, podem repetir-se no tempo e no espaço, dentro do mesmo sítio ou entre sítios diferentes da região. Os produtos sedimentares desses processos são definidos como fácies $\underline{\text { arqueológicas ou arqueofácies }}{ }^{57}$. A fácies arqueológica é uma unidade sedimentar, não confinada estratigraficamente, caracterizada por um conjunto de atributos deposicionais que permitirão interpretar a atividade responsável pela sua formação.

A análise de arqueofácies é entendida como a descrição e classificação de uma sucessão vertical ou perfil estratigráfico seguida da interpretação dos processos antrópicos, ou sucessão de atividades de deposição. Esta análise permite a descrição padronizada das sucessões verticais e auxilia no estabelecimento de relações entre as diferentes arqueofácies identificadas. As características descritas e os atributos estudados auxiliam na interpretação das atividades associadas à evolução (formação e alteração) e/ou construção dos sítios. Deve-se lembrar que, apesar de ser realizada na escala bidimensional, a partir das sucessões estratigráficas, a análise de arqueofácies aponta à reconstrução tridimensional da dinâmica de formação e evolução dos sítios construídos (ver Courty 2001).

\footnotetext{
${ }^{57} \mathrm{O}$ conceito de fácies arqueológica não é equiparável à camada ou unidade arqueológica definidas por Harris (1991). A fácies arqueológica não possui valor necessariamente cronológico, nem meramente descritivo, mas sim também interpretativo.
} 


\subsubsection{Descrição, caracterização e interpretação}

A análise de arqueofácies envolve quatro etapas fundamentais:

1. Descrição detalhada em campo das sucessões verticais segundo a identificação de cinco atributos principais. Variações em qualquer um dos cinco atributos já é requisito suficiente para distinguir entre fácies arqueológicas na sucessão vertical:

- Composição da matriz (incluindo textura, cor e mineralogia).

- Componentes macroscópicos (grãos de areia, concha, ossos de peixe, carvão, artefatos, enterramentos humanos etc. com estimativa visual de porcentagem).

- Forma das fácies (natureza dos limites, se abruptos, graduais, difusos etc., e espessura).

- Estruturas internas (estruturas de combustão, fossas, buracos de estaca, lentes de areia, cinzas, carvão etc.).

- Orientação (fábrica ou tama) dos componentes macroscópicos na matriz.

2. Caracterização das arqueofácies através de análise, no laboratório, das suas propriedades físicas, químicas, isotópicas, biológicas, mineralógicas, micromorfológicas etc.

3. Construção de modelos de arqueofácies, a partir da literatura disponível sobre depósitos semelhantes, com a possibilidade de coleta de amostras experimentais sobre feições antrópicas conhecidas (fogueiras, superfícies de pisoteamento, áreas de preparação de alimentos etc.) e de comparaçãoes interculturais.

4. Interpretação das arqueofácies em termos de processos deposicionais e pósdeposicionais, tanto naturais como antrópicos, e uso dos dados produzidos na construção de explicações culturais e ambientais.

Apesar de não serem critérios utilizados na identificação de arqueofácies, outras propriedades devem ser incluídas na descrição como, por exemplo: abundância e espessura de raízes; presença de estruturas pedogênicas; consistência e compactação. Estas propriedades referem-se à alteração dos sedimentos por processos pedológicos. 
Sua consideração complementa o estudo da formação dos depósitos com informações sobre sua alteração pós-abandono.

A identificação de arqueofácies em campo é sempre complementada com análises no laboratório. Este aprofundamento na composição de cada arqueofácies permitirá caracterizar completamente as semelhanças e diferenças entre elas. A partir do arranjo espacial relativo de cada arqueofácies na sucessão vertical, pode-se identificar a existência de uma ou mais associações de arqueofácies. Cada associação expressa a mudança ou permanência de fácies arqueológicas em termos de atividades ou comportamentos que podem corresponder a uma mesma atividade.

$\mathrm{Na}$ interpretação da composição e arranjo espacial das diferentes arqueofácies na sucessão vertical, utiliza-se a comparação arqueológica intercultural, a arqueologia experimental e análises de macro-vestígios. Este complemento é necessário na elaboração de modelos que expliquem os atributos das diferentes arqueofácies e do depósito arqueológico em conjunto, interpretados em termos de processos de deposição antrópicos, processos de alteração natural e dinâmica da ocupação do espaço. Nesta etapa, é importante avaliar o efeito da equifinalidade, segundo o qual resultados semelhantes podem ter origens distintas. Para isso, toda comparação intercultural deve restringir-se ao processo de deposição enquanto ação mecânica, física ou química, sem avançar, porém, no significado desse processo. A interpretação dos significados associados a cada atividade construtiva (ou deposição de cada arqueofácies) é realizada no contexto cultural específico de estudo.

\subsubsection{Estratigrafia e pedogênese}

Em alguns depósitos arqueológicos pode-se observar uma estratigrafia complexa que envolve a combinação de quatro processos: 1) episódios deposicionais, com crescimento vertical do depósito; 2) deposição e crescimento vertical por agentes naturais (e.g. processos eólicos); 3) alteração pedogênica de sedimentos naturais ou antrópicos a partir da decomposição de resíduos depositados em superfície pela ocupação humana; 4) extração de sedimentos, com escavação de covas, nivelação do terreno etc. No primeiro caso, o depósito ou camada será descrito em termos de arqueofácies, por se tratar de produtos de deposição antrópica. No segundo caso, o 
depósito ou camada se descreverá em termos de fácies sedimentares, por derivar de agentes de deposição naturais. No terceiro caso, o depósito ou camada apresentará uma combinação de fácies antrópicas e naturais alteradas pela pedogênese e será tratado em termos de fácies ou arqueofácies com desenvolvimento de antropossolo ${ }^{58}$.

Este tipo de depósito é frequente em arqueologia e o mais complexo de abordar, devido a que abrange uma fusão entre conceitos de estratificação e pedogênese. Podem ser tratados como "perfis pedoestratigráficos", segundo a terminologia adotada por Arroyo-Kalin (2008) para as terras pretas amazônicas, que envolvem conjuntamente processos de sedimentação e formação de horizontes de solo. No geral, toda sucessão estratigráfica em depósitos arqueológicos construídos pode ser descrita em termos de pedoestratificação, por incluir tanto os processos antrópicos de deposição do sítio, como a alteração pedogênica durante e após o abandono.

No caso dos sambaquis e concheiros, o processo dominante é a deposição antrópica e, pela composição dos sítios, existe boa preservação da estratificação, cuja visibilidade não é obliterada pela pedogênese. Neste trabalho, os sambaquis e concheiros são tratados em termos de arqueofácies. No caso em que a formação do depósito e sua configuração atual estejam marcadas pela pedogênese (formação de horizontes de solo) sobre sedimentos antrópicos ou naturais, o sítio será tratado em termos de pedoestratificação, com desenvolvimento de antropossolo.

Cabe ressaltar que em estratigrafia, o termo pedoestratigrafia usa-se com significado diferente do uso dado em arqueologia. No código norte-americano de estratigrafia (NACSN, 1983), uma unidade pedoestratigráfica define-se como um corpo de rocha enterrado com um ou mais horizontes de solo, desenvolvido sobre unidades litoestratigráficas, aloestratigráficas ou litodérmicas antigas e cobertos por outras unidades litoestratigráficas, aloestratigráficas ou litodérmicas ${ }^{59}$. Outro termo que pode se confundir com a abordagem aqui proposta é o de pedofácies. Diferente de unidades pedoestratigráficas, uma pedofácies refere-se a paleossolos lateralmente contíguos, que se diferenciam como resultado da sua posição diferencial em relação a uma planície de inundação antiga (Bown and Kraus, 1987).

\footnotetext{
${ }^{58}$ Antrossolos são entendidos como solos, ou horizontes de solo, cuja formação e características foram influenciadas pela ação humana (Eidt, 1984; Limbrey, 1975).

${ }^{59}$ As unidades pedoestratigráficas diferenciam-se de outras unidades estratigráficas por serem produtos da alteração de uma ou mais unidades estratigráficas antigas, como resultado da ação de processos em superfície (Cremeens and Hart, 1995).
} 
Neste trabalho, adota-se a terminologia proposta por Arroyo-Kalin (2008), de perfis pedoestratigráficos, chamando à atenção para as diferenças que existem entre o uso do mesmo termo em arqueologia e sedimentologia.

\subsection{FUNDAMENTOS DA ANÁLISE DE MICROFÁCIES}

A análise de microfácies realiza-se a partir do estudo micromorfológico dos sedimentos arqueológicos. Responde aos mesmos objetivos da analise de fácies, com a diferença de que as descrições e interpretações são realizadas na escala microscópica. As interpretações no nível microscópico envolvem igualmente uma aproximação dialética com outras informações derivadas da análise estratigráfica (identificação de fácies e arqueofácies na sucessão vertical), materiais faunísticos, artefatuais e demais componentes orgânicos e inorgânicos do depósito. Modelos sobre formação e alteração de outros contextos arqueológicos, etnoarqueológicos, experimentais e naturais, assimiláveis ao caso de estudo, também são úteis na sua interpretação das microfácies arqueológicas (ver Matthews et al., 1997).

O conceito de microfácies é tradicionalmente utilizado para estudar as histórias deposicionais e diagenéticas de rochas carbonáticas, através de dados sedimentológicos e paleontológicos que podem ser unicamente extraídos da análise de seções delgadas (Flugel 2004). O conceito de microfácies arqueológicas ${ }^{60}$ foi adotado por Courty (2001) como ferramenta para entender a formação das unidades ou camadas arqueológicas e sua variabilidade tempo-espacial.

\footnotetext{
${ }^{60}$ Nos últimos tempos, trabalhos geoarqueológicos utilizaram o conceito de microfácies para estudar a evolução e formação de sítios arqueológicos, principalmente em cavernas, mas também em contextos urbanos do Neolítico, entre outros (ver Ge et al., 1993; Goldberg et al., 2009; Macphail et al., 1997; Matthews et al., 1997 a; Vallverdu, 2009; Wattez, 1990).
} 


\subsubsection{Arqueofácies e microfácies arqueológicas}

As microfácies arqueológicas, assim como as arqueofácies, possuem valor descritivo e interpretativo, e definem-se a partir do agrupamento de características micromorfológicas semelhantes em seções delgadas. Estas características servem para inferir o processo responsável pela formação da microfácies a partir da identificação da origem, meio de transporte e evolução pós-deposicional ou diagenética do sedimento na escala microscópica (Courty et al., 1989; Vallverdu, 2009). As similaridades indicam uma origem análoga para as microfácies, ou seja, que o mesmo processo de deposição teria sido responsável pela formação de microfácies semelhantes (Courty 2001). Associações de microfácies também podem ser identificadas e relacionadas com processos específicos de formação de sítio, como por exemplo, episódios sucessivos de deposição e abandono do sítio, desenvolvimento recorrente de antrossolo sobre um tipo de substrato, entre outros.

Existe uma relação bilateral entre a identificação de arqueofácies em campo e a identificação de microfácies na seção delgada. Por um lado, a identificação de microfácies é fundamental na completa caracterização de arqueofácies e interpretação dos processos antrópicos e naturais vinculados com sua formação e alteração. Por outro lado, uma análise de microfácies completa tem como requisito fundamental o trabalho de campo prévio e a descrição macroscópica dos perfis.

No entanto, a relação entre arqueofácies e microfácies, apesar de bilateral, não é necessariamente direta. Uma arqueofácies identificada em campo é formada, no mínimo, por uma microfácies, mas pode também incluir múltiplas microfácies na sua composição. Isto porque a avaliação microscópica das arqueofácies pode mostrar uma maior complexidade do que o observado a olho nu, com presença de microestratificações ou componentes sedimentares de origem diversa em uma única arqueofácies. 


\subsubsection{Identificação e classificação}

Os critérios utilizados para identificação e distinção de microfácies em uma mesma seção delgada ou em diferentes seções delgadas do mesmo sítio são ainda variáveis em arqueologia. Segundo Courty (2001), as microfácies se classificam de acordo ao grau de alteração antrópica que apresentam os sedimentos a respeito do solo ou sedimento natural. Esta estratégia de classificação é freqüentemente utilizada no estudo micromorfológico de sítios arqueológicos em cavernas do Paleolítico e em tells do próximo oriente (Courty, 2001; Courty et al., 2012; Vallverdu, 2009). No entanto, a diversidade de contextos arqueológicos e a falta de modelos abrangentes fazem com que cada sítio seja tomado como único, e que os critérios sejam definidos em função das características de contextos específicos.

Para o caso dos sambaquis e concheiros, que representam depósitos completamente antrópicos e não solos ou sedimentos naturais alterados pela ação humana, os critérios para a diferenciação de microfácies seguem a lógica proposta para a identificação de arqueofácies no campo. Ou seja, priorizam-se os atributos deposicionais ou penecontemporâneos à deposição na identificação de microfácies e não o grau de alteração antrópica de um sedimento natural, como proposto por Courty (2001). Esta estratégia vincula-se com a proposta de (Goldberg et al., 2009), que usam o conceito de microfácies acunhado por Courty (2001), mas no sentido sedimentológico de Flugel (2001), como mudanças litológicas numa mesma seção delgada. Assim, definem-se os seguintes atributos diagnósticos na diferenciação de microfácies em seções delgadas de sambaquis e concheiros. Qualquer variação em um dos atributos é suficiente para a diferenciação entre microfácies:

- Fração grossa: a diversidade, freqüência, completitude, orientação e distribuição dos componentes grossos, principalmente malacológicos, é fundamental na interpretação da atividade deposicional e da alteração pós-deposicional produzida durante a ocupação ou após o abandono do sítio.

- Micromassa: sua composição é chave no entendimento dos processos deposicionais e tafonômicos. $\mathrm{Na}$ descrição, consideram-se suas 
propriedades ópticas a PPL (limpidez) e XPL (b-fábrica ou fábrica de birrefringência).

- Microestrutura: oferece informação sobre o grau e tipo de alteração pósdeposicional e pedogênica.

- Porosidade: ajuda a esclarecer a compactação antropogênica e/ou alteração biológica dos sedimentos arqueológicos.

- Razão g/f: define a proporção numérica, dada em porcentagem, entre a fração fina e grossa, permite avaliar a variação entre microfácies que apresentam a mesma composição, mas que podem ter sido produzidas por atividades diferentes. A distribuição relacionada $\mathrm{g} / \mathrm{f}$ define o arranjo e relação entre componentes finos e grosos na lâmina, que pode ser de quatro tipos: mónica, quitónica, gefúrica, enáulica ou porfírica (Anexo, Figura A.1).

Após a identificação de microfácies, segundo os critérios mencionados, realizase sua classificação a partir da comparação sistemática de todas as microfácies identificadas em um mesmo sítio, ou em sítios da mesma região. Esta classificação permite identificar tendências gerais na origem, modo e/ou condições de deposição de cada microfácies (Courty 2001). Seguindo Courty (2001), para classificação de microfácies serão considerados três aspectos: 1) relação entre as propriedades identificadas no campo e na escala microscópica; 2) propriedades micromorfológicas que sejam comuns a todas, ou pelo menos parte, das arqueofácies identificadas na sucessão vertical; 3) propriedades micromorfológicas que sejam comuns às microfácies identificadas em uma mesma arqueofácies ou em arqueofácies discretas na em diferentes porções do sítio (variação lateral).

$\mathrm{Na}$ etapa de classificação, pode-se chegar á conclusão de que microfácies semelhantes aparecem em arqueofácies identificadas em campo como diferentes. As semelhanças micromorfológicas entre arqueofácies discretas podem ser interpretadas como indicador de origens similares ou, no mínimo, de modos de deposição semelhantes (Courty 2001). Assim, a mesma microfácies pode acontecer reiteradas vezes no mesmo perfil estratigráfico, em diferentes perfis dentro de um mesmo sítio, ou em perfis de sítios distintos, indicando processos análogos na formação dos depósitos. A analogia na escala microscópica pode decorrer de similaridade de fonte ou de processo deposicional, mas não necessariamente de forma, posição, espessuras e taxas 
de deposição. Assim, microfácies análogas em fácies distintas não significam necessariamente que as fácies devam ser redefinidas totalmente como análogas.

\subsection{NOMENCLATURA}

Para diferenciar as fácies arqueológicas $(\mathrm{AF})$ das fácies naturais na descrição das sucessões verticais em campo, serão utilizadas duas nomenclaturas diferentes. As arqueofácies serão classificadas segundo sistema numérico da base até o topo da sucessão (AF 1, AF 2, AF 3, ...), enquanto as fácies naturais serão classificadas segundo sistema alfabético seqüencial da base até o topo da sucessão (Fácies A, Fácies B, Fácies C, ...). Quando mais de uma amostra é coletada da mesma arqueofácies, será utilizada uma nomenclatura alfanumérica para identificar as diferentes amostras. Por exemplo, se três blocos inalterados são coletados da AF 1, cada amostra será identificada como 1a, $1 \mathrm{~b}$ e $1 \mathrm{c}$.

$\mathrm{Na}$ descrição micromorfológica, será utilizado o conceito de microfácies $(\mathrm{mF})$. Arqueofácies (AF) e microfácies $(\mathrm{mF})$ serão utilizadas de maneira complementar neste trabalho. Como explicado no tópico 1.2.2, a relação entre arqueofácies e microfácies não é direta, e sempre existe a possibilidade de uma arqueofácies incluir mais de uma microfácies em seção delgada. Quando uma única microfácies é identificada, o número da $\mathrm{mF}$ corresponderá com o da $\mathrm{AF}$, ou seja, se na $\mathrm{AF} 2$ identificou-se uma única microfácies, esta será classificada como mF 2. Nos casos em que existir mais de uma microfácies por arqueofácies, a classificação incluirá sempre o número da arqueofácies, mais uma subclassificação numérica da microfácies à qual pertence. Por exemplo, se na AF 3 observaram-se três microfácies, cada microfácies será identificada da seguinte maneira: mF 3.1, mF 3.2 e mF 3.3. Nos casos em que a mesma microfácies seja descrita em diferentes amostras da mesma arqueofácies, utiliza-se o sistema alfanumérico de classificação, ou seja, se duas amostras foram coletadas da arqueofácies 4 (amostras 4a e 4b), então as microfácies correspondentes serão identificadas como $\mathrm{mF} 4 \mathrm{a}$ e mF 4b. 


\section{AMOSTRAGEM}

O trabalho de campo e amostragem realizados nesta tese foram dirigidos à caracterização e interpretação de arqueofácies nos oito sambaquis analisados. Coletaram-se amostras de sedimento total, para análises granulométricas e isotópicas, amostras de sedimento por volume padrão, para zooarqueologia, e amostras indeformadas para micromorfologia e microscopia eletrônica de varredura. Como complemento à caracterização e interpretação das arqueofácies, amostras extra-sítio foram coletadas de depósitos naturais nas proximidades de alguns sambaquis, assim como coleções experimentais foram confeccionadas para fornecer parâmetros de referência na leitura e interpretação de arqueofácies e microfácies.

Para o estudo de caso comparativo, o do concheiro etno-histórico Tunel 7, foi utilizada uma coleção de amostras arqueológicas, naturais e experimentais para análise micromorfológica, coletadas na década de 1990 e nunca antes analisadas. Os diferentes procedimentos serão apresentados conforme os dois contextos geográficos de estudo: Santa Catarina e Terra do Fogo.

\subsection{SAMBAQUIS}

\subsubsection{Amostragem arqueológica}

Em todos os sambaquis estudados, foram realizadas as seguintes atividades em campo: 1) descrição do contexto geológico-geomorfológico de localização; 2) escolha das seções verticais que melhor representam a composição do sambaqui; 3) descrição e identificação de arqueofácies, segundo critérios definidos no tópico 1.2; 4) amostragem de sedimento total ( $\sim 300 \mathrm{~g})$ e de blocos coesivos indeformados $(10 \times 5 \times 6 \mathrm{~cm})$ em cada uma das arqueofácies identificadas nos perfis; 5) coleta, por volume padrão, para zooarqueologia, realizada somente nos sítios que, até o momento, não foram caracterizados quanto ao conteúdo faunístico; 6) amostragem na área de controle fora do 
sítio ( 200 g de sedimento) para identificação de fácies deposicionais naturais e reconhecimento de áreas fonte de materiais constituintes dos sambaquis.

A amostragem de sedimento total foi realizada naquelas arqueofácies nas quais o conteúdo faunístico não era predominante, ou seja, nas quais se identificaram sedimentos terrígenos em porcentagem estimada visualmente superior a $20 \%$. Coletouse um total de 21 amostras de sedimento total para análise granulométrica, das quais 18 foram utilizadas para análises isotópicas. A coleta de amostras por volume para análise zooarqueológica seguiu a proposta de Scheel-Ybert et al. (2005) e visou caracterizar o conteúdo faunístico das arqueofácies.

Um total de 23 blocos inalterados para análise micromorfológica foi coletado das diferentes arqueofácies identificadas nos oito sambaquis estudados. Para coleta no campo de cada amostra destinada à micromorfologia, um bloco de material foi esculpido cuidadosamente na seção exposta, com ajuda de canivete e espátula. Uma vez esculpido, encaixou-se nele o recipiente de amostragem (que neste caso foram caixas de papelão de $10 \times 6 \times 4 \mathrm{~cm}$ ) e efetuou-se a extração do bloco, com a mínima alteração possível das amostras. Uma vez extraídos, os blocos foram embrulhados com filme de PVC e fita crepe, e sua orientação (topo e base) indicada com uma seta. A escolha das posições de amostragem fez-se de modo a abranger a totalidade das mudanças estratigráficas observadas nas seções verticais dos sambaquis estudados (ver Courty et al., 1989; Goldberg \& Macphail, 2008), com ênfase nos limites entre arqueofácies.

\subsubsection{Amostragem externa}

O componente natural mais recorrente na composição dos sambaquis, embora menos conspícuo que as conchas, são as areias terrígenas, principalmente quartzosas. Este componente é primordial nos sistemas deposicionais da região, identificados por Giannini (1993) como lagunar, barreira e eólico. Para avaliar os componentes naturais nos sedimentos que compõem os sambaquis optou-se por estudar a fração areia terrígena e comparar as areias no sambaqui com as areias dos depósitos naturais. Desta maneira, evita-se a interferência de sedimentos finos na comparação, suscetíveis a lixiviação, e elementos orgânicos, sempre mais abundantes nos sítios arqueológicos que nos depósitos naturais. 
Em quatro dos sítios estudados (Caipora, Santa Marta 8, Santa Marta 10 e Cubículo1), foram abertas trincheiras em depósitos naturais a poucas dezenas de metros dos sítios. Em todas as trincheiras abertas, foram coletadas amostras de sedimento total para realização de análises granulométrica e isotópica. Unicamente na fácies superior (crosta orgânica) da trincheira externa ao sítio Santa Marta 10, coletou-se também uma amostra indeformada para micromorfologia. $\mathrm{Na}$ trincheira aberta nas proximidades do sítio Caipora, coletou-se amostra apenas da fácies superior. No sítio Cubículo 1, coletaram-se amostras das duas fácies identificadas, assim como no sítio Santa Marta 10. Na trincheira próxima ao sítio Santa Marta 8, foram coletadas amostras de todas as fácies, exceto da superior.

Apesar de não se contar com datações nos sedimentos naturais que permitam correlacionar a idade do depósito com o intervalo de formação dos sambaquis, a comparação entre a fração areia terrígena do depósito natural e arqueológico, em termos de proveniência e disponibilidade de sedimentos no momento de funcionamento dos sítios, ainda é possível; especialmente naqueles sítios localizados no sistema lagunar, como Caipora e Cubículo 1, sistema que se caracteriza por taxa de sedimentação baixa, o que significa que amostras superficiais não são necessariamente mais recentes que os sambaquis localizados nas proximidades (ver Fornari, 2010; Nascimento, 2010).

Nos sambaquis localizados no sistema deposicional eólico, a comparação granulométrica e cronológica está respaldada pela idade inferida do depósito natural amostrado a partir da identificação da geração de dunas à qual pertence, como no caso de Santa Marta 10. No sítio Santa Marta 8, a identificação de uma camada arqueológica centimétrica na trincheira aberta para amostragem externa, da mesma composição que o sambaqui, estabeleceu um limite cronológico, para o depósito natural amostrado, que habilita a comparação. Para os demais sambaquis onde não houve necessidade de amostragem externa (Morrinhos, Jabuticabeira 1 e Galheta 4), a comparação granulométrica foi realizada com dados disponíveis na bibliografia (Fornari, 2010; Giannini, 1993; Giannini et al., 2007; Martinho, 2004; Nascimento, 2010; Sawakuchi, 2003; Tanaka, 2007; Villagran, 2008) em trincheiras e testemunhos localizados próximos aos sambaquis e de cronologia semelhante. 


\subsubsection{Experimental}

O uso de abordagens experimentais é ainda incipiente na micromorfologia arqueológica $^{61}$. Neste trabalho, a amostragem experimental visa fornecer parâmetros de referência sobre elementos conhecidos que podem ser encontrados no registro arqueológico. Especialmente no que refere a estruturas de combustão, a sua identificação no campo pode ser enganosa em sambaquis, onde a granulação grossa do substrato da fogueira, composto principalmente por conchas, areia e ossos de peixe, pode comprometer a preservação dos subprodutos da queima, como cinzas e microcarvões. Ao mesmo tempo, a ubiqüidade de resíduos de queima, que formam parte da matriz sedimentar destes sítios (ver Bianchini 2008; Klokler 2008; Villagran 2008, 2010; Villagran et al. 2009, 2010), pode levar a conclusões precipitadas quanto à presença de fogueiras estruturadas. Os resíduos da queima podem apresentar diversas configurações em contextos arqueológicos (e.g. fogueiras in situ vs. fogueiras retrabalhadas), assim como seguir diferentes trajetórias de alteração sin e pósdeposicionais. Para a identificação certeira de contextos de queima in situ ou de seus restos remanejados, foram confeccionadas duas coleções de queima experimentais.

A primeira coleção de amostras obteve-se a partir de duas fogueiras experimentais, uma acesa sobre paleoduna eólica e outra sobre sedimentos retrabalhados de sambaqui. A primeira fogueira trata-se de uma pequena depressão escavada na areia, de $30 \mathrm{~cm}$ de diâmetro, sobre depósito de geração eólica 2 (prémáxima inundação holocênica conforme Giannini, 1993 e Giannini et al., 2007) na localidade de Bentos, cerca de $5 \mathrm{~km}$ a norte da cidade de Laguna. A segunda foi acesa sobre restos de retrabalhamento do sambaqui da Cabeçuda, situado na ponta de mesmo nome, também em Laguna. A temperatura de ambas foi medida a intervalos de 15 minutos, com uso de termopares conectados a termômetro digital. O combustível

\footnotetext{
${ }^{61}$ Os antecedentes que existem sobre micromorfologia experimental incluem o trabalho de Macphail et al. (2003), no montículo experimental de Wareham e em pisos de ocupação na Bretanha (Macphail, 2004), os estudos geo-etnoarqueológicos de Shahack-Gross (2003, 2004) e Shahack-Gross et al. (2008), em sítios pastoris, e de Mallol et al. (2007) em fogueiras dos grupos Hadza. Em fogueiras experimentais, o trabalho de Miller et al. (2010) apresenta parâmetros para a identificação de fogueiras in situ e retrabalhadas, a partir do estudo, na escala microscópica, de seis contextos de retrabalhamento antrópico dos resíduos de queima. Em concheiros, fogueiras experimentais foram realizadas por March \& Ferreri (1989), com importante aporte de informações a respeito da morfologia e gradiente de alteração térmica de fogueiras planas em substrato conchífero, porém, sem dados quanto às características micromorfológicas desse tipo específico de estrutura de combustão.
} 
utilizado para as fogueiras incluiu unicamente troncos, galhos e grama seca de espécies locais coletadas dos arredores de cada local escolhido para a experiência. Uma vez acesas as fogueiras, a elas adicionaram-se conchas de Anomalocardia brasiliana recémcoletadas no seu ambiente de vida, assim como restos de peixe, principalmente ossos de esqueletos descarnados. As conchas foram compradas em mercado local de Florianópolis e os restos de peixe foram obtidos de uma indústria local de processamento dos peixes pescados das lagoas da região. Cada vez que estes materiais eram jogados no fogo, mediu-se a temperatura das chamas e observou-se a alteração térmica superficial (abertura das conchas, desidratação dos ossos, carbonização, calcinação e queima superficial com coloração avermelhada a marrom). A descrição das fogueiras e objetivos da amostragem encontra-se no Quadro 4.1.

A segunda coleção experimental visou completar a caracterização de estruturas de combustão em sambaquis da região, com um estudo específico sobre os efeitos da queima em conchas da espécie de molusco neles mais freqüente, a Anomalocardia brasiliana. A proposta é que os atributos observados na alteração térmica das conchas desta espécie possam auxiliar na inferência da temperatura de queima em fogueiras in situ, ou na identificação de materiais retrabalhados de contextos de queima diferentes (a partir da mistura de materiais com temperaturas de queima diversas).

A coleção foi elaborada a partir da queima controlada das conchas de $A$. brasiliana, em mufla, a intervalos de temperatura de 200, 300, 400, 500, 600, 700 e $800^{\circ} \mathrm{C}$.

Quadro 4.1 Amostragem experimental em fogueiras e queima controlada de moluscos para atuar como referência na identificação de fogueiras in situ e de resíduos queimados remanejados nos sambaquis.

\begin{tabular}{|c|c|c|}
\hline Contexto & Descrição & Objetivo \\
\hline $\begin{array}{l}\text { Fogueira sobre } \\
\text { paleoduna } \\
\text { eólica }\end{array}$ & $\begin{array}{l}\text { Na localidade de Bentos, } \\
\text { Laguna, sobre depósitos } \\
\text { arenosos de geração eólica } 2\end{array}$ & $\begin{array}{l}\text { Caracterizar fogueiras in situ em substrato arenoso. } \\
\text { Avaliar a temperatura máxima de queima em areias. }\end{array}$ \\
\hline $\begin{array}{l}\text { Fogueira sobre } \\
\text { substrato } \\
\text { conchífero }\end{array}$ & $\begin{array}{l}\text { Sobre depósito de } \\
\text { retrabalhamento do sambaqui } \\
\text { Cabeçuda, Laguna }\end{array}$ & $\begin{array}{l}\text { Caracterizar fogueiras in situ em substrato } \\
\text { conchífero. Avaliar as características macro e } \\
\text { microscópicas da queima em sambaquis }\end{array}$ \\
\hline $\begin{array}{l}\text { Queima } \\
\text { controlada de } A \text {. } \\
\text { brasiliana }\end{array}$ & $\begin{array}{l}\text { Em mufla, a } 200,300,400 \\
500,600,700 \text { e } 800^{\circ} \mathrm{C}\end{array}$ & $\begin{array}{l}\text { Identificar conchas queimadas em seção delgada, } \\
\text { registrar as características ópticas de sua queima a } \\
\text { diferentes temperaturas, obter parâmetros para } \\
\text { reconhecer fogueiras retrabalhadas e in situ }\end{array}$ \\
\hline
\end{tabular}




\subsection{CASO DE ESTUDO COMPARATIVO: CONCHEIRO TÚNEL 7}

\subsubsection{Amostragem arqueológica}

No concheiro Túnel 7, foram estudadas duas coleções micromorfológicas que provêm de coletas realizadas durante os trabalhos de campo de 1990 e 1992, no litoral norte do Canal Beagle. Consistem em uma coluna de amostragem no anel de conchas periférico (sete amostras), e nove seções delgadas de amostras coletadas, em planta, em cinco fogueiras antrópicas identificadas durante a escavação na área central do concheiro. Esta estratégia de amostragem é pouco freqüente em estudos micromorfológicos, que geralmente enfatizam variações verticais. Seu valor reside na possibilidade de entender tanto as características estratigráficas como as variações espaciais laterais do sítio, o que permitirá articular melhor a informação sedimentar com a diversidade de comportamentos e atividades associadas à formação do concheiro.

\subsubsection{Amostragem externa}

O uso de análogos modernos recuperados de feições e elementos conhecidos, como fogueiras ou áreas de pisoteamento, apesar de ser extremamente útil na interpretação dos múltiplos significados que caracterizam as microfácies arqueológicas, não é freqüente. Em alguns casos, utilizam-se amostras coletadas de solos das proximidades dos sítios arqueológicos para atuar como material de controle e identificar os aportes e modificações introduzidos no substrato pela atividade antrópica (ver Arroyo-Kalin, 2008; Macphail et al., 2003; Shahack-Gross, 2003; Vallverdu, 2009).

Uma coleção de amostras de controle foi feita durante o trabalho de campo de 1995 no litoral norte do Canal Beagle. Esta coleção inclui uma série de feições e elementos deposicionais regionais conhecidos, com destaque para contextos naturais. $\mathrm{O}$ objetivo desta coleta é avaliar os processos de alteração locais, vinculados

principalmente a fatores climáticos, e caracterizar em seção delgada materiais conhecidos, para facilitar sua posterior identificação nas seções provenientes dos sítios arqueológicos. 
A coleção de referência em questão consiste em cinco amostras coletadas do seguinte grupo de elementos naturais: 1) caminho de animais, pisoteado pelo gado diaramente, para avaliar os efeitos físicos do pisoteamento; 2) praia de seixos, próxima ao concheiro Lanashuaia, para caracterização do depósito e identificação de componentes da praia no sítio arqueológico; 3) solo sob floresta de Nothofagus sp., a poucos metros da costa, para avaliar as condições locais de decomposição, bioturbação e pedogênese.

\subsubsection{Experimental}

A amostragem experimental foi realizada durante a atividade de campo de 1995. Esta amostragem foi pioneira em estudos micromorfológicos e motivou e serviu como modelo para a realização das fogueiras experimentais e da coleção de valvas queimadas de A. brasiliana voltadas ao estudo dos sambaquis catarinenses. A coleção inclui três fogueiras de função diferente, acesas sobre substratos diversos: 1) fogueira efêmera sobre grama; 2) fogueira efêmera sobre praia de seixos; 3 ) fogueira do acampamento dos arqueólogos. A descrição das fogueiras aparece no Quadro 4.2. Todas as amostras foram impregnadas logo após a coleta, segundo procedimento descrito por Solé (1991), e laminadas em 2009 no laboratório Earthslides (Cambridge, Inglaterra).

Junto com as fogueiras, elaborou-se uma coleção de conchas de Mytilus edulis, principal componente malacológico dos concheiros do Canal Beagle, queimadas sob condições controladas em mufla a intervalos de temperatura de 200, 300, 400, 500, 600, 700 e $800^{\circ} \mathrm{C}$. 
Quadro 4.2. Amostragem experimental em fogueiras e queima controlada de moluscos para atuar como referência na identificação de fogueiras in situ e resíduos queimados remanejados em concheiros do Canal Beagle.

\begin{tabular}{|c|c|c|}
\hline Contexto & Descrição & $\begin{array}{c}\text { Objetivo } \\
\end{array}$ \\
\hline $\begin{array}{l}\text { Fogueira acesa no } \\
\text { prado }\end{array}$ & $\begin{array}{l}\text { De curta duração, sobre } \\
\text { grama em área costeira }\end{array}$ & $\begin{array}{l}\text { Caracterizar a configuração e preservação de fogueiras } \\
\text { efêmeras sobre gramíneas }\end{array}$ \\
\hline $\begin{array}{l}\text { Fogueira acesa na } \\
\text { praia de seixos }\end{array}$ & $\begin{array}{l}\text { De curta duração, } \\
\text { próxima ao concheiro } \\
\text { Lanashuaia }\end{array}$ & $\begin{array}{l}\text { Caracterizar a configuração e preservação de fogueiras } \\
\text { efêmeras sobre praia de cascalho }\end{array}$ \\
\hline $\begin{array}{l}\text { Fogueira acesa no } \\
\text { acampamento dos } \\
\text { arqueólogos }\end{array}$ & $\begin{array}{l}\text { Utilizada pela equipe } \\
\text { durante um mês de } \\
\text { campo }\end{array}$ & $\begin{array}{l}\text { Caracterizar a configuração e preservação de fogueiras } \\
\text { de longa duração }\end{array}$ \\
\hline $\begin{array}{l}\text { Combustão } \\
\text { controlada de } \\
\text { Mytilus edulis }\end{array}$ & $\begin{array}{l}\text { Em mufla, a } 200,300 \\
400,500,600,700 \mathrm{e} \\
800^{\circ} \mathrm{C}\end{array}$ & $\begin{array}{l}\text { Identificar conchas queimadas em seção delgada, } \\
\text { registrar as características ópticas de sua queima a } \\
\text { diferentes temperaturas, obter parâmetros para } \\
\text { reconhecer fogueiras retrabalhadas e in situ }\end{array}$ \\
\hline
\end{tabular}

\section{PROCEDIMENTOS ANALÍTICOS}

A etapa de caracterização laboratorial é fundamental na análise de arqueofácies e consiste na realização de ensaios que proporcionem informações mais detalhadas sobre a natureza das fácies arqueológicas identificadas em campo. As características composicionais dos sedimentos permitirão confirmar a identificação de fácies realizada no campo e aprofundar ou refinar a descrição das propriedades de cada arqueofácies, para contar com parâmetros de comparação intra e inter-sítio. As análises que serão realizadas neste trabalho se descrevem nos próximos tópicos.

\subsection{MICROMORFOLOGIA}

Neste trabalho, a micromorfologia tem um papel fundamental na caracterização de arqueofácies. Esta técnica envolve a descrição microscópica dos componentes de solos e sedimentos, a maneira em que estes se relacionam entre si e as hierarquias existentes entre os diferentes processos atuantes nos depósitos (Courty, 2001; Courty et al., 1989; Goldberg and Macphail, 2008). A integração da micromorfologia ao acervo das 
ferramentas geoarqueológicas padrão é cada vez maior. Apesar do seu primeiro uso em arqueologia remontar à década de 1950 (Cornwall, 1958; Darlymple, 1958), é nos últimos 20 anos que houve uma explosão do seu uso em pesquisas arqueológicas. Esta recente valorização da micromorfologia deve-se principalmente à sua resposta a demandas de pesquisas de alta resolução, no que se refere à reconstrução paleoambiental e processos de formação de sítio $^{62}$.

Apesar da crescente quantidade de pesquisas em micromorfologia de depósitos arqueológicos, ainda existem contextos nos quais a técnica é pouco utilizada. Entre estes se encontram os sítios concheiros, caracterizados por estratigrafias complexas formadas por sedimentos porosos, nos quais domina a fração grossa formada por valvas de diversas espécies de moluscos e gastrópodes. A primeira aproximação à micromorfologia de concheiros foi realizada pela equipe de pesquisa que trabalha com os concheiros do Canal Beagle desde 1986. Para estes pesquisadores, estudos microestratigráficos são fundamentais como complemento da análise de processos de formação de sítio, ao prover com informações de alta definição a identificação de episódios de acumulação de conchas, áreas de pisoteamento, períodos de abandono, alterações tafonômicas etc.

Até o momento, os únicos trabalhos sobre micromorfologia de concheiros da América do Sul derivam da análise dos concheiros fueguinos (Balbo et al., 2010; Taulé, 1996) e do estudo do sítio Jabuticabeira II realizado por Villagran (2008) e Menezes (2009). Neste sentido, a pesquisa aqui proposta dá continuidade a estes trabalhos, que têm demonstrado o valor da micromorfologia como ferramenta no estudo de concheiros.

Dos oito sambaquis estudados nesta tese, foram coletados 24 blocos inalterados para micromorfologia. As amostras foram secas em estufa a $50^{\circ} \mathrm{C}$, impregnadas com mistura de resina, endurecedor e solvente, e laminadas em seções delgadas de 14 x 6.7 $\mathrm{cm}$, de 11 × 7.6 e de 7.5 × $5 \mathrm{~cm}$, todas com $30 \mu \mathrm{m}$ de espessura, no laboratório

\footnotetext{
${ }^{62}$ Nas últimas décadas, a técnica tem sido aplicada em grande variedade de contextos culturais, que incluem: sítios em cavernas e abrigos (Araujo et al., 2008; Courty \& Vallverdu, 2001; Goldberg, 2000; Goldberg \& Arpin, 1999; Homsey \& Capo, 2006; Karkanas, 2000; Karkanas et al., 2007; Mallol et al., 2009; Schiegl, 1996); pisos de ocupação ( Courty, 2001; Ge et al., 1993; Gebhardt \& Langohr, 1999; Goldberg \& Whitbred, 1993; Macphail, 2004; Matthews et al., 1997; Shahack-Gross et al., 2005); atividades agrícolas e de adubação (Adderley et al., 2006; Guttmann, 2005; Macphail et al., 1990); depósitos ictiológicos (fish middens) (Simpson, 1996; Simpson et al., 2005; Simpson \& Milek, 1999; Villagran et al., 2009a); montículos de terra (earthen mounds) (Cremeens, 2005; Macphail et al., 2003); sítios de pastoreio (Goldberg \& Whitbred, 1993; Shahack-Gross, 2003; Shahack-Gross, 2004; ShahackGross \& Finkelstein, 2008); terras pretas antropogênicas (Arroyo-Kalin, 2008; Devos et al., 2009; Lima, 2002; Schaefer et al. 2004); sítios paleoíndios a céu aberto ( Macphail \& McAvoy, 2008); entre outros.
} 
Earthslides (Cambridge, Inglaterra). As amostras para micromorfologia coletadas das fogueiras experimentais e da queima controlada de $A$. brasiliana foram impregnadas a vácuo com mistura de resina epóxi, endurecedor e álcool etílico como diluente, segundo procedimento descrito por de Paula et al. (1991) e laminadas em seções delgadas de 4.5 x $2.5 \mathrm{~cm}$ no laboratório de laminação do Instituto de Geociências (IGc/USP). A análise micromorfológica foi realizada ao estereomicroscópio Zeiss Stemi SV11 e microscópio óptico petrográfico Zeiss Axioplan 2, sob luz polarizada plana (PPL), luz polarizada cruzada (XPL) e luz ultravioleta (UVL) no laboratório de petrografia do Instituto de Geociências (IGc/USP).

As amostras do concheiro Tunel 7 (coluna e fogueiras) e valvas queimadas de M. edulis foram impregnadas segundo procedimento exposto por Solé (1991) e laminadas no Instituto de Geologia Jaume Almera (CSIC, Espanha) em seções de 7 x 5 $\mathrm{cm}$. As amostras de contextos naturais foram impregnadas no Instituto de Geologia Jaume Almera (CSIC, Espanha) e laminadas em 2009 no laboratório Earthslides (Cambridge, Inglaterra). Todas as amostras foram analisadas sob PPL, XPL e luz incidente oblíqua (OIL) com ajuda de um estereomicroscópio Leica MZ95 e microscópio óptico de luz polarizada Olympus BX51, no Laboratório de Arqueologia da Institução Milá i Fontanals (CSIC, Barcelona).

A descrição das lâminas foi feita segundo roteiros sugeridos por Bullock et al. (1985), Courty et al. (1989), Fitzpatrick (1993) e Stoops (2003). As porcentagens de porosidade e components da fração grossa foram realizadas por estimação visual auxiliada por diagramas de referência tomados de Stoops (2003). A porcentagem de porosidade foi estimada em relação ao volume total da amostra e as porcentagens da fração grossa foram estimadas em relação aos diversos componentes.

A identificação de conchas com alteração térmica foi realizada em case aos parâmetros definidos pelos experimentos de queima de A. brasiliana e Mytilus edulis. Alem das propriedades ópticas da queima (a PPL e XPL), conchas queimadas a diversa temperatura também foram identificadas pela coloração amarela dos fragmentos na luz ultravioleta (Courty et al., 1989). A queima em ossos foi identificada, em seção delgada, quando os fragmentos apresentam coloração avermelhada, castanha ou preta (PPL) nas bordas ou superfície, assim como alta birrefringência (XPL) e ausência de fosforescência na luz ultravioleta (Courty et al., 1989; Schiegl et al., 2003). 


\subsection{GRANULOMETRIA DA FRAÇÃO TERRÍGENA}

A granulometria será utilizada como parâmetro de comparação entre sedimentos arqueológicos e sedimentos naturais, para conhecer a origem das areias terrígenas que compõem os sedimentos dos sambaquis. Para isso, é necessário descartar o componente orgânico e inorgânico bioclástico dos sedimentos arqueológicos e naturais e assim poder relacionar ambos os grupos de amostras com base exclusivamente na fração areia terrígena.

O método desenvolvido para separação da fração terrígena, em amostras de sedimentos arqueológicos e naturais, requer o ataque químico, primeiro com $\mathrm{HCl}(50 \%)$ a frio, para eliminar carbonatos de cálcio $\left(\mathrm{CaCO}_{3}\right)$ e ossos, e depois com peróxido de hidrogênio $\left(\mathrm{H}_{2} \mathrm{O}_{2}\right)$ em chapa quente a $90^{\circ} \mathrm{C}$, para retirar a matéria orgânica (MO). Nos sedimentos arqueológicos, as amostras são em seguida desagregadas em almofariz com pistilo de borracha e os carvões presentes na fração areia (escolhida para comparação) são intencionalmente fragmentados até alcançar a fração fina (silte/ argila), para ser posteriormente retirados por lavagem em peneira. Em ambos os conjuntos de amostras, somente a fração areia do material resistente restante, supostamente dominado por terrígenos silicáticos, principalmente quartzo e feldspato, será peneirado e sua granulometria determinada.

As distribuições granulométricas obtidas por este método serão utilizadas para determinação de estatísticas descritivas (assimetria, desvio padrão, diâmetro médio e curtose) pelo método analítico dos momentos de Pearson, no programa MOMENTOS.xls. Todas as amostras foram processadas no laboratório de sedimentologia do Instituo de Geociências da Universidade de São Paulo (IGc/USP). Os resultados das análises granulométricas encontram-se no Anexo, Tabela A.1.

$\mathrm{Na}$ amostragem externa, a comparação entre a fração terrígena do sambaqui e dos sedimentos naturais será realizada a partir da apreciação visual dos histogramas de distribuição granulométrica. Nos casos em que é possível a comparação dos dados dos sambaquis com dados obtidos na bibliografia sobre os depósitos naturais das proximidades dos sítios, serão comparadas as estatísticas descritivas entre sedimentos arqueológicos e naturais mediante o uso de diagramas de caixa (boxplot). No caso dos sítios Morrinhos e Jabuticabeira 1, utilizou-se na construção de gráficos, dados 
provenientes de diferentes fácies identificadas no sistema lagunar, assim como diferentes arqueofácies no sambaqui, com número de amostras equivalente ou pouco superior no depósito natural.

\subsection{ISOTOPIA DE CARBONO $\left(\delta^{13} \mathrm{C}\right)$ E NITROGÊNIO $\left(\delta^{15} \mathrm{~N}\right)$}

A análise de isótopos estáveis de carbono e nitrogênio $\left(\delta^{13} \mathrm{C}\right.$ e $\left.\delta^{15} \mathrm{~N}\right)$ na matéria orgânica (MO) de solos e sedimentos, junto com a determinação da razão $\mathrm{C} / \mathrm{N}$, permite rastrear a origem dos materiais orgânicos. A razão $\mathrm{C} / \mathrm{N}\left(\mathrm{C}_{\text {orgânico }} / \mathrm{N}_{\text {total }}\right)$ possibilita diferenciar o aporte de MO de origem aquática ou marinha (algas e fitoplâncton) e de MO terrestre (plantas em geral). Os valores de $\delta^{13} \mathrm{C}$ utilizam-se para refinar, na identificação de plantas terrestres, as que pertencem ao tipo $\mathrm{C}_{3}$ (espécies arbóreas, arbustivas e algumas Poaceae) ou $\mathrm{C}_{4}$ (maioria das Poaceae). Estes tipos referem-se ao ciclo fotossintético de captura de $\mathrm{CO}_{2}$ da planta e sua identificação ajuda, em termos gerais, a inferir a presença de vegetação arbórea e de gramíneas, respectivamente. Os valores de $\delta^{15} \mathrm{~N}$, por sua vez, permitem identificar a fonte de nitratos nos sedimentos, que podem derivar da decomposição de resíduos vegetais ou animais, tanto marinhos como terrestres (animais ou vegetais) (Kendall, 1998; Meyers, 1997; Sifeddine et al., 2004; White, 2001).

Em sedimentos naturais, estas informações auxiliam na reconstrução paleoambiental e paleoclimática, a partir das mudanças detectadas no tipo de vegetação associada à composição isotópica da MO no depósito ${ }^{63}$ (Sifeddine et al., 2004; White, 2001). Em arqueologia, análises isotópicas são utilizadas na determinação da dieta de populações humanas, a partir de dados obtidos do colágeno nos ossos. Estes estudos permitem diferenciar entre o consumo prioritário de espécies terrestres ou marinhas (Bogaard et al., 2007; Fogel et al., 1997; De Niro and Epstein, 1978; De Niro, 1987; Schoeninger and De Niro, 1984). Em sedimentos arqueológicos, análises isotópicas de C e N na MO (total e fração húmica) são utilizadas na identificação e delimitação de

\footnotetext{
${ }^{63} \mathrm{Em}$ áreas costeiras, o uso de indicadores isotópicos permite também determinar, a partir de abordagens multiproxy, o contexto de deposição do material sedimentar que acompanha a matéria orgânica no depósito, em termos de maior ou menor influência de sedimentos continentais ou marinhos (Lamb et al., 2006; Wilson et al., 2005).
} 
antigas áreas de cultivo de milho (Fernández et al., 2005; Webb et al., 2004; Wright et al., 2009), por exemplo, e na identificação de áreas de pastoreio (Shahack-Gross and Finkelstein, 2008; Shahack-Gross et al., 2008).

$\mathrm{Na}$ área de estudo desta pesquisa, trabalhos recentes usaram análises isotópicas de $\delta^{13} \mathrm{C}$ e $\delta^{15} \mathrm{~N}$ para estudar a evolução sedimentar do litoral centro-sul catarinense a partir da combinação dos dados isotópicos com análises micropaleontológicas de pólen e diatomáceas (Amaral, 2008; Amaral et al., 2012) e sedimentológicas (Nascimento, 2010). Em contexto arqueológico, análises isotópicas foram realizadas nos sambaquis Jabuticabeira 2, Encantada 3 e Carniça 3 (Menezes, 2009), no que constituiu o primeiro estudo isotópico de $\mathrm{MO}$ em sambaquis. Os resultados promissores obtidos por Menezes (2009) motivaram a utilização da técnica neste trabalho.

Para estudar a origem e o tipo de MO contida nas arqueofácies identificadas nos oito sambaquis estudados, foi realizada a determinação das porcentagens de $\mathrm{C}$ orgânico e $\mathrm{N}$ total e determinação dos isótopos estáveis $\delta^{13} \mathrm{C}$ e $\delta^{15} \mathrm{~N}$ e razão $\mathrm{C} / \mathrm{N}$. A preparação de amostras para isotopia de $\mathrm{C}$ e $\mathrm{N}$ na $\mathrm{MO}$ envolve a secagem e peneiramento prévios, em malha de 0,250 mm, para recuperação da fração areia muito fina. Em seguida, procedese a remoção de material vegetal (madeira, raízes) e de carbonato macroscópico com pinça e por flotação em solução de $\mathrm{HCl}$ de $0,01 \mathrm{M}$. Uma vez extraídos os restos visíveis de biodetritos, as amostras são lavadas com água destilada, desagregadas em almofariz de ágata com pistilo de porcelana, e secas em estufa a $50{ }^{\circ} \mathrm{C}$. Para amostras provenientes de arqueofácies ricas em carbonatos cálcicos, associados à degradação das valvas de moluscos, o sedimento foi pré-tratado com $\mathrm{HCl}$ a $30 \%$ para remoção dos carbonatos. Este tratamento é realizado para evitar a influência do $\mathrm{CaCO}_{3}$ na determinação do C orgânico total (ver Megens, 2002; Xu et al., 2006)

Do material já seco, são feitas duas séries de cápsulas de tungstênio: uma para determinação de $\mathrm{N}$ total e $\delta^{15} \mathrm{~N}$; e outra para determinação de $\mathrm{C}$ total e $\delta^{13} \mathrm{C}$. No primeiro caso, separam-se entre 20 e $30 \mathrm{~g}$ de sedimento para amostras mais lamosas e ricas em MO, e entre 50 e 60 g para amostras arenosas, pobres em MO. No segundo caso, foram separados entre 5 e $15 \mathrm{~g}$ de material em amostras com maior concentração de MO, e entre 25 e $30 \mathrm{~g}$ em amostras arenosas, com menor conteúdo orgânico.

A análise elementar e de isótopos estáveis de $\mathrm{C}$ e $\mathrm{N}$ foi realizada no laboratório de isótopos estáveis do Centro de Energia Nucelar na Agricultura da Universidade de São Paulo, campus Piracicaba (CENA/USP), com analisador elementar acoplado a um 
espectrômetro de massa ANCA SL 2020 da Europa Scientific. Os resultados de C e N serão apresentados em porcentagem de peso seco e os dados de razão isotópica determinada em relação ao padrão internacional $\mathrm{PDB}$ para ${ }^{13} \mathrm{C}$ e em relação ao ar para ${ }^{15} \mathrm{~N}$, com precisão analítica de $+/-0,2 \%$.

Os resultados das análises isotópicas apresentam-se no Anexo, Tabela A.2. A alta correlação entre os valores de C orgânico e N total (Anexo, Figura A.2), indica que os valores de $\mathrm{N}$ podem ser utilizados como representativos do conteúdo de $\mathrm{N}$ orgânico nas amostras analisadas.

\subsection{MICROSCOPIA ELETRÔNICA DE VARREDURA}

Análises de microscopia eletrônica de varredura (MEV), com espectrometria de energia dispersiva (sistema MEV-EED) foram realizadas com a finalidade de conhecer a composição química de componentes específicos da fração fina em amostras de interesse. Estas análises utilizam-se de sensores de elétrons secundários (SE), para obtenção de imagens de microrelevo, e sensores de elétrons retroespalhados (QSBD), para obtenção de imagens de concentração de elementos químicos mais leves (tons de cinza mais escuros) ou mais pesados. O uso do detector de EED permite ainda inferir a composição química qualitativa (ou semiquantitativa, no caso de amostras de superfície plana, como seções delgadas) dos materiais estudados.

Para esta análise, foram utilizadas seções delgadas sem lamínula recobertas com ouro ou carbono. Ao serem as seções delgadas confeccionadas com impregnação prévia por resina, uma amostra da resina é sempre estudada para conhecer sua composição química e estabelecer um parâmetro composicional de referência.

As seções delgadas polidas em amostras de sambaquis foram confeccionadas no laboratório de laminação do Instituto de Geociências (IGc/USP). A análise foi realizada no laboratório de microscopia eletrônica de varredura do Instituto de Geociências (IGc/USP) com microscópio eletrônico Leo 441i, com detector EED (Oxford) para determinação de composição química semiqualitativa. O estudo de microscopia eletrônica de amostras do concheiro Tunel 7 foi realizado sobre blocos polidos, para as seções delgadas provenientes da coluna de amostragem no anel de conchas periférico, e 
em seções delgadas, sem lamínula, para as amostras de fogueiras centrais. As análises foram realizadas no serviço de microscopia da Universidade Autônoma de Barcelona (UAB), com microscópio eletrônico JSM-6300.

\subsection{ZOOARQUEOLOGIA}

Amostragem para zooarqueologia foi realizada naqueles sambaquis que não foram objeto de estudos faunísticos prévios. Esta amostragem seguiu a proposta de Scheel-Ybert et al. (2005), adaptada de Figuti (1992), que enfatiza a padronização de coletas faunísticas para habilitar a comparação intra e inter-sítio. Este procedimento evita a coleta seletiva, freqüentemente realizada em amostragens zooarqueológicas, através da extração de volumes padronizados de sedimento das seções verticais dos sítios. Neste trabalho, a amostragem por volumes dirige-se unicamente à identificação e quantificação das diferentes espécies de moluscos em cada arqueofácies amostrada na sucessão vertical, e o tratamento das amostras no laboratório segue tal finalidade.

Meio balde de sedimento de cada arqueofácies foi coletada dos sítios Cubículo 1, Morrinhos e Santa Marta 10. As amostras foram pesadas e posteriormente peneiradas e lavadas simultaneamente em malhas de $4,0 \mathrm{~mm}$ e $2,0 \mathrm{~mm}$. O material retido nestas malhas foi deixado para secar a temperatura ambiente e, em seguida, pesado. Unicamente o material retido na malha de $4,0 \mathrm{~mm}$ foi triado por espécie de molusco identificada. O retido na malha de 2,0 foi pesado, para estimação do grau de fragmentação dos componentes, e submetido a estimativa visual da porcentagem de fragmentos de osso de peixe. As subamostras por espécie foram pesadas e, com o valor do peso total coletado no balde, calculou-se a concentração de espécie de molusco por amostra de cada arqueofácies. Os resultados da análise zooarqueológica nos sítios Santa Marta 10, Morrinhos, Cubículo 1 e Carniça 3 encontra-se no Anexo, Tabela A.3. 


\section{SUMÁRIO}

No Quadro 4.3. apresentam-se as diferentes análises propostas neste trabalho e a quantidade de amostras, por ensaio laboratorial. O quadro contém o detalhamento de análises nos oito sambaquis estudados e no concheiro fueguino, junto com as análises realizadas nos locais de amostragem externa ao sítio em quatro dos sambaquis estudados e com a amostragem experimental em fogueiras e queima controlada de moluscos.

Quadro 4.3. Síntese das diferentes análises realizadas por sítio arqueológico, na amostragem externa aos sítios e na amostragem experimental (fogueiras e queima controlada de moluscos). TdF: Terra do Fogo; SC: Santa Catarina.

\begin{tabular}{|c|c|c|c|c|c|}
\hline \multirow[b]{2}{*}{ SÍTIOS } & Micromorfologia & Granulometria & $\begin{array}{l}\text { Isotopia } \\
\text { de C e N }\end{array}$ & $\begin{array}{c}\text { Química } \\
\text { multi- } \\
\text { elementar }\end{array}$ & Zooarqueologia \\
\hline & \multicolumn{5}{|c|}{$\mathrm{N}^{0}$ de amostras } \\
\hline Caipora & 5 & 2 & 2 & - & - \\
\hline Cubiculo 1 & 1 & 1 & 1 & 1 & 5 \\
\hline Morrinhos & 4 & 3 & 2 & 1 & 3 \\
\hline Jabuticabeira 1 & 5 & 8 & 7 & 1 & - \\
\hline Santa Marta 10 & 2 & 2 & 1 & 1 & 1 \\
\hline Carniça 3 & 1 & 1 & 1 & 1 & 1 \\
\hline Galheta 4 & 2 & 2 & 2 & 1 & - \\
\hline Santa Marta 8 & 3 & 2 & 2 & 2 & - \\
\hline Tunel 7 & 16 & - & - & - & - \\
\hline Sub-total & 39 & 21 & 18 & 8 & 10 \\
\hline
\end{tabular}

\section{AMOSTRAGEM}

\section{EXTERNA}

\begin{tabular}{|c|c|c|c|c|c|}
\hline Caipora & - & 1 & 1 & 1 & - \\
\hline Cubiculo 1 & - & 2 & 2 & 2 & - \\
\hline Santa Marta 8 & - & 2 & 1 & 2 & - \\
\hline Santa Marta 10 & 1 & 1 & 1 & 1 & - \\
\hline Túnel 7 & 5 & - & - & - & - \\
\hline Sub-total & 1 & 6 & 5 & 6 & - \\
\hline
\end{tabular}

\section{AMOSTRAGEM}

\section{EXPERIMENTAL}

\begin{tabular}{lccccc}
\hline Fogueiras TdF & 4 & - & - & - & - \\
Fogueiras SC & 2 & & & - & - \\
Queima de Mytilus & 11 & - & - & - & \\
edulis & & & & \\
Queima de $A$. & 7 & & & \\
brasiliana & & &
\end{tabular}

\begin{tabular}{llllll}
\hline TOTAL & 58 & 27 & 23 & 14 & 10 \\
\hline
\end{tabular}




\section{CAPÍTULO 5: GEOARQUEOLOGIA DE SAMBAQUIS DO LITORAL SUL DE SANTA CATARINA E CONCHEIRO ETNOHISTÓRICO DA TERRA DO FOGO}

A análise de arqueofácies proposta para este trabalho contemplou a descrição das sucessões estratigráficas em sambaquis, de acordo com atributos deposicionais definidos por Villagran (2008) e Villagran et al. (2009). A identificação de arqueofácies representa o primeiro passo para o reconhecimento de processos deposicionais recorrentes na formação de um sambaqui, ou de vários da mesma região. Esta identificação no campo é seguida da caracterização das fácies arqueológicas através de procedimentos de laboratório que, neste trabalho, incluíram granulometria da fração terrígena, isotopia de carbono $\left(\delta^{13} \mathrm{C}\right)$ e nitrogênio $\left(\delta^{15} \mathrm{~N}\right)$ da $\mathrm{MO}$ no sedimento, micromorfologia e microscopia eletrônica de varredura. Para complementar o estudo das microfácies arqueológicas e fornecer parâmetros de referência que auxiliem na sua descrição e interpretação, foram elaboradas duas coleções experimentais, uma de fogueiras em substrato arenoso e conchífero, e outra de queima controlada de Anomalocardia brasiliana, principal componente malacológico dos sambaquis da região.

Nos próximos tópicos, apresentam-se primeiro os resultados da abordagem experimental em sambaquis catarinenses, seguida da análise geoarqueológica dos oito sambaquis analisados, agrupados quanto ao padrão estratigráfico, dentro da classificação proposta por Giannini et al. (2010), em sambaquis conchíferos, de núcleo quartzo-arenoso e montículos ictiológicos. Encerra este capítulo a análise das coleções de micromorfologia experimental (fogueiras e queima controlada de Mytilus edulis) e arqueológica (anel de conchas e fogueiras centrais) no concheiro etno-histórico Túnel 7. 


\section{COLEÇÃO DE REFERÊNCIA EXPERIMENTAL}

\subsection{FOGUEIRAS}

Foram realizadas duas fogueiras experimentais sobre substrato conhecido no litoral sul de Santa Catarina. A primeira fogueira foi feita em forma de bacia, escavada sobre substrato arenoso em paleoduna eólica. A segunda fogueira experimental foi acesa em superfície plana, sobre depósito de retrabalhamento do sambaqui Cabeçuda. Em ambos os casos, utilizaram-se espécies de árvores locais como combustível, assim como conchas e restos de peixe, para aproximar-se o máximo possível da realidade encontrada no registro arqueológico.

\subsubsection{Temperatura}

Na Figura 5.1, apresentam-se as temperaturas alcançadas pelas duas fogueiras experimentais, tanto no centro da combustão como no substrato (sob o meio da fogueira, a cerca de $5 \mathrm{~cm}$ de profundidade). As informações apresentadas indicam que altas temperaturas, no entorno dos $900^{\circ} \mathrm{C}$, podem ser rapidamente alcançadas, inclusive em fogueiras efêmeras, de uma hora de duração, como as realizadas neste experimento. $\mathrm{Na}$ fogueira sobre paleoduna, a elevada temperatura máxima alcançada, de $900^{\circ} \mathrm{C}$, foi possivelmente favorecida pela ação do vento no local. Situação diferente foi observada na fogueira sobre depósito retrabalhado de sambaqui. Acesa em local protegido da ação dos ventos, esta fogueira, além de demandar maior quantidade de combustível, atingiu temperaturas menores, inferiores a $800^{\circ} \mathrm{C}$ (Figura 5.2 A-B). 


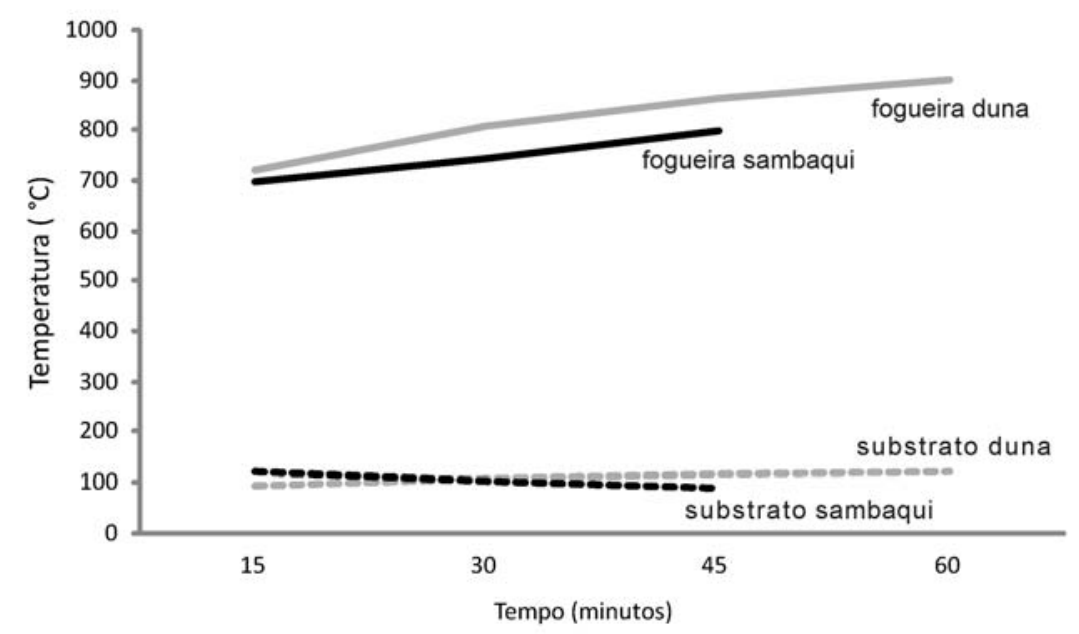

\begin{tabular}{llccccc}
\hline & & \multicolumn{3}{c}{ Temberatura $^{\circ}{ }^{\circ} \mathbf{C}$} \\
Fogueira & Contexto & $\mathbf{1 5}$ min. & $\mathbf{3 0}$ min. & $\mathbf{4 5}$ min. & $\mathbf{6 0}$ min. & Máxima \\
Duna & Fogueira (superficie) & 720 & 808 & 865 & 900 & 900 \\
& Substrato $(-5 \mathrm{~cm})$ & 95 & 109 & 115 & 119 & 119 \\
Sambaqui & Fogueira (superficie) & 698 & 746 & 800 & - & 800 \\
& Substrato $(-5 \mathrm{~cm})$ & 120 & 102 & 91 & - & 120 \\
\hline
\end{tabular}

Figura 5.1. Gráfico e tabela com as temperaturas atingidas no centro de combustão e no substrato (a $5 \mathrm{~cm}$ da superfície), durante uma hora de queima, em duas fogueiras experimentais (sobre paleoduna eólica e sobre depósito de retrabalhamento de sambaqui).

Apesar do substrato a $5 \mathrm{~cm}$ de profundidade ter atingido temperaturas cerca de 700 a $800^{\circ} \mathrm{C}$ menores que o epicentro da fogueira, tanto o sedimento arenoso como o conchífero apresentaram preservação de calor até 12 horas após a finalização da queima. A fogueira em paleoduna alcançou temperaturas de até $100^{\circ} \mathrm{C}$, nas cinzas, quatro horas depois de apagada (Figura 5.2 C). A fogueira no substrato conchífero apresentou temperaturas de até $81^{\circ} \mathrm{C}$ nas cinzas, 12 horas depois de apagada, com

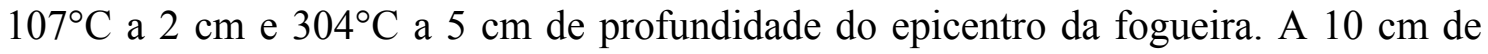
profundidade, a temperatura diminuía para $50^{\circ} \mathrm{C}$ e a $15 \mathrm{~cm}$ não ultrapassava $32^{\circ} \mathrm{C}$ (Figura 5.2 D). 

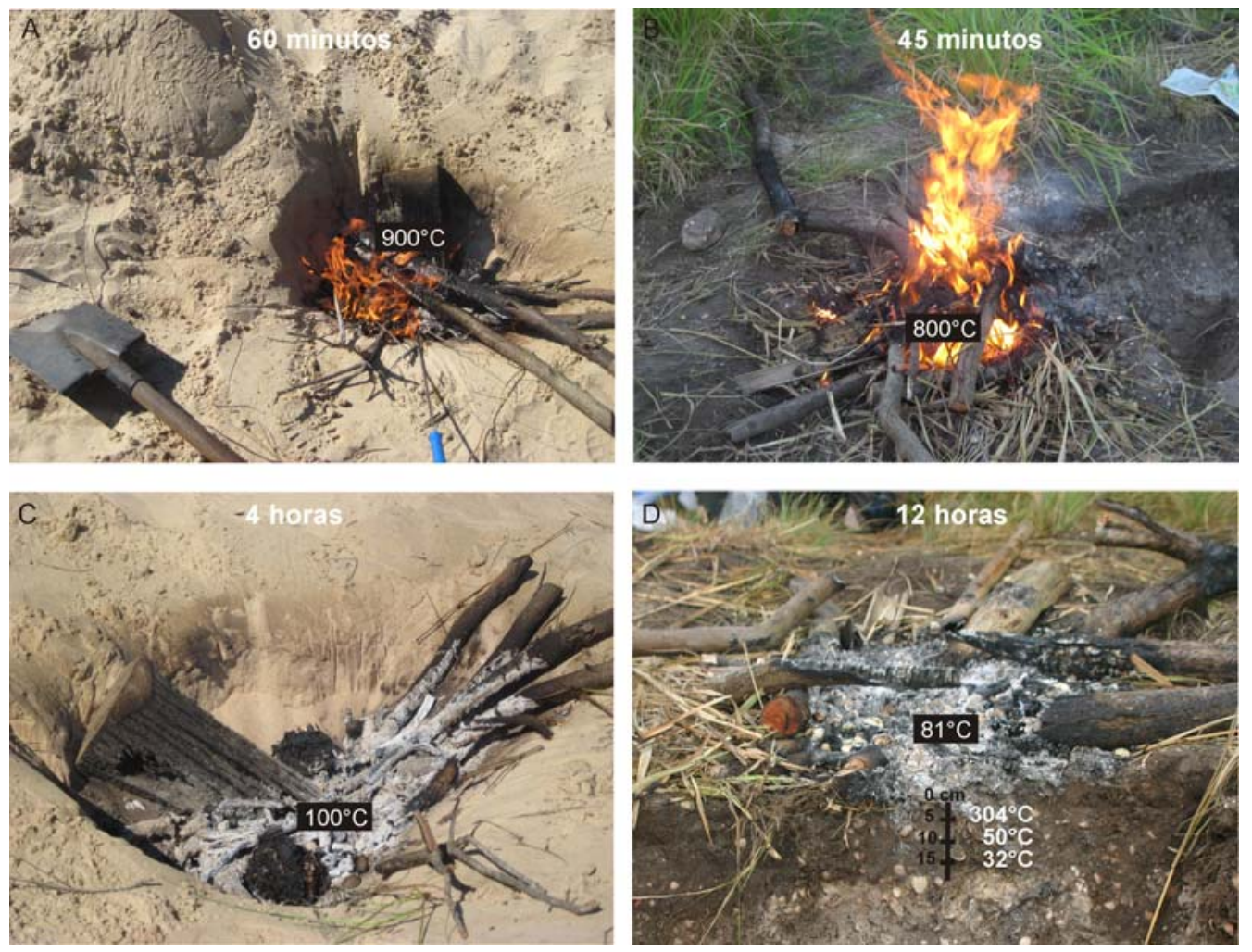

Figura 5.2. Fotografias das duas fogueiras experimentais: A) fogueira sobre paleoduna eólica, com indicação da temperatura atingida a 60 minutos do inicio da queima; B) fogueira sobre depósito de retrabalhamento de sambaqui, com indicação da temperatura atingida a 45 minutos do inicio da queima; C) fogueira sobre paleoduna eólica, apagada, com indicação da temperatura do substrato, quatro horas depois do apagado o fogo; D) fogueira sobre depósito de retrabalhamento de sambaqui, apagada, com indiicação das temperaturas do substrato e a diferentes profundidades, 12 horas depois de apagado o fogo.

\subsubsection{Forma e composição}

$\mathrm{Na}$ fogueira em paleoduna observou-se a formação de crosta delgada (milimétrica), de coloração marrom escuro na areia das bordas e laterais da área atingida pelas chamas no interior desta cavidade, o (Figura 5.3 A,D). Nesta fogueira, todos os componentes faunísticos (conchas e restos de peixe) sofreram calcinação e carbonização (Figura 5.3 B,C). 
A
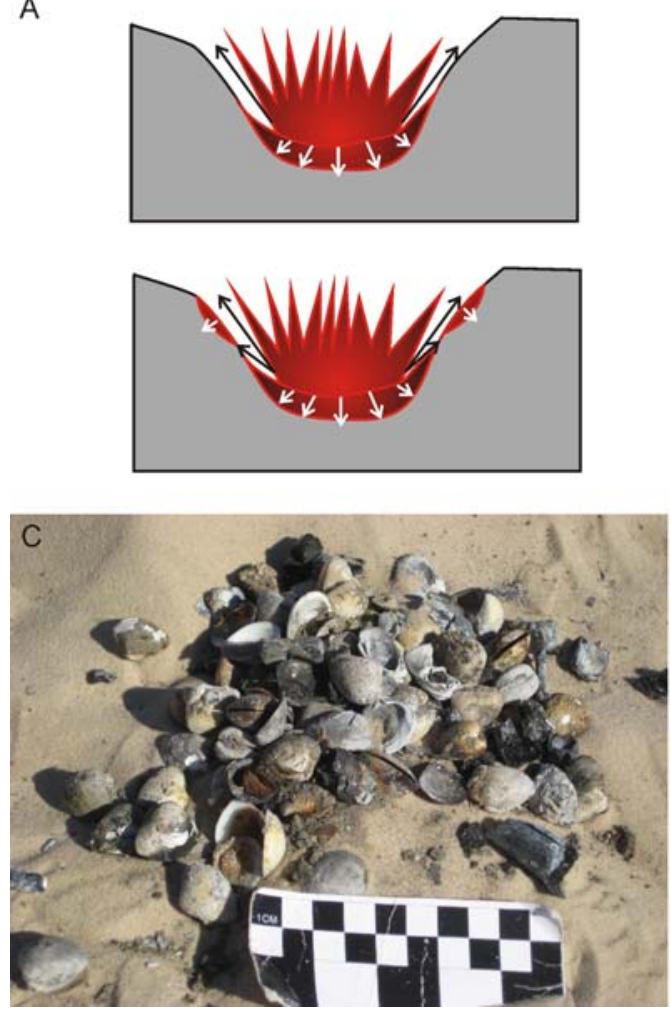
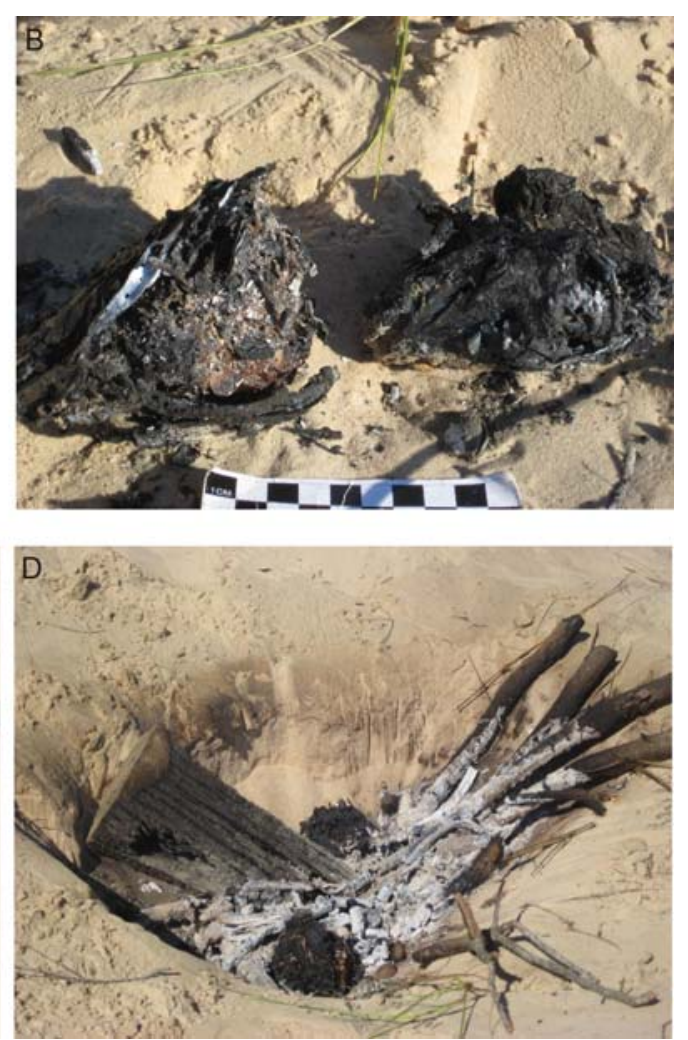

Figura 5.3. Fogueira sobre paleoduna eólica: A) esquema de alteração do substrato produzido por fogueiras em forma de bacia, como a realizada, nesta pesquisa, sobre areia dunar (modificado de March, 1996); as setas brancas indicam a trajetória do calor no inicio do fogo (esquema superior) e algumas horas depois, enquanto as setas prets indicam a trajetória do calor subaéreo; B) duas cabeças de peixe queimadas na fogueira; C) conchas de Anomalocardia brasiliana, após retiradas da fogueira; D) configuração da fogueira após apagada. Note-se o escurecimento do perímetro da bacia onde foi acesa a fogueira, como previsto no modelo de March (1996).

As fogueiras feitas sobre depósito de retrabalhamento de sambaqui e sobre paleoduna eólica diferiram entre si quanto à forma e quanto ao padrão observado de alteração térmica dos materiais. A primeira diferença refere-se ao fato de a fogueira no sambaqui ter sido acesa sobre substrato conchífero plano. De acordo com March (1996), isto provoca diferenças substanciais não somente quanto à forma da distribuição do produto de queima, mas também no tipo de alteração térmica de seus componentes (March, 1996). Assim, na paleoduna, todos os materiais foram calcinados ou carbonizados. Já na fogueira plana, observou-se uma área sub-circular de 30 a $40 \mathrm{~cm}$ de diâmetro, onde todos os componentes (conchas e ossos) estavam calcinados, bordejada por uma faixa de cerca de $10 \mathrm{~cm}$ de largura, com restos carbonizados (Figura 5.4 A,B). Fora da área de calcinação-carbonização desta fogueira, não se observaram alterações térmicas nos materiais na forma de mudanças texturais ou de coloração. 
A friabilidade do sedimento arenoso da paleoduna eólica impossibilitou o corte transversal da fogueira, que visaria observar em secção vertical as características da respectiva estrutura de combustão. Na fogueira sobre substrato conchífero, o corte vertical foi possível, e permitiu notar a forma lenticular típica de estruturas de combustão (Schiegl, 1996; Weiner, 2002), com núcleo de cor cinza claro, formado por cinzas, conchas e ossos calcinados, carvões e ossos carbonizados (Figura 5.4 C,D).

A
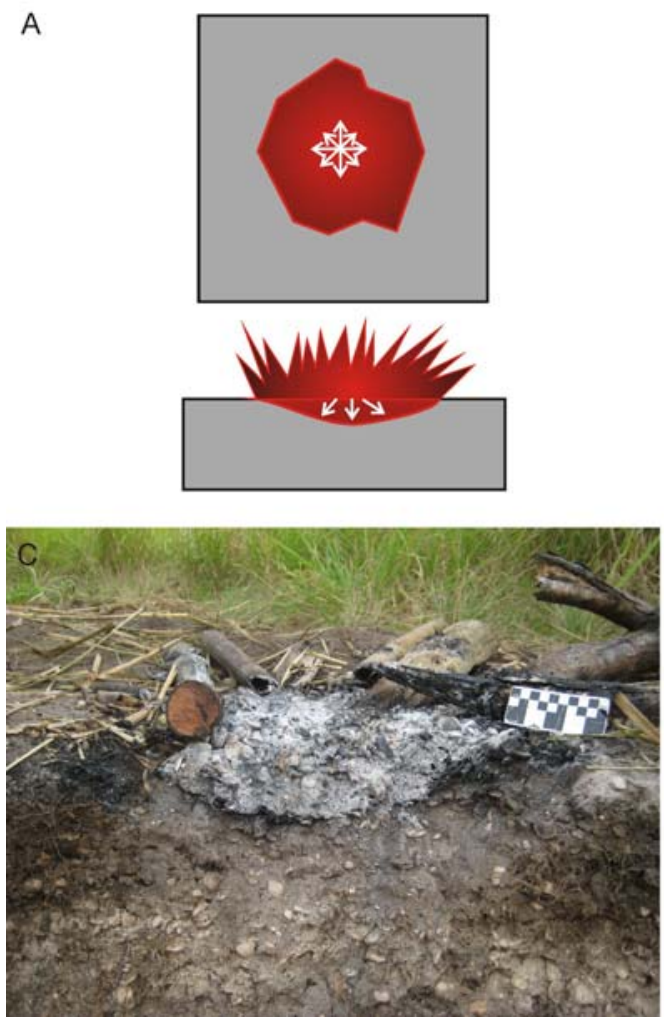
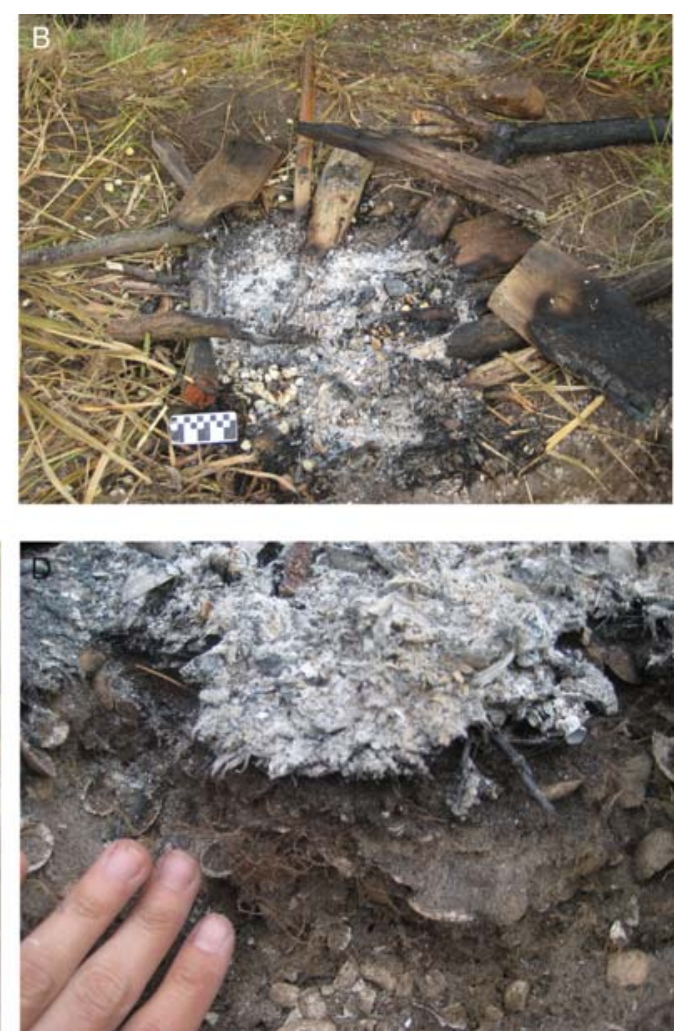

Figura 5.4. Fogueira sobre depósito de retrabalhamento do sambaqui Cabeçuda: A) esquema de alteração do substrato produzido por fogueiras planas (modificado de March, 1996); as setas brancas indicam a trajetória do calor sob a perspectiva horizontal da fogueira (esquema superior) e em seção vertical (esquema inferior); B) fogueira plana sobre o sambaqui, apagada; C) seção de alteração térmica; D) detalhe da alteração do substrato, em que se vê camada lenticular decimétrica de cinzas sobre lâmina milimétrica de material carbonizado. Notem-se os formatos horizontal e vertical da fogueira plana, coincidentes com o previsto no modelo de March (1996). 


\subsubsection{Alteração do substrato e preservação}

As experiências de queima controlada em substrato arenoso e conchífero ofereceram observações de primeira mão que auxiliarão na interpretação do registro arqueológico. Constatou-se, por exemplo, que a preservação de restos de fogueiras em sedimentos arenosos (eólicos, no caso) é comprometida pela baixa coesão do substrato, independentemente da quantidade de materiais utilizados na combustão e da temperatura atingida pela fogueira. Ao mesmo tempo, apesar das elevadas temperaturas (de até $900^{\circ} \mathrm{C}$ ) alcançadas na fogueira em paleoduna, não se provocaram grandes alterações no substrato sedimentar, como rubefação ou carbonização (ver Berna et al., 2007; Mallol et al., 2007; Schiegl et al., 2003), o que pode ser atribuído à escassez de argilominerais e de MO na sua constituição. Desse modo, estruturas de combustão em substrato arenoso, como dunas ou paleodunas eólicas pouco cimentadas, devem caracterizar-se por baixo impacto da temperatura sobre o substrato e por potencial elevado de deflação eólica, o que implica dificuldades para sua preservação e/ou identificação no registro arqueológico ${ }^{64}$.

No caso da fogueira sobre substrato conchífero, a experimentação permitiu identificar com maior clareza a forma e o gradiente de alteração térmica de estruturas de combustão in situ. Estas informações poderão ser extrapoladas ao contexto arqueológico para melhor caracterização e identificação de fogueiras em sambaquis. Assim, uma fogueira in situ no sambaqui deverá apresentar o formato lenticular típico, oval em planta e côncavo-plano na seção vertical (Figura 5.4 A,C), com núcleo composto por material calcinado de coloração cinza claro e periferia carbonizada de cor preta, tanto na seção vertical como na horizontal. A rubefação do substrato não se observou nesta experiência (Figura 5.4 D). Admitida a presença, neste caso, de argilominerais e MO fina passíveis de sofrer rubefação, o não evidenciamento deste efeito pode ser atribuído à curta duração da fogueira. Assim, fogueiras de curta duração (poucas horas) não provocariam este tipo específico de alteração térmica, e sim aquelas que ficam acesas

\footnotetext{
${ }^{64}$ No trabalho de Compton \& Franceschini (2005) descrevem-se fogueiras antrópicas identificadas na área de deflação de dunas aólicas da costa da oeste da África do Sul, formadas por concentrações de quartzo termoalterado sobre sedimentos calcáreos. Nesse caso particular, a presença de fragmentos de quartzo e o substrato calcáreo teria favorecido a preservação das fogueiras.
} 
por períodos de tempo longos o suficiente para transferência mais efetiva de calor ao sedimento.

\subsubsection{Micromorfologia de fogueira sobre substrato conchífero}

Amostras para análise micromorfológica foram coletadas unicamente da fogueira sobre substrato conchífero, uma vez que na fogueira sobre substrato eólico a friabilidade do sedimento impossibilitou a coleta de blocos inalterados. Esta amostragem visa à identificação, a partir da análise micromorfológica, de contextos de queima in situ nos sambaquis da região, já que as amostras coletadas representam microfácies de combustão primária na definição de Wattez (1992), isto é, que não sofreram retrabalhamento pós-deposicional.

Uma amostra de bloco inalterado para micromorfologia foi tomada da periferia da fogueira, em local onde o material apresentava coesão suficiente isso. Já no epicentro da estrutura de combustão, o alto teor de areia e cinzas impossibilitou a coleta dos blocos. Na Figura 5.5, reúnem-se fotomicrografias da massa basal da estrutura de combustão e de elementos de destaque na assembleia de componentes da fração grossa. A partir da avaliação microscópica da fogueira sobre substrato conchífero, extraem-se os seguintes indicadores de contextos primários de queima:

- Padrão de distribuição aleatório dos componentes da fração grossa.

- Alta fragmentação dos ossos, chegando à fração silte.

- Sinais de queima nas conchas, tanto inteiras quanto fragmentadas (ver tópico 1.2).

- Homogeneidade no grau de alteração térmica dos fragmentos de osso, apesar de distribuídos aleatoriamente.

- Baixa freqüência de micromassa, formada principalmente por material carbonático fino, possivelmente associado a cinzas de madeira. 

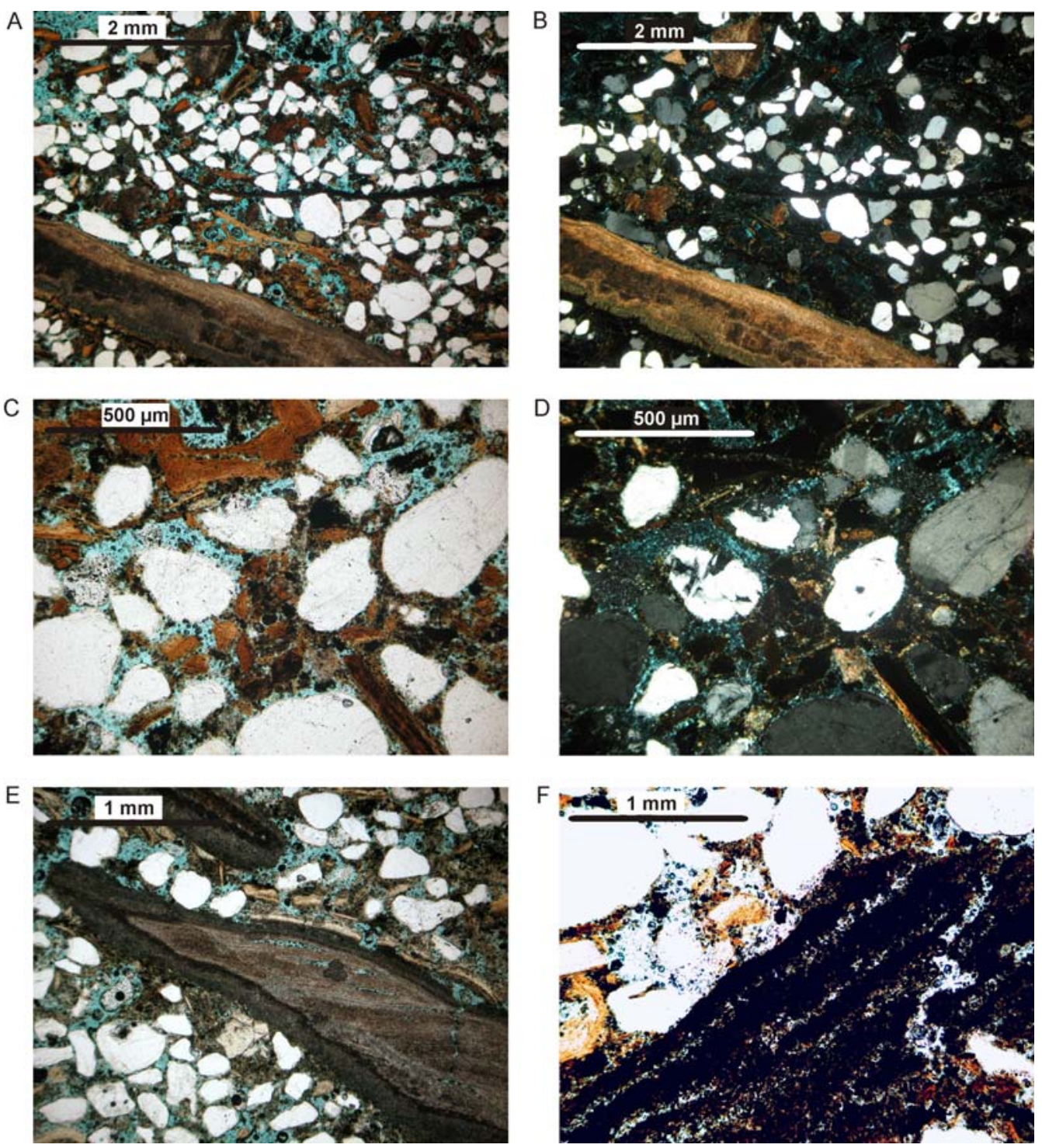

Figura 5.5. Fotomicrografias de seção delgada coletada na periferia da fogueira acesa sobre substrato conchífero (depósito de retrabalhamento do sambaqui Cabeçuda): (A, B) massa basal composta por grãos de quartzo, fragmentos de osso queimados e carbonizados e fragmentos de concha, a PPL e XPL; C, D) detalhe da fração fina composta por fragmentos de osso queimado na fração silte entre áreas de micrita carbonática, a PPL e XPL; E) concha com sinais de alteração térmica (coloração cinza escuro e fissuras internas) em matriz micrítica associada a cinzas de madeira, a PPL. F) carvão em processo de transformação para cinza, a PPL. 


\subsection{QUEIMA CONTROLADA DE ANOMALOCARDIA BRASILIANA}

A segunda etapa da experimentação envolveu a criação de uma coleção de referência de queima do bivalve Anomalocardia brasiliana, principal componente malacológico dos sambaquis catarinenses. No Quadro 5.1, apresentam-se as observações das diferentes seções delgadas de queima de Anomalocardia brasiliana a temperaturas de $200^{\circ} \mathrm{C}$ até $800^{\circ} \mathrm{C}$.

Análises de difratometria de raios-X realizadas por Colonese nas faces interna e externa da valva de Anomalocardia brasiliana fresca confirmaram a aragonítica de ambas (Anexo, Figura A.3), como já mostrado em outros estudos (Bezerra et al., 2009). A face interna das valvas de A. brasiliana corresponde a camada nacarada, composta por plateletas poligonais (tijolos) de aragonita, ligadas entre se por um biopolímero. Esta camada interna transforma-se totalmente em calcita a $500^{\circ} \mathrm{C}$, e em óxido de cálcio $(\mathrm{CaO})$ a $1000^{\circ} \mathrm{C}$ (Balmain et al., 1999; Bourrat et al., 2007; Huang and Li, 2009). Já a aragonita que compõe a face externa da valva transforma-se em calcita a temperaturas levemente menores, na ordem dos $360-380^{\circ} \mathrm{C}$. A maior temperatura de mudança de fase da camada interna, nacarada, em relação à externa, deve-se à maior influência de matriz orgânica na sua constituição (Ren et al., 2009).

No nível de observação macroscópico, a transformação térmica de $A$. brasiliana envolve o escurecimento geral da concha, desde a superfície até o interior. $O$ escurecimento vai de marrom escuro, a $200^{\circ} \mathrm{C}$, passando por preto, a $400^{\circ} \mathrm{C}$, até cinza e branco, a temperaturas maiores que $500^{\circ} \mathrm{C}$. No nível microscópico de observação, o escurecimento da valva vai de laranja escuro (PPL) até $300^{\circ} \mathrm{C}$, passando por marrom escuro, até $600^{\circ} \mathrm{C}$, e preto, a $800^{\circ} \mathrm{C}$. Paralelo ao escurecimento da concha, ocorre a carbonização e volatilização do perióstraco, a partir de $500^{\circ} \mathrm{C}$, e a formação de pequenas fissuras longitudinais e transversais à superfície da valva, possivelmente relacionadas com a perda de água e outros voláteis da matriz orgânica da concha (Gaffey et al., 1991). A formação de pseudo-vacúolos ocorre a partir dos $800^{\circ} \mathrm{C}$.

As descrições agrupadas no Quadro 5.1 podem ajudar a interpretar fogueiras in situ ou retrabalhadas em termos de pirotecnologia e processos de formação. Por exemplo, cada vez que uma valva de Anomalocardia brasiliana em contexto arqueológico seja encontrada com intensa deformação de suas lâminas internas, fissuras 
alongadas, coloração preta (PPL) e opacidade (XPL), pode-se inferir que ela sofreu queima sob temperatura superior a $800^{\circ} \mathrm{C}$. Se um conjunto de valvas queimadas a altas temperaturas é encontrado em associação gradual até valvas queimadas a temperaturas menores, junto com restos de cinzas, carvões e agregados de argila rubefacta, pode-se inferir a presença de uma fogueira in situ.

Quadro 5.1. Descrição das alterações térmicas observadas nas conchas de Anomalocardia brasiliana, queimadas na mufla a temperaturas de 200 a $800^{\circ} \mathrm{C}$.

\begin{tabular}{|c|c|c|}
\hline Temperatura & Descrição & Figura \\
\hline $200^{\circ} \mathrm{C}$ & Valva bem preservada. Sem alterações evidentes. & 5.6 \\
\hline $300^{\circ} \mathrm{C}$ & $\begin{array}{l}\text { Semelhante à anterior. Perióstraco bem preservado, com cor laranja escuro } \\
\text { (PPL). }\end{array}$ & 5.6 \\
\hline $400^{\circ} \mathrm{C}$ & $\begin{array}{l}\text { Leve escurecimento. Perióstraco totalmente preto, descolado da valva em } \\
\text { algumas partes. }\end{array}$ & 5.7 \\
\hline $500^{\circ} \mathrm{C}$ & $\begin{array}{l}\text { Perióstraco preto e quebradiço. Valva com fissuras longitudinais, paralelas } \\
\text { à face interna. }\end{array}$ & 5.7 \\
\hline $600^{\circ} \mathrm{C}$ & $\begin{array}{l}\text { Escurecimento geral da valva, cor marrom escuro (PPL), marrom escuro } \\
\text { avermelhado (XPL), mais atenuado na face externa da valva. } \\
\text { Desaparecimento do perióstraco. Aumento em frequência das fissuras } \\
\text { longitudinais paralelas à face interna da valva e aparecimento de fissuras } \\
\text { transversais à valva, desenvolvidas do exterior até o interior. }\end{array}$ & 5.8 \\
\hline $700^{\circ} \mathrm{C}$ & $\begin{array}{l}\text { Escurecimento geral da valva, mais atenuado na face exterior. Aumento em } \\
\text { frequência das fissuras longitudinais. }\end{array}$ & 5.8 \\
\hline $800^{\circ} \mathrm{C}$ & $\begin{array}{l}\text { Deterioração geral da valva. Borda preta na face externa e cor cinza } \\
\text { transparente (PPL) no restante da valva. Fissuras longitudinais com } \\
\text { morfologia de pseudo-vacúolos. Fissuras transversais. }\end{array}$ & 5.9 \\
\hline
\end{tabular}



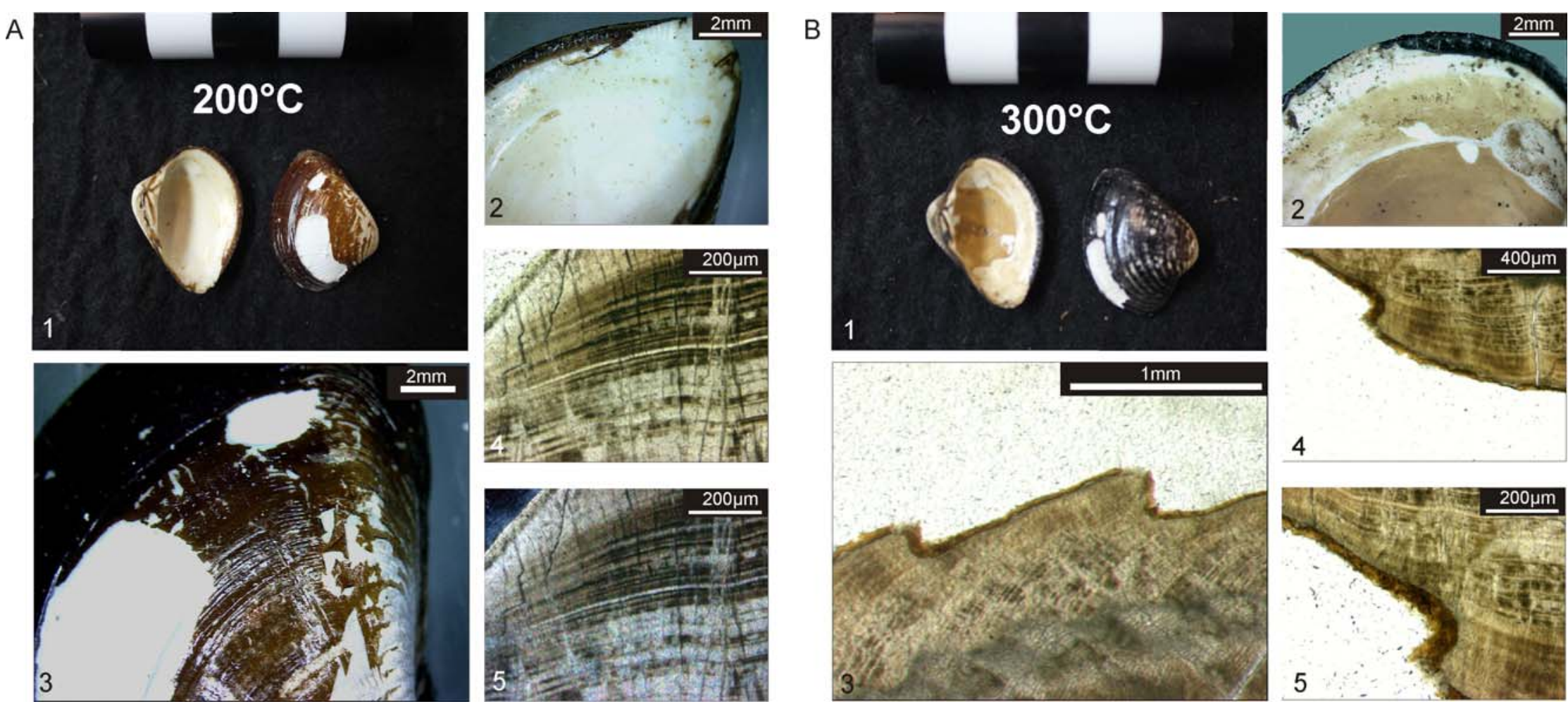

Figura 5.6. Alteração de Anomalocardia brasiliana a temperaturas de $200^{\circ} \mathrm{C}$ e $300^{\circ} \mathrm{C}$ : A1) concha queimada a $200^{\circ} \mathrm{C}$, com preservação do perióstraco; A2) borda enegrecida da face interna da valva; A3) detalhe da superfície queimada da face externa da valva; A4-5) fotomicrografias da valva queimada, com camadas de crescimento, a PPL e XPL; B1) concha queimada a $300^{\circ} \mathrm{C}$; B2) borda enegrecida e superfície escurecida da face interior da valva; B3) fotomicrografia da superfície da valva, com perióstraco preservado; B4-5) detalhe do perióstraco ainda aderido à valva. 

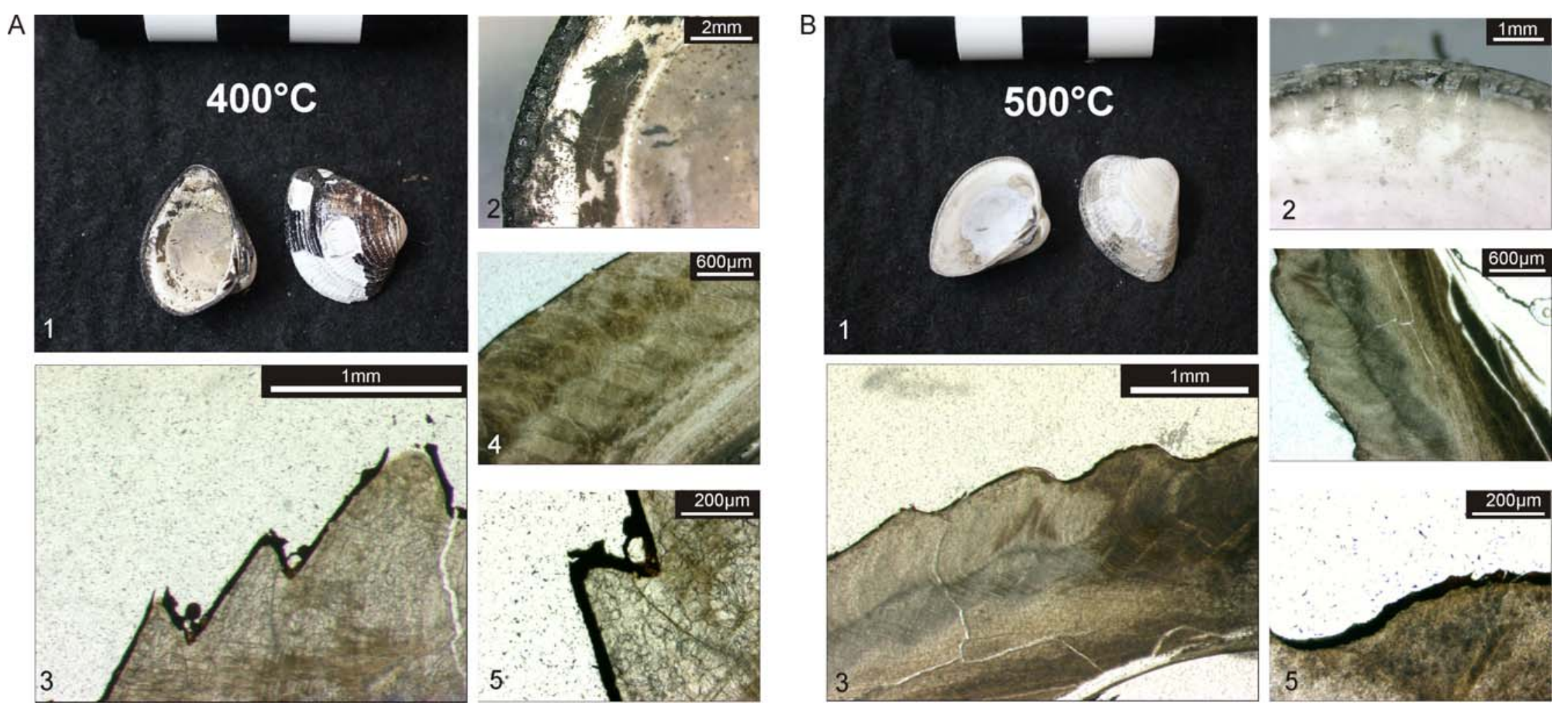

Figura 5.7. Alteração de Anomalocardia brasiliana a $400^{\circ} \mathrm{C}$ e $500^{\circ} \mathrm{C}$ : A1) concha queimada a $400^{\circ} \mathrm{C}$, com preservação do perióstraco; A2) borda carbonizada da face interna da valva e superfície enegrecida; A3) fotomicrografia da concha queimada, com perióstraco ainda preservado; A4) fotomicrografia da valva escurecida; 5) detalhe do perióstraco queimado; B1) concha queimada a $500^{\circ} \mathrm{C}$; B2) borda acinzentada e superfície esbranquiçada da face interna da valva; B3) fotomicrografia da superfície cor marrom escuro; B4) fotomicrografia da valva queimada, com escurecimento pronunciado na face interna; B5) detalhe do perióstraco, ainda aderido à valva. 

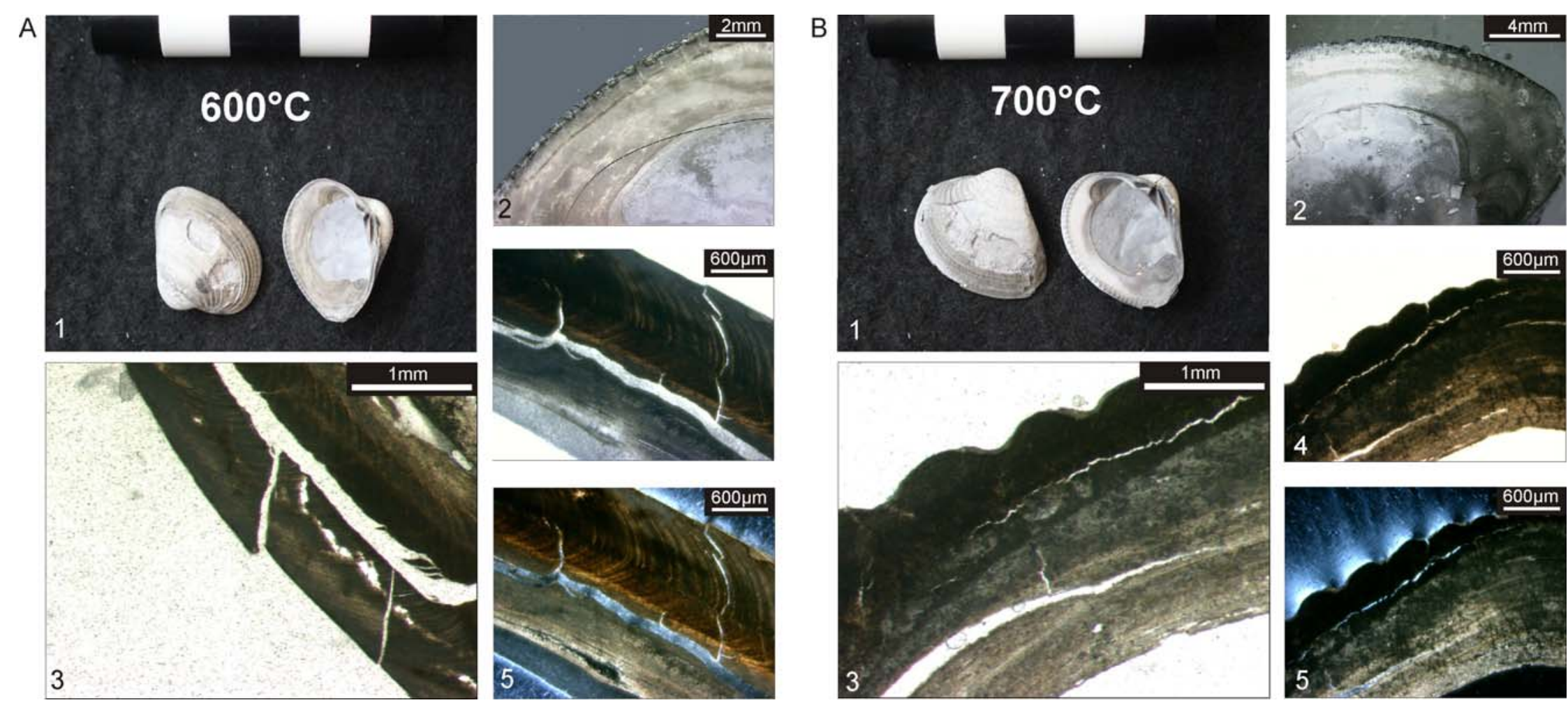

Figura 5.8. Alteração de Anomalocardia brasiliana a $600^{\circ} \mathrm{C}$ e $700^{\circ} \mathrm{C}$ : A1) concha queimada a $600^{\circ} \mathrm{C}$; A2) borda acinzentada da face interna da valva; A3) fotomicrografia da concha queimada enegrecida, sem perióstraco, com fissuras longitudinais e transversais; A4-5) fotomicrografia da valva escurecida a PPL e XPL. B1) concha quemada a 700 ${ }^{\circ}$ C; B2) borda acinzentada da face interna da valva; B3) fotomicrografia da concha queimada, preta a cinza escuro; B4-5) fotomicrografia da valva a PPL e XPL. 

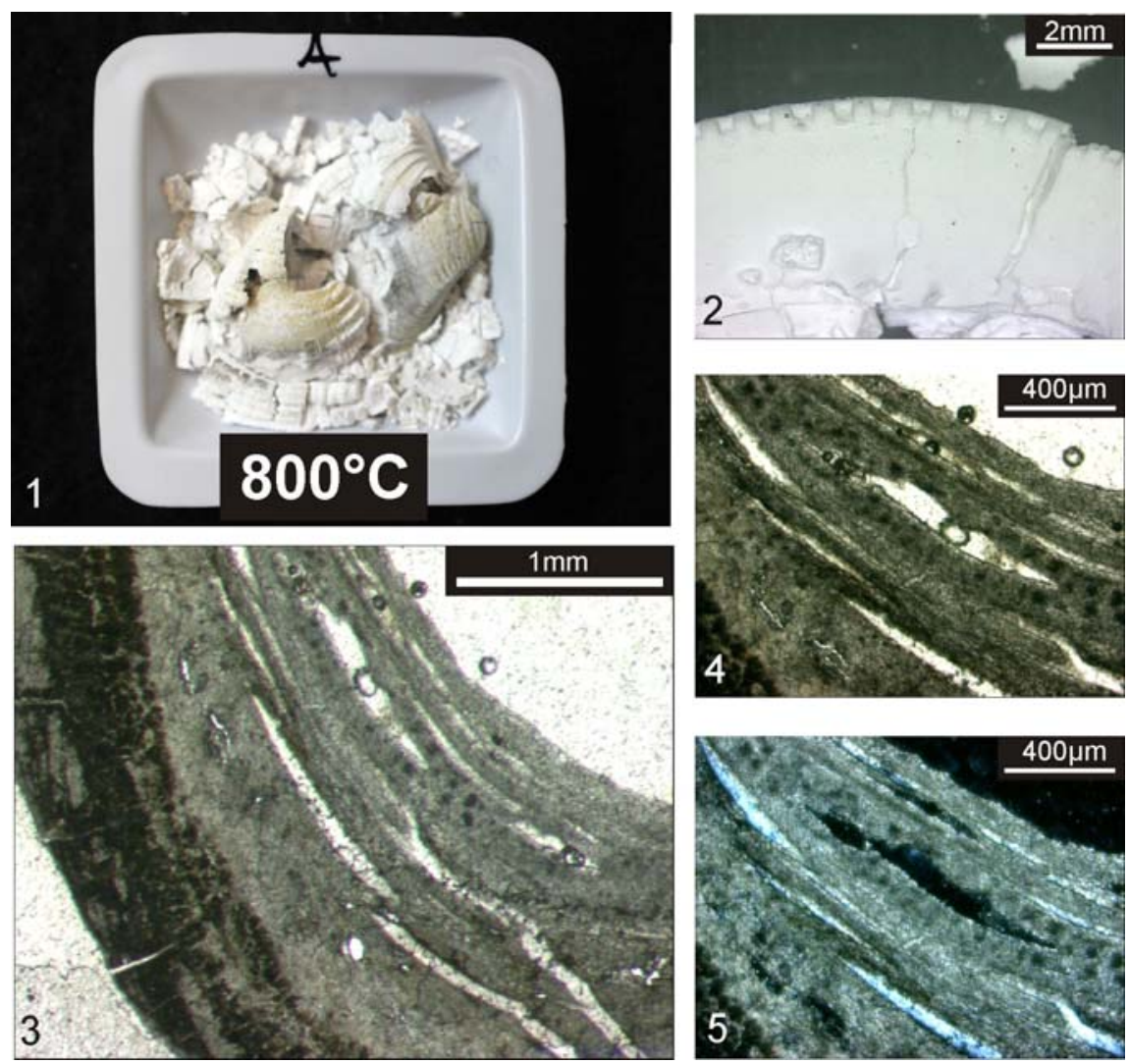

Figura 5.9. Alteração de Anomalocardia brasiliana a $800^{\circ} \mathrm{C}$ : A1) concha queimada a $800^{\circ} \mathrm{C}$, tão fragilizada que não se manteve inteira; A2) valva calcinada; A3) fotomicrografia da valva calcinada, de cor cinza, com pseudo-vacúolos; A4-5) fotomicrografia da valva calcinada, a PPL e XPL

\section{SAMBAQUIS DO LITORAL CATARINENSE}

Neste tópico, apresentam-se os resultados da análise estratigráfica, isotópica, granulométrica e micromorfológica dos oito sambaquis estudados na tese. Os dados serão organizados conforme os três padrões estratigráficos identificados por Giannini et al. (2010) nos sambaquis da área de estudo. Os quatro primeiros sítios, Caipora, Cubículo 1, Morrinhos e Jabuticabeira 1, pertencem ao padrão estratigráfico conchífero, os dois seguintes, Santa Marta 10 e Carniça 3, são classificados como sambaquis de núcleo quartzo-arenoso, enquanto os dois últimos, Santa Marta 8 e Galheta 4, são montículos ictiológicos. 


\subsection{PADRÃO ESTRATIGRÁFICO CONCHÍFERO}

\subsubsection{Caipora}

Neste sambaqui, localizado sobre embasamento granitóide, a aproximadamente 16 $\mathrm{km}$ da atual linha de costa, foram identificadas quatro arqueofácies, mais um horizonte pedogênico A desenvolvido no topo da sucessão estratigráfica (Figura 5.10). Trata-se de sítio característico do setor interno, já que compartilha com outros sítios desse setor a presença predominante de Ostrea sp. e Anomalocardia brasiliana.

A AF 1, na base do sambaqui, abrange um sepultamento humano próximo ao contato com o granito. Diferencia-se do resto das arqueofácies identificadas por apresentar menor freqüência de conchas e maior conteúdo terrígeno. De fato, no estudo zooarqueológico realizado por Ferraz (2010), a AF $1^{65}$ apresenta fragmentos líticos na fração cascalho em mais de $50 \%$ da sua composição.

A AF 2, de espessura centimétrica e formada por areia lamosa preta, apresenta semelhanças, quanto à composição e forma de ocorrência, com as camadas pretas centimétricas que aparecem intercaladamente na camada conchífera e no depósito ictiológico do sítio Jabuticabeira 2 (Fish et al., 2000; Klokler, 2008; Villagran, 2008). No sítio Caipora, não foram observados sepultamentos associados a esta arqueofácies, ainda que isto possa se dever à limitação da sucessão vertical analisada.

A AF 3, que aparece intercalada com a AF 2 a partir dos $80 \mathrm{~cm}$ de profundidade, apresenta conchas inteiras de moluscos, misturadas com fragmentos de concha de tamanho diverso $(3 \mathrm{~cm}$ até $1 \mathrm{~mm})$. $\mathrm{Na}$ identificação faunística realizada por Ferraz (2010), a AF $3^{66}$ é constituída por cerca de $60 \%$ de conchas de Ostrea sp., pouco mais de $10 \%$ de Anomalocardia brasiliana, $5 \%$ de gastrópodes indeterminados e aproximadamente $15 \%$ de fragmentos líticos.

A AF 4, superior, é composta principalmente por fragmentos de conchas de diversas espécies e fragmentos de ossos de peixe. Na sua porção superior, apresenta desenvolvimento de solo incipiente de estrutura granular, com maior freqüência de

\footnotetext{
${ }^{65}$ A arqueofácies 1 , identificada neste trabalho, corresponde à camada 6 da descrição estratigráfica realizada por Ferraz (2010).

${ }^{66}$ A arqueofácies 3, identificada neste trabalho, corresponde à 4 da descrição estratigráfica realizada por Ferraz (2010).
} 
raízes finas $(<5 \mathrm{~mm})$. A assembléia faunística da $\mathrm{AF} 4^{67}$ é semelhante a da $\mathrm{AF} 3$, com pouco mais de $60 \%$ de Ostrea sp., menos de $10 \%$ de Anomalocardia brasiliana e quase $10 \%$ de fragmentos líticos, com porcentagem menor que 5\% de gastrópodes indeterminados e de marisco (Ferraz 2010).

\section{Granulometria}

Análises granulométricas foram realizadas para verificar o vínculo da fração terrígena presente no sambaqui com aquela disponível nas imediações do sítio, relacionada com sedimentos coluvionares, provenientes dos morros graníticos das proximidades, e lagunares. Para realizar a comparação, coletaram-se amostras de trincheira aberta a cerca de $80 \mathrm{~m}$ a nordeste da seção estudada do sambaqui Caipora (Figura 5.11). Nesta trincheira, observa-se mudança gradual, da base até o topo, de fácies de argila siltosa (Fácies A) a argila arenosa (Fácies B). Destaca-se a presença de areia grossa e muita grossa, grânulos e pequenos seixos, inclusive de feldspato e líticos granitóides. Esta sucessão pode ser interpretada como uma fácies de margem lagunar com maior aporte de colúvio (formado por areias angulosas) até o topo.

\footnotetext{
${ }^{67}$ A arqueofácies 4 , identificada neste trabalho, corresponde à camada 3 da descrição estratigráfica realizada por Ferraz (2010).
} 


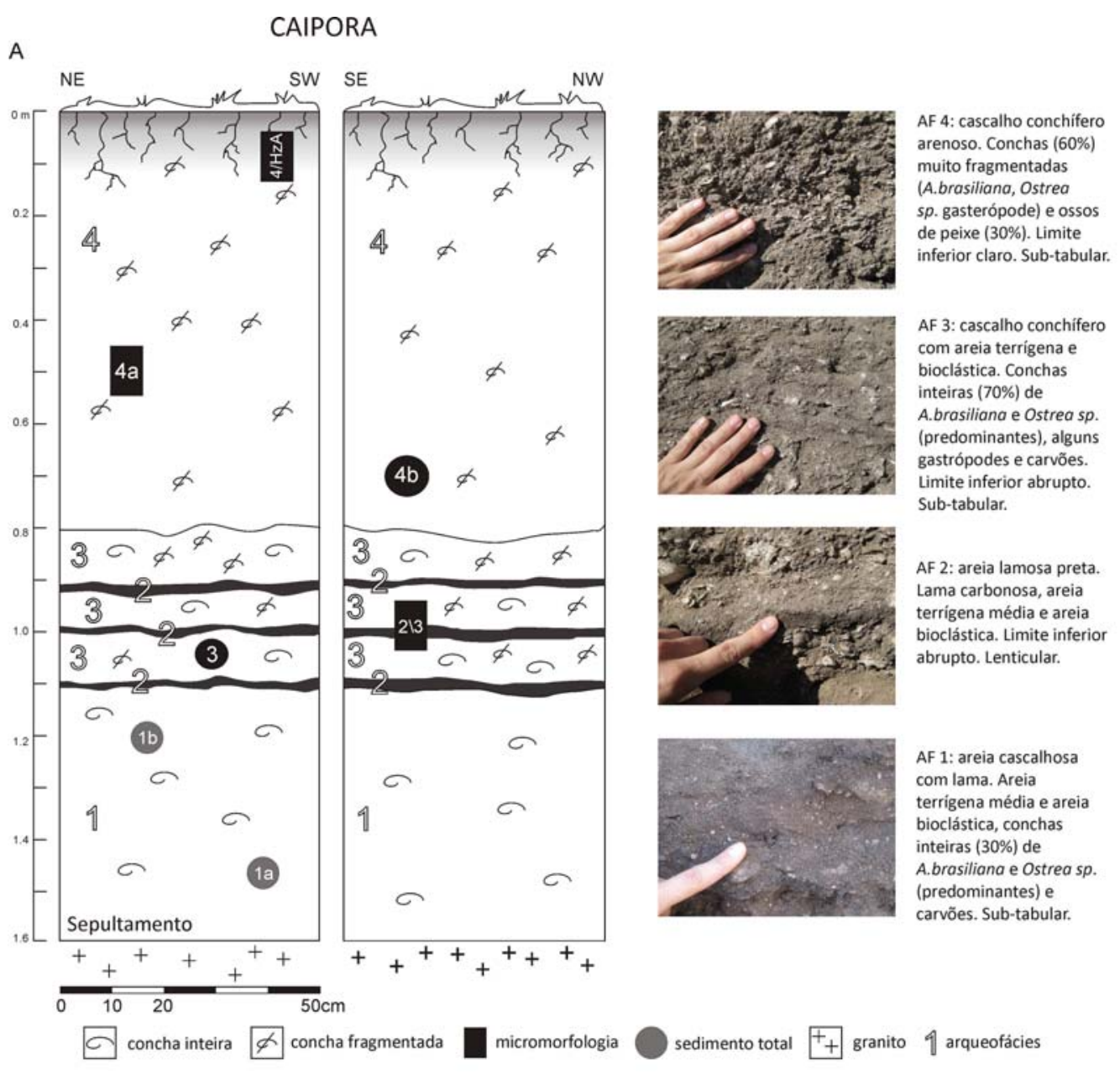

B

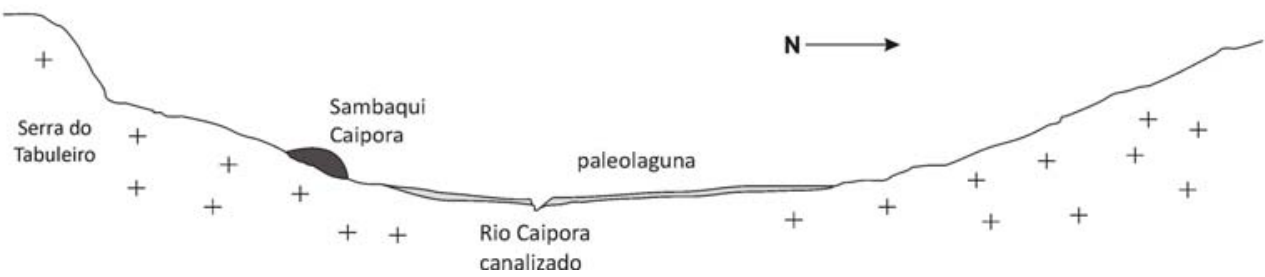

Figura 5.10. Seção vertical estudada do sítio Caipora; A) localização dos pontos de amostragem e descrição das arqueofácies identificadas; B) seção transversal esquemática (sem escala) da área de localização do sítio. 

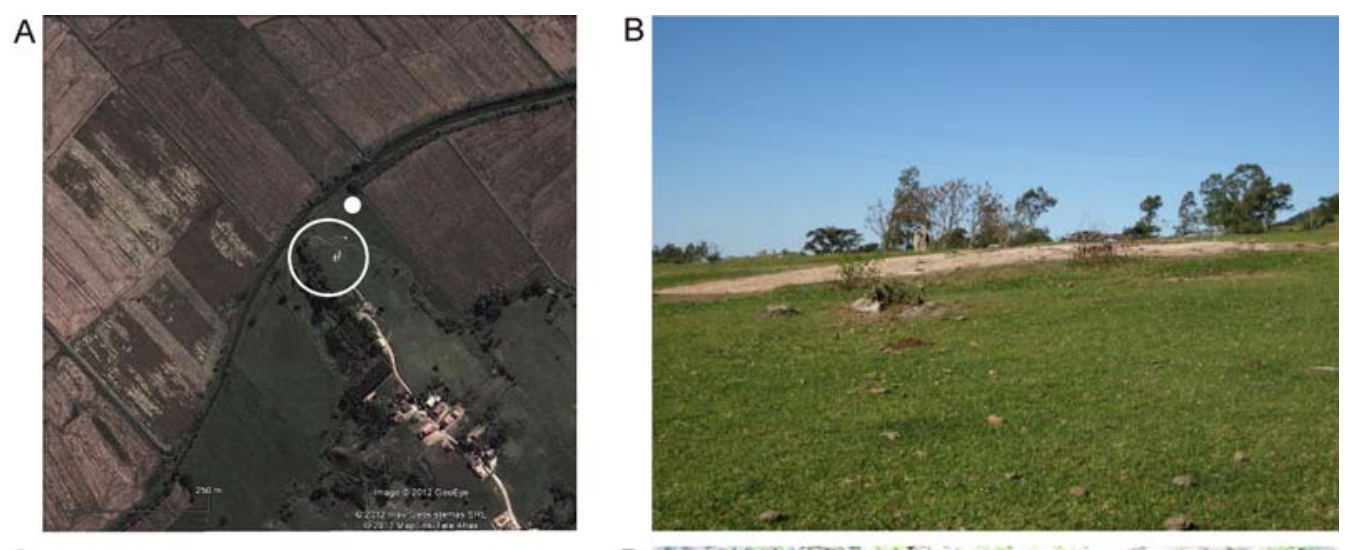

$$
\begin{aligned}
& \text { Fácies } B(0-40 \mathrm{~cm}) \text { : argila } \\
& \text { arenosa, marrom (10YR 4/3), } \\
& \text { em contato gradual com a fácies } \\
& \text { inferior. } \\
& \text { Fácies } A(>40 \mathrm{~cm}) \text { : argila siltosa, } \\
& \text { marrom acinzentado } \\
& (10 Y R 4 / 2)
\end{aligned}
$$

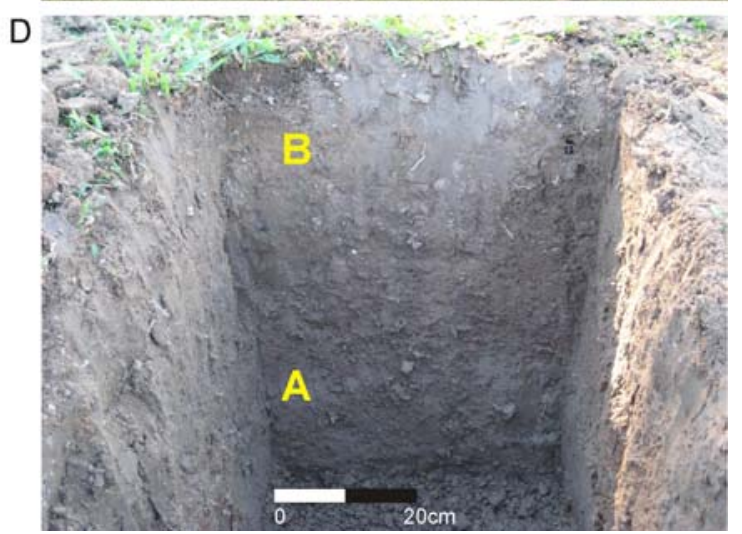

Figura 5.11. Amostragem externa ao sítio Caipora: A) localização do ponto de amostragem; B) entorno de localização do sítio com afloramento granítico localizado a SE do sambaqui; C) descrição das fácies identificadas; D) trincheira amostrada com localização das fácies.

O histograma da distribuição granulométrica da Fácies A (Figura 5.12 A), comparado com o histograma da distribuição granulométrica da AF 1 do sambaqui Caipora, mostra maior presença de grânulos no sambaqui e domínio das frações areia média e areia muito fina no depósito natural. A diferença nas distribuições granulométricas evidencia a escassa relação do depósito antrópico com os sedimentos naturais de paleolaguna adjacentes; em contrapartida, o depósito antrópico é dominado pelas classes grânulos e areia muito grossa, atribuídas ao aporte coluvionar. Ao mesmo tempo, a distribuição granulométrica da AF 1 apresenta a polimodalidade e assimetria que, segundo Brochier (2002), caracteriza os sedimentos arqueológicos ${ }^{68}$. Distribuições granulométricas polimodais assimétricas são típicas de misturas de várias populações de sedimentos (Spencer, 1963; Visher, 1969).

\footnotetext{
${ }^{68}$ Distribuições polimodais foram constatadas também nos sedimentos do sambaqui Jabuticabeira 2 (Villagran, 2008).
} 

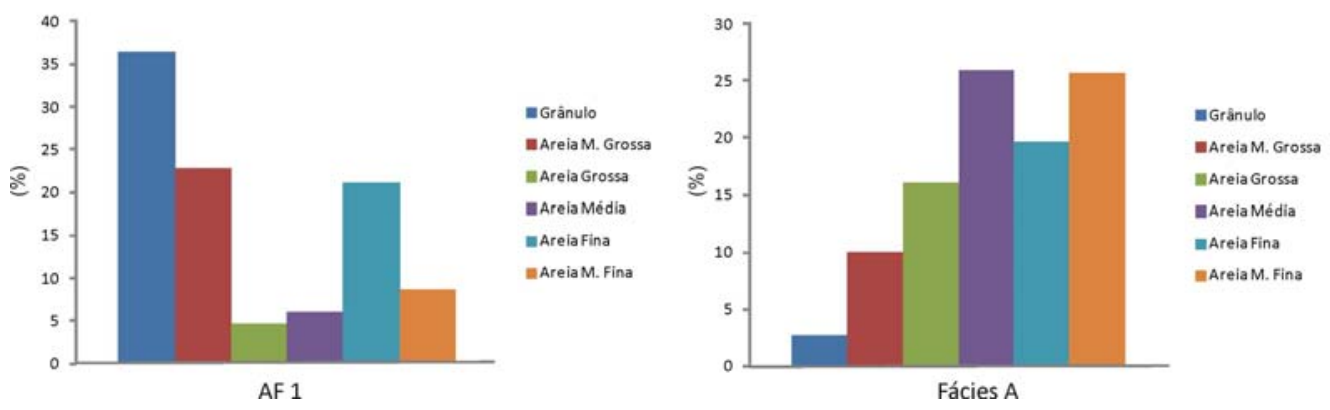

Figura 5.12. Histogramas da distribuição granulométrica para a Fácies A do ponto de amostragem externo ao sambaqui Caipora e da AF 1 do mesmo sambaqui. Note-se o domínio dos pelíticos na Fácies A e das frações grânulo, areia muito grossa e areia fina na AF 1 .

A análise com microscópio estereoscópico dos grãos que compõem os sedimentos da $\mathrm{AF} 1$, retidos nas malhas de $1 \mathrm{~mm}$ (areia muito grossa) e $0,5 \mathrm{~mm}$ (areia grossa), indica o predomínio da fração terrígena (fragmentos líticos, quartzo, feldspato). A observação dos grãos na lupa confirma o domínio de componentes mineralógicos angulosos, junto com feldspatos euédricos e fragmentos líticos granitóides, que corrobora a origem coluvionar já detectada na análise ganulométrica. Dentre os componentes biológicos (concha, osso e carvão), observa-se leve predomínio de conchas, neste caso fragmentadas, sobre restos ósseos (Figura 5.13). Nesta escala de análise, as proporções de conchas e de ossos não aparecem tão díspares quanto na análise zooarqueológica, onde se constatou predomínio marcante das conchas.

CAIPORA - AF 1

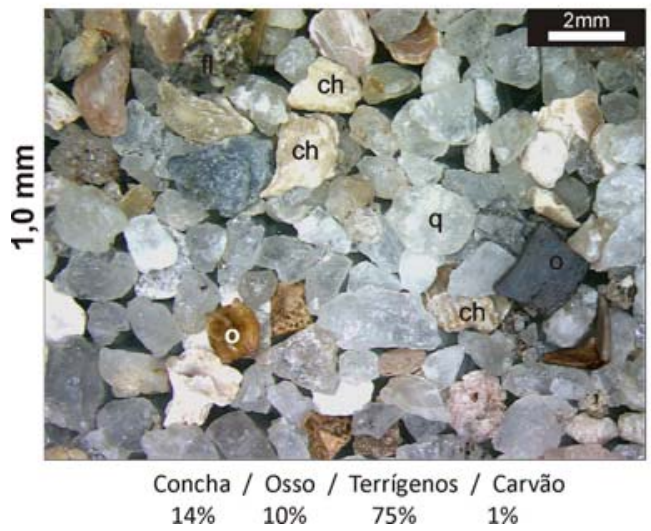

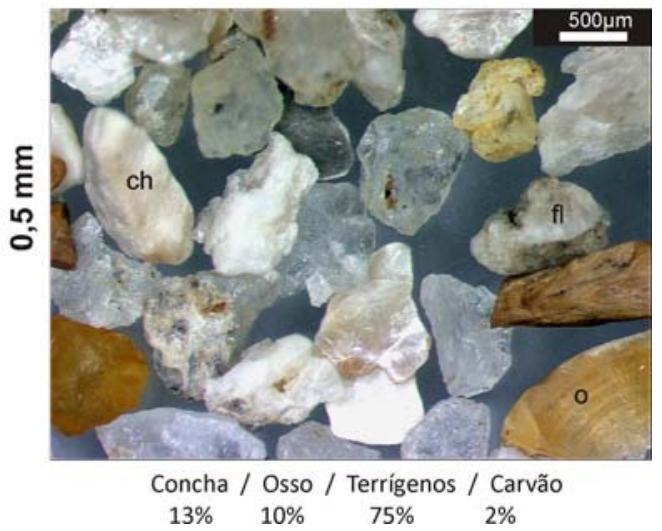

$13 \% \quad 10 \% \quad 75 \% \quad 2 \%$

Figura 5.13. Fotomicrografias à lupa estereoscópica dos grãos retidos nas malhas de $1,0 \mathrm{~mm}$ e $0,5 \mathrm{~mm}$ da arqueofacies 1 do sítio Caipora. Note-se a presença de ossos (o), conchas (ch), fragmentos líticos (fl) e quartzo (q). 
Isótopos de Ce N ( $\left.\delta^{13} \mathrm{Ce} \delta^{53} \mathrm{~N}\right)$

Análises de isótopos de $\mathrm{C}$ e $\mathrm{N}$ foram realizadas exclusivamente na $\mathrm{AF} 1$ e na Fácies $\mathrm{A}$ da amostragem externa. Os valores de $\delta^{13} \mathrm{C}$ indicam a presença de $\mathrm{MO}$ derivada de algas ou da decomposição de plantas de ciclo fotossintético $\mathrm{C}_{3}$. Para diferenciar entre as duas fontes possíveis de $\mathrm{MO}$, combinaram-se os dados de $\delta^{13} \mathrm{C}$ com os de razão $\mathrm{C} / \mathrm{N}$. Os valores de razão $\mathrm{C} / \mathrm{N}$ confirmam a presença de plantas $\mathrm{C}_{3}$ no sedimento do sambaqui e excluem a possibilidade de se encontrarem algas como componente orgânico principal no sítio (Figura 5.14 A).
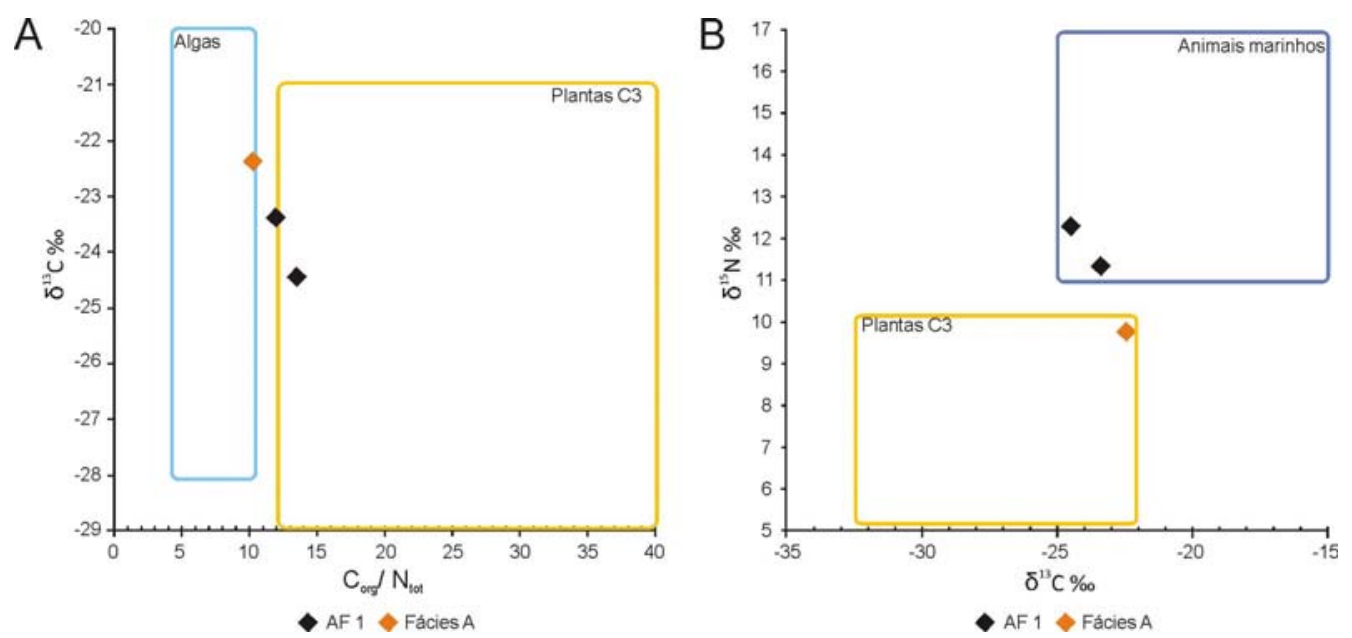

Figura 5.14. Análises isotópicas $\left(\delta^{13} \mathrm{C}\right.$ e $\delta^{15} \mathrm{~N}$ e razão $\left.\mathrm{C} / \mathrm{N}\right)$ de duas amostras provenientes da $\mathrm{AF} 1$ do sítio Caipora, e uma amostra da Fácies A da trincheira aberta em área externa ao sítio: A) gráfico de valores de $\delta^{13} \mathrm{C}$ e razão $\mathrm{C} / \mathrm{N}$ com intervalos definidos para plantas de ciclo fotossintético $\mathrm{C} 3$ e algas, segundo parâmetros de Boutton (1996), Lamb et al. (2006), Meyers (1997), De Niro e Epstein (1978), De Niro e Hastrof (1985) e Sifeddine et al. (2004); B) gráfico dos valores de $\delta^{15} \mathrm{~N}$ e $\delta^{13} \mathrm{C}$ com intervalos definidos para plantas de ciclo fotossintético C3 e animais marinhos, segundo parâmetros definidos por Ben-David et al. (1998), Commisso \& Nelson (2006), Fogg et al. (1998), Morris et al. (2005) e De Niro (1987).

Os valores de $\delta^{15} \mathrm{~N}$ na AF 1 mostram que, além do componente vegetal, pode existir aporte de nitratos de origem animal nos sedimentos do sambaqui (Figura 5.14 B). Solos onde houve aporte de tecidos animais apresentam valores de $\delta^{15} \mathrm{~N}$ de $+8 \%$ a $+20 \%$, devido ao enriquecimento metabólico de $\delta^{15} \mathrm{~N}$ nos animais com relação à sua dieta (Fogg et al., 1998; Kendall, 1998). Assim, o sítio Caipora apresenta mistura de fontes de $\mathrm{MO}$ : plantas $\mathrm{C}_{3}$ e resíduos derivados da decomposição de tecidos animais.

Dentre os diferentes tipos de resíduos animais que podem existir na MO de solos e sedimentos, os valores encontrados no sambaqui Caipora correspondem ao intervalo definido para resíduos de animais marinhos, segundo dados de referência em Ben-David et al. (1998), Commisso \& Nelson (2006), Fogg et al. (1998), Morris et al. (2005) e De 
Niro (1987). Isto é condizente com a assembleia arqueofaunística do sítio, caracterizada pelo predomínio de moluscos (Ferraz, 2010), e com as constatações realizadas a partir da descrição macroscópica das sucessões estratigráficas, onde se observou a presença de conchas e ossos de peixe.

Cabe ressaltar que, na amostra coletada na trincheira externa ao sítio Caipora (Fácies $\mathrm{A}$ ), os valores de $\delta^{13} \mathrm{C}$ e $\delta^{15} \mathrm{~N}$ indicam unicamente presença de plantas $\mathrm{C}_{3}$ (Figura 5.14 A,B). Em relação a esses valores, a MO do sambaqui mostra enriquecimento em nitrogênio derivado da ação antrópica, associada com a deposição de restos de animais, ricos em nitratos de origem animal.

\section{Micromorfologia}

Amostras para micromorfologia foram coletadas das AF 3 e 4, assim como da transição entre as AF 2 e 3, e da AF 4 com o horizonte pedogênico A. Na Figura 5.15, apresenta-se o desenho esquemático das cinco seções delgadas analisadas no sambaqui, com a identificação das microfácies observadas em cada lâmina. Nas amostras 3, 4a e $4 \mathrm{~b}$ foi identificada uma única microfácies, correspondente às $\mathrm{AF} 3$ e 4, respectivamente. $\mathrm{Na}$ amostra 2/3 foram identificadas duas microfácies, correspondentes às $\mathrm{AF} 2$ e 3, assim como na amostra 4/HzA identificaram-se duas microfácies, que representam a AF 4 e o horizonte de solo superficial que se desenvolve no topo da sucessão vertical. A Tabela 5.1 reúne a descrição geral de porosidade, microestrutura, razão g/f (grosso/fino), distribuição relacionada $\mathrm{g} / \mathrm{f}$, componentes inorgânicos e orgânicos da fração grossa, micromassa, limpidez, b-fábrica e feições pedológicas das cinco lâminas analisadas do sítio Caipora, com as microfácies identificadas em cada lâmina. 


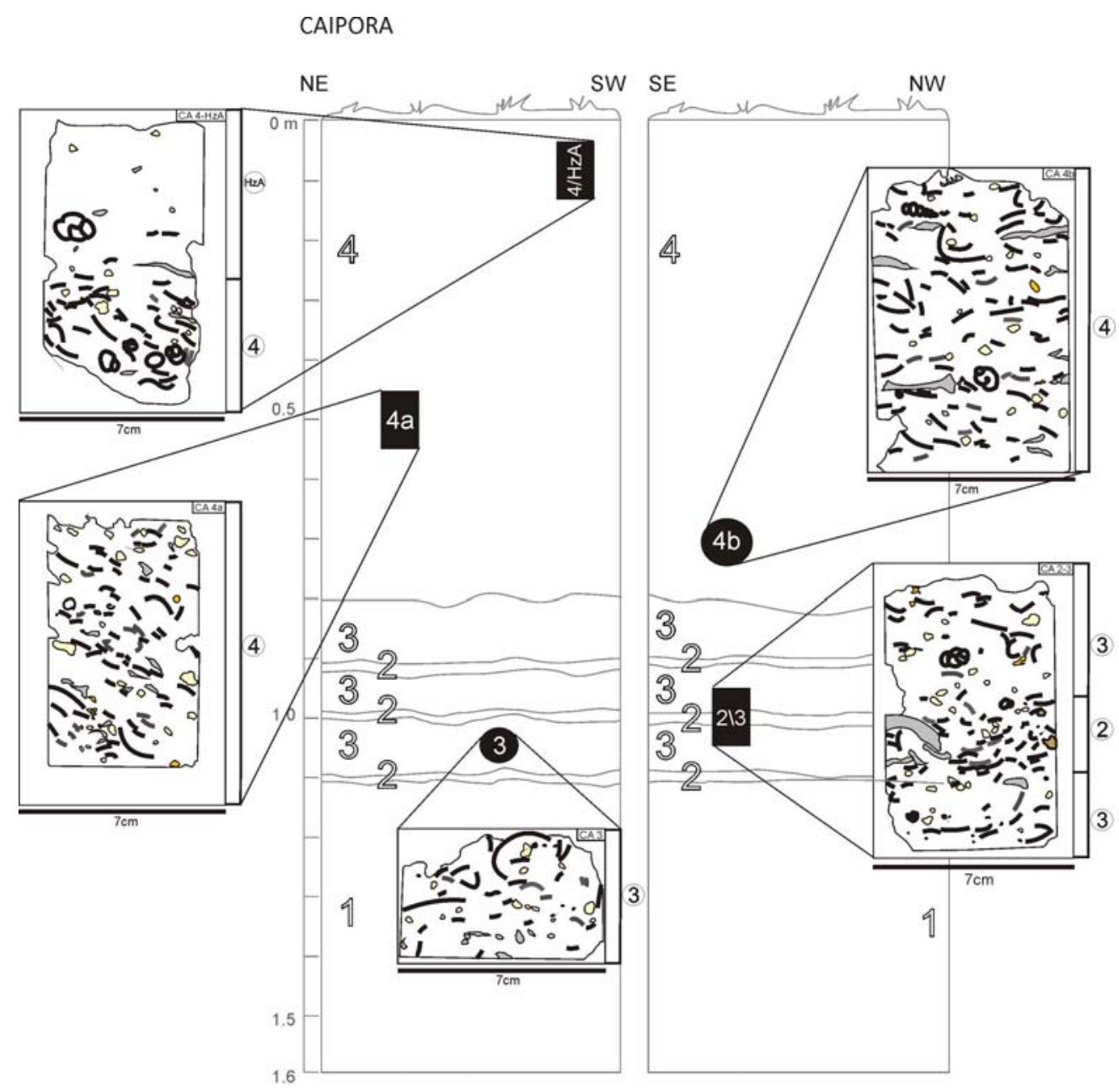

1AF 5 microfacies $\square$ concha $\square$ ostra $[$ osso $\square$ agregado de argila $\square$ carvăo $\square$ concha queimada $\square$ fragmento litico

Figura 5.15. Desenho esquemático das cinco seções delgadas analisadas no sítio Caipora, com localização do bloco de amostragem na sucessão vertical e identificação de microfácies na lâmina. 
Tabela 5.1. Descrição micromorfológica do sambaqui Caipora.

\begin{tabular}{|c|c|c|c|c|c|c|c|c|c|c|c|c|c|c|c|c|c|c|c|c|c|c|}
\hline \multirow[b]{2}{*}{ Am. } & \multirow[b]{2}{*}{$\mathbf{m F}$} & \multirow[b]{2}{*}{ 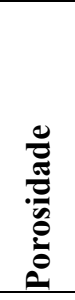 } & \multirow[b]{2}{*}{$\%$} & \multirow[b]{2}{*}{ 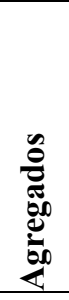 } & \multirow[b]{2}{*}{ Tam. } & \multirow[b]{2}{*}{ Microestrutura } & \multirow[b]{2}{*}{ 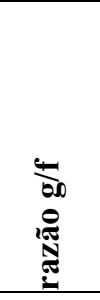 } & \multirow[b]{2}{*}{$\begin{array}{l}\overrightarrow{00} \\
\dot{0} \\
\dot{0} \\
\dot{0} \\
\dot{0} \\
\dot{0}\end{array}$} & \multirow[b]{2}{*}{ 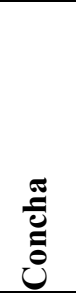 } & \multicolumn{3}{|c|}{ Fr. min. gr. } & \multirow[b]{2}{*}{ 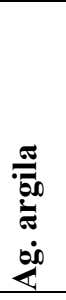 } & \multirow[b]{2}{*}{ 它 } & \multicolumn{2}{|c|}{$\begin{array}{c}\text { Fr. org. } \\
\text { gr. }\end{array}$} & \multicolumn{5}{|c|}{ Micromassa } & \multirow[b]{2}{*}{ FP } \\
\hline & & & & & & & & & & 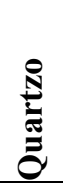 & 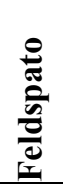 & 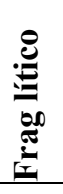 & & & 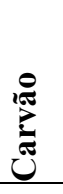 & 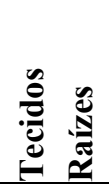 & $\dot{\theta}$ & $\%$ & : & 苞 & Composição & \\
\hline \multirow[t]{2}{*}{$2-3$} & 2 & e-cx & 30 & gr & $\begin{array}{l}100- \\
300 \mu \mathrm{m}\end{array}$ & $\begin{array}{l}\text { Microagregados } \\
\text { interligados } \\
\text { intergranulares }\end{array}$ & $80 / 20$ & $\begin{array}{l}\text { en, } \\
\text { por } \\
\text { quit }\end{array}$ & $\bullet \bullet$ & $\bullet$ & $\bullet$ & $\bullet$ & • & $\bullet$ & $\bullet$ & & & $\begin{array}{l}95 \\
5\end{array}$ & & & $\begin{array}{l}\text { Micrita e argila } \\
\text { Microcarvão }\end{array}$ & $\begin{array}{l}\text { rev } \\
\text { Fe-nod }\end{array}$ \\
\hline & 3 & $\begin{array}{c}\text { e-cx } \\
\text { vs }\end{array}$ & 40 & gr & $\begin{array}{l}100- \\
300 \mu \mathrm{m}\end{array}$ & $\begin{array}{l}\text { Microagregados } \\
\text { interligados } \\
\text { intergranulares }\end{array}$ & $80 / 20$ & $\begin{array}{l}\text { en, } \\
\text { por } \\
\text { quit }\end{array}$ & $\bullet \bullet$ & $\bullet$ & $\bullet \bullet$ & $\bullet$ & • & $\bullet$ & $\bullet$ & & & $\begin{array}{l}95 \\
5\end{array}$ & & & $\begin{array}{l}\text { Micrita e argila } \\
\text { Microcarvão }\end{array}$ & $\begin{array}{l}\text { rev } \\
\text { Fe-nod }\end{array}$ \\
\hline 3 & 3 & e-cx & 25 & $\mathrm{gr}$ & $\begin{array}{l}150- \\
450 \mu \mathrm{m}\end{array}$ & $\begin{array}{l}\text { Microagregados } \\
\text { interligados } \\
\text { intergranulares }\end{array}$ & $80 / 20$ & $\begin{array}{l}\text { quit } \\
\text { gef }\end{array}$ & $\cdots$ & $\cdots$ & $\bullet \bullet$ & $\bullet$ & & $\cdots$ & • & & & $\begin{array}{l}95 \\
5\end{array}$ & $\begin{array}{l}\text { pt } \\
\text { op }\end{array}$ & $\begin{array}{l}\text { cri } \\
\text { ind }\end{array}$ & $\begin{array}{l}\text { Micrita e argila } \\
\text { Microcarvão }\end{array}$ & $\begin{array}{l}\text { rev } \\
\text { Fe-nod }\end{array}$ \\
\hline $4 a$ & 4 & $\begin{array}{l}\text { e-cx } \\
\text { vs }\end{array}$ & 40 & gr & $\begin{array}{l}100- \\
350 \mu \mathrm{m}\end{array}$ & $\begin{array}{l}\text { Microagregados } \\
\text { interligados } \\
\text { intergranulares }\end{array}$ & $80 / 20$ & $\begin{array}{l}\text { en } \\
\text { gef } \\
\text { quit }\end{array}$ & $\bullet \bullet$ & $\cdots$ & $\bullet \bullet$ & $\bullet$ & & $\bullet$ & • & & & $\begin{array}{l}95 \\
5\end{array}$ & $\begin{array}{l}\text { pt } \\
\text { op }\end{array}$ & $\begin{array}{l}\text { cri } \\
\text { ind }\end{array}$ & $\begin{array}{l}\text { Micrita e argila } \\
\text { Microcavão }\end{array}$ & $\begin{array}{l}\text { rev } \\
\text { hiporev } \\
\text { Fe-nod }\end{array}$ \\
\hline
\end{tabular}

Freqüências de classes segundo Bullock et al. (1985): • Muito Poucas (<5\%); •• Poucas (5-15\%); ••• Comum (15-30\%); ••• Freqüente (30-50\%); •••• Dominante (50-70\%); •...• Muito dominante $(>70 \%)$. Am. $=$ amostra; $\mathrm{mF}=$ microfácies; Tam.= tamanho; Fr. min. gr. = fração mineral grossa; Fr. org. gr. = fração orgânica grossa; FP = feições pedológicas. O singificado das demais abreviações utilizadas nesta tabela encontra-se no Anexo, Tabela A.5. 
Tabela 5.1. continuação.

\begin{tabular}{|c|c|c|c|c|c|c|c|c|c|c|c|c|c|c|c|c|c|c|c|c|c|c|}
\hline \multirow[b]{2}{*}{ Am } & \multirow[b]{2}{*}{$\mathbf{m F}$} & \multirow[b]{2}{*}{ 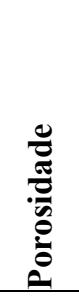 } & \multirow[b]{2}{*}{$\%$} & \multirow[b]{2}{*}{ 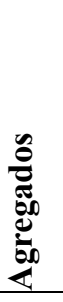 } & \multirow[b]{2}{*}{ Tam. } & \multirow[b]{2}{*}{ Microestrutura } & \multirow[b]{2}{*}{ 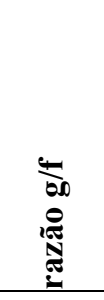 } & \multirow[b]{2}{*}{$\begin{array}{l}\omega_{00}^{+} \\
\dot{0} \\
\dot{0} \\
\dot{0} \\
\dot{0}\end{array}$} & \multicolumn{6}{|c|}{ Fr. min. gr. } & \multicolumn{2}{|c|}{$\begin{array}{c}\text { Fr. org. } \\
\text { gr. }\end{array}$} & \multicolumn{5}{|c|}{ Micromassa } & \multirow[b]{2}{*}{ FP } \\
\hline & & & & & & & & & ن⿺辶ّ & 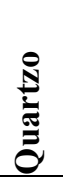 & 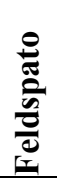 & 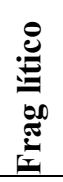 & 苞 & 容 & 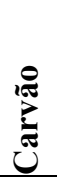 & 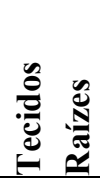 & $\dot{0}$ & $\%$ & $\frac{\sqrt[0]{0}}{2}$ & 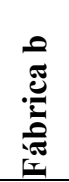 & Composição & \\
\hline $4 b$ & 4 & $\begin{array}{l}\text { e-cx } \\
\text { cn } \\
\text { fs }\end{array}$ & 30 & gr & $\begin{array}{l}100- \\
300 \mu \mathrm{m}\end{array}$ & $\begin{array}{l}\text { Microagregados } \\
\text { interligados } \\
\text { intergranulares }\end{array}$ & $80 / 20$ & $\begin{array}{l}\text { en } \\
\text { gef } \\
\text { quit }\end{array}$ & $\bullet \bullet \bullet$ & $\bullet \bullet$ & $\cdots$ & $\bullet$ & • & $\bullet$ & & & & $\begin{array}{l}95 \\
5\end{array}$ & $\begin{array}{l}\mathrm{pt} \\
\text { op }\end{array}$ & $\begin{array}{l}\text { cri } \\
\text { ind }\end{array}$ & $\begin{array}{l}\text { Micrita e argila } \\
\text { Microcavão }\end{array}$ & $\begin{array}{l}\text { rev } \\
\text { Fe-nod }\end{array}$ \\
\hline \multirow[t]{2}{*}{$\mathrm{HzA} / 4$} & 4 & $\begin{array}{l}\text { e-cx } \\
\text { vs }\end{array}$ & 30 & gr & $\begin{array}{l}150- \\
450 \mu \mathrm{m}\end{array}$ & $\begin{array}{l}\text { Microagregados } \\
\text { interligados } \\
\text { intergranulares }\end{array}$ & $70 / 30$ & $\begin{array}{l}\text { gef } \\
\text { quit } \\
\text { en }\end{array}$ & $\bullet \bullet \bullet$ & $\bullet \bullet$ & $\bullet$ & $\bullet$ & & $\bullet$ & & • & & $\begin{array}{l}95 \\
5\end{array}$ & $\begin{array}{l}\text { pt } \\
\text { op }\end{array}$ & $\begin{array}{l}\text { cri } \\
\text { ind }\end{array}$ & $\begin{array}{l}\text { Micrita e argila } \\
\text { Microcavão }\end{array}$ & $\begin{array}{l}\text { rev } \\
\text { hiporev } \\
\text { Fe-nod } \\
\text { ench } \\
\text { exc }\end{array}$ \\
\hline & $\begin{array}{c}\mathrm{Hz} \\
\mathrm{A}\end{array}$ & $\begin{array}{l}\mathrm{cm} \\
\mathrm{cn} \\
\mathrm{fs}\end{array}$ & 15 & gr & $\begin{array}{l}250- \\
500 \mu \mathrm{m}\end{array}$ & $\begin{array}{l}\text { Grânulos } \\
\text { coesivos }\end{array}$ & $50 / 50$ & por & $\bullet \bullet$ & $\bullet \bullet \bullet$ & $\cdots$ & $\bullet$ & & $\bullet$ & & $\bullet$ & & & $\mathrm{pt}$ & cri & Argila e micrita & $\begin{array}{l}\text { rev } \\
\text { hiporev } \\
\text { Fe-nod } \\
\text { exc }\end{array}$ \\
\hline
\end{tabular}


Tabela 5.2. Componentes minerais e orgânicos da fração grossa da amostra CA 2-3.

\begin{tabular}{|c|c|c|c|c|c|c|c|c|c|c|}
\hline \multicolumn{11}{|l|}{ CA 2-3 } \\
\hline & $\mathbf{m F}$ & $\%$ & Tamanho & Forma & Arredondamento & Seleção & $\begin{array}{c}\text { Distribuição } \\
\text { básica }\end{array}$ & $\begin{array}{c}\text { Orientação } \\
\text { básica }\end{array}$ & $\begin{array}{l}\text { Distribuição } \\
\text { referenciada }\end{array}$ & Alteração \\
\hline Concha & 2 & 43 & Vários & - & - & Não selecionado & Aleatória/ linear & $\begin{array}{l}80 \% \text { paralelismo } \\
\text { de ângulo baixo }\end{array}$ & $\begin{array}{l}\text { Inclinado á } \\
\text { superfície }\end{array}$ & $\begin{array}{l}\text { Queima e } \\
\text { dissolução }\end{array}$ \\
\hline Quartzo & 2 & 20 & $\begin{array}{l}\text { Areia grossa a } \\
\text { fina }\end{array}$ & Equidimensional & Subanguloso & Seleção moderada & Aleatória & - & - & - \\
\hline Feldspato & 2 & 15 & Areia média & Equidimensional & Subanguloso & Bem selecionado & Aleatória & - & - & - \\
\hline Frag. Lít. & 2 & 5 & $\begin{array}{l}\text { Grânulo, areia } \\
\text { muito grossa }\end{array}$ & Equidimensional & Subanguloso & Bem selecionado & Aleatória & - & - & - \\
\hline Osso & 2 & 10 & Vários & - & - & Não selecionado & Aleatória & - & - & $\begin{array}{l}\text { Queima e } \\
\text { dissolução }\end{array}$ \\
\hline Ag. argila & 2 & 2 & Grânulo & Equidimensional & Anguloso & Não selecionado & Aleatória & - & - & - \\
\hline Carvão & 2 & 5 & Vários & - & Anguloso & Não selecionado & Aleatória & - & - & - \\
\hline Concha & 3 & 43 & Vários & - & - & Não selecionado & Aleatória & - & - & $\begin{array}{l}\text { Queima e } \\
\text { dissolução }\end{array}$ \\
\hline Quartzo & 3 & 20 & $\begin{array}{l}\text { Areia grossa a } \\
\text { fina }\end{array}$ & Equidimensional & Subanguloso & Bem selecionado & Aleatória & - & - & - \\
\hline Feldspato & 3 & 15 & Areia média & Equidimensional & Subanguloso & Seleção moderada & Aleatória & - & - & - \\
\hline Frag. Lít. & 3 & 5 & $\begin{array}{l}\text { Grânulo, areia } \\
\text { muito grossa }\end{array}$ & Equidimensional & Subanguloso & Bem selecionado & Aleatória & - & - & - \\
\hline Osso & 3 & 10 & Vários & - & - & Não selecionado & Aleatória & - & - & $\begin{array}{l}\text { Queima e } \\
\text { dissolução }\end{array}$ \\
\hline Ag. argila & 3 & 2 & Grânulo & Equidimensional & Anguloso & Não selecionado & Aleatória & - & - & - \\
\hline Carvão & 3 & 5 & Vários & - & Anguloso & Não selecionado & Aleatória & - & - & - \\
\hline
\end{tabular}


Tabela 5.3. Componentes minerais e orgânicos da fração grossa da amostra CA 3.

\begin{tabular}{|c|c|c|c|c|c|c|c|c|c|c|}
\hline \multicolumn{11}{|l|}{ CA 3} \\
\hline & $\mathbf{m F}$ & $\%$ & Tamanho & Forma & Arredondamento & Seleção & $\begin{array}{c}\text { Distribuição } \\
\text { básica }\end{array}$ & $\begin{array}{c}\text { Orientação } \\
\text { básica }\end{array}$ & $\begin{array}{l}\text { Distribuição } \\
\text { referenciada }\end{array}$ & Alteração \\
\hline Concha & & 40 & Vários & - & 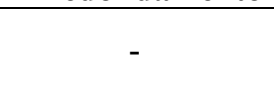 & Não selecionado & Aleatória & ( & - & $\begin{array}{l}\text { Queima e } \\
\text { dissolução }\end{array}$ \\
\hline Quartzo & & 25 & $\begin{array}{c}\text { Areia grossa a } \\
\text { fina }\end{array}$ & Equidimensional & Subanguloso & Seleção moderada & Aleatória & - & - & - \\
\hline Feldspato & & 14 & Areia média & Equidimensional & Subanguloso & Bem selecionado & Aleatória & - & - & - \\
\hline Frag. Lít. & & 10 & $\begin{array}{l}\text { Grânulo, areia } \\
\text { mto. grossa }\end{array}$ & Equidimensional & Subanguloso & Bem selecionado & Aleatória & - & - & - \\
\hline Osso & & 10 & Vários & - & - & Não selecionado & Aleatória & - & - & $\begin{array}{l}\text { Queima e } \\
\text { dissolução }\end{array}$ \\
\hline Carvão & & 1 & Vários & - & - & Não selecionado & Aleatória & - & - & - \\
\hline
\end{tabular}


Tabela 5.4. Componentes minerais e orgânicos da fração grossa da amostra CA 4a.

\begin{tabular}{|c|c|c|c|c|c|c|c|c|c|c|}
\hline \multicolumn{11}{|l|}{ CA 4a } \\
\hline & $\mathbf{m F}$ & $\%$ & Tamanho & Forma & Arredondamento & Seleção & $\begin{array}{l}\text { Distribuiçãa } \\
\text { básica }\end{array}$ & $\begin{array}{c}\text { Orientação } \\
\text { básica }\end{array}$ & $\begin{array}{l}\text { Distribuição } \\
\text { referenciada }\end{array}$ & Alteração \\
\hline Concha & & 30 & Vários & - & - & Não selecionado & Aleatória/ linear & $\begin{array}{l}30 \% \text { paralelismo } \\
\text { de ângulo baixio }\end{array}$ & $\begin{array}{l}\text { Inclinado á } \\
\text { superfície }\end{array}$ & $\begin{array}{l}\text { Queima e } \\
\text { dissolução }\end{array}$ \\
\hline Quartzo & & 25 & $\begin{array}{c}\text { Areia grossa a } \\
\text { fina }\end{array}$ & Equidimensional & Subanguloso & Seleção moderada & Aleatória & 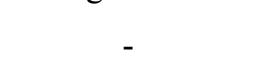 & - & - \\
\hline Feldspato & & 28 & Areia média & Equidimensional & Subanguloso & Bem selecionado & Aleatória & - & - & - \\
\hline Frag. Lít. & & 10 & $\begin{array}{l}\text { Grânulo, areia } \\
\text { mto. grossa }\end{array}$ & Equidimensional & Subanguloso & Bem selecionado & Aleatória & - & - & - \\
\hline Osso & & 5 & Vários & - & - & Não selecionado & Aleatória & - & - & $\begin{array}{l}\text { Queima e } \\
\text { dissolução }\end{array}$ \\
\hline Carvão & & 2 & Vários & - & - & Não selecionado & Aleatória & - & - & - \\
\hline
\end{tabular}


Tabela 5.5. Componentes minerais e orgânicos da fração grossa da amostra CA 4b.

\begin{tabular}{|c|c|c|c|c|c|c|c|c|c|c|}
\hline \multicolumn{11}{|l|}{ CA 4b } \\
\hline & $\mathbf{m F}$ & $\%$ & Tamanho & Forma & Arredondamento & Seleção & $\begin{array}{l}\text { Distribuiçãa } \\
\text { básica }\end{array}$ & $\begin{array}{c}\text { Orientação } \\
\text { básica }\end{array}$ & $\begin{array}{l}\text { Distribuição } \\
\text { referenciada }\end{array}$ & Alteração \\
\hline Concha & & 33 & Vários & - & 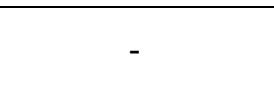 & Não selecionado & Aleatória/ linear & $\begin{array}{l}50 \% \text { paralelismo } \\
\text { de ângulo baixo }\end{array}$ & $\begin{array}{l}\text { Inclinado á } \\
\text { superfície }\end{array}$ & $\begin{array}{l}\text { Queima e } \\
\text { dissolução }\end{array}$ \\
\hline Quartzo & & 25 & $\begin{array}{c}\text { Areia grossa a } \\
\text { fina }\end{array}$ & Equidimensional & Subanguloso & Seleção moderada & Aleatória & 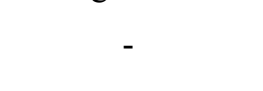 & - & - \\
\hline Feldspato & & 20 & Areia média & Equidimensional & Subanguloso & Bem selecionado & Aleatória & - & - & - \\
\hline Frag. Lít. & & 9 & $\begin{array}{l}\text { Grânulo, areia } \\
\text { mto. grossa }\end{array}$ & Equidimensional & Subanguloso & Bem selecionado & Aleatória & - & - & - \\
\hline Osso & & 10 & Vários & - & - & Não selecionado & Aleatória & - & - & $\begin{array}{l}\text { Queima e } \\
\text { dissolução }\end{array}$ \\
\hline Equinóide & & 1 & $625-645 \mu \mathrm{m}$ & - & - & $\begin{array}{l}\text { Muito bem } \\
\text { selecionado }\end{array}$ & Aleatória & - & - & 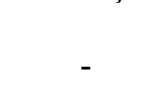 \\
\hline Carvão & & 2 & Vários & - & - & Não selecionado & Aleatória & - & - & - \\
\hline
\end{tabular}


Tabela 5.6. Componentes minerais e orgânicos da fração grossa da amostra CA HA-4.

\begin{tabular}{|c|c|c|c|c|c|c|c|c|c|c|}
\hline \multicolumn{11}{|l|}{ CA HA-4 } \\
\hline & $\mathbf{m F}$ & $\%$ & Tamanho & Forma & $\begin{array}{c}\text { Grau de } \\
\text { Arredondamento }\end{array}$ & Seleção & $\begin{array}{l}\text { Distribuiçãa } \\
\text { básica }\end{array}$ & $\begin{array}{c}\text { Orientação } \\
\text { básica }\end{array}$ & $\begin{array}{l}\text { Distribuição } \\
\text { referenciada }\end{array}$ & Alteração \\
\hline Concha & $\mathrm{HzA}$ & 15 & Vários & - & 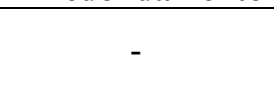 & Não selecionado & Aleatória & 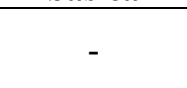 & (1) & $\begin{array}{l}\text { Queima e } \\
\text { dissolução }\end{array}$ \\
\hline Quartzo & $\mathrm{HzA}$ & 45 & $\begin{array}{l}\text { Areia média a } \\
\text { fina }\end{array}$ & Equidimensional & Subanguloso & Bem selecionado & Aleatória & - & - & - \\
\hline Feldspato & $\mathrm{HzA}$ & 20 & $\begin{array}{l}\text { Areia média a } \\
\text { fina }\end{array}$ & Equidimensional & Subanguloso & Bem selecionado & Aleatória & - & - & - \\
\hline Frag. Lít. & $\mathrm{HzA}$ & 5 & Grânulo & Equidimensional & Subanguloso & Bem selecionado & Aleatória & - & - & - \\
\hline Osso & $\mathrm{HzA}$ & 10 & Vários & - & - & Não selecionado & Aleatória & - & - & $\begin{array}{l}\text { Queima e } \\
\text { dissolução }\end{array}$ \\
\hline Raízes & $\mathrm{HzA}$ & 5 & $\sim 300 \mu \mathrm{m}$ & - & - & - & Aleatória & - & - & - \\
\hline Concha & 4 & 43 & Vários & - & - & Não selecionado & Aleatória & - & - & $\begin{array}{l}\text { Queima e } \\
\text { dissolução }\end{array}$ \\
\hline Quartzo & 4 & 30 & $\begin{array}{l}\text { Areia grossa a } \\
\text { fina }\end{array}$ & Equidimensional & Subanguloso & Seleção moderada & Aleatória & - & - & - \\
\hline Feldspato & 4 & 10 & $\begin{array}{l}\text { Areia média a } \\
\text { fina }\end{array}$ & Equidimensional & Subanguloso & Bem selecionado & Aleatória & - & - & - \\
\hline Frag. Lít. & 4 & 5 & $\begin{array}{l}\text { Grânulo, areia } \\
\text { muito grossa }\end{array}$ & Equidimensional & Subanguloso & Bem selecionado & Aleatória & - & - & - \\
\hline Osso & 4 & 10 & Vários & - & - & Não selecionado & Aleatória & - & - & $\begin{array}{l}\text { Queima e } \\
\text { dissolução }\end{array}$ \\
\hline Raízes & 4 & 2 & $\sim 200 \mu \mathrm{m}$ & - & - & - & Aleatória & - & - & - \\
\hline
\end{tabular}


Em todas as microfácies estudadas, a fração grossa aparece composta por conchas, grãos de quartzo, feldspato, fragmentos líticos e ósseos. Todas as microfácies têm distribuição espacial aleatória da fração grossa, exceto nas $\mathrm{mF} 2$ e 4 , onde se observam conchas com trama sub-horizontal (Tabelas 5.2 a 5.4).

Poucas diferenças se observam na proporção dos diversos componentes da fração grossa, com domínio constante de fragmentos de concha e terrígenos (Figura 5.16A). A fração mineral terrígena grossa inclui quartzo, feldspato e fragmentos líticos subangulosos; relaciona-se com o transporte de sedimentos oriundos do afloramento granítico das proximidades do sítio.

Dentre as conchas, observam-se espécies diversas de bivalves (Figura 5.16 C, D) e gastrópodes (Figura 5.16 A, B). Em todos os casos, observam-se proporções variáveis, entre 10 e 20\%, de conchas com sinais de queima (Tabelas 5.2 a 5.6). A identificação de efeito de queima nas conchas foi realizada segundo as observações do experimento apresentado no tópico 1.2. Na Figura 5.17 E e F, mostra-se um exemplo de fragmento de concha queimado possivelmente a temperaturas maiores que $600^{\circ} \mathrm{C}$, dada a coloração marrom escura a preta, a birrefringência baixa e a presença de fissuras longitudinais. Além das conchas, que representam o componente mais conspícuo do sítio, observaram-se igualmente numerosos fragmentos de osso. Os ossos apresentam sinais de queima, com coloração vermelho escuro (PPL) (Figura 5.17 A, B, E, F) e dissolução, como bordas suaves e birrefringência baixa nos fragmentos aparentemente não queimados. Em alguns casos, é possível identificar o tipo de osso, como no caso da vértebra da Figura 5.17 C, D. 

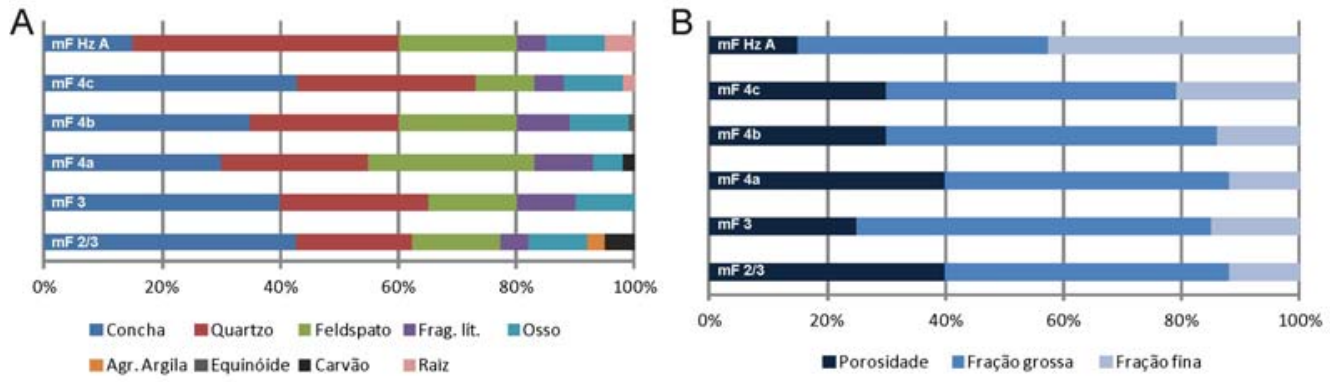

Figura 5.16. Gráficos com porcentagens dos diferentes componentes microscópicos das $\mathrm{mF} 2,3,4 \mathrm{e}$ horizonte de solo superficial (Hz A) do sítio Caipora: A) freqüências de componentes da fração grossa; B) relação de porcentagens de poros, fração grossa e fração fina. Note-se a diminuição da porosidade e aumento da fração fina no horizonte superficial.
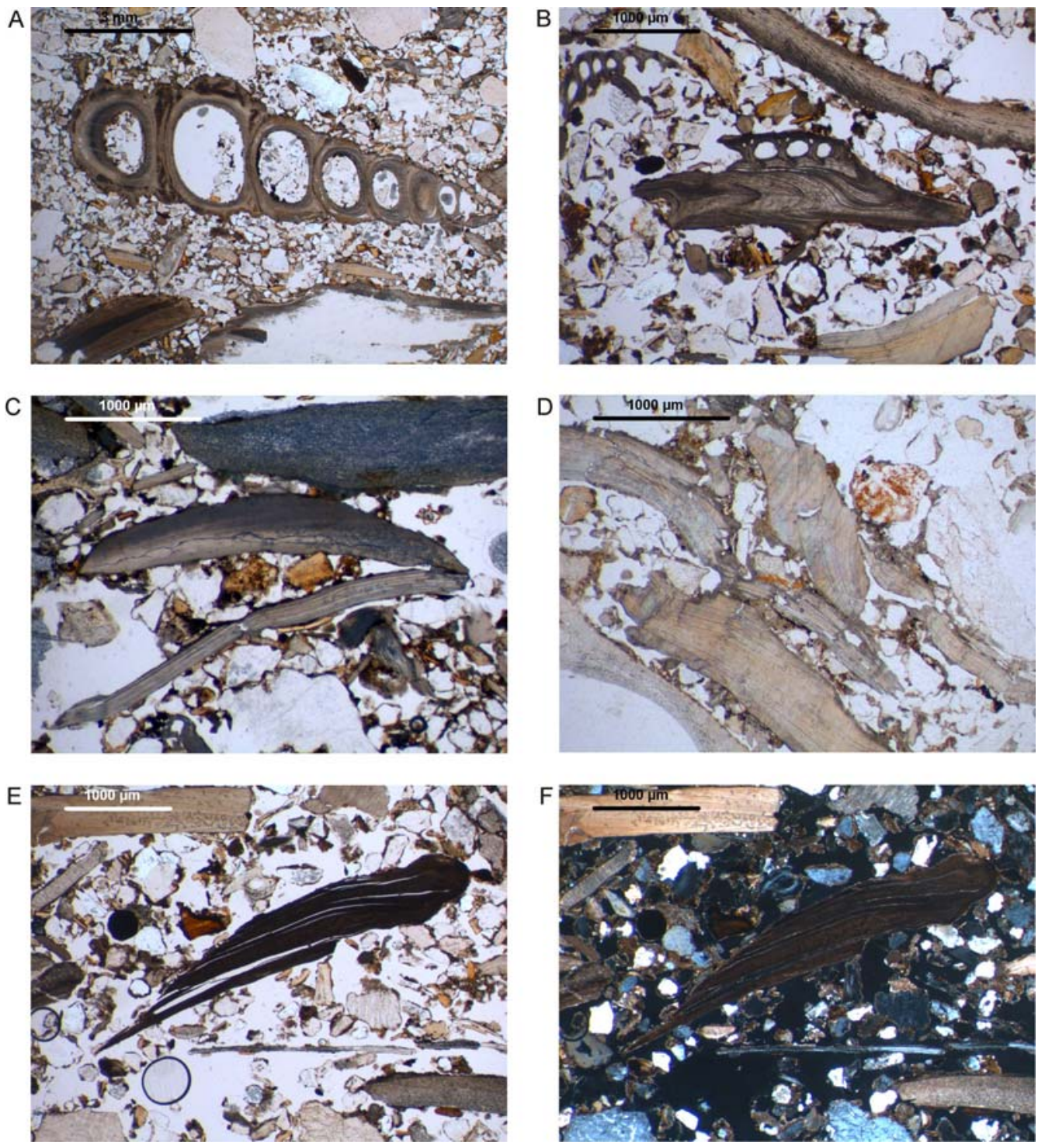

Figura 5.17. Fotomicrografias de moluscos encontrados no sítio Caipora: A) gastrópode; B) fragmentos de concha de craca; C) bivalve indeterminado; D) fragmentos de ostra, identificados pela fibrosidade longitudinal da concha; E, F) concha queimada a temperatura maior que $600^{\circ} \mathrm{C}$, a PPL e XPL. 

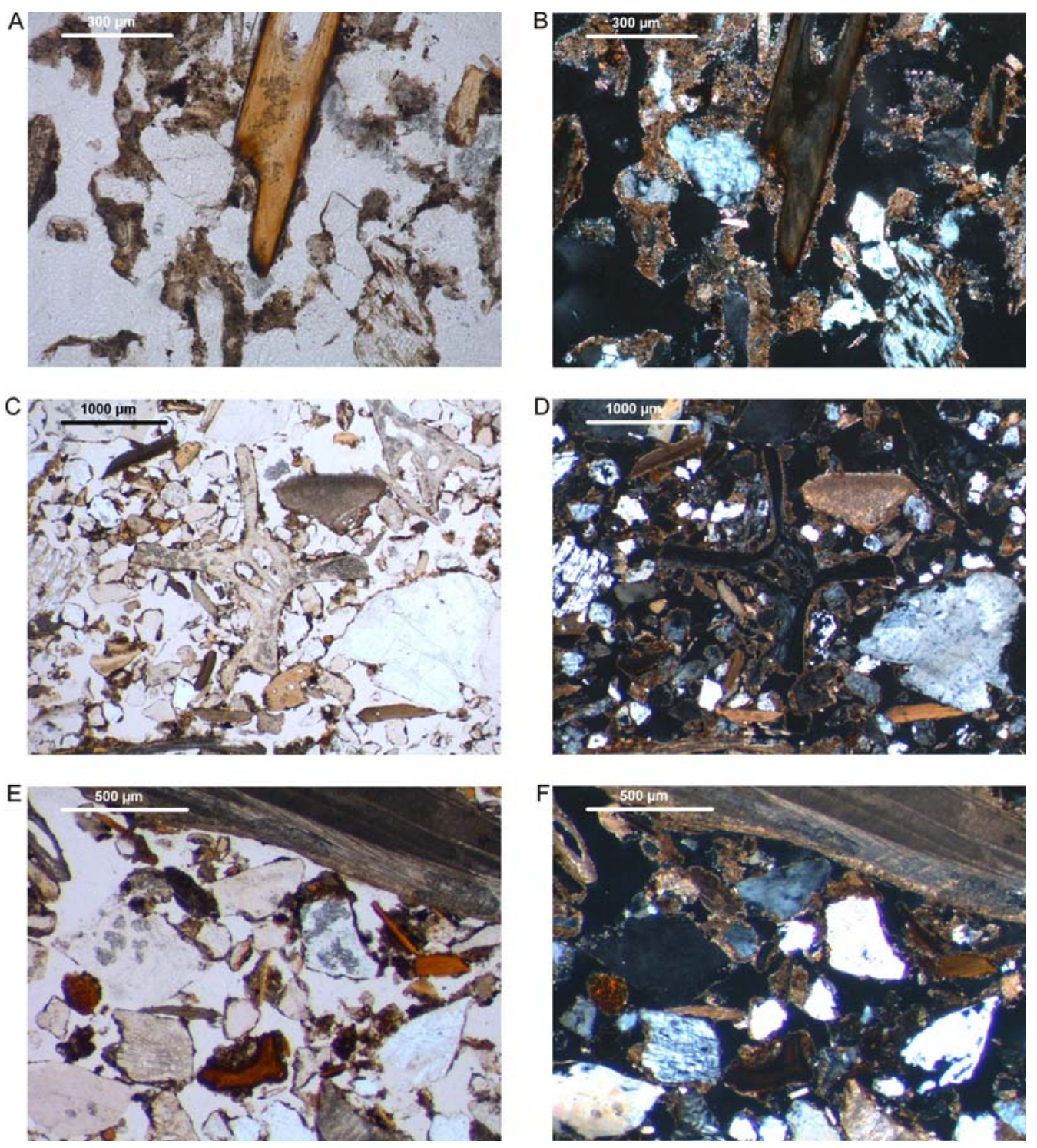

Figura 5.18. Fotomicrografias de ossos queimados no sítio Caipora: A, B) ossos queimados, reconhecidos respectivamente por bordas avermelhadas, a PPL, e birrefringência baixa, a XPL; C, D) vértebras de peixe, freqüentemente encontradas e facilmente identificáveis em seção delgada, a PPL e XPL.

Em toda a seção vertical, a micromassa é formada por grânulos ${ }^{69}$ mamilares coesivos, microestrutura de microagregados intergranulares interligados e vazios de empacotamento complexo, com presença subordinada de vazios vesiculares, canais, fissuras e vazios em câmara. A distribuição relacionada $\mathrm{g} / \mathrm{f}$ varia entre gefúrica, quitónica e enáulica em todas as amostras, menos na microfácies correspondente ao horizonte A incipiente, que apresenta tipo porfírico (Tabela 5.1).

\footnotetext{
${ }^{69}$ Em micromorfologia, o termo grânulo usa-se para referir a agregados massivos de material fino, sem relação com o uso do termo como classe granulométrica (partículas de 2-4 mm).
} 
A micromassa predominante é cristalítica e pontuada, às vezes turva, formada por mistura entre argila organomineral ${ }^{70}$ e micrita derivada da dissolução e precipitação do carbonato de cálcio das conchas (Figura 5.19 C-F, 5.20 C-F. 5.22 C-F). Dentre os agregados, observam-se, em todos os casos, fragmentos na fração silte de ossos e conchas, junto com microcarvões e nódulos de óxi-hidróxidos de ferro. As diferenças de coloração na micromassa, que vai de marrom escuro a marrom cinzento, devem-se à maior ou menor quantidade de argila organomineral na fração fina. Quanto maior o conteúdo de argila organomineral, mais amarronzada é a coloração, e, quanto menor, e com maior proporção de micrita, mais cinzenta ela é. Em toda a seção vertical, exceto na microfácies correspondente ao horizonte A incipiente, existe outra micromassa subordinada, de coloração preta, opaca e indiferenciada, formada por microcarvões que se apresentam na forma de agregados $(<300 \mu \mathrm{m})$ e revestimentos (Tabela 5.1).

Análises com microscopia eletrônica de varredura (MEV) e espectrometria de energia dispersiva (EED) foram realizadas unicamente na seção delgada CA 2/3 para checar a composição da fração fina inferida pelas propriedades ópticas. As microanálises semiquantitativas no sistema MEV-EED mostram predomínio de sílica na micromassa ( $\sim 30 \%)$, seguido de $\mathrm{Ca}(\sim 9 \%)$, $\mathrm{Al}(\sim 7-8 \%)$, Fe $(\sim 3 \%)$ e P $(\sim 1-2 \%)$ com concentração menor a $1 \%$ de outros elementos $(\mathrm{K}, \mathrm{Mg}, \mathrm{Ti}, \mathrm{Na}, \mathrm{Mn}$ ) (Anexo, Figura A.4). Esta composição confirma a presença de argilominerais com carbonato de cálcio derivado da dissolução das conchas, junto a minerais secundários formados a partir da dissolução e precipitação da apatita dos ossos.

As $\mathrm{mF} 2$ diferencia-se da $\mathrm{mF} 3$ unicamente na maior concentração de fragmentos de concha com orientação sub-horizontal. No restante de atributos, ambas as microfácies apresentam a mesma porosidade, tipo de agregados, microestrutura e distribuição relacionada g/f (Figura 5.19 B; Tabela 5.1). A composição da fração grossa e micromassa não variam (Tabela 5.2). $\mathrm{Na} \mathrm{mF} \mathrm{3,} \mathrm{destaca-se} \mathrm{a} \mathrm{alta} \mathrm{fragmentação} \mathrm{das}$ conchas, apesar de que, no campo, a AF 3 parecia conter mais conchas inteiras que o restante da seção (Figura 5.19 C, D). Os ossos aparecem igualmente muito fragmentados e com sinais de queima (cor vermelho escuro a preto) (Figura 5.19 E, F).

A mF 4 apresenta características semelhantes nas três seções estudadas (Figura 5.20). Destaca-se a maior proporção de conchas com traços de queima a temperatura

\footnotetext{
${ }^{70}$ Entende-se por argila organomineral a fração fina formada por argilominerais ligados a particulas de MO coloidal.
} 
superior aos $500^{\circ} \mathrm{C}$ (cor cinza escuro a preto, fissuras internas, baixa birrefringência). As conchas e ossos estão muito fragmentados, com poucos indivíduos inteiros e todos com marcas de dissolução na forma de micrita e espato precipitado na borda dos fragmentos (Figura 5.20 C, D). A assembléia faunística inclui restos de bivalves e gastrópodes. Entre 30 e 50\% das conchas inteiras, mais fragmentos grossos de concha, identificados na $\mathrm{mF} 4$, apresentam distribuição sub-horizontal. O restante dos componentes ocorre aleatoriamente distribuído (Tabela 5.1, 5.4 e 5.5).

$\mathrm{Na}$ amostra $\mathrm{CA} \mathrm{4b}$, identificaram-se dois espinhos de equinóide (Figura 5.21), associados à presença de restos de ouriço do mar no sítio. Este achado sugere transporte até o sítio de espécies que vivem tipicamente em costões rochosos.

A microfácies mais diferenciada do restante da seção corresponde à porção superficial da amostra CA HzA-4, que representa a formação de solo incipiente no topo da coluna (Figura 5.23). Esta microfácies apresenta microestrutura de grânulos coesivos, interligados, maior compactação, menor conteúdo de conchas e micromassa marrom avermelhado composta principalmente por argila organomineral, com micrita (Figura 5.23). Os fragmentos de concha e osso apresentam também sinais de queima. A transição entre o horizonte de solo e a $\mathrm{mF} 4$ é abrupta, formada por microestrutura granular com alta separação.

As feições pedológicas incluem, em todos os casos, alta freqüência de revestimentos típicos e descontínuos, não laminados, de coloração marrom escuro, formados por micrita impura com argila organomineral e microcarvões (Figura 5.22 A, B). Também existem, em menor proporção, revestimentos não laminados, cor cinza escuro, de micrita com inclusões de partículas opacas. Na micromassa, observam-se nódulos de óxi-hidróxidos de ferro órticos, com tamanhos entre 50 a $100 \mu \mathrm{m}$ e impregnação moderada a alta. $\mathrm{Na} \mathrm{mF} 4$, além dos revestimentos de micrita e nódulos de ferro, também aparecem hiporrevestimentos-revestimentos de óxidos de ferro de impregnação moderada e enchimentos densos e incompletos de micrita (Figura 5.22 C, D). Excrementos elipsóides foram observados unicamente na amostra mais superficial, tanto na $\mathrm{mF} 4$ como na $\mathrm{mF} \mathrm{Hz} \mathrm{A} \mathrm{(Tabela} \mathrm{5.1).}$ 
A

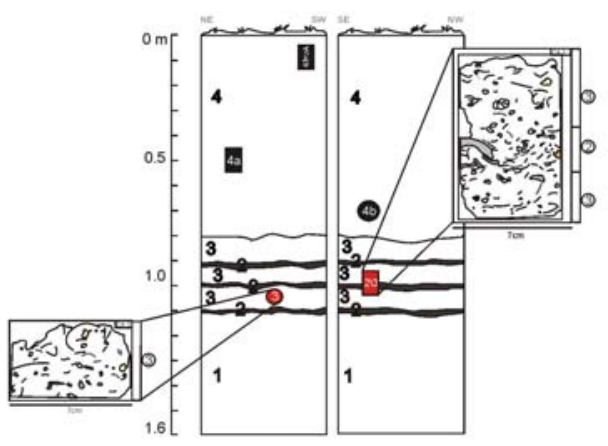

C
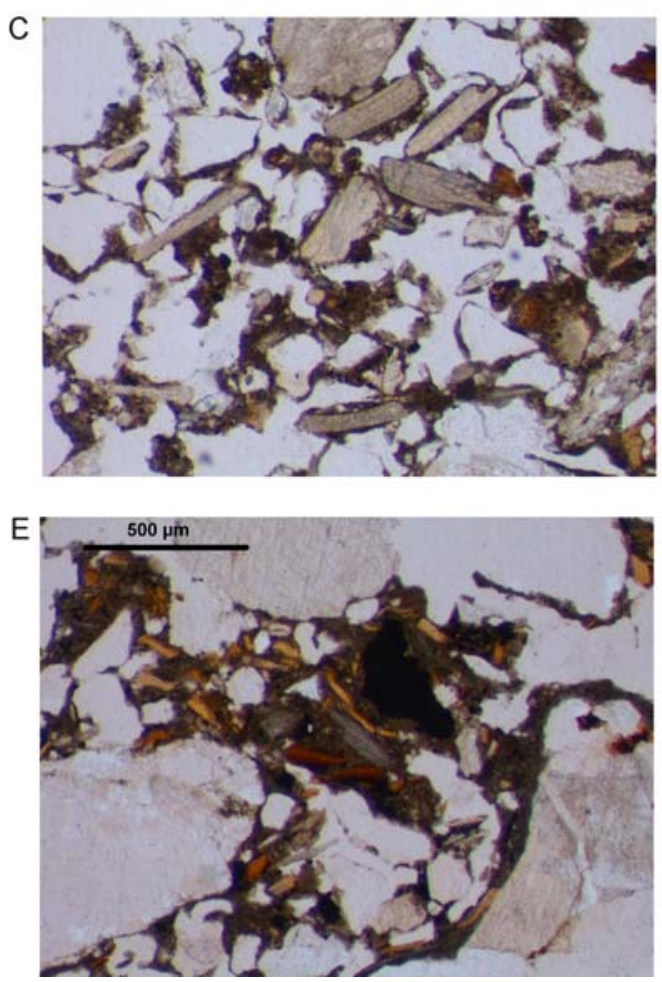
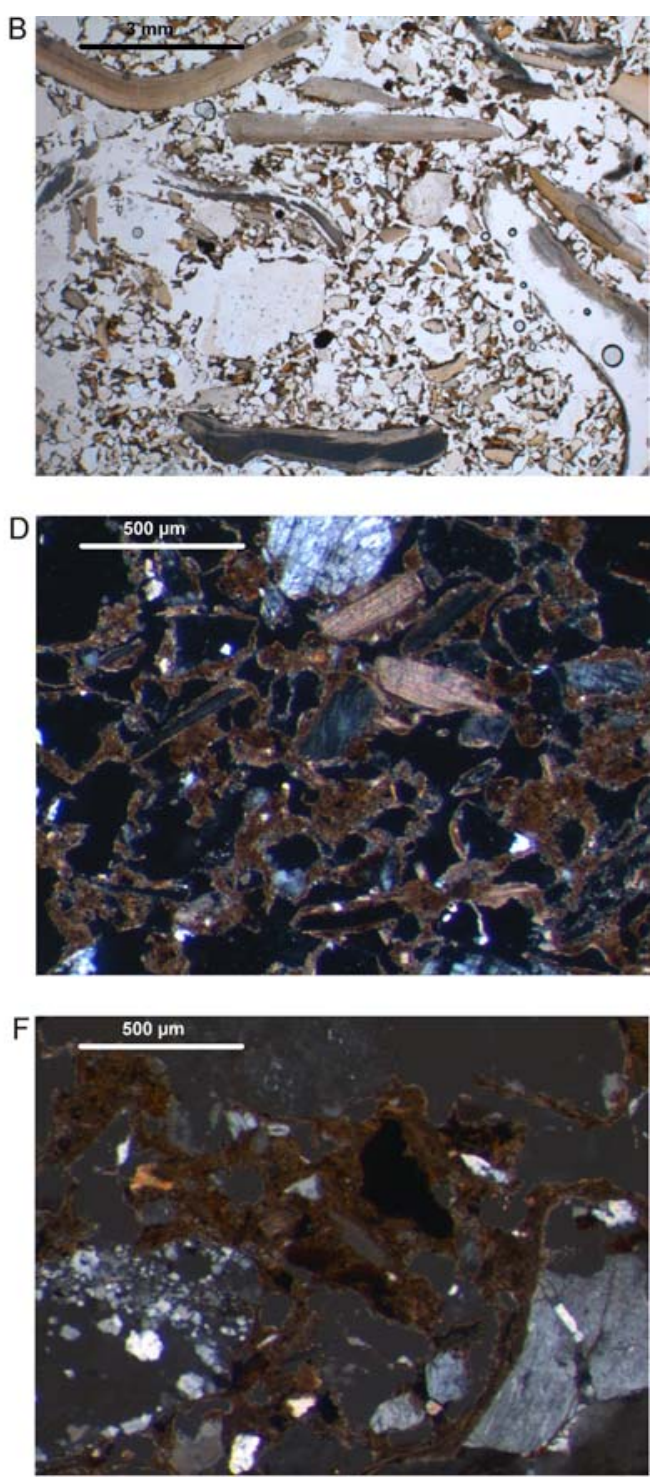

Figura 5.19. Fotomicrografias da $\mathrm{mF}$ 3: A) seção vertical esquemática com localização da amostra para micromorfologia; B) massa basal composta por fragmentos de concha, osso, e grãos minerais, PPL; C, D) microestrutura de microagregados intergranulares interligados, composta por mistura de argilominerais com micrita secundária, a PPL e XPL; E, F) detalhe da micromassa, com finos fragmentos de osso queimado e agregados de microcarvões no interior, a PPL e XPL. 
A
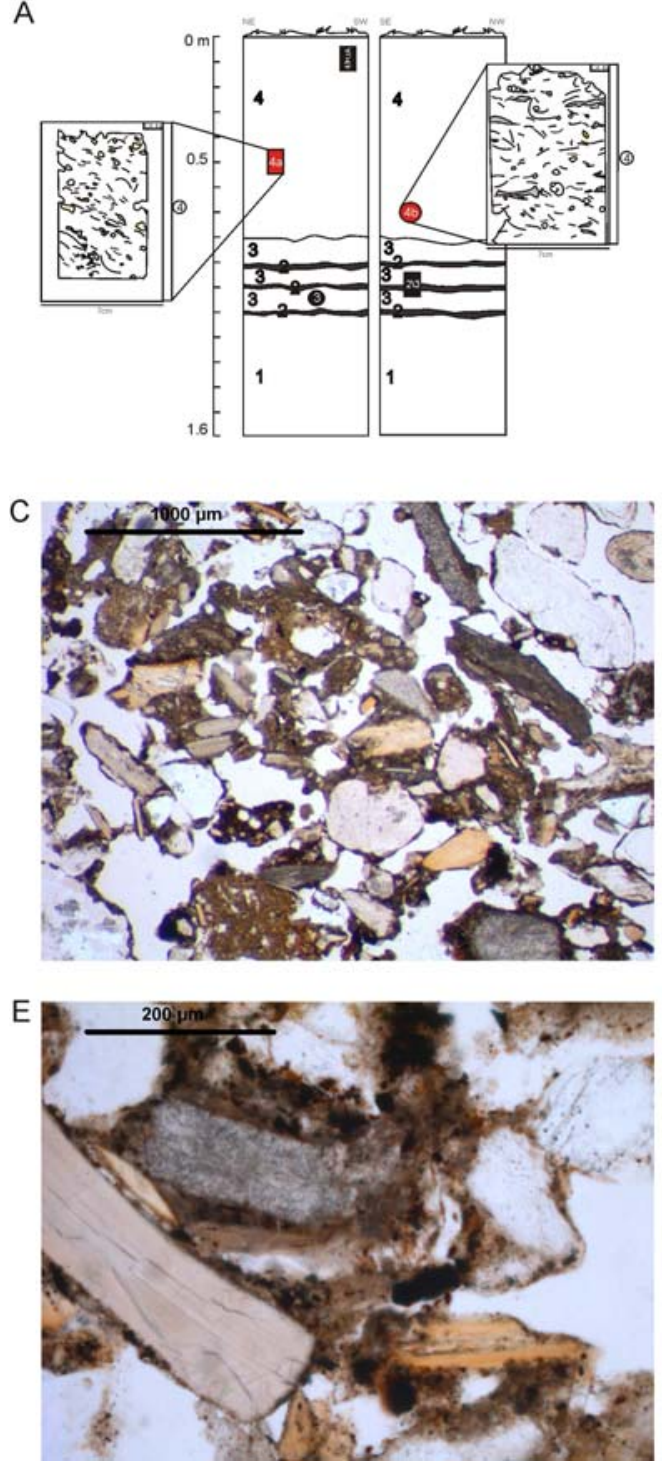
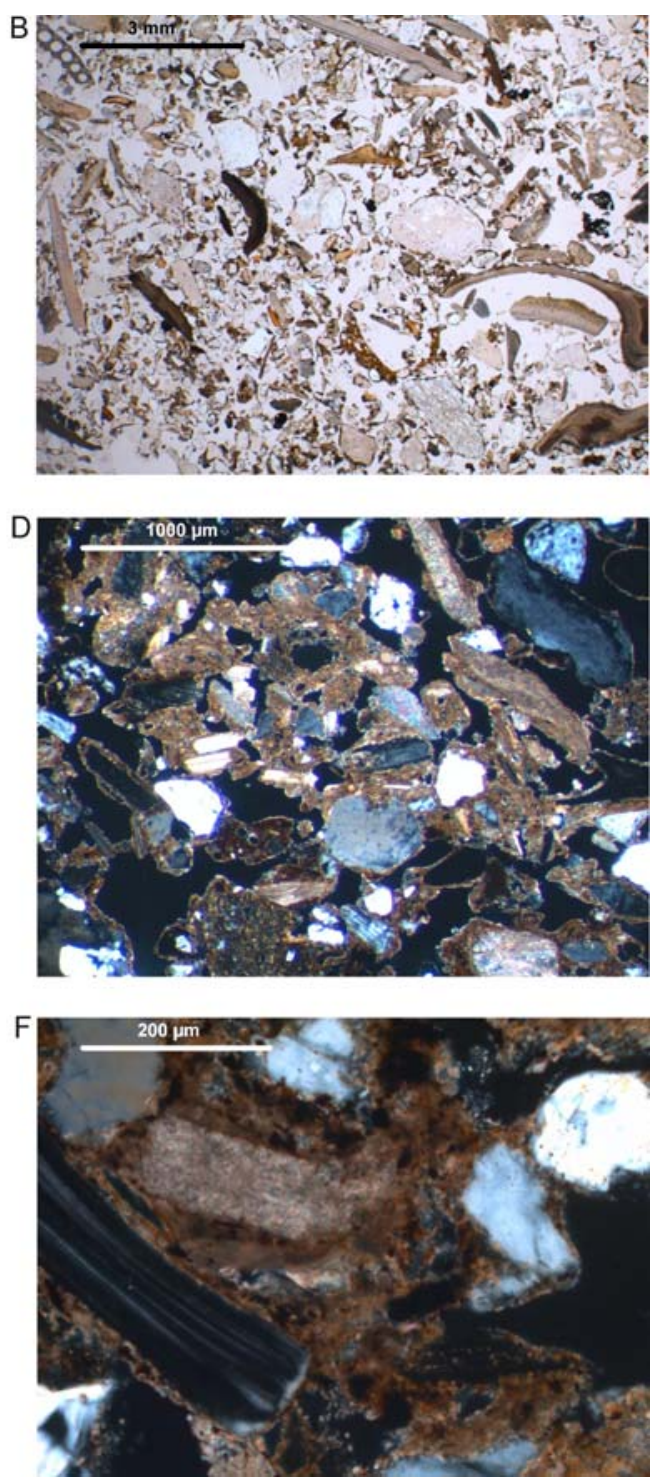

Figura 5.20. Fotomicrografias da $\mathrm{mF}$ 4: A) seção vertical esquemática com localização da amostra para micromorfologia; B) massa basal composta por fragmentos de concha, conchas queimadas, ossos, e grãos minerais, PPL; C, D) microestrutura de microagregados integranulares interligados, composta por mistura de argilominerais com micrita secundária a PPL e XPL; E, F) detalhe da micromassa, com fragmentos de osso queimado, concha e grãos de quartzo, a PPL e XPL. 

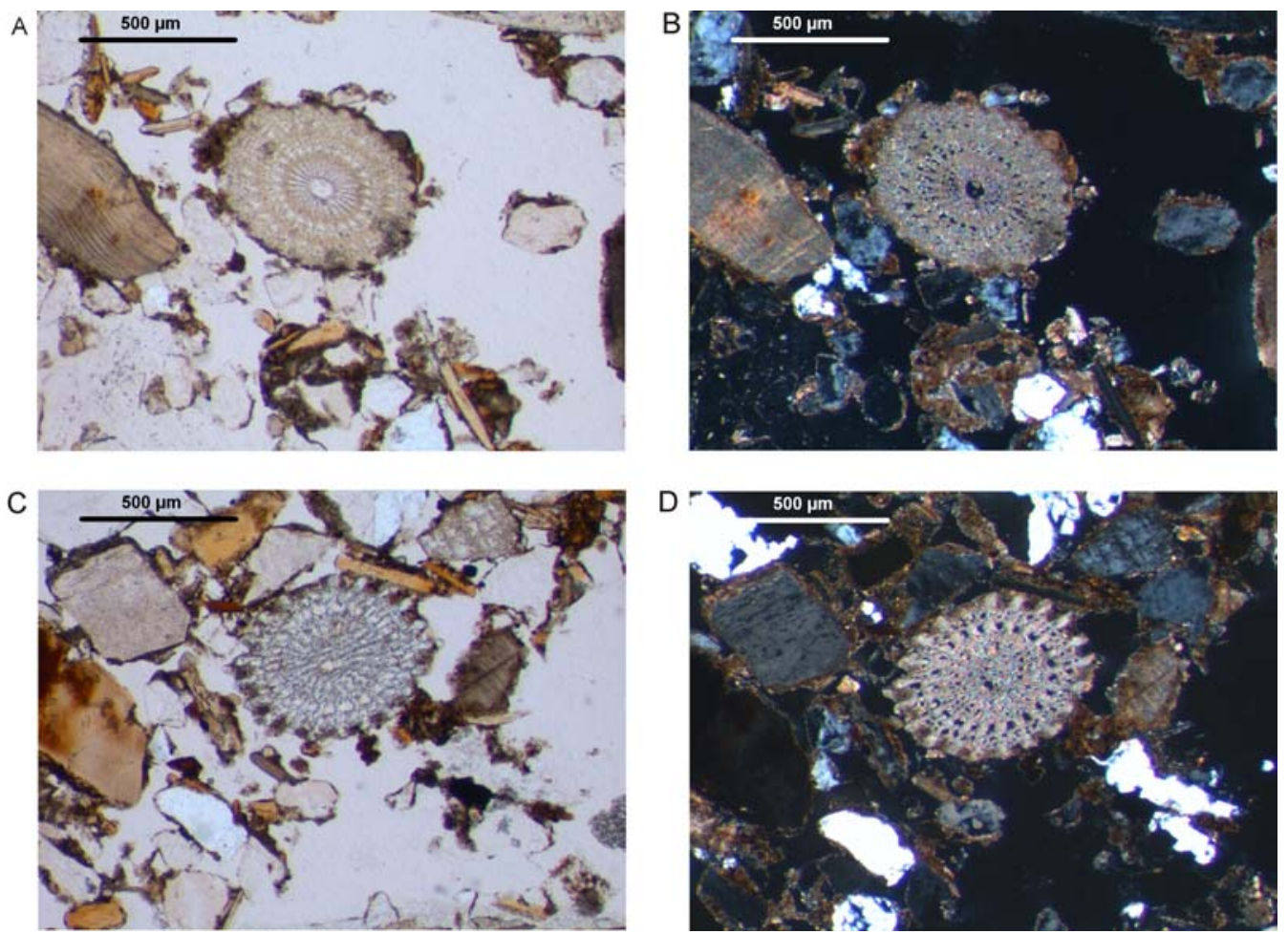

Figura 5.21. Fotomicografias de espinhos de equinoide encontrados na $\mathrm{mF} 4 \mathrm{~b}$ do sítio Caipora, a PPL $(\mathrm{A}, \mathrm{C})$ e XPL $(\mathrm{B}, \mathrm{D})$.
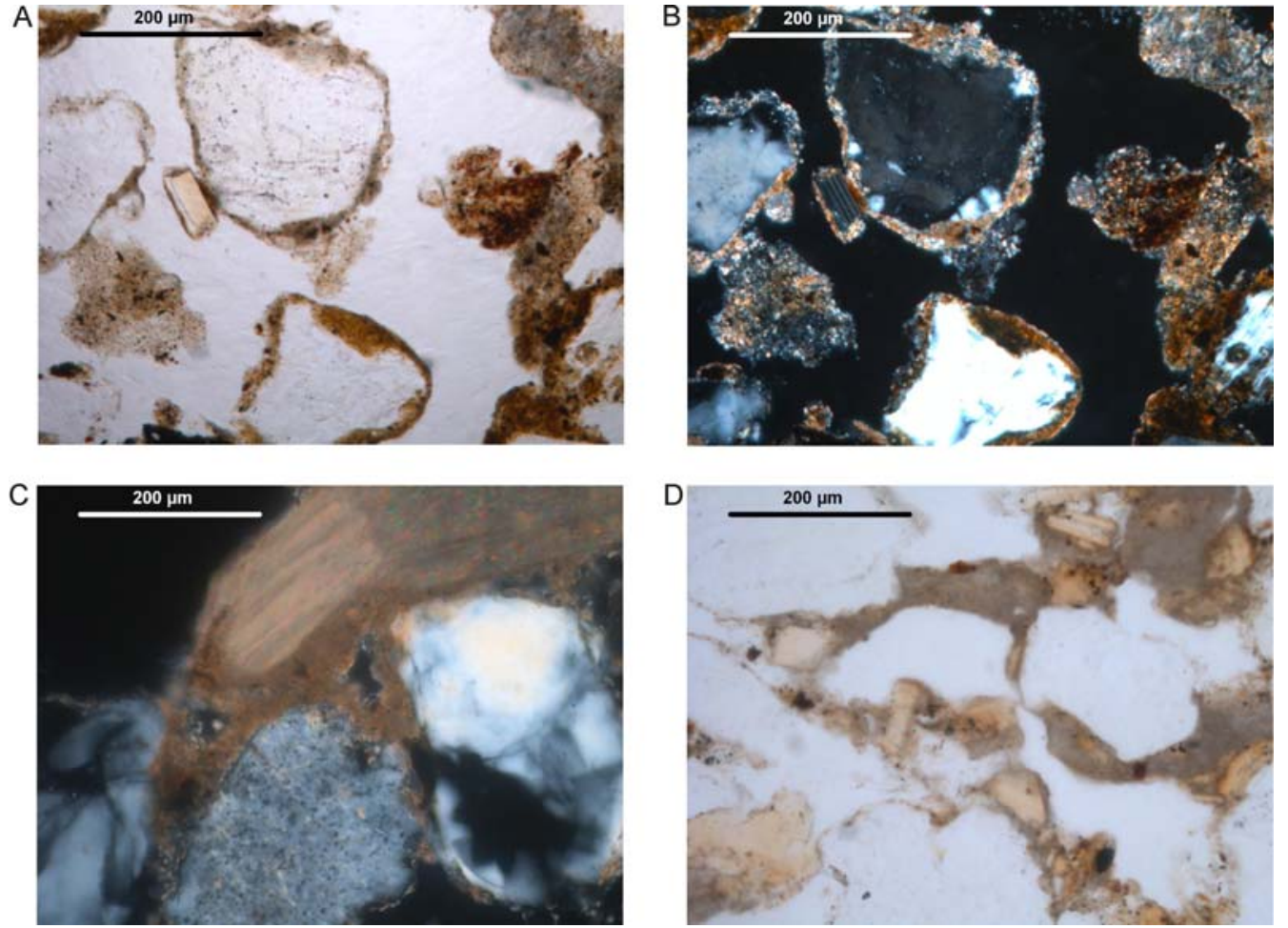

Figura 5.22. Feições pedológicas do sítio Caipora: A, B) revestimentos de micrita e argilominerais impuros, a PPL e XPL; C, D) enchimentos de micrita límpida, a PPL e XPL. Os enchimentos caracterizam-se por ocuparem a totalidade do poro ou vazio em que infiltram, enquanto os revetimentos cobrem apenas as paredes dos poros e/ou a superfície dos componentes da fração grossa. 
A
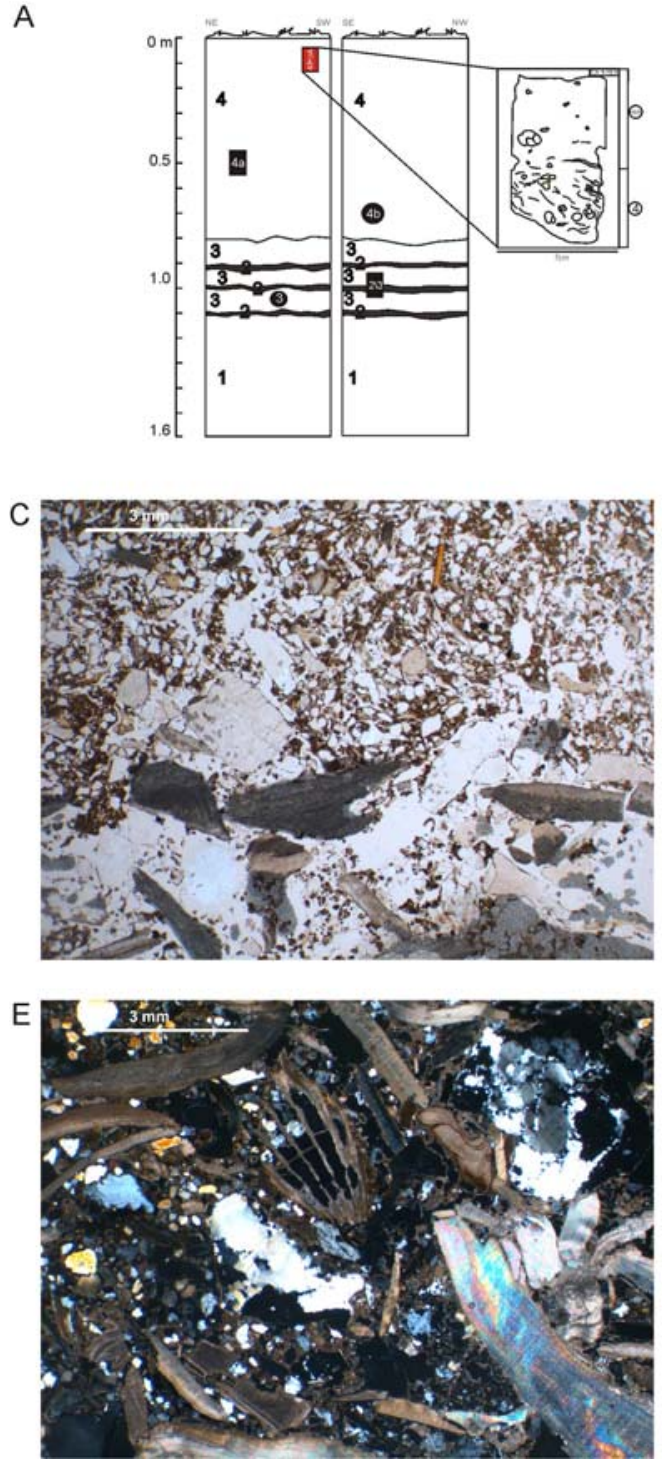
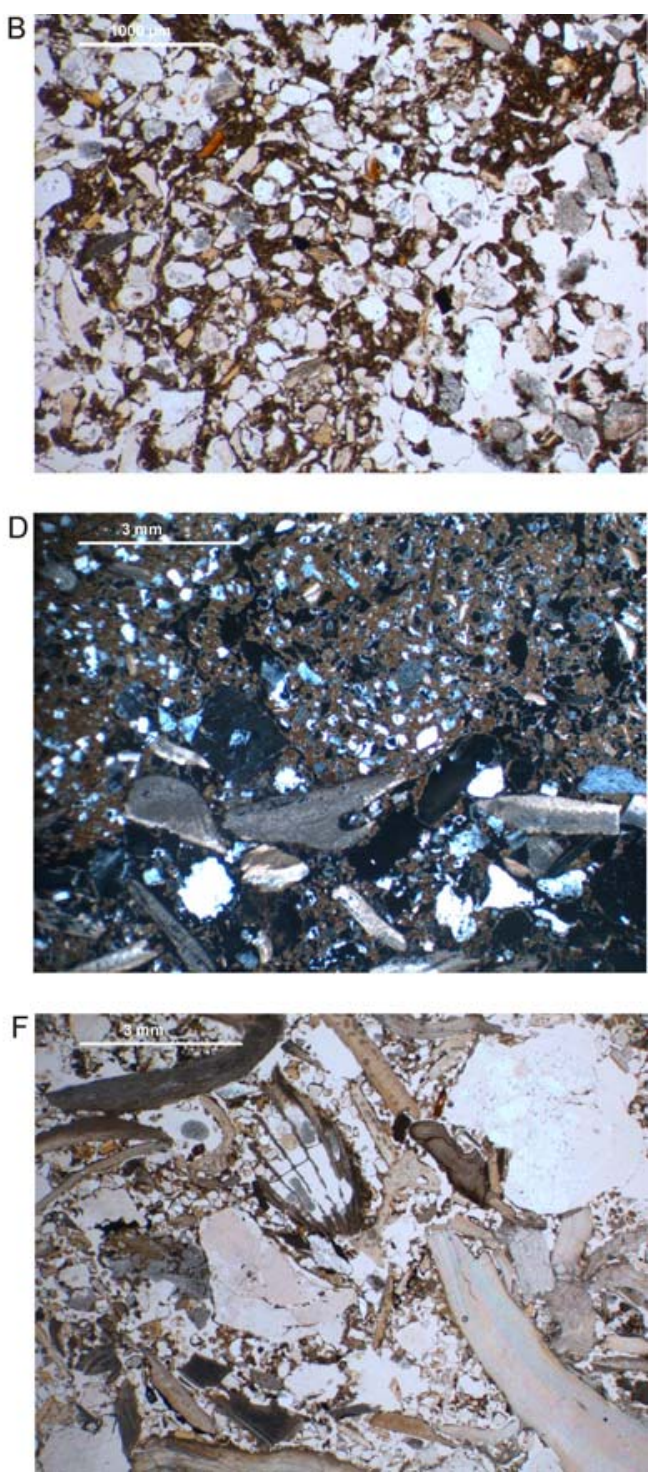

Figura 5.23. Fotomicrografias da transição entre $\mathrm{mF} 4$ e horizonte de solo na superfície da seção vertical analisada: A) seção vertical esquemática com localização da amostra para micromorfologia; B) massa basal composta principalmente por grãos de quartzo, feldspato e fragmentos líticos, com presença subordinada de conchas e ossos no horizonte A superficial, PPL; C, D) transição entre o horizonte de solo, sem conchas, e a mF 4, com fragmentos de conchas e maior porosidade, a PPL e XPL; E, F) detalhe da massa basal da $\mathrm{mF} 4$, com fragmentos de concha de diverso tamanho, a PPL e XPL.

Em termos gerais, toda a coluna do sítio Caipora caracteriza-se pela intensa dissolução e precipitação do carbonato de cálcio das conchas que compõem o sambaqui. Este processo não biogênico de formação de microfábricas carbonáticas está relacionado com a existência de solução de solo hiper-saturada em carbonato de cálcio, derivada da alteração química das conchas, que causa precipitação e cristalização na forma de micromassas cristalinas de carbonato de cálcio (Brewer, 1964). Estas 
micromassas, também chamadas de micromassas alfa em calcretes (Alonso-Zarza and Wright, 2010), podem incluir cristais de tamanho micrítico até espático e inclusive partes de cristais mais grossos distribuídos entre a micrita ou microesparita.

A precipitação e cristalização de carbonato de cálcio observam-se na micromassa micrítica que caracteriza o sítio Caipora e na recorrência de feições pedológicas como revestimentos, hiporrevestimentos-revestimentos e enchimentos de micrita, com conteúdo variável de argila organomineral e microcarvões. A microestrutura formada por carbonato de cálcio secundário na forma de microagregados interligados (pontes/ meniscos), indica condições vadosas de formação, ou seja, formação em condições de não saturação de água em ambiente de percolação. As mesmas condições de formação são sugeridas pelos nódulos de óxi-hidróxido de ferro que se observam recorrentemente da base ao topo do perfil.

\subsubsection{Cubículo 1}

O sítio Cubículo 1, localizado a aproximadamente $4 \mathrm{~km}$ a nordeste do sítio Caipora e aproximadamente $15 \mathrm{~km}$ da atual linha de costa, apresenta forma lenticular, com topo convexo. As camadas estão compostas por material solto e muito friável, com alta concentração de sepultamentos humanos visíveis nas seções expostas. $\mathrm{Na}$ seção escolhida para estudo, identificaram-se nove arqueofácies, com desenvolvimento de horizonte de solo no topo do sambaqui (Figura 5.24). A base da seção não chega a expor o contato inferior do sambaqui, provavelmente com o embasamento granítico.

A AF 1, na base, diferencia-se do resto da sucessão pela alta freqüência de conchas e ossos de peixe muito fragmentados ( $>50 \%)$. Na AF 2, aumenta a presença de conchas inteiras e fragmentos grossos $(>1 \mathrm{~cm})$ de conchas e ossos de peixe. $\mathrm{Na}$ assembleia arqueofaunística, dominam Ostrea sp. (70\%) e A. brasiliana (14\%), com frequência subordinada de Chione cancelata (1\%), otólitos de bagre e corvina e gastrópodes $(<1 \%)$. A AF 3 contém o mesmo tipo de areia de ossos fragmentados que se observou na AF 1, porém, com maior frequência de conchas (61\% de Ostrea sp. e 20 $\%$ de A. brasiliana e $\%$ Chione cancelata) e com lentes de carvão.

$\mathrm{Na}$ AF 4, aumenta a quantidade de conchas inteiras que também aparecem fragmentadas em matriz de areia bioclástica e ossos moídos. Predomina Ostrea sp. 
( $\sim 80 \%$ ), com frequência menor a $1 \%$ de $A$. brasiliana e outros bivalves e gastrópodes ${ }^{71}$. A AF 5 destaca-se pela espessura centimétrica, coloração preta e maior conteúdo de lama. A concentração de sepultamentos humanos aumenta tanto sobre como nas proximidades desta arqueofácies. Neste sentido, AF 5 apresenta características semelhantes às camadas pretas centimétricas descritas nos sítios Jabuticabeira 2 e Caipora. Acima da AF 5, observa-se uma camada de areia bioclástica, composta principalmente por fragmentos de ossos de peixe, identificada como AF 6. A AF 7 diferencia-se pela alta frequência de conchas inteiras (90\%), com presença subordinada de ossos de peixe e carvões. Na assembleia arqueofaunística desta arqueofácies, predomina Ostrea sp. (77\%), seguida de A. brasiliana (5\%). Na AF 8, o predomínio é de Ostrea sp. (93\% na análise arqueofáunística ${ }^{72}$ ), sem $A$. brasiliana, e com porcentagens menores que $0,5 \%$ de outros bivalves e gastrópodes. $\mathrm{Na}$ AF 9 , no topo da sucessão, observa-se a alteração pedogênica do depósito arqueológico, com maior teor de lama que de cascalho bioclástico, e transição cortante (de 2 a $5 \mathrm{~cm}$ ) com a arqueofácies subjacente.

\section{$\underline{\text { Granulometria }}$}

$\mathrm{Na}$ amostragem externa ao sítio, realizada em trincheira aberta a cerca de $40 \mathrm{~m}$ a noroeste da seção estudada do sambaqui, identificaram-se duas fácies. A sucessão observada corresponde a fácies de areia grossa com lama sobreposta por fácies de argila arenosa (Figura 5.25). Esta sucessão pode ser interpretada como fácies de margem lagunar, onde a ação das ondas consegue transportar grãos de areia maiores, seguida de fácies de brejo, onde as águas são rasas e calmas e sedimentam materiais finos armadilhados em meio à vegetação rasteira. As areias angulosas e grossas que caracterizam a fácies inferior teriam chegado à paleolaguna por escoamento superficial (enxurradas desconfinadas) a partir dos morros graníticos das proximidades, localizados cerca de 120 m a SE da seção amostrada.

\footnotetext{
${ }^{71}$ Análise zooarqueológica da AF 1 realizada por Daniela Klokler.

${ }^{72}$ Análise zooarqueológica da AF 4 realizada por Daniela Klokler.
} 


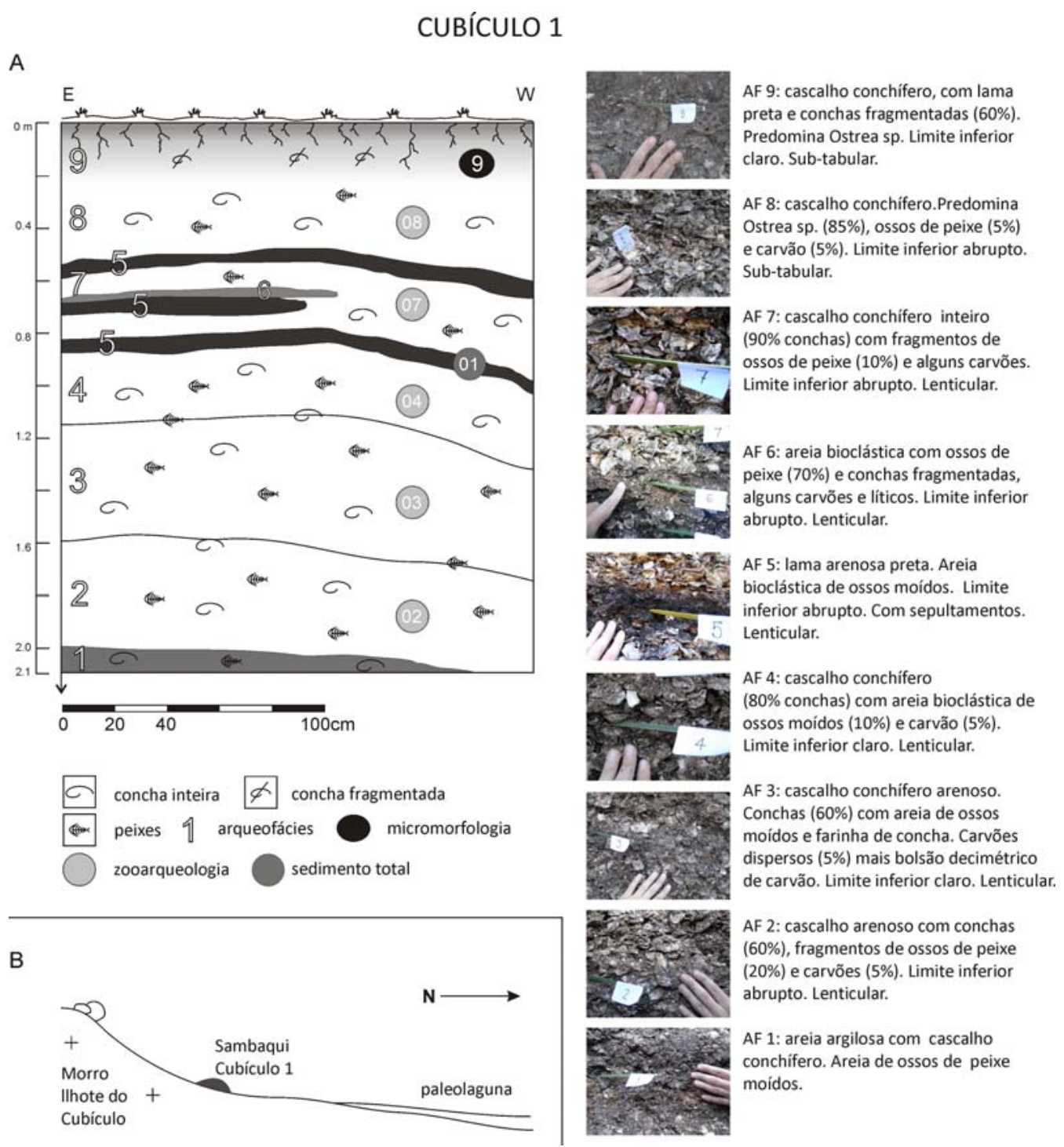

Figura 5.24. Seção vertical estudada do sítio Cubículo 1: A) localização dos pontos de amostragem e descrição das arqueofácies identificadas; B) seção transversal esquemática (sem escala) da área de localização do sítio.

Análises granulométricas da fração terrígena foram realizadas nas amostras provenientes da $\mathrm{AF} 5$, assim como das duas fácies identificadas na amostragem externa ao sítio. Estas análises confirmam as observações realizadas em campo, ao mostrar o domínio das classes grânulo e areia muito grossa, supostamente ligadas ao aporte coluvionar, na Fácies A, inferior, e a diminuição destas duas classes, acompanhada de aumento no teor de areia grossa a areia fina na Fácies B, superior (Figura 5.26 A, C). Na AF 5, observa-se a distribuição granulométrica bimodal que caracteriza os sedimentos arqueológicos de sambaquis, com moda nas frações areia muito grossa e areia fina. 
Como observado no sítio Caipora, a distribuição bimodal indica aporte de várias populações de sedimentos na fração terrígena do sambaqui.

Diferente do sítio Caipora, a observação no microscópio estereoscópico das frações areia muito grossa e grosssa da AF 5 mostra o predomínio de fragmentos de conchas, com freqüência subordinada de ossos, terrígenos (grãos de quartzo, feldspato e fragmentos líticos) e carvão (Figura 5.27).
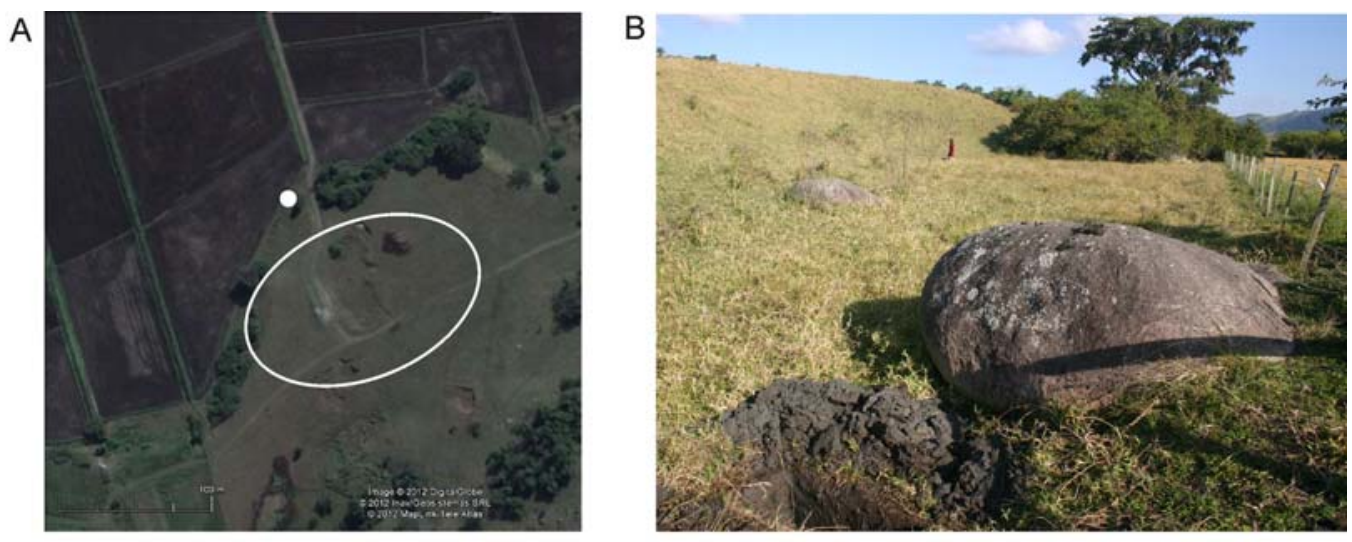

C

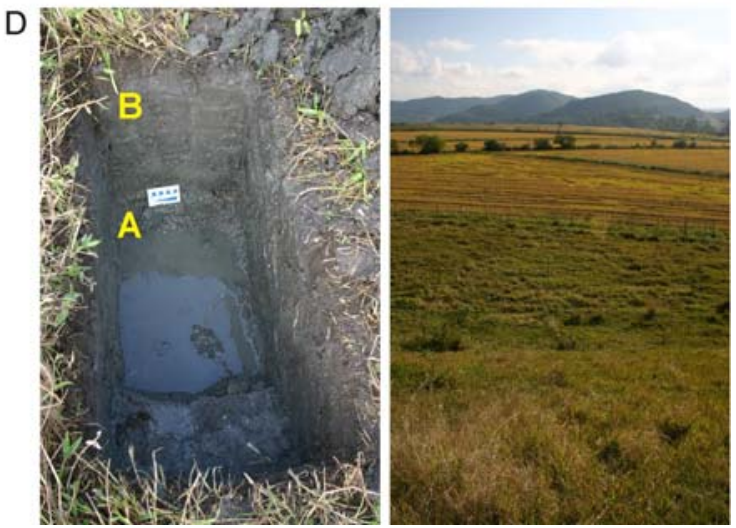

Figura 5.25. Amostragem externa ao sítio Cubículo 1: A) localização do ponto de coleta; B) entorno de localização; C) descrição das fácies identificadas; D) trincheira amostrada, com posição das fácies. 


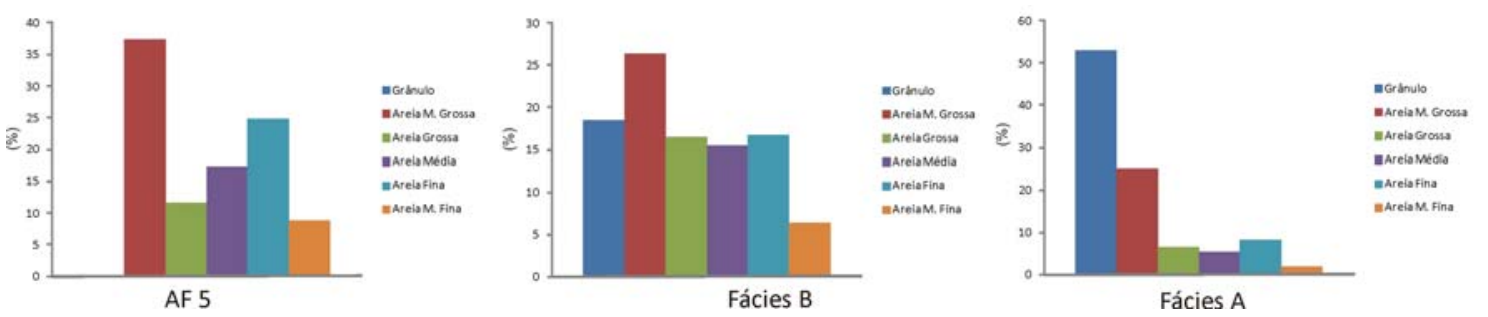

Figura 5.26. Histogramas da distribuição granulométrica para as Fácies A e B do ponto de amostragem externa ao sambaqui Cubículo 1, e da AF 5 do mesmo sambaqui. Note-se o domínio de grânulos e pelíticos nas Fácies A e B, respectivamente, e a distribuição bimodal na AF 5.

CUBíCULO 1 - AF 5

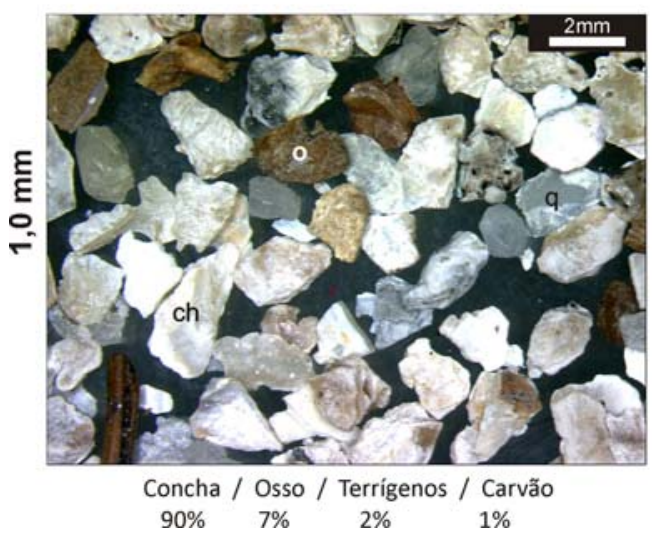

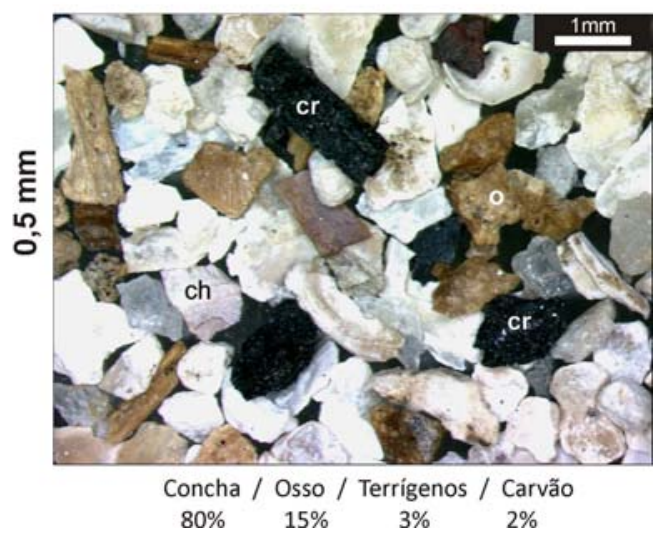

$80 \% \quad 15 \% \quad 3 \% \quad 2 \%$

Figura 5.27. Fotomicrografias à lupa estereoscópica dos grãos retidos nas malhas de $1,0 \mathrm{~mm}$ e $0,5 \mathrm{~mm}$ da AF 5 do sítio Cubículo 1. Note-se presença de ossos (o), conchas (ch), carvão (cr) e quartzo (q).

\section{Isótopos de $C$ e $N\left(\delta^{13} \mathrm{Ce} \delta^{53} N\right)$}

Os valores de razão $\mathrm{C} / \mathrm{N}$ da $\mathrm{MO}$ que compõe a $\mathrm{AF} 5$ sugerem presença de restos vegetais de plantas terrestres de ciclo fotossintético $\mathrm{C}_{3}$ no sambaqui (Figura $5.28 \mathrm{~A}$; Tabela A.1). Ao combinar os valores de $\delta^{13} \mathrm{C}$ com os de $\delta^{15} \mathrm{~N}$ da $\mathrm{MO}$, tem-se indicação de possível mistura de restos vegetais com resíduos derivados de decomposição de tecido animal, como no sitio Caipora (Figura $5.28 \mathrm{~B}$ ). $\mathrm{O}$ valor de $\delta^{15} \mathrm{~N}$ da $\mathrm{AF} 5$ aproxima-se do intervalo definido para solos enriquecidos em restos de tecidos de animais marinhos (valores de $\delta^{15} \mathrm{~N}$ superiores a $+11 \%$ ), segundo Ben-David et al. (1998), Commisso \& Nelson (2006), Fogg et al. (1998), Morris et al. (2005) e De Niro (1987). No entanto, apesar do enriquecimento em $\delta^{15} \mathrm{~N}$, é provável que a MO da AF 5 derive principalmente de espécies arbustivas já que os valores isotópicos posicionam a amostra próximo ao intervalo definido para plantas $\mathrm{C}_{3}$. $\mathrm{O}$ domínio de vegetais possivelmente relaciona-se à alta frequência de carvões no sedimento, com aporte 
subordinado de resíduos da decomposição de tecido animal, vinculados à presença conspícua de ossos de peixe.

Diferente da situação observada no sambaqui, os valores de $\delta^{13} \mathrm{C}$ e $\delta^{15} \mathrm{~N}$ das fácies naturais, na trincheira externa ao sítio, indicam aporte exclusivo de MO de origem vegetal. Os valores de $\delta^{13} \mathrm{C}$ e $\delta^{15} \mathrm{~N}$ da Fácies A são muito próximos daqueles registrados para a Fácies B e indicam mistura de MO de origem terrestre e aquática (Figura 5.28 A, B).
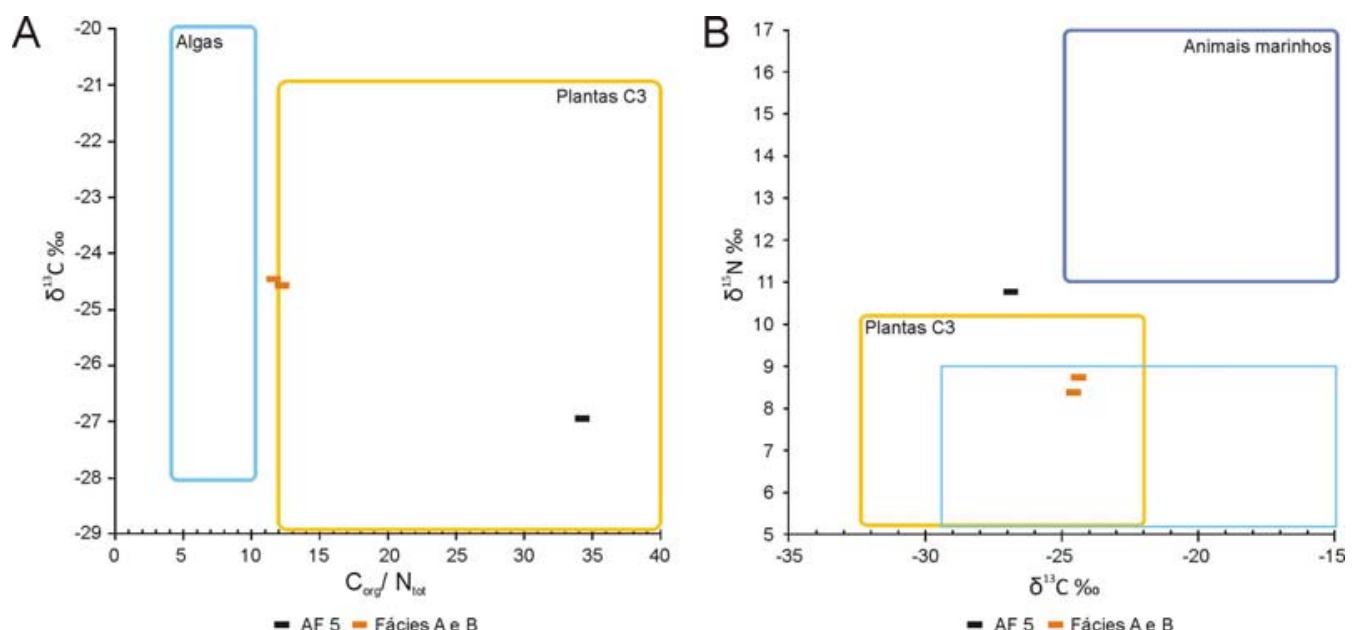

5.28. Análises isotópicas $\left(\delta^{13} \mathrm{C}\right.$ e $\delta^{15} \mathrm{~N}$ e razão $\left.\mathrm{C} / \mathrm{N}\right)$ de amostra proveniente da $\mathrm{AF} 5$ do sítio Cubículo 1 , e de amostras das Fácies A e B da trincheira aberta em área externa ao sítio: A) gráfico de valores de $\delta^{13} \mathrm{C}$ e razão $\mathrm{C} / \mathrm{N}$ com intervalos definidos para plantas de ciclo fotossintético $\mathrm{C} 3$ e algas; $\mathrm{B}$ ) gráfico dos valores de $\delta^{15} \mathrm{~N}$ e $\delta^{13} \mathrm{C}$ com intervalos definidos para plantas de ciclo fotossintético $\mathrm{C} 3$ e animais marinhos.

\section{Micromorfologia}

A alta friabilidade dos sedimentos que compõem este sambaqui, formados principalmente por bioclastos (conchas e ossos de peixe) inteiros e fragmentados, sob presença subordinada de fração fina coesiva, inviabilizou a coleta de amostras indeformadas para micromorfologia, exceto na AF 9, a mais coesiva da seção estudada, onde se conseguiu coletar um bloco de sedimento.

Na seção delgada da AF 9 observaram-se duas microfácies, que correspondem ao horizonte de solo superficial do topo do sambaqui (mF HzA) e à $\mathrm{AF} 9$ propriamente dita (mF 9) (Figura 5.29; Tabela 5.7). Os componentes da fração grossa incluem conchas, quartzo, feldspato, fragmentos líticos, ossos, raízes frescas, carvão e restos de tecidos (Tabela 5.8; Figura 5.30). Ambas as microfácies apresentam microestrutura grumosa (Figura $31 \mathrm{~B}, \mathrm{C}$ ), com micromassa formada por mistura, de cor marrom (PPL), de argila 
organomineral (Figura $31 \mathrm{E}, \mathrm{F}$ ). A granulometria, grau de isotropia e o arredondamento dos grãos minerais (quartzo, feldspato e fragmentos líticos) confirmam a relação dos sedimentos terrígenos do sambaqui com depósitos coluvionares associados aos morros graníticos da região (Tabela 5.8).

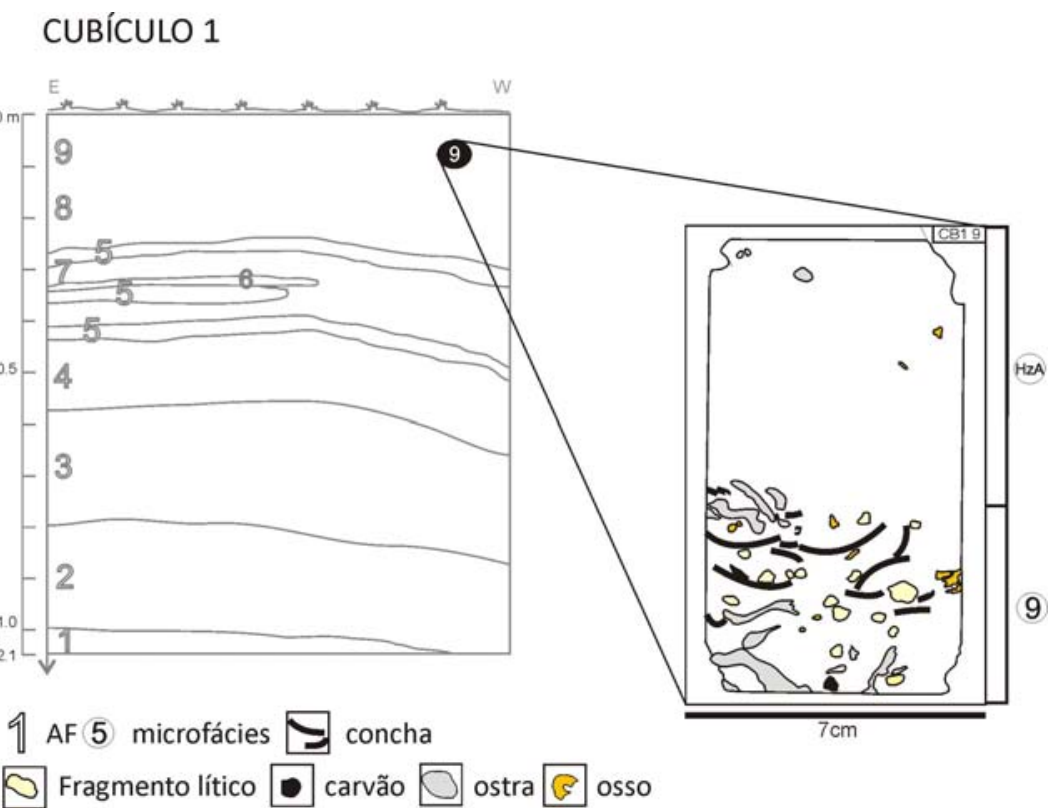

Figura 5.29. Desenho esquemático da seção delgada analisada no sítio Cubículo 1, com localização do bloco de amostragem na sucessão vertical e identificação de microfácies na lâmina.
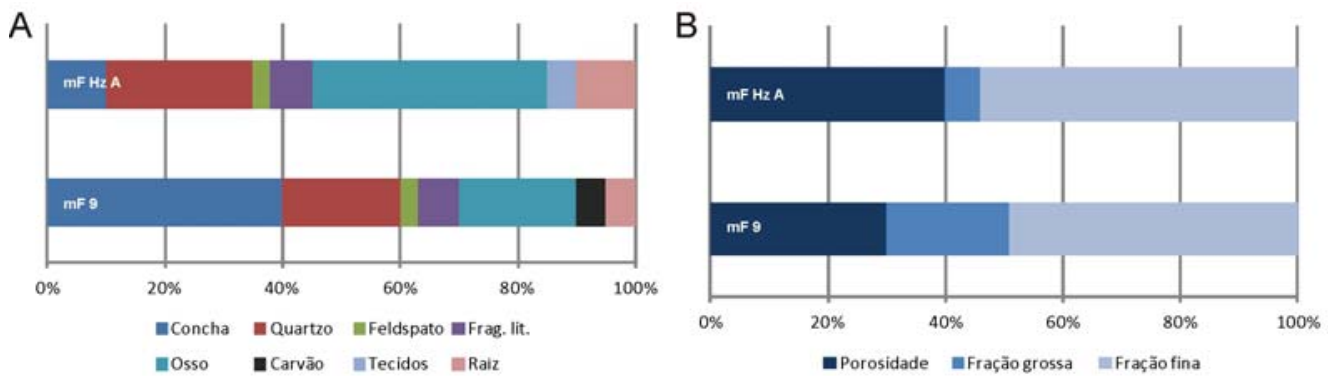

Figura 5.30. Gráficos com porcentagens dos diferentes componentes microscópicos da $\mathrm{mF} 9$ e do horizonte de solo superficial (Hz A) do sítio Cubículo 1: A) frequências de componentes da fração grossa; B) relação entre as porcentagens de poros, fração grossa e fração fina. Note-se o aumento da porosidade e da fração fina no horizonte superficial. 
Tabela 5.7. Descrição micromorfológica do sambaqui Cubículo 1.

\begin{tabular}{|c|c|c|c|c|c|c|c|c|c|c|c|c|c|c|c|c|c|c|c|c|c|}
\hline \multirow[b]{2}{*}{ Am } & \multirow[b]{2}{*}{$\mathbf{m F}$} & \multirow[b]{2}{*}{ 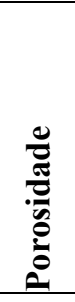 } & \multirow[b]{2}{*}{$\%$} & \multirow[b]{2}{*}{ 冚 } & \multirow[b]{2}{*}{ Tam. } & \multirow[b]{2}{*}{ Microestrutura } & \multirow[b]{2}{*}{ 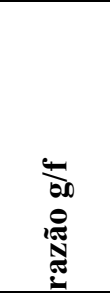 } & \multirow[b]{2}{*}{$\begin{array}{l}\stackrel{+0}{0} \\
\dot{0} \\
\dot{0} \\
\dot{0} \\
\dot{0}\end{array}$} & \multirow[b]{2}{*}{ 选 } & \multicolumn{3}{|c|}{ Fr. min. gr. } & \multicolumn{3}{|c|}{$\begin{array}{l}\text { Fr. org. } \\
\text { gr. }\end{array}$} & \multicolumn{5}{|c|}{ Micromassa } & \multirow[b]{2}{*}{ FP } \\
\hline & & & & & & & & & & 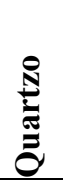 & 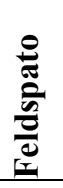 & 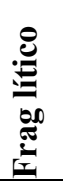 & 容 & 党 & $\underset{\mathscr{n}}{\tilde{n}}$ & $\dot{\theta}$ & $\%$ & 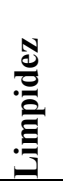 & 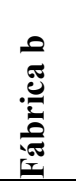 & Composição & \\
\hline \multirow[t]{2}{*}{ HA-9 } & HA & $\begin{array}{l}\text { vs } \\
\text { re } \\
\text { cn } \\
\text { fs }\end{array}$ & 40 & $\mathrm{cr}$ & $2-5 \mathrm{~mm}$ & $\begin{array}{c}\text { Grumosa solta e } \\
\text { coesiva }\end{array}$ & $10 / 90$ & mon & $\bullet$ & $\bullet \bullet$ & $\bullet$ & $\bullet$ & $\bullet \bullet$ & • & $\bullet$ & & & $\begin{array}{l}\mathrm{pt} \\
\mathrm{ms}\end{array}$ & ind & $\begin{array}{l}\text { Argila e matéria } \\
\text { orgânica }\end{array}$ & $\begin{array}{c}\text { Fe-nod } \\
\text { rev } \\
\text { exc }\end{array}$ \\
\hline & 9 & $\begin{array}{c}\text { e-cx } \\
\text { fs } \\
\text { vs } \\
\text { cn }\end{array}$ & 30 & $\mathrm{cr}$ & $<1 \mathrm{~mm}$ & Grumosa coesiva & $30 / 70$ & en & $\cdots$ & $\bullet \bullet$ & • & $\bullet$ & $\bullet \bullet$ & • & • & & & $\begin{array}{l}\mathrm{pt} \\
\mathrm{ms}\end{array}$ & ind & $\begin{array}{l}\text { Argila e matéria } \\
\text { orgânica }\end{array}$ & $\begin{array}{c}\text { Fe-nod } \\
\text { rev } \\
\text { exc }\end{array}$ \\
\hline
\end{tabular}

Freqüências de classes segundo Bullock et al. (1985): • Muito Poucas (<5\%); •• Poucas (5-15\%); ••• Comum (15-30\%); ••• Freqüente (30-50\%); •••• Dominante (50-70\%); •... Muito dominante $(>70 \%)$. Am. $=$ amostra; $\mathrm{mF}=$ microfácies; Tam.= tamanho; Fr. min. gr. = fração mineral grossa; Fr. org. gr. $=$ fração orgânica grossa; FP = feições pedológicas. O singificado das demais abreviações utilizadas nesta tabela encontra-se no Anexo, Tabela A.5. 
Tabela 5.8. Componentes minerais e orgânicos da fração grossa da amostra CB1-9.

\begin{tabular}{|c|c|c|c|c|c|c|c|c|c|c|}
\hline \multicolumn{11}{|l|}{ CB1-9 } \\
\hline & $\mathbf{m F}$ & $\%$ & Tamanho & Forma & Arredondamento & Seleção & $\begin{array}{c}\text { Distribuiçãa o } \\
\text { básica }\end{array}$ & $\begin{array}{c}\text { Orientação } \\
\text { básica }\end{array}$ & $\begin{array}{l}\text { Distribuição } \\
\text { referenciada }\end{array}$ & Alteração \\
\hline Concha & HA & 10 & Vários & - & 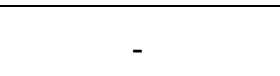 & Não selecionado & Aleatória & 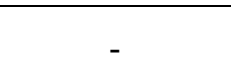 & 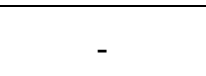 & Dissolução \\
\hline Quartzo & HA & 25 & $\begin{array}{l}\text { Areia média a } \\
\text { fina }\end{array}$ & Equidimensional & $\begin{array}{l}\text { Subanguloso e } \\
\text { subarredondado }\end{array}$ & Seleção moderada & Aleatória & - & - & - \\
\hline Feldspato & HA & 3 & $\begin{array}{l}\text { Areia média a } \\
\text { mto. fina }\end{array}$ & Equidimensional & $\begin{array}{l}\text { Subanguloso e } \\
\text { subarredondado }\end{array}$ & Seleção moderada & Aleatória & - & - & - \\
\hline Frag.lítico & HA & 7 & Areia fina & Equidimensional & $\begin{array}{c}\text { Subanguloso e } \\
\text { subarredondado }\end{array}$ & Bem selecionado & Aleatória & - & - & - \\
\hline Osso & HA & 40 & $\begin{array}{l}\text { Silte, areia } \\
\text { média }\end{array}$ & - & 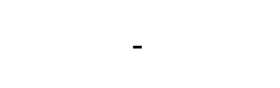 & Seleção moderada & Aleatória & - & - & $\begin{array}{l}\text { Queima e } \\
\text { dissolução }\end{array}$ \\
\hline Tecidos & HA & 5 & $\sim 300 \mu \mathrm{m}$ & - & - & Não selecionado & Aleatória & - & - & - \\
\hline Raízes & HÁ & 10 & $300-500 \mu \mathrm{m}$ & - & - & - & Aleatória & - & - & - \\
\hline Concha & 9 & 40 & Vários & - & - & Não selecionado & Linear & $\begin{array}{l}\text { Paralelismo de } \\
\text { ângulo baixo }\end{array}$ & $\begin{array}{l}\text { Inclinado à } \\
\text { superfície }\end{array}$ & Dissolução \\
\hline Quartzo & 9 & 20 & $\begin{array}{l}\text { Areia média a } \\
\text { fina }\end{array}$ & Equidimensional & $\begin{array}{l}\text { Subanguloso e } \\
\text { subarredondado }\end{array}$ & Seleção moderada & Aleatória & 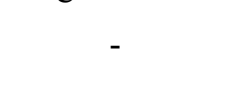 & - & - \\
\hline Feldspato & 9 & 3 & $\begin{array}{l}\text { Areia média a } \\
\text { mto. fina }\end{array}$ & Equidimensional & $\begin{array}{l}\text { Subanguloso e } \\
\text { subarredondado }\end{array}$ & Seleção moderada & Aleatória & - & - & - \\
\hline Frag.lítico & 9 & 7 & $\begin{array}{l}\text { Areia mto. } \\
\text { grossa, grânulo }\end{array}$ & Equidimensional & Subanguloso & Seleção moderada & Aleatória & - & - & - \\
\hline Osso & 9 & 20 & $\begin{array}{l}\text { Silte, areia } \\
\text { média }\end{array}$ & - & - & Seleção moderada & Aleatória & - & - & - \\
\hline Carvão & 9 & 5 & $5 \mathrm{~mm}$ & - & Anguloso & Não selecionado & Aleatória & - & - & - \\
\hline Raízes & 9 & 5 & $300-500 \mu \mathrm{m}$ & - & - & - & Aleatória & - & - & - \\
\hline
\end{tabular}


$\mathrm{Na}$ mF HzA, ressalta a proporção elevada de fração fina, com razão g/f de 10:90 (Tabela 5.7). A microestrutura é formada pela combinação de grumos porosos coesivos, de tamanho variável (Figura 5.31 B). Dentro destes grumos, observam-se diversos bioporos, regulares, vesículas, canais e fissuras (Figura $5.31 \mathrm{E}, \mathrm{F}$ ). Fora dos grumos, observam-se numerosos canais associados com a atividade biológica do solo (fauna e raízes). A presença de conchas na fração grossa é subordinada (10\%) (Tabela 5.8), em contraste à de fragmentos de osso (40\%). Ambos os componentes apresentam sinais de queima e de dissolução.

$\mathrm{Na}$ mF 9, os grumos são de tamanho menor que no horizonte de alteração, apesar de igualmente coesivos (Figura $5.31 \mathrm{C}$, D). A porosidade é de empacotamento complexo e a microestrutura varia entre grumosa e de agregados intergranulares (Tabela 5.7). A freqüência de conchas aumenta em comparação com o horizonte $A$, enquanto a presença de ossos diminui (Tabela 5.8). Tanto as conchas quanto os ossos apresentam sinais de queima e dissolução (Figura 5.32 A, B, F). Nesta microfácies, as conchas estão distribuídas sub-horizontalmente (Tabela 5.8).

As feições pedológicas incluem nódulos de óxi-hidróxidos de ferro órticos, de impregnação forte a moderada, revestimentos contínuos de argila organomineral, sem laminação, ao redor dos fragmentos de osso e grãos minerais, assim como excrementos esféricos, de coloração vermelho escuro (Figura 5.32 E), e excrementos mamilares, de coloração marrom e composição igual à da micromassa. 
A
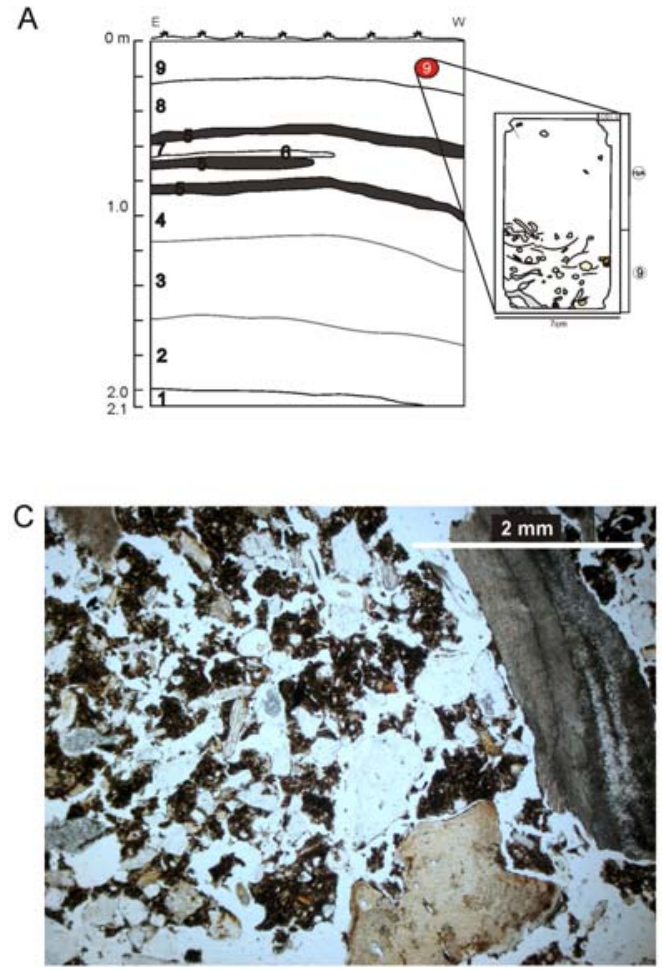

$\mathrm{E}$

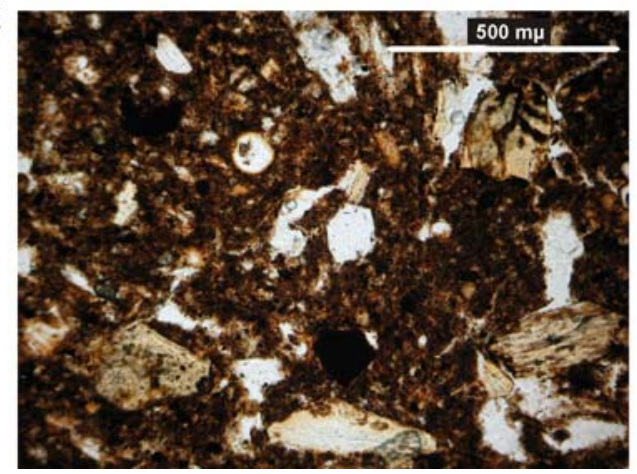

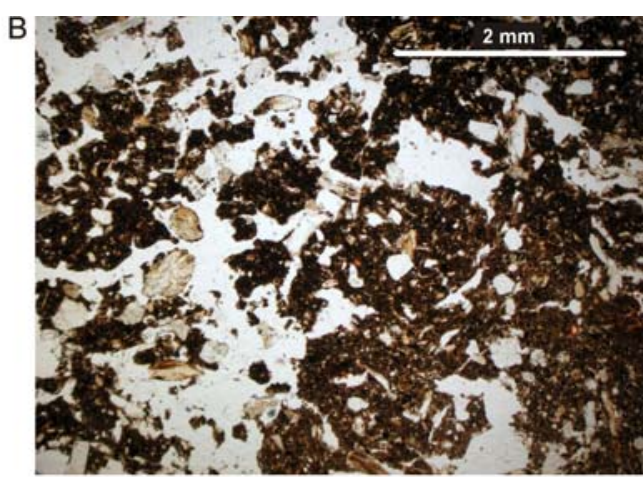
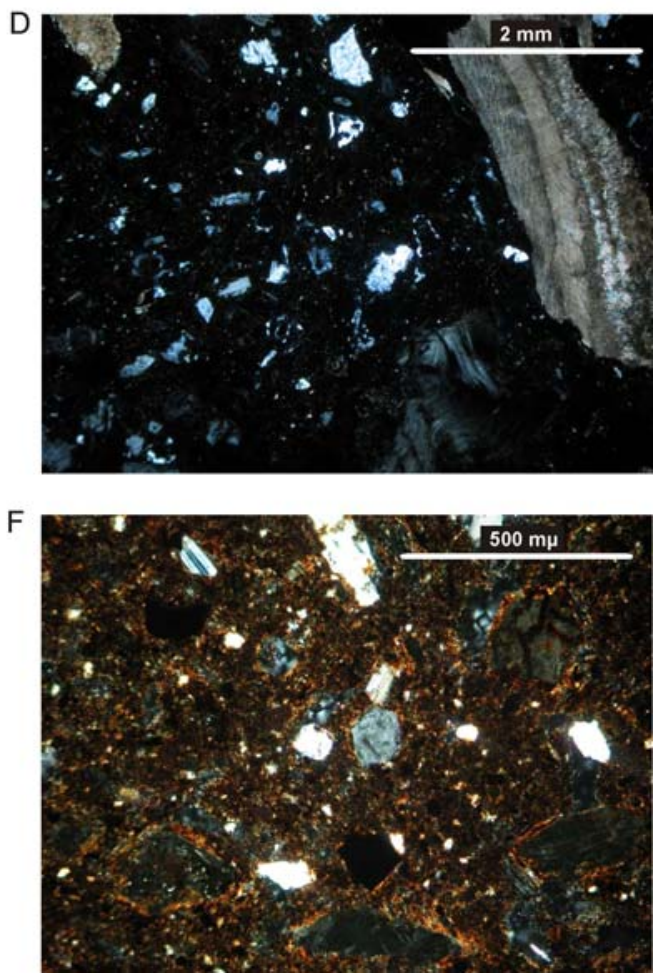

Figura 5.31. Fotomicrografias da mF 9 e mF HzA do sítio Cubículo 1: A) seção vertical esquemática com localização da amostra para micromorfologia; B) massa basal do horizonte superficial (mF HzA) com maior freqüência de raízes e poucas conchas em relação a $\mathrm{mF} 9$, PPL; C, D) massa basal da $\mathrm{mF} 9 \mathrm{com}$ microestrutura de grumos coesivos e fragmentos de concha e ossos, PPL e XPL; E, F) detalhe da micromassa composta por argilominerais e MO, com fragmentos de osso e carvão, PPL e XPL. 

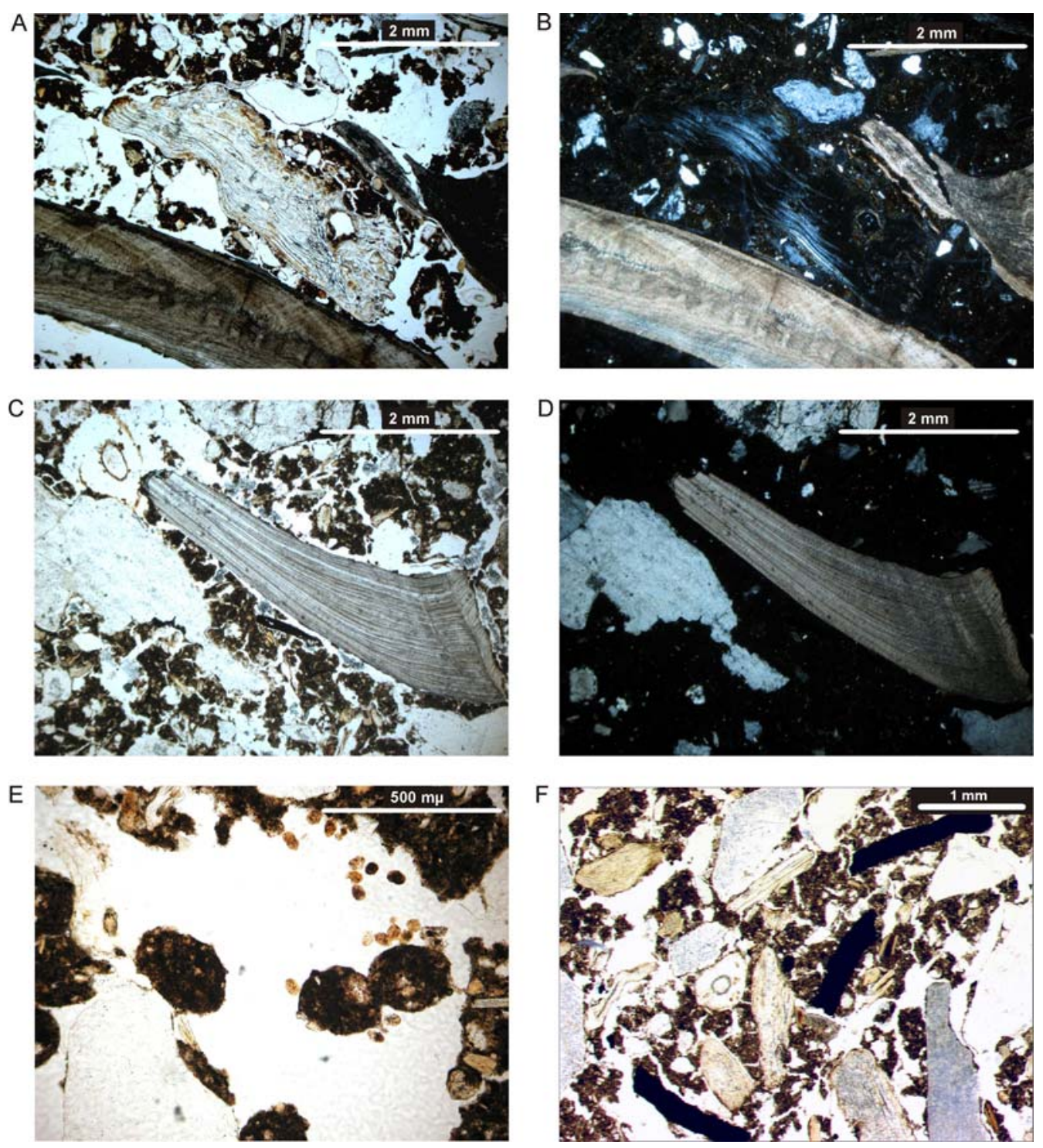

Figura 5.32. Fotomicrografias de elementos encontrados no sítio Cubículo: A, B) concha queimada e fragmento de osso com sinais de dissolução, PPL e XPL; C, D) fragmento de concha de Ostrea sp., PPL e XPL; E) excrementos elipsóides no horizonte de solo superficial, PPL; F) fragmentos de concha, concha queimada (fragmentos pretos) e ossos na $\mathrm{mF}$ 9, PPL.

\subsubsection{Morrinhos}

O sítio Morrinhos é um dos maiores sambaquis da área de estudo, com aproximadamente $130 \mathrm{~m}$ de cumprimento, $100 \mathrm{~m}$ de largura e $10 \mathrm{~m}$ de altura (Assunção 2010). A porção do sítio atualmente preservada localiza-se na face norte do morro das Congonhas, onde se observa uma seção exposta de aproximadamente $20 \mathrm{~m}$ que acompanha a borda do testemunho cristalino. A seção trabalhada neste estudo, de 3,45 $\mathrm{m}$ de altura, representa a porção média do sambaqui em termos de espessura, já que não 
alcança o contato com o embasamento granitóide, nem o topo atual do sítio, este situado aproximadamente $1 \mathrm{~m}$ acima.

Apesar da altura métrica da seção, foram nela identificadas somente quatro arqueofácies (Figura 5.33). A AF 1, na base da seção, é composta principalmente por valvas de Anomalocardia brasiliana inteiras (60\%), com freqüência subordinada de fragmentos de ossos de peixe e de mariscos $(20 \%)$. A análise zooarqueológica confirma o predomínio de A. brasiliana (38\%), seguido de mariscos (13\%) e cerca de $45 \%$ de fragmentos de concha de tamanho menor que $2 \mathrm{~mm}^{73}$. A AF 2, de espessura centimétrica, geometria lenticular e composta por lama preta com ossos de peixe, é semelhante às camadas pretas também observadas nos sambaquis Caipora, Cubículo1 e Jabuticabeira 2. Porém, no sítio Morrinhos, assim como em Caipora, não foram identificados sepultamentos humanos nesta arqueofácies.

A AF 3, associada em todos os casos à AF 2, constitui-se de uma mistura de conchas inteiras e fragmentadas, principalmente de Anomalocardia brasiliana, entre outras espécies de moluscos. Acompanha o componente conchífero uma areia bioclástica, composta por fragmentos de concha e ossos de peixe (50\%). De espessura decimétrica, AF 3 apresenta áreas esparsas com maior concentração de conchas inteiras. A análise zooarqueológica corrobora o domínio de A. brasiliana (64\%), com cerca de 2\% de Ostrea sp., $1 \%$ de marisco e menos de 1\% de otólitos de bagre e corvina. Os restantes $32 \%$ estão formados por fragmentos indeterminados de molusco.

A AF 4, no topo da sucessão estratigráfica, é composta quase exclusivamente de fragmentos de concha e osso (50\%) com orientação sub-horizontal, junto com areia bioclástica e lama (50\%). Sua composição assemelha-se à AF 4 do sítio Caipora, também no topo da sucessão estratigráfica. Pela posição superficial de ambas arqueofácies, a semelhança pode significar que a alta degradação dos componentes bioclásticos e a compactação das arqueofácies possa ser um atributo pós-deposicional associado com a alteração pedogênica dos sedimentos arqueológicos. Apesar de apresentar alta frequência de fragmentos de concha de tamanho menor a $2 \mathrm{~mm}(\sim 42 \%)$, como AF 1, AF 4 é a única arqueofácies da sucessão com domínio de Ostrea sp. (26\%), seguido de mariscos $(\sim 17 \%)$, ossos $(2 \%)$ e, por último, A. brasiliana $(\sim 1 \%)^{74}$.

\footnotetext{
${ }^{73}$ Análise zooarqueológica da AF 1 realizada por Daniela Klokler.

${ }^{74}$ Análise zooarqueológica da AF 4 realizada por Daniela Klokler. 


\section{Granulometria}

Análises granulométricas da fração terrígena foram realizadas unicamente nas amostras provenientes das AF 2, 3 e 4. Na Figura 5.34 A, apresentam-se os histogramas da distribuição granulométrica das três arqueofácies analisadas. Diferente dos sambaquis Caipora e Cubículo, o sítio Morrinhos tem distribuições unimodais. Isto sugere o aporte de uma única fonte de sedimentos terrígenos em cada arqueofácies, ao contrário do observado nos sambaquis Caipora e Cubículo. As modas ocorrem nas classes areia média, areia fina e areia muito fina, para AF 2, 3 e 4, respectivamente, o que pode significar mudança da fonte de sedimentos terrígenos de uma arqueofácies para outra.

Para aprofundar na determinação da possível fonte de sedimentos terrígenos no sambaqui, compararam-se as estatísticas descritivas (diâmetro médio, desvio padrão e assimetria) da distribuição granulométrica das três arqueofácies do sambaqui Morrinhos com as de amostras paleolagunares e deltaicas extraídas de um testemunho localizado a cerca de $2 \mathrm{~km}$ do sambaqui (Nascimento 2011). Este testemunho foi escolhido para comparação pela sua proximidade com o sítio arqueológico e porque sua cronologia corresponde com o intervalo de ocupação do sítio. Os diagramas da Figura 5.34 B mostram que o intervalo interquartis da fração terrígena do sítio Morrinhos apresenta maior sobreposição com o de depósitos paleolagunares de que com o de depósitos deltaicos, pelo menos em relação a diâmetro médio e assimetria. Especificamente, o diagrama de caixa para o desvio padrão indica maior variabilidade de grau de seleção nos sedimentos arqueológicos de que nos naturais, o que pode ser interpretado como resultado da variação nas fontes de material terrígeno que compõe as diferentes arqueofácies, como já sugerido pela análise da Figura 5.34 A. Em contrapartida, o grau de seleção é em média ligeiramente mais alto nas arqueofácies de que nos sedimentos naturais, sejam os deltaicos sejam os paleolagunares, o que pode talvez indicar que a derivação de cada arqueofácies, em termos de fração terrígena, é a partir de fontes sedimentares bem determinadas no espaço e pouco variáveis no tempo. 


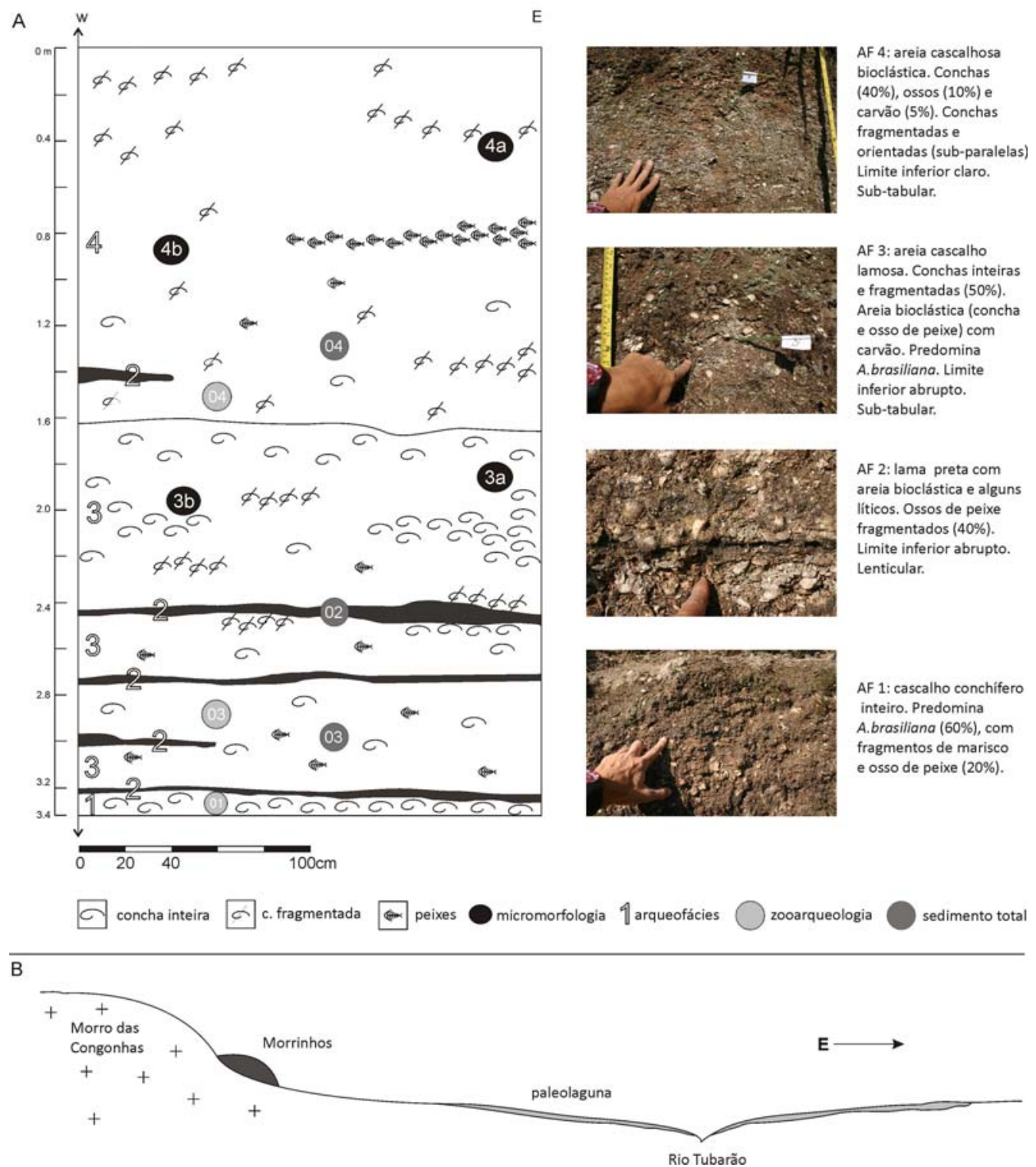

Figura 5.33. Seção vertical estudada do sítio Morrinhos: A) localização dos pontos de amostragem e descrição das arqueofácies identificadas; B) seção transversal esquemática (sem escala) da área de localização do sítio. 

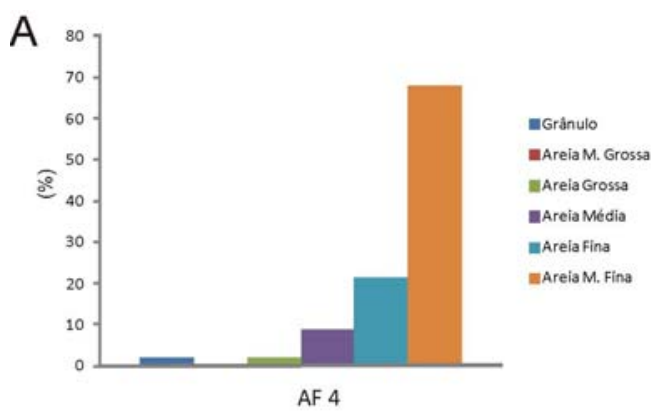

B
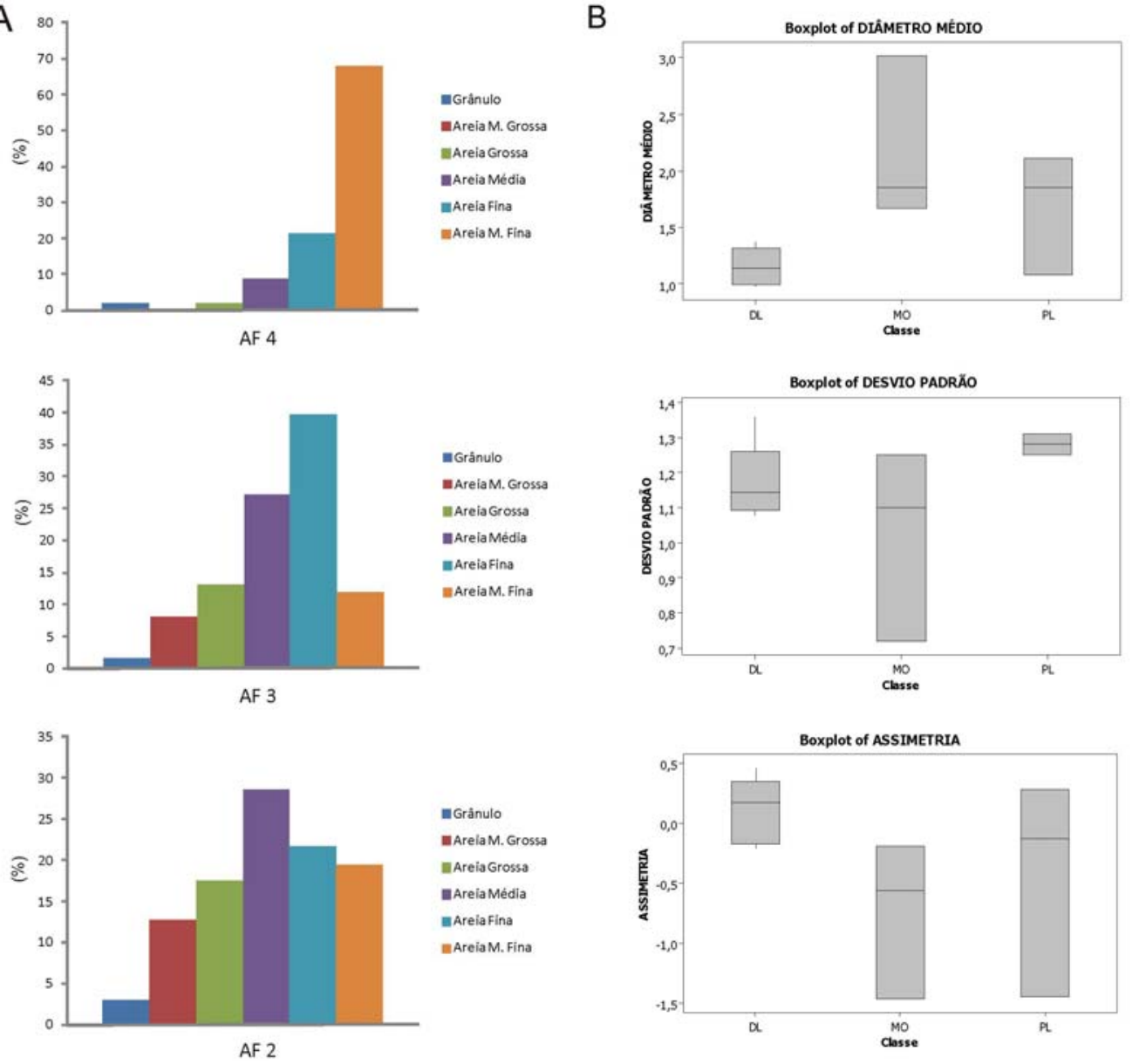

Figura 5.34. Gráficos das distribuições granulométricas e parâmetros estatísticos para o sítio Morrinhos e amostragem em sedimentos naturais das proximidades: A) histogramas da distribuição granulométrica para as AF 2, 3 e 4 do sambaqui Morrinhos; note-se o domínio da fração areia média, fina e muito fina para as $\mathrm{AF} 2,3$ e 4, respectivamente; B) diagramas em caixa (boxplot) dos parâmetros estatísticos diâmetro médio, desvio padrão e assimetria para o conjunto de amostras do sítio Morrinhos e amostras deltaicas (DL) e paleolagunares (PL) do testemunho TB2 (Nascimento, 2010) coletado a aproximadamente $2 \mathrm{~km}$ do sambaqui.

A avaliação no microscópio estereoscópico da fração retida nas malhas de 1,0 mm (areia grossa) e 0,5 mm (areia média) das AF 2, 3 e 4 mostra o predomínio de fragmentos de concha na composição do sambaqui (Figura 5.35). Na classe granulométrica areia grossa, a composição é essencialmente conchífera, enquanto na areia média a porcentagem de ossos aumenta. Unicamente na AF 3, o conteúdo de ossos é considerável também na classe areia grossa. Os resultados indicam que as AF 2, 3 e 4 diferenciam-se pelo conteúdo de conchas, majoritário na AF 2, e de ossos de peixe, dominante na AF 3. Apesar de estar igualmente localizado sobre embasamento cristalino, o sambaqui Morrinhos diferencia-se do Caipora pelo teor comparativamente baixo de terrígenos. 

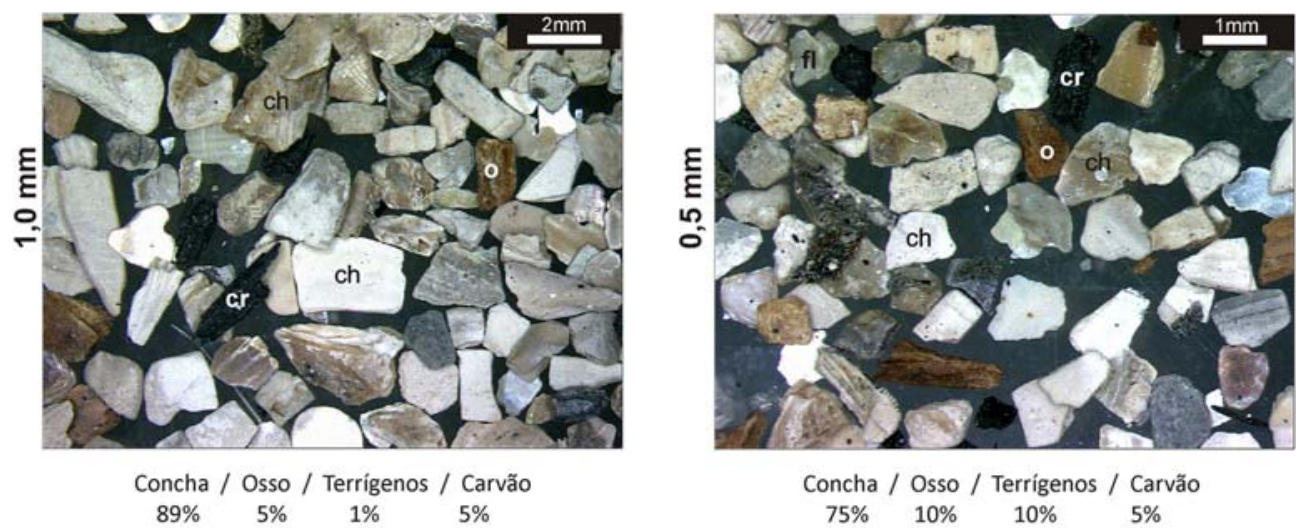

MORRINHOS - AF 3

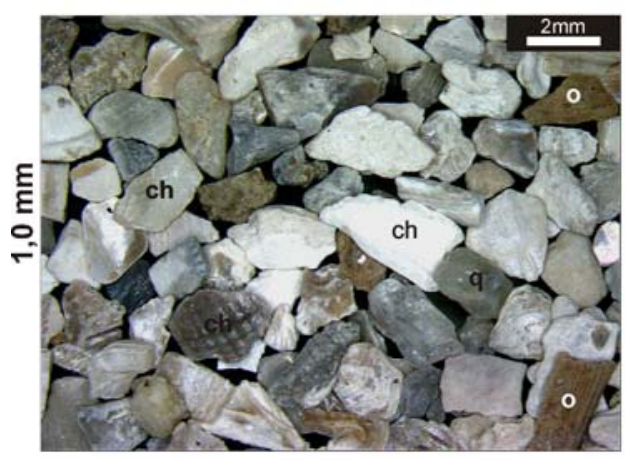

Concha / Osso / Terrígenos / Carvão

$69 \% \quad 25 \% \quad 5 \% \quad 1 \%$

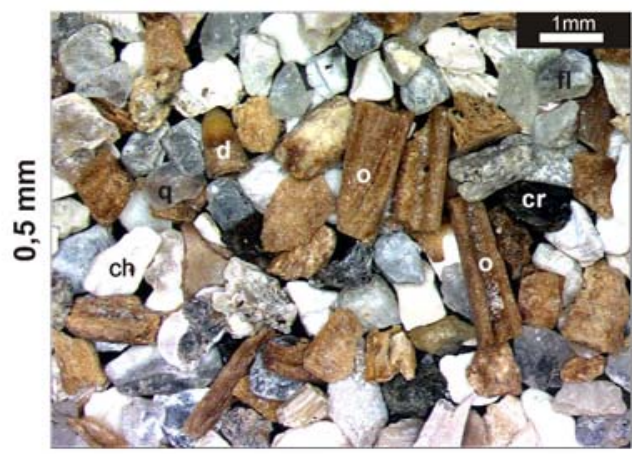

Concha / Osso / Terrígenos / Carvão

$59 \% \quad 25 \% \quad 15 \% \quad 1 \%$

MORRINHOS - AF 4

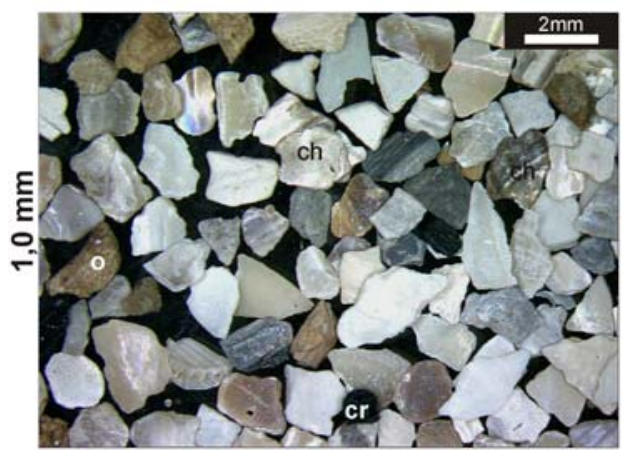

Concha / Osso / Terrigenos / Carvão

$85 \% \quad 12 \% \quad 2 \% \quad 1 \%$

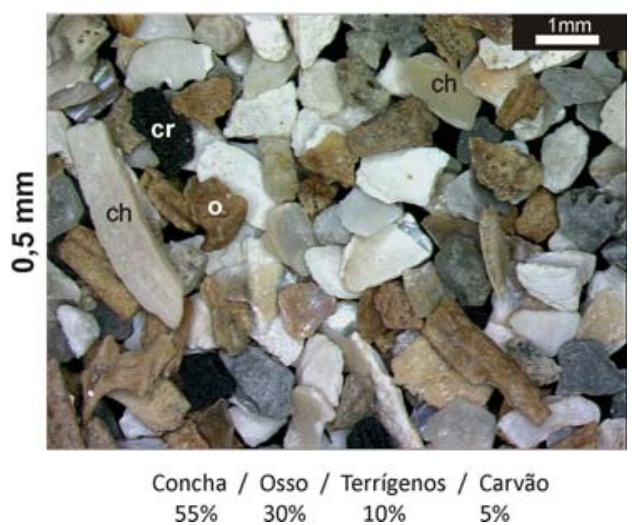

Figura 5.35. Fotomicrografias à lupa estereoscópica dos grãos retidos nas malhas de 1,0 mm e 0,5 mm das arqueofacies 2, 3 e 4 do sítio Morrinhos. Note-se a presença de ossos (o), conchas (ch), carvão (cr) e quartzo (q).

Isótopos de $\operatorname{CeN}\left(\delta^{13} \mathrm{Ce}^{53} \mathrm{~N}\right)$

A análise isotópica dos sedimentos das AF 2 e 4 permite observar clara diferença composicional na MO. Na AF 2, de geometria lenticular e composta por lama preta, os 
valores de $\delta^{13} \mathrm{C}$ e razão $\mathrm{C} / \mathrm{N}$ indicam deposição de plantas terrestres de ciclo fotossintético $\mathrm{C}_{3}$ (Figura $5.36 \mathrm{~A}$ ). $\mathrm{O}$ valor de $\delta^{15} \mathrm{~N}$, semelhante ao relatado na AF 5 de Cubículo 1, indica influência de plantas $C_{3}$, com leve enriquecimento de $N$, possivelmente associado à presença de restos de tecidos animais (Figura 5.36 B).

$\mathrm{Na} \mathrm{AF} 4$, os valores de $\delta^{13} \mathrm{C}$ e razão $\mathrm{C} / \mathrm{N}$ indicam igualmente presença de plantas $\mathrm{C}_{3}$ (Figura 5.36 A). No entanto, ao combinar estes dados com o valor de $\delta^{15} \mathrm{~N}$ torna-se notório o enriquecimento de $\mathrm{N}$ associado à presença de restos de animais marinhos (Figura 5.36 B), como igualmente relatado na AF 4 do sitio Caipora. Esta situação reforça a diferença observada no nível macroscópico entre as AF 2 e 4. Assim, a MO da AF 2, centimétrica e composta por lama preta e ossos de peixe fragmentados, é essencialmente vegetal, diferente da AF 4, decimétrica e com conteúdo conspícuo de conchas de moluscos, composta por uma mistura entre resíduos vegetais e restos de tecidos animais.
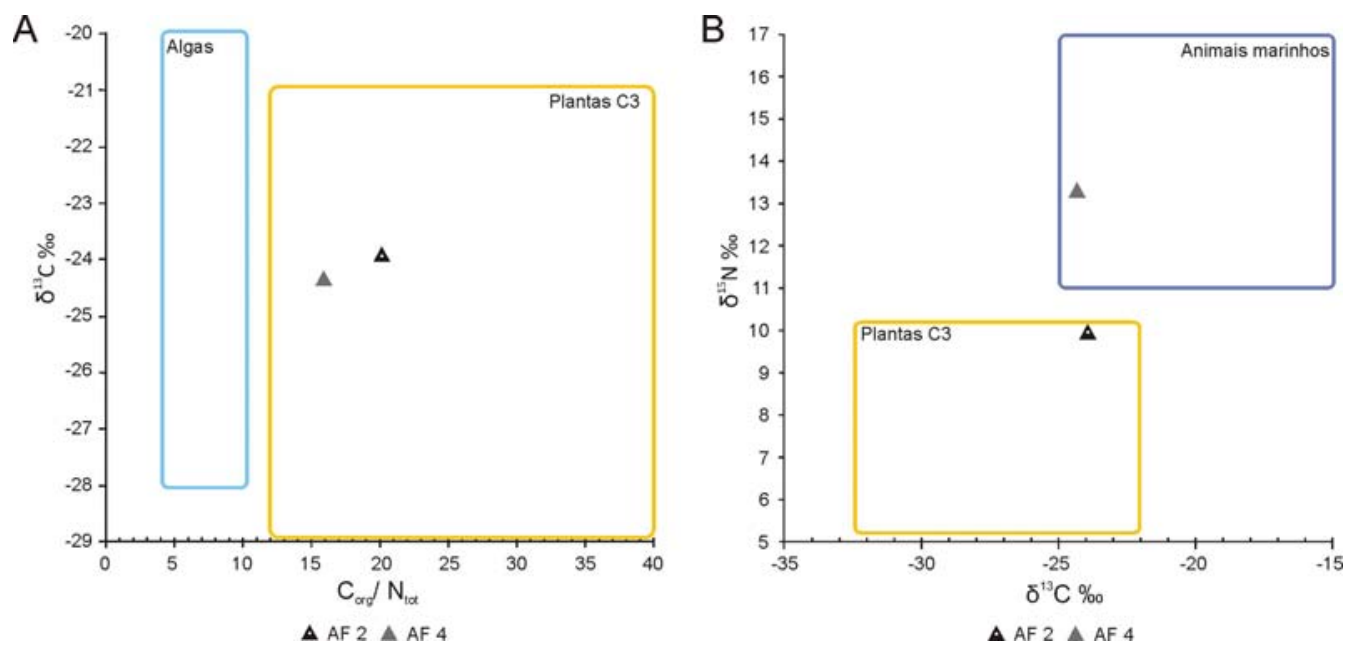

Figura 5.36. Análises isotópicas $\left(\delta^{13} \mathrm{C}\right.$ e $\delta^{15} \mathrm{~N}$ e razão $\left.\mathrm{C} / \mathrm{N}\right)$ de amostras provenientes das $\mathrm{AF} 2$ e 4 do sítio Morrinhos: A) gráfico de valores de $\delta^{13} \mathrm{C}$ e razão $\mathrm{C} / \mathrm{N}$ com intervalos definidos para plantas de ciclo fotossintético $\mathrm{C} 3$ e algas; B) gráfico dos valores de $\delta^{15} \mathrm{~N}$ e $\delta^{13} \mathrm{C}$ com intervalos definidos para plantas de ciclo fotossintético C3 e animais marinhos.

\section{Micromorfologia}

Para análise micromorfológica, foram coletadas quatro amostras indeformadas da seção vertical estudada, duas correspondentes à AF 3 e duas à AF 4 (Figura 5.33). Na Figura 5.37, apresenta-se o desenho esquemático das quatro lâminas analisadas, com as diferentes microfácies identificadas. A Tabela 5.9 agrupa a descrição geral destas quatro lâminas. Em conjunto, AF 3 e 4 apresentam grande heterogeneidade, muitas vezes com 
mais de uma microfácies identificada em cada seção delgada (Figura 5.37; Tabela 5.9). Destaca-se igualmente a variação lateral observada neste sítio, já que seções delgadas da mesma arqueofácies, coletadas a pouco mais de $1 \mathrm{~m}$ de distância uma da outra, apresentam diferentes sucessões de microfácies.

A diferenciação de microfácies levou em consideração quatro parâmetros básicos: a microestrutura, que varia entre microagregados intergranulares, grãos revestidos interligados e maciça; a distribuição relacionada $\mathrm{g} / \mathrm{f}$, que pode ser enáulica, quitônica ou porfírica; a diversidade de componentes da fração grossa, com microfácies de maior conteúdo conchífero vs. microfácies compostas essencialmente por areia quartzosa; e a composição da micromassa, que varia de micrita com argilominerais e microcarvões a argila maciça com diatomáceas.

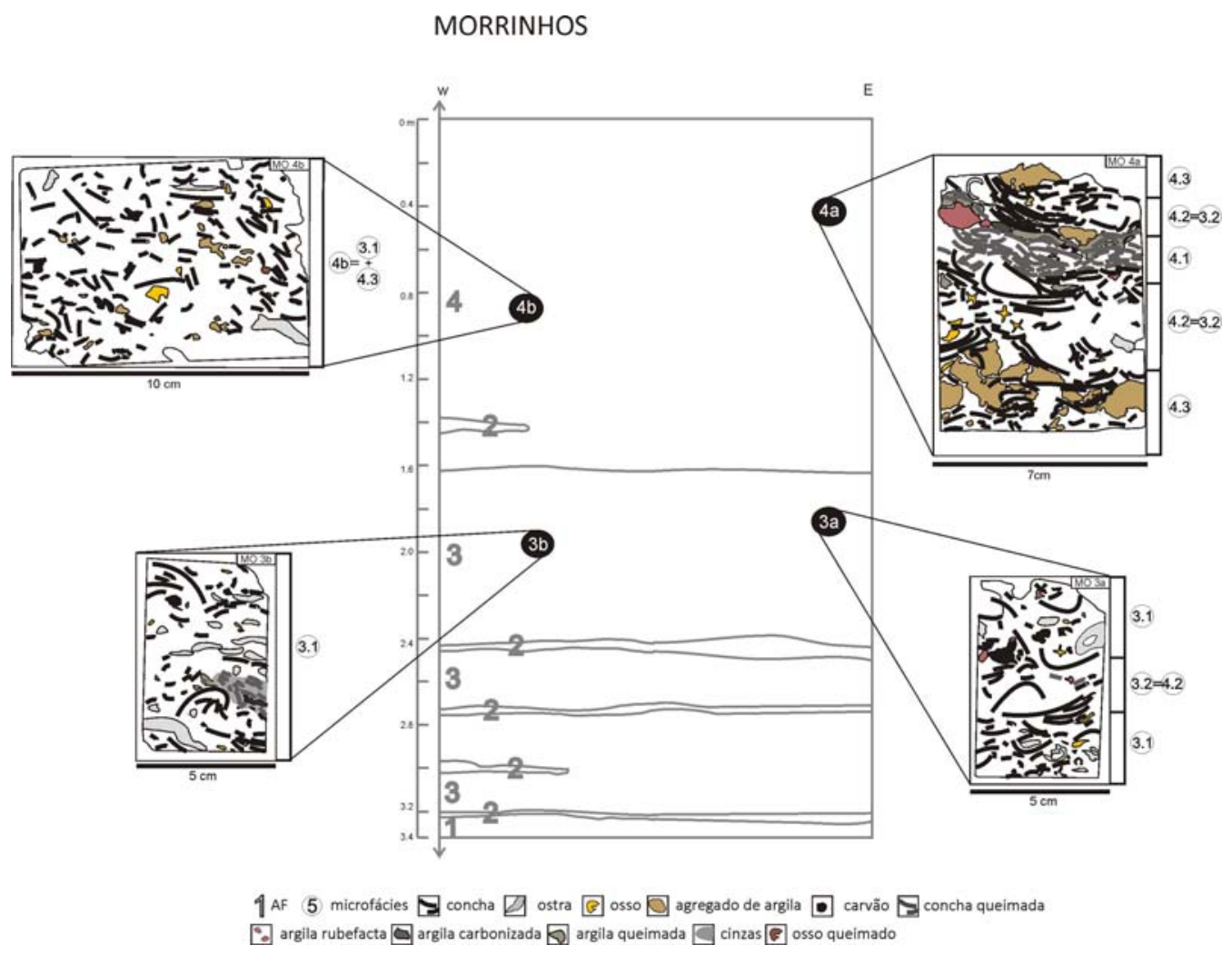

Figura 5.37. Desenho esquemático das quatro seções delgadas analisadas no sítio Morrinhos, com localização do bloco de amostragem na sucessão vertical e identificação de microfácies na lâmina. = significa equivalência entre microfácies identificadas em lâminas diferentes; + significa microfácies que envolve atributos de microfácies diferentes identificadas em outras lâminas.

O sítio Morrinhos destaca-se pela diversidade de componentes da fração grossa que, além dos fragmentos de concha, grãos minerais e ossos, característicos de 
sambaquis, inclui outros elementos como escória vítrea ${ }^{75}$, grãos de argila glauconítica, agregados de argila queimada, diatomáceas e inclusive restos de perióstraco queimado (Figura 5.38 A). Em todos os casos, a fração mineral apresenta granulometria areia fina a areia muito fina, distribuição aleatória, boa seleção e morfometria caracterizada por grãos equidimensionais subangulosos a subarredondados. Os fragmentos de concha e ossos apresentam, em todos os casos, frequências variáveis de queima e dissolução. Em ambas arqueofácies estudadas, existem microfácies com distribuição sub-horizontal dos fragmentos de concha (Tabela 5.10-5.13). Na maioria dos casos, a porosidade apresenta freqüências entre 20 e $40 \%$, com duas exceções de porosidade baixa, entre 10 e $20 \%$, nas microfácies em que domina a fração fina sobre a fração grossa (Figura 5.38 B).
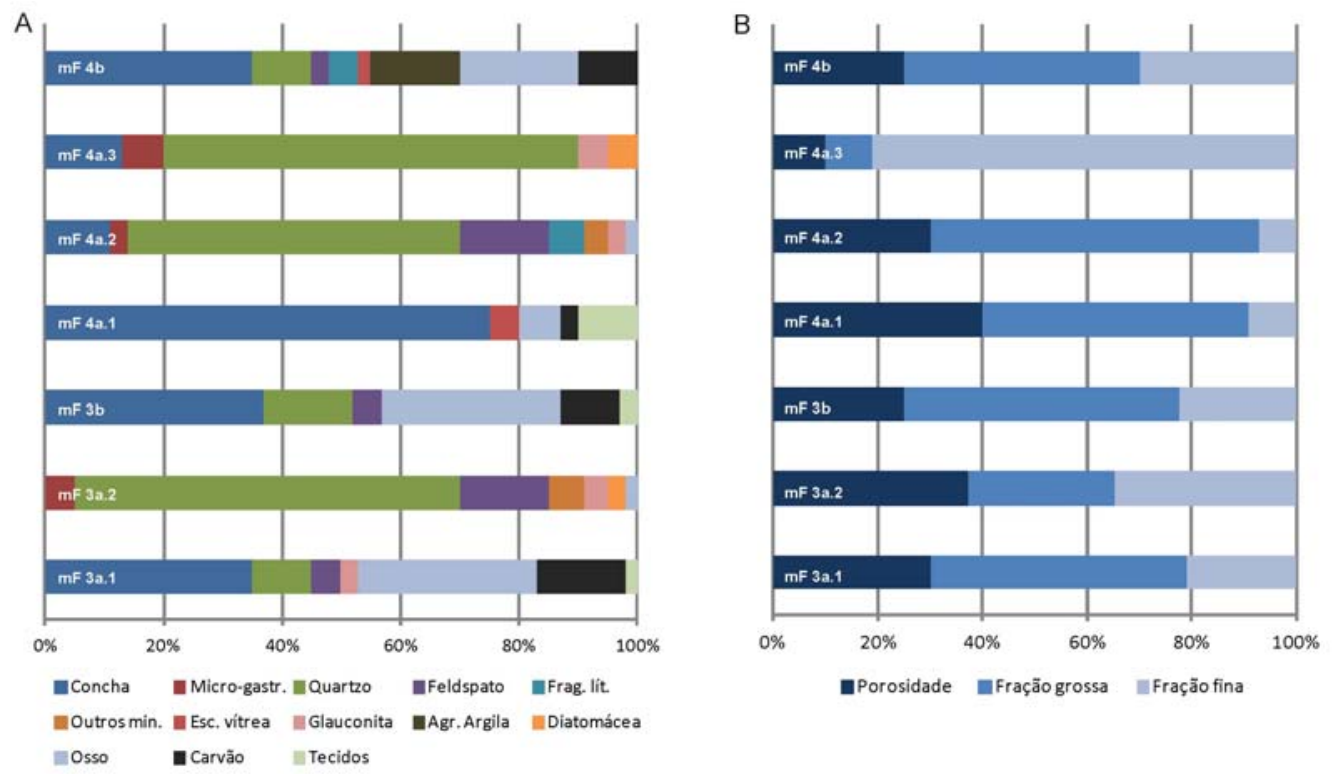

Figura 5.38. Gráficos com porcentagens dos diferentes componentes microscópicos das microfácies identificadas nas AF $3(\mathrm{mF}$ 3a.1, 3a.2 e 3b) e 4 ( $\mathrm{mf} 4 \mathrm{a} .1$, 4a.2, 4a.3 e 4b) do sítio Morrinhos: A) freqüências de componentes da fração grossa; B) relação entre as porcentagens de poros, fração grossa e fração fina.

\footnotetext{
${ }^{75}$ A escória vítrea forma parte dos resíduos gerados a partir da queima de tecidos de plantas, junto com agregados microcristalinos de carbonato de cálcio (POCC), estruturas de sílica inalterada e material criptocristalino. Forma-se pelo derretimento da sílica biogênica, um fenômeno de escala restrita à zona de maior temperatura de uma fogueira (Canti 2003).
} 
Tabela 5.9. Descrição micromorfológica do sambaqui Morrinhos.

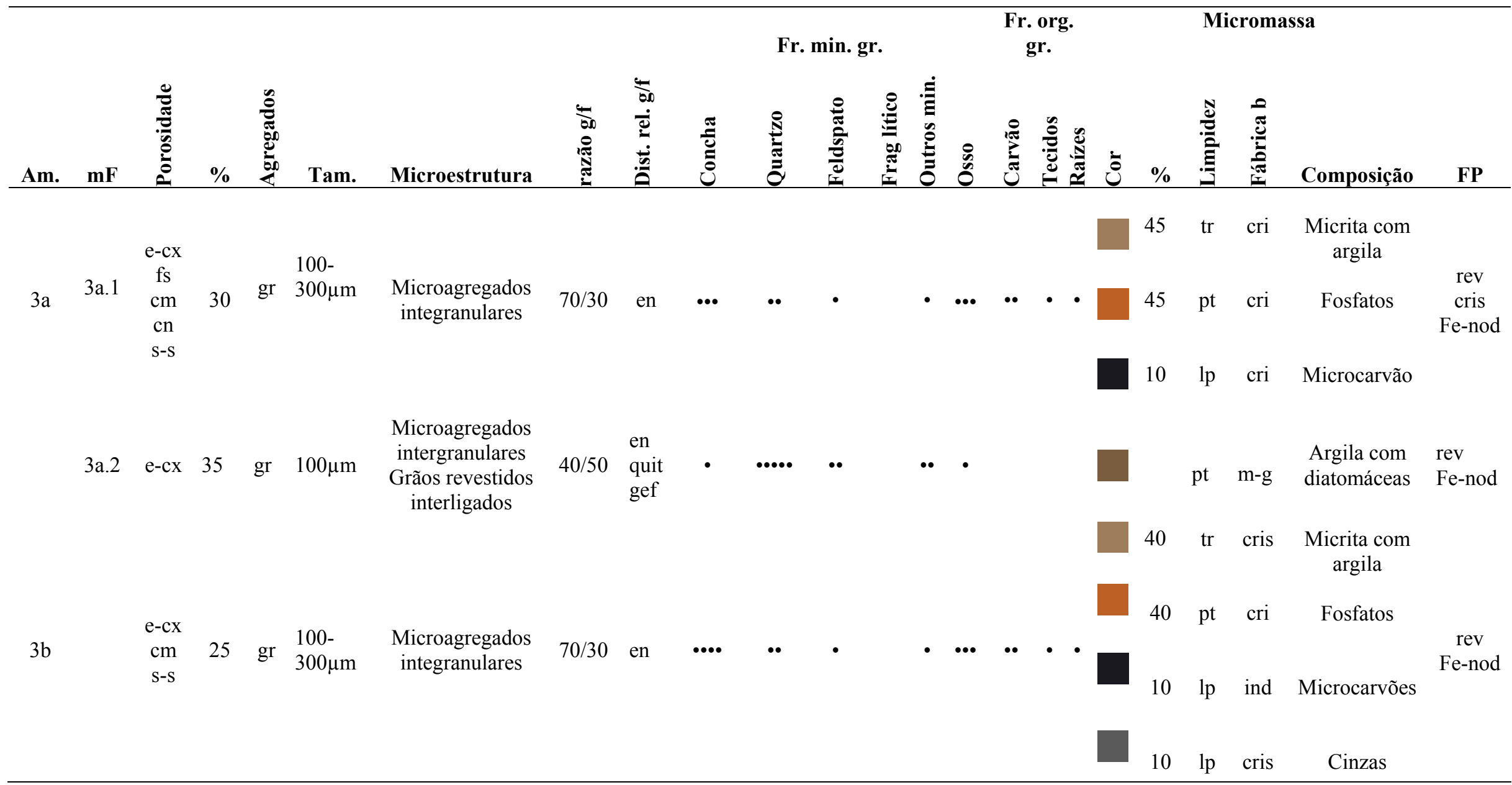

Freqüências de classes segundo Bullock et al. (1985): • Muito Poucas (<5\%); •• Poucas (5-15\%); ••• Comum (15-30\%); •••• Freqüente (30-50\%); •••• Dominante (50-70\%); •...• Muito dominante $(>70 \%)$. Am. $=$ amostra; $\mathrm{mF}=$ microfácies; Tam. $=$ tamanho; Fr. min. gr. = fração mineral grossa; Fr. org. gr. $=$ fração orgânica grossa; FP = feições pedológicas. O singificado das demais abreviações utilizadas nesta tabela encontra-se no Anexo, Tabela A.5. 


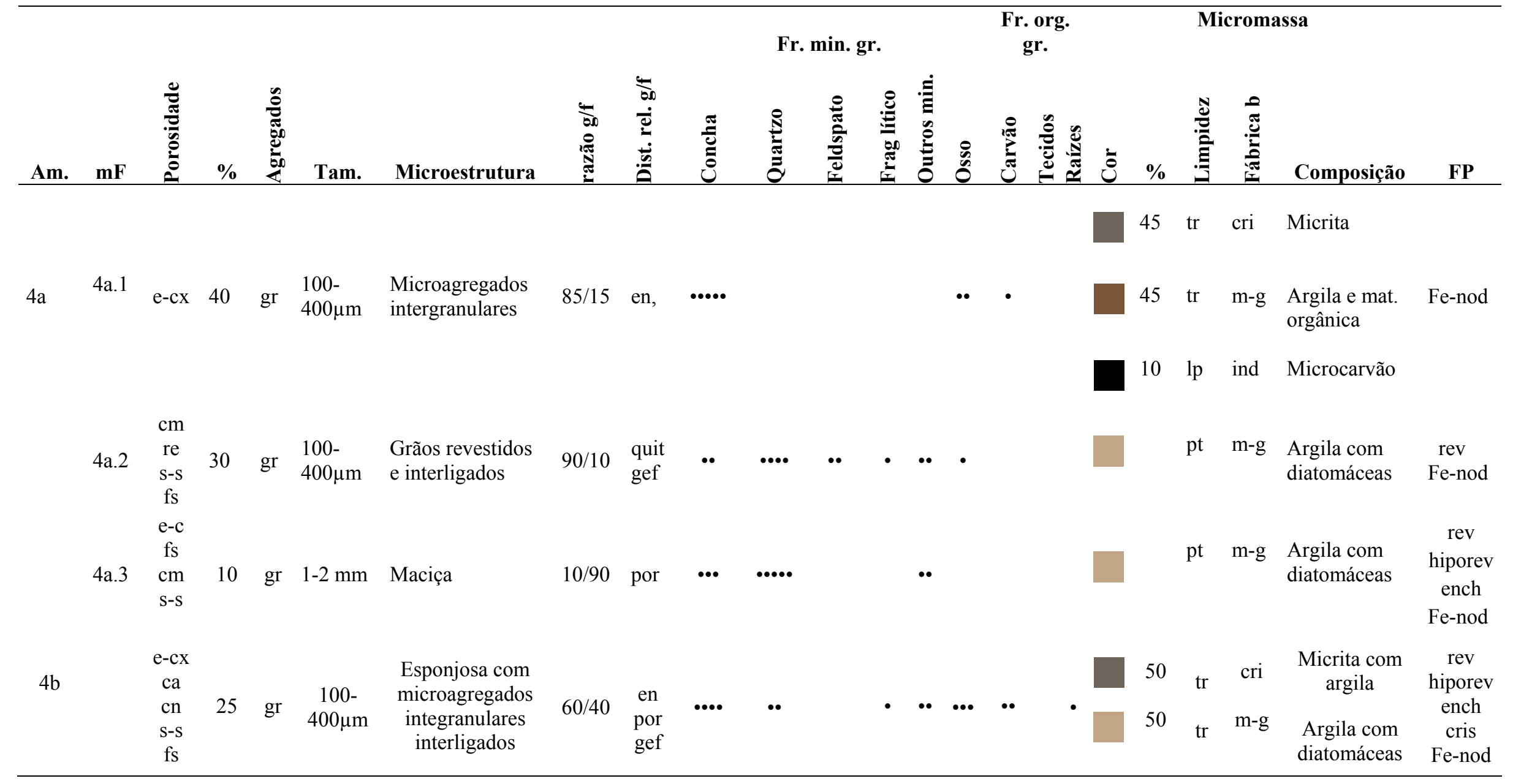


Tabela 5.10. Componentes minerais e orgânicos da fração grossa da amostra MO-3a.

\begin{tabular}{|c|c|c|c|c|c|c|c|c|c|c|}
\hline MO-3a & $\mathbf{m F}$ & $\%$ & Tamanho & Forma & Arredondamento & Seleção & $\begin{array}{c}\text { Distribuição } \\
\text { básica }\end{array}$ & $\begin{array}{c}\text { Orientação } \\
\text { básica }\end{array}$ & $\begin{array}{l}\text { Distribuição } \\
\text { referenciada }\end{array}$ & Alteração \\
\hline Conchas & $3 a .1$ & 30 & Vários & - & 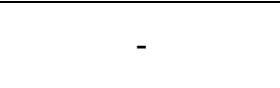 & Não selecionado & Aleatória/ linear & $\begin{array}{l}20 \% \text { paralelismo } \\
\text { de ângulo baixo }\end{array}$ & $\begin{array}{l}\text { Inclinada à } \\
\text { superfície }\end{array}$ & Dissolução \\
\hline Quartzo & $3 a .1$ & 10 & $\begin{array}{l}\text { Areia média a } \\
\text { mto. fina }\end{array}$ & Equidimensional & $\begin{array}{l}\text { Subanguloso } \\
\text { subarredondado }\end{array}$ & Seleção moderada & Aleatória & 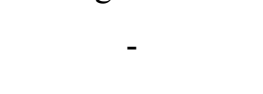 & - & \\
\hline Feldspato & $3 a .1$ & 5 & Areia mto. fina & Equidimensional & $\begin{array}{c}\text { Subanguloso } \\
\text { subarredondado }\end{array}$ & Bem selecionado & Aleatória & - & - & \\
\hline Glauco. & $3 a .1$ & 3 & Areia mto. fina & Equidimensional & Arredondado & Bem selecionado & Aleatória & - & - & \\
\hline Ossos & $3 a .1$ & 30 & Vários & - & - & Não selecionado & Aleatória & - & - & $\begin{array}{l}\text { Queima e } \\
\text { dissolução }\end{array}$ \\
\hline Carvão & $3 a .1$ & 15 & Vários & - & - & Não selecionado & Aleatória & - & - & \\
\hline Tecidos & $3 a .1$ & 2 & $300 \mu \mathrm{m}$ & - & - & Não selecionado & Aleatória & - & - & Silicificado \\
\hline Raízes & $3 a .1$ & 5 & Vários & - & - & Não selecionado & Aleatória & - & - & \\
\hline Gastróp. & $3 a .2$ & 5 & $220 \mu \mathrm{m}$ & - & - & Bem selecionado & Aleatória & - & - & Dissolução \\
\hline Quartzo & $3 a .2$ & 65 & $\begin{array}{l}\text { Areia média a } \\
\text { mto. fina }\end{array}$ & Equidimensional & Subarredondado & Seleção moderada & Aleatória & - & - & - \\
\hline Feldspato & $3 a .2$ & 15 & Areia mto. fina & Equidimensional & Subarredondado & Bem selecionado & Aleatória & - & - & - \\
\hline Min. pes. & $3 a .2$ & 3 & Areia mto. fina & Equidimensional & $\begin{array}{l}\text { Arredondado } \\
\text { subarredondado }\end{array}$ & Bem selecionado & Aleatória & & & \\
\hline Min. op. & $3 a .2$ & 3 & Areia mto. fina & Equidimensional & Arredondado & Bem selecionado & Aleatória & & & \\
\hline Glauco. & $3 a .2$ & 4 & Areia mto. fina & Equidimensional & Arredondado & Bem selecionado & Aleatória & & & \\
\hline Diatom. & $3 a .2$ & 3 & Silte & - & - & Bem selecionado & Aleatória & & & \\
\hline Osso & $3 a .2$ & 2 & Areia mto. fina & - & - & Seleção pobre & Aleatória & - & - & \\
\hline
\end{tabular}


Tabela 5.11. Componentes minerais e orgânicos da fração grossa da amostra MO-3b.

\begin{tabular}{|c|c|c|c|c|c|c|c|c|c|c|}
\hline \multicolumn{11}{|l|}{ MO-3b } \\
\hline & $\mathbf{m F}$ & $\%$ & Tamanho & Forma & Arredondamento & Seleção & $\begin{array}{l}\text { Distribuiçãão } \\
\text { básica }\end{array}$ & $\begin{array}{l}\text { Orientação } \\
\text { básica }\end{array}$ & $\begin{array}{l}\text { Distribuição } \\
\text { referenciada }\end{array}$ & Alteração \\
\hline Concha & & 35 & Vários & - & - & Não selecionado & Aleatória/ linear & $\begin{array}{l}10 \% \text { paralelismo } \\
\text { de ângulo baixo }\end{array}$ & $\begin{array}{l}\text { Inclinada à } \\
\text { superfície }\end{array}$ & $\begin{array}{c}10 \% \\
\text { queimado a } \\
\mathrm{T}>600^{\circ} \mathrm{C}\end{array}$ \\
\hline Quartzo & & 15 & $\begin{array}{l}\text { Areia média a } \\
\text { mto. fina }\end{array}$ & Equidimensional & $\begin{array}{l}\text { Subanguloso } \\
\text { subarredondado }\end{array}$ & Bem selecionado & $\begin{array}{l}\text { Seleção } \\
\text { moderada }\end{array}$ & - & - & - \\
\hline Feldspato & & 5 & Areia fina & Equidimensional & $\begin{array}{l}\text { Subanguloso } \\
\text { subarredondado }\end{array}$ & Bem selecionado & Aleatória & - & - & - \\
\hline Osso & & 29 & Vários & - & - & Não selecionado & Aleatória & - & - & $\begin{array}{l}\text { Queima e } \\
\text { dissolução }\end{array}$ \\
\hline Carvão & & 10 & $2-5 \mathrm{~mm}$ & - & & Seleção moderada & Aleatória & - & - & - \\
\hline Tecidos & & 3 & $300 \mu \mathrm{m}$ & - & - & Não selecionado & Aleatória & - & - & - \\
\hline Raízes & & 3 & Vários & - & - & - & Aleatória & - & - & - \\
\hline
\end{tabular}


Tabela 5.12. Componentes minerais e orgânicos da fração grossa da amostra MO-4a.

\begin{tabular}{|c|c|c|c|c|c|c|c|c|c|c|}
\hline \multicolumn{11}{|l|}{ MO-4a } \\
\hline & $\mathbf{m F}$ & $\%$ & Tamanho & Forma & Arredondamento & Seleção & $\begin{array}{c}\text { Distribuição } \\
\text { básica }\end{array}$ & $\begin{array}{c}\text { Orientação } \\
\text { básica }\end{array}$ & $\begin{array}{l}\text { Distribuição } \\
\text { referenciada }\end{array}$ & Alteração \\
\hline Concha & 4a.1 & 65 & Vários & - & 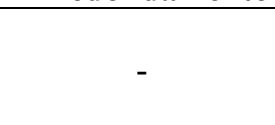 & Seleção moderada & Linear & $\begin{array}{l}\text { Paralelismo de } \\
\text { ângulo baixo }\end{array}$ & $\begin{array}{l}\text { Inclinado à } \\
\text { superfície }\end{array}$ & $\begin{array}{c}30 \% \\
\text { queimado a } \\
\mathrm{T}>600^{\circ} \mathrm{C}\end{array}$ \\
\hline Es. vítrea & $4 a .1$ & 5 & Vários & Vários & Arredondado & Não selecionado & Aleatória & - & - & - \\
\hline Osso & $4 a .1$ & 7 & Vários & - & - & Não selecionado & Aleatória & - & - & Queima \\
\hline Carvão & $4 a .1$ & 3 & Vários & - & - & Não selecionado & Aleatória & - & - & - \\
\hline Tecidos & $4 a .1$ & 10 & Vários & - & - & Não selecionado & Aleatória & - & - & - \\
\hline Peri. carb. & $4 a .1$ & 5 & Vários & - & - & - & Aleatória & - & - & - \\
\hline Arg. quei. & 4a.1 & 5 & $1-3 \mathrm{~mm}$ & Vários & Anguloso & Não selecionado & Aleatória & - & - & - \\
\hline Concha & $4 a .2$ & 11 & Vários & - & - & Não selecionado & Linear & $\begin{array}{l}\text { Paralelismo de } \\
\text { ângulo baixo }\end{array}$ & $\begin{array}{l}\text { Inclinado à } \\
\text { superfície }\end{array}$ & $5 \%$ queima \\
\hline Micro-ga. & $4 a .2$ & 3 & $100 \mu \mathrm{m}$ & - & - & Bem selecionado & Aleatória & - & - & - \\
\hline Quartzo & 4a.2 & 56 & Areia fina & Equidimensional & $\begin{array}{l}\text { Subanguloso } \\
\text { subarredondado }\end{array}$ & Bem selecionado & Aleatória & - & - & - \\
\hline Feldspato & $4 a .2$ & 15 & Areia fina & Equidimensional & $\begin{array}{l}\text { Subanguloso } \\
\text { subarredondado }\end{array}$ & Seleção moderada & Aleatória & - & - & - \\
\hline Frag.lítico & $4 a .2$ & 6 & $\begin{array}{l}\text { Areia média e } \\
\text { fina }\end{array}$ & Equidimensional & $\begin{array}{c}\text { Subanguloso } \\
\text { subarredondado }\end{array}$ & Seleção moderada & Aleatória & - & - & - \\
\hline Min. pes. & 4a.2 & 4 & Areia mto. fina & Equidimensional & Suarredondado & Bem selecionado & Aleatória & - & - & - \\
\hline Glauco. & $4 a .2$ & 3 & Areia mto. fina & Equidimensionaç & Arredondado & Bem selecionado & Aleatória & - & - & - \\
\hline Osso & $4 a .2$ & 2 & Vários & - & - & Não selecionado & Aleatória & - & - & Queimado \\
\hline Concha & $4 a .3$ & 13 & Vários & - & - & Não selecionado & Aleatória & - & - & - \\
\hline Quartzo & 4a.3 & 70 & Areia mto. fina & Equidimensional & Subanguloso & Bem selecionado & Aleatória & - & - & - \\
\hline Gastróp. & 4a.3 & 7 & $100 \mu \mathrm{m}$ & - & - & Bem selecionado & Aleatória & - & - & - \\
\hline Glauco. & $4 a .3$ & 5 & Areia mto. fina & Equidimensional & Arredondado & Bem selecionado & Aleatória & - & - & - \\
\hline Diatom. & 4a. 3 & 5 & Silte & - & - & Bem selecionado & Aleatória & - & - & - \\
\hline
\end{tabular}


Tabela 5.13. Componentes minerais e orgânicos da fração grossa da amostra MO-4b.

\begin{tabular}{|c|c|c|c|c|c|c|c|c|c|c|}
\hline \multicolumn{11}{|l|}{ MO-4b } \\
\hline & $\mathbf{m F}$ & $\%$ & Tamanho & Forma & Arredondamento & Seleção & $\begin{array}{c}\text { Distribuiçãa } \\
\text { básica }\end{array}$ & $\begin{array}{l}\text { Orientação } \\
\text { básica }\end{array}$ & $\begin{array}{l}\text { Distribuição } \\
\text { referenciada }\end{array}$ & Alteração \\
\hline Concha & & 37 & Vários & - & 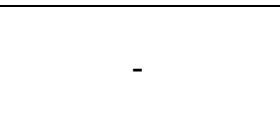 & Não selecionado & Aleatória & $\begin{array}{l}10 \% \text { paralelismo } \\
\text { de ângulo baixo }\end{array}$ & $\begin{array}{l}\text { Inclinada à } \\
\text { superfície }\end{array}$ & $\begin{array}{c}10 \% \\
\text { queimado a } \\
\mathrm{T}>600^{\circ} \mathrm{C}\end{array}$ \\
\hline Quartzo & & 10 & $\begin{array}{l}\text { Areia média a } \\
\text { fina }\end{array}$ & Equidimensional & $\begin{array}{l}\text { Subanguloso } \\
\text { subarredondado }\end{array}$ & Seleção moderada & Aleatória & - & - & - \\
\hline Feldspato & & 3 & Areia fina & Equidimensionap & $\begin{array}{l}\text { Subanguloso } \\
\text { subarredondado }\end{array}$ & Bem selecionado & Aleatória & - & - & - \\
\hline Frag. lít. & & 5 & Areia média & Equidimensional & Subanguloso & Bem selecionado & Aleatória & - & - & - \\
\hline Esc. vít. & & 2 & $200-300 \mu \mathrm{m}$ & Vários & Arredondado & Não selecionado & Aleatória & - & - & - \\
\hline Ag. argila & & 10 & $1-5 \mathrm{~mm}$ & Vários & Arredondado & Não selecionado & Aleatória & & & Fissuras \\
\hline Osso & & 20 & Vários & - & - & Não selecionado & Aleatória & - & - & $\begin{array}{l}\text { Queima e } \\
\text { dissolução }\end{array}$ \\
\hline Carvão & & 10 & Vários & - & - & Não selecionado & Aleatória & - & - & - \\
\hline Raízes & & 3 & Vários & - & - & - & Aleatória & - & - & - \\
\hline
\end{tabular}


A AF 3 apresenta pelo menos duas microfácies. Na lâmina 3a, a microfácies dominante ( $\mathrm{mF}$ 3a.1) compõe-se de fragmentos de concha com distribuição subhorizontal, fragmentos de osso com sinais de queima e dissolução, grãos de quartzo, feldspato e carvão, entre outros componentes (Figura 5.39 A, B). A microestrutura desta microfácies é de microagregados integranulares e micromassa composta por mistura de micrita com argilominerais, fosfatos secundários e microcarvões (Figura 5.39 C, D; Tabela 5.9). Os fosfatos secundários derivam da intensa dissolução dos ossos e aparecem freqüentemente associados a finos fragmentos na fração silte (Figura 5.40 AD). A formação de fosfatos secundários é favorecida pelas condições de $\mathrm{pH}$ e regime hidrológico do depósito, que provocam dissolução e recristalização do mineral do osso (Berna et al., 2004; Lucas and Prévôt, 1991; Trueman et al., 2004).

A segunda microfácies da seção delgada $3 \mathrm{a}(\mathrm{mF} 3 \mathrm{a} .2)$ apresenta baixa frequência de conchas e ossos $(<5 \%)$ e fração grossa formada por grãos minerais, revestidos e interligados, de quartzo e feldspato. Não contém conchas de bivalves, mas de uma espécie de gastrópode, de aproximadamente $250 \mu \mathrm{m}$ de comprimento. Este gastrópode corresponde com indivíduos juvenis da espécie Heleobia sp. (Stimpson 1865), espécie tipicamente estuarina-lagunar que habita substrato argilo-arenoso (Rios, 1985). Entre o componente mineral, observam-se frequências que, no total, são menores que $5 \%$ de minerais pesados, minerais opacos, grãos de argila glauconítica e diversas espécies de diatomáceas (Figura 5.39 E, F).

A identificação de argila glauconítica foi realizada pelas suas propriedades ópticas, tais como aspecto criptocristalino, coloração verde e cor de interferência de primeira ordem (birrefringência máxima estimada em torno de 0,020 ) em padrão pontilhado. Contribuiu para a identificação a ocorrência na forma de grãos com tamanho entre 20 e $30 \mu \mathrm{m}$ e forma subequidimensinal subarredondada, hábito frequente dentre clastos de glauconita descritos na literatura (Dillemburg et al., 2000). A diatomácea que predomina na $\mathrm{mF}$ 3a.2 é Paralia sulcata, espécie euritrópica, que tolera variações de salinidade das águas de 5 até 40 \%o (Amaral 2011, comunicação pessoal), muito freqüente em sedimento paleolagunares da região (Amaral 2008; Amaral et al. 2012).

A seção $3 b$ apresenta uma única microfácies, semelhante à $\mathrm{mF}$ 3a.1 (Figura 5.37), composta por fragmentos de concha, ossos e grãos de quartzo, todos de distribuição aleatória (Figura 5.41 A, B). Aproximadamente 10\% dos fragmentos de 
concha apresentam distribuição sub-horizontal. Os ossos apresentam distribuição aleatória, alta fragmentação, sinais de dissolução e queima (Figura 5.41 C, D). A micromassa constitui-se de micrita com argilominerais, fosfatos e microcavões (Figura 5.41 E, F). Esta microfácies contém áreas de concentração de conchas queimadas a temperaturas maiores aos $600^{\circ} \mathrm{C}(10 \%$ do total de conchas) associadas a fração fina composta por cinzas de madeira. A identificação de cinzas baseia-se na presença de agregados microcristalinos de cristais romboédricos de calcita, desenvolvidos como pseudomorfos de oxalato de cálcio (POCC) (Brochier, 1983; Canti, 2003). Estes cristais identificam-se em seção delgada pela forma e coloração cinzenta em PPL, com a birrefringência do carbonato de cálcio sob polarizadores cruzados (Figura 5.42). Junto com as cinzas, observam-se restos de tecidos vegetais silicificados. A existência de cinzas bem preservadas nesta seção delgada reforça a idéia de que a micrita que compõe a fração fina resulta da precipitação do carbonato de cálcio dissolvido das conchas, e não da dissolução e precipitação de cinzas não preservadas.

$\mathrm{Na}$ seção delgada $4 \mathrm{a}$, destaca-se a presença de três microfácies claramente diferenciadas pela microestrutura, composição da fração grossa e composição da micromassa (mF 4a.1, 4a.2 e 4a.3) (Figura 5.43 B). Destas microfácies, mF 4a.1 é semelhante às $\mathrm{mF} 3 \mathrm{a} .1$ e $3 \mathrm{~b}$, mas com maior freqüência de materiais queimados $(30 \%$ do total de conchas) e menor proporção de ossos (7\%) e fosfatos secundários (Figura $5.43 \mathrm{C}$ ). A mF 4a.2 assemelha-se à mF 3a.2 (Figura $5.43 \mathrm{D}, \mathrm{E}$ ) e a $\mathrm{mF} 4 \mathrm{a} .3$ é formada por agregados de lama milimétricos a centimétricos, nos quais se observam as mesmas espécies de diatomáceas e gastrópodes das mF 4a.2 e 3a.2 (Figura 5.37; Figura 5.43 F).

A $\mathrm{mF}$ 4a.1 é formada por uma mistura de conchas de diversas espécies de moluscos, distribuídas sub-horizontalmente (Figura $5.44 \mathrm{~A}$ ), com sinais de queima a temperatura superior aos $600^{\circ} \mathrm{C}$ em $30 \%$ dos casos (Figura $5.44 \mathrm{~B}$ ). Os demais componentes da fração grossa incluem fragmentos de ossos queimados, resíduos de escória vítrea (Figura 5.44 C), carvão e restos de perióstraco carbonizado (Figura 5.44 D, E). Todos os componentes encontram-se em meio a micromassa essencialmente micrítica, relacionada com a dissolução das conchas e com a presença de cinzas, com áreas de concentração de argila organomineral, argila rubefacta (Figura 5.44 A) e microcarvões.

O elemento de maior destaque na $\mathrm{mF}$ 4a.1 está representado por uma acumulação milimétrica de tecidos silicificados de distribuição horizontal a sub- 
horizontal (Figura 5.45). Estes tecidos correspondem a restos de epidermis e mesofilo de plantas, possivelmente Juncaceae (Madella 2010, comunicação pessoal). Observa-se intercalação entre fitólitos alongados e arredondados que poderia representar diferentes cortes do mesmo tecido, ou seja, cortes transversais intercalados com cortes longitudinais. Este tipo de combinação do mesmo tecido poderia corresponder a material trançado, como tapetes ou cestaria.

A $\mathrm{mF}$ 4a.2 é constituída por grãos de quartzo, feldspato e fragmentos líticos revestidos e interligados $(\sim 70 \%)$, com freqüência subordinada de conchas, gastrópodes, fragmentos de osso, minerais pesados e grãos de argila glauconítica. A mF 4a.3 apresenta agregados milimétricos a centimétricos de lama maciça, formada por argila mosqueada granida (stiple-speckled), com gastrópodes (Figura 5.46 A, B) e diatomáceas (Figura $5.46 \mathrm{C}, \mathrm{D}$ ). Na assembleia de diatomáceas, domina a espécie Paralia sulcata (Amaral 2011, comunicação pessoal).

A seção delgada correspondente à amostra $4 \mathrm{~b}$ apresenta mistura entre as $\mathrm{mF} 3 \mathrm{a} .1$ e 4a.3 (Figura 5.37). A massa basal inclui conchas de moluscos, ossos queimados, grãos minerais (quartzo, feldspato e fragmentos líticos) e carvão (Figura $5.47 \mathrm{C}, \mathrm{D}$ ), assim como agregados milimétricos de argila da mesma composição que a mf 4a.3, com gastrópodes e diatomáceas (Figura 5.47 B). A micromassa é uma mistura de micrita com argilominerais (Figura $5.47 \mathrm{E}, \mathrm{F}$ ).

Ao longo da seção vertical estudada, e nas diferentes arqueofácies amostradas, as feições pedológicas não variam. Destaca-se a presença constante de revestimentos não laminados, de carbonato de cálcio, tanto ao redor dos componentes da fração grossa como em vazios (Figura 5.48 A-D), e de nódulos de óxi-hidróxidos de ferro órticos, seja na micromassa de micrita com argilominerais seja na argila mosqueada granida que compõe os agregados de lama (Figura 5.48 F). Nas microfácies com maior conteúdo de argilominerais, observam-se, igualmente, hiporrevestimentos de óxi-hidróxidos de ferro e, em alguns casos, enchimentos densos e incompletos de micrita. As cristalizações aparecem na forma de espato (Figura 5.48 E). Apesar de não terem sido observados excrementos da fauna do solo, a microestrutura esponjosa e de agregados intergranulares interligados, assim como os vazios em câmera e canais, indicam bioturbação no sedimento.

Assim como observado no sitio Caipora, as feições pedológicas do sítio Morrinhos indicam intensa precipitação do carbonato de cálcio das conchas que 
compõem o sambaqui. Da mesma maneira, os nódulos e hiporrevestimentos de óxihidróxido de ferro indicam ciclos de alagamento e dessecação dos sedimentos, junto com condições vadosas de formação. No entanto, este processo de alteração da fábrica original ainda preserva relativamente intactas as relações entre diferentes microfácies, a exemplo das seções delgadas $3 \mathrm{a}$ e $4 \mathrm{a}$, assim como aquelas microfácies associadas com a queima de materiais, como observado na $\mathrm{mF} 3 \mathrm{~b}$ e $4 \mathrm{a} .1$. As cinzas de madeira que, pela sua composição carbonática, seriam suscetíveis à dissolução, preservaram-se neste sambaqui, em associação com conchas e ossos queimados, tecidos silicificados e argila rubefacta.

Portanto, pode-se pensar que, apesar da precipitação dos componentes biológicos do sambaqui (conchas e ossos), existe boa preservação das microfácies associadas com eventos de deposição específicos. Da mesma maneira, a maior diversidade de microfácies que se observa no setor de coleta das amostras $3 \mathrm{a}$ e $4 \mathrm{a}$, em oposição às amostras $3 \mathrm{~b}$ e $4 \mathrm{~b}$, situadas a pouco mais de $1 \mathrm{~m}$ de distância, indica variabilidade lateral. Neste sentido, as seções delgadas 3a e 4a poderiam abranger áreas de maior intensidade de ocupação, enquanto as amostras $3 \mathrm{~b}$ e $4 \mathrm{~b}$ estariam localizadas em áreas periféricas de deposição massiva de resíduos retrabalhados. 
A
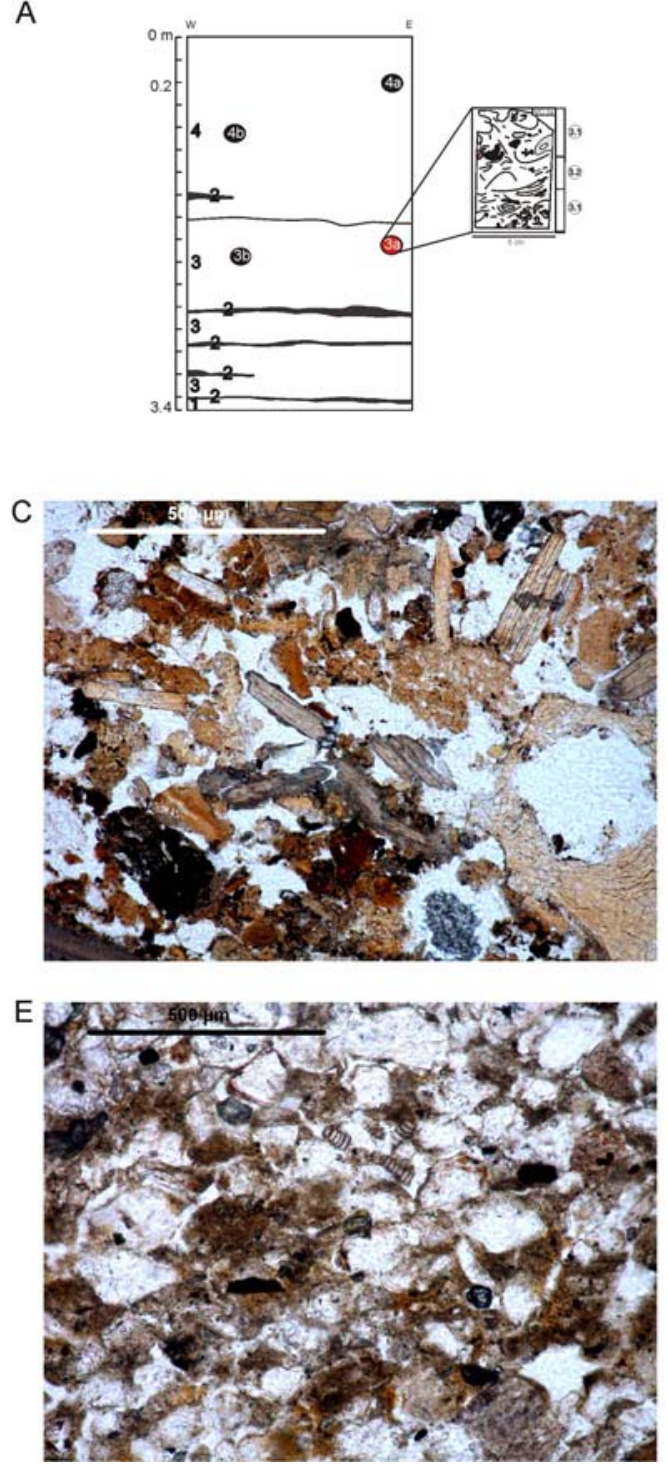
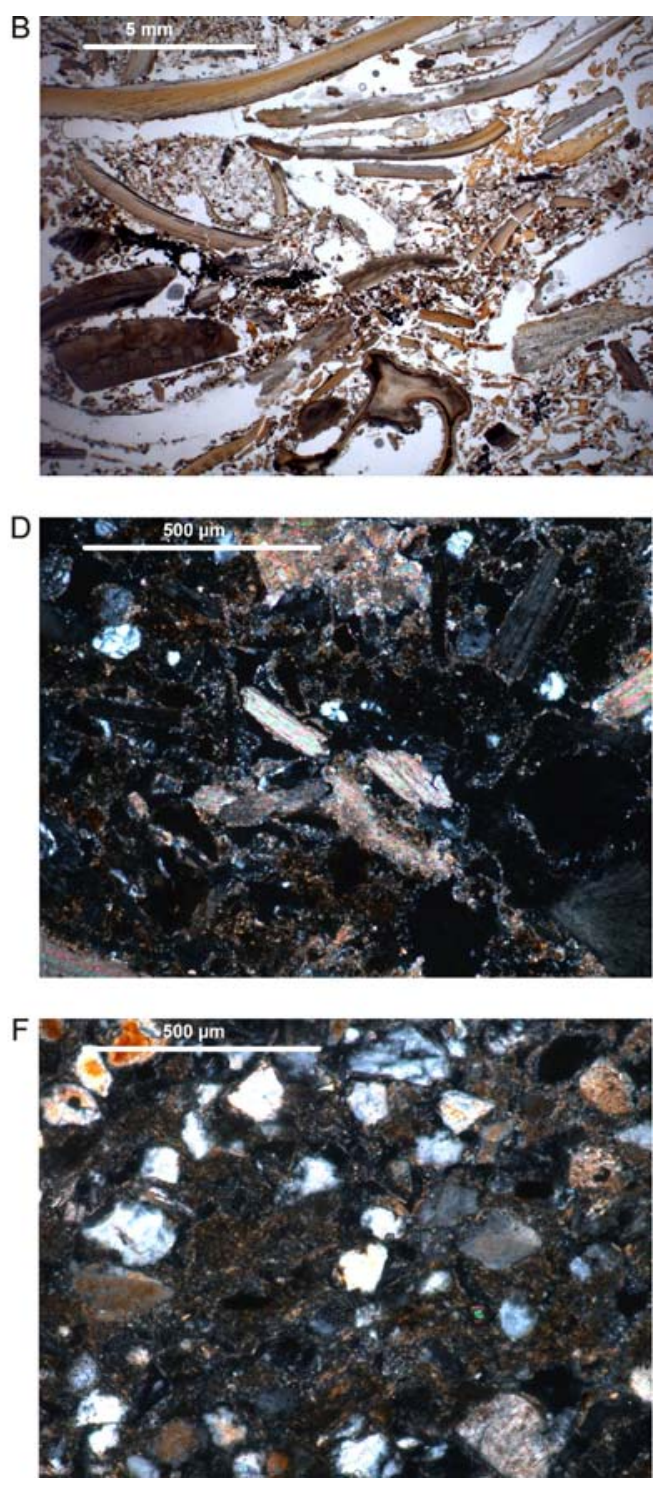

Figura 5.39. Fotomicrografias da $\mathrm{mF} 3$, amostra 3a, do sítio Morrinhos: A) seção vertical esquemática

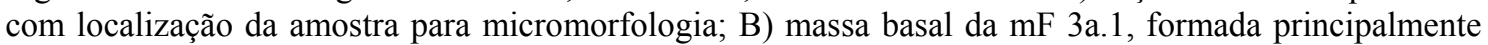
por conchas de distribuição sub-horizontal e fragmentos de osso, PPL; C, D) detalhe da massa basal da $\mathrm{mF}$ 3a.1, com fragmentos de concha e osso em meio a micromassa fosfática com áreas de concentração de micrita associada à dissolução das conchas, PPL e XPL; E, F) massa basal da mf 3a.2, com grãos de quartzo e feldspato em micromassa de argilominerais, com diatomáceas, PPL e XPL. 

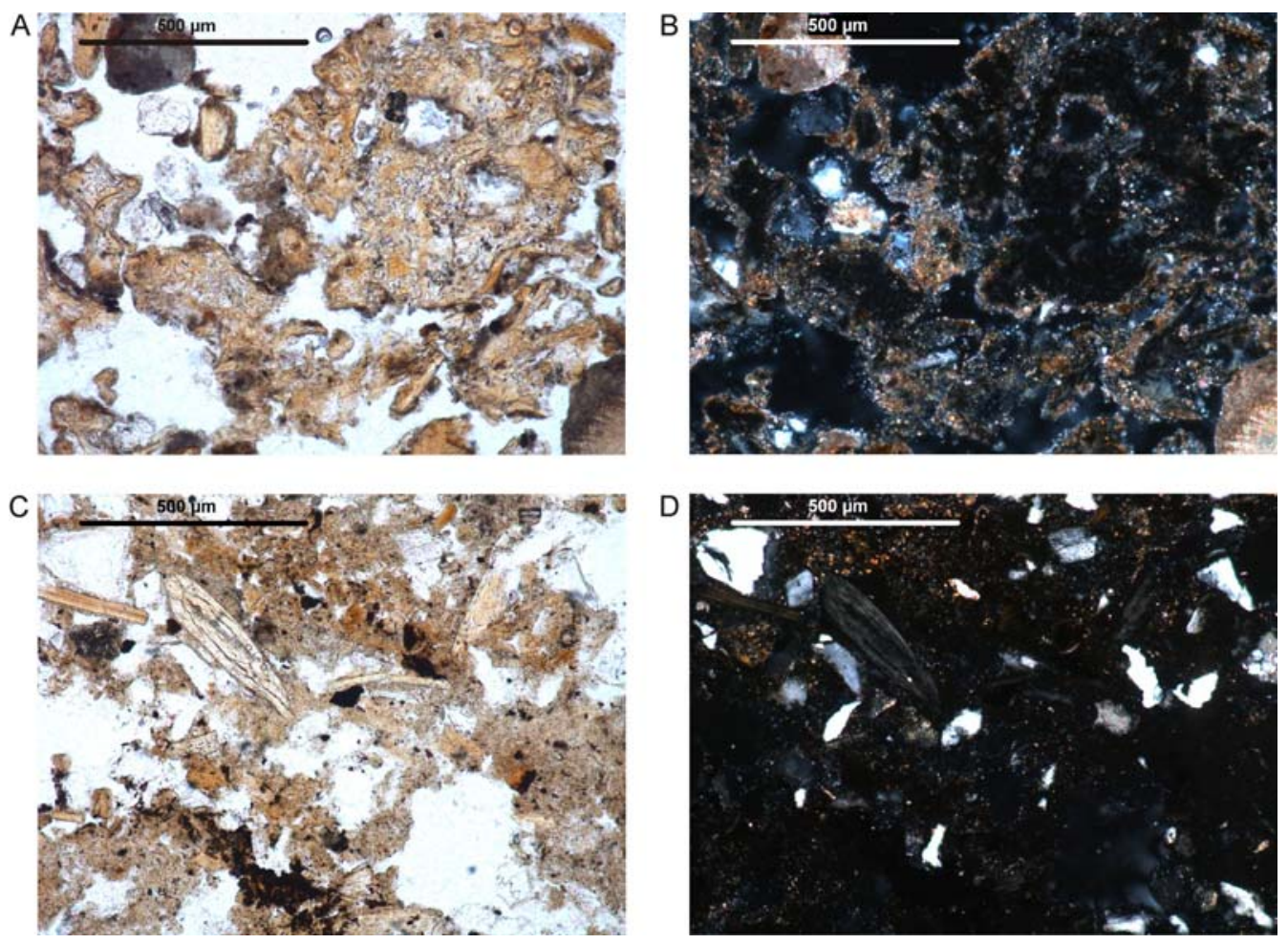

Figura 5.40. Fotomicrografias da micromassa da $\mathrm{mF}$ 3a.1: A, B) fragmento de osso com sinais de dissolução e revestimento de micrita, PPL e XPL. C, D) fragmentos de osso, em micromassa fosfática de baixa birrefringência, PPL e XPL. 
A

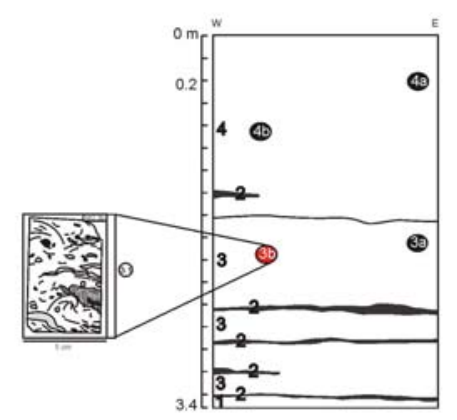

C
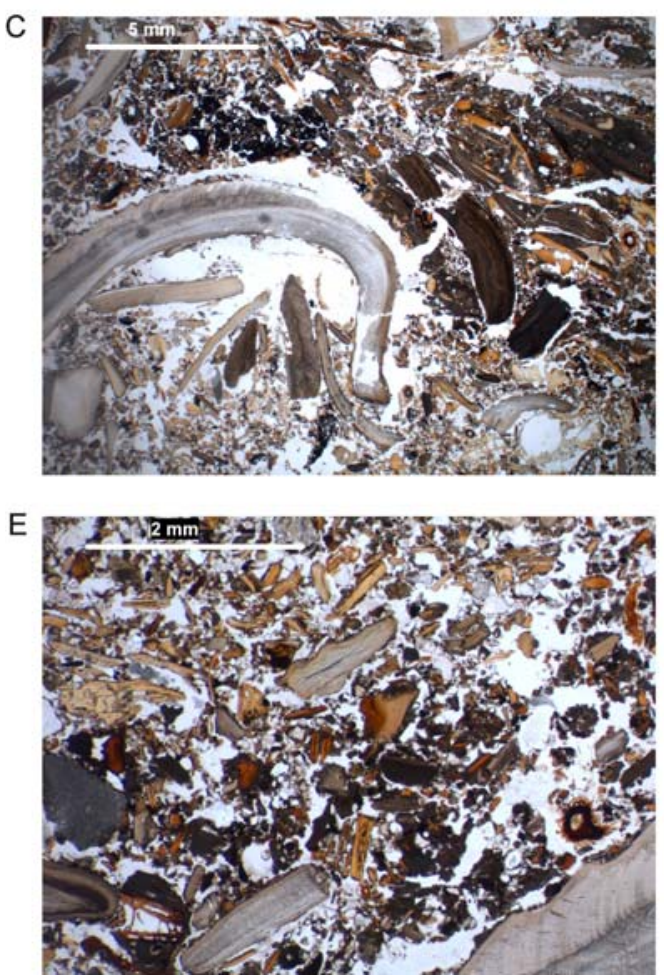

B
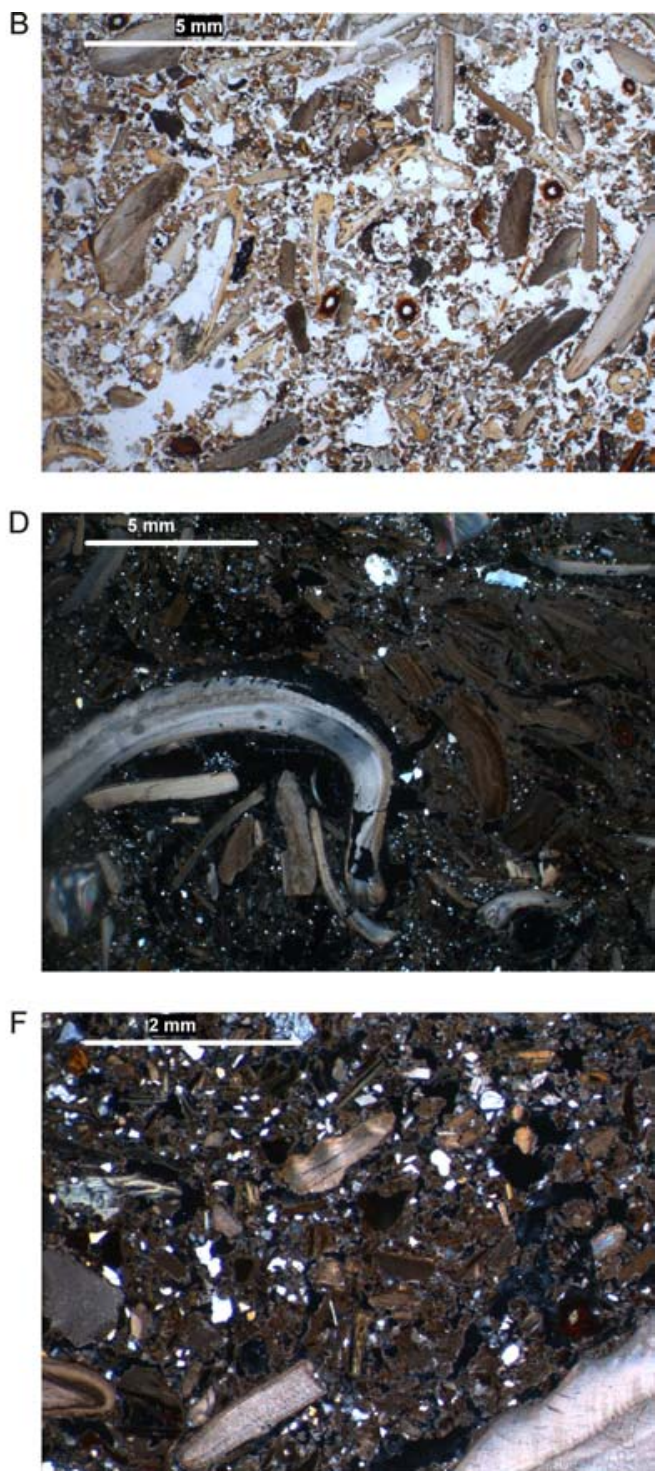

Figura 5.41. Fotomicrografias da $\mathrm{mF}$ 3, amostra 3b, do sítio Morrinhos: A) seção vertical esquemática com localização da amostra para micromorfologia; B) massa basal composta por fragmentos de concha e ossos, com alguns indivíduos queimados, com microestrutura de microagregados intergranulares e presença de raízes frescas, PPL; C, D) área de concentração de conchas e ossos queimados, carvão e cinzas sobre concha de molusco sem evidências de queima, PPL, XPL; E, F) micromassa composta por micrita com argilominerais, fosfatos e microcarvões entre finos fragmentos de osso queimado, PPL e XPL. 

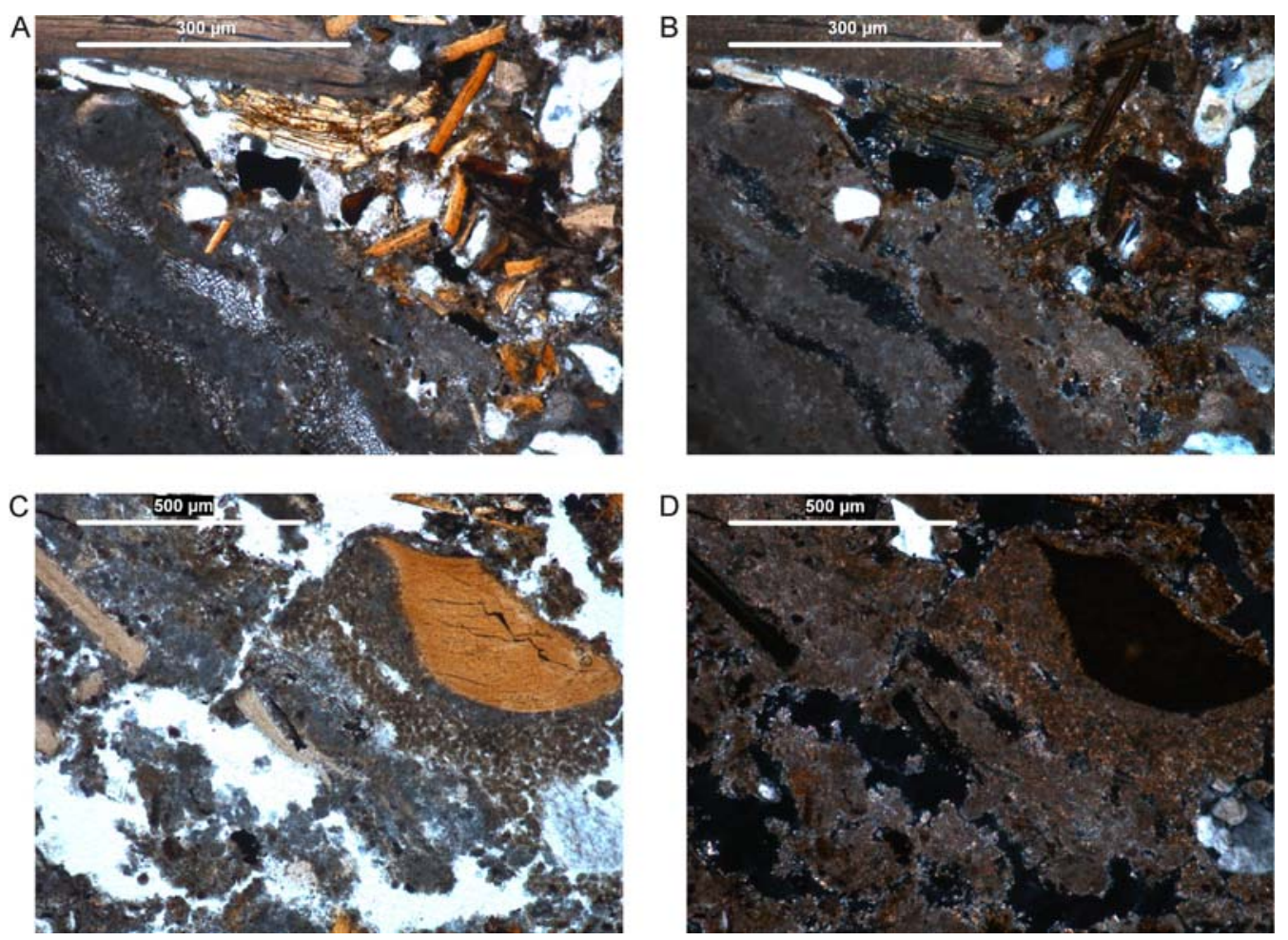

Figura 5.42. Fotomicrografias de cinzas de madeira identificadas na seção delgada 3a do sítio Morrinhos: A, B) área de concentração de cinzas entre restos de tecido silicificado, com concentração de fragmentos de osso queimados na porção superior em meio a micromassa de argila rubefacta, PPL e XPL; C, D) concentração de cinzas rubefactas, PPL e XPL. 
A
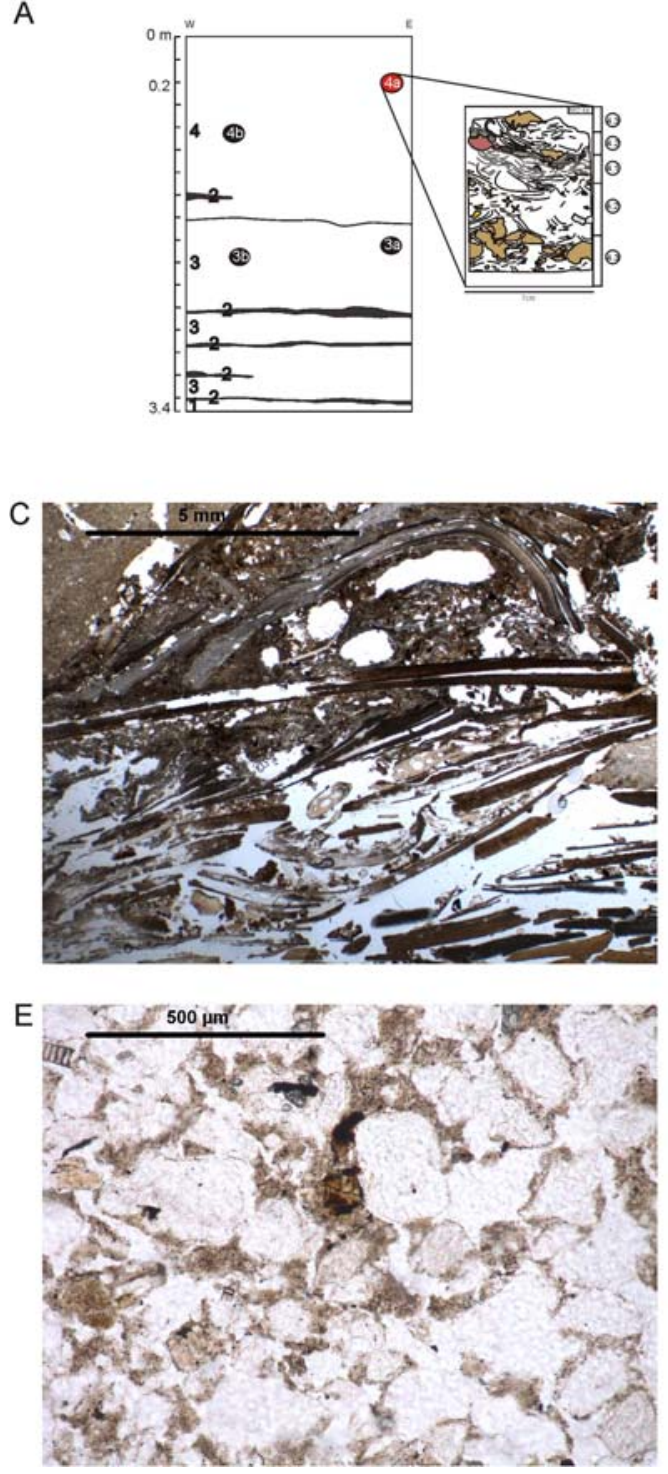
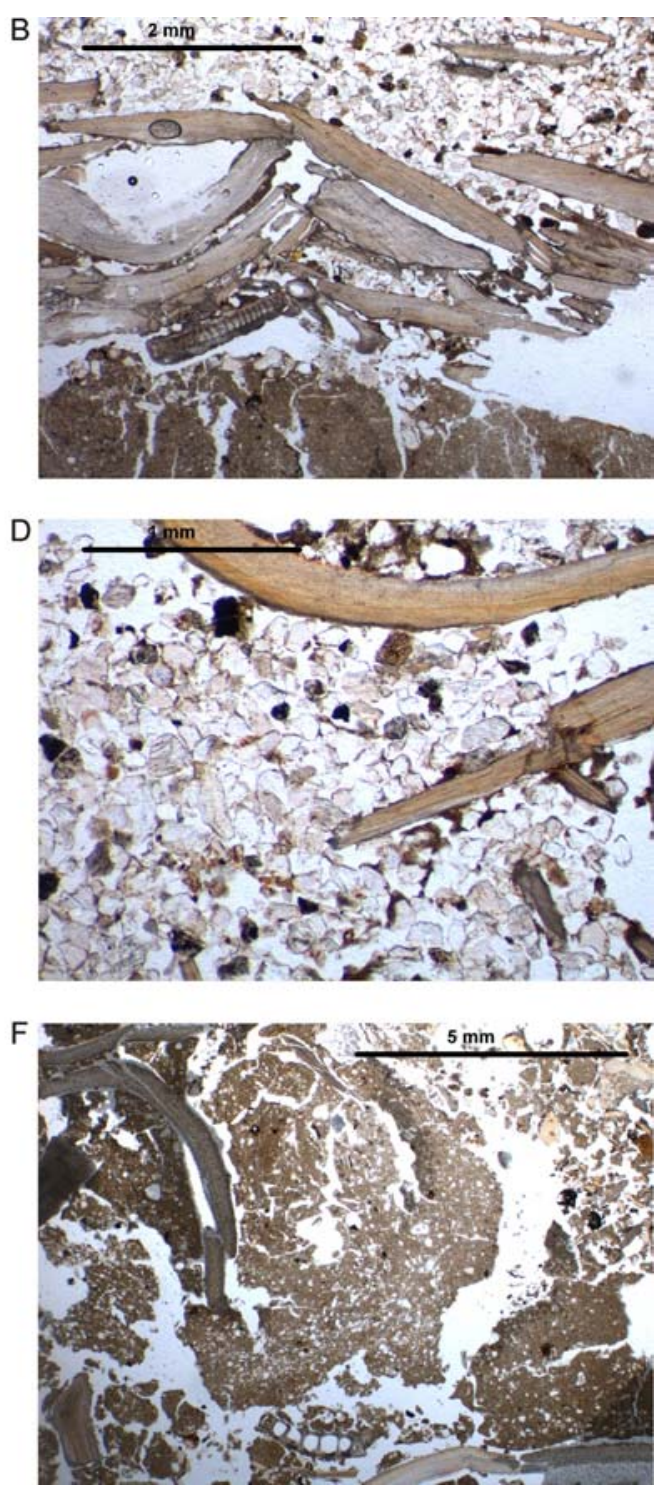

Figura 5.43. Fotomicrografias da $\mathrm{mF} 4$, amostra 4a, do sítio Morrinhos; A) seção vertical esquemática, com localização da amostra para micromorfologia; B) porção da seção delgada com as três microfácies identificadas, PPL; C) concentração de conchas queimadas a temperatura superior a $600^{\circ} \mathrm{C}$ na $\mathrm{mF} 4 \mathrm{a} .1$, PPL; D) massa basal da $\mathrm{mF}$ 4a.2 com microestrutura de grãos de quartzo e feldspato revestidos interligados, com alguns fragmentos de concha, PPL; E) detalhe da $\mathrm{mF} 4 \mathrm{a} .2$ com micromassa composta por argilominerais, PPL; F) agregado milimétrico de lama que caracteriza à mF 4a.3, PPL. 

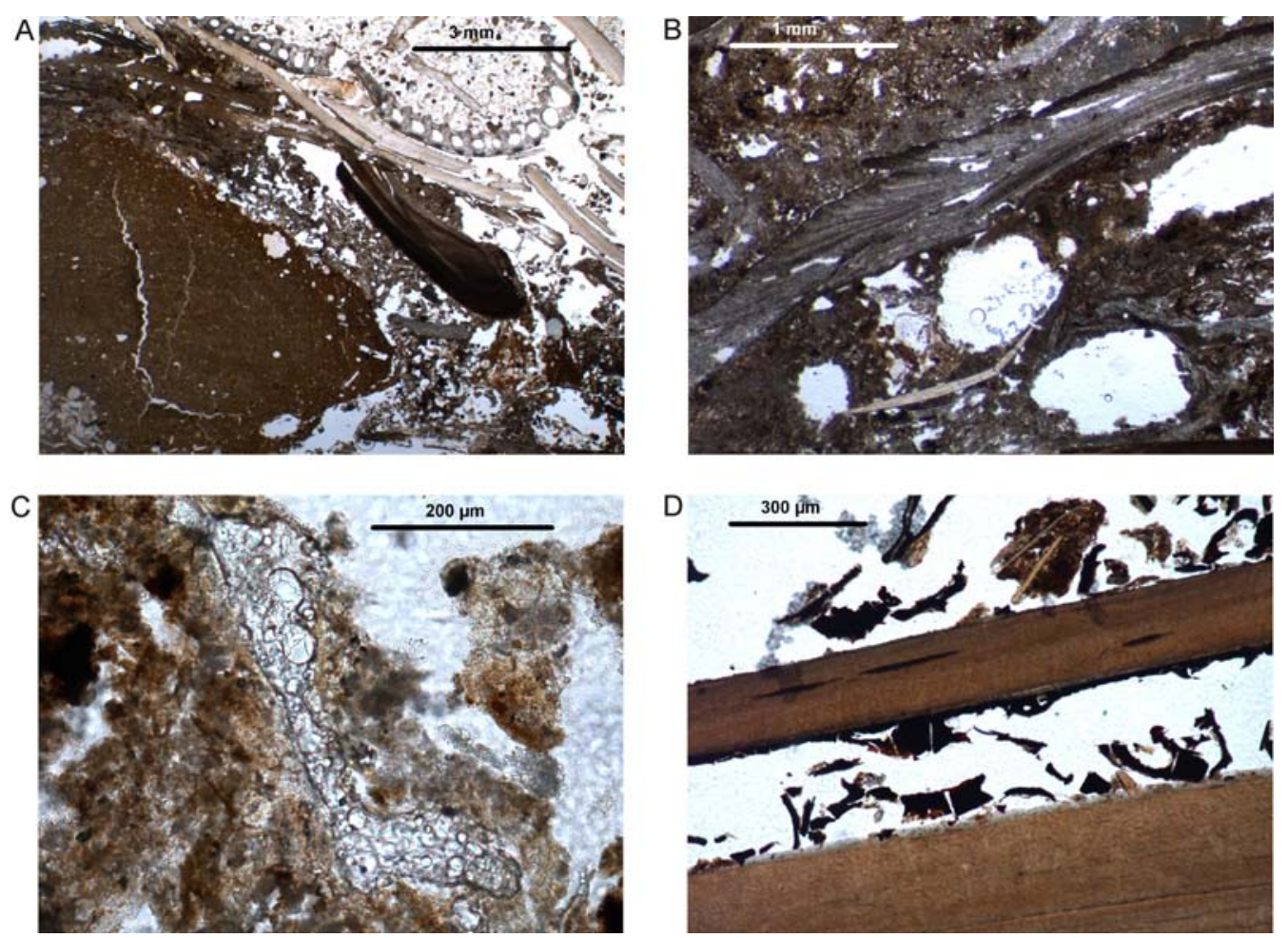

Figura 5.44. Fotomicrografias de elementos de destaque na $\mathrm{mF}$ 4a.1: A) agregado de argila rubefacta associado a conchas queimadas a diferentes temperaturas de, pelo menos, duas espécies de moluscos, PPL; B) concha queimada a $800^{\circ} \mathrm{C}$ em micromassa composta por cinzas e argila rubefacta, PPL; C) escória vítrea, PPL; D) concha com fragmentos de perióstraco carbonizado, alguns já separados da valva e outros ainda aderidos, PPL.
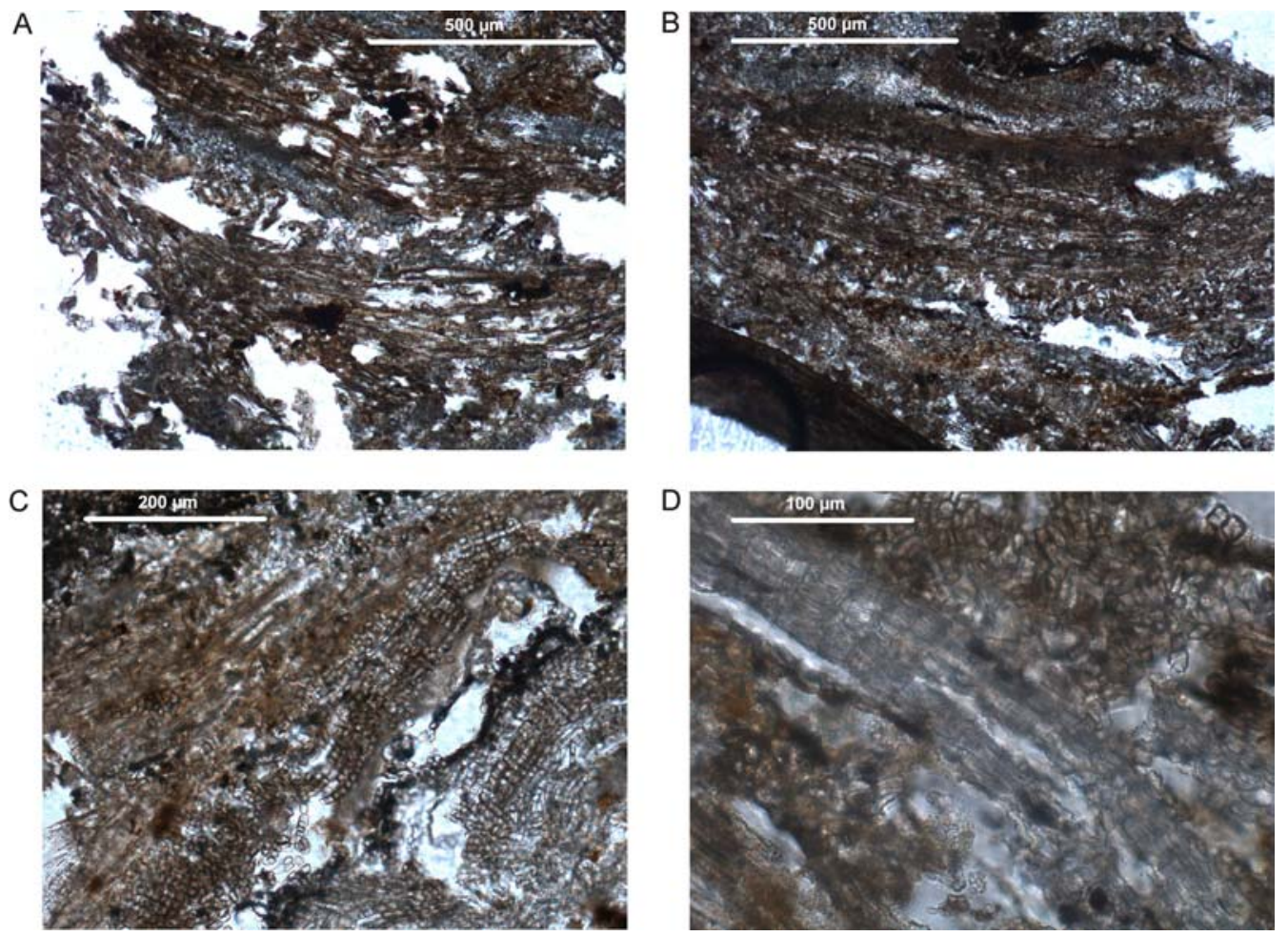

Figura 5.45. Restos de tecidos silicificados na $\mathrm{mF}$ 4a.1: A-C) intercalação entre células alongadas e arredondadas, PPL; D) detalhe dos tecidos vegetais observados, PPL. 

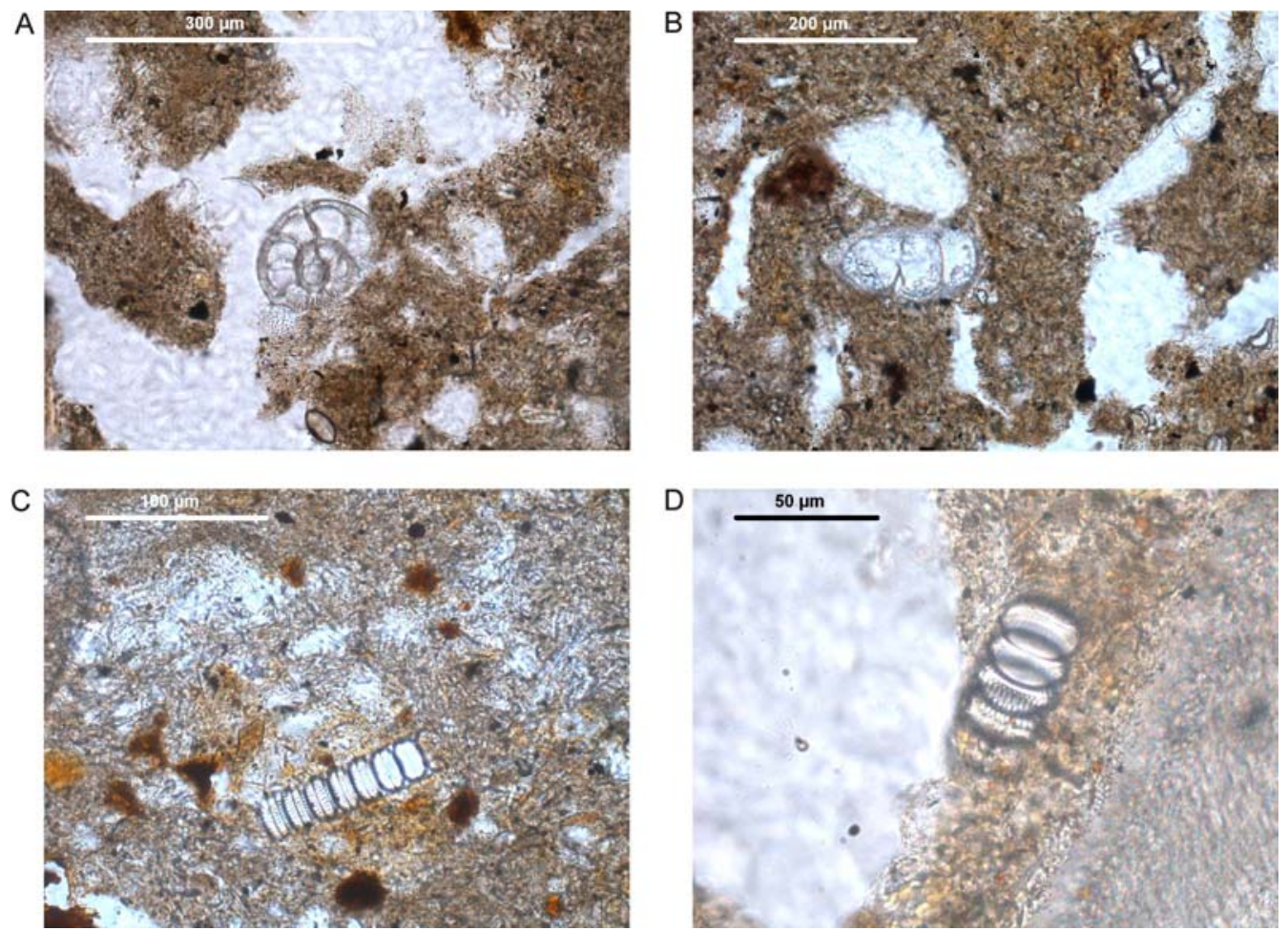

Figura 5.46. Componentes inorgânicos de origem biológica dentro dos agregados de lama da $\mathrm{mF}$ 4a.3: A, B) gastrópode, PPL; C, D) espécie de diatomácea encontrada com maior freqüência nos agregados de lama (Paralia sulcata), PPL. 
A

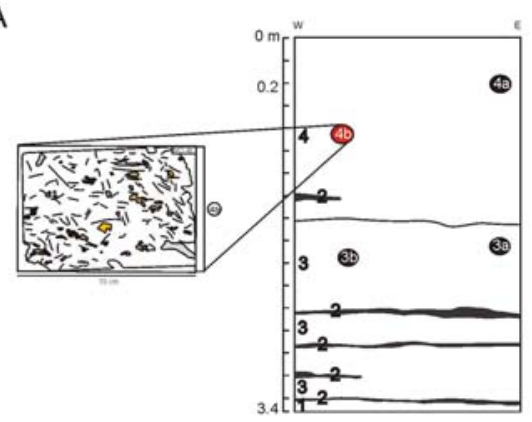

C

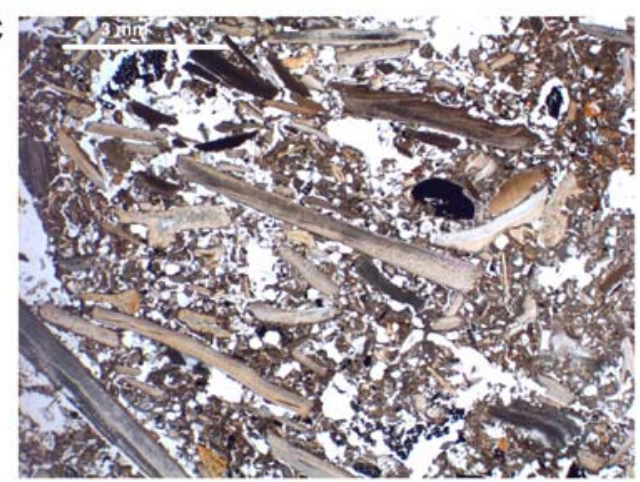

E

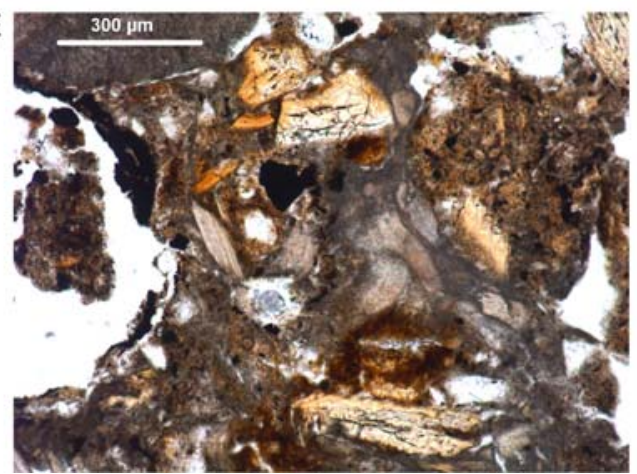

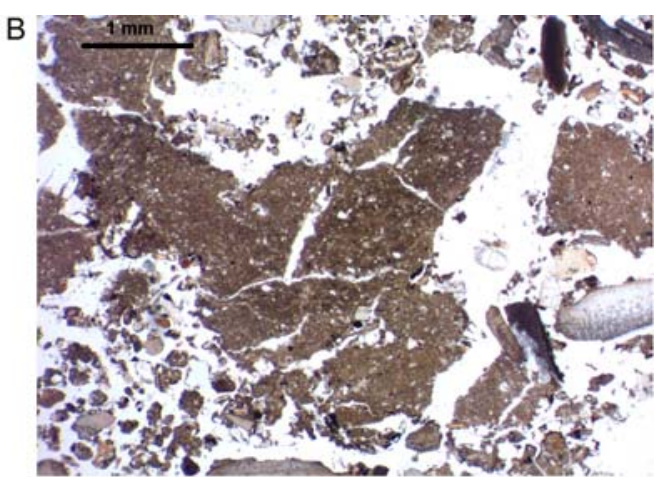
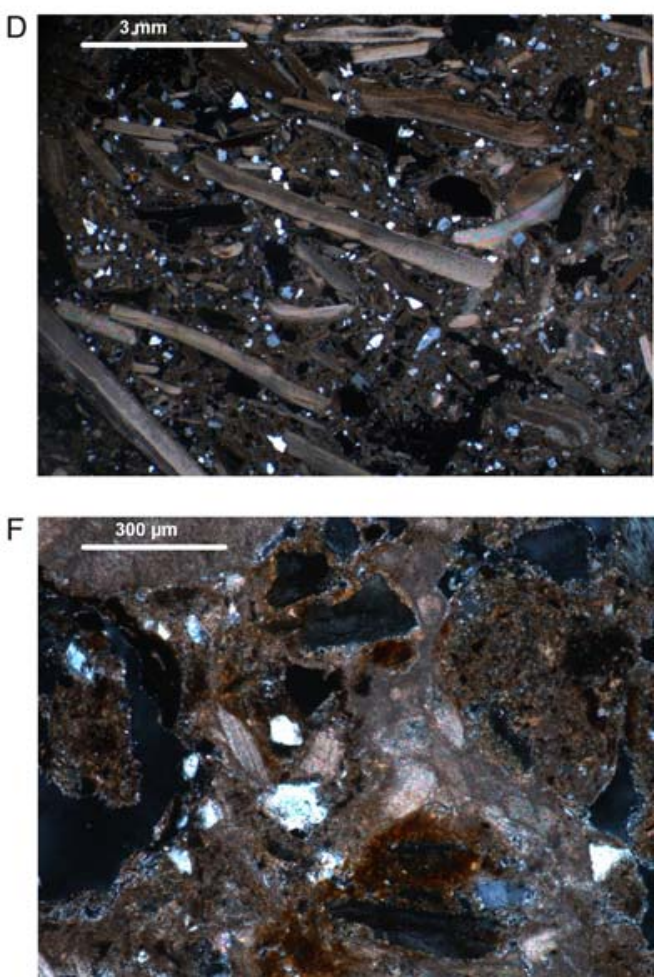

Figura 5.47. Fotomicrografias da $\mathrm{mF} 4$, amostra 4b, do sítio Morrinhos: A) seção vertical esquemática com localização da amostra para micromorfologia; B) agregado de lama, PPL; C, D) massa basal com fragmentos de concha e ossos com sinais de queima, em microestrutura esponjosa com microagregados intergranulares interligados, PPL e XPL; E, F) detalhe da micromassa formada por micrita com argilominerais, nódulos órticos de óxi-hidróxido de ferro e enchimentos de micrita, PPL e XPL. 

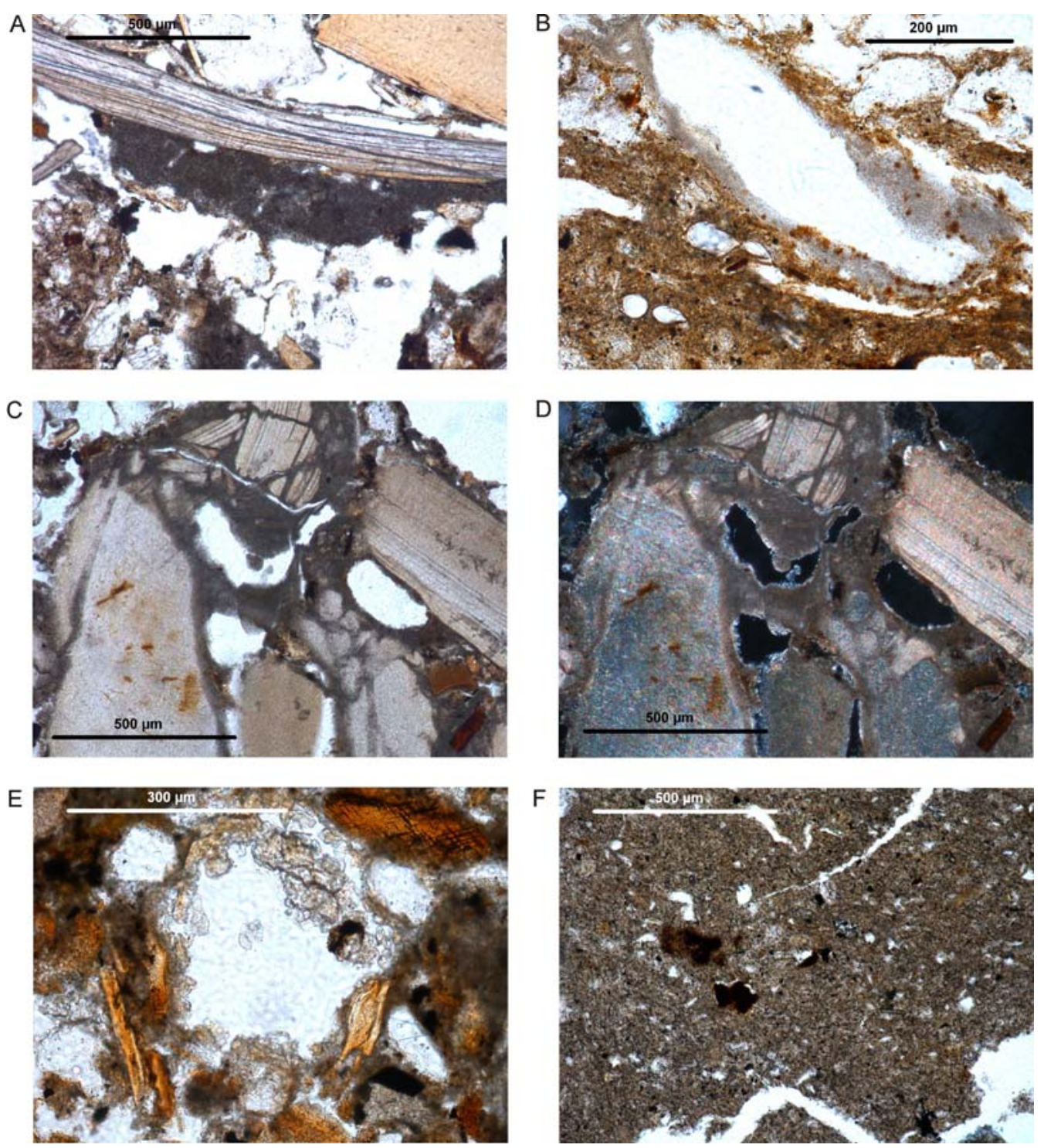

Figura 5.48. Feições pedológicas do sítio Morrinhos: A) revestimento pendular de micrita, PPL; B) Revestimento contínuo, não laminado de microespato redor de um vazio, PPL; C, D) enchimento denso incompleto de micrita proveniente da dissolução e precipitação do carbonato de cálcio das conchas, PPL e XPL; E) revestimento de espato, PPL; F) nódulo órtico de óxi-hidróxido de ferro em agregado de lama, PPL.

\subsubsection{Jabuticabeira 1}

Devido à exploração sofrida no século XX, existem atualmente várias seções verticais expostas para observação da constituição interna do sambaqui Jabuticabeira 1. Nas duas seções escolhidas para este estudo, localizadas na porção central, podem-se observar as camadas centimétricas e decimétricas, de morfologia lenticular convexa, que compõem o sambaqui. Esta estratificação permite interpretar a sua formação a partir 
da superposição e do incremento de grandes montículos de conchas, como igualmente observado no sítio Jabuticabeira 2 (Bendazzoli, 2007; Fish et al., 2000; Klokler, 2008) localizado a pouco mais de $2 \mathrm{~km}$ a sudeste ${ }^{76}$.
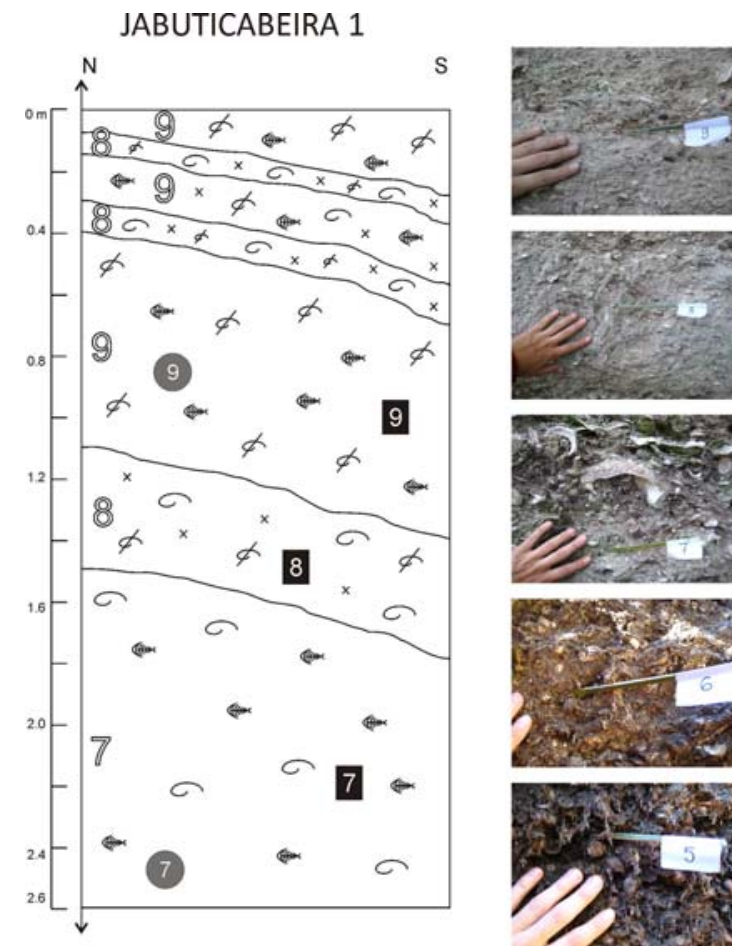

Af 9: cascalho conchifero com lama. Conchas muito fragmentadas de ostra e marisco (70\%), ossos de peixe $(20 \%)$ e alguns carvões. Fração fina composta por farinha de concha. Com bolsöes de ossos de peixe fragmentados. Limite inferior abrupto. Fração grossa sub-horizontal paralela. Sub-tabular.

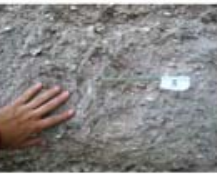

AF 8: cascalho conchifero. Conchas inteiras e fragmentadas $(80 \%)$, ossos de peixe fragmentados (10\%) e alguns carvões. Predomina A. brasiliana. Fração fina composta por farinha de concha. Camada concrecionada. Limite inferior abrupto. Sub-Tabular.

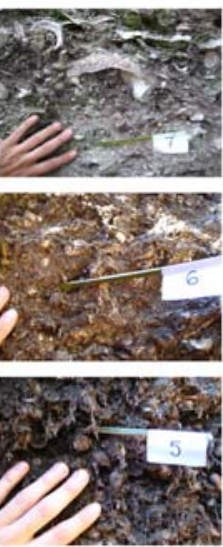

Af 7: cascalho conchifero arenoso com lama, Conchas inteiras $(70 \%$, predomina A.brasiliana e Ostrea $s p$ ). Fração fina composta por farinha de concha. Bolsões de Ostrea sp. Limite inferior abrupto. Sub-tabular.
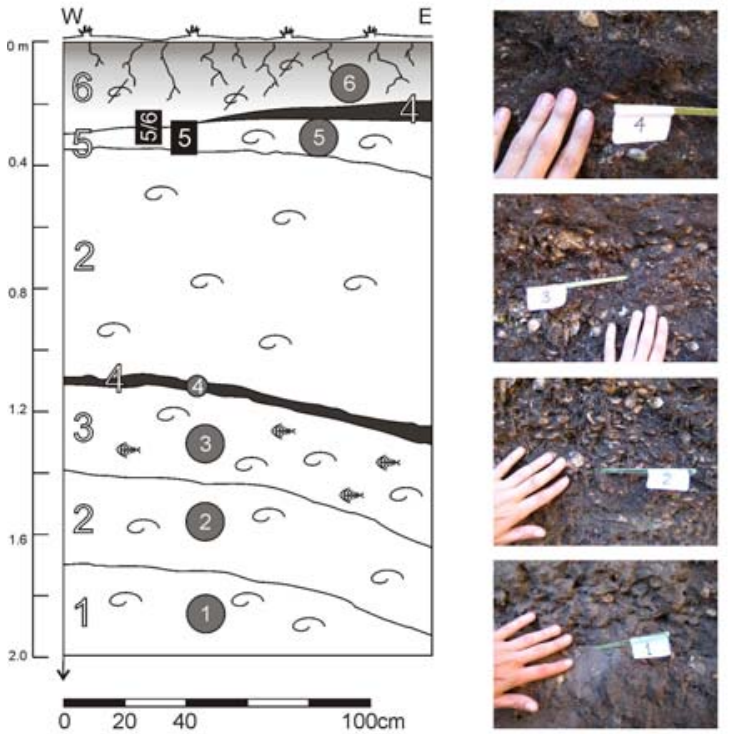

AF 6: cascalho conchifero com lama. Concha fragmentada $(60 \%)$, fragmentos de ossos de peixe (40\%). Muito compacta. Limite inferior abrupto. Sub-tabular.

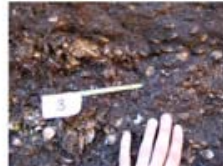

AF 3: cascalho conchifero arenoso com lama carbonosa preta. Conchas inteiras e fragmentadas $(30 \%)$, ossos de peixe fragmentados (50\%). predomina A. brasiliana.

Limite inferior claro. Lenticular.

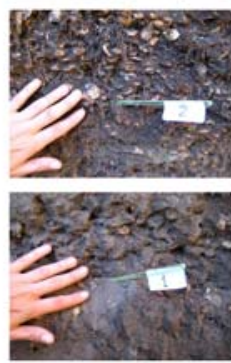

AF 5: cascalho conchifero arenoso com lama. Areia terrígena média e lama carbonosa. Conchas inteiras $(80 \%)$ e ossos de peixe fragmentados (10\%).predomina A.brasiliana. Limite inferior claro. Lenticular.

Af 4: areia lamosa. Lama carbonosa preta com ossos de peixe fragmentados (50\%). Limite abrupto $(<2 \mathrm{~cm})$. Lenticular

AF 2: cascalho conchifero arenoso com lama carbonosa. Conchas inteiras (40\%), predomina A.brasiliana. Limite inferior claro. Lenticular.

AF 1: areia cascalhosa com lama. Areia terrígena fina a média e cascalho conchifero.

Conchas inteiras $(20 \%)$ e ossos de peixe.

Predomina A. brasiliana. Lenticular.

concha inteira $\not \varnothing$ concha fragmentada

peixes 1 arqueofácies

micromorfologia

Figura 5.49. Seções verticais estudadas do sítio Jabuticabeira 1, com localização dos pontos de amostragem e descrição das arqueofácies identificadas.

76 Estas mesmas constatações já tinham sido realizadas na década de 1960 por Bocchi \& Liberatore (1968: 3) ao descrever a estratigrafia dos dois sambaquis de Jabuticabeira: "Ambos os sambaquis não apresentam estratificações paralelas, mas sim uma estratificação descontínua que nos lembra amontoamentos, mostrando uma inclinação de repouso natural.” 
Na seção inferior, de $2 \mathrm{~m}$ de altura, identificaram-se seis arqueofácies (Figura 5.49). Esta seção apresenta sedimentos soltos ou de escassa coesão, diferente da seção superior onde as camadas encontram-se concrecionadas. A AF 1, base da seção, é composta por areia, lama e conchas inteiras, principalmente de A. brasiliana, com alguns indivíduos de Ostrea sp. e frequência subordinada de ossos de peixe. Na AF 2, aumenta a quantidade de conchas, tanto inteiras como fragmentadas. A AF 3 apresenta predomínio de ossos de peixe (50\%), seguido de conchas inteiras e fragmentadas de $A$. brasiliana e Ostrea sp., em matriz composta por areia média e fina em lama carbonosa preta. A AF 4, de morfologia lenticular e espessura centimétrica, composta por areia lamosa e ossos de peixe, apresenta semelhança de forma e composição com as camadas pretas já observadas nos sambaquis Jabuticabeira 2 (Fish et al., 2000; Klokler, 2008; Villagran, 2008), Caipora, Cubículo 1 e Morrinhos.

A AF 5 aparece uma única vez na seção vertical inferior, associada à AF 4. Diferencia-se das AF 4 e 2 pela espessura (maior que AF 4 e menor que AF 2) e por apresentar maior freqüência de conchas inteiras (80\%), principalmente $A$. brasiliana, e de fragmentos de osso de peixe (10\%). O topo da seção inferior, representado pela AF 6, mostra sinais de se tratar de resíduos de moinha, pela alta compactação do sedimento e fragmentação das conchas.

$\mathrm{Na}$ análise zooarqueológica realizada por Ferraz (2010) na mesma seção vertical estudada nesta tese, determinou-se igualmente o predomínio de A. brasiliana. Nas camadas identificadas por Ferraz (2010) que puderam ser correlacionadas com as arqueofácies deste estudo, observaram-se as seguintes frequências por espécie: AF $1^{77}$ contém cerca de $95 \%$ de $A$. brasiliana; AF $2^{78}$, nas suas três ocorrências, apresenta freqüência entre 90 e $95 \%$ de A. brasiliana, com 5 a $10 \%$ de Ostrea sp.; AF $3^{79}$ apresenta cerca de $70 \%$ de $A$. brasiliana, menos de $5 \%$ de gastrópodes e ossos de peixe, e $20 \%$ de Ostrea sp.; AF $5^{80}$ apresenta cerca de $75 \%$ de A. brasiliana e $20 \%$ de Ostrea sp.

\footnotetext{
77 A arqueofácies 1, identificada neste trabalho, corresponde à camada 1 da descrição estratigráfica realizada por Ferraz (2010).

78 A arqueofácies 2, identificada neste trabalho, corresponde às camadas 2,5 e 6 da descrição estratigráfica realizada por Ferraz (2010).

${ }^{79}$ A arqueofácies 3 , identificada neste trabalho, corresponde à camada 4 da descrição estratigráfica realizada por Ferraz (2010).

${ }^{80}$ A arqueofácies 5, identificada neste trabalho, corresponde à camada 7 da descrição estratigráfica realizada por Ferraz (2010).
} 
Na seção superior foram identificadas unicamente três arqueofácies (Figura 5.49). $\mathrm{Na}$ base desta seção, aparece uma única vez a AF 7, composta por conchas inteiras, principalmente de Ostrea sp. e A. brasiliana, em matriz formada por farinha carbonática, interpretada como produto da alteração pós-deposicional das conchas. Apresenta bolsões dispersos de Ostrea sp. e lentes centimétricas de carvão. A AF 8 é essencialmente concrecionada e formada por conchas inteiras e fragmentadas $(80 \%)$, ossos de peixe fragmentados (10\%) e carvão. Assim como na AF 7, a fração fina compõe-se principalmente por uma farinha carbonática. A AF 9 diferencia-se da AF 8 por três motivos: é mais friável e, portanto, menos concrecionada; sua fração grossa (conchas de Ostrea sp. e marisco) apresenta orientação sub-horizontal; e contém lentes centimétricas de fragmentos de osso de peixe. Na porção superior desta seção, observase uma intercalação entre as AF 8 e 9 que se repete até o topo do corte vertical.

Análises zooarqueológicas realizadas por Ferraz (2010) igualmente mostram o aumento na proporção de Ostrea $\mathrm{sp}$. em relação A. brasiliana na seção superior. A AF $7^{81}$ é composta por cerca de $30 \%$ de Ostrea sp. e pouco mais de 50\% de A. brasiliana. $\mathrm{Na}$ AF $8^{82}$, há cerca de $80 \%$ de $A$. brasiliana, $10 \%$ de Ostrea sp. e menos de $5 \%$ de gastrópodes, marisco e ossos de peixe. Na AF $9^{83}$, Ostrea sp. alcança aproximadamente $55 \%$ da concentração total de conchas, com $20 \%$ de $A$. brasiliana, quase $25 \%$ de gastrópodes e mais de $10 \%$ de mariscos.

\section{Granulometria}

Análises granulométricas da fração terrígena foram realizadas nas amostras provenientes das AF 1, 2, 3, 4, 5, 6, 7 e 9. Na Figura 5.50, apresentam-se os histogramas da distribuição granulométrica das oito arqueofácies analisadas. Como observado no sítio Morrinhos, este sambaqui apresenta distribuições unimodais em cinco das seis arqueofácies analisadas na seção inferior (AF 1 a AF 5). No topo da seção inferior, representado pela AF 6, a porcentagem de areia fina iguala-se à de areia média e nas duas arqueofácies analisadas na seção superior (AF 7 e AF 9), a porcentagem de areia

\footnotetext{
${ }^{81}$ A arqueofácies 7, identificada neste trabalho, corresponde às camadas 17 e 18 da descrição estratigráfica realizada por Ferraz (2010).

${ }^{82} \mathrm{~A}$ arqueofácies 8 , identificada neste trabalho, corresponde à camada 19 da descrição estratigráfica realizada por Ferraz (2010).

${ }^{83}$ A arqueofácies 9 , identificada neste trabalho, corresponde à camada 20 da descrição estratigráfica realizada por Ferraz (2010).
} 
fina ultrapassa a de areia média. Esta variação na moda da fração terrígena, ao longo da seção vertical do sambaqui, pode indicar uma mudança na fonte de sedimentos terrígenos, ou uma mudança de processo deposicional no local onde os sedimentos e moluscos eram coletados.

A
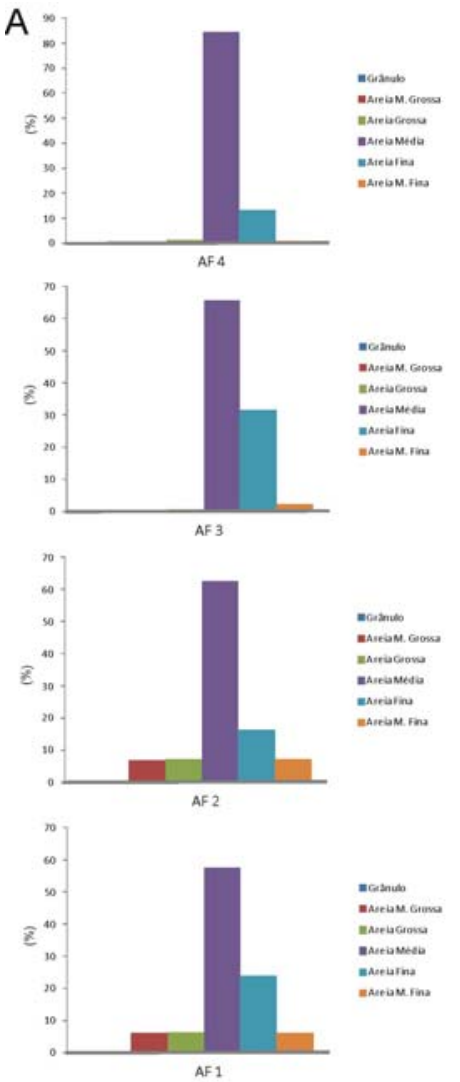
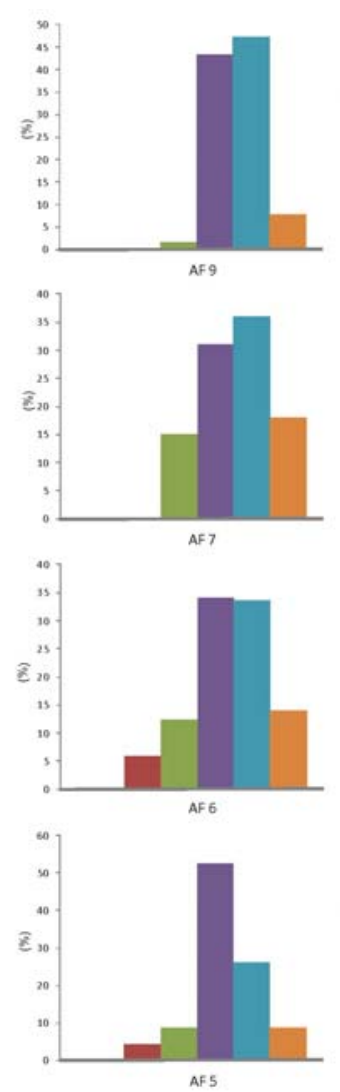

B
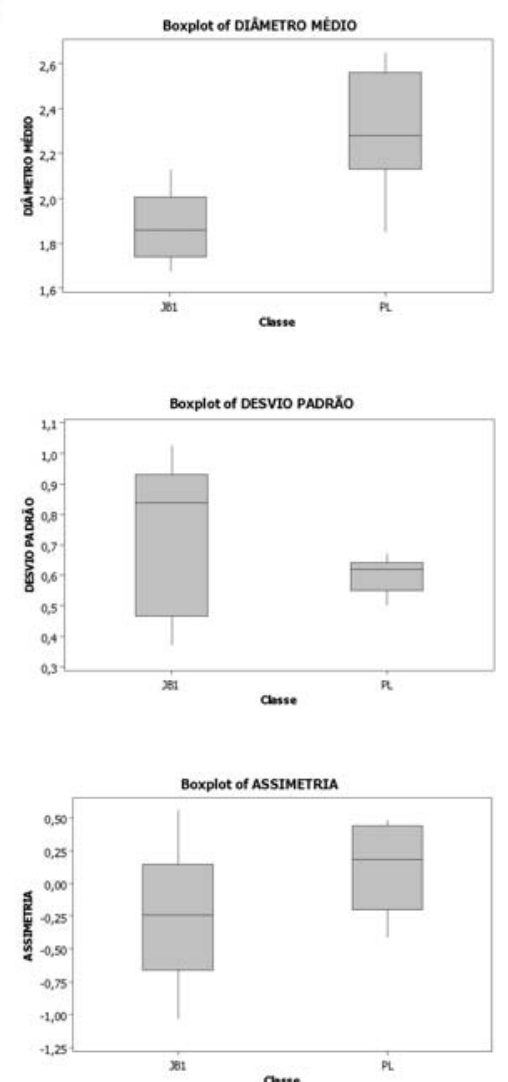

Figura 5.50. Gráficos das distribuições granulométricas e parâmetros estatísticos para o sítio Jabuticabeira $1 \mathrm{e}$ amostragem em sedimentos naturais das proximidades: A) histogramas da distribuição granulométrica para as $\mathrm{AF} 1,2,3,4,5,6,7$ e 9 do sambaqui Jabuticabeira 1. Note-se o domínio da fração areia média para as arqueofácies analisadas na seção inferior (AF 1 a AF 5) e aumento progressivo da fração areia fina no topo da seção inferior (AF 6) e na seção superior (AF 7 e AF 9); B) diagramas em caixa (boxplot) das estatísticas diâmetro médio, desvio padrão e assimetria para o conjunto de amostras do sítio Jabuticabeira 1 e amostras paleolagunares (PL) das sondagens realizadas nas proximidades do sambaqui Jabuticabeira 2 (Villagran, 2010) localizado a pouco mais de $2 \mathrm{~km}$ de Jabuticabeira 1. 


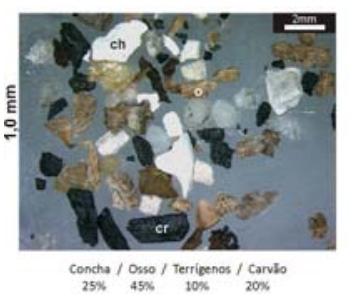

JABUTICABEIRA 1 - AF 3

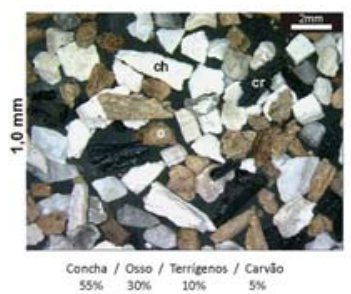

JABUTICABEIRA 1 - AF 5

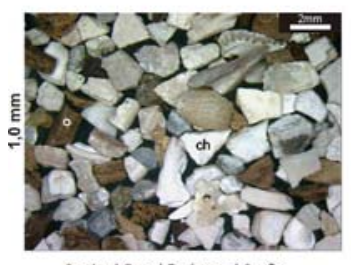

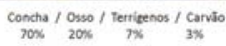

JABUTICABEIRA 1 - AF 7

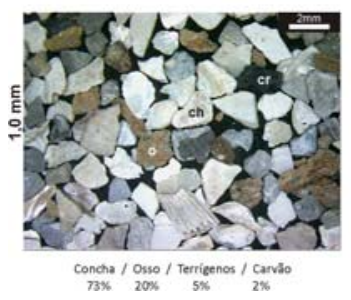

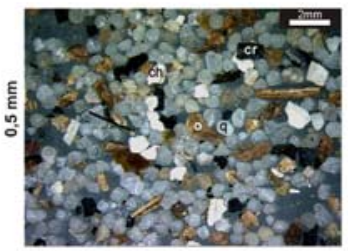

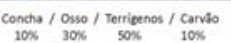

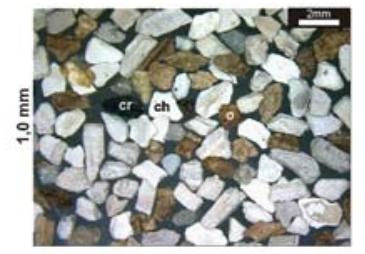

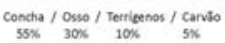

JABUTICABEIRA 1 - AF 4

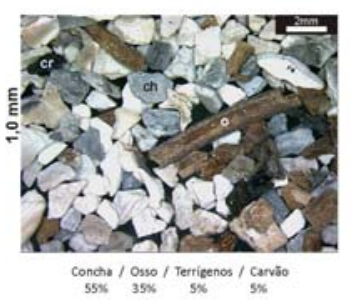

JABUTICABEIRA 1 - AF 6

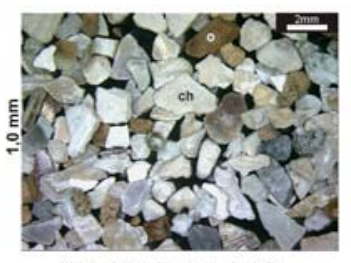

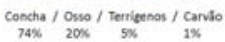

JABUTICABEIRA 1 - AF 9

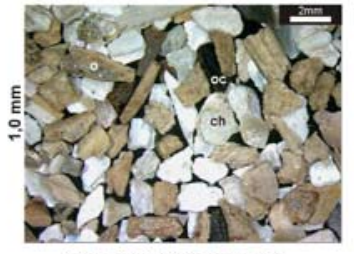

Concha / Osso / Teriegenos / Canaso
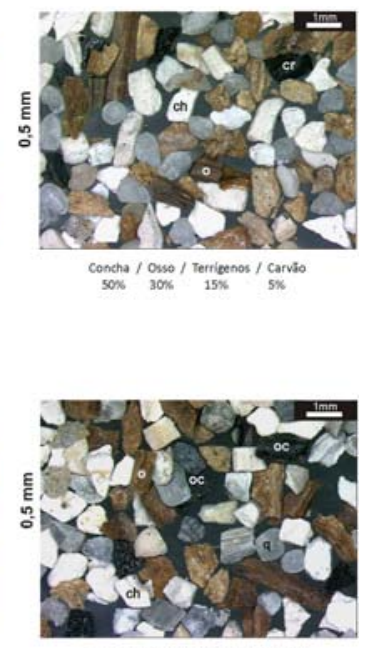

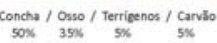

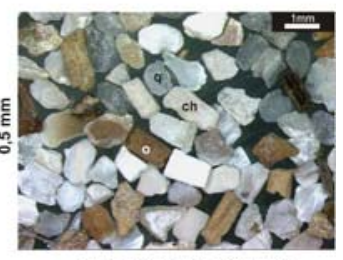

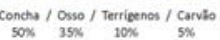

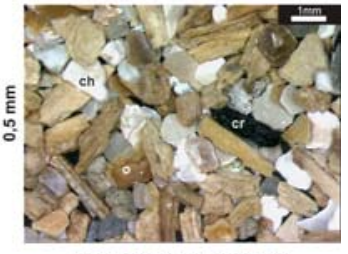

concha / Osso / Tererienos / Canso

Figura 5.51. Fotomicrografias à lupa estereoscópica dos grãos retidos nas malhas de $1,0 \mathrm{~mm}$ e $0,5 \mathrm{~mm}$ das arqueofacies 1, 2, 3, 4, 5, 6, 7 e 9 do sítio Jabuticabeira 1. Note-se a presença de ossos (o), conchas (ch), carvão (cr), grãos de quartzo (q) e fragmentos de osso carbonizado (oc). 
A comparação da fração terrígena de Jabuticabeira 1 com sedimentos naturais foi realizada com os dados obtidos para trincheiras superficiais abertas nas proximidades do sambaqui Jabuticabeira 2, localizado a pouco mais de $2 \mathrm{~km}$ de Jabuticabeira 1. Os depósitos das proximidades de Jabuticabeira 2 foram caracterizados como paleolagunares (Villagran, 2008), e sua idade é contemporânea com a formação de Jabuticabeira $1^{84}$ (Menezes, 2009). Os diagramas da Figura 5.50 B mostram que a variabilidade do diâmetro médio, representada pelo intervalo interquartis, é menor no sambaqui que nos depósitos paleolagunares, com clara tendência para sedimentos mais grossos no sambaqui. A maior frequência de grossos no sambaqui, em relação aos sedimentos paleolagunares, pode-se dever a dois fatores: a presença de restos de conchas mal digeridos no tratamento prévio das amostras para remosão de bioclastos, que aparecem como fragmentos grossos na análise granulométrica; ou sedimentos coluvionares no sítio, provenientes do morro granítico das proximidades de Jabuticabeira 1. Já a variabilidade para desvio padrão e assimetria é maior no sambaqui que nos depósitos paleolagunares, com leve tendência para menor grau de seleção granulométrica e assimetria mais negativa no sambaqui.

Das $\mathrm{AF} 1,2,3,4,5,6,7$ e 9, foi realizada a observação no microscópio estereoscópico da fração retida nas malhas de $1,0 \mathrm{~mm}$ (areia grossa) e 0,5 mm (areia média). Na Figura 5.51, podem-se observar as diferenças na composição da fração grossa das arqueofácies que compõem o sambaqui Jabuticabeira 1, com variações que envolvem principalmente as frequências de fragmentos de concha e osso de peixe. A AF 1 destaca-se pela alta porcentagem de fragmentos de carvão na classe areia grossa $(20 \%)$ e de terrígenos na classe areia média (50\%). As AF 2 e 3 diferenciam-se principalmente pela proporção de ossos de peixe na fração areia média, maior em AF 3 $(60 \%)$ que em AF $2(30 \%)$.

$\mathrm{Na} \mathrm{AF} 4$, a frequência de ossos na fração areia média diminui até a metade (35\%), enquanto a freqüência de fragmentos de conchas se mantém estável em comparação com AF 2 e AF 3 ( $50 \%)$. Poucas mudanças se observam entre as AF 5, 6 e 7, que registram incremento na porcentagem de fragmentos de concha na classe areia grossa $(\sim 70 \%)$ e na frequência de fragmentos de osso (entre 30 e $40 \%)$ na classe areia média. Por último, AF 9 destaca-se pelo domínio de fragmentos de osso de peixe nas

\footnotetext{
${ }^{84}$ Uma camada de conchas de Anomalocardia brasiliana, localizada a $60 \mathrm{~cm}$ de profundidade em uma
} trincheira aberta nas proximidades de Jabuticabeira 2, foi datada em 3698-4104 anos cal (Menezes 2009). 
classes areia grossa e média (70\% e 60\%, respectivamente). A freqüência de conchas em AF 9 é de $25 \%$ em ambas as classes granulométricas, semelhante ao observado na AF 1.

\section{Isótopos de Ce N $\left(\delta^{13} C\right.$ e $\left.\delta^{53} N\right)$}

Amostras de sedimento total para análise de isótopos de $\mathrm{C}$ e $\mathrm{N}\left(\delta^{13} \mathrm{C}\right.$ e $\left.\delta^{15} \mathrm{~N}\right)$ foram coletadas em todas as arqueofácies identificadas na seção vertical inferior (AF 1 a 6) e unicamente na AF 7 da seção superior. Isto se deve à maior friabilidade dos sedimentos da seção inferior em contraste ao concrecionamento das arqueofácies identificadas na seção superior, o qual dificultou a coleta de amostras. Na Figura 5.52 A, pode-se observar o agrupamento de todas as arqueofácies no campo definido para plantas de ciclo fotossintético $\mathrm{C}_{3}$. Somente AF 1 mostra proximidade ao campo corresponde a algas (razão C/N entre 4 e 10 segundo Lamb et al., 2006 e Meyers, 1997). No entanto, no gráfico da Figura 5.52 B fica claro como nenhuma das amostras do sítio apresenta valores de $\delta^{15} \mathrm{~N}$ e $\delta^{13} \mathrm{C}$ correspondente a plantas aquáticas $\left(\delta^{15} \mathrm{~N}\right.$ entre $+5 \mathrm{e}+9$ $\%$ ). Portanto, parece mais provável que AF 1 apresente a mesma tendência do resto de arqueofácies analisadas e possua $\mathrm{MO}$ de plantas terrestres $\mathrm{C}_{3}$.

Como se discutiu para os outros sambaquis de padrão estratigráfico conchífero analisados (Caipora, Cubículo 1 e Morrinhos), a assinatura isotópica de todas as arqueofácies do sítio Jabuticabeira 1 indica mistura de restos de origem vegetal (plantas $\mathrm{C}_{3}$ ) e resíduos vinculados à decomposição de tecidos de animais marinhos (possivelmente peixes e moluscos). Apenas AF 4 desloca-se claramente do conjunto arqueofácies no gráfico da Figura $5.52 \mathrm{~A}$, onde se combinam os valores de $\delta^{13} \mathrm{C}$ e razão $\mathrm{C} / \mathrm{N}$. Já no gráfico da Figura $5.52 \mathrm{~B}$, onde se relacionam os valores $\delta^{13} \mathrm{C}$ e $\delta^{15} \mathrm{~N}$, AF 4 agrupa-se com o restante de amostras. Isto pode indicar o predomínio de plantas $\mathrm{C}_{3}$ na MO de AF 4, com leve influência de $\mathrm{N}$ de origem aquática.

A AF 4 tem a particularidade de pertencer ao conjunto de camadas pretas, lenticulares e centimétricas, que se observam intercaladamente nas seções verticais dos sambaquis de padrão estratigráfico conchífero (AF 5 do sítio Cubículo 1 e AF 2 do sítio Morrinhos). Isto determina um padrão composicional intra e inter-sítio nas arqueofácies lenticulares e pretas, compostas por carvões e ossos queimados, cujo teor de $\mathrm{MO}$ se diferencia das arqueofácies decimétricas conchíferas que representam grande parte do volume dos grandes sambaquis. 

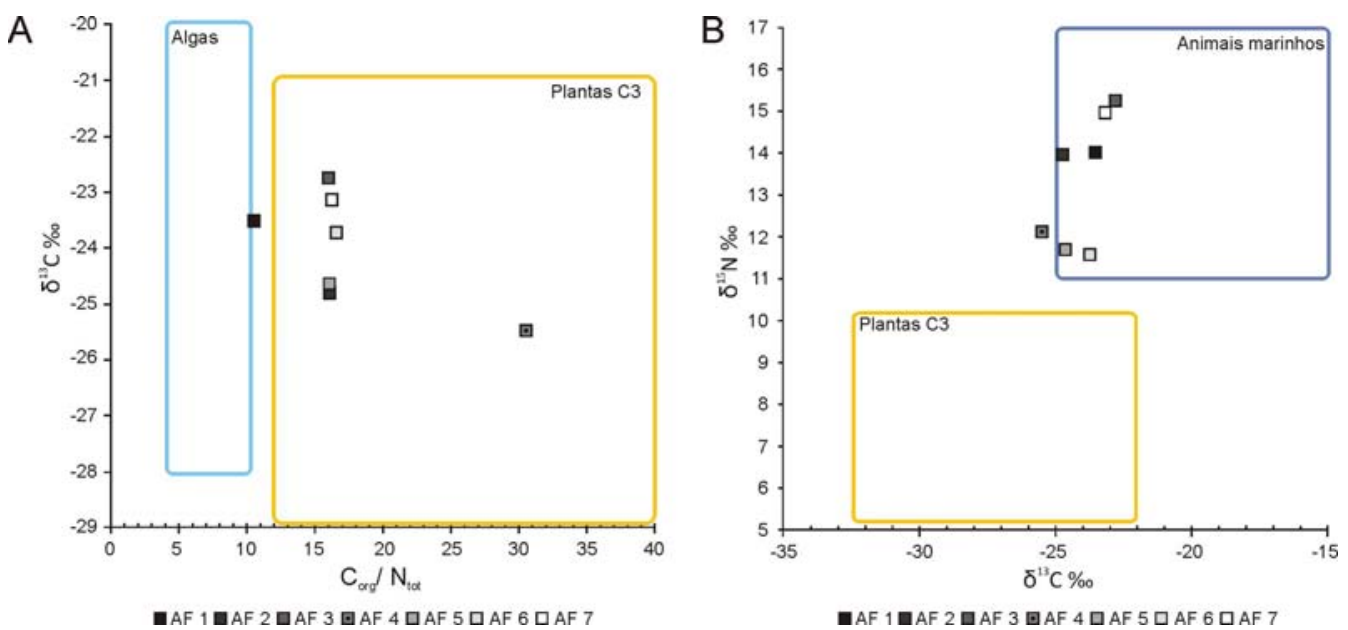

Figura 5.52. Análises isotópicas $\left(\delta^{13} \mathrm{C}\right.$ e $\delta^{15} \mathrm{~N}$ e razão $\left.\mathrm{C} / \mathrm{N}\right)$ de amostras provenientes das $\mathrm{AF} 1,2,3,4,5$, 6 e 7 do sítio Jabuticabeira 1: A) gráfico de valores de $\delta^{13} \mathrm{C}$ e razão $\mathrm{C} / \mathrm{N}$ com intervalos definidos para plantas de ciclo fotossintético $\mathrm{C} 3$ e algas; B) gráfico dos valores de $\delta^{15} \mathrm{~N}$ e $\delta^{13} \mathrm{C}$, com intervalos definidos para plantas de ciclo fotossintético $\mathrm{C} 3$ e animais marinhos.

\section{Micromorfologia}

Para análise micromorfológica, coletaram-se cinco amostras indeformadas das AF 5, 6, 7, 8 e 9. Na Tabela 5.14, apresenta-se a descrição geral das cinco lâminas analisadas. De todas as seções delgadas, apenas a correspondente à AF 7 apresentou quatro microfácies. No restante de lâminas, cada arqueofácies identificada em campo correspondeu uma única microfácies.
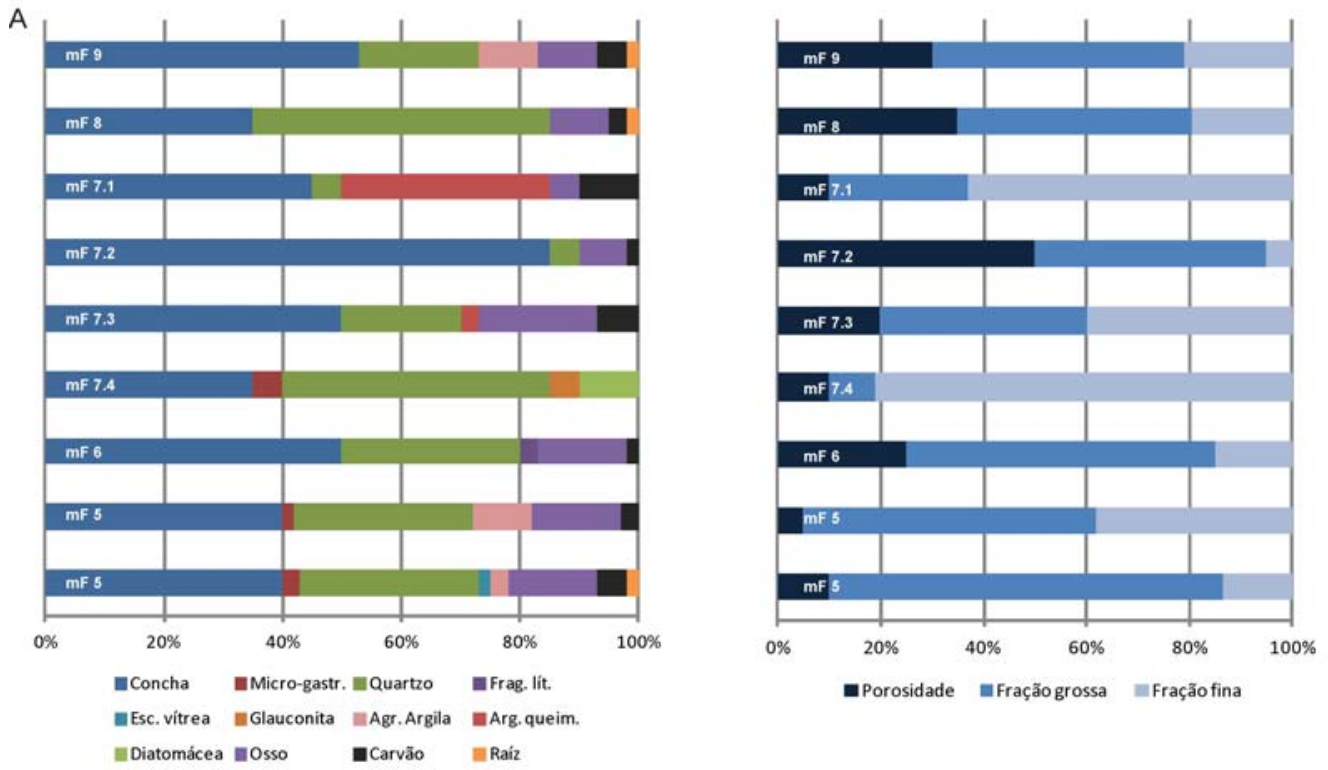

Figura 5.54. Gráficos com porcentagens dos diferentes componentes microscópicos das microfácies identificadas nas AF 5 ( $\mathrm{mF} \mathrm{5),} 6$ ( $\mathrm{mF}$ 6), 7 ( $\mathrm{mF} 7.1,7.2,7.3$ e 7.4), 8 ( $\mathrm{mF} \mathrm{8)} \mathrm{e} 9$ ( $\mathrm{mF}$ 9) do sítio Jabuticabeira 1: A) freqüências de componentes da fração grossa; B) relação entre as porcentagens de poros, fração grossa e fração fina. 


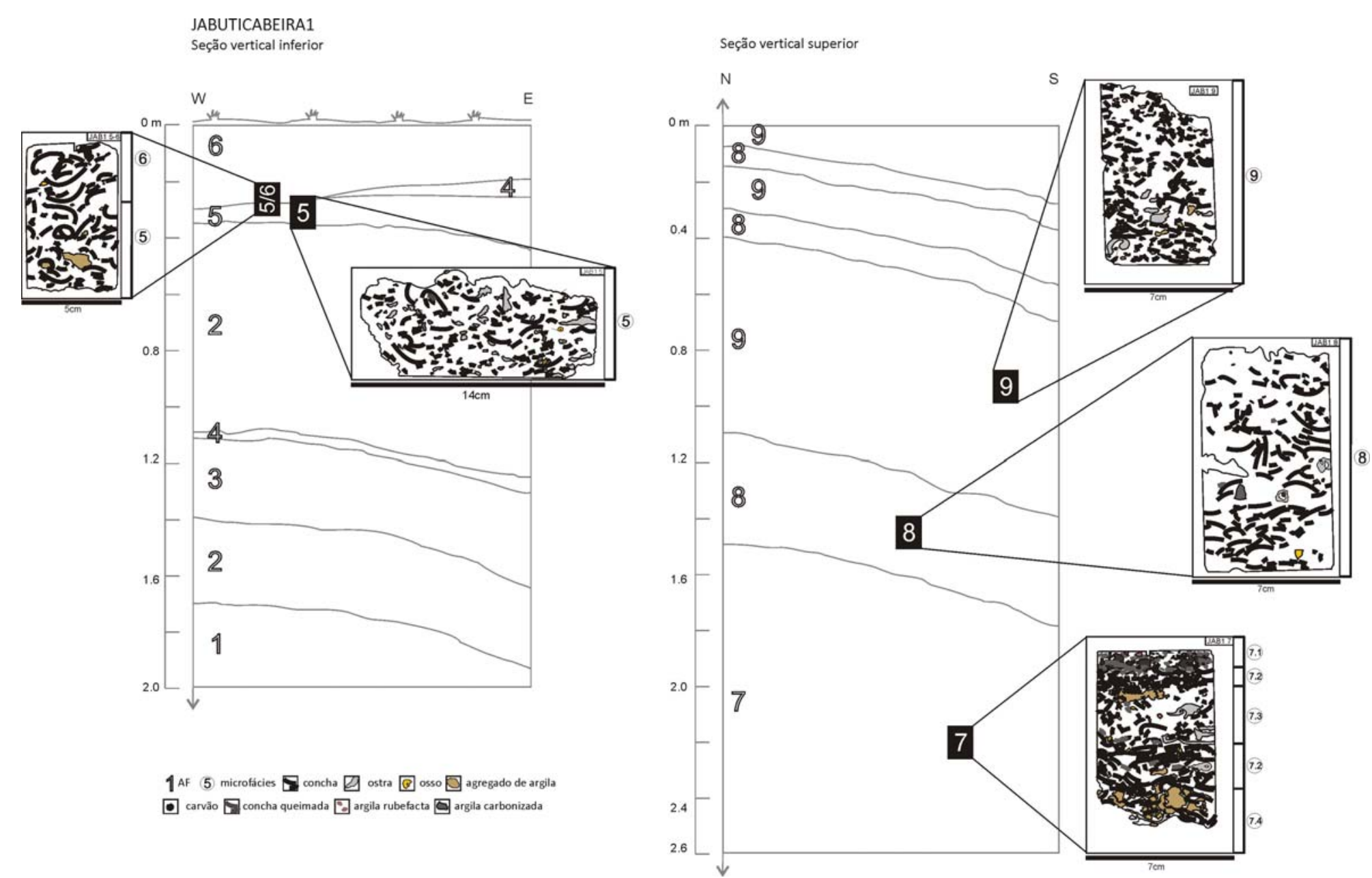

Figura 5.53. Desenho esquemático das cinco seções delgadas analisadas no sítio Jabuticabeira 1, com localização do bloco de amostragem na sucessão vertical inferior (esquerda) e superior (direita) e identificação de microfácies na lâmina. 


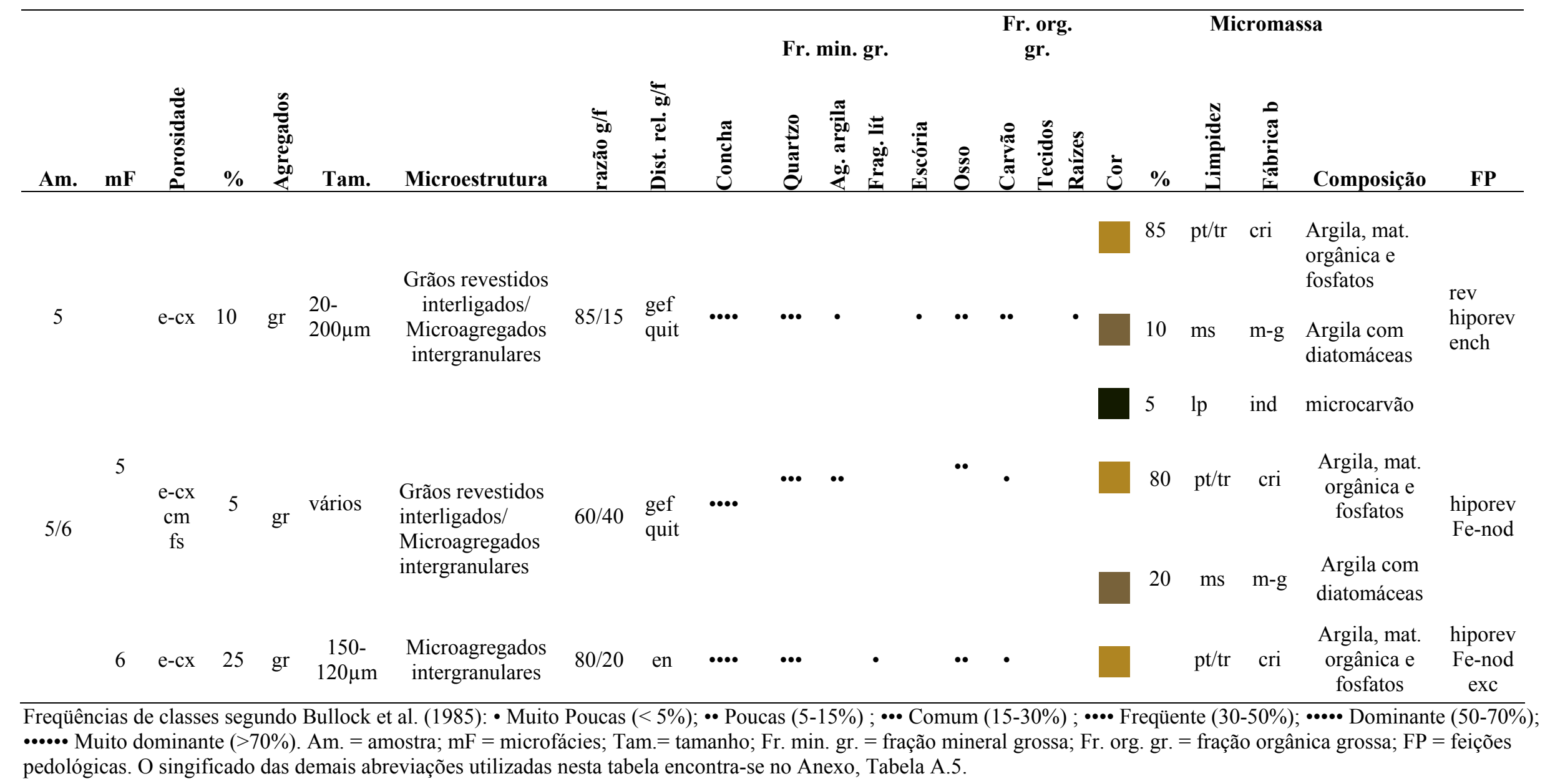




\begin{tabular}{|c|c|c|c|c|c|c|c|c|c|c|c|c|c|c|c|c|c|c|c|c|c|}
\hline Am. & $\mathbf{m F}$ & 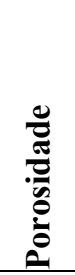 & $\%$ & 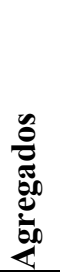 & Tam. & Microestrutura & 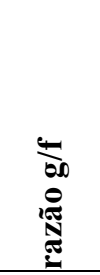 & 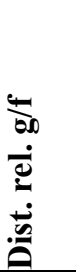 & 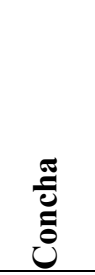 & 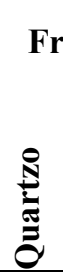 & 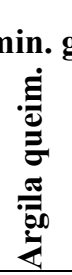 & 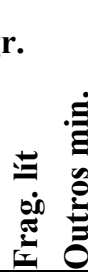 & $\begin{array}{l}0 \\
0 \\
0 \\
0\end{array}$ & 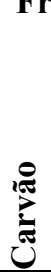 & 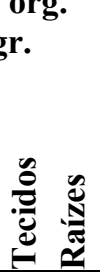 & $\dot{\theta}$ & $\%$ & 窇 & 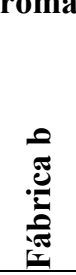 & Composição & FP \\
\hline \multirow[t]{4}{*}{7} & 7.1 & $\begin{array}{l}\text { e-cx } \\
\text { fs } \\
\mathrm{cm}\end{array}$ & 20 & $\mathrm{gr}$ & $\begin{array}{c}50- \\
100 \mu \mathrm{m}\end{array}$ & $\begin{array}{l}\text { Microagregados } \\
\text { intergranulares }\end{array}$ & $30 / 70$ & $\begin{array}{l}\text { en } \\
\text { por }\end{array}$ & $\bullet \bullet$ & $\bullet$ & $\cdots \bullet$ & & $\bullet$ & $\bullet$ & & & 50 & $\mathrm{pt}$ & ind & $\begin{array}{c}\text { Argila } \\
\text { rubefactada } \\
\text { Argila } \\
\text { carbonizada }\end{array}$ & \multirow[t]{2}{*}{ Cris } \\
\hline & 7.2 & e-cx & 50 & $\mathrm{gr}$ & $\begin{array}{c}100-200 \\
\mu \mathrm{m}\end{array}$ & $\begin{array}{l}\text { Microagregados } \\
\text { intergranulares }\end{array}$ & $90 / 10$ & en & $\bullet \bullet \bullet \bullet$ & $\bullet$ & & & $\bullet \bullet$ & $\bullet$ & & & & $\mathrm{pt}$ & cri & $\begin{array}{c}\text { Argila, micrita } \\
\text { e mat. } \\
\text { orgânica }\end{array}$ & \\
\hline & 7.3 & $\begin{array}{l}\mathrm{e}-\mathrm{cx} \\
\mathrm{fs} \\
\mathrm{cm} \\
\mathrm{cn}\end{array}$ & 20 & $\mathrm{gr}$ & vários & $\begin{array}{l}\text { Microagregados } \\
\text { intergranulares/ } \\
\text { grânulos } \\
\text { coesivos }\end{array}$ & $50 / 50$ & $\begin{array}{l}\text { en } \\
\text { por }\end{array}$ & $\bullet \bullet \bullet$ & $\bullet$ & $\bullet$ & & $\bullet$ & $\bullet$ & & & 80 & $\mathrm{~ms}$ & $\mathrm{~m}-\mathrm{g}$ & $\begin{array}{l}\text { Argila, micrita } \\
\text { e mat. } \\
\text { orgânica } \\
\text { Argila com } \\
\text { diatomáceas }\end{array}$ & $\begin{array}{l}\text { hiporev } \\
\text { ench } \\
\text { Fe-nod }\end{array}$ \\
\hline & 7.4 & fs & 10 & ag & $0,5-1 \mathrm{~cm}$ & Maciça & $10 / 90$ & por & $\bullet \bullet$ & $\bullet \bullet$ & & • & & & & & & $\mathrm{ms}$ & $\mathrm{m}-\mathrm{g}$ & $\begin{array}{l}\text { Argila com } \\
\text { diatomáceas }\end{array}$ & $\begin{array}{c}\text { rev } \\
\text { hiporev } \\
\text { Fe-nod }\end{array}$ \\
\hline
\end{tabular}


Fr. min. gr. gr.

Micromassa

\begin{tabular}{|c|c|c|c|c|c|c|c|c|c|c|c|c|c|c|c|c|c|c|c|c|c|}
\hline Am. & $\mathbf{m F}$ & 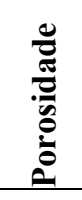 & $\%$ & 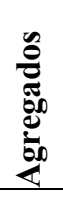 & Tam. & Microestrutura & స్తు & 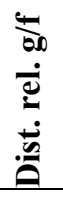 & ن̃ & 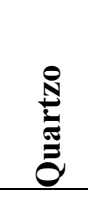 & 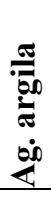 & 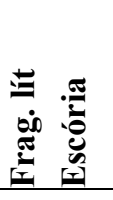 & 离 & 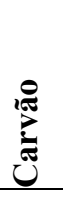 & 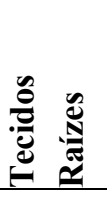 & $\dot{\tilde{\theta}}$ & $\%$ & 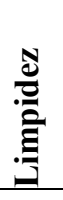 & 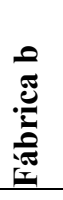 & Composição & FP \\
\hline 8 & & $\begin{array}{l}\text { e-cx } \\
\mathrm{cm} \\
\text { fs }\end{array}$ & 35 & gr & vários & $\begin{array}{l}\text { Microagregados } \\
\text { intergranulares/ } \\
\text { grânulos } \\
\text { coesivos }\end{array}$ & $70 / 30$ & en & $\cdots$ & $\bullet \bullet \bullet$ & & & $\bullet \bullet$ & $\bullet$ & $\bullet$ & & & $\mathrm{pt}$ & cri & $\begin{array}{l}\text { Argila, micrita } \\
\text { e mat. } \\
\text { orgânica }\end{array}$ & $\begin{array}{c}\text { rev } \\
\text { Fe-nod }\end{array}$ \\
\hline 9 & & $\begin{array}{l}\mathrm{e}-\mathrm{cx} \\
\mathrm{cm} \\
\mathrm{fs}\end{array}$ & 30 & gr & vários & $\begin{array}{l}\text { Microagregados } \\
\text { intergranulares/ } \\
\text { grânulos } \\
\text { coesivos }\end{array}$ & $70 / 30$ & en & $\bullet \bullet \bullet$ & $\bullet \bullet$ & $\bullet \bullet$ & & $\bullet \bullet$ & $\bullet \bullet$ & • & & & $\mathrm{pt}$ & cri & $\begin{array}{l}\text { Argila, micrita } \\
\text { e mat. } \\
\text { orgânica }\end{array}$ & $\begin{array}{c}\text { rev } \\
\text { ench } \\
\text { Fe-nod }\end{array}$ \\
\hline
\end{tabular}


Tabela 5.15. Componentes minerais e orgânicos da fração grossa da amostra JB1-5.

\begin{tabular}{|c|c|c|c|c|c|c|c|c|c|c|}
\hline \multicolumn{11}{|l|}{ JB1-5 } \\
\hline & $\mathbf{m F}$ & $\%$ & Tamanho & Forma & Arredondamento & Seleção & $\begin{array}{c}\text { Distribuiç̧ão } \\
\text { básica }\end{array}$ & $\begin{array}{c}\text { Orientação } \\
\text { básica }\end{array}$ & $\begin{array}{l}\text { Distribuição } \\
\text { referenciada }\end{array}$ & Alteração \\
\hline Concha & & 30 & Vários & - & ther & Não selecionado & Linear & $\begin{array}{l}\text { Paralelismo de } \\
\text { ângulo baixo }\end{array}$ & $\begin{array}{l}\text { Inclinado à } \\
\text { superfície }\end{array}$ & $x_{0}$ \\
\hline Gastróp. & & 3 & $100 \mu \mathrm{m}$ & - & - & Bem selecionado & Aleatória & - & - & - \\
\hline Quartzo & & 40 & $\begin{array}{l}\text { Areia média e } \\
\text { fina }\end{array}$ & Equidimensional & Arredondado & Bem selecionado & Aleatória & - & - & - \\
\hline Esc. vítrea & & 2 & Vários & Vários & Arredondado & Não selecionado & Aleatória & - & - & - \\
\hline Ag. argila & & 3 & $1-2 \mathrm{~mm}$ & Vários & Anguloso & Não selecionado & Aleatória & - & - & - \\
\hline Osso & & 15 & Vários & - & Subanguloso & Não selecionado & Aleatória & - & - & $\begin{array}{l}\text { Queima e } \\
\text { dissolução }\end{array}$ \\
\hline Carvão & & 5 & Vários & - & - & Não selecionado & Aleatória & - & - & - \\
\hline Raízes & & 2 & Vários & - & - & - & Aleatória & - & - & - \\
\hline
\end{tabular}


Tabela 5.16. Componentes minerais e orgânicos da fração grossa da amostra JB1-5/6.

\begin{tabular}{|c|c|c|c|c|c|c|c|c|c|c|}
\hline \multicolumn{11}{|l|}{ JB1-5/6 } \\
\hline & $\mathbf{m F}$ & $\%$ & Tamanho & Forma & Arredondamento & Seleção & $\begin{array}{c}\text { Distribuiçãão } \\
\text { básica }\end{array}$ & $\begin{array}{c}\text { Orientação } \\
\text { básica }\end{array}$ & $\begin{array}{l}\text { Distribuição } \\
\text { referenciada }\end{array}$ & Alteração \\
\hline Concha & 5 & 40 & Vários & - & - & Não selecionado & Aleatória & - & - & Dissolução \\
\hline Gastróp. & 5 & 2 & $100 \mu \mathrm{m}$ & - & - & Bem selecionado & Aleatória & - & - & - \\
\hline Quartzo & 5 & 30 & $\begin{array}{l}\text { Areia média e } \\
\text { fina }\end{array}$ & Equidimensional & $\begin{array}{l}\text { Arredondado- } \\
\text { subarredondado }\end{array}$ & Bem selecionado & Aleatória & - & - & - \\
\hline Ag. argila & 6 & 10 & $1 \mathrm{~cm}$ & - & - & Não selecionado & Aleatória & - & - & - \\
\hline Osso & 5 & 15 & $\begin{array}{l}\text { Areia fina a } \\
\text { média }\end{array}$ & - & - & Seleção pobre & Aleatória & - & - & $\begin{array}{l}\text { Queima e } \\
\text { dissolução }\end{array}$ \\
\hline Carvão & 5 & 3 & Areia grossa & - & Anguloso & Não selecionado & Aleatória & - & - & - \\
\hline Concha & 6 & 50 & Vários & - & - & Não selecionado & Aleatória & - & - & Dissolução \\
\hline Quartzo & 6 & 30 & $\begin{array}{l}\text { Areia média e } \\
\text { fina }\end{array}$ & Equidimensional & $\begin{array}{l}\text { Arredondado- } \\
\text { subarredondado }\end{array}$ & Bem selecionado & Aleatória & - & - & 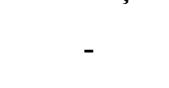 \\
\hline Frag. lít. & 6 & 3 & Areia grossa & Lenticular & Subanguloso & Não selecionado & Aleatória & - & - & - \\
\hline Osso & 6 & 15 & $\begin{array}{l}\text { Areia fina a } \\
\text { média }\end{array}$ & - & - & Seleção pobre & Aleatória & - & - & $\begin{array}{l}\text { Queima e } \\
\text { dissolução }\end{array}$ \\
\hline Carvão & 6 & 2 & Areia grossa & - & Anguloso & Não selecionado & Aleatória & - & - & - \\
\hline
\end{tabular}


Tabela 5.17. Componentes minerais e orgânicos da fração grossa da amostra JB1-7

\begin{tabular}{|c|c|c|c|c|c|c|c|c|c|c|}
\hline \multicolumn{11}{|l|}{ JB1-7 } \\
\hline & $\mathbf{m F}$ & $\%$ & Tamanho & Forma & Arredondamento & Seleção & $\begin{array}{c}\text { Distribuição } \\
\text { básica }\end{array}$ & $\begin{array}{l}\text { Orientação } \\
\text { básica }\end{array}$ & $\begin{array}{l}\text { Distribuição } \\
\text { referenciada }\end{array}$ & Alteração \\
\hline Concha & 7.1 & 45 & Vários & - & 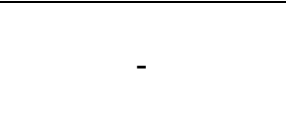 & Não selecionado & Linear & Paralela & $\begin{array}{l}\text { Paralela à } \\
\text { superfície }\end{array}$ & $\begin{array}{c}30 \% \\
\text { queimado a } \\
\mathrm{T}>600^{\circ} \mathrm{C}\end{array}$ \\
\hline Quartzo & 7.1 & 5 & $\begin{array}{l}\text { Areia média e } \\
\text { fina }\end{array}$ & Equidimensional & $\begin{array}{l}\text { Arredondado- } \\
\text { subarredondado }\end{array}$ & Bem selecionado & Aleatória & - & - & 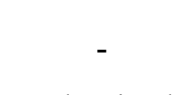 \\
\hline Arg. quei. & 7.1 & 35 & $0,5-1,0 \mathrm{~cm}$ & - & 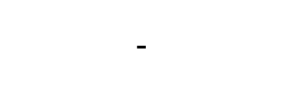 & Não selecionado & Aleatória & - & - & $\begin{array}{l}\text { Carbonizado } \\
\text { e rubificado }\end{array}$ \\
\hline Osso & 7.1 & 5 & Vários & - & - & Não selecionado & Aleatória & - & - & Queima \\
\hline Carvão & 7.1 & 10 & Vários & - & - & Não selecionado & Aleatória & - & - & - \\
\hline Concha & 7.2 & 85 & Vários & - & 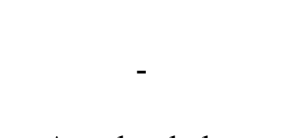 & Não selecionado & Linear & Paralela & $\begin{array}{l}\text { Paralela à } \\
\text { superfície }\end{array}$ & $\begin{array}{c}10 \% \\
\text { queimado a } \\
\mathrm{T}>600^{\circ} \mathrm{C}\end{array}$ \\
\hline Quartzo & 7.2 & 5 & $\begin{array}{l}\text { Areia média e } \\
\text { fina }\end{array}$ & Equidimensional & $\begin{array}{l}\text { Arredondado- } \\
\text { subarredondado }\end{array}$ & Bem selecionado & Aleatória & - & - & - \\
\hline Osso & 7.2 & 8 & Vários & - & - & Não selecionado & Aleatória & - & - & Queima \\
\hline Carvão & 7.2 & 2 & Vários & - & - & Não selecionado & Aleatória & - & - & - \\
\hline
\end{tabular}


Tabela 5.17. Continuação.

\begin{tabular}{|c|c|c|c|c|c|c|c|c|c|c|}
\hline \multicolumn{11}{|l|}{ JB1-7 } \\
\hline & $\mathbf{m F}$ & $\%$ & Tamanho & Forma & Arredondamento & Seleção & $\begin{array}{c}\text { Distribuição } \\
\text { básica }\end{array}$ & $\begin{array}{c}\text { Orientação } \\
\text { básica }\end{array}$ & $\begin{array}{l}\text { Distribuição } \\
\text { referenciada }\end{array}$ & Alteração \\
\hline Concha & 7.3 & 50 & Vários & - & 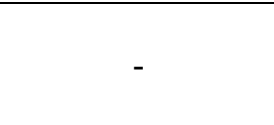 & Não selecionado & Aleatória/Linear & $20 \%$ paralela & $\begin{array}{l}\text { Paralela à } \\
\text { superfície }\end{array}$ & $\begin{array}{c}10 \% \\
\text { queimado a } \\
\mathrm{T}>600^{\circ} \mathrm{C}\end{array}$ \\
\hline Quartzo & 7.3 & 20 & $\begin{array}{l}\text { Areia média e } \\
\text { fina }\end{array}$ & Equidimensional & $\begin{array}{l}\text { Arredondado- } \\
\text { subarredondado }\end{array}$ & Bem selecionado & Aleatória & - & - & - \\
\hline Arg. quei. & 7.3 & 3 & $2 \mathrm{~mm}$ & - & - & Não selecionado & Aleatória & - & - & Rubificado \\
\hline Osso & 7.3 & 20 & Vários & - & - & Não selecionado & Aleatória & - & - & Queima \\
\hline Carvão & 7.3 & 7 & Vários & - & - & Não selecionado & Aleatória & - & - & - \\
\hline Concha & 7.4 & 35 & Vários & - & - & Não selecionado & Linear & Paralela & $\begin{array}{l}\text { Paralela à } \\
\text { superfície }\end{array}$ & $\begin{array}{c}5 \% \\
\text { queimado a } \\
\mathrm{T}>600^{\circ} \mathrm{C}\end{array}$ \\
\hline Gastróp. & 7.4 & 5 & $100 \mu \mathrm{m}$ & - & - & Bem selecionado & Aleatória & - & - & - \\
\hline Quartzo & 7.4 & 45 & $\begin{array}{l}\text { Areia média e } \\
\text { fina }\end{array}$ & Equidimensional & $\begin{array}{l}\text { Arredondado- } \\
\text { subarredondado }\end{array}$ & Bem selecionado & Aleatória & - & - & - \\
\hline Glauco. & 7.4 & 5 & $50-100 \mu \mathrm{m}$ & Equidimensional & Arredondado & Bem selecionado & Aleatória & - & - & - \\
\hline Diatom. & 7.4 & 10 & Silte & - & - & Bem selecionado & Aleatória & - & - & - \\
\hline
\end{tabular}


Tabela 5.18. Componentes minerais e orgânicos da fração grossa da amostra JB1-8.

\begin{tabular}{|c|c|c|c|c|c|c|c|c|c|c|}
\hline \multicolumn{11}{|l|}{ JB1-8 } \\
\hline & $\mathbf{m F}$ & $\%$ & Tamanho & Forma & Arredondamento & Seleção & $\begin{array}{l}\text { Distribuiçãão } \\
\text { básica }\end{array}$ & $\begin{array}{l}\text { Orientação } \\
\text { básica }\end{array}$ & $\begin{array}{l}\text { Distribuiçãa } \\
\text { referenciada }\end{array}$ & Alteração \\
\hline Concha & & 35 & Vários & - & - & Não selecionado & Aleatória/Linear & $\begin{array}{l}10 \% \text { paralelismo } \\
\text { de ângulo baixo }\end{array}$ & $\begin{array}{l}\text { Inclinada à } \\
\text { superfície }\end{array}$ & Dissolução \\
\hline Quartzo & & 50 & $\begin{array}{l}\text { Areia média e } \\
\text { fina }\end{array}$ & Equidimensional & $\begin{array}{l}\text { Arredondado- } \\
\text { subarredondado }\end{array}$ & Bem selecionado & Aleatória & 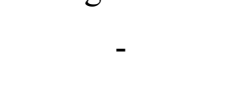 & $\mathrm{T}$ & - \\
\hline Osso & & 10 & Vários & - & - & Não selecionado & Aleatória & - & - & Queima \\
\hline Carvão & & 3 & Vários & - & - & Não selecionado & Aleatória & - & - & - \\
\hline Raízes & & 2 & Vários & - & - & - & Aleatória & - & - & - \\
\hline
\end{tabular}

Tabela 5.19. Componentes minerais e orgânicos da fração grossa da amostra JB1-9.

\begin{tabular}{|c|c|c|c|c|c|c|c|c|c|c|}
\hline \multicolumn{11}{|l|}{ JB1-9 } \\
\hline & $\mathbf{m F}$ & $\%$ & Tamanho & Forma & Arredondamento & Seleção & $\begin{array}{c}\text { Distribuiçãa } \\
\text { básica }\end{array}$ & $\begin{array}{c}\text { Orientação } \\
\text { básica }\end{array}$ & $\begin{array}{l}\text { Distribuiçãa o } \\
\text { referenciada }\end{array}$ & Alteração \\
\hline Concha & & 53 & Vários & - & 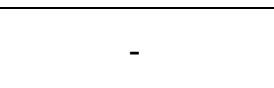 & Não selecionado & Aleatória/Linear & $\begin{array}{l}70 \% \text { paralelismo } \\
\text { de ângulo baixo }\end{array}$ & $\begin{array}{l}\text { Inclinada à } \\
\text { superfície }\end{array}$ & Dissolução \\
\hline Quartzo & & 20 & $\begin{array}{l}\text { Areia média e } \\
\text { fina }\end{array}$ & Equidimensional & $\begin{array}{l}\text { Arredondado- } \\
\text { subarredondado }\end{array}$ & Bem selecionado & Aleatória & $=0$ & - & - \\
\hline Ag. argila & & 10 & 1-4 mm & - & - & Não selecionado & Aleatória & - & - & - \\
\hline Osso & & 10 & Vários & - & - & Não selecionado & Aleatória & - & - & $\begin{array}{l}\text { Queima e } \\
\text { dissolução }\end{array}$ \\
\hline Carvão & & 5 & Vários & - & - & Não selecionado & Aleatória & - & - & - \\
\hline Raízes & & 2 & Vários & - & - & - & Aleatória & - & - & - \\
\hline
\end{tabular}


O sambaqui Jabuticabeira 1 apresenta semelhanças com o sítio Morrinhos em termos da diversidade de componentes da fração grossa. Incluem-se: fragmentos de concha, com 10 a 100\% distribuídas sub-horizontalmente; areia quartzosa de granulometria média a fina; fragmentos de osso (com sinais de queima e dissolução); carvão; escória vítrea; e agregados milimétricos de argilominerais contendo grãos de argila glauconítica, gastrópodes e diatomáceas (Figura 5.54 A; Tabelas 5.15 a 5.19). Os agregados de argilomineral apresentam a mesma composição que os agregados que compõem a $\mathrm{mF} 4 \mathrm{a} .3$ e que foram identificados na fração grossa da $\mathrm{mF} 4 \mathrm{~b}$ do sítio Morrinhos.

Diferente do sítio Morrinhos, Jabuticabeira 1 não contém feldspatos na fração grossa e é muito pobre em fragmentos líticos (um único fragmento lítico foi observado na $\mathrm{mF}$ 6). A fração grossa mineral é composta principalmente por grãos equidimensionais, arredondados a subarredondados de quartzo de granulometria areia média a fina (Tabelas 5.15 a 5.19). Isto sugere que a fração grossa mineral de Jabuticabeira 1 não estaria relacionada com o afloramento granítico sobre o qual repousa parte do sítio, como no caso do sítio Morrinhos, mas com outra fonte de sedimentos próxima ao local de levantamento do sambaqui. Isto sustenta a hipótese, levantada anteriormente, sobre a areia gossa e muito grossa terrígen evidenciada na análise granulométrica ser um artefato laboratorial, associado com ossos e conchas mal digeridos pelo ataque ácido.

A porosidade varia entre 5 e $50 \%$ nas diferentes microfácies analisadas, com freqüências menores que $20 \%$ em cinco casos $(\mathrm{mF} 5, \mathrm{mF} 7.1, \mathrm{mF} 7.3 \mathrm{e} \mathrm{mF} \mathrm{7.4)} \mathrm{e}$ freqüências superiores a $20 \%$ nos quatro casos restantes $(\mathrm{mF} 6, \mathrm{mF} 8 \mathrm{e} \mathrm{mF} \mathrm{9).} \mathrm{A} \mathrm{fração}$ grossa predomina em todas as microfácies, exceto naquelas formadas principalmente por agregados de argilominerais com diatomáceas $(\mathrm{mF} 7.1$, onde os agregados estão queimados e mF 7.4) (Figura 5.54 B). A fração fina é, no geral, uma mistura de argilominerais com fosfatos, micrita e MO. Dependendo da microfácies, predominam os fosfatos sobre a micrita.

Análises com sistema MEV-EED realizadas em lâmina sem lamínula da amostra JB1-8 (mF 8) confirmam a composição da micromassa inferida a partir das propriedades ópticas. O cálcio é o elemento químico predominante na fração fina ( 24\%), seguido de Si $(\sim 14 \%)$, P $(\sim 11 \%), \operatorname{Sr}(\sim 1.9 \%)$ e $\mathrm{Na}(\sim 1.5 \%)$, com teores menores que $1 \%$ de outros elementos ( $\mathrm{Fe}, \mathrm{Al}$ e $\mathrm{Mg}$ ). A proporção entre $\mathrm{Ca}$ e $\mathrm{P}$ (razão $\mathrm{Ca} / \mathrm{P}$ de 2.18) indica presença 
de fosfatos derivados da dissolução dos ossos (Adderley et al., 2004; Le Geros and Le Geros, 1984; Schaefer et al., 2004). A concentração de Si na fração fina sugere mistura com resíduos silicosos associados à queima de material vegetal. As micro-análises com sistema MEV-EES também corroboraram a composição aluminossilicática dos agregados de argila (Anexo, Figura A.5).

A $\mathrm{mF} 5$ é formada por uma mistura de argilominerais com fosfatos secundários, MO e microcarvões. Todos os componentes malacológicos da fração grossa, inclusive os fragmentos menores (cumprimento inferior a $500 \mu \mathrm{m}$ ), apresentam distribuição horizontal a sub-horizontal (Figura 5.55 B). Observam-se, nesta microfácies, agregados de argilominerais com diatomáceas. (Figura 5.55 C-D; Figura 5.56 B). Na micromassa, observam-se enchimentos, revestimentos e hiporrevestimentos de micrita associados com a precipitação de carbonato atribuído à dissolução das conchas (Figura 5.55 E-F). Dentre os componentes da fração grossa, destacam-se os agregados de escória vítrea, produzidos pela fusão térmica de material silicoso, como fitólitos e diatomáceas (Figura 5.56 A). Uma espécie de gastrópode foi encontrada na $\mathrm{mF} \mathrm{5}$, semelhante ao observado nas AF 3 e 4 do sítio Morrinhos (Figura 5.56 C). Os fragmentos de osso apresentam sinais de queima e dissolução (Figura 5.56 D).

A $\mathrm{mF} 6$ diferencia-se da $\mathrm{mF} 5$ pela distribuição aleatória dos fragmentos de concha, microestrutura de microagregados intergranulares e ausência de agregados de argilominerais com diatomáceas (Figura $5.57 \mathrm{~B}$ ). A micromassa é a mesma que na $\mathrm{mF}$ 5, com mistura de argilominerais, MO e fosfatos derivados da precipitação do fosfato dissolvido dos ossos (Figura 5.57 C-D).

A seção delgada correspondente à AF 7 é a que apresentou maior complexidade dentro do perfil analisadom apesar de, na descrição macroscópica, não mostrar indícios de micro-estratificação. Foram identificadas quatro microfácies sucessivas nesta lâmina (Figura 5.53; Tabela 5.14). A mF 7.1, de $1 \mathrm{~cm}$ de espessura, caracteriza-se por estar completamente queimada (Figura 5.58 A-B). Os fragmentos de concha apresentam, em todos os casos, sinais de alteração térmica, com $30 \%$ dos fragmentos a temperaturas superiores a $600^{\circ} \mathrm{C}$ (Tabela 5.17). Os agregados de argilominerais com diatomáceas, que perfazem $50 \%$ da fração fina desta microfácies, estão carbonizados ou rubificados (Figura 5.59 A-D). O restante da fração fina compõe-se de argilominerais, micrita e MO. Apesar de se tratar de uma microfácies completamente queimada, não se observaram áreas de concentração de cinzas de madeira. As áreas de concentração de 
micrita estão relacionadas com a alteração de conchas queimadas a temperaturas no entorno dos $800^{\circ} \mathrm{C}$ (Figura $5.59 \mathrm{E}-\mathrm{F}$ ). Dentro dos agregados de argila queimada, identificam-se as mesmas espécies de diatomáceas que se observaram nos agregados de lama do sítio Morrinhos e da mF 5 de Jabuticabeira 1 (Figura 5.59 D).

A $\mathrm{mF} 7.2$, de $0,7 \mathrm{~cm}$ de espessura, imediatamente inferior a $\mathrm{mF} 7.1$, apresenta microestrutura de microagregados intergranulares com fragmentos de concha de distribuição horizontal (Figura 5.58 D), 10\% dos quais contêm evidências de queima a temperatura superior a $600^{\circ} \mathrm{C}$. Nesta microfácies, domina a fração grossa, formada por conchas, grãos de quartzo, fragmentos de osso e carvão. A mF 7.3, com 2,6 cm de espessura, apresenta, em $80 \%$ da sua área, microestrutura de microagregados intergranulares com grãos coesivos e $20 \%$ de microestrutura maciça formada por macro-agregados de argilominerais com diatomáceas (Figura 5.58 E). Aproximadamente $20 \%$ dos fragmentos de concha estão orientados sub-horizontalmente e cerca de $10 \%$ apresentam sinais de queima a temperatura superior a $600^{\circ} \mathrm{C}$ (Tabela 5.17). Abaixo da $\mathrm{mF} 7.3$ volta a aparecer a $\mathrm{mF} 7.2$, com aproximadamente $2 \mathrm{~cm}$ de espessura.

A última microfácies identificada na $\mathrm{AF} 7(\mathrm{mF}$ 7.4) é formada por agregados milimétricos a centimétricos de argilominerais (Figura $5.58 \mathrm{~F}$ ). Entre os agregados, observam-se gastrópodes (Figura $5.60 \mathrm{~A}$ ), fragmentos de concha de distribuição horizontal, 5\% deles queimados a temperaturas maiores que $600^{\circ} \mathrm{C}$ (Figura $5.60 \mathrm{~B}$ ), diatomáceas (Figura 5.60 C-D) e grãos de argila glauconítica (Figura 5.60 E-F).

A identificação das espécies de diatomáceas que aparecem na $\mathrm{mF} 7.4$ mostra a existência de Triceratium flavus, Actinoptycus vulgaris e fragmentos de Biddulphia pulchella e Coscinodiscus sp (Amaral 2011, comunicação pessoal). O predomínio de Paralia sulcata já foi detectado em sedimentos paleolagunares da região (Amaral, 2008; Amaral et al., 2012). Trata-se de uma espécie marinha euritrópica, que tolera variações de salinidade das águas de 5 até 40 \%. Biddulphia pulchella é igualmente euritrópica, enquanto Triceratium flavus e Actinoptycus vulgaris são espécies marinhas estenotópicas, que não toleram grandes variações na salinidade das águas (vivem em condições de salinidade entre 30 e 40\%o). Assim, a assembleia de diatomáceas encontrada nos agregados de lama indica águas meso a eusalinas ( $>5$ a 40\%). Estes agregados de argila devem corresponder, portanto, a sedimentos associados a fundo 
estuarino-lagunar, hipótese reforçada pela granulação fina e pela alta freqüência de Paralia sulcata.

As microfácies $\mathrm{mF} 8$ e mF 9 apresentam muitas semelhanças entre si em termos de microestrutura (microagregados integranulares e grânulos coesivos), composição da fração grossa (conchas, grãos de quartzo, ossos e carvões) e da micromassa (argilominerais com micrita e MO) (Figura 5.61 C-D; Tabela 5.14). A diferença reside nos agregados de argilominerais com diatomáceas na mF 9 (Figura $5.62 \mathrm{~B}-\mathrm{D}$, junto com maior freqüência de fragmentos de concha de distribuição sub-horizontal também na $\mathrm{mF} 9$, diferente da $\mathrm{mF} 8$, onde as conchas estão distribuídas aleatoriamente (Figura 5.61 B, Figura 5.62 B; Tabela 5.18, 5.19).

O sítio Jabuticabeira 1 possui as mesmas feições pedológicas observadas em outros sambaquis de padrão estratigráfico conchífero (Caipora, Morrinhos). As mais recorrentes são os revestimentos, hiporrevestimentos e enchimentos de carbonato de cálcio relacionado com a precipitação do carbonato dissolvido das conchas. Além destas feições carbonáticas, observaram-se ainda nódulos órticos de óxi-hidróxido de ferro, cuja formação pode relacionar-se com o regime hidrológico local, sendo favorecida por chuvas sazonais e episódios de alagamento e ressecação dos sedimentos. Como observado no sambaqui Morrinhos, a alteração intempérica dos sedimentos arqueológicos não destrói totalmente as microfácies e é possível identificar no sambaqui áreas de atividade bem preservadas. A diferença entre as $\mathrm{mF}$ 5, 6, 8 e 9, de composição relativamente homogênea, e a $\mathrm{mF} 7$, microestratificada, indica a existência de pelo menos dois tipos de episódios deposicionais na formação do sambaqui: deposição massiva de material retrabalhado; e deposição de finas lentes de materiais de proveniência diversa, atribuídos a períodos de ocupação mais intensa. 
A
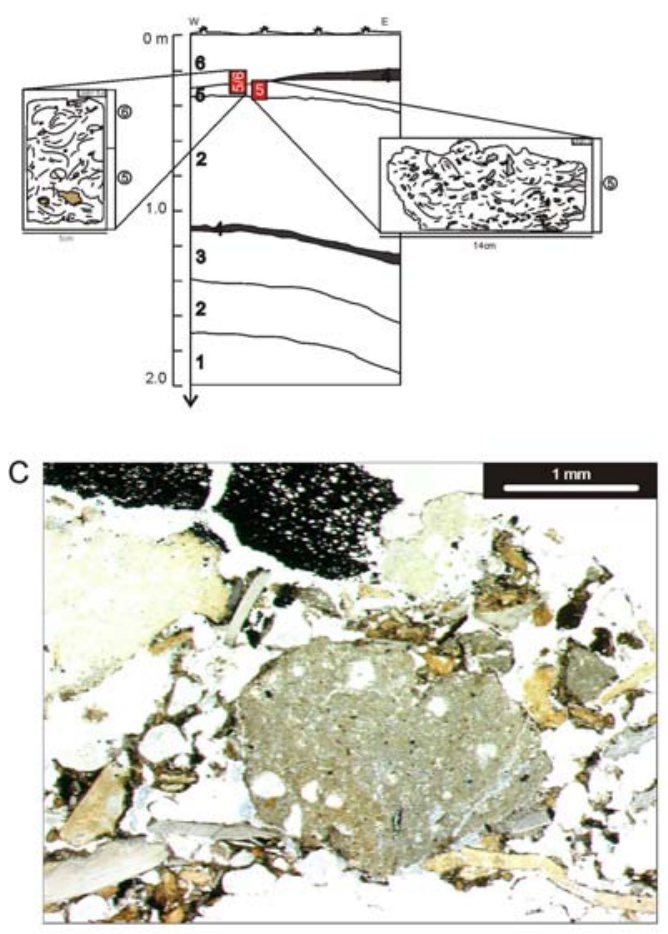

$\mathrm{E}$

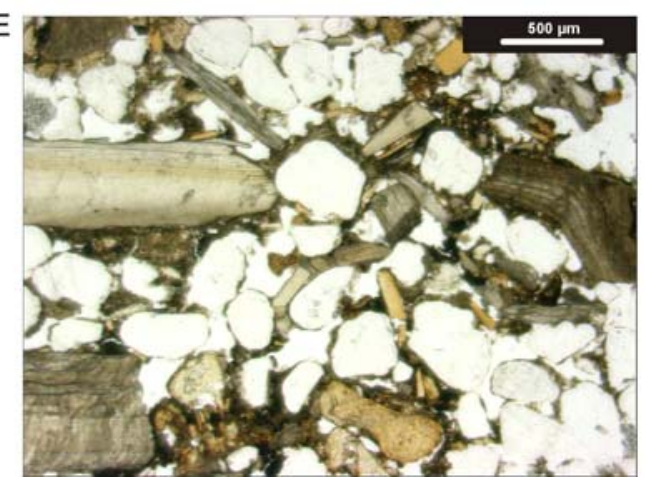

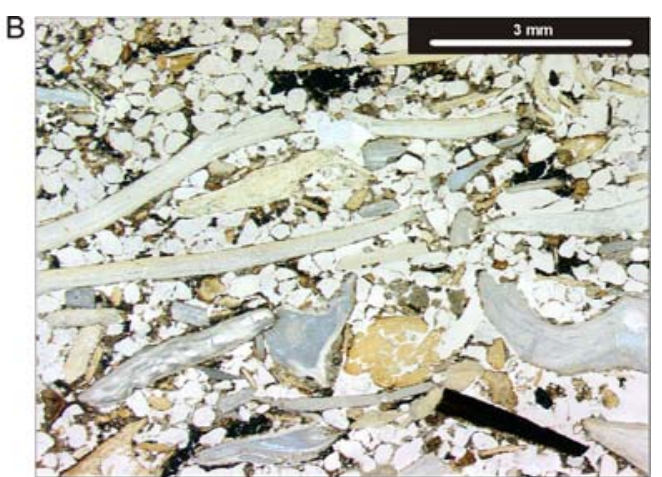
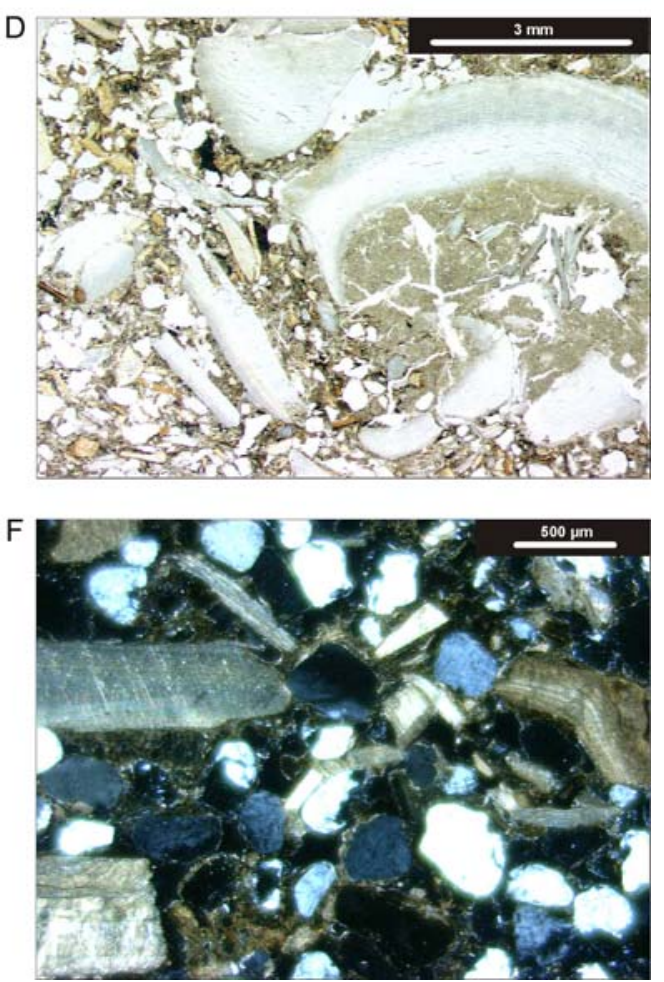

Figura 5.55. Fotomicrografias da $\mathrm{mF} 5$, amostras 5 e 5/6, do sítio Jabuticabeira 1: A) seção vertical esquemática, com localização da amostra para micromorfologia; B) massa basal da $\mathrm{mF} 5$ formada por conchas de distribuição sub-horizontal com alguns fragmentos de osso e carvão, PPL; C) agregado milimétrico de argilomineral, PPL; D) agregado de argilominerais associado à face côncava de concha de Anomalocardia brasiliana; E, F) micromassa de grãos revestidos interligados, PPL e XPL. 

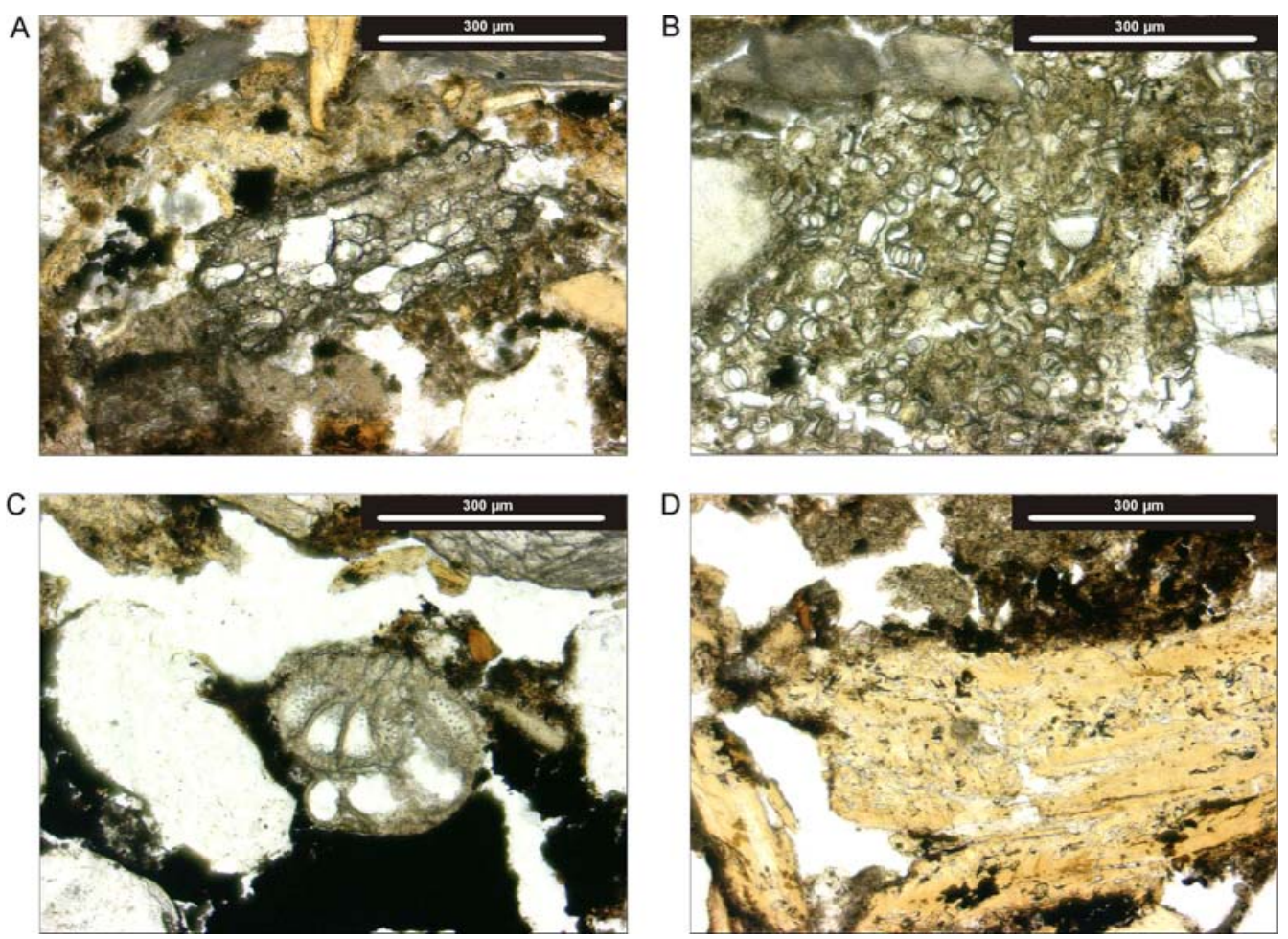

Figura 5.56. Fotomicrografias de elementos de componentes da fração grossa da $\mathrm{mF} 5$ (PPL): A) escória vítrea; B) concentração de diatomáceas da espécie Paralia sulcata em agregado de argilominerais; C) gastrópode; D) fragmento de osso, com sinais de dissolução.

A
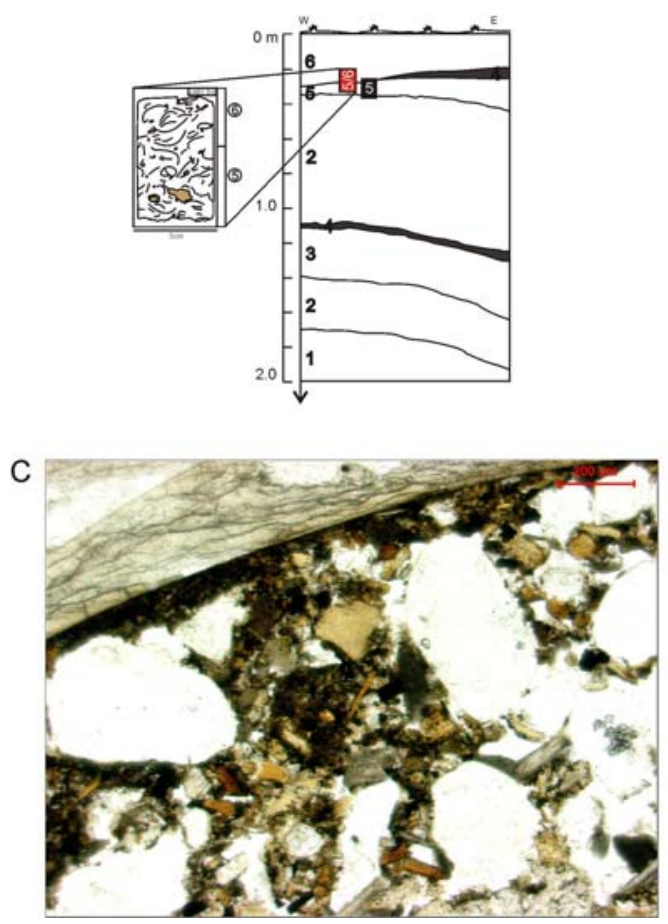
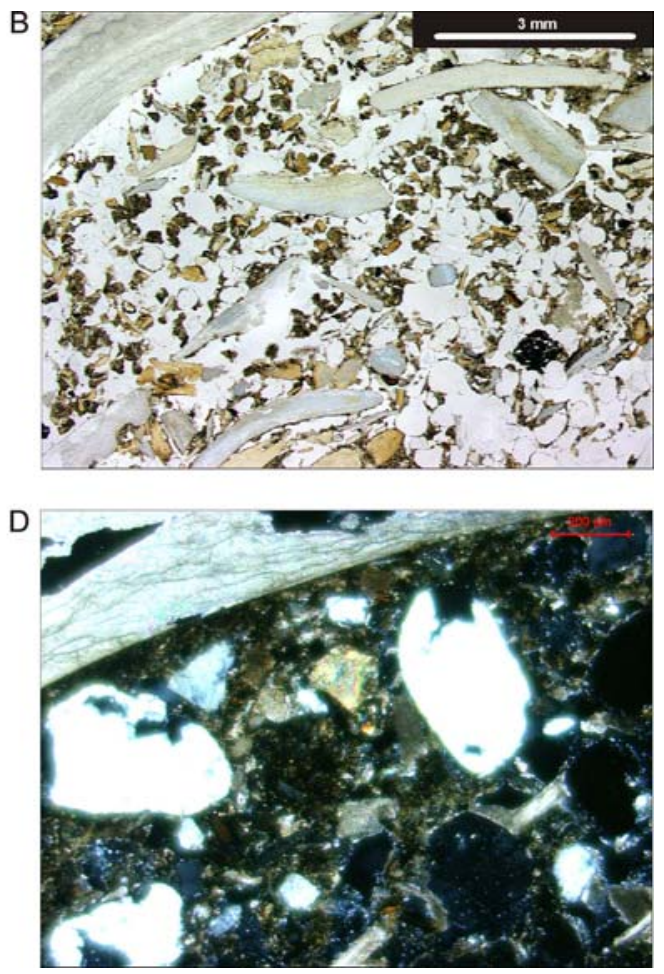

Figura 5.57. Fotomicrografias da $\mathrm{mF} 6$, amostra 5/6, do sítio Jabuticabeira 1: A) seção vertical esquemática com localização da amostra para micromorfologia; B) massa basal formada por fragmentos de concha, osso e grãos de quartzo em microestrutura de microagregados intergranulares, PPL; C, D) detalhe da micromassa composta por argilominerais, $\mathrm{MO}$ e fosfatos, com inclusões de fragmentos de osso na fração silte, PPL e XPL. 
A

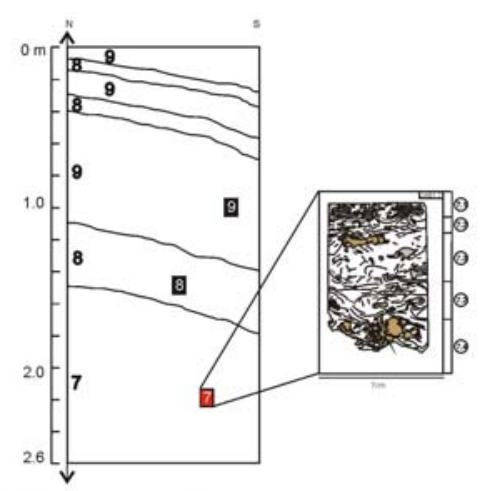

C
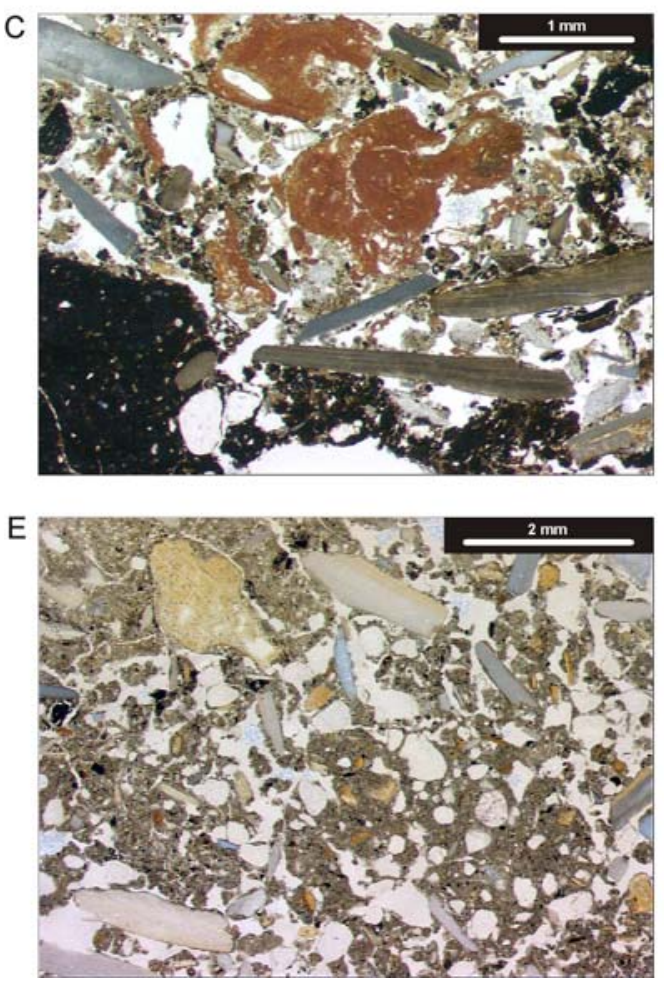
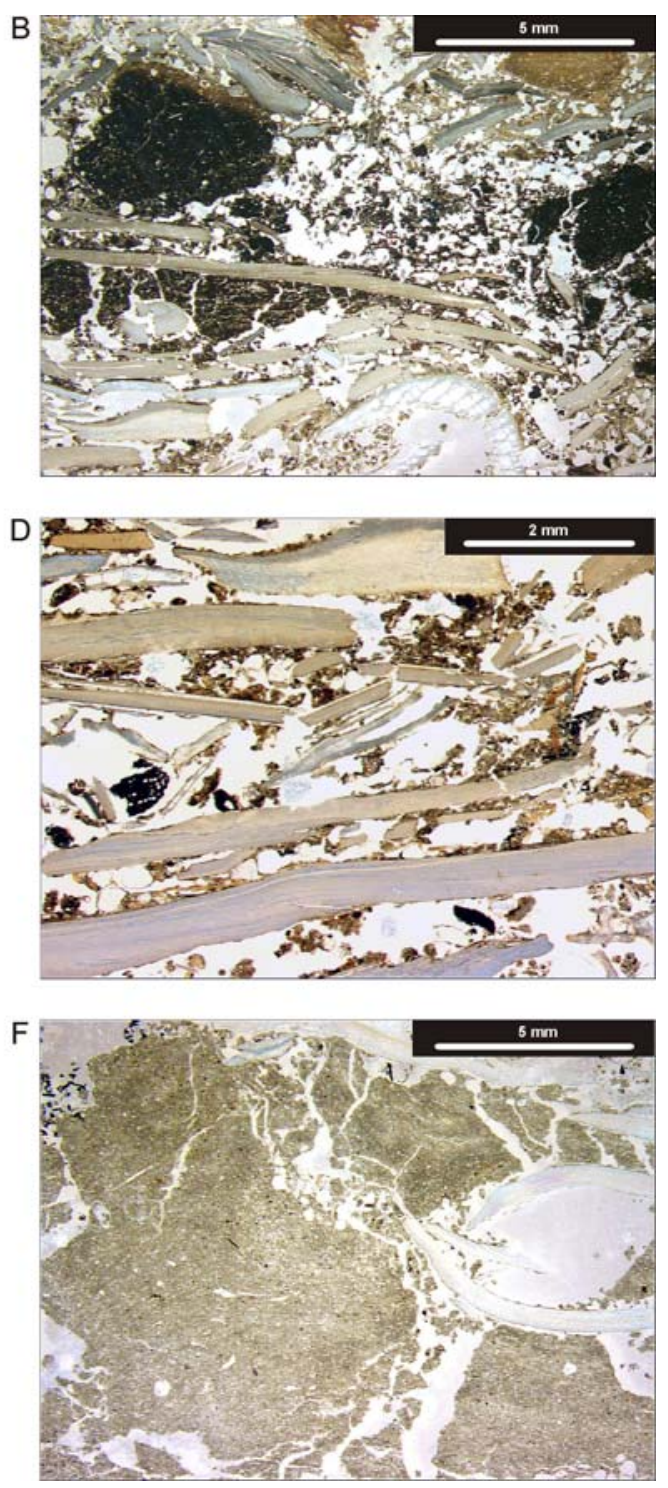

Figura 5.58. Fotomicrografias da $\mathrm{mF} 7$ do sítio Jabuticabeira 1: A) seção vertical esquemática com

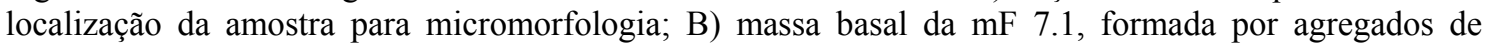
argilominerais rubefactos e carbonizados com camada de conchas queimadas a temperaturas maiores que $600^{\circ} \mathrm{C}$, PPL; C) detalhe de agregado de argila rubefacta, PPL; D) massa basal da $\mathrm{mF} 7.2$, formada por fragmentos de concha de distribuição horizontal entre microagregados intergranulares, PPL; E) massa basal da mF 7.3, composta por argilominerais com micrita e MO em microestrutura de grânulos coesivos, PPL; F) massa basal da mF 7.4 formada por agregados centimétricos de argilominerais, PPL. 

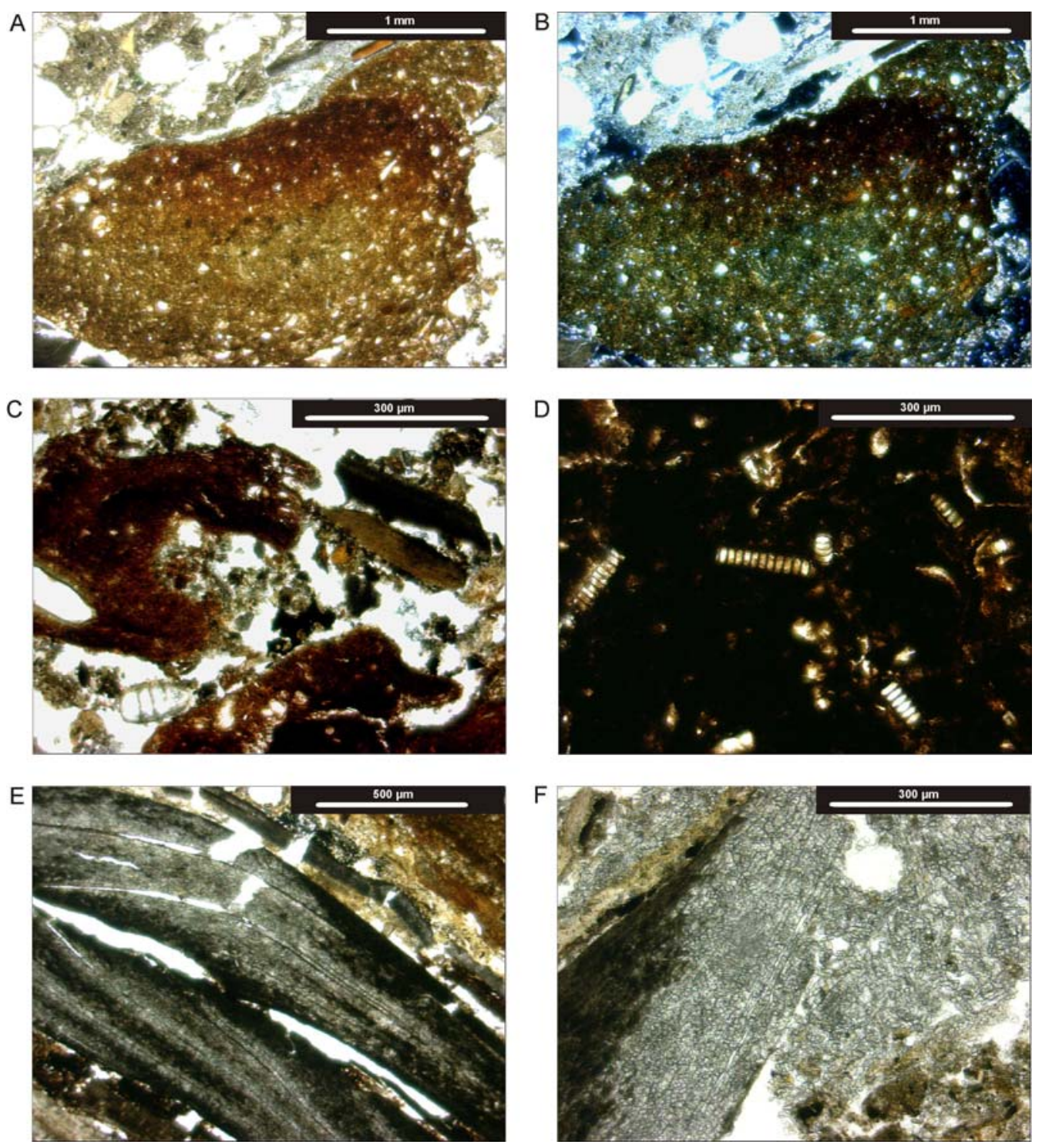

Figura 5.59. Fotomicrografias de elementos de destaque na $\mathrm{mF}$ 7.1: A, B) agregado de argila rubefacta, PPL e XPL; C) agregado de argila queimada com gastrópode, PPL; D) interior de agregado de argila queimada com diatomáceas da espécie Paralia sulcata; E) concha queimada a temperatura superior a $700^{\circ} \mathrm{C}$, PPL; F) detalhe de concha queimada a temperatura superior a $800^{\circ} \mathrm{C}$, com concentração de espato associada a degradação da concha calcinada, PPL. 

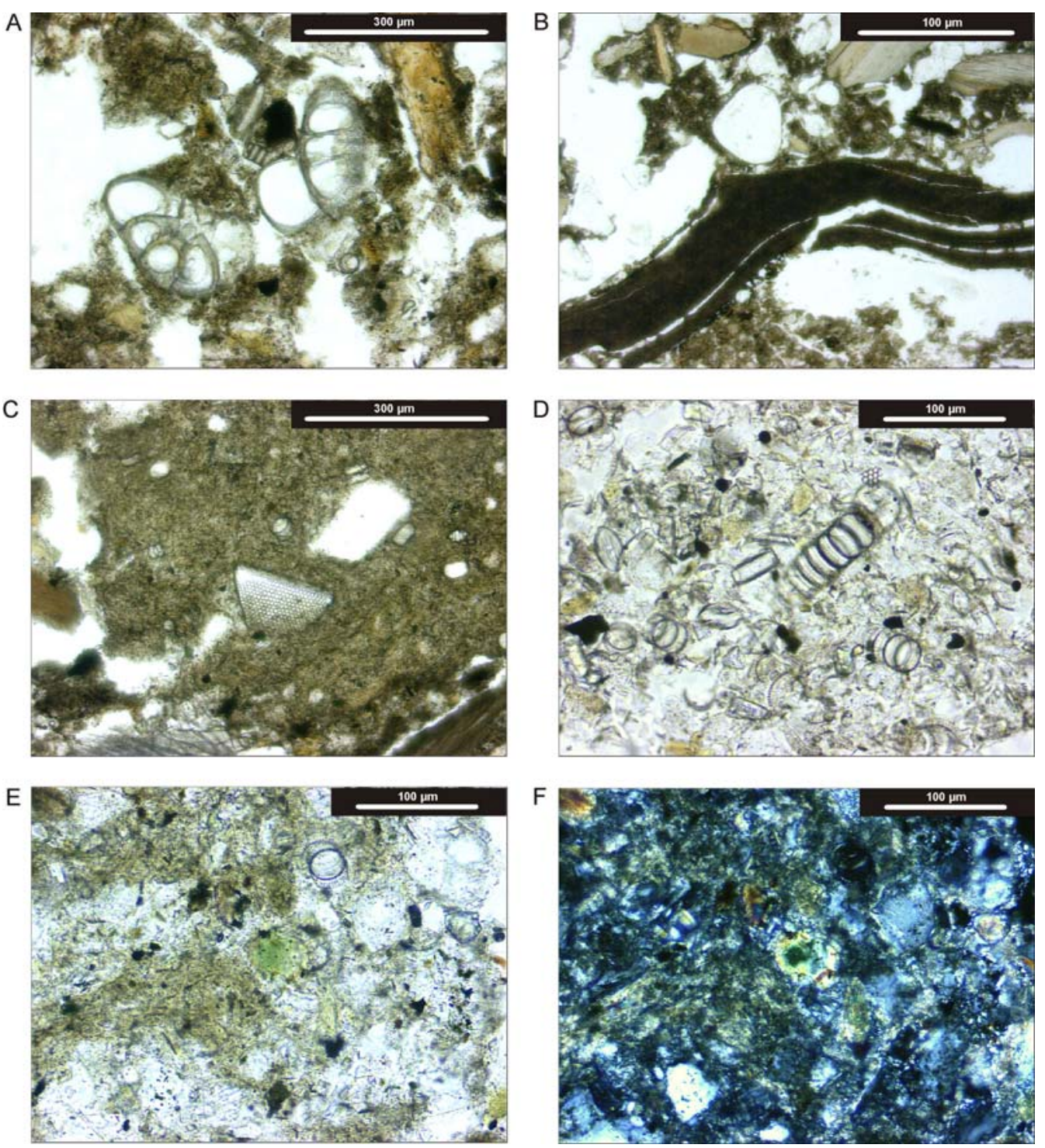

Figura 5.60. Fotomicrografias de elementos de destaque nas $\mathrm{mF} 7.3$ e 7.4: A) gastrópodes na $\mathrm{mF}$ 7.3, PPL; B) concha queimada a temperatura superior a $600^{\circ} \mathrm{C}$ na $\mathrm{mF} 7.3$, PPL; C) agregado de argila da $\mathrm{mF}$ 7.4, com diatomácea de espécie Triceratum flavus, PPL; D) concentração de diatomáceas das espécies Paralia sulcata, Actinoptycus vulgaris e Coscinodiscus sp., na $\mathrm{mF}$ 7.3, PPL; E, F) grão de argila glauconítica em agregado de argilominerais da mF 7.4, PPL e XPL. 
A
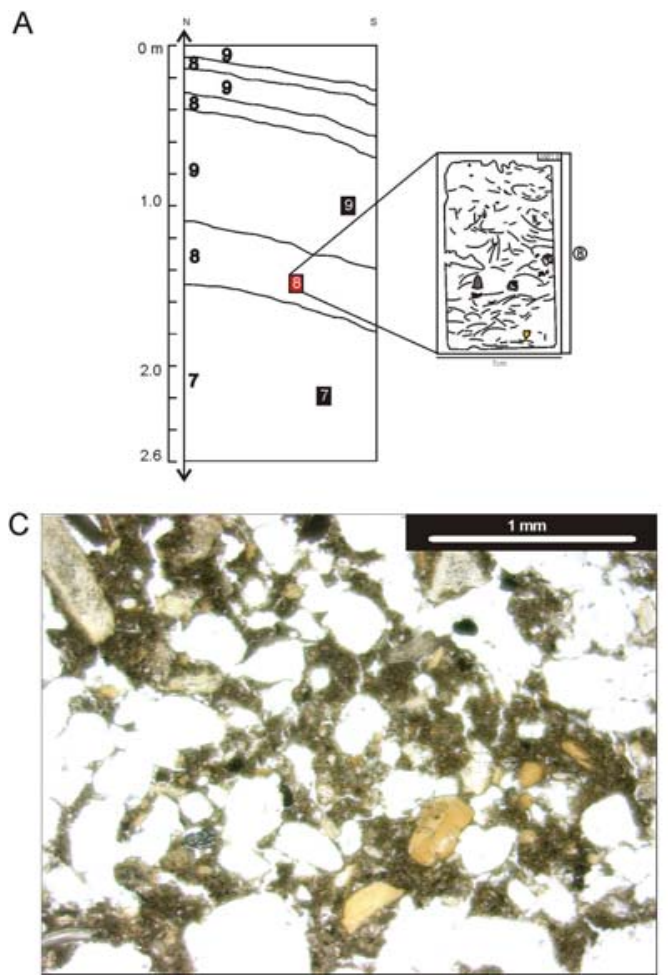
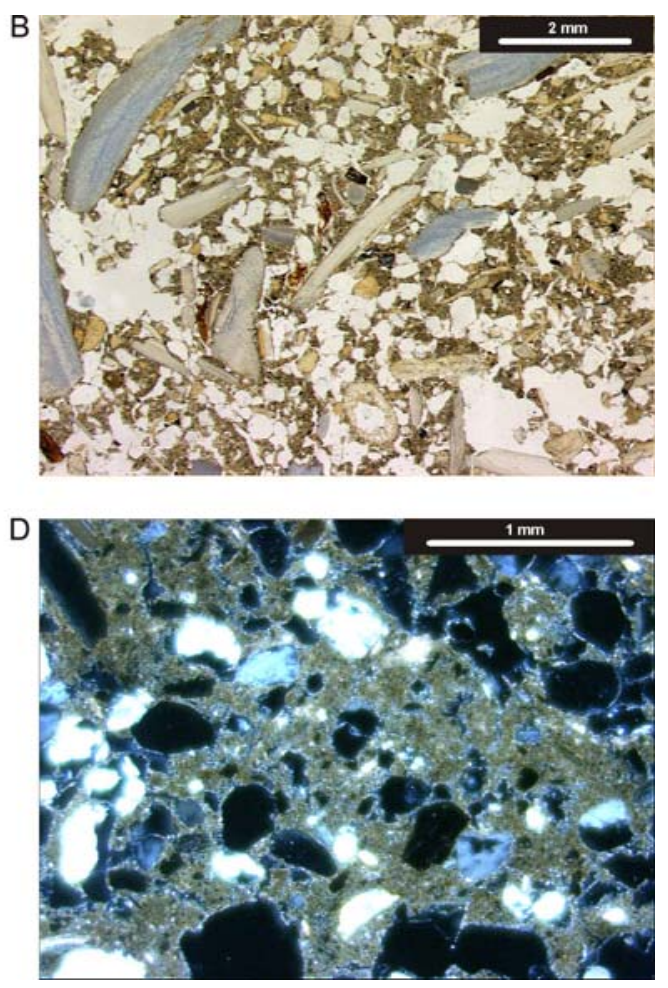

Figura 5.61. Fotomicrografias da $\mathrm{mF} 8$ do sítio Jabuticabeira 1: A) seção vertical esquemática com localização da amostra para micromorfologia; B) massa basal da $\mathrm{mF} 8$, formada por fragmentos de concha com distribuição aleatória; C, D) micromassa formada por argilominerais e micrita, PPL e XPL.

A
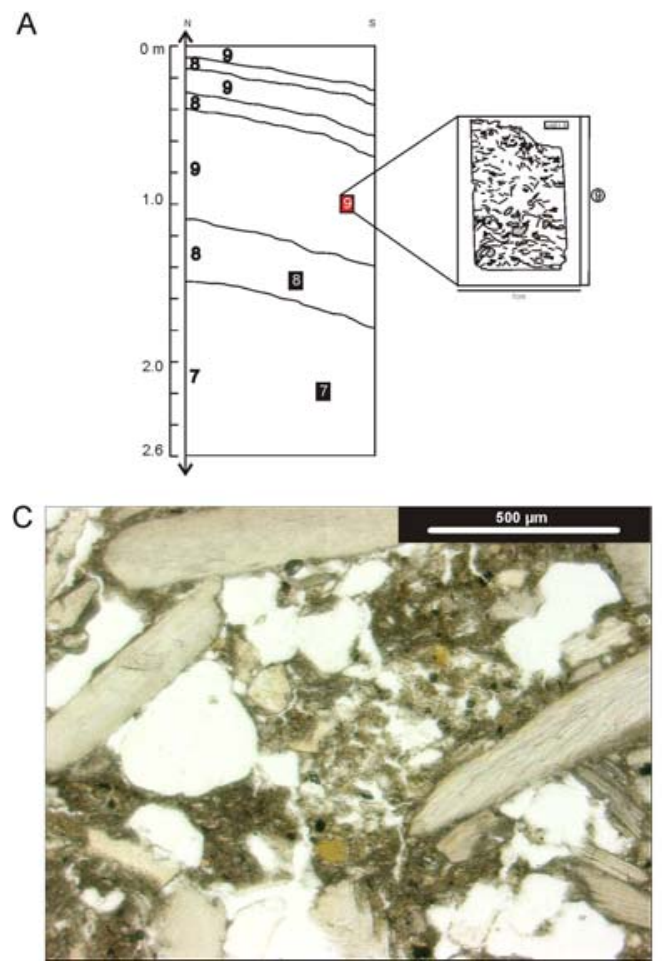
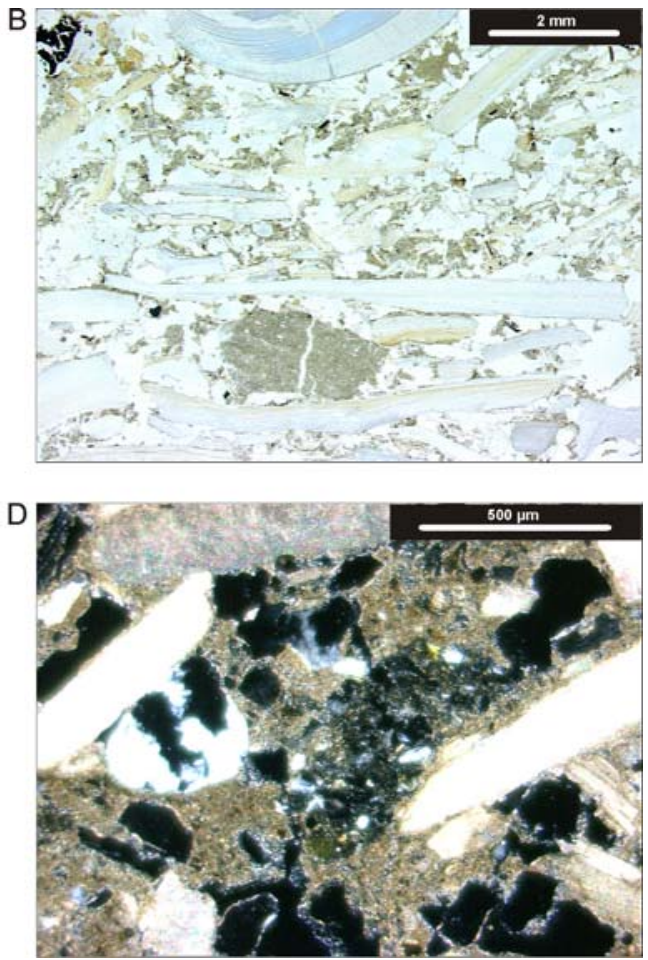

Figura 5.62. Fotomicrografias da $\mathrm{mF} 9$ do sítio Jabuticabeira 1: A) seção vertical esquemática com localização da amostra para micromorfologia; B) massa basal da $\mathrm{mF} 9$ formada por fragmentos de concha de distribuição horizontal com agregados milimétricos de argilominerais, PPL; C, D) micromassa formada por argilominerais e micrita, com agregados de argilominerais, PPL e XPL. 


\subsection{SAMBAQUIS DE NÚCLEO ARENOSO}

\subsubsection{Santa Marta 10}

Este sambaqui é o mais antigo do setor externo. Contém uma única datação (6180-5750 anos cal AP) que indicaria a data possível de formação do anel de conchas que compõe o sítio. Este anel, identificado em campo como AF 1, encontra-se inserido em uma camada de areia lamosa preta (Fácies B) (Figura 5.63). Ambos os depósitos se situam sobre núcleo arenoso correspondente a paleoduna de geração eólica 2, identificada com base na coloração amarelada, no grau moderado de cimentação e coesão (menor que o da geração 1 do mesmo local) e na presença de bandas de impregnação (Giannini et al., 2007). Esta geração é tipicamente formada, na região, antes do máximo transgressivo holocênico (Giannini e Suguio, 1994; Giannini et al., 2007; Giannini, 1993).

A análise zooarqueológica mostra o predomínio de $A$. brasiliana, tanto inteira $(\sim 50 \%)$ como fragmentada $(\sim 48 \%)$, no anel de conchas. $\mathrm{Na}$ assembleia arqueofaunística, destaca-se a frequência elevada de indivíduos juvenis de A. brasiliana, mais de $4 \%$ da porcentagem total desta espécie.

O núcleo arenoso do sambaqui é referido como Fácies A. Tanto a Fácies A como a B apresentam a mesma granulação, formada por areia fina a muito fina bem selecionada, com a única diferença de que B contém acumulação de MO coloidal. A transição entre uma fácies e outra é abrupta e caracterizada pela presença de bioturbações, como pedotúbulos. Isto sugere que ambas as fácies poderiam formar parte do mesmo tipo de depósito arenoso sobre o qual se desenvolveu um horizonte de solo iluvial (B de espodossolo), correspondente à Fácies B, a partir da migração de solutos orgânicos gerados em superfície.

A acumulação de MO que caracteriza a Fácies B, identificada pela coloração preta, é mais intensa na área compreendida pelo sítio arqueológico, onde atinge 20 a 30 $\mathrm{cm}$ de espessura. Uma acumulação semelhante se observa também em toda a área adjacente ao sítio, sobre as paleodunas que afloram no local, na forma de um fino horizonte de 2 a $3 \mathrm{~cm}$ de espessura, de coloração marrom escuro, sobre o qual se desenvolve vegetação de musgos. Na área externa ao sítio Santa Marta 10, esta sucessão 
foi identificada como fácies de areia fina, de formato côncavo, sobreposta por fácies centimétrica de areia lamosa preta. Esta seqüência de fácies é interpretada como depósito eólico (Fácies A2), com acumulação de MO e argilominerais no topo (Fácies B2).

Ao considerar que a diferenciação entre as Fácies A e B se deve e processos pedogênicos, a relação entre a Fácies B e AF 1 (anel de conchas), que recobre em toda a sua extensão, poderia ser explicada pela seguinte sucessão de eventos:

1) A ocupação humana sobre a paleoduna, então possivelmente uma duna ativa, ocasionou a presença da AF 1 (anel de conchas).

2) Esta ocupação pode ter sido concomitante ou prévia à deposição de um segundo evento de deposição eólica, representado pela Fácies B, no setor que cobre a camada de conchas; esta fácies ocorre com cor preta somente neste local, o que pode ser atribuído à acumulação de $\mathrm{MO}$, que causou pedogênese diferenciada, por atividade humana.

3) Os processos pedogênicos que ocasionaram a formação do horizonte preto superior na Fácies B teriam sido posteriores à ocupação, como sugerido pela ausência localizada de bandas de impregnação embaixo da AF1 (as conchas teriam retardado ou dificultado a infiltração de materiais finos).

4) O horizonte pedogênico superior, que tem continuidade fora do sítio porém com menor espessura, ter-se-ia formado com maior intensidade e penetração vertical na área ocupada, devido ao aporte antrópico de material orgânico no sítio arqueológico.

5) As evidências de pedogênese sobre a Fácies B, atribuída ao segundo evento de deposição eólica, sugerem que o aporte de material orgânico teria sido concomitante ou penecontemporâneo a este evento.

A combinação de episódios de deposição e pedogênse identificados no sítio Santa Marta 10, com ênfase para a formação de horizonte de solo, transformam este sambaqui em exemplo de perfil pedo-estratigráfio, como definido no capítulo 4 tópico 1.1.2. 
A
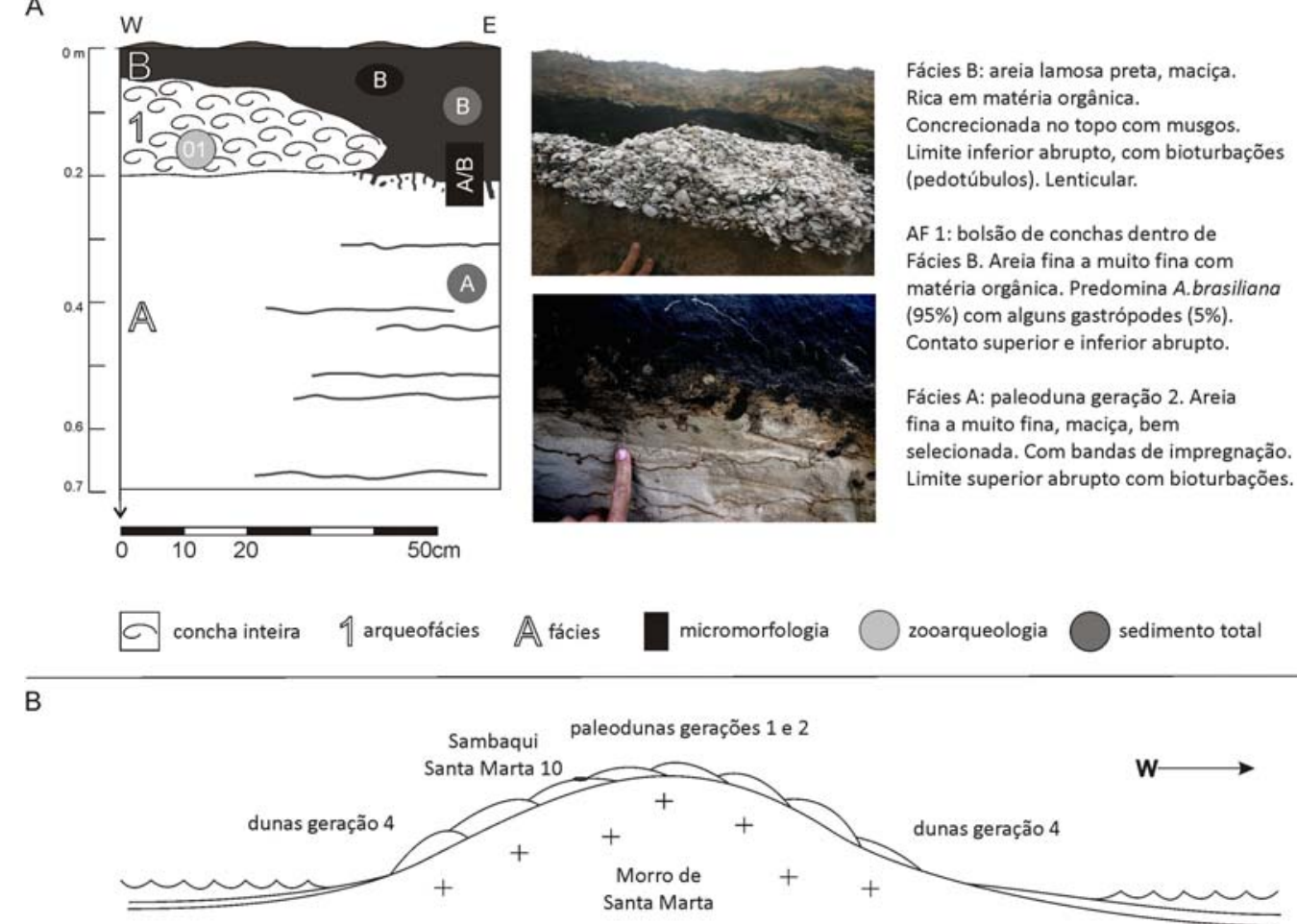

Figura 5.63. Seção vertical estudada do sítio Santa Marta 10: A) localização dos pontos de amostragem e descrição das arqueofácies identificadas; B) seção transversal esquemática (sem escala) da área de localização do sítio.

\section{$\underline{\text { Granulometria }}$}

Análises granulométricas da fração terrígena foram realizadas nas Fácies A e B, identificadas no sambaqui, e na Fácies B2 em área externa ao sítio onde se observou uma sucessão de fácies de areia fina (Fácies A2) sobreposta por fácies centimétrica de areia lamosa preta (Fácies B2) (Figura 5.64). As distribuições granulométricas da Figura 5.65 têm moda na fração areia fina. O leve aumento na concentração de areia média, em detrimento da areia muito fina, nas Fácies B e B2 em comparação com A, permite sugerir que estas fácies, mais expostas, possuem caráter mais deflacionar que a subjacente. $\mathrm{O}$ fato de esta concentração de areia média ser mais pronunciada em $\mathrm{B}$, situada no sambaqui, de que em B2, fora dele, indica também que o sítio pode ter funcionado como armadilha de material grosso. Esta tendência de acumulação de fração grossa no sítio é confirmada mediante o exame do diâmetro médio, cujo valor é mais grosso no sambaqui (Fácies A e B, identificadas como SM10) que na amostra externa a ele (Fácies B2, identificada como SM10*) (Figura 5.65 B). A comparação das estatísticas das análises granulométricas das Fácies A, B e B2, com os dados 
recuperados de Giannini (1993), Giannini et al. (2007), Martinho (2004) e Sawakuchi (2003) em sedimentos de geração eólica 2, na porção que vai do Cabo de Santa Marta até a praia Grande do Sul, mostram certa afinidade destes sedimentos com os depósitos eólicos (Figura 5.65 B).

No entanto, os dados para a geração eólica 2 mostram maior teor de grossos que nas amostras coletadas dentro e nas proximidades do sambaqui Santa Marta 10. Esta diferença pode-se dever ao fato de que só areia eólica mais fina consegue chegar no alto do morro. A comparação foi feita com base a distribuições de fração areia de amostras coletadas em vários afloramentos de geração eólica 2 e não exclusivamente do Morro de Santa Marta.
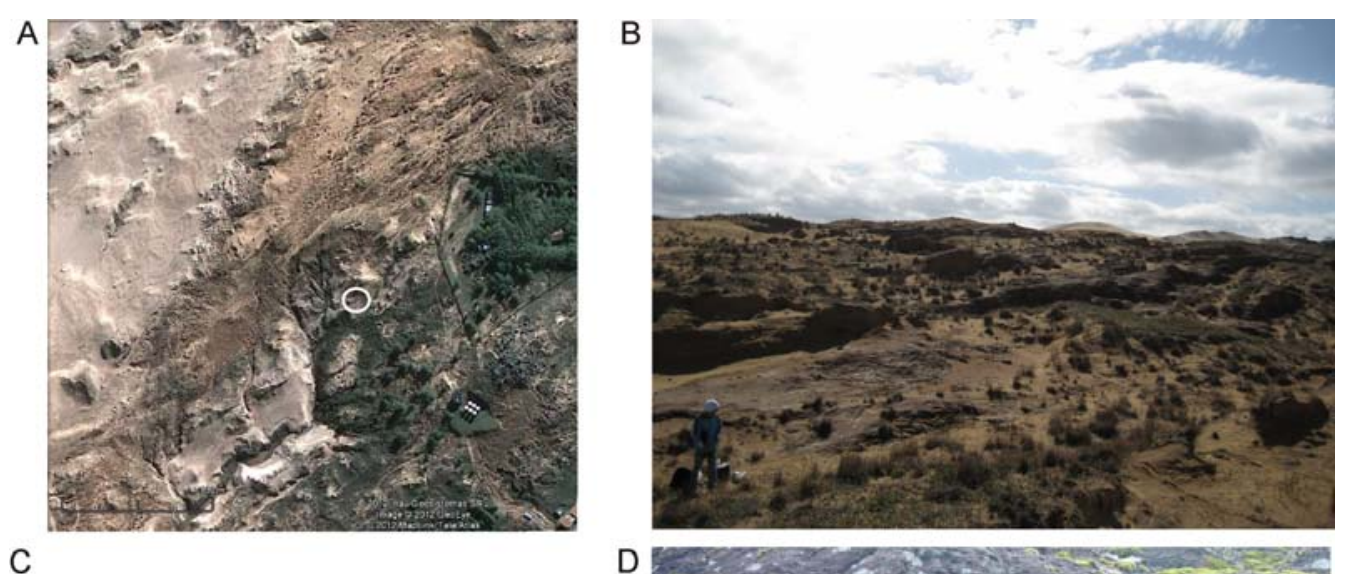

$$
\begin{aligned}
& \text { Fácies B }(0-10 \mathrm{~cm}) \text { : areia lamosa } \\
& \text { preta }(10 \text { Y } 2 / 1) \text {, com contato } \\
& \text { inferior abrupto e com } \\
& \text { bioturbações. }
\end{aligned}
$$

Fácies $A(>10 \mathrm{~cm})$ : areia fina, maciça, bem selecionada, amarela (10YR 6/3), com bandas de impregnação.

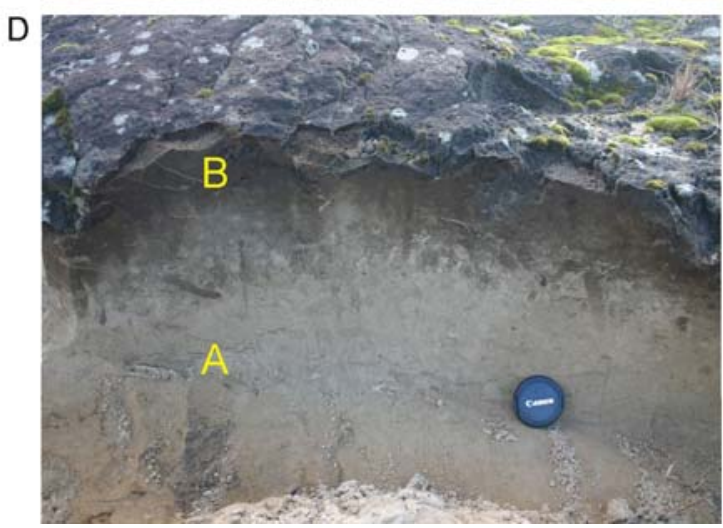

Figura 5.64. Amostragem externa ao sítio Santa Marta 10: A) localização do ponto de amostragem; B) entorno de localização; C) descrição das fácies identificadas; D) trincheira amostrada com localização das fácies. 

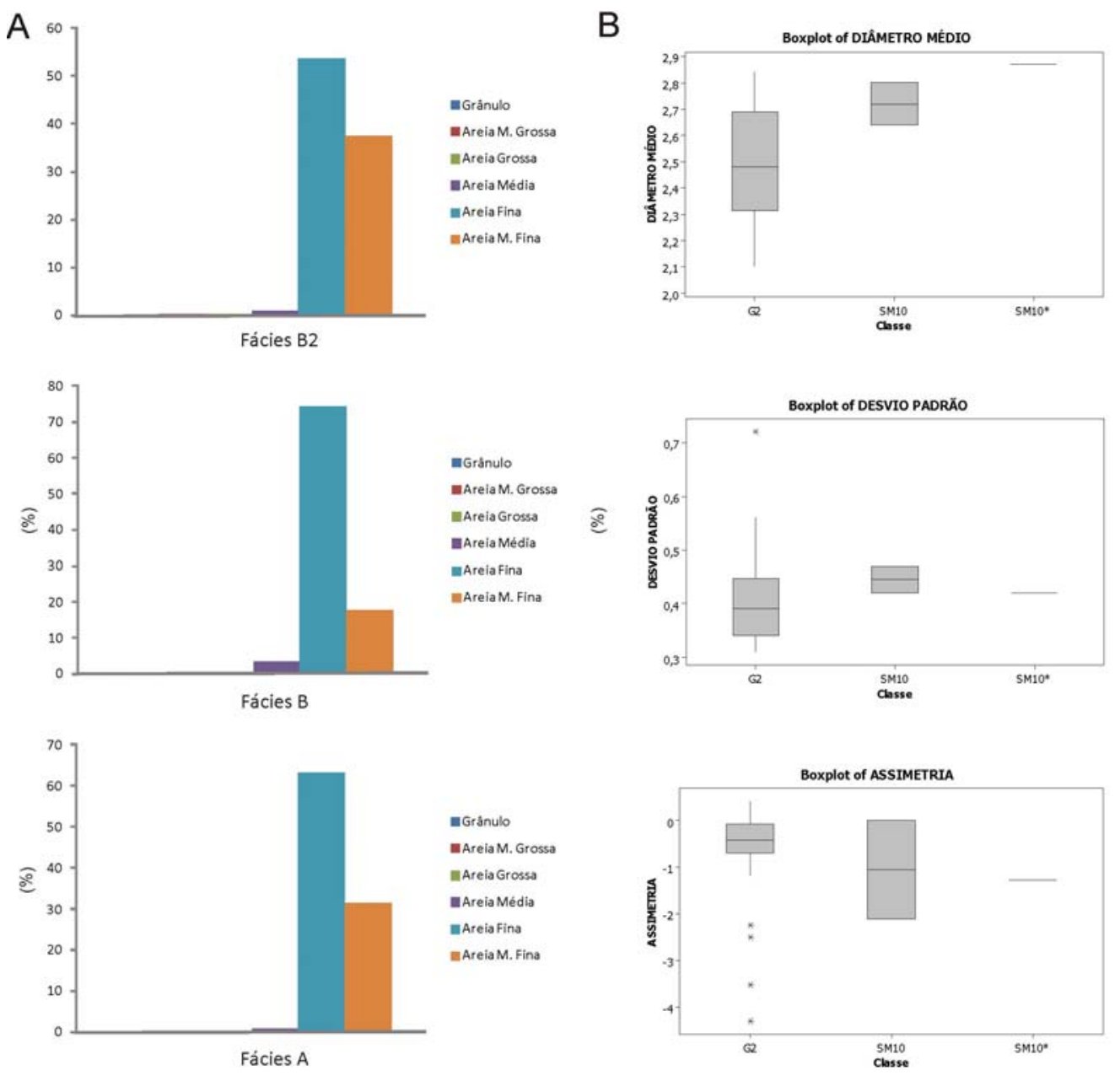

Figura 5.65. Gráficos das distribuições granulométricas e estatísticas descritivas para o sítio Santa Marta 10 e amostras de sedimentos naturais das proximidades: A) histogramas da distribuição granulométrica para as Fácies A e B identificadas no sítio Santa Marta 10 e Fácies B2 do ponto de amostragem externa ao sambaqui; note-se o domínio da fração areia fina em todas as amostras; B) diagramas em caixa (boxplot) das estatísticas diâmetro médio, desvio padrão e assimetria para amostra da Fácies $\mathrm{B}$ do sítio Santa Marta 10 (SM10), das Fácies A e B2 da amostragem externa (SM10*) e das amostras da geração de dunas eólicas 2 (G2) tomadas de Giannini et al. (2007), Giannini (1993), Martinho (2004) e Sawakuchi (2003).

\section{Isótopos de $C$ e $N\left(\delta^{13} C\right.$ e $\left.\delta^{53} N\right)$}

Os estudos isotópicos $\left(\delta^{13} \mathrm{C}, \delta^{15} \mathrm{~N}\right.$ e razão $\left.\mathrm{C} / \mathrm{N}\right)$ realizados na $\mathrm{MO}$ das Fácies B e B2 (Anexo, Tabela A.1) mostram que, em ambos os casos, existem restos de plantas de ciclo fotossintético $\mathrm{C}_{3}$, segundo intervalos definidos por Boutton (1996), Lamb et al. (2006), Meyers (1997), Sifeddine et al. (2004) e White (2001) (Figura 5.66).

No caso da Fácies B2, a assinatura isotópica de plantas $C_{3}$ pode representar a vegetação que atualmente se desenvolve sobre as paleodunas de geração 2 no local de estudo. No campo, observou-se sobre os afloramentos de paleodunas a presença de 
musgos, que pertencem ao grupo de plantas de ciclo fotossintético $\mathrm{C}_{3}$ (Raven et al., 1998; Skrzypek et al., 2007 a, 2007b). Na Fácies B, que se limita à área compreendida pelo sítio arqueológico, a diferença em coloração e espessura do horizonte orgânico em relação à Fácies B2, fora do sítio, indica que outro processo, diferente da colonização da duna por musgos, poderia ser também responsável pela acumulação de espécies $\mathrm{C}_{3}$ no local. Este processo estaria vinculado á ocupação humana e deposição antrópica de restos vegetais derivados, principalmente, de espécies arbustivas. Estes resíduos podem vincular-se à deposição antrópica direta das plantas, ou aos remanentes da queima de tronco e galhos no sambaqui.
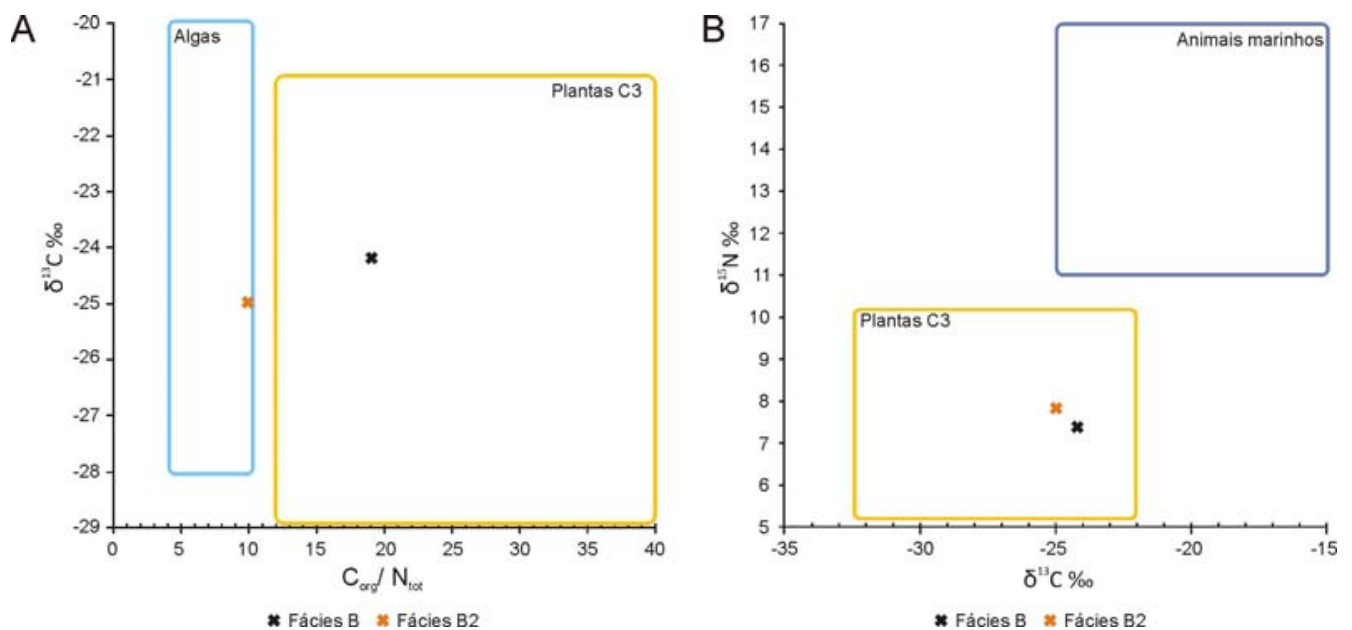

Figura 5.66. Análises isotópicas $\left(\delta^{13} \mathrm{C}\right.$ e $\delta^{15} \mathrm{~N}$ e razão $\left.\mathrm{C} / \mathrm{N}\right)$ de amostras provenientes das Fácies $\mathrm{B}$ e $\mathrm{B} 2$ do sítio Santa Marta 10: A) gráfico de valores de $\delta^{13} \mathrm{C}$ e razão $\mathrm{C} / \mathrm{N}$ com intervalos definidos para plantas de ciclo fotossintético $\mathrm{C} 3$ e algas; B) gráfico dos valores de $\delta^{15} \mathrm{~N}$ e $\delta^{13} \mathrm{C}$, com intervalos definidos para plantas de ciclo fotossintético $\mathrm{C} 3$ e animais marinhos.

\section{Micromorfologia}

Três amostras para micromorfologia foram coletadas do sítio Santa Marta 10: uma da transição entra as Fácies A e B, outra da Fácies B e uma última da Fácies B2, obtida, em área externa ao sítio, da camada superficial marrom escuro sobre paleoduna (Figura 5.67; Tabela 5.20). Duas microfácies foram identificadas na amostra SM10 A/B (mF A e mF B) assim como na amostra SM10 B2 (mF A2 e B2). A composição, freqüência, distribuição, granulometria, forma e arredondamento dos componentes da fração grossa (quartzo, feldspato, minerais pesados, minerais opacos e clastos de argila) de todas as amostras são semelhantes entre si (Figura 5.68 A; Tabela 5.21-5.23). 


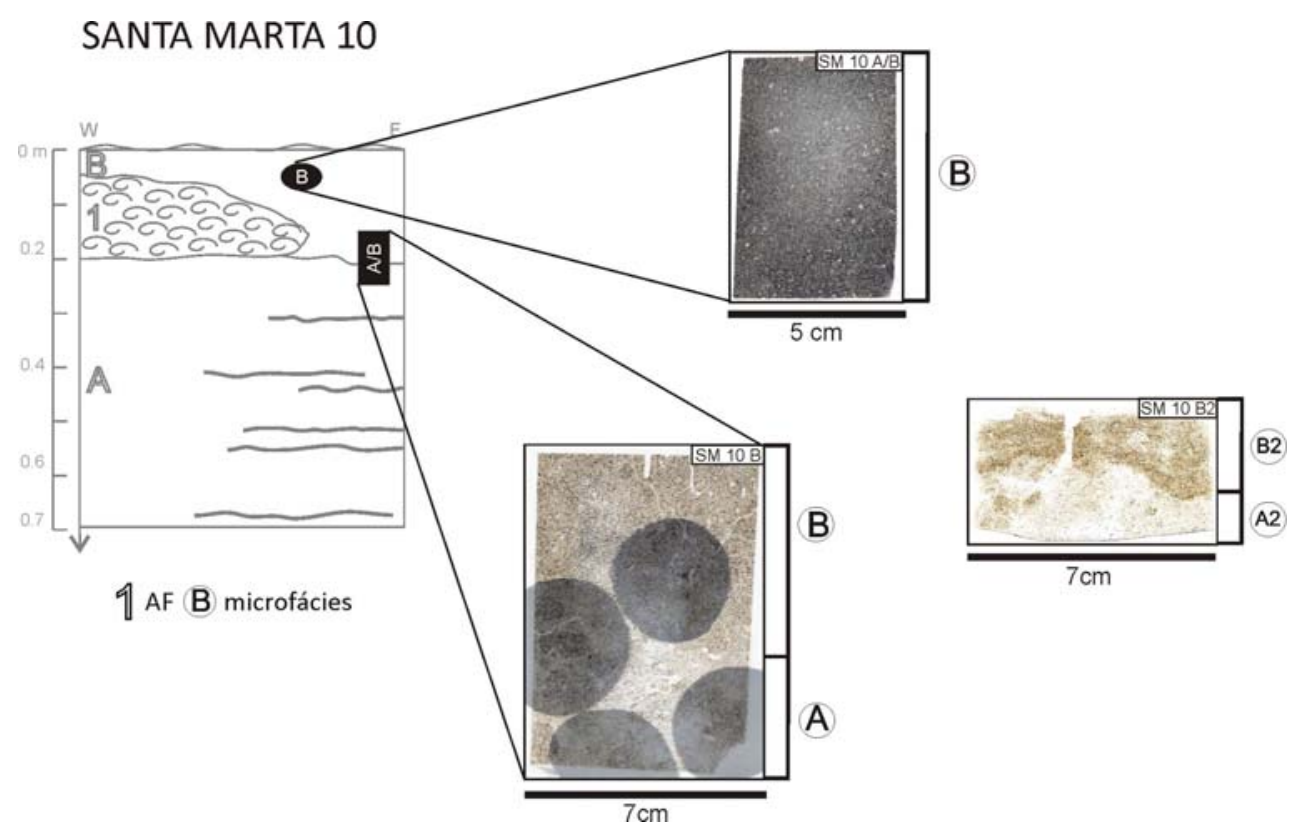

Figura 5.67. Seções delgadas analisadas no sítio Santa Marta 10 (amotras SM 10 A e SM 10 A/B) e fora do sítio (SM 10 B2), com localização dos blocos de amostragem na sucessão vertical e identificação de microfácies na lâmina.
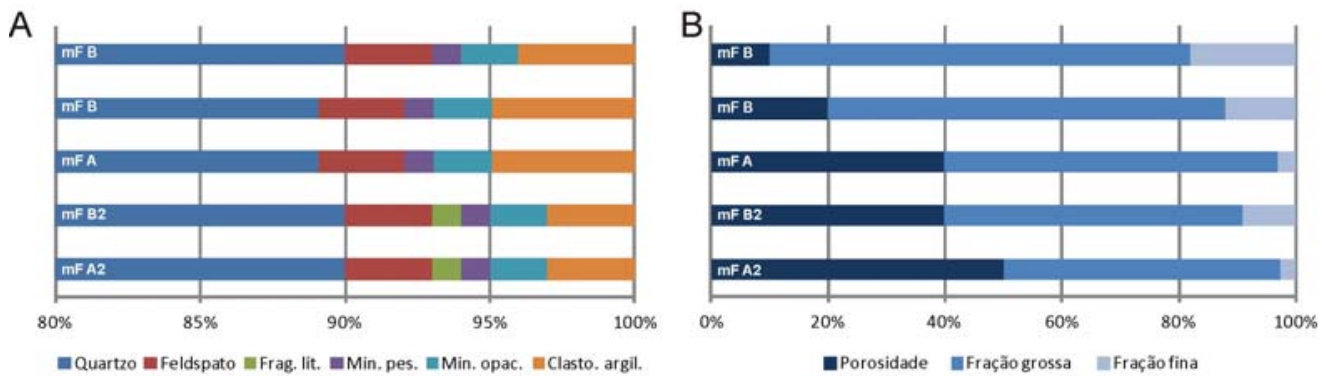

Figura 5.68. Gráficos com porcentagens dos diferentes componentes microscópicos das microfácies identificadas nas Fácies A (mF A), B (mF B), A2 (mF A2) e B2 (mF B2) do sítio Santa Marta 10: A) freqüências de componentes da fração grossa; B) relação entre as porcentagens de poros, fração grossa e fração fina. 
Tabela 5.20. Descrição micromorfológica do sambaqui Santa Marta 10.

\begin{tabular}{|c|c|c|c|c|c|c|c|c|c|c|c|c|c|c|c|c|c|c|c|c|c|c|}
\hline \multirow[b]{2}{*}{ Am. } & \multirow[b]{2}{*}{$\mathbf{m F}$} & \multirow[b]{2}{*}{ 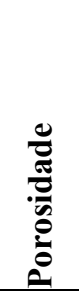 } & \multirow[b]{2}{*}{$\%$} & \multirow[b]{2}{*}{ 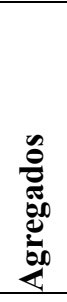 } & \multirow[b]{2}{*}{ Tam. } & \multirow[b]{2}{*}{ Microestrutura } & \multirow[b]{2}{*}{ స్తు } & \multirow[b]{2}{*}{ 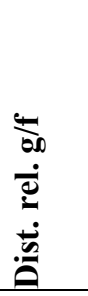 } & \multirow[b]{2}{*}{ 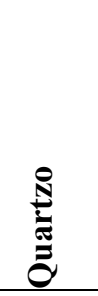 } & \multicolumn{4}{|c|}{ Fr. min. gr. } & \multirow[b]{2}{*}{ 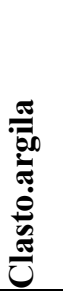 } & \multicolumn{2}{|c|}{$\begin{array}{c}\text { Fr. org. } \\
\text { gr. }\end{array}$} & \multicolumn{5}{|c|}{ Micromassa } & \multirow[b]{2}{*}{ FP } \\
\hline & & & & & & & & & & 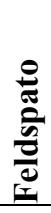 & 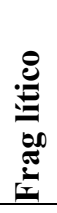 & 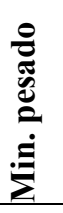 & 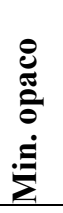 & & 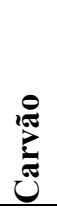 & 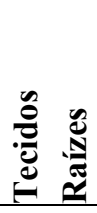 & نे & $\%$ & 党 & 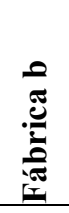 & Composição & \\
\hline \multirow[t]{2}{*}{ A-B } & A & $\begin{array}{l}\text { e-s } \\
\text { e-cx } \\
\text { cn }\end{array}$ & 40 & gr & $\sim 50 \mu \mathrm{m}$ & $\begin{array}{l}\text { Grãos simples e } \\
\text { revestidos }\end{array}$ & $95 / 5$ & quit & $\cdots \cdots$ & - & & • & • & • & & & & & op & ind & $\begin{array}{l}\text { Matéria } \\
\text { orgânica } \\
\text { monomórfica }\end{array}$ & rev \\
\hline & B & $\begin{array}{l}\text { e-cx } \\
\text { cn } \\
\text { vs }\end{array}$ & 20 & gr & $\begin{array}{l}50- \\
100 \mu \mathrm{m}\end{array}$ & Grãos revestidos & $85 / 15$ & quit & $\cdots \cdots$ & - & & • & - & - & & & & & op & ind & $\begin{array}{l}\text { Matéria } \\
\text { orgânica } \\
\text { monomórfica }\end{array}$ & rev \\
\hline B & & $e-c x$ & 10 & gr & $\begin{array}{l}50- \\
100 \mu \mathrm{m}\end{array}$ & $\begin{array}{l}\text { Grãos revestidos } \\
\text { e microagregados } \\
\text { intergranulares }\end{array}$ & $80 / 20$ & $\begin{array}{l}\text { quit } \\
\text { gef } \\
\text { en }\end{array}$ & $\cdots \cdots \bullet$ & - & & • & $\bullet$ & - & & & & & op & ind & $\begin{array}{l}\text { Matéria } \\
\text { orgânica } \\
\text { monomórfica }\end{array}$ & rev \\
\hline \multirow[t]{2}{*}{ B2 } & B2 & e-s & & gr & $\sim 50 \mu \mathrm{m}$ & $\begin{array}{l}\text { Grãos simples e } \\
\text { revestidos }\end{array}$ & $95 / 5$ & $\begin{array}{l}\text { mon } \\
\text { quit }\end{array}$ & $\cdots \cdots$ & - & - & • & $\bullet$ & - & & & & & op & ind & $\begin{array}{l}\text { Matéria } \\
\text { orgânica } \\
\text { monomórfica }\end{array}$ & rev \\
\hline & $\mathrm{A} 2$ & e-cx & & gr & $\sim 50 \mu \mathrm{m}$ & $\begin{array}{l}\text { Grãos revestidos } \\
\text { e interligados }\end{array}$ & $85 / 15$ & $\begin{array}{l}\text { quit } \\
\text { gef }\end{array}$ & $\cdots \cdots \bullet$ & • & • & • & • & • & & & & & & mo & Argila iluvial, & $\begin{array}{l}\text { rev } \\
\text { ench }\end{array}$ \\
\hline
\end{tabular}

Freqüências de classes segundo Bullock et al. (1985): • Muito Poucas (<5\%); •• Poucas (5-15\%); ••• Comum (15-30\%) ; •••• Freqüente (30-50\%); ••••• Dominante (50-70\%); ..... Muito dominante $(>70 \%)$. Am. = amostra; $\mathrm{mF}=$ microfácies; Tam.= tamanho; Fr. min. gr. = fração mineral grossa; Fr. org. gr. = fração orgânica grossa; FP = feições pedológicas. O singificado das demais abreviações utilizadas nesta tabela encontra-se no Anexo, Tabela A.5. 
Tabela 5.21. Componentes minerais e orgânicos da fração grossa da amostra SM10 A/B.

\begin{tabular}{|c|c|c|c|c|c|c|c|c|c|c|}
\hline \multicolumn{11}{|l|}{$\begin{array}{l}\text { SM10 } \\
\text { A-B }\end{array}$} \\
\hline & $\mathbf{m F}$ & $\%$ & Tamanho & Forma & Arredondamento & Seleção & $\begin{array}{c}\text { Distribuição } \\
\text { básica }\end{array}$ & $\begin{array}{l}\text { Orientação } \\
\text { básica }\end{array}$ & $\begin{array}{l}\text { Distribuição } \\
\text { referenciada }\end{array}$ & Alteração \\
\hline Quartzo & $\mathrm{B}$ & 90 & $\begin{array}{l}\text { Areia fina a } \\
\text { mto. fina }\end{array}$ & Equidimensional & $\begin{array}{l}\text { Subarredondado e } \\
\text { subanguloso }\end{array}$ & Bem selecionado & Aleatória & 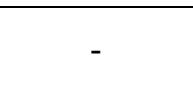 & 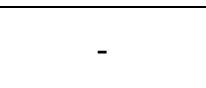 & 3 \\
\hline Feldspato & B & 3 & Areia mto. fina & Equidimensional & $\begin{array}{l}\text { Subarredondado e } \\
\text { subanguloso }\end{array}$ & $\begin{array}{l}\text { Mto. bem } \\
\text { selecionado }\end{array}$ & Aleatória & - & - & - \\
\hline Min. pes. & B & 1 & Areia mto. fina & Equidimensional & Arredondado & $\begin{array}{l}\text { Mto. bem } \\
\text { selecionado }\end{array}$ & Aleatória & - & - & - \\
\hline Min. op. & B & 2 & Areia mto. fina & Equidimensional & Arredondado & $\begin{array}{l}\text { Mto. bem } \\
\text { selecionado }\end{array}$ & Aleatória & - & - & - \\
\hline Clas. arg. & B & 4 & Areia mto. fina & Equidimensional & Arredondado & $\begin{array}{l}\text { Mto. bem } \\
\text { selecionado }\end{array}$ & Aleatória & - & - & - \\
\hline Quartzo & A & 90 & $\begin{array}{l}\text { Areia fina a } \\
\text { mto. fina }\end{array}$ & Equidimensional & $\begin{array}{l}\text { Arredondado e } \\
\text { subarredondado }\end{array}$ & Bem selecionado & Aleatória & - & - & - \\
\hline Feldspato & A & 3 & Areia mto. fina & Equidimensional & $\begin{array}{l}\text { Subarredondado e } \\
\text { subanguloso }\end{array}$ & $\begin{array}{l}\text { Mto. bem } \\
\text { selecionado }\end{array}$ & Aleatória & - & - & - \\
\hline Min. pes. & A & 1 & Areia mto. fina & Equidimensional & Arredondado & $\begin{array}{l}\text { Mto. bem } \\
\text { selecionado }\end{array}$ & Aleatória & - & - & - \\
\hline Min. op. & A & 2 & Areia mto. fina & - & Arredondado & $\begin{array}{l}\text { Mto. bem } \\
\text { selecionado }\end{array}$ & Aleatória & - & - & - \\
\hline Clas. arg. & A & 4 & Areia mto. fina & Equidimensional & Arredondado & $\begin{array}{c}\text { Mto. bem } \\
\text { selecionado }\end{array}$ & Aleatória & - & - & - \\
\hline
\end{tabular}


Tabela 5.22. Componentes minerais e orgânicos da fração grossa da amostra SM10 B.

\begin{tabular}{|c|c|c|c|c|c|c|c|c|c|c|}
\hline \multicolumn{11}{|l|}{ SM10 B } \\
\hline & $\mathbf{m F}$ & $\%$ & Tamanho & Forma & Arredondamento & Seleção & $\begin{array}{c}\text { Distribuição } \\
\text { básica }\end{array}$ & $\begin{array}{c}\text { Orientação } \\
\text { básica }\end{array}$ & $\begin{array}{l}\text { Distribuição } \\
\text { referenciada }\end{array}$ & Alteração \\
\hline Quartzo & & 90 & $\begin{array}{l}\text { Areia fina a } \\
\text { mto. fina }\end{array}$ & Equidimensional & $\begin{array}{l}\text { Subarredondado e } \\
\text { subanguloso }\end{array}$ & Bem selecionado & Aleatória & worston & (2) & 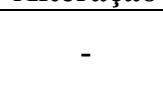 \\
\hline Feldspato & & 3 & Areia mto. fina & Equidimensional & $\begin{array}{l}\text { Subarredondado e } \\
\text { subanguloso }\end{array}$ & $\begin{array}{c}\text { Mto. bem } \\
\text { selecionado }\end{array}$ & Aleatória & - & - & - \\
\hline Min. pes. & & 1 & Areia mto. fina & Equidimensional & Arredondado & $\begin{array}{c}\text { Mto. bem } \\
\text { selecionado }\end{array}$ & Aleatória & - & - & - \\
\hline Min. op. & & 2 & Areia mto. fina & Equidimensional & Arredondado & $\begin{array}{c}\text { Mto. bem } \\
\text { selecionado }\end{array}$ & Aleatória & - & - & - \\
\hline Clas. arg. & & 4 & Areia mto. fina & Equidimensional & Arredondado & $\begin{array}{c}\text { Mto. bem } \\
\text { selecionado }\end{array}$ & Aleatória & - & - & - \\
\hline
\end{tabular}


Tabela 5.23. Componentes minerais e orgânicos da fração grossa da amostra SM10 B2.

\begin{tabular}{|c|c|c|c|c|c|c|c|c|c|c|}
\hline \multicolumn{11}{|l|}{ SM10 B2 } \\
\hline & $\mathbf{m F}$ & $\%$ & Tamanho & Forma & Arredondamento & Seleção & $\begin{array}{c}\text { Distribuição } \\
\text { básica }\end{array}$ & $\begin{array}{c}\text { Orientação } \\
\text { básica }\end{array}$ & $\begin{array}{l}\text { Distribuição } \\
\text { referenciada }\end{array}$ & Alteração \\
\hline Quartzo & $\mathrm{B} 2$ & 90 & $\begin{array}{l}\text { Areia fina a } \\
\text { mto. fina }\end{array}$ & Equidimensional & $\begin{array}{l}\text { Subarredondado e } \\
\text { subanguloso }\end{array}$ & Bem selecionado & Aleatória & 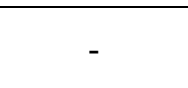 & 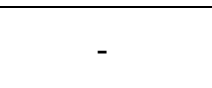 & $x_{3}$ \\
\hline Feldspato & B2 & 3 & Areia mto. fina & Equidimensional & $\begin{array}{l}\text { Subarredondado e } \\
\text { subanguloso }\end{array}$ & $\begin{array}{l}\text { Mto. bem } \\
\text { selecionado }\end{array}$ & Aleatória & - & - & - \\
\hline Frag.lítico & $\mathrm{B} 2$ & 1 & Areia mto. fina & $\begin{array}{l}\text { Equidimensional } \\
\text { cilíndrico }\end{array}$ & $\begin{array}{l}\text { Arredondado e } \\
\text { subarredondado }\end{array}$ & Bem selecionado & Aleatória & - & - & - \\
\hline Min. pes. & B2 & 2 & Areia mto. fina & Equidimensional & Arredondado & $\begin{array}{l}\text { Mto. bem } \\
\text { selecionado }\end{array}$ & Aleatória & - & - & - \\
\hline Min. op. & B2 & 1 & Areia mto. fina & Equidimensional & Arredondado & $\begin{array}{l}\text { Mto. bem } \\
\text { selecionado }\end{array}$ & Aleatória & - & - & - \\
\hline Clas. arg. & B2 & 3 & Areia mto. fina & Equidimensional & Arredondado & $\begin{array}{c}\text { Mto. bem } \\
\text { selecionado }\end{array}$ & Aleatória & - & - & - \\
\hline Quartzo & $\mathrm{A} 2$ & 90 & $\begin{array}{l}\text { Areia fina a } \\
\text { mto. fina }\end{array}$ & Equidimensional & $\begin{array}{l}\text { Subarredondado e } \\
\text { subanguloso }\end{array}$ & Bem selecionado & Aleatória & - & - & - \\
\hline Feldspato & $\mathrm{A} 2$ & 3 & Areia mto. fina & Equidimensional & $\begin{array}{l}\text { Subarredondado e } \\
\text { subanguloso }\end{array}$ & $\begin{array}{l}\text { Mto. bem } \\
\text { selecionado }\end{array}$ & Aleatória & - & - & - \\
\hline Frag.lítico & $\mathrm{A} 2$ & 1 & Areia mto. fina & $\begin{array}{l}\text { Equidimensional } \\
\text { cilíndrico }\end{array}$ & $\begin{array}{l}\text { Arredondado e } \\
\text { subarredondado }\end{array}$ & Bem selecionado & Aleatória & - & - & - \\
\hline Min. pes. & $\mathrm{A} 2$ & 2 & Areia mto. fina & Equidimensional & Arredondado & $\begin{array}{l}\text { Mto. bem } \\
\text { selecionado }\end{array}$ & Aleatória & - & - & - \\
\hline Min. op. & A2 & 1 & Areia mto. fina & Equidimensional & Arredondado & $\begin{array}{l}\text { Mto. bem } \\
\text { selecionado }\end{array}$ & Aleatória & - & - & - \\
\hline Clas. arg. & $\mathrm{A} 2$ & 3 & Areia mto. fina & Equidimensional & Arredondado & $\begin{array}{l}\text { Mto. bem } \\
\text { selecionado }\end{array}$ & Aleatória & - & - & - \\
\hline
\end{tabular}


As características da fração grossa são condizentes com as encontradas por Martinho e Giannini (2001), em estudo petrográfico, nas paleodunas de geração eólica 2 do Morro de Santa Marta. Segundo os autores, a granulometria modal destes depósitos eólicos é areia fina a muito fina, com empacotamento aberto e cimento formado por argilominerais. A fração grossa, ou arcabouço segundo a terminologia utilizada na petrografia sedimentar, é formada por quartzo (83-89\%), seguido de componentes líticos extra e intraclásticos (8 a $13 \%$ ) e grãos de feldspato (2 \%). Dentre os componentes líticos que se mencionam no trabalho de Martinho e Giannini (2001), predominam os clastos de argila arredondados, assim como nas observações realizadas nesta tese (Figura 5.68 A; Figura 5.69 A, B), junto com minerais pessados opacos e anisotrópicos (Figura 5.68 A; Figura 5.69 C,D). As mF A e A2 são as que apresentam a maior semelhança com as descrições de Martinho \& Giannini (2001) para dunas de geração eólica 2, com microestrutura de grãos simples e revestidos por $\mathrm{MO}$, em A, e argilominerais, em A2 (Figura 5.70).

Todas as amostras analisadas apresentam fração fina na forma de revestimentos contínuos ao redor dos grãos minerais, que resulta em microestrutura de grãos revestidos e/ou interligados e distribuição relacionada $\mathrm{g} / \mathrm{f}$ de tipo quitônico e gefúrico, com ocasionais agregados integranulares na Fácies B (com microestrutura de microagregados intergranulares e distribuição relacionada $\mathrm{g} / \mathrm{f}$ de tipo enáulico). A diferença maior entre as amostras refere à presença de fração fina composta por MO monomórfica na sucessão estratigráfica do sítio Santa Marta 10 (mF A e B), contrário à matriz de argila mineral que caracteriza os sedimentos eólicos extra-sítio (mF A2 e B2). Em termos gerais, as mF A e A2 são mais porosas e com menor teor de fração fina que as $\mathrm{mF}$ B e B2 (Figura 5.68 B).

$\mathrm{Na} \mathrm{mF}$ B, observou-se a presença de revestimentos de MO monomórfica ao redor dos grãos minerais. Estes revestimentos são indicadores de horizontes B espódicos (Buurman and Jongmans, 2005; Wilson and Righi, 2010) (Figuras 5.71). As gretas que se observam nos revestimentos e em alguns dos agregados de MO são interpretadas como feições de dessecamento de gels de MO altamente hidratados (Buurman \& Jongmans, 2005; De Connick 1980). Nos agregados, as gretas de dessecação, formadas pela dissecação e dissolução de finos, são descritas como porosidade cavitária policôncava e indicam, junto com a subdivisão dos agregados de MO em unidades menores, processos de despodzolização (Coelho, 2008) (Figura 5.71 F). 
$\mathrm{Na}$ mF B2, observaram-se múltiplos revestimentos de argila microlaminados, de cor marrom avermelhado (PPL), contínuos ao redor dos grãos e pendentes nos poros, junto com alguns enchimentos de argila microlaminada (Figura 5.72). Na mF A2, encontraram-se revestimentos de MO monomórfica, mas em quantidade e espessura menor que o observado na Fácies B.

As mF B e B2, apesar de terem sido desenvolvidas sobre o mesmo substrato de paleoduna eólica, diferenciam-se pela microestrutura e composição da fração fina. $\mathrm{Na}$ mF B2, a microestrutura é de grãos revestidos e interligados por revestimentos de argilominerais, enquanto na $\mathrm{mF} \mathrm{B}$ a microestrutura é de grãos revestidos por $\mathrm{MO}$ monomórfica. A composição semiquantitativa da fração fina na $\mathrm{mF} B$ foi determinada por sistema MEV-EED. Os agregados e revestimentos pretos que se observam na seção delgada estão compostos por Si ( 34\%), Al ( 11\%), Fe $(\sim 2-3 \%), \mathrm{Na}(\sim 2 \%)$, Ca $(\sim 1.5 \%), \mathrm{K}(\sim 1 \%)$ e $\mathrm{Mg}(0.8 \%)$ (Anexo, Figura A.6). A composição indica a presença de compostos de $\mathrm{Al}$ junto à $\mathrm{MO}$, como seria esperável em horizontes espódicos cimentados, nos quais a MO monomórfica aparece complexada a compostos metálicos (Van Breemen and Buurman, 2003; De Connick, 1980).
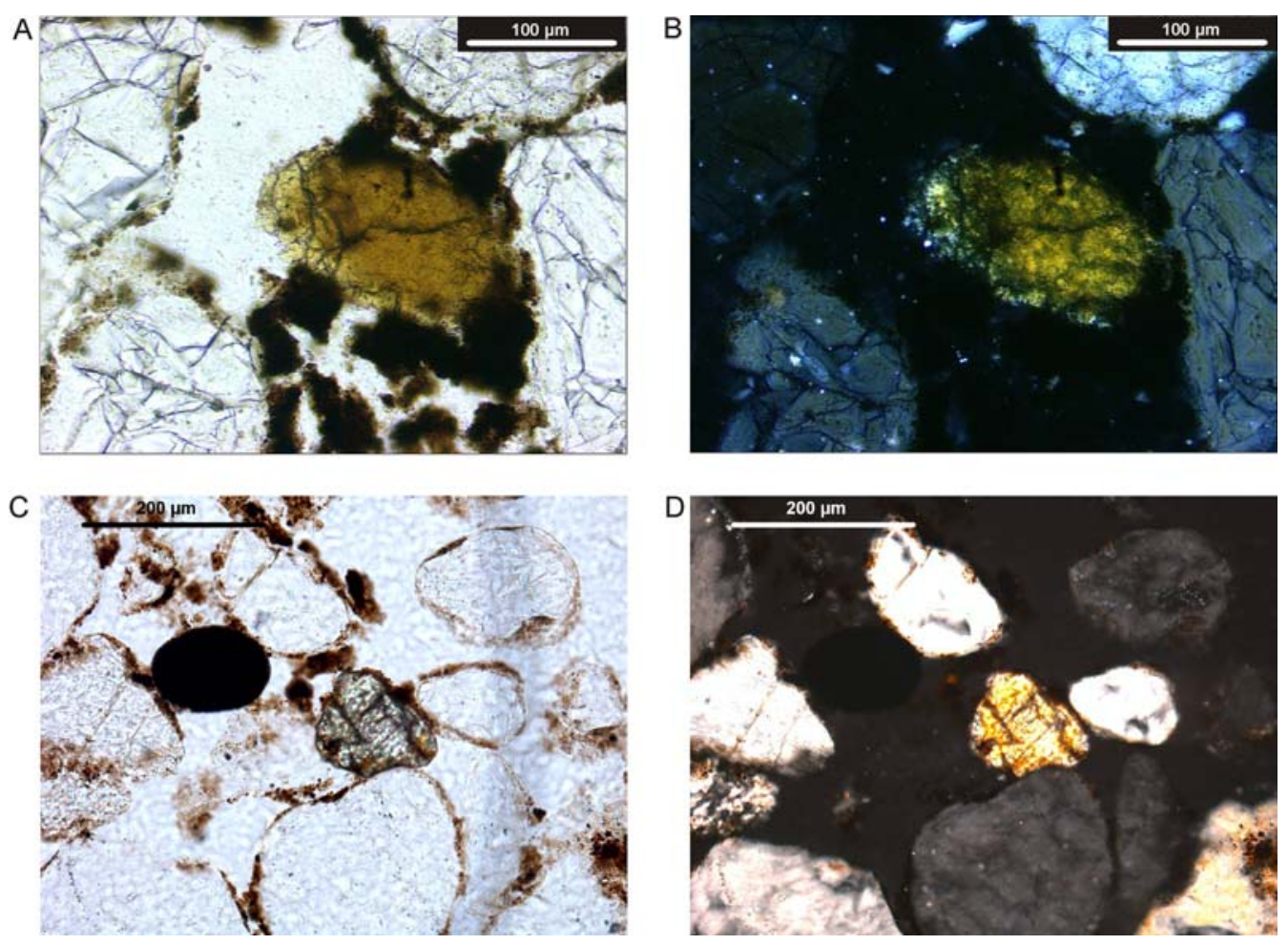

Figura 5.69. Fotomicrografias de grãos minerais no sítio Santa Marta 10: A, B) mineral opaco e mineral pesado anisotrópico, PPL e XPL; C, D) clasto de argila. Pelas suas propriedades ópticas, como coloração esverdeada (PPL) e cor de interferência laranja os clastos de argila poderiam ser esmectita ou glauconita. 
A presença de revestimentos orgânicos no sítio arqueológico e de revestimentos de argilominerais na área imediatamente externa deve-se à ação do mesmo processo de transporte de $\mathrm{MO}$ e compostos de $\mathrm{Al}$ e/ou Fe em solução ao longo do perfil. A única diferença está em que, na área externa ao sítio, existiu uma acumulação de argilominerais que foi erodida, e que favoreceu a migração de argila em dispersão ao longo do perfil pela ação das chuvas; enquanto no sambaqui, foi a acumulação de resíduos orgânicos o que favoreceu a produção e migração de ácidos orgânicos. A disponibilidade de cátions de $\mathrm{Fe}$ ou $\mathrm{Al}$ em certas partes do perfil, derivados do intemperismo dos feldspatos ou minerais pesados, teria provocado a floculação da MO e dos argilominerais, na forma de agregados intergranulares e/ou revestimentos ao redor dos grãos.

A
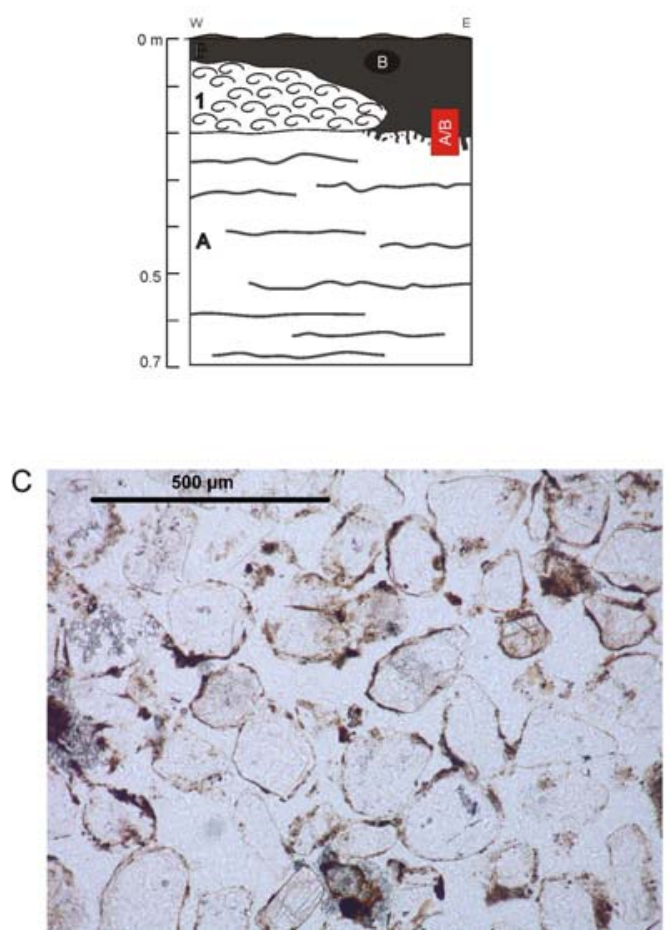
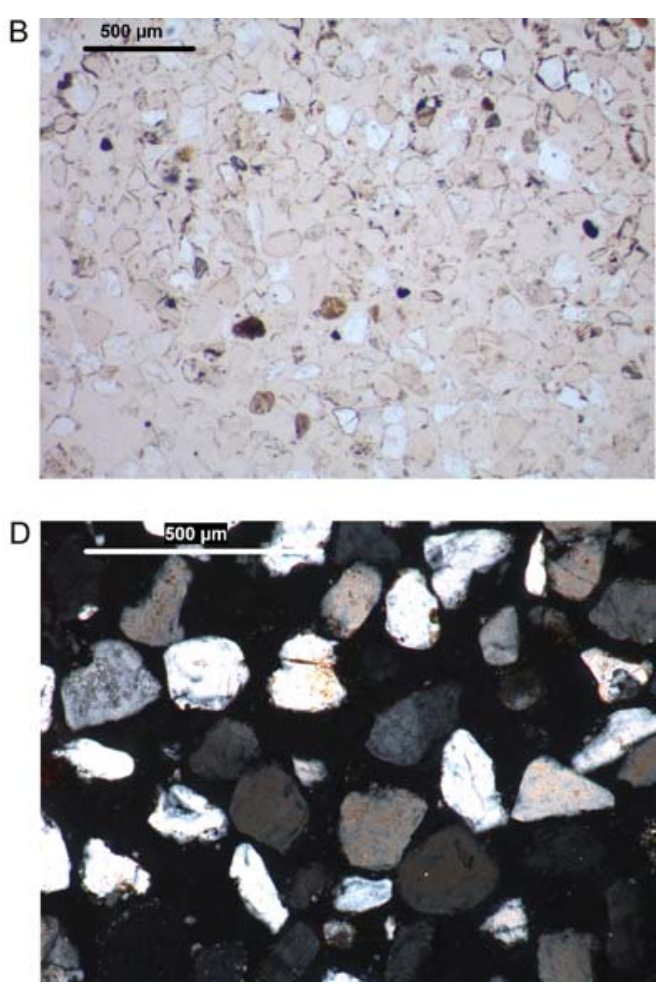

Figura 5.70. Fotomicrografias da mF A do sítio Santa Marta 10: A) seção vertical esquemática, com localização da amostra para micromorfologia; B) massa basal composta por grãos de quartzo, feldspato, minerais pesados e opacos, PPL; C, D) detalhe dos revestimentos delgados de MO ao redor dos grãos minerais, PPL e XPL. 
A

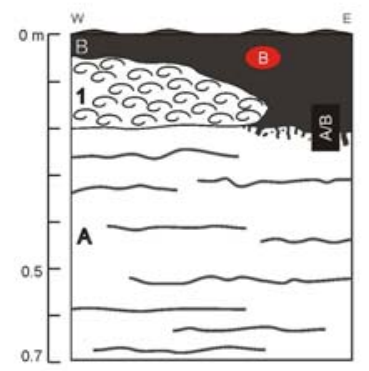

C
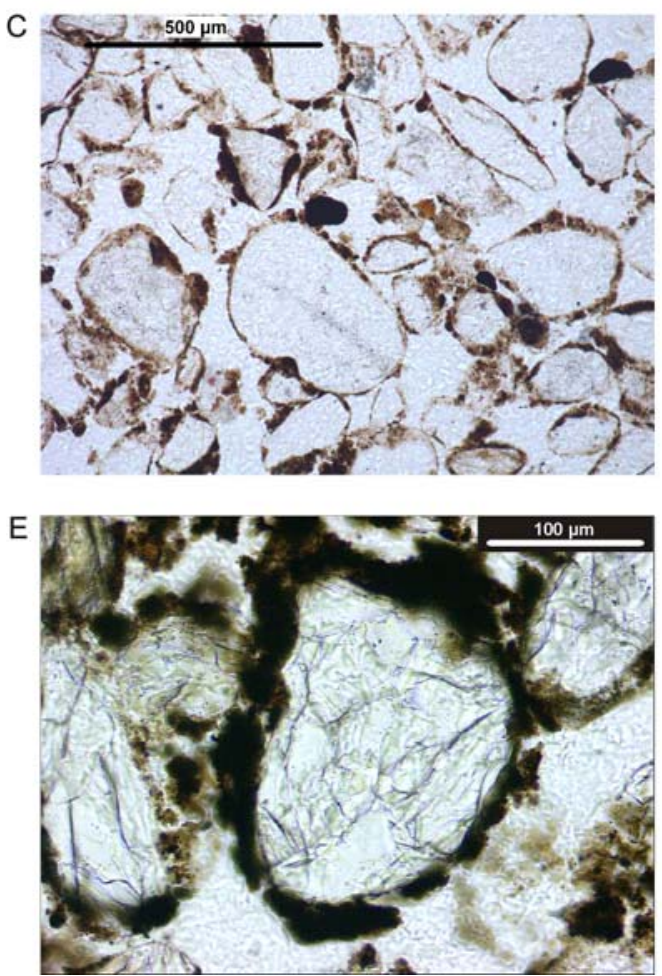
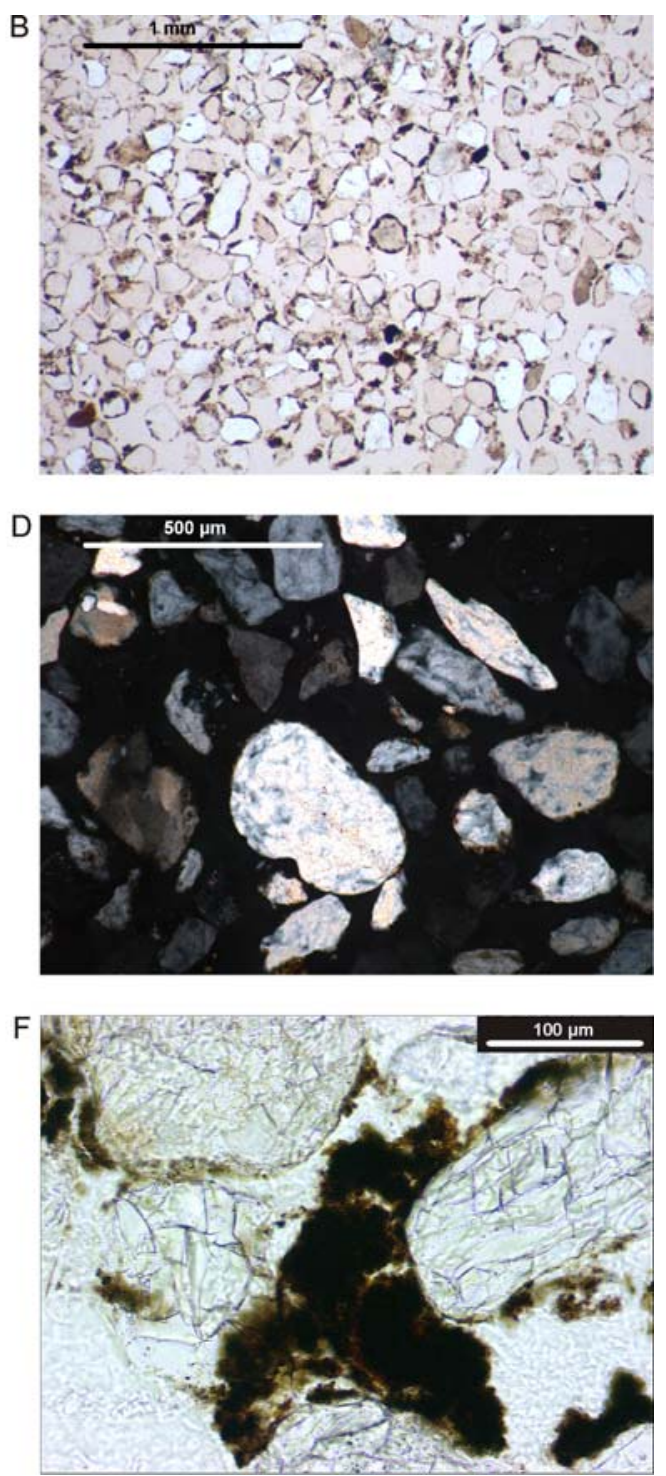

Figura 5.71. Fotomicrografias da $\mathrm{mF} \mathrm{B}$ do sítio Santa Marta 10: A) seção vertical esquemática, com localização da amostra para micromorfologia; B) massa basal composta por grãos de quartzo, feldspato, minerais pesados e opacos, PPL; C, D) microestrutura de grãos revestidos, PPL e XPL; E, F) detalhe dos revestimentos de $\mathrm{MO}$ ao redor dos grãos da fração grossa, PPL. 

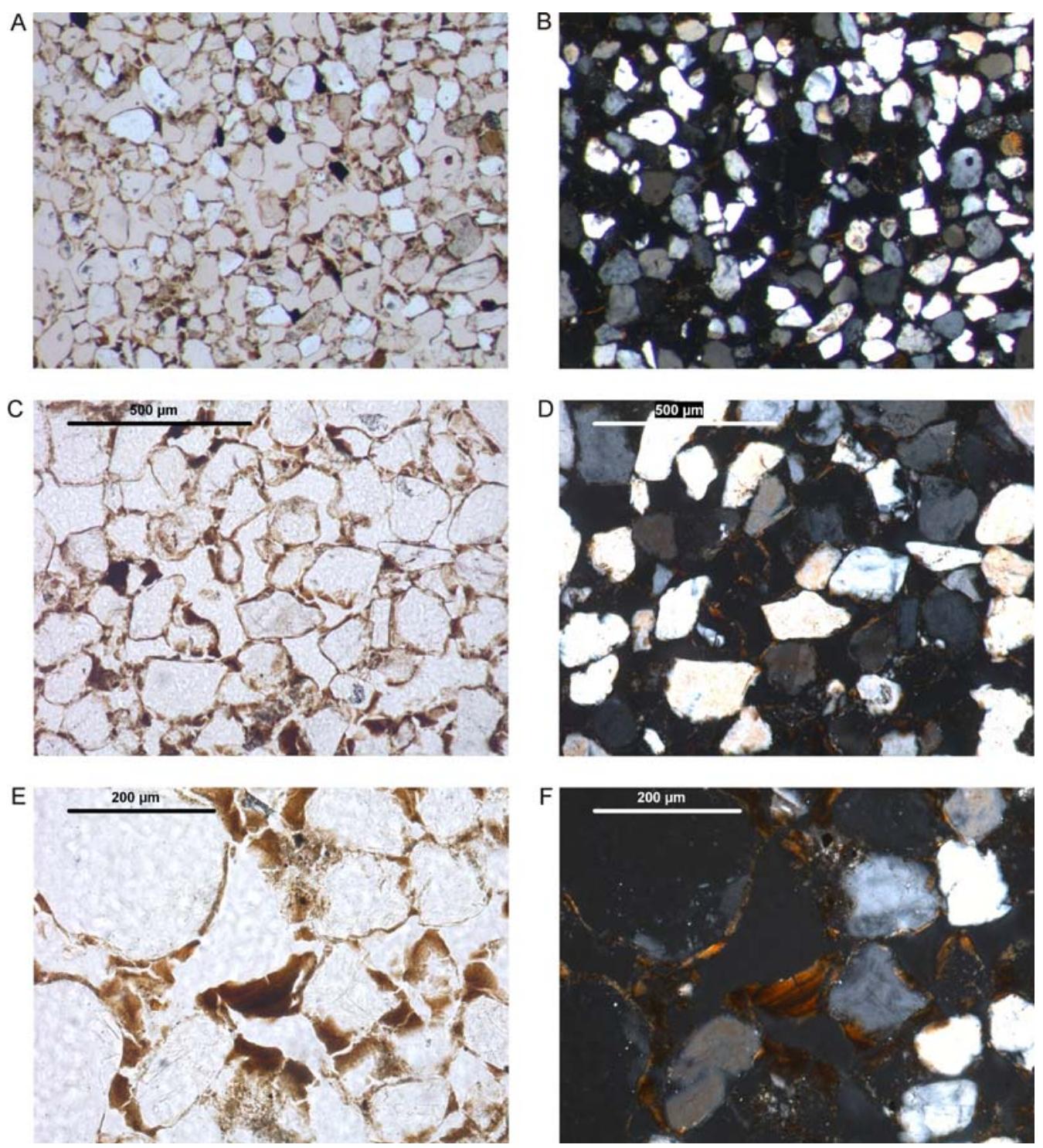

Figura 5.72. Fotomicrografias da mF B2 nas proximidades do sítio Santa Marta 10: A, B) massa basal composta por grãos simples e interligados, PPL e XPL; C-F) detalhe dos revestimentos de argila microlaminada, PPL e XPL.

\subsubsection{Carniça 3}

Localizado sobre paleopontal lagunar, na região de Campos Verdes, este sambaqui apresenta estratigrafia simples, semelhante à observada no sítio Santa Marta 10. No entanto, apesar da similaridade visual de ambos os sítios, existem duas diferenças importantes entre eles, referentes a seus processos de formação: no Carniça 3, as conchas estão dispersas na camada preta superficial e não aglutinadas em forma de anel; apesar de ambos apresentarem núcleo arenoso, estudos sedimentológicos 
mostraram que, no sítio Carniça 3, este núcleo teria origem antrópica (Tanaka 2007; Tanaka et al; 2009) e não eólica como no caso do Santa Marta 10.

Assim, o sítio Carniça 3, com estratigrafia e composição semelhantes a outros sambaquis de núcleo arenoso que se localizam exclusivamente no setor externo, é formado por uma arqueofácies monticular de areia fina, maciça e amarela (AF 1), sobreposta por arqueofácies de areia lamosa preta com conchas (AF 2) (Figura 5.73). Análises zooarqueológicas mostram composição quase exclusiva de $A$. brasiliana, com indivíduos inteiros, às vezes fechados, e também fragmentos.

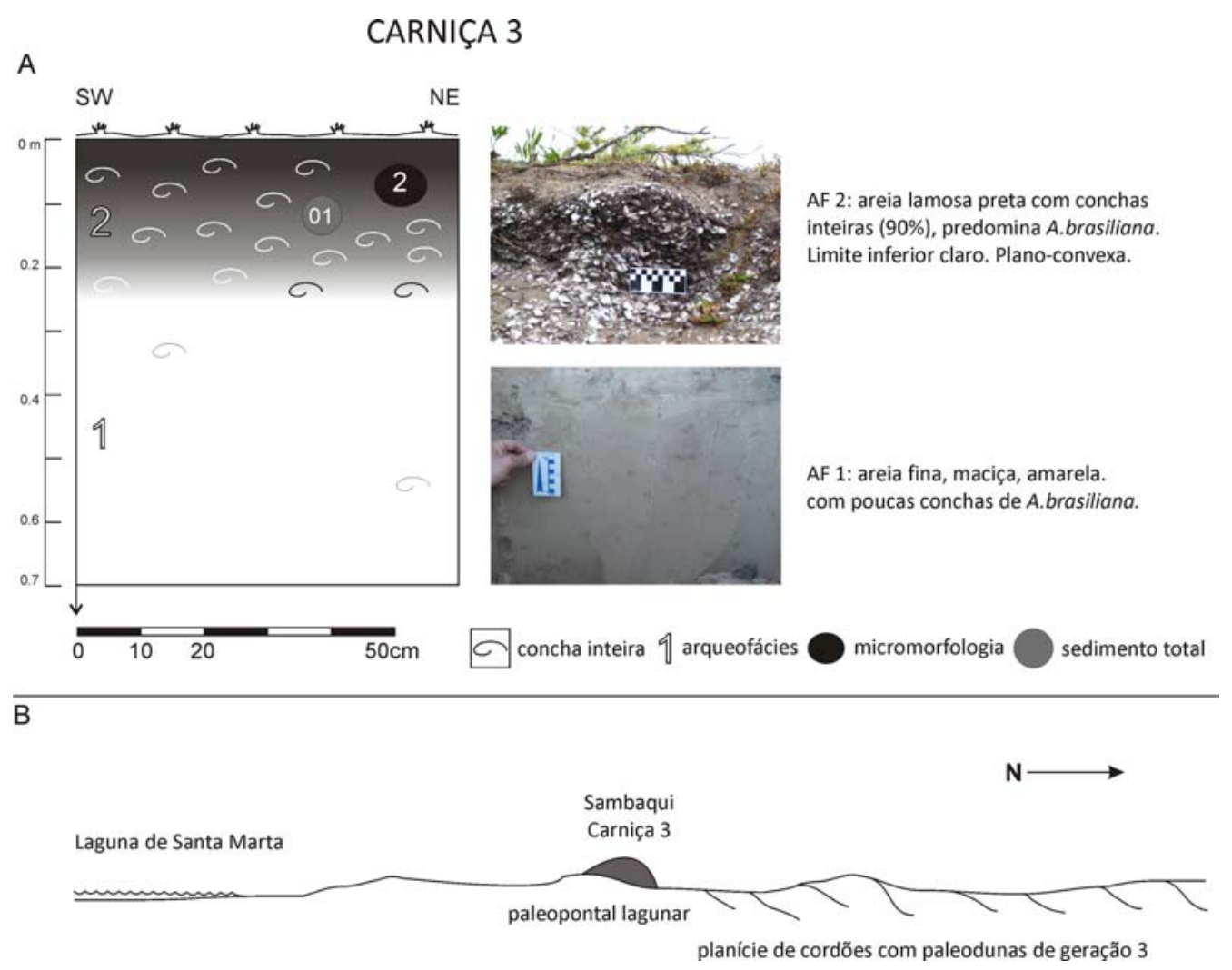

Figura 5.73. Seção vertical estudada do sítio Carniça 3: A) localização dos pontos de amostragem e descrição das arqueofácies identificadas; B) seção transversal esquemática (sem escala) da área de localização do sítio.

\section{$\underline{\text { Granulometria }}$}

Na Figura 5.74 A, apresenta-se o histograma da distribuição granulométrica das AF 1 e 2 do sambaqui Carniça 3. Os dados referentes à AF 1 foram tomados de Tanaka (2007). Ambas as distribuições têm moda na fração areia fina. Os parâmetros estatísticos da distribuição granulométrica da AF 2 fram comparados com dados da 
geração de dunas eólicas 3 que, segundo Tanaka et al. (2009), se superpõem aos cordões litorâneos de Campos Verdes na porção sudeste. Os dados foram tomados de Giannini (1993), Giannini et al. (2007), Martinho (2004) e Sawakuchi (2003), junto com dados extraídos de Tanaka (2007) sobre os cordões litorâneos. A comparação dos parâmetros estatísticos (diâmetro médio, desvio padrão, assimetria) (Figura 5.74 B) mostra a afinidade do sedimento terrígeno da AF 2 com depósitos eólicos de geração 3 e cordões litorâneos, como já constatado por Tanaka $(2007,2009)$ e Menezes (2009).

A comparação das estatísticas descritivas (diâmetro médio, desvio padrão, assimetria) (Figura 5.74 B) mostra leve afinidade do sedimento terrígeno da AF 2 com depósitos eólicos e cordões litorâneos, como já constatado por Tanaka $(2007,2009)$ e Menezes (2009). No entanto, a afinidade não é completa e pode-se estar diante de outro caso de artefato laboratorial, como já mencionado para Jabuticabeira 1, por exemplo, com possível presença de restos de biodetritos aumentando os grossos das AF 1 e 2 .

A
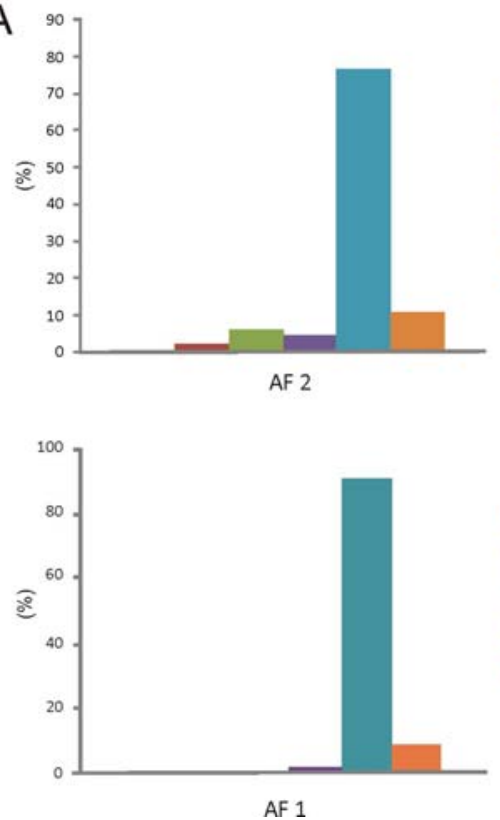

B

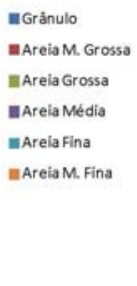

mGrảnulo

mareia M. Grossa

mareia Grossa

mareia Média

mareia Fina

areia M. Fina
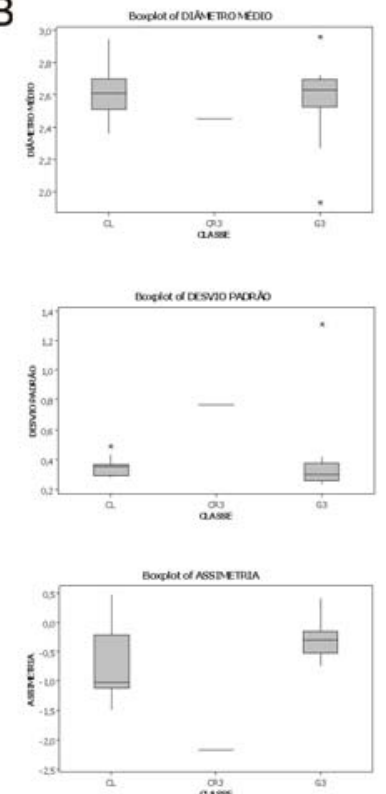

Figura 5.74. Gráficos das distribuições granulométricas e parâmetros estatísticos para o sítio Carniça 3 e amostragem em sedimentos naturais das proximidades: A) histogramas da distribuição granulométrica para as Fácies $\mathrm{A}$ e $\mathrm{B}$ identificadas no sítio Carniça 3; os dados referentes à AF $\mathrm{A}$ foram tomados de Tanaka (2007); note-se o domínio da fração areia fina na AF 1 e de areia muito fina na $\mathrm{AF} 2$; B) diagramas em caixa (boxplot) das estatísticas diâmetro médio, desvio padrão e assimetria para $\mathrm{AF} 2$ de Carniça 3 (CR3), dunas de geração 2 (G3) e amostras de cordões litorâneos (CL) tomados de Tanaka (2007).

A observação no microscópio estereoscópico das frações areia muito grossa (retida na malha de $1,0 \mathrm{~mm}$ ) e areia grossa (malha de $0,5 \mathrm{~mm}$ ) da AF 2 confirma o 
predomínio dos fragmentos de concha na composição da camada superior do sambaqui, com presença subordinada de ossos e carvão (Figura 5.75). A maior parte dos fragmentos encontra-se recoberta por um fino revestimento preto que, pela coloração e textura, parece ser do mesmo tipo de material argiloso preto e orgânico que compõe esta arqueofácies. Entre os ossos de peixe, de baixa freqüência de aparição, identificaram-se fragmentos com sinais de carbonização (coloração preta) e calcinação (coloração cinza a branco) (Figura 5. 75).

\section{CARNIÇA 3 - AF 2}
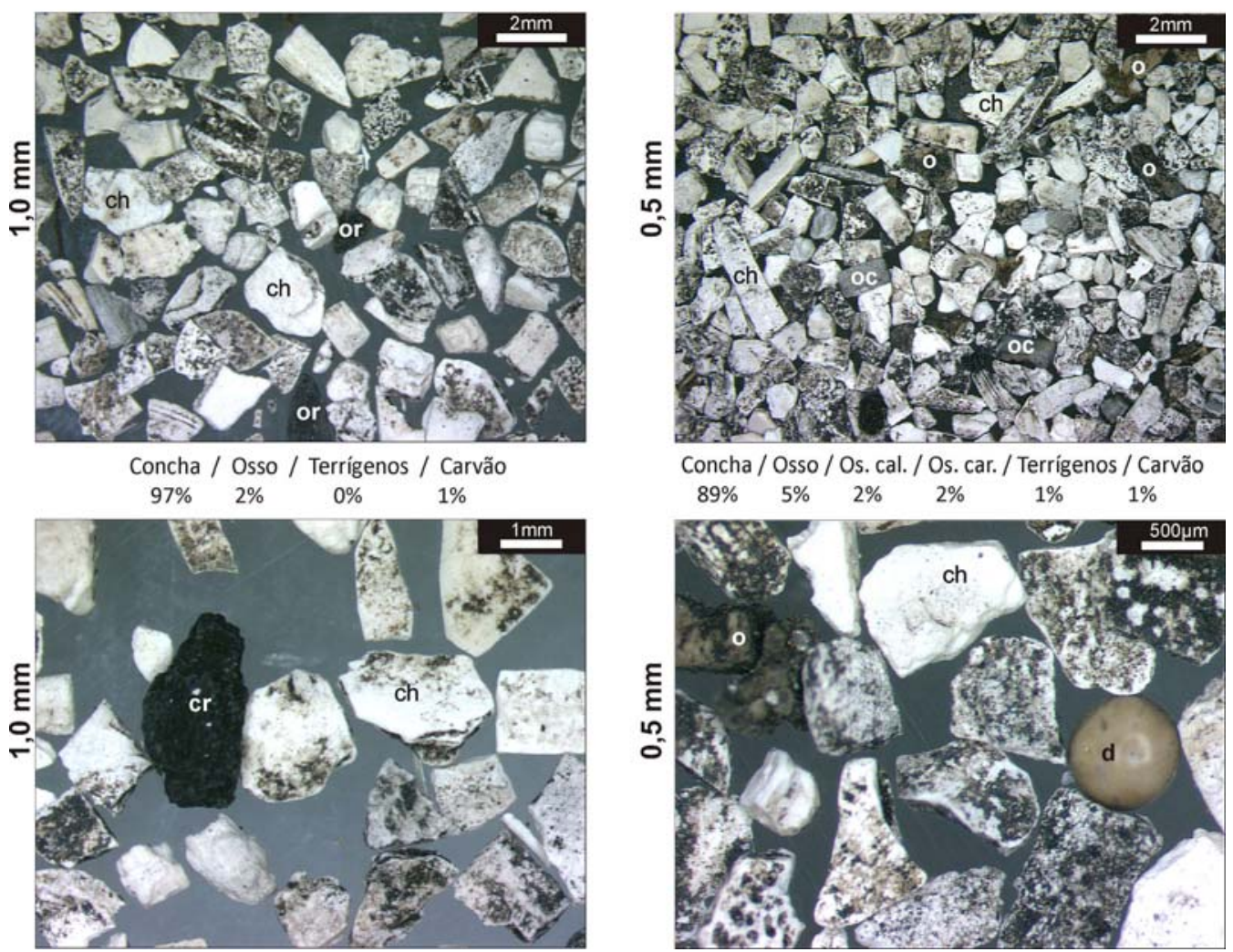

Concha / Osso / Os. cal. / Os. car. / Terrigenos / Carvão

$\begin{array}{llllll}89 & 5 \% & 2 \% & 2 \% & 1 \% & 1 \%\end{array}$

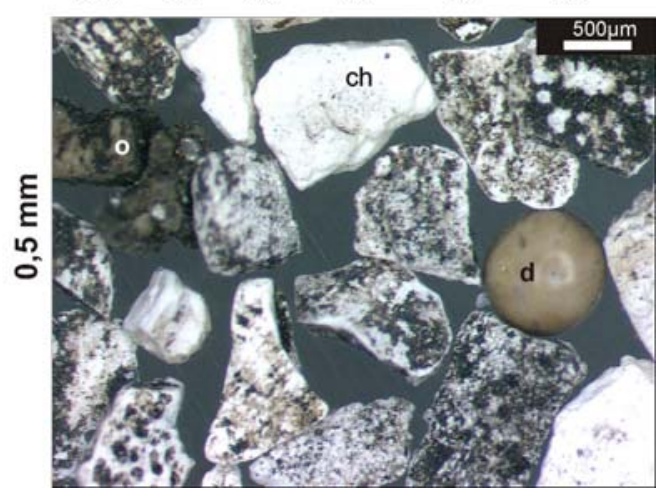

Figura 5.75. Fotomicrografias à lupa estereoscópica de grãos retidos nas malhas de 1,0 mm e 0,5 mm, da arqueofacies 2 do sítio Carniça 3. Note-se a presença de ossos (o), conchas (ch), carvão (cr) e dente de miraguaia (d).

\section{Isótopos de $C$ e $N\left(\delta^{13} C\right.$ e $\left.\delta^{53} N\right)$}

As análises isotópicas realizadas na $\mathrm{MO}$ da $\mathrm{AF} 2\left(\delta^{13} \mathrm{C}, \delta^{15} \mathrm{~N}\right.$ e razão $\left.\mathrm{C} / \mathrm{N}\right)$ confirmam o relatado por Menezes (2009) da presença, no sambaqui, de resíduos de plantas de ciclo fotossintético $\mathrm{C}_{3}$. Os valores de $\delta^{13} \mathrm{C}$ e razão $\mathrm{C} / \mathrm{N}$, situam esta amostra no intervalo definido para plantas $\mathrm{C}_{3}$. A combinação dos dados de $\delta^{13} \mathrm{C} \operatorname{com} \delta^{15} \mathrm{~N}$ voltam a confirmar esta composição (Figura 5.76). 
No trabalho de Menezes (2009), a semelhança no sinal isotópico da MO de outro sambaqui de núcleo arenoso, o sítio Encantada 3, e de depósitos paleolagunares (cordões litorâneos paleolagunares) das proximidades, é interpretada como indicador de origem análoga para a MO do depósito arqueológico e natural. Pela semelhança estratigráfica e composicional entre sambaquis de núcleo arenoso, a autora estende a interpretação ao sítio Carniça 3. Isto significa que, em sambaquis de núcleo arenoso, sedimentos paleolagunares eram retransportados para deposição no sítio. No entanto, a presença de plantas $\mathrm{C}_{3}$ em Carniça 3 , detectada neste trabalho, pode estar vinculada também à existência de resíduos de queima no depósito, derivados da combustão de espécies arbustivas, como sugerem a presença de carvões na AF 2. Apesar de não se terem evidências de fogueiras estruturadas no sambaqui, os carvões, ossos carbonizados e ossos calcinados, indicam existência de resíduos de queima no sítio.
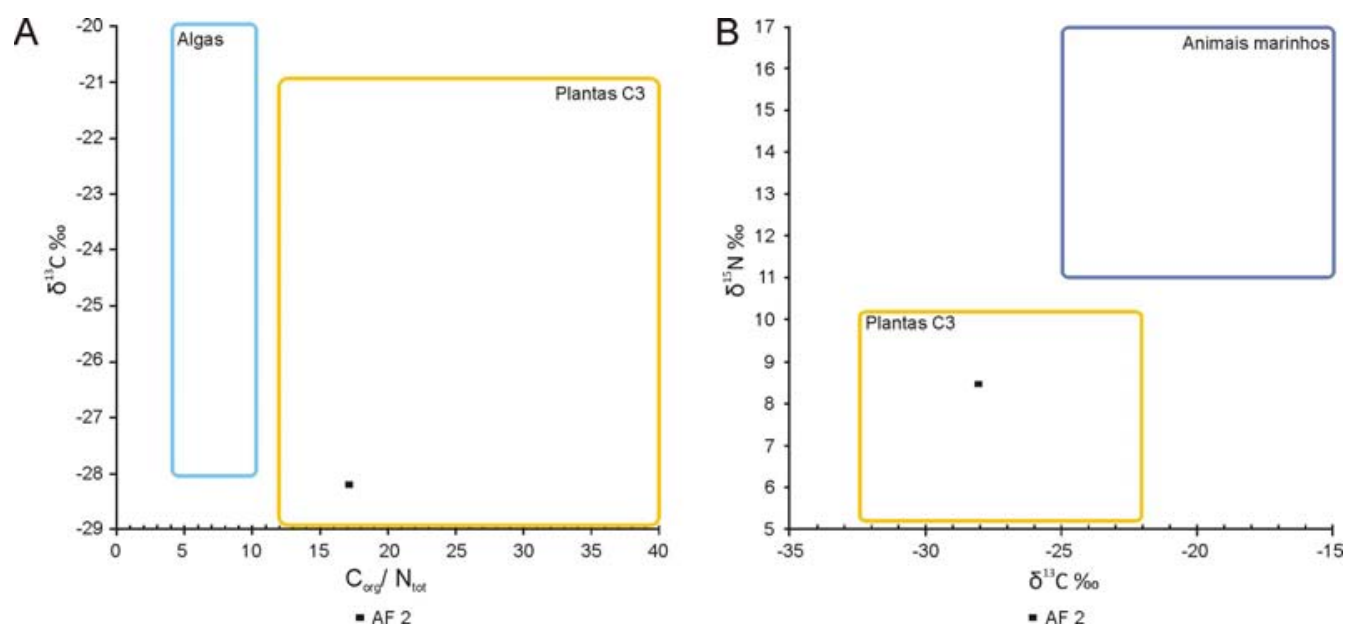

Figura 5.76. Análises isotópicas $\left(\delta^{13} \mathrm{C}\right.$ e $\delta^{15} \mathrm{~N}$ e razão $\left.\mathrm{C} / \mathrm{N}\right)$ de amostra proveniente da AF 2 do sítio Carniça 3: A) gráfico de valores de $\delta^{13} \mathrm{C}$ e razão $\mathrm{C} / \mathrm{N}$ com intervalos definidos para plantas de ciclo fotossintético $\mathrm{C} 3$ e algas; B) gráfico dos valores de $\delta^{15} \mathrm{~N}$ e $\delta^{13} \mathrm{C}$ com intervalos definidos para plantas de ciclo fotossintético C3 e animais marinhos.

\section{Micromorfologia}

Para análise micromorfológica, coletou-se uma única amostra da AF 2 (Figura 5.77). Na mF 2 destaca a alta porosidade (60\%) e a presença de conchas inteiras junto com grãos de quartzo, com freqüência menor que $10 \%$ de feldspatos, fragmentos de osso e raízes (Figura 5.78; Tabela 5.24). Na assembleia malacológica, domina a espécie A. brasiliana, com cerca de $10 \%$ das valvas distribuídas sub-horizontalmente (Figura 5.79 B-D; Tabela 5.25). 


\section{CARNIÇA 3}

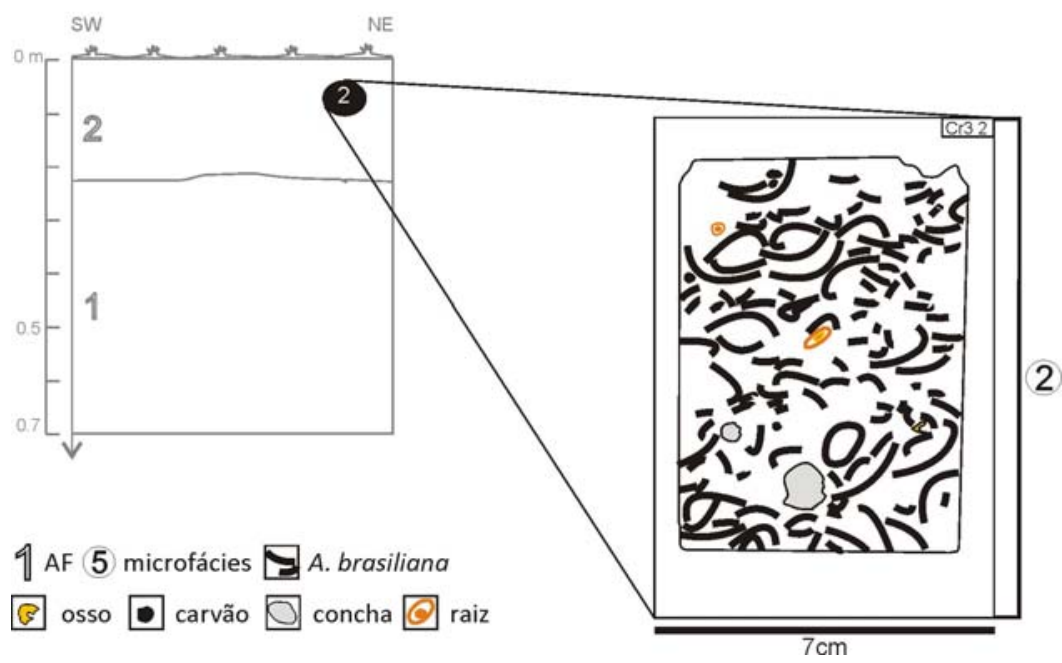

Figura 5.77. Desenho esquemático da seção delgada analisada no sítio Carniça 3, com localização do bloco de amostragem na sucessão vertical e identificação de microfácies na lâmina.
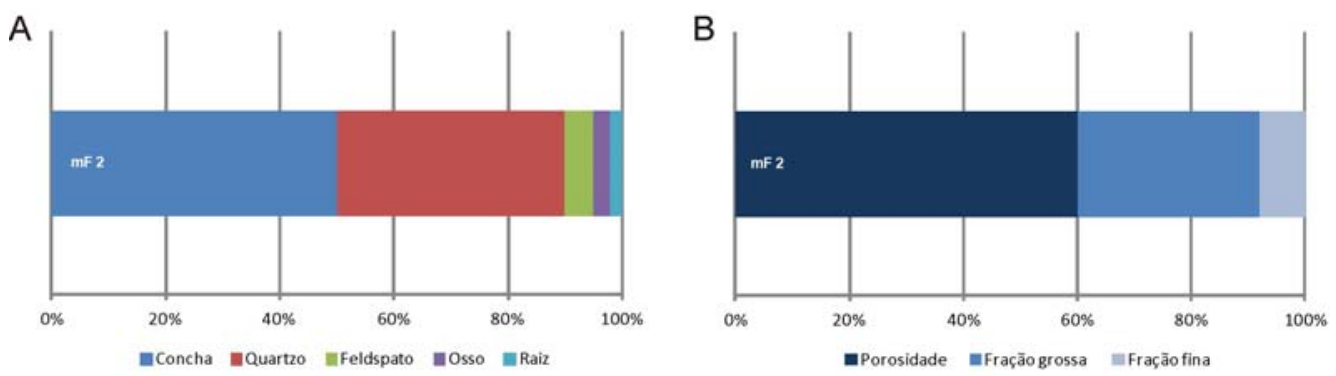

Figura 5.78. Gráficos com porcentagens dos diferentes componentes microscópicos da $\mathrm{mF} 2$ do sítio Carniça 3: A) freqüências de componentes da fração grossa; B) relação entre as porcentagens de poros, fração grossa e fração fina. 
Tabela 5.24. Descrição micromorfológica do sambaqui Carniça 3.

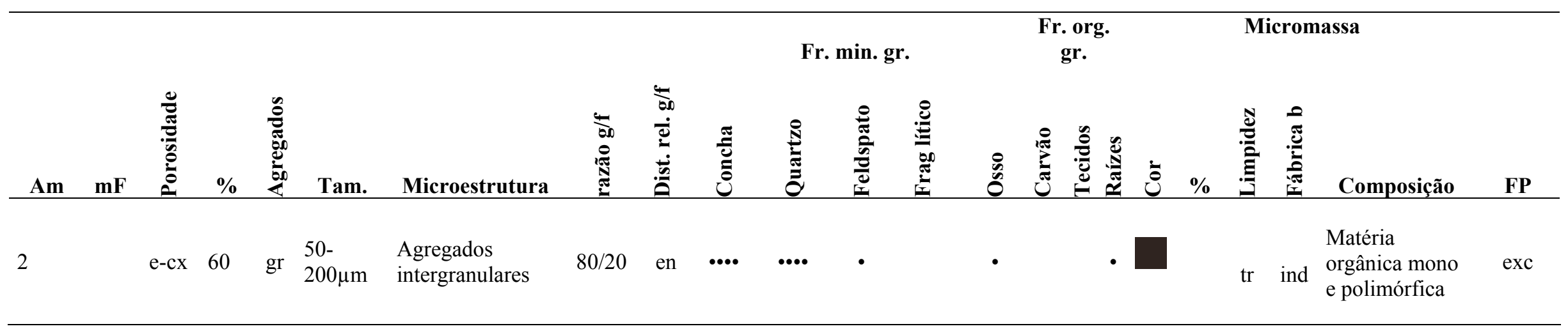

Freqüências de classes segundo Bullock et al. (1985): • Muito Poucas $(<5 \%) ; \bullet$ Poucas $(5-15 \%) ; \cdots$ Comum $(15-30 \%) ; \cdots \cdots$ Freqüente $(30-50 \%) ; \cdots \cdots$ Dominante $(50-70 \%)$; ...... Muito dominante $(>70 \%)$. Am. = amostra; $\mathrm{mF}=$ microfácies; Tam. $=$ tamanho; Fr. min. gr. $=$ fração mineral grossa; Fr. org. gr. $=$ fração orgânica grossa; $\mathrm{FP}=$ feições pedológicas. O singificado das demais abreviações utilizadas nesta tabela encontra-se no Anexo, Tabela A.5. 
Tabela 5.25. Componentes minerais e orgânicos da fração grossa da amostra CR 32 .

\begin{tabular}{|c|c|c|c|c|c|c|c|c|c|c|}
\hline \multicolumn{11}{|l|}{ CR3 2} \\
\hline & $\mathbf{m F}$ & $\%$ & Tamanho & Forma & Arredondamento & Seleção & $\begin{array}{c}\text { Distribuiçãa } \\
\text { básica }\end{array}$ & $\begin{array}{c}\text { Orientação } \\
\text { básica }\end{array}$ & $\begin{array}{l}\text { Distribuição } \\
\text { referenciada }\end{array}$ & Alteração \\
\hline Concha & & 50 & Vários & - & 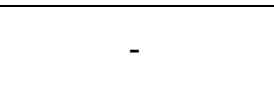 & Bem selecionado & Aleatória/linear & $\begin{array}{l}10 \% \text { paralelismo } \\
\text { de ângulo baixo }\end{array}$ & $\begin{array}{l}\text { Inclinada à } \\
\text { superfície }\end{array}$ & $\begin{array}{l}\text { Queima e } \\
\text { dissolução }\end{array}$ \\
\hline Quartzo & & 40 & Areia fina & Equidimensional & $\begin{array}{l}\text { Arredondado e } \\
\text { subarredondado }\end{array}$ & $\begin{array}{l}\text { Mto. bem } \\
\text { selecionado }\end{array}$ & Aleatória & - & - & - \\
\hline Feldspato & & 5 & Areia mto. fina & Equidimensional & $\begin{array}{l}\text { Arredondado e } \\
\text { subarredondado }\end{array}$ & $\begin{array}{l}\text { Mto. bem } \\
\text { selecionado }\end{array}$ & Aleatória & - & - & - \\
\hline Osso & & 3 & $\begin{array}{l}\text { Areia fina a } \\
\text { grossa }\end{array}$ & - & (1) & Seleção moderada & Aleatória & - & - & $\begin{array}{l}\text { Queima e } \\
\text { dissolução }\end{array}$ \\
\hline Raízes & & 2 & $\sim 300 \mu \mathrm{m}$ & - & - & - & Aleatória & - & - & - \\
\hline
\end{tabular}


A microestrutura de microagregados intergranulares é formada pela atividade biológica que produz grânulos pretos, mamilares e muito finos (de 50 a $200 \mu \mathrm{m}$ de diâmetro) em forma de pellets soldados de MO polimórfica (Figura 5.79 E-F). A presença desta micromassa, somado à existência de pseudo-revestimentos de MO polimórfica e de revestimentos contínuos e descontínuos de MO preta, monomórfica, em cerca de $80 \%$ dos componentes da fração grossa, permite associar a AF 2 com horizonte B espódico, incipiente (Van Breemen and Buurman, 2003). As evidências de podzolização que se observam nos sambaquis Carniça 3 e Santa Marta 10, sugerem que recorrência deste processo, tanto em sambaquis de núcleo arenoso, como em outros tipos de ocupação humana sobre substrato semelhante, como dunas ou paleodunas eólicas.

O fato de a fração fina orgânica do sítio Carniça 3 apresentar microestrutura assimilável a horizonte espódico permite sugerir que a AF 2 registraria um episódio deposicional de resíduos orgânicos, junto com areia e conchas, com posterior alteração pedogênica e formação de solo. Isto transforma a sucessão estratigráfica deste sambaqui em perfil pedo-estratigráfico (sensu Arroyo-Kalin 2010), como também observado em Santa Marta 10.

Parte dos fragmentos de osso mostra sinais de queima (Figura 5.80 A), enquanto algumas conchas apresentam traços de bioerosão, na forma de finos canais superficiais, conhecidos como microborings (Bromley, 1992; Glaub, 2004)(Figura 5.80 B-C). Estes icnofósseis, de diâmetro menor que $100 \mu \mathrm{m}$ e muito comuns em substrato calcáreo, são produzidos em ambiente subaquático por pequenas esponjas, briozoários, algas vermelhas, algas verdes, cianobactérias, fungos e outros micróbios (Bromley, 1992; Glaub, 2004). A presença de bioerosões nas conchas do sambaqui é um atributo herdado do depósito onde o molusco vivia.

Dentro e associado às raízes, destaca-se a presença recorrente de excrementos elipsoidais de ácaros (Figura 5.80 D). 
A
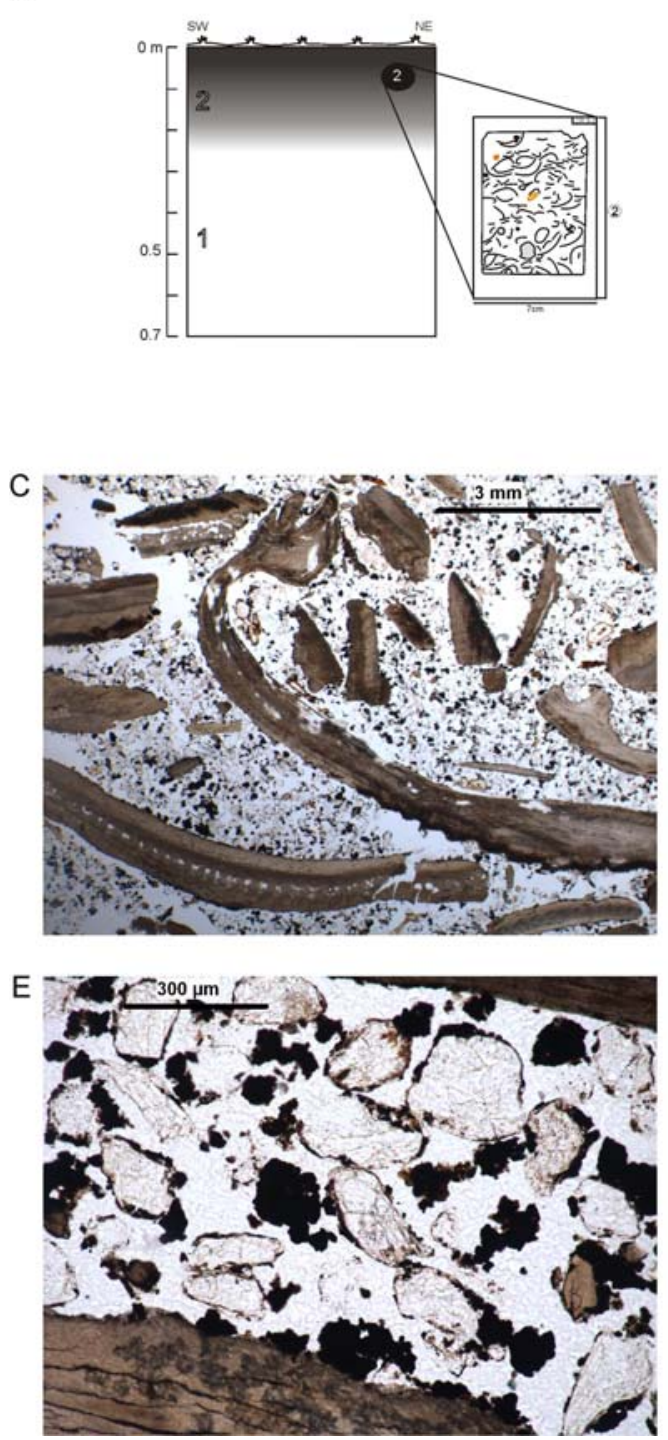
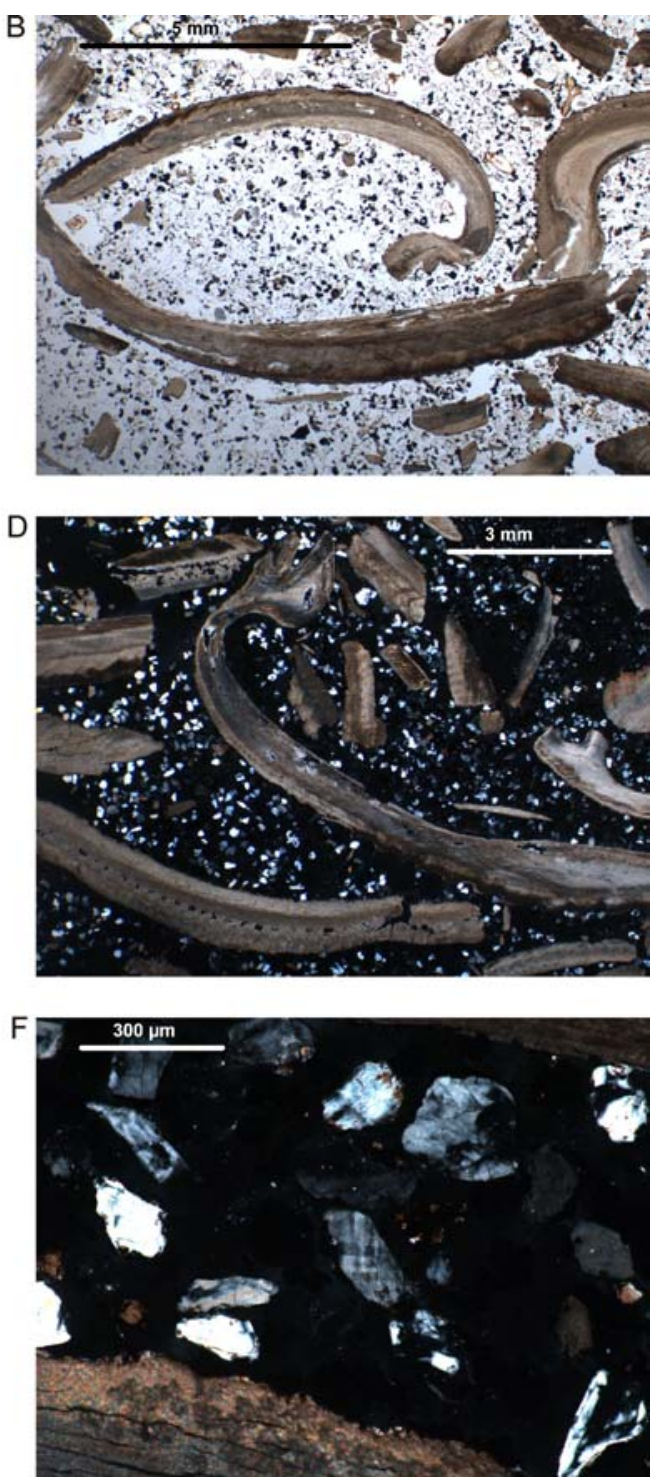

Figura 5.79. Fotomicrografias da $\mathrm{mF} 2$ do sítio Carniça: A) seção vertical esquemática, com localização da amostra para micromorfologia; B) massa basal composta por conchas de Anomalocardia brasiliana inteiras com distribuição (trama/ arranjo) sub-horizontal, PPL; C, D) massa basal com conchas inteiras e fragmentadas, a PPL e XPL; E, F) micromassa composta por agregados de MO polimórfica em forma de pellets, a PPL e XPL. 

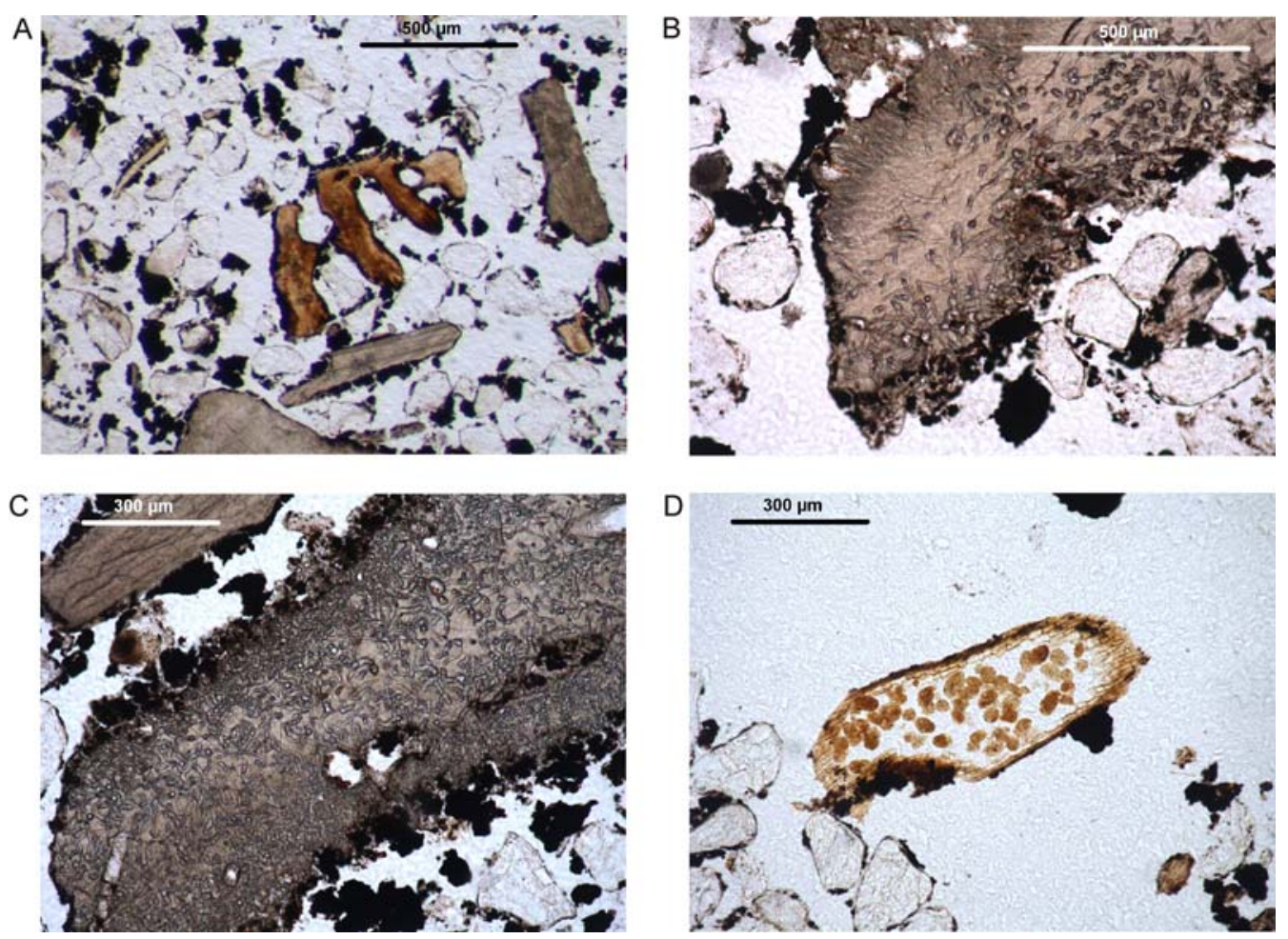

Figura 5.80. Fotomigrografias de elementos de interesse na $\mathrm{mF} 2$ do sítio Carniça 3: A) fragmento de osso com sinais de queima; B, C) conchas com bioerosão; D) excrementos elipsóides de ácaros dentro de raiz, PPL.

\subsection{MONTÍCULOS ICTIOLÓGICOS}

\subsubsection{Santa Marta 8}

O sítio Santa Marta 8, localizado no paleotômbolo à retaguarda da ponta de Santa Marta, apresenta três particularidades que o posicionam como sítio chave no entendimento do processo de mudança na ocupação pré-colonial do litoral sul catarinense: é o montículo ictiológico mais antigo da região, com cerca de 1500 anos; contém cultura material associada aos grupos do planalto (cerâmica de tradição Taquara/Itararé), mas não se encontra sobre costão rochoso, como os demais sítios da região com esta característica, como Costão do Ilhote e Galheta 4; e apresenta semelhanças composicionais com a camada preta do sambaqui Jabuticabeira 2, dada a presença em ambos de acumulação massiva de ossos de peixe, carvão e areia associada a enterramentos humanos. 
A sucessão estratigráfica estudada mostra uma mistura maciça de ossos de peixe com areia e carvão, sobre areia amarela com poucos elementos antrópicos (conchas, ossos e carvão). Três arqueofácies foram identificadas, sendo que a AF 1, inferior, parece corresponder ao substrato arenoso natural, com alguns artefatos intrusivos da arqueofácies superior. A AF 2, intermediária, é composta por areia lamosa preta com aproximadamente $10 \%$ de ossos de peixe e algumas conchas $(<3 \%)$. AF 2 pode representar uma feição pós-deposicional formada por iluviação do material fino da AF 3, superior. A AF 3 abrange a maior parte da sucessão estratigráfica e trata-se de areia cascalho-lamosa com aproximadamente $30 \%$ de ossos de peixe, que também se distribuem em forma de bolsões (Figura 5.81).

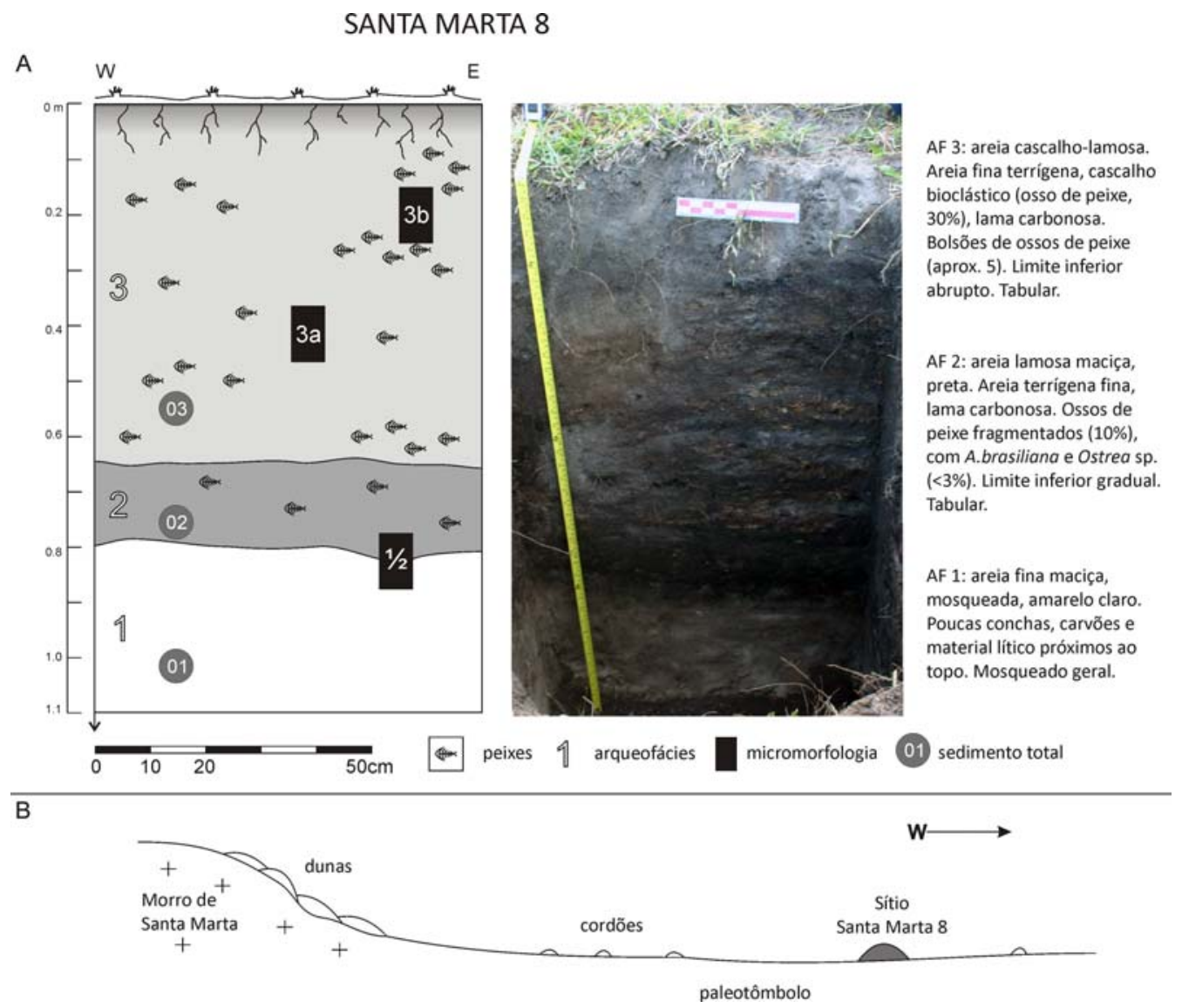

Figura 5.81. Seção vertical estudada do sítio Santa Marta 8: A) localização dos pontos de amostragem e descrição das arqueofácies identificadas; B) seção transversal esquemática (sem escala) da área de localização do sítio. 


\section{Granulometria}

$\mathrm{Na}$ trincheira aberta a sudeste do sítio Santa Marta 8, a sucessão observada apresenta uma fácies arenosa inferior (Fácies A), seguida de fácies centimétrica de areia lamosa preta (Fácies B) e areia fina marrom no topo (Fácies C) (Figura 5.82). A interpretação desta sucessão resulta ambígua já que a fácies inferior parece corresponder a areias eólicas, mas as duas fácies superiores podem corresponder tanto a depósitos naturais quanto a culturais modernos, haja vista os relatos sobre aterramento desta área. A Fácies B preta, intermediária, poderia ser tanto um depósito natural, de tipo brejo, quanto um sedimento orgânico de aterro moderno, ou inclusive um remanescente de ocupação pré-colonial contemporâneo à ocupação do sambaqui. A fácies arenosa superior também admite uma origem tanto natural, já que poderia tratar-se de areia eólica, quanto antrópica, como componente do mesmo aterro.
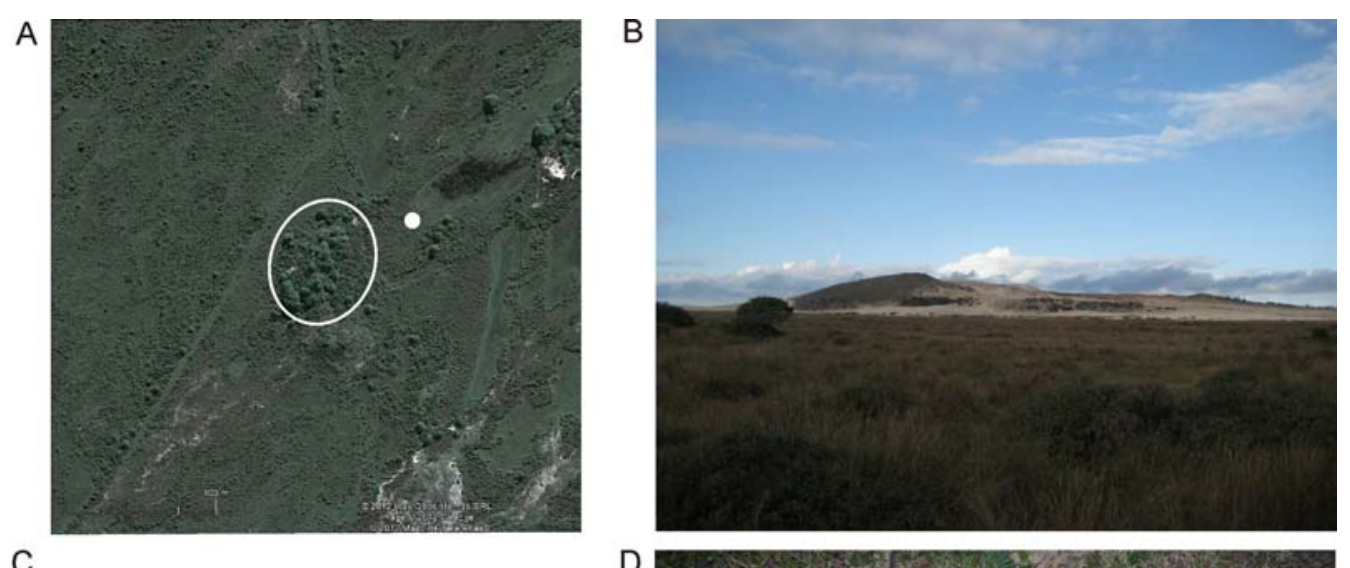

$$
\begin{aligned}
& \text { Fácies C }(0-27 \mathrm{~cm}) \text { : areia fina } \\
& \text { marrom acinzentado (10YR 5/2). } \\
& \text { Fácies B }(27-37 \mathrm{~cm}) \text { : areia fina } \\
& \text { lamosa, preta }(10 \text { Y } 2 / 2) \text {, maciça. } \\
& \text { Fácies A (>37 cm): areia fina bem } \\
& \text { selecionada, amarela (10YR } 7 / 3) \text {, } \\
& \text { maciça. }
\end{aligned}
$$

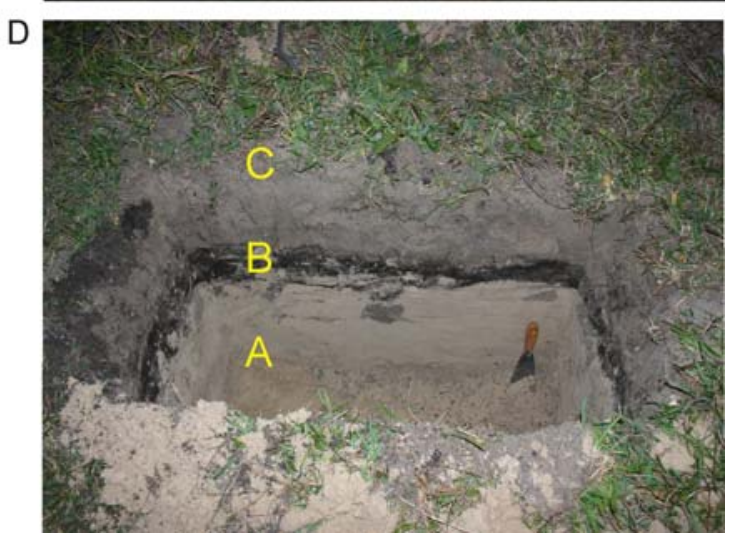

Figura 5.82. Amostragem externa ao sítio Santa Marta 8: A) localização do ponto de amostragem; B) entorno de localização; C) descrição das fácies identificadas; D) trincheira amostrada com localização das fácies.

Amostras para análises granulométricas foram coletadas das AF 1, 2 e 3 e das Fácies A e B identificadas na trincheira aberta em área externa ao sítio. Em todas as 
amostras, tanto no sítio como na trincheira externa, observa-se moda na fração areia fina, com presença subordinada de areia muito fina, e de areia média e grossa unicamente na Fácies B (Figura 5.83). A observação no microscópio estereoscópico das frações areia muito grossa e areia grossa das AF 1, 2 e 3 confirmam o predomínio dos fragmentos de osso, inclusive carbonizados e calcinados, na composição do sambaqui, com presença subordinada de carvão (Figura 5.84). Cabe destacar que a observação no microscópio estereoscópico da Fácies B determina a origem antrópica destes sedimentos (Figura 5.85). Na Fácies B, as frações areia grossa e areia média estão composta quase totalmente por fragmentos de osso, em frequências semelhantes às observadas no sambaqui. Isto indica que os sedimentos do sambaqui e da Fácies B fora do sítio têm origens semelhantes e, portanto, podem ser contemporâneas.
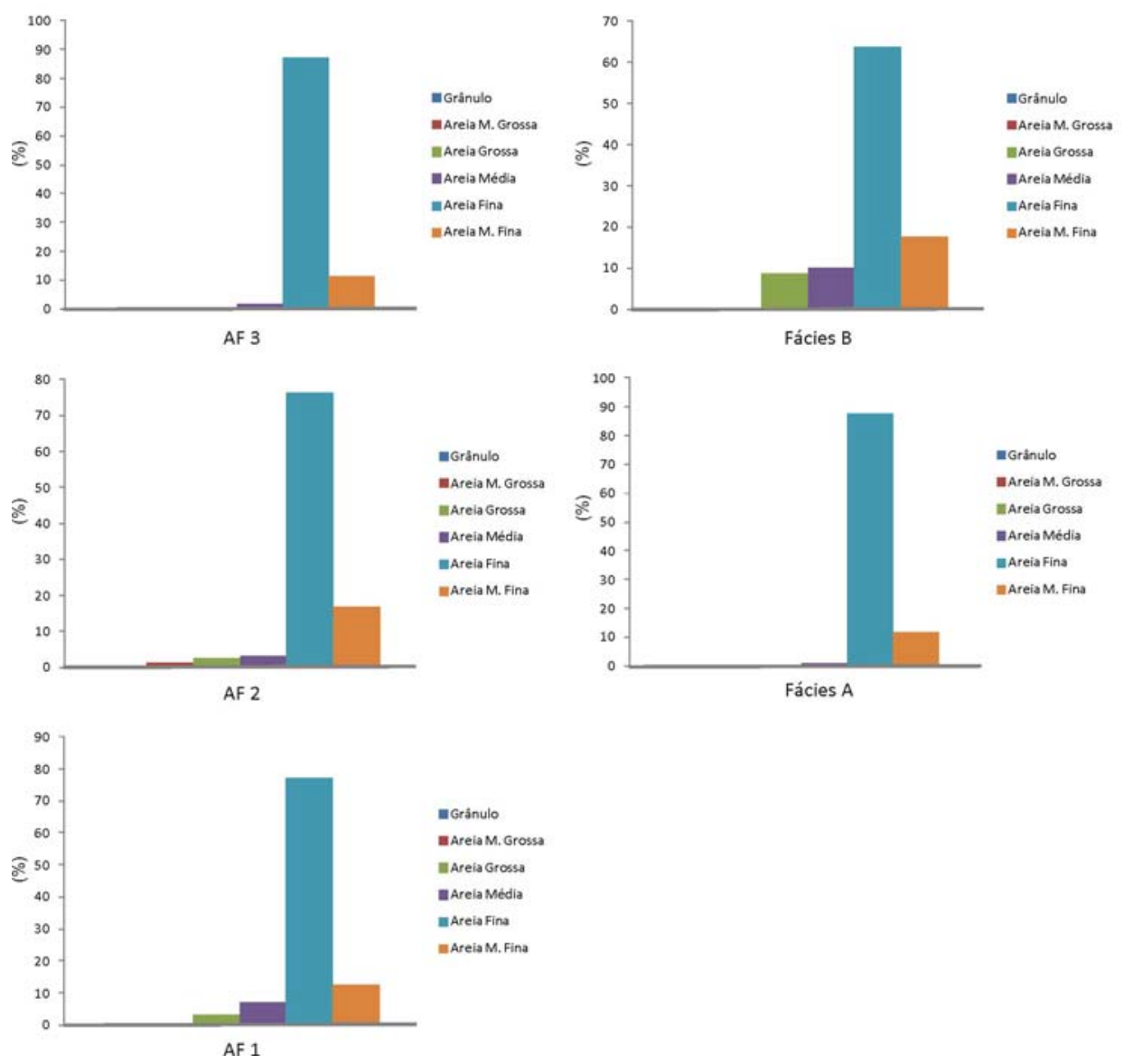

Figura 5.83. Histogramas da distribuição granulométrica para as AF 1, 2 e 3 do sítio Santa Marta 8 e Fácies A e B identificadas na trincheira de amostragem externa ao sítio. Note-se o domínio da fração areia fina em todas as amostras. 

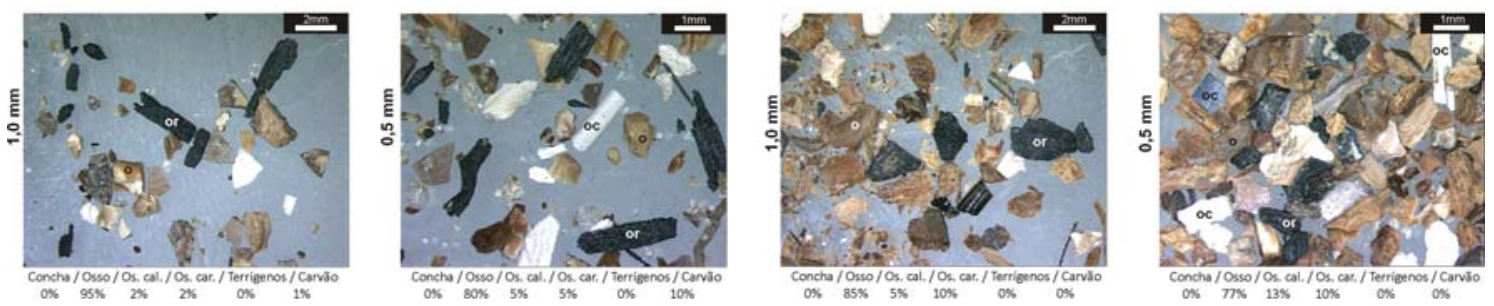

SANTA MARTA 8 - AF 3

SANTA MARTA 8 - Fácies B
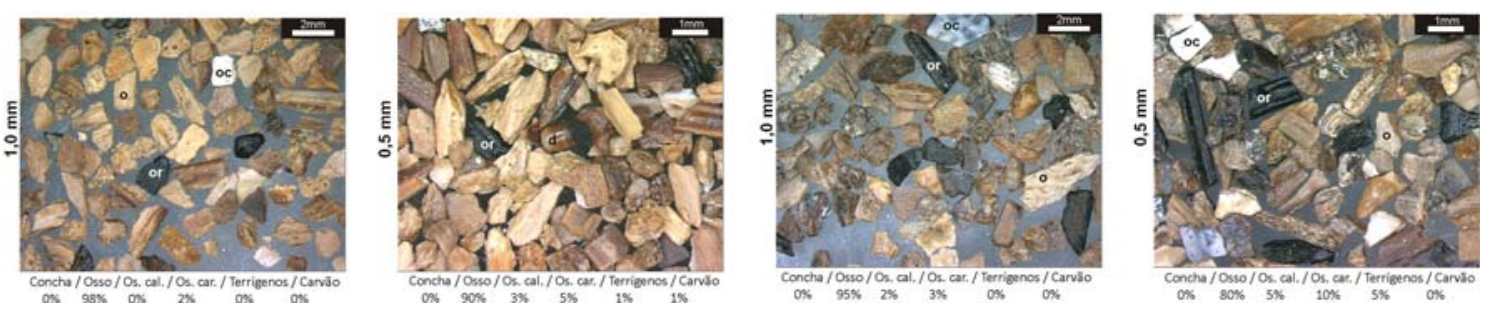

Figura 5.84. Fotomicrografias à lupa estereoscópica de grãos retidos nas malhas de $1,0 \mathrm{~mm}$ e $0,5 \mathrm{~mm}$, da arqueofacies 1, 2 e 3 do sítio Santa Marta 8 e Fácies B da trincheira aberta em área externa ao sítio. Notese a presença de ossos (o), osso carbonizado (or), e osso calcinado (oc) e dente (d).

\section{Isótopos de Ce N $\left(\delta^{13} \mathrm{Ce} \delta^{53} N\right)$}

Análises isotópicas foram realizadas na MO das AF 2 e 3 e da Fácies B da trincheira de amostragem externa ao sítio (Figura 5.85; Anexo, Tabela A.1). Nos sedimentos arqueológicos, observa-se mistura de restos vegetais e resíduos de origem animal. Esta tendência já foi relatada por Menezes (2008) na camada preta de Jabuticabeira 2, com a qual este sambaqui apresenta grandes semelhanças composicionais, onde existe uma. Os resíduos de animais, neste caso marinhos (Figura 5.86 B), vinculam-se ao conteúdo faunístico deste sambaqui, composto principalmente por ossos de peixe.

A amostra correspondente à Fácies $\mathrm{B}$ da sondagem próxima ao sítio Santa Marta 8 apresenta valores de $\delta^{13} \mathrm{C}$ e $\delta^{15} \mathrm{~N}$ semelhantes ao observado no sambaqui, ou seja, presença de resíduos de origem animal decompostos. Isto, somado às observações na lupa, que indicaram presença exclusiva de fragmentos de ossos de peixe nas frações areia muito grossa e grossa dos sedimentos da Fácies B, indica que esta fácies, de espessura centimétrica, inter-estratificada entre depósitos arenosos, possa ser parte da área ocupada pelo grupo construtor do sítio Santa Marta 8. De fato, estudos geofísicos realizados na região compreendida entre os sítios Santa Marta 4, 5, 7 e 8 indicaram a 
presença de anomalias em subsuperfície associadas à existência de vestígios de ocupação em locais externos aos sítios (Rodrigues 2009).
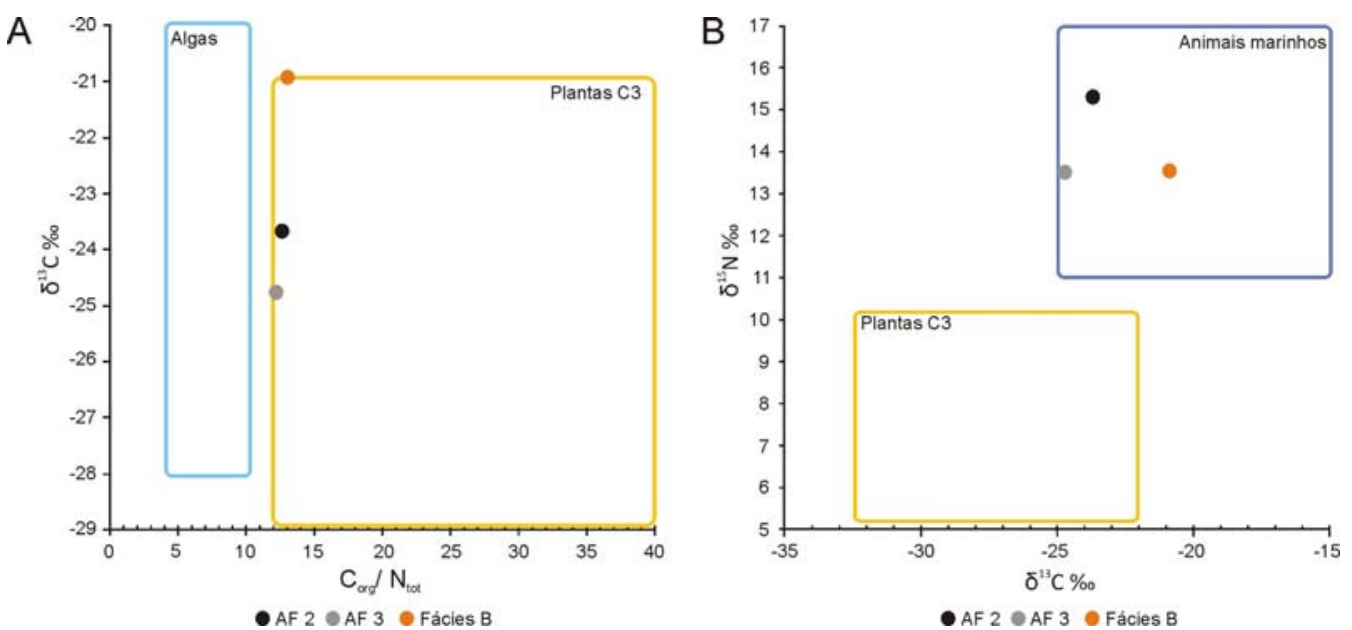

Figura 5.85. Análises isotópicas $\left(\delta^{13} \mathrm{C}\right.$ e $\left.\delta^{15} \mathrm{~N}\right)$ e razão $\mathrm{C} / \mathrm{N}$ de amostras provenientes das $\mathrm{AF} 2$ e 3 do sítio Santa Marta 8 e Fácies B da amostragem extra-sítio: A) gráfico de valores de $\delta^{13} \mathrm{C}$ e razão $\mathrm{C} / \mathrm{N}$ com intervalos definidos para plantas de ciclo fotossintético $\mathrm{C} 3$ e algas; B) gráfico dos valores de $\delta^{15} \mathrm{~N}$ e $\delta^{13} \mathrm{C}$ com intervalos definidos para plantas de ciclo fotossintético $\mathrm{C} 3$ e animais marinhos.

\section{Micromorfologia}

Três amostras para micromorfologia foram extraídas da seção vertical analisada. A primeira abrange o contato entre as AF 1 e AF 2 (amostra 1/2), e as outras duas foram coletadas da AF 3 (amostras 3a e 3b). Duas microfácies foram identificadas na amostra $1 / 2$, e correspondem às $m F 1$ e 2 , respectivamente. Nas amostras $3 a$ e $3 b$, a única microfácies identificada ( $\mathrm{mF}$ 3) caracteriza-se por bolsões de concentração de ossos de peixe (Figura 5.86).

$\mathrm{Na}$ Tabela 5.26, apresenta-se a descrição micromorfológica das três seções delgadas analisadas no sítio Santa Marta 8. As três microfácies identificadas compõe-se principalmente de fragmentos de ossos de peixe e grãos de quartzo (que, juntos, totalizam $\sim 90 \%$ ), com freqüência menor que $10 \%$ de feldspatos, carvão, fragmentos líticos, escória vítrea e minerais pesados (Figura 5.87 A). Cabe ressaltar que a mF 1 diferencia-se das restantes por ser essencialmente mineral, com alguns elementos antrópicos (ossos, carvão e escória). A porosidade varia pouco ao longo da seção vertical (entre 40 e $45 \%$ ), com valor mínimo na mF 2 (20\%) (Figura 5.87 B). A porcentagem de fração fina é mínima na $\mathrm{mF} 1(<5 \%)$. 
Os fragmentos de osso apresentam distribuição horizontal a sub-horizontal em todas as microfácies, exceto $\mathrm{mF} 1$, onde sua frequência é a mínima no perfil e a distribuição aleatória (Tabela 27 a 28). Esta distribuição preferencial dos macrofragmentos sugere compactação do depósito e boa preservação da fábrica original.

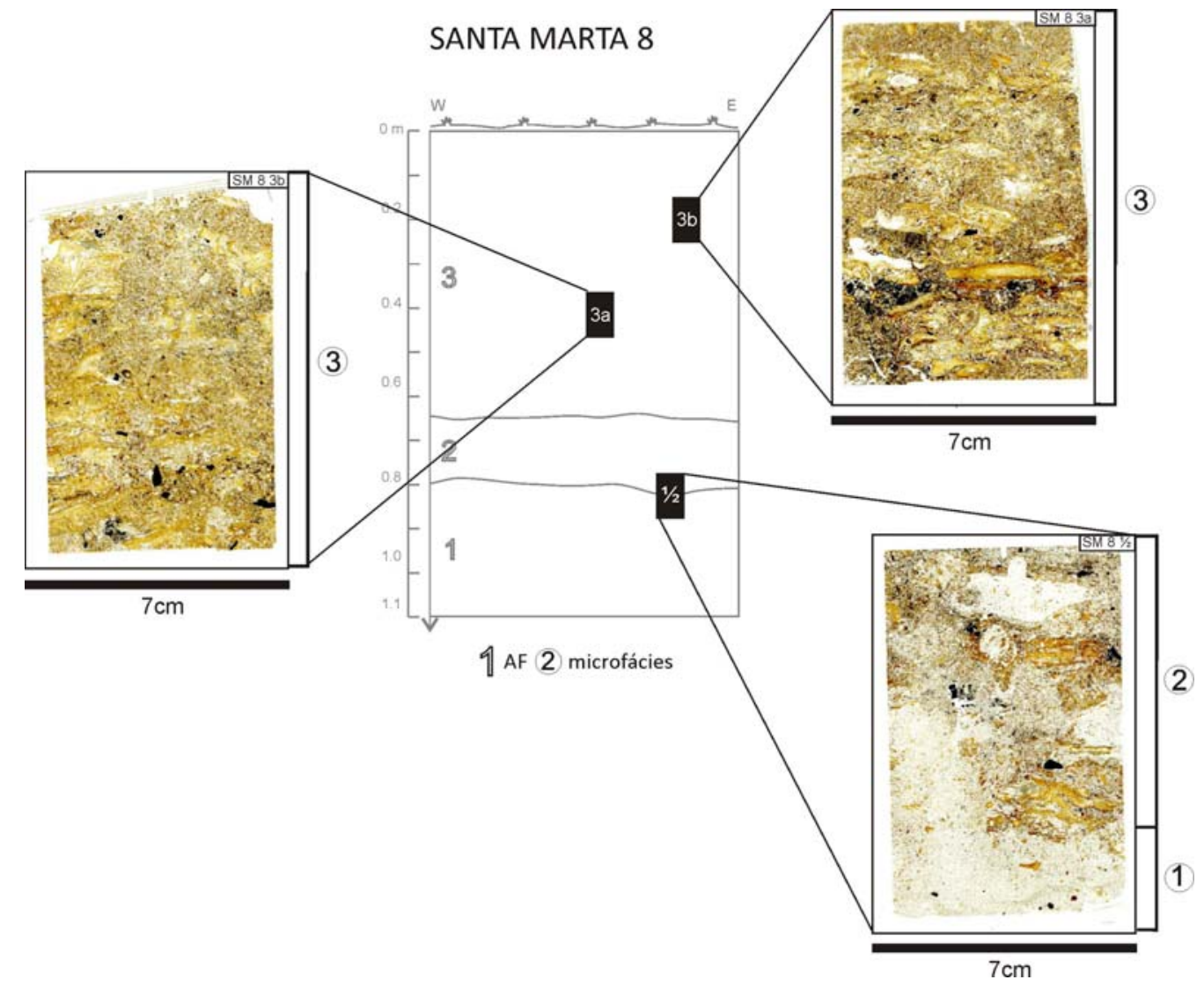

Figura 5.86. Seções delgadas analisadas no sítio Santa Marta 8, com localização do bloco de amostragem na sucessão vertical e identificação de microfácies na lâmina.
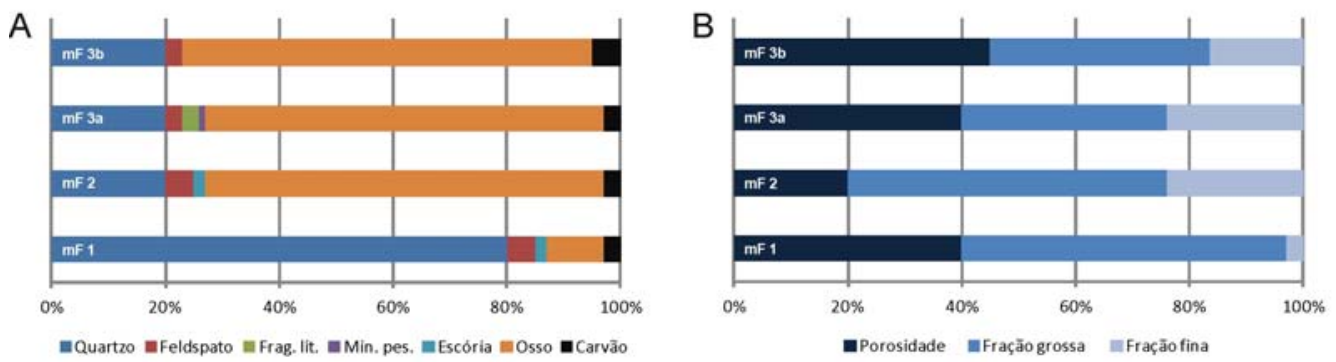

Figura 5.87. Gráficos com porcentagens dos diferentes componentes microscópicos das $\mathrm{mF} 1,2,3 \mathrm{a}$ e $3 \mathrm{~b}$ do sítio Santa Marta 8. A) freqüências de componentes da fração grossa; B) relação entre as porcentagens de poros, fração grossa e fração fina. 


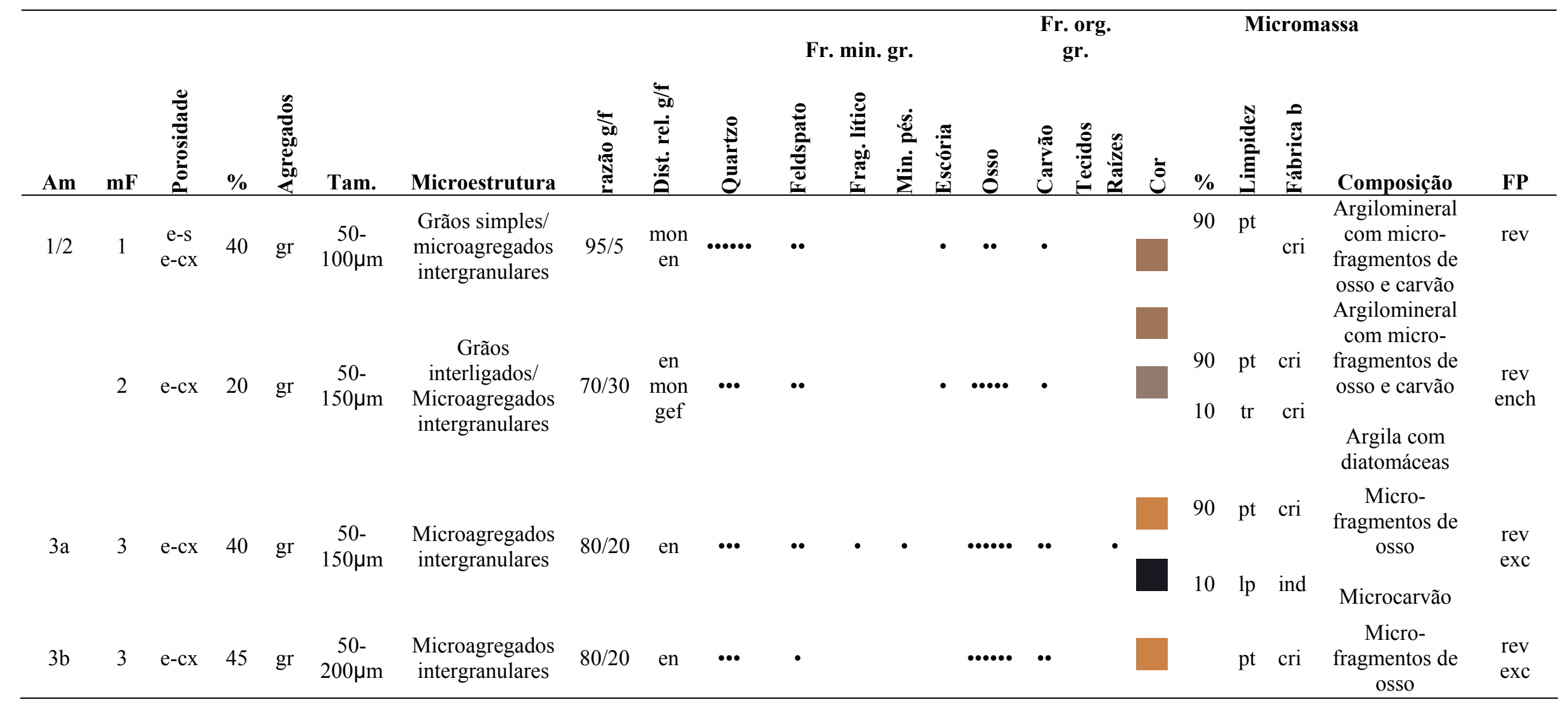

Freqüências de classes segundo Bullock et al. (1985): • Muito Poucas $(<5 \%) ; \bullet \bullet$ Poucas $(5-15 \%) ; \cdots \bullet$ Comum (15-30\%); ••• Freqüente (30-50\%); •••• Dominante (50-70\%); •... Muito dominante $(>70 \%)$. Am. = amostra; $\mathrm{mF}=$ microfácies; Tam.= tamanho; Fr. min. gr. = fração mineral grossa; Fr. org. gr. = fração orgânica grossa; FP = feições pedológicas. O singificado das demais abreviações utilizadas nesta tabela encontra-se no Anexo, Tabela A.5. 
Tabela 5.27. Componentes minerais e orgânicos da fração grossa da amostra SM8-1/2.

\begin{tabular}{|c|c|c|c|c|c|c|c|c|c|c|}
\hline \multicolumn{11}{|l|}{ SM8 1/2 } \\
\hline & $\mathbf{m F}$ & $\%$ & Tamanho & Forma & Arredondamento & Seleção & $\begin{array}{c}\text { Distribuiçãa } \\
\text { básica }\end{array}$ & $\begin{array}{c}\text { Orientação } \\
\text { básica }\end{array}$ & $\begin{array}{l}\text { Distribuição } \\
\text { referenciada }\end{array}$ & Alteração \\
\hline Quartzo & 1 & 80 & Areia fina e & Equidimensional & $\begin{array}{l}\text { Arredondado- } \\
\text { subarredondado }\end{array}$ & Bem selecionado & Aleatória & 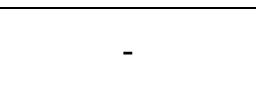 & 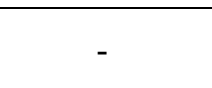 & 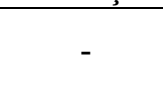 \\
\hline Feldspato & 1 & 5 & Areia fina & Equidimensional & $\begin{array}{l}\text { Arredondado- } \\
\text { subarredondado }\end{array}$ & Bem selecionado & Aleatória & - & - & - \\
\hline Escória & 1 & 2 & $50-100 \mu \mathrm{m}$ & Vários & Arredondado & Seleção pobre & Aleatória & - & - & - \\
\hline Osso & 1 & 10 & Vários & - & - & Não selecionado & Aleatória & - & - & $\begin{array}{l}\text { Queima e } \\
\text { dissolução }\end{array}$ \\
\hline Carvão & 1 & 3 & Vários & - & - & Não selecionado & Aleatória & - & - & - \\
\hline Quartzo & 2 & 20 & $\begin{array}{l}\text { Areia fina } \mathrm{e} \\
\text { mto. fina }\end{array}$ & Equidimensional & $\begin{array}{l}\text { Arredondado- } \\
\text { subarredondado }\end{array}$ & Bem selecionado & Aleatória & - & - & - \\
\hline Feldspato & 2 & 5 & Areia fina & Equidimensional & $\begin{array}{l}\text { Arredondado- } \\
\text { subarredondado }\end{array}$ & Bem selecionado & Aleatória & - & - & - \\
\hline Escória & 2 & 2 & $50-100 \mu \mathrm{m}$ & Vários & Arredondado & Seleção pobre & Aleatória & - & - & - \\
\hline Osso & 2 & 70 & Vários & - & - & Não selecionado & Linear/ Aleatória & $\begin{array}{l}80 \% \text { paralelismo } \\
\text { de ângulo baixo }\end{array}$ & $\begin{array}{l}\text { Inclinada à } \\
\text { superfície }\end{array}$ & $\begin{array}{l}\text { Queima e } \\
\text { dissolução }\end{array}$ \\
\hline Carvão & 2 & 3 & Vários & - & - & Não selecionado & Aleatória & - & - & - \\
\hline
\end{tabular}


Tabela 5.28. Componentes minerais e orgânicos da fração grossa da amostra SM8-3a.

\begin{tabular}{|c|c|c|c|c|c|c|c|c|c|c|}
\hline \multicolumn{11}{|l|}{ SM8 3a } \\
\hline & $\mathbf{m F}$ & $\%$ & Tamanho & Forma & Arredondamento & Seleção & $\begin{array}{c}\text { Distribuiçãa } \\
\text { básica }\end{array}$ & $\begin{array}{c}\text { Orientação } \\
\text { básica }\end{array}$ & $\begin{array}{l}\text { Distribuição } \\
\text { referenciada }\end{array}$ & Alteração \\
\hline Quartzo & 3 & 20 & Areia fina & Equidimensional & $\begin{array}{c}\text { Arredondado- } \\
\text { subarredondado }\end{array}$ & Bem selecionado & Aleatória & 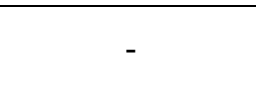 & 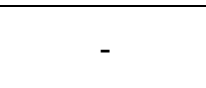 & 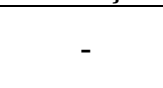 \\
\hline Feldspato & 3 & 3 & Areia fina & Equidimensional & $\begin{array}{l}\text { Arredondado- } \\
\text { subarredondado }\end{array}$ & Bem selecionado & Aleatória & - & - & - \\
\hline Farg. lít. & 3 & 3 & Areia fina & Equidimensional & $\begin{array}{l}\text { Arredondado- } \\
\text { subarredondado }\end{array}$ & Bem selecionado & Aleatória & - & - & - \\
\hline Min. pes. & 3 & 1 & Areia mto. fina & Equidimensional & $\begin{array}{l}\text { Arredondado- } \\
\text { subarredondado }\end{array}$ & Bem selecionado & Aleatória & - & - & - \\
\hline Osso & 3 & 70 & Vários & - & ( & Não selecionado & Linear/ Aleatória & $\begin{array}{l}80 \% \text { paralelismo } \\
\text { de ângulo baixo }\end{array}$ & $\begin{array}{l}\text { Inclinada à } \\
\text { superfície }\end{array}$ & $\begin{array}{l}\text { Queima e } \\
\text { dissolução }\end{array}$ \\
\hline Carvão & 3 & 3 & Vários & - & - & Não selecionado & Aleatória & - & - & - \\
\hline
\end{tabular}

Tabela 5.29. Componentes minerais e orgânicos da fração grossa da amostra SM8-3b

\begin{tabular}{|c|c|c|c|c|c|c|c|c|c|c|}
\hline \multicolumn{11}{|l|}{ SM8 3b } \\
\hline & $\mathbf{m F}$ & $\%$ & Tamanho & Forma & Arredondamento & Seleção & $\begin{array}{c}\text { Distribuição } \\
\text { básica }\end{array}$ & $\begin{array}{l}\text { Orientação } \\
\text { básica }\end{array}$ & $\begin{array}{l}\text { Distribuição } \\
\text { referenciada }\end{array}$ & Alteração \\
\hline Quartzo & 3 & 20 & Areia fina & Equidimensional & $\begin{array}{l}\text { Arredondado- } \\
\text { subarredondado }\end{array}$ & Bem selecionado & Aleatória & 然 & (5) & - \\
\hline Feldspato & 3 & 3 & Areia fina & Equidimensional & $\begin{array}{l}\text { Arredondado- } \\
\text { subarredondado }\end{array}$ & Bem selecionado & Aleatória & - & - & - \\
\hline Osso & 3 & 72 & Vários & - & the & Não selecionado & Linear/ Aleatória & $\begin{array}{c}80 \% \text { paralelismo } \\
\text { de ângulo baixo }\end{array}$ & $\begin{array}{l}\text { Inclinada à } \\
\text { superfície }\end{array}$ & $\begin{array}{l}\text { Queima e } \\
\text { dissolução }\end{array}$ \\
\hline Carvão & 3 & 5 & Vários & - & - & Não selecionado & Aleatória & - & - & - \\
\hline
\end{tabular}


O substrato arenoso do sítio Santa Marta 8 é representado pela $\mathrm{mF}$ 1, composta principalmente por grãos de areia quartzosa com $10 \%$ de ossos e $3 \%$ de carvões. A baixa frequência de componentes antrópicos (osso e carvão) confirma a suposição realizada no trabalho de campo, sobre a natureza intrusiva dos componentes antrópicos desta arqueofácies. A mF 1 apresenta microestrutura de grãos simples (Figura 5.88 C) com finos microagregados intergranulares formados por mistura de argilomineral castanho claro a transparente (PPL) com micro-fragmentos de osso e micro-carvão (Figura $5.88 \mathrm{D}$ ). O contato com a $\mathrm{mF} 2$, superior, caracteriza-se pelo incremento de fragmentos maiores de osso e carvão, aumento na proporção de fração fina e microestrutura de grãos interligados e microagregados intergranulares (Figura 5.88 A, E).

A fração fina da $\mathrm{mF} 2$ permanece a mesma da $\mathrm{mF}$ 1, mas aumenta em proporção (Figura 5.88 F) e inclui também concentrações maciças de argilominerais com diatomáceas (Figura 5.89 A), e agregados transparentes (PPL) de espículas de esponja e diatomáceas (Figura $5.90 \mathrm{~B} ; 5.92$ A). Em algumas partes, a micromassa é totalmente transparente, com micro-fragmentos de osso e microcarvão, associada a resíduos silícáticos e escória vítrea (Figura 5.89 C, D). Diatomáceas são também observadas isoladamente ou formando pequenos agrupamentos associados aos fragmentos de osso (5.92 B, C). Entre as espécies identificadas na $\mathrm{mF} 2$ está Grammatophora oceânica, espécie eusalina, euritópica, que indica presença de espécies marinhas no sambaqui. $\mathrm{Na}$ $\mathrm{mF}$ 2, destaca-se a presença de revestimentos e enchimentos, impuros, microlaminados, mosqueados e de birrefringência baixa (XPL) de argilominerais (Figura 5.89 E, F). Estes revestimentos formam meniscos entre os componentes da fração grossa, o que resulta na microestrutura de grãos interligados que caracteriza à $\mathrm{mF} 2$. Todos os fragmentos de osso nesta microfácies apresentam perda de colágeno relacionada com a queima.

A mF 3 possui características semelhantes nas duas seções delgadas analisadas. Apresenta microestrutura de microagregados intergranulares e fração grossa composta em mais de $70 \%$ por fragmentos de osso, com grãos minerais na fração areia fina (Figura 5.90 A-D). As feições pedológicas incluem revestimentos descontínuos, pontuados (PPL) e indiferenciados (XPL), formados pelo transporte da fração fina, e excrementos esferoides na forma de microagregados densos. Os fragmentos de osso de tamanho milimétrico até centimétrico aparecem formando bolsões discretos nas 
lâminas, com distribuição sub-horizontal e evidências de fragmentação in situ. Os fragmentos de osso menores estão distribuídos aleatoriamente.

A fração fina da mF 3 deriva-se da degradação de fragmentos de osso em finas partículas fosfáticas. Trata-se de agregados de microfragmentos de osso que formam matriz castanha claro amarelada (PPL), de birrefringência baixa até indiferenciada (XPL) (Figura 5.90 E, F). Em alguns casos, observam-se agregados entre os componentes da fração grossa e como finos revestimentos, formados pelo que parece ser mineral fosfático secundário, de limpidez pontuada (PPL) pela presença de microcarvão. A composição semi-quantitativa da fração fina desta microfácies foi determinada com sistema MEV-EED. O domínio de $\mathrm{P}$ e Ca $(\sim 15 \%$ e 27-28\%, respectivamente), seguido de Si ( 9-11\%) indicam presença de fosfatos secundários e resíduos silicáticos derivados da queima de plantas (Anexo, Figura A.7).

Assim como na $\mathrm{mF} 2$, identificaram-se na $\mathrm{mF} 3$ diatomáceas dispersas misturadas entre os fragmentos de osso e entre fitólitos. Foram identificadas as espécies Actinoptychus senarius, espécie eusalina euritópica, e Diploneis ovalis, espécie oligosalina, entre outras (Amaral, comunicação pessoal).

Os fragmentos de osso apresentam birrefringência mais baixa que aquela associada aos ossos frescos. A alteração na birrefringência associa-se à deterioração do colágeno por queima, dissolução ou alteração microbiana (Figura 5.91 A-D). Aproximadamente $15 \%$ deles apresentam sinais de queima na coloração avermelhada e nas bordas pretas (PPL) e entre 70-90\% dos ossos não tem fluorescência (UV). A alta porcentagem de ossos sem fluorescência confirma a degradação do colágeno por queima ou bioerosão. Fragmentos maiores apresentam fluorescência unicamente na porção interna, que ter-se-ia preservado da degradação do colágeno. Pela dificuldade de distinguir, unicamente com base em propriedades ópticas, entre ossos com sinais de queima e/ou dissolução, possivelmente a porcentagem de ossos queimados neste depósito esteja subestimada.

No entanto, a alta fragmentação dos ossos que se observa na $\mathrm{mF} 3$ sugere, indiretamente, duas trajetórias de ateração: que grande parte dos fragmentos sofreu, de fato, alteração térmica, já que a queima torna o mineral do osso mais resistente à alteração química (Karkanas, 2000), porém, mais suscetível à fragmentação por pressões físicas (Steiner et al., 1995); ou que o intemperismo prolongado favoreceu a fragmentação, ao provocar mudanças cristalográficas na fração mineral do osso que lhe 
outorgam as mesmas propriedades que a queima, como resistência à dissolução e suscetibilidade à quebra (Berna et al., 2004). Pelas evidências de queima e dissolução observadas nos fragmentos ósseos de todo o depósito, uma combinação de ambos os processos parece ser a trajetória mais provável.

A queima de ossos observada na $\mathrm{mF} 3$ não foi realizada no local. Isto pode ser inferido a partir de três indicadores: não se identificaram fogueiras estruturadas no perfil estratigráfico; a microfácies apresenta mistura de ossos queimados a diversas temperaturas (ver Schiegl et al., 2003); e não se observa substrato carbonizado ou rubificado embaixo da mF 3 (ver Mallol et al., 2007; Schiegl, 1996; Weiner, 2002). Os três indicadores micromorfológicos de queima in situ, observados na experiência de queima discutida no tópico 1.1.4, estão ausentes na $\mathrm{mF} 3$.

Em termos gerais, mF 3 caracteriza-se pela mistura de: bolsões de ossos milimétricos, associados a micro-estratificação formada por sucessão de micro-camadas de osso e carvão esmagados, em associação com agregados de diatomáceas; e áreas com microestrutura de agregados intergranulares, formadas por finos fragmentos de osso, fosfatos secundários e microcarvão, de distribuição aleatória, que indicam retrabalhamento biológico do depósito. Esta massa basal sugere que $\mathrm{mF} 3$ formou-se pela deposição de resíduos faunísticos alterados por queima e/ou dissolução e de outros tipos de resíduos de queima, como escória vítrea e carvões, misturados com material terrígeno contendo agregados de diatomáceas.

A massa basal da mF 3 indica a mesma re-deposição de resíduos já observada na camada preta de Jabuticabeira 2 (Villagran 2008). Assim, as semelhanças que se observaram em campo entre Santa Marta 8 e a camada preta de Jabuticabeira 2 se correspondem na escala microscópica. A alta concentração de ossos, muitos deles queimados, junto com a presença de diatomáceas e micromassa formada por microfragmentos de osso, microcarvão e agregados de fosfatos secundários são atributos de ambos os sítios. 
A
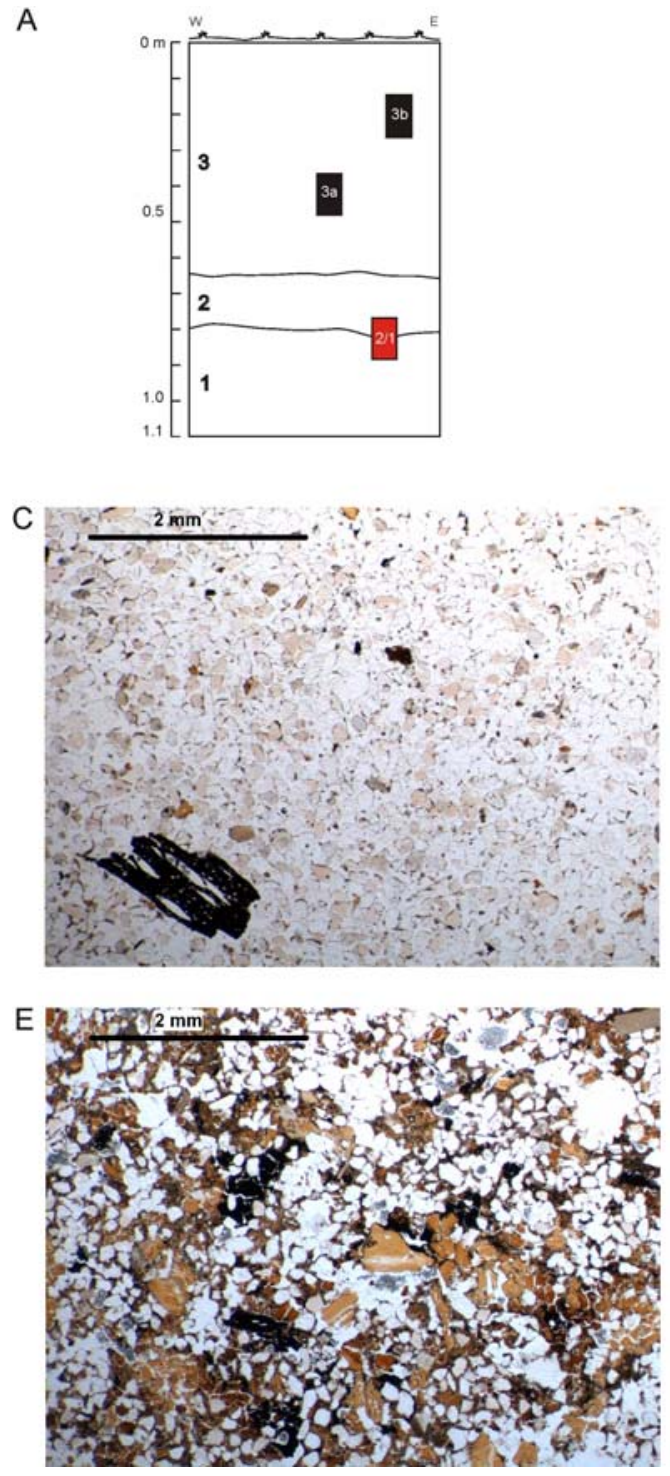
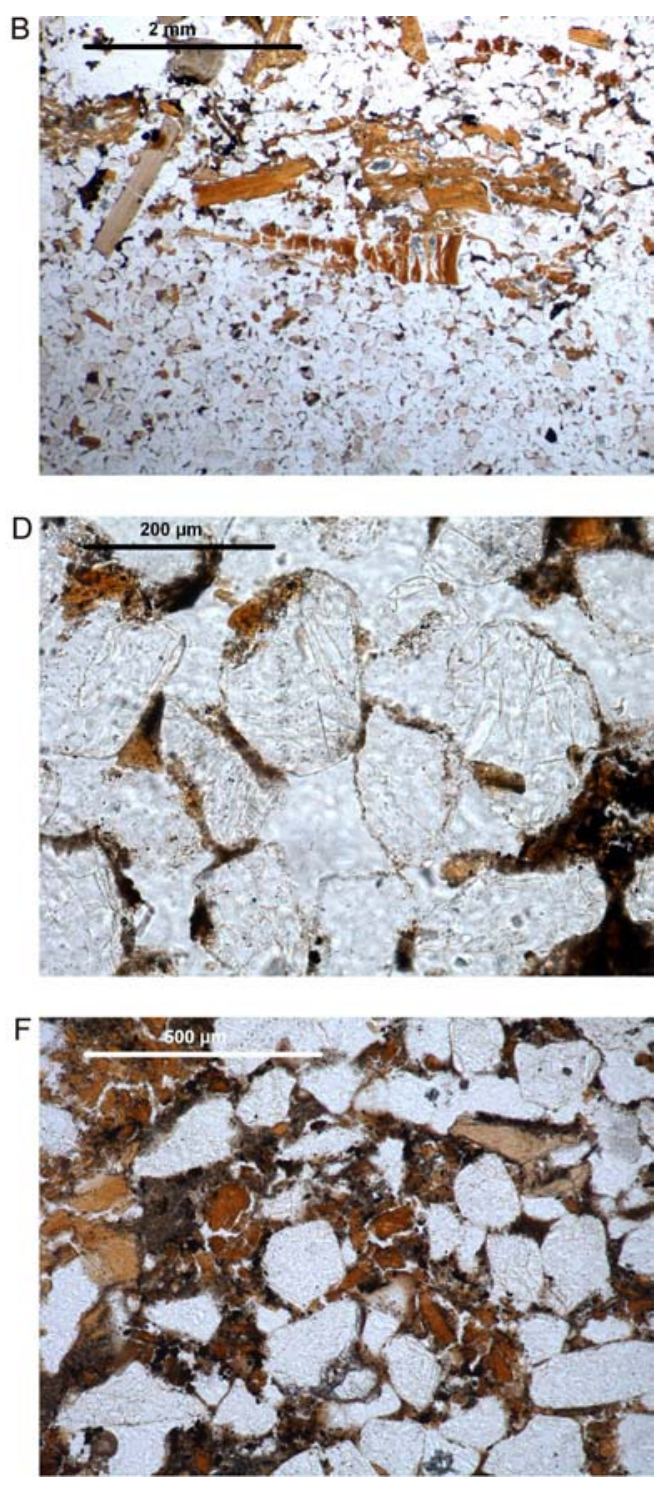

Figura 5.88. Fotomicrografias das $\mathrm{mF} 1$ e 2 do sítio Santa Marta 8: A) seção vertical esquemática, com localização da amostra para micromorfologia; B) contato entre a $\mathrm{mF}$ 1, inferior, e a $\mathrm{mF} 2$, superior, PPL; C) massa basal da $\mathrm{mF} 1$ composta por grãos de quartzo, PPL; D) microestrutura de grãos interligados da $\mathrm{mF}$ 1, formada por micromassa de argilominerais com micro-fragmentos de osso e microcarvão, PPL; E) massa basal da mF 2 formada por ossos, fragmentados e inteiros, carvão e grãos de quartzo, PPL; F) microestrutura da $\mathrm{mF} 2$ formada por microagregados intergranulares e grãos revestidos, PPL. 

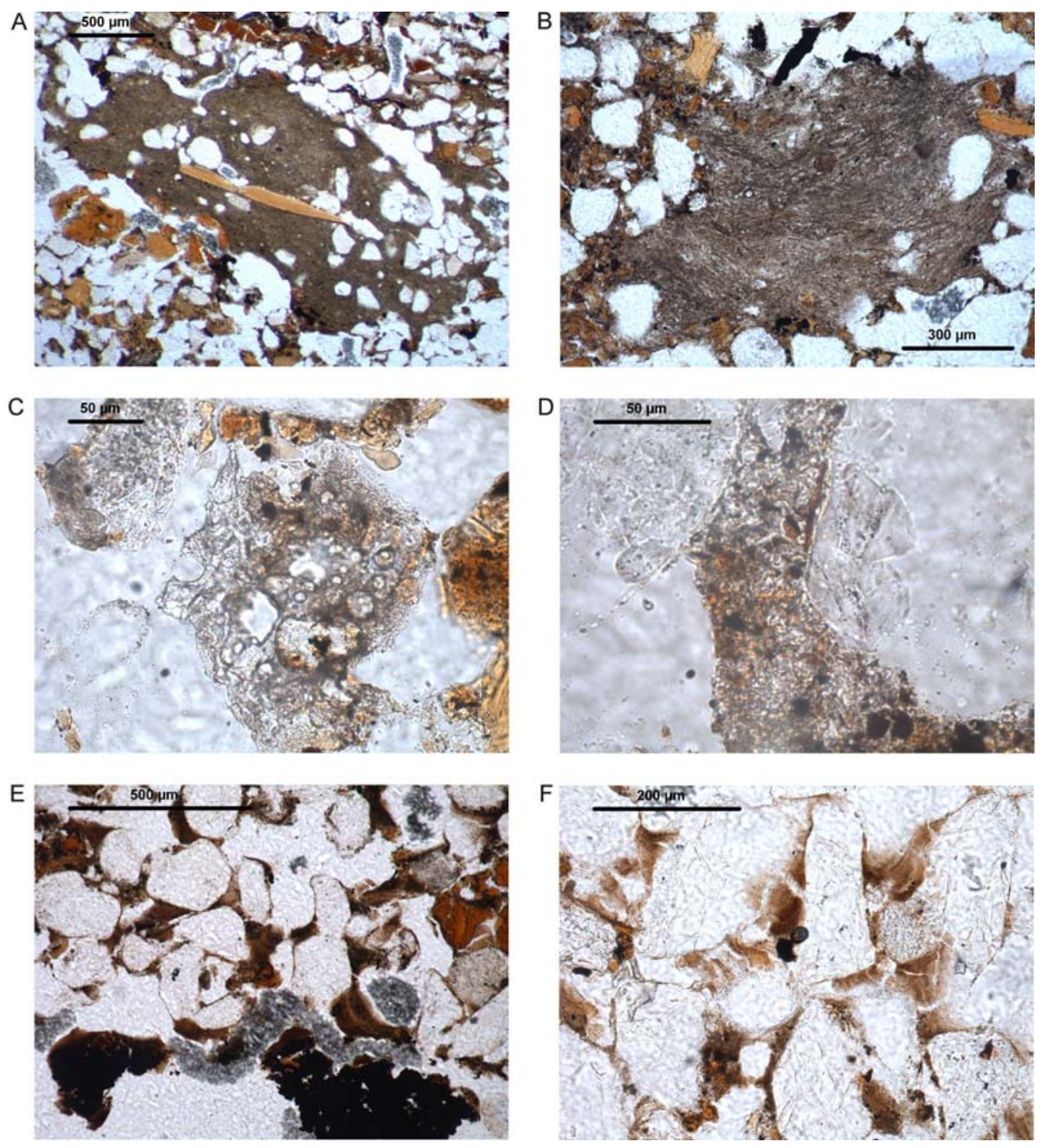

Figura 5.89. Fotomicrografias de elementos de interesse na $\mathrm{mF} 2$ do sítio Santa Marta 8: A) agregado de argilominerais com diatomáceas, PPL; B) concentração de espículas de esponja e diatomáceas, PPL; C) agregado de escória vítrea, PPL; D) micromassa transparente com microcarvão e micro-fragmentos de osso, PPL; E, F) revestimentos impuros, micro-laminados, PPL. 
A

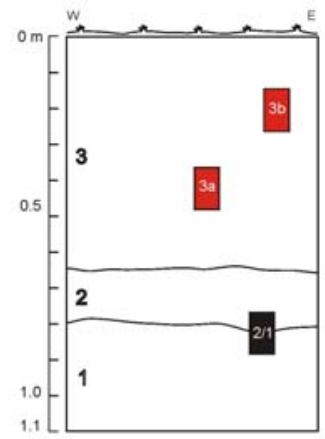

C
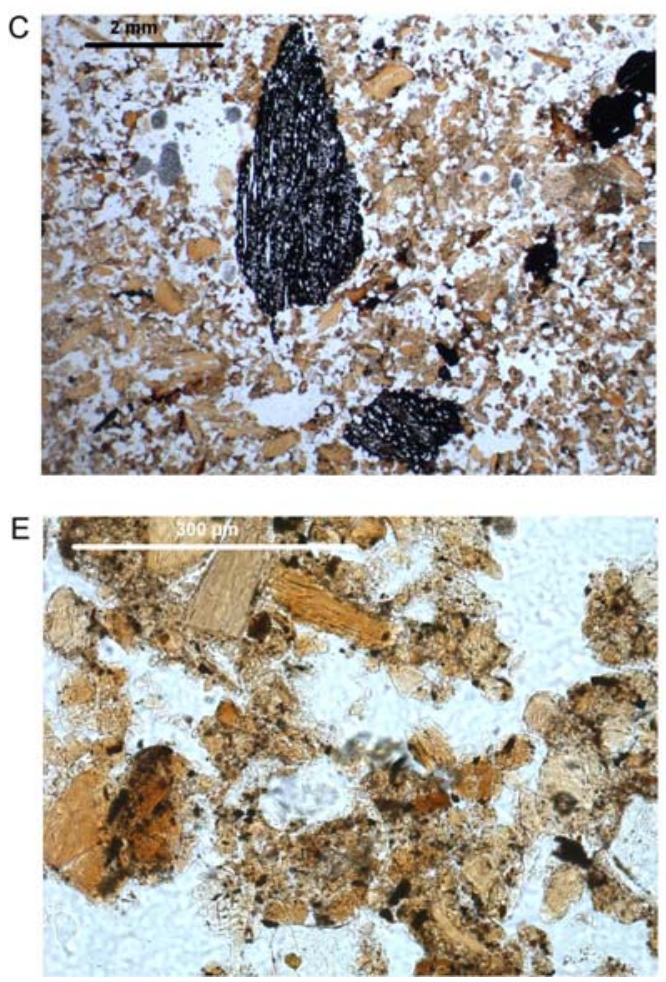
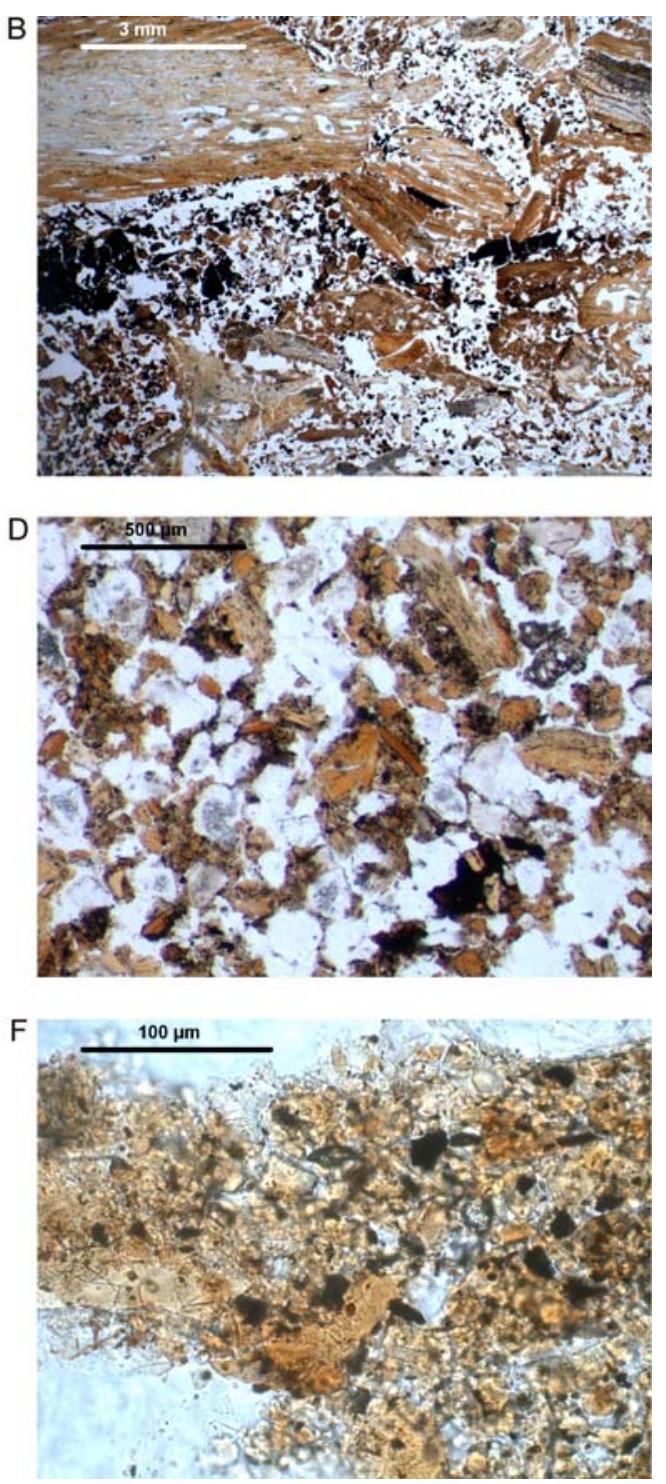

Figura 5.90. Fotomicrografias da $\mathrm{mF} 3$ do sítio Santa Marta 8: A) seção vertical esquemática, com localização das amostras para micromorfologia; B, C) massa basal composta por bolsões de fragmentos de osso milimétricos, carvão e grãos de quartzo, PPL; D) áreas com microestrutura de microagregados intergranulares, PPL; E, F) detalhe da micromassa formada por micro-fragmentos de osso, agregados de fosfato secundário e microcarvão, PPL. 

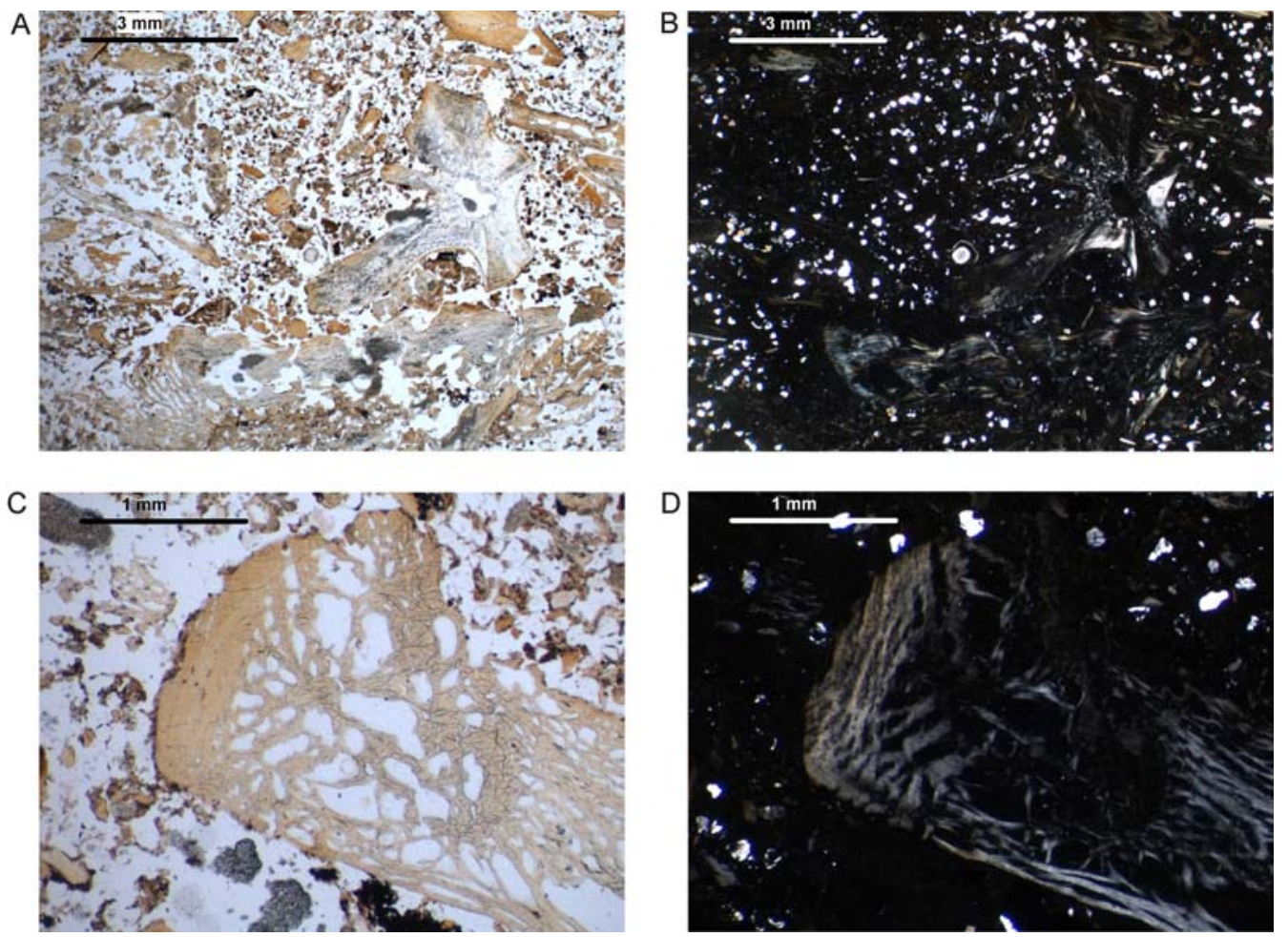

Figura 5.91. Fotomicrografias de fragmentos de osso na $\mathrm{mF} 3$ com birrefringência baixa, de primeira ordem, a PPL (A, C) e XPL (B, D).
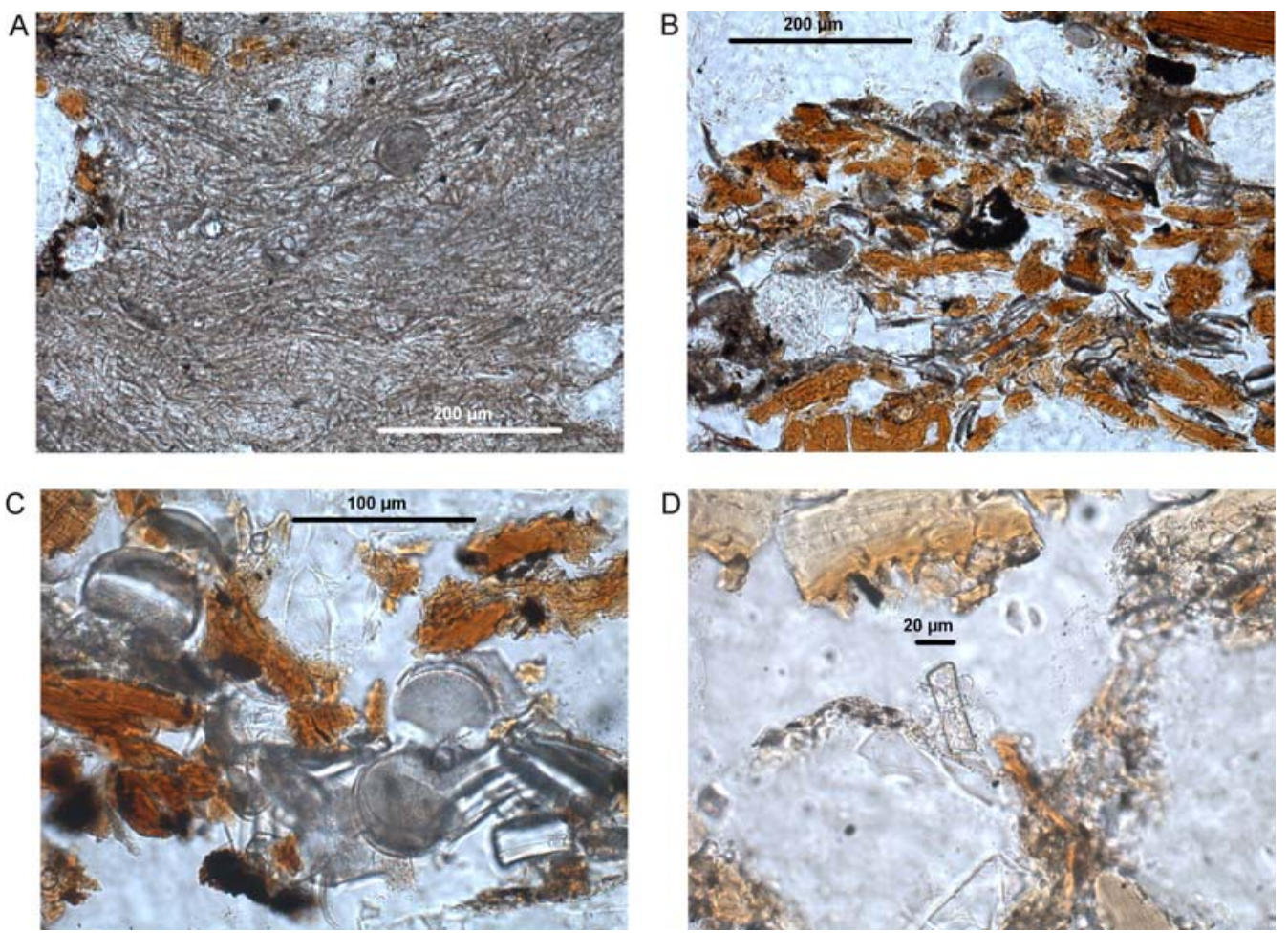

Figura 5.92. Fotomicrografias de partículas silicosas na $\mathrm{mF} 2$ e 3: A) detalhe de agregado de espículas de esponja e diatomáceas na $\mathrm{mF} 2$, PPL; B) diatomáceas e fitólitos entre fragmentos de osso de peixe na $\mathrm{mF}$ 2, PPL; C) detalhe de B, com frústula da diatomácea Coscinodiscus excentricus; D) fitólito alongado na $\mathrm{mF} 3$, com sinais de derretimento, PPL. 


\subsubsection{Galheta 4}

O sítio Galheta 4 cobre uma área extensa da ponta da Galheta, onde também se encontram dois sambaquis de padrão estratigráfico conchífero (Galheta 1 e 2). A sucessão estratigráfica é composta por fácies arenosa, com bandas de impregnação (Fácies A), superposta por camada de areia lamosa preta com ossos de peixe e carvão (AF 1) e camada de areia amarelo claro (Fácies B) (Figura 5.93)

Apesar de corresponder à categoria de montículo ictiológico pela sua cronologia (aproximadamente 800 anos AP) e composição (predomínio de ossos de peixe), este sítio assemelha-se a Santa Marta 10 por apresentar características de perfil pedoestratigráfico. Assim, todos estes sítios teriam sido formados a partir da combinação de episódios de deposição antrópica e natural, e alteração do substrato por ocupação superficial, sem episódio construtivo. No caso de Santa Marta 10, o anel de conchas evidencia a deposição antrópica, enquanto a Fácies B, superficial, mostra a incorporação ao substrato eólico de resíduos orgânicos vinculados com a ocupação humana.

No sítio Galheta 4, a areia que compõe a Fácies A, inferior, poderia ter sido depositada antropicamente, para formar um montículo, assim como a AF 1, preta e intermediária, e a Fácies B, superior. No entanto, as observações de campo sugerem que a Fácies A seria natural (areia eólica) e que a própria ocupação humana no local teria favorecido, a partir de deposição de diversos resíduos orgânicos, a formação de um antropossolo no topo desta duna, representado pela AF 1. A presença da AF 1 relacionase provavelmente à posterior formação de bandas de impregnação na Fácies A, formadas pelo transporte vertical e cimentação de Fe ou Fe e Mn (com ou sem MO). A Fácies B também seria naturalmente depositada, e corresponderia a areia eólica recente.

A ocupação superficial teria resultado na formação de uma extensa camada de areia lamosa preta com bioclastos (principalmente ossos de peixe) sobre as dunas empoleiradas que cobrem o costão rochoso. Os episódios construtivos estariam associados com a deposição de quantidades massivas de restos faunísticos acima dos sepultamentos identificados no local. Neste caso, a deposição eólica atua como fator determinante no crescimento vertical do sítio.

Deve-se esclarecer que, no caso de Santa Marta 10, a camada superficial preta é denominada de Fácies, e não arqueofácies, por não mostrar nenhuma evidência macroscópica de se tratar de episódio deposicional de origem antrópica, e sim 
meramente eólico. No sítio Carniça 3, esta camada é denominada de arqueofácies já que, pelo seu conteúdo bioclástico, trata-se do produto da deposição antrópica. No sítio Galheta 4, observa-se uma situação semelhante a Carniça 3. A camada superficial preta é denominada de arqueofácies por incluir na sua composição numerosos fragmentos de osso e carvão, visíveis na avaliação macroscópica dos perfis, indicadores de deposição antrópica no local.

\section{$\underline{\text { Granulometria }}$}

Análises granulométricas realizadas na fração terrígena das Fácies A e B e da AF 1 mostram o predomínio da fração areia muito fina na Fácies A, inferior, e aumento da fração areia fina na AF 1 e na Fácies B, superiores (Figura 5.94). As distribuições granulométricas das três amostras foram comparadas com dados das quatro gerações de dunas eólicas identificadas na região que vai do cabo de Santa Marta até a praia Grande do Sul (Giannini, 1993; Giannini et al., 2007; Martinho, 2004; Sawakuchi, 2003). Para o parâmetro diâmetro médio existe pouca afinidade das Fácies A, B e AF 1 com dunas eólicas. Para o desvio padrão observa-se afinidade da Fácies A com dunas de geração 2 e da AF 1 e Fácies B com dunas de geração 3. No parâmetro assimetria, unicamente a AF 1 e Fácies B voltam a mostrar afinidade com dunas de geração 3 (Figura 5.94 B).

A observação ao microscópio estereoscópico das frações retidas na malha de 1,0 e $0,5 \mathrm{~mm}$ da AF 1 constata o predomínio de restos antrópicos, como fragmentos de osso carbonizados e calcinados (Figura 5.95). 


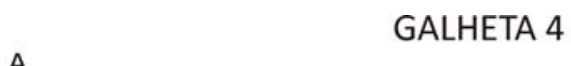

A
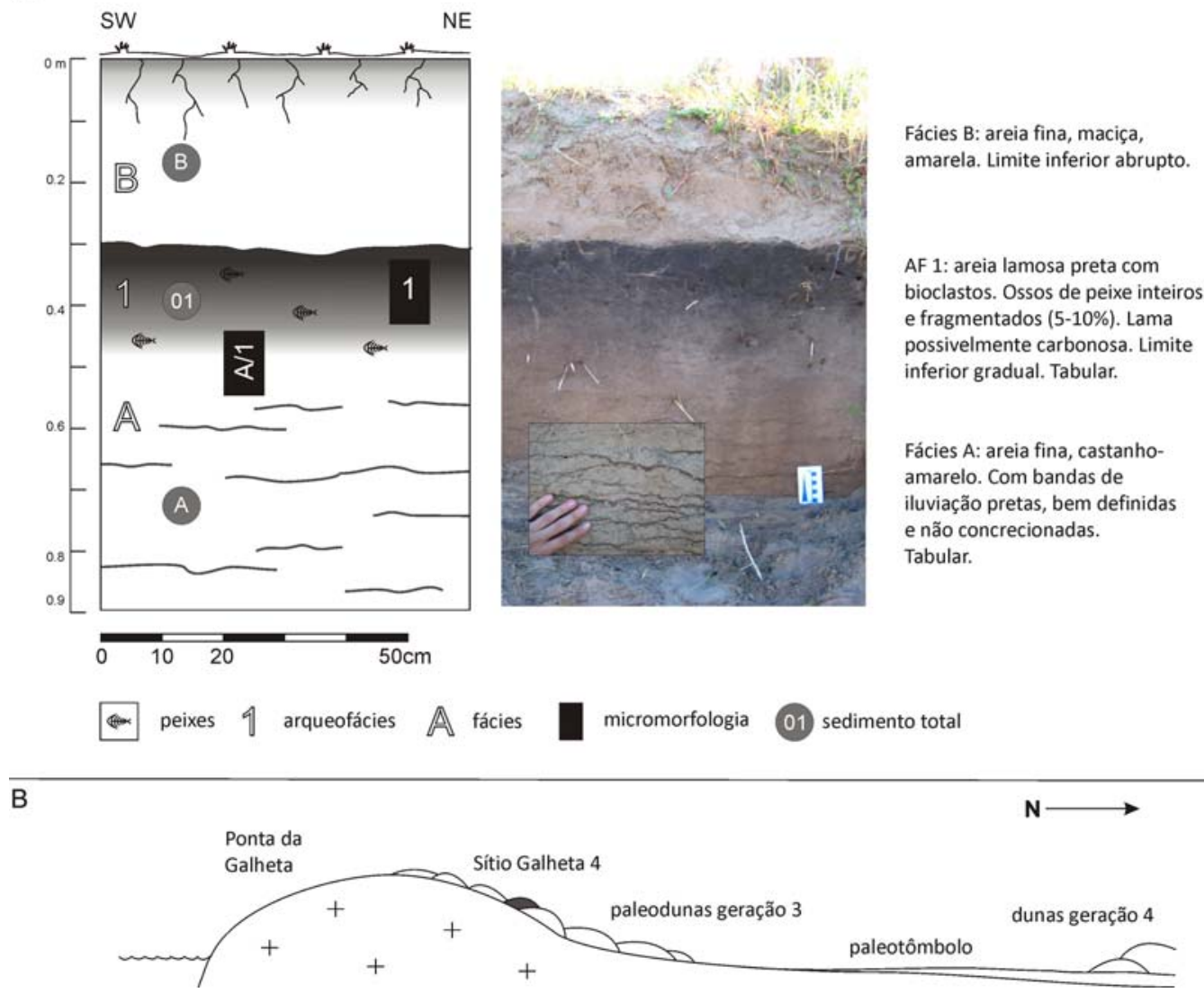

Figura 5.93. Seção vertical estudada do sítio Galheta 4: A) localização dos pontos de amostragem e descrição das arqueofácies identificadas; B) seção transversal esquemática (sem escala) da área de localização do sítio. 

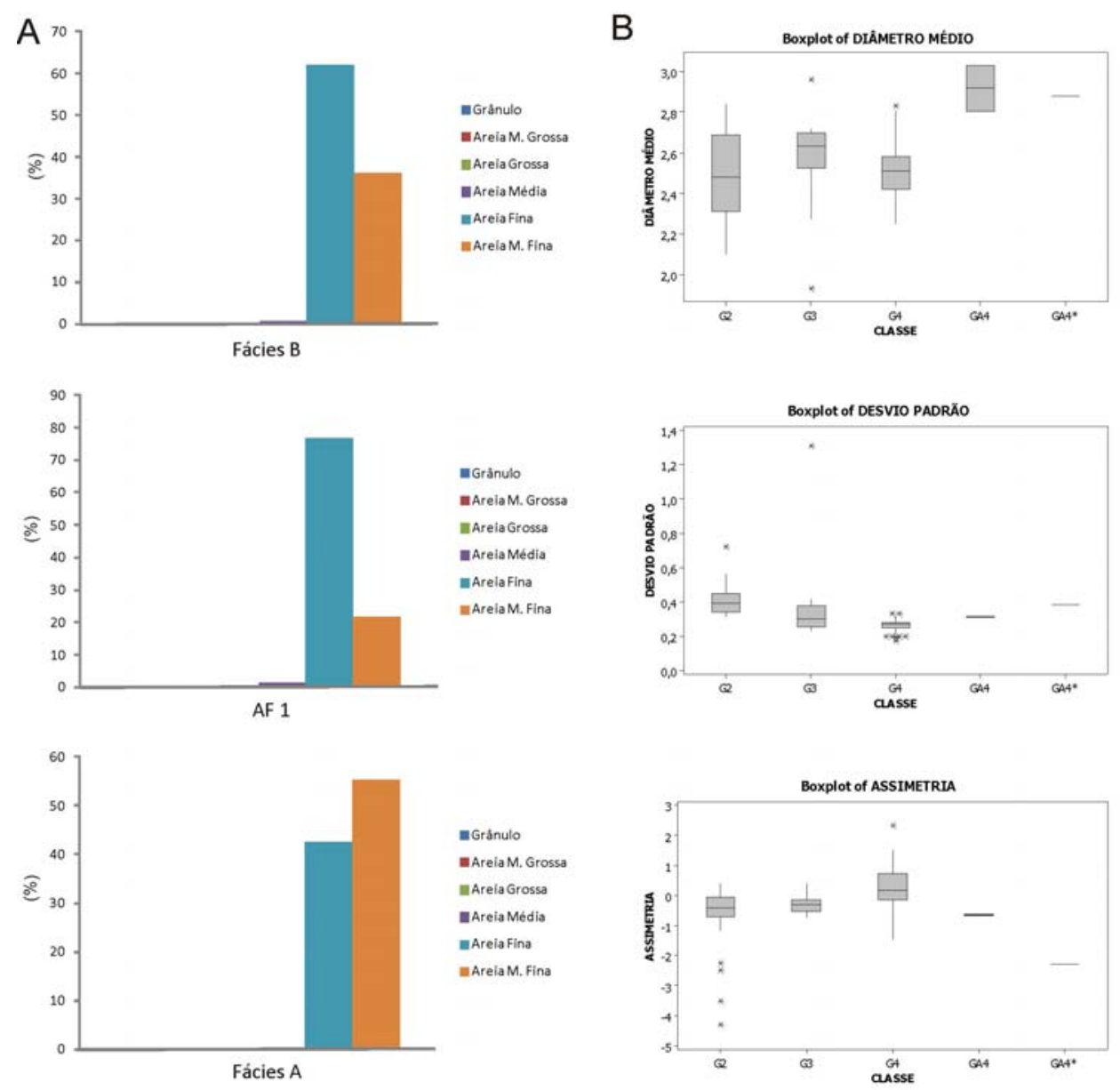

Figura 5.94. Gráficos das distribuições granulométricas e parâmetros estatísticos para o sítio Galheta 4 e amostragem em sedimentos naturais das proximidades: A) histogramas da distribuição granulométrica para as Fácies A, B e AF 1; note-se o domínio da fração areia muito fina na Fácies A e areia fina na AF 1 e Fácies B; B) diagramas em caixa (boxplot) das estatísticas diâmetro médio, desvio padrão e assimetria para AF 1 do sítio Galheta 4 (GA4), Fácies A (GA4*) e geração de dunas eólicas 1 (G1), 2 (G2), 3 (G3) e 4 (G4) tomadas de Giannini et al., (2007), Giannini (1993), Martinho (2004) e Sawakuchi (2003). 

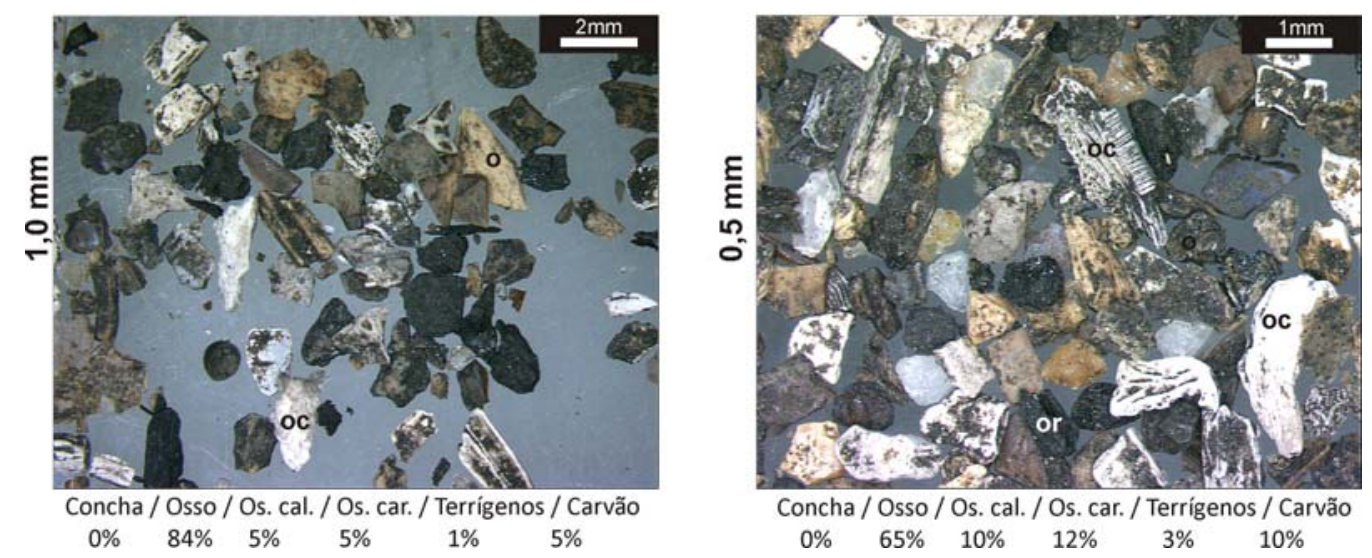

Figura 5.95. Fotomicrografias à lupa estereoscópica de grãos retidos nas malhas de $1,0 \mathrm{~mm}$ e $0,5 \mathrm{~mm}$, da arqueofacies 1 do sítio Galheta 4. Note-se a presença de ossos (o), osso carbonizado (Os.car. $=$ or) e osso calcinado $($ Os.cal. $=$ oc $)$.

\section{Isótopos de Ce N $\left(\delta^{13} C\right.$ e $\left.\delta^{53} N\right)$}

Análises isotópicas foram realizadas na MO da AF1 e Fácies B (Figura 5.96; Anexo, Tabela A.1). Como observado em outros sambaquis conchíferos e montículos ictiológicos da região, a assinatura isotópica da AF 1 indica presença de resíduos de origem animal. Especialmente o sítio Galheta 4 e Santa Marta 8 apresentam os valores mais positivos de $\delta^{15} \mathrm{~N}$ e mais negativos de $\delta^{13} \mathrm{C}$ de todos os sítios analisados. A amostra proveniente da Fácies $\mathrm{B}$, interpretada como depósito eólico que cobriu a área de ocupação, diferencia-se claramente da camada de ocupação por conter MO de origem vegetal, especificamente plantas $C_{3}$, associada à vegetação que cresce atualmente sobre o depósito. 

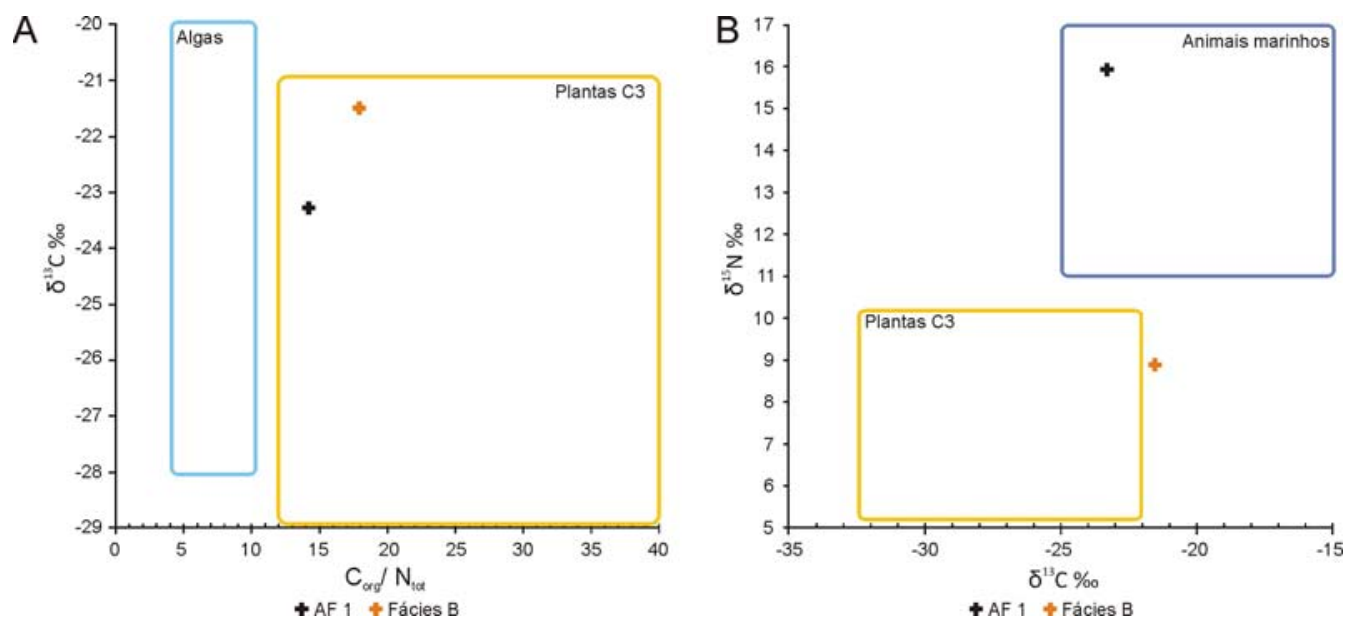

Figura 5. 96. Análises isotópicas $\left(\delta^{13} \mathrm{C}\right.$ e $\delta^{15} \mathrm{~N}$ e razão $\left.\mathrm{C} / \mathrm{N}\right)$ de amostras provenientes da AF 1 e Fácies B do sítio Galheta 4: A) gráfico de valores de $\delta^{13} \mathrm{C}$ e razão $\mathrm{C} / \mathrm{N}$ com intervalos definidos para plantas de ciclo fotossintético $\mathrm{C} 3$ e algas; B) Gráfico dos valores de $\delta^{15} \mathrm{~N}$ e $\delta^{13} \mathrm{C}$ com intervalos definidos para plantas de ciclo fotossintético $\mathrm{C} 3$ e animais marinhos.

\section{Micromorfologia}

Duas seções delgadas para análise micromorfológica foram coletadas do sítio Galheta 4. Uma delas abrange o contato gradual entre a Fácies A e AF 1 (amostra A/1), e outra a porção superior da AF 1 (amostra 1). Como o contato entre a Fácies A e a AF 1 é gradual, não se observaram microfácies diferenciadas na seção delgada A/1 (Figura 5.97). Na Tabela 5.30, apresenta-se a descrição micromorfológica das duas seções delgadas analisadas. 


\section{GALHETA 4}

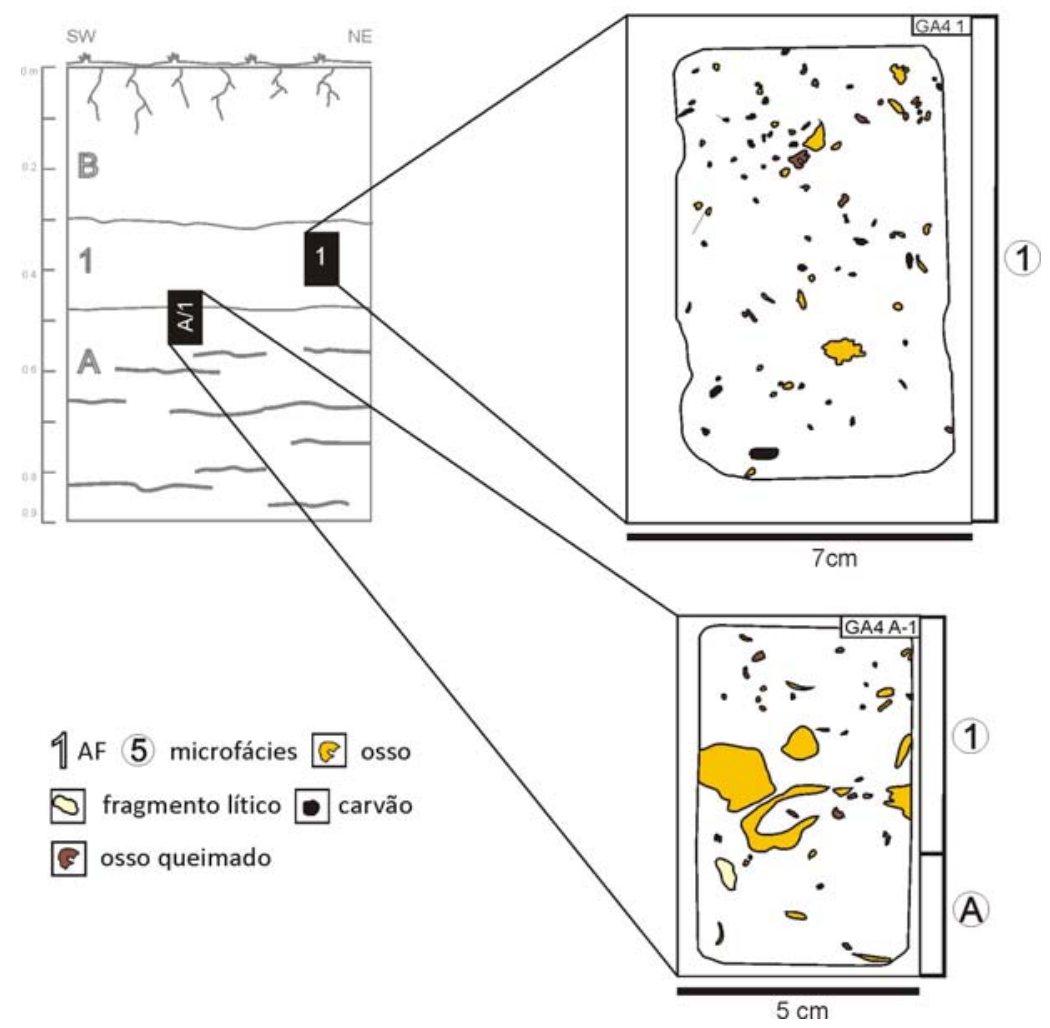

Figura 5.97. Desenho esquemático das seções delgadas analisadas no sítio Galheta 4, com localização dos blocos de amostragem na sucessão vertical e identificação de microfácies nas lâminas.
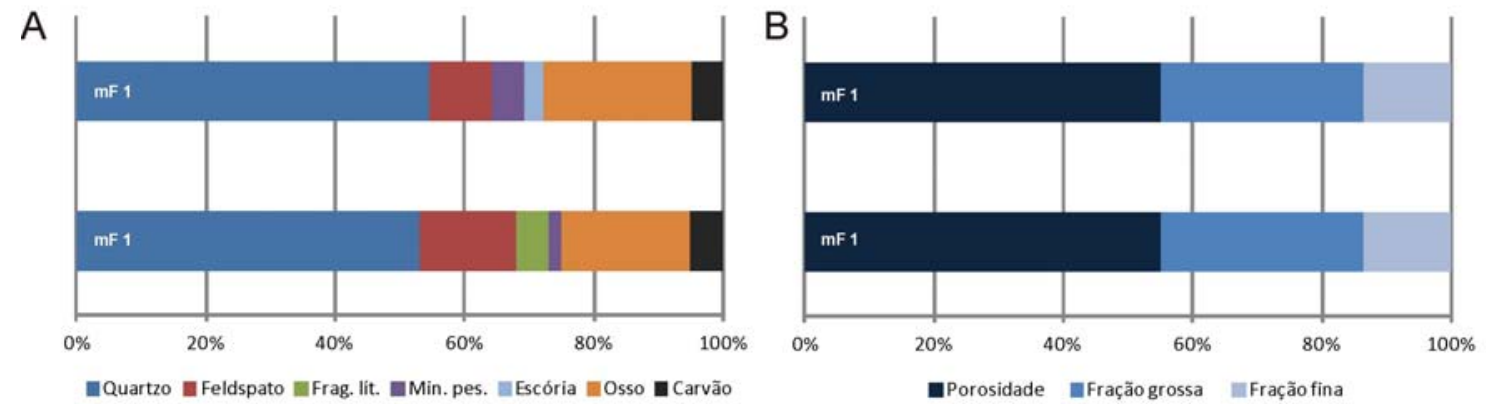

Figura 5.98. Gráficos com porcentagens dos diferentes componentes microscópicos da $\mathrm{mF} 1$ do sítio Galheta 4: A) frequências de componentes da fração grossa; B) relação entre as porcentagens de poros, fração grossa e fração fina. 
Tabela 5.30 . Descrição micromorfológica do sítio Galheta 4.

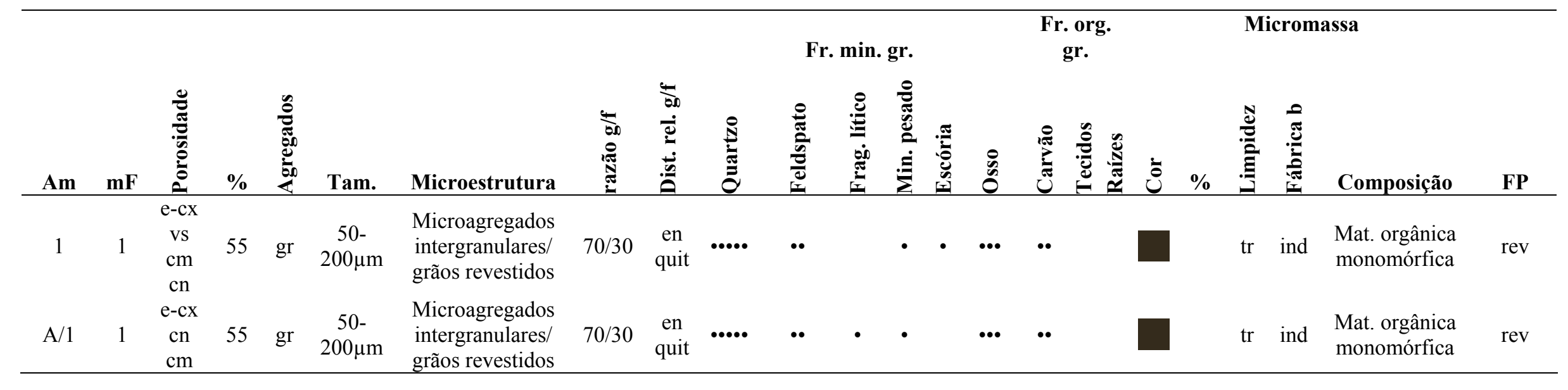

Freqüências de classes segundo Bullock et al. (1985): • Muito Poucas $(<5 \%) ; \bullet$ Poucas $(5-15 \%) ; \cdots$ Comum $(15-30 \%) ; \cdots \cdot \bullet$ Freqüente (30-50\%); $\cdots . . \bullet$ Dominante $(50-70 \%)$; ...... Muito dominante $(>70 \%)$. Am. $=$ amostra; $\mathrm{mF}=$ microfácies; Tam. $=$ tamanho; Fr. min. gr. $=$ fração mineral grossa; Fr. org. gr. = fração orgânica grossa; $\mathrm{FP}=$ feições pedológicas. O singificado das demais abreviações utilizadas nesta tabela encontra-se no Anexo, Tabela A.5. 
Tabela 5.31. Componentes minerais e orgânicos da fração grossa da amostra GA4-1.

\begin{tabular}{|c|c|c|c|c|c|c|c|c|c|c|}
\hline \multicolumn{11}{|l|}{ GA4 1} \\
\hline & $\mathbf{m F}$ & $\%$ & Tamanho & Forma & Arredondamento & Seleção & $\begin{array}{c}\text { Distribuição } \\
\text { básica }\end{array}$ & $\begin{array}{c}\text { Orientação } \\
\text { básica }\end{array}$ & $\begin{array}{l}\text { Distribuição } \\
\text { referenciada }\end{array}$ & Alteração \\
\hline Quartzo & & 55 & Areia fina & Equidimensional & Arredondado & Bem selecionado & Aleatória & - & - & - \\
\hline Feldspato & & 10 & Areia fina & Equidimensional & Arredondado & Bem selecionado & Aleatória & - & - & - \\
\hline Min. pes. & & 4 & Areia mto. fina & Equidimensional & Arredondado & Bem selecionado & Aleatória & - & - & - \\
\hline Escória & & 3 & $100 \mu \mathrm{m}$ & - & - & Bem selecionado & Aleatória & - & - & - \\
\hline Osso & & 23 & $\begin{array}{l}\text { Areia fina a } \\
\text { mto. fina }\end{array}$ & - & - & Seleção moderada & Aleatória & - & - & $\begin{array}{l}\text { Queima e } \\
\text { dissolução }\end{array}$ \\
\hline Carvão & & 5 & Vários & - & - & Não selecionado & Aletória & - & - & - \\
\hline
\end{tabular}

Tabela. 5.32. Componentes minerais e orgânicos da fração grossa da amostra GA4-A/1

\begin{tabular}{|c|c|c|c|c|c|c|c|c|c|c|}
\hline \multicolumn{11}{|l|}{ GA4 1} \\
\hline & $\mathbf{m F}$ & $\%$ & Tamanho & Forma & Arredondamento & Seleção & $\begin{array}{c}\text { Distribuiçãão } \\
\text { básica }\end{array}$ & $\begin{array}{c}\text { Orientação } \\
\text { básica }\end{array}$ & $\begin{array}{l}\text { Distribuição } \\
\text { referenciada }\end{array}$ & Alteração \\
\hline Quartzo & & 53 & Areia fina & Equidimensional & Arredondado & Bem selecionado & Aleatória & - & - & - \\
\hline Feldspato & & 15 & Areia fina & Equidimensional & Arredondado & Bem selecionado & Aleatória & - & - & - \\
\hline Frag. lít. & & 5 & Cascalho & Equidimensional & Subanguloso & Não selecionado & Aleatória & - & - & - \\
\hline Min. pes & & 2 & Areia mto. fina & Equidimensional & Arredondado & Bem selecionado & Aleatória & - & - & - \\
\hline Osso & & 20 & $\begin{array}{c}\text { Areia fina a } \\
\text { mto. fina }\end{array}$ & 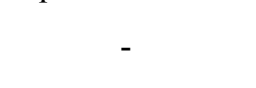 & - & Seleção moderada & Aleatória & - & - & $\begin{array}{l}\text { Queima e } \\
\text { dissolução }\end{array}$ \\
\hline Carvão & & 5 & Vários & - & - & Não selecionado & Aletória & - & - & - \\
\hline
\end{tabular}


A mF 1 apresenta as mesmas características micromorfológicas nas duas seções delgadas analisadas. A fração grossa é composta por grãos de quartzo ( $50 \%)$ e feldspato (10-15\%) arredondados, na fração areia fina, com freqüência menor que 5\% de minerais pesados e fragmentos líticos. Os componentes antrópicos incluem cerca de $20 \%$ de fragmentos de osso, 5\% de carvão e 3\% de escória vítrea (Figura 5.98 A; Tabela $5.31,5.32)$. A mF 1 apresenta porosidade superior a 50\%, com cerca de $25 \%$ de fração fina (Figura 5.98 B) distribuída em microestrutura de microagregados intergranulares e grãos revestidos, composta de MO monomórfica e microcarvão (Figura 5.99 A-F; Tabela 5.30). Destaca-se na fração grossa a aparição recorrente de escória vítrea e fitólitos (Figura 5.100 A-C).

A micromassa de grãos revestidos, formada por MO monomórfica, com microagregados intergranulares em forma de pellets, permite associar a $\mathrm{mF} 1 \mathrm{com}$ horizonte espódico incipiente (Van Breemen and Buurman, 2003; Wilson and Righi, 2010). Os revestimentos ao redor dos componentes antrópicos da fração grossa, como ossos e escória vítrea (Figura 5.100 A, D), indicam que o processo de migração da MO teria sido posterior à deposição destes materiais. Evidências de podzolização já foram identificadas na análise micromorfológica da AF 2 do sambaqui Carniça 3 e da Fácies B de Santa Marta 10. A sua identificação no sítio Galheta 4 confirma a ubiquidade deste processo em ocupações humanas sobre dunas eólicas.

Assim como no sítio Santa Marta 10, análises com sistema MEV-EED confirmam a presença de compostos de Fe e Al junto à MO da AF 1 (Anexo, Figura A.8). 
A
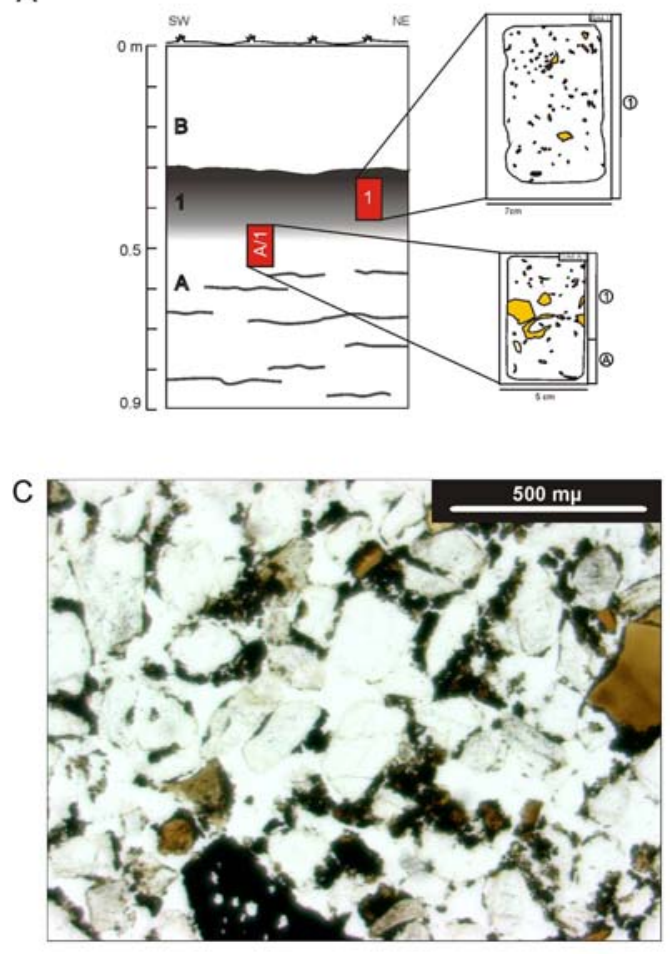

E

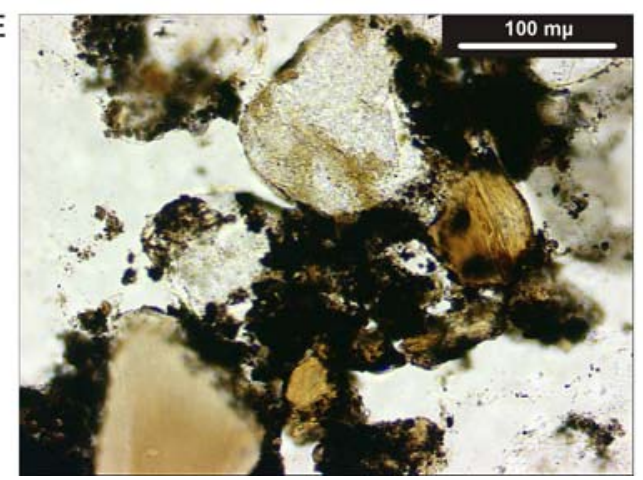

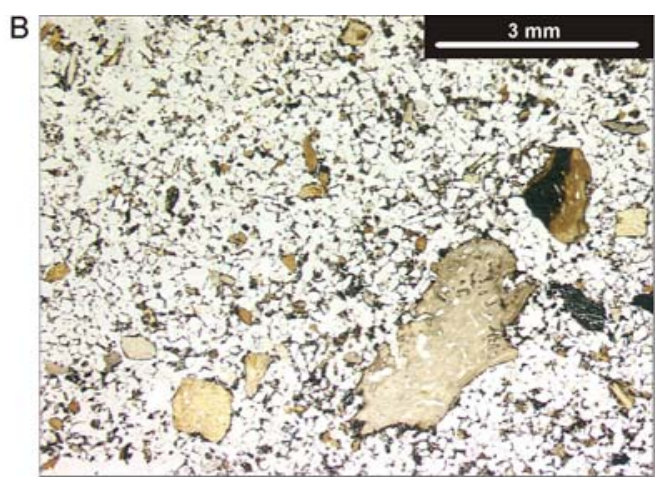
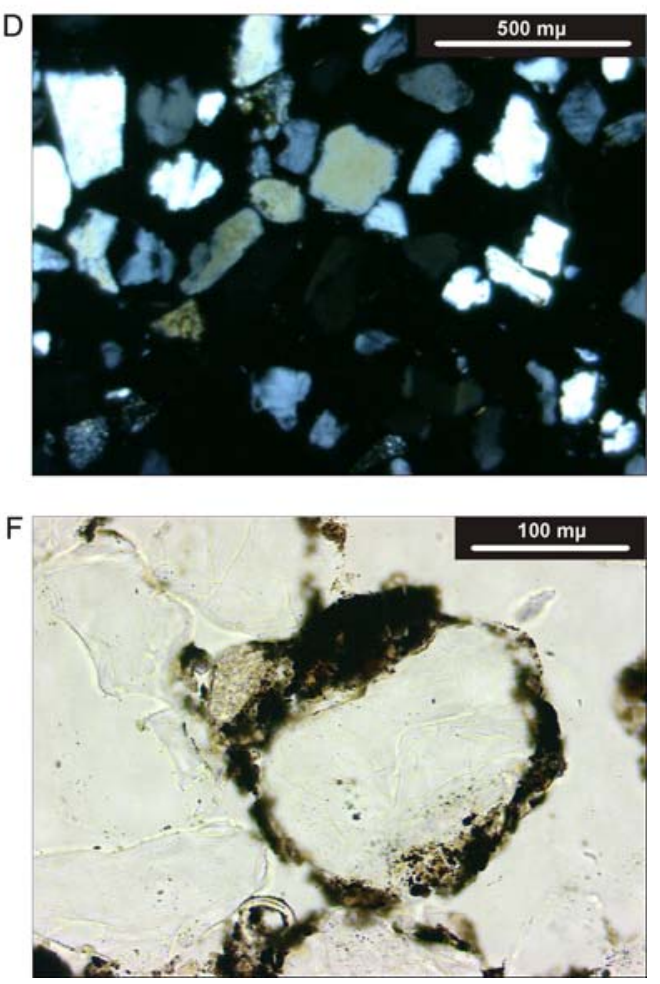

Figura 5.99. Fotomicrografias da $\mathrm{mF} 1$ do sítio Galheta 4: A) seção vertical esquemática, com localização da amostra para micromorfologia; B) massa basal composta por grãos de areia quartzosa e fragmentos de osso queimado, PPL; C, D) micromassa composta por MO monomórfica, PPL e XPL; E) detalhe da micromassa com inclusões de fragmentos de osso, PPL; F) revestimento de MO monomórfica ao redor de grão de quartzo, PPL. 

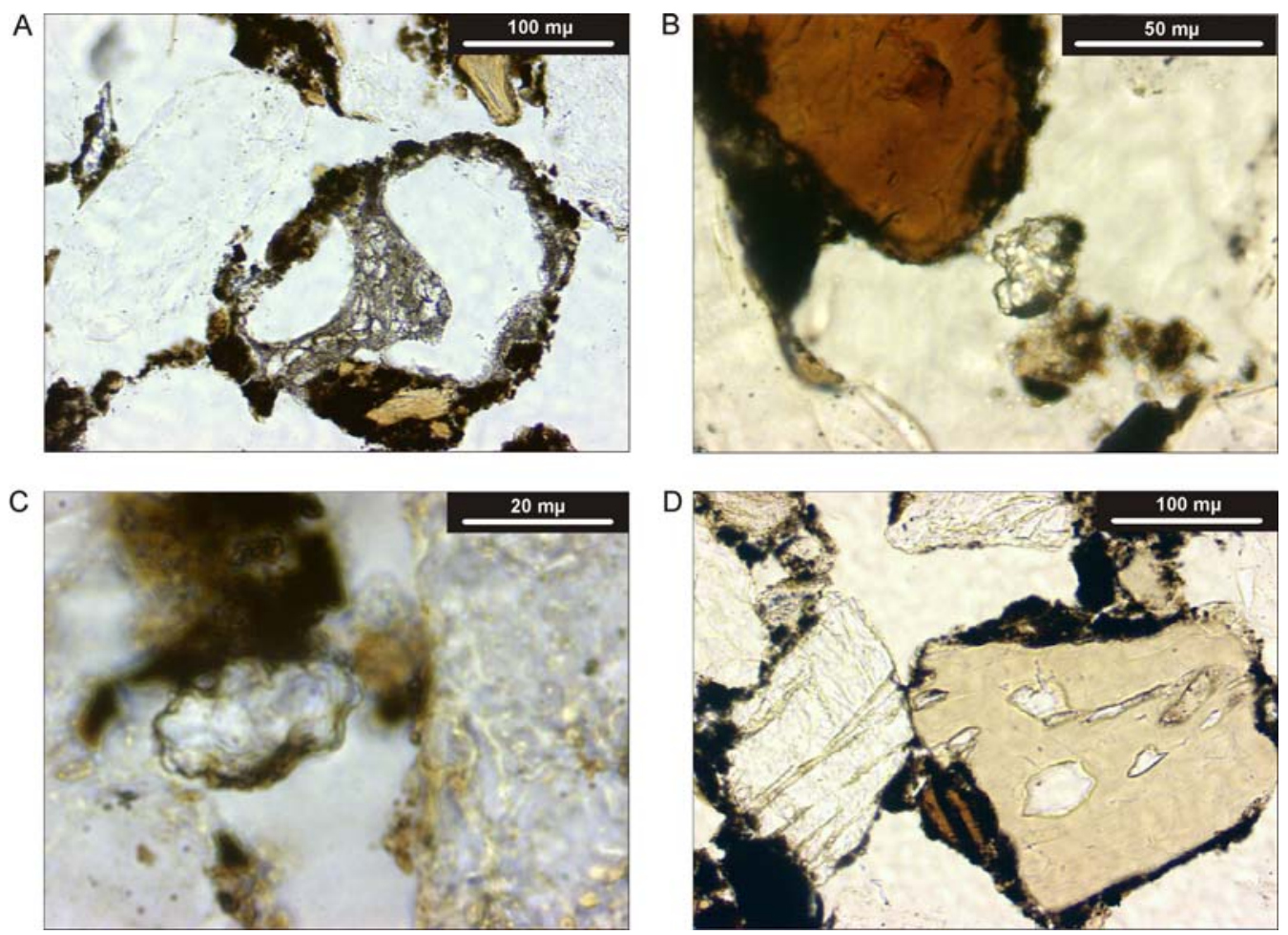

Figura 5.100. Fotomicrografias de elementos identificados na $\mathrm{mF} 1$ do sítio Galhera 4: A) revestimento de MO monomórfica ao redor de escória vítrea, PPL; B, C) fitólito PPL; D) revestimento de MO monomórfica com inclusões de finos fragmentos de osso ao redor de fragmento de osso, PPL. 


\section{GEOARQUEOLOGIA DE UM CONCHEIRO ETNO-HISTÓRICO NA TERRA DO FOGO}

As informações produzidas a partir da análise geoarqueológica dos sambaquis catarinenses serão comparadas com outro contexto arqueológico semelhante, com a finalidade de testar o método desenvolvido para estudo dos sambaquis em outros contextos, neste caso, em concheiros de climas frios, e poder achar possíveis relações no registro geoarqueológico de ambos. Um único concheiro será tomado como caso de estudo, o sítio Túnel 7, descrito no Capítulo 3, tópico 4.2, associado aos grupos Yamana que habitaram as costas do Canal Beagle em tempos históricos (ver Capítulo 2, tópico 5.1). Assim como para os sambaquis catarinenses, combinaram-se os resultados da abordagem experimental com a análise do sítio arqueológico. A seguir, apresentam-se os resultados da coleção de referência experimental de amostras para micromorfologia, elaborada sobre contextos naturais, fogueiras e queima controlada de moluscos, seguido dos resultados da análise micro-estratigráfica do sítio Túnel 7.

\subsection{COLEÇÃO DE REFERÊNCIA EXPERIMENTAL}

A coleção de referência de contextos naturais e elementos conhecidos consiste em cinco amostras coletadas do seguinte grupo de elementos: 1) caminho de animais, pisoteado pelo gado diariamente; 2) depósito de praia, próxima a um dos concheiros escavados; 3) e horizonte A sob floresta de Nothofagus sp. A coleção de fogueiras experimentais inclui duas fogueiras efêmeras, acesas por menos de uma hora e amostradas imediatamente após o esfriamento, no prado na praia de seixos; e uma fogueira utilizada durante um mês de campo no acampamento dos arqueólogos. Para realização do experimento de queima de Mytilus edulis, oito valvas do molusco foram queimadas na mufla a temperaturas entre 200 e $800^{\circ}$ C. A seguir, apresenta-se a discussão da análise micromorfológica da amostragem experimental organizada segundo os objetivos da amostragem. 


\subsubsection{Indicadores de pisoteamento}

A amostra do caminho de animais permitiu observar alguns dos indicadores de pisoteamento animal a céu aberto mencionados em Courty et al. (1989) e ShahackGross (2003), tais como: compactação laminar da camada de grama superficial; desenvolvimento de microestrutura laminar próxima à superfície do solo; distribuição linear e paralela à superfície dos resíduos vegetais; fissuras; e atividade de fungos, observada pela presença de esporos e hifas (filamentos de fungos).

Esta seção delgada apresenta três microfácies sucessivas. A microfácies superficial tem microestrutura formada por agregados lenticulares, de até $5 \mathrm{~mm}$ de cumprimento, compostos de tecidos vegetais frescos, matéria orgânica e fragmentos líticos (Figura 5.101 A). A microfácies intermediária representa a transição entre a porção de solo com aporte de resíduos orgânicos frescos, e o solo natural com matéria orgânica decomposta e maior freqüência de fragmentos líticos. Contém uma concentração linear de esporos de fungo (200-220 $\mu \mathrm{m}$ cada conjunto de esporos) paralela à superfície (Figura 5.101 B). A microfácies inferior apresenta microestrutura de microagregados intergranulares (200-300 $\mu \mathrm{m}$ de largura) de composição orgânica, e fração grossa com maior quantidade e tamanho de fragmentos líticos.

Pelo contexto climático onde foi coletada a amostra, a formação dos vazios e agregados lenticulares pode também ter sido provocada, ou incrementada, pelo congelamento sazonal do solo (ver Van Vliet-Lanoe, 2010; Fitzpatrick, 1993; Van Vliet-Lanoe, 1998). No entanto, pela proximidade com a superfície do solo e pela ausência de traços de lentes de gelo nos poros e de segregação granulométrica nos agregados lenticulares (Van Vliet-Lanoe and Coward, 1984; Van Vliet-Lanoe, 1998), parece mais provável a microestrutura laminar ter sido provocada por pisoteamento de que por congelamento do solo. 


\subsubsection{Tafonomia de ossos}

As praias do Canal Beagle contêm, além de seixos arredondados, fragmentos de ossos de mamíferos marinhos e conchas. Na seção delgada, os fragmentos de ossos são de cor cinza (PPL), com baixa birrefringência (XPL), bordas arredondadas e muitas marcas de dissolução, especialmente aumento dos canais (Figura 5.101 C). Os fragmentos de concha são angulosos com diferentes colorações (roxo, cinza, cinza claro, marrom claro) a PPL (Figura 5.101 D). A micromassa é mínima e aparece na forma de agregados organominerais, de dimensões diversas.

Os ossos mostram amplas áreas de dissolução, na forma de aumento dos canais internos e espaços trabeculares e destruções focais microscópicas (microscopical focal destructions) causadas pelo ataque microbiano (ver Hacket, 1981; Hedges, 1995; Jans, 2004; Piepenbrink, 1989; Trueman and Martill, 2002). Estes ossos não estão compostos de hidroxiapatita, como seria esperado em ossos frescos, mas de um mineral autígeno de composição calcítica e birrefringência alta, que se desenvolve como calcita espática, no preenchimento de poros, e como calcita microcristalina, nas áreas dissolvidas ao redor dos ósteons.

Trueman et al. (2004) determinaram que a substituição mineral em ossos expostos a condições subaéreas é um processo rápido, inclusive em climas úmidos, e que em condições evaporíticas o processo seria ainda mais intenso. Nas praias do Canal Beagle, a intensa ação do vento promoveria condições de evaporação que podem ter favorecido a precipitação do carbonato autígeno, a partir da dissolução dos ossos, em pouco tempo. Pode-se pensar que unicamente os ossos depositados nas praias da região teriam sofrido intemperismo físico-químico por exposição subaérea. Em contexto arqueológico, especificamente nos concheiros da região, onde os ossos são soterrados em ambiente alcalino (pela presença de conchas) e protegidos dos efeitos da evaporação, não se observaria esta característica.

\subsubsection{Alteração microbiana}

A amostra de solo sob a floresta apresenta três microfácies. A primeira é a camada de decomposição de topo (camada F, apud Babel 1975), que corresponde à 
serrapilheira, com resíduos de tecidos frescos, raízes e madeira em decomposição. Nesta microfácies, destacam-se tecidos com flobafenos e tecidos melanizados pela ação de fungos (ver Todisco and Bhiry, 2008) (Figura 5.101 E). A segunda microfácies, de posição intermediária, consiste de camada de substâncias húmicas (camada $\mathrm{H}$, apud Babel 1975), porosa, com microestrutura de agregados mamilares e coloração castanha avermelhada brilhante (PPL). Contém raízes frescas, resíduos de tecidos com flobafenos e fragmentos de madeira. A alta birrefringência dos tecidos de celulose denota a presença de material não completamente decomposto. A micromassa é castanha escura (PPL), formada por material vegetal em decomposição, com aproximadamente $5 \%$ de grãos minerais na fração silte (Figura 5.101 F). A terceira microfácies, inferior, identificada como horizonte A húmico $\left(A_{h}\right)$ subjacente (Babel 1975), é menos porosa até a base e apresenta microestrutura esponjosa a grumosa com cavidades, vazios em câmara e estrela. Fragmentos líticos são abundantes, com traços de alteração in situ. Contém fragmentos de carvão, bem selecionados (areia fina a média) remanescentes de incêndios nas proximidades. A fração fina é marrom-amarela (PPL) ponteada, formada por mistura de argilominerais com matéria orgânica. As feições pedológicas incluem nódulos de óxi- hidróxidos de ferro, nódulos alteromórficos e excrementos de ácaros.

Ao juntar as evidências oferecidas pelas amostras de praia com a do solo, configuram-se vários indicadores de intensa atividade biológica na região, apesar da temperatura subpolar. Usualmente, climas frios são associados com a inibição da ação dos microrganismos (Hedges, 2002; Nicholson, 1993), mas no caso da coleção experimental analisada, resulta claro que os microrganismos (fungos e bactérias) são importantes agentes tafonômicos tanto em contexto subaéreo como subsuperficial. As destruições focais microscópicas observadas em ossos da praia e as características micromorfológicas das amostras de solo (decomposição dos tecidos vegetais, tipo de microestrutura e feições pedológicas) confirmam esta observação ${ }^{85}$. Isto significa que, nos sítios arqueológicos da região, há de se encontrar bioturbações intensas, contrário ao que se esperaria do contexto climático no qual se localizam.

\footnotetext{
${ }^{85}$ Observações semelhantes foram realizadas por Todisco \& Bhiry (2008) no estudo de sítios de paleoesquimós em contexto periglacial. Os autores identificaram destruições focais microscópicas (microscopical focal destructions) causadas pelo ataque microbiano nos ossos, apesar das temperaturas extremamente baixas.
} 

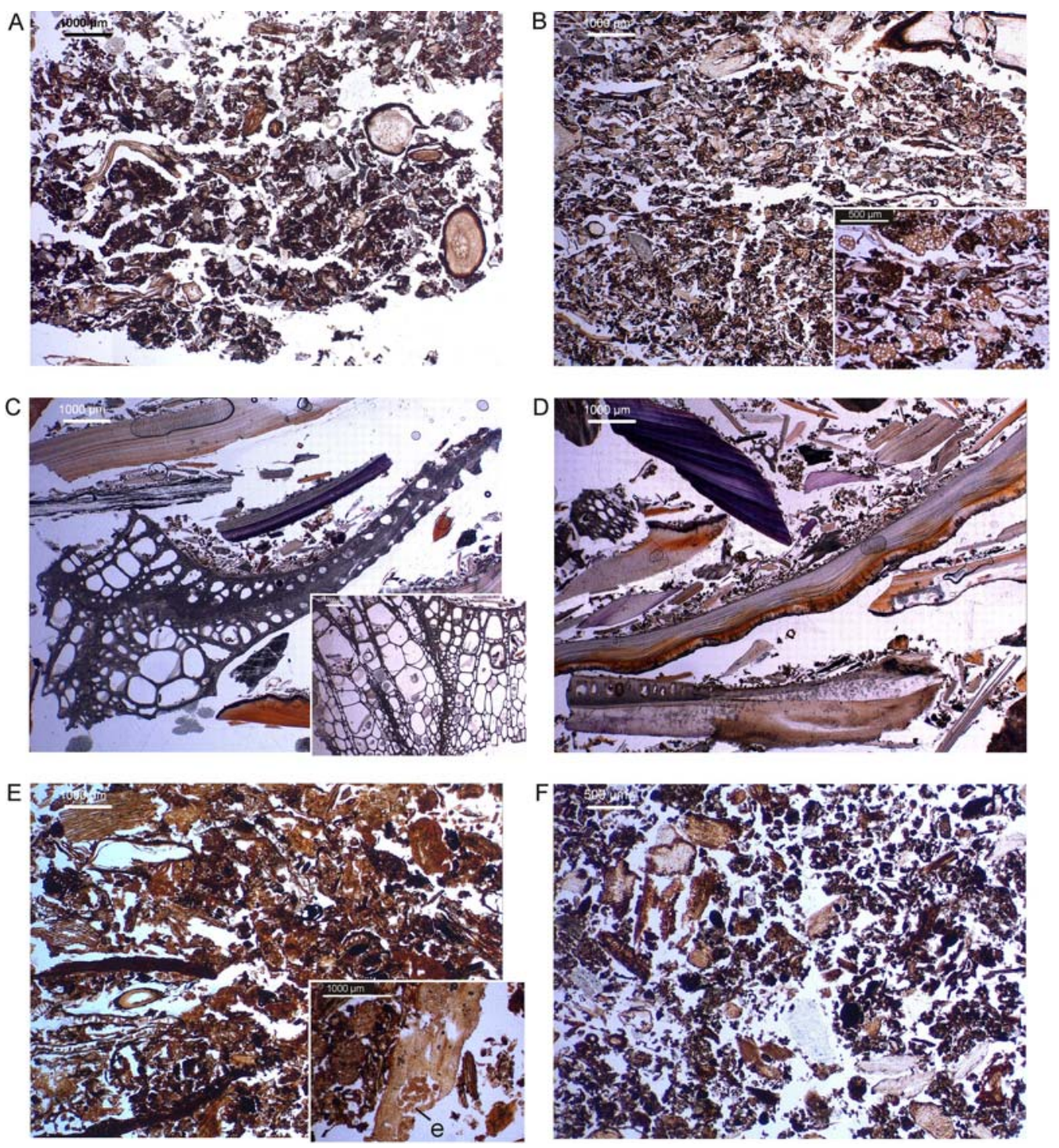

Figura 5.101. Fotomicrografias da coleção de referência experimental: A) microfácies superior da amostra do caminho de animais, com agregados lenticulares, PPL; B) microfácies intermediária do caminho de animais, com detalhe da concentração de esporas de fungos (e); C) praia de seixos próxima aos concheiros, notando-se o predomínio de ossos de mamífero marinho, com detalhe de ósteons dissolvidos, PPL; D) praia de seixos com fragmentos de concha de coloração diversa, PPL; E) serrapilheira sob a floresta de Nothofagus sp., em que se nota concentração de excrementos de ácaros dentro de tecido de madeira, PPL; F) camada de substâncias húmicas (camada H) sob a floresta, com agregados de matéria orgânica decomposta, PPL.

\subsubsection{Fogueiras: tafonomia e preservação}

Fogueira sobre o prado: a microfácies resultante desta fogueira inclui uma acumulação, na porção inferior da lâmina, de fragmentos de carvão centimétricos, com fitólitos e resíduos de tecidos. A micromassa é cinzenta (PPL) com b-fábrica cristalítica de composição calcítica associada às cinzas de madeira (Figura 5.102 A). 

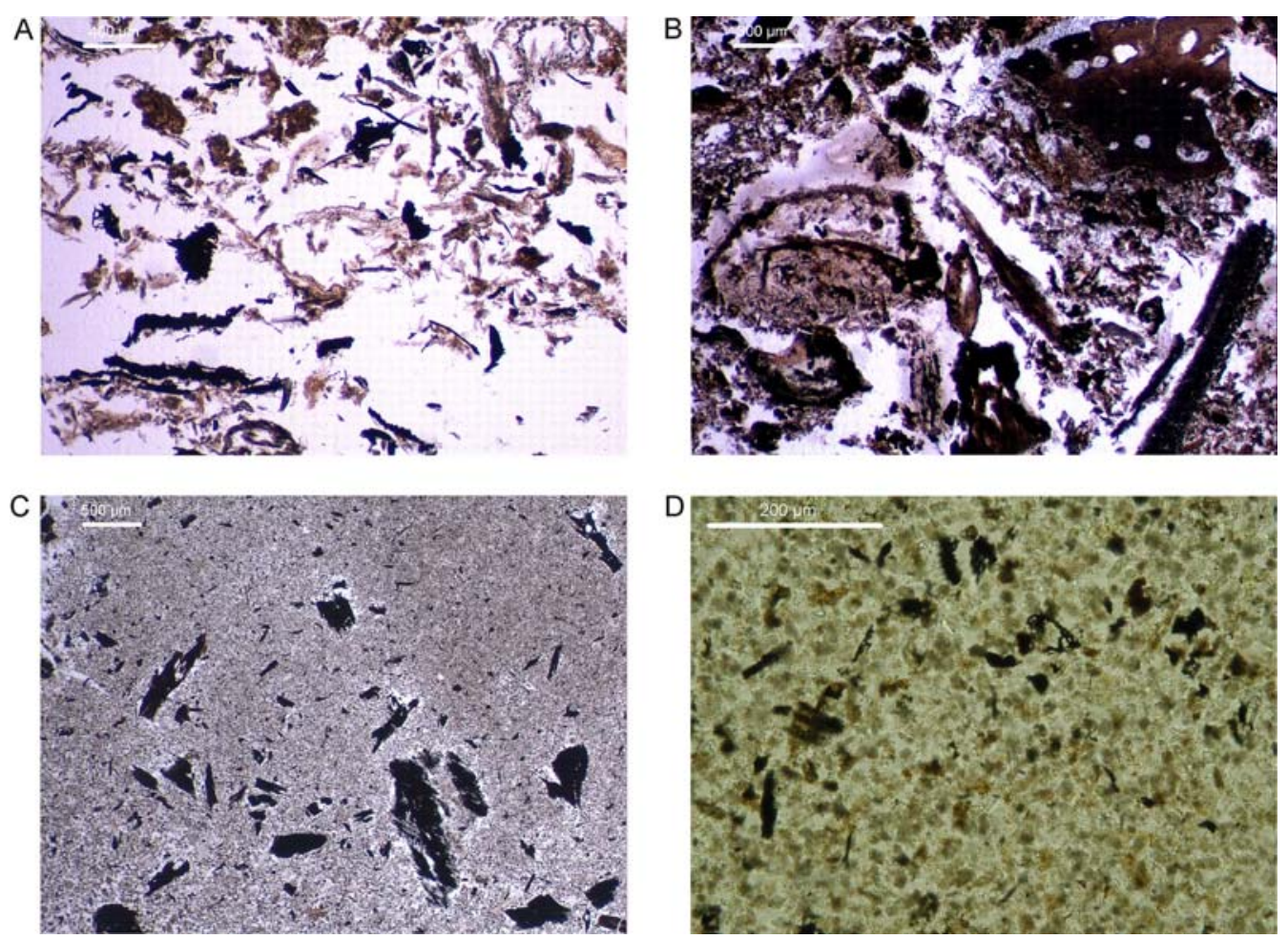

Figura 5.102. Fotomicrografias das três fogueiras experimentais estudadas na Terra do Fogo: A) camada milimétrica de cinzas e resíduos vegetais oxidados na fogueira sobre o prado, PPL; B) fogueira na praia, com fragmentos de osso de mamífero marinho queimados, PPL; C) fogueira no acampamento dos arqueólogos, formada por cinzas, carvão e argila rubefacta, PPL; D) agregados de POCC.

Fogueira na praia de seixos: na camada de cinzas, a fração grossa encontra-se quase exclusivamente composta por fragmentos de osso pouco birrefringentes (XPL) e com marcas de dissolução. Alguns ossos são completamente isótropos e outros, ainda anisótropos, apresentam manchas escuras de birrefringência baixa, que corresponderiam a áreas queimadas. A fração fina é uma mistura mosqueada de calcita e material orgânico, de coloração marrom-acinzentada (Figura 5.102 C).

Fogueira no acampamento dos arqueólogos: apresenta microestrutura maciça, marrom acinzentada (PPL) e mosqueada, de argilominerais e calcita, com b-fábrica cristalítica. A fração grossa é composta de fragmentos de carvão, madeiras parcialmente queimadas e fitólitos. As feições pedológicas incluem canais de fauna e nódulos de óxihidróxidos de ferro. Nesta lâmina, destaca-se o fato de poder observar-se a distribuição in situ dos agregados de POCC (segundo Canti, 2003) (Figura 5.102 C, D).

As estruturas de combustão analisadas foram amostradas imediatamente após o esfriamento e, portanto, trata-se de estruturas in situ, ou fácies de combustão primárias, como definido por Wattez (1992). Isto permite extrair informações quanto à preservação de camadas queimadas em condições frias e sua alteração tafonômica após o abandono. 
As fogueiras efêmeras, de curta duração e baixa intensidade de queima (350-450 C), resultam em camadas finas e milimétricas de cinzas misturadas com resíduos vegetais oxidados e microcarvões, sobre camada de material carbonizado (ver Wattez 1992). Estes atributos são independentes do substrato e as fogueiras, tanto na praia quanto no prado, apresentam a mesma configuração. A única diferença está na fração grossa, composta de carvões de Dymis winteri, no prado, e de ossos de mamífero marinho queimados, na praia.

Amostras não foram coletadas do substrato na fogueira sobre o prado, mas a espessura centimétrica da amostra e a presença de pequenos agregados de argila rubefacta permitem sugerir que este episódio de queima não induziu maiores alterações no solo preexistente. Os ossos da fogueira na praia foram oxidados e manchados na superfície. Os efeitos do fogo nestes ossos altamente intemperizados não foi tão evidente devido a que, antes da queima, a maior parte da matriz de colágeno já tinha sido perdida por intemperismo, com recristalização mineral parcial. Amplas áreas de dissolução e intensa alteração microbiana indicam intemperismo bioquímico dos ossos na praia. A observação destas feições em ossos com birrefringência elevada, de calcita, pode auxiliar a evitar erros na interpretação de contextos arqueológicos, como por exemplo, assumir que ossos com estas características estiveram expostos a altas temperaturas (calcinados) quando, de fato, só teriam sido transportados ao sítio da praia.

O longo período de tempo durante o qual ficou acesa a fogueira no acampamento dos arqueólogos conduziu à formação de uma camada de cinzas centimétrica, que representa uma mistura de diferentes episódios de queima. O longo tempo de uso da fogueira também pode ser observado em feições pedológicas, como canais de fauna e nódulos ferruginosos. A estrutura maciça composta de cristais de carbonato de cálcio, alguns fitólitos e pouco carvão e microcarvão, indicam temperaturas de queima elevadas $\left(>500^{\circ} \mathrm{C}\right.$ ) e combustão completa da madeira utilizada como combustível (ver Wattez 1992; Mallol et al. 2007).

A preservação de cinzas em contextos arqueológicos na costa do Canal Beagle estaria condicionada por dois fatores: o regime hidrológico; e a alta suscetibilidade à dissolução deste material calcítico. Embora a pluviosidade média anual da região seja de $500 \mathrm{~mm}$, não existe estação seca e as chuvas são constantes ao longo do ano. Por este motivo, as condições favoráveis para preservação de cinzas demandariam substrato argiloso, para evitar a lixiviação, ou solução do solo saturada em cálcio, para evitar a dissolução. Igualmente, a intensa atividade biológica, cujos efeitos se observaram em 
todas as amostras de diversos contextos (praia, prado, solo de floresta) também seria um importante agente de perturbação.

\subsubsection{Queima controlada de Mytilus edulis}

Cada valva de Mytilus edulis é formada por duas camadas carbonáticas recobertas por uma lâmina externa orgânica (o perióstraco). A concha carbonática é composta por uma camada exterior de calcita e uma camada interior nacarada de aragonita. A camada externa constitui-se de prismas de calcita colunares, enquanto que a camada interior tem textura laminar de cristais de aragonita paralelos ao interior da valva (Burgoin, 1988). A análise dos efeitos microscópicos da queima de Mytilus edulis mostra uma seqüência de alterações que vão desde a perda da lâmina orgânica (perióstraco) e separação da camada interior (aragonitica) da exterior (calcítica), até a completa deformação da concha. No Quadro 5.2, apresenta-se a descrição da transformação sequencial das conchas a temperaturas entre 200 e $800^{\circ} \mathrm{C}$, e as Figuras 5.103-5.105 mostram as fotografias e fotomicrografias do processo de queima.

A queima sequencial de Mytilus edulis oferece indicadores para estimar a temperatura de queima das fogueiras a partir da coloração, forma, textura e características mineralógicas das conchas em seção delgada. A informação sobre intensidade da queima pode ser igualmente associada à função da estrutura de combustão (ver Mallol et al., 2007) que, junto com a evidência artefatual associada à fogueira, pode ajudar a interpretar a função do sítio como um todo. 

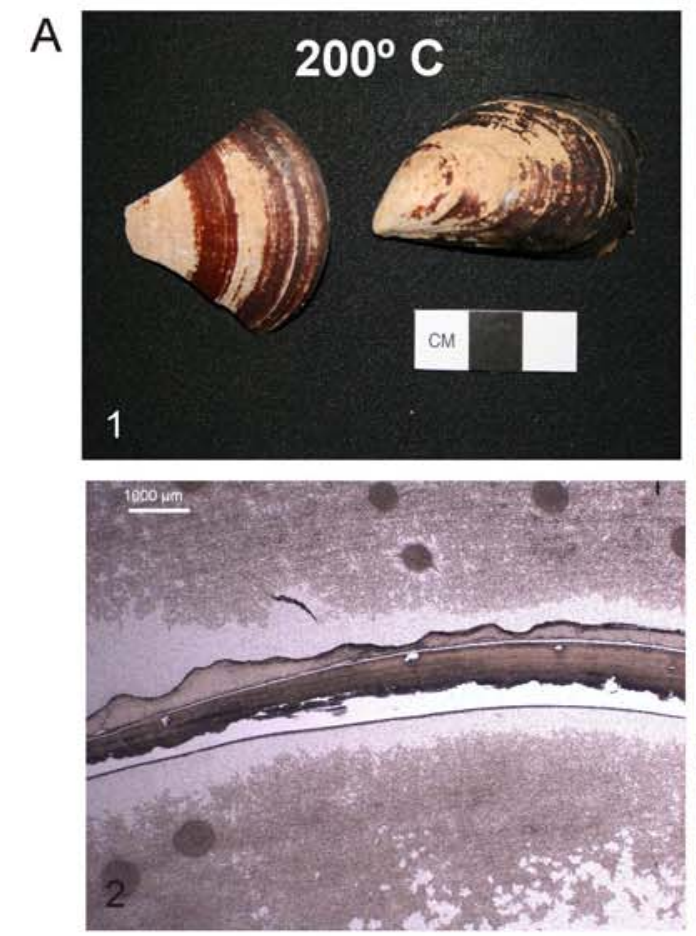
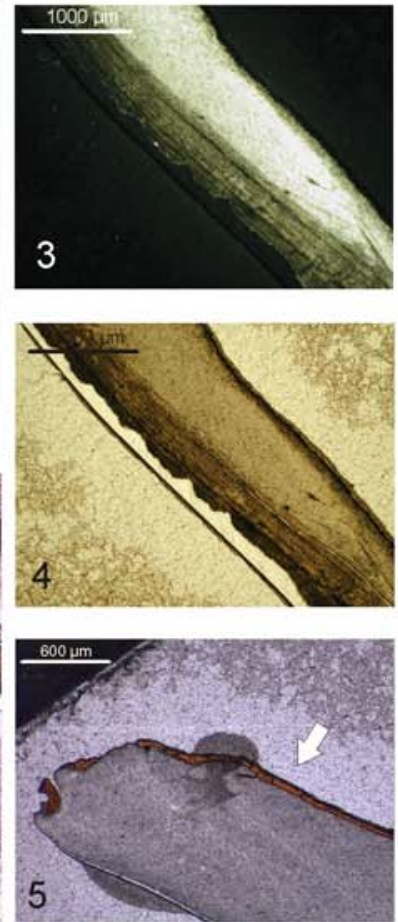

B
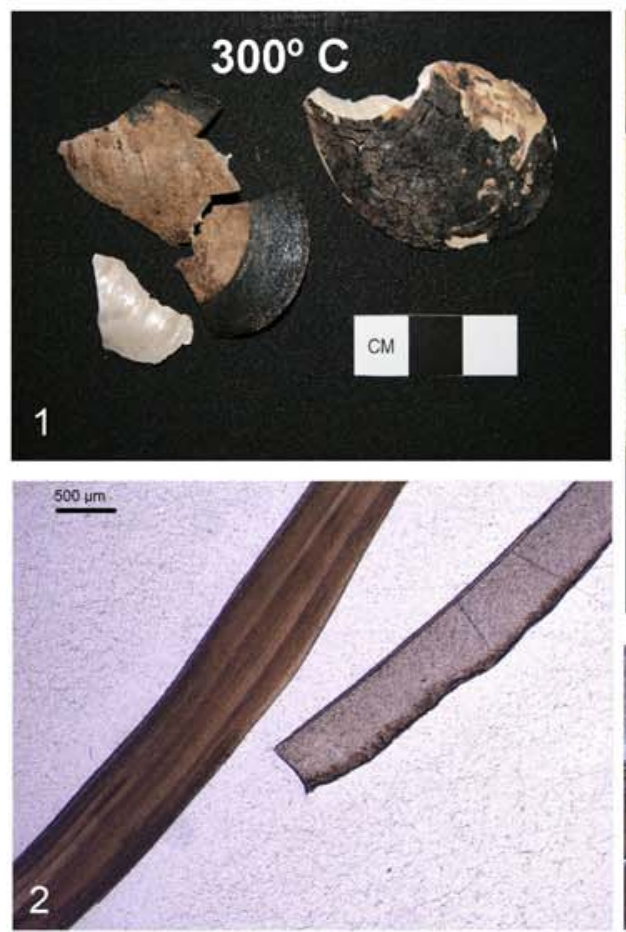
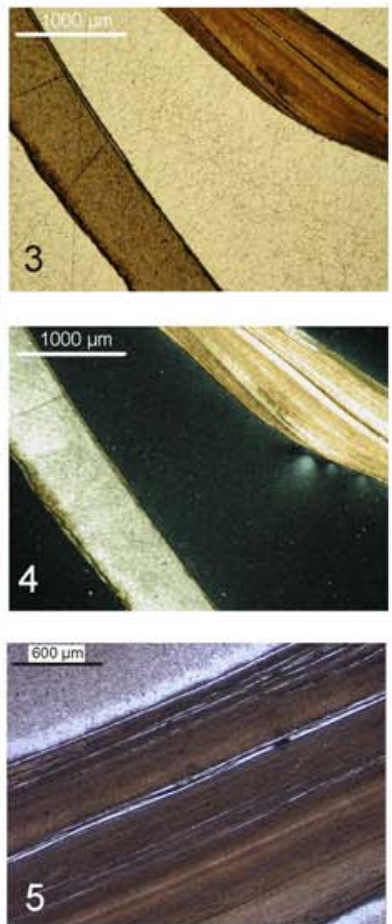

Figura 5.103. Alteração de Mytilus edulis a $200^{\circ} \mathrm{C}$ e $300^{\circ} \mathrm{C}$ : A1) concha queimada a $200^{\circ} \mathrm{C}$ com superfície avermelhada; A2-4) fotomicrografias das camada interna e externa ainda preservadas, com escurecimento das bordas, PPL e XPL; A5) detalhe de perióstraco preservado; B1) concha queimada a 200 C; B2-5) fotomicrografias da concha queimada; note-se camada interna avermelhada e com fissuras incipientes, PPL e XPL. 

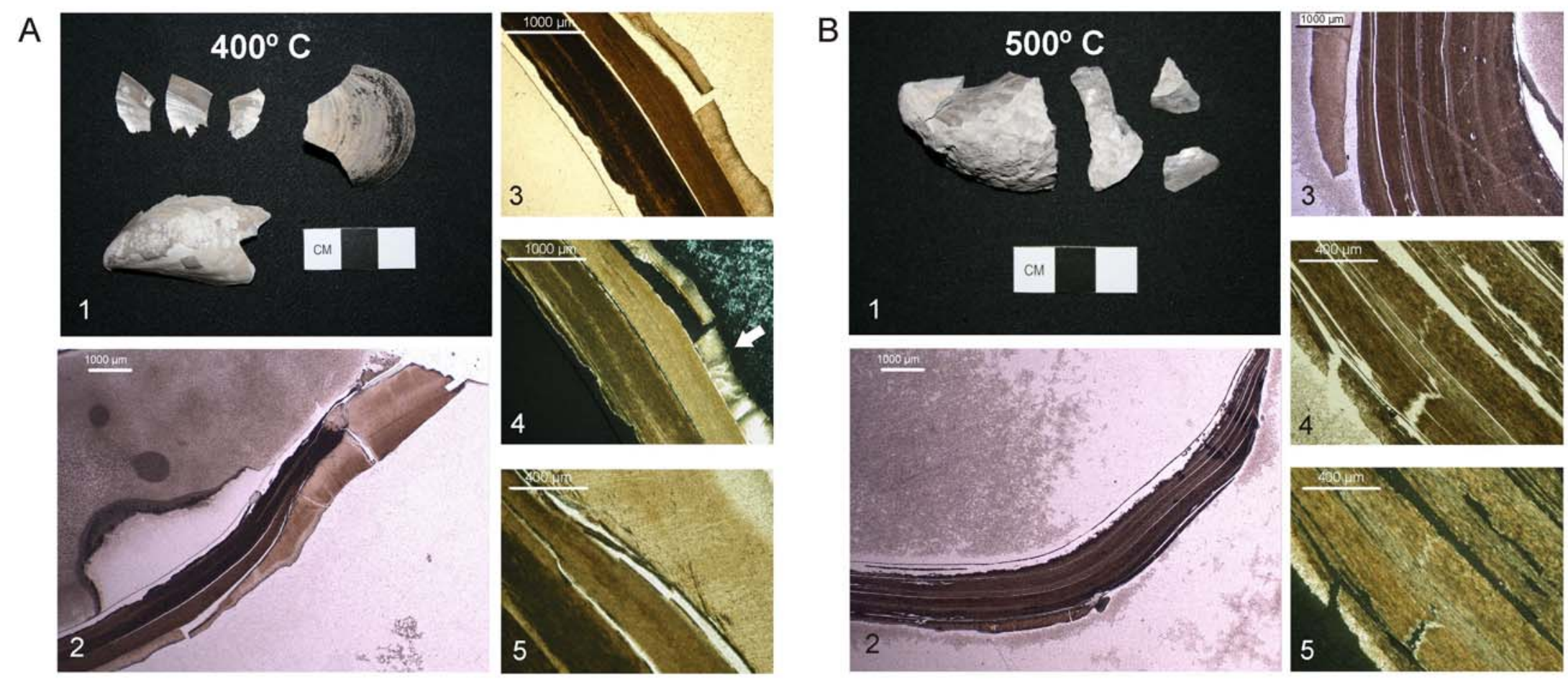

Figura 5.104. Alteração de Mytilus edulis a $400^{\circ} \mathrm{C}$ e $500^{\circ} \mathrm{C}$ : A1) concha queimada a $400^{\circ} \mathrm{C}$, com coloração acinzentada; A2-5) fotomicrografias da concha queimada com formação de fissuras longitudinais, escurecimento e coloração avermelhada da camada interna e mudança no tamanho dos cristais da calcita que compõe a camada exterior, PPL e XPL; B1) concha queimada a $500^{\circ} \mathrm{C}$ de coloração acinzentada e alta fragilidade; B2-5) fotomicrografias mostrando separação completa da valva interna e externa e múltiplas fissuras longitudinais e transversais à superfície da valva, PPL e XPL. 

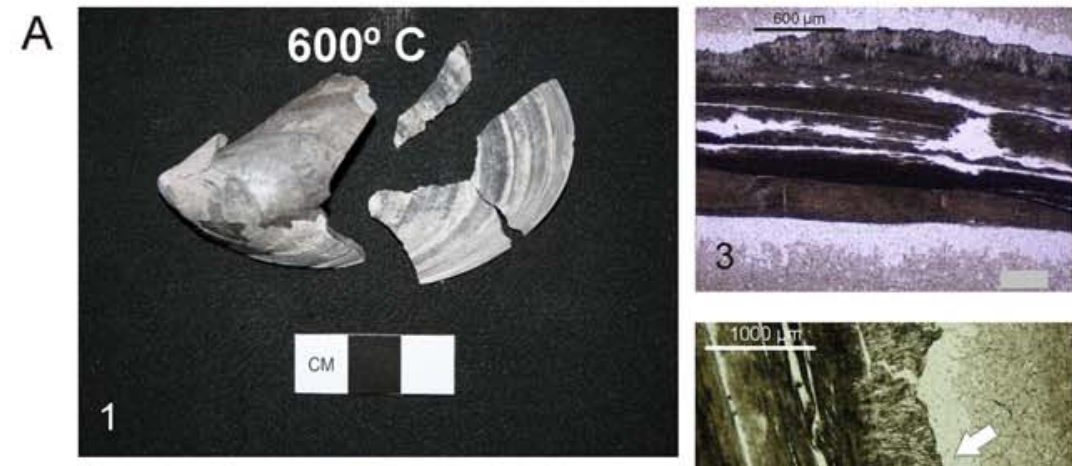

B
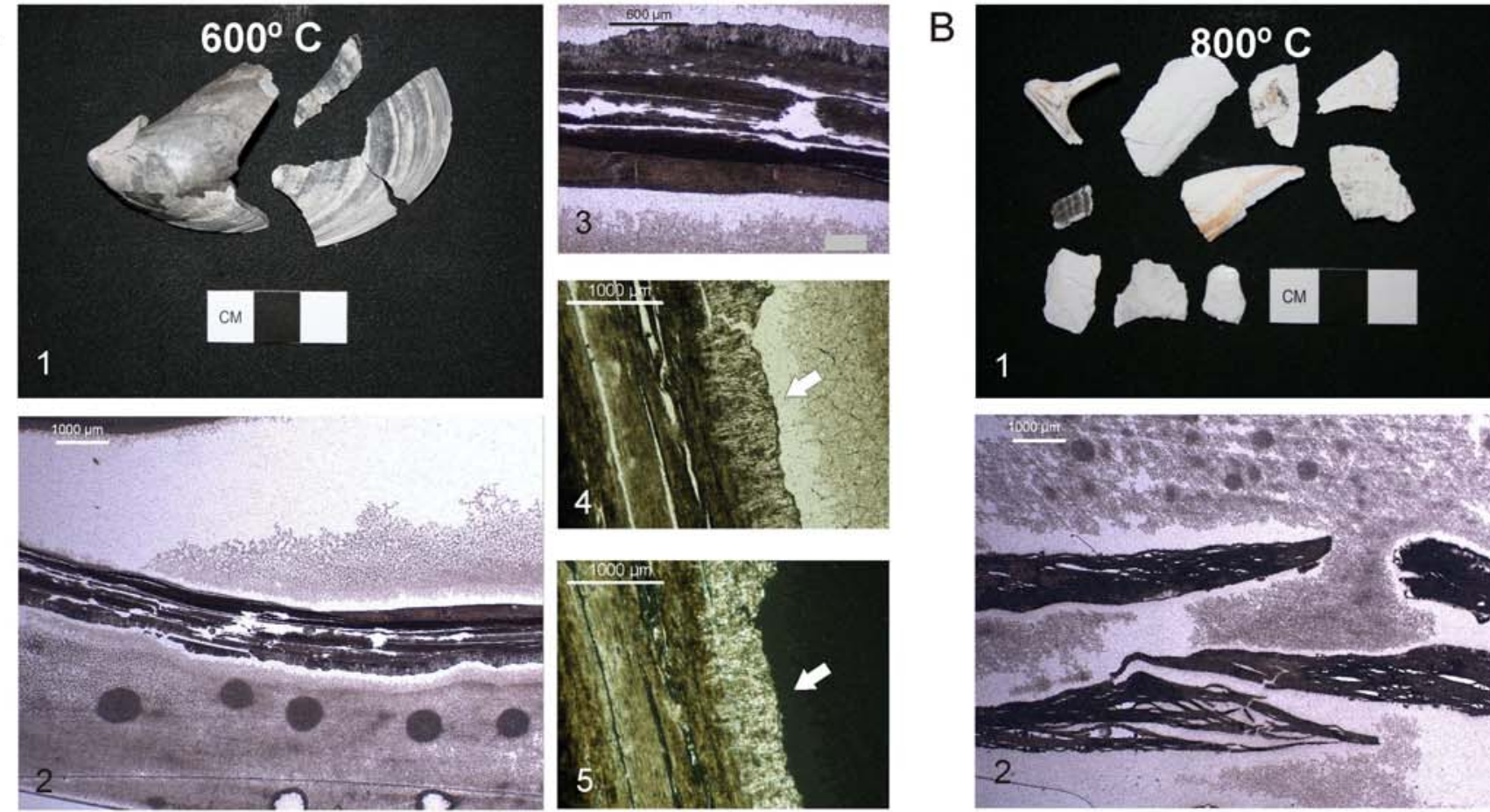

3 ay
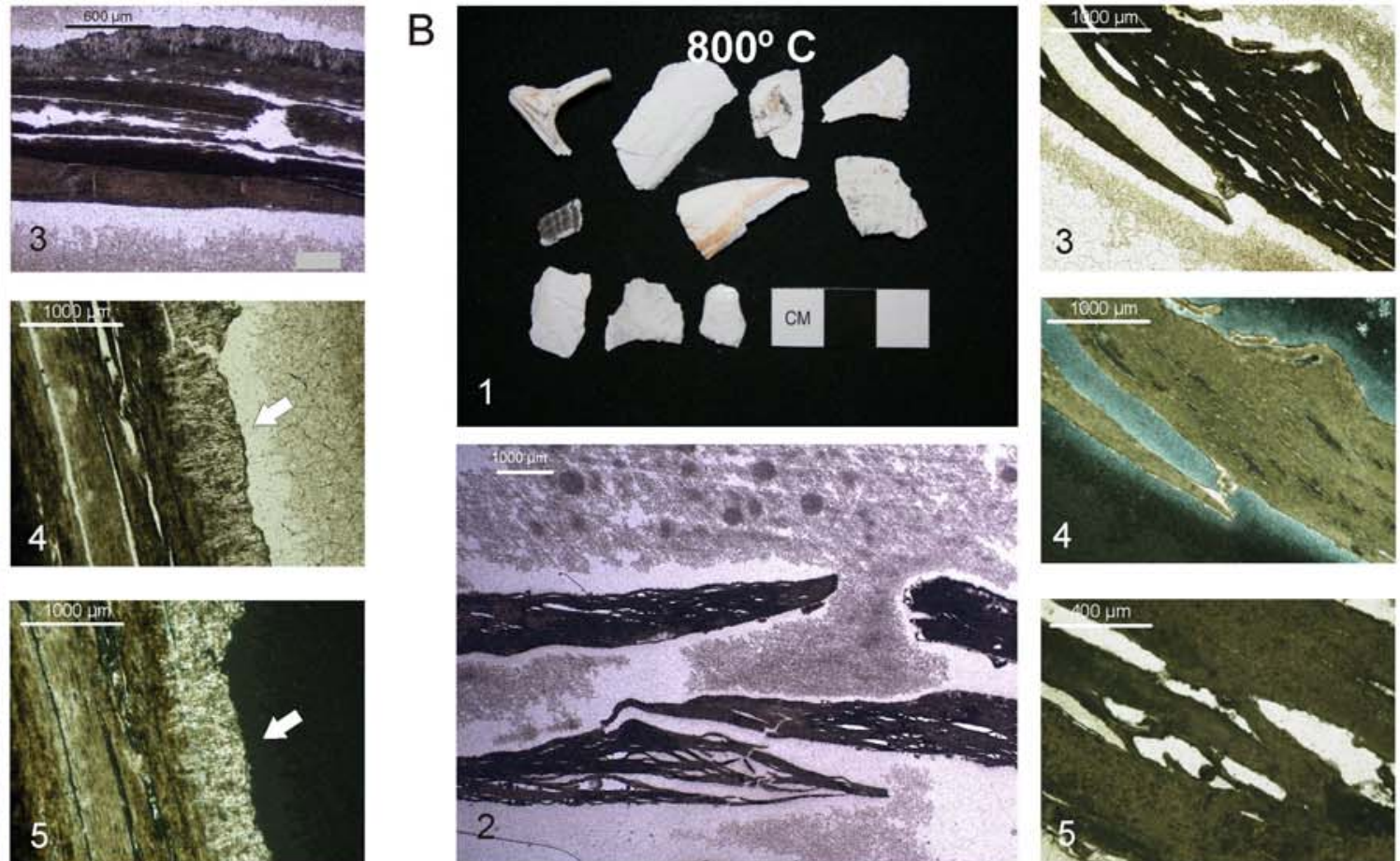

Figura 5.105. Alteração de Mytilus edulis a $700^{\circ} \mathrm{C}$ e $800^{\circ} \mathrm{C}$ : A1) concha queimada a $600^{\circ} \mathrm{C}$, com coloração acinzentada; A2-5) fotomicrografias da concha queimada de coloração castanho escuro a preta (PPL) e manchas escuras a XPL, com fissuras na camada interior e calcita fibrosa na camada exterior da valva; B1) concha queimada a $800^{\circ} \mathrm{C}$, com cor branca; B2-5) valva completamente deformada de coloração preta (PPL) com pseudo-vacuólos. 
Quadro 5.2. Alterações microscópicas de valvas de Mytilus edulis, queimadas de 200 a $800{ }^{\circ} \mathrm{C}$.

\begin{tabular}{|c|c|c|}
\hline Temperatura & Descrição & Figura \\
\hline $200^{\circ} \mathrm{C}$ & $\begin{array}{l}\text { Partes do perióstraco ainda preservadas. } \\
\text { Camadas interna e externa da concha ainda interconectadas. }\end{array}$ & 5.103 \\
\hline $300^{\circ} \mathrm{C}$ & $\begin{array}{l}\text { Perda total do perióstraco. } \\
\text { Camada interna com início de fissuras ao longo do contato entre } \\
\text { lâminas, aquisição de coloração avermelhada (PPL) e começo de } \\
\text { separação da camada externa. }\end{array}$ & 5.103 \\
\hline $400^{\circ} \mathrm{C}$ & $\begin{array}{l}\text { Separação quase completa entre camadas interna e externa. } \\
\text { Mudança na orientação dos cristais de calcita na camada externa. } \\
\text { Camada interna com mais fissuras e textura rugosa, cor marrom escura } \\
\text { (PPL) no lado côncavo, e vermelha (PPL) no lado convexo. } \\
\text { Ausência de extinção óptica a XPL (ambos os lados da concha). }\end{array}$ & 5.104 \\
\hline $500^{\circ} \mathrm{C}$ & $\begin{array}{l}\text { Aparência desgastada das camadas interna e externa. } \\
\text { Buracos e fissuras, manchas pretas, textura rugosa e coloração marrom } \\
\text { escura a preta e PPL. }\end{array}$ & 5.104 \\
\hline $600^{\circ} \mathrm{C}$ & $\begin{array}{l}\text { Transformação da camada externa em calcita fibrosa, cor cinza escuro } \\
\text { a preto (PPL). } \\
\text { Camada interna com cor marrom escura (PPL), extensamente fissurada. }\end{array}$ & 5.105 \\
\hline $700^{\circ} \mathrm{C}$ & Amostra muito polida, descartada para análise. & - \\
\hline $800^{\circ} \mathrm{C}$ & $\begin{array}{l}\text { Fim do experimento: completa perda da forma da valva, cor preta a } \\
\text { PPL e opacidade aumentada a XPL (marrom escuro grisáceo). } \\
\text { Lâminas da camada interna completamente deformadas, com pseudo- } \\
\text { vacúolos em seu interior. }\end{array}$ & 5.105 \\
\hline
\end{tabular}

\subsection{MICROMORFOLOGIA DO CONCHEIRO TÚNEL 7}

A análise geoarqueológica do concheiro etno-histórico Túnel 7 foi feita a partir de coleção de amostras para micromorfologia que não tinha sido analisada até o momento. Como não houve trabalho de campo prévio com o objetivo de identificar arqueofácies, os resultados da análise micromorfológica serão apresentados de maneira diferente da adotada nos sambaquis, com ênfase nas microfácies arqueológicas identificadas nas seções delgadas. Além disso, a amostragem neste concheiro não foi feita unicamente a partir de seções verticais expostas, mas também de seções planas horizontais, amostradas durante a escavação do sítio, em cinco das dez fogueiras centrais identificadas no local onde teria estado a cabana de moradia. Assim, os resultados da análise do sítio Túnel 7 serão apresentados na segguinte ordem: primeiro, a análise micro-estratigráfica realizada sobre uma coluna de amostragem coletada no anel de conchas periférico; segundo, o estudo das cinco fogueiras localizadas na área central de moradia. 


\subsubsection{Microestratigrafia do anel de conchas}

A sucessão vertical do sítio Túnel 7, de 30 a $60 \mathrm{~cm}$ de altura, é composta pela seguinte sucessão, do topo à base: camada de sedimentos castanho avermelhados, que corresponde a depósito coluvionar com formação de solo no topo; camada de concheiro, formada por inter-estratificação de lâminas de concheiro compacto, terras conchíferas (concheiro compacto com 20-50\% de sedimentos), terras pretas (sedimentos finos e orgânicos) e lâminas de seixos; e substrato de paleopraia de seixos (Orquera 1996, Orquera \& Piana 1996b) (Figura 5.106 A).

Para análise micromorfológica, coletaram-se duas colunas, de $60 \mathrm{~cm}$ cada uma, da sucessão vertical exposta pela escavação do sítio, localizada próxima à praia atual. A coluna 11 (C11) situa-se numa área identificada como passagem, através do anel de conchas, desde o exterior até a área central de moradia (Figura 5.106 A). A análise micromorfológica da C11 foi realizada por Balbo et al. (2010). Estes autores identificaram três tipos de atividades a partir dos atributos micromorfológicos das 11 seções delgadas analisadas: 1) eventos discretos de deposição de resíduos, caracterizados por baixa fragmentação das conchas, distribuídas sub-horizontalmente; 2) fases de frequentação, identificadas pela alta fragmentação das conchas com distribuição aleatória; 3) abandono temporário do sítio, com desenvolvimento de solo em blocos angulosos.

Nesta tese, será analisada a coluna 12 (C12), localizada no anel de conchas a menos de $1 \mathrm{~m}$ de distância a leste da C11 (Figura 5.106 A). A descrição e análise foi realizada segundo os princípios da análise de microfácies arqueológicas explicados no Capítulo 4, tópico 1.2.1. A coluna de amostragem será tomada como uma grande amostra, apesar de ter sido subdividida em sete seções delgadas para sua análise. Assim, a identificação de microfácies será realizada por lâmina, com referência à coluna como um todo. Desse modo, na apresentação dos resultados serão discutidos primeiro os atributos comuns a toda a coluna, seguido dos atributos próprios de cada microfácies.

$\mathrm{Na}$ Tabela 5.33, apresenta-se a descrição micromorfológica das sete seções delgadas analisadas da coluna de amostragem no anel de conchas. Cinco microfacies foram identificadas na seção vertical da C12. A identificação baseou-se nas diferenças entre os componentes da fração grossa (frequência, completitude, orientação e distribuição), microestrutura, porosidade e razão g/f. Na Figura 5.106 B, mostra-se o desenho esquemático da $\mathrm{C} 12$ junto com o desenho esquemático da $\mathrm{C} 11$, estudada por 
Balbo et al. (2010), com identificação de microfácies em cada coluna e correlação entre as duas sucessões verticais.

A fração grossa de todas as lâminas é composta por conchas (principalmente mexilhão), fragmentos líticos arredondados na fração cascalho, carvão e alguns ossos queimados. A maioria das conchas está inteira e, quando fragmentada, existe continuidade entre os fragmentos, o que indica quebra in situ. Os fragmentos líticos estão igualmente fissurados mas não deslocados. A micromassa é preta (PPL), opaca a turva e indiferenciada, formada por finos grânulos de matéria orgânica polimórfica, restos de tecidos, microcarvão e, às vezes, finos fragmentos de osso (Figura 5.107 A-B).

A microestrutura predominante, de grânulos mamilares interligados, resulta da atividade biológica, como observado na amostragem de referência em solos da região (ver tópico 3.1.3). A recente cronologia do sítio teria permitido a boa preservação dos componentes orgânicos originais na forma de madeira e serrapilheira parcialmente decomposta. Uma feição pedológica recorrente na sucessão analisada são cristais aciculares de carbonato de cálcio, de poucos micrômetros de espessura e 20-40 $\mu \mathrm{m}$ de comprimento (Figura 5.107 C-F).

A mF 1 corresponde à camada superficial do anel de conchas e aparece uma única vez na sucessão vertical (Figura 5.106 B; Tabela 5.33). Caracteriza-se pela baixa porosidade $(20 \%)$ e alta compactação da massa basal. Quase $50 \%$ das conchas estão distribuídas sub-horizontalmente, a maioria fragmentada, mas com cotinuidade entre os fragmentos. Os demais componentes da fração grossa (cascalho, carvão e restos de tecidos) apresentam distribuição aleatória. A micromassa compõe-se de grânulos interconectados compostos de matéria orgânica polimórfica, microcarvão, madeira decomposta e restos de plantas oxidados (Figura 5.108 A, B).

A $\mathrm{mF} 2$ representa um tipo de solo de microestrutura em blocos angulosos que se desenvolve nos concheiros da região, definido como middensol por Balbo et al. (2010). Este solo caracteriza-se pela microestrutura de blocos angulosos formada por prismas, de 5 x 5 mm, com finas fissuras no interior (Figura 5.108 A, C; Tabela 5.33). Os blocos incluem abundantes fragmentos de concha e osso (na fração areia fina a silte) em fração fina organomineral, de cor castanha escura (PPL), com restos de tecidos e cristais aciculares de carbonato de cálcio dentro, que lhe outorgam uma fábrica-b cristalítica (Figura 5.110 A,C).

A mF 3 caracteriza-se pela alta frequência de conchas inteiras, sempre com continuidade dos fragmentos quando quebradas (Figura 5.110 D, E). A distribuição das 
conchas é sub-horizontal na maioria dos casos (60\%), às vezes oblíquas (30\%) ou, numa minoria, subverticais (20\%) (Figura 5.109 A, B, E, F). Os fragmentos de concha menores também estão orientados. Menos de 2\% dos fragmentos de concha apresentam sinais de queima. Em alguns casos, o perióstraco esta ainda preservado. Os fragmentos de carvão são mais grossos e melhor preservados que nas microfácies restantes. Os fragmentos líticos apresentam-se fissurados, o que indica alteração pós-deposicional pelo intemperismo físico (Van Vliet-Lanoe, 2010), sem retrabalhamento. A fração fina compõe-se de grânulos finos mamilares, formados por uma mistura de matéria orgânica polimórfica, microcarvão, e restos de plantas oxidados (Figura 5.110 A, B; Tabela 5.33). Unicamente nas partes mais inferiores da sucessão vertical, a micromassa apresenta áreas de micrita e esparita.

A mF 4 caracteriza-se por alta razão g/f (90/10) e distribuição horizontal dos fragmentos de concha, sempre com empacotamento fechado (Figura 5.108 E, F; Figura 5.110 E, F). A fração fina é semelhante à descrita para a $\mathrm{mF} 3$, mas em menor abundância e na forma de grânulos muito finos $(100-150 \mu \mathrm{m})$ e soltos (Figura 5.109 C, D; Tabela 5.33).

A última microfacies identificada, $\mathrm{mF} 5$, corresponde a uma faixa de seixos de aproximadamente $2 \mathrm{~cm}$ de espessura. Os espaços entre os clastos estão parcialmente recheados de grânulos mamilares, de composição orgânica, como descritos para as $\mathrm{mF} 3$ e 4 (Figura 5.110 A, D; Tabela 5.33).

A partir da análise realizada por Balbo et al. (2010), adiciona-se mais uma microfácies, classificada como $\mathrm{mF} 6$, que aparece unicamente na metade inferior da C11. Esta microfácies é dominada pela fração fina, da mesma composição que as mF 3 e 4, com fragmentos de concha de distribuição aleatória (aproximadamente 10\% queimados), fragmentos líticos arredondados e carvão. 


\section{TÚNEL 7}

A
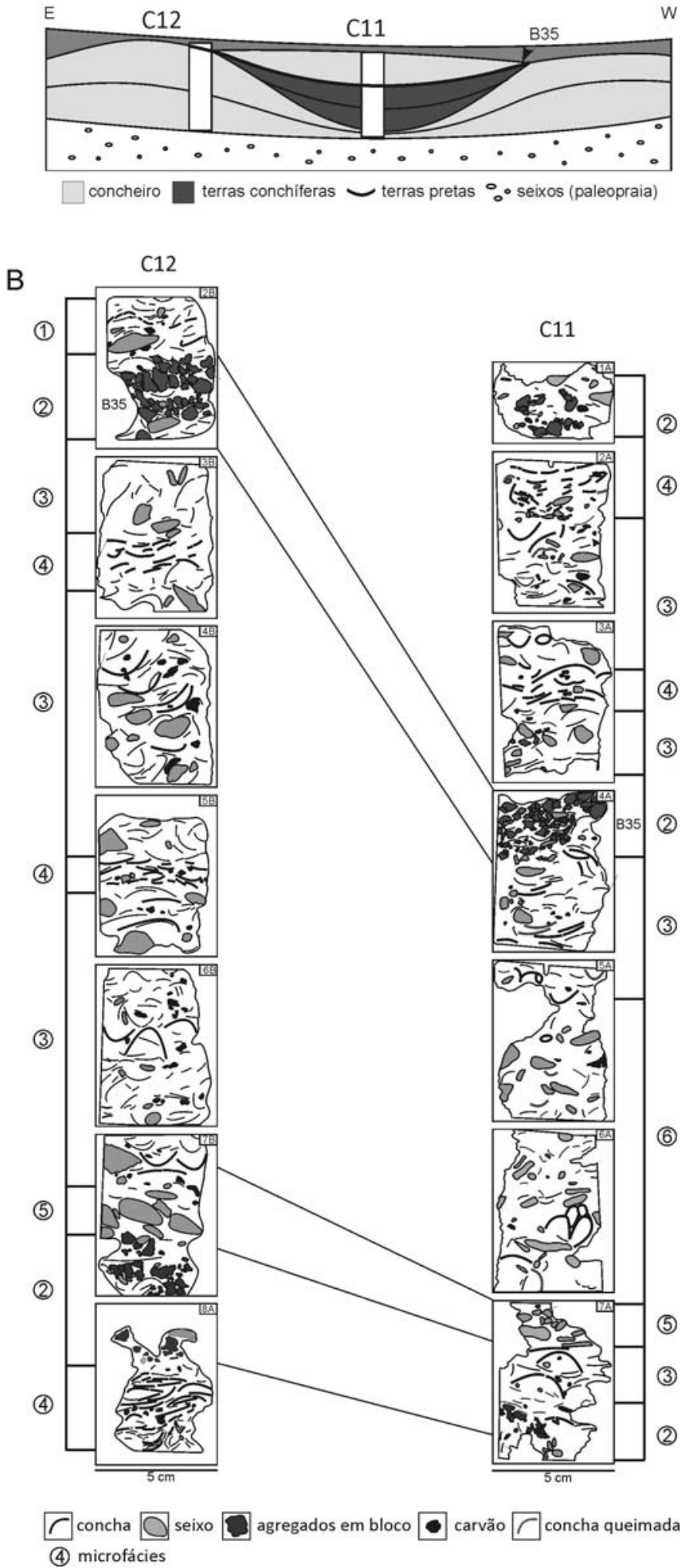

Figura 5.106. Macro e microestratigrafia do concheiro Túnel 7: A) sucessão vertical esquemática, a partir de informações disponíveis em Orquera (1996), com localização das duas colunas de amostragem para micromorfologia (C11 e C12); B) microfácies identificadas na C11 e C12, com correlação entre as sucessões estratigráficas de cada coluna. Note-se correspondência da unidade B35. 
Tabela 5.33. Descrição micromorfológica da coluna de amostragem do sítio Túnel 7.

\begin{tabular}{|c|c|c|c|c|c|c|c|c|c|c|c|c|c|c|c|c|c|c|}
\hline \multirow{3}{*}{ Am } & \multirow{3}{*}{$\mathbf{m F}$} & \multirow[b]{3}{*}{ 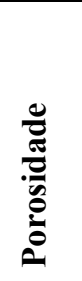 } & \multirow{3}{*}{$\%$} & \multirow[b]{3}{*}{ 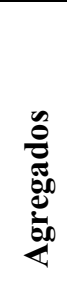 } & \multirow{3}{*}{ Tam. } & \multirow{3}{*}{ Microestrutura } & \multirow[b]{3}{*}{ 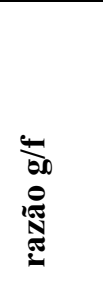 } & \multirow[b]{3}{*}{$\begin{array}{l}\overrightarrow{00} \\
\dot{0} \\
\dot{0} \\
\dot{0} \\
\dot{0}\end{array}$} & \multicolumn{3}{|c|}{ Fr. min. gr } & \multicolumn{2}{|c|}{ Fr. org. gr. } & \multicolumn{4}{|c|}{ Micromassa } & \multirow{3}{*}{ FP } \\
\hline & & & & & & & & & & & & & & & & & Composição & \\
\hline & & & & & & & & & $\begin{array}{l}\frac{\pi}{e} \\
\text { U் }\end{array}$ & 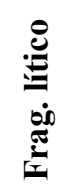 & $\begin{array}{l}8 \\
\text { ô }\end{array}$ & 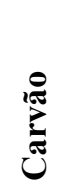 & 葛 & $\dot{\theta}$ & & 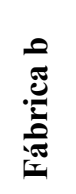 & & \\
\hline $2 \mathrm{~B}$ & 1 & e-cx & 20 & $\mathrm{gr}$ & $250 \mu \mathrm{m}$ & $\begin{array}{l}\text { Microagregados } \\
\text { intergranulares }\end{array}$ & $50 / 50$ & en & $\cdots$ & $\bullet \bullet$ & & $\bullet \bullet$ & $\bullet$ & & $\begin{array}{l}\text { op } \\
\text { tr }\end{array}$ & ind & $\begin{array}{l}\text { Mat. orgânica } \\
\text { polimórfica }\end{array}$ & $10 \%$ cris \\
\hline \multirow[t]{2}{*}{$3 B$} & 3 & $e-c x$ & 40 & $\mathrm{gr}$ & $150-250 \mu \mathrm{m}$ & $\begin{array}{l}\text { Microagregados } \\
\text { intergranulares }\end{array}$ & $60 / 40$ & en & $\cdots$ & $\bullet$ & • & $\bullet$ & & & $\begin{array}{l}\text { op } \\
\text { tr }\end{array}$ & ind & $\begin{array}{l}\text { Mat. orgânica } \\
\text { polimórfica }\end{array}$ & $30 \%$ cris \\
\hline & 4 & $e-c x$ & 30 & gr & $100-150 \mu \mathrm{m}$ & $\begin{array}{l}\text { Microagregados } \\
\text { intergranulares }\end{array}$ & $90 / 10$ & en & $\cdots \bullet$ & $\bullet$ & & & & & $\begin{array}{l}\text { op } \\
\operatorname{tr}\end{array}$ & ind & $\begin{array}{l}\text { Mat. orgânica } \\
\text { polimórfica }\end{array}$ & $30 \%$ cris \\
\hline $4 \mathrm{~B}$ & 3 & e-cx & 40 & gr & $150-250 \mu \mathrm{m}$ & $\begin{array}{l}\text { Microagregados } \\
\text { intergranulares }\end{array}$ & $70 / 30$ & en & $\cdots$ & $\bullet$ & - & $\bullet$ & $\bullet$ & & $\begin{array}{l}\text { op } \\
\operatorname{tr}\end{array}$ & ind & $\begin{array}{l}\text { Mat. orgânica } \\
\text { polimórfica }\end{array}$ & $40 \%$ cris \\
\hline $5 \mathrm{~B}$ & 4 & e-cx & 50 & $\mathrm{gr}$ & $100-150 \mu \mathrm{m}$ & $\begin{array}{l}\text { Microagregados } \\
\text { intergranulares }\end{array}$ & $90 / 10$ & en & $\cdots \bullet \bullet$ & $\bullet$ & & $\bullet$ & $\bullet$ & & $\begin{array}{l}\text { op } \\
\operatorname{tr}\end{array}$ & ind & $\begin{array}{l}\text { Mat. orgânica } \\
\text { polimórfica }\end{array}$ & $20 \%$ cris \\
\hline $6 \mathrm{~B}$ & 3 & e-cx & 40 & $\mathrm{gr}$ & $150-250 \mu \mathrm{m}$ & $\begin{array}{l}\text { Microagregados } \\
\text { intergranulares }\end{array}$ & $60 / 40$ & en & $\bullet \bullet \bullet$ & $\bullet$ & • & $\bullet$ & • & & $\begin{array}{l}\text { op } \\
\text { tr }\end{array}$ & ind & $\begin{array}{l}\text { Mat. orgânica } \\
\text { polimórfica }\end{array}$ & $20 \%$ cris \\
\hline
\end{tabular}

Freqüências de classes segundo Bullock et al. (1985): • Muito Poucas (<5\%); •• Poucas (5-15\%); ••• Comum (15-30\%) ; ••• Freqüente (30-50\%); ••••• Dominante (50-70\%);

•... Muito dominante $(>70 \%)$. O singificado das abreviações utilizadas nesta tabela encontra-se no Anexo, Tabela A.5. 
Continuação Tabela 5.33.

\begin{tabular}{|c|c|c|c|c|c|c|c|c|c|c|c|c|c|c|c|c|c|c|}
\hline \multirow{3}{*}{ Am } & \multirow{3}{*}{$\mathbf{m F}$} & \multirow[b]{3}{*}{ 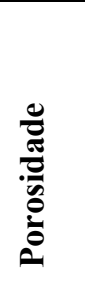 } & \multirow{3}{*}{$\%$} & \multirow{3}{*}{ 串 } & \multirow{3}{*}{ Tam. } & \multirow{3}{*}{ Microestrutura } & \multirow[b]{3}{*}{ 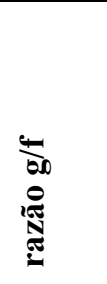 } & \multirow[b]{3}{*}{$\begin{array}{l}\underbrace{}_{00} \\
\dot{0} \\
\dot{0} \\
\dot{0} \\
\dot{0}\end{array}$} & \multicolumn{3}{|c|}{ Fr. min. gr } & \multicolumn{2}{|c|}{ Fr. org. gr. } & \multicolumn{4}{|c|}{ Micromassa } & \multirow{3}{*}{ FP } \\
\hline & & & & & & & & & & & & & & & & & Composição & \\
\hline & & & & & & & & & نَّ & 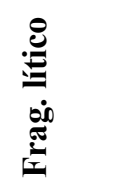 & ڤ̆ & 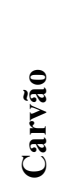 & $\underset{\mathscr{e}}{\stackrel{0}{e}}$ & $\dot{\theta}$ & 胥 & 苞 & & \\
\hline \multirow[t]{3}{*}{$7 \mathrm{~B}$} & 3 & e-cx & 40 & gr & $150-250 \mu \mathrm{m}$ & $\begin{array}{l}\text { Microagregados } \\
\text { intergranulares }\end{array}$ & $50 / 50$ & en & $\cdots$ & $\bullet$ & $\cdot$ & $\bullet$ & $\bullet$ & & $\begin{array}{l}\text { op } \\
\text { tr }\end{array}$ & ind & $\begin{array}{l}\text { Mat. orgânica } \\
\text { polimórfica }\end{array}$ & $10 \%$ cris \\
\hline & 5 & $e-c x$ & 60 & gr & $100-150 \mu \mathrm{m}$ & $\begin{array}{l}\text { Microagregados } \\
\text { Intergranulares }\end{array}$ & $80 / 20$ & mon & $\bullet$ & $\bullet \bullet \bullet \bullet$ & & & & & $\begin{array}{l}\text { op } \\
\text { tr }\end{array}$ & ind & $\begin{array}{l}\text { Mat. orgânica } \\
\text { polimórfica }\end{array}$ & \\
\hline & 2 & fs & 30 & $\mathrm{pr}$ & $3 \times 5 \mathrm{~mm}$ & Blocos & $60 / 40$ & por & $\bullet$ & $\bullet$ & - & $\bullet$ & & & $\begin{array}{l}\text { op } \\
\text { tr }\end{array}$ & cri & $\begin{array}{l}\text { Argila } \\
\text { organomineral }\end{array}$ & $50 \%$ cris \\
\hline \multirow[t]{3}{*}{$8 \mathrm{~B}$} & 2 & fs & 30 & pr & $5 \times 6 \mathrm{~mm}$ & Blocos & $30 / 70$ & por & $\bullet$ & $\bullet$ & • & $\bullet$ & & & $\begin{array}{l}\text { op } \\
\text { tr }\end{array}$ & cri & $\begin{array}{l}\text { Argila } \\
\text { organomineral }\end{array}$ & $50 \%$ cris \\
\hline & 3 & e-cx & 40 & gr & $150-250 \mu \mathrm{m}$ & $\begin{array}{l}\text { Microagregados } \\
\text { intergranulares }\end{array}$ & $50 / 50$ & en & $\bullet . . \bullet \bullet$ & $\bullet$ & • & $\cdots$ & • & & $\begin{array}{l}\text { op } \\
\text { tr }\end{array}$ & ind & $\begin{array}{l}\text { Mat. orgânica } \\
\text { polimórfica }\end{array}$ & $20 \%$ cris \\
\hline & 4 & $e-c x$ & 50 & gr & $100-250 \mu \mathrm{m}$ & $\begin{array}{l}\text { Microagregados } \\
\text { intergranulares }\end{array}$ & $90 / 10$ & en & $\cdots$ & $\bullet$ & $\bullet$ & $\cdots$ & & & $\begin{array}{l}\text { op } \\
\text { tr }\end{array}$ & ind & $\begin{array}{l}\text { Mat. orgânica } \\
\text { polimórfica }\end{array}$ & $20 \%$ cris \\
\hline
\end{tabular}



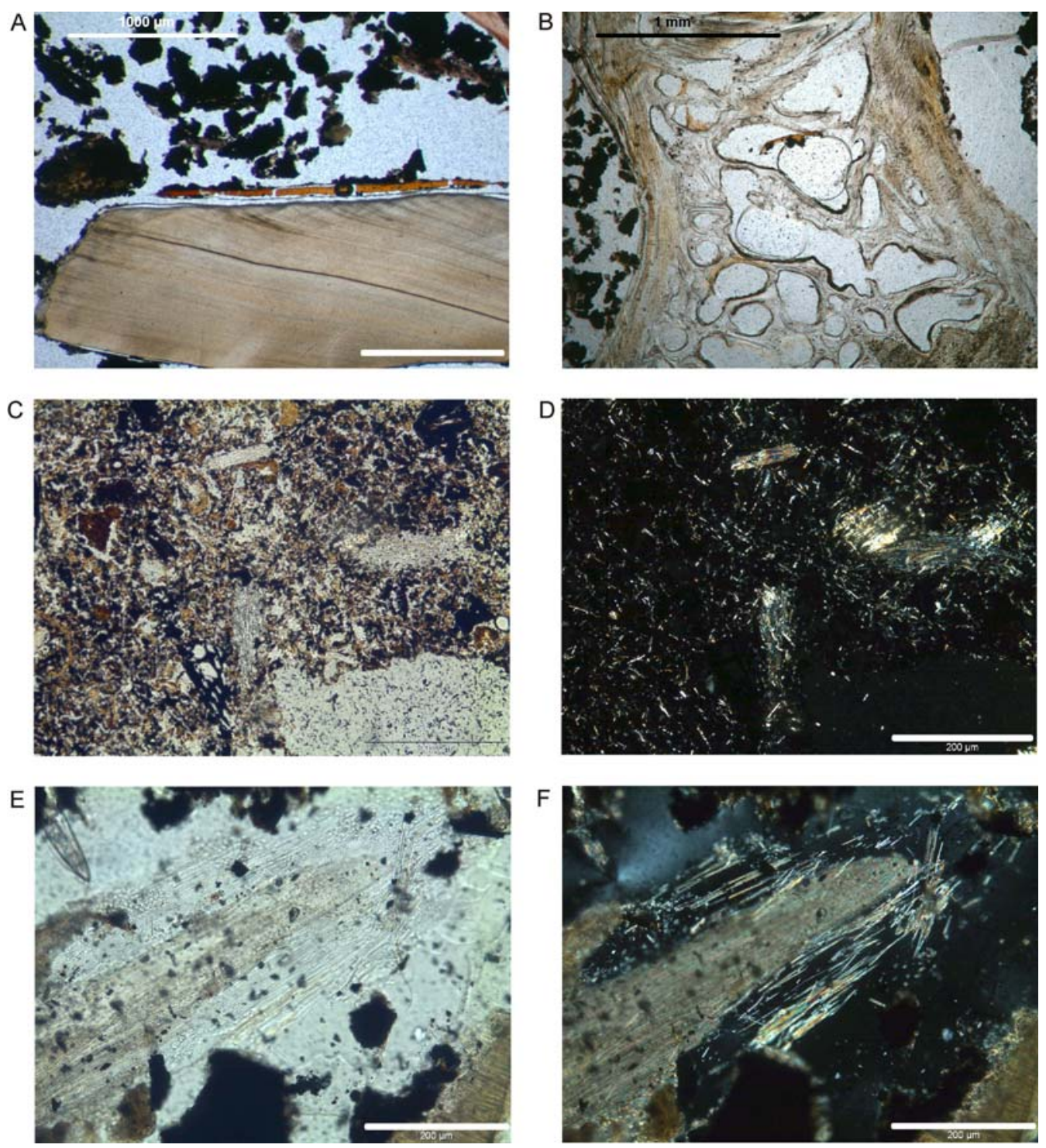

Figura 5.107. Fotomicrografias de elementos encontrados no concheiro Túnel 7: A) concha com perióstraco preservado, acompanhada de micromassa de agregados mamilares pretos, PPL; B) fragmento de osso intemperizado, identificado graças à seção delgada de referência coletada da praia de seixos, PPL; C) detalhe de agregados em blocos angulares que caracterizam à $\mathrm{mF} 2$, com cristais aciculares de calcita na micromassa, PPL e XPL; D) mesmo agregado de C, a XPL; E, F) fragmento de concha com cristais aciculares de calcita que se desprendem, PPL e XPL. 
A

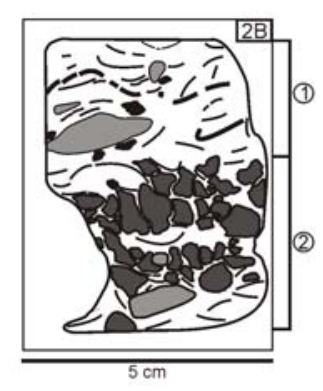

C

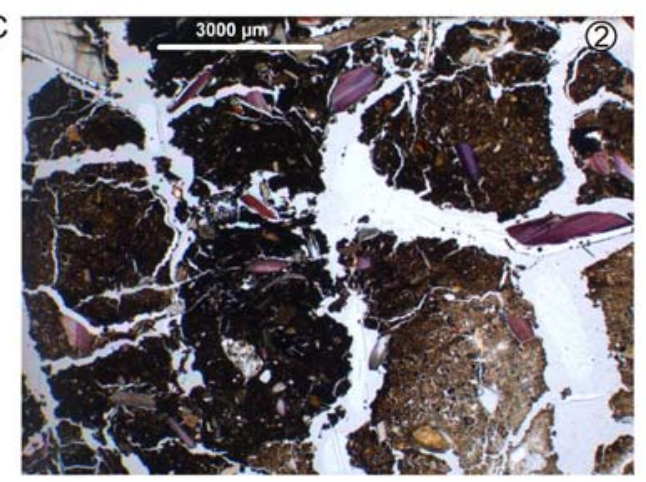

E

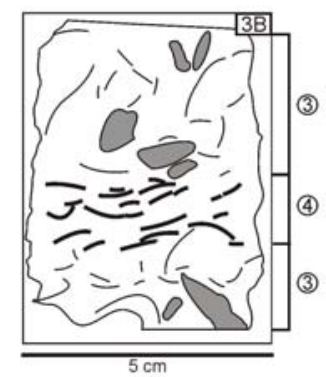

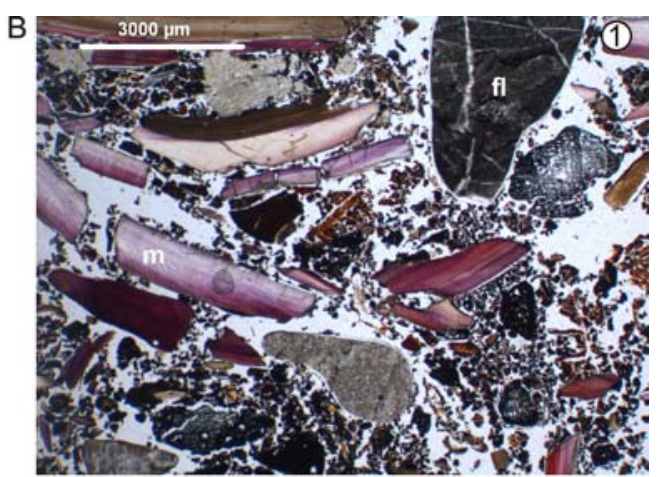
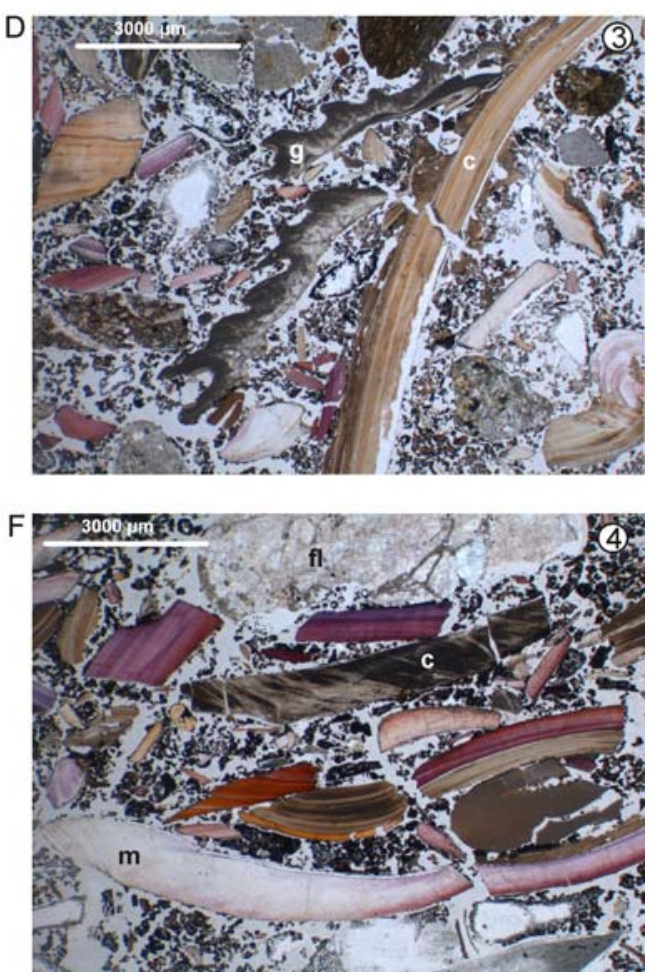

Figura 5.108. Fotomicrografias das seções delgadas 2B e 3B da coluna 12 do sítio Túnel 7 (PPL): A) desenho esquemático da seção delgada $2 \mathrm{~B}$; B) $\mathrm{mF} 1$, com fragmentos de concha (c) e fragmentos líticos (fl); C) $\mathrm{mF} 2$, com blocos angulosos de argila organomineral com finos fragmentos de concha e osso; D) $\mathrm{mF} 3$, com fragmentos de concha de espécie indeterminada e fragmentos de concha de gastrópode $(\mathrm{g})$; E) desenho esquemático da seção delgada 3B; F) $\mathrm{mF} 4$, formada por conchas de espécie indeterminada, conchas de mexilhão (m) e fragmentos líticos de distribuição horizontal e empacotamento fechado. 
A

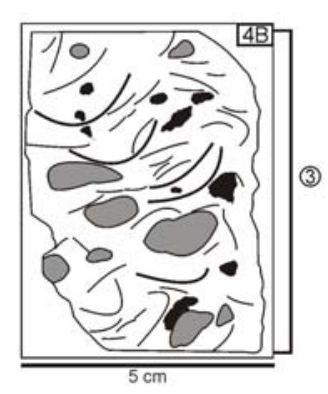

C

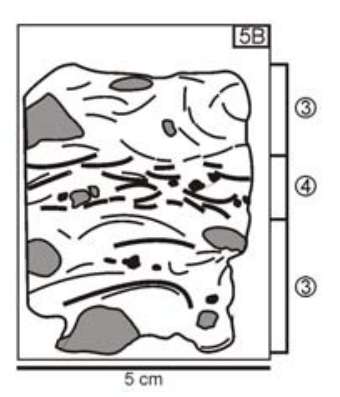

$\mathrm{E}$

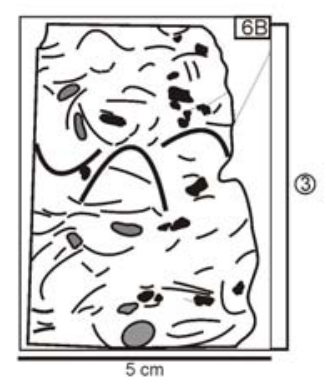

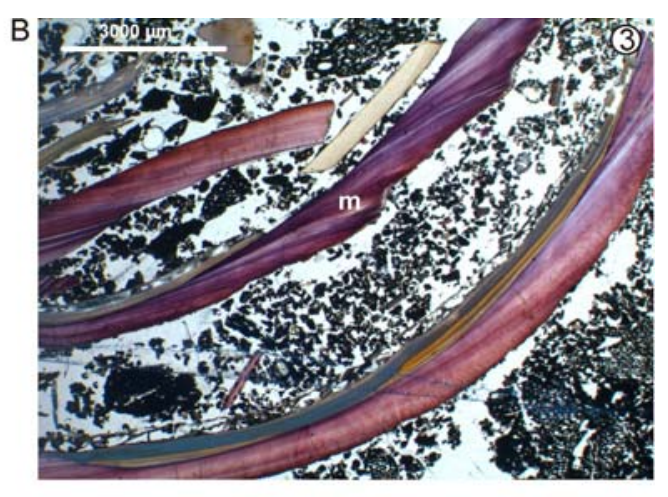
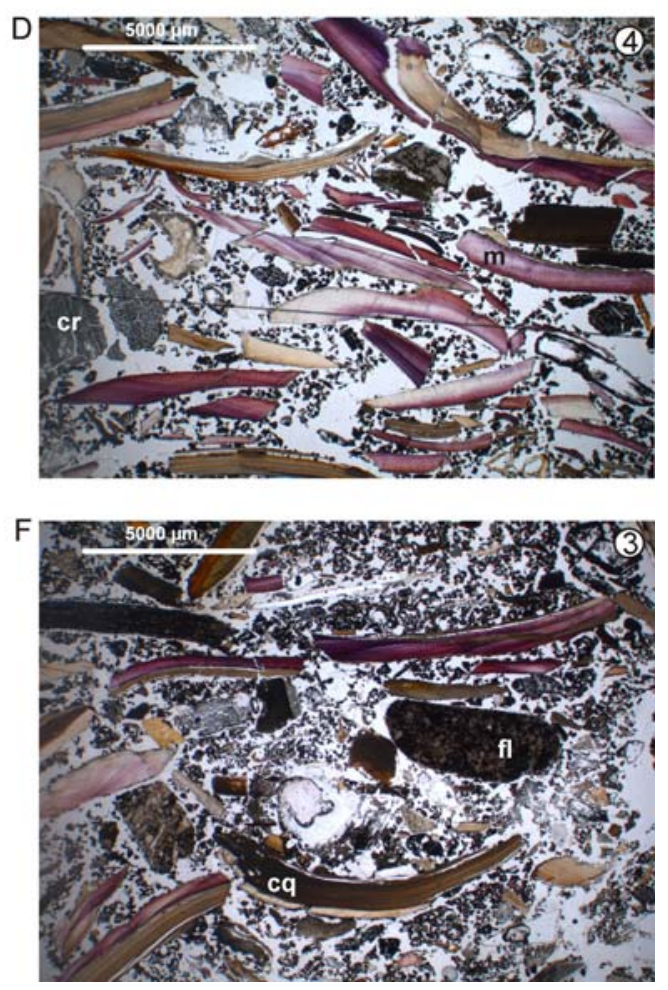

Figura 5.109. Fotomicrografias das seções delgadas 4B, 5B e 6B da coluna 12 do sítio Túnel 7 (PPL): A) desenho esquemático da seção delgada $4 \mathrm{~B} ; \mathrm{B}) \mathrm{mF}$ com conchas de mexilhão $(\mathrm{m})$ inteiras; $\mathrm{C}$ ) desenho esquemático da seção delgada $5 \mathrm{~B} ; \mathrm{D}) \mathrm{mF} 4$, com conchas de mexilhão e carvão (cr) de distribuição horizontal; E) desenho esquemático da seção delgada $6 \mathrm{~B} ; \mathrm{F}) \mathrm{mF} 3 \mathrm{com}$ conchas de mexilhão fragmentadas in situ, fragmentos líticos (fl) e concha queimada (cq). 
A
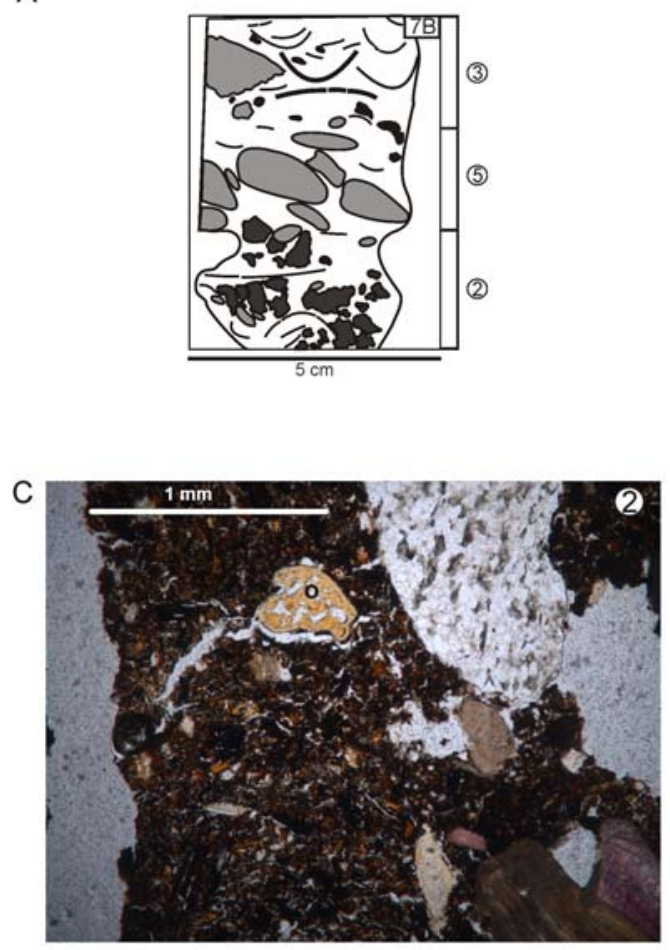

$\mathrm{E}$

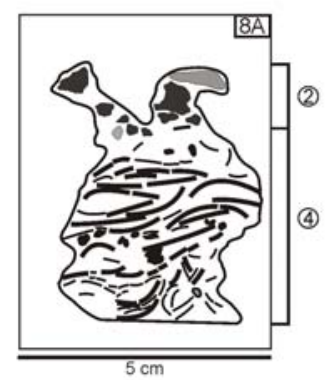

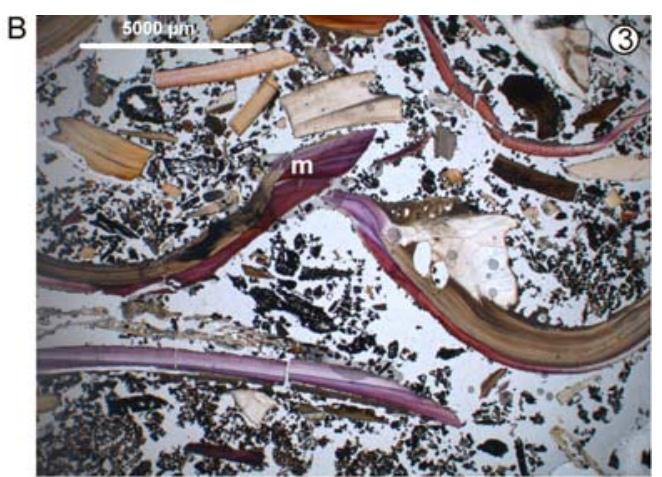
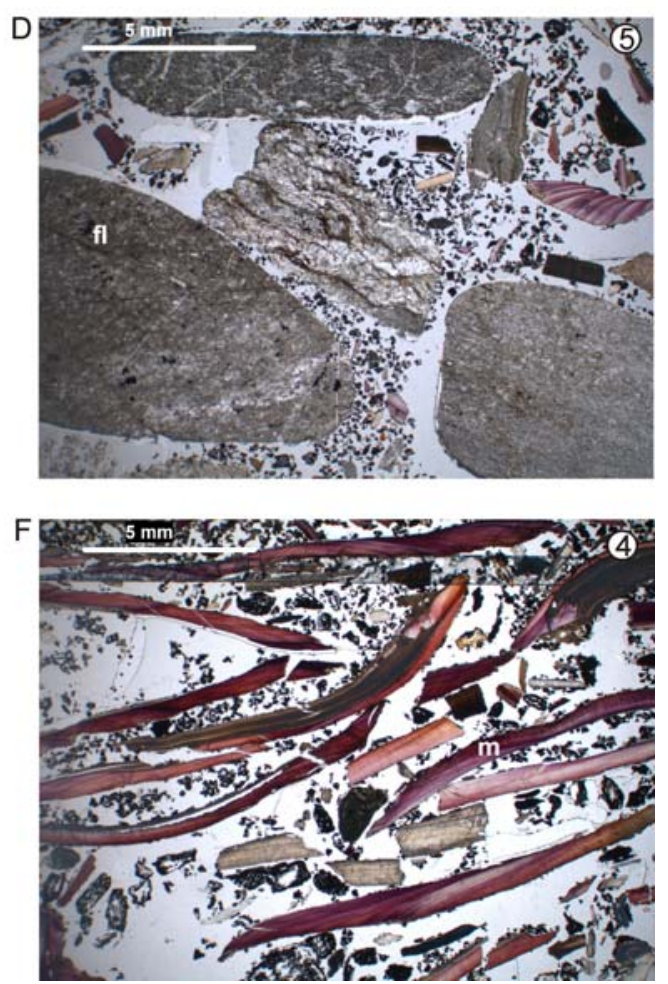

Figura 5.110. Fotomicrografias das seções delgadas 7B e 8B da coluna 12 do sítio Túnel 7 (PPL): A) desenho esquemático da seção delgada $7 \mathrm{~B}$; B) $\mathrm{mF} 3$, com conchas inteiras de mexilhão $(\mathrm{m})$ e conchas fragmentadas in situ; C) detalhe de bloco anguloso da $\mathrm{mF} 2$ com fragmento de osso no interior (o); $\mathrm{D}$ ) $\mathrm{mF}$ 5, composta por camada de seixos (fl); E) desenho esquemático da seção delgada 8B; F) $\mathrm{mF} 4$, composta por conchas de mexilhão de distribuição horizontal e empacotamento fechado.

\subsubsection{Micromorfologia da área central de habitação}

$\mathrm{Na}$ área central do concheiro Túnel 7, onde teria estado localizada a cabana de moradia, foi identificada uma sucessão de dez estruturas de combustão. Segundo Estevez \& Vila (2006), as fogueiras representam dez reocupações do sítio. Para análise micromorfológica, foram coletadas nove amostras provenientes das fogueiras identificadas, do topo até a base do concheiro, como AC4, AC5, AC6, AC8 e AC10 (Figura 5.111). Estas fogueiras foram analisadas espacialmente em trabalhos prévios 
(Estevez and Vila, 2006; Piqué, 1999; Wunsch, 1996) e correspondem a cinco das dez fases de ocupação do sítio definidas por Estevez \& Vila (1996).

A fogueira mais antiga (AC10), que corresponde ao primeiro episódio de ocupação do concheiro na primavera, contém grande concentração de ossos de cetáceo e guanaco. A fogueira AC8 representa o quinto episódio de ocupação, do qual se encontraram resíduos de lascamento, tanto dentro como fora da área de habitação. Da quinta ocupação, foram identificadas fogueiras periféricas à fogueira central amostrada, o que foi interpretado como indicador de uso do sítio no inverno. A sexta ocupação está representada pela fogueira AC6, que teria acontecido no começo do verão. A sétima ocupação, representada pela fogueira AC5, contém lascas de osso, derivadas da confecção de pontas de flecha. As ocupações oito e nove, que teriam acontecido muito próximas no tempo, estão representadas pela fogueira AC4, que contém artefatos líticos com restos de cetáceo, guanaco, peixe e ave, interpretado como ocupação do sítio no verão (Estevez and Vila, 2006).

A descrição micromorfológica das cinco fogueiras centrais analisadas do sítio Túnel 7 aparece na Tabela 5.34. Em todas as fogueiras destaca a presença de fragmentos e conchas inteiras queimadas, identificadas graças à experiência apresentada no tópico 3.1.5. Conchas queimadas foram identificadas a partir da presença de fissuras longitudianis, deformação das valvas, presença de pseudo-vacúolos, textura irregular e coloração avermelhada, marrom escura e preta a PPL. A fração fina das fogueiras superiores (AC4, 5 e parte da AC6) esta composta de finos grânulos e grumos de microcarvão, com fragmentos grossos de carvão. A micromassa das fogueiras inferiores (AC8 e 10) é composta por argila rubefacta e micrita, com baixa frequência de carvões inteiros e microestrutura esponjosa e em câmara. Restos de tecidos ou resíduos orgânicos estão ausentes. Todos os fragmentos líticos encontram-se oxidados e com fissuras, o que indica intemperismo químico e físico, possivelmente relacionado com a exposição a ciclos repetitivos de aquecimento e esfriamento. As feições pedológicas incluem revestimentos impuros de calcita e microcarvão, nódulos órticos de óxihidróxido de ferro (mais freqüentes nas fogueiras inferiores, AC8 e AC10) e ocasionais cristais aciculares de calcita (unicamente nas fogueiras superiores, AC4 e AC5).

Em geral, todas as fogueiras são similares quanto aos componentes da fração grossa e as feições pedológicas. No entanto, as cinco fogueiras podem ser agrupadas em duas microfácies (definidas como $\mathrm{mF} 7 \mathrm{e} \mathrm{mF}$ 8), de acordo com suas diferenças quanto 
a frequência de conchas queimadas a temperatura superior aos $500^{\circ} \mathrm{C}$, porosidade, microestrutura e composição da micromassa (Figura 5.111).

A mF 7 (AC4, AC5 e AC6) é porosa e apresenta uma mistura de conchas queimadas a diversas temperaturas (mas sempre acima dos $200^{\circ} \mathrm{C}$ ), fragmentos líticos (muitos deles oxidados e fissurados), ossos queimados e carvão. Aproximadamente $20 \%$ das conchas mostram evidências de terem sido queimadas a temperatura superior a $500^{\circ} \mathrm{C}$. As conchas têm distribuição sub-horizontal e seus fragmentos apresentam continuidade lateral. A fração fina é composta por grãos de areia muito fina a média (100-300 $\mu \mathrm{m})$ e grumos pretos inter-conectados $(\sim 600 \mu \mathrm{m})$, compostos de microcarvão, tecido oxidado e áreas de concentração de micrita.

A mF 8 (AC6, AC8 e AC10) é mais compacta e caracteriza-se pela fração grossa composta de fragmentos de concha queimados a temperatura superior a $500^{\circ} \mathrm{C}$, de distribuição aleatória. Inclui componentes líticos oxidados e quebrados, ossos queimados e ossos alterados provenientes das praias das proximidades. A micromassa compõe-se de cinzas, na forma de micrita impura, com microcarvão e argila rubefacta, em microestrutura em câmera. A presença dos agregados de POCC sugere a boa preservação das cinzas (ver Canti, 2003). Os fragmentos grossos de carvão são escassos $(<2 \%)$. Existem numerosos nódulos e hiporrevestimentos impregnantes de óxihidróxidos de ferro, assim como revestimentos calcíticos micro-laminados em forma de crescente. As bioturbações são evidentes, na forma de canais e câmaras.

As seções delgadas da AC6 mostram uma composição mista, que combina os atributos descritos para a $\mathrm{mF} 7$ (grânulos soltos de microcarvão) e para a $\mathrm{mF} 8$ (agregados grossos de argila rubefacta e micrita). A fração grossa mineral também é uma combinação das duas microfácies anteriores, com conchas queimadas a temepratura média e alta, fragmentos líticos oxidados e fissurados, carvão e ossos queimados. Isto sugere que AC6 pode ser produto do retrabalhamento da microfácies identificada nas fogueiras superiores $(\mathrm{mF} 7)$ e inferiores $(\mathrm{mF} 8)$.

Em termos gerais, a maior diferença que se destaca entre as microfácies identificadas no anel de conchas $(\mathrm{mF} 1-6)$ e as da área central $(\mathrm{mF} 7$ e 8$)$ refere-se à micromassa e à maior freqüência de conchas queimadas e muito fragmentadas na área central. A queima das conchas foi identificada graças aos atributos apresentados no tópico 3.1.5, como presença de fissuras longitudinais, deformação da valva, textura irregular, coloração avermelhada, castanho escuro a preto e pseudo-vacúolos. 
Tabela 5.34. Descrição micromorfológica das fogueiras (AC) identificadas na área central de Tunel 7.

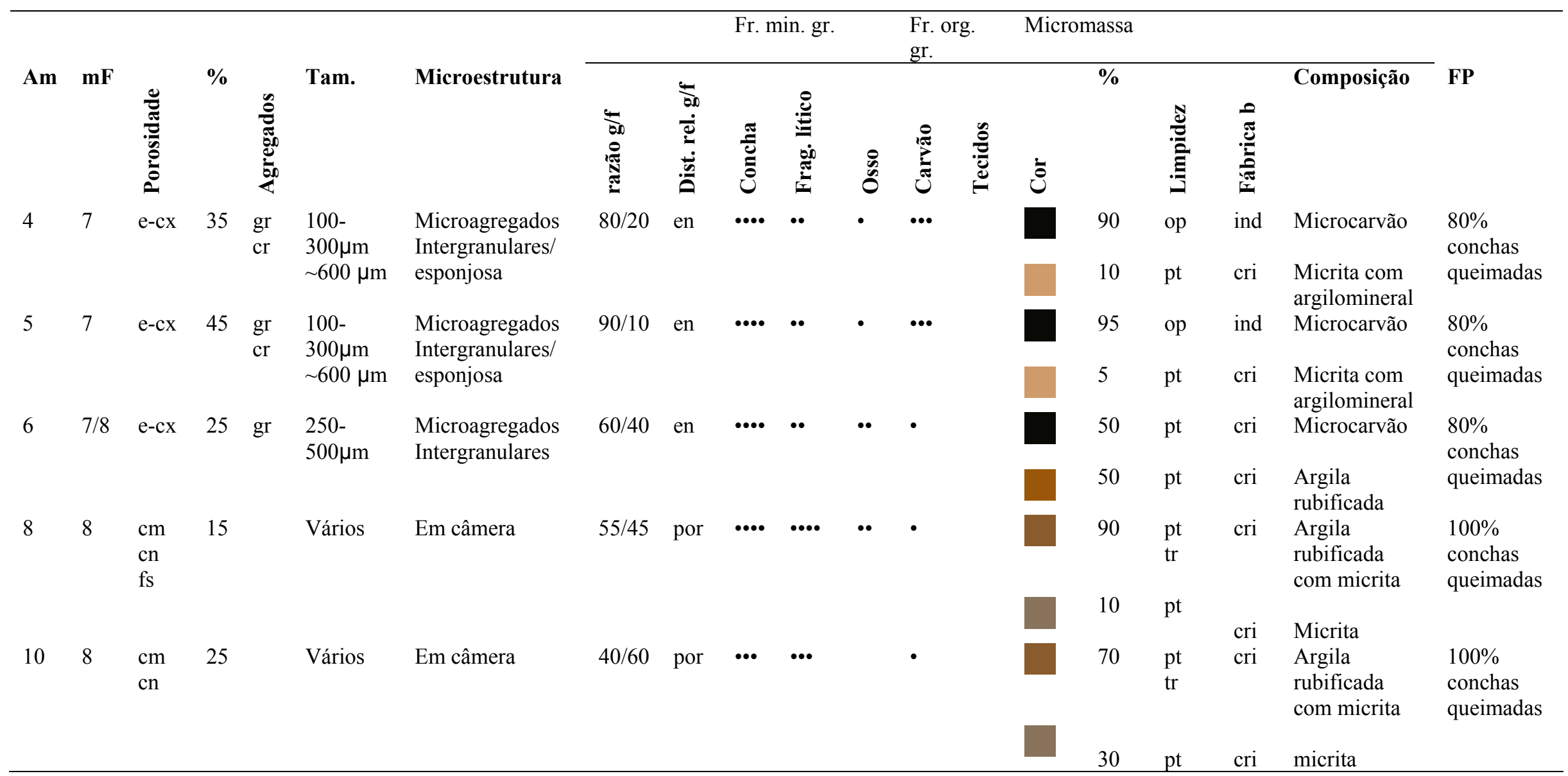

Freqüências de classes segundo Bullock et al. (1985): • Muito Poucas $(<5 \%) ; \bullet \bullet$ Poucas $(5-15 \%) ; \cdots \bullet$ Comum $(15-30 \%) ; \bullet \bullet \bullet$ Freqüente $(30-50 \%) ; \bullet \bullet \bullet \bullet$ Dominante $(50-70 \%)$; ..... Muito dominante $(>70 \%)$. O singificado das abreviações utilizadas nesta tabela encontra-se no Anexo, Tabela A.5. 
TÚNEL 7
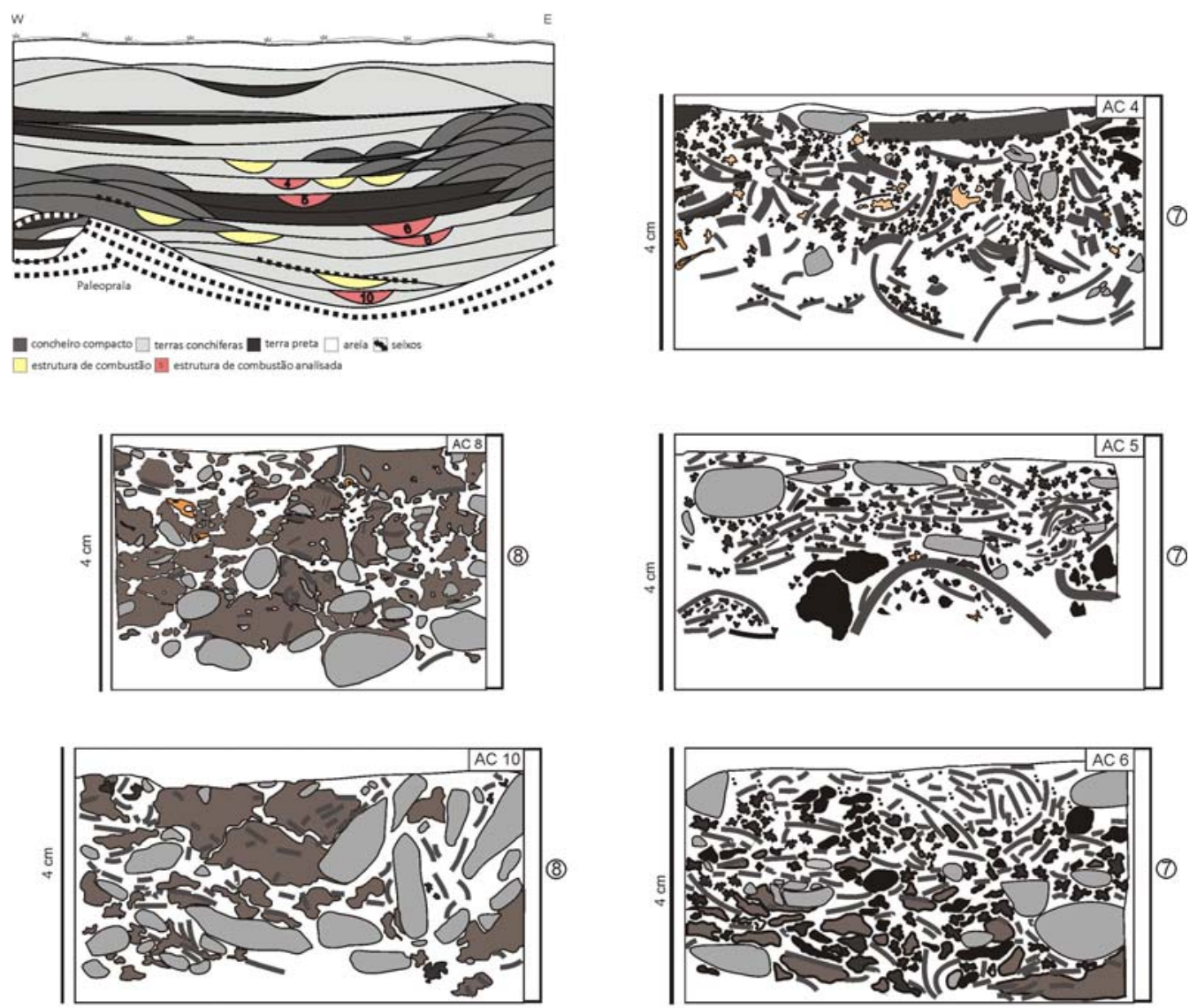

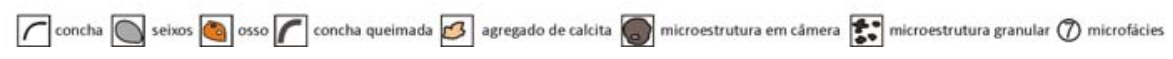

Figura 5.111. Seção esquemática, sem escala, do sítio Túnel 7, com localização das cinco fogueiras estudadas (AC4, 5, 6, 8 e 10) e desenho esquemático das seções delgadas de cada fogueira, com identificação de microfácies. 
A
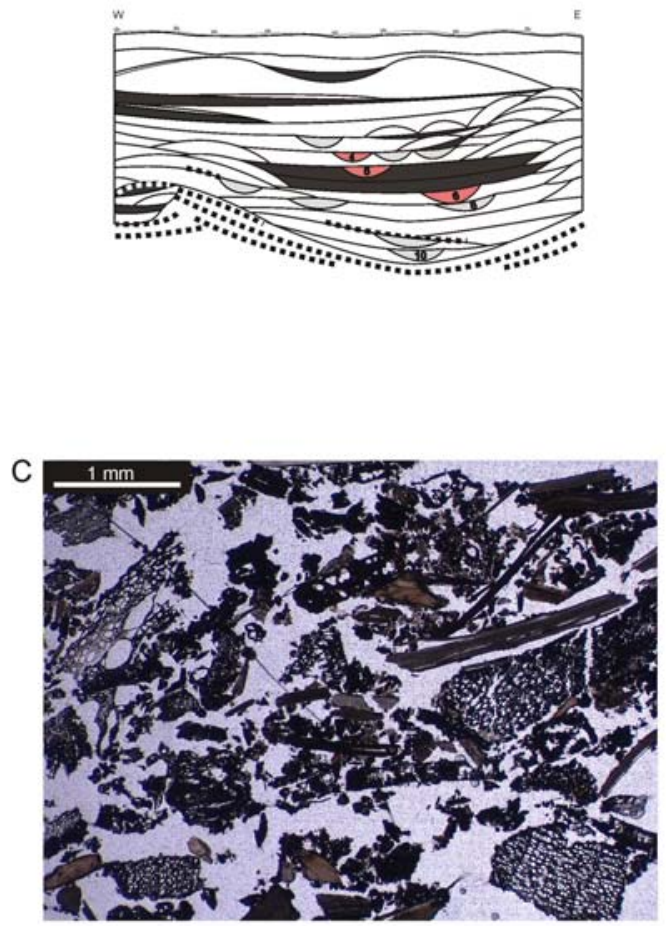

E

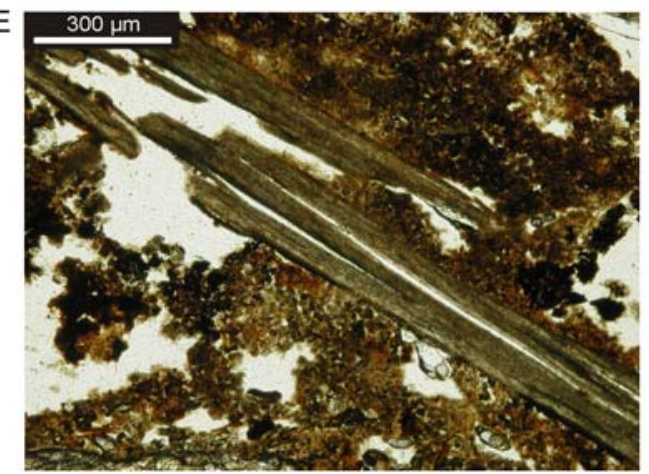

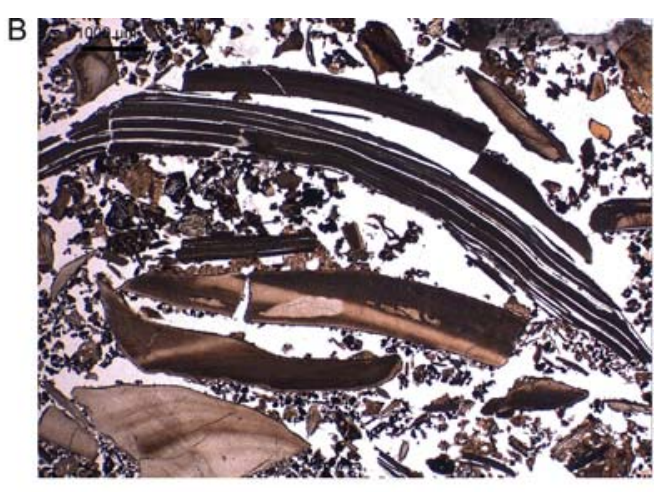
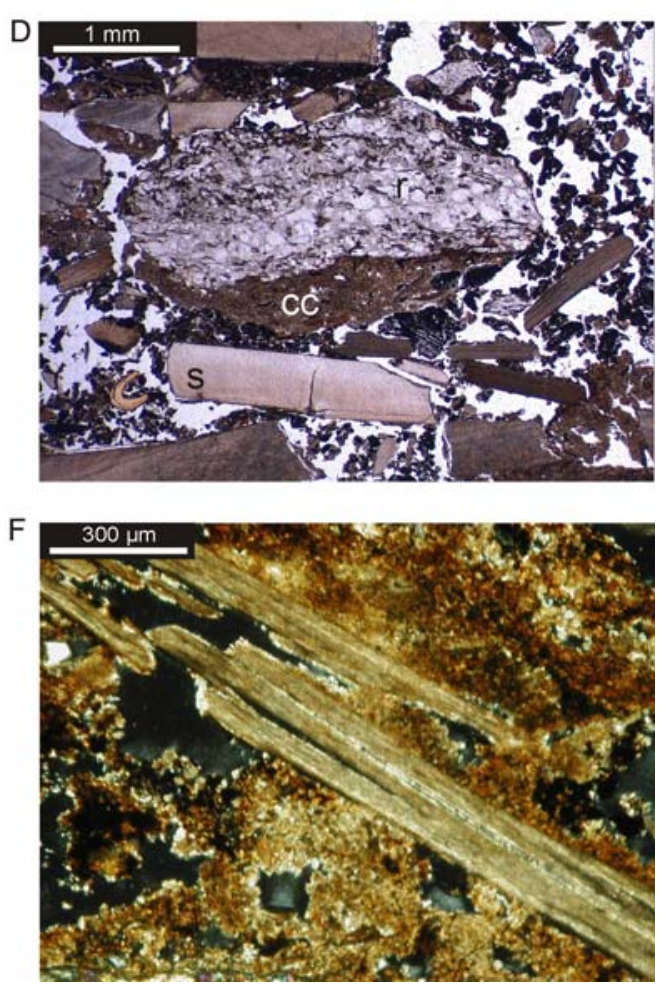

Figura 5.112. Fotomicrografias da $\mathrm{mF} 7$ (AC4, 5 e 6): A) seção vertical esquemática, com localização das fogueiras amostradas para micromorfologia; B) micromassa da AC 4, composta por fragmentos de concha queimados com grânulos soltos de microcarvão, PPL; C) micromassa da AC5 composta por fragmentos de concha queimados e carvão, entre grânulos finos de microcarvão, PPL; D) revestimento pendente de calcita na AC 6, PPL; E, F) parte da micromassa da AC 6 formada por cinzas e argila rubefacta, PPL e XPL. 
A

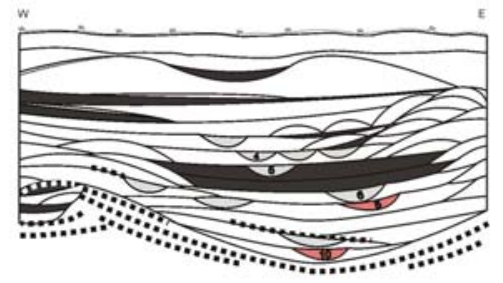

C
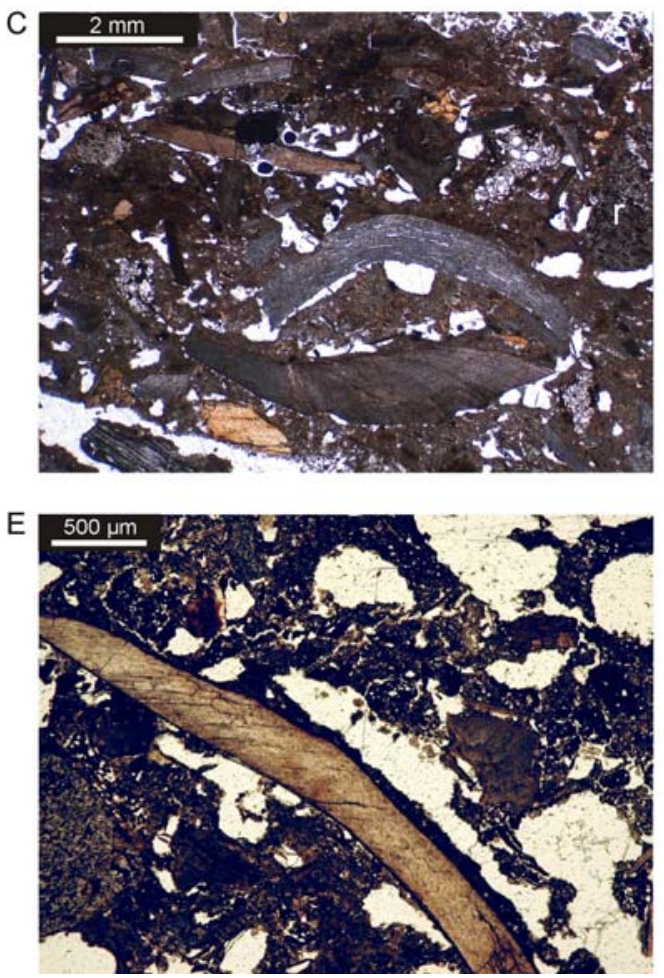
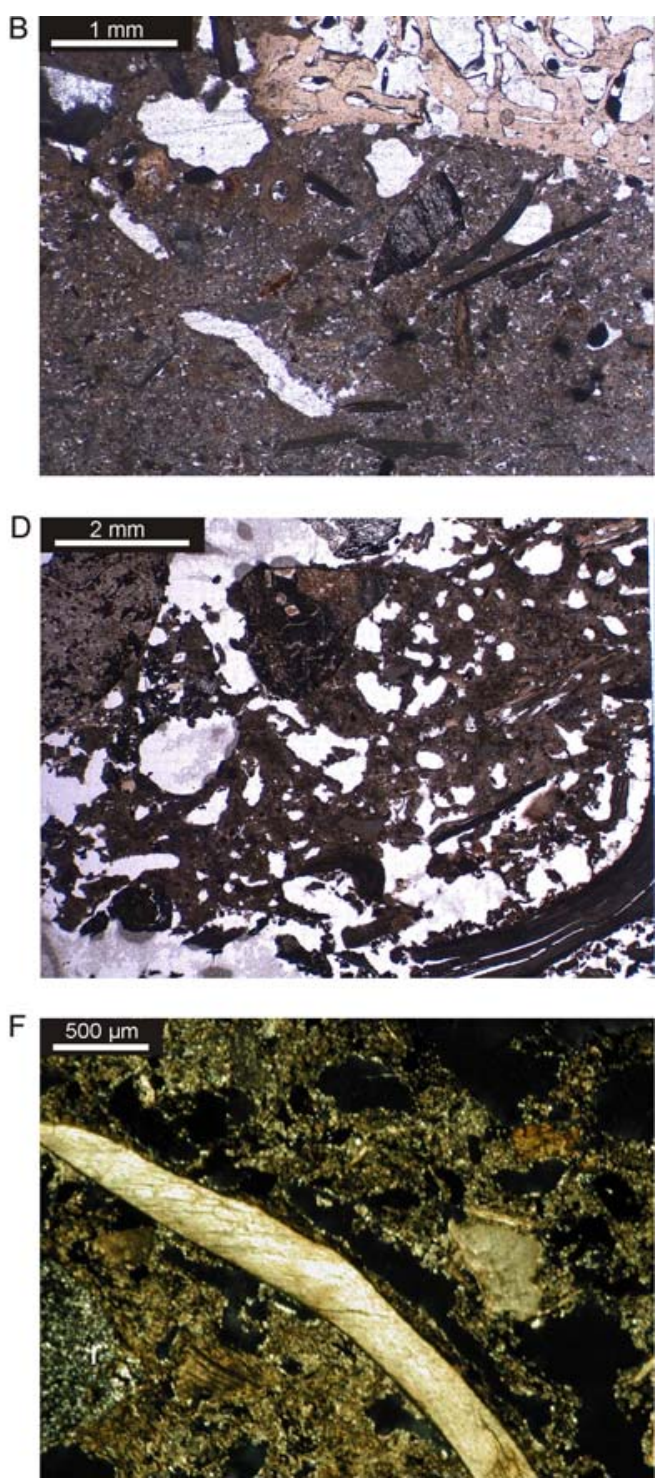

Figura 5.113. Fotomicrografias da mF 8 (AC 8 e 10): A) seção vertical esquemática, com localização das fogueiras amostradas para micromorfologia; B, C) massa basal da AC8, com microestrutura em câmara com conchas e ossos queimados, fragmentos líticos e vazios em canal e em câmara, PPL; D) massa basal da $\mathrm{AC10}$, com microestrutura em câmera e fração grossa composta por conchas queimadas e fragmentos líticos, PPL; E, F) micromassa da AC8, formada por cinzas e argila rubefacta, PPL e XPL. 


\section{CAPÍTULO 6: DISCUSSÃO}

A discussão dos resultados apresentados no Capítulo 5 começará pela composição dos sedimentos arqueológicos, desde a matéria orgânica até os componentes inorgânicos (sedimentos terrígenos) e faunísticos (conchas e ossos de peixe). A seguir, será discutida a alteração pós-deposicional ou tafonomia dos sedimentos arqueológicos, para finalizar com as informações micromorfológicas. Uma vez discutidos os diferentes aspectos da composição e formação dos sedimentos arqueológicos nos três tipos de sambaquis estudados, apresenta-se a avaliação conjunta das evidências composicionais (macro e microscópicas) em relação à estratigrafia, morfologia dos sítios e contexto geológico-geomorfológico de localização.

\section{PADRÃO ESTRATIGRÁFICO CONCHÍFERO}

A partir da descrição macroscópica feita em campo, existem três grupos de arqueofácies diferentes nos sambaquis conchíferos analisados. Dentre as arqueofácies amostradas para análises granulométricas, faunísticas, isotópicas e micromorfológicas, distinguem-se: 1) as de espessura decimétrica, compostas principalmente por sedimentos terrígenos (AF 1 de Caipora e AF 1 de Jabuticabeira 1); 2) as de espessura decimétrica, compostas principalmente por conchas e ossos (AF 3 e 4 de Caipora, AF 2, 3, 4, 7, 8 e 9 de Cubículo 1; AF 3 e 4 de Morrinhos, e AF 2, 3, 5, 6, 7 e 9 de Jabuticabeira 1); e 3) as de espessura centimétrica pretas, compostas por MO e fragmentos de osso queimado (AF 2 de Caipora, AF 2 de Morrinhos, AF 5 de Cubículo 1 e AF 4 de Jabuticabeira 1).

O primeiro grupo inclui as arqueofácies que contêm mais de $50 \%$ de sedimentos terrígenos na fração areia grossa (no restante de arqueofácies a porcentagem de terrígenos não supera 15\%) (Figura 5.13 e 5.51). A semelhança entre ambas as arqueofácies também se evidencia na composição faunística, dominada por conchas inteiras (20-30\%), e na posição basal que estas conchas ocupam na sucessão vertical. Estas evidências sugerem atividades e propósitos possivelmente análogos na formação 
das arqueofácies inaugurais dos sítios, diferentes daqueles que originaram as demais arqueofácies identificadas nas sucessões verticais.

Nos restantes sambaquis conchíferos analisados (Cubículo 1 e Morrinhos), não se alcançou o contato do sítio com o depósito natural subjacente e, portanto, desconhece-se se o padrão observado em Caipora e Jabuticabeira 1 é a eles extensivo. Porém, cabe mencionar que no sítio Jabuticabeira 2, formado por sedimentos terrígenos e conchas inteiras, observou-se o mesmo tipo de depósito inaugural sobre a paleoduna que compõe seu substrato.

O segundo conjunto é o mais numeroso e agrupa a maior parte de arqueofácies descritas nos quatro sambaquis analisados. Estas arqueofácies não só predominam em numero, más também no volume que ocupam nas sucessões verticais analisadas. Variações dentro deste grupo incluem diferenças na forma da arqueofácies, porcentagem de ossos de peixe, espécie de molusco dominante, proporção de conchas fragmentadas vs. conchas inteiras e presença de estruturas internas, como lâminas de carvão, cinzas ou areia.

O terceiro conjunto agrupa as arqueofácies que apresentam semelhança, em coloração, composição e forma, com as denominadas camadas funerárias do sítio Jabuticabeira 2. Aparecem nos quatro sambaquis analisados, sempre intercaladas com arqueofácies do segundo grupo. Assim, a modo de síntese pode-se dizer que:

Três grandes conjuntos de arqueofácies compõem os sítios Caipora, Cubículo 1, Morrinhos e Jabuticabeira 1 (a seguir ordenadas por freqüência de aparição):

1) Arqueofácies com predomínio de conchas.

2) Arqueofácies lenticulares pretas.

3) Arqueofácies com predomínio de sedimentos terrígenos.

Nos tópicos a seguir, apresenta-se a discussão das análises laboratoriais realizadas nas arqueofácies amostradas dos quatro sambaquis conchíferos analisados. 


\subsection{SEDIMENTOS TERRÍGENOS}

Nos sambaquis de padrão estratigráfico conchífero identificou-se um padrão na proveniência das areias terrígenas, com presença de materiais provenientes dos depósitos naturais situados nas proximidades. Alguns sítios (Caipora e Cubículo 1) mostram distribuições bimodais, o que pode estar relacionado à existência de duas fontes sedimentares. Outros sambaquis (Morrinhos e Jabuticabeira 1) apresentam distribuição unimodal e, portanto, possuem maior probabilidade de terem uma única fonte para as areias terrígenas.

No sítio Caipora, a bimodalidade da distribuição granulométrica (grânulos com areia muito grossa; e areia fina) indica duas fontes de sedimentos terrígenos. A moda mais grossa está associada a depósitos coluvionares do afloramento granítico que existe nas proximidades. A outra moda, na classe areia fina, pode estar associada a depósitos paleolagunares próximos ao sambaqui, que têm moda nas frações areia média e muito fina. No sítio Cubículo 1, a moda nas classes areia grossa e areia fina sugerem duas possibilidades: duas fontes de sedimentos diferenciadas, coluvionar, por um lado, e lagunar, por outro; uma única fonte, de sedimentos da fácies de brejo lagunar com aporte de colúvio, como observado na fácies superior da trincheira aberta nas proximidades do sambaqui.

As estatísticas descritivas das distribuições granulométricas do sítio Morrinhos, comparadas com as de amostras naturais de um testemunho localizado a $2 \mathrm{~km}$ do sítio (ver Nascimento 2011), indicam leve afinidade com sedimentos paleolagunares. Em duas das estatísticas, diâmetro médio e assimetria, os sedimentos do sambaqui apresentam sobreposição com os sedimentos paleolagunares, mas não com os deltaicos.

No sítio Jabuticabeira 1, identificou-se maior relação das areias terrígenas com depósitos paleolagunares das proximidades do sítio Jabuticabeira 2 e tendência para sedimentos mais grossos no sambaqui. A maior frequência de grossos no sítio pode ter resultado da digestão incompleta das conchas e ossos no tratamento prévio às análises granulométricas; ou à presença de sedimentos coluvionares, haja vista a presença de granitos aflorando a menos de $5 \mathrm{~m}$ do sítio. Assim: 
Análises granulométricas mostram afinidade com sedimentos coluvionares, relacionados com afloramentos graníticos das proximidades, nos sítios Caipora e Cubículo 1; e principalmente com sedimentos paleolagunares nos sítios Morrinhos e Jabuticabeira 1.

O próximo tópico será reservado à discussão das variações intra e inter-sítio nas distribuições granulométricas dos quatro sambaquis conchíferos estudados.

\subsubsection{Proveniência das areias terrígenas}

As areias terrígenas representam um componente fortuito dos sambaquis e não sedimentos intencionalmente coletados e depositados nos sítios. Isto se interpreta pela aleatoriedade na distribuição dos sedimentos terrígenos que se misturam com os restos faunísticos e carvão, entre outros. Caso se tratasse de depósitos arenosos intencionais e discretos, observar-se-iam camadas espessas de areia na estratigrafia e, pelo momento, não se conhece nenhum sambaqui conchífero que apresente depósitos desse tipo. Camadas de areia restringem-se a lentes centimétricas ocasionais em meio a camadas conchíferas maiores ou associadas às camadas centimétricas pretas ${ }^{86}$.

Ao considerar que as areias terrígenas se incorporaram casualmente aos sedimentos dos sambaquis, pode-se pensar que a sua chegada até os sítios esteja relacionada aos componentes mais abundantes dos sambaquis: moluscos, ossos e carvão. Esta relação pode-se dever a dois fatores que, por sua vez, indicam comportamentos diferenciados: 1) as areias terrígenas refletem o substrato onde habita a espécie de moluscos predominante nos sítios; 2) as areias terrígenas refletem o substrato onde moluscos e demais restos biológicos (ossos e carvão) foram acumulados pelos humanos antes de serem depositados no sambaqui.

A primeira das hipóteses é sugerida pela relação observada entre espécie predominante de moluscos e moda da distribuição granulométrica. Por exemplo, as AF $1,2,3$ e 5 de Jabuticabeira 1 têm moda na fração areia média e são compostas principalmente por Anomalocardia brasiliana (70-95 \%). Já nas AF 7 e 9, observa-se

\footnotetext{
${ }^{86}$ Cabe ressaltar que em vários concheiros naturais da área de estudo, observam-se estratificações planoparalelas ou cruzadas com alternância de lâminas de areia pura, sem bioclastos, e lâminas de conchas com areia (Guerra, 1953; Giannini, 1993; Caruso Jr., 1995; Caruso Jr. et al., 2000).
} 
aumento no teor de areia fina e muito fina e composição à base de A. brasiliana junto com Ostrea sp. (40-60\% de ambas as espécies) e mariscos. Neste caso, pode-se pensar que a mudança na moda das distribuições granulométricas esteja relacionada, em parte, com a malacofauna predominante em cada arqueofácies.

No geral, naquelas arqueofácies onde domina Ostrea sp. junto com marisco (AF 1 do sítio Caipora, AF 4 do sitio Morrinhos e AF 7 e 9 de Jabuticabeira 1), as classes areia fina e areia muito fina igualam ou superam a areia média. Já nas arqueofácies onde Anomalocardia brasiliana predomina (AF 1, 2, 3 e 5 de Jabuticabeira 1), a moda é em areia média. Uma exceção se observa na AF 3 do sítio Morrinhos, com predomínio de A. brasiliana e moda em areia fina.

A associação entre arqueofácies com moda na classe areia media e conchas de $A$. brasiliana, observada no sítio Jabuticabeira 1, pode-se explicar pela localização do banco de moluscos explorado para levantamento do sítio dentro do sistema lagunar. Por exemplo, em trincheiras abertas entre 50 e $100 \mathrm{~m}$ a sul do sambaqui Jabuticabeira 2, identificaram-se fácies de areia com conchas de A. brasiliana, associadas ao sistema lagunar, com moda na fração areia média (Villagran 2008). Depósitos semelhantes podem ter existido nas proximidades de Jabuticabeira 1, situado menos de $2 \mathrm{~km}$ a NW de Jabuticabeira $2^{87}$. Isto explicaria o domínio de grossos registrado na análise granulométrica dos sedimentos de Jabuticabeira 1, suposto anteriormente como resultado da presença de sedimentos coluvionares e/ou como artefato laboratorial.

Já a associação de $A$. brasiliana e sedimentos com moda na fração areia fina observada na AF 3 do sítio Morrinhos é coerente com os dados de Fornari (2010) para concheiros naturais nas margens da laguna de Garopaba do Sul. Nestes depósitos, a autora identificou predomínio de $A$. brasiliana em fácies com moda em areia fina. A associação das arqueofácies com predomínio de Ostrea sp. e as classes areia fina e muito fina é mais difícil de explicar já que Ostrea sp. vive sempre fixada a substrato duro, como costões rochosos ou outras conchas, e não em substrato arenoso. No entanto, estas arqueofácies apresentam conteúdo de mariscos superior ao de $A$. brasiliana, o que pode sugerir que a moda detectada esteja relacionada a este componente faunístico e não às ostras.

\footnotetext{
${ }^{87}$ Neste sentido, cabe mencionar um caso estudado no litoral de São Paulo, onde encontrou-se banco de A. brasiliana em praia localizada dentro de uma enseada protegida, cujos sedimentos apresentam moda na fração areia média (Schaeffer-Novelli, 1976).
} 
A hipótese sobre retrabalhamento do substrato onde os componentes antrópicos eram acumulados antes da deposição no sambaqui é sugerida pela presença recorrente de sedimentos coluvionares, associados com afloramentos graníticos das proximidades, em dois dos quatro sambaquis conchíferos analisados. Estes sedimentos podem representar o substrato do local de habitação, em locais naturalmente elevados, como morros granitoides, onde moluscos e ossos eram acumulados antes da deposição no sambaqui. Pelas evidências disponíveis, não há como afirmar que as duas hipóteses sejam excludentes entre si. Assim, cabe supor que:

A fração terrígena nos sambaquis conchíferos inclui tanto sedimentos do banco de moluscos explorado quanto sedimentos das áreas de ocupação próximas aos sambaquis, nas quais os materiais que compõem os sítios (moluscos, ossos, carvão etc.) eram acumulados pelos sambaquieiros.

\subsubsection{Relação entre arqueofácies}

Não se observaram diferenças destacáveis entre os três grupos de arqueofácies descritos no começo deste tópico, no que se refere aos dados granulométricos da fração terrígena. A única diferença notável é quanto ao teor de terrígenos, no que as arqueofácies pertencentes ao terceiro grupo separam-se das demais pelos valores mais altos. Na comparação entre o segundo e terceiro grupo, não se constatou um padrão inter ou intra-sítio. Dos sítios que tiveram mais de uma arqueofácies analisada (Morrinhos e Jabuticabeira 1), apenas o Morrinhos apresentou distribuição diferenciada entre as arqueofácies conchíferas e lenticulares pretas, o que, segundo o raciocínio apresentado no tópico anterior, pode indicar diferentes locais de coleta para as distintas espécies faunísticas que compõem cada arqueofácies. 


\subsection{ASSEMBLEIA MALACOLÓGICA}

Em termos gerais, os moluscos predominantes nos sambaquis do litoral Sudeste brasileiro, que podem perfazer de 80 até $90 \%$ da assembleia faunística, são somente três: ostras (Ostrea sp. ou Crassostrea sp.); berbigão (Anomalocardia brasiliana); e marisco (Mytella guyanensis ou Brachiodontes sp.). Outras espécies de moluscos aparecem nos sítios, mas em frequência inferior a 10\% (Figuti, 2008).

A espécie de moluscos dominante é usualmente usada como indicador indireto do ambiente, nas adjacências do sambaqui, de onde os moluscos eram coletados. Por exemplo, sambaquis compostos principalmente por $A$. brasiliana são associados ao sistema de lagunas costeiras, já que estes bivalves habitam fundos arenosos e arenolodosos de águas salobras (salinidade de 16-35\%o) ${ }^{88}$, enquanto sítios compostos por Crassostrea sp. associam-se a ecossistemas de mangue. Nesta tese, o componente malacológico principal toma-se unicamente como indicador do ambiente no local de coleta, não definido a priori como próximo ao sítio.

Nos sambaquis analisados, duas espécies são dominantes: Anomalocardia brasiliana e Ostrea sp. Não existem grandes diferenças em termos de frequência de espécies entre as arqueofácies do mesmo sítio (ver Anexo, Tabela A.3 para os sítios Cubículo 1 e Morrinhos e Ferraz, 2010, para Caipora e Jabuticabeira 1). No geral, a espécie dominante distribui-se homogeneamente ao longo das sucessões verticais, com variação máxima de $20 \%$ entre as arqueofácies. Exceções ocorrem no sítio Jabuticabeira 1, entre as arqueofácies identificadas na seção inferior (AF 1 a 5 ), dominadas por A. brasiliana, e na seção superior (AF 7 a 9), com domínio de Ostrea sp. (tópico 1.1.2), e no sítio Morrinhos, onde Ostrea sp. domina na AF 4, superior, enquanto A. brasiliana domina em AF 1 e 3.

No Quadro 6.1, listam-se todas as espécies de moluscos identificadas nos sítios Caipora, Cubículo 1, Morrinhos e Jabuticabeira 1, acompanhadas de breve descrição do substrato e ambiente de vida. No Quadro 6.2, apresenta-se a frequência de distribuição de espécies de moluscos por sítio, com destaque, em negrito, para as espécies que vivem sobre substrato rochoso.

\footnotetext{
${ }^{88}$ A. brasiliana é encontrada desde lagunas e estuários salobros (salinidade de $16 \%$ ), e em manguezais associados, até lagunas salinas (valores de 38 \%o) (Grotta and Lunetta, 1980; Monti et al., 1991; Narchi, 1972, 1976; Schaeffer-Novelli, 1976).
} 
Quadro 6.1. Espécies de moluscos identificadas nos sambaquis Caipora, Cubículo 1, Morrinhos e Jabuticabeira 1, com descrição do substrato e ambiente onde a espécie vive. Dados de vermetídeos e cirripídeos tomados de Laborel and Laborel-Deguen (1996). Demais moluscos tomados de Rios (1985).

\begin{tabular}{|c|c|c|}
\hline Espécie & Substrato & Ambiente \\
\hline $\begin{array}{l}\text { Anomalocardia brasiliana } \\
\text { (Gmelin 1791) }\end{array}$ & Areia ou areia lamosa & $\begin{array}{l}\text { Baías ou estuários e regiões entremarés, até } \\
5 \mathrm{~m} \text { de profundidade. Eurihalina }\end{array}$ \\
\hline Ostrea $\mathrm{sp}$ & $\begin{array}{l}\text { Rocha, conchas mortas ou } \\
\text { bancos de mexilhões }\end{array}$ & De 1 até $100 \mathrm{~m}$ de profundidade. Eurihalina \\
\hline $\begin{array}{l}\text { Heleobia } \text { sp. } \\
\text { (Stimpson } 1865 \text { ) }\end{array}$ & $\begin{array}{l}\text { Lama, areia lamosa ou } \\
\text { algas verdes }\end{array}$ & $\begin{array}{l}\text { Estuários e lagunas até } 5 \mathrm{~cm} \mathrm{de} \\
\text { profundidade }\end{array}$ \\
\hline $\begin{array}{l}\text { Macoma sp. } \\
\text { (Orbigny 1846) }\end{array}$ & Areia lamosa & Região entremarés, em estuários e lagunas \\
\hline $\begin{array}{l}\text { Nassarius vivex } \\
\text { (Say 1822) }\end{array}$ & Lama ou planície arenosa & Água rasa e salobra, em estuários e lagunas. \\
\hline $\begin{array}{l}\text { Ceritium sp. } \\
\text { (Born } 1778 \text { ) }\end{array}$ & Areia, lama ou rocha & $\begin{array}{l}\text { Região entremarés, até } 80 \mathrm{~m} \text { de } \\
\text { profundidade }\end{array}$ \\
\hline $\begin{array}{l}\text { Chione cancelata } \\
\text { (Linnaeus 1767) }\end{array}$ & $\begin{array}{l}\text { Areia, areia lamosa ou areia } \\
\text { entre rochas }\end{array}$ & $\begin{array}{l}\text { Região entremarés até } 140 \mathrm{~m} \text { de } \\
\text { profundidade }\end{array}$ \\
\hline $\begin{array}{l}\text { Bula striata } \\
\text { (Bruguiere 1792) }\end{array}$ & Areia & Região entremarés \\
\hline $\begin{array}{l}\text { Littorina flava } \\
\text { (King \& Broderip 1832) }\end{array}$ & $\begin{array}{l}\text { Rocha ou vegetação de } \\
\text { mangue }\end{array}$ & Região supramaré \\
\hline $\begin{array}{l}\text { Thais haemastoma } \\
\text { (Linnaeus 1767) }\end{array}$ & Rocha & $\begin{array}{l}\text { Região entremarés, próxima a bancos de } \\
\text { ostras. }\end{array}$ \\
\hline $\begin{array}{l}\text { Neritina virginea } \\
\text { (Linnaeus } 1758 \text { ) }\end{array}$ & $\begin{array}{l}\text { Lama, raízes de mangue, } \\
\text { rocha e conchas }\end{array}$ & $\begin{array}{l}\text { Águas salobras, também em praias rochosas } \\
\text { abrigadas }\end{array}$ \\
\hline $\begin{array}{l}\text { Crepidula sp. } \\
\text { (Gmelin 1791) }\end{array}$ & Rocha, corais ou mangue & $\begin{array}{l}12 \text { a } 36 \text { m de profundidade. Ambiente } \\
\text { marinho de baixa energia }\end{array}$ \\
\hline $\begin{array}{l}\text { Lucina pectinata } \\
\text { (Gmelin 1791) }\end{array}$ & Areia lamosa & $\begin{array}{l}\text { Água rasa, de } 15 \text { a } 20 \mathrm{~cm} \text { de profundidade, } \\
\text { em estuários e lagunas. Eurihalina }\end{array}$ \\
\hline $\begin{array}{l}\text { Trachycardium muricatum } \\
\text { (Linnaeus 1758) }\end{array}$ & $\begin{array}{l}\text { Areia, areia lamosa ou areia } \\
\text { entre rochas }\end{array}$ & Baixios de enseadas e baías \\
\hline $\begin{array}{l}\text { Lirophora paphia } \\
\text { (Linnaeus 1767) }\end{array}$ & Areia & De 10 a $100 \mathrm{~m}$ de profundidade \\
\hline $\begin{array}{l}\text { Tellina angulosa } \\
\text { (Linnaeus 1758) }\end{array}$ & Areia ou areia lamosa & $\begin{array}{l}\text { Região entremarés, até } 10 \mathrm{~m} \text { de } \\
\text { profundidade. }\end{array}$ \\
\hline $\begin{array}{l}\text { Cyrtopleura costata } \\
\text { (Linnaeus 1758) }\end{array}$ & $\begin{array}{l}\text { Perfurante em substratos } \\
\text { lodosos e rochas de baixa } \\
\text { resistência }\end{array}$ & $\begin{array}{l}\text { Ambiente marinho, até } 10 \mathrm{~m} \text { de } \\
\text { profundidade }\end{array}$ \\
\hline $\begin{array}{l}\text { Marisco (Mytella sp. e } \\
\text { Brachiondontes sp.) }\end{array}$ & $\begin{array}{l}\text { Fundo lodoso de lagoas e/ou } \\
\text { substratos duros }\end{array}$ & Região entremarés. \\
\hline Vermetídeos & Rocha & $\begin{array}{l}\text { Topo da zona infralitoral, com alta energia } \\
\text { de impacto das ondas. }\end{array}$ \\
\hline Craca (cirripídeos) & Rocha & Região entremarés \\
\hline Olivela sp. & Areia ou areia lamosa & Águas rasas e profundas \\
\hline Dosinia $\mathrm{sp}$ & Areia & Até $60 \mathrm{~m}$ de profundidade \\
\hline $\begin{array}{l}\text { Mesodesma sp. } \\
\text { (Deshayes 1854) }\end{array}$ & Areia & Região entremarés \\
\hline Mactra sp. & Areia & Região inframaré \\
\hline Anadara sp. & Areia, cascalho ou lama & $\begin{array}{l}\text { Região inframaré, de } 5 \text { a } 75 \mathrm{~m} \mathrm{de} \\
\text { profundidade }\end{array}$ \\
\hline Donax sp. & Praias arenosas & $\begin{array}{l}\text { Região entremarés. Ambiente marinho de } \\
\text { alta energia }\end{array}$ \\
\hline
\end{tabular}


Quadro 6.2. Distribuição de espécies de moluscos nos sítios Caipora, Cubículo 1, Morrinhos e Jabuticabeira $1 . \bullet \bullet=$ espécie dominante $(50-70 \%) ; \cdot \bullet=$ espécie freqüente $(10-50 \%) ; \cdot \bullet=$ poucos indivíduos ou fragmentos $(1-10 \%) ; \cdot=$ ocasionais $(<1 \%)$. As espécies identificadas em negrito são aquelas que vivem aderidas a substrato rochoso em mar aberto.

\begin{tabular}{|c|c|c|c|c|}
\hline Espécie & Caipora & Cubículo 1 & Morrinhos & Jabuticabeira 1 \\
\hline Anomalocardia brasiliana & $\ddot{\bullet}$ & $\bullet$ & 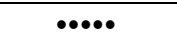 & $\cdots$ \\
\hline Ostrea sp. & ..... & ..... & .• & .. \\
\hline Macoma sp. & • & - & - & • \\
\hline Nassarius vivex & - & - & - & - \\
\hline Ceritium sp. & - & - & & - \\
\hline Chione cancelata & - & .• & - & - \\
\hline Bula striata & & & - & \\
\hline Littorina flava & • & & - & \\
\hline Thais haemastoma & & & - & - \\
\hline Neritina virginea & - & - & - & - \\
\hline Crepídula sp. & - & - & - & - \\
\hline Lucina pectinata & - & - & - & - \\
\hline Trachycardium muricatum & • & - & & - \\
\hline Lirophora paphia & & - & & \\
\hline Tellina angulosa & & - & & \\
\hline Cyrtopleura costata & & & - & - \\
\hline Marisco & •• & - & .• & •• \\
\hline Vermetídeos & - & - & & \\
\hline Craca & - & - & - & - \\
\hline Olivela sp. & - & & & - \\
\hline Pinctada radiata & - & & & \\
\hline Dosinia sp. & - & & & - \\
\hline Mesodesma sp. & - & & & - \\
\hline Mactra sp. & & & & - \\
\hline Anadara sp. & & & & - \\
\hline Donax sp. & & & & - \\
\hline Ossos & - & - & - & - \\
\hline Malha de $2 \mathrm{~mm}$ & ... & .• & ..• & ..• \\
\hline
\end{tabular}

A partir das informações agrupadas nos Quadros 6.1 e 6.2, inferem-se quatro questões maiores sobre a assembleia malacológica dos sambaquis analisados: 1) existe coleta seletiva de espécies em cada sítio, com preferência por Anomalocardia brasiliana ou Ostrea sp., exceto no sítio Jabuticabeira 1 onde metade do sítio (seção inferior) é composta por A. brasiliana e outra metade (seção superior), por Ostrea sp. e marisco; 2) a frequência comparativamente baixa $(<1 \%)$ de espécies, que, mesmo adultas, possuem carapaça com tamanho menor que 1,5 cm (Nassarius vivex, Littorina flava, Neritina virginea, entre outras) sugere que estes indivíduos teriam sido incorporados acidentalmente no ato da coleta, por se acharem no banco de moluscos onde a espécie dominante foi extraída; 3 ) na maior parte dos sítios, observa-se mistura de espécies que habitam substrato arenoso e areno-lodoso em águas salobras, junto com espécies que vivem aderidas a rochas em águas marinhas, o que indica mais de uma proveniência para a fauna encontrada nos sedimentos do sambaqui; 4) alguns sítios (Caipora, 
Cubículo 1 e seção superior de Jabuticabeira 1) apresentam maior frequência que os outros de espécies exclusivas de costões rochosos de mar aberto (Ostrea sp., vermetídeos), interpretada como escolha preferencial por estes locais de coleta, associada ou não à proximidade dos costões rochosos aos sambaquis.

\subsubsection{Relação entre espécies predominantes}

A preferência por A. brasiliana como para levantamento de sambaquis do litoral sul de Santa Catarina já fora constatada em trabalhos zooarqueológicos anteriores (Klokler 2001, 2008; Ferraz 2010). Em alguns casos, como os sambaquis Caipora e Cubículo 1, a preferência é dada por Ostrea sp., enquanto em outros dois, Jabuticabeira 1 e Morrinhos, passa-se do uso preferencial de A. brasiliana, nas camadas basais do sambaqui, para o de Ostrea sp., no topo.

Esta mudança, registrada ao longo da seção vertical de dois grandes sambaquis conchíferos da região, de cronologia entre 5000 e 2000 anos AP, opõe-se à tradicional associação entre sambaquis antigos e composição predominante de ostra. Tal associação foi proposta originalmente por Krone (1914) para o litoral de São Paulo e depois adotada por vários autores (Bigarella, 1949; Fairbridge, 1976; Hurt, 1974; Piazza, 1982; Prous, 1992; Rohr, 1969). Para esses autores, esta suposta associação estaria vinculada à evolução geológica da costa durante o Holoceno, e sobretudo às mudanças do NRM. Segundo esta visão, os sistemas costeiros, antes da máxima transgressão holocênica, teriam sido mais abertos, com maior oceanidade das águas, o que favoreceria o desenvolvimento de Ostrea sp. e Crassostrea sp. (ostra do mangue) sobre A. brasiliana. As mudanças resultantes da descida do NRM após o máximo transgressivo holocênico, com formação de lagunas costeiras, teriam favorecido o desenvolvimento de grandes bancos de $A$. brasiliana que passariam a ser intensamente explorados pelas populações pré-históricas.

Nos sambaquis antigos, como Caipora, tanto o contexto geológicogeomorfológico de localização do sítio quanto o NRM no momento em que ele era construído explicariam o domínio de Ostrea sp. Há cerca de 7500 anos atrás, os morros granitoides circundantes teriam estado em contato direto com as águas da antiga paleobaía que caracterizava a região, provavelmente antes mesmo do máximo transgressivo holocênico. A presença de águas marinhas teria favorecido $o$ 
desenvolvimento de Ostrea sp. no costões, o sistema lagunar não estava ainda configuradao e, portanto, eram rados ou asutens os fundos favoráveis para desenvolvimento de A.brasiliana.

A presença de vermetídeos nos sambaquis Caipora e Cubículo 1, frequentemente aderidos às carapaças de Ostrea sp., corrobora a exploração de costões de mar aberto já que, apesar de Ostrea sp. admitir variações na salinidade das águas (Rios, 1985), os vermetídeos habitam unicamente costões de águas francamente marinhas. Outras espécies de gastrópodos bentônicos de costa rochosa, como Litorina flava, Crepídula sp., Thais haemastoma e algumas de marisco (Brachiodontes sp.) reforçam a interpretação da exploração de costões.

A inversão observada nos sítios Morrinhos e Jabuticabeira 1, também registrada em sambaquis conchíferos do litoral norte de Santa Catarina (sítio Espinheiros 2, por exemplo) (Figuti and Klokler, 1996; Figuti, 2008), indica que a opção por um ou outro tipo de molusco (Ostrea sp. ou A. brasiliana) responde, também, a escolhas culturais ${ }^{89}$. Isto significa que a presença de Ostrea $\mathrm{sp}$. nos sambaquis vai além da correlação com fatores ambientais, que restringiram ou favoreceram a disponibilidade de certas espécies de moluscos nas proximidades dos sítios ao longo do tempo, mas envolve também a exploração intencional de espécies de costões rochosos, inclusive afastados do local.

A exploração conjunta de espécies de costões rochosos com a macrofauna estuarino-lagunar é clara quando se observam sambaquis com camadas compostos por A. brasiliana junto com Ostrea sp. e marisco, ou alternância de camadas com predomínio de uma ou outra espécie. Tal é o caso, por exemplo, dos sítios Jabuticabeira 2 (Klokler 2008) e Ponta do Morro Azul (Kneip 2004) e, especificamente, da AF 7 do Jabuticabeira 1. Isto porque Ostrea sp. e A. brasiliana não convivem frequentemente no mesmo ambiente, embora existam algumas exceções. A. brasiliana vive exclusivamente enterrada (até $10 \mathrm{~cm}$ de profundidade) em fundos areno-lodosos a arenosos, em águas salobras $^{90}$, rasas, com pouco material em suspensão (Narchi, 1972; Schaeffer-Novelli,

\footnotetext{
${ }^{89}$ Segundo Figuti (2012, comunicação pessoal) a associação dos sítios mais antigos com Ostrea sp. podese dever à diferença na taxa de reprodução desta espécie em relação a Anomalocardia brasiliana. As ostras reproduzem-se mais lentamente e, para não causar a exaustão do recurso, deve ser coletada em intervalos de tempo suficientes para permitir que os moluscos cheguem à idade reprodutiva. Já $A$. brasiliana tem taxa de reprodução alta e admite exploração contínua. Esta constatação teria provocado, segundo Figuti, o troca da coleta de Ostrea sp. por A. brasiliana. Uma hipótese semelhante foi proposta por Hurt (1974) para explicar a presença de Crassostrea sp. unicamente nos níveis inferiores dos sambaquis.

${ }^{90}$ A. brasiliana é encontrada desde lagunas e estuários salobros (salinidade de $16 \%$ ), e em manguezais associados, até lagunas salinas (valores de 38 \%o) (Grotta and Lunetta, 1980; Monti et al., 1991; Narchi, 1972, 1976; Schaeffer-Novelli, 1976). Ocorre na forma de manchas com grande densidade de indivíduos
} 
1976), enquanto Ostrea sp. habita aderida a substrato duro em mar de alta energia (Rios, 1985).

O domínio de $A$. brasiliana nos sambaquis da área de estudo está ligado à proliferação desta espécie no sistema lagunar, cujo fechamento caracterizou a região desde o Holoceno Médio. Tal proliferação teria conduzido à exploração mais intensa. Porém, apesar do incremento no uso de A. brasiliana, não ter-se-ia abandonado a exploração de recursos de costões rochosos. Os costões, apesar de estarem localizados progressivamente a maior distância dos sítios, agora construídos nas margens paleolagunares, ainda proviam de ostras, espécies exploradas desde o começo da ocupação humana na região, . Isto pode ser constatado no sítio Cubículo 1, cuja idade corresponde com o momento posterior ao fechamento do sistema lagunar e está, no entanto, composto predominantemente de Ostrea sp.

Existe sempre predomínio de uma espécie de molusco em cada arqueofácies amostrada, que pode ser A. brasiliana, coletada em depósitos paleolagunares, ou Ostrea sp., coletada em costões rochosos. O domínio de uma ou outra espécie relaciona-se com o contexto geológico-geomorfológico de localização do sítio, com fatores ambientais, relacionados com a descida do NRM durante o Holoceno, e com escolhas culturais.

\subsubsection{Disponibilidade de espécies: comparação com concheiros naturais}

A espécie A. brasiliana é predominante tanto nos sambaquis do litoral sul de Santa Catarina como na maioria dos concheiros naturais que existem na região. Estes depósitos de acumulação massiva de conchas encontram-se em fácies arenosas e lamosas associadas ao sistema lagunar. Podem conter grande concentração de indivíduos inteiros como fragmentados e estão datados entre 8000 e 1600 anos AP (Caruso Jr., 1995; Fornari, 2010; Nascimento, 2010).

(Schaeffer-Novelli, 1976) e, apesar de se reproduzir continuamente ao longo do ano, estudos realizados no litoral de São Paulo observaram dois picos reprodutivos maiores ao ano, um no outono (fevereiro a abril) e outro na primavera (agosto a novembro) (Grotta and Lunetta, 1982; Narchi, 1976). 
Segundo Caruso Jr. (1995) e Caruso Jr. et al. (2000), os grandes concheiros que caracterizam a região de Tubarão, Garopaba do Sul e Jaguaruna são constituídos de conchas retrabalhadas, originalmente depositadas em fácies lamosas do sistema lagunar ou fácies arenosas marinhas. Eventos de alta energia teriam provocado o retrabalhamento e acumulação das conchas, como mostrado pela mistura de espécies de habitats distintos (estuarinas, lagunares e marinhas) e de conchas inteiras com fragmentadas e pela presença de estruturas sedimentares sugestivas da ação de ondas ou correntes.

$\mathrm{Na}$ região de Jabuticabeira, encontra-se um dos concheiros naturais mais extensos da área de estudo, onde predomina A. brasiliana. Este depósito envolve diferentes jazidas, e aparece mesmo ancorado na elevação granítica da região de Mato Alto (Figura 6.1). Na sua porção central, no bairro de Jabuticabeira, ele apresenta 1300 $\mathrm{m}$ de cumprimento em direção NW-SE, largura de 150 até $1000 \mathrm{~m}$ e espessura de $0,5 \mathrm{a}$ 4,5 m. Neste local, obteve-se uma datação de $3720 \pm 60$ anos AP (Caruso Jr., 1995; Caruso Jr. et al., 2000). Na porção próxima à Laguna Delfino, Martin et al. (1986) dataram o depósito em $3830 \pm 180$ anos AP. Em toda sua extensão, o concheiro encontra-se coberto por camada de areia lamosa, rica me detritos vegetais e, em algumas porções, apresenta laminação plano-paralela e gradação inversa. Em coleta realizada por Klokler (2008) numa porção deste concheiro localizado nas proximidades do sambaqui Encantada 3, constatou-se proporção de $86 \%$ de A. brasiliana na composição, com frequências menores que 10\% de outras espécies (Macoma sp., Lucina sp., ostras, gastrópodes etc.).

Outro extenso concheiro natural aparece na região do Camacho, a leste da Laguna de Garopaba do Sul, sob a barreira arenosa. Este depósito tem $3000 \mathrm{~m}$ de cumprimento, em direção NE-SW, 900 a $1650 \mathrm{~m}$ de largura e 0,2 até 2,0 m de espessura (Figura 6.1). Na região de Campos Verdes, outro grande concheiro natural foi localizado por Hurt (1974) nas proximidades, e inclusive subjacente, ao grande sambaqui Carniça 1. O depósito foi datado em $3350 \pm 150$ anos AP a uma profundidade de $1,5 \mathrm{~m}$.

Segundo Caruso Jr. (1995), as idades dos moluscos nos concheiros naturais não representam fielmente a idade de deposição, por terem-se formado pelo retrabalhamento, em eventos de tempestade, de depósitos de concha preexistentes. $\mathrm{O}$ autor vincula estes eventos com a existência de um sistema mais aberto suscetível às flutuações do NRM do mar no Holoceno. No entanto, análises sedimentológicas e 
tafonômicas realizadas por Fornari (2010) oferecem evidencias sobre a formação dos concheiros como resultado de eventos de alta energia dentro do sistema lagunar, especificamente nas margens lagunares, o que permitiria associar a assembleia de moluscos no concheiro com aquela que habitava a antiga paleolaguna. A autora encontrou fácies com bivalves fechados e articulados, indivíduos em posição de vida, sinais de pouco transporte etc., o que sugere que parte das conchas pode ser usada para indicar a idade do depósito em que se encontram ${ }^{91}$.

Fornari (2010) localizou concheiros naturais em trincheiras e testemunhos próximos às margens da laguna Garopaba do Sul (Figura 6.1). Este depósitos apresentam idades de 5560-5320 até 2645-2165 anos cal AP e profundidade de 0,3 até 2,6 $\mathrm{m}^{92}$. O molusco predominante, em todos os casos, é sempre A. brasiliana, seguido de Crassostrea sp., com frequência inferior a $10 \%$ de outros bivalves e gastrópodes ${ }^{93}$. Na região do Rio do Meio, mesmos autores identificam concheiros com idades de 22501850 até 2680-2300 anos cal AP e profundidades de 0,3 até 2,4 m. Nestes depósitos, também detectam o domínio de A. brasiliana. Em termos gerais, a maior mistura entre espécies lagunares/estuarinas e espécies marinhas foi achada naqueles concheiros localizados próximos às paleodesembocaduras da laguna Garopaba do Sul. Na margem oeste da mesma laguna, os concheiros estão compostos majoritariamente por espécies lagunares, apesar de existirem alguns indivíduos de espécies marinhas.

Nas fácies lagunares associadas ao delta do Rio Tubarão, Nascimento (2011) também encontra concheiros naturais em sondagens e testemunhos, a profundidades de 0,1 até 1,8 m e com idades que vão de 8013-7800 até 1918-1645 anos cal AP (Figura 6.1). Nestes concheiros, a espécie melhor distribuída é Divaricella quadrisulcata, especialmente a profundidades maiores, com aumento na proporção de $A$. brasiliana ate

\footnotetext{
${ }^{91}$ Neste sentido, cabe mencionar as observações realizadas por Hurt (1974) no concheiro natural da região de Campos Verdes. Dos trabalhos anteriores ao ano 2000, o autor é o único em oferecer informações sobre a tafonomia das conchas no depósito ao mencionar que, no concheiro natural, as conchas estão inteiras, algumas articuladas e "limpas", em contraste com as conchas "sujas" do sambaquis e as conchas fragmentadas dos depósitos de praia.

${ }^{92}$ Em sondagens até $13 \mathrm{~m}$ de profundidade, Fornari (2010) também identifica concheiros com idade de 8185-7990 anos cal AP.

${ }^{93}$ A identificação de Crassostrea sp. nos testemunhos abertos nas proximidades da margem oeste da Laguna de Garopaba do Sul (Fornari, 2010), é coerente com o achado de carvão de espécies de mangue realizado por Scheel-Ybert et al. (2009) no sambaqui Encantada 3, localizado na mesma área amostrada por Fornari (2010). Ambas as evidências tornam mais robusta a inferência da presença de mangue na região há cerca de 5000 anos atrás. A convivência de Crassostrea sp. com A. brasiliana já foi constatada em uma laguna salobra do Caribe, onde ambas espécies habitam em ecossistema de mangue (Monti et al., 1991).
} 
o topo dos testemunhos. Divaricella quadrisulcata habitaria águas francamente marinhas (Rios, 1985) e, em vista disso, sua presença é interpretada pelo autor como indicação da existência de sistema deposicional mais aberto antes da chegada dos sedimentos deltaicos.

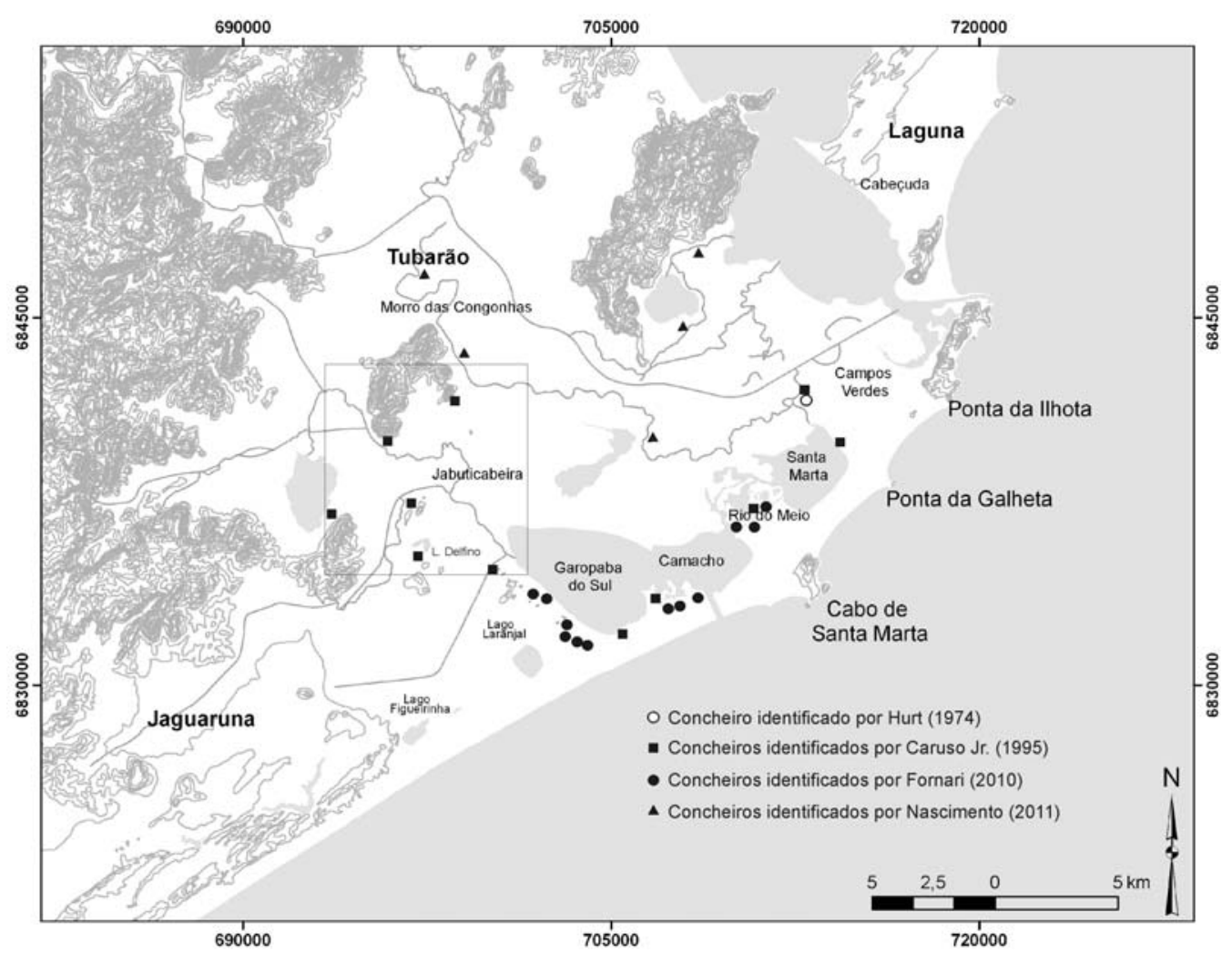

Figura 6.1. Mapa da área de estudo, com localização dos concheiros naturais identificados por Hurt (1974), Caruso Jr. (1995), Fornari (2010) e Nascimento (2011).

Pela cronologia dos depósitos naturais e assembleia malacológica que apresentam, cabe pensar que alguns deles teriam sido contemporâneos ao momento em que os sambaquis conchíferos eram ativos. Nesse momento, os bancos de moluscos que deram origem aos concheiros naturais estariam em superfície e os seus componentes malacológicos estariam disponíveis para exploração. Isto não significa que conchas mortas foram usadas no levantamento dos sambaquis, possibilidade já refutada em trabalhos anteriores (Giannini et al. 2010). De acordo com o processo de formação dos concheiros, o que hoje em dia se vê como depósitos massivos de conchas mortas, relacionados aos eventos de mais alta energia dentro do respectivo sistema deposicional, pode agrupar indivíduos contemporâneos que viviam dentro do sistema lagunar. Assim, alguns dos concheiros, especialmente aqueles que contêm acumulações de conchas 
inteiras, refletem o retrabalhamento de moluscos que, na época de formação dos sítios, estavam vivos e se achavam disponíveis para coleta pelas populações pré-históricas. No entanto, existem também na região concheiros cuja assembleia malacológica foi retrabalhada sucessivas vezes e são, portanto, oriundas de eventos muito mais antigos e de sistemas abertos, onde as tempestades podem ter transporte maior. Neste segundo caso, não haveria disponibilidade, seja física ou cronológica, para exploração humana pré-histórica.

Cabe mencionar uma importante diferença tafonômica entre os concheiros naturais e os sambaquis. As conchas no concheiro natural estão melhor preservadas, enquanto nos sambaquis apresentam sinais de queima, dissolução, manchas amareladas e películas de coloração escura ao redor (Klokler et al. 2011). Por exemplo, no sítio Morrinhos, observaram-se fragmentos e carapaças inteiras de A. brasiliana queimados, misturados com carapaças inteiras deste molusco, bem preservadas. No sítio Cubículo 1, foram também achados fragmentos de vermetídeos com sinais de queima. Esta diferença pode-se relacionar com o processamento antrópico ao qual foram expostas antes da deposição no sambaquis, e com o intemperismo e/ou pedodiagênese mais intensa que sofrem as conchas carbonáticas em depósitos subaéreos e altamente porosos.

Pela cronologia, composição faunística, tafonomia e posição estratigráfica, pode-se supor que parte dos concheiros naturais da área de estudo, mas não necessariamente todos, são produto do retrabalhamento restrito ao sistema lagunar, e podem ser usados como reflexo da assembleia de moluscos disponível para as populações costeiras nos bancos que eram ativos durante a formação dos sambaquis.

\subsubsection{Coleta seletiva}

A mistura, em uma mesma arqueofácies, entre espécies que habitam diferentes substratos, mostra a heterogeneidade da assembleia malacológica dos sambaquis. Este atributo já havia sido constatado por Klokler $(2001,2008)$ no sambaqui Jabuticabeira 2, para o qual a autora interpreta mistura de proveniências, usos e processamentos nas conchas utilizadas, em última instância, para elevação do sítio. 
Em todas as arqueofácies estudadas observa-se presença de espécies que habitam fundos areno-lodosos, em águas calmas, com espécies que vivem em costões rochosos sob mais alta energia hidrodinâmica. Há mistura de espécies estuarinas/lagunares e espécies. Esta variedade sugere que cada arqueofácies no sambaqui represente o produto da coleta de moluscos oriundos de diferentes fontes ou contextos de ocorrência, desde margens lagunares até costões rochosos. Assim, os sedimentos dos sambaquis não resultam do transporte direto de um único local.

Se se soma a isso o fato de que, apesar da diversidade de espécies, sempre há predomínio de A. brasiliana ou Ostrea sp., isto pode indicar que o comportamento de coleta dos grupos litorâneos envolvia exploração de diversos contextos onde há proliferação de moluscos, mas sempre direcionados à captura de uma espécie. A exploração sequencial e/ou simultânea de diversos contextos, fundos lagunares e costões rochosos, pode estar relacionada com uma medida de prevenção da superexploração dos depósitos, como proposto por Mannino and Thomas (2002) para concheiros do Mesolítico no litoral sul da Grã Bretanha.

Nos concheiros naturais, a assembleia também apresenta heterogeneidade de proveniências, mas a mistura no sambaqui parece não refletir diretamente a mistura própria do depósito natural. Neste sentido, cabe mencionar a comparação, realizada por Klokler (2008), entre a assembleia malacológica do sambaqui Jabuticabeira 2 e o concheiro natural localizado nas proximidades do sambaqui Encantada 3. Em ambos os depósitos predomina A. brasiliana ( $86 \%$ no sambaqui vs. $89 \%$ no concheiro natural) junto com outras espécies de moluscos. No entanto, no sambaqui existem altas concentrações de mariscos, espécie de bivalve que não é achada nos concheiros naturais da região (Caruso Jr., 1995; Fornari, 2010; Hurt, 1974; Nascimento, 2010) (ver tópico 1.2.2).Da mesma maneira, nos sambaquis existe mistura de conchas com ossos inteiros e fragmentados de peixe, situação que tampouco existe nos concheiros naturais.

Outro elemento que corrobora a coleta seletiva realizada nos sambaquis é a baixa frequência de aparição de indivíduos juvenis. Por exemplo, as populações de $A$. brasiliana nos depósitos naturais são multimodais, já que o ciclo reprodutivo desta espécie é quase continuo (apesar de existirem pulsos maiores no outono e na primavera), com mistura de indivíduos maiores e fluxos irregulares de juvenis (Narchi 1972, 1976). Isto significa que, nos depósitos naturais onde este molusco se desenvolve, existe mistura de indivíduos adultos e juvenis. De tivesse ocorrido coleta não seletiva e transporte direto a partir do banco de moluscos, existiriam indivíduos juvenis nos 
sambaquis. No entanto, na análise arqueofaunística observaram-se frequências mínimas de $A$. brasiliana juvenis, menores que $1 \%$ nas AF 2 e 3 do sítio Morrinhos, e total ausência de juvenis nas AF 2, 3, 4, 7 e 8 do sítio Cubículo 1.

Apesar de existir coleta seletiva de espécies em cada sítio, com preferência por Anomalocardia brasiliana ou Ostrea sp., há mistura de espécies que habitam substrato arenoso e areno-lodoso em águas salobras, junto com espécies que vivem aderidas a rochas em ambiente marinho, o que indica mistura de proveniências na assembleia faunística dos sambaqui. Esta mistura também indica que não há redeposição direta do material faunístico coletado nos bancos de moluscos, mas mistura com espécies de ambientes diversos e com outros componentes não pertencentes aos depósitos naturais.

\subsection{COMPONENTES ORGÂNICOS}

Apesar dos restos malacológicos serem o elemento de maior destaque nas sucessões estratigráficas de sambaquis conchíferos, existem nos sítios também restos orgânicos, identificados pela sua grnulação fina e/ou coloração preta, que podem incluir desde resíduos vegetais até microfragmentos de carvão. Nos sítios maiores, com conteúdo malacológico proeminente, como Jabuticabeira 1 ou Morrinhos, o aporte de resíduos orgânicos é, a simples vista, pouco conspícuo. No entanto, conhecer o tipo de resíduo orgânico que acompanha o conteúdo faunístico é diagnóstico na interpretação das atividades associadas à deposição de cada arqueofácies e à formação do sambaqui.

\subsubsection{Componentes vegetais}

A determinação da composição orgânica dos sambaquis foi realizada a partir de análises isotópicas de $\mathrm{C}$ e $\mathrm{N}\left(\delta^{13} \mathrm{C}\right.$ e $\left.\delta^{15} \mathrm{~N}\right)$ e razão $\mathrm{C} / \mathrm{N}$. Os valores de $\delta^{13} \mathrm{C}$ nos quatro sambaquis conchíferos analisados varia entre $-26,93 \%$ e $-22,74 \%$. O valor mínimo corresponde à AF 5 do sambaqui Cubículo 1, enquanto o valor máximo corresponde à AF 3 do sambaqui Jabuticabeira 1. Como aparece na Figura 6.2 A, C, em todos os casos os valores de $\delta^{13} \mathrm{C}$ e razão $\mathrm{C} / \mathrm{N}$ encontram-se dentro do intervalo definido para plantas 
terrestres de ciclo fotossintético $C_{3}\left(\delta^{13} \mathrm{C}\right.$ entre $-21 \%$ a $-34 \%$ e razão $\mathrm{C} / \mathrm{N}$ superior a 12$)$ (Boutton, 1996; Lamb et al., 2006 b; Meyers, 1997; De Niro and Epstein, 1978; De Niro and Hastrof, 1985; Sifeddine et al., 2004). Um único caso situa-se próximo ao campo correspondente às algas (AF 1 de Jabuticabeira 1$)$, mas o valor de $\delta^{15} \mathrm{~N}(+14,99)$ permite refutar a associação com plantas aquáticas e confirmar a presença de plantas terrestres $\mathrm{C}_{3}$.

As plantas de ciclo fotossintético $\mathrm{C}_{3}$ formam quase $90 \%$ das espécies vegetais do planeta e incluem, majoritariamente, espécies arbóreas e arbustivas, espécies cultivadas e algumas Poaceae. As plantas de ciclo fotossintético $\mathrm{C}_{4}$ incluem as Poceaea de climas tropicais, subtropicais e temperados, em áreas com precipitação intensa durante o verão, assim como algumas espécies cultivadas, tais como o milho (Cabido et al., 1997; Collatz et al., 1998; Ehleringer et al., 1997; Rundel, 1980; White, 2001). Nos sambaquis, o predomínio de plantas $\mathrm{C}_{3}$ estaria, em parte, relacionado com a presença de espécies arbóreas e arbustivas, como demonstrado pela alta frequência de carvões e microcarvões que se identifica em campo e em seção delgada. Estas madeiras teriam sido coletadas, para uso como combustível, das matas de restinga existentes nas proximidades dos sítios, assim como de espécies da floresta pluvial de encosta Atlântica, como já mostrado pelas análises antracológicas realizadas por Bianchini (2008), no sítio Jabuticabeira 2, e por Scheel-Ybert (2000, 2001), em outros sambaquis do litoral brasileiro. Não se pode excluir a possibilidade dos valores de $\delta^{13} \mathrm{C}$ e razão $\mathrm{C} / \mathrm{N}$ indicarem, igualmente, a presença de Poaceae $\mathrm{C}_{3}$, além das espécies arbustivas. Apesar de serem tradicionalmente associadas a climas frios e altitude elevada (Cabido et al., 1997; Cavagnaro, 1988; Ehleringer et al., 1997; Rundel, 1980; Tieszen, 1991), as Poaceae $\mathrm{C}_{3}$ podem existir em áreas pantanosas e inundáveis do sistema lagunar e deltaico associadas a gramíneas $\mathrm{C}_{4}$ ou a espécies arbustivas $\mathrm{C}_{3}{ }^{94}$. Neste caso, estas espécies poderiam ter sido utilizadas na confecção de artefatos (cestaria) e/ou mobiliário (trançados de fibras vegetais, tapetes).

\footnotetext{
${ }^{94}$ De fato, em áreas litorâneas da Guiana Francesa existem espécies de Poaceae $\mathrm{C}_{3}$ em associação com Poaceae $\mathrm{C}_{4}$, que se desenvolvem em áreas inundáveis associadas a manguezais, como pântanos e brejos (Iriarte et al., 2010).
} 
Há presença de MO associada a espécies de ciclo fotossintético $\mathrm{C}_{3}$ em todas as arqueofácies analisadas. Isto pode estar relacionado à presença de carvões e microcarvões derivados da combustão de espécies arbóreas e arbustivas da mata de restinga ou da floresta pluvial de encosta Atlântica. Outra explicação possível refere à presença de Poacea $\mathrm{C}_{3}$ relacionada com a presença de restos de artefatos confeccionados em fibra vegetal (cestaria) e/ou mobiliário elaborado com a mesma técnica (tapetes). 
A

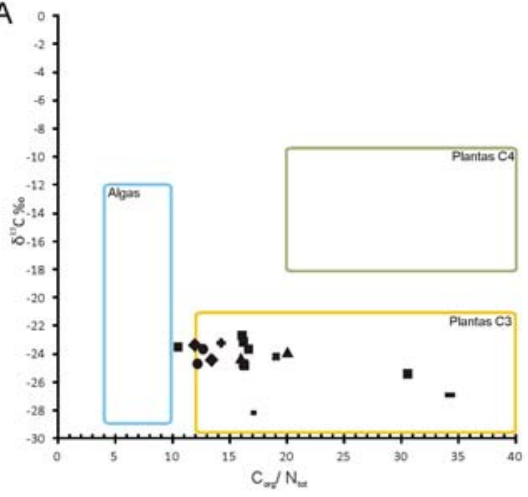

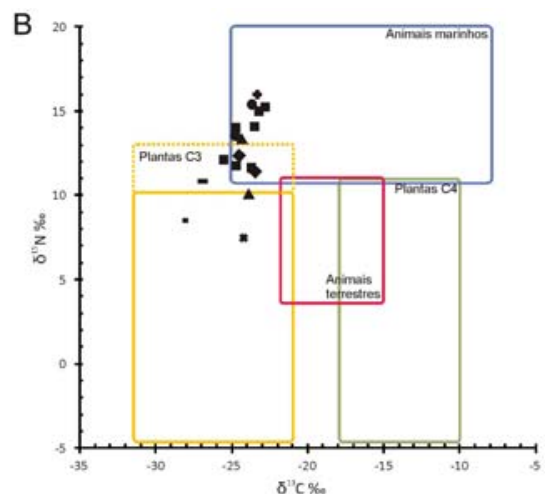

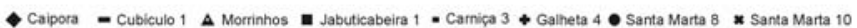
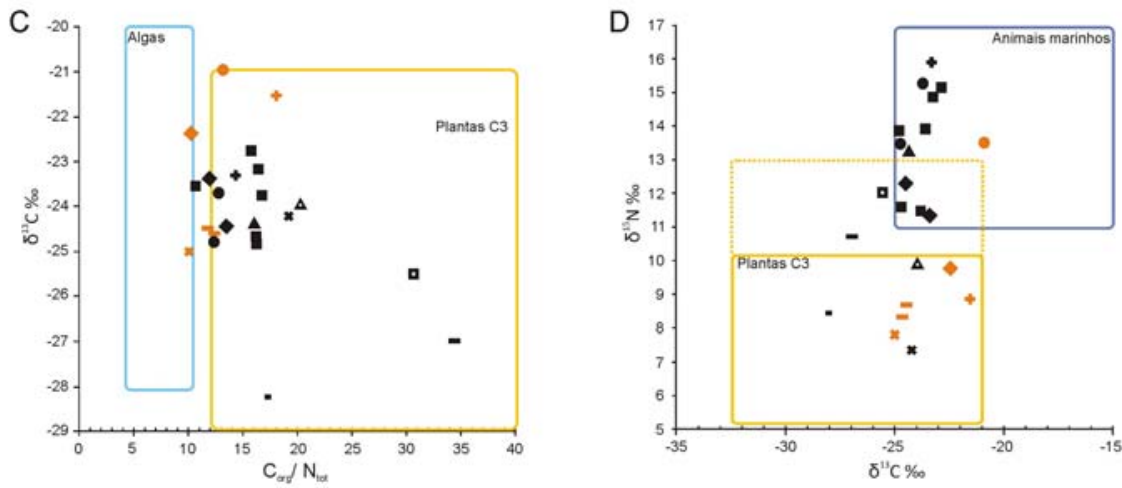

Caipora
- Fácies A

Gaineta $4 \bullet$ Santa Marta $8 \times$ Santa Marta
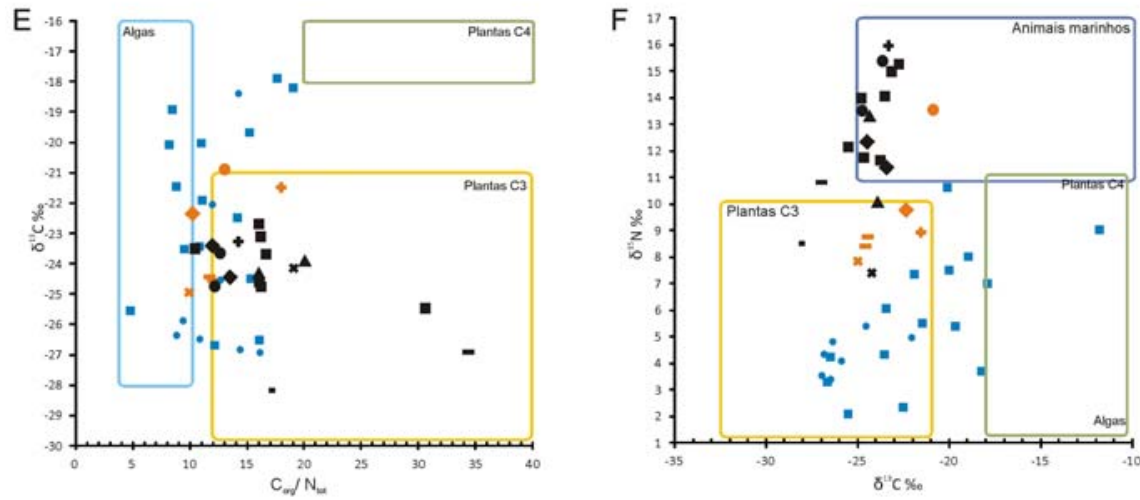

- Caipora - Cubiculo 1

Fies A Fàcies Ae B

- Focies lagunares o Facies detaicos

+ Galheta $4 \bullet$ Santa Marta 8 * Santa Marta 10

Figura 6.2. Análises isotópicas $\left(\delta^{13} \mathrm{C}\right.$ e $\delta^{15} \mathrm{~N}$ e razão $\left.\mathrm{C} / \mathrm{N}\right)$ de amostras provenientes dos oito sambaquis analisados nesta tese e de trincheiras de amostragem externas a cinco deles: Caipora, Cubículo 1, Galheta 4, Santa Marta 8 e Santa Marta 10: A) gráfico de valores de $\delta^{13} \mathrm{C}$ e razão $\mathrm{C} / \mathrm{N}$ para amostras coletadas em sambaquis conchíferos, com intervalos definidos para plantas de ciclo fotossintético $\mathrm{C}_{3}, \mathrm{C}_{4}$ e algas; $\mathrm{B}$ ) gráfico dos valores de $\delta^{15} \mathrm{~N}$ e $\delta^{13} \mathrm{C}$ para amostras coletadas em sambaquis conchíferos, com intervalos definidos para plantas de ciclo fotossintético $\mathrm{C}_{3}, \mathrm{C}_{4}$, animais marinhos e animais terrestres; C) gráfico de valores de $\delta^{13} \mathrm{C}$ e razão $\mathrm{C} / \mathrm{N}$ para todas as amostras analisadas nesta tese, com intervalos definidos para plantas de ciclo fotossintético $\mathrm{C}_{3}$ e algas; D) gráfico dos valores de $\delta^{15} \mathrm{~N}$ e $\delta^{13} \mathrm{C}$ para todas as amostras analisadas nesta tese, com intervalos definidos para plantas de ciclo fotossintético $\mathrm{C}_{3}$ e animais marinhos; E) gráfico de valores de $\delta^{13} \mathrm{C}$ e razão $\mathrm{C} / \mathrm{N}$ com intervalos definidos para plantas de ciclo fotossintético $\mathrm{C}_{3}$, $\mathrm{C}_{4}$ e algas para amostras provenientes dos oito sambaquis analisados nesta tese e amostras de testemunhos coletados por Amaral (2008), Amaral et al. (2012) e Nascimento (2011) em fácies lagunares e deltaicas da região de estudo; F) gráfico dos valores de $\delta^{15} \mathrm{~N}$ e $\delta^{13} \mathrm{C}$ com intervalos definidos para plantas de ciclo fotossintético $\mathrm{C}_{3}, \mathrm{C}_{4}$ e animais marinhos. 


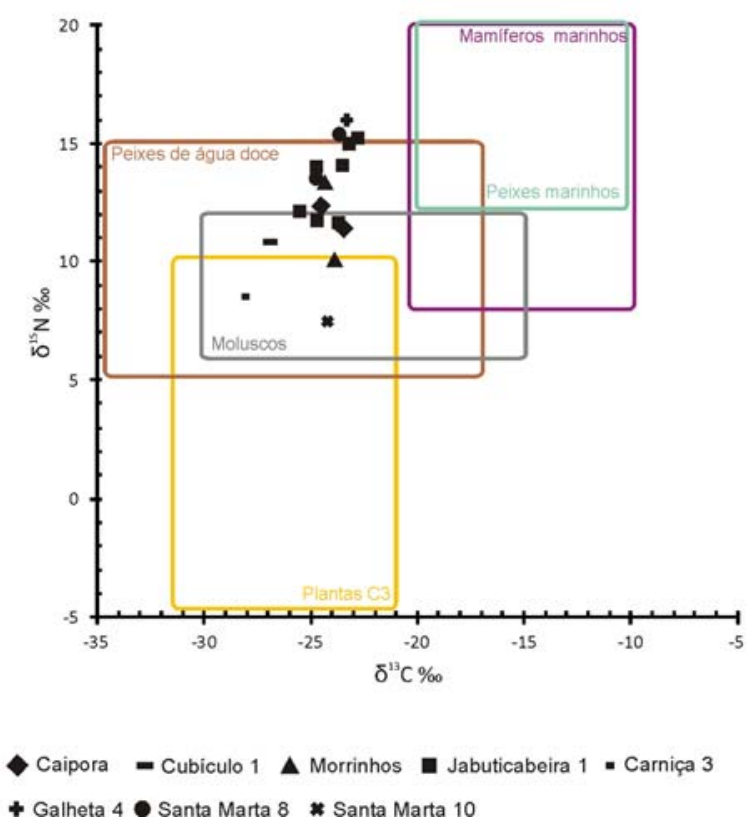

Figura 6.3. Gráfico dos valores de $\delta^{13} \mathrm{C}$ e $\delta^{15} \mathrm{~N}$ de amostras provenientes dos quatro sambaquis conchíferos analisados, com intervalos de referência para plantas de ciclo fotossintético $\mathrm{C}_{3}$, moluscos, peixes de água doce, peixes marinhos e mamíferos marinhos.

\subsubsection{Resíduos de origem animal}

Nos sambaquis conchíferos, assim como nos montículos ictiológicos que serão discutidos no tópico 3.1, destacam-se os altos valores de $\delta^{15} \mathrm{~N}$, que variam entre $+10,05 \%$ e e $+15,23 \%$. O valor mínimo corresponde à $\mathrm{AF} 2$ do sambaqui Morrinhos e o valor máximo à AF 3 do sítio Jabuticabeira 1. Valores elevados de $\delta^{15} \mathrm{~N}$ podem se relacionar a dois fatores fundamentais: enriquecimento pós-deposicional, que em tecidos vegetais pode ser de até 20\%, segundo De Niro \& Hastrof (1985); ou presença de resíduos de organismos de nível trófico maior que as plantas, ou seja, resíduos de origem animal (De Niro, 1987).

A primeira opção parece a menos plausível, neste caso. Isto porque o enriquecimento de até 20\% referido por De Niro \& Hastrof (1985) foi detectado em tecidos vegetais preservados e não na MO total do solo ou sedimento. Outros estudos mostram que as alterações diagenéticas na composição isotópica da $\mathrm{MO}$ de solos e sedimentos não seria intensa o suficiente para impedir a diferenciação da sua origem (Meyers and Lallier-Vergés, 1999; Wilson et al., 2005). Ao mesmo tempo, a detecção de MO derivada de espécies arbustivas nos sedimentos de sambaquis, relacionada com a presença de carvão na fração orgânica fina, também refuta o enriquecimento diagenético 
de nitratos. Os resíduos vegetais carbonizados têm maior potencial para preservação da assinatura isotópica da planta prévia à queima e, portanto, são bons indicadores de origem da MO (Hall et al., 2008; De Niro and Hastrof, 1985).

Isto significa que os altos valores de $\delta^{15} \mathrm{~N}$ não estariam relacionados à contaminação dos resíduos vegetais pelo tempo de deposição, mas à mistura de MO de origem vegetal com um componente rico em nitratos: os resíduos de origem animal. Esta hipótese já foi proposta por Menezes (2009) a partir do estudo isotópico das camadas centimétricas pretas que aparecem intercaladas às camadas conchíferas no sambaqui Jabuticabeira 2, onde a autora detecta mistura entre MO de origem vegetal e animal.

Segundo Fogg et al. (1998), os valores de $\delta^{15} \mathrm{~N}$ são úteis na diferenciação entre resíduos de origem animal e MO do solo. $\mathrm{O} \delta^{15} \mathrm{~N}$ na $\mathrm{MO}$ varia de $-5 \%$ a $+10 \%$ (até +13\% em alguns casos) (Kendall, 1998; White, 2001), enquanto em solos enriquecidos com nitratos de origem animal, o $\delta^{15} \mathrm{~N}$ varia de $+8 \%$ a $+20 \%$. Isto porque os tecidos animais estão enriquecidos em $\delta^{15} \mathrm{~N}$ em relação a sua dieta, devido ao processo de fracionamento isotópico (Schoeller, 1999; Schoeninger and De Niro, 1984). Somado a isso, os subprodutos dos resíduos animais podem estar inclusive mais enriquecidos em $\delta^{15} \mathrm{~N}$ que o próprio tecido e, em alguns casos, resíduos animais com $\delta^{15} \mathrm{~N}$ de $+5 \%$ o podem ser converter em nitrato com $\delta^{15} \mathrm{~N}$ entre +10 e $+20 \%$ (Kendall, 1998).

Os animais marinhos, que representam a base alimentícia das populações costeiras e cujos restos acumularam-se nos sambaquis, apresentam valores de fracionamento e enriquecimento de ${ }^{15} \mathrm{~N}$ maiores em comparação com os animais terrestres (ver Commisso and Nelson, 2006; Schoeninger and De Niro, 1984). A cadeia alimentar da fauna marinha tem até sete níveis tróficos, o que resulta em enriquecimento no $\delta^{15} \mathrm{~N}$ de até $+7 \%$ entre produtores primários e predadores; diferente da fauna terrestre que, por ter no máximo três níveis tróficos, tem enriquecimento de apenas $+3 \%{ }^{95}$ (Schoeninger and De Niro, 1984; White, 2001). A influência do nitrogênio de origem marinha em solos e sedimentos é tal que, na vegetação terrestre que cresce associada a corpos de água, sobre substrato onde houve deposição de fezes e urina de peixes, a assinatura isotópica apresenta valores de $\delta^{15} \mathrm{~N}$ até $10 \%$ mais altos que a

\footnotetext{
95 Animais marinhos apresentam, em média, um enriquecimento médio de $\delta^{15} \mathrm{~N}$ de $+9 \%$ em relação aos animais terrestres. $\mathrm{O} \delta^{15} \mathrm{~N}$ de animais marinhos (aves, peixes e mamíferos) varia de $+9.4 \mathrm{a}+23 \%$, enquanto os valores para animais terrestres (aves e mamíferos) não ultrapassam $+10 \%$, ficando, em média, em torno de $+5.9 \pm 2.2 \%$ (Schoeninger and De Niro, 1984).
} 
vegetação que cresce fora da influência da fauna marinha, assim como valores de $\delta^{13} \mathrm{C}$ mais negativos que o esperado (Ben-David et al., 1998; Wainright et al., 1998) ${ }^{96}$.

Valores de $\delta^{15} \mathrm{~N}$ superiores a $+10 \%$ também foram identificados como indicadores da presença de adubo animal (animal manure) e excrementos em solos naturais (Bol et al., 2005; Choi et al., 2002; Kendall, 1998) e arqueológicos (Bogaard et al., 2007; Commisso and Nelson, 2006; Shahack-Gross and Finkelstein, 2008; ShahackGross et al., 2008). Shahack-Gross \& Finkelstein (2008) associam valores de $\delta^{15} \mathrm{~N}$ superiores $+9 \%$ na $\mathrm{MO}$ de sedimentos arqueológicos com a deposição de excrementos de animais herbívoros (associação respaldada pela comparação com amostras de excrementos modernos). Os autores utilizam os isótopos de $\mathrm{C}$ e $\mathrm{N}$, entre outras evidências, na detecção de sítios associados à ocupação de grupos pastoris.

No entanto, a presença de excrementos de herbívoros, como os estudados por Shahack-Gross \& Finkelstein (2008), é descartada para os sedimentos dos sambaquis por dois motivos: em primeiro lugar, em seção delgada não se encontraram esferulitas de calcita, indicadores micromorfológicos de excrementos de animais herbívoros (Brochier, 1992; Canti, 1998, 1997; Shahack-Gross et al., 2008) que, pela sua composição calcítica, teriam sido bem preservados em sedimentos ricos em carbonato de cálcio (Canti, 1999; Shahack-Gross, 2011); tampouco se encontraram concentrações de fitólitos de gramíneas, componente mineral conspícuo nos excrementos destes animais (Albert et al., 2008; Shahack-Gross, 2011); em segundo lugar, e mais importante, existe total ausência de evidências arqueológicas de fauna herbívora associada aos grupos construtores de sambaquis.

A presença de excrementos de animais omnívoros, que inclui os humanos, não pode ser totalmente descartada com base exclusivamente em dados isotópicos, já que excrementos de onívoros também apresentam valores altos de $\delta^{15} \mathrm{~N}$, no entorno de $+10 \mathrm{a}$ +22\%o (Choi et al., 2002; Heaton, 1986). Porém, em seção delgada, não se observaram indícios da existência de excrementos humanos ou de outro animal omnívoro (ou herbívoro) nos sedimentos dos sambaquis. Para detecção certeira de excrementos em sedimentos arqueológicos, utilizam-se biomarcadores específicos, como o coprostanol, indicador da existência de fezes em solos e sedimentos (Van Bergen et al., 1999; Birk et al., 2011; Bull et al., 2002; Shillito et al., 2011).

\footnotetext{
${ }^{96}$ Em contexto arqueológico, Commisso \& Nelson (2006) identificam incrementos nos valores de $\delta^{15} \mathrm{~N}$ (superiores a $+10 \%$ ) na vegetação que cresce sobre middens formados pela acumulação de restos ósseos de animais marinhos.
} 
Nos gráficos da Figura 6.2 B, D e da Figura 6.3, apresenta-se o diagrama de dispersão de $\delta^{15} \mathrm{~N}$ e $\delta^{13} \mathrm{C}$ dos sambaquis conchíferos analisados junto com os campos definidos na bibliografia para plantas terrestres de ciclo fotossintético $\mathrm{C}_{3}$, animais terrestres e animais marinhos (mamíferos, peixes e moluscos). Para construção dos quadros de referência, foram unicamente utilizados dados disponíveis na literatura correspondentes a MO vegetal, tecidos e resíduos animais, e não os dados obtidos a partir da análise isotópica do colágeno dos ossos. A distribuição dos pontos, com altos valores de $\delta^{15} \mathrm{~N}$ e valores negativos de $\delta^{13} \mathrm{C}$, evidencia um padrão, na composição destes sedimentos, indicativo de mistura de resíduos de plantas $\mathrm{C}_{3}$ com resíduos animais marinhos; isto é coerente com a natureza heterogênea dos sedimentos de sambaquis, como estabelecido em trabalhos anteriores (Villagran et al., 2009 b).

De fato, os quatro sambaquis conchíferos apresentam valores de $\delta^{15} \mathrm{~N}$ e $\delta^{13} \mathrm{C}$ semelhantes aos relatados em depósitos secundários de acumulação de resíduos (middens ou trash pits) estudados por Shahack-Gross et al. (2008), onde os altos valores de $\delta^{15} \mathrm{~N}$ (entre +10 e $+12 \%$ ) se correspondem com valores mínimos de $\delta^{13} \mathrm{C}$ (entre -22 e -20\%). Estes depósitos contêm uma grande quantidade de carvões, cinzas de madeira e fragmentos de osso misturados (Shahack-Gross, 2004), assim como os sambaquis analisados.

A assinatura de animais marinhos nos sedimentos de sambaquis é condizente com a composição faunística dos sítios, dominada por conchas de moluscos e ossos de peixe. Porém, os dados isotópicos também assinalam que os resíduos derivam principalmente da decomposição de restos de peixes, mas não de moluscos. Os moluscos apresentam valores negativos de $\delta^{13} \mathrm{C}(-15$ a $-30 \%)$ em contraposição a valores baixos de $\delta^{15} \mathrm{~N}$, entre +6 e $+12 \%$, por se tratar de consumidores primários (Compton et al., 2008; France, 1994; Gustafson et al., 2007; De Masi, 1999; Richards and Hedges, 1999; Wen et al., 2010; Yesner et al., 2003). Peixes marinhos apresentam valores de $\delta^{13} \mathrm{C}$ de -11 a $-20 \%$ e $\delta^{15} \mathrm{~N}$ de +11 a $+19 \%$, enquanto peixes de água doce têm, comparativamente, $\delta^{13} \mathrm{C}$ mais negativo (de -35 a $-18 \%$ ) e $\delta^{15} \mathrm{~N}$ menor $(\mathrm{de}+5 \mathrm{a}$ +15\%) (Barrett et al., 2011; Dufour et al., 1999; Gomez Otero, 2006; De Masi, 1999; Richards and Hedges, 1999; Schoeninger and De Niro, 1984; Walker and DeNiro, 1986; Yesner et al., 2003).

A posição intermediária da nuvem de pontos da amostragem em sambaquis, situada entre os intervalos definidos para peixes de água doce e de água salgada (Figura 6.3), pode indicar a presença de resíduos de peixes que se alimentaram em ambos os 
ambientes aquáticos, como sugerem Schoeninger \& De Niro (1984). Tal mistura de águas é típica de estuários e lagunas costeiras, de onde teriam sido coletados os peixes consumidos pelas populações litorâneas, como indicam as análises zooarqueológicas (Klokler, 2001, 2008; Nishida, 2007).

Além de MO de origem vegetal, há nos sedimentos dos sambaquis analisados resíduos derivados da decomposição de tecido animal, vinculado com a presença de restos de peixe e moluscos nos sítios.

\subsubsection{Relação com sedimentos naturais}

Para investigar a relação entre a $\mathrm{MO}$ dos sambaquis com o contexto de localização dos sítios, realizaram-se análises isotópicas das fácies argila siltosa e argila arenosa das trincheiras abertas nas proximidades dos sítios Caipora e Cubiculo 1, respectivamente. Os gráficos de dispersão da Figura $6.2 \mathrm{C}$ e D mostram a distribuição das amostras coletadas em sambaquis e sedimentos naturais. Especialmente no gráfico da Figura 6.2 D, pode-se observar o agrupamento das amostras naturais no intervalo definido para MO vegetal, especificamente para plantas de ciclo fotossintético $\mathrm{C}_{3}$; diferente das amostras arqueológicas que, como discutido no tópico anterior, apresentam enriquecimento de nitratos de origem marinha.

Para fortalecer o conjunto de amostras extra-sítio e observar mais claramente a diferença composicional entre sedimentos arqueológicos e naturais, foram lançados nos gráficos de dispersão de $\delta^{13} \mathrm{C}$, razão $\mathrm{C} / \mathrm{N}$ e $\delta^{15} \mathrm{~N}$, dados disponíveis na bibliografia sobre composição isotópica de sedimentos naturais da região de estudo, tomados dos trabalhos de Amaral (2008), Amaral et al. (2012) e Nascimento (2010). Dos testemunhos coletados e sondagens realizadas pelos autores, foram selecionadas para comparação unicamente aquelas amostras de idade igual ou inferior ao intervalo de ocupação sambaquieira na região. No Anexo, Tabela A.5, apresentam-se as coordenadas UTM dos testemunhos realizados pelos autores mencionados, utilizados para comparação. No Anexo, Tabela A.6, agrupam-se os resultados da análise isotópica em depósitos naturais $\left(\delta^{13} \mathrm{C}, \delta^{15} \mathrm{~N}\right.$ e razão $\left.\mathrm{C} / \mathrm{N}\right)$ com descrição das características texturais da fácies analisada e sistema deposicional associado. 
No gráfico da Figura 6.2 E, observa-se a maior diversidade de componentes vegetais, tanto terrestres como aquáticos, que caracteriza os sedimentos naturais, diferente dos sambaquis que se agrupam no campo correspondente a plantas terrestres $\mathrm{C}_{3}$. Já no gráfico da Figura 6.2 F, nota-se clara diferenciação entre amostras naturais e arqueológicas, com gradiente de distribuição dos pontos desde as amostras lagunares e deltaicas, passando pelas amostras naturais nas proximidades dos sambaquis até as amostras arqueológicas. As amostras naturais agrupam-se nos campos definidos para plantas terrestres e aquáticas, enquanto as amostras arqueológicas deslocam-se até o campo definido para plantas $\mathrm{C}_{3}$ e resíduos de animais marinhos.

A MO associada aos locais de ocupação humana caracteriza-se pelo enriquecimento, em relação à MO dos depósitos naturais de mesma idade, em nitratos de origem marinha, o que se deve à mistura de resíduos animais (e.g., peixes e moluscos) e vegetais.

\subsubsection{Relação entre arqueofácies}

Embora os limites para cada componente-fonte de $\mathrm{MO}$ (plantas $\mathrm{C}_{3}$ e animais marinhos) não sejam rígidos, as doze amostras analisadas dos sambaquis conchíferos podem ser agrupadas, de maneira geral, em três conjuntos de acordo com a sua posição no gráfico da Figura 6.1 D: 1) sedimentos com MO vegetal (uma amostra); 2) mistura de resíduos vegetais e animais com predomínio de componentes vegetais (seis amostras); 3) mistura de resíduos vegetais e animais com predomínio de restos da decomposição de tecidos de animais marinhos (cinco amostras).

A amostra pertencente ao primeiro conjunto corresponde à AF 2 do sítio Morrinhos. As amostras do segundo conjunto correspondem a AF 5 do Cubículo 1, AF 1 do Caipora e AF 4, 5 e 6 de Jabuticabeira 1. Com base na observação macroscópica em campo, estas arqueofácies apresentam coloração preta a castanha escura, que indica predomínio de componentes orgânicos, junto a conchas e ossos. O terceiro conjunto de amostras (AF 1, 2, 3 e 7 de Jabuticabeira 1 e AF 4 do sítio Morrinhos) posiciona-se fora do quadro correspondente a plantas terrestres $C_{3}$, no intervalo definido pela variação isotópica de animais marinhos, principalmente peixes e moluscos. 
Estes três grupos se relacionam, por sua vez, com dois dos três grupos de arqueofácies que caracterizam os sambaquis de padrão estratigráfico conchífero. As arqueofácies predominantemente conchíferas mostram, na maioria dos casos, predomínio de resíduos animais sobre os vegetais. Isto sugere que conchas e ossos teriam chegado ao depósito ainda com resíduos da carne. As arqueofácies lenticulares pretas (AF 2 do sítio Morrinhos, AF 5 do Cubículo 1 e AF 4 de Jabuticabeira 1) mostram predomínio e/ou exclusividade de restos vegetais associados a queima e decomposição de espécies $\mathrm{C}_{3}$.

O predomínio de espécies vegetais nas arqueofácies lenticulares pretas pode ser explicado pelo fato de os componentes animais, representados por fragmentos ósseos, estarem maiormente queimados, ou seja, despojados da carne. Cabe mencionar que no sambaqui Jabuticabeira 2, as arqueofácies pretas também estão compostas majoritariamente por ossos queimados ( $70 \%$ de ossos queimados em oposição a $5 \%$ nas arqueofácies conchíferas) (Klokler, 2008; Nishida, 2007; Villagran et al., 2010, 2011 b) e apresentam maior diversidade de espécies lenhosas que as arqueofácies conchíferas (Bianchini, 2008). No entanto, outra explicação possível refere à maior concentração de restos vegetais nas arqueofácies pretas. Como discutido no tópico 1.3.1., o predomínio de resíduos vegetais pode-se relacionar à maior deposição de restos de plantas usadas como combustível (madeiras) e/ou com a presença de plantas com uso mobiliário e/ou artefatual nesta arqueofácies.

O potencial uso mobiliário de plantas foi observado nos perfis estratigráficos dos sítios Espinheiros 2 (Afonso and DeBlasis, 1994) e Cubatão 1 (Petrykowski et al., 2007), localizados na região de Joinville, onde camadas de extensão métrica compostas por de fibras trançadas afloram. Nestes sítios, os restos vegetais preservaram nas porções inferiores dos perfis graças às condições redutoras oferecidas pelo alagamento constante e/ou intermitente do substrato. Nas porções superiores dos perfís, permanentemente em condição subaérea, o material vegetal não preservou. Isto permite interpretar que as arqueofácies centimétricas pretas possam ser o resultado da degradação de superfícies cobertas por trançados de fibras vegetais, sobre as quais se realizaram atividades diferenciadas das arqueofácies conchíferas; como evidencia a maior concentração de ossos queimados e carvão nas arqueofácies pretas em relação ás arqueofácies conchíferas. 
As arqueofácies predominantemente conchíferas mostram, no geral, predomínio de resíduos de origem animal sobre os de MO vegetal. As arqueofácies lenticulares pretas mostram predomínio, e até exclusividade, de resíduos de origem vegetal de espécies $\mathrm{C}_{3}$. Isto pode ser explicado pela maior deposição de restos de combustível (material lenhoso) nas arqueofácies pretas, ou pela existência dos subprodutos da degradação de antigas superfícies cobertas por trançados de fibras vegetais, como se observa em outros sambaquis da região, sobre os quais ter-se-iam realizado atividades diferenciadas das arqueofácies conchíferas, como indica a maior concentração de ossos queimados e carvões.

\subsection{MICRO-COMPONENTES}

Análises micromorfológicas foram realizadas em 15 seções delgadas dos quatro sambaquis de padrão estratigráfico conchífero. Nesta análise, identificaram-se microcomponentes recorrentes nos quatro sítios, assim como componentes específicos para cada sítio ou subgrupo de sítios. Os componentes gerais, que aparecem em todos os sambaquis, servem para entender padrões espaço-temporais na construção dos sítios. Os componentes específicos, que se encontram unicamente em alguns dos sambaquis analisados, servem para identificar diferenças entre eles. Estas diferenças não são necessariamente funcionais, mas também podem refletir mudanças nos processos de formação, relacionadas com fatores como cronologia dos sítios, localização na paisagem e alteração tafonômica, entre outros.

Dentre os componentes comuns a todos os sambaquis, identificam-se dois grupos:

1. Componentes minerais: grãos de quartzo, com distribuição aleatória.

2. Componentes orgânicos: conchas inteiras e fragmentadas de diversas espécies de moluscos e gastrópodes; fragmentos de osso de peixe de tamanho diverso; e carvão. Conchas e ossos apresentam sinais de dissolução e frequências variáveis (de 5 a 30 \%) de espécimes com evidência de queima a temperatura superior a $600^{\circ} \mathrm{C}$. Ambos possuem 
distribuição aleatória e unicamente as conchas podem também apresentar, em algumas microfácies, distribuição horizontal e/ou sub-horizontal.

Outros componentes minerais e orgânicos aparecem unicamente em alguns dos sítios analisados, como fragmentos líticos, grãos de feldspato, minerais pesados, pelotas de argila glauconítica, diatomáceas, raízes frescas, entre outros. Dentre o grupo de componentes específicos, existe um subconjunto de materiais biológicos e minerais alterados antrAs duas coisas?opicamente mediante queima, que inclui escória vítrea e agregados de argila queimada. Estes materiais são referidos como produtos de alteração antrópica e servem para inferir comportamentos relacionados com o uso do fogo. Nos tópicos a seguir, discutem-se os componentes minerais, biológicos, produto da alteração antrópica e fração fina dos quatro sambaquis conchíferos analisados.

\subsubsection{Componentes minerais}

Grãos de quartzo e feldspato, principalmente, e fragmentos líticos, em menor abundância, são os componentes minerais mais frequentes nos quatro sítios analisados. Como discutido no tópico 1.1.1, estes materiais incorporam-se aos sedimentos dos sambaquis por transporte antrópico e podem ter duas proveniências: areias terrígenas associadas ao substrato onde habita o molusco predominante, no caso dos grãos de quartzo e feldspato; e/ou sedimentos coluvionares das proximidades do sítio, e onde os materiais teriam sido acumulados previamente à deposição no sambaqui, no caso de frações grossas (grãos de quartzo, feldspato e fragmentos líticos). A influência de uma e outra fonte de sedimentos varia nos diferentes sítios, com maior frequência de sedimentos coluvionares em Caipora, Cubículo 1 e Morrinhos, e areias quartzosas em Jabuticabeira 1.

A observação microscópica dos componentes minerais corrobora as informações aventadas pela análise granulométrica e observação na lupa e permite aprofundar questões levantadas pelas análises quantitativas, mas que não podem ser respondidas por esse tipo de análise. De fato, existe maior aporte de sedimentos coluvionares em Caipora que, além de estar dominado pelas frações grossas, apresenta teor de feldspatos e fragmentos líticos que iguala, ou até ultrapassa, a frequência de grãos de quartzo. Em Cubículo 1, aumenta a diferença entre a porcentagem de grãos de quartzo, por um lado, e grãos de feldspato e fragmentos líticos, por outro (relação de 2:1). Isto sugere aporte 
conjunto de sedimentos coluvionares e de areias quartzosas relacionadas, como sugerido pelas análises granulométricas, com sedimentos paleolagunares das proximidades. Em Morrinhos, diminui a incidência de fragmentos líticos e aumenta a diferença entre quartzo e feldspato (relação de 3:1). Já em Jabuticabeira 1, há presença exclusiva de areias quartzosas, nas frações areia média e areia fina, o que indica, como proposto pela comparação granulométrica, domínio de sedimentos paleolagunares. A ausência de feldspatos e/ou fragmentos líticos permite descartar a hipótese de aporte coluvionar, suposto com base no domínio de grossos no sambaqui, e reafirma a hipótese sugerida pela análise malacológica, de coleta em bancos de moluscos com moda da fração terrígena situada na classe areia média.

A observação microscópica dos sedimentos permitiu identificar outra diferença composicional entre as arqueofácies dos quatro sítios estudados. Aquelas arqueofácies que contêm agregados de lama com areias quartzosas finas correspondem com as arqueofácies dominadas por Ostrea sp. e marisco, nas quais a análise granulométrica indicou moda na fração areia fina e muito fina (AF 4 do sitio Morrinhos e AF 7 e 9 de Jabuticabeira 1). Assim, a presença dos agregados pode ser determinante na moda registrada pelas análises granulométricas e, ao mesmo tempo, sugere uma relação entre o domínio de Ostrea sp. e marisco e a presença de agregados de lama em determinadas arqueofácies. A associação entre os agregados de lama e arqueofácies com Ostrea sp. não reflete o substrato de coleta desta espécie, mas indica a multi-proveniência dos materiais sedimentários e faunísticos que caracteriza os sambaquis. Em depósitos naturais não existe coexistência de Ostrea sp. com Heleobia sp. e diatomáceas estuarinas em substrato lamoso.

Outros componentes minerais identificados incluem: pesados, opacos, agregados de argila, incluindo grãos de argila glauconítica. Como a porcentagem total destes componentes é geralmente baixa $(<5 \%)$, sua presença em alguns sítios e ausência em outros não responderia a escolhas relacionadas com o processo de formação, mas às características dos depósitos naturais que, intencionalmente ou não, eram retransportados até os sambaquis

Dentre os componentes minerais minoritários, cabe mencionar a importância, em termos de significado paleoambiental, dos grãos de argila glauconítica que se observam dentro dos agregados de lama dos sítios Morrinhos e Jabuticabeira 1. O adjetivo glauconítico refere-se a um conjunto de argilominerais 2:1 formados na eodiagênese, sob baixa taxa de sedimentação e influência de águas marinhas, em 
condições moderadamente redutoras (Odin and Fullagar, 1988; Odin and Matter, 1981; Odin, 1988). As pelotilhas glauconíticas são mais encontradas hoje na plataforma continental, no entanto, foram observadas nos sítios Morrinhos e Jabuticabeira 1 dentro de agregados de lama associados a depósitos paleolagunares, conforme interpretado pela sua granulometria fina e assembleia de diatomáceas. Isto indica retrabalhamento mecânico das argilas glauconíticas a partir da plataforma continental e, conseqüentemente, origem alóctone ao sistema lagunar, via aporte marinho ${ }^{97}$.

A análise micromorfológica corrobora e refina as constatações realizadas pelas análises quantitativas (granulometria e zooarqueologia). Confirma-se predomínio de sedimentos coluvionares em Caipora e Cubículo 1 e de sedimentos paleolagunares em Morrinhos e Jabuticabeira 1. Observa-se associação entre arqueofácies com moda nas frações areia fina e muito fina, com domínio de Ostrea sp. e mariscos, e presença de agregados de lama de origem paleolagunar.

\subsubsection{Componentes biológicos principais: conchas e ossos}

O componente biológico mais conspícuo dos sambaquis analisados são as conchas de moluscos. Conchas podem aparecer tanto inteiras como fragmentadas e em diversos tamanhos, desde areia fina até, no caso de conchas completas bem preservadas, vários centímetros de cumprimento. Conchas queimadas a temperatura superior aos $600^{\circ} \mathrm{C}$, identificadas a partir do experimento apresentado no Capítulo 5, tópico 1.2, aparecem comumente misturadas entre materiais sem evidências de queima ou com indícios de queima a temperatura menor.

Traços de dissolução do carbonato das conchas são igualmente visíveis em todos os sambaquis conchíferos. A dissolução do carbonato é observada na forma de revestimentos de micrita e micro-espato ao redor dos fragmentos de concha, enchimentos de micrita que se desprendem de fragmentos de concha e ingressam em

\footnotetext{
${ }^{97}$ No trabalho realizado por Dillenburg et al. (2000) na laguna costeira de Tramandaí (Rio Grande do Sul), constatou-se presença de minerais glauconíticos unicamente nos depósitos marinhos que constituem o substrato da sedimentação lagunar na região. Esse substrato, de idade pleistocênica, é formado por areias finas depositadas em antepraia. Toda a sucessão de sedimentação lagunar, com fácies de margem e fundo, não contêm minerais glauconíticos, ou estes ocorrem como traços.
} 
agregados de matriz argilosa, e na forma de cristais de espato aderidos às bordas de fragmentos de concha. Na maioria dos casos, as conchas apresentam distribuição aleatória, especialmente quando os fragmentos são menores. Em algumas microfácies específicas, observou-se distribuição horizontal e/ou sub-horizontal de conchas inteiras e fragmentadas.

A distribuição horizontal ou sub-horizontal das conchas pode estar relacionada ao ato da depositação ou aos efeitos da compressão dos sedimentos na medida em que camadas construtivas são sucessivamente depositadas sobre o sítio (ver Andrews, 2006). A consolidação pode estar igualmente associada à compactação do substrato por pisoteamento humano sobre o sambaqui. No entanto, outros indicadores micromorfológicos de pisoteamento em concheiros, como continuidade lateral dos fragmentos (ver Balbo et al., 2010; Villagran et al., 2011 a), ou indicadores de pisoteamento em outros contextos, como distribuição linear/paralela à superfície dos demais componentes da fração grossa, ossos fissurados in situ, microestrutura laminar ou massiva (Goldberg et al., 2009, 2012; Miller et al., 2010; Schiegl et al., 2003) não foram identificados.

A dissolução e reprecipitação do carbonato de cálcio das conchas são constantes ao longo dos quatro sambaquis conchíferos analisados. A orientação horizontal e subhorizontal que apresentam as conchas inteiras, e fragmentos maiores na seção delgada, não estaria relacionada à compactação por pisoteamento, mas possivelmente à consolidação pós-deposicional do sedimento pelo peso exercido pelas camadas superiores.

Os ossos, segundo componente biológico mais frequente em sambaquis conchíferos, aparecem sempre fragmentados em diversos tamanhos, com predomínio de fragmentos finos até a fração silte. Em algumas ocasiões, identificam-se ossos inteiros, como vértebras, por exemplo, que, pela sua forma, são mais resistentes à fragmentação. $\mathrm{Na}$ maioria dos casos, a fragmentação não parece ser in situ, já que não existe continuidade lateral entre fragmentos de ossos adjacentes. Além disso, fragmentos contíguos mostram diferenças de coloração (PPL) e birrefringência (XPL) entre si. 
Pela variação de coloração que apresentam os ossos em seção delgada, tanto a PPL como XPL, infere-se mistura de materiais com diversos graus de queima ${ }^{98}$. Exemplares com graus variáveis de queima foram observados em todas as amostras analisadas, misturados com os demais componentes da fração grossa. Especialmente nos fragmentos grossos de osso, é possível observar traços de dissolução no interior do osso na forma de micro-canais sinuosos de espessura variável; apesar disso, os fragmentos maiores são também os que mais frequentemente apresentam fosforescência vinculada com a preservação do colágeno.

Ossos com sinais de queima indicam contato direto com o fogo (Shipman et al., 1984), o que pode ser relacionado com a ação de jogar os ossos nas fogueiras, ou com a de acender a fogueira sobre substrato rico em ossos (Bennett, 1999). Independentemente da intenção ou não na queima dos materiais, existe um gradiente de alteração térmica dos ossos em condições subaéreas e no substrato. Apenas os ossos em contato direto com o fogo sofrem calcinação e, quanto mais afastados da ação das chamas, menor será a alteração. O grau de alteração térmica de ossos enterrados sob fogueiras depende do tempo de queima, da textura do substrato (arenoso, argiloso) e da temperatura da fogueira $^{99}$. (Bennett, 1999; Steiner et al., 1995). Isto foi constatado na fogueira experimental acesa sobre depósito de retrabalhamento do sambaqui Cabeçuda, descrita no Capítulo 5, tópico 1.1.4. Nesta fogueira, observou-se alta fragmentação dos ossos que estavam inteiros quando jogados ao fogo, juntamente com calcinação dos ossos localizados em contato com as chamas, e carbonização e rubefação daqueles mais afastados do fogo ${ }^{100}$.

A alteração térmica dos ossos, direta ou indireta, pode significar três atividades: 1) uso dos ossos como combustível nas fogueiras; 2) deposição de restos consumidos nas fogueiras, vinculado com noções de higiene e limpeza; 3) queima acidental de

\footnotetext{
${ }^{98}$ As mudanças na coloração estão relacionadas com a destruição térmica da matriz orgânica dos ossos (Bennett, 1999; Steiner et al., 1995).

${ }^{99}$ Bennett (1999) identificou que a carbonização dos ossos não é resultado somente da distância às chamas, mas também do tempo de exposição indireta à fonte de calor. No experimento realizado pelo autor, ossos enterrados em substrato arenoso estavam carbonizados a $5 \mathrm{~cm}$ de profundidade e não mostravam alteração nenhuma a mais de $15 \mathrm{~cm}$. Já na experiência de Steiner et al. (1995), a carbonização observou-se até os $5 \mathrm{~cm}$ de profundidade.

${ }^{100}$ A fragmentação dos ossos resulta das alterações físico-químicas induzidas pela queima, a qual pode provocar tanto tensões internas capazes de quebrar o material quanto aumento de fragilidade às pressões físicas (Steiner et al., 1995).
} 
resíduos já descartados presentes no substrato das fogueiras (Cain, 2005; Costamagno et al., 2002).

A queima de ossos como combustível complementar à madeira é sustentada por trabalhos em arqueologia experimental que demonstraram que o ato de jogar ossos em fogueiras já acesas estende a durabilidade do fogo, além de economizar o uso de madeiras e assim reduzir a produção de resíduos orgânicos (Costamagno et al., 1998; Thery-Parisot, 2002; Yravedra et al., 2005). No entanto, o uso de ossos como combustível é geralmente associado à não disponibilidade de materiais lenhosos nas proximidades dos sítios. Além disso, o relato mais comum é de que os ossos utilizados sejam de mamíferos, e não de peixes. Nos contextos em que infere o uso de ossos como combustível, os restos de fogueiras apresentam acumulações de ossos e cinzas, com raros carvões. Entretanto, nos sambaquis estudados nesta tese, e no sítio Jabuticabeira 2, onde se realizaram previamente estudos antracológicos (Bianchini, 2008; Bianchini et al., 2007), os carvões são frequentes.

A segunda hipótese, de queima vinculada com práticas de higiene, implica que todos, ou a grande maioria dos ossos, devam estar completamente queimados, no mínimo até a carbonização. No entanto, apesar da quantidade de ossos com sinais de alteração térmica ser alta nas seções delgadas analisadas, diferenças na coloração (a PPL e XPL) e fluorescência indicam variabilidade nas temperaturas de queima, inclusive com presença de restos não queimados. Além disso, a assinatura isotópica de restos de tecido animal, conforme mostrado no tópico 1.3.2, indica que nem todos os ossos eram despojados da carne na hora da deposição no sambaqui.

Assim, pode-se concluir que a terceira hipótese, de queima acidental causada por uma fogueira acesa acima da acumulação de ossos, seja a mais provável. A queima indireta provocaria diversos graus de alteração térmica, como carbonização, calcinação e superfícies avermelhadas naqueles materiais próximos ao núcleo da queima. Em outros, mais afastados da fonte do calor, haveria preservação das características texturais originais. Como se discutirá no próximo tópico, a ausência de fogueiras estruturadas nas seções em sambaquis aqui analisadas, assim como a ausência, nessas seções, do gradiente de alteração térmica que se registra habitualmente em ossos e sedimentos sob fogueiras (ver Bennett, 1999; Berna et al., 2007; Canti and Linford, 2000; Steiner et al., 1995), sugere que o sambaqui contenha restos de retrabalhamento de depósitos, onde ossos e demais resíduos orgânicos teriam sido previamente acumulados e queimados. 
Misturas de conchas e ossos queimados a temperatura diversa, distribuídos, na maioria dos casos, aleatoriamente na seção delgada, indicam retrabalhamento de resíduos queimados em outro local.

\subsubsection{Componentes biológicos secundários}

O terceiro componente biológico mais frequente em sambaquis são os carvões, que sempre apresentam distribuição aleatória. Em alguns casos, sua fragmentação por pressão física provoca o aparecimento de zonas com concentração de fração fina (na fração argila) preta e opaca.

Outros componentes biológicos incluem: raízes frescas, diatomáceas, tecidos silicificados, gastrópodes e espinhos de equinóide. As raízes frescas são mais abundantes naquelas microfácies que apresentam desenvolvimento de solo de estrutura granular, ou em microfácies próximas à superfície das seções verticais analisadas. Restos de tecidos silicificados, ou fitólitos dispersos, foram menos frequentes que o esperado, já que as análises isotópicas mostram presença de restos vegetais. Os restos de tecidos estão ausentes em todas as amostras estudadas, com exceção das $\mathrm{mF} 3.1 \mathrm{e} \mathrm{mF}$ 4.1 do sítio Morrinhos, onde aparecem em frequência de $3 \%$ e $10 \%$, respectivamente.

Os tecidos silicificados são compostos por células de plantas (fitólitos), articuladas segundo a morfologia do tecido original da qual derivam. Os fitólitos, compostos por opala, são biomineralizações comuns nos órgãos aéreos das plantas, especialmente nas Poaceae (gramíneas) (Albert et al., 2000; Brochier, 2002; Courty et al., 1989). Apenas os sítios Cubículo 1 e Morrinhos apresentaram este componente, em baixa frequência. No sítio Morrinhos, os restos de tecidos estão sempre associados a microfácies compostas por materiais queimados, como conchas, ossos e argila rubificada ou carbonizada.

Com exceção dos carvões, que são mais resistentes à degradação bioquímica (Schmidt and Noack, 2000; De Souza Falcão et al., 2003), outros restos vegetais derivados da queima, como tecidos silicificados ou fitólitos dispersos (Albert and Cabanes, 2008; Albert et al., 2000, 2008; Schiegl, 1996), são praticamente ausentes nos sambaquis analisados. A ausência destes restos pode resultar de fatores deposicionais (baixa quantidade destes materiais nos sítios) ou tafonômicos (má preservação e/ou 
percolação). Material vegetal não lenhoso, especialmente gramíneas, pode ter sido utilizado principalmente para acender as fogueiras e, portanto, constituiriam uma porção menor do volume do combustível usado e dos restos das estruturas de combustão (ver Albert et al., 2012; Mallol et al., 2007; Schiegl et al., 2003).

Por outro lado, a ausência de fitólitos pode-se dever igualmente a motivos tafonômicos, vinculados com a lavagem destes componentes, favorecida pelas chuvas e porosidade do depósito, e/ou com a alcalinidade da solução intersticial dos sedimentos dos sambaquis. A grande concentração de conchas no depósito resulta em $\mathrm{pH}$ elevado (maior que 7), o que favorece a dissolução dos componentes silicosos opalinos (Albert et al., 2000; Karkanas, 2000; Karkanas et al., 2007; Shahackgross et al., 2004); especialmente se existe passagem eficiente de água através dos sedimentos (Karkanas, 2010). No entanto, a boa preservação de diatomáceas dentro dos agregados de lama nos sítios Morrinhos e Jabuticabeira 1, também compostas de opala, permite refutar a possibilidade dos fitólitos estarem ausentes por dissolução e reforça a hipótese de pouca deposição destes materiais nos sambaquis.

Agregados de diatomáceas foram observadas nos sítios Morrinhos e Jabuticabeira 1. A identificação realizada por Amaral (2011, comunicação pessoal) indica espécies diagnósticas de águas estuarino/lagunares. A espécie de diatomáceas dominante, Paralia sulcata, é um táxon marinho euritrópico, que tolera variações na salinidade das águas de 5 até 40 \%o (Moreira-Filho et al., 1985). Em sedimentos paleolagunares da região de estudo, Amaral (2008) e Amaral et al. (2012) identificaram predomínio desta espécie em fácies de argila arenosa, inclusive com conchas, datadas de ca. 4200 até 2700 AP. O domínio desta espécie, junto com as variações em espécies subordinadas, é interpretado por mesmos autores como indicador da redução na salinidade das águas, associada ao fechamento da conexão do sistema lagunar com o oceano.

O segundo componente biológico dos agregados de lama são indivíduos juvenis da espécie Heleobia sp. Nos concheiros naturais estudados por Fornari (2010), nas margens da laguna Garopaba do Sul, a espécie Heleobia australis predomina sobre $A$. brasiliana quando há redução na salinidade das águas, produto do fechamento do sistema lagunar. Em trabalho realizado por Netto et al. (2012) com populações vivas deste gastrópode na mesma laguna, observou-se tendência de proliferação da espécie quando a salinidade das águas é reduzida (0.2-1.6\%o). Assim, o domínio de Paralia sulcata em agregados de lama com Heleobia sp. confirma a associação destes 
sedimentos com o sistema lagunar, com significativo aporte de água doce. Neste sentido, diatomáceas e gastrópodes nos agregados servem como bioindicadores do contexto deposicional de onde os sedimentos foram coletados.

Outro elemento potencialmente diagnóstico para inferir comportamentos de coleta são os espinhos de equinóide, associados a ouriços do mar, identificados unicamente no sítio Caipora. Os espinhos de equinoides correspondem aí a 2\% do total da fração grossa e foram identificados apenas na sua seção basal, onde apresentam diâmetro entre 625 e $645 \mu \mathrm{m}$ e composição carbonática. Como a identificação na seção longitudinal é mais difícil, é provável que sua concentração na lâmina esteja subestimada.

Os equinodermos são invertebrados marinhos que vivem em águas rasas ou profundas de salinidade normal. Dentre eles, os equinoides destacam-se como típicos integrantes da associação biológica infralitoral de costões rochosos de mar aberto (Laborel 1986), embora possam ocorrer também na zona mesolitoral, em poças permanentes de água de borrifo sobre a rocha. A presença destas espécies marinhas nos sedimentos do sambaqui permite sugerir que, durante o uso do sítio (que, pela idade de 7570-7320 anos cal. AP, na base, teria começado antes do máximo transgressivo na região), o sistema era aberto à influência direta do mar. Isto significa que, nas proximidades do sambaqui, teriam existido costões rochosos em contato com o mar, o qual se encontrava, na época, em progressivo avanço sobre o continente. Estes costões estariam associados ao embasamento granitoide que atualmente delimita, a NW e W, a planície deltaica do rio Tubarão.

Dos componentes biológicos secundários, podem-se extrair as seguintes informações: os carvões são onipresentes em todas as seções verticais analisadas; a baixa freqüência de fitólitos e/ou tecidos silificados sugere escassa deposição destes materiais nos sítios, possivelmente associada ao uso de gramíneas unicamente para acender as fogueiras e/ou lavagem pela ação das chuvas; espécies de diatomáceas e gastrópode identificadas nos agregados de lama dos sítios Morrinhos e Jabuticabeira 1 confirmam a associação destes agregados com sedimentos paleolagunares; presença de espinhos de equinóide em Caipora indicam influência de águas marinhas nas proximdiades do sambaqui. 


\subsubsection{Produtos da alteração antrópica}

$\mathrm{Na}$ categoria definida como produtos da alteração antrópica, agrupam-se aqueles elementos que aparecem em concentração total menor que 3\% e que sofreram alteração térmica por ação humana. Estes componentes incluem: escória vítrea; perióstraco carbonizado; e agregados de argila queimada.

Como escória vítrea, também chamada de agregados de material silicoso, agrupam-se aqueles resíduos da queima de madeiras a altas temperaturas formados por agregados de sílica amorfa com textura vesicular (Berna et al., 2004; Canti, 2003; Courty et al., 1989; Schiegl, 1996; Schiegl et al., 1994; Weiner, 2002). Estes microagregados formam-se pela fusão de células silicificadas das plantas, quando submetidas a temperaturas superiores a $800^{\circ} \mathrm{C}$.

Os restos de perióstraco carbonizado identificaram-se unicamente no sítio Morrinhos, em microfácies compostas por conchas queimadas, tecidos silicificados e argila rubificada. Pelo experimento apresentado no Capítulo 5, tópico 1.2, pode-se inferir que a presença do perióstraco carbonizado associado à superfície da concha queimada, indica temperaturas de aquecimento de até 400 ou $500^{\circ} \mathrm{C}$.

Por último, os agregados de argila rubefacta ${ }^{101}$, observados nos sítio Morrinhos e Jabuticabeira 1, sempre associados às microfácies compostas por conchas queimadas a altas temperaturas, carvão e tecidos silicificados, resultam da combustão dos agregados de lama que aparecem nos mesmos sítios. Isto infere-se pela semelhança entre ambos agregados (queimados e não queimados) compostos pela mesma assembleia de diatomáceas e espécie de gastrópode. Substrato rubefacto é um claro indicador de queima in situ (Berna et al., 2007; Canti and Linford, 2000; Mallol et al., 2007; Schieg1 et al., 2003; Wattez, 1992), no entanto, em Morrinhos e Jabuticabeira 1, encontram-se unicamente alguns agregados rubefactos, junto com agregados carbonizados, misturados com outros materiais queimados. Este arranjo não parece indicar queima in situ no sambaqui, mas sim retrabalhamento de materiais queimados em outro local.

\footnotetext{
101 A rubefação da argila produz-se pela oxidação do ferro que compõe os argilominerais e matéria orgânica durante a queima dos agregados, neste caso, em fogueiras antrópica.
} 
Existem diversos materiais produzidos pela queima antrópica nos sambaquis, além das conchas e ossos. Incluem-se agregados de argila rubefacta, escória vítrea, tecidos silicificados e períostraco carbonizado.

\subsubsection{Fração fina}

A fração fina dominante nos quatro sambaquis conchíferos analisados é formada por dois componentes principais: 1) argila organomineral; e 2) micrita. Como componentes subordinados, registra-se a existência de fosfatos secundários, cinzas de madeira e agregados de lama com diatomáceas (nos sítios Morrinhos e Jabuticabeira 1). Em todos os sambaquis, observa-se predomínio de microestrutura de microagregados intergranulares, vazios de empacotamento complexo e distribuição relacionada $\mathrm{g} / \mathrm{f}$ de tipo enáulica. Em algumas microfácies, aparece microestrutura grumosa, como naquelas associadas a desenvolvimento de solos, nos sítios Caipora e Cubículo 1, e de grãos revestidos interligados. Poros relacionados com a ação biológica de raízes e fauna do solo, como vesículas, canais e vazios em câmera, foram identificados em todos os casos estudados.

A fração fina do sítio Caipora é cristalítica, às vezes turva, formada por mistura entre argila organomineral e micrita. A micrita é considerada parte da micromassa pela sua distribuição, mas possui, de fato, caráter pós-deposicional autígeno, de cimento, já que deriva da dissolução e reprecipitação do carbonato de cálcio das conchas que compõem os sítios. Esta composição silicática/carbonática, inferida pelos atributos ópticos à luz polarizada do material fino, foi confirmada por análises com sistema MEV-EED da micromassa, onde se detectou sílica e alumínio, associados a argilominerais, assim como cálcio, relacionado com a micrita. Uma pequena porcentagem de fósforo foi igualmente detectada (1-2\%), o que sugere dissolução e precipitação da apatita dos ossos ou de outros resíduos fosfáticos de origem orgânica.

O sítio Cubículo 1 apresenta micromassa de argila organomineral marrom escura (PPL), sem a micrita que caracteriza a massa basal fina dos outros sambaquis. Isto pode estar relacionado ao fato da amostra analisada estar próxima à superfície do sambaqui, onde se observou também desenvolvimento de solo de estrutura granular com poucas conchas. Neste sentido, a dissolução do material conchífero por processos 
intempéricos e pedogênicos teria provocado a percolação do carbonato de cálcio em solução até os níveis inferiores do sambaqui, não amostrados neste estudo.

Os sítios Morrinhos e Jabuticabeira 1 apresentam micromassa semelhante, formada por mistura de micrita com argilominerais, fosfatos secundários e microcarvões. Esta micromassa cristalítica, pontuada a turva, aparece misturada com agregados milimétricos de lama com diatomáceas que, em alguns casos, formam microfácies discretas nas seções delgadas. Os agregados de lama estão compostos por argila mineral castanho claro (PPL), são maciços (distribuição relacionada $\mathrm{g} / \mathrm{f}$ de tipo porfírico) e contêm fissuras produzidas pelo ressecamento dos argilominerais.

Análises com sistema MEV-EED numa das amostras de Jabuticabeira 1 confirmaram que a micromassa apresenta domínio de cálcio, sílica e fósforo na sua composição. A concentração de $\mathrm{Ca}$ está associada à precipitação do carbonato dissolvido das conchas. No entanto, os altos valores de $\mathrm{P}$ indicam também minerais secundários derivados da alteração dos ossos de peixe e outros resíduos orgânicos e parte do Ca pode provir daí. A alta porcentagem de sílica e baixo teor de alumínio sugerem que a sílica pode estar relacionada a resíduos silicosos derivados da queima de material vegetal (ver Canti, 2003; Schiegl et al., 1994) e não à presença de argilominerais.

De modo geral, a composição da fração fina dos sítios Caipora e Cubículo 1 distingue-se da situação observada nos sítios Jabuticabeira 1 e Morrinhos. Em Caipora e Cubículo 1, destacam-se os argilominerais, enquanto a micromassa dos sítios Morrinhos e Jabuticabeira 1 é essencialmente micrítica e fosfática, com MO e argilominerais em menor abundância. Isto significa que, nos primeiros dois sítios, existe maior teor de materiais terrígenos finos, enquanto nos últimos domina a fração fina pós-deposicional, relacionada com a alteração das conchas e ossos. Esta diferença pode estar associada aos padrões composicionais já notados a partir das análises granulométricas.

O aporte coluvionar detectado em Caipora e Cubículo 1, com presença de sedimentos de brejo lagunar no segundo, estaria associado à maior porcentagem de argilominerais nestes dois sambaquis. Isto suporta a hipótese de coleta acidental do substrato de acumulação de materiais próximo ao sítio. Já nos sítios Morrinhos e Jabuticabeira 1, há maior frequência de areias quartzosas, escassez de argilominerais e afinidade granulométrica das areias terrígenas com sedimentos paleolagunares. Nestes sítios, os argilominerais aparecem unicamente nos agregados de lama com diatomáceas. 
Em seção delgada, os agregados de lama aparecem incrustados e delimitados por concentrações horizontais e sub-horizontais de fragmentos de marisco e, em raras ocasiões, associam-se a conchas de $A$. brasiliana. Pela associação com lama de origem paleolagunar, pode-se inferir que os fragmentos de marisco correspondem à espécie Mytella sp., que vive em fundos lodosos de lagunas em regiões entremarés ${ }^{102}$ (De Souza et al., 2011).

A fração fina dos sambaquis conchíferos reflete o tipo de sedimento que foi retrabalhado para formação do sambaqui. No caso dos sítios Caipora e Cubículo 1, há presença de areias terrígenas e argilominerais associados com depósitos coluvionares e, no caso de Cubículo 1, também de brejo lagunar. Nos sítios Morrinhos e Jabuticabeira 1 não teria havido retrabalhamento de sedimentos finos, mas somente de depósitos arenosos. A fração fina de estes sítios é essencialmente resultado da alteração pósdeposicional de conchas e ossos, associados a agregados de lama de origem paleolagunar.

A presença de cinzas de madeira no sítio Morrinhos serve como indicador da boa preservação deste componente nos sambaquis. Pela sua composição carbonática, os cristais de POCC que compõem as cinzas seriam facilmente dissolvidos em depósitos subaéreos porosos sob clima sub-tropical. A preservação das cinzas estaria relacionada com o pH elevado (9-13.5) dos sedimentos dos sambaquis, determinado pela alta concentração de conchas, já que cinzas são altamente alcalinas (Etiégni and Campbell, 1991). A preservação de cinzas e baixa concentração nos sítios analisados sugere, indiretamente, que a ausência de cinzas em outras áreas amostradas dos quatro sambaquis conchíferos deve-se menos a processos tafonômicos, como dissolução, que à não deposição destes materiais. Esta interpretação fundamenta-se na baixa frequência de fitólitos, mencionada anteriormente.

No entanto, não se pode descartar a possibilidade de parte das cinzas ter sido dissolvida e recristalizada com outros componentes solúveis dos depósitos, como fosfato de cálcio dos ossos (ver Berna et al., 2004; Karkanas, 2000; Schiegl, 1996; Weiner, 2002) ou carbonato de cálcio das conchas. Esta hipótese não pôde ser

${ }^{102}$ Mytella sp. também aparece enterrada em lama siltosa e lama húmica em manguezais, a profundidade média de 1,0 cm, associada a estuários e lagunas (Bacon, 1975; Nishida et al., 1995). 
confirmada com base em análises ópticas e de composição elementar realizadas neste trabalho. Para isso, seriam necessários outros ensaios como DRX (difratometria de raios-x) ou FTIR (espectroscopia de infravermelho por transformada de Fourier).

A baixa freqüência de cinzas de madeira indica escassa deposição deste material nos sambaquis e/ou dissolução e reprecipitação destes materiais em neoformações minerais.

\subsection{ALTERAÇÃO PÓS-DEPOSICIONAL}

$\mathrm{Na}$ alteração pós-deposicional dos sedimentos que compõem os sambaquis conchíferos, identificam-se dois agentes: intempéricos (abióticos) e biológicos. Os agentes intempéricos estão relacionados com $\mathrm{pH}$ e regime hidrológico do depósito. $\mathrm{O}$ processo de maior destaque é a dissolução e reprecipitação do carbonato de cálcio das conchas. Este mineral precipita na forma de micrita, que aparece misturada com a matriz de argilominerais e, em ocasiões, na forma de espato ou micro-espato. Outras tramas do carbonato precipitado são na forma de revestimentos, hipo-revestimentos e enchimentos, densos e incompletos, de micrita cinza escura (PPL), com inclusões de partículas opacas (possivelmente microcarvões). Observam-se também revestimentos de micrita impura, com argila organomineral e microcarvões.

A microestrutura micrítica, na forma de microagregados interligados ou grãos revestidos interligados indica formação em condições de não saturação da água, em ambiente de percolação. O mesmo tipo de ambiente é sugerido por outras evidências de alteração intempérica, como nódulos de oxi-hidróxido de ferro órticos, e alguns hiporevestimentos de oxi-hidróxido de ferro, de impregnação moderada a alta que se observam ao longo dos perfis dos quatro sambaquis conchíferos analisados. Estes nódulos aparecem tanto na micromassa de micrita com argilominerais, como nos agregados de lama e indicam ciclos de alagamento e dessecação dos sedimentos, junto com condições vadosas de formação.

Além da dissolução do carbonato de cálcio das conchas, observam-se nos sítios Morrinhos e Jabuticabeira 1 micromassas formadas por fosfatos secundários. Pelas propriedades ópticas do material (Adderley et al., 2004; Goldberg and Nathan, 1975; Lucas and Prévôt, 1991; Simpson et al., 2000) e pela proporção entre Ca e P detectadas 
nas análises com sistema MEV-EED (Le Geros and Le Geros, 1984; Schaefer et al., 2004), estas micromassas derivariam da dissolução do mineral do osso ${ }^{103}$. Somado a isso, o regime hidrológico nos sambaquis e a alta porosidade dos sedimentos favorecem a dissolução e recristalização do fosfato do osso nas porções inferiores da sucessão vertical (ver Berna et al., 2004; Gordon and Buikstra, 1981; Lucas and Prévôt, 1991; Schiegl, 1996; Trueman et al., 2004; Weiner, 2002) ${ }^{104}$. Cabe mencionar que a alteração dos ossos e restos de tecidos pode ser mediada, igualmente, pela ação de microrganismos nos sedimentos (ver Gilinskaya et al., 2007).

No entanto, ao constatar-se que grande parte dos fragmentos de osso estão queimados, o que lhes outorga maior resistência à alteração química (Shahack-Gross, 1997; Steiner et al., 1995), e que existe intensa dissolução do carbonato de cálcio das conchas, que alcaliniza o pH do depósito e favorece a preservação dos ossos (Berna et al., 2004; Gordon and Buikstra, 1981; Nielsen-Marsh et al., 2007) (ver tópico 1.7.5), pode-se pensar que os fosfatos secundários derivem, também, do fósforo liberado na degradação de resíduos orgânicos. A presença de tecidos animais nos sambaquis foi constatada pelas análises isotópicas. $\mathrm{O}$ nível de análises aqui realizadas não permite diferenciar se a origem dos fosfatos é óssea, ou se existe uma combinação com outros resíduos orgânicos, como carne ou fluidos. Para isso, outras análises seriam necessárias, como, por exemplo, FTIR, GS/MS (cromatografia gasosa acoplada à espectrometria de massa) e espectroscopia Raman.

Evidências de alteração biológica observam-se na forma de excrementos elipsóides, esféricos e mamilares, de composição semelhante à da micromassa, frequentes nas amostras superficiais dos sítios Caipora e Cubículo 1. Outros indicadores da ação biológica são os vazios em câmera e canais, assim como os agregados mamilares, frequentemente interligados, que compõem a micromassa.

Apesar dos processos de alteração mencionados, existe preservação das relações entre diferentes microfácies naquelas arqueofácies que apresentam micro-estratificação. Tal é o caso da AF 4 do sítio Morrinhos e da AF 7 de Jabuticabeira 1. Isto significa que não existem perturbações físicas maiores no depósito, capazes de ocasionar

\footnotetext{
${ }^{103}$ A alteração dos ossos enterrados começa pela degradação da matriz orgânica (colágeno), que acontece rapidamente pela ação microbiana, em simultaneidade com a lenta degradação química. Uma vez despojado do colágeno, o fosfato do osso fica exposto e começa a alteração química da fração inorgânica através da dissolução e reprecipitação mineral, aumento da porosidade etc. (Berna et al., 2004; Hedges, 2002; Jans et al., 2002; Jans, 2004; Nielsen-Marsh et al., 2007; Smith et al., 2007; Trueman and Martill, 2002; White and Hannus, 1983).

${ }^{104}$ Por exemplo, no sítio Jabuticabeira 2 constatou-se a presença de uma concreção fosfática embaixo da camada preta superior deste sambaqui, formada por $80-90 \%$ de ossos de peixe (Mazini, 2007).
} 
redistribuição de componentes. Permite interpretar assim, indiretamente, que o alto grau de mistura de componentes no sambaqui seja um atributo deposicional e não pósdeposicional.

A alteração tafonômica dos sambaquis conchíferos envolve, principalmente, a dissolução e precipitação do carbonato de cálcio das conchas, favorecido pelo regime hidrológico e porosidade dos depósitos. Também há dissolução e precipitação do fosfato dos ossos de peixe e de outros resíduos biológicos. Alterações de origem biológica observam-se na forma de excrementos e de vazios em câmara, canais e vesículas, que indicam passagem de raízes e da fauna do solo.

\subsection{MICROFÁCIES}

A identificação de microfácies levou em consideração os cinco parâmetros mencionados no Capítulo 4, tópico 1.2.2 (fração grossa, micromassa, microestrutura, porosidade e razão g/f). No sítio Caipora, identificaram-se quatro microfácies correspondentes às AF $2(\mathrm{mF} 2), 3(\mathrm{mF} 3), 4(\mathrm{mF} 4)$ e horizonte de solo superficial $(\mathrm{mF}$ HzA). Após avaliação em conjunto das seções delgadas, o número de microfácies podese reduzir a somente três: $\mathrm{mF} 2, \mathrm{mF} 3 / 4$ e mF HzA. A mF 2 diferencia-se das mF 3 e 4 pela orientação sub-horizontal das conchas e fragmentos de concha. A mF 4 difere da $\mathrm{mF} 3$ pelo maior conteúdo de conchas com traços de queima a temperatura superior aos $500^{\circ} \mathrm{C}$. A microfácies que mais se distingue do conjunto, em termos de microestrutura, compactação, frequência de conchas e micromassa, materializa a formação de solo incipiente no topo da coluna (mF HzA).

$\mathrm{Na}$ seção delgada do sítio Cubículo 1, identificaram-se duas microfácies, correspondentes à AF 9 ( $\mathrm{mF}$ 9) e ao horizonte de solo no topo da coluna (mF HzA). Como observado no sítio Caipora, a mF HzA caracteriza-se pelo domínio da fração fina sobre a fração grossa, com baixa frequência de componentes biológicos (conchas e osso), grumos soltos e também coesivos de argila organomineral. As microfácies superficiais das seções verticais dos sítios Caipora e Cubículo apresentam características semlhantes entre si, relacionadas, possivelmente, à alteração pedogênica. 
No sítio Morrinhos, foram identificadas oito microfácies a partir das quatro seções delgadas analisadas (correspondentes às AF 3 e 4). $\mathrm{O}$ atributo mais interessante foi a variedade lateral detectada nas duas arqueofácies amostradas. No caso da AF 3, identificaram-se duas microfácies ( $\mathrm{mF} 3.1$ e mF 3.2), enquanto na AF 4 identificaram-se quatro $(\mathrm{mF} 4.1, \mathrm{mF} 4.2, \mathrm{mF} 4.3 \mathrm{e} \mathrm{mF} \mathrm{4b)}$. Do conjunto de microfácies observadas na $\mathrm{AF} 4, \mathrm{a} \mathrm{mF} 4.2$ é assimilável à $\mathrm{mF} 3.2$, enquanto $\mathrm{a} \mathrm{mF} 4 \mathrm{~b}$ é composta pela combinação da $\mathrm{mF} 3.1$ e mF 4.3. Isto significa que na $\mathrm{AF} 4$ existem unicamente duas microfácies.

A microfácies dominante na seção do sítio Morrinhos, em termos de superfície nas lâminas delgadas, é a mF 3.1. Esta microfácies representa a típica composição e microestrutura de sambaquis conchíferos, já observada nos sítios Caipora e Cubículo 1 (concha, osso, grãos minerais, carvão, microagregados integranulares, micrita, argilominerais, fosfatos e microcarvões). A segunda microfácies mais frequente corresponde à $\mathrm{mF}$ 3.2/4.2, composta por grãos minerais revestidos e interligados por argilominerais. A terceira microfácies destacável corresponde aos agregados de lama com diatomáceas que aparecem como camadas discretas (no caso da mF 4.3) e inclusive misturados dentro de microfácies do tipo $\mathrm{mF} 3.1$.

No sítio Morrinhos, identificou-se também uma microfácies composta completamente por material queimado. A mF 4.1 contém conchas distribuídas subhorizontalmente e queimadas a temperatura superior a $600^{\circ} \mathrm{C}$, ossos queimados, escória vítrea, carvão e conchas com restos de perióstraco carbonizado. A micromassa é essencialmente micrítica, relacionada principalmente com a presença de cinzas, com alguns agregados de argila rubefacta. Destaca-se uma concentração de tecidos silicificados que, pelo arranjo interno, pode corresponder a restos de material trançado.

Por último, no sambaqui Jabuticabeira 1 identificaram-se nove microfácies. Quatro destas microfácies apareceram em uma única seção. Em termos gerais, as microfácies que compõem este sambaqui apresentam a mesma mistura de materiais observada nos sítios Caipora, Cubículo 1 e Morrinhos. A maior diferença com os demais sambaquis conchíferos analisados reside na maior porcentagem de conchas, com distribuição paralela à superfície, no sítio Jabuticabeira 1 .

As microfácies 5 e 6 apresentam composição, microestrutura e micromassa semelhantes. A mF 5 diferencia-se da $\mathrm{mF} 6$ pela distribuição paralela a sub-horizontal das conchas e pela presença dos agregados de lama com diatomáceas, também observados na mF 4.3 e $4 \mathrm{~b}$ de Morrinhos. A AF 7 foi a única do sítio a apresentar micro-estratificação em seção delgada. Nesta lâmina, foram descritas quatro microfácies 
sucessivas. A mF 7.1 é similar à $\mathrm{mF} 4.1$ do sítio Morrinhos, composta por material queimado (conchas submetidas a temperaturas de $800^{\circ} \mathrm{C}$ ), ossos e agregados de argila rubefacta e carbonizada. A mF 7.2 é formada por concentração de conchas com empacotamento fechado e distribuição horizontal, com alguns fragmentos de concha queimados. A mF 7.3 é semelhante à $\mathrm{mF} 5$, e também à $\mathrm{mF} 4 \mathrm{~b}$ do sítio Morrinhos, por conter conchas em microestrutura de microagregados intergranulares com agregados de lama. A mF 7.4 compõe-se exclusivamente por agregados de lama com diatomáceas e gastrópode. As mF 8 e 9 são quase idênticas, diferenciando-se unicamente pela presença de agregados de lama e maior frequência de conchas com distribuição sub-horizontal na $\mathrm{mF} 9$.

\subsubsection{Recorrência de microfácies intra e inter-sítio}

A avaliação geral das 23 microfácies descritas nos quatro sambaquis conchíferos analisados mostrou semelhanças e correspondências entre microfácies do mesmo sítio e de sítios diferentes. Por exemplo, microfácies compostas por agregados de lama com diatomáceas, argila glauconítica e gastrópodes foram identificadas no sítio Morrinhos e Jabuticabeira 1. Da mesma maneira, microfácies compostas por mistura de conchas inteiras e fragmentadas, ossos, carvão e grãos minerais em matriz composta de argilominerais, micrita e fosfatos são dominantes nos quatro sambaquis estudados.

Em termos gerais, as diferenças entre as 23 microfácies referem-se a variações nas porcentagens de três elementos: 1) conchas, ossos e grãos minerais na fração grossa; 2) porosidade; e 3) fração fina. O predomínio de um ou outro destes fatores está diretamente associado aos demais atributos listados no Capitulo 4, tópico 1.2.2 como diagnósticos na diferenciação de microfácies em sambaquis. Estes fatores incluem microestrutura e distribuição relacionada g/f. Por exemplo, as microfácies compostas por agregados de lama estão associadas a maiores teores de fração fina, menor frequência de grãos minerais, microestrutura maciça e distribuição relacionada porfírica. Já as microfácies com maior porcentagem de conchas e menor teor de fração fina são aquelas com microestrutura de microagregados intergranulares e distribuição relacionada $\mathrm{g} / \mathrm{f}$ de tipo enáulica.

Para aprofundar-se no exame da existência de microfácies recorrentes inter e intra-sítio, realizou-se a análise de componentes principais, que levou em consideração 
os cinco parâmetros de maior peso na diferenciação quantitativa e qualitativa das 23 microfácies descritas. Estes parâmetros referem-se a porcentagem de: 1) conchas; 2) ossos; 3) grãos minerais (somatória de grãos de quartzo, feldspato e fragmentos líticos); 4) porosidade; 5) fração fina. As variáveis escolhidas tiveram que ser normalizadas já que, na descrição micromorfológica, foram estimadas em relação à porcentagem total por categoria $^{105}$.

A partir da análise de componentes principais assim realizada, identificaram-se, pelo menos, três agrupamentos de microfácies (Figura 6.4). O primeiro agrupamento envolve as microfácies 4.3 do sítio Morrinhos e 7.4 de Jabuticabeira 1, compostas por agregados de lama com diatomáceas (grupo A da Figura 6.4). Este grupo caracteriza-se por ter a maior porcentagem de fração fina do conjunto (46-47\%). O segundo agrupamento abarca as microfácies 3.2 e 4.2 do sítio Morrinhos, já descritas como semelhantes (grupo B da Figura 6.4) por conter grãos de quartzo revestidos por argilominerais (53-60\%), com pouquíssimas conchas (0-8 \%). O terceiro agrupamento envolve as microfácies compostas por conchas com empacotamento fechado e distribuição horizontal, que têm os valores máximos de frequência de conchas (53-55 \%) e porosidade (32-33 \%) e os valores mínimos de fração fina (3-7 \%). Estas são a mF 4.1 do sítio Morrinhos, onde as conchas estão completamente queimadas, e a mF 7.2 de Jabuticabeira 1, onde apenas $5 \%$ das conchas encontram-se queimadas (grupo C da Figura 6.4).

O quarto agrupamento abrange a nuvem de pontos localizada na área central do gráfico da Figura 6.4 (grupo D) na qual, em termos gerais, distinguem-se dois subconjuntos de microfácies com frequência de conchas entre 20 e $40 \%$ e teores variáveis de grãos minerais (11-42 \%) e ossos (3-24\%): 1) um subconjunto envolve as $\mathrm{mF} 2,3,4 \mathrm{a}, 4 \mathrm{~b}$ e 4 do sítio Caipora e a $\mathrm{mF} 8$ de Jabuticabeira 1, com porcentagem de ossos no entorno de $7 \%$; 2) o outro agrupa as mF 9 e HzA, do sítios Cubículo 1, mF 3.1, 3 b e 4b, do sítio Morrinhos, e mF 5, 6, 7.3 e 9, do Jabuticabeira 1, com frequência de ossos de 10 a $23 \%$. Somente duas microfácies não se agrupam em nenhum dos

\footnotetext{
${ }^{105}$ A estimação dos componentes da fração grossa foi realizada em relação à sua porcentagem total, sem considerar à porosidade ou fração fina. Da mesma maneira, a estimação da porosidade levou em consideração a frequência de vazios em relação à somatória da fração grossa e fina; assim como a estimação da fração fina somente considerou a relação da micromassa com a fração grossa, sem ponderar a porosidade. Portanto, prévio à análise estatística, as cinco variáveis foram normalizadas em relação a um valor total de 100. Desta maneira, permite-se avaliar a relação entre as variáveis utilizadas para comparação e agrupamento das amostras.
} 
conjuntos anteriores. Estas correspondem à $\mathrm{mF} \mathrm{HzA}$ do sítio Caipora e $\mathrm{mF} 7.1$ do Jabuticabeira 1.

Os quatro grandes grupos identificados pela análise de componentes principais servem de base para definir microfácies maiores nos sambaquis de padrão estratigráfico conchífero. No próximo tópico, discute-se o significado dos conjuntos maiores de microfácies em termos de atividade de deposição e proveniência do material.
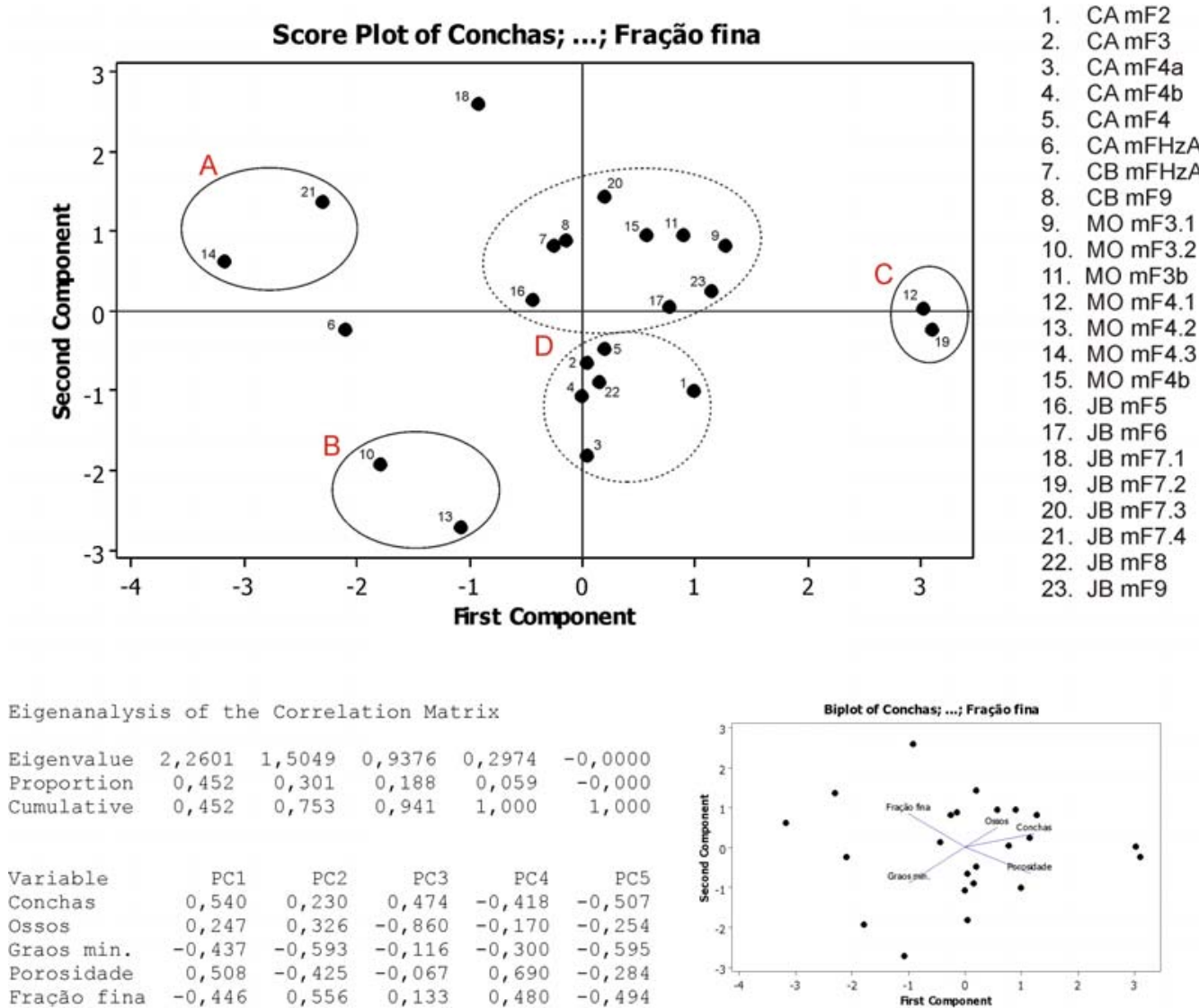

Figura 6.4. Gráfico de componentes principais para 23 seções delgadas dos quatro sambaquis conchíferos analisados.

\subsubsection{Microfácies tipo A: retrabalhamento de resíduos com predomínio de conchas}

Este tipo de microfácies foi identificado em mais da metade das lâminas analisadas por sítio. No diagrama da Figura 6.4, agrupa-se nos dois subconjuntos localizados no centro do gráfico (identificados como grupo D): Caipora $\mathrm{mF} 3$ e 4; 
Cubículo1 mF 9; Morrinhos mF 3.1 e 4b; Jabuticabeira $1 \mathrm{mF}$ 5, 6, 8 e 9. características desta microfácies listam-se no Quadro 6.3.

Quadro 6.3. Características da microfácies tipo A.

\begin{tabular}{|c|c|}
\hline \multicolumn{2}{|r|}{ MICROFÁCIES TIPO A } \\
\hline Microestrutura & $\begin{array}{l}\text { Microagregados intergranulares e grãos revestidos e interligados, com grânulos } \\
\text { coesivos }(100-300 \mu \mathrm{m})\end{array}$ \\
\hline Dist. rel. g/f & Enáulica, com áreas de tipo gefúrica e quitónica \\
\hline Vazios & De empacotamento complexo, com canais, vazios em câmara e vesículas \\
\hline Porosidade & $20-30 \%$ \\
\hline Razão g/f & $70 / 30$ \\
\hline Fração grossa & $\begin{array}{l}\text { 1) Conchas }(20-40 \%) \text { inteiras e fragmentadas com conchas queimadas; } 2) \text { grãos } \\
\text { minerais }(\sim 10-40 \%) \text {, com domínio de areias quartzosas, seguido de grãos de } \\
\text { feldspato e fragmentos líticos; } 3 \text { ) fragmentos de osso de diverso tamanho }(3-24 \%) \text {, } \\
\text { com domínio na fração areia muito fina e sinais de queima e dissolução }\end{array}$ \\
\hline $\begin{array}{l}\text { Distribuição da } \\
\text { fração grossa }\end{array}$ & $\begin{array}{l}\text { Grãos minerais e ossos com distribuição aleatória. Conchas com frequência } \\
\text { variável }(10-100 \%) \text {, de distribuição horizontal a sub-horizontal }\end{array}$ \\
\hline Comp. menores & $\begin{array}{l}\text { Ocasional presença de agregados de lama com diatomáceas, fragmentos de carvão. } \\
\text { Frequência total menor que } 1 \% \text { de escórias vítreas, espinhos de equinoide e restos } \\
\text { de tecidos }\end{array}$ \\
\hline Micromassa & Mistura de argilominerais com MO e micrita, mais fosfatos secundários \\
\hline
\end{tabular}

As microfácies agrupadas no tipo $\mathrm{A}$ são as que apresentam a maior complexidade pré-deposicional das sucessões analisadas, por conter uma mistura de materiais inteiros, fragmentados, queimados a diversa temperatura e distribuídos, na maior parte dos casos, aleatoriamente. Apenas as conchas inteiras ou em fragmentos maiores apresentam distribuição horizontal e sub-horizontal. Isto provavelmente se relaciona com o a deposição do material e/ou consolidação pós-deposicional dos sedimentos (ver Andrews 2005).

Como discutido no tópico 1.4.2, a maior parte dos fragmentos de osso, bem como alguns fragmentos de concha, estão queimados. Porém, a queima não teria acontecido no local, já que não se observam outros indicadores macro e microscópicos de fogueiras in situ. Por exemplo, nas sucessões verticais analisadas, não há evidências de estruturas de combustão semelhantes à fogueira experimental acesa sobre substrato conchífero, apresentada no Capítulo 5, tópico 1.1.2. Tampouco se observaram fogueiras como as identificadas no sítio Jabuticabeira 2, sempre associadas a sepultamentos humanos (ver Bendazzoli, 2007; Fish et al., 2000; Klokler, 2001, 2008; Nishida, 2007; Villagran, 2008).

Em seção delgada, as microfácies tipo A envolvem uma mistura de restos queimados a temperaturas diversas, junto com materiais não queimados. Os restos queimados incluem: conchas aquecidas a temperatura de $400^{\circ} \mathrm{C}$ até $800^{\circ} \mathrm{C}$ (segundo 
experiência mostrada no Capítulo 5, tópico 1.2); fragmentos de osso com alteração superficial (temperaturas menores que $\left.400^{\circ} \mathrm{C}\right)$; fragmentos carbonizados $\left(400-500^{\circ} \mathrm{C}\right.$ ) ou calcinados $\left(600-700^{\circ} \mathrm{C}\right)$; carvões $\left(280^{\circ} \mathrm{C}\right)$; e, ocasionalmente, escória vítrea $\left(+800^{\circ}\right.$ C). A micromassa compóe-se de mistura de argilominerais com micrita derivada da precipitação do carbonato dissolvido das conchas, assim como fosfatos secundários associados à alteração dos ossos ou resíduos biológicos. Ocasionalmente, observam-se finas lentes (até $5 \mathrm{~mm}$ de cumprimento e $1 \mathrm{~mm}$ de espessura) de micromassa carbonoas, resultado da quebra de fragmentos isolados de carvão. Outras evidências micromorfológicas de fogueiras in situ, como substrato rubefacto, acumulação de cinzas de madeira e/ou gramíneas, agregados silicosos ou micromassa carbonosa associada à deposição massiva de microcarvões (ver Berna et al., 2004; Courty et al., 1989, 2012; Goldberg et al., 2009, 2012; Karkanas et al., 2007; Mallol et al., 2007; Miller et al., 2010; Schiegl, 1996) não foram observadas na microfácies tipo A.

Apesar de que lentes discretas de cinzas, acompanhadas de material queimado (Courty et al., 1989; Wattez, 1992), são frequentemente usadas como evidência de queima no local, a pequena acumulação de cinzas de madeira encontrada na seção delgada MO 3b tampouco indica queima in situ. Neste caso, as cinzas formam uma lente centimétrica que repousa sobre a face externa de uma concha de A. brasiliana inteira, sem evidências de queima. Se as cinzas tivessem sido produzidas no local, a concha sobre a qual se depositaram também apresentaria evidências de alteração térmica. Por outro lado, o fato de cinzas de madeira terem-se preservado neste local indica que sua ausência não se deve à dissolução, mas sim ao fato de não terem sido depositadas massivamente nos sambaquis.

Isto vincula-se com a ausência de fitólitos, mencionada no tópico 1.5.2, e a baixa frequência de escória vítrea e/ou agregados de material silicoso. Carvão, cinzas de madeira ou gramíneas, fitólitos e agregados de material silicoso são típicos subprodutos da queima de material vegetal (Albert and Cabanes, 2008; Canti, 2003; Schiegl, 1996; Schiegl et al., 1994). A baixa frequência destes componentes nos sambaquis, com exceção dos carvões, sugere baixa taxa de deposição nos sítios.

Portanto, as características micromorfológicas permitem inferir que a microfácies de tipo A contém os produtos do retrabalhamento, seja por varrido ou redepositação, de materiais depositados e também queimados em local diferente do de acúmulo final (ver Courty et al., 2012; Goldberg et al., 2009, 2012; Miller et al., 2010; Schiegl et al., 2003). Esta área de queima poderia estar localizada sobre o sambaqui ou 
fora do sítio, sobre o depósito natural de onde teriam vindo, casualmente, parte dos componentes terrígenos.

O empacotamento aberto dos componentes e a porosidade desta microfácies excluem a possibilidade de retrabalhamento por pisoteamento. Nenhum indicador micromorfológico de pisoteamento, tanto em concheiros (ver Balbo et al., 2010; Villagran et al., 2011 a) como em outros contextos (ver Goldberg et al., 2009, 2012; Miller et al., 2010; Schiegl et al., 2003) foi identificado nesta microfácies.

\subsubsection{Microfácies tipo B: retrabalhamento de fogueiras}

$\mathrm{Na}$ categoria $\mathrm{B}$, incluem-se as microfácies que apresentam assembleia de componentes alterados termicamente, como cinzas, conchas e ossos queimados, agregados de argila rubefacta e carvão. No gráfico da Figura 6.4, estas microfácies não mostram agrupamento claro, já que materiais queimados não foram considerados como variáveis na análise de componentes principais. No mesmo gráfico, a mF 7.1 de Jabuticabeira 1 aparece separada dos quatro agrupamentos principais, enquanto a $\mathrm{mF}$ 4.1 de Morrinhos agrupa-se com a mF 7.2 de Jabuticabeira 1, localizada, na lâmina, imediatamente abaixo de $\mathrm{mF}$ 7.1. As características desta microfácies agrupam-se no Quadro 6.4.

Quadro 6.4. Características da microfácies tipo B.

\section{MICROFÁCIES TIPO B}

\begin{tabular}{ll}
\hline Microestrutura & Microagregados intergranulares \\
$\begin{array}{l}\text { Dist. rel. g/f } \\
\text { Vazios }\end{array}$ & Enáulica e porfírica \\
Porosidade & Vazios de empacotamento complexo \\
Razão g/f & $20-40 \%$ \\
Fração grossa & $30 / 70$ e $85 / 15$ \\
& 1) Conchas $(53-55 \%), 30 \%$ da quais apresentam queima a temperatura superior a \\
Distribuição da & $\left.600^{\circ} \mathrm{C} ; 2\right)$ fragmentos de osso $(5 \%)$ com sinais de queima. \\
fração grossa & Conchas com distribuição sub-horizontal; ossos com distribuição aleatória \\
$\begin{array}{l}\text { Comp. menores } \\
\text { Micromassa }\end{array}$ & Perióstraco queimado, restos de tecidos silicificados \\
\hline
\end{tabular}

Pela assembleia de componentes e características micromorfológicas, estas microfácies podem ser interpretadas como resíduos de fogueiras in situ (ver Aldeias et al., 2012; Courty et al., 2012; Goldberg et al., 2009, 2012; Miller et al., 2010; Vallverdú et al., 2012). No entanto, assim como discutido para as microfácies tipo A, 
existem evidências que impedem a associação direta da microfácies B com estruturas de combustão. O primeiro indicador é o contato abrupto que apresentam com as microfácies inferiores, sem evidências de alteração térmica. Na hipótese de a queima ter acontecido no local, existiria um gradiente de alteração dos materiais desde o núcleo da queima até alguns centímetros no substrato (Berna et al., 2007; Canti and Linford, 2000; Miller et al., 2010). No caso dos sambaquis, esta alteração envolveria conchas queimadas junto com concentrações de carvões e cinzas.

Apesar de a rubefação do substrato ser frequentemente usada como indicador de sedimentos expostos a altas temperaturas e de fogueiras in situ (Mallol et al., 2007; Schiegl et al., 2003; Wattez, 1992; Weiner, 2002), este atributo não necessariamente aparece em fogueiras de curta duração sobre substrato conchífero, como mostrado na fogueira experimental discutida no Capítulo 5, tópico 1.1.3. No entanto, não é unicamente a falta de substrato rubefacto o que impede a associação com queima in situ na microfácies tipo $\mathrm{B}$, mas sim também a ausência de estruturas de combustão visíveis no perfil, como mostrado no Capítulo 5, tópico 1.1.2.

Além disso, na microfácies tipo B do sítio Morrinhos, existe uma concentração milimétrica de agregados de argila queimada, com um grande agregado de argila rubefacta, acima de conchas com evidências de queima a temperatura superior aos $600^{\circ}$ C. Isto indicaria uma inversão na estratificação típica de queima in situ, na qual as conchas queimadas repousariam sobre a argila queimada e rubefacta. Na microfácies B do sítio Jabuticabeira 1, observa-se uma inversão semelhante, já que existe concentração de agregados milimétricos de argila rubefacta acima da lente de conchas queimadas que se misturam com agregados de argila carbonizada.

Todos estes indicadores sugerem que, apesar de conter uma associação de componentes com indiscutível alteração térmica, a microfácies tipo B não representa fogueiras in situ e sim, novamente, o retrabalhamento de materiais. A grande diferença com a microfácies tipo A é que, no caso da microfácies $\mathrm{B}$, todos os componentes estão queimados, tanto da fração grossa como da fração fina. Esta diferença pode sugerir que o transporte desde o local original onde a fogueira teria estado acesa não seria longo, o que favoreceu a manutenção do arranjo relativo de materiais. Ao mesmo tempo, a associação com microfácies de tipo A sugere que a microfácies de tipo B possa ter resultado da queima sobre depósitos de microfácies de tipo A.

Concentração de materiais queimados sobre substrato não queimado foi descrita por Schiegl et al. (2003) em um sítio em caverna do Paleolítico. Os autores interpretam 
tal associação como produto da deposição secundária (dumping) de restos de uma fogueira localizada a poucos metros de distância, na entrada da caverna. Miller et al. (2010) também identificaram associação ente materiais queimados sobre substrato não alterado em fogueiras experimentais varridas a pouca distância da área de queima. Isto pode significar que a microfácies de tipo B possa ter resultado do retrabalhamento do materrial de fogueiras localizadas a pouca distância da área final de deposição.

\subsubsection{Microfácies tipo C: agregados de lama de depósitos paleolagunares}

O tipo $\mathrm{C}$ concentra as microfácies compostas por agregados de lama com diatomáceas, grãos de argila glauconítica e gastrópode. No gráfico da Figura 6.4, corresponde ao grupo A que inclui: Morrinhos $\mathrm{mF} 4.3$ e Jabuticabeira $1 \mathrm{mF}$ 7.4. As características desta microfácies agrupam-se no Quadro 6.5.

Quadro 6.5. Características da microfácies tipo C.

\begin{tabular}{ll}
\hline & \multicolumn{1}{c}{ MICROFÁCIES TIPO C } \\
\hline Microestrutura & Maciça \\
Dist. rel. g/f & Porfírico \\
Vazios & Em câmara, regulares, em fissuras, de empacotamento composto \\
Porosidade & $10 \%$ \\
Razão g/f & $10 / 90$ \\
Fração grossa & 1) Grãos de quartzo e argila glauconítica $(26-40 \%)$ na fração areia muito fina; 2) \\
& $\begin{array}{l}\text { conchas de bivalve e de Heleobia } \text { sp. (7-20 \%); 3) diatomáceas (3-5\%), com } \\
\text { predomínio de Paralia sulcata }\end{array}$ \\
$\begin{array}{l}\text { Distribuição da } \\
\text { fração grossa } \\
\text { Micromassa }\end{array}$ & Aleatória \\
\hline
\end{tabular}

Pela granulometria e assembleia faunística (diatomáceas e gastrópode), os agregados de lama teriam sido coletados em fundos lagunares lamosos. Estes agregados teriam vindo junto com as conchas de marisco, da espécie Mytella sp., que aparecem em alta frequência nos dois sambaquis onde os agregados foram observados (Morrinhos e Jabuticabeira 1). Estes mesmos agregados aparecem queimados, rubefactos e carbonizados nas microfácies de tipo $\mathrm{B}$, em associação com conchas queimadas $\mathrm{e}$ tecidos silicificados. 


\subsubsection{Microfácies tipo D: areia com revestimentos de argila}

As microfácies do tipo D concentram-se no grupo B do gráfico da Figura 6.4: Morrinhos mF 3.2 e 4.2. Aparece, portanto, unicamente no sambaqui Morrinhos, composta por areias quartzosas e feldspáticas, com poucas conchas, revestidas por argilominerais com concentrações de diatomáceas. As características desta microfácies agrupam-se no Quadro 6.6.

Quadro 6.6. Características da microfácies tipo D.

\begin{tabular}{|c|c|}
\hline \multicolumn{2}{|r|}{ MICROFÁCIES TIPO D } \\
\hline Microestrutura & Microagregados intergranulares e grãos revestidos interligados \\
\hline Dist. rel. g/f & Enáulica, quitónica e gefúrica \\
\hline Vazios & Vazios de empacotamento complexo \\
\hline Porosidade & $30 \%$ \\
\hline Razão g/f & $90 / 10$ \\
\hline Fração grossa & $\begin{array}{l}\text { 1) Grãos de quartzo }(55-65 \%) \text { e feldspato }(15 \%) \text {, na fração areia fina; } 2) \text { conchas } \\
\text { inteiras e fragmentadas }(10-15 \%) ; 3) \text { minerais pesados anisotrópicos, opacos, } \\
\text { grãos de argila glauconítica (total }<10 \%) \text {, na fração areia muito fina; 4) Heleobia } \\
\text { sp. }(3-5 \%) \text {; } 5 \text { ) diatomáceas }(3 \%) \text {; fragmentos de osso }(2 \%)\end{array}$ \\
\hline $\begin{array}{l}\text { Distribuição da } \\
\text { fração grossa }\end{array}$ & Aleatória \\
\hline Micromassa & $\begin{array}{l}\text { Argilominerais castanho claro (PPL) na forma de revestimentos e agregados } \\
\text { esféricos }\end{array}$ \\
\hline
\end{tabular}

As microfácies do tipo D representam lâminas de areia com presença intrusiva de conchas e micromassa formada pela compactação mecânica e iluviação de agregados de argilominerais, do mesmo tipo que compõe os agregados de lama da microfácies tipo B.

\subsubsection{Microfácies tipo E: desenvolvimento de solo no topo do sambaqui}

$\mathrm{Na}$ categoria E, agrupam-se as microfácies localizadas no topo das sucessões estratigráficas dos sítios Caipora e Cubículo 1, nos quais já tinha sido constatado, em campo, o desenvolvimento de solo incipiente: Caipora mF HzA e Cubículo $1 \mathrm{mF}$ HzA. As características desta microfácies agrupam-se no Quadro 6.7. 
Quadro 6.7. Características da microfácies tipo E.

\begin{tabular}{ll}
\hline & \multicolumn{1}{c}{ MICROFÁCIES TIPO E } \\
\hline Microestrutura & $\begin{array}{l}\text { Grânulos coesivos }(250-500 \mu \mathrm{m} \text { de cumprimento) e/ou microestrutura grumosa } \\
\text { coesiva (agregados de } 2-5 \mathrm{~mm})\end{array}$ \\
Dist. rel. g/f & Porfírico e mônico \\
Vazios & Em câmara, canais, fissuras e vesículas \\
Porosidade & $10-20 \%$ \\
Razão g/f & $50 / 50$ até $10 / 90$ \\
Fração grossa & 1) Grãos de quartzo, feldspato e fragmentos líticos $(20-45 \%) ; 2)$ fragmentos de \\
& osso $(6-20 \%)$ com sinais de dissolução e queima a temperatura diversa; 3) \\
fragmentos de concha $(10 \%)$ \\
Distribuição da & Aleatória \\
fração grossa & \\
Micromassa & Argilominerais com MO e micrita \\
\hline
\end{tabular}

Pela sua posição superficial na sucessão vertical e contato abrupto com microfácies de tipo A, este tipo de microfácies teria resultado da deposição sobre os sambaquis de materials terrígenos dos arredores (grãos de quartzo e argilominerais) com sedimento retrabalhado da superfície do sambaqui (fragmentos finos de concha e osso).

\subsection{FORMAÇÃO DE SAMBAQUIS CONCHÍFEROS}

A partir das informações reunidas nos tópicos anteriores, derivadas da interpretação dos dados de campo, análises granulométricas, faunísticas, isotópicas e micromorfológicas, pode-se dizer, a modo de síntese, que os sambaquis conchíferos são depósitos produzidos pelo retrabalhamento de materiais de proveniência diversa. Isto significa que existem poucos indicadores de depósitos primários e robustas evidências que apontam à deposição massiva de resíduos alimentares.

A identificação de arqueofácies feita no campo mostra que a estratigrafia aparentemente complexa dos sítios pode ser resumida em três arqueofácies maiores: 1) com predomínio de conchas e ossos; 2) lenticulares pretas com restos vegetais, carvão e ossos queimados; 3 ) com predomínio de sedimentos terrígenos, com conchas inteiras na base dos depósitos. Os materiais terrígenos que compõem as arqueofácies refletem o contexto geológico-geomorfológico imediato de localização dos sítios (afloramentos graníticos e depósitos paleolagunares), assim como os sedimentos do banco de moluscos explorado. As arqueofácies com predomínio de conchas apresentam, além dos macro-moluscos predominantes (A. brasiliana ou Ostrea sp.), ossos de peixe, resíduos 
da decomposição de tecidos animais e plantas arbustivas. Estas arqueofácies seriam produto do retrabalhamento e concentração de resíduos. Já as arqueofácies lenticulares pretas estão compostas, principalmente, por restos de plantas, com influência de nitratos de origem animal. Estas arqueofácies poderiam representar superfícies de ocupação diferenciadas, formadas pelos resíduos da hipotética existência de fibras vegetais trançadas.

Dos três conjuntos de arqueofácies, o primeiro apresenta a maior diversidade no nível micromorfológico. Cinco tipos de microfácies foram identificados neste grupo, recorrentes tanto no nível intra-sítio e inter-sítio, o que sugere a existência de processos deposicionais de formação de sambaquis repetidos no tempo e no espaço. As características micromorfológicas gerais dos sambaquis conchíferos permitem atribuir as microfácies predominantes (microfácies tipo A e B) a depósitos secundários de tipo midden, definidos como depósitos de acumulação de elementos descartados após uso ou consumo (Beck and Hill Jr, 2004; Needham and Spence, 1997; Schiffer, 1972, 1983; Wilson, 1994). Estes depósitos assumem a forma de montículo ou camada espessa dentro da estratigrafia dos sítios, compostos por uma mistura aleatória de materiais orgânicos (tecidos vegetais, carvão), restos não comestíveis de alimentos (ossos e conchas) e detritos associados à produção de artefatos ${ }^{106}$.

A mistura de materiais, que envolve desde sedimentos naturais, resíduos de fogueiras (cinzas, escória vítrea, carvão), ossos com diversos graus de queima, fragmentação e decomposição, conchas inteiras ou fragmentadas, com dissolução intensa e queima, sugere retrabalhamento de materiais vindos de fontes diversas. Ou seja, os sambaquis conchíferos estão compostos, majoritariamente, de materiais retrabalhados de depósitos naturais e de depósitos de acumulação de resíduos e fogueiras. Isto significa que, nestes sítios, material descartado imediatamente após uso ou coleta encontra-se depositado junto com material que já sofreu processos de alteração, seja antrópica, como queima, seja natural, como intemperismo. A complexa história pré-deposicional dos componentes permite associar estes sítios com depósitos terciários ou de midden secundário (ver Courty et al., 1989; Schiffer, 1983). Observação

\footnotetext{
${ }^{106}$ Em seção delgada, os middens apresentam microestrutura de microagregados intergranulares, vazios de empacotamento complexo, porosidade alta, componentes biológicos e biominerais com bordas angulosas, distribuição aleatória da fração grossa e micromassa heterogênea formada por matéria orgânica, fosfatos e argilominerais (Courty et al., 1989; Goldberg and Whitbred, 1993; Matthews et al., 1997; Simpson, 1996).
} 
semelhante foi realizada na camada preta do sítio Jabuticabeira 2, onde existe a mesma mistura de materiais queimados a diversa temperatura, com materiais intemperizados em matriz predominantemente fosfática (Villagran, 2008, 2010; Villagran et al., 2009 a, 2010). Apesar de não conter conchas na sua composição, as características dos componentes da camada preta, em termos de história deposicional, são assemelháveis ao observado nos quatro sambaquis conchíferos analisados.

A prática de acumular resíduos na formação dos sítios mostra uma permanência milenar no sistema sócio-cultural das populações costeiras, já que se observa desde o sambaqui conchífero mais antigo da área de estudo (datado em ca. 7500 AP) até sítios com cerca de 2000 anos de antiguidade. Este período abrange as fases 1, 2 e 3 de ocupação sambaquieira do litoral sul catarinense (segundo Giannini et al. 2010), com mais de 5500 anos de duração total. A extensão geográfica e temporal deste padrão deposicional resulta chave para entender o significado das práticas associadas à formação dos sambaquis, com deposição continua de conchas e demais resíduos.

Cabe ressaltar que as evidências apontam à acumulação de materiais em área externa ao sambaquis (especificamente para as microfácies de tipo A) junto com redeposição de restos de fogueiras acesas, provavelmente, sobre o sítio (para as microfácies de tipo B). Isto indica que áreas de habitação e/ou acumulação/queima de resíduos associadas aos grandes sambaquis podem se encontrar fora do sítio e não seriam detectáveis a simples vista, pela ação de retrabalhamento até os sambaquis. Além disso, pela intensa dinâmica de assoreamento do sistema lagunar que caracterizou a região desde o Holoceno Médio, estas superfícies estariam, atualmente, soterradas por sedimentos modernos.

\section{NÚCLEO ARENOSO}

Os sambaquis de núcleo arenoso (Santa Marta 10 e Carniça 3) estão todos localizados no setor externo e situados sobre, ou em meio a, dunas e paleodunas eólicas. A partir da identificação de fácies e arqueofácies realizada em campo, identificaram-se duas unidades maiores nestes sítios: 1) arqueofácies decimétrica superficial preta, com MO e conchas (AF 2 de Carniça 3 e Fácies B mais AF 1 de Santa Marta 10); 2) fácies 
ou arqueofácies métrica inferior, composta por areias quartzosas (AF 1 de Carniça 3 e Fácies A de Santa Marta 10).

A escolha pela denominação de fácies ou arqueofácies em cada sítio é dada pela origem antrópica ou natural do depósito. No caso do sítio Carniça 3, estudos sedimentológicos indicaram que a deposição do núcleo arenoso é de origem antrópica, e não eólica (Tanaka 2007; Tanaka et al. 2009). A sua cronologia, 3810-3360 anos cal. $\mathrm{AP}$, é contemporânea às paleodunas de geração 3 da região, posteriores à máxima transgressão holocênica. Pelo contrário, o sítio Santa Marta 10 está localizado sobre paleodunas de geração 2 formadas, segundo Giannini (1993) e Giannini et al. (2007), antes do máximo transgressivo na região, por sua vez datado como anterior a 5700 anos AP (Angulo et al. 1999, 2006). A cronologia do sítio, 6180-5750 anos cal AP, é coerente com a idade proposta para os depósitos eólicos.

Duas arqueofácies compõem os sítios Carniça 3 e Santa Marta 10:

1) Arqueofácies superficial preta, com $\mathrm{MO}$ e conchas

2) Arqueofácies/fácies inferior, formada por areias quartzosas

Nos tópicos a seguir, apresenta-se a discussão das análises laboratoriais realizadas nas arqueofácies e fácies amostradas dos dois sambaquis de núcleo arenoso analisados.

\subsection{SEDIMENTOS TERRÍGENOS}

Nos sambaquis de núcleo arenoso, a relação entre depósitos arqueológicos e naturais é mais facilmente observável, graças à menor influência antrópica na composição dos sedimentos arqueológicos. Tanto no sambaqui Santa Marta 10 como Carniça 3, a comparação entre as distribuições granulométricas das frações arenosas terrígenas presentes no núcleo arenoso e na camada de areia lamosa preta superior (Fácies B e AF 2, respectivamente) indica similaridade entre ambos. Isto é interpretado como indicador de proveniências análogas para os sedimentos terrígenos que compõem o núcleo arenoso e a camada de areia lamosa superficial. 
No caso de Santa Marta 10, a estratigrafia do sítio sugere deposição eólica para as areias que compõem a Fácies B, e deposição antrópica apenas para o anel de conchas, identificado como AF 1. Estas areias estariam associadas às paleodunas eólicas de geração 2 que afloram nas proximidades do sítio, como mostrado pela comparação com os dados sedimentológicos tomados de Giannini (1993), Sawakuchi (2003), Martinho (2004), Giannini et al. (2007). Em Carniça 3, a presença de conchas de A. brasiliana e de fragmentos de osso e carvão em meio às areias quartzosas que compõem a $\mathrm{AF} 2$ indica deposição antrópica para os sedimentos terrígenos. Estas areias teriam sido coletadas em depósitos paleolagunares da planície de Campos Verdes.

As areias quartzosas que compõem a arqueofácies superficial e núcleo arenoso mostram afinidade com depósitos eólicos e/ou paleolagunares das proximidades dos sambaquis.

\subsection{ASSEMBLEIA MALACOLÓGICA}

Três espécies de moluscos e um gastrópode (Quadro 6.8) foram identificados na assembleia malacológica dos sambaquis de núcleo arenoso. A escassa diversidade associa-se ao domínio, e quase exclusividade, de A. brasiliana. A exclusividade de uma espécie contrasta com a diversidade relatada para os sambaquis conchíferos nos quais, apesar de existirem pelo menos duas espécies dominantes (A. brasiliana ou Ostrea sp.) a maior diversidade específica permitiu interpretar multi-preveniência para os moluscos que compõem os sítios.

As conchas de $A$. brasiliana aparecem comumente inteiras, com frequência de $\sim 50 \%$, em Santa Marta 10, e $\sim 86 \%$, em Carniça 3 (Quadro 6.9). A porcentagem de fragmentos de conchas desta espécie é maior em Santa Marta 10 (48\% contra $12 \%$ em Carniça 3). Pela cronologia de Santa Marta 10 (cerca de 6000 AP) e Carnila Carniça 3 (3500 AP) pode-se inferir que o uso de $A$. brasiliana caracteriza os sambaquis de núcleo arenoso desde os momentos mais remotos de ocupação sambaquieira na região. Isto corrobora as observações de Peixoto (2009), realizada nos sambaquis de núcleo arenoso Encantada 3, Canto da Lagoa 1 e 2, Lagoa dos Bixos 2 e Carniça 3, 6 e 7. Observação 
semelhante foi realizada por Assunção (2010), que realizou sondagens em vários sambaquis de núcleo arenoso da região de Campos Verdes e Santa Marta.

O fato de se achar alta concentração de $A$. brasiliana em Santa Marta 10, o sítio mais antigo do setor externo, com conchas datadas em 6180-5750 anos cal AP, indica que havia disponibilidade desta espécie na região desde a época aproximada da máxima transgressão holocênica, quando o sistema era supostamejnte mais aberto. Em praias de mar aberto, é possível achar bancos de A. brasiliana, sempre que existam as condições de salinidade das águas (entre 38 e 16 partes por mil) e de energia (moderada) favoráveis ao desenvolvimento deste molusco. Tais condições são encontradas em praias protegidas, de enseadas e baías, como reporta Schaeffer-Novelli (1976) no litoral norte de São Paulo. Nos concheiros naturais estudados por Fornari (2010), localizados na margem sudoeste da atual laguna Garopaba do Sul, achou-se domínio de $A$. brasiliana a profundidades de até 2,2 m e idades de 5560-5320 anos cal AP. Nos testemunhos analisados por Nascimento (2011), também se encontraram concheiros naturais com A. brasiliana datados de 8013-7800 anos cal. AP. Estes depósitos encontram-se em locais que, há 7900 ou 4700 anos atrás, seriam costas protegidas da ação direta do mar, com aporte de água doce por rios que drenavam a paleobaía.

Apesar da semelhança composicional entre os dois sambaquis de núcleo arenoso estudados, destaca-se uma divergência marcante na frequência de indivíduos de $A$. brasiliana juvenis. Como representativos de indivíduos juvenis, foram consideradas as conchas de $A$. brasiliana de cumprimento menor que $1 \mathrm{~cm}$ já que, acima do intervalo de comprimento entre 0,8 e $1,0 \mathrm{~cm}$, os indivíduos já são considerados sexualmente maduros (Grotta and Lunetta, 1980). Em Santa Marta 10, conchas inteiras e menores que $1 \mathrm{~cm}$ de comprimento, inclusive fechadas, perfazem mais de $4 \%$ do total desta espécie. Em Carniça 3, pelo contrário, nenhum indivíduo juvenil foi recuperado. Isto pode indicar uma diferença na estratégia de acumulação e coleta para formação de cada sítio, com coleta direcionada a indivíduos adultos em Carniça 3, vs. coleta sem seleção, embora focada na recuperação de A. brasiliana, em Santa Marta 10.

Esta diferença pode relacionar-se com o contraste no formato do depósito faunístico de cada sítio. O anel de conchas que caracteriza Santa Marta 10, e que não foi observado em nenhum outro sambaqui da região, parece representar o produto direto da coleta, transporte e acumulação dos componentes a partir de um concheiro natural, possivelmente ativo durante a formação do sambaqui. Já em Carniça 3, onde se destaca a quase exclusividade de $A$. brasiliana adultas na assembléia faunística, as conchas 
estão misturadas com areia, alguns ossos de peixe e matéria orgânica; existe, portanto, coleta seletiva com processamento dos moluscos, junto com outros restos orgânicos, prévio à deposição. A maior seleção observada em Carniça 3 pode-se dever, também, ao desenvolvimento de estratégias de coleta de moluscos com uso de instrumentos mais elaborados e seletivos, como redes, por exemplo. Estes artefatos não afetariam os indivíduos juvenis e, desta maneira, favoreceriam a reprodução do banco de moluscos.

Quadro 6.8. Espécies de moluscos identificadas nos sambaquis Santa Marta 10 e carniça 3, com descrição do substrato e ambiente onde a espécie vive. Dados sobre vermetídeos e cirripídeos tomados de Laborel and Laborel-Deguen (1996). Demais moluscos tomados de Rios (1985).

\begin{tabular}{|c|c|c|}
\hline Espécie & Substrato & Ambiente \\
\hline $\begin{array}{l}\text { Anomalocardia brasiliana } \\
\text { (Gmelin 1791) }\end{array}$ & Arenoso e areno-lamoso & $\begin{array}{l}\text { Até } 5 \mathrm{~m} \text { de profundidade, em regiões } \\
\text { entremarés ede baías, estuários e lagunas. } \\
\text { Eurihalina }\end{array}$ \\
\hline $\begin{array}{l}\text { Heleobia } \text { sp. } \\
\text { (Stimpson 1865) }\end{array}$ & $\begin{array}{l}\text { Lamoso ou areno-lamoso, } \\
\text { também sobre algas verdes }\end{array}$ & Estuários e lagunas. \\
\hline $\begin{array}{l}\text { Macoma sp. } \\
\text { (Orbigny 1846) }\end{array}$ & Areno-lodoso & Região entremarés em estuários e lagunas. \\
\hline $\begin{array}{l}\text { Nassarius vivex } \\
\text { (Say 1822) }\end{array}$ & $\begin{array}{l}\text { Lamosos e de planícies } \\
\text { arenosas }\end{array}$ & $\begin{array}{l}\text { Água rasa e salobra, em estuários e } \\
\text { lagunas. }\end{array}$ \\
\hline
\end{tabular}

Quadro 6.9. Distribuição de espécies de moluscos nos sítios Santa Marta 10 e Carniça 3. •••• = espécie dominante $(50-70 \%) ; \cdots=$ espécie frequente $(10-50 \%) ; \bullet=$ poucos indivíduos ou fragmentos $(1-10 \%) ; \bullet$ $=$ ocasionais $(<1 \%)$.

\begin{tabular}{lcc}
\hline Espécie & Santa Marta 10 & Carniça 3 \\
\hline Anomalocardia brasiliana & $\bullet \bullet$ & $\cdots$ \\
Heleobia sp. & $\bullet$ & \\
Macoma sp. & $\bullet$ & \\
Nassarius vivex & $\bullet$ & $\bullet$ \\
Malha de $2 \mathrm{~mm}$ & $\bullet$ & $\cdots$ \\
\hline
\end{tabular}


Nos sambaquis de núcleo arenoso, há domínio, e quase exclusividade, da espécie $A$. brasiliana. A presença desta espécie no sítio Santa Marta 10, o mais antigo do setor externo, indica disponibilidade deste molusco desde antes do máximo transgressivo holocênico, assim como seu uso na construção de sítios desde o início da ocupação sambaquieira na região. O formato anelar da acumulação de conchas observado em Santa Marta 10, com freqüência considerável de indivíduos juvenis, sugere coleta não selecionada, embora direcionada a captura desta espécie. A aleatoriedade da disposição das conchas em Carniça 3 indica deposição conjunta com sedimentos terrígenos e outros resíduos antrópicos derivados da queima. A ausência de indivíduos juvenis, contrário ao observado em Santa Marta 10, sugere coleta seletiva e/ou uso de instrumentos de coleta que favorecem a captura de indivíduos adultos.

\subsection{COMPONENTES VEGETAIS}

Análises isotópicas de $\mathrm{C}$ e $\mathrm{N}\left(\delta^{13} \mathrm{C}\right.$ e $\left.\delta^{15} \mathrm{~N}\right)$ realizadas nos sítios Santa Marta 10 e Carniça 3 indicaram a presença exclusiva de plantas de ciclo fotossintético $C_{3}$ na camada de areia lamosa preta (com conchas, no caso de Carniça 3) que recobre os sambaquis. Estes sambaquis apresentam os menores valores de $\delta^{15} \mathrm{~N}$ dos oito sambaquis analisados nesta tese: $+7,39$ e $+8,5$, para Santa Marta 10 e Carniça 3, respectivamente (Figura 6.2 D). Isto significa que, diferente do observado nos sambaquis conchíferos, não existe $\mathrm{MO}$ derivada de resíduos animais nos sambaquis de núcleo arenoso e sim unicamente MO vegetal. Esta MO estaria vinculada principalmente à decomposição de espécies $\mathrm{C}_{3}$ sobre o montículo arenoso.

Interpreta-se que a MO está associada à ação humana no local e não corresponde à vegetação que atualmente cobre os montículos por dois motivos: espessura decimétrica e coloração preta das arqueofácies amostradas, que não se corresponde com o delgado horizonte de solo castanho claro que se desenvolve atualmente nos depósitos eólicos da região; e presença de conchas de moluscos misturadas com areia e material orgânico, no caso do Carniça 3, e na forma de bolsão de forma anelar, no caso de Santa Marta 10. 
Unicamente em Santa Marta 10, coletou-se amostra do horizonte de solo superficial que se desenvolve sobre as paleodunas próximas ao sítio. A assinatura isotópica da MO no sambaqui e na paleoduna apresentaram valores muito próximos de $\delta^{13} \mathrm{C}$ e $\delta^{15} \mathrm{~N}$ (Figura $6.2 \mathrm{D}$ ), o que poderia ser interpretado como indicação de origem análoga. No entanto, existe uma diferença importante de razão $\mathrm{C} / \mathrm{N}$ entre a amostra arqueológica e a natural, com valores de 19.11 e 10.00, respectivamente. Esta diferença está vinculada ao teor de C orgânico, com concentração de 1,72 \% no sambaqui e de 0,20 \% no depósito natural. Os valores de nitrogênio total não apresentam diferenças consideráveis (valores de 7,39 \% e 7,82 \% no sambaqui e depósito natural, respectivamente). Isto significa que existe uma fração de $\mathrm{C}$ no sambaqui diferente da que compõe o solo sobre a paleoduna, que resulta no enriquecimento de quase $100 \%$ do valor de $\mathrm{C}$ orgânico no sítio arqueológico, apesar de ambos os depósitos estarem compostos por MO derivada de espécies $\mathrm{C}_{3}$.

$\mathrm{Na}$ paleoduna, a MO estaria vinculada a musgos que crescem no topo, pertencentes ao grupo de plantas de ciclo fotossintético $C_{3}$ (Raven et al., 1998; Skrzypek et al., 2007 a, 2007b). No sambaqui, a diferença nos valores de C orgânico podem dever-se à presença de resíduos da queima de espécies arbustivas, como carvões e micro-carvões. Pelo método utilizado para determinação da porcentagem de $\mathrm{C}$ orgânico, que envolve o aquecimento das amostras a $550^{\circ} \mathrm{C}$, é possível que parte do $\mathrm{C}$ dos carvões tenha sido volatilizado e medido como componente do $\mathrm{CO}_{2}$ liberado na combustão, o que provocou a super-estimação do teor de C orgânico no sambaqui.

No trabalho de Menezes (2009), valores semelhantes de $\delta^{13} \mathrm{C}$ e $\delta^{15} \mathrm{~N}$ foram observados na MO do sítio Encantada 3 e no depósito paleolagunar das proximidades, com presença de plantas $\mathrm{C}_{3}$ em ambos. A autora interpreta isso como indicador de origens análogas para a MO dos depósitos arqueológicos e paleolagunares das proximidades, interpretação que é extrapolada ao sítio Carniça 3 pela semelhança estratigráfica e composicional com Encantada 3. No entanto, apesar da assinatura isotópica de Carniça 3 corresponder com plantas $\mathrm{C}_{3}$, a razão $\mathrm{C} / \mathrm{N}$ é tão alta quanto em Santa Marta 10, com valores de 17, neste trabalho, e 21-22, em Menezes (2009). Isto sugere que o mesmo enriquecimento por C elementar, interpretado para Santa Marta 10 como derivado da presença de microcarvões, pode ter causado a super-estimação do valor de C orgânico em Carniça 3. De fato, em Carniça 3, existem outras evidências, neste caso diretas, da presença de materiais queimados na arqueofácies superficial, como ossos de peixe calcinados, carbonizados e carvões. 
A MO da arqueofácies superficial preta em Carniça 3 e Santa Marta 10 compõe-se por restos de plantas $\mathrm{C}_{3}$. Estes restos incluem, além da $\mathrm{MO}$ resultante da decomposição de tecidos frescos, microcarvões derivados da queima de espécies arbustivas.

\subsection{MICRO-COMPONENTES}

Análises micromorfológicas foram realizadas em quatro seções delgadas. Três amostras correspondem ao sítio Santa Marta 10 e incluem lâminas do sambaqui e de depósito de paleoduna eólica das proximidades. Do sambaqui Carniça 3 coletou-se uma única amostra da camada superior de areia lamosa com conchas. Apesar da semelhança aparente entre ambos os sambaquis, diferenças macroscópicas observam-se na distribuição dos componentes malacológicos, aglomerados em anel de conchas em Santa Marta 10 e misturados à matriz arenosa e orgânica em Carniça 3. No nível microscópico, outras diferenças foram observadas, relativas à presença de componentes de origem antrópica, como ossos e carvão, e à MO da camada superficial.

O componente mineral comum aos dois sítios estudados são os grãos de quartzo e feldspato, arredondados a subarredondados, na fração areia fina e muito fina. Em Santa Marta 10, aparecem fragmentos líticos, minerais pesados anisotrópicos, minerais opacos e clastos de argila em frequencia total menor que $3 \%$. Estes componentes já haviam sido identificados em seção delgada por Martinho \& Giannini (2001) em paleodunas eólicas de geração 2 no morro Santa Marta.

Entre os componentes biológicos e biominerais, destacam-se as conchas de $A$. brasiliana, que perfazem $50 \%$ da fração grossa de Carniça 3, e os fragmentos de osso (3\%), queimados e com marcas de dissolução. Nenhum destes componentes biológicos foi identificado em Santa Marta 10. Neste sambaqui, a influência antrópica identifica-se pelo anel de conchas e pela espessura da fácies de areia lamosa preta superior (Fácies B), que representa resíduos de acumulação humana de material vegetal sobre o depósito eólico. A diferença de componentes biológicos em ambos os sambaquis sugere divergências nos processos de formação de ambos, apesar das similaridades macroscópicas aparentes. 
A fração fina de Santa Marta 10 é formada por revestimentos de MO monomórfica e agregados de MO polimórfica. Em Carniça 3, a MO é polimórfica com ocasionais revestimentos de MO monomórifca e pseudo-revestimentos de MO polimórfica. A microestrutura em ambos os sambaquis é de microagregados intergranulares, na forma de pellets, com grãos revestidos de MO. Revestimentos de MO monomórfica e microestrutura de microagregados integranulares na forma de pellets de MO polimórfica são indicadores de horizontes de solo espódicos (Van Breemen and Buurman, 2003; Buurman and Jongmans, 2005; Wilson and Righi, 2010).

O desenvolvimento de horizontes espódicos é um atributo característico dos sambaquis de núcleo arenoso, independente da função ou uso dos sítios no passado ${ }^{107}$. No entanto, o tipo de horizonte espódico pode ajudar a entender melhor o processo de formação de cada sítio. Os horizontes espódicos representam os produtos da modificação de restos orgânicos depositados no topo dos montículos arenosos, e sua migração vertical, ou a decomposição in situ de resíduos vegetais. A formação de horizontes espódicos em sedimentos arenosos e bem drenados, como os sambaquis aqui analisados, será discutida no próximo tópico.

A análise micromorfológica mostra duas semelhanças e duas diferenças fundamentais entre os sítios Santa Marta 10 e Carniça 3. As semelhanças são o predomínio de areias quartzosas na fração grossa mineral e de fácies/arqueofácies lamosas pretas superiores. As diferenças referem-se a: 1) presença de conchas de A. brasiliana, junto com fragmentos de osso queimado e carvão, unicamente em Carniça 3; 2) MO de tipo monomórfica em Santa Marta 10, na forma de revestimentos, e de tipo polimórfica em Carniça 3, na forma de pellets.

\footnotetext{
${ }^{107} \mathrm{O}$ processo de podzolização ocorre naturalmente na região costeira estudada. No mapa de solos do estado de Santa Catarina, escala 1:250.000 (<http://mapoteca.cnps.embrapa.br $>$ ), espodossolos são mapeados na área de estudo associados a antigos depósitos lagunares e eólicos ao oeste da laguna Garopaba do Sul e nas regiões de Rio do Meio (entre as lagunas Camacho e Santa Marta) e Campos Verdes, associados a relevos planos sob vegetação de mata e campos de restinga. Da mesma maneira, os revestimentos de argila mineral identificados na Fácies A2 da paleoduna eólica nas proximidades de Santa Marta 10 evidenciam a iluviação de materiais finos em perfis arenosos e bem drenados.
} 


\subsection{ESPODOSSOLOS SOBRE DUNAS EÓLICAS}

\subsubsection{Definição}

Os espodossolos são solos minerais, desenvolvidos maiormente em substrato arenoso, que se caracterizam por apresentar uma sucessão de três horizontes sobre o horizonte C mineral: horizonte A superficial escuro; seguido de horizonte eluvial (E) de coloração cinza claro ou branca (neste último caso, dito E álbico); e horizonte iluvial B, espódico $\left(\mathrm{B}_{\mathrm{h}}, \mathrm{B}_{\mathrm{s}}\right.$ ou $\left.\mathrm{B}_{\mathrm{hs}}\right)$ de cor preta a marrom avermelhado, enriquecido em matéria orgânica, Al e/ou Fe (Van Breemen and Buurman, 2003; Lundström et al., 2000).

Segundo os sistemas de classificação de solos da FAO-Unesco (1997) e a taxonomia de solos americana (Soil-Survey-Staff, 1998), os espodossolos definem-se pela presença de horizonte $\mathrm{B}$ espódico a partir dos $12 \mathrm{~cm}$ de profundidade, com acumulação iluvial de MO associada a complexos de sílica-alumínio ou húmusalumínio, com ou sem ferro. Este horizonte desenvolve-se debaixo de horizonte O, A, $\mathrm{A}_{\mathrm{p}}$ ou $\mathrm{E}$, com mais de $2,5 \mathrm{~cm}$ de espessura. A $\mathrm{MO}$ e complexos organometálicos no horizonte B aparecem na forma de revestimentos ao redor dos grãos minerais ou de pellets entre os grãos (Van Breemen and Buurman, 2003).

Os espodossolos, tradicionalmente descritos sob florestas boreais, são também comuns em climas temperados e tropicais, desenvolvidos em materiais parentais pobres e silicáticos, como dunas eólicas, cordões litorâneos e terraços marinhos sob florestas de restinga (Van Breemen and Buurman, 2003; Coelho, 2008; Embrapa, 2006; Skjemstad et al., 1992). Sua formação envolve diversos processos físico-químicos e existem pelo menos duas teorias sobre a formação dos horizontes espódicos. A mais popular refere-se à produção de ácidos orgânicos no horizonte superficial que, na ausência de cátions divalentes neutralizantes, são transportados em solução como carbono orgânico dissolvido (DOC) (também referido como MO altamente humificada) que pode estar complexada, ou não, a $\mathrm{Al}$ e/ou $\mathrm{Fe}^{108}$. Este processo resulta na formação de

\footnotetext{
${ }^{108}$ A produção de ácidos orgânicos solúveis é favorecida pela decomposição incompleta da liteira e pela alta exsudação de ácidos orgânicos por plantas e fungos. Quando o material parental é pobre em minerais intemperizáveis, como no caso de solos arenosos, a capacidade tamponante é insuficiente para neutralizar os ácidos orgânicos formados pela decomposição da vegetação. Estes ácidos também intemperizam os minerais primários, liberando Si e íons metálicos $(\mathrm{Fe}, \mathrm{Al})$. Estes componentes migrarão favorecidos pela ação da água da chuva percolante até porções inferiores do perfil. O transporte cessa quando a matéria orgânica, ou complexos de matéria orgânica com com $\mathrm{Al}$ e/ou Fe, precipitam por saturação, ou por
} 
revestimentos de MO monomórfica ao redor dos grãos minerais, no horizonte B espódico, freqüentemente com gretas de dessecação.

A segunda teoria refere-se à produção in situ de MO no horizonte B pela degradação microbiana de raízes ou detritos vegetais, sem solubilização ou deslocamento na fase líquida. Este processo daria lugar à formação de pellets de MO polimórfica, que podem aparecer soldados (welded), na forma de agregados, ou perder a sua forma original (flowed pellets) e aparecer como pseudo-revestimentos ao redor dos grãos de areia (Van Breemen and Buurman, 2003; Buurman and Jongmans, 2005, 2002; Buurman et al., 2005; De Connick, 1980; Phillips and Fitzpatrick, 2008).

Segundo Buurman \& Jongmans (2002, 2005), ambos os processos aventados podem explicar a formação de horizontes espódicos em solos arenosos e bem drenados. Tal é o caso dos sambaquis de núcleo arenoso, nos quais a MO aparece tanto na forma de revestimentos monomórficos, como de pellets de MO polimórfica.

\subsubsection{Formação de espodossolos em sambaquis de núcleo arenoso}

No caso de Santa Marta 10, a MO na fácies B superior, que representa o horizonte B espódico, aparece maiormente na forma de revestimentos de MO monomórfica com gretas. Isto significa que houve iluviação de MO desde o horizonte superficial (Buurman \& Jongmans 2002, 2005; De Connick 1980; Phillips \& Fitzpatrick 1999). A presença de bandas de impregnação no horizonte $\mathrm{C}$ (identificado como fácies $\mathrm{A}$ ) também corrobora este processo, já que a formação das bandas (ou horizontes plácicos) deve-se igualmente ao transporte e precipitação da MO no frente de percolação, em locais onde a água perde a capacidade de transporte ${ }^{109}$.

Em Carniça 3, o horizonte espódico está representado pela AF 2. Na AF 1, que representa o horizonte $C$, não se observaram bandas de impregnação. Neste sambaqui, a MO aparece maiormente na forma de pellets de MO polimórfica, mas também como pseudo-revestimentos formados pela lavagem e desagregação dos pellets, junto com alguns revestimentos de MO monomórfica. Isto significa que houve tanto iluviação de

detenção natural do fluxo de água. Esta precipitação resulta no horizonte iluvial rico em matéria orgânica e metais solúveis, conhecido como horizonte espódico ( $\left.\mathrm{B}_{\mathrm{h}}\right)$ (Van Breemen and Buurman, 2003).

${ }^{109}$ Em espodossolos bem drenados, formam-se finas bandas de morfologia irregular debaixo do horizonte $\mathrm{B}$, que refletem descontinuidades no sistema de poros do solo, como canais de raízes, estratificação sedimentar etc. (Van Breemen and Buurman, 2003; Buurman and Jongmans, 2005). 
MO como decomposição de materiais orgânicos in situ no horizonte B. Portanto, podese pensar que a acumulação de MO na AF 2 de Carniça 3 derive da decomposição de materiais vegetais (principalmente espécies arbustivas, como indicado pela análise isotópica) que foram depositados junto com as areias quartzosas e conchas de molusco. A iluviação de MO solúvel foi menor neste sambaqui, dada a menor freqüência de revestimentos de MO monomórfica, além de ter sido possivelmente dificultada pela presença das conchas de molusco inteiras.

No Brasil, espodossolos em terraços marinhos do Quaternário costeiro foram estudados para o Estado de São Paulo, nos municípios de Bertioga, Cananéia e Ilha Cumprida (Coelho et al., 2010; Coelho, 2008; Gomes, 2005; Lopes, 2010). Nestes solos, identificou-se a formação de horizontes espódicos a partir da mobilização, transporte e precipitação de MO iluvial e da decomposição in situ de raízes. Identificouse também uma correlação entre a idade dos depósitos e os atributos morfológicos dos espodossolos, com menor espessura dos horizontes espódicos e ausência de cimentação nos depósitos mais recentes. Ao extrapolar tais conclusões aos sambaquis estudados, pode-se pensar que de fato a maior cimentação e espessura do horizonte espódico em Santa Marta 10 é condizente com a maior antiguidade do sítio. Santa Marta 10 é mais de 3000 anos anterior a Carniça 3. Em Carniça 3, pelo contrário, não há cimentação por revestimentos orgânicos, o sedimento é mais friável e o horizonte espódico menos espesso.

Nos dois sambaquis analisados, o horizonte B aflora em superfície e não há horizonte superficial de acumulação de restos orgânicos, nem horizonte eluvial. Esta ausência relaciona-se à interrupção no suplemento de material orgânico no topo do depósito arenoso. O abandono do sítio e o cessar da deposição antrópica de material vegetal provocaram o desaparecimento do horizonte $\mathrm{O}$, fonte dos ácidos orgânicos e agente de retenção de sedimentos. Quando há interrupção no suprimento de material vegetal fresco, a química da MO no horizonte A adota os atributos do horizonte $\mathrm{E}$, onde os metais são removidos pela MO iluvial e transportados até o horizonte B inferior. Também no horizonte $\mathrm{E}$, os restos orgânicos, não complexados por metais, são consumidos pelos microrganismos do solo (Buurman \& Jongmans, 2005; Buurman et al. 2005). Isto deixa o horizonte A, agora com as características de horizonte $\mathrm{E}$, 
desprovido de componentes orgânicos e metálicos que outorguem coesão ao sedimento que, ao ficar exposto, será erodido pela ação eólica até o total desaparecimento ${ }^{110}$.

O fenômeno de decapitação de horizontes de solo é frequente em áreas expostas como esta, onde a erosão eólica é intensa. A perda de horizontes A e E por erosão eólica foi quantificada em espodossolos arenosos, usados para agricultura, na Alemanha. Medidas de erosão eólica indicaram que até 172 toneladas do material de solo por hectare podem ser removidas pelo vento quando o solo está desprovido da vegetação (Sauer et al., 2007).

\subsubsection{Microcarvões e formação de horizontes espódicos}

Unicamente em Carniça 3 foram achados carvões macroscópicos na observação à lupa da fração retida na malha de $1 \mathrm{~mm}$, assim como fragmentos de osso calcinado e carbonizado, tanto na malha de $1 \mathrm{~mm}$ como na de 0,5 $\mathrm{mm}$. Fragmentos de osso também foram identificados em seção delgada, junto com partículas opacas, pretas, que podem corresponder a microcarvões. Em Santa Marta 10, apesar de não terem sido observados carvões macro ou microscópicos, a alta concentração de $\mathrm{C}$ orgânico sugere a presença destas partículas no sedimento. A presença de $\mathrm{C}$ derivado de microcarvões é de interesse na discussão sobre a formação do horizonte espódico nos sambaquis de núcleo arenoso.

Existem relatos, na literatura, da presença de carvões e microcarvões (como finas partículas de 50-100 $\mu \mathrm{m}$ ) na MO de horizontes B espódicos em solos arenosos, e que perfazem a fração dominante de carbono nos horizontes B e C (Buurman et al., 2008). O carvão, também denominado de carbono preto ${ }^{111}$, é resistente à decomposição por ser quimicamente recalcitrante, o que favorece a sua permanência nos sedimentos (Czimczik and Masiello, 2007), além de contribuir com a estabilização e retenção da MO (Glaser, 2000; Liang et al., 2006; Lima et al., 2002 a).

\footnotetext{
${ }^{110}$ Como o horizonte E pode ser erodido por causas naturais ou antrópicas (lavoura), ou pode estar mascarado pela coloração do material parental ou pela presença de MO ou atividade biológica, a sua existência não é usada como critério diagnóstico de espodossolos nos sistemas de classificação da FAOUnesco ou na taxonomia de solos norte-americana. Nestes sistemas, a identificação de MO, Al ou Fe iluvial são suficientes para identificação dos horizontes espódicos (Stutzer, 1998).

${ }^{111} \mathrm{O}$ carbono preto (black carbon) produz-se a partir da combustão de materiais orgânicos tais como combustíveis fósseis, madeira e vegetação (Schmidt and Noack, 2000). Do ponto de vista químico é considerado inerte, embora estudos recentes mostraram que pode ser suscetível a alterações diagenéticas (Cohen-Ofri et al., 2006).
} 
$\mathrm{Na}$ Amazônia, fragmentos de carvão nas frações areia e silte, junto com fragmentos de argila rubefacta, foram identificados em espodossolo arenoso associado ao sítio arqueológico Dona Stella (Arroyo-Kalin, 2008). Neste local, identificou-se um extenso sítio lítico, pré-cerâmico, datado entre 10,8-10,6 e 5,3-5,1 kA cal. AP, em horizonte espódico que se localiza sob horizonte eluvial de até $1.5 \mathrm{~m}$ de profundidade. O estudo macromorfológico, geoquímico e micromorfológico realizado por ArroyoKalin (2008) concluiu que o perfil de solo atual resultou da transformação de um latossolo argilico (clayey Oxisol), com seqüência $\mathrm{A}+\mathrm{AB}+\mathrm{B}$, em um gigantesco espodossolo. A ocupação humana, cujos restos se observam atualmente no horizonte B espódico, teria acontecido sobre um antigo perfil $\mathrm{A}+\mathrm{AB}$, que hoje se observa como sequência $\mathrm{EB}+\mathrm{B}_{\mathrm{h}}$. Este horizonte teria sido podzolizado e gradualmente soterrado por sedimentos arenosos derivados da erosão de horizontes eluviais a partir de porções mais altas do relevo. Pela análise micromorfológica, o autor observou que no atual horizonte espódico a MO não é exclusivamente de origem iluvial, como propõe a teoria clássica sobre formação de espodossolos (ver Burrman \& Jongmans, 2005), mas que inclui uma porção considerável de microcarvões que aparecem como agregados intergranulares, cuja origem não seria iluvial, mas deposicional e associada à ocupação humana pretérita.

$\mathrm{Na}$ Dinamarca, foi encontrada uma pequena ocorrência de espodossolo, de $2 \mathrm{~m}$ de diâmetro, em área de neossolos quartzarênicos (Arenosol) utilizados em tempos préhistóricos para agricultura (Kristiansen, 2001). O espodossolo está associado a um local de queima de carvão, datado de tempos medievais. No entanto, como a influência do carvão no processo de podzolização é ainda um tema pouco desenvolvido na literatura, os autores não aprofundam na temática.

Assim, espodossolos podem formar-se a partir de acumulações de MO não necessariamente derivadas da liteira superficial pobre em nutrientes em solos arenosos e bem drenados, mas também de acumulações de carbono preto derivado da queima de plantas, como se observou tanto em solos naturais como em solos associados à ocupação humana. Nos sambaquis de núcleo arenoso, microcarvões associados a fogueiras antrópicas podem vir a fazer parte da MO que perfaz o horizonte espódico, especialmente da MO que aparece na forma de agregados intergranulares (ver ArroyoKalin 2008). Microcarvões são essencialmente deposicionais e podem fazer parte da MO polimórfica, mas se a sua granulação é fina o suficiente, podem ser transportados desde horizontes superiores junto com a água de chuva que percola no solo. 
A influência humana como agente na formação de espodossolos também foi observada na Grã Bretanha, Dinamarca, Holanda, Alemanha, França e Bélgica, em solos deflorestados para práticas agrícolas que remontam até o Neolítico (ver referências em Macphail, 1989; Mikkelsen et al., 2007; Sauer et al., 2007). Por exemplo, grandes áreas de floresta foram transformadas em campos para agricultura através do desmatamento e queima durante a Idade do Bronze na Inglaterra. Isto teria desencadeado a remoção dos nutrientes do solo, acidificação e incremento da iluviação que, em última instância, provocou a transformação de antigos solos de areia argilosa, associados a florestas, em espodossolos (Dimbleby, 1962).

\subsection{MICROFÁCIES}

A identificação de microfácies nos sambaquis de núcleo arenoso foi mais simples que nos sambaquis de padrão estratigráfico conchífero, devido à maior simplicidade e semelhança das microfábricas. Segundo os cinco parâmetros mencionados no Capítulo 4, tópico 1.2.2, no sítio Santa Marta 10 foram identificadas duas microfácies, uma correspondente a Fácies B e outra a Fácies A, subjacente. A Fácies B foi descrita como horizonte espódico. A Fácies A representa o núcleo arenoso de paleoduna de geração 2. No sambaqui Carniça 3, identificou-se uma única microfácies correspondente à $\mathrm{AF} 2$, também descrita como horizonte espódico, na qual aparecem conchas inteiras de $A$. brasiliana, fragmentos de osso queimado e carvões.

Assim, existem três microfácies nos sambaquis de núcleo arenoso estudados: 1) horizonte B espódico com revestimentos de MO monomórfica; 2) horizonte B espódico com pellets de MO polimórfica em arcabouço de conchas; 3) sedimentos eólicos.

\subsubsection{Microfácies tipo F: horizonte espódico iluvial}

A microfácies tipo F refere-se à amostra coletada da Fácies B do sítio Santa Marta 10, interpretada como horizonte espódico desenvolvido sobre sedimentos eólicos. Suas características micromorfológicas agrupam-se no Quadro 6.10. 
Quadro 6.10. Características da microfácies tipo F.

\begin{tabular}{ll}
\hline & \multicolumn{1}{c}{ MICROFÁCIES TIPO F } \\
\hline Microestrutura & Grãos revestidos e microagregados intergranulares (50-100 $\mu$ m de comprimento) \\
$\begin{array}{l}\text { Dist. rel. g/f } \\
\text { Vazios }\end{array}$ & Quitónica, com áreas de distribuição gefúrica e enáulica \\
Porosidade & De empacotamento complexo, canais e vesículas \\
Razão g/f & $10-20 \%$ \\
Fração grossa & $90 / 20$ \\
& 1) Grãos de quartzo subarredondados e subangulosos, nas classes areia fina e areia \\
muito fina $(90 \%) ; 2)$ grãos de feldspato $(3 \%) ; 3)$ minerais pesados anisótropos e \\
opacos $(3 \%) ; 4)$ clastos de argila $(4 \%) .2$ a 4 na fração areia muito fina. \\
$\begin{array}{l}\text { Distribuição da } \\
\text { Micrão grossa }\end{array}$ & Aleatória \\
\hline
\end{tabular}

Pela presença de MO iluvial, esta microfácies ter-se-ia formado a partir da degradação de resíduos vegetais depositados no topo do sítio, sobre um episódio de deposição eólica que soterrou o anel de conchas que caracteriza este sambaqui como sugere a análise estratigráfica do sítio apresentada no Capítulo 5, tópico 2.2.1.

\subsubsection{Microfácies tipo G: horizonte espódico em matriz de conchas e areia}

Esta microfácies representa a AF 2 do sambaqui Carniça 3, interpretada como horizonte espódico desenvolvido sobre montículo arenoso formado pelo retrabalhamento antrópico de sedimentos eólicos ou de cordões litorâneos. As suas características micromorfológicas agrupam-se no Quadro 6.11.

Quadro 6.11. Características da microfácies tipo G.

\begin{tabular}{|c|c|}
\hline \multicolumn{2}{|r|}{ MICROFÁCIES TIPO G } \\
\hline Microestrutura & $\begin{array}{l}\text { Microagregados intergranulares }(50-200 \mu \mathrm{m} \text { de comprimento) com pseudo- } \\
\text { revestimentos }\end{array}$ \\
\hline Dist. rel. g/f & Enáulica \\
\hline Vazios & De empacotamento complexo \\
\hline Porosidade & $60 \%$ \\
\hline Razão g/f & $80 / 20$ \\
\hline Fração grossa & $\begin{array}{l}\text { 1) Conchas inteiras e fragmentadas de } A \text {. brasiliana ( } 3 \% \text { com sinais de alteração } \\
\text { térmica a baixa temperatura); 2) grãos de quartzo arredondados e subarredondados } \\
\text { na fração areia fina }(40 \%) \text {; 2) grãos de feldspato na fração areia muito fina }(5 \%) \text {; } \\
\text { 3) fragmentos de osso na fração areia fina a grossa }(3 \%)\end{array}$ \\
\hline $\begin{array}{l}\text { Distribuição da } \\
\text { fração grossa }\end{array}$ & Conchas com distribuição sub-horizontal; ossos com distribuição aleatória \\
\hline Com. menores & Raízes frescas \\
\hline Micromassa & $\begin{array}{l}\text { MO polimórfica na forma de pellets, com pseudo-revestimentos de pellets soldados } \\
\text { e ocasionais revestimentos de MO monomórfica }\end{array}$ \\
\hline
\end{tabular}


Nesta microfácies, domina a micromassa de agregados tipo pellets de $\mathrm{MO}$ polimórfica, entre e aderidos à fração grossa, sobre os revestimentos de $\mathrm{MO}$ monomórfica. Isto significa que o teor de MO iluvial neste horizonte é menor que em Santa Marta 10, por exemplo, e que a MO presente é maiormente deposicional. Assim, pode-se pensar que a formação de AF 2 envolveu a deposição de conchas inteiras, com resíduos da queima, como ossos e carvões.

\subsubsection{Microfácies tipo H: duna eólica}

Esta microfácies, de origem natural, corresponde à Fácies A de Santa Marta 10 e representa sedimentos eólicos de geração 2. Suas características micromorfológicas agrupam-se no Quadro 6.12.

Quadro 6.12. Características da microfácies tipo H.

\begin{tabular}{|c|c|}
\hline \multicolumn{2}{|r|}{ MICROFÁCIES TIPO H } \\
\hline Microestrutura & Grãos simples e revestidos \\
\hline Dist. rel. g/f & Mónica e quitónica \\
\hline Vazios & De empacotamento simples \\
\hline Porosidade & $40 \%$ \\
\hline Razão g/f & $95 / 5$ \\
\hline Fração grossa & $\begin{array}{l}\text { 1) Grãos de quartzo arredondados e subarredondados na fração areia fina a muito } \\
\text { fina }(90 \%) ; 2 \text { ) grãos de feldspato }(3 \%) ; 3) \text { minerais pesados anisotrópicos e } \\
\text { opacos }(3 \%) ; 4) \text { clastos de argila }(4 \%) .2 \text { a } 4 \text { na fração areia muito fina. }\end{array}$ \\
\hline $\begin{array}{l}\text { Distribuição da } \\
\text { fração grossa }\end{array}$ & Aleatória \\
\hline Micromassa & MO monomórfica na forma de revestimentos \\
\hline
\end{tabular}

\subsection{FORMAÇÃO DE SAMBAQUIS DE NÚCLEO ARENOSO}

Os sambaquis de núcleo arenoso são sítios concomitantes aos conchíferos, desde as épocas mais remotas, até hoje documentadas, de ocupação da costa catarinense pelos grupos sambaquieiros. Apesar de serem comumente considerados estruturas satélite aos grandes sambaquis conchíferos (ver Assunção 2010 e Peixoto 2008), os sambaquis de núcleo arenoso comportam características únicas que os definem como locais exclusivos para a realização de atividades específicas. Com isto, quer-se dizer que não parece haver relação direta entre os sambaquis de núcleo arenoso e os grandes sambaquis 
conchíferos, pelo menos em termos de processos de formação, apesar da proximidade frequentemente observada entre ambos os tipos de sítio.

No caso de Santa Marta 10, o sambaqui de núcleo arenoso mais antigo da região, a ocupação consistiu na deposição massiva de conchas de moluscos, na forma de anel, sobre paleoduna eólica. Esta estrutura particular teria sido soterrada posteriormente por areia, de transporte eólico ou antrópico das proximidades, e recoberto com material vegetal, possivelmente queimado, como indica a análise estratigráfica do sítio. Já Carniça 3 teria sido completamente erguido pela ação humana, com transporte de sedimentos arenosos, para construir o núcleo do sítio, e deposição, no topo, de conchas com areia e alguns resíduos de queima.

Em ambos os casos, resulta clara a natureza efêmera da ocupação em comparação com os grandes sambaquis conchíferos, no entanto, alguns indicadores servem para entender que, apesar da simplicidade, existiu planejamento e intenção na construção dos sítios. Em Santa Marta 10, a coleta e transporte de moluscos desde a costa, provavelmente de baía, até o topo do morro de Santa Marta, a quase $25 \mathrm{~m}$ de altura sobre o nível do mar, teria sido a ação mais planejada e demorada na formação do sítio. Da mesma maneira, em Carniça 3, a coleta e transporte de areias para elevação de um montículo de quase $5 \mathrm{~m}$ de altura, também responde a um projeto planificado de construção de formas antrópicas na paisagem. Estes processos eram culminados, e fechados, pela deposição de restos vegetais, principalmente, e restos ósseos queimados. Como mostrado no Capítulo 5, tópico 1.1, é extremamente difícil identificar fogueiras antigas acesas sobre substrato arenoso, o que impossibilita o reconhecimento do local original onde teria sido efetuada a queima, seja nas proximidades ou sobre Carniça 3 e Santa Marta 10. Outra alternativa seria pensar na queima e/ou deterioro in situ, de estruturas de cobertura feitas com materiais vegetais (troncos, folhas, galhos). 
Como já proposto para o sambaqui de núcleo arenoso Encantada 3 (Klokler et al., 2011; Villagran et al., 2011 b) a pouca diversidade de atividades identificadas neste tipo de sítio impedem a sua associação com sítios de habitação ou sítios funerários. No entanto, existe um propósito claro na sua construção, como mencionado antes, que pode estar vinculado ao levantamento de marcadores territoriais, ou à realização de rituais de caráter esporádico, como cerimônias de iniciação ou ritos de passagem ${ }^{112}$.

\section{MONTÍCULOS ICTIOLÓGICOS}

Os sítios analisados que se agrupam na categoria de montículos ictiológicos estão localizados no setor externo e pertencem à fase 4 de ocupação pré-histórica do litoral (Giannini et al. 2010), momento associado à intensificação do contato com os grupos Jê do interior. Ambos os sítios são definidos nesta tese como "mistos" por apresentarem uma conjunção de atributos próprios das culturas litorâneas, como economias marítimas e sepultamentos em montículos compostos por restos faunísticos, com elementos dos grupos do planalto, como cerâmica Taquara/ Itararé.

A partir da descrição macroscópica feita em campo, existem três grupos de arqueofácies diferentes nos sambaquis conchíferos analisados. Dois grupos agrupam depósitos de caráter antrópico e um inclui o substrato natural, de natureza arenosa, onde se estabelece a ocupação. Entre as fácies ou arqueofácies descritas e amostradas, distinguem-se entre: 1) arqueofácies decimétricas com predomínio de fragmentos de osso (AF 2 e 3 de Santa Marta 8); e 2) arqueofácies decimétricas pretas com restos

\footnotetext{
${ }^{112}$ A modo de exemplo, cabe citar o caso dos sítios associados com os rituais conhecidos como Chiejaus e Kina, praticados entre os Yamana da Terra do Fogo. Estas cerimônias realizavam-se a cada três ou cinco anos e tinham o propósito, no caso do Chiejaus, de instruir os jovens homens e mulheres do grupo quanto a seus papéis na sociedade e, no caso do Kina, de reforçar o papel dos homens como líderes do grupo. Apesar de serem realizados com regularidade, estes rituais não possuíam momentos ou circunstâncias fixas e preestabelecidas para sua realização; mas existiam algumas preferências, como disponibilidade de madeiras nas proximidades, cercania com outras cabanas etc. (Vila et al., 2004). Neste sentido, pode-se pensar que os sambaquis de núcleo arenoso podem ser remanescentes dos rituais de funcionamento interno da comunidade sambaquieira, onde se instruía aos jovens membros do grupo as suas funções socialmente estabelecidas.
} 
ósseos e vegetais queimados (AF 1 de Galheta 4); 3) fácies/arqueofácies arenosa com elementos antrópicos intrusivos (Fácies A de Galheta 4 e AF 1 de Santa Marta 8).

Três grupos de arqueofácies/fácies compõem os sítios Santa Marta 8 e Galheta 4:

1) Decimétrica, com domínio de fragmentos de osso

2) Decimétrica preta, com restos (ósseos e vegetais) queimados

3) Arqueofácies/fácies arenosa, com elementos antrópicos intrusivos (fragmentos de osso e carvão).

Nos tópicos a seguir, apresenta-se a discussão das análises laboratoriais realizadas nas arqueofácies amostradas nos dois montículos ictiológicos.

\subsection{SEDIMENTOS TERRÍGENOS}

As análises granulométricas realizadas nos sítios Santa Marta 8 e Galheta 4 confirmam a tendência, observada tanto nos sambaquis conchíferos como nos sambaquis de núcleo arenoso, de controle geográfico nas areias terrígenas dos sítios arqueológicos.

No sítio Santa Marta 8, existe afinidade entre o depósito arqueológico e o sedimento natural amostrado na trincheira extra-sítio, ambos com moda na fração areia fina. No Galheta 4, o depósito eólico subjacente (Fácies A) apresenta moda na fração areia muito fina, enquanto a camada de ocupação e o depósito eólico superior têm moda na fração areia fina. A comparação da estatística descritiva das distribuições granulométricas no sítio arqueológico com as quatro gerações de dunas eólicas identificadas na região indica afinidade com paleodunas de geração eólica 3, para a AF 1 e fácies B, e com paleodunas de geração 2, para a Fácies A. A afinidade da Fácies A com as dunas de geração 2 é reforçada pela coloração amarelada e presença de bandas de impregnação, características frequentes nesta geração de dunas segundo Giannini (1993). Esta observação é também coerente com a cronologia do sítio, já que a ocupação em Galheta 4 teria acontecido sobre dunas de geração 2 já estabilizadas, momento em que dunas de geração 3, cuja formação inclui os últimos séculos (Giannini 1993), estavam ainda ativas. 
As areias terrígenas dos montículos Santa Marta 8 e Galheta 4 assemelham-se, em termos granulométricos, aos depósitos arenosos das proximidades dos sítios.

\subsection{RESÍDUOS VEGETAIS E ANIMAIS}

Análises isotópicas de $\mathrm{C}$ e $\mathrm{N}\left(\delta^{13} \mathrm{C}\right.$ e $\left.\delta^{15} \mathrm{~N}\right)$ e razão $\mathrm{C} / \mathrm{N}$ foram realizadas em três amostras arqueológicas e duas amostras de sedimento natural. No sítio Santa Marta 8, analisou-se a MO das AF 2 e 3, e da Fácies B extra-sítio, enquanto no Galheta 4 foi analisada a MO da AF 1 e da Facies B, depósito arenoso que cobre a camada de ocupação.

Os valores de $\delta^{13} \mathrm{C}$ nas amostras arqueológicas variam de $-20,80 \%$ a $-22,83 \%$, o que indica presença de plantas $C_{3}$ tanto no sítio Santa Marta 8 como no Galheta 4 (segundo valores de referência em: Boutton, 1996; Lamb et al., 2006; Meyers, 1997; De Niro and Epstein, 1978; De Niro and Hastrof, 1985; Sifeddine et al., 2004). Os valores de $\delta^{15} \mathrm{~N}$ são os mais altos do conjunto de amostras analisadas nesta tese, com valor mínimo de 13,52\%, para a AF 3 de Santa Marta 8, e valor máximo de 15,94\%o, na AF 1 de Galheta 4. Estes valores indicam alta concentração de resíduos de origem animal na MO (Fogg et al. 1998; Kendall 1998; Schoeninger \& DeNiro 1984), especialmente de animais marinhos (Bem-David et al. 1998; Comisso \& Nelson 2006; Schoeninger \& DeNiro 1984; Wainright et al. 1998), misturados com restos de plantas $\mathrm{C}_{3}$. Esta constatação é condizente com a assembleia faunística dos dois montículos ictiológicos, onde destaca a concentração de ossos de peixe, especialmente em Santa Marta 8, junto com carvões.

Como mostrado no Capítulo 5, tópico 2.3.1, as análises isotópicas, junto com a observação à lupa da amostra proveniente da Fácies $\mathrm{B}$ da trincheira aberta nas proximidades de Santa Marta 8, indicam ocupação humana na região em local externo aos sambaquis e sem construção de estrutura monticular. A Fácies B, de areia lamosa preta, foi identificada em campo entre duas fácies arenosas, uma de areia clara subjacente (Fácies A) e outra de areia fina marrom superior (Fácies C). A assinatura isotópica de $\delta^{13} \mathrm{C}$ e $\delta^{15} \mathrm{~N}$ neste depósito indica presença de resíduos de origem animal 
decompostos $\left(\delta^{15} \mathrm{~N}\right.$ de $13,54 \%$ ). Isto mostra a influência antrópica na sua formação e uma possível contemporaneidade à ocupação de Santa Marta 8 (embora seja necessária uma datação para corroborar essa hipótese). A existência de locais de ocupação fora dos sambaquis na região do paleotômbolo de Santa Marta é igualmente sugerida pelos estudos geofísicos realizados por Rodrigues (2009), onde observaram-se anomalias em sub-superfície interpretadas como possíveis áreas de ocupação humana pré-colonial.

As arqueofácies que constituem os montículos ictiológicos estão compostas por uma mistura entre resíduos derivados da decomposição de restos de animais marinhos e plantas $\mathrm{C}_{3}$. A aproximadamente $100 \mathrm{~m}$ a NE de Santa Marta 8, detectou-se uma camada de ocupação soterrada por sedimentos arenosos modernos, com o mesmo predomínio de resíduos de origem animal observado na MO do sambaqui. Isto demonstra a existência de áreas de ocupação localizadas nas proximidades dos sambaquis, como já sugerido para os sambaquis de padrão estratigráfico conchífero.

\subsection{MICRO-COMPONENTES}

Nos dois montículos estudados, coletaram-se cinco amostras para análise micromorfológica. No Santa Marta 8, uma amostra é do contato entre as AF 1 e 2 e outras duas amostras são da AF 3. No Galheta 4, uma amostra foi coletada da transição entre a Fácies A e AF 1, e outra da AF 1. A observação na escala microscópica permite definir que, em termos gerais, Santa Marta 8 apresenta semelhanças com os sambaquis conchíferos, enquanto Galheta 4 é similar aos sambaquis de núcleo arenoso pela presença de sedimentação eólica. A maior diferença que se observa entre os montículos ictiológicos e os sambaquis conchíferos e de núcleo arenoso refere-se à substituição das conchas por ossos inteiros e fragmentados.

\subsubsection{Componentes minerais}

A fração mineral em ambos os sítios é dominada por grãos de quartzo, arredondados a subarredondados na fração areia fina a muito fina, com presença 
subordinada de feldspatos arredondados, minerais pesados e ocasionais fragmentos líticos. Estes componentes são predominantes nas fácies e arqueofácies que representam o substrato de ocupação dos dois sítios analisados (Fácies A em Galheta 4 e AF 1 em Santa Marta 8), onde também aparecem misturados com componentes biológicos (ossos, carvão) e produtos da alteração antrópica (escória vítrea) intrusivos, provenientes das arqueofácies superiores.

Em termos quantitativos, grãos de quartzo dominam a fração mineral da $\mathrm{AF} 1$ de Santa Marta 8 (80\%), junto com grãos de feldspato (5\%). A concentração de grãos minerais diminui nas AF 2 e 3, com redução de até 25\%. Em Galheta 4, grãos de quartzo predominam tanto na Fácies A, como na AF1 ( $55 \%)$.

A análise micromorfológica corrobora as constatações realizadas pela análise granulométrica, ao confirmar o predomínio de areias quartzosas em ambos os montículos ictiológicos. No Santa Marta 8, existe diminuição na porcentagem de sedimentos terrígenos entre o substrato de ocupação (AF 1) e os depósitos antrópicos (AF 2 e 3). Já no Galheta 4, existe paridade na porcentagem de areias.

\subsubsection{Componentes biológicos, biominerais e produtos da alteração antrópica}

Os componentes biológicos e produtos da alteração antrópica, como fragmentos de osso, carvão e escória vítrea, representam $80 \%$ da fração grossa das AF 2 e 3 do sítio Santa Marta 8, e cerca de $50 \%$ da AF 1 do Galheta 4. Destes componentes, os fragmentos de osso predominam em ambos os sítios, no entanto, existem algumas diferenças, que se referem a: 1) frequência de aparição; 2) tamanho dos fragmentos; 3) distribuição básica; 4) estado de alteração.

Tanto na observação macroscópica em campo como no estudo microscópico, a concentração de ossos é sempre maior no sítio Santa Marta 8, onde eles perfazem a maior parte da fração grossa (70\% vs. $20 \%$ no Galheta 4). Esta diferença está associada ao tamanho dos fragmentos, com predomínio de espécimes centimétricos, incluindo ossos inteiros, no Santa Marta 8. No Galheta 4, há predomínio de fragmentos menores, na fração areia fina a muito fina, com seleção granulométrica moderada. As diferenças de frequência e tamanho dos ossos observam-se-se, igualmente, na distribuição deste 
componente nas lâminas. Nas AF 2 e 3 de Santa Marta 8, cerca de 80\% dos ossos têm distribuição horizontal, enquanto no Galheta 4 todos os fragmentos, maiores e menores, estão distribuídos aleatoriamente. Por último, outra diferença refere-se ao estado de alteração dos ossos, com predomínio de ossos queimados, no sítio Galheta 4, versus intemperizados, no Santa Marta 8.

Em termos gerais, a distribuição e alteração dos componentes do sítio Santa Marta 8 são semelhantes ao descrito para sambaquis de padrão estratigráfico conchífero. Por exemplo, a maioria dos ossos apresenta birrefringência e fosforescência variáveis, inclusive fragmentos contíguos, associadas à perda de colágeno e mudanças mineralógicas relacionadas com a queima (Mccutcheon, 1992; Schiegl et al., 2003), ou à degradação do colágeno por dissolução ou ataque microbiano (Schoeninger et al., 1989; Trueman and Martill, 2002; Trueman et al., 2004).

No sítio Santa Marta 8, há evidências de contato direto dos ossos com o fogo, mistura de materiais com diversos graus de queima (identificados pelas suas propriedades ópticas a PPL, XPL e UV), alta fragmentação dos ossos menores (produto da fragilidade provocada pela queima) e nenhuma evidência, no perfil analisado, de fogueira in situ. Isto indica retrabalhamento de restos queimados, localizados a diferentes distâncias da fonte de calor, desde uma área de acumulação e queima. Como também discutido para os sambaquis conchíferos, a assinatura isotópica de restos de tecido animal indica que existe aporte de tecidos moles e não unicamente ossos.

Apesar da distribuição horizontal dos restos ósseos na $\mathrm{AF} 3$, não existem evidências de pisoteamento intenso sobre o depósito, como empacotamento fechado ou baixa porosidade. Pelo contrário, os fragmentos de osso maiores estão bem preservados e não há indícios de alterações físicas, além das produzidas pela passagem da fauna e raízes no solo. No entanto, na AF 2 a situação é diferente, já que aí se encontra menor porosidade e empacotamento fechado dos componentes da fração grossa (grãos de quartzo e fragmentos de osso). Além disso, a micromassa é essencialmente mineral, com microcarvões e matéria orgânica. Isto sugere que AF 2 possa representar o substrato da primeira ocupação do sítio, sem episódio construtivo. Acima deste terreno, teria começado a atividade de deposição de resíduos.

A distribuição aleatória e seleção mderada dos fragmentos de osso e carvão no montículo Galheta 4, junto com a espessura decimétrica da camada de ocupação (AF 1) (menos espessa que na porção do sítio onde foram achados sepultamentos recobertos por ossos de peixe), sugerem que a área de amostragem representa um local periférico 
do núcleo de ocupação. A esta porção do sítio, chegariam os fragmentos mais finos, transportados pelo intenso vento do local, e ocasionais fragmentos maiores. Na camada de ocupação, cerca de $90 \%$ dos fragmentos de osso estão queimados, enquanto os $10 \%$ restantes apresentam graus variáveis de destruição do colágeno, devida tanto à queima como à alteração microbiana. A cotidianidade da ocupação e transporte eólico de partículas teria formado uma camada delgada de restos de queima associados a ocupação sobre o substrato de duna eólica estabilizada.

As características microscópicas dos componentes biológicos e produtos da alteração antrópica no montículo Santa Marta 8 indicam retrabalhamento de materiais acumulados, e queimados, em local diferente da deposição final. Estas evidências também sugerem presença de um episódio de ocupação sobre os substrato arenoso prévio ao levantamento do montículo. No Galheta 4, a granulometria e seleção moderada dos fragmentos de osso, junto com a pouca espessura da camada de ocupação (AF 1), sugerem que a seção vertical amostrada representa uma área periférica do núcleo da ocupação, com transporte eólico de materiais antrópicos a partir das proximidades.

\subsubsection{Fração fina}

Em Santa Marta 8, a fração fina é essencialmente fosfática, derivada da fragmentação dos ossos em finas partículas na fração silte e da dissolução e precipitação do mineral dos ossos (inferido pelas propriedades ópticas e pela proporção entre $\mathrm{Ca}$ e $\mathrm{P}$ detectadas nas análises com sistema MEV-EED). A maior vulnerabilidade dos ossos de peixe à dissolução (Szpak, 2011), junto com o regime hidrológico da área de estudo, teriam favorecido a alteração diagenética destes materiais (ver Berna et al., 2004; Gordon and Buikstra, 1981; Lucas and Prévôt, 1991; Schiegl, 1996; Trueman et al., 2004; Weiner, 2002). A alteração dos ossos teria sido mais intensa no montículo ictiológico que nos sambaquis conchíferos, devido à ausência de conchas que alcalinizem o pH e protejam os ossos da dissolução (ver Berna et al., 2004; Gordon and Buikstra, 1981; Nielsen-Marsh et al., 2007).

Unicamente na AF 2, que se encontra no contato entre o substrato arenoso e o montículo ictiológico ( $\mathrm{AF}$ 3), observou-se matriz de argilominerais misturada com 
microcarvões e fragmentos de osso, inclusive na forma de revestimentos impuros ao redor dos componentes da fração grossa e das paredes dos poros. A presença de revestimentos impuros, micro-laminados, indica iluviação de componentes finos até as arqueofácies inferiores. Este processo é semelhante ao observado na duna eólica amostrada nas proximidades de Santa Marta 10 e é característico do desenvolvimento de solos sobre depósitos arenosos em áreas com pluviosidade constante ${ }^{113}$.

Os revestimentos impuros que caracterizam a AF 2 indicam deslocamento de partículas de argila junto com MO em dispersão desde a superfície do solo. A formação de revestimentos impuros associa-se a fatores naturais e também antrópicas. Entre os fatores naturais, os revestimentos impuros consideram-se indicadores das fases iniciais do deslocamento de argilas (Kuhn et al., 2010). Entre os antrópicas, está o desmatamento, cultivo, ou pisoteamento (animal ou humano) sobre superfície do solo sem vegetação (Beckman and Smith, 1974; Carter and Davidson, 1998; Courty et al., 1989; Gebhardt and Langohr, 1999; Jongerius, 1983; Macphail, 1989; Macphail et al., 1987, 1990). Após a retirada da vegetação, quando a superfície do solo fica exposta, o impacto da água da chuva nos agregados torna-se maior e provoca sua destruição, com migração da lama resultante até a subsuperfície. Os indicadores de compactação na AF 2, junto com a presença de revestimentos impuros, reforçam a hipótese da AF 2 se tratar de uma superfície de ocupação anterior à construção do montículo, sobre a qual houve pisoteamento humano.

A fração fina de Santa Marta 8 também apresenta áreas de concentração de materiais silicosos, como agregados de escória vítrea e alguns fitólitos, que representam os resíduos da queima de material vegetal. Estes materiais foram também identificados na micromassa da camada preta de Jabuticabeira 2 (Villagran, 2008; Villgran et al. 2009, 2010), em microfácies compostas por ossos alterados intempérica e termicamente. A associação entre resíduos de material vegetal e ósseo queimados, tanto em Santa

\footnotetext{
${ }^{113}$ Solos arenosos e silicáticos oferecem as condições de $\mathrm{pH}$, cátions disponíveis e MO dissolvida para a dispersão das argilas e migração vertical, favorecida pela porosidade e água das chuvas. As argilas depositam-se quando há interrupção no suprimento de água, quando diminui a porosidade ou quando uma alta concentração de eletrólitos favorece a floculação. A água das argilas é sugada até as paredes dos poros e os minerais de argila permanecem com orientação paralela às paredes dos poros (Dorronsoro and Aguiar, 1988). A repetição deste ciclo, durante o próximo episódio de chuvas, resulta no alargamento do revestimento, com deposição de micro-camadas de argila límpida ou impura de acordo com as mudanças no regime hidrológico e transporte de MO dispersa. A formação de meniscos e revestimentos contínuos ao redor dos grãos de areia, que se observam principalmente nos revestimentos da $\mathrm{AF} 2$, deve-se a sucção e evaporação lenta da água das argilas, com retenção por adsorção e capilaridade de argilominerais em suspensão ao redor dos grãos de areia (Kuhn et al., 2010).
} 
Marta 8 como na camada preta de Jabuticabeira 2, pode ser tomada como indicativa de afinidade nos processos de formação de ambos os depósitos.

No sítio Galheta 4, a fração fina apresenta as mesmas características descritas para os sambaquis de núcleo arenoso, com micromassa de grãos revestidos de MO monomórfica, indicativa de iluviação de MO dissolvida, e pellets de MO polimórfica com microcarvões, que aponta à decomposição in situ de resíduos vegetais (Van Breemen and Buurman, 2003; Buurman and Jongmans, 2005; Wilson and Righi, 2010). A inclusão de finos fragmentos de osso nos revestimentos de MO sugere que a iluviação do material orgânico foi posterior à deposição dos resíduos, neste caso ossos, carvão e microcarvão.

$\mathrm{Na}$ observação macroscópica do perfil estudado no Galheta 4, observa-se a formação de um horizonte eluvial incipiente embaixo do horizonte espódico (ver Figura 5.94). Este tipo de horizonte eluvial forma-se pela percolação lateral da água no solo, responsável, também, pela presença de bifurcações nas bandas de impregnação que se observam na fácies A (Wilson and Righi, 2010).

No sítio Santa Marta 8, a composição da micromassa evidencia a dissolução e precipitação de minerais fosfáticos derivados, principalmente, da alteração química dos ossos e da decomposição de resíduos orgânicos. A mistura do material fosfático com resíduos silicosos derivados da queima de material vegetal aponta à semelhança do Santa Marta 8 com a camada preta do Jabuticabeira 2. Unicamente na AF 2, que se encontra no contato entre o substrato arenoso natural (AF 1) e a arqueofácies construtiva (AF 3), acharam-se evidências de pisoteamento em superfície. Estas evidências, junto com a alta compactação do depósito, apóiam a hipótese da AF 2 se tratar de uma superfície de ocupação, anterior ao levantamento do montículo. No sítio Galheta 4, existem evidências de formação de horizonte espódico na AF 1 a partir da degradação e iluviação de MO depositada em superfície, e junto com os fragmentos de osso, carvão e microcarvão. 


\subsection{MICROFÁCIES}

Nas cinco seções delgadas analisadas nos sítios Santa Marta 8 e Galheta 4, foram identificadas quatro microfácies, três das quais aparecem exclusivamente no Santa Marta 8. A quarta representa a camada de ocupação no Galheta 4. As três microfácies identificadas no Santa Marta 8 correspondem com as arqueofácies descritas em campo: substrato arenoso sobre o qual se estabelece a ocupação (AF 1); camada de ocupação pré-levantamento do montículo (AF 2 ); e montículo ictiológico propriamente dito (AF 3). No Galheta 4, as duas seções delgadas analisadas envolvem a AF 1 e a transição com a paleoduna eólica subjacente.

\subsubsection{Microfácies tipo I: retrabalhamento de resíduos com predomínio de ossos}

A microfácies tipo I agrupa as duas seções delgadas coletadas na AF 3 no sítio Santa Marta 8 ( $\mathrm{mF}$ 3a e 3b), que representam acumulação monticular de ossos de peixe e demais detritos antrópicos. As suas características micromorfológicas agrupam-se no Quadro 6.13.

Quadro 6.13. Características da microfácies tipo I.

\begin{tabular}{ll}
\hline & \multicolumn{1}{c}{ MICROFÁCIES TIPO I } \\
\hline Microestrutura & Microagregados intergranulares \\
Dist. rel. g/f & Enáulica \\
Vazios & De empacotamento complexo \\
Porosidade & $40-45 \%$ \\
Razão g/f & $80 / 20$ \\
Fração grossa & 1) Fragmentos de osso (70 \%) de tamanho variável, com perda de colágeno \\
& associada a queima, alteração microbiana e dissolução; 2) grãos de quartzo \\
& arredondados e subarredondados na fração areia fina e muito fina (20 \%); 3) grãos \\
de feldspato na fração areia fina (3\%); ocasionais fragmentos líticos na fração areia \\
fina e fragmentos de carvão (total de 3\%). \\
Distribuição da & Ossos com distribuição horizontal e sub-horizontal (80 \%). Grãos minerais e carvão \\
fração grossa & com distribuição aleatória \\
Comp. menores & Ocasional presença de fitólitos, agregados de diatomáceas e diatomáceas dispersas \\
Micromassa & Agregados de micro-fragmentos de apatita biogênica com fosfato secundário, áreas \\
& de micromassa carbonosa (produto da compactação física de carvões) e de \\
& micromassa silicosa associada à combustão de plantas \\
\hline
\end{tabular}

Esta microfácies representa o produto da deposição massiva de restos, principalmente ósseos, com evidência de queima em local diferente do de deposição 
final. Assemelha-se à microfácies de tipo A, descrita para os sambaquis de padrão estratigráfico conchífero, sem a presença de conchas e da micrita relacionada com a sua degradação. A alta porosidade do depósito e a boa preservação dos fragmentos maiores de osso sugerem que não houve pisoteamento. A distribuição horizontal dos osso está possivelmente associada ao momento de deposição do material e consolidação posterior dos sedimentos (ver Andrews 2005). A micromassa é essencialmente composta por finos agregados de fragmentos de osso que possuem aparência de fosfatos secundários, mas que, na realidade, formaram-se pela debilitação do osso por processos bioquímicos e fragmentação física posterior.

A pesar da semelhança, em termos de processo de formação cultural, entre a microfácies tipo I e a microfácies tipo A, descrita para os sambaquis conchíferos, existe uma diferença entre ambas. No sítio Santa Marta 8, há mais restos vegetais que nos sambaquis conchíferos, na forma de resíduos silicosos e fitólitos. Isto sugere que houve maior aporte de plantas na formação dos montículos ictiológicos. Frequências comparáveis de matriz silicosa e resíduos associados a epiderme de gramíneas foram identificados também na camada preta de Jabuticabera 2, semelhante em composição e cronologia com Santa Marta 8.

Assim como proposto para a camada preta de Jabuticabeira 2 e para a microfácies tipo $\mathrm{A}$ dos sambaquis conchíferos, as características macro e micromorfológicas da microfácies tipo I são assemelháveis a depósitos secundários de tipo midden. Isto estende ainda mais, no tempo, a prática de acumulação de resíduos na construção dos sítios da região, o que teria perdurado até e após a intensificação do contato com os grupos do planalto. Neste sentido, a continuidade desta prática, já mostrada para Jabuticabeira 2 (Villagran et al. 2010), deve ser explicada no contexto de interação entre as duas populações, já que não existem montículos formados por ossos de peixe em sítios do planalto associados às populações Jê. Isto sugere que, apesar da intensificação dos contatos e chegada da cerâmica Taquara/Itararé ao litoral, seria a mesma população litorânea a responsável pelo levantamento dos sambaquis a que formou os montículos ictiológicos. 


\subsubsection{Microfácies tipo J: ocupação sobre depósito arenoso}

A microfácies tipo J aparece unicamente no sítio Santa Marta 8 e corresponde com a AF 2 ( $\mathrm{mF}$ 2), localizada entre o substrato arenoso (AF 1) e o montículo propriamente dito (AF 3). Suas características agrupam-se no Quadro 6.14.

Quadro 6.14. Características da microfácies tipo J.

\begin{tabular}{ll}
\hline & \multicolumn{1}{c}{ MICROFÁCIES TIPO J } \\
\hline Microestrutura & Grãos interligados e microagregados intergranulares \\
Dist. rel. g/f & Enáulica-mónica e gefúrica \\
Vazios & De empacotamento complexo \\
Porosidade & $20 \%$ \\
Razão g/f & $70 / 30$ \\
Fração grossa & 1) Fragmentos de osso $(70 \%)$ de tamanho variável, todos queimados; 2) grãos de \\
& quartzo arredondados na fração areia fina a muito fina $(20 \%) ; 3)$ grãos de \\
& feldspato arredondados na fração areia fina; 4) fragmentos de carvão de tamanho \\
diverso $(3 \%)$ & \\
Distribuição da & Ossos com distribuição aleatória e sub-horizontal. Grãos minerais e carvões \\
fração grossa & distribuídos aleatoriamente \\
Comp. menores & Escória vítrea $(2 \%)$ com 50 a $100 \mu$ m de comprimento \\
Micromassa & Argilominerais com micro-fragmentos de osso e microcarvões na forma de \\
& agregados intergranulares e de revestimentos \\
\hline
\end{tabular}

Esta microfácies foi interpretada como resultado da ocupação humana sobre o substrato arenoso, que representa a base natural do sítio. Este depósito, composto principalmente por resíduos ósseos e vegetais queimados, teria sido compactado por pisoteamento pelos ocupantes do local. Tal inferência baseia-se na distribuição horizontal dos fragmentos de osso, no empactoamento fechado dos componente da fração grossa e na baixa porosidade do depósito, em comparação com as microfácies sub e sobrejacente, além da presença de revestimentos e enchimentos de argila impura. Os revestimentos de argila impura são associados à quebra física de agregados de lama em solo exposto, sem vegetação, e à lavagem e deslocamento vertical destes materiais, até a sub-superficie, produzida pela passagem da água de chuva.

\subsubsection{Microfácies tipo K: substrato arenoso}

A microfácies tipo $\mathrm{K}$ aparece unicamente no sítio Santa Marta 8 e representa o substrato arenoso da ocupação no local $(\mathrm{mF} 1)$ com elementos antrópicos intrusivos vindos depósito de ocupação superior. Suas características agrupam-se no Quadro 6.15. 
Quadro 6.15. Características da microfácies tipo K.

\begin{tabular}{ll}
\hline & \multicolumn{1}{c}{ MICROFÁCIES TIPO K } \\
\hline Microestrutura & Grãos simples e microagregados intergranulares \\
Dist. rel. g/f & Mónica e enáulica \\
Vazios & De empacotamento simples e complexo \\
Porosidade & $40 \%$ \\
Razão g/f & $95 / 5$ \\
Fração grossa & 1) Grãos de quartzo arredondados na fração areia fina $(80 \%) ; 2)$ grãos de \\
& $\begin{array}{l}\text { feldspato arredondados na fração areia fina }(5 \%) ; 3) \text { fragmentos de osso de } \\
\text { tamanho variável }(10 \%) ; 4) \text { carvão }(3 \%)\end{array}$ \\
$\begin{array}{l}\text { Distribuição da } \\
\text { fração grossa }\end{array}$ & Grãos minerais, fragmentos de osso e carvão com distribuição aleatória \\
Comp. menores & Escória vítrea (2\%) de 50 a 100 pm de comprimento \\
Micromassa & Argilominerais com micro-fragmentos de osso e microcarvões na forma de \\
& revestimentos e finos agregados intergranulares \\
\hline
\end{tabular}

Esta microfácies formou-se a partir do deslocamento vertical dos restos de ocupação na superfície do depósito arenoso, que serve de base ao sítio Santa Marta 8. A formação da microfácies tipo $J$ provocou a infiltração e intrusão de elementos antrópicos, como fragmentos de osso, carvão e escória vítrea, no depósito arenoso. Os revestimentos de argila impuros, micro-laminados, não são autóctones do depósito e terse-iam formado como resultado do pisoteamento humano em superfície, como explicado no tópico 3.3.3.

\subsubsection{Microfácies tipo L: horizonte espódico em matriz de ossos e areia}

A microfácies do tipo L representa a camada de ocupação analisada no sítio Galheta 4, que corresponde com a AF 1 (mF 1). Suas características agrupam-se no Quadro 6.16. 
Quadro 6.16. Características da microfácies tipo L.

\begin{tabular}{|c|c|}
\hline \multicolumn{2}{|r|}{ MICROFÁCIES TIPO L } \\
\hline Microestrutura & Microagregados intergranulares e grãos revestidos \\
\hline Dist. rel. g/f & Enáulica e quitónica \\
\hline Vazios & De empacotamento complexo, com vazioes em vesículas, em câmara e canais \\
\hline Porosidade & $55 \%$ \\
\hline Razão g/f & $70 / 30$ \\
\hline Fração grossa & $\begin{array}{l}\text { 1) Grãos de quartzo arredondados na fração areia fina }(55 \%) ; 2) \text { grãos de feldspato } \\
\text { arredondados na fração areia fina }(10 \%) ; 3) \text { fragmentos de osso, principalmente na } \\
\text { fração areia fina a muito fina, com alguns fragmentos maiores }(20 \%) \text { em sua } \\
\text { maioria queimados }(90 \% \text { do total); 4) minerais pesados e fragmentos líticos } \\
\text { (frequência total menor que } 5 \%)\end{array}$ \\
\hline $\begin{array}{l}\text { Distribuição da } \\
\text { fração grossa }\end{array}$ & Grãos minerais, fragmentos de osso e carvão com distribuição aleatória \\
\hline Comp. menores & Escória vítrea $(3 \%)$ \\
\hline Micromassa & $\begin{array}{l}\text { MO monomórfica na forma de revestimentos e MO polimórfica, com incrustações } \\
\text { de finos fragmentos de osso, na forma de agregados intergranulares e pseudo- } \\
\text { revestimentos }\end{array}$ \\
\hline
\end{tabular}

A camada de ocupação no sítio Galheta 4 apresenta características semelhantes às descritas para os sambaquis de núcleo arenoso Santa Marta 10 e Carniça 3. Este sítio, possui em comum com aqueles dois o fato de ser produto de ocupação sobre depósito arenoso, nesta caso, eólico. A formação de horizontes espódicos, já aventada pela análise micromorfológica nos sambaquis de núcleo arenoso, repete-se no sítio Galheta 4. As evidências de podzolização estão na presença de revestimentos de $\mathrm{MO}$ monomôrfica ao redor dos componentes da fração grossa, de agregados soldados de MO polimórfica na forma de pellets (welded aggregates) e de pseudo-revestimentos de MO monomórfica.

Pela natureza dos revestimentos de $\mathrm{MO}$, que abrangem inclusões de finos fragmentos de osso, pode-se pensar que há tanto MO dissolvida, que chegou por iluviação desde a superfície do depósito, como MO derivada da transformação de tecidos vegetais in situ. As análises realizadas com MEV-EED, que detectaram enriquecimento em alumínio e ferro nos agregados integranulares, permitem interpretar a presença de MO iluvial nos pellets de MO polimórfica. Estes agregados formam-se pela ação da fauna do solo, que mistura restos de plantas e qualquer outro material na fração silte (Wilson and Righi, 2010). A formação de bandas de impregnação na AF 1 também atesta a iluviação de componentes, apesar de que horizontes espódicos e plácicos não se formam pelo mesmo processo (Conry et al., 1996).

A MO momonórfica e a polimórfica podem formar simultaneamente no solo, mas o predomínio de MO monomórfica é geralmente associado a estágios mais avançados de podzolização (De Connick, 1980). Isto corresponde com as observações 
realizadas nesta tese, onde a MO monomórfica é dominante em Santa Marta 10, o mais antigo dos sambaquis com horizonte espódico, enquanto MO polmórfica predomina nos sítios Carniça 3 e Galheta 4. Outra semelhança entre Galheta 4 e Carniça 3 refere-se à presença efetiva carvão, no primeiro, e inferida a partir das análises isotópicas, no segundo, junto com ossos queimados, carbonizados e calcinados na camada de ocupação, com frequencias maiores no Galheta 4 onde não há aporte de conchas. Isto leva a pensar, novamente, na influência de microcarvões na formação de horizontes espódicos em depósitos arenosos.

\subsection{FORMAÇÃO DE MONTÍCULOS ICTIOLÓGICOS}

O sítio Santa Marta 8 contém os restos mais antigos de cerâmica Taquara/ Itararé do litoral sul catarinense. Datado em 1691-1416 anos cal. AP, este sítio apresenta semelhanças de forma e composição com a camada preta de Jabuticabeira 2; com a diferença de que, no Santa Marta 8, não há sobreposição a sambaqui conchífero. De fato, a camada preta no Jabuticabeira 2 é cerca de 100 anos mais antiga que Santa Marta 8 e a ocupação de ambos seria contemporânea. Ambos os depósitos mostram claras semelhanças no processo de formação, com deposição de restos ósseos queimados em local diferente do final, junto com sedimentos terrígenos, carvão e resíduos da queima de plantas. Nesta dinâmica, os sedimentos terrígenos são componente casual por representar o substrato de acumulação e queima de materiais prévios à deposição no sambaqui. O mesmo padrão de retrabalhamento de resíduos foi observado nos sambaquis conchíferos, o que indica continuidade no processo acumulatico, apesar da substituição das conchas por ossos de peixe.

O sítio Galheta 4, fundado 700 anos depois do início da ocupação em Santa Marta 8, cerca de 100-200 anos após o abandono da camada preta de Jabuticabeira 2, é um montículo ictiológico sobre depósito arenoso com sepultamentos humanos e cerâmica. Apesar das diferenças composicionais com Santa Marta 8, que o aproximam aos sambaquis de núcleo arenoso, a cronologia do sítio, a presença de cerâmica Taquara/ Itararé, os sepultamentos humanos e os ossos de peixe misturados na matriz arenosa, sem conchas, permitem agrupá-lo na categoria de montículo ictiológico. A formação deste sítio sugere acumulação de resíduos de queima (ossos e microcarvão) 
sobre duna eólica estabilizada, com aporte eólico constante de outros resíduos desde o núcleo da ocupação, onde se encontraram os sepultamentos humanos.

Os montículos ictiológicos são os sítios de menor representação na área de estudo, com unicamente quatro sítios; dois correspondem aos sambaquis analisados nesta tese; outro é o sítio Costão do Ilhote, com estratigrafia e composição semelhante a Galheta 4; e o último corresponde à camada preta de Jabuticabeira 2. A mudança composicional relacionada com o aparecimento dos montículos ictiológicos coincide cronologicamente com dois fatores fundamentais na evolução da área: a dessalinização e assoreamento progressivo das grandes lagunas costeiras; e a chegada dos grupos Jê provenientes do planalto.

Visitas realizadas em vários sambaquis conchíferos da região indicam que a sobreposição de montículo ictiológico sobre sambaqui conchífero é atributo exclusivo de Jabuticabeira 2, e não um fenômeno de extensão regional, como tinha sido inicialmente suposto. Pode-se pensar que os próprios montículos ictiológicos (ou camadas pretas) tenham sido aproveitados também pela atividade mineradora que explorou os sambaquis até pelo menos a década de 1960; ou inclusive removidos para atingir as camadas conchíferas subjacentes, de maior valor econômico. No entanto, as descrições de camadas superiores compostas principalmente por fragmentos ósseos, que aparecem em relatórios do Ministério de Minas e Energia (Bocchi and Liberatore, 1968), tampouco coincidem com a situação observada nos montículos ictiológicos, Nestes relatórios, descreve-se a presença de camadas de até $30 \mathrm{~cm}$ no topo de sítios como Garopaba do Sul 1, por exemplo, com alta concentração de ossos de peixe, levemente litificada, cor cinza escuro a preto e distribuição restrita no sambaqui.

Pelas características estratigráficas, composicionais e micromorfológicas descritas neste tópico, os montículos ictiológicos, também definidos como sítios mistos pela presença de cerâmica Taquara/ Itararé, mostram evidências de continuidade no processo de formação em relação aos sambaquis conchíferos. A única e maior diferença refere-se à substituição das conchas por ossos de peixe como material construtivo. Isto resulta fundamental na discussão da relação entre os grupos do planalto e do litoral há 1500 anos.

Como discutido no Capítulo 2, tópico 3.5.2, não há ainda evidências contundentes que apoiem a tradicional visão dos grupos interioranos chegando ao litoral em tempos recentes. Além das evidências artefatuais e bioantropológicas que sustentam uma relação de continuidade entre sambaquis e sítios mistos, os resultados aqui apresentados 
sobre processos de formação dos sítios tampouco apoiam à hipótese de migração dos grupos Jê até o litoral. A semelhança no processo de formação de sambaquis conchíferos e montículos ictiológicos indicam continuidade do padrão e mudança possivelmente relacionada com pressões externas ao grupo. Estas pressões teriam motivado o abandono das conchas, que não deve ser considerado elemento menor na avaliação da intensidade e consequências do contato entre os dois grupos em questão. Para que o símbolo mais característico das culturas litorâneas, as conchas, fosse substituído formação dos sítios, as pressões e conflitos com os grupos Jê devem ter provavelmente ultrapassado um nível de tolerância na interação dos grupos.

\section{CONCHEIRO ETNOHISTÓRICO NA TERRA DO FOGO}

O estudo micromorfológico das amostras coletadas no sítio Túnel 7, tanto da sucessão vertical do concheiro como da planta de escavação, foi realizado seguindo a identificação de microfácies, a partir do arranjo de componentes nas seções delgadas analisadas. Esta abordagem geoarquelógica, junto com a informação etnográfica, permite unir a evidência sedimentar com atividades conhecidas associadas à formação dos sítios, além do consumo e descarte de alimentos.

\subsection{MICRO-COMPONENTES}

A fração grossa do sítio Tunel 7 é composta majoritariamente por conchas de molusco, fragmentos líticos, carvão e, em último lugar, fragmentos de osso. A maior parte das conchas corresponde ao gênero Mytilidae, o mexilhão (cerca de 95\%), junto com Nacella sp. e outras espécies de gastrópodes (5\%). Ambas as espécies são facilmente identificáveis em seção delgada pela sua forma e coloração. As conchas de Mytilidae apresentam cor roxa a rosa escuro, enquanto as conchas de Nacella sp. são retas no corte longitudinal e de cor amarela a marrom. A alta proporção de mexilhões observada em seção delgada corresponde com os estudos arqueofaunísticos realizados 
no sítio, que mostraram cerca de $95 \%$ de moluscos e $5 \%$ de ossos de mamífero, peixe e ave (Estevez et al., 1996; Orquera and Piana, 2001; Verdún, 2006, 2010).

Os restos de osso macroscópicos estão bem preservados e apenas uma pequena porção apresenta sinais de queima (Orquera \& Piana 2001). Em seção delgada, a maior parte dos ossos apresenta evidências de queima, o que pode ter favorecido a preservação destes finos fragmentos, já que a queima aumenta a resistência da hidroxiapatita à dissolução (Berna et al., 2004; Karkanas, 2000). A escassa representação de restos de ossos em seção delgada pode estar associada a atividades de limpeza e redeposição dos materiais queimados, com o descarte de fragmentos maiores até uma porção do sítio; com isto, sobraria, no anel de conchas, unicamente aqueles micro-fragmentos que não foram selecionados para descarte em outro local.

\subsection{TAFONOMIA DE CONCHEIROS EM CLIMA FRIO}

Diferentemente dos sambaquis brasileiros, onde a dissolução química de carbonatos e fosfatos é intensa devido ao clima e regime hidrológico predominante, no concheiro fueguino as alterações físicas, relacionadas com as baixas temperaturas, são o processo tafonômico de maior atuação. Atualmente, o clima no litoral do Canal Beagle é frío subantártico, com temperaturas médias de $5^{\circ} \mathrm{C}$ e precipitação anual média de 570 mm (Rabassa et al. 2000). O contexto climático traz consequências detectáveis na análise micromorfológica, tanto na microestrutra como na distribuição espacial e alteração dos componentes da fração grossa.

Os agregados angulosos que caracterizam a $\mathrm{mF} 2$ indicam a ação de processos de congelamento-derretimento dentro do concheiro (Van Vliet-Lanoe, 2010). O predomínio da fração fina argilosa na $\mathrm{mF} 2$ teria favorecido a formação destes blocos angulosos, em oposição a escassa fração fina detectada em outras microfácies. Igualmente, a distribuição aleatória e às vezes perpendicular ao substrato de vários fragmentos de concha na $\mathrm{mF} 3$ e especialmente na $\mathrm{mF} 6$ também pode ser considerada evidência da ação do congelamento do sedimento do concheiro. A formação de grandes cristais de gelo nos poros, e seu derretimento posterior, provocaria a reorganização dos componentes maiores. 
O efeito mais interessante de alteração física associada com as baixas temperaturas dentro do concheiro observa-se, em micro-escala, nas valvas de moluscos. Os numerosos cristais de carbonato acicular, que aparecem tanto no anel de conchas como nas camadas superiores da área central de habitação, derivam do intemperismo físico das conchas de molusco. Estes cristais aciculares assemelham-se a finas agulhas carbonáticas que se desprendem das conchas de molusco. Os cristais aparecem na forma de agregados de agulhas orientadas ou como acumulações de cristais isolados dentro da fração fina, que teriam se formado por retrabalhamento dos agregados originais. Estes cristais são semelhantes, e podem ser confundidos, com a calcita acicular fibrosa (needle-fiber calcite), um tipo de biomineralização carbonática autigênica formada por fungos na rizosfera durante as fases iniciais de pedogênese (Bajnóczi and Kovács-Kis, 2006; Becze-Deàk, 1997; Jones et al., 1993; Verrecchia et al., 1994).

No sítio Túnel 7 , os carbonatos aciculares são produto do congelamento das conchas, que provoca a desagregação das finas lâminas de cristais de carbonato de cálcio que compõem as valvas de molusco. A formação dos cristais pode ser explicada pelo seguinte processo: a superfície intemperizada das conchas absorve as moléculas de água, as quais ingressam no espaço inter-cristalino; quando as temperaturas caem até o ponto de congelamento da água, o fluido que ingressou no espaço inter-cristalino congela e expande, o que provoca a quebra das lâminas de cristais de carbonato de cálcio e libera, assim, milhares de agulhas carbonáticas ao sedimento. De fato, a fração fina da $\mathrm{mF} 2$, onde a ação do congelamento é mais evidente, apresenta a maior concentração de cristais aciculares, o que corrobora a maior intensidade de processos de congelamento-derretimento nesta microfácies, afetando tanto o sedimento como a integridade das conchas.

A preservação deste finos cristais carbonáticos no Túnel 7, apesar das baixas temperaturas das costas do Canal Beagle (que favoreceriam a dissolução dos carbonatos), pode dever-se à presença de solução de solo saturada em carbonato de cálcio dentro do concheiro.

Os processos de congelamento e derretimento não são o unico agente tafonômico que atua neste concheiro. A ação biológica, apesar das baixas temperaturas da região, é um agente de alteração ativo tanto no anel de concha como na área central do concheiro. No anel de conchas, a microestrutura de grânulos interconectados denota a ação de microrganismos no solo, possivelmente favorecida pela alta concentração de detritos orgânicos nesta área de descarte de resíduos. Nas fogueiras centrais, a presença de 
vazios em câmara e canais também indica a ação da fauna do solo dentro do concheiro. Estas evidências, junto com aquelas apresentadas no Capítulo 5, tópico 3.1.3 no estudo micromorfológico de amostras de solo sob floresta, indicam ação biológica intensa, apesar das baixas temperaturas que caracterizam a região.

Feições pedológicas na área central do concheiro incluem revestimentos de calcita impuros, revestimentos de microcarvão, nódulos órticos de óxi-hidróxidos ferro e hiporevestimentos impregnativos de óxi-hidróxidos de ferro. Neste sentido, os nódulos e hipo-revestimentos de óxi-hidróxido de ferro denotam episódios de saturação de água na área central do concheiro, mais compactada que o resto do concheiro, de duração moderada (até alguns dias). Dse fossem mais duradouros os epsódios de saturação, haveria indicadores de redução do ferro (Lindbo et al., 2010).

\subsection{MICROFÁCIES}

A identificação de microfácies no Túnel 7 foi realizada de acordo aos mesmos critérios utilizados para os sambaquis catarinenses. A fração grossa de todas as lâminas é composta por conchas (principalmente mexilhão), fragmentos líticos arredondados na fração cascalho, carvão e alguns ossos queimados. A proporção relativa entre os quatro componentes da fração grossa varia ao longo da sucessão vertical, o que permitiu a identificação de cinco microfácies na coluna estratigráfica coletada no anel de conchas. $\mathrm{Na}$ porção central do concheiro, onde se coletaram amostras de quatro fogueiras, identificaram-se duas microfácies de acordo com a alteração térmica das conchas e mudanças na fração finna.

\subsubsection{Microfácies estratigráficas}

Trabalhos anteriores realizados com seções delgadas do Túnel 7, coletadas em uma área de passagem localizada no anel de conchas periférico (coluna de amostragem identificada como C11) (Figura 5.107 A), identificaram três atividades cotidianas na sucessão vertical. Esta identificação foi realizada a partir da correlação entre os dados micromorfológicos (características da fração grossa, microestrutura e razão g/f) e as 
informações etnográficas disponíveis para as populações yamana (Gusinde, 1937). As atividades são: 1) eventos de deposição de resíduos fora da cabana central; 2) freqüentação do sítio; 3) e abandono do concheiro (Balbo et al., 2010). Para esta tese, as atividades identificadas por Balbo et al. (2010) na análise de C11 foram extrapoladas às microfácies descritas na C12. A extrapolação foi realizada com base na semelhança nas características micromorfológicas utilizadas para identificação de atividades cotidianas na coluna $\mathrm{C} 11$.

Nos Quadro 6.17 e 6.18, agrupam-se as características micromorfológicas das cinco microfácies identificadas na sucessão vertical da coluna C12.

Quadro 6.17. Características da microfácies 1, 2 e 3 da C12 no concheiro Túnel 7.

\begin{tabular}{|c|c|}
\hline \multicolumn{2}{|r|}{ MICROFÁCIES 1} \\
\hline Microestrutura & $\begin{array}{l}\begin{array}{l}\text { Microagregados intergranulares, } \\
\text { comprimento) }\end{array}\end{array}$ \\
\hline Dist. rel. g/f & Enáulica \\
\hline Vazios & De empacotamento complexo \\
\hline Porosidade & $20 \%$ \\
\hline Razão g/f & $50 / 50$ \\
\hline Fração grossa & $\begin{array}{l}\text { 1) Fragmentos de concha }(50 \%) ; 2) \text { fragmentos líticos na fração grânulo e } \\
\text { seixo }(20 \%) ; 3 \text { ) carvão }(20 \%) ; 4) \text { tecidos }(10 \%)\end{array}$ \\
\hline $\begin{array}{l}\text { Distribuição da } \\
\text { frração grossa }\end{array}$ & $\begin{array}{l}\text { Conchas com distribuição sub-horizontal }(50 \%) \text {; outros componentes com } \\
\text { distribuição aleatória }\end{array}$ \\
\hline Micromassa & MO polimórfica, microcarvões, madeira decomposta, restos de plantas oxidados \\
\hline \multicolumn{2}{|r|}{ MICROFÁCIES 2} \\
\hline Microestrutura & Blocos angulosos na forma de prismas ( $5 \times 5 \mathrm{~mm}$ de comprimento) \\
\hline Dist. rel. $g / \mathbf{f}$ & Porfírica \\
\hline Vazios & Fissuras \\
\hline Porosidade & $20 \%$ \\
\hline Razão g/f & $30 / 70$ \\
\hline Fração grossa & $\begin{array}{l}\text { 1) Fragmentos de concha na fração areia muito fina }(5 \%) ; 2) \text { fragmentos de } \\
\text { osso na fração areia muito fina }(2 \%) ; 3) \text { carvão }(5 \%) ; 4) \text { restos de tecidos }(5 \\
\%)\end{array}$ \\
\hline $\begin{array}{l}\text { Distribuição da } \\
\text { frração grossa }\end{array}$ & Aleatória \\
\hline Micromassa & Argila organomineral castanho escuro (PPL) com cristais de calcita acicular \\
\hline \multicolumn{2}{|r|}{ MICROFÁCIES 3} \\
\hline Microestrutura & Microagregados intergranulares, com grânulos (150-250 $\mu \mathrm{m}$ de comprimento) \\
\hline Dist. rel. g/f & Enáulica \\
\hline Vazios & Vazios de empacotamento complexo \\
\hline Porosidade & $40 \%$ \\
\hline Razão g/f & $70 / 30$ \\
\hline Fração grossa & $\begin{array}{l}\text { 1) Conchas inteiras e fragmentadas }(30-40 \% \text { frescas e } 5 \% \text { queimadas }) ; 2) \\
\text { fragmentos líticos na fração grânulo }(20 \%) ; 3) \text { carvão }(10-15 \%) ; 4) \text { ossos } \\
\text { queimados }(5 \%)\end{array}$ \\
\hline $\begin{array}{l}\text { Distribuição da } \\
\text { frração grossa }\end{array}$ & $\begin{array}{l}\text { Conchas com distribuição sub-horizontal (60\%); outros componentes com } \\
\text { distribuição aleatória }\end{array}$ \\
\hline Micromassa & MO polimórfica, microcarvão, restos de tecidos e cristais de calcita aciculares \\
\hline
\end{tabular}


A microfácies superior, que fecha a sucessão vertical, corresponde a $\mathrm{mF} 1$, que aparece uma única vez na $\mathrm{C} 12$. Apresenta mistura de componentes do concheiro (conchas e carvão) com matéria orgânica e liteira fresca, o que indica que não representa uma microfácies original do concheiro e sim a deposição de sedimentos do concheiro erodidos, junto com liteira da floresta circundante sobre a microfácies de abandono final do sítio.

Os momentos de abandono do concheiro são identificados como $\mathrm{mF} 2$, que aparece duas vezes na $\mathrm{C} 12$ e três na $\mathrm{C} 11$. O abandono do sítio caracteriza-se pelo desenvolvimento de solo raso com microestrutura de blocos angulosos. Este solo desenvolve-se a partir da deposição sobre o concheiro, especialmente na área central, de sedimentos coluvionares ou eólicos durante os momentos de abandono. O predomínio de fração fina na $\mathrm{mF} 2$ favoreceu o desenvolvimento de blocos angulosos, como resultado da retração por dessecação associada ao congelamento do solo (Van VlietLanoe, 2010).

A correlação estratigráfica entre a C11 e C12 (ver Figura 5.107 B) indica três momentos de abandono do concheiro com desenvolvimento de solo em blocos angulosos: um episódio próximo à base do concheiro; outro no centro da $\mathrm{C} 11$, que se correlaciona com o topo da $\mathrm{C} 12$; e o último no topo da $\mathrm{C} 11$. A correlação entre a $\mathrm{mF} 2$ no meio da $\mathrm{C} 11$ com a $\mathrm{mF} 2$ no topo da $\mathrm{C} 12$ está representada pela unidade $\mathrm{B} 35$, identificada desde 1990 nos trabalhos de campo no Túnel 7. A unidade B35 é uma camada côncava, de 2 a $3 \mathrm{~cm}$ de espessura, composta por material fino e orgânico que cobre quase a totalidade do concheiro. Esta camada é importante, já que dela foram extraídos os fragmentos de carvão utilizados para datação dendrocronológica do sítio (1776 e 1898 AD) (Piana \& Orquera, 1996). A seqüência de dez ocupações do concheiro identificadas por Estevez \& Vila (2006) e as cinco fogueiras centrais estudadas nesta tese estão todas situadas por debaixo da unidade B35. Isto mostra a diferença que existe entre as taxas de sedimentação na área central de ocupação, com 25 $\mathrm{cm}$ de altura, e o anel de conchas periférico, com mais de $40 \mathrm{~cm}$.

A mF 3 domina a sucessão vertical das duas colunas analisadas. Representa quase a metade da sucessão vertical da $\mathrm{C} 12$ e mais de um terço da sucessão na $\mathrm{C} 11$. A maior frequência de conchas inteiras, junto com a diversidade e distribuição aleatória de componentes da fração grossa (carvão, seixos e ossos queimados) e os finos agregados que compõem a micromassa levam a interpretar esta microfácies como resultado do descarte de detritos na periferia da cabana de habitação, onde os Yamana costumavam 
jogar os resíduos cotidianos. Esta acumulação rápida e conspícua estava motivada pela intenção de manter limpa a área de habitação, mas também pode responder à intenção de construir uma elevação ao redor da cabana para proteção contra os ventos, a infiltração da água etc, como mencionado por vários cronistas (Bridges 1947; Gusinde 1986; Martial 2005).

Quadro 6.18. Características da microfácies 4 e 5 da C12 no concheiro Túnel 7.

\begin{tabular}{|c|c|}
\hline \multicolumn{2}{|r|}{ MICROFÁCIES 4} \\
\hline Microestrutura & $\begin{array}{l}\text { Microagregados intergranulares, com grânulos finos e soltos }(150-300 \mu \mathrm{m} \\
\text { de comprimento) }\end{array}$ \\
\hline Dist. rel. g/f & Enáulica \\
\hline Vazios & De empacotamento complexo \\
\hline Porosidade & $30 \%$ \\
\hline Razão g/f & $90 / 10$ \\
\hline Fração grossa & $\begin{array}{l}\text { 1) Fragmentos de concha }(70 \%) ; 2) \text { fragmentos líticos }(10-15 \%) ; 3) \\
\text { carvão }(5-10 \% \text {; } 4) \text { tecidos }(2 \%)\end{array}$ \\
\hline $\begin{array}{l}\text { Distribuição da frração } \\
\text { grossa }\end{array}$ & $\begin{array}{l}\text { Fragmentos de concha com distribuição sub-horizontal. Outros } \\
\text { componentes com distribuição aleatória }\end{array}$ \\
\hline Micromassa & $\begin{array}{l}\text { MO polimórfica, microcarvão, restos de tecidos e cristais de calcita } \\
\text { aciculares }\end{array}$ \\
\hline \multicolumn{2}{|r|}{ MICROFÁCIES 5} \\
\hline Microestrutura & $\begin{array}{l}\text { Microagregados intergranulares com grânulos finos e soltos }(150-300 \mu \mathrm{m} \\
\text { de comprimento) }\end{array}$ \\
\hline Dist. rel. g/f & Enáulica, mónica \\
\hline Vazios & Empacotamento complexo \\
\hline Porosidade & $60 \%$ \\
\hline Razão g/f & $80 / 20$ \\
\hline Fração grossa & $\begin{array}{l}\text { 1) Fragmentos líticos na fração seixo }(90 \%) ; 2) \text { fragmentos de concha de } \\
\text { tamanho diverso }(10 \%)\end{array}$ \\
\hline $\begin{array}{l}\text { Distribuição da frração } \\
\text { grossa }\end{array}$ & Aleatória \\
\hline Micromassa & $\begin{array}{l}\text { MO polimórfica, microcarvão, restos de tecidos e cristais de calcita } \\
\text { aciculares }\end{array}$ \\
\hline
\end{tabular}

A mF 4 aparece como lentes de 1 a $2 \mathrm{~cm}$ de espessura intercaladas na $\mathrm{mF} 3$ ao longo da sucessão vertical e também na base do concheiro. Nesta microfácies, as conchas estão mais compactadas, com distribuição sub-horizontal, empacotamento fechado e fragmentação in situ. A fração fina é menos abundante que na $\mathrm{mF} 3$. Isto leva a interpretar a mF 4 como ligada a episódios de pressão superficial sobre o concheiro, possivelmente por pisoteamento, que conduziram à compactação e fragmentação das conchas. A natureza episódica destes eventos de pisoteamento é deduzida pelo fato de que se manteve a continuidade dos fragmentos laterais. Se tivesse havido retrabalhamento intenso, não se preservaria esta continuidade.

$\mathrm{Na} \mathrm{mF} 4$, localizada na base da $\mathrm{C} 12$, foram identificados cerca de $5 \%$ de ossos de mamífero, com birrefringência característica de calcita, e amplas áreas de dissolução 
ao redor dos ósteons. Estes atributos mineralógicos e morfológicos foram descritos no Capítulo 5, tópico 3.1.2, para os ossos de mamífero que compõem naturalmente os sedimentos das praias do Canal Beagle. A presença destes ossos intemperizados na base do concheiro é condizente com a proximidade dos sedimentos praiais subjacentes. A mF 5 representa uma lente de seixos que se estende pelas duas colunas amostradas no anel de conchas.

A mF 6 é a única microfácies que foi identificada na área de passagem sobre o concheiro $(\mathrm{C} 11)$, mas não no anel de conchas periférico $(\mathrm{C} 12)$. Esta microfácies foi interpretada por Balbo et al. (2010) como momentos de frequentação mais intensa do sítio, com reorganização dos componentes microscópicos. Dentre as suas características micromorfológicas está razão g/f baixa (maior teor de fração fina), fragmentos de concha, seixos e carvão aleatoriamente distribuídos. Contém a maior quantidade de fragmentos de concha queimados, identificados graças à experimentação apresentada do Capítulo 5, tópico 3.1.5, o que serve como indicador da sua conexão direta com a área central onde se localizavam as fogueiras.

A mF 6 esta presente unicamente na porção inferior da C11 e desaparece na porção superior da sucessão vertical, onde $\mathrm{mF} 3$ é dominante. Esta transição corresponde a momento de abandono do sítio, identificado pela $\mathrm{mF} 2$ correspondente à unidade B35, onde houve deslocamento da cabana central, o que provocou mudança na localização da área de passagem através do concheiro. Assim, a transição entre a mF 6 e $\mathrm{mF} 3$ indica que houve deslocamento da cabana central e que a área de passagem passou a receber o descarte de conchas e detritos de ocupação $(\mathrm{mF} 3)$, integrando-se ao anel periférico.

\subsubsection{Microfácies centrais (fogueiras)}

As características micromorfológicas das cinco fogueiras centrais de Túnel 7 analisadas nesta tese foram agrupadas em duas microfácies principais: $\mathrm{mF} 7 \mathrm{e} \mathrm{mF} 8$. No Quadro 6.19, agrupam-se as características micromorfológicas das $\mathrm{mF} \quad 7$ e 8 identificadas na área central do Túnel 7. 
Quadro 6.19. Características da microfácies 7 e 8 na área central do concheiro Túnel 7.

\begin{tabular}{|c|c|}
\hline \multicolumn{2}{|r|}{ MICROFÁCIES 7} \\
\hline Microestrutura & $\begin{array}{l}\text { Microagregados intergranulares }(100-300 \mu \mathrm{m} \text { de cumprimento }) \text { e áreas de } \\
\text { microestrutura esponjosa }(\sim 600 \mu \mathrm{m})\end{array}$ \\
\hline Dist. rel. g/f & Enáulica \\
\hline Vazios & De empacotamento complexo \\
\hline Porosidade & $40 \%$ \\
\hline Razão g/f & $80 / 20$ \\
\hline Fração grossa & $\begin{array}{l}\text { 1) Fragmentos de concha }(50 \%) \text { queimados a diversas temperaturas }(20 \% \text { do } \\
\left.\left.\text { total a temperatura superior aos } 500^{\circ} \mathrm{C}\right) ; 2\right) \text { fragmentos líticos na fração seixo, } \\
\text { queimados }(20 \%) ; 3 \text { ) carvão }(30 \%) ; 4) \text { ossos queimados }(2 \%)\end{array}$ \\
\hline $\begin{array}{l}\text { Distribuição da } \\
\text { frração grossa }\end{array}$ & $\begin{array}{l}\text { Fragmentos de concha com distribuição sub-horizontal; demais elementos com } \\
\text { distribuição aleatória }\end{array}$ \\
\hline Micromassa & Microcarvoes, tecidos de plantas oxidados, micrita \\
\hline \multicolumn{2}{|r|}{ MICROFÁCIES 8} \\
\hline Microestrutura & Em câmara \\
\hline Dist. rel. g/f & Porfírica \\
\hline Vazios & Em canal, câmara e fissuras \\
\hline Porosidade & $20 \%$ \\
\hline Razão g/f & $50 / 50$ \\
\hline Fração grossa & $\begin{array}{l}\text { 1) Fragmentos de concha queimados a temperatura superior a } 500^{\circ} \mathrm{C}(20-30 \%) \text {; } \\
\text { 2) fragmentos líticos na fração seixo, queimados }(30-40 \%) ; 3) \text { ossos queimados } \\
(5 \%)\end{array}$ \\
\hline $\begin{array}{l}\text { Distribuição da } \\
\text { frração grossa }\end{array}$ & Aleatória \\
\hline Micromassa & Cinzas com argila rubefacta \\
\hline
\end{tabular}

A mF 7 está associada às fogueiras superiores (AC 4 e AC 5), caracterizadas por conter conchas queimadas, seixos, carvão e fragmentos de osso em micromassa composta por agregados finos $(100-300 \mu \mathrm{m})$ de microcarvão. A partir da comparação com o experimento de queima de conchas de Mytilus edulis apresentado no Capítulo 5, tópico 3.1.5, infere-se que as conchas na $\mathrm{mF} 7$ foram queimadas a temperatura não superior a $500^{\circ} \mathrm{C}$. O padrão de alteração térmica das conchas e a ausência de substrato rubefacto confirmam assim temperatura moderada para as fogueiras da $\mathrm{mF} 7$ (categoria de fogueiras dentre $350-450^{\circ} \mathrm{C}$ segundo classificação de Wattez 1992).

A mF 8 agrupa as fogueiras inferiores (AC 8 e AC 10), que contêm seixos, conchas queimadas e fragmentos de osso em meio a micromassa micrítica com argila rubefacta de baixa porosidade. De acordo com o modelo experimental de queima de Mytilus edulis, os fragmentos de concha teriam sido queimados a altas temperaturas, superiores a $500-600^{\circ} \mathrm{C}$. A presença de conchas queimadas a estas temperaturas e a rubefação da micromassa indicam que estas fogueiras são estruturas de combustão de alta intensidade (ver Mallol et al. 2007; Schiegl et al. 1996; Wattez 1992; Weiner et al. 2002). A boa preservação das características microscópicas da $\mathrm{mF} 8$ correspondem ao 
modelo tafonômico desenvolvido a partir da análise de fogueiras experimentais, apresentado no Capítulo 5, tópico 3.1.4. Este modelo postula que, pela alta porosidade dos concheiros e o regime hidrológico do Canal Beagle, as estruturas de combustão ou camadas de cinzas só se preservam se situadas sobre substrato argiloso em solução de solo saturada em carbonato de cálcio, que evite a dissolução e lixiviação dos carbonatos. Esta situação corresponde ao encontrado nas fogueiras inferiores analisadas. A bioturbação, indicada pelos vazios em câmara e canais, não teria obliterado completamente o arranjo original de materiais.

A transição entre a $\mathrm{mF} 8$ e a $\mathrm{mF} 7$ é marcada por uma camada preta de sedimentos coluvionares, que aparece unicamente na área central de habitação e não é visível em nenhuma das colunas estudadas no anel de conchas periférico. $O$ fato de que a mF 7 seja a única microfácies observada acima desta unidade pode ser explicada pela tafonomia do sítio ou pela própria formação cultural do depósito, embora uma combinação de ambos os fatores seja mais provável. Na hipótese tafonômica, o predomínio de $\mathrm{mF} 7$ nas fogueiras superiores pode estar relacionado com a possível redução na acumulação de sedimentos coluvionares, na medida em que o sítio aumentava em altura. Isto teria prejudicado a boa preservação das estruturas de combustão, já que, ao diminuir a chegada de sedimentos finos, o substrato fica mais poroso, o que aumenta erosão e lavagem de componentes. Esta situação é contrária ao que acontece nas fogueiras inferiores, onde a presença de sedimentos coluvionares ou eólicos sugere maior sedimentação, menos erosão e, portanto, melhor preservação (ver Mallol et al. 2007).

No entanto, esta situação não explica o predomínio de conchas queimadas a altas temperaturas nas fogueiras inferiores $(\mathrm{mF} 8)$. A segunda hipótese, de caráter cultural, aponta para diferenças na temperatura alcançada pelas fogueiras inferiores e superiores relacionada, por sua vez, com funções diferentes. De fato, análises faunísticas e isotópicas mostraram que as fases de ocupação associadas com as fogueiras AC 5 e AC 4 correspondem a ocupações no outono e na primavera/verão. Pelo contrário, a fogueira AC 8 representa ocupação no inverno (Colonese et al., 2011; Estevez and Vila, 2006; Juan-Muns, 1992; Mameli and Estevez, 2004). Isto sugere que as diferenças entre a mF 7 e a mF 8 podem estar relacionadas com mudanças nas necessidades de aquecimento dos habitantes da cabana, vinculadas com a estação de freqüentação do sítio (as fogueiras de inverno demandam maior intensidade de queima) ou com a localização das fogueiras dentro da cabana (fogueiras secundárias são menos intensas). 
Neste sentido, a mistura entre $\mathrm{mF} 7 \mathrm{e} \mathrm{mF} 8$, que se observa na $\mathrm{AC} 6$, pode indicar retrabalhamento de resíduos oriundos de uma fogueira de alta intensidade com resíduos de fogueira de baixa temperatura. Ambas as estruturas de combustão, central e secundária, podem ter sido acessadas simultaneamente dentro da cabana durante a ocupação do sítio representado pela fogueira AC 6. A mistura pode ter sido causada pela ocupação cotidiana e pelo pisoteamento na cabana central.

\subsection{FORMAÇÃO DO CONCHEIRO DOMÉSTICO}

O concheiro Túnel 7 compõe-se de duas áreas principais, as quais podem ser definidas, com base em suas propriedades morfológicas e composicionais, como sendo: 1) anel de conchas periférico; e 2) área central de moradia. A análise micromorfológica aqui proposta, em combinação com os relatos etnográficos sobre os assentamentos yamana, mostram a complexidade espacial e sedimentológica dos concheiros. Apesar da maioria dos componentes ser comum tanto ao anel de conchas quanto às fogueiras centrais, diferenças na freqüência relativa dos componentes, alterações pósdeposicionais, arranjo etc., servem como indicadores da rede de eventos que caracteriza a construção dos concheiros.

Diferenças espaciais dentro do concheiro Túnel 7 já tinham sido detectadas pelas análises zooarqueológicas (Estevez et al. 1996; Estevez \& Vila 2006; Verdún 2006, 2010). Verdún (2010), a partir de análises de componentes principais, concluiu que densidades maiores de conchas apareciam na periferia do sítio (no anel de conchas) em relação à área central, onde dominam os seixos e os sedimentos finos. Neste sentido, a análise micromorfológica aqui apresentada corrobora as constatações anteriores e mostra outras diferenças significativas entre a área central e a periferia do concheiro. Por exemplo, conchas queimadas estão quase ausentes no anel de conchas, com exceção da $\mathrm{mF} 6$ na $\mathrm{C} 11$, que representa a área de passagem entre o exterior e a cabana de moradia através do anel de conchas. Pelo contrário, conchas queimadas caracterizam a área central de moradia.

Apesar de que os cronistas descrevem a prática de jogar moluscos ao fogo para abrir a concha e extrair a carne (Gusinde 1986; Martial 2005; Wilkes 1844), a baixa frequência de conchas queimadas no anel periférico permite aventar duas 
possibilidades: que as conchas no anel periférico não foram jogadas ao fogo, o que implica, como corolário, que não teriam sido consumidas; ou que a temperatura de aquecimento dos moluscos para abertura não foi alta o bastante para alterar as conchas. A segunda hipótese parece a mais provável, já que as conchas de mexilhão se abrem facilmente a temperaturas no entorno dos $100^{\circ} \mathrm{C}$. O achado de conchas queimadas a temperatura superior aos $500^{\circ} \mathrm{C}$ sugere que foram jogadas à fogueira ou que se encontravam no substrato onde foi acesso o fogo.

$\mathrm{O}$ anel de conchas periférico ter-se-ia formado a partir da deposição massiva de conchas, dominantemente frescas, seixos, restos de plantas, carvão, ossos queimados e demais detritos cotidianos. Os cronistas têm descrito estes episódios como parte da rotina de manutenção da área de moradia que, com o tempo, leva à formação de montículos e anéis de conchas tão altos quanto as próprias cabanas (Bridges 1975; Despard 1863; Gusinde 1986; Martial 2005). A concentração de cinzas, argila e seixos é maior na área central, onde os sedimentos são também mais compactos. Estas observações também coincidem com os relatos etnográficos que descrevem as fogueiras yamana acesas sobre acumulações de seixos (Lovisato, 1884) e conchas (Bridges, 1987), com os restos de comida sendo ocasionalmente jogados no fogo (Gusinde 1986).

A existência de dois tipos de fogueiras surge da análise de microfácies aqui proposta. Diferentes estruturas de combustão parecem ter atendido a funções diferentes de acordo com as necessidades de aquecimento dos moradores da cabana, expressas na temperatura máxima de combustão. Assim, fogueiras acesas durante a ocupação do sítio no inverno atingem temperaturas maiores de queima, enquanto fogueiras acesas no verão, assim como fogueiras periféricas, atingem temperaturas moderadas.

A existência de áreas periféricas e centrais dentro dos concheiros yamana não necessariamente significa a discriminação de um espaço a favor do outro. A formação do concheiro assume a forma de um continuum de processos cotidianos, onde há uma sucessão de processos de produção de detritos, na área central de moradia, e descarte de resíduos fora da cabana, no anel periférico. 


\section{ANALOGIA GEO-ETNOARQUEOLÓGICA}

Como proposto no Capítulo 1, tópico 3.2.2, os resultados da análise micromorfológica dos sambaquis catarinenses será contrastado com os resultados do estudo micro-estratigráfico realizado no concheiro etnohistórico Túnel 7. A comparação entre ambos os registros será realizada com base no processo de formação dos concheiros, como ação mecânica. O significado do processo será avaliado como corolário à formação dos sítios, através do filtro imposto pelas diferenças étnicas, cronológicas e geográficas entre ambas as culturas.

Dos três padrões estratigráficos estudados nesta tese, os sambaquis conchíferos são os que apresentam maior semelhança macroscópica com os concheiros do Canal Beagle. Apesar das diferenças volumétricas entre ambos, trata-se de concheiros estratificados, compostos maiormente por conchas de espécies locais (Mytilus edulis, no caso fueguino, e A. brasiliana, no caso catarinense), com ossos, carvões e grãos minerais (seixos e areias, na Terra do Fogo e Santa Catarina, respectivamente). No caso dos concheiros do Holoceno médio, como o sítio Túnel 1, os perfis estratigráficos apresentam semelhanças, em termos de forma e composição das camadas, com os sambaquis catarinenses (ver Figura 6.5 A e B). Já o concheiro etno-histórico analisado nesta tese, com escassos $30 \mathrm{~cm}$ de altura, na área central, e $60 \mathrm{~cm}$ de altura, no anel de conchas, assemelha-se aos sambaquis catarinenses principalmente pela composição; com predomínio de conchas e outros resíduos (carvão, ossos e grãos minerais).

Pela idade recente do concheiro Túnel 7 , não se pode saber se a ocupação contínua deste concheiro teria levado à formação de estruturas maiores, a longo prazo, como as apresentadas na Figura 6.5 A e B. De fato, a ocupação diacrônica de concheiros menores, como os agrupamentos da Figura 6.5 D-F, podem servir de imagem ilustrativa para a formação dos grandes sambaquis conchíferos. No entanto, uma diferença chave refere ao sistema de assentamento estabelecido em ambas as regiões. Na Terra do Fogo, há maior dispersão horizontal nas ocupações, com formação de concheiros espalhados, próximos um do outro, todo ao longo da costa do Canal Beagle. Já em Santa Catarina, há maior focalização das ocupações com maior reiteração e, conseqüentemente, crescimento vertical dos sítios. O que não pode-se saber, a partir das evidências apresentadas neste trabalho, é se essa focalização dos sambaquieiros devia-se à 
identificação e/ou domínio do território a partir de áreas de sepultamento comunais, ou à marcação de lugares ótimos de captação de recursos, ou uma combinação dos dois.

A comparação com o concheiro Túnel 7 resulta de interesse para refinamento dos processos de formação dos sambaquis conchíferos devido ao controle etnográfíco que existe sobre a formação do sítio. Este concheiro, de associação étnica conhecida, foi formado a partir de ocupações domésticas descontinuas, mas recorrentes ao longo de, pelo menos, um século, como explicado no Capítulo 2, tópico 5.1.2 e no Capítulo 3, tópico 4.2. O registro arqueológico, tanto dos concheiros históricos como de alguns concheiros pré-históricos (embora nos concheiros pré-históricos as evidências ainda sejam questionáveis), é indicativo da existência de uma cabana na área central do sítio, onde se mantinham fogueiras ativas e realizavam-se demais atividades cotidianas (Estévez \& Vila 2006; Estévez et al. 2001; Orquera 1996; Orquera \& Piana 1996a, 1999a, 2000; Piana et al. 2000). 

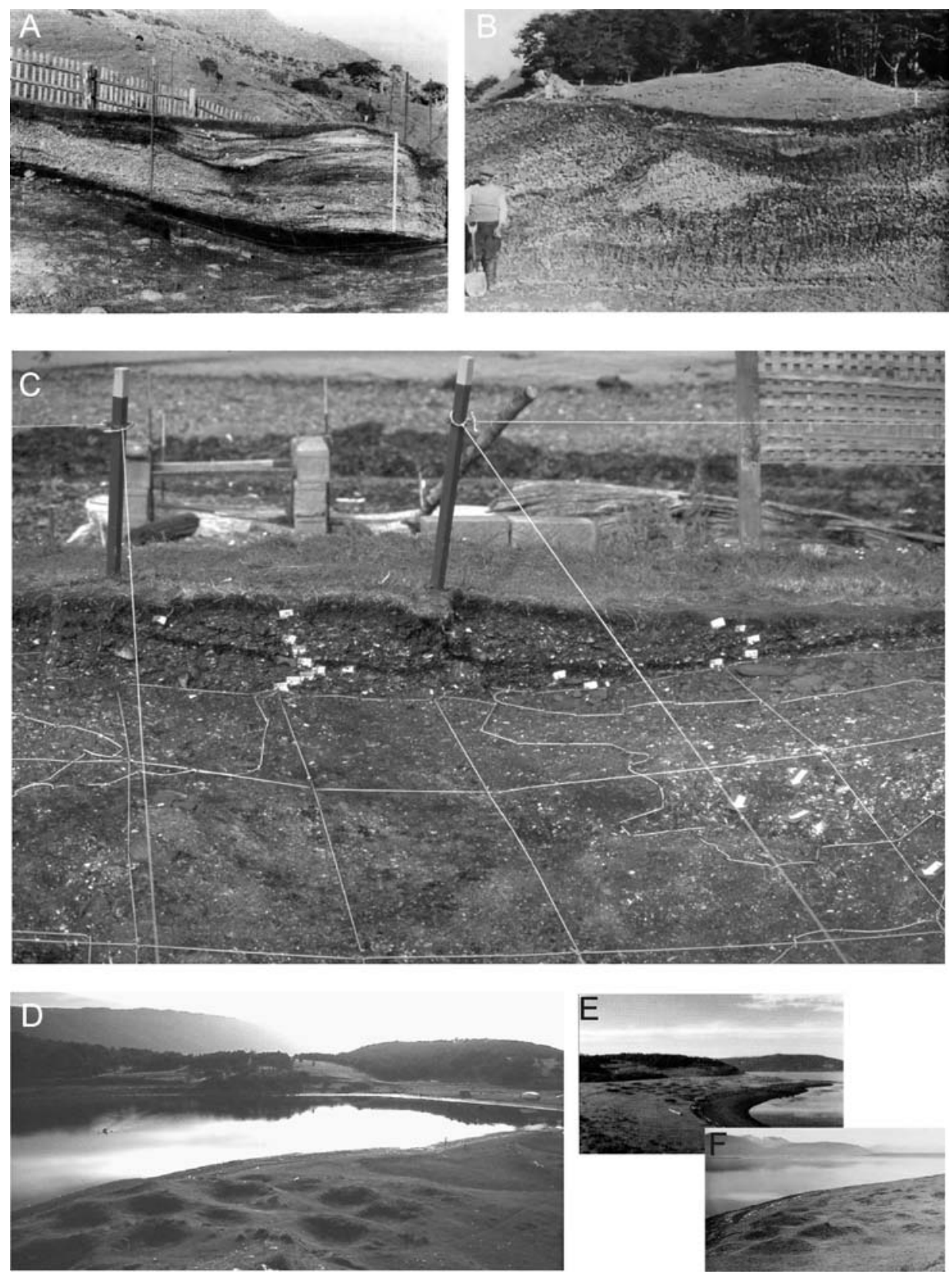

Figura 6.5. Concheiros do Canal Beagle: A) perfil do sítio Túnel 1 (Orquera \& Piana 1999: 33); B) perfil de um concheiro na Ilha Navarino (Handbook of South American Indians, volume 1, 1945: 28); C) perfil estratigráfico do sítio Túnel 7; D) concheiros anelares na Baía Cambaceres; E) sítio Kurakani (Orquera \& Piana 1999: 25); E) concheiros da Ilha Navarino (Handbook of South American Indians, volume 1, 1945: 27).

Em termos de processos de formação, avaliados a partir da análise micromorfológica, vários elementos são comuns aos dois contextos analisados. Das cinco microfácies identificadas nos sambaquis conchíferos, três podem ser comparadas com as microfácies identificadas no sítio Túnel 7. Por exemplo, a alteração pedogênica de ambos os concheiros é observável a partir da formação de microestrutura de blocos subangulosos, no caso de Túnel 7 ( $\mathrm{mF}$ 2), e de microestrutra de grânulos coesivos, nos 
sambaquis conchíferos $(\mathrm{mF}$ E). A razão $\mathrm{g} / \mathrm{f}$ nestas microfácies apresenta, em ambos os casos, tendência ao predomínio da fração fina sobre a fração grossa (10/90 em sambaquis e 30/70 em Túnel 7). As diferenças em termos de pedogênese relacionam-se com o contexto climático no qual se localizam os sítios, com maior incidência de agentes de congelamento e derretimento na Terra do Fogo, e de dissolução e lixiviação de solutos, em Santa Catarina. O congelamento do substrato é identificado através dos blocos subangulares da $\mathrm{mF} 2$ e dos cristais de calcita acicular que se distribuem ao longo do sedimento, associados à fragmentação física das lâminas que compõem as valvas de moluscos. A dissolução de carbonatos e fosfatos, associada ao regime hidrológico e contexto climático dos sambaquis catarinenses, observa-se através da baixa frequência de conchas na $\mathrm{mF} \mathrm{E}$ e nas micromassas micríticas, com diversas feições pedológicas (como revestimentos e enchimentos de micrita e espato) que aparecem nas porções inferiores do perfil.

Nos dois contextos, identifica-se, igualmente, a microfácies típica de eventos de deposição massiva de elementos descartados, com predomínio de conchas, o que caracteriza os sítios concheiros em geral. No caso dos sambaquis catarinenses, os episódios de descarte estão representados pela $\mathrm{mF} \mathrm{A}$, enquanto no concheiro fueguino estão representados pela $\mathrm{mF} 3$. Ambas as microfácies assemelham-se na microestrutura de agregados intergranulares, na distribuição relacionada g/f de tipo enáulica, na razão g/f de 70/30 e na distribuição sub-horizontal das conchas inteiras. Embora a ação de deposição massiva de resíduos seja a mesma em ambos os casos, existem diferenças entre ambas as microfácies, além daquela produzida pela alteração pós-deposicional do sedimento, com feições de precipitação de carbonatos nos sambaquis e de congelamento no Túnel 7. Uma das diferenças refere-se à maior quantidade de conchas e ossos queimados nos sambaquis conchíferos, com quantidades desprezíveis no Túnel 7.

Esta diferença resulta chave para respaldar a interpretação dada à $\mathrm{mF} \mathrm{A}$. A mF 3 é associada ao descarte secundário dos resíduos produzidos dentro da cabana de moradia, localizada na área central do concheiro, do lado do anel de conchas. A ausência de conchas queimadas foi interpretada como devida à não alteração térmica dos moluscos ou baixa incidência do fogo na textura das valvas, quando jogada nas brasas para abertura e extração da carne. Nos sambaquis conchíferos, existe retrabalhamento e mistura de conchas e ossos queimados a temperaturas diversas, cujo aquecimento não aconteceu no local. Isto foi interpretado como evidência da complexa história pré-deposicional dos elementos que compõem os sambaquis. 
Assim, pelos relatos etnográficos e evidência micromorfológica, pode-se supor que o concheiro fueguino é, de fato, um depósito secundário formado pelo descarte imediato dos resíduos produzidos na área central de moradia. Se o sambaqui fosse igualmente um depósito secundário, nele haveria apenas resíduos cuja história prédeposicional envolvesse consumo e descarte, como no caso fueguino, e não descarte, queima e retrabalhamento para deposição última no sambaqui, como aqui evidenciado. Estas características são as que permitem associar os sambaquis conchíferos com depósitos terciários, o que representa uma diferença chave entre os dois contextos aqui discutidos.

Em síntese, a história deposicional dos sambaquis é muito mais complexa que a do concheiro fueguino. No litoral brasileiro, a acumulação de resíduos no mesmo local prolonga-se durante milhares de anos, enquanto no concheiro Túnel 7 somente se registraram dez momentos breves de acumulação ao longo de, no máximo, um século. Esta diferencia substancial, evidenciada pela análise geoarqueológica, respalda as propostas de uma estrutura social mais numerosa entre os sambaquieiros, com maior densidade populacional e com sedentarismo, como também sugere a grande concentração de sepultamentos que caracteriza aos sambaquis catarinenses (ver Fish et al., 2000; DeBlasis et al., 2007; Gaspar et al. 2008). Essa sedentarização pode envolver a realização de tarefas muito mais diversificadas na costa do Brasil que na Terra do Fogo. Além disso, na Terra do Fogo não houve consumo de vegetais e não se realizaram os processos culinários que envolvem o processamento de plantas para consumo, como teria acontecido entre os sambaquieiros.

Neste sentido, a mF G descrita para o sambaqui de núcleo arenoso Carniça 3 assemelha-se também, em termos de composição e arranjo dos materiais, à mF 3 . Ambas as microfácies apresentam microestrutura de microagregados intergranulares, formados por MO e microcarvões, distribuição relacionada $\mathrm{g} / \mathrm{f}$ de tipo enáulica, vazios de empacotamento complexo, conchas inteiras bem preservadas, com distribuição subhorizontal e demais elementos (grãos minerais, carvões, ossos queimados, fragmentos de concha) com distribuição aleatória. A maior semelhança entre ambas as microfácies, que as diferencia da $\mathrm{mF} \mathrm{A}$ dos sambaquis conchíferos, é a baixa, senão nula, frequência de conchas queimadas. Isto pode ser interpretado como sinal de afinidade, em termos de proveniência dos materiais e atividade de deposição. Assim, a mF G também representa o produto de descarte secundário, sobre o núcleo arenoso, de materiais processados nas proximidades do sítio, assim como a $\mathrm{mF} 3$ representa o descarte imediato de materiais 
consumidos na cabana de moradia. Em ambos os casos, há mistura entre conchas frescas com resíduos de queima. A associação entre a ação de descarte secundário que caracteriza às $\mathrm{mF} \mathrm{G} \mathrm{e} \mathrm{mF} 3$ não significa, necessariamente, que os sambaquis de núcleo arenoso possam ser assimilados a ocupações domésticas, como Túnel 7. Como discutido no tópico 2.7, os sambaquis de núcleo arenoso resultam de ocupações efêmeras mais planejadas, aparentemente não relacionadas com contextos domésticos nem funerários.

Outro elemento que contribui à discussão da relação entre microfácies estudadas em sambaquis e no sítio Túnel 7 são as fogueiras da cabana de moradia do concheiro fueguino. Estas fogueiras foram identificadas como $\mathrm{mF} 7$, quando a temperatura de combustão é moderada, e $\mathrm{mF} 8$, quando atinge temperaturas superiores a $600^{\circ} \mathrm{C}$. Nenhuma microfácies semelhante foi identificada nos sambaquis conchíferos. Isto porque fogueiras in situ não foram observadas nas sucessões verticais analisadas, mas unicamente os produtos do retrabalhamento a curta distância de fogueiras acesas sobre o sambaqui, categorizados como $\mathrm{mF}$ B. As $\mathrm{mF} \mathrm{B} \mathrm{e} \mathrm{mF} 7$ e 8 são aparentemente semelhantes, mas com algumas diferenças. Entre as semelhanças, cabe mencionar a microestrutura de microagregados intergranulares e a presença de agregados de argila rubefacta, cinzas de madeira e conchas queimadas, com porcentagem superior a 20-30 $\%$ de conchas aquecidas a temperatura superior a $500^{\circ} \mathrm{C}$. As diferenças referem-se ao arranjo dos materiais, com evidências de inversão entre agregados queimados e rubefactos na $\mathrm{mF} \mathrm{B}$ que, ao mesmo tempo, apresenta menor espessura (cerca de $1 \mathrm{~cm}$ ) que as $\mathrm{mF} 7$ e $8(4 \mathrm{~cm})$. Pode-se dizer que a $\mathrm{mF} B$ apresenta maiores semelhanças com a $\mathrm{mF} 7$, o que indica que, a fogueira original da qual provêm os materiais, teria atingido temperaturas moderadas.

Por último, microfácies de pisoteamento sobre os sítios, como a $\mathrm{mF} 4$ identificada no anel de conchas do Túnel 7, não foram observadas nos sambaquis conchíferos estudados. Isto sugere que, pelo menos nas seções verticais analisadas, não se identificaram áreas de pisoteamento ou trânsito de pessoas sobre o sambaqui. Pelo grande volume dos sambaquis analisados, resulta ousado extrapolar esta observação ao total dos sítios e admitir que não teria havido pisoteamento sobre os sambaquis. O que pode ser dito, pelo momento, é que evidências de pisos de ocupação não foram observadas, ainda, nestes sítios.

Assim, a comparação geo-etnoarqueológica entre ambos os contextos confirma as diferenças intrínsecas à formação dos dois tipos de concheiros aqui analisados. A observação da dinâmica de formação de um pequeno concheiro doméstico, comparado 
com os grandes sambaquis catarinenses, destaca o complexo processo de formação dos sambaquis que, como corolário, pode também evidenciar a complexidade de sua função e de seu significado. Isto remete aos modelos de construção de sambaquis apresentados no Capítulo 2, tópico 4.1. A formação de anéis de conchas periféricos à área central de ocupação, que caracteriza o concheiro Túnel 7, foi proposto por diversos autores como modelo para a construção de alguns sambaquis (sítios Conquista 9, Mar Casado, Araujo II e Ilhote do Leste) (Guidon 1964; Orssich 1977; Tenório et al. 2008; Tiburtius 1966) e como modelo geral para a formação destes sítios (Gaspar \& DeBlasis 1992). No entanto, a evidência geoarqueológica mostra a intrincada sucessão de ações envolvidas na formação dos sambaquis, que vai além da deposição imediata, e secundária, de detritos de alimentação nos arredores do local de moradia.

Tanto os aborígenes fueguinos como os sambaquis brasileiros foram, por muitos anos, comparados e considerados análogos a tribos marginais a partir da proposta do Handbook of South American Indians. Nos oito volumes que constituem esta obra, a América do Sul foi subdividida em quatro grandes áreas culturais que correspondiam, também, a estágios evolutivos, com a região andina como grande centro as inovações culturais e, as áreas litorâneas, como regiões marginais (Steward, 1946). Assim, a assimilação de ambas as culturas parecia conveniente, por se localizarem ambas em áreas costeiras, consideradas como marginais; mas trazia como consequência a visão do sambaqui como estrutura tão simples quanto a cultura humana que a produziu. Da mesma maneira, os aborígenes fueguinos foram tomados como estereótipo e imagem etnográfica do escasso potencial evolutivo das culturas litorâneas.

Deixando de lado os estereótipos evolucionistas, pode-se dizer que a cultura de construtores de sambaquis e os aborígenes fueguinos compartilham vários traços, tanto em termos organizacionais como materiais. Por exemplo: 1) em ambos os casos o acervo artefatual inclui objetos líticos, lascados e polidos, assim como em concha e osso; 2) enterramentos humanos são achados em numerosos sambaquis e também foram relatados para concheiros da ilha Navarino, ilhas do arquipélago do Cabo de Hornos, Chiloé, costa norte do Canal Beagle e litoral nordeste e noroeste da ilha Grande de Terra do Fogo; 3) apesar das diferenças volumétricas, concheiros fueguinos e sambaquis são estratificados, diferentemente dos concheiros da Patagônia, por exemplo, onde os sítios costumam ter pouca expressão vertical (menos de $1 \mathrm{~m}$ ) e consistir de camadas delgadas de concheiro aflorantes em dunas ou voçorocas, ou ainda montículos pequenos, sem estratificação interna, depositados sobre dunas eólicas (Borella \& Favier Dubois 2008; 
Caracotche et al. 2005; Gomez Otero et al. 1998; Gomez Otero 2006; Muñoz et al. 2009; Zubimendi 2007; Zubimendi et al. 2005); 4) ambas as culturas podem ser definidas como caçadores-coletores marítimos, segundo a definição (Yesner, 1980) ou culturas marítimas (sensu Diegues, 2004), ou seja, grupos com subsistência e tecnologia baseadas na exploração de espécies aquáticas (segundo definição de Alvarez et al., 2011); 4) a existência de canoas é comprovada para os aborígenes fueguinos e, evidências indiretas, como discutidas no Capítulo 2, tópico 3.3, sugerem a existência desta tecnologia entre os sambaquieiros; 5) apesar dos concheiros serem o remanescente cultural mais conspícuo de ambas as culturas litorâneas, a subsistência dos grupos não estava baseada no consumo de moluscos, mas de peixes, no caso dos sambaquis, e de guanaco e lobo marinho, no caso fueguino; 6) por último, ambas as sociedades têm escassa ou limitada incidência na reprodução dos recursos, denominador comum que pode desembocar, em sociedades de pescadores-caçadores-coletores, em estratégias sociais muito diferentes (Vila and Estevez, 2010).

Apesar das diferenças a respeito do tamanho dos concheiros deixados por ambas as populações, Yamana e sambaquieiros, não há diferenças quanto ao valor simbólico e papel social destas estruturas. Tanto o local de moradia quanto os locais de deposição dos mortos (interpretação mais freqüente dada para os sambaquis catarinenses) são elementos sociais em si mesmos, agentes ativos na transmissão de normas, crenças e tradições. A grande diferença entre ambos diz respeito às evidências da complexa história pré-deposicional dos sedimentos que compõem os sambaquis, em oposição ao concheiro fueguino, cuja repetição manteve-se durante milhares de anos, até deixar na paisagem grandiosas estruturas em concha. $\mathrm{O}$ volume dos sambaquis conchíferos e a longa vida de ocupação dos sítios sugere maior quantidade de pessoas envolvidas na formação dos sambaquis. Na Terra do Fogo, pelo contrário, nunca se chegaram a alcançar as dimensões de acumulação de conchas que caracterizam o litoral catarinense. Inclusive os concheiros mais antigos da Terra do Fogo não alcançam as dimensões dos sambaquis catarinenses, atingida pela reiteração da ocupação dos sítios e acumulação continua e ininterrupta. Nos sambaquis, acumulação está frequentemente associada ao sepultamento dos mortos, mas não se pode saber, ainda, se o objetivo de sepultamento doss mortos foi causa da acumulação ou a conseqüência da reiteração da ocupação e uso do sítio.

Para finalizar, a análise geoarqueológica dos sambaquis catarinenses mostra que a complexidade na formação dos sítios não se interpreta unicamente a partir do tamanho 
e/ou presença de sepultamentos humanos, mas também a partir da intrincada sucessão de eventos de consumo, alteração e deposição que permite caracterizar os sedimentos dos sítios como depósitos terciários. Assim, a partir da comparação geoetnoarqueológica aqui proposta, detectam-se diferenças entre o concheiro fueguino e os sambaquis que se referem à diversidade de atividades representadas, tamanho, reiteração e continuidade da ocupação. Isto leva a pensar que as diferenças possam estar relacionadas ao maior número de pessoas envolvidas e à maior diversidade de atividades produtivas (como processamento de vegetais, por exemplo) associadas com os grupos sambaquieiros. 


\section{CAPÍTULO 7. CONCLUSÕES}

Os processos de formação dos oito sambaquis estudados nesta tese foram discutidos de acordo com o padrão estratigráfico ao qual pertencem (conchífero, de núcleo arenoso ou em montículo ictiológico). As diferenças de morfologia, estratigrafia

e composição, agrupadas nos três padrões mencionados, expressam contrastes e semelhanças no processo de formação. A relação sincrônica e diacrônica entre eles reflete modelos concomitantes e sucessivos de ocupação do espaço, que serão explicados a partir da permanência e mudança nos processos de formação.

A combinação dos dados micromorfológicos com os dados provenientes de outras análises (física, isotópica, zooarqueológica) permite descomplicar a estratigrafia de sambaquis ao mostrar que muitas das diferenças observadas a olho nu respondem a processos comuns. Por exemplo, na maior parte dos casos, como nos sambaquis de padrão estratigráfico conchífero e montículos ictiológicos, observa-se que os sítios representam depósitos terciários de retrabalhamento de resíduos. No entanto, a descomplicação da intrincada estratigrafia dos sítios não significa simplicidade de formação. Como mostrado a partir da comparação etno-geoarqueológica com o concheiro Túnel 7, existe sucessão de atividades na história pré-deposicional dos sedimentos que compõem os sambaquis, cujo reconhecimento afasta interpretações da sua formação baseadas na mera deposição secundária de resíduos descartados.

O número de pesquisas que mostram a complexidade na formação e simbolismo associado aos sambaquis é crescente. A análise apresentada nesta tese soma-se a este corpo de dados e reafirma que não há simplicidade nem unidirecionalidade na formação e crescimento dos sambaquis. 


\section{COMEÇO E AUGE DOS SAMBAQUIS}

Os sítios mais antigos da região de estudo são os sambaquis Caipora e Santa Marta 10, localizados respectivamente no setor interno e externo da planície litorânea. O sítio Caipora testemunha a presença humana na região há cerca de 7500 anos e evidencia que a construção de sambaquis conchíferos muito provavelmente já acontecia antes do máximo transgressivo holocênico na região. Como proposto no Capítulo 2, tópicos 3.1 e 3.2, atualmente as evidências apontam para a hipótese dos grupos sambaquieiros do litoral atlântico representarem uma unidade cultural independente dos grupos do interior. Outras evidências também indicam que a colonização da costa teria acontecido exclusivamente por via litorânea e os grupos construtores de sambaquis seriam herdeiros dessa tradição.

Se for tomado o sítio Caipora como representante dos primeiros sambaquis conchíferos desta porção do litoral, chega-se a uma conclusão substancial: desde o começo da cultura de sambaquieira na região, o levantamento dos sítios consistia no retrabalhamento de materiais descartados e queimados em outro local, que seriam retransportados para deposição final no sambaqui. Esta tradição teria perdurado por milhares de anos até, e inclusive durante, a intensificação do contato com os grupos interioranos, entre 1700 e 1500 anos atrás. Esta evidência é extremamente importante na discussão sobre a ausência de áreas de moradia associadas aos grandes sambaquis conchíferos. A identificação destas áreas pode estar sendo mascarada pelo hábito de retrabalhamento de resíduos que existe desde os momentos mais remotos de ocupação sambaquieira na região.

O ritmo de uso e formação dos sambaquis conchíferos sugere padrões semisedentários de ocupação e permite identificar três elementos comuns no que se refere à sua localização na paisagem: 1) todos se encontram próximos a bancos de moluscos; 2) todos foram erguidos próximos a praias de baías ou mar aberto ou praias lagunares; 3 ) todos foram construídos a partir da acumulação de resíduos, com ênfase na deposição de conchas e restos de peixe.

As evidências apresentadas neste trabalho, sobre o processo de formação dos sambaquis desde o sítio mais antigo até os mais novos (Cubículo 1, Morrinhos e 
Jabuticabeira 1), vão contra a crença tradicional de que o levantamento de montículos de conchas é uma tarefa simples. Há clara diferença entre transporte direto de conchas a partir de um banco de moluscos e a formação de sambaquis. Como mostrado na discussão do Capítulo 6, as evidências apontam para a possibilidade de coleta e transporte a partir de diversos contextos onde há proliferação de moluscos, e não desde um único local. Além disso, a queima de alguns moluscos e preservação de outros, a alta frequência de resíduos de origem animal, como ossos de peixe, principalmente queimados, os resíduos da queima de plantas e os indícios de fogueiras acesas sobre o sítio e varridas a curta distância são alguns dos indicadores da complexa história prédeposicional dos sedimentos. Neste sentido, a formação do sambaqui teria requerido mais esforços e trabalho que a simples coleta, consumo e descarte de moluscos e restos de peixe usados como alimento.

A complexidade envolvida na elevação dos sambaquis conchíferos, mostrada pelas análises geoarqueológicas, serve como indicador de que o próprio sedimento do sambaqui, e não unicamente o seu volume ou presença de enterramentos, é reflexo da significância social destas estruturas (ver Sherwood \& Kidder, 2011, para os mounds do Arcaico e Formativo da América do Norte). Considerar os sambaquis unicamente como recipientes para sepultamento dos mortos do grupo significa, em última instância, assumir que o sambaqui não representa um objetivo em si mesmo, mas simplesmente o meio para alcançar um objetivo. No entanto, e seguindo o argumento de Sherwood \& Kidder (2011), esta visão corre o risco de desconsiderar ao sedimento formado pela prática recorrente de deposição de resíduos, seja ou não relacionada a sepultamentos, como de igual valor social e simbólico.

O levantamento dos sambaquis conchíferos, embora tenha durado, em alguns casos, milhares de anos, é produto de esforços repetitivos. Há recorrência de espessas camadas que respondem ao mesmo processo de formação, em sítios cuja cronologia se estende por mais de 5000 anos. Há também intercalação com camadas de poucos centímetros de espessura compostas por restos de plantas e ósseos queimados, que indica, pelo menos, dois diferentes tipos de processos deposicionais associados à formação dos sítios. A repetição na formação dos sambaquis pode ter-se transformado, ao longo do tempo e na medida em que aumentava o volume dos sítios, em projeto arquitetônico. Os sambaquis conchíferos podem ter começado como construções espontâneas que, posteriormente, adquiriram uma identidade própria. 
Inclusive em tempos recentes, a grandiosidade dos sambaquis impõe-se na nossa percepção do ambiente e resulta impossível não imaginar o impacto visual que estes sítios teriam tido para os visitantes de sua época, ou mesmo entre os próprios sambaquieiros. No entanto, não se pode ter certeza, a partir da análise geoarqueológica aqui apresentada, se o significado destas estruturas teria sido o mesmo desde os primeiros sambaquis conchíferos ou se mudou na medida em que crescia o estabelecimento e/ou poder do grupo na região. O que é claramente identificável é a recorrência no processo de formação dos sítios. È possível que, no início, não tenha existido ainda o valor normativo e simbólico dos depósitos como estruturas conspícuas na paisagem. Uma atividade rotineira, como a acumulação de resíduos e subprodutos alimentares, pode ter-se transformado em uma prática cerimonial cíclica, relacionada com o retrabalhamento de substâncias vitais que refletem a vida econômica do grupo (conchas e peixes) (ver Johansen, 2004), direcionada aos sepultamentos de mortos como estratégia de marcação do lugar de vida ancestral.

Concomitante ao levantamento dos sambaquis conchíferos, erguia-se outro tipo de sítio cujo processo de formação é mais direcional e simples. Estes são os sambaquis de núcleo arenoso, representados nesta tese pelos sítios Santa Marta 10 e Carniça 3. O retrabalhamento de materiais também está evidenciado nestes depósitos, mas a história pré-deposicional é menos complexa que para os sambaquis conchíferos. Parece haver, nos sambaquis de núcleo arenoso, evidências da destruição de restos de fogueiras, nas quais eram queimadas plantas, principalmente, e alguns resíduos animais, em segunda instância. No entanto, tal destruição favorecia a construção de uma nova estrutura na paisagem, que teria ficado como memória dos acontecimentos.

Pelas suas características físicas e composicionais, estes sítios teriam resultado de ocupações efêmeras, mas planejadas. Estes sítios, que aparecem unicamente no setor externo, não apresentam ainda evidências claras de se tratar de áreas de moradia e podem ser, entre outras explicações possíveis, os remanescentes de antigas estruturas de cobertura, ou antigas áreas de celebração de rituais esporádicos (como ritos de iniciação ou passagem). Neste sentido, tenta-se reforçar que ritual em caçadores-coletores não se limita apenas às práticas associadas com o tratamento dos mortos. 


\section{COLAPSO E SURGIMENTO DA UMA NOVA ORDEM}

O final do projeto de arquitetura em conchas está marcado, arqueologicamente, pela aparição, sobre os sambaquis, de restos cerâmicos da tradição Taquara/ Itararé, associados com os grupos Jê do planalto, e pelo surgimento dos aqui denominados sítios mistos (ver definição em Capítulo 2, tópico 3.5.1). Na área de estudo, tanto os sítios Santa Marta 8 como Galheta 4 pertencem a esta categoria e foram estudados com a finalidade de entender a sua relação, em termos de processos de formação, com os sambaquis conchíferos e de núcleo arenoso.

Antes de passar à discussão dos resultados apresentados nesta tese, é necessário expor a perspectiva adotada para a suposta chegada dos grupos ceramistas ao litoral. Como mencionado no Capítulo 2, tópico 3.5.2, acredita-se que não teria havido chegada massiva dos Jê à costa, mas sim uma intensificação no contato e domínio dos ceramistas sobre os pescadores-caçadores-coletores do litoral, evidenciada pela adoção da tecnologia cerâmica e pelo abandono da deposição de conchas. Isto se interpreta a partir das diferenças entre os sítios mistos do litoral e os sítios típicos dos Jê do planalto meridional. No litoral há evidências de pesca intensiva e acumulação de restos de resíduos, inclusive para sepultar os mortos, com tecnologia em osso e concha (ausente na tradição Taquara/Itararé); no planalto há assentamentos semi-permanentes, subsistência baseada na caça de mamíferos da mata de araucárias e de encosta, coleta de pinhão e inclusive agricultura, com práticas funerárias que envolvem a cremação dos corpos (Beber, 2004; Behling et al., 2007; Gessert et al., em prensa; Iriarte and Behling, 2007; Iriarte et al., 2008; Lavina, 1994; De Masi, 1999, 2007; Reis, 1980; Rohr, 1971; Schmitz and Becker, 1991). Unicamente em tempos históricos, os Jê meridionais transformaram a sua dinâmica de ocupação, por causa do contato com os colonizadores e, possivelmente, com grupos guaranis em expansão, até organizações nômades e de alta mobilidade, em fluxo sazonal entre a mata atlântica e a floresta de araucárias, com algumas incursões até o litoral. (Farias, 2005; Lavina, 1994; Noelli, 1999; Paula, 1924; Ploetz and Métraux, 1930; Santos, 1973).

Pelas características dos sítios mistos, como os estudados nesta tese, parece difícil pensar que grupos Jê tivessem mudado radicalmente após a suposta descida do planalto até o litoral há 1500 anos. Esta situação, como já mencionado por Prous (1992), parece 
pouco provável. Neste sentido, comunidades marítimas, dependentes da pesca, como também assinalam as análises isotópicas (Bastos 2009) e bioantropológicas (Neves 1988; Okumura 2007; Scherer et al. 2006; Wesolowsky 2000) realizados em indivíduos sepultados nos sítios mistos, não se desenvolvem em alguns anos, mas são processos históricos que se constroem através da inter-relação socioeconômica e simbólica do grupo com o mar (Diegues, 2004).

O que parece ter havido no litoral é a introdução de uma tecnologia, sem modificação no sistema de produção característico das comunidades pescadoras, mas com intensificação na violência e com abandono do simbolismo associado à arquitetura em conchas. Neste sentido, a adoção da tecnologia cerâmica não necessariamente envolveu mudanças irreversíveis nas práticas de subsistência entre grupos coletorespescadores, mas mostra continuidade com o processamento de recursos marinhos (ver Craig et al., 2011). Antes de associar a desaparição de uma tradição cultural com a desaparição de um grupo, é necessário considerar também que as crenças e tradições associadas aos símbolos e padrões materiais que se utilizam para identificar grupos sociais no passado estão sujeitos a mudanças (Nelson and Hegmon, 2001). Da mesma maneira, a inviabilidade do hábito de formação de sambaquis, causada pelas diferenças idiossincráticas essenciais entre os sambaquieiros e os grupos ceramistas (Gaspar et al. 2007), poderia estar vinculada a uma mudança ideológica associada a um novo contexto político, e não necessariamente à invasão do território e desaparição do grupo sambaquieiro. Isso testemunha as marcas de violência, claros indicadores de poder de um grupo sobre outro (Angelbeck, 2009).

A análise geoarqueológica aqui proposta vai ao encontro das hipóteses propostas. No caso do sítio Santa Marta 8, demonstrou-se a continuidade no processo de formação com os sambaquis conchíferos, além da aparição da tecnologia cerâmica. O mesmo padrão de retrabalhamento de resíduos acumulados e queimados em local diferente do final observa-se não unicamente neste sambaqui, mas também na camada preta que recobre grande parte do sambaqui Jabuticabeira 2. Ambos os depósitos, de idade e composição semelhante, podem servir de evidência para entender o tipo de contato estabelecido entre os grupos costeiros e interioranos em tempo recente, que desembocou na obsolescência da arquitetura em conchas. Já no sítio Galheta 4, não se identifica o mesmo padrão dos sambaquis conchíferos, mas sim a exploração intensa de recursos aquáticos e deposição de seus resíduos sobre os mortos. 
Assim, apenas o material teria sido abandonado, junto com a adoção da tecnologia cerâmica, mas não o habito de retrabalhamento de resíduos. Esta mudança certamente acarretou uma alteração no papel social dos montículos, não unicamente em forma, mas também em significado. Pode-se pensar, hipoteticamente, que o abandono do uso das conchas representa uma reação às mudanças impostas no sistema social e político das comunidades costeiras a partir da intensificação dos contatos com os grupos do interior. O surgimento dos montículos ictiológicos pode responder a uma intencionalidade de querer diferenciar a nova ordem sociopolítica imposta pela tensões com os grupos ceramistas.

Pode-se pensar que sambaquieiros e Jê compartilhavam um sistema relativamente pacífico de intercâmbio desde a chegada dos Jê ao planalto meridional, cerca de 3000 anos atrás, em pleno auge da cultura sambaquieira na costa. Este sistema de interação social poderia ter-se intensificado como resultado do crescimento demográfico, do estabelecimento de aldeias mais permanentes no planalto, por volta de 1400 a 900 anos AP (Iriarte \& Behling, 2007), e da expansão dos Jê até o sul do país provocada pela pressão guarani (Noelli 1999). O crescimento no interior associar-se-ia a um aumento nas ocupações na encosta e no contato com a planície litorânea, que exercia maior pressão sobre os grupos costeiros. Neste momento, começam a aparecer as concentrações de cerâmica no litoral, o que coincide com a desestabilização da cultura clássica sambaquieiros, com menor número de sítios e declínio da arquitetura em conchas. Este período, após 1500 AP, caracteriza-se também pelo aumento nos conflitos na costa (ver Lessa, 2005; Lessa \& Scherer, 2008), bem como do intercâmbio de indivíduos com o interior (ver Bastos 2009; Okumura 2007), com mudança radical no padrão de residência pós-marital (Hubbe et al. 2009).

Não se trataria, portanto, de a invasão do litoral por grupos do planalto meridional ter provocado a desestabilização de uma suposta arquitetura monumental; mas sim de a pressão geográfica, política e, principalmente, ideológica, exercida pelos ceramistas interioranos, ter motivado uma reestruturação da cultura tradicional da costa. 


\section{REFERÊNCIAS BIBLIOGRÁFICAS}

Ab'Saber, A. N. (1984) 'Tipos De Habitat Do Homem Do Sambaqui', Revista de Pré-História $6: 121-22$.

Ab'Saber, A. N. and Bernard, W. (1953) 'Sambaquis Da Região Lagunar De Cananéia', Boletim do Instituto Oceanográfico 4:215-38.

Adams, J. (2002) Maritime Archaeology, Encyclopedia of historical archaeologyp. 328-30.

Adderley, W. P., Alberts, I. L., Simpson, I. a and Wess, T. J. (2004) 'Calcium-iron-phosphate Features in Archaeological Sediments: Characterization Through Microfocus Synchrotron X-ray Scattering Analyses', Journal of Archaeological Science 31(9):1215-24.

Afonso, M. C. (1999) 'O Sambaqui Espinheiros II: Uma Contribuição à Arqueologia Do Litoral Norte De Santa Catarina', Revista do CEPA 23:118-23.

Afonso, M. C. (2008) 'Geoarqueologia Em Ambientes Costeiros: o Papel Da Água No Registro Arqueológico e Na Paisagem', in J. C. Rubin and R. T. Silva (eds) Geoarqueologia: Teoria e Prática, pp.93-106. Goiânia: Universidade Católica de Goiás.

Afonso, M. C. and DeBlasis, P. (1994) 'Aspectos Da Formação De Um Grande Sambaqui: Alguns Indicadores Em Espinheiros II, Joinville’, Revista do Museu de Arqueologia e Etnologia 4:21-30.

Albert, R., Bar-Yosef, O., Meignen, L. and Weiner, S. (2000) 'Phytoliths in the Middle Palaeolithic Deposits of Kebara Cave, Mt Carmel, Israel: Study of the Plant Materials Used for Fuel and Other Purposes', Journal of Archaeological Science 27(10):931-47.

Albert, R. M., Berna, F. and Goldberg, P. (2012) 'Insights on Neanderthal Fire Use at Kebara Cave (Israel) Through High Resolution Study of Prehistoric Combustion Features: Evidence from Phytoliths and Thin Sections', Quaternary International 247:278-93.

Albert, R. M. and Cabanes, D. (2008) 'Fire in Prehistory : An Experimental Approach to Combustion Processes and Phytolith Remains', Israel Journal of Earth Sciences 56:17589.

Albert, R. M., Shahack-gross, R., Cabanes, D., Gilboa, A., Lev-yadun, S., Portillo, M., Sharon, I., Boaretto, E., Weiner, S. and Maria, R. (2008) 'Phytolith-rich Layers from the Late Bronze and Iron Ages at Tel Dor (Israel): Mode of Formation and Archaeological Significance', Journal of Archaeological Science 35(1):57-75.

Aldeias, V., Goldberg, P., Sandgathe, D., Berna, F., Dibble, H. L., McPherron, S. P., Turq, A. and Rezek, Z. (2012) 'Evidence for Neandertal Use of Fire at Roc De Marsal (France)', Journal of Archaeological Science 39(7):2414-23.

Alonso-Zarza, A. M. and Wright, V. P. (2010) 'Calcretes', in A. M. Alonso-Zarza and L. H. Tanner (eds) Developments in Sedimentology 61: Carbonates in Continental Settings, Facies, Environments and Processes, pp.225-67. Amsterdam: Elsevier.

Alvarez, M., Briz Godino, I., Balbo, A. and Madella, M. (2011) 'Shell Middens as Archives of Past Environments, Human Dispersal and Specialized Resource Management', Quaternary International 239(1-2):1-7.

Alvarez, M., Vázquez, M. and Piana, E. (2008) 'Prácticas Mortuorias Entre Los Cazadoresrecolectores Del Canal Beagle: El Caso De Shamakush Entierro', Magallania (Punta Arenas) 36(2):105-21.

Alves, C. C. (2008) Análise Zooarqueológica De Um Sambaqui Fluvial: o Caso Do Sítio Capelinha I. Universidade de São Paulo.

Alvim, M. C. M. and Gomes, J. (1989) 'Análise e Interpretação Das Condições Patológicas Em Crânios Humanos De Sítio Arqueológico', Revista de Pré-História 7:127-45.

Alvim, M. C. M. and Seyfreth, G. (1968) 'Estudo Morfológico Do Úmero Na População Do Sambaqui De Cabeçuda (Laguna, Santa Catarina)', Revista do Museu Paulista 24:1-14.

Alvim, M. C. M., Vieira, M. I. and Cheuiche, L. M. (1975) 'Os Construtores Dos Sambaquis De Cabeçudas, SC e De Piaçaguera, SP: Estudo Morfológico Comparativo', Arquivos de Anatomia e Antropologia 1:393-406. 
Amaral, P. G. C. (2008) Evolução Da Sedimentação Lagunar Holocênica Na Região De Jaguaruna, Estado De Santa Catarina: Uma Abordagem Sedimentológicamicropaleontológica Integrada. Universidade de São Paulo.

Amaral, P. G., Fonseca Giannini, P. C., Sylvestre, F. and Ruiz Pessenda, L. C. (2012) 'Paleoenvironmental Reconstruction of a Late Quaternary Lagoon System in Southern Brazil (Jaguaruna Region, Santa Catarina State) Based on Multi-proxy Analysis', Journal of Quaternary Science 27(2):181-91.

Amenomori, S. N. (2001) Potencial Analítico De Sedimentos e Solos Aplicados à Arqueologia. Universidade de São Paulo.

Amenomori, S. N. (2005) Paisagem Das Ilhas, as Ilhas Da Paisagem: a Ocupação Dos Grupos Pescadores-coletores Pré-históricos No Litoral Norte Do Estado De São Paulo. Universidade de São Paulo.

Amâncio, S. and Dominguez, J. M. L. (2003) 'Avaliação De Áreas Potenciais à Presença De Sambaquis Na Costa Do Estado De Sergipe Utilizando Como Ponto De Partida Uma Compreensão Da Evolução Da Zona Costeira Nos Últimos 5600 Anos AP', Canindé 3:223-44.

Anderton, R. (1985) 'Clastic Facies Models and Facies Analysis', in Sedimnetology: Recent Developments and Applied Aspects, pp.31-47. Oxford: Blackwell Scientific Publications.

Andrews, B. N. (2006) 'Sediment Consolidation and Archaeological Site Formation', Geoarchaeology 21(5):461-78.

Andrus, C. F. T. and Crowe, D. E. (2000) 'Geochemical Analysis of Crassostrea Virginica as a Method to Determine Season of Capture', Journal of Archaeological Science 27:33-42.

Angelbeck, W. O. (2009) "They Recognize No Superior Chief" Power, Practice, Anarchism and Warfare in the Coast Salish Past. The University of British Columbia.

Angulo, R., Giannini, P. C. F., Suguio, K. and Pessenda, L. C. R. (1999) 'Relative Sea-level Change During the Last 5500 Years in the Laguna-Imbituba Region (Santa Catarina, Brazil), Based on Vermetid Radiocarbon Ages', Marine Geology 159:323-39.

Angulo, R., Lessa, G. and Souza, M. (2006) 'A Critical Review of Mid- to late-Holocene Sealevel Fluctuations on the Eastern Brazilian Coastline', Quaternary Science Reviews 25(56):486-506.

Arnold, J. E., Amobs, E. L. and Larson, D. O. (1997) 'Geophysical Surveys of Stratigraphically Complex Island California Sites: New Implications for Household Archaeology’, Antiquity 71:157-68.

Arriaza, B. T., Standen, V. G., Belmonte, E., Rosello, E. and Nials, F. (2001) 'The Peopling of the Arica Coast During the Preceramic: a Preliminary View', Chungará 33(1):31-36.

Arroyo-Kalin, M. (2008) Steps Towards an Ecology of Landscape : a Geoarchaeological Approach to the Study of Anthropogenic Dark Earths in the Central Amazon Region, Brazil. University of Cambridge.

Arroyo-Kalin, M. (2010) 'The Amazonian Formative: Crop Domestication and Anthropogenic Soils', Diversity 2(4):473-504.

Assunçao, D. (2010) Sambaquis Da Paleolaguna De Santa Marta: Em Busca Do Contexto Regional No Litoral Sul De Santa Catarina. Universidade de São Paulo.

Attenbrow, V. (1992) 'Shell Bed or Shell Midden', Australian Archaeology 34:3-21.

Bacon, P. R. (1975) 'Shell Form, Byssal Development and Habitat of Mytella Guayanensis (Lamarck) and M. Falcata (Orbigny) (Pellecipoda: Mytilidae) in Trinidad, West Indies', Journal of Molluscan Studies 41(6):511-20.

Bailey, G. and Flemming, N. (2008) 'Archaeology of the Continental Shelf: Marine Resources, Submerged Landscapes and Underwater Archaeology', Quaternary Science Reviews 27(23-24):2153-65.

Bailey, G. N. (1977) 'Shell Mound, Hell Middens, Raised Beaches in the Cape York Peninsula', Mankind 11:132-43.

Bailey, G. N. and Craighead, A. S. (2003) 'Late Pleistocene and Holocene Coastal Palaeoeconomies: A Reconsideration of the Molluscan Evidence from Northern Spain', Geoarchaeology 18(2):175-204. 
Bajnóczi, B. and Kovács-Kis, V. (2006) 'Origin of Pedogenic Needle-fiber Calcite Revealed by Micromorphology and Stable Isotope Composition-a Case Study of a Quaternary Paleosol from Hungary', Chemie der Erde - Geochemistry 66(3):203-12.

Balbo, A. L., Madella, M., Vila, A. and Estévez, J. (2010) 'Micromorphological Perspectives on the Stratigraphical Excavation of Shell Middens: a First Approximation from the Ethnohistorical Site Tunel VII, Tierra Del Fuego (Argentina)', Journal of Archaeological Science 37(6):1252-59.

Balmain, J., Hannoyer, B. and Lopez, E. (1999) 'Fourier Transform Infrared Spectroscopy (FTIR) and X-ray Diffraction Analyses of Mineral and Organic Matrix During Heating of Mother of Pearl (nacre) from the Shell of the Mollusc Pinctada Maxima.', Journal of biomedical materials research 48(5):749-54.

Balée, W. (1988) 'Historical Ecology: Premises and Postulates', in W. Balée (ed.) Advances in Historical Ecology, pp.13-29. New York: Columbia University Press.

Balée, W. (1994) Footprints of the Forest: Ka'apor Ethnobotany - the Historical Ecology of Plant Utilization by an Amazonian People New York: Columbia University Press.

Balée, W. (2006) 'The Research Program of Historical Ecology', Annual Review of Anthropology 35(1):75-98.

Balée, W. and Erickson, C. L. (2006) 'Time, Complexity and Historical Ecology', in W. Balée and C. Erickson (eds) Time and Complexity in Historical Ecology, pp.1-17. New York: Columbia University Press.

Bandeira, A. (2008) Ocupaçoes Humanas Pré-históricas No Litoral Maranhense: Um Estudo Arqueológico Sobre o Sambaqui Do Bacanga Na Ilha De São Luis, Maranhão. Universidade de São Paulo.

Bandeira, D. (1992) Mudança Na Estratégia De Subsistência. O Sítio Arqueológico Enseada I. Um Estudo De Caso. Universidade Federal de Santa Catarina.

Bandeira, D. (1999) 'Os Sítios Arqueológicos Do Litoral De Santa Catarina (Rio LEssa e Enseada I) e a Problemática Da Tradiçao Taquara-Itararé Vista Através Da Alimentaçao', Revista do CEPA 23(29):189-96.

Barbosa, M. (1999) 'Reconstrução Espacial De Um Assentamento De Pescadores-coletoresCaçadores Pré-históricos No Rio De Janeiro', in M. C. Tenório (ed.) Pré-história Da Terra Brasilis, pp.376-80. Rio de Janeiro: Universidade Federal do Rio de Janeiro.

Barbosa, M. (2001) Espaço e Organizaçao Social Entre o Grupo Social Do Sambaqui IBV4, Cabo Frio RJ. Universidade Federal do Rio de Janeiro.

Barbosa, M. (2007) A Ocupação Pré-colonial Da Região Dos Lagos, RJ: Sistema De Assentamento e Relações Intersocietais Entre Grupos Sambaquianos e Grupos Ceramistas Tupinambá Da Tradiçao Una. Universidade de São Paulo.

Barreto, C. (1988) A Ocupaçao Pré-colonial Do Vale Do Ribeira De Iguape, SP: Os Sítios Concheiros Do Médio Curso. Universidade de São Paulo.

Barrett, J. H., Orton, D., Johnstone, C., Harland, J., Van Neer, W., Ervynck, A., Roberts, C., Locker, A., Amundsen, C., Enghoff, I. B., Hamilton-Dyer, S., Heinrich, D., Hufthammer, A. K., Jones, A. K. G., Jonsson, L., Makowiecki, D., Pope, P., O’Connell, T. C., de Roo, T. and Richards, M. (2011) 'Interpreting the Expansion of Sea Fishing in Medieval Europe Using Stable Isotope Analysis of Archaeological Cod Bones', Journal of Archaeological Science 38(7):1516-24.

Bartolomucci, L. B. G. (2006) Variabilidade Biológica De Sambaquieiros Através De Morfologia Dentária. Universidade de São Paulo.

Bastos, M. (2009) Mobilidade Humana Na Pré-história Do Litoral Brasileiro: Análise De Isótopos Instáveis De Estrôncio No Sambaqui Do Forte Marechal Luz. Fundaçao OSwaldo Cruz.

Bateman, M. D., Carr, A. S., Murray-Wallace, C. V., Roberts, D. L. and Holmes, P. J. (2008) ‘A Dating Intercomparison Study on Late Stone Age Coastal Midden Deposits, South Africa', Geoarchaeology 23(6):715-41.

Beber, M. V. (2004) O Sistema De Assentamento Dos Grupos Ceramistas Do Planalto Sulbrasileiro: o Caso Da Tradiçoes Taquara/ Itararé. Universidade Vale do Rio dos Sinos. 
Beck, A. (1971) 'Os Sambaquis Da Região Do Litoral De Laguna - Santa Catarina', in $O$ Homem Pré-histórico Na América, São Paulo: Instituto de Pré-história, Universidade de São Paulo.

Beck, A. (1972) A Variação Do Conteúdo Cultural Dos Sambaquis - Litoral De Santa Catarina. Universidade de São Paulo.

Beck, C. and Jones, G. T. (2010) 'Clovis and Western Stemmed: Population Migration and the Meeting of Two Technologies in the Intermountain West', American Antiquity 75(1):81116.

Beck, M. E. and Hill Jr, M. E. (2004) 'Rubbish, Relatives, and Residence: The Family Use of Middens', Journal of Archaeological Method and Theory 11(3):297-333.

Beckman, G. G. and Smith, K. J. (1974) 'Micromorphological Changes in Surface Soils Following Wetting, Drying and Trampling', in G. K. Rutherford (ed.) Soil Microscopy, pp.832-45. Ontario: The Limestone Press.

Becze-Deàk, J. (1997) 'Small Scale Secondary CaCO3 Accumulations in Selected Sections of the European Loess Belt. Morphological Forms and Potential for Paleoenvironmental Reconstruction', Geoderma 76(3-4):221-52.

Behling, H., Pillar, V. D., Müller, S. C. and Overbeck, G. E. (2007) 'Late-Holocene Fire History in a Forest Grassland Mosaic in Southern Brazil: Implications for Conservation', Applied Vegetation Science 10:81-90.

Beltrão, M. C. and Kneip, L. M. (1967) 'Arqueologia e Geomorfologia: Tentativa De Uma Abordagem Interdisciplinas', Boletim Carioca de Geografia 18:1-16.

Ben-David, M., Bowyer, R. T. T., Duffy, L. K. K., Roby, D. D. D., Schell, M. and Schell, D. M. (1998) 'Social Behavior and Ecosystem Processes: River Otter Latrines and Nutrient Dynamics of Terrestrial Vegetation', Ecology 79(7):2567-71.

Bendazzoli, C. (2007) O Processo De Formação Dos Sambaquis: Uma Leitura Estratigráfica Do Sitio Jabuticabeira II, SC. Universidade de São Paulo.

Bennett, J. L. (1999) 'Thermal Alteration of Buried Bone', Journal of Archaeological Science 26(1):1-8.

Van Bergen, P. F., Bull, I. D., Eversherd, R. P. and Simpson, I. (1999) 'Muck n Molecules: Organic Geochemical Methods for Detecting Ancient Manuring', Antiquity 73:86-93.

Berna, F., Behar, A., Shahack-Gross, R., Berg, J., Boaretto, E., Gilboa, A., Sharon, I., Shalev, S., Shilstein, S. and Yahalom-Mack, N. (2007) 'Sediments Exposed to High Temperatures: Reconstructing Pyrotechnological Processes in Late Bronze and Iron Age Strata at Tel Dor (Israel)', Journal of Archaeological Science 34(3):358-73.

Berna, F., Matthews, A. and Weiner, S. (2004) 'Solubilities of Bone Mineral from Archaeological Sites: The Recrystallization Window', Journal of Archaeological Science 31(7):867-82.

Bezerra, U. T., Almeida, F. L. P., Silva, L. B., Barbosa, N. P., Passos, T. A. and Cavalcante, D. G. L. (2009) Production of Filler Aggregate from Waste of Bivalves Molluscs Shells, in Proceedings of the 11th International Conference on Non-conventional Materials and Technologies (NOCMAT 2009).

Bianchini, G. F. (2008) Fogo e Paisagem: Evidências De Práticas Rituais e Construção Do Ambiente a Partir Da Análise Antracológica De Um Sambaqui No Litorral Sul De Santa Catarina. Universidade Federal do Rio de Janeiro.

Bianchini, G. F., Scheel-ybert, R. and Gaspar, M. D. (2007) 'Estaca De Lauraceae Em Contexto Funerário (sítio Jaboticabeira II, Santa Catarina, Brasil)', Revista do Museu de Arqueologia e Etnologia 17:223-29.

Bicho, N. F. (1994) 'The End of the Paleolithic and the Mesolithic in Portugal', Current Anthropology 35(5):664.

Bicho, N. and Haws, J. (2008) 'At the Land's End: Marine Resources and the Importance of Fluctuations in the Coastline in the Prehistoric Hunter-gatherer Economy of Portugal', Quaternary Science Reviews 27(23-24):2166-75.

Bigarella, J. J. (1949) 'Nota Prévia Sobre a Composiçao Dos Sambaquis Do Paraná e Santa Catarina', Arquivos de Biologia e Tecnologia 4:95-105. 
Bigarella, J. J. (1950) 'Contribuição Ao Estudo Dos Sambaquis No Estado Do Paraná', Arquivos de Biologia e Tecnologia V-VI:231-345.

Bigarella, J. J. (1965) 'Subsídios Para o Estudo Das Variações De Nível Oceânico No Quaternário Brasileiro', Anais Da Academia Brasileira De Ciencias 37:263-178.

Bigarella, J. J. (1976) 'Considerações a Respeito Das Variações Do Nível Do Mar e Dataçoes Radiométricas', Cadernos de Arqueologia 1:105-18.

Biocca, E., Hoge, A. and Schreiber, G. (1947) 'Contribuiçoes Ao Estudo De Alguns Sambaquis Da Ilha De Santo Amaro (Estado De São Paulo)', Revista do Museu Paulista 1:153-71.

Bird, D. (2002) 'Explaining Shellfish Variability in Middens on the Meriam Islands, Torres Strait, Australia', Journal of Archaeological Science 29(5):457-69.

Bird, D. W. and Bliege Bird, R. L. (1997) 'Meriam of the Torres Strait Islands, Australia : Testing Predictions of a Central Place Foraging Model', Journal of Archaeological Science 24:39-63.

Bird, D. W. and Bliege Bird, R. L. (2000) 'The Ethnoarchaeology of Juvenile Foragers: Shellfishing Strategies Among Meriam Children', Journal of Anthropological Archaeology 19(4):461-76.

Birk, J. J., Teixeira, W. G., Neves, E. G. and Glaser, B. (2011) 'Faeces Deposition on Amazonian Anthrosols as Assessed from 5 $\beta$-stanols', Journal of Archaeological Science 38(6):1209-20.

Bocchi, P. R. and Liberatore, G. (1968) Relatório Preliminar Da Vistoria Efetuada Junto Aos Sambaquis e Concheiros Naturais (terraços) No Leste Do Estado De Santa Catarina Entre as Cidades De Jaguaruna e Imbituba Florianópolis.

Bogaard, a., Heaton, T. H. E., Poulton, P. and Merbach, I. (2007) 'The Impact of Manuring on Nitrogen Isotope Ratios in Cereals: Archaeological Implications for Reconstruction of Diet and Crop Management Practices', Journal of Archaeological Science 34(3):335-43.

Bol, R., Eriksen, J., Smith, P., Garnett, M. H., Coleman, K. and Christensen, B. T. (2005) 'The Natural Abundance of 13C, 15N, 34S and 14C in Archived (1923-2000) Plant and Soil Samples from the Askov Long-term Experiments on Animal Manure and Mineral Fertilizer.', Rapid communications in mass spectrometry : RCM 19(22):3216-26.

Bonomo, M. and Aguirre, M. L. (2009) 'Holocene Molluscs from Archaeological Sites of the Pampean Region of Argentina: Approaches to Past Human Uses', Geoarchaeology 24(1):59-85.

Borella, F. and Favier Dubois, C. (2008) Investigaciones Arqueológicas En La Costa Del Golfo De San Matías, Provincia De Río Negro, (consulted www.soc.uncien.edu.ar/newsletter/nro10)

Bourrat, X., Francke, L., Lopez, E., Rousseau, M., Stempflé, P., Angellier, M. and Albéric, P. (2007) 'Nacre Biocrystal Behaviour', CrystEngComm 9(12):1178.

Boutton, T. W. (1996) 'Stable Carbon Isotope Ratios of Soil Organic Matter and Their Use as Indicators of Vegetation and Climate Change', in T. W. BOUTTON and S. I. YAMASAKI (eds) Mass Spectrometry of Soils, pp.47-82. New York: Marcel Dekker.

Bowlder, S. (1976) 'Hook, Line, and Dilly Bag: An Interpretation of an Australian Coastal Shell Midden', Mankind 10:248-58.

Bown, T. M. and Kraus, M. J. (1987) 'Integration of Channels and Floodplains Suits 1: Developmental Sequence and Lateral Relations of Alluvial Paleosols', Journal of Sedimentary Petrology 57:587-601.

Boyadjian, C. H. (2007) Microfósseis Contidos No Cálculo Dentário Como Evidência Do Uso De Recursos Vegetais Nos Sambaquis De Jabuticabeira II (SC) e Moraes (SP). Universidade de São Paulo.

Bracco, R. (1999) 'Desarrollo Cultural y Evolucion Ambiental En La Region Este De Uruguay', in Ediciones Del Quinto Centenario, pp.43-73. Montevideo: Universidad de la República.

Van Breemen, N. and Buurman, P. (2003) Soil Formation New York: Kluwer Academic Publishers.

Brewer, R. (1964) Fabric and Mineral Analysis of Soils New York: Wiley.

Bridges, L. (1975) El Último Confin De La Tierra Buenos Aires: Marymar. 
Bridges, T. (1885) 'The Yahgans of Tierra Del Fuego', Journal of the Royal Anthropological Institute 14:288-89.

Bridges, T. (1886) 'El Confín Sur De La República: La Tierra Del Fuego y Sus Habitantes', Boletín del Instituto Geográfico Argentino VII VII:200-212.

Bridges, T. (1893) 'La Tierra Del Fuego y Sus Habitantes', Boletín del instituto Geográfico Argentino 15:221-41.

Bridges, T. (1987) Yamana-English DictionaryF. Hastermann and M. Gusinde (eds) Buenos Aires: Zagier \& Urruty Publications.

Briz, I. (2004) Dinàmiques Econòmiques De Producció-consum En El Registre Lític Caçadorrecol.lector De L'extrem Sud Americà. La Societat Yàmana. Universidad Autónoma de Barcelona.

Briz, I., Clemente, I., Pijoan, J., Terradas, X. and Vila, A. (2005) 'Stone Tools in Ethnoarchaeological Contexts: Theoretical-methodological Inferences', in L'outillage Lithique En Contextes Ethnoarchéologiques, pp.1-8.

Brochado, J. P. (1984) An Ecological Model to the Spread of Pottery and Agriculture into Eastern South America. University of Illinois.

Brochier, J. (1992) 'Shepherds and Sediments: Geo-ethnoarchaeology of Pastoral Sites', Journal of Anthropological Archaeology 11(1):47-102.

Brochier, J. E. (1983) 'Bergeries Et Feux De Bois Néolithiques Dans Lê Midi De La France. Caractérisation Et Incendence Sur Lê Raisonnement Sédimentologique', Quartar 33:18193.

Brochier, J. E. (2002) 'Les Sediments Anthropiques: Methodes D'etude Et Perspectives', in J. C. Miskovsky (ed.) Géologie De La Préhistoire, pp.453-77. Perpignan: Geopré: Presses Universitaires de Perpignan.

Brochier, L. L. (2009) Controles Geoarqueológicos e Modelos Morfoestratigráficos: Implicaçoes Para o Estudo Das Ocupações Pré-históricas Na Costa Sul-sudeste Do Brasil. Universidade de São Paulo.

Bromley, R. (1992) 'Bioerosion: Eating Rocks for Fun and Profit', in C. Maples and R. West (eds) Short Courses in Paleontology, Number 5, Trace Fossils, pp.121-29. Knoxville: The Paleontological Sciety.

Bryan, A. L. (1961) 'Excavation of a Brazilian Shell Mound', Science 1(148-151):174-75.

Bryan, A. L. (1993) 'The Sambaqui at Forte Marechal Luz, State of Santa Catarina, Brazil', in A. L. Bryan and R. Grhun (eds) Brazilian Studies, Oregon: Center for the study of the first Americans.

Bujalesky, G., Coronato, A., Roig, C. and Rabassa, C. J. (2004) 'Holocene Differential Tectonic Movements Along the Argentine Sector of the Beagle Channel (Tierra Del Fuego) Inferred from Marine Palaeoenvironments', Boletino de Geofísica Teórica Ed Applicata 45:23538.

Bull, I. D., Lockheart, M. J., Elhmmali, M. M., Roberts, D. J. and Evershed, R. P. (2002) 'The Origin of Faeces by Means of Biomarker Detection.', Environment international 27(8):647-54.

Bullock, P. N., Fedoroff, N., Jongerius, A. and Stoops, G. (1985) Handbook for Soil Thin Section Description Wolverhampton: Waine Research Publications.

Burgoin, B. P. (1988) 'A Rapid and Inexpensive Technique to Separate the Calcite and Nacreous Layers in Mytilus Edulis Shells', Marine Environmental Research 25:125-29.

Butzer, K. (1989) Arqueología, Una Ecología Del Hombre Barcelona: Ediciones Bellaterra.

Buurman, P., van Bergen, P. F., Jongmans, a. G., Meijer, E. L., Duran, B. and van Lagen, B. (2005) 'Spatial and Temporal Variation in Podzol Organic Matter Studied by Pyrolysisgas Chromatography/mass Spectrometry and Micromorphology', European Journal of Soil Science 56(2):253-70.

Buurman, P. and Jongmans, a. G. (2005) 'Podzolisation and Soil Organic Matter Dynamics', Geoderma 125(1-2):71-83.

Buurman, P. and Jongmans, A. G. (2002) 'Podzolization - An Additional Paradigm', Edafologia 9(2):107-14. 
Buurman, P., Jongmans, A. G. and Nierop, K. G. J. (2008) 'Comparison of Michigan and Dutch Podzolized Soils: Organic Matter Characterization by Micromorphology and PyrolysisGC/MS', Soil Science Society of America Journal 72(5):1344.

Cabido, M., Ateca, N., Astegiano, M. E. and Anton, A. M. (1997) 'Distribution of C3 and C4 Grasses Along an Altitudinal Distribution Gradient in Central Argentina', Journal of Biogeography 24(2):197-204.

Cain, C. R. (2005) 'Using Burned Animal Bone to Look at Middle Stone Age Occupation and Behavior', Journal of Archaeological Science 32(6):873-84.

Calippo, F. R. (2004) Os Sambaquis Submersos De Cananéia: Um Estudo De Caso De Arqueologia Subaquática. Universidade de São Paulo.

Calippo, F. R. (2010) Sociedade Sambaquieira, Comunidades Maritimas. Universidade de São Paulo.

Candel, M. S., Borromei, A. M., Martínez, M. a., Gordillo, S., Quattrocchio, M. and Rabassa, J. (2009) 'Middle-Late Holocene Palynology and Marine Mollusks from Archipiélago Cormoranes Area, Beagle Channel, Southern Tierra Del Fuego, Argentina', Palaeogeography, Palaeoclimatology, Palaeoecology 273(1-2):111-22.

Cannon, A. (2000) Settlement and Sea-Levels on the Central Coast of British Columbia: Evidence from Shell Midden Cores, American Antiquity 65p. 67.

Canti, M. (1998) 'The Micromorphological Identification of Faecal Spherulites from Archaeological and Modern Materials', Journal of Archaeological Science 25(5):435-44.

Canti, M. (2003) 'Aspects of the Chemical and Microscopic Characteristics of Plant Ashes Found in Archaeological Soils', Catena 54(3):339-61.

Canti, M. G. (1997) 'An Investigation of Microscopic Calcareous Spherulites From', Journal of Archaeological Science:219-31.

Canti, M. G. (1999) 'The Production and Preservation of Faecal Spherulites: Animals, Environment and Taphonomy', Journal of Archaeological Science 26:251-58.

Canti, M. G. and Linford, N. (2000) 'The Effects of Fire on Archaeological Soils and Sediments: Temperature and Colour Relationships', Proceedings of the Prehistoric Society 66:385-95.

Carter, S. P. and Davidson, D. A. (1998) 'An Evaluation of the Contribution of Soil Micromorphology to the Study of Ancient Arable Agriculture', Geoarchaeology 13(6):535-47.

Caruso Jr., F. (1995) Mapa Geológico e De Recursos Minerais Do Sudeste De Santa Catarina. Escala 1:100.000 Brasília: Departamento Nacional de Produçao Mineral - DPNM.

Caruso Jr., F., Suguio, K. and Nakamura, T. (2000) 'The Quaternary Geological History of the Santa Catarina Southeastern Region (Brazil)', Anais da Academia Brasileira de Ciências $72(2)$

Carvalho, E. (1987) 'Estudo Arqueológico Do Sítio Corondó', Boletim do IAB 2:1-65.

Carvalho, M. and Seyfreth, G. (1971) 'Estudo Morfológico Do Úmero Da População Do Sambaquí Cabeçuda (Laguna, Santa Catarina)', in O Homem Antigo Na América, São Paulo: Instituto de Pré-história, Universidade de São Paulo.

Castilho, P. V. (2005) Mamíferos Marinhos: Um Recurso De Populaçoes Humanas Précoloniais Do Litoral Catarinense. Universidade Federal do Paraná.

Castilho, P. V. D. and Simões-Lopes, P. C. (2008) 'Sea Mammals in Archaeological Sites on the Southern Coast of Brazil', Revista do Museu de Arqueologia e Etnologia 18:101-13.

Castro Faria, L. (1952) 'Pesquisas De Antropologia Física No Brasil', Boletim do Museu Nacional 13

Castro Faria, L. (1959) 'O Problema Da Proteção Aos Sambaquis', Arquivos do Museu Nacional 49:95-137.

Cavagnaro, J. B. (1988) 'Distribution of C3 and C4 Grasses at Different Altitudes in a Temperate Arid Region of Argentina', Oecologia 76(2):273-77.

Chadwick, W. J. and Madsen, J. A. (2000) 'The Application of Ground-penetrating Radar to a Coastal Prehistoric Archaeological Site, Cape Henlopen, Delaware, USA', Geoarchaeology 15(8):765- 781. 
Chmyz, I. (1976) 'A Ocupação Do Litoral Dos Estados Do Paraná e Santa Catarina Por Povos Ceramistas', Estudos Brasileiros 1:7-43.

Choi, W., Lee, S., Ro, H., Kim, K. and Yoo, S. (2002) 'Natural 15 N Abundances of Maize and Soil Amended with Urea and Composted Pig Manure', Plant and Soil 245:223-32.

Claasen, C. (1986) 'Shellfishing Seasons in the Prehistoric Southeastern United States', American Antiquity(51):21-37.

Claassen, C. (1986) 'Temporal Patterns in Marine Shellfish Species Use Along the Atlantic Coast in the Southeastern United States', Southeastern Archaeology 5:120-37.

Claassen, C. (1991) 'Normative Thinking in Shell-bearing Sites', Archaeological Method and Theory 3:249-98.

Claassen, C. (1996) 'A Consideration of the Social Organization of the Shell Mound Archaic', in K. Sassaman and D. Anderson (eds) Archaeology of the Mid-Holocene Southeast, pp.235-58. Gainsville: University of Florida Press.

Claassen, C. (1998) Shells Cambridge: Cambridge University Press.

Coelho, M. R., Martins, V. M., Vidal-torrado, P., Souza, C. R., Otero-Perez, X. L. and Macías, F. (2010) 'Relaçao Solo-relevo-substrato Geológico Nas Restingas Da Planície Costeira Do Estado De São Paulo', Revista Brasileira de Ciência do Solo 34:833-46.

Coelho, P. M. R. (2008) Caracterizaçao e Gênese De Espodossolos Da Planície Costeira Do Estado De São Paulo. Universidade de São Paulo.

Cohen-Ofri, I., Weiner, L., Boaretto, E., Mintz, G. and Weiner, S. (2006) 'Modern and Fossil Charcoal: Aspects of Structure and Diagenesis', Journal of Archaeological Science 33(3):428-39.

Collatz, G. J., Berry, J. A. and Clark, J. S. (1998) 'Effects of Climate and Atmospheric C02 Partial Pressure on the Global Distribution of C4 Grasses: Present, Past, and Future', Oecologia 114:441-54.

Collet, G. and Prous, A. (1977) 'Primeiro Informe Sobre Os Sambaquis Fluviais Da Região De Itaoca (SP)', Arquivos do Museu de História Natural 2:36-50.

Colonese, A. C., Camarós, E., Verdún, E., Estevez, J., Giralt, S. and Rejas, M. (2011) 'Archaeozoological Research of Shell Middens : New Insights Into Hunter-GathererFisher Coastal Exploitation in Tierra Del Fuego', The Journal of Island and Coastal Archaeology 6(2):37-41.

Commisso, R. and Nelson, D. (2006) 'Modern Plant $\delta 15 \mathrm{~N}$ Values Reflect Ancient Human Activity', Journal of Archaeological Science 33(8):1167-76.

Compton, J. and Franceschini, G. (2005) 'Holocene Geoarchaeology of the Sixteen Mile Beach Barrier Dunes in the Western Cape, South Africa', Quaternary Research 63(1):99-107.

Compton, T. J., Kentie, R., Storey, A. W., Veltheim, I., Pearson, G. B. and Piersma, T. (2008) 'Carbon Isotope Signatures Reveal That Diet Is Related to the Relative Sizes of the Gills and Palps in Bivalves', Journal of Experimental Marine Biology and Ecology 361(2):10410.

De Connick, F. (1980) 'Major Mechanisms in Formation of Spodic Horizons', Geoderma 24:101-28.

Conry, M. J., Conick, F. and Stoops, G. (1996) 'The Properties, Genesis and Significance of a Man-made Iron Pan Podzol Near Castletownbere, Ireland', European Journal of Soil Science 47(3):279-84.

Cornwall, I. W. (1958) Soils for the Archaeologist London: Phoenix House.

Coronato, A., Salemme, M. and Rabassa, J. (1999) 'Palaeoenvironmental Conditions During the Early Peopling of Southernmost South America (Late Glacial-Early Holocene, 14-8 Ka B.P.)', Quaternary International 53,54:77-92.

Corrêa, G. R. (2007) Caracterização Pedológica De Arqueo-antropossolos No Brasil: Sambaquis Da Região Dos Lagos (RJ) e Terras Pretas De Índio Na Região Do Baixo Rio Negro/Solimóes (AM). Universidade Federal de Viçosa.

Cortez-Sanchez, M., Morales-Muniz, A., Simon-Vallejo, M., Bergada-Zapata, M., DelgadoHuertas, A., Lopez-Garcia, P., Lopez-Saez, J., Lozano-Francisco, M., Riquelme-Cantal, J. and Rosello-Izquierdo, E. (2008) 'Palaeoenvironmental and Cultural Dynamics of the 
Coast of Málaga (Andalusia, Spain) During the Upper Pleistocene and Early Holocene', Quaternary Science Reviews 27(23-24):2176-93.

Costamagno, S., Griggo, C. and Mourre, V. (1998) 'Approche Expérimentale D'um Problème Taphonomique: Utilisation De Combustible Osseux Au Paléolithique', Préhistoire Européenne 13:167-94.

Costamagno, S., Thery-parisot, I. and Brugal, J. (2002) 'Taphonomic Consequences of the Use of Bones as Fuel. Experimental Data and Archaeological Applications', in T. O'Connor (ed.) 9th ICAZ Conferece: Biosphere to Lithosphere, pp.51-62. Dublin.

Courty, M. A. (2001) 'Microfacies Analysis Assisting Archaeological Stratigraphy', in P. Goldberg V. T. Holliday and C. Reid Ferring (eds) Earth Sciences and Archaeology, pp.205-39. New York: Kluwer.

Courty, M. A., Goldberg, P. and Macphail, R. I. (1989) Soils and Micromorphology in Archaeology Cambridge: Cambridge University Press.

Courty, M.-A., Carbonell, E., Vallverdú Poch, J. and Banerjee, R. (2012) 'Microstratigraphic and Multi-analytical Evidence for Advanced Neanderthal Pyrotechnology at Abric Romani (Capellades, Spain)', Quaternary International 247:294-312.

Craig, O. E., Steele, V. J., Fischer, a., Hartz, S., Andersen, S. H., Donohoe, P., Glykou, a., Saul, H., Jones, D. M., Koch, E. and Heron, C. P. (2011) 'Ancient Lipids Reveal Continuity in Culinary Practices Across the Transition to Agriculture in Northern Europe', Proceedings of the National Academy of Sciences

Crancio, F. and Kneip, L. M. (1994) 'Cultura Material e Subsistência Das Populaces Préhistóricas De Saquarema, RJ', Documentos de Trabalho 2:1-71.

Criado-Boado, F. (1989) 'Megalitos, Espacio, Pensamiento', Trabajos de Prehistoria 46:75-98.

Criado-Boado, F. (1993) 'Visibilidad e Interpretación De Registro Arqueológico', Trabajos de Prehistoria 50:39-56.

Criado-Boado, F. (1999) 'Del Terreno Al Espacio: Planteamientos y Problemas Para La Arqueología Del Paisaje', CAPA 6

Cruz, F. W., Burns, S. J., Karmann, I., Sharp, W. D., Vuille, M. and Ferrari, J. a. (2006) 'A Stalagmite Record of Changes in Atmospheric Circulation and Soil Processes in the Brazilian Subtropics During the Late Pleistocene', Quaternary Science Reviews 25(2122):2749-61.

Czimczik, C. I. and Masiello, C. A. (2007) 'Controls on Black Carbon Storage in Soils', Global Biogeochemical Cycles 21(3):GB3005.

Dalan, R. A., Musser, J. M. and Stein, J. K. (1992) 'Gephysical Exploration of the Shell Midden’, in J. K. Stein (ed.) Deciphering a Shell Midden, pp.43-59. San Diego: Academic Press.

Darlymple, J. B. (1958) 'The Application of Soil Micromorphology to Fossil Soils and Other Deposits from Archaeological Sites', Journal of Soil Science 9:199-205.

Darwin, C. (1839) 'Journal and Remarks (1832-1836)', in Narrative of the Surveying Voyages of His Majesty's Ships Adventure and Beagle Between the Years 1826-1836. Examination of the Southern Shores of South America. Volume III, London: Henry Coburn.

DeBlasis, P. and Farias, D. (2007) Proejto Arqueológico Sambquis e Paisagem: Pesquisas No Sitio Galheta IV, Campanha 2007.

DeBlasis, P., Fish, S. K., Gaspar, M. D. and Fish, P. R. (1998) 'Some References for the Discussion of Complexity Among the Sambaqui Moundbuilders from the Southern Shores of Brazil', Revista de Arqueologia Americana 15:75-105.

DeBlasis, P., Kneip, A., Scheel-Ybert, R., Giannini, P. C. F. and Gaspar, M. D. (2007) 'Sambaquis e Paisagem: Dinâmica Natural e Arqueologia Regional No Litoral Sul Do Brasil', Revista de Arqueología Sudamericana 3(1):29-61.

DeFrance, S., Grayso, N. and Wise, K. (2009) 'Documenting 12,000 Years of Coastal Occupation on the Osmore Littoral, Peru', Journal of Field Archaeology2 34:227-46.

DeFrance, S., Keefer, D. K., Richardson, J. B. and Alvarez, A. U. (2001) 'Late Paleo-indian Coastal Foragers: Specilized Extractive Behavior at Quebrada Tacahuay, Peru', Latin American Antiquity 12(4):413-26. 
Denevan, W. M. (1992) 'The Pristine Myth: The Landscape If the Americas in 1492', Annals of the Association of American Geographers 82(3):369-85.

Deo, J. N., Stone, J. O. and Stein, J. K. (2004) 'Building Confidence in Shell : Variations in the Marine Radiocarbon Reservoir Correction for the Northwest Coast over the Past 3000 Years', American Archaeology 69(4):771-86.

Despard, G. P. (1863) 'Fireland, or, Tierra Del Fuego', Sunday at Home X:676-80, 696-98, 716-18, 731-34, 744-48.

Dias, O. (1976) 'A Evolução Da Cultura Em Minas Gerais e No Rio De Janeiro', Anuário de Divulgação Cientifica 3:110-30.

Dias, O. (1987) Pré-história e Arqueologia Da Região Sudeste Do Brasil Rio de Janeiro: Instituto de Arqueologia Brasileira.

Dias, O. and Carvalho, E. (1980) 'A Pré-história Da Serra Fluminense e a Utilização Das Grutas Do Estado Do Rio De Janeiro', Pesquisas 31

Diegues, C. A. (2004) A Pesca Construindo Sociedades São Paulo: NUPAUB - USP.

Dillehay, T. D. (1999) Monte Verde: A Late Pleistocene Settlement in Chile, Volume 2: The Archaeological Context and Interpretation Washingotn DC: Smithsonian Institution Press.

Dillemburg, S. R., Laybauer, L., Mexias, A. S., Dani, N., Barboza, E. G. and Lummertz, C. N. (2000) 'Significado Estratigráfico De Minerais Glauconíticos Da Planície Costeira Do Rio Grande Do Sul, Região Da Laguna De Tramandaí', Revista Brasileira de Geociências 30(4):649-54.

Dimbleby, G. W. (1962) The Development of British Heathlands and Their Soils Oxford: Oxford University Press.

Dixon, E. J. (2001) 'Human Colonization of the Americas : Timing, Technology and Process', Quaternary Science Reviews 20:277-99.

Dorronsoro, C. and Aguiar, J. (1988) 'El Proceso De Iluviación De Arcilla', Anales de Edafología e Agrobiología 47:311-50.

Duarte, P. (1968) O Sambaqui Visto Através De Alguns Sambaquis São Paulo: Instituto de Préhistória da Universidade de São Paulo.

Dufour, E., Bocherens, H. and Mariotti, A. (1999) 'Palaeodietary Implications of Isotopic Variability in Eurasian', Journal of Archaeological Science 26:617-27.

Ehleringer, J. R., Cerling, T. E. and Helliker, B. R. (1997) 'C4 Photosynthesis, Atmospheric CO 2 , and Climate', Oecologia 112(3):285-99.

Eidt, R. C. (1984) Advances in Abandoned Settlement Analysis. Application to Prehistoric Anthrosols in Colombia, South America Milwakee: The Center for Latin America, University of Wisconsin-Milwaukee.

Embrapa (2006) Sistema Brasileiro De Classificação De Solos Rio de Janeiro: Embrapa-SPI.

Emery, A. K. O. and Edwards, R. L. (1966) 'Archaeological Potential of the Atlantic Continental Shelf', American Antiqui 31(5):733-37.

Emperaire, J. and Laming-Emperaire, A. (1956) (a) 'Algunas Nuevas Aportaciones Sobre Los Sambaquis Del Brasil Meridional’, Compás Número Esp:31-36.

Emperaire, J. and Laming-Emperaire, A. (1956) (b) 'Les Sambaquis De La Côte Meridionale Du Brésil: Compagnes De Fouilles (1954-1956)', Journal de la Société dês Américanistes 45:5-163.

Erickson, C. L. (2000) 'An Artificial Landascape-scale Fishery in the Bolivian Amazon', Nature 408(November):190-93.

Erickson, C. L. (2008) 'The Historical Ecology of a Domesticated Landscape', in H. Silverman and W. H. Isbell (eds) Handbook of South American Archaeology, pp.157-83. New York: Springer.

Erickson, C. L. and Balée, W. (2006) 'The Historical Ecology of a Complex Landscape in Bolivia', in W. Balée and C. L. Erickson (eds) Time and Complexity in Historical Ecology: Studies in the Neotropical Lowlands, pp.187-233. New York: Columbia University Press.

Erlandson, J. M. (1988) (a) 'Cultural Evolution and Paleogeography on the Santa Barbara Coast: a 9600 Year 14C Record from Southern California', Radiocarbon 30:25-39. 
Erlandson, J. M. (1988) (b) 'Cultural Evolution and Paleogepgraphy on the Santa Barbara Coast: a 9600-year 14C Record from Southern California', Radiocarbon 30(1):25-39.

Erlandson, J. M. (1994) Early Hunter-Gatherers of the California Coast New York: Prenum Press.

Erlandson, J. M. (2001) 'The Archaeology of Aquatic Adaptations : Paradigms for a New Millennium', Journal of Archaeological Research 9(4):287-350.

Erlandson, J. M. (2002) 'Anatomically Modern Humans, Maritime Voyaging, and the Pleistocene Colonization of the Americas', in N. Jablonski (ed.) The First Americans: The Pleistocene Colonization of the New World, pp.59-95. San Francisco: University of California Press.

Erlandson, J. M. (2007) 'Sea Change: The Paleocoastal Occupations of Daisy Cave', in S. W. Neusius and G. T. Gross (eds) Seeking Our Past: An Introduction to North American Archaeology, pp.135-43. Oxford: Oxford University Press.

Erlandson, J. M. and Braje, T. J. (2011) 'From Asia to the Americas by Boat? Paleogeography, Paleoecology, and Stemmed Points of the Northwest Pacific', Quaternary International 239(1-2):28-37.

Erlandson, J. M., Graham, M. H., Bourque, B. J., Corbett, D., Estes, J. a. and Steneck, R. S. (2007) 'The Kelp Highway Hypothesis: Marine Ecology, the Coastal Migration Theory, and the Peopling of the Americas', The Journal of Island and Coastal Archaeology 2(2):161-74.

Erlandson, J. M. and Rick, T. C. (2002) 'A 9700 Yr Old Shell Midden on San Miguel Island, Carlifornia', Antiquity 76:315-16.

Erlandson, J., Moss, M. and Deslauriers, M. (2008) 'Life on the Edge: Early Maritime Cultures of the Pacific Coast of North America', Quaternary Science Reviews 27(23-24):2232-45.

Estevez, J. (2009) 'Ethnoarchaeology in the Uttermost Part of the Earth', Arctic Anthropology 46:132-43.

Estevez, J., Juan-Muns, N., Martinez, J., Piqué, R. and Schiavini, A. (1996) 'Zooarqueología e Antracología: Estratégias De Aprovechamiento De Los Recursos Animales y Vegetales En Túnel VII', Treballs d'Etnoarqueologia: Encuentro en los Conchales Fueguinos 3:143238.

Estevez, J. and Martinez, J. (1997) 'Archaeozoological Researches at the Beagle Channel, Argentina.', Anthropozoologica, 25, 26:237-46.

Estevez, J., Piana, E., Schiavini, A. and Juan-Muns, N. (2001) 'Archaeological Analysis of Shell Middens in the Beagle Channel, Tierra Del Fuego Island', International Journal of Osteoarchaeology 11(1-2):24-33.

Estevez, J. and Vila, A. (1996) 'Etnoarqueología: El Nombre De La Cosa', Treballs d'Etnoarqueologia: Encuentro en los Conchales Fueguinos 3:17-23.

Estevez, J. and Vila, A. (1998) 'Tierra Del Fuego, Lugar De Encuentros', Revista de Antropologia 15:187-219.

Estevez, J. and Vila, A. (2006) 'Variability in the Lithic and Faunal Record Through 10 Reoccupations of a XIX Century Yamana Hut', Journal of Anthropological Archaeology 25(4):408-23.

Estevez, J. and Vila, A. (2007) '20 Years of Ethnoarchaeological Reserach in Tierra Del Fuego: Some Thoughts for Eropean Shell-midden Archaeology', in Shell Middens in Atlantic Europe, pp.183-95.

Estevez, J., Vila, A., Terradas, X., Piqué, R., Taulé, M., Gibaja, J. J. and Ruiz, G. (1998) 'Cazar o No Cazar, ¿es Ésta La Cuestión?', Boletin de Antropología Americana 33:5-24.

Etiégni, L. and Campbell, a. G. (1991) 'Physical and Chemical Characteristics of Wood Ash', Bioresource Technology 37(2):173-78.

FAO-Unesco (1997) Soil Map of the World Wageningen: International Soil Reference and Information Center.

Fa, D. (2008) 'Effects of Tidal Amplitude on Intertidal Resource Availability and Dispersal Pressure in Prehistoric Human Coastal Populations: The Mediterranean-Atlantic Transition', Quaternary Science Reviews 27(23-24):2194-2209. 
Fagundes, N. J. R., Kanitz, R., Eckert, R., Valls, A. C. S., Bogo, M. R., Salzano, F. M., Smith, D. G., Jr, W. A. S., Zago, M. A., Ribeiro-dos-santos, A. K., Santos, S. E. B., Petzl-erler, M. L. and Bonatto, S. L. (2008) 'Mitochondrial Population Genomics Supports a Single Pre-Clovis Origin with a Coastal Route for the Peopling of the Americas', American Journal of Human Genetics 82(March):583-92.

Fairbridge, R. W. (1976) 'Shellfish-eating Preceramic Indians in Coastal Brazil', Science 191(4225):353-59.

Farias, D. (2005) DISTRIBUIÇÃO E PADRÃO DE ASSENTAMENTO - PROPOSTAS PARA OS SÍTIOS DA TRADIÇÃO UMBU NA ENCOSTA DE SANTA.

Favier Dubois, C. M., Borella, F. and Tykot, R. H. (2009) 'Explorando Tendencias En El Uso Humano Del Espacio y Los Recursos En El Litoral Rionegrino (Argentina) Durante El Holoceno Medio y Tardío', in M. Salemme F. Santiago M. Alvarez E. Piana E. Vazquez and E. Mansur (eds) Arqueologia De La Patagonia: Una Mirada Desde El Último Confin, pp.985-98. Ushuaia: Editorial Utopías.

Fedje, D. W. and Christensen, T. (1999) 'Modeling Paleoshorelines and Locating Early Holocene Coastal Sites in Haida Gwaii', American Antiquity 64(4):635-52.

Fernández, F. G., Johnson, K. D., Terry, R. E., Nelson, S. and Webster, D. (2005) 'Soil Resources of the Ancient Maya at Piedras Negras, Guatemala', Soil Science Society of America Journal 69(6):2020-32.

Ferraz, T. (2010) Estudo Comparativo Dos Sambaquis Caipora, Lageado e Jaboticabeira I : Interpretações Acerca Da Mudança De Material Construtivo Ao Longo Do Tempo. Universidade de São Paulo.

Figuti, L. (1992) Les Sambaquis COSIPA (4200 à 1200 Ans BP): Étude De La Subsistance Chez Les Peuples Préhistoriques De Pêcheurs-ramasseurs De Bivalves De La Côte Centrale De L'état De São Paulo, Brésil. Museum National d'Histoire Naturelle.

Figuti, L. (1993) 'O Homem Pré-histórico, o Molusco e o Sambaqui: Considerações Sobre a Subsistência Dos Povos Sambaquieiros', Revista do Museu de Arqueologia e Etnologia 3:67-80.

Figuti, L. (2008) 'A Recipe for a Sambaqui : Considerations on Brazilian Shell Mound Composition and Building', in A. Antczak and R. Cipriani (eds) Early Human Impact on Megamollusks, pp.67-80. Oxford: BAR Archaeopress.

Figuti, L. and Klokler, D. (1996) 'Resultados Preliminares Dos Vestígios Zooarqueológicos Do Sambaqui Espinheiros II (Joinville, SC)', Revista do Museu de Arqueologia e Etnologia 6:169-88.

Filippini, J. (2004) Biodistância Entre Sambaquieiros Fluviais e Costeiros: Uma Abordagem Não-Métrica Craniana Entre Três Sítios Fluviais Do Vale Do Ribeira- SP (Moraes, Capelinha e Pavão XVI) e Três Costeiros Do Sul e Sudeste Do Brasil (Piaçaguera, Jabuticabeira II e Tenóri. Universidade de São Paulo.

Filippini, J. and Eggers, S. (2005) 'Distância Biológica Entre Sambaquieiros Fluviais (Moraes Vale Do Ribeira - SP) e Construtores De Sítios Litorâneos (Piaçaguera e Tenório - SP e Jabuticabeira II - SC)', Revista do Museu de Arqueologia e Etnologia 15-16:165-80.

Fish, S. K., Blasis, P. D., Gaspar, M. D. and Fish, P. R. (2000) 'Eventos Incrementais Na Construçao De Sambaquis, Litoral Sul Do Estado De Santa Catarina', Revista do Museu de Arqueologia e Etnologia 10:69-87.

Fitz-Roy, R. (1839) 'Proceedings of the Firs Expedition 1826-1830 Under the Command of Captain P. Parker King, R.N., F.R.S.', in Narrative of the Surveying Voyages of His Majesty's Ships Adventure and Beagle Between 1826 and 1836: Examination of the Southern Shores of South America, London: Henry Coburn.

Fitzpatrick, E. A. (1993) Soil Microscopy and Micromorphology New York: John Wiley \& Sons.

Fix, A. G. (2005) 'Rapid Deployment of the Five Founding Amerind mtDNA Haplogroups via Coastal and Riverine Colonization.', American journal of physical anthropology 128(2):430-36.

Fladmark, K. R. (1979) 'Routes: Alternate Migration Corridors for Early Man in North America', American Antiquity 44:55-69. 
Fletcher, R. (1989) 'The Message of Material Behaviour: a Preliminary Discussion of Nonverbal Meaning', in I. Hodder (ed.) The Meaning of Things, pp.33-44. London: Harper Colins Academic.

Flores, C. and Lira, N. (2006) 'Aspectos Comunes Para Sitios De Cazadores Recolectores Costeros En Los Canales Patagónicos Septentrionales', Boletín de la Sociedad Chilena de Arqueología 39:103-12.

Fogel, M., Tuross, N., Johnson, B. and Miller, G. (1997) 'Biogeochemical Record of Ancient Humans', Organic Geochemistry 27(5-6):275-87.

Fogg, G., Rolston, D. E., Decker, D. L., Louie, D. T. and Grismer, M. E. (1998) 'Spatial Variation in N Isotope Values Beneath Nitate Contamination Sources', Ground Water 36(3):418-26.

Fornari, M. (2010) Evoluçao Sedimentar Holocênica Da Retrobarreira Na Região De Jaguaruna-Laguna, Santa Catarina, Brasil. Universidade de São Paulo.

Fossari, T. D. (2004) A População Pré-colonial Jê Na Paisagem Da Ilha De Santa Catarina.

France, R. L. (1994) 'Nitrogen Isotopic Composition of Marine and Freshwater Invertebrates', 115(1984):205-7.

French, C. (2003) Geoarchaeology in Action: Studies in Soil Micromorphology and Landscape Evolution London, New York: Routledge.

Gaffey, S. J., Kolak, J. J. and Bronnimann, C. E. (1991) 'Effects of Drying , Heating, Annealing, and Roasting on Carbonate Skeletal Material, with Geochemical and Diagenetic Implications', Geochimi 55:1627-40.

Gaspar, M. D. (1991) Aspectos Da Organizaçao Social De Pescadores-coletores: Região Compreendida Entre a Ilha Grande e o Delta Do Paraiba Do Sul, Rio De Janeiro. Universidade de São Paulo.

Gaspar, M. D. (1995) 'Dataçoes, Construçao De Sambaquis e Identidade Social Dos Pescadores, Coletores e Caçadores', Anais da VIII Reunião Científica PUCRS 1(1):37798.

Gaspar, M. D. (1998) 'Considerations of the Sambaquis of the Brazilian Coast', Antiquity 72(277):592-615.

Gaspar, M. D. (2000) Sambaquis: Arqueologia Do Litoral Rio de Janeiro: Jorge Zahar Editora.

Gaspar, M. D. (2004) 'Cultura: Comunicaçao, Arte, Oralidade Na Pré-história Do Brasil', Revista do Museu de Arqueologia e Etnologia 14:153-68.

Gaspar, M. D., Barbosa, D. and Barbosa, M. (1994) 'Análise Do Processo Cognitivo De Construção Do Sambaqui Ilha Da Boa Vista (RJ)', Clio 1:110-24.

Gaspar, M. D., Buarque, A., Cordeiro, J. and Escórcio, E. (2007) 'Tratamento Dos Mortos Entre Os Sambaquieiros, Tupinambá e Goitacá Que Ocuparam a Região Dos Lagos, Estado Do Rio De Janeiro', Revista do Museu de Arqueologia e Etnologia 17:169-89.

Gaspar, M. D. and DeBlasis, P. (1992) Construção De Sambaquis: Sintese Das Discussões Do Grupo De Trabalho e Colocaçao Da Proposta Original, in Anais Da VI Reunião Cientifica Da Sociedade De Arqueologia Brasileira. Rio De Janeiro.

Gaspar, M. D., DeBlasis, P., Fish, S. K. and Fish, P. R. (2008) 'Sambaqui (Shell Mound) Societies of Coastal Brazil', in H. Silverman and W. H. Isbell (eds) Handbook of South American Archaeology, pp.319-37. New York: Springer.

Ge, T., Courty, M. A., Matthews, M. and Wattez, J. (1993) 'Sedimentary Formation Processes of Occupation Surfaces', in P. Goldberg D. T. Nash and M. D. Petraglia (eds) Formation Processes in Archaeological Contexts, pp.149-63. Madison: Prehistory Press.

Gebhardt, A. and Langohr, R. (1999) 'Micromorphological Study of Construction Materials and Living Floors in the Medieval Motte of Werken (West Flanders, Belgium)', Geoarchaeology 14(7):595-620.

Le Geros, R. Z. and Le Geros, J. P. (1984) 'Phosphate Minerals in Human Tissue', in J. O. Nriagu and P. B. Moore (eds) Phosphate Minerals, pp.351-85. Berlin: Springer-Verlag.

Gessert, S., Iriarte, J., Ríos, R. C. and Behling, H. forthcoming. 'Late Holocene Vegetation and Environmental Dynamics of the Araucaria Forest Region in Misiones Province, NE Argentina', NorthReview of Palaeobotany and Palinology 
Giannini, P. C. F. (1993) Sistemas Deposicionais No Quaternário Costeiro Entre Jaguaruna e Imbituba, SC. Universidade de São Paulo.

Giannini, P. C. F. (2002) 'Complexo Lagunar Centro-Sul Catarinense: Valioso Patrimônio Sedimentológico, Arqueológico e Histórico', in C. Schobbenhaus D. A. Campos E. T. Queiroz M. Winge and M. Berbert-Born (eds) Sitios Geológicos e Paleontológicos Do Brasil, pp.213-22. Brasilia: DNPM.

Giannini, P. C. F., Deblasis, P., Sawakuchi, A. O. and Amaral, P. G. C. (2005) Processos e Materiais Geológicos e a Construção De Sambaquis No Litoral Sul De, in Anais Do Congresso Da Associaçao Brasileira De Estudos Do Quaternário (ABEQUA), Guarapari 2005.

Giannini, P. C. F., Sawakuchi, a. O., Martinho, C. T. and Tatumi, S. H. (2007) 'Eolian Depositional Episodes Controlled by Late Quaternary Relative Sea Level Changes on the Imbituba-Laguna Coast (southern Brazil)', Marine Geology 237(3-4):143-68.

Giannini, P. C. F., Sawakuchi, A. O. and Martinho, C. T. (2001) A Estratigrafia De Seqüências Na Evolução Das Dunas Costeiras De Santa Catarina, Sul Do Brasil, in Actas Do Congresso Do Quaternário Dos Países De Língua Ibérica 1.

Giannini, P. C. F. and Suguio, K. (1994) Diferenciação Entre Depósitos Eólicos Quaternários Na Costa Centro-sul De Santa Catarina, in Congresso Brasileiro De Geologia 38: Resumos Expandidos.

Giannini, P. C. F., Villagran, X. S., Fornari, M., Rodrigues, D., Menezes, P., Tanaka, A. P., Assunçao, D., De Blasis, P. and Amaral, P. (2010) 'Interações Entre Evolução Sedimentar e Ocupação Humana Pré-histórica Na Costa Centro-sul De Santa Catarina , Brasil Interactions Between Sedimentary Evolution and Prehistoric Human Occupation in the South-central Coast of Santa Catarina , Brazil', Bolteim do Museu Paraense Emílio Goeldi. Série Ciências Humanas 5(1):105-28.

Gilinskaya, L. G., Zanin, Y. N. and Rudina, N. a. (2007) 'Bacterial Genesis of Calcium Phosphates in Human Organism and Nature', Lithology and Mineral Resources 42(1):5667.

Glaser, B. (2000) 'Black Carbon in Density Fractions of Anthropogenic Soils of the Brazilian Amazon Region', Organic Geochemistry 31(7-8):669-78.

Glaub, I. (2004) 'Recent and Subrecent Microborings from Upwelling Area Off Mauritania (West Africa) and Their Implications for Paleoecology', in D. McIlroy (ed.) The Application of Ichnololgy to Palaeoenvironmental and Stratigraphic Analysis, pp.63-76. London: The Geological Society.

Gnecco, C. (2003) 'Against Ecological Reductionism: Late Pleistocene Hunter-gatherers in the Tropical Forests of Northern South America', Quaternary International 109-110:13-21.

Goldberg, P., Dibble, H., Berna, F., Sandgathe, D., McPherron, S. J. P. and Turq, A. (2012) 'New Evidence on Neandertal Use of Fire: Examples from Roc De Marsal and Pech De l'Azé IV', Quaternary International 247:325-40.

Goldberg, P. and Macphail, R. I. (2008) Practical and Theoretical Geoarchaeoogy Oxford: Blaclwell Publishing.

Goldberg, P., Miller, C. E., Schiegl, S., Ligouis, B., Berna, F., Conard, N. J. and Wadley, L. (2009) 'Bedding, Hearths, and Site Maintenance in the Middle Stone Age of Sibudu Cave, KwaZulu-Natal, South Africa', Archaeological and Anthropological Sciences 1(2):95122.

Goldberg, P. and Nathan, Y. (1975) 'The Phosphate Mineralogy of Et Tabun Cave, Mount Carmel, Israel', Mineralogical Magazine 40:253-58.

Goldberg, P. and Whitbred, I. (1993) 'Micromorphological Study of a Bedouin Tent Floor', in P. Goldberg D. T. Nash and M. D. Petraglia (eds) Formation Processes in Archaeological Contexts, pp.156-88. Madison: Prehistory Press.

Gomes, F. H. (2005) Gênese e Classificação De Solos Sob Vegetação De Restinga Na Ilha Do Cardoso-SP. Universidade de São Paulo.

Gomes, M. J. . (2003) Utilização De Métodos Geofísicos Em Sambaquis Fluviais, Região Do Vale Do Ribeira De Iguape - SP/PR. Universidade de São Paulo. 
Gomez Otero, F. (2006) Dieta, Uso Del Espacio y Evolución En Poblaciones Cazadorasrecolectoras De La Costa Centro - Septentrional De Patagonia Durante El Holoceno Medio y Tardio.

Gomez Otero, F., Lanata, J. L. and Prieto, A. (1998) 'Arqueología De La Costa Atlántica Patagónica', Revista de Arqueología Americana 15:107-85.

González-José, R., Bortolini, M. C., Santos, F. R. and Bonatto, S. L. (2008) 'The Peopling of America: Craniofacial Shape Variation on a Continental Scale and Its Interpretation from an Interdisciplinary View.', American journal of physical anthropology 137(2):175-87.

Gordillo, S., Bujalesky, G., Pirazzoli, P., Rabassa, J. and Saliege, J. (1992) 'Holocene Raised Beaches Along the Northern Coast of the Beagle Channel, Tierra Del Fuego, Argentina', Palaeogeography, Palaeoclimatology, Palaeoecology 99(1-2):41-54.

Gordillo, S., Coronato, A. and Rabassa, J. (1993) 'Late Quaternary Evolution of a Subantarctic Paleofjord, Tierra Del Fuego', Quaternary Science Reviews 99:41-54.

Gordon, C. and Buikstra, J. E. (1981) 'Soil pH, Bone Preservation and Sampling Bias at Mortuary Sites', American Antiquity 46(3):566-71.

Grotta, M. and Lunetta, J. E. (1980) 'Cíclo Sexual De Anomalocardia Brasiliana (Gmelin 1970) Do Litoral Do Estado Da Paraíba', Revista Nordestina de Biologia 3:5-55.

Grotta, M. and Lunetta, J. E. (1982) 'Reproductive Physiological Variation of Anomalocardia Brasiliana (Gmelin 1971) (Mollusca - Bivalvia), in Different Latitudes', Revista Nordestina de Biologia 5:21-28.

Guerra, A. T. (1950) 'Contribuição Da Geomorfologia Ao Estudo Dos Sambaquis', Boletim Carioca de Geografia 4:5-13.

Guerra, A. T. (1953) Notas Sobre Alguns Sambaquis e Terraços Do Litoral De Laguna (Santa Cataria), in Anais Da Associaçao De Geógrafos Do Brasil (1950-1951).

Guidon, N. (1964) 'Nota Prévia Sobre o Sambaqui Mar Casado', in Homenaje a Fernando Marquez-Miranda, pp.176-204. Madrid: Universidad Complutense de Madrid.

Gusinde, M. (1937) Los Indios De Tierra Del Fuego. Tomo Segundo, Volumen III, Cuarta Parte: El Mundo Espiritual De Los Yámana.

Gusinde, M. (1951) Hombres Primitivos En La Tierra Del Fuego (de Investigador a Compañero De Tribu) Sevilla.

Gusinde, M. (1982) Los Indios De Tierra Del Fuego: Los Selknam Buenos Aires: Centro Argentino de Etnología Americana.

Gusinde, M. (1986) (a) Los Indios De Tierra Del Fuego: Los Yamana Buenos Aires: CAEA.

Gusinde, M. (1986) (b) Los Indios De Tierra Del Fuego: Los Yamana Buenos Aires: Centro Argentino de Etnología Americana.

Gustafson, L., Showers, W., Kwak, T., Levine, J. and Stoskopf, M. (2007) 'Temporal and Spatial Variability in Stable Isotope Compositions of a Freshwater Mussel: Implications for Biomonitoring and Ecological Studies.', Oecologia 152(1):140-50.

Hacket, C. J. (1981) 'Microscopical Focal Destruction (tunnels) in Exhumed Human Bones', Medicine, Science and the Law 21:243-65.

Hall, G., Woodborne, S. and Scholes, M. (2008) 'Stable Carbon Isotope Ratios from Archaeological Charcoal as Palaeoenvironmental Indicators', Chemical Geology 247(34):384-400.

Harris, Edward, C. (1991) Principios De La Estratigrafia Arqueológica Barcelona: Editorial Crítica.

Hassan, F. (1978) 'Sediments in Archaeology: Methods and Implications for Palaeoenvironmental and Cultural Analyses', Journal of Field Archaeology 5(2):197-213.

Heaton, T. H. E. (1986) 'Isotopic Studies of Nitrogen Pollution in the Hydrosphere and Atmosphere: a Review', Chemical Geology 59:87-102.

Heckenberger, M. J. (1996) War and Peace in the Shadow of Empire: Sociopolitical Change in the Upper Xingu of Southeastern Amazonia. University of Pittsburgh.

Heckenberger, M. J., Kuikuro, A., Kuikuro, U. T., Russell, J. C., Schmidt, M., Fausto, C. and Franchetto, B. (2003) 'Amazonia 1492: Pristine Forest or Cultural Parkland?', Science 301(5640):1710-14. 
Hedges, R. (1995) 'Measurements and Relationships of Diagenetic Alteration of Bone from Three Archaeological Sites', Journal of Archaeological Science 22(2):201-9.

Hedges, R. E. M. (2002) 'Bone Diagenesis: An Overview of Processes', Archaeometry 44(3):319-28.

Henderson, W. G., Anderson, L. C. and McGIMSEY, C. R. (2002) 'Distinguishing Natural and Archaeological Deposits: Stratigraphy, Taxonomy, and Taphonomy of Holocene ShellRich Accumulations from the Louisiana Chenier Plain', Palaios 17(2):192-205.

Heusser, C. J. (1960) 'Late-Pleistocene Environments of North Paci"c North America: An Elaboration of Late-glacial and Post-glacial Cli- Matic, Physiographic, and Biotic Changes', American Geographical Society. 35

Huang, Z. and Li, X. (2009) 'Nanoscale Structural and Mechanical Characterization of Heat Treated Nacre', Materials Science and Engineering: C 29(6):1803-7.

Hubbe, M., Harvati, K. and Neves, W. (2011) 'Paleoamerican Morphology in the Context of European and East Asian Late Pleistocene Variation: Implications for Human Dispersion into the New World.', American journal of physical anthropology 144(3):442-53.

Hubbe, M., Neves, W. A., Castro de Oliveira, E. and Strauss, A. (2009) 'Postmarital Residence Practice in Southern Brazilian Coastal Groups: Continuity and Change', Latin American Antiquity 20(2):267-78.

Hughen, K. A., Baillie, M. G. L., Bard, E., Beck, J. W., Bertrand, C. J. H., Blackwell, P. G., Buck, C. E., Burr, G. S., Cutler, K. B., Damon, P. E., Edwards, R. L., Fairbanks, R. G., Friedrich, M., Guilderson, T. P., Kromer, B., McCormak, G., Manning, S., Ramsey, C. B., Reimer, P. J., Reimer, R. W., Remmele, S., Southon, J. R., Stuiver, M., Talamo, S., Taylor, F. W. and Van der Plicht, J. Weyhenmeyer, C. E. (2004) 'Marine04 Marine Radiocarbon Age Calibration, 0-26 Cal Kyr BP', Radiocarbon 46(3):1059-86.

Hurt, W. (1974) The Interrelationships Between the Natural Environment and Four Sambaqui, Coast of Santa Catarina, Brazil. Indiana University Museum.

Hurt, W. and Blasi, O. (1960) 'O Sambaqui Do Macedo. A52B - Paraná - Brasil', Arqueologia $2: 7-73$.

Hyades, P. (1885) 'Une Année Au Cap Horn', Le Tour du Monde XLXIX(1):385-416.

Hyades, P. (1887) 'Ethnographie Des Fuéguiens', Bulletins de la Société d'Anthropologie de Paris X:327-45.

Hyades, P. and Deniker, J. (1891) Mission Scientifique Au Cap Horn (1882-1883). Tome VII. Anthropologie, Ethnographie Paris: Gauthier-Villars et fils.

Ingold, T. (1993) 'The Temporality of the Landscape', World Archaeology 25(2):152-74.

Ingold, T. (2000) 'The Optimal Forager and the Economic Man', in T. Ingold (ed.) The Perception of the Environment: Essays on Livelihood, Dwelling and Skill, pp.21-39. New York: Routledge.

Ingold, T. (2002) On the Social Relations of the Hunter-gatherer BandR. B. Lee and R. Daly (eds) Cambridge: Cambridge University Press.

Iriarte, J. and Behling, H. (2007) 'The Expansion of $<\mathrm{I}>$ Araucaria $</ \mathrm{I}>$ Forest in the Southern Brazilian Highlands During the Last 4000 Years and Its Implications for the Development of the Taquara/Itararé Tradition', Environmental Archaeology 12(2):115-27.

Iriarte, J., Gillam, J. C. and Marozzi, O. (2008) 'Monumental Burials and Memorial Feasting : an Example from the Southern Brazilian Highlands', Antiquity 82:947-61.

Iriarte, J., Glaser, B., Watling, J., Wainwright, A., Birk, J. J., Renard, D., Rostain, S. and McKey, D. (2010) 'Late Holocene Neotropical Agricultural Landscapes: Phytolith and Stable Carbon Isotope Analysis of Raised Fields from French Guianan Coastal Savannahs', Journal of Archaeological Science 37(12):2984-94.

Isla, F. I. and Bujalesky, G. G. (2000) 'Cannibalisation of Holocene Gravel Beach-ridge Plains,northern Tierra Del Fuego, Argentina', Marine Geology 170(1-2):105-22.

Jans, M. (2004) 'Characterisation of Microbial Attack on Archaeological Bone', Journal of Archaeological Science 31(1):87-95.

Jans, M. M. E., Kars, H., Nielsen-Marsh, C. M., Smith, C. I., NOrd, A. G., Arthur, P. and Earl, N. (2002) 'In Situ Preservation of Archaeological Bone: a Histological Study Within a Multidisciplinary Approach', Archaeometry 3:343-52. 
Jerardino, A., Castilla, J. C., Ramirez, J. M. and Hermosilla, N. (1992) 'Early Coastal Subsistence Patterns in Central Chile : A Systematic Study of the Marine- Invertebrate Fauna from the Site of Curaumilla-1', Latin American Antiquity 3(1):43-62.

Johansen, P. G. (2004) 'Landscape, Monumental Architecture, and Ritual: a Reconsideration of the South Indian Ashmounds', Journal of Anthropological Archaeology 23(3):309-30.

Johnson, J. R., Stafford, T. W., West, G. J. and Rockwell, T. K. (2007) 'Before and After the Younger Dryas: Chronostratigraphic and Paleoenvironmental Research at Arlington Springs, Santa Rosa Island, California', Eos 88:42A-03.

Jones, B., Kahle, C. F., Unn, G., Edmonton, A. and Canada, A. T. (1993) 'Morphology, Relationship, and Origin of Fiber and Dendrite Calcite Crystals', Journal of Sedimen 63(6):1018-31.

Jones, T. L., Fitzgerald, R. T., Kennett, D. J., Miksieck, C. H., Fagan, J. L., Sharp, J. and J., E. (2002) 'The Cross Creek Site (CA-SLO-1797) and Its Implications for New World Colonization', American Antiquity 67:221-30.

Jongerius, A. (1983) 'Micromorphology in Agriculture', in P. Bullock and C. P. Murphy (eds) Soil Micromorphology, pp.111-38. Berkhamsted: AB Academic Publishers.

Juan-Muns, N. (1992) La Pesca Com Alternativa Eco- Nòmica Per Als Yamana, Nòmades Canoers Del Canal Beagle (Tierra Del Fuego, Argentina). Universidad Autónoma de Barcelona.

Kampf, N. and Kern, D. (2005) 'O Solo Como Registro Da Ocupação Humana Pré-histórica Na Amazônia', in P. Vidal-Torrado L. R. F. Alleoni M. Cooper A. P. Silva and E. J. Cardoso (eds) Tópicos Em Ciência Do Solo, pp.277-320. Viçosa: Sociedade Brasileira de Ciência do Solo.

Karkanas, P. (2000) 'Diagenesis in Prehistoric Caves: The Use of Minerals That Form In Situ to Assess the Completeness of the Archaeological Record', Journal of Archaeological Science 27(10):915-29.

Karkanas, P. (2010) 'Preservation of Anthropogenic Materials Under Different Geochemical Processes: A Mineralogical Approach', Quaternary International 214(1-2):63-69.

Karkanas, P., Shahack-Gross, R., Ayalon, A., Bar-Matthews, M., Barkai, R., Frumkin, A., Gopher, A. and Stiner, M. C. (2007) 'Evidence for Habitual Use of Fire at the End of the Lower Paleolithic: Site-formation Processes at Qesem Cave, Israel.', Journal of human evolution 53(2):197-212.

Karl, R. (2000) The Relative Chronology of Cultural Episodes at the Coastal Sambaqui, Jabuticabeira II, in Santa Catarina, Brazil. University of Arizona.

Keefer, D. K. (1998) 'Early Maritime Economy and El Niño Events at Quebrada Tacahuay, Peru', Science 281(5384):1833-35.

Kelly, R. (2003) 'Maybe We Do Know When People First Came to North America; and What Does It Mean If We Do?', Quaternary International 109-110:133-45.

Kendall, C. (1998) 'Tracing Nitrogen Sources and Cycling in Catchments', in C. Kendall and J. J. McDonell (eds) Isotope Tracers in Catchment Hydrology, pp.519-76. Amsterdam: Elsevier B.V.

Kennett, D. (2005) The Island Chumash. Behavioral Ecology of a Maritime Society Berkeley: University of California Press.

Kern, A. (1982) 'Paleo-paisagens e Povoamento Pré-histórico Do Rio Grande Do Sul', Estudos Ibero Americanos 8:154-208.

Klokler, D. M. (2001) Construindo Ou Deixando Um Sambaqui. Universidade de São Paulo.

Klokler, D. M. (2008) Food for Body and Soul: Mortuary Ritual in Shell Mounds (Laguna Brazil). University of Arizona.

Klokler, D., Villagran, X. S., Giannini, P. C. F., Peixoto, S. and Deblasis, P. (2011) 'Juntos Na Costa: Zooarqueologia e Geoarqueologia De Sambaquis Do Litoral Sul Catarinense', Revista do Museu de Arqueologia e Etnologia 20:53-75.

Kneip, A. (2004) O Povo Da Lagoa: Uso Do SIG Para Modelamento e Simulaçao Na Área Arqueológica Do Camacho. Universidade de São Paulo.

Kneip, L. M. (1994) 'Cultura Material e Subsistência Das Populações Pré-históricas De Saquarema, RJ', Documentos de Trabalho 2:1-71. 
Kneip, L. M., Coelho, A., Cunha, F. and Mello, E. (1975) 'O Sambaqui Do Forte: Correlações Arqueológicas, Geológicas e Faunísticas (Cabo Frio, RJ - Brasil)', Anais da Academia Brasileira de Ciências 47:91-97.

Koppers, W. (1997) Entre Los Fueguinos Punta Arenas: Ediciones de la Universidad de Magallanes y progrma Chile Austral de la Unión Europea.

Kristiansen, S. M. (2001) 'Present-day Soil Distribution Explained by Prehistoric Land-use : Podzol - Arenosol Variation in an Ancient Woodland in Denmark', Geoderma 103:27189.

Krone, R. (1914) Informações Etnographicas Do Valle Do Rio Ribeira De Iguape São Paulo: Rothschild \& Company.

Kuhn, P., Aguilar, J. and Miedema, R. (2010) 'Textural Pedofeatures and Related Horizons', in G. Stoops V. Marcelino and F. Mees (eds) Interpretation of Micromorphological Features of Soils and Regoliths, pp.217-50. Amsterdam: Elsevier.

Laborel, J. and Laborel-Deguen, F. (1996) 'Biological Indicators of Holocene Sea-level and Climatic Variations on Rocky Coasts of Tropical and Subtropical Regions', Quaternary International 31:53-60.

Lamb, A. L., Wilson, G. P. and Leng, M. J. (2006) (a) 'A Review of Coastal Palaeoclimate and Relative Sea-level Reconstructions Using $\delta 13 \mathrm{C}$ and C/N Ratios in Organic Material', Earth-Science Reviews 75(1-4):29-57.

Lamb, A., Wilson, G. and Leng, M. (2006) (b) 'A Review of Coastal Palaeoclimate and Relative Sea-level Reconstructions Using $\delta 13 \mathrm{C}$ and $\mathrm{C} / \mathrm{N}$ Ratios in Organic Material', Earth-Science Reviews 75(1-4):29-57.

Laming, A. (1960) 'Novas Perspectivas Sobre a Pré-história Do Sul Do Brasil', Anhembi 113(38)

Laming-Emperaire, A. (1975) 'Problemes De Prehistoire Brasilienne', Annales: Économies, Sociétés, Civilisations 5:1229-60.

Lasiak, T. (1991) 'The Suceptibility And/or Resilience of Rocky Littoral Molluscs to Stock Depletion by Indigenous Coastal People of Transkei, Suthern Africa', Biological Conservation 56:245-64.

Lavina, R. (1994) Os Xokleng De Santa Catarina: Uma Etnohistória e Sugestões Para Os Arqueológos.

Legoupil, D. (1993) 'El Archipiélago Del Cabo De Hornos y La Costa Sur De La Isla Navarino: Poblamiento y Modelos Económicos', Anales del Instituto de la Patagonia 22:101-21.

Legoupil, D. (2005) 'Recolectores De Moluscos Tempranos En El Sureste De La Isla De Chiloe', Magallania 33(1):51-61.

Leonardos, O. H. (1938) 'Concheiros Naturais e Sambaquis', Avulsos: Serviço de fomento da Produção Mineral 37:1-109.

Lessa, A. (2005) 'Reflexões Preliminares Sobre Paleoepidemiologia Da Violência Em Grupos Ceramistas Litorâneos: I) Sítio Praia Da Tapera - SC', Revista do Museu de Arqueologia e Etnologia 15:199-207.

Lessa, A. and Scherer, L. Z. (2008) 'O Outro Lado Do Paraíso: Novos Dados e Reflexões Sobre Violência Entre Pescadores-coletores Pré-coloniais', Revista do Museu de Arqueologia e Etnologia 18:89-100.

Liang, B., Lehmann, J., Solomon, D., Kinyangi, J., Grossman, J., O’Neill, B., Skjemstad, J. O., Thies, J., Luizão, F. J., Petersen, J. and Neves, E. G. (2006) 'Black Carbon Increases Cation Exchange Capacity in Soils', Soil Science Society of America Journal 70(5):1719.

Lightfoot, K. and Cerrato, R. (1988) 'Prehistoric Shellfish Exploitation in Coastal New York', Journal of Field Archaeology 15:141-49.

Lima, H., Schaefer, C. E. G. R., Mello, J. W. V., Gilkes, R. J. and Ker, J. C. (2002) (a) 'Pedogenesis and pre-Colombian Land Use of "Terra Preta Anthrosols" ("Indian Black Earth") of Western Amazonia', Geoderma 110(1-2):1-17.

Lima, T. A. (1991) Dos Mariscos Aos Peixes: Um Estudo Zooarqueológico Da Mudança De Subsistência Ne Pré-história Do Rio De Janeiro. Universidade de São Paulo.

Lima, T. A. (1999) 'Em Busca Dos Frutos Do Mar: Os Pescadores-coletores Do Litoral Centrosul Do Brasil', Revista da Universidade de São Paulo 44:270-327. 
Lima, T. A. and Lopez Mazz, J. (1999) 'La Emergencia De Complejidad Entre Los Cazadores Recolectores Da La Costa Atlántica Meridional Sudamericana', Revista de Arqueologia Americana 17, 18, 19:129-75.

Lima, T. A., Macario, K. D., Anjos, R. M., Gomes, P. R. S., Coimbra, M. M. and Elmore, D. (2002) (b) 'The Antiquity of the Prehistoric Settlement of the Central-south Brazilian Coast', Radiocarbon 44(3):733-38.

Limbrey, S. (1975) Soil Science and Archaeology London: Academic Press.

Lindbo, D., Stolt, M. H. and Vepaskas, M. J. (2010) 'Redoximorphic Features', in G. Stoops V. Marcelino and F. Mees (eds) Interpretation of Micromorphological Features of Soils and Regoliths, pp.129-47. Amsterdam: Elsevier.

Lopes, J. M. (2010) Caracterizaçao e Evolução Das Substâncias Húmicas De Horizontes Espódicos Na Planície Costeira Deo Estado De São Paulo. Universidade de São Paulo.

Lopez Mazz, J., Piñeiro, G., Castiñeira, C. and Gascue, A. (1996) 'Ocupacion Humana En El Litoral Atlantico Del Uruguay: Aproximación Paleoambiental Al Conocimiento De Los Sitios Costeros: Sitio "La Esmeralda"", in Jornadas De Antropología d Ela Cuenca Del Plata: Arqueología e Bioantropología, pp.28-35. Rosario: Universidad Nacional de Rosario.

Lothrop, S. K. (1928) The Indians of Tierra Del Fuego New York: Museum of the American Indian, Heye Foundation.

Lovisato, D. (1884) 'Appunti Etnografici Con Accenni Geologici Sulla Terra Del Fuoco', Cosmos VIII(4):129-51.

Luby, E. M. (2004) 'Shell Mounds and Mortuary Behavior in the San Francisco Bay Area', North American Archaeologist 25(1):1-33.

Luby, E. M. and Gruber, M. F. (1999) 'The Dead Must Be Fed: Symbolic Meanings of the Shellmounds of the San Francisco Bay Area', Cambridge Archaeological Journal 9:95108.

Lucas, J. and Prévôt, L. E. (1991) 'Phosphates and Fossil Preservation', in P. A. Allison and D. E. G. Briggs (eds) Taphonomy: Releasing the Data Locked in the Fossil Record, pp.389409. New York: Plenum Press.

Lundström, U. ., van Breemen, N. and Bain, D. (2000) 'The Podzolization Process. A Review', Geoderma 94(2-4):91-107.

Macphail, R. (2004) 'Archaeological Soil and Pollen Analysis of Experimental Floor Deposits; with Special Reference to Butser Ancient Farm, Hampshire, UK', Journal of Archaeological Science 31(2):175-91.

Macphail, R. I. (1989) 'Paleosols in Archaeology: Their Role in Understanding Flandrian Pedogenesis', in P. Wright (ed.) Paleosols: Their Recognition and Interpretation, pp.26390. Oxford: Blackwell Scientific Publications.

Macphail, R. I., Courty, M. A., Hather, J. and Wattez, J. (1997) 'The Soil Micromorphological Evidence of Domestic Occupation and Stabling Activities', Memorie dell'Instituto Italiano di Paleontologia Umana V:53-88.

Macphail, R. I., Crowther, J., Acott, T. G., Bell, M. G. and Cruise, J. M. (2003) 'The Experimental Earthwork at Wareham, Dorset Ah Horizons', Journal of Archaeological Science:77-93.

Macphail, R. I. R. I., Courty, M. A. and Gebhardt, A. (1990) 'Soil Micromorphological Evidence of Early Agriculture', World Archaeology 22(1):53-69.

Macphail, R. I., Romans, J. C. C. and Roberston, L. (1987) 'The Application of Micromorphology to the Understanding of Holocene Soil Development in the British Isles; with Special Reference Ot Early Cultivation', in N. Fedoroff L. M. Bresson and M. A. Courty (eds) Micromorphologie Des Sols - Soil Micromorphology, pp.647-56. Paris: AFES.

Mallol, C., Marlowe, F., Wood, B. and Porter, C. (2007) 'Earth, Wind, and Fire: Ethnoarchaeological Signals of Hadza Fires', Journal of Archaeological Science 34(12):2035-52.

Mameli, L. (2000) Análisis Arqueofaunistico Del Yacimiento Arqueológico Túnel VII, Tierra Del Fuego, Argentina. Universidade Autónoma de Barcelona. 
Mameli, L. and Estevez, J. (2004) 'Etnoarqueozoología De Aves: El Ejemplo Del Extremo Sur Americano', Treballs d'Etnoarqueologia 5

Mandryk, C. A. S. C. a. ., Josenhans, H., Fedje, D. W. D. W. and Mathewes, R. W. R. W. (2001) 'Late Quaternary Paleoenvironments of Northwestern North America : Implications for Inland Versus Coastal Migration Routes', Quaternary Science Reviews 20(1-3):301-14.

Mannino, M. a. and Thomas, K. D. (2002) 'Depletion of a Resource? The Impact of Prehistoric Human Foraging on Intertidal Mollusc Communities and Its Significance for Human Settlement, Mobility and Dispersal', World Archaeology 33(3):452-74.

March, R. (1996) 'L'etude Des Structures De Combustion Prehistoriques: Una Approche Interdisciplinaire', in O. Bar-Yosef L. Cavalli-Sforza R. March and D. Piperno (eds) XIII International Congresso of Prehistoric and Protohistoric Sciences, Forli-Italia, 8-14 September. Colloquia 5: The Lower and Middle Paleolithic, pp.251-75.

March, R. and Ferreri, J. C. (1989) Sobre El Estudio De Estructuras De Combustión Arqueológicas Mediante Replicaciones y Modelos Numéricos, in Actes Du Colloque De Nemours 1987. Mémoires Du Musée De Préhistoire d'Ile De France 2.

Marean, C. W., Bar-Matthews, M., Bernatchez, J., Fisher, E., Goldberg, P., Herries, A. I. R., Jacobs, Z., Jerardino, A., Karkanas, P., Minichillo, T., Nilssen, P. J., Thompson, E., Watts, I. and Williams, H. M. (2007) 'Early Human Use of Marine Resources and Pigment in South Africa During the Middle Pleistocene.', Nature 449(7164):905-8.

Markgraf, V. (1993) 'Paleoenvironments and Paleoclimates in Tierra Del Fuego and Southernmost Patagonia, South America', Palaeogeography, Palaeoclimatology, Palaeoecology 102(1-2):53-68.

Martial, L.-F. (2005) Mision Al Cabo De Hornos Buenos Aires: Zagier \& Urruty Publications.

Martin, L. and Suguio, K. (1976) (a) Les Variations Du Niveau De La Mer Au Quaternaire Récent Dans Le Sud De L'état De São Paulo (Brésil): Utilisation De "sambaquis" (kjokkenmodings) Dans La Détermination Des Anciennes Lignes De Rivage Holocènes, in Actas Del XLII Congreso Internacional De Americanistas.

Martin, L. and Suguio, K. (1976) (b) O Quaternário Marinho Do Litoral Do Estado De São Paulo, in Anais Do XIX Congrresso Brasileiro De Geologia, Belo Horizonte (MG).

Martin, L., Suguio, K. and Flexor, J. M. (1986) 'Shell Middens as a Source for Additional Information in Holocene Shoreline and Sea-level Reconstruction: Examples from the Coast of Brazil', in O. Van de Plasseche (ed.) Sea-Level Research: AManual for the Collection and Evaluation of Data, pp.503-21. Amsterdam: University of Amsterdam.

Martinho, C. T. (2004) Morfodinâmica e Sedimentología De Campos De Dunas Transgressivas Da Região De Jaguaruna-Imbituba, Santa Catarina. Universidade de São Paulo.

Martinho, C. T. and Giannini, P. C. F. (2001) 'Petrografia e Microscopia Eletrônica De Varredura De Diferentes Geraçoes De Pelaodunas Eólicas Quaternárias Do Morro De Santa Marta, Município De Laguna, SC', Pesquisas em Geociências 28(2):53-66.

De Masi, M. A. (1999) Mobility of Prehistoric Hunther-gatherers on Southern Brazilian Coast, Santa Catarina Island. University of Stanford.

De Masi, M. A. (2001) 'Pescadores Coletores Da Costa Sul Do Brasil', Pesquisas 57

De Masi, M. A. (2007) Análise De Isotopos Estáveis De 13/12C e 15/14N Em Resíduos De Incrustações Carbonizadas De Fundo De Recipientes Cerâmicos Das Terras Altas Do Sul Do Brasil, in Anais Do XIV Congresso Da Sociedade De Arqueologia Brasileira.

Mason, O. K. (1993) 'The Geoarchaeology of Beach Ridges and Cheniers: Studies of Coastal Evolution Using Archaeological Data', Journal of Coastal Research 9(1):126-46.

Massone, M. (1987) 'Los Cazadores Paleoíndios De Tres Arroyos', Anales del Instituto de la Patagonia 17:47-60.

Massone, M. (1996) 'Hombre Temprano y Paleomabientes En La Región De Magallanes. Evaluación Crítica y Perspectivas', Anales del Instituto de la Patagonia 24:81-98.

Matthews, W., French, C. A., Lawrence, T., Cutler, D. F. and Jones, M. K. (1997) 'Microstratigraphic Traces of Site Formation Processes and Human Activities', World Archaeology 29:281-308. 
Mazini, E. (2007) Terra Preta e Concreções Carbonáticas No Sambaqui De Jabuticabeira II: Um Modelo De Evolução Diagenética. Relatório De Iniciaçao Científica PIBIB/CNPq São Paulo.

McCormac, F. G., Hogg, A. G., Blackwell, P. G., Buck, C. E., Higham, T. F. G. and Reimer, P. J. (2004) 'SHCal04 Southern Heisphere Calibration 0-11.0 Cal Kyr BP', Radiocarbon 46(3):1087-92.

Mccutcheon, P. T. (1992) 'Burned Archaeological Bone', in J. K. Stein (ed.) Deciphering a Shell Midden, pp.347-70. San Diego: Plenum Press.

Meehan, B. (1982) Shell Bed to Shell Midden Canberra: Australian Institute of Aboriginal Studies.

Megens, L. (2002) 'Stable Carbon and Radiocarbon Isotope Compositions of Particle Size Fractions to Determine Origins of Sedimentary Organic Matter in an Estuary', Organic Geochemistry 33(8):945-52.

Mello, C. L. (2001) 'Considerções Estratigráficas e Sedimentológicas a Respeito Da Formação Do Sambaqui Manitiba I', Documentos de Trabalho 5:81-91.

Mendonça de Souza, A. (1991) 'História Da Arqueologia Brasileira', Pesquisas 46

Mendonça de Souza, S. (1995) Estresse, Doença e Adaptabilidade. Estudo Comparativo De Dois Grupos Pré-históricos Em Perspectiva Biocultural. Escola Nacional de Saúde Pública.

Menezes, P. (2009) Análise De Fácies e Proveniencia Sedimentar Em Sambaquis Do Litoral Centro-sul De Santa Catarina. Universidade de São Paulo.

Mentz Ribeiro, P. A., Ribeiro, C. T. and Silveira, I. (1977) 'A Ocorrência De Zoólitos No Planalto Meridional, Barros Casals, RS, Brasil', Revista do CEPA 5:5-32.

Meyers, P. (1997) 'Organic Geochemical Proxies of Paleoceanographic, Paleolimnologic, and Paleoclimatic Processes', Organic Geochemistry 27(5-6):213-50.

Meyers, P. and Lallier-Vergés, E. (1999) 'Lacustrine Sedimentary Organic Records of Late Quaternary Paleoclimates', Journal of Paleolimnology 21:345-72.

Mikkelsen, J. H., Langohr, R. and Macphail, R. I. (2007) 'Soilscape and Land-Use Evolution Related to Drift Sand Movements Since the Bronze Age in Eastern Jutland, Denmark', Online 22(2):155-79.

Miller, C. E., Conrad, N., Goldberg, P. and Berna, F. (2010) 'Analyse Micromorphologique De Structures De Combustion Expérimentales Anthropiquement Remaniées’, P@leontologie: Revue biligue de Préhistoire 2:25-37.

Miller, D. E., Yates, R. J., Jerardino, A. and Parkington, J. E. (1995) 'Late Holocene Change in the Southern Cape, South Africa', Science 29(95):3-10.

Milner, N., Barrett, J. and Welsh, J. (2007) 'Marine Resource Intensification in Viking Age Europe: The Molluscan Evidence from Quoygrew, Orkney', Journal of Archaeological Science 34(9): 1461-72.

Miotti, L. (2003) 'Patagonia: a Paradox for Building Images of the First Americans During the Pleistocene/Holocene Transition', Quaternary International 109-110:147-73.

Miotti, L. L. and Salemme, M. (2004) 'Poblamiento , Movilidad y Territorios Entre Las Sociedades Cazadoras-recolectoras De Patagonia Populations in Patagonia', Complutum 15:177-206.

Monti, D., Frenkiel, L. and Moueza, M. (1991) 'Demography and Growth of Anomalocardia Brasiliana (Gmelin) (Bivalvia: Veneridae) in a Mangrove, in Guadeloupe (French West Indies)', Journal of Molluscan Research 57:249-57.

Moreira-Filho, H., Moreira, I. M. V. and Mosimann, R. M. S. (1985) 'Catálogo Das Ditomáceas (Chrysophyta - Bacillariophyceae) Marinhas e Estuarinas Do Estado De Santa Catarina, Brasil', Insula 15:33-88.

Morey, D. F. and Crothers, G. M. (1998) 'Clearing Up Clouded Waters: Palaeoenvironmental Analysis of Freshwater Mussel Assemblages from the Green River Shell Middens, Western Kentucky', Journal of Archaeological Science 25(9):907-26.

Morey, D. F., Crothers, G. M., Stein, J. K., Fenton, J. P. and Herrmann, N. P. (2002) 'The Fluvial and Geomorphic Context of Indian Knoll, an Archaic Shell Midden in WestCentral Kentucky', Geoarchaeology 17(6):521-53. 
Morner, N. A. (1987) 'Sea-level Changes and Tectonics in Tierra Del Fuego', INQUA, Neotectonics Commission Bulletin 10

Morner, N. A. (1991) 'Holocene Sea-level Changes in the Tierra Del Fuego Region', Global Changes in South America during the Quaternary. Publicação especial do Boletim do Instituto de Geociencias (IGc/USP) 8:133-51.

Morris, A. E. L., Stark, J. M. and Gilbert, B. K. (2005) 'Evaluation of Isotopic Fractionation Error on Calculations of Marine-derived Nitrogen in Terrestrial Ecosystems', Canadian Journal of Forensic Research 35:1604-16.

Moss, M. L. (1993) 'Shellfish, Gender, and Status on the Northwest Coast: Reconciling Archeological, Ethnographic, and Ethnohistorical Records of the Tlingit', American Anthropologist 95:631-52.

Muckelroy, K. (1978) Maritime Archaeology Cambridge: Cam.

NACSN (1983) 'North American Stratigraphic Code', American Association of Petroleum Geologists Bulletin 67(5):841-75.

Narchi, W. (1972) 'Comparative Study of the Functional Morphology of Anomalocardia Brasiliana (Gmelin 1791) and Tivela Mactroides (Born, 1778) (Bivalvia, Veneridae)', Bulletin of Marine Science 22:643-70.

Narchi, W. (1976) 'Ciclo Anual Da Gametogênese De Anomalocardia Brasiliana (Gmelin, 1791) (Mollusca Bivalvia)', Bolteim de Zoologia 1:331-50.

Nascimento, D. R. (2010) Evoluçao Sedimentar Holocênica Do Delta Do Rio Tubarão , Estado De Santa Catarina. Universidade de São Paulo.

Needham, S. and Spence, T. (1997) 'Refuse and the Formation of Middens', Antiquity 71:7790.

Nelson, M. C. and Hegmon, M. (2001) 'Abandonment Is Not as It Seems : An Approach to the Relationship Between Site and Regional Abandonment', American Antiquity 66(2):21335 .

Netto, S. a., Domingos, A. M. and Kurtz, M. N. (2012) 'Effects of Artificial Breaching of a Temporarily Open/Closed Estuary on Benthic Macroinvertebrates (Camacho Lagoon, Southern Brazil)', Estuaries and Coasts

Neves, E. G. and Petersen, J. (2006) 'Political Economy and Pre-Columbian Landscape Transformations in Central Amazonia', in Time and Complexity in Historical Ecology, pp.279-310. New York: Columbia University Press.

Neves, W. A. (1988) 'Paleogenética Dos Grupos Pré-históricos Do Litoral Sul Do Brasil (Paraná e Santa Catarina)', Pesquisas 43

Neves, W. A., Hubbe, M., Okumura, M. M., González-José, R., Figuti, L., Eggers, S. and De Blasis, P. (2005) 'A New Early Holocene Human Skeleton from Brazil: Implications for the Settlement of the New World.', Journal of Human Evolutionman evolution 48(4):40314.

Neves, W. A. and Okumura, M. M. M. (2005) 'Afinidades Biológicas De Grupos Pré-históricos Do Vale Do Rio Ribeira De Iguape (SP): Uma Análise Preliminar', Revista de Antropologia 48(2):525-58.

Neves, W. A. and Wesolowski, V. (2002) 'Economy, Nutrition and Disease in Preshitoric Coastal Brazil: a Case Study from the State of Santa Catarina', in R. H. Steckel and J. C. Rose (eds) The Backbone of History, pp.376-402. Cambridge: Cambridge University Press.

Neves, W., Prous, a, Gonzalezjose, R., Kipnis, R. and Powell, J. (2003) 'Early Holocene Human Skeletal Remains from Santana Do Riacho, Brazil: Implications for the Settlement of the New World', Journal of Human Evolution 45(1):19-42.

Nicholson, R. A. (1993) 'A Morphological Investigation of Burnt Animal Bone and an Evaluation of Its Utility in Archaeology', Journal of Archaeological Science 20(4):41128.

Nielsen-Marsh, C., Smith, C., Jans, M., Nord, A., Kars, H. and Collins, M. (2007) 'Bone Diagenesis in the European Holocene II: Taphonomic and Environmental Considerations', Journal of Archaeological Science 34(9):1523-31.

De Niro, M. (1987) 'Stable Isotopy and Archaeology', American Scientist 75:182-91. 
De Niro, M. and Epstein, S. (1978) 'Influence of Diet on the Distribution of Carbon Isotopes in Animals', Geochimica et Cosmochimica Acta 42:495-506.

De Niro, M. J. and Hastrof, C. A. (1985) 'Alteration of 15N/14N and 13C/12C Ratios of Plant Matter During the Initial Stages of Diagenesis: Studies Utilizong Archaeological Specimens from Peru', Geochimica et Cosmochimica Acta 49:97-115.

Nishida, A. K., Maria, R. and Leonel, V. (1995) 'Occurrence, Population Dynamics and Habitat Characterizatlon of Mytella Guyanensis ( Lamarck, 1819 ) ( Mollusca, Bivalvia ) Ln the Paraíba Do Norte River Estuary', Boletim do Instituto Oceanográfico 43(1):41-49.

Nishida, P. (2001) Estudo Zooarqueológico Do Sítio Mar Virado Ubatuba - SP. Universidade de São Paulo.

Nishida, P. (2007) A Coisa Ficou Preta: Estudo Do Processo De Formaçao Da Terra Preta Do Sítio Arqueológico Jabuticabeira II. Universidade de São Paulo.

Noelli, F. S. (1999) 'A Ocupaçao Humana Na Região Sul Do Brasile: Arqueologia, Debates e Perspectivas', Revista da Universidade de São Paulo 44:218-69.

Noelli, F. S. (2000) 'Repensando Os Rótulos e a História Dos Jê No Sul Do Brasil a Partir De Uma Interpretação Interdisciplinar', in L. T. Mota F. S. Noelli and T. S. (eds) Uri e Wãxi Estudos Interdisciplinares Dos Kaingang, pp.9-57. Londrina: Editora Universidade Estadual de Londrina.

Ocampo, C. E. and Rivas, P. H. (2000) 'Nuevos Fechados 14C De La Costa Norte De La Isla Navarino', Anales del Instituto de la Patagonia 28:197-214.

Odin, G. S. (1988) 'Conclusion to the Study of Green Marine Clays', in G. S. Odin (ed.) Green Marine Clays, pp.399-418. Amsterdam: Elsevier.

Odin, G. S. and Fullagar, P. D. (1988) 'Geological Significance of the Glaucony Facies', in G. S. Odin (ed.) Green Marine Clays, pp.337-97. Amsterdam: Elsevier.

Odin, G. S. and Matter, A. (1981) 'De Glauconiarum Origine', Sedimentology 28(5):611-41.

Okumura, M. (2007) Diversidade Morfológica Craniana, Micro-evolução e Ocupação Préhistórica Da Costa Brasileira. Universidade de São Paulo.

Okumura, M. and Eggers, S. (2005) 'Análise Da Exostose Do Meato Auditivo Externo Como Um Marcador De Atividade Aquática Em Restos Esqueletais Humanos Da Costa e Do Interior Do Brasil', Revista do Museu de Arqueologia e Etnologia 15,16:181-97.

Oliveira, M. S. (2000) Os Sambaquis Da Planície Costeira De Joinville, Litoral Norte De Santa Catarina: Geologia, Paleogeografia e Conservação in Situ. Universidade Federal de Santa Catarina.

Orquera, L. (2005) 'Mid-Holocene Littoral Adaptation at the Southern End of South America', Quaternary International 132(1):107-15.

Orquera, L. A. (1996) 'Tunel VII: La Estratigrafía', Treballs d'Etnoarqueologia: Encuentro en los Conchales Fueguinos 3:83-103.

Orquera, L. A. (1999) 'El Consumo De Moluscos Por Los Canoeros Del Extremo Sur', Relaciones de la Sociedad Argentina de Antropología 24:307-27.

Orquera, L. A., Legoupil, D. and Piana, E. L. (2011) 'Littoral Adaptation at the Southern End of South America', Quaternary International 239(1-2):61-69.

Orquera, L. A. and Piana, E. (1996) (a) 'Tunel VII En La Secuencia Arqueológica Del Canal Beagle: Hipótesis y Expectativas De Los Investigadores Argentinos', Treballs d'Etnoarqueologia: Encuentro en los Conchales Fueguinos 3:25-45.

Orquera, L. A. and Piana, E. (1996) (b) 'Tunel VII: La Excavación', Treballs d'Etnoarqueologia: Encuentro en los Conchales Fueguinos 3:47-73.

Orquera, L. A. and Piana, E. L. (1992) 'Un Paso Hacia La Resolucion Del Palimpsesto', in L. A. Borrero and J. L. Lanata (eds) Análisis Espacial En La Arqueología Patagónica, pp.21-52. Buenos Aires: Búsqueda de Ayllu SRL.

Orquera, L. A. and Piana, E. L. (1999) (a) Arqueologia De La Region Del Canal Beagle Buenos Aires: Sociedad Argentina de Antropología.

Orquera, L. A. and Piana, E. L. (1999) (b) La Vida Material y Social De Los Yamana.

Orquera, L. A. and Piana, E. L. (2000) 'Composicion De Conchales De La Costa Del Canal Beagle - Primera Parte', Relaciones de la Sociedad Argentina de Antropología 25:249-74. 
Orquera, L. A. and Piana, E. L. (2001) 'Composicion De Conchales De La Costa Del Canal Beagle - Segunda Parte', Relaciones de la Sociedad Argentina de Antropología 26:34568.

Orquera, L. A. and Piana, E. L. (2006) 'El Poblamiento Inicial Del Area Litoral Sudamericana Sudoccidental', Magallania (Punta Arenas) 34(2):21-36.

Orquera, L. A. and Piana, E. L. (2009) 'Sea Nomads of the Beagle Channel in Southernmost South America: Over Six Thousand Years of Coastal Adaptation and Stability', The Journal of Island and Coastal Archaeology 4(1):61-81.

Orssich, A. S. (1977) 'O Sambaqui Do Araujo I, Nota Previa', Cadernos de Arqueologia 2:160.

Panarello, H., Zangrando, F., Tessone, A., Kozameh, L. and Testa, N. (2006) 'Análisis Comparativo De Paleodietas Humanas Entre La Región Del Canal Beagle Y Península Mitre: Perspectivas Desde Los Isótopos Estables', Magallania (Punta Arenas) 34(2):1-18.

Parker Pearson, M. and Richards, C. (1994) 'Ordering the World: Perceptions of Architecture, Space and Time', in M. Parker Pearson and C. Richards (eds) Architecture and Order: Approaches to Social Space, pp.1-37. London: Routledge.

Paula, J. M. de (1924) Memória Sobre Os Botocudos Do Paraná e Santa Catarina Organizado Pelo Serviço De Proteção Aos Índios Sob a Inspeção Do Dr. José M. De Paula, in Anais Do XX Congresso Internacional De Americanistas. (Rio De Janeiro 1922).

Peixoto, S. (2008) Pequenos Aos Montes: Uma Análise Dos Processos De Formação Dos Sambaquis De Pequeno Porte Do Litoral Sul De Santa Catarina. Universidade Federal do Rio de Janeiro.

Perreti, G. (2009) Sambaquis Da Barreira Da Itapeva. Uma Perspectiva Geoarqueológica.

Petronilho, C. C. (2005) Comprometimento Articular Como Um Marcador De Atividade Em Um Grande Sambaqui Cemitério. Universidade de São Paulo.

Petrykowski, S., De Mello, J. and Bandeira, D. (2007) 'Paleoetnobotânica Dos Macrorestos Vegetais Do Tipo Trançados De Fibras Encontrados No Sambaqui Cubatão I, Joinville SC', Revista do Museu de Arqueologia e Etnologia 17:211-22.

Phillips, D. H. and Fitzpatrick, E. A. (2008) 'Biological Influences on the Morphology and Micromorphology of Selected Podzols (Spodosols) and Cambisols (Inceptisols) from the Eastern United States and North-east Scotland', Geoderma 90:327-64.

Piana, E. L., Estevez, J. and Vila, A. (2000) 'Lanashuaia: Un Sitio De Canoeros Del Siglo Pasado En La Costa Norte Del Canal Beagle', in Desde El País De Los Gigantes: Perspectivas Arqueológicas En Patagonia, Rio Gallegos: Universidad Nacional de la Patagonia Austral.

Piana, E. L. and Orquera, L. A. (2009) 'The Southern Top of the World: The First Peopling of Patagonia and Tierra Del Fuego and the Cultural Endurance of the Fuegian Sea-Nomads', Arctic Anthropology 46(1-2):103-17.

Piana, E., Tessone, A. and Zangrando, F. (2006) 'Contextos Mortuorios En La Región Del Canal Beagle... Del Hallazgo Fortuito a La Búsqueda Sistemática', Magallania (Punta Arenas) 34(1):103-17.

Piana, E., Vazquez, M. M., Alvarez, M. and Rua, N. (2007) Ajej I: Excavación De Rescate En La Costa Del Canal Beagle, in Arqueología Argentina En Los Inicios. Publicación Del XIV Congreso Nacional De Arqueología Argentina.

Piana, L. A. and Vazquez, M. (2009) 'Arqueología De Rescate En El Canal Beagle', in M. Salemme F. Santiago M. Álvarez E. Piana M. Vázquez and M. E. Mansur (eds) Arqueología De La Patagonia - Una Mirada Desde El Último Confín, pp.455-68. Ushuaia: Editorial Utopías.

Piana, L. E., Vazquez, M. and Alvarez, M. (2008) 'Nuevos Resultados Del Estudio Del Sitio Ajej I: Un Aporte a La Variabilidad De Estrategias De Los Canoeros Fueguinos', Runa 29:101-21.

Piazza, W. (1982) A Colonização De Santa Catarina Porto Alegre: Palloti.

Piazza, W. and Prous, A. (1979) Documents Pour La Préhistoire Du Brésil Méridional 2 : L ' État De Santa Catarina Paris: EHESS. 
Piepenbrink, H. (1989) 'Examples of Chemical Changes During Fossilisation', Applied Geochemistry 4(3):273-80.

Piqué, R. (1999) 'Producción y Uso Del Combustible Vegetal: Una Evaluación Arqueológica', Treballs d'Etnoarqueologia: Encuentro en los Conchales Fueguinos:1-307.

Piqué, R. (2006) 'El Uso De La Madera Entre Las Sociedades Fueguinas: Los Artefactos De Las Colecciones Etnográficas Del Museo Luigi Pigorini’, in Finis Térrea. Viaggiatori, Esploratori e Missionari Italiani Nella Terra Del Fuoco, pp.182-92.

Pitblado, B. L. (2011) 'A Tale of Two Migrations: Reconciling Recent Biological and Archaeological Evidence for the Pleistocene Peopling of the Americas', Journal of Archaeological Research

Plens, C. R. (2007) Sítio Moraes, Uma Biografia Não Autorizada: Análise Do Processo De Formaçao De Um Sambaqui Fluvial. Universidade de São Paulo.

Ploetz, H. and Métraux, A. (1930) 'La Civilizatíon Matérialle Et La Vie Sociale Et Religieuse Des Indiens Ze Du Brésil Méridional Et Oiental', Revista do Instituto de Etnologia de la Universidade de Tucuman 1

Porter, S. (1984) 'Holocene Sea-level Changes Along the Strait of Magellan and Beagle Channel, Southernmost South America', Quaternary Research 22(1):59-67.

Prous, A. (1974) 'Les Sculptures Préhistoriques Du Sud-Brésilien', Bulletin de la Société préhistorique française 71(7):210-17.

Prous, A. (1992) Arqueologia Brasileira Brasilia: Universidade de Brasilia.

Rabassa, J., Coronato, A., Bujalesky, G., Salemme, M., Roig, C., Meglioli, A., Heusser, C., Gordillo, S., Roig, F., Borromei, A. and Quattrochio, M. (2000) 'Quaternary of Tierra Del Fuego, Southernmost South America: An Updated Review', Quaternary International 6871(1):217-40.

Rabassa, J., Heusser, C. J. and Stuckenrath, R. (1986) 'New Data on Holocene Sea Transgression in the Beagle Channel: Tierra Del Fuego, Argentina', Quaternary of South America and Antarctic Peninsula 4:291-309.

Ramos, J., Bernal, D., Dominguezbella, S., Calado, D., Ruiz, B., Gil, M., Clemente, I., Duran, J., Vijande, E. and Chamorro, S. (2008) 'The Benzú Rockshelter: a Middle Palaeolithic Site on the North African Coast', Quaternary Science Reviews 27(23-24):2210-18.

Rauth, J. W. (1963) Notas Arqueológicas Sôbre Uma Formação De Um Sambaqui Na Ilha Das Cóbras. Paranaguá Paranaguá: Faculdade Estadual de Filosofia, Ciência e Letras.

Raven, J. A., Griffiths, H., Smith, E. C. and Vaughn, K. C. (1998) 'New Perspectives in the Biophysics and Physiology of Bryophytes', in J. W. Bates N. W. Ashton and J. G. Duckett (eds) Bryology in the Twenty-first Century, pp.261-75. London: Maney Publishing and the British Bryological Society.

Reis, M. J. (1980) A Problemática Arqueológica Das Estruturas Subterrâneas No Planalto Catarinense. Universidade de São Paulo.

Reitz, E. J. (1988) 'Faunal Remains from Paloma, an Archaic Site in Peru', American Anthropologist 90(2):310-22.

Ren, F., Wan, X., Ma, Z. and Su, J. (2009) 'Study on Microstructure and Thermodynamics of Nacre in Mussel Shell', Materials Chemistry and Physics 114(1):367-70.

Richards, M. P. and Hedges, R. E. M. (1999) 'Stable Isotope Evidence for Similarities in the Types of Marine Foods Used by Late Mesolithic Humans at Sites Along the Atlantic Coast of Europe', Journal of Archaeological Science 26(6):717-22.

Rick, T. C. (2002) 'Eolian Processes, Ground Cover, and the Archaeology of Coastal Dunes: A Taphonomic Case Study from San Miguel Island, California, U.S.A.', Geoarchaeology 17(8):811-33.

Rick, T. C., Erlandson, J. M. and Vellanoweth, R. L. (2001) 'Paleocoastal Marine Fishing on the Pacific Coast of the Americas : Perspectives from Daisy Cave, California', American Antiquity 66(4):595-613.

Rick, T., Vellanoweth, R. and Erlandson, J. (2005) 'Radiocarbon Dating and the "old Shell" Problem: Direct Dating of Artifacts and Cultural Chronologies in Coastal and Other Aquatic Regions', Journal of Archaeological Science 32(11):1641-48. 
Rios, E. C. (1985) Seashells of Brazil Rio Grande: Fundação Cidade do Rio Grande, Fundação Universidade do Rio Grande, Museu Oceanográfico.

Rivas, P. H., Ocampo, C. E. and Aspillaga, E. (1999) 'Poblamiento Temprano De Los Canales Patagónicos: El Núcleo Ecotonal Septentrional.', Anales del Instituto de la Patagonia 27:221-30.

Rodrigues, S. I. (2009) Contribuições Dos Métodos GPR e Eletromagnético Indutivo Em Estudos De Sitios Arqueológicos De Sambaquis Costeiros No Estado De Santa Catarina. Universidade de São Paulo.

Rodrigues, S. I., Porsani, J. L., Santos, V. R. N., DeBlasis, P. A. D. and Giannini, P. C. F. (2009) 'GPR and Inductive Electromagnetic Surveys Applied in Three Coastal Sambaqui (shell Mounds) Archaeological Sites in Santa Catarina State, South Brazil', Journal of Archaeological Science 36(10):2081-88.

Rodrigues-Carvalho, C. (2003) Marcadores De Estresse Ocupacional Em Populaces Sambaquieiras No Litoral Fluminense. Escola Nacional de Saúde Pública.

Rohr, P. J. A. (1969) 'Os Sítios Arqueológicos Do Município Sul-catarinense De Jaguaruna', Pesquisas 22:1-39.

Rohr, P. J. A. (1971) 'Os Sítios Arqueológicos Do Planalto Catarinense', Pesquisas 24:1-56.

Rohr, P. J. A. (1972) 'A Pesquisa Arqueológica No Estado De Santa Catarina', Dédalo 16:4965.

Rohr, P. J. A. (1984) 'Sítios Arqueológicos De Santa Catarina', Anais do Museu de Antropologia 17:77-168.

Roosevelt, A. C. (1991) 'Eight Millenium Pottery from a Prehistoric Shell Midden in the Brazillian Amazon', Science 254(5038):1621-22.

Rosendahl, D., Ulm, S. and Weisler, M. (2007) 'Using Foraminifera to Distinguish Between Natural and Cultural Shell Deposits in Coastal Eastern Australia', Journal of Archaeological Science 34(10):1584-93.

Rothhammer, F. and Dillehay, T. D. (2009) 'The Late Pleistocene Colonization of South America: An Interdisciplinary Perspective.', Annals of human genetics 73(Pt 5):540-49.

Rowland, M. (1994) 'Size Isn't Everything: Shell Mounds, Middens and Natural Deposits', Australian Archaeology 39:118-24.

Rudwick, M. J. (1976) The Meaning of Fossils New York: Neale Watson Academic Publications.

Rundel, P. W. (1980) 'The Ecological Distribution of C4 and C3 Grasses in the Hawaiian Islands', Oecologia 45(3):354-59.

Russo, M. (2004) 'Measuring Shell Rings for Social Inequality', in J. L. Gibson and P. J. Carr (eds) Signs of Power: The Rise of Cultural Complexity in the Southeast, pp.26-70. Tuscaloosa: University of Alabama Press.

Salemme, M. and Miotti, L. (2008) 'Archeological Hunter-Gatherer Landscapes Since the Latest Pleistocene in Fuego-Patagonia', Developments in Quaternary Science 11:437-83.

San Roman, M., Salas, K. and Fontugne, M. (2009) 'Primeros Avances En La Reconstrucción De Secuencias De Ocupación De Cazadores Recolectores Marinos Em El Estrecho De Magallanes, Patagonia Meridional', in M. Salemme F. Santiago M. Alvarez E. Piana and E. Mansur (eds) Arqueologia De La Patagonia: Una Mirada Desde El Último Confin, pp.35-45. Ushuaia: Editorial Utopías.

Sandweiss, D. H. (1996) 'Geoarchaeological Evidence from Peru for a 5000 Yrs BP Onset of El Niño’, Science 273(5281):1531-32.

Sandweiss, D. H. (2003) 'Terminal Pleistocene Through Mid-Holocene Archaeological Sites as Paleoclimatic Archives for the Peruvian Coast', Palaeogeography, Palaeoclimatology, Palaeoecology 194(1-3):23-40.

Santana, C. C. S. (2007) Sambaquis Perilagunares Da Zona Costeira De Conde, Bahía. Universidade Federal da Bahía.

Santana, C. C. S., Dominguez, J. M. L. and Gaspar, M. D. (2003) A Aplicação Da Geologia Evolutiva Nas Pesquisas Sobre Sambaquis Na Bahia, in Anais Do XII Congresso Nacional De Arqueologia Brasileira, São Paulo. 
Santos, S. C. dos (1973) Índios e Brancos No Sul Do Brasil - a Dramática Experiência Dos Xokleng Florianópolis: Edeme.

Santos, V. R. N., Porsani, J. L., Mendonça, C. A., Rodrigues, S. I. and DeBlasis, P. D. (2009) 'Reduction of Topography Effect in Inductive Electromagnetic Profiles: Application on Coastal Sambaqui (shell Mound) Archaeological Site in Santa Catarina State, Brazil', Journal of Archaeological Science 36(10):2089-95.

Sauer, D., Sponagel, H., Sommer, M., Giani, L., Jahn, R. and Stahr, K. (2007) 'Podzol: Soil of the Year 2007. A Review on Its Genesis, Occurrence, and Functions', Journal of Plant Nutrition and Soil Science 170(5):581-97.

Sawakuchi, A. O. (2003) Sistemas Deposicionais Eólicos Quaternários Na Costa Centro-sul Catarinense: Relações Com o Nível Do Mar. Universidade de São Paulo.

Schaan, D. (2010) 'Long-Term Human Induced Impacts on Marajó Island Landscapes, Amazon Estuary', Diversity 2(2):182-206.

Schaan, D. P. (2008) 'The Nonagricultural Chiefdoms of Marajó Island', in H. Silverman and W. Isbell (eds) Handbook of South American Archaeology, pp.339-57. New York: Springer.

Schaefer, C. E. G. R., Lima, H. N., Gilkes, R. J. and Mello, J. W. V. (2004) 'Micromorphology and Electron Microprobe Analysis of Phosphorus and Potassium Forms of an Indian Black Earth (IBE) Anthrosol from Western Amazonia', Australian Journal of Soil Research 42(4):401-9.

Schaeffer-Novelli, Y. (1976) Alguns Aspectos Ecológicos e Análise Da População De Anomalocardia Brasiliana (Gmelin 1791) Mollusca-Bivalvia, Na Praia Do Saco Da Riberia, Ubatuba, Estado De São Paulo. Universidade de São Paulo.

Scheel-Ybert, R. (2000) 'Vegetation Stability in the Southeastern Brazilian Coastal Area from 5500 to 1400 14C Yr BP Deduced from Charcoal Analysis.', Review of palaeobotany and palynology 110(1-2):111-38.

Scheel-Ybert, R. (2001) 'Man and Vegetation in Southeastern Brazil During the Late Holocene', Journal of Archaeological Science 28(5):471-80.

Scheel-Ybert, R., Bianchini, G. and DeBlasis, P. (2009) 'Registro De Mangue Em Um Sambaqui De Pequeno Porte Do Litoral Sul De Santa Catarina, Brasil, a Cerca De 4900 Anos Cal BP, e Considerações Sobre o Processo De Ocupação Do Sítio Encantada-III', Revista do Museu de Arqueologia e Etnologia 19:103-18.

Scheel-Ybert, R., Eggers, S., Wesolowski, V., Petronilho, C. C., Boyadjian, C. H., Deblasis, P., Barbosa, M. and Gaspar, M. D. (2003) 'Novas Perspectivas Na Reconstituição Do Modo De Vida Dos Sambaquieiros : Uma Abordagem Multidisciplinar', Revista de Arqueologia SAB 16:109-37.

Scheel-Ybert, R., Klökler, D., Gaspar, M. D. and Figuti, L. (2005) 'Proposta De Amostragem Padronizada Para Macro-vestígios Bioarqueológicos: Antracologia, Arqueobotânica, Zooarqueologia', Revista do Museu de Arqueologia e Etnologia 15-16:139-63.

Scherer, L. Z., Rodrigues-Carvalho, C. and Schmitz, P. I. (2006) 'Marcadores De Estresse Musculo-esquelético Em Populaces Pescadoras, Caçadoras e Coletaroas Do Litoral Central De Santa Catarina', Pesquisas 63:55-80.

Schiavini, A. (1993) 'Los Lobos Marinos Como Recurso Para Cazadores-recolectores Marinos: El Caso De Tierra Del Fuego', Latin American Antiquity 4:346-66.

Schiegl, S. (1996) 'Ash Deposits in Hayonim and Kebara Caves, Israel: Macroscopic, Microscopic and Mineralogical Observations, and Their Archaeological Implications', Journal of Archaeological Science 23(5):763-81.

Schiegl, S., Goldberg, P., Pfretzschner, H.-U. and Conard, N. J. (2003) 'Paleolithic Burnt Bone Horizons from the Swabian Jura: Distinguishing Betweenin Situ Fireplaces and Dumping Areas', Geoarchaeology 18(5):541-65.

Schiegl, S., Lev-Yadun, S., Bar-Yosef, O., El Goresy, A. and Weiner, S. (1994) 'Siliceous Aggregates from Prehistoric Wood Ash: a Major Component of Sediments in Kebara and Hayonim Caves (Israel)', Israel Journal of Earth Sciences 43:267-78.

Schiffer, M. (1972) 'Archaeological Context \& Systemic Context', American Antiquity $37(2): 156-65$. 
Schiffer, M. (1983) 'Toward the Identification of Formation Processes', American Antiquity 48(4):675-706.

Schimmel, P. B., Porsani, J. L., Figuti, L. and DeBlasis, P. (2002) 'Aplicação De Métodos Geofísicos Em Arqueologia: Primeiros Resultados Obtidos No Sambaqui Fluvial Capelinha, Cajati-SP, Brasil', Revista do Museu de Arqueologia e Etnologia 12:43-54.

Schmidt, M. J. and Heckenberger, M. J. J. (2009) 'Amerindian Anthrosols: Amazonian Dark Earth Formation in the Upper Xingu', in W. I. Woods W. G. Teixeira J. Lehmann C. Steiner A. WinklerPrins and L. Rebellato (eds) Amazonian Dark Earths: Wim Sombroek's Vision, pp.163-91. Berlin: Springer Science, Business Media B.V.

Schmidt, M. W. and Noack, A. G. (2000) 'Black Carbon in Soils and Sediments: Analyses, Distribution, Implications, and Current Challenges', Global Biochemical Cycles 14(3):777-93.

Schmitz, P. I. (1981) 'Contribuciones a La Prehistória De Brasil', Pesquisa 32

Schmitz, P. I. (1984) Caçadores e Coletores Da Pré-histórica Do Brasil São Leopoldo: Instituto Anchietano de Pesquisas.

Schmitz, P. I. (1988) 'As Tradições Ceramistas Do Planalto Sul-brasileiro', Documentos 2:75130.

Schmitz, P. I. (1999) 'Cerâmica Taquara e Itararé Em Concheiros', Revista do CEPA 23(29): 177-79.

Schmitz, P. I. and Becker, I. B. (1991) 'Os Primitivos Engenheiros Do Planalto e Suas Estruturas Subterrâneas: a Tradição Taquara’, Documentos 5:67-106.

Schmitz, P. I., Becker, I. B., La Salvia, F., Lazzarotto, D. and Mentz Ribeiro, P. A. (1988) 'Pesquisas Sobra a Tradição Taquara No Nordeste Do Rio Grande Do Sul', Documentos 2:5-74.

Schmitz, P. I. and Bittencourt, A. L. V. (1996) 'O Sítio Arqueológico Do Pântano Do Sul, S.C.', Pesquisas 53:77-124.

Schmitz, P. I., De Masi, M. A., Verardi, I., Lavina, R. and Jacobus, A. L. (1992) 'Escavações Arqueológicas Do Pe. João Alfredo Rohr, S.J. O Sítio Arqueológico Da Armação Do Sul', Pesquisas 48

Schmitz, P. I., De Masi, M. A., Verardi, I., Lavina, R. and Jacobus, A. L. (1993) 'Escavações Arqueológicas Do Pe. João Alfredo Rohr, S.J. O Sítio Arqueológico Praia Das Laranjeiras II, Uma Aldeia De Tradição Ceramista Itararé', Pesquisas 49

Schmitz, P. I. P. I. (1996) 'Visão De Conjunto Dos Sítios Da Tapera, Armação Do Sul, Laranjeiras I e II, Pântano Do Sul e Cabeçudas', Pesquisas 53:183-90.

Schoeller, D. A. (1999) 'Isotope Fractionation : Why Aren' $t$ We What We Eat ?', Journal of Archaeological Science 26:667-73.

Schoeninger, M. J. and De Niro, M. (1984) 'Nitrogen and Carbon Isotopic Composition of Bone Collagen from Marine and Terrestrial Animals', Geochimica et Cosmochimica Acta 48:625-39.

Schoeninger, M., Moore, K., Murray, M. and Kingston, J. (1989) 'Detection of Bone Preservation in Archaeological and Fossil Samples', Applied Geochemistry 4(3):281-92.

Van der Schriek, T., Passmore, D. G., Franco, F., Stevenson, A. C., Boomer, I. and Rola, J. (2008) 'Holocene Palaeoecology and Floodplain Evolution of the Muge Tributary, Lower Tagus Basin, Portugal', Quaternary International 189:135-51.

Van der Schriek, T., Passmore, D. G., Stevenson, a. C. and Rolao, J. (2007) 'The Palaeogeography of Mesolithic Settlement-subsistence and Shell Midden Formation in the Muge Valley, Lower Tagus Basin, Portugal', The Holocene 17(3):369-85.

Segers, P. A. (1908) 'Primera Observación De Una Causa Nueva De Enfermedad Del Hígado Causando Una Hipertrofia y Cirrhosis Atrófica Consecutives, Por Excesividad Functional Debida a Absorción De Toxinas, y Primera Observación De Esplenomegalia Concomitante Con Hipertrofia Del ', Semana Médica XV:1117-20.

Serrano, A. (1938) 'Los Sambaquis o Concheros Brasileños', Revista del Instituto de Antropología de la Universidad Nacional de Tucumán 1(3):43-89. 
Serrano, A. (1946) 'The Sambaquis of the Brazilian Coast', in J. Steward (ed.) Handbook of South American Indians: Volume 1, the Marginal Tribes, pp.401-8. Washington: Smithsonian Institution.

Shahack-Gross, R. (1997) 'Black-Coloured Bones in Hayonim Cave, Israel: Differentiating Between Burning and Oxide Staining', Journal of Archaeological Science 24(5):439-46.

Shahack-Gross, R. (2003) 'Geo-Ethnoarchaeology of Pastoral Sites: The Identification of Livestock Enclosures in Abandoned Maasai Settlements', Journal of Archaeological Science 30(4):439-59.

Shahack-Gross, R. (2004) 'Reconstruction of Spatial Organization in Abandoned Maasai Settlements: Implications for Site Structure in the Pastoral Neolithic of East Africa', Journal of Archaeological Science 31(10):1395-1411.

Shahack-Gross, R. (2011) 'Herbivorous Livestock Dung: Formation, Taphonomy, Methods for Identification, and Archaeological Significance', Journal of Archaeological Science 38(2):205-18.

Shahack-Gross, R. and Finkelstein, I. (2008) 'Subsistence Practices in an Arid Environment: a Geoarchaeological Investigation in an Iron Age Site, the Negev Highlands, Israel', Journal of Archaeological Science 35(4):965-82.

Shahack-Gross, R., Simons, A. and Ambrose, S. H. (2008) 'Identification of Pastoral Sites Using Stable Nitrogen and Carbon Isotopes from Bulk Sediment Samples: a Case Study in Modern and Archaeological Pastoral Settlements in Kenya', Journal of Archaeological Science 35(4):983-90.

Shahackgross, R., Berna, F., Karkanas, P. and Weiner, S. (2004) 'Bat Guano and Preservation of Archaeological Remains in Cave Sites', Journal of Archaeological Science 31(9):125972.

Sherwood, S. C. and Kidder, T. R. (2011) 'The DaVincis of Dirt: Geoarchaeological Perspectives on Native American Mound Building in the Mississippi River Basin', Journal of Anthropological Archaeology 30(1):69-87.

Shillito, L.-M., Bull, I. D., Matthews, W., Almond, M. J., Williams, J. M. and Evershed, R. P. (2011) 'Biomolecular and Micromorphological Analysis of Suspected Faecal Deposits at Neolithic Çatalhöyük, Turkey’, Journal of Archaeological Science 38(8):1869-77.

Shipman, P., Foster, G. and Schoeninger, M. (1984) 'Burnt Bones and Teeth: An Experimental Study of Color, Morphology, Crystal Structure and Shrinkage', Journal of Archaeological Science 2:307-25.

Sifeddine, A., Wirrmann, D., Albuquerque, a, Turcq, B., Cordeiro, R., Gurgel, M. and Abrao, J. (2004) 'Bulk Composition of Sedimentary Organic Matter Used in Palaeoenvironmental Reconstructions: Examples from the Tropical Belt of South America and Africa', Palaeogeography, Palaeoclimatology, Palaeoecology 214(1-2):41-53.

Silva, C. C. (2000) Herança Geológica Como Ferramenta Para a Prospecção De Sambaquis No Litoral Norte Do Estado Da Bahia: o Exemplo Do Sambaqui Ilha Das Ostras. Universidade Federal da Bahía.

Silva, S. B., Schmitz, P. I., Rogge, J., De Masi, M. A., Jacobus, A. L. and Batista da Silva, S. (1990) 'Escavações Arqueológicas Do Pe. João Rohr - O Sítio Arqueológico Da Praia Da Tapera: Um Assentamento Itararé e Tupiguarani', Pesquisas 45

Simpson, I. (1996) 'Interpretation of Midden Formation Processes at Robert's Haven, Caithness, Scotland Using Thin Section Micromorphology', Journal of Archaeological Science 23(4):543-56.

Simpson, I., Perdikaris, S., Cook, G., Campbell, J. and Teesdale, W. J. (2000) 'Cultural Sediment Analyses and Transitions in Early Fishing Activity at Langenesvaeret, Vesteralen, Northern Norway', Geoarchaeology 15(8):743-63.

Simões, M. (1975) Contribuiçoes Do Museu Paraense Emílio Goeldi à Arqueologia Da Amazonia Belém: Museu Paraense Emílio Goeldi.

Skjemstad, J., Fitzpatrick, R., Zarcinas, B. and Thompson, C. (1992) 'Genesis of Podzols on Coastal Dunes in Southern Queensland .II. Geochemistry and Forms of Elements as Deduced from Various Soil Extraction Procedures', Australian Journal of Soil Research 30(5):615. 
Skrzypek, G., Kaluzny, a, Wojtun, B. and Jedrysek, M. (2007) (a) 'The Carbon Stable Isotopic Composition of Mosses: A Record of Temperature Variation', Organic Geochemistry 38(10): 1770-81.

Skrzypek, G., Kałuzny, A. and Jedrysek, M. O. (2007) (b) 'Carbon Stable Isotope Analyses of Mosses--comparisons of Bulk Organic Matter and Extracted Nitrocellulose.', Journal of the American Society for Mass Spectrometry 18(8):1453-58.

Smith, C., Nielsenmarsh, C., Jans, M. and Collins, M. (2007) 'Bone Diagenesis in the European Holocene I: Patterns and Mechanisms', Journal of Archaeological Science 34(9):1485-93.

Soil-Survey-Staff (1998) Keys to Soil Taxonomy Washington: USDA-NRSC.

De Souza Falcão, P. N., Comerford, N. and Lehmann, J. (2003) 'Determining Nutrient Bioavailability of Amazonian Dark Earth Soils: Methodological Challenges', in J. Lehmann D. Kern B. Glaser and B. Woods (eds) Amazonian Dark Earths: Origin, Properties, Management, pp.255-70. Netherlands: Kluwer Academic Publishers.

de Souza, R. C. C. L., Lima, T. A. and da Silva, E. (2011) Conchas Marinhas De Sambaquis Do Brasil Rio de Janeiro: Technical Books.

Spears, J. R. (1895) The Gold Diggins of Cape Horn (a Study of Life in Tierra Del Fuego and Patagonia) New York, London: G. P. Putnam's Sons.

Spegazzini, C. (1882) 'Costumbres De Los Habitantes De La Tierra Del Fuego', Anales de la Sociedad Cientifica Argentina XIV:159-151.

Spencer, D. W. (1963) 'The Interpretation of Grain Size Distributions Curves of Clastic Sediments', Journal of Sedimentary Petrology 33:180-90.

Stambuk, P. (1986) Rosa Yagán (el Último Eslabón) Santiago: Editorial Andrés Bello.

Steager, P. W. (1965) 'The Yaghan and Alacaluf: An Ecological Description', The Kroeber Anthropological Society Papers 32:69-76.

Stein, J. (2003) 'Big Sites-Short Time: Accumulation Rates in Archaeological Sites', Journal of Archaeological Science 30(3):297-316.

Stein, J. K. (1985) 'Interpreting Sediments in Cultural Settings', in J. Stein and W. Farrand (eds) Archaeological Sediments in Context, Orono: University of Main.

Stein, J. K. (1987) 'Deposits for Archaeologists.', Advances in Archaeological Method and Theory 11:337-95.

Stein, J. K. (1992) (a) Deciphering a Shell Midden New York: Academic Press.

Stein, J. K. (1992) (b) 'Interpreting Stratification of a Shell Midden', in J. K. Stein (ed.) Deciphering a Shell Midden, pp.71-93. San Diego: Academic Press.

Stein, J. K. (1992) (c) 'Sediment Analysis of the British Camp Shell Midden', in J. K. Stein (ed.) Deciphering a Shell Midden, pp.135-62. San Diego: Academic Press.

Stein, J. K. (1992) (d) 'The Analysis of Shell Middens', in J. K. Stein (ed.) Deciphering a Shell Midden, pp.1-24. San Diego: Academic Press.

Stein, J. K. (1996) 'Geoarchaeology and Archaeoestratigraphy: View from a Northwest Coast Shell Midden', in E. J. Reitz L. A. Newsom and S. J. Scudder (eds) Case Studies in Environmental Archaeology, pp.35-52. New York: Plenum Press.

Stein, J. K. and Farrand, W. (1985) 'Context and Geoarchaeology: An Introduction', in J. K. Stein and W. Farrand (eds) Archaeological Sediments in Context, pp.1-3. Orono: University of Maine.

Stein, J. K., Kornbacher, K. D. and Tyler, J. L. (1992) 'British Camp Shell Midden Stratigraphy', in J. K. Stein (ed.) Deciphering a Shell Midden, pp.92-134. San Diego: Academic Press.

Steiner, M. C., Weiner, S. and Bar-Yosef, O. (1995) 'Differential Burning and Fragmentation of Archaeological Bone', Journal of Archaeological Science 22:223-37.

Steward, J. ed. (1946) Handbook of South American Indians Washington DC: Smithsonian Institution.

Stewart, A. M., Keith, D. and Scottie, J. (2004) 'Caribou Crossings and Cultural Meanings: Placing Traditional Knowledge and Archaeology in Context in an Inuit Landscape', Journal of Archaeological Method and Theory 11(2):183-211. 
Stiner, M. C., Bicho, N. F., Lindly, J. and Ferring, R. (2003) 'Mesolithic to Neolithic Transitions: New Results from Shell Middens in the Western Algavre, Portugual', Antiquity 77:75-86.

Stiner, M., Munro, N., Surovell, T., Tchernov, E. and Bar-Yosef, O. (1999) 'Paleolithic Population Growth Pulses Evidenced by Small Animal Exploitation', Science 283(5399):190-94.

Stone, T. (1995) 'Shell Mound Formation in Coastal Northern Australia', Science 129:77-100.

Stoops, G. (2003) Guidelines for Analysis and Description of Soil and Regolith Thin Sections Madison: Soil Science Society of America.

Storto, C., Eggers, S. and Lahr, M. (1999) 'Estudo Preliminar Das Paleopatologias Da População Do Sambaqui Jabuticabeira II, Jaguaruna, SC', Revista do Museu de Arqueologia e Etnologia 9:61-71.

Stuiver, M. and Reimer, P. (1993) 'Extended 14C Database and Revised CALIB Radiocarbon Calibration Program', Radiocarbon 35(1):215-30.

Stutzer, A. (1998) 'Early Stages of Podzolisation in Young Aeolian Sediments, Western Jutland', Catena 32:115-29.

Suguio, K. (1993) 'Relationship Between Shell Middens and Nelithic Paleoshorelines with Examples from Brazil and Japan', Revista do Museu de Arqueologia e Etnologia 3:55-65.

Suguio, K., Martin, L. and Flexor, J. M. (1976) 'Les Variations Relatives Du Niveau Moyen De La Mer Au Quaternaire Récent Dans La Région De Cananéia-Iguape, São Paulo', Boletim do Instituto Geológico 7:113-27.

Suguio, K., Martin, L. and Flexor, J. M. (1992) 'Paleoshorelines and the Sambaquis of Brazil', in L. L. Johnson and M. Stright (eds) Paleoshorelines and Prehistory, pp.83-99. Boca Raton: CRC Press.

Sullivan, M. and Connor, S. O. (1993) 'Middens and Cheniers: Implications of Australian Research', Australian Archaeology 67:776-81.

Szabó, K. and Amesbury, J. R. (2011) 'Molluscs in a World of Islands: The Use of Shellfish as a Food Resource in the Tropical Island Asia-Pacific Region', Quaternary International 239(1-2):8-18.

Tanaka, A. P. B. (2007) Evoluçao Sedimentar Da Planície Retrobarreira De Campos Verdes (Laguna, SC) e Os Sambaquis De Carniça São Leopoldo.

Tanaka, A. P. B. (2010) Sedimentologia, Cronologia e Dinâmica Progradacional Das Planícies Costeiras De Campos Verdes e Ji (Laguna, SC). Universidade de São Paulo.

Tanaka, A. P. B., Giannini, P. C. F. and Fornari, M. (2009) 'A Planície Costeira Holocênica De Campos Verdes ( Laguna, SC ): Evolução Sedimentar Inferida a Partir De Georradar ( GPR ), Granulometria e Minerais Pesados', 39(4):750-66.

Taulé, M. (1996) 'Primeros Trabajos Micromorfológicos Em Concheros De La Cosa Del Canal Beagle (Tierra Del Fuego, Argentina)', Treballs d'Etnoarqueologia: Encuentro en los Conchales Fueguinos 3:113-26.

Tenório, M. C. (2003) Dinâmica De Ocupação Pré-histórica No Litoral Brasileiro. Universidade Católica do Rio Grande do Sul.

Tenório, M. C. (2004) 'Identidade Cultural e Origem Dos Sambaquis', Revista do Museu de Arqueologia e Etnologia 14:169-78.

Tenório, M. C., Afonso, M. C., Canabarro, D., Pinto, D., Gonzalez, M.M.B. Amenomori, S. N. and Angulo, R. J. (2005) O Sítio Ou Os Sítios Da Ilha Do Cabo Frio: Primeiros Resultados, in Anais Do XIII Congresso Da Sociedade De Arqueologia Brasileira, Campo Grande.

Tenório, M. C., Pinto, D. and Afonso, M. C. (2008) 'Dinâmica De Ocupação, Contatos e Trocas No Litoral Do Rio De Janeiro No Período De 4000 a 2000 Anos Antes Do Presente', Arquivos do Museu Nacional 66(2):311-21.

Thery-Parisot, I. (2002) 'Fuel Management (bone and Wood) During the Lower Aurignacian in the Pataud Rock Shelter (Lower Palaeolithic, Les Eyzies De Tayac, Dordogne, France). Contribution of Experimentation', Journal of Archaeological Science 29:1415-21.

Tiburtius, G. (1966) 'O Sambaqui Da Conquista (NR-9)', Bolteim Paranaense de Geografia 18,19:71-126. 
Tiburtius, G. (1996) ‘A Coleção De Guilherme Tiburtius', in Arquivos De Guilherme Tiburtius I, pp.13-28. Joinville: Fundação Cultural de Joinville, Museu Arqueológico de Sambaqui de Joinville.

Tiburtius, G., Bigarella, I. K. and Bigarella, J. J. (1950) 'Nota Prévia Sobre a Jazida Paleoetnográfica De Itacoara (Joinville, Estado De Santa Catarina)', Arquivos de Biologia e Tecnologia $\mathrm{V}, \mathrm{VI}: 315-40$.

Tieszen, L. L. (1991) 'Natural Variations in the Carbon Isotope Values of Plants: Implications for Archaeology, Ecology, and Paleoecology', Journal of Archaeological Science 18(3):227-48.

Todisco, D. and Bhiry, N. (2008) 'Micromorphology of Periglacial Sediments from the Tayara Site, Qikirtaq Island, Nunavik (Canada)', Catena 76(1):1-21.

Trueman, C., Behrensmeyer, A. K., Tuross, N. and Weiner, S. (2004) 'Mineralogical and Compositional Changes in Bones Exposed on Soil Surfaces in Amboseli National Park, Kenya: Diagenetic Mechanisms and the Role of Sediment Pore Fluids', Journal of Archaeological Science 31(6):721-39.

Trueman, C. N. and Martill, D. M. (2002) 'The Long-term Survival of Bone: The Role of Bioerosion', Archaeometry 44(3):371-82.

Uchôa, D. P. (1981) 'Ocupação Do Litoral Sul-sudeste Brasileiro Por Grupos Coletorpescadores Holocênicos', Arquivos do Museu de História Natural 6,7:133-43.

Urban, G. (1992) 'A História Da Cultura Brasileira Segundo as Línguas Nativas', in História Dos Índios No Brasil, pp.87-102. São Paulo: Companhia das Letras.

Vallverdu, J. (2009) Micromorfología De Las Facies Sedimentárias De La Sierra De Atapuerca y Del Nivel J Del Abric Romaní. Implicaciones Geoarqueológicas e Paleoetnográficas. Universitat Rovira i Virigili.

Vallverdú, J., Alonso, S., Bargalló, A., Bartrolí, R., Campeny, G., Carrancho, Á., Expósito, I., Fontanals, M., Gabucio, J., Gómez, B., Prats, J. M., Sañudo, P., Solé, À., Vilalta, J. and Carbonell, E. (2012) 'Combustion Structures of Archaeological Level O and Mousterian Activity Areas with Use of Fire at the Abric Romaní Rockshelter (NE Iberian Peninsula)', Quaternary International 247:313-24.

Verdún, E. (2006) 'Análisis De La Malacofauna De Un Conchero. El Ejemplo De Túnel VII (Tierra Del Fuego, Argentina)', RAMPAS 8:53-69.

Verdún, E. (2010) 'Molluscs as Sedimentary Components . Another Perspective of Analysis', MUNIBE 31:294-301.

Verrecchia, E. P., Karin, A., P, L. D., Continentale, S., G, U. M. R., Su, T. D. and Cn, R. S. (1994) 'Needle-fiber Calcite: a Critical Review and a Proposed Classification', Journal of Sedimentary Research A64(3):650-64.

Vila, A. and Estevez, J. (2010) 'El Factor Marginado En CR: De La Tierra Del Fuego a La Costa Noroeste', Treballs d'Etnoarqueologia: La excepción y la norma, las sociedades indigenas de la costa noroeste de norteamérica desde la arqueología 8:183-216.

Vila, A., Estevez, J., Piana, E., Madella, M., Barceló, J. A., Zurro, D., Clemente, I., Terradas, X., Verdún, E., Piqué, R., Mameli, L. and Briz, I. (2010) Microstratigraphy of Shell Middens of Tierra Del Fuego, Archaeologyp. 1-21.

Vila, A., Mameli, L., Terradas, X., Estevez, J., Moreno, F., Verdún, E., Zurro, D., Clemente, I., Piqué, R., Briz, I. and Barceló, J. A. (2007) 'Investigaçoes Etnoarqueológicas En Tierra Del Fuego (1986-2006): Reflexiones Para La Arqueología Prehistórica Europea’, Trabajos de Prehistoria 64(2):37-53.

Vila, A., Piqué, R. and Mansur, E. (2004) 'Etnoarqueología De Rituales En Sociedades Cazadoras-recolectoras', in Catalunya-América. Fonts i Documents De Recerca, pp.28494.

Vila, A., Toselli, A., Briz, I. and Zurro, D. (2006) 'Trevase Acrítico De Categorías Etnográficas a La Práctica Arqueológica', Treballs d'Etnoarqueologia: Etnoarqueología de la prehistória: más allá de la analogía 6:337-48.

Villagran, X. S. (2008) Análise De Arqueofácies Na Camada Preta Do Sambaqui Jabuticabeira II. Universidade de São Paulo. 
Villagran, X. S. (2010) Geoarqueologia De Um Sambaqui Monumental: Estratigrafias Que Falam São Paulo: Annablume Editora.

Villagran, X. S., Balbo, A. L., Madella, M., Vila, A. and Estevez, J. (2011) (a) 'Stratigraphic and Spatial Variability in Shell Middens: Microfacies Identification at the Ethnohistoric Site Tunel VII ( Tierra Del Fuego, Argentina)', Journal of Archaeological Science 38(3):588-604.

Villagran, X. S., DeBlasis, P. and Giannini, P. C. F. (2009) (a) 'Primeros Estudios Micromorfológicos En Sambaquís Brasileños (sitio Jabuticabeira II, Estado De Santa Catarina)', Intersecciones en Antropología 10:359-64.

Villagran, X. S., Giannini, P. C. F. and DeBlasis, P. (2009) (b) 'Archaeofacies Analysis: Using Depositional Attributes to Identify Anthropic Processes of Deposition in a Monumental Shell Mound of Santa Catarina State, Southern Brazil', Geoarchaeology 24(3):311-35.

Villagran, X. S., Klokler, D., Nishida, P., Gaspar, M. D. and De Blasis, P. (2010) 'Lecturas Estratigraficas: Arquitetura Funeraria y Depositación De Residuos En El Sambaquí Jabuticabeira II', Latin American Antiquity 21(2):195-216.

Villagran, X. S., Klokler, D., Peixoto, S., DeBlasis, P. and Giannini, P. C. F. (2011) (b) 'Building Coastal Landscapes: Zooarchaeology and Geoarchaeology of Brazilian Shell Mounds', The Journal of Island and Coastal Archaeology 6(2):211-34.

Visher, G. S. (1969) 'Grain Size Distributions and Depositional Processes', Journal of Sedimentary Petrology 39:1074-1106.

Van Vliet-Lanoe, B. (1998) 'Frost and Soils : Implications for Paleosols, Paleoclimates and Stratigraphy', Catena: $157-83$.

Van Vliet-Lanoe, B. (2010) 'Frost Action', in G. Stoops V. Marcelino and F. Mees (eds) Interpretation of Micromorphological Features of Soils and Regoliths, pp.81-108. Amsterdam: Elsevier.

Van Vliet-Lanoe, B. and Coward, J. P. (1984) 'Structures Caused by Repeated Freezing and Thawing in Various Loamy Sediments: a Comparison Af Active, Fossil and Experimental Data', Earth Surface Processes and Landforms 9:553-65.

Volman, T. P. (1978) 'Early Archeological Evidence for Shellfish Collecting', Science 201(4359):911-13.

Wainright, S. C. C., Haney, J. C. C., Kerr, C., Golovkin, A. N. N. and Flint, M. V. V. (1998) 'Utilization of Nitrogen Derived from Seabird Guano by Terrestrial and Marine Plants at St . Paul, Pribilof Islands, Bering Sea, Alaska', Marine Biology 131(1):63-71.

Walker, P. L. and DeNiro, M. J. (1986) 'Stable Nitrogen and Carbon Isotope Ratios in Bone Collagen as Indices of Prehistoric Dietary Dependence on Marine and Terrestrial Resources in Southern California.', American journal of physical anthropology 71(1):5161.

Walker, R. G. (1983) Facies Models Toronto: Geological Association of Canada.

Wang, Y. J., Auler, A. S., Edwards, R. L., Cheng, H., Ito, E. and Solheid, M. (2006) 'Interhemispheric Anti-phasing of Rainfall During the Last Glacial Period', Quaternary Science Reviews 25:3391-3403.

Waselkov, G. A. (1987) 'Shellfish Gathering and Shell Midden Archaeology', Advances in Archaeological Method and Theory 10:93-210.

Wattez, J. (1990) Dynamique De Formation Des Structures De Combustion De La Fin Du Paléolithique Au Néolitique Moyen. Approche Méthodologique Et Implications Culturelles. Université de Paris I.

Wattez, J. (1992) Dynamique De Formation Des Structures De Combustion De La Fin Du Paleolithique Ao Neolithique Moyen. Université de Paris I.

Webb, E., Schwarcz, H. and Healy, P. (2004) 'Detection of Ancient Maize in Lowland Maya Soils Using Stable Carbon Isotopes: Evidence from Caracol, Belize', Journal of Archaeological Science 31(8):1039-52.

Weddell, J. (1825) A Voyage Towards the South Pole Performed in the Years 1822-1824 Containing... and a Visit to Tierra Del Fuego with a Particular Account of the Inhabitants London. 
Weiner, S. (2002) 'Three-dimensional Distribution of Minerals in the Sediments of Hayonim Cave, Israel: Diagenetic Processes and Archaeological Implications', Journal of Archaeological Science 29(11):1289-1308.

Wen, Z., Xie, P. and Xu, J. (2010) 'Mussel Isotope Signature as Indicator of Nutrient Pollution in a Freshwater Eutrophic Lake: Species, Spatial, and Seasonal Variability', Environmental monitoring and assessment 163(1-4):139-47.

Wesolowski, V. (2000) A Prática Da Horticultura Entre Os Construtores De Sambaquis e Acampamentos Litorâneos Da Região Da Baía De São Francisco, Santa Catarina: Uma Abordagem Bio-antropológica. Universidade de São Paulo.

Wesolowski, V., Mendonça de Souza, S., Reinhard, K. and Ceccantini, G. (2007) 'Grânulos De Amido e Fitólitos Em Cálculos Dentários Humanos: Contribuição Ao Estudo Do Modo De Vida e Subsistência De Grupos Sambaquianos Do Litoral Sul Do Brasil', Revista do Museu de Arqueologia e Etnologia 17:191-210.

White, E. M. and Hannus, L. A. (1983) 'Chemical Weathering of Bone in Archaeological Soils', American Antiquity 48(2):316-22.

White, W. M. (2001) 'Stable Isotope Geochemistry', in Geochemistry, pp.370-420.

Whittacker, F. H. and Stein, J. K. (1992) 'Shell Midden Boundaries in Relation to Past and Present Shorelines', in J. K. Stein (ed.) Deciphering a Shell Midden, pp.25-42. San Diego: Academic Press.

Wiener, C. (1875) 'Estudo Sobre Os Sambaquis Do Sul Do Brasil', Arquivos do Museu Nacional 1(1):1-29.

Wilkes, C. (1844) U.S. Exploring Expedition During the Years 1838, 1839, 1840, 1841, 1842, Under the Command of Captain Fitz-Roy R.N. Volume I Philadelphia: C. Sherman.

Wilson, D. (1994) 'Identification and Assesment of Secondary Refuse Aggregates', Journal of Archaeological Science 1(1):41-68.

Wilson, G. P., Lamb, A. L., Meng, M. J., Gonzalez, S. and Huddard, D. (2005) ' $\delta 13 \mathrm{C}$ and C/N as Potential Coastal Palaeoenvironmental Indicators in the Mersey Estuary, UK', Quaternary Science Reviews 24:2015-29.

Wilson, M. A. and Righi, D. (2010) 'Spodic Materials', in G. Stoops V. Marcelino and F. Mees (eds) Interpretation of Micromorphological Features of Soils and Regoliths, pp.251-73. Amsterdam: Elsevier.

Woods, W. (2003) 'Development of Anthrosol Research', in J. Lehmann D. Kern B. Glaser and W. Woods (eds) Amazonian Dark Earths: Origin, Properties and Management, pp.3-14. Dordrecht: Kluwer Academic Publishers.

Wright, D. R., Terry, R. E. and Eberl, M. (2009) 'Soil Properties and Stable Carbon Isotope Analysis of Landscape Features in the Petexbatún Region of Guatemala', Geoarchaeology 24(4):466-91.

Wunsch, G. (1996) 'De La Articulación Espacial Del Registro Arqueológico a La Gestión Del Espacio Social: Um Ejemplo De Aplicación Del Análisis De Las Interrelaciones Espaciales (ANITES)', Treballs d'Etnoarqueologia: Encuentro en los Conchales Fueguinos 1:127-42.

Xu, H., Ai, L., Tan, L. and an, Z. (2006) 'Stable Isotopes in Bulk Carbonates and Organic Matter in Recent Sediments of Lake Qinghai and Their Climatic Implications', Chemical Geology 235(3-4):262-75.

Yesner, D. R. (1980) 'Maritime Hunter-gatherers: Ecology and Prehistory', Current Anthropology 21(6):727-50.

Yesner, D. R., Figuerero Torres, M. J., Guichon, R. A. and Borrero, L. A. (2003) 'Stable Isotope Analysis of Human Bone and Ethnohistoric Subsistence Patterns in Tierra Del Fuego', Journal of Anthropological Archaeology 22(3):279-91.

Yravedra, J., Baena, J., Arrizabalaga, A. and Iriarte, M. J. (2005) 'El Empleo De Material Óseo Como Combustible Durante El Paleolítico Medio y Superior En El Cantábrico. Observaciones Experimentales', Museo de Altamira, Monografías 20:369-83.

Zangrando, F. A., Tessone, A. and Vazquez, M. (2009) 'El Uso De Espacios Marginales Em El Archipiélago Fuegiono: Implicaciones De La Evidencia Arqueológico De Bahía Valentín', in M. Salemme F. Santiago M. Alvarez E. Piana E. Vazquez and E. Mansur (eds) 
Arqueologia De La Patagonia: Una Mirada Desde El Último Confin, pp.47-62. Ushuaia: Editorial Utopías.

Zubimendi, M. Á. (2007) Discusión Sobre Las Malacofaunas Presentes En Sitios Arqueológicos De La Patagonia Continental Argentina, in VI Jornadas De Arqueología e Historia De Las Regiones Pampeana y Patagónica.

Zurro, D., Madella, M., Briz, I. and Vila, a (2009) 'Variability of the Phytolith Record in Fisher-hunter-gatherer Sites: An Example from the Yamana Society (Beagle Channel, Tierra Del Fuego, Argentina)', Quaternary International 193(1-2):184-91. 
ANEXO 1: Figuras e tabelas complementares 

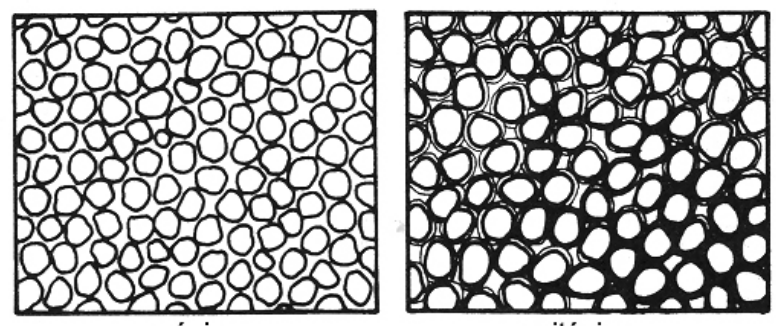

mónica

quitónica
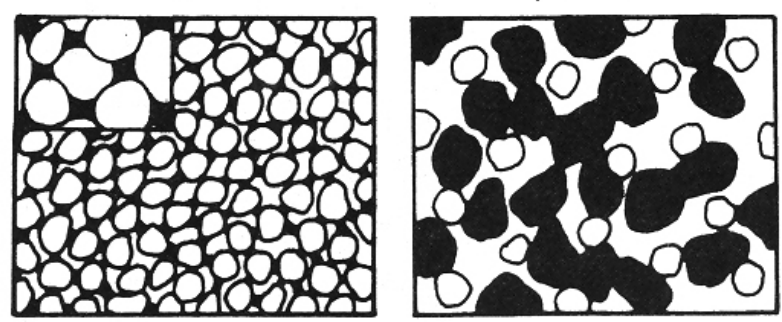

gefúrica

enáulica grossa

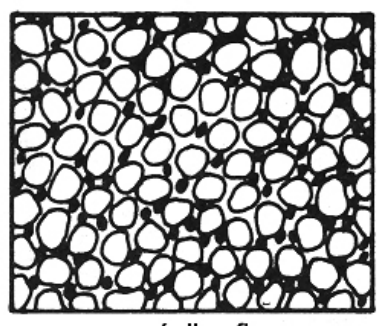

enáulica fina

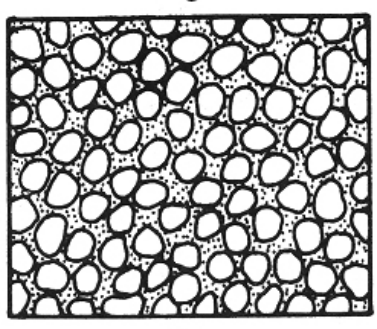

porfírica

Figura A.1. Diferentes tipos de distribuições relacionadas g/f (adaptado de Stoops, 2003). 


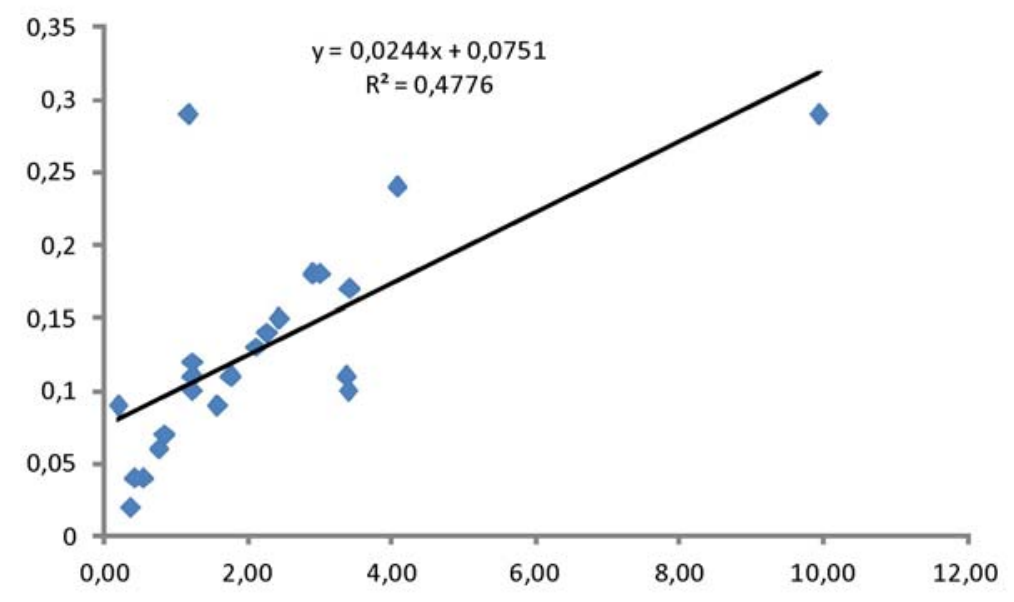

Figura A.2. Diagrama de regressão linear entre os valores de $\mathrm{C}$ orgânico e $\mathrm{N}$ total. $\mathrm{O}$ elevado índice de correlação indica que os dados de $\mathrm{N}$ total podem ser usados como reflexo da concentração de $\mathrm{N}$ orgânico na MO. 


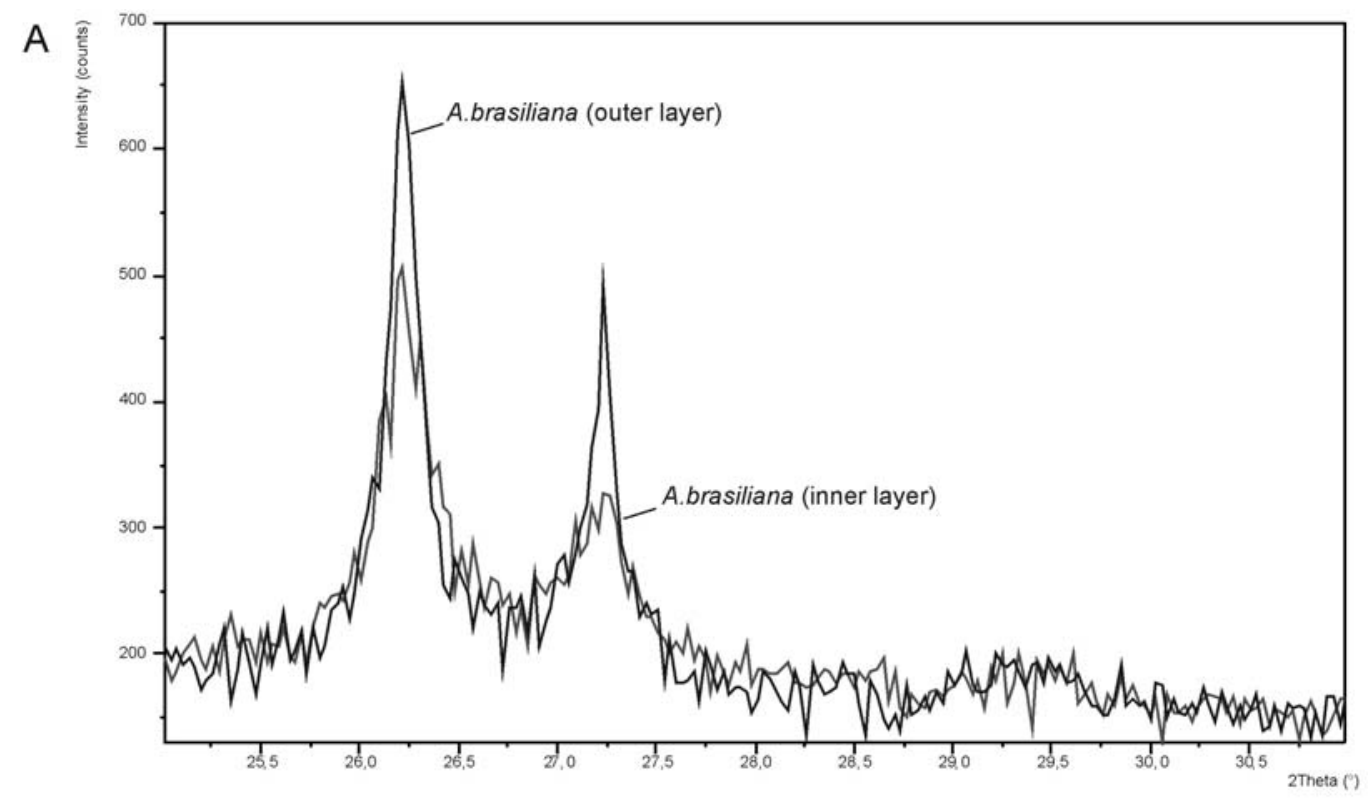

B

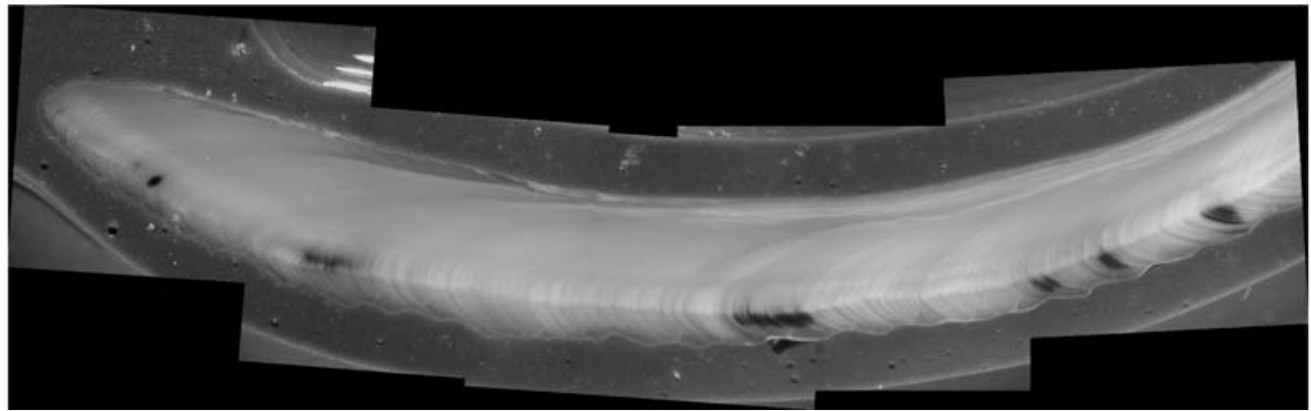

Figura A.3. Análise mineralógica e óptica da concha de Anomalocardia brasiliana: A) difratograma obtido a partir de amostra da concha, com picos correspondentes a aragonita; B) imagem tomada com microscópio esteoreosópico de seção da concha de Anomalocardia brasiliana. Note-se as camadas de crescimento da valva. 

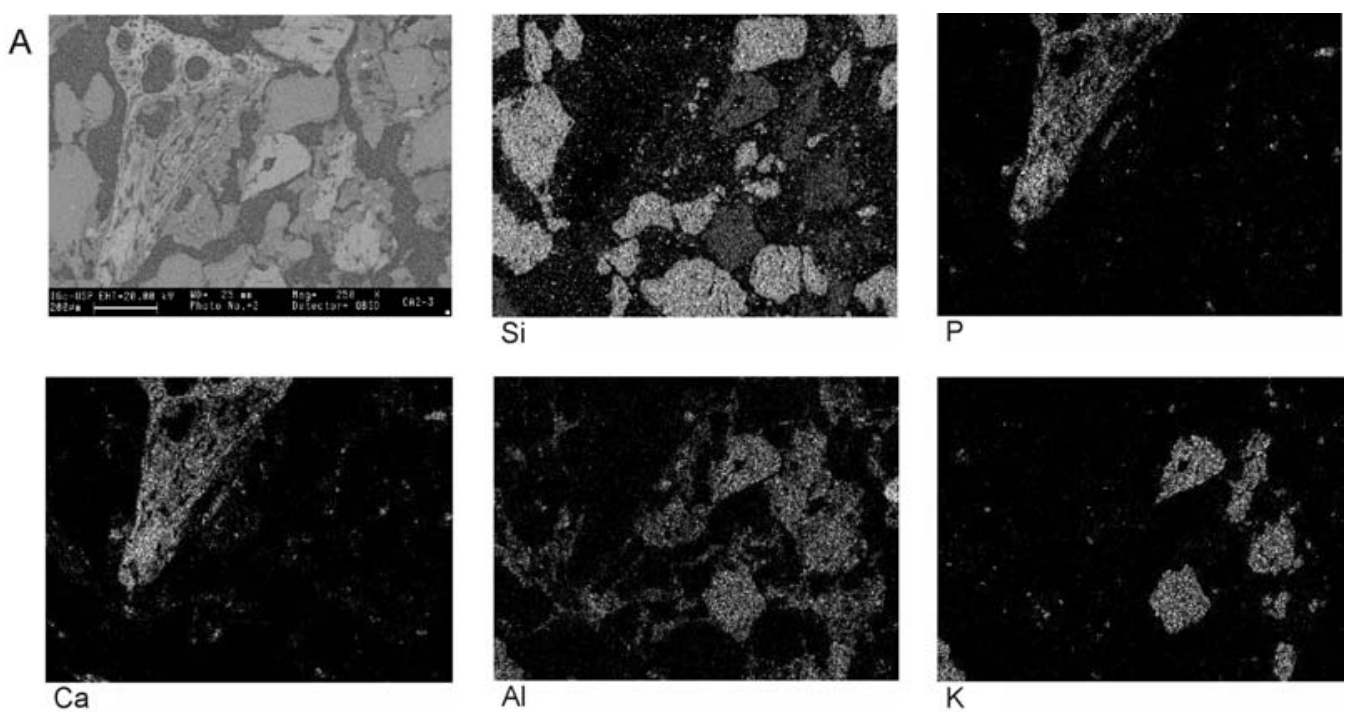

B

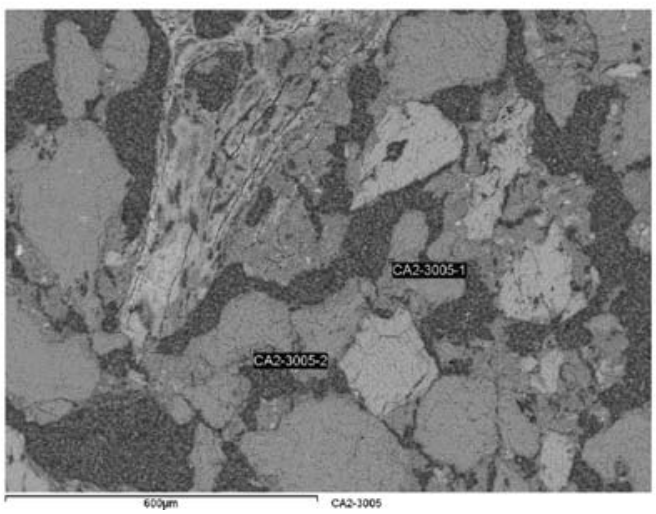

\begin{tabular}{ll}
\multicolumn{2}{c}{ CA2-3005-1 } \\
Elemento & Peso (\%) \\
OK & 44.49 \\
$\mathrm{NaK}$ & 0.35 \\
$\mathrm{Mg} \mathrm{K}$ & 0.45 \\
$\mathrm{AlK}$ & 7.55 \\
$\mathrm{Si} \mathrm{K}$ & 31.93 \\
$\mathrm{PK}$ & 1.71 \\
$\mathrm{KK}$ & 0.82 \\
$\mathrm{CaK}$ & 8.97 \\
Ti K & 0.38 \\
$\mathrm{MnK}$ & 0.29 \\
Fe K & 3.05 \\
& \\
Total & 100.00
\end{tabular}

CA2-3005-2

Elemento Peso (\%)

$\begin{array}{ll}\text { O K } & 44.05 \\ \mathrm{NaK} & 0.71\end{array}$

$\mathrm{MgK} \quad 0.56$

AlK $\quad 8.47$

Si K 29.18

$\begin{array}{ll}\text { PK } & 0.82 \\ \text { KK } & 3.05\end{array}$

KK

CaK $\quad 9.70$

$\begin{array}{ll}\text { TiK } & 0.28 \\ \text { Mn K } & 0.24\end{array}$

FeK $\quad 2.70$

SK $\quad 0.24$

Total $\quad 100.00$

Figura A.4. Análise de seção delgada da amostra CA 2-3 (sítio Caipora) em microscópio eletrônico de varredura: A) mapeamento elementar; B) imagem de elétrons retroespalhados (QSBD) com pontos de microanálise e tabela com resultados da análise semi-quantitativa. 
A

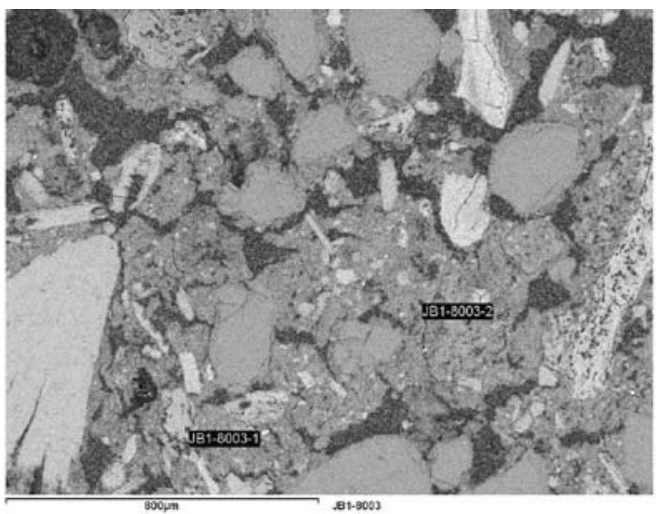

B

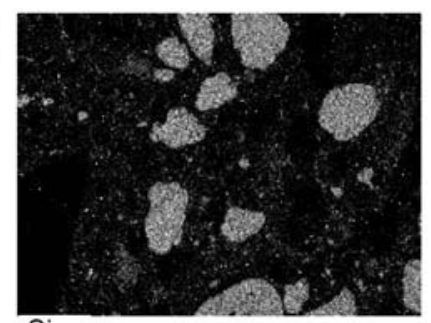

$\mathrm{Si}$

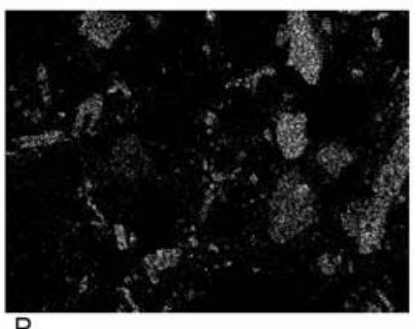

JB1-8003-1

Elemento Peso (\%)

OK $\quad 40.07$

Na K $\quad 0.30$

AlK 10.24

SiK $\quad 34.21$

KK $\quad 15.18$

Total

100.00

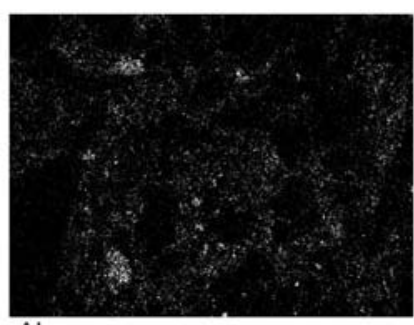

Al

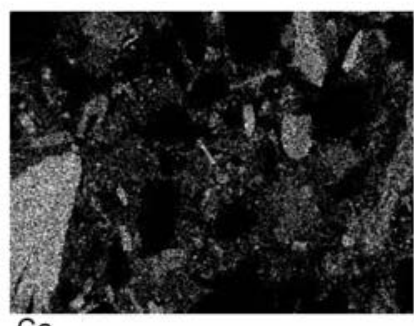

JB1-8003-2

Elemento Peso (\%)

OK 43.91

\begin{tabular}{ll} 
NaK & 1.52 \\
\hline$g K$ & 0.61
\end{tabular}

AlK

Alk $\quad 0.89$

$\begin{array}{ll}\text { SiK } & 14.60 \\ \text { PK } & 10.93\end{array}$

CaK 24.70

$\begin{array}{ll}\text { CaK } & 24.70 \\ \text { FeK } & 0.95\end{array}$

Sr K 1.89

Total $\quad 100.00$
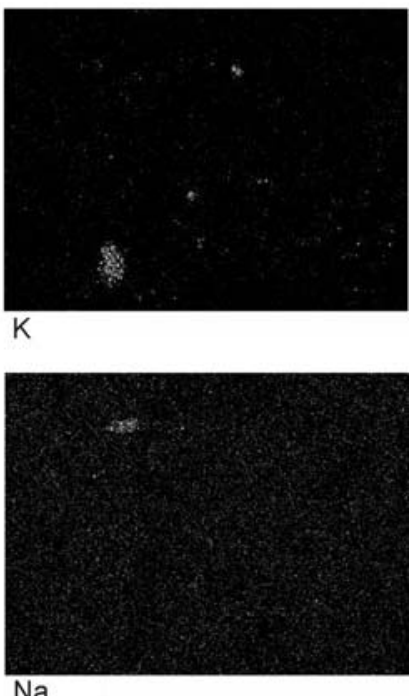

Figura A.5. Análise de seção delgada da amostra JB1-8 (sítio Jabuticabeira 1) em microscópio eletrônico de varredura: A) imagem de elétrons retroespalhados (QSBD) com pontos de microanálise e tabela com resultados da análise semi-quantitativa; B) mapeamento elementar. 


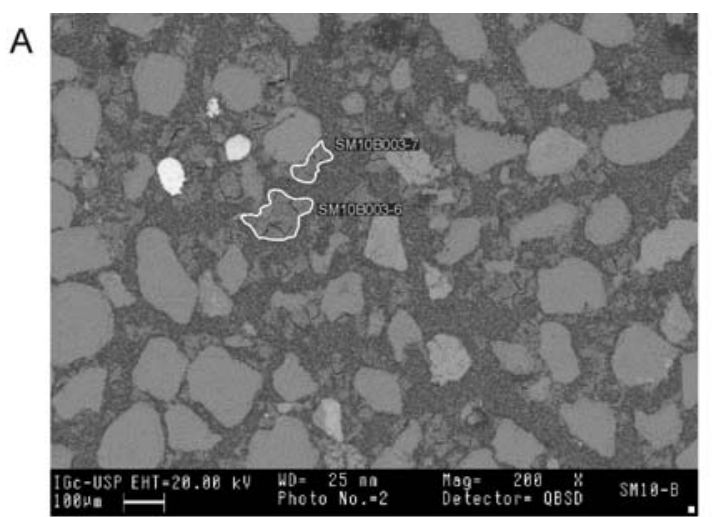

\begin{tabular}{llll}
\multicolumn{2}{c}{ SM10B003-6 } & \multicolumn{2}{c}{ SM10B003-7 } \\
Elemento & Peso (\%) & Elemento & Peso (\%) \\
OK & 44.72 & $\mathrm{OK}$ & 46.17 \\
$\mathrm{NaK}$ & 1.93 & $\mathrm{NaK}$ & 2.18 \\
$\mathrm{Mg} \mathrm{K}$ & 0.80 & $\mathrm{Mg} \mathrm{K}$ & 0.81 \\
$\mathrm{AlK}$ & 10.96 & $\mathrm{AlK}$ & 12.71 \\
$\mathrm{Si} \mathrm{K}$ & 36.27 & $\mathrm{Si} \mathrm{K}$ & 31.43 \\
$\mathrm{KK}$ & 1.02 & $\mathrm{KK}$ & 0.78 \\
$\mathrm{Ca} \mathrm{K}$ & 1.42 & $\mathrm{CaK}$ & 1.74 \\
$\mathrm{Fe} \mathrm{L}$ & 2.88 & Fe K & 3.70 \\
Total & \multirow{2}{*}{100.00} & Ti K & 0.47 \\
& & Total & 100.00
\end{tabular}

B
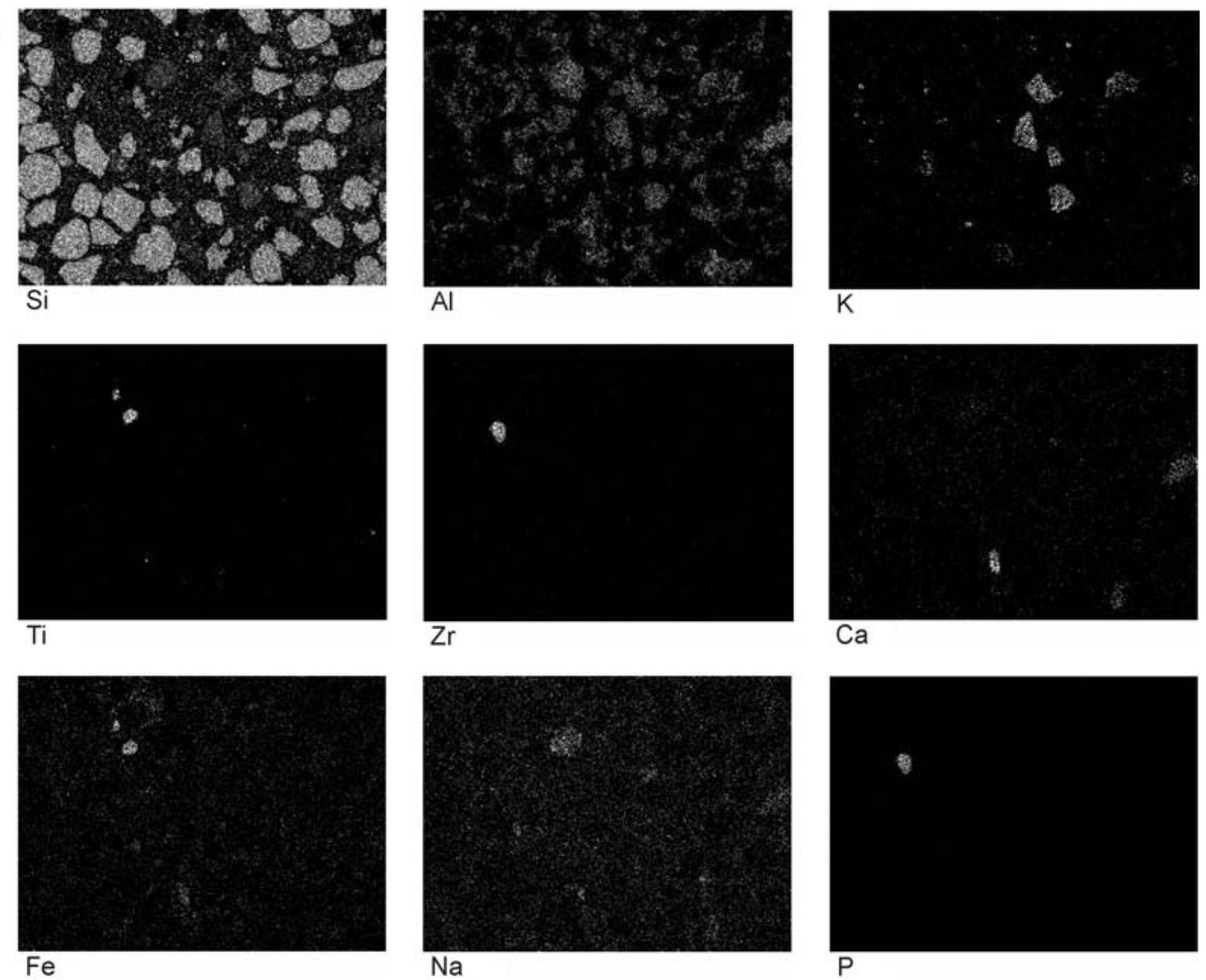

Figura A.6. Análise de seção delgada da amostra SM10-B (sítio Santa Marta 10) em microscópio eletrônico de varredura: A) imagem de elétrons retroespalhados (QSBD) com pontos de microanálise e tabela com resultados da análise semi-quantitativa; B) mapeamento elementar. 
A

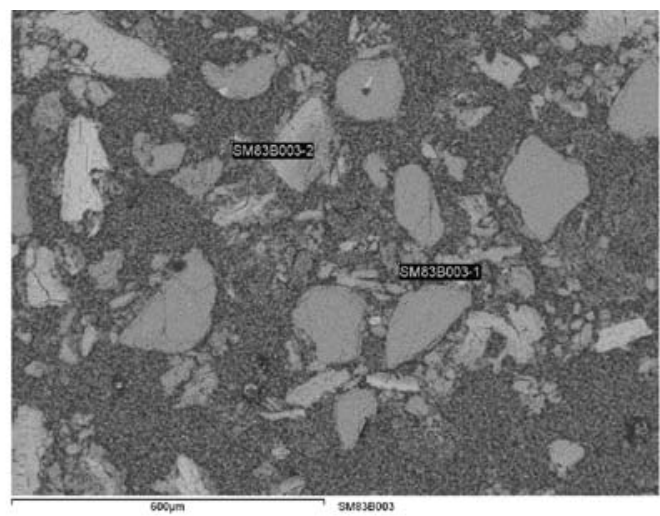

B

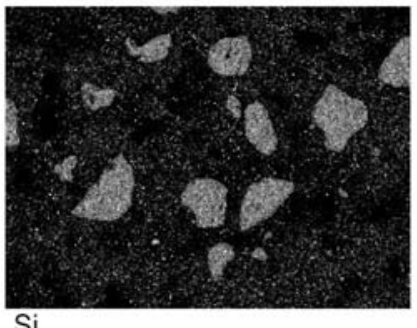

Si

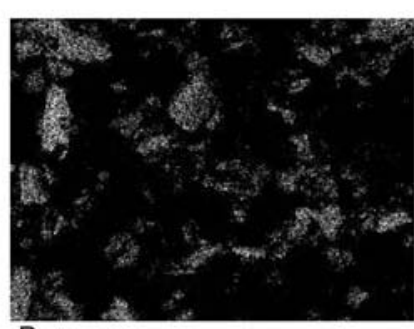

P
SM8-3B003-1

Elemento Peso (\%)

OK $\quad 43.10$

Na K $\quad 0.66$

$\begin{array}{ll}M g K & 0.31 \\ \text { AlK } & 0.21\end{array}$

SiK

$\begin{array}{ll}\text { SiK } & 11.09 \\ \text { PK } & 15.23\end{array}$

$\begin{array}{ll}\text { CaK } & 15.23 \\ \text { Ca K } & 27.73\end{array}$

$\mathrm{SrL} \quad 1.60$

Total $\quad 100.00$
SM83B003-2

Elemento Peso (\%)

$\begin{array}{ll}\text { O K } & 44.20 \\ \text { NaK } & 1.17\end{array}$

$\begin{array}{ll}\mathrm{MgK} & \mathrm{O}\end{array}$

AlK $\quad 0.29$

SiK 0.29

SiK $\quad 9.88$

CaK 28.72

ClK $\quad 0.28$

KK $\quad 0.12$

Total $\quad 100.00$

Figura A.7. Análise de seção delgada da amostra SM8-3 (sítio Santa Marta 8) em microscópio eletrônico de varredura: A) imagem de elétrons retroespalhados (QSBD) com pontos de microanálise e tabela com resultados da análise semi-quantitativa; B) mapeamento elementar. 

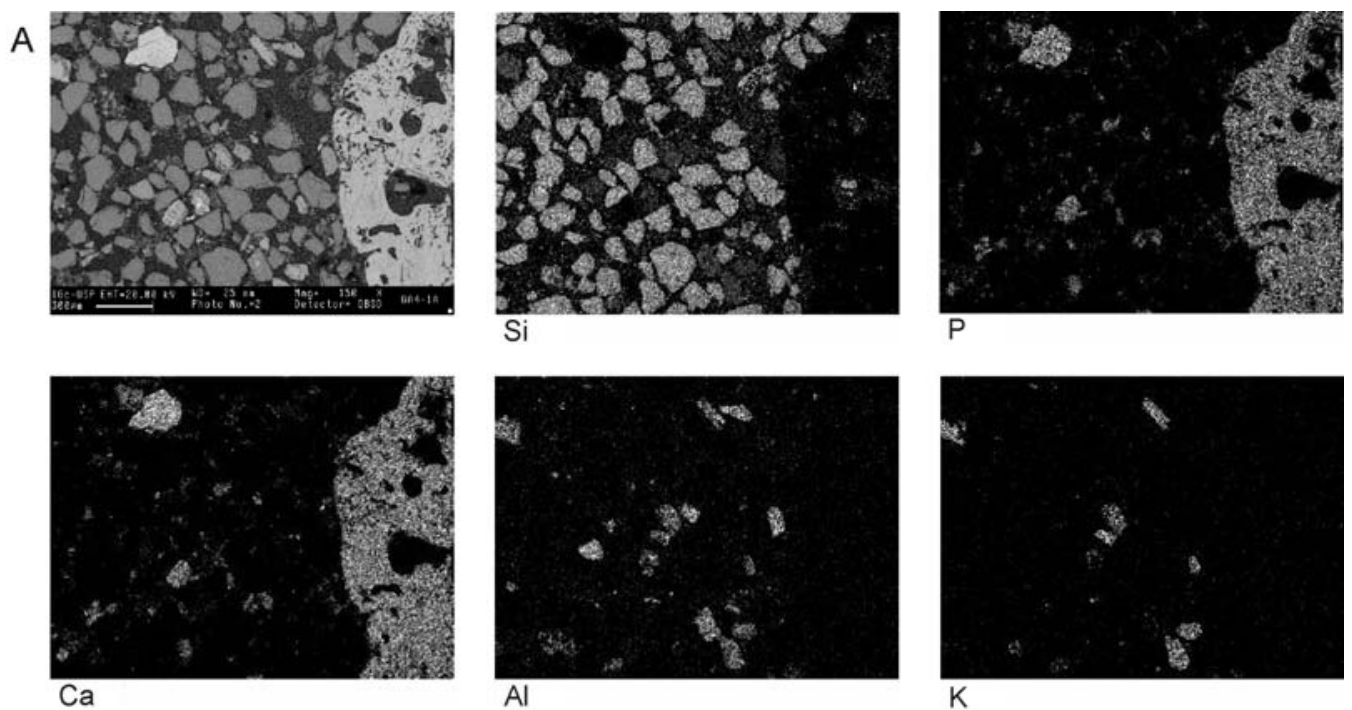

B
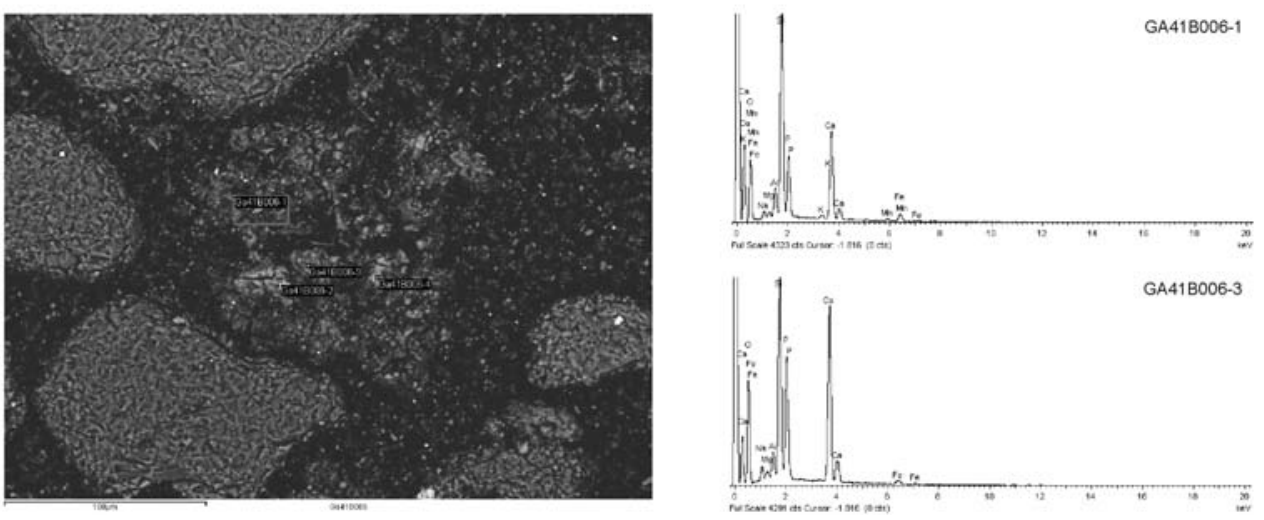

Figura A.8. Análise de seção delgada da amostra GA4-1 (sítio Galheta 4) em microscópio eletrônico de varredura: A) mapeamento elementar; B) imagem de elétrons retroespalhados (QSBD) com pontos de microanálise e gráfico com picos da análise semi-quantitativa. 
Tabela A.1. Resultados das análises granulométricas e parâmetros estatísticos para sedimentos arqueológicos e depósitos naturais. Todas as amostras arqueológicas foram tratadas segundo procedimento descrito no Capítulo 4, tópico 3.2. No calculo dos momentos não foram considerados os sedimentos pelíticos.

\begin{tabular}{|c|c|c|c|c|c|c|c|c|c|c|c|c|c|c|c|}
\hline \multicolumn{5}{|c|}{$\begin{array}{l}\text { PARÂMETROS ESTATÍSTICOS DA DISTRIBUIÇÃO GRANULOMÉTRICA } \\
\text { (Phi) }\end{array}$} & \multicolumn{11}{|c|}{ FAIXA GRANULOMÉTRICA (\%) } \\
\hline \multirow[b]{2}{*}{ CÓDIGO } & \multirow{2}{*}{$\begin{array}{l}\text { DIÃMETRO } \\
\text { MÉDIO }\end{array}$} & \multirow[b]{2}{*}{$\begin{array}{l}\text { DESVIO } \\
\text { PADRÃO }\end{array}$} & \multirow[b]{2}{*}{ ASSIMETRIA } & \multirow[b]{2}{*}{ CURTOSE } & \multicolumn{3}{|c|}{ CASCALHO } & \multicolumn{6}{|c|}{ AREIA } & \multicolumn{2}{|c|}{ PELÍTICOS } \\
\hline & & & & & SEIXOS & GRÂNULO & TOTAL & $\begin{array}{c}\text { MUITO } \\
\text { GROSSA }\end{array}$ & GROSSA & MÉDIA & FINA & $\begin{array}{l}\text { MUITO } \\
\text { FINA }\end{array}$ & TOTAL & SILTE & ARGILA \\
\hline CA-1a & 1,76 & 0,84 & $-1,17$ & 4,21 & 0,00 & 0,03 & 0,03 & 5,33 & 10,44 & 31,31 & 50,46 & 2,43 & 99,97 & 0,00 & 0,00 \\
\hline CA-1b & 0,35 & 1,78 & 0,59 & 1,70 & 0,00 & 36,42 & 36,42 & 22,82 & 4,71 & 6,14 & 21,14 & 8,76 & 63,58 & 0,00 & 0,00 \\
\hline CA-A & 1,82 & 1,37 & $-0,41$ & 2,17 & 0,00 & 1,26 & 1,26 & 4,80 & 7,65 & 12,41 & 9,39 & 12,30 & 46,54 & 36,44 & 52,20 \\
\hline CB1-5 & 0,95 & 1,44 & 0,10 & 1,50 & 0,00 & 0,00 & 0,00 & 37,29 & 11,61 & 17,36 & 24,81 & 8,93 & 100,00 & 0,00 & 0,00 \\
\hline CB1-A & $-0,43$ & 1,27 & 1,61 & 4,38 & 0,00 & 48,13 & 48,13 & 22,72 & 5,89 & 4,79 & 7,37 & 1,76 & 42,53 & 6,46 & 9,34 \\
\hline CB1-B & 0,59 & 1,49 & 0,38 & 1,86 & 0,00 & 8,45 & 8,45 & 12,07 & 7,57 & 7,09 & 7,69 & 2,92 & 37,34 & 30,45 & 54,21 \\
\hline MO-2 & 3,02 & 0,72 & $-1,46$ & 5,10 & 0,00 & 0,00 & 0,00 & 0,22 & 1,87 & 8,63 & 21,38 & 67,90 & 100,00 & 0,00 & 0,00 \\
\hline MO-3 & 1,67 & 1,25 & $-0,19$ & 2,14 & 0,00 & 0,00 & 0,00 & 12,76 & 17,52 & 28,65 & 21,69 & 19,38 & 100,00 & 0,00 & 0,00 \\
\hline MO-4 & 1,85 & 1,10 & $-0,56$ & 2,71 & 0,00 & 0,00 & 0,00 & 8,00 & 13,07 & 27,25 & 39,74 & 11,94 & 100,00 & 0,00 & 0,00 \\
\hline JAB1-1 & 1,74 & 0,84 & $-0,72$ & 5,01 & 0,00 & 0,00 & 0,00 & 6,07 & 6,33 & 57,47 & 24,00 & 6,13 & 100,00 & 0,00 & 0,00 \\
\hline JAB1-2 & 1,68 & 0,88 & $-0,51$ & 4,56 & 0,00 & 0,00 & 0,00 & 6,85 & 7,15 & 62,63 & 16,23 & 7,14 & 100,00 & 0,00 & 0,00 \\
\hline JAB1-3 & 1,89 & 0,43 & 0,55 & 8,40 & 0,00 & 0,00 & 0,00 & 0,19 & 0,59 & 65,57 & 31,44 & 2,21 & 100,00 & 0,00 & 0,00 \\
\hline JAB1-4 & 1,74 & 0,37 & $-1,04$ & 15,32 & 0,00 & 0,00 & 0,00 & 0,53 & 1,12 & 84,42 & 13,21 & 0,72 & 100,00 & 0,00 & 0,00 \\
\hline JAB1-5 & 1,83 & 0,83 & $-0,19$ & 3,99 & 0,00 & 0,00 & 0,00 & 4,14 & 8,53 & 52,51 & 26,12 & 8,70 & 100,00 & 0,00 & 0,00 \\
\hline JAB1-6 & 1,90 & 1,02 & $-0,29$ & 2,62 & 0,00 & 0,00 & 0,00 & 5,91 & 12,43 & 34,13 & 33,58 & 13,96 & 100,00 & 0,00 & 0,00 \\
\hline JAB1-7 & 2,04 & 0,95 & $-0,06$ & 2,35 & 0,00 & 0,00 & 0,00 & 0,00 & 15,02 & 31,07 & 35,97 & 17,94 & 100,00 & 0,00 & 0,00 \\
\hline JAB1-9 & 2,13 & 0,58 & 0,21 & 3,18 & 0,00 & 0,00 & 0,00 & 0,08 & 1,65 & 43,29 & 47,20 & 7,77 & 100,00 & 0,00 & 0,00 \\
\hline SM10-A & 2,80 & 0,47 & $-2,12$ & 16,97 & 0,00 & 0,00 & 0,00 & 0,45 & 0,13 & 0,99 & 63,29 & 31,61 & 96,47 & 0,07 & 3,53 \\
\hline SM10-B & 2,64 & 0,42 & 0,01 & 3,23 & 0,00 & 0,00 & 0,00 & 0,00 & 0,07 & 3,51 & 74,48 & 17,77 & 95,82 & 0,29 & 4,18 \\
\hline SM10-B2 & 2,87 & 0,42 & $-1,28$ & 10,11 & 0,00 & 0,00 & 0,00 & 0,14 & 0,12 & 0,89 & 53,61 & 37,46 & 92,23 & 2,49 & 7,77 \\
\hline CR3-2 & 2,83 & 0,63 & $-0,90$ & 2,77 & 0,00 & 0,00 & 0,00 & 0,00 & 0,00 & 11,11 & 28,74 & 60,14 & 100,00 & 0,00 & 0,00 \\
\hline SM8-1 & 2,51 & 0,58 & $-0,67$ & 4,76 & 0,00 & 0,00 & 0,00 & 0,00 & 3,19 & 7,05 & 77,14 & 12,61 & 100,00 & 0,00 & 0,00 \\
\hline SM8-2 & 2,60 & 0,69 & $-1,11$ & 6,92 & 0,00 & 0,00 & 0,00 & 1,22 & 2,47 & 3,27 & 76,15 & 16,89 & 100,00 & 0,00 & 0,00 \\
\hline SM8-3 & 2,72 & 0,30 & $-0,44$ & 6,76 & 0,00 & 0,00 & 0,00 & 0,00 & 0,05 & 1,56 & 87,09 & 11,29 & 100,00 & 0,00 & 0,00 \\
\hline SM8-A & 2,68 & 0,30 & $-0,11$ & 3,18 & 0,00 & 0,00 & 0,00 & 0,00 & 0,00 & 0,67 & 87,51 & 11,82 & 100,00 & 0,00 & 0,00 \\
\hline SM8-B & 2,43 & 0,80 & $-1,08$ & 4,05 & 0,00 & 0,00 & 0,00 & 0,00 & 8,60 & 10,21 & 63,59 & 17,61 & 100,00 & 0,00 & 0,00 \\
\hline GA4-1 & 2,80 & 0,32 & $-0,63$ & 7,44 & 0,00 & 0,00 & 0,00 & 0,00 & 0,09 & 1,50 & 76,72 & 21,70 & 100,00 & 0,00 & 0,00 \\
\hline GA4-A & 3,03 & 0,31 & $-0,69$ & 5,23 & 0,00 & 0,00 & 0,00 & 0,00 & 0,04 & 0,19 & 42,62 & 55,35 & 98,21 & 0,69 & 1,79 \\
\hline GA4-B & 2,88 & 0,38 & $-2,28$ & 21,93 & 0,00 & 0,08 & 0,08 & 0,07 & 0,21 & 0,57 & 62,16 & 35,96 & 98,96 & 0,14 & 0,95 \\
\hline
\end{tabular}


Tabela A.2. Concentrações de carbono e nitrogênio total (\%), $\delta 13 \mathrm{C}$ e $\delta 15 \mathrm{~N}(\%)$ nas arqueofácies identificadas nos 8 sambaquis estudados e nos pontos de amostragem extra-sítio.

\begin{tabular}{|c|c|c|c|c|c|}
\hline Sítio & C orgânico (\%) & ${ }^{13} \mathrm{C}(\delta \mathrm{PDB})$ & $\mathrm{N}$ total $(\%)$ & ${ }^{15} \mathrm{~N}(\delta \mathrm{ar})$ & Razão C/N \\
\hline CA-4 & 0,54 & $-24,47$ & 0,04 & 12,31 & 13,50 \\
\hline CA-5 & 0,84 & $-23,40$ & 0,07 & 11,36 & 12,00 \\
\hline $\mathrm{CB} 1-5$ & 9,94 & $-26,93$ & 0,29 & 10,82 & 34,28 \\
\hline MO-2 & 3,41 & $-23,91$ & 0,17 & 10,05 & 20,06 \\
\hline MO-4 & 1,76 & $-24,35$ & 0,11 & 13,32 & 16,00 \\
\hline JB1-1 & 0,42 & $-23,53$ & 0,04 & 14,03 & 10,50 \\
\hline JB1-2 & 2,43 & $-24,76$ & 0,15 & 13,97 & 16,20 \\
\hline JB1-3 & 2,90 & $-22,74$ & 0,18 & 15,23 & 16,11 \\
\hline JB1-4 & 3,37 & $-25,48$ & 0,11 & 12,10 & 30,64 \\
\hline JB1-5 & 2,26 & $-24,65$ & 0,14 & 11,70 & 16,14 \\
\hline JB1-6 & 3,00 & $-23,72$ & 0,18 & 11,59 & 16,67 \\
\hline JB1-7 & 2,11 & $-23,14$ & 0,13 & 14,99 & 16,23 \\
\hline CR3-1 & 4,08 & $-28,17$ & 0,24 & 8,50 & 17,00 \\
\hline SM8-2 & 0,76 & $-23,65$ & 0,06 & 15,34 & 12,67 \\
\hline SM8-3 & 1,22 & $-24,73$ & 0,10 & 13,52 & 12,20 \\
\hline SM10-B & 1,72 & $-24,19$ & 0,09 & 7,39 & 19,11 \\
\hline GA4-1 & 1,57 & $-23,28$ & 0,11 & 15,94 & 14,27 \\
\hline Extra-sítio & C orgânico (\%) & ${ }^{13} \mathrm{C}(\delta \mathrm{PDB})$ & $\mathrm{N}$ total $(\%)$ & ${ }^{15} \mathrm{~N}(\delta a r)$ & Razão C/N \\
\hline CA-A & 1,23 & $-22,36$ & 0,12 & 9,78 & 10,25 \\
\hline CB1-A & 1,22 & $-24,55$ & 0,10 & 8,40 & 12,20 \\
\hline CB1-B & 3,40 & $-24,44$ & 0,29 & 8,75 & 11,72 \\
\hline SM8-B & 1,17 & $-20,89$ & 0,09 & 13,54 & 13,00 \\
\hline SM10-B2 & 0,20 & $-24,97$ & 0,02 & 7,82 & 10,00 \\
\hline GA4-B & 0,36 & $-21,50$ & 0,02 & 8,91 & 18,00 \\
\hline
\end{tabular}


Tabela A.3. Porcentagens de espécies malacológicas identificadas a partir da análise zooarqueológica dos sítios Santa Marta 10, Morrinhos, Cubículo 1 e Carniça 3. A identificação e estimação das frequências foram realizadas a partir de volumes padronizados de sedimento extraído das arqueofácies de interesse, as porcentagens foram calculadas a partir do peso de cada espécie e elemento identificado em relação ao peso total.

$(\%)$

\begin{tabular}{|c|c|c|c|c|c|c|c|c|c|c|c|c|c|c|c|c|c|c|c|c|c|c|c|c|c|c|c|c|c|}
\hline & & \\
\hline & 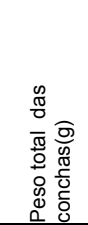 & 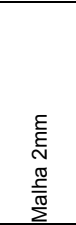 & 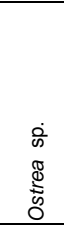 & 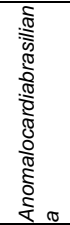 & 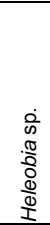 & 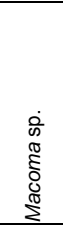 & 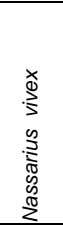 & 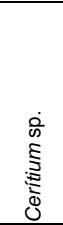 & 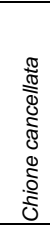 & 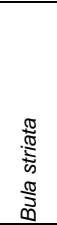 & 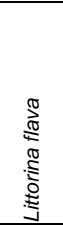 & 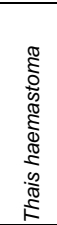 & 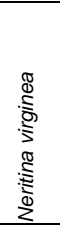 & $\begin{array}{l}0 \\
0 \\
\frac{\pi}{3} \\
\frac{0}{0} \\
\frac{0}{0} \\
0\end{array}$ & 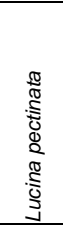 & 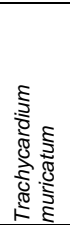 & 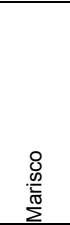 & 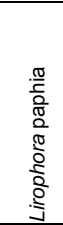 & 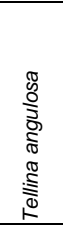 & 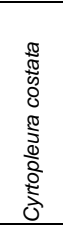 & $\begin{array}{l}\mathbb{0} \\
\stackrel{8}{0} \\
\end{array}$ & 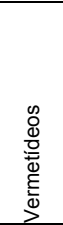 & $\begin{array}{l}\text { on } \\
\text { o. } \\
0 \\
0\end{array}$ & 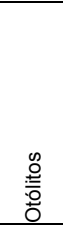 & 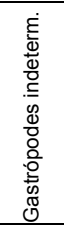 & 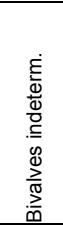 & 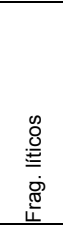 & 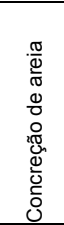 & 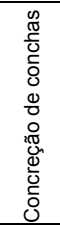 \\
\hline $\begin{array}{l}\text { SM10-1 } \\
\text { MO-1 }\end{array}$ & $\begin{array}{l}1535,81 \\
1607,54\end{array}$ & $\begin{array}{l}48,83 \\
45,10\end{array}$ & & $\begin{array}{l}50,46 \\
38,19\end{array}$ & 0,13 & $\begin{array}{l}0,07 \\
0,01\end{array}$ & 0,13 & & & & & & & & & & & & & & & & & & & & & 0,38 & \\
\hline $\begin{array}{l}\text { MO-1 } \\
\text { MO-3 }\end{array}$ & $\begin{array}{r}1607,54 \\
912,8\end{array}$ & 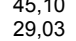 & $\begin{array}{l}1,36 \\
2,32\end{array}$ & $\begin{array}{l}38,19 \\
64,18\end{array}$ & & $\begin{array}{l}0,01 \\
0,24\end{array}$ & $\begin{array}{l}0,17 \\
0,06\end{array}$ & & 0,29 & 0,19 & $\begin{array}{l}0,02 \\
0,01\end{array}$ & 0,31 & 0,04 & 0,02 & $\begin{array}{l}0,29 \\
0,80\end{array}$ & & $\begin{array}{r}13,23 \\
1,55\end{array}$ & & & & 0,51 & & $\begin{array}{l}0,16 \\
0.23\end{array}$ & 120 & $\begin{array}{l}0,05 \\
012\end{array}$ & & $\begin{array}{l}0,06 \\
0\end{array}$ & & \\
\hline MO-4 & $\begin{array}{r}1603,42 \\
\end{array}$ & 42,72 & $\begin{array}{r}2,26 \\
26,13\end{array}$ & 1,35 & & 0,13 & 0,14 & & 0,11 & 0,01 & & 0,20 & & 0,12 & 0,00 & & 17,85 & & & 0,79 & 0,24 & & 2,04 & $1,<0$ & & & & & 8,16 \\
\hline CB1-2 & 1210,15 & 11,40 & 70,65 & 14,42 & & & 0,02 & 0,14 & 1,01 & & & & & & & 0,04 & 0,05 & & & & & 0,12 & 0,02 & 0,50 & & 0,14 & 1,47 & & \\
\hline CB1-3 & & 13,06 & 61,69 & 20,69 & & & 0,09 & 0,17 & 2,61 & & & & 0,06 & 0,01 & & & 0,00 & 0,09 & & & & 0,02 & 0,29 & 0,04 & 0,06 & 0,17 & 0,75 & & \\
\hline CB1-4 & 1065,57 & 17,74 & 79,49 & 0,47 & & 0,03 & 0,02 & 0,04 & 0,01 & & & & 0,12 & 0,01 & & 0,07 & 0,81 & & & & 0,03 & 0,36 & 0,73 & & & & & & \\
\hline CB1-7 & & $\begin{array}{l}13,70 \\
5\end{array}$ & 77,16 & 5,42 & & & 0,02 & 0,05 & 0,35 & & & & 0,01 & 0,15 & & 0,20 & 0,18 & & 0,03 & & 0,08 & & 0,16 & & & 0,24 & 2,26 & & \\
\hline $\begin{array}{l}\text { CB1-8 } \\
\text { CR3-2 }\end{array}$ & $\begin{array}{l}828,45 \\
266,73\end{array}$ & $\begin{array}{r}5,55 \\
12,90\end{array}$ & 92,94 & 86,53 & & & $\begin{array}{l}0,07 \\
0,57\end{array}$ & 0,30 & 0,51 & & & & 0,01 & 0,06 & 0,10 & & & & & & 0,01 & 0,00 & 0,01 & & 0,01 & 0,40 & 0,02 & & \\
\hline
\end{tabular}


Tabela A.5. Lista de abreviações utilizadas nas tabelas de descrição micromorfológica do Capítulo 5.

\begin{tabular}{|c|c|c|c|c|c|}
\hline \multicolumn{2}{|l|}{ Porosidade } & \multicolumn{2}{|l|}{ Agregados/peds } & \multicolumn{2}{|l|}{$\begin{array}{l}\text { Dustribuição } \\
\text { relacionada g/f }\end{array}$} \\
\hline Empacotamento complexo & $e-c x$ & Grânulos & $\mathrm{gr}$ & Porfírica & por \\
\hline Empacotamento composto & $\mathrm{e}-\mathrm{cm}$ & Grumos & $\mathrm{cm}$ & Gefúrica & gef \\
\hline Empacotamento simples & e-s & Apedal & ap & Quitónica & quit \\
\hline Câmara & $\mathrm{cm}$ & & & Mónica & mon \\
\hline Vesícula & vs & & & Enáulica & en \\
\hline Canal & $\mathrm{cn}$ & & & Fechada & $\mathrm{f}$ \\
\hline Fissura & fs & & & Espaçamento simples & e-s \\
\hline \multirow{3}{*}{$\begin{array}{l}\text { Star-shaped } \\
\text { regulares }\end{array}$} & S-S & & & Espaçamento duplo & e-d \\
\hline & re & & & Grosso & $\mathrm{gr}$ \\
\hline & & & & Fino & fn \\
\hline Limpidez & & Fabrica b & & Feições pedológicas & \\
\hline Ponteado & $\mathrm{pt}$ & Indiferenciada & ind & Revestimentos & rev \\
\hline Mosqueado & $\mathrm{ms}$ & Cristalítica & cri & Nódulos de ferro & Fe-nod \\
\hline Límpido & $\mathrm{lp}$ & Mosqueada-granida & $\mathrm{m}-\mathrm{g}$ & Enchimentos & ench \\
\hline Turvo & $\operatorname{tr}$ & & & Hiporevestimentos & hiporev \\
\hline \multirow[t]{2}{*}{ Opaco } & op & & & Excrementos & exc \\
\hline & & & & Cristais & cris \\
\hline
\end{tabular}


Tabela A.6. Coordenadas UTM das trincheiras de amostragem extra-sítio abertas nesta tese e dos testemunhos analisados por Nascimento (2011) e Amaral (2008) usados como referência.

\begin{tabular}{llcc}
\hline Código & $\begin{array}{l}\text { Coord. } \\
\text { (UTM, zona 22J) }\end{array}$ & $\mathbf{N}^{\circ}$ amostras & Referência \\
\hline CA & E685967/S6838087 & 1 & $*$ \\
CB1 & E689428/S6838934 & 2 & $*$ \\
SM8 & E711562/S6835102 & 1 & $*$ \\
SM10 & E713010/S6834346 & 1 & $*$ \\
GA4 & E716313/S6838045 & 1 & $*$ \\
TB1 & E698254/S6850006 & 2 & (Nascimento 2011) \\
TB2 & E699341/S6842426 & 2 & (Nascimento 2011) \\
GD1 & E700803/S6840860 & 2 & (Nascimento 2011) \\
GD2 & E700288/S6839248 & 2 & (Nascimento 2011) \\
GD3 & E703168/S6837206 & 4 & (Nascimento 2011) \\
MD1 & E706608/S6839550 & 2 & (Nascimento 2011) \\
SB1 & E707924/S6844218 & 4 & (Nascimento 2011) \\
FIG & E696144/S6828081 & 2 & (Amaral 2008) \\
RIA & E695659/S6829937 & 2 & (Amaral 2008) \\
\hline
\end{tabular}


Tabela A.7. Fácies amostradas para análises isotópicas em trincheiras extra-sítio e provenientes dos testemunhos analisados por Nascimento (2011) e Amaral (2008), com descrição da textura, sistema deposicional associado e concentração de $\delta^{13} \mathrm{C}, \delta^{15} \mathrm{~N}$ e razão $\mathrm{C} / \mathrm{N}(\mathrm{S}=$ sistema deposicional; $\mathrm{L}=$ lagunar, $\mathrm{D}=$ deltaico, $\mathrm{E}=$ eólico, $\mathrm{C}=$ coluvio).

\begin{tabular}{llcccc}
\hline Amostra & Descrição & $\mathbf{S}$ & $\boldsymbol{\delta}^{\mathbf{1 3}} \mathbf{C}$ & $\boldsymbol{\delta}^{\mathbf{1 5}} \mathbf{N}$ & $\mathbf{C} / \mathbf{N}$ \\
\hline CA-A & Argila lamosa & $\mathrm{L}$ & $-22,36$ & 9,78 & 10,25 \\
CB1-A & Areia lamosa & $\mathrm{C}$ & $-24,55$ & 8,40 & 12,20 \\
CB1-B & Argila arenosa & $\mathrm{L}$ & $-24,44$ & 8,75 & 11,72 \\
SM8-B & Areia lamosa & - & $-20,89$ & 13,54 & 13,00 \\
SM10-B2 & Areia lamosa & $\mathrm{E}$ & $-24,97$ & 7,82 & 10,00 \\
GA4-B & Areia & $\mathrm{E}$ & $-21,50$ & 8,91 & 18,00 \\
TB1-725 & Areia fina lamosa com conchas & $\mathrm{L}$ & $-26,68$ & 3,29 & 12,20 \\
TB1-795 & Areia fina lamosa com conchas & $\mathrm{L}$ & $-26,50$ & 4,24 & 16,12 \\
TB2-750 & Lama com conchas & $\mathrm{L}$ & $-25,54$ & 2,11 & 4,80 \\
TB2-875 & Lama com conchas & $\mathrm{L}$ & $-23,52$ & 4,32 & 9,53 \\
GD1-10 & Turfa & $\mathrm{D}$ & $-25,88$ & 4,08 & 9,40 \\
GD1-50 & Lama com detritos vegetais & $\mathrm{D}$ & $-22,05$ & 4,97 & 11,91 \\
GD2-26 & Lama & $\mathrm{D}$ & $-26,36$ & 4,82 & 8,86 \\
GD2-106 & Lama & $\mathrm{D}$ & $-26,48$ & 3,4 & 10,87 \\
GD3-79 & Turfa & $\mathrm{D}$ & $-18,41$ & 0,09 & 14,22 \\
GD3-199 & Areia fina lamosa com detritos vegetais & $\mathrm{D}$ & $-26,94$ & 3,52 & 16,14 \\
GD3-279 & Lama com areia lamosa e conchas & $\mathrm{L}$ & $-20,04$ & 7,5 & 11,03 \\
GD3-359 & Lama com areia lamosa e conchas & $\mathrm{L}$ & $-19,68$ & 5,4 & 15,22 \\
MD1-40 & Areia fina com lâminas de lama e detritos vegetais & $\mathrm{D}$ & $-26,83$ & 4,33 & 14,41 \\
MD1-127 & Areia fina lamosa & $\mathrm{L}$ & $-21,47$ & 5,52 & 8,77 \\
SB1-325 & Lama & $\mathrm{D}$ & $-24,54$ & 5,4 & 12,63 \\
SB1-425 & Areia fina lamosa com conchas & $\mathrm{L}$ & $-23,43$ & 6,06 & 10,83 \\
SB1-625 & Lama com conchas & $\mathrm{L}$ & $-21,92$ & 7,34 & 11.06 \\
SB1-975 & Lama com conchas & $\mathrm{L}$ & $-18,94$ & 8,02 & 8,455 \\
SB1-1225 & Lama com conchas & $\mathrm{L}$ & $-11,82$ & 8,98 & 14,543 \\
FIG-40 & Argila arenosa com fragmentos vegetais & $\mathrm{L}$ & $-22,5$ & 2,31 & 14,15 \\
FIG-70 & Areia fina argilosa maciça & $\mathrm{L}$ & $-18,2$ & 3,7 & 10,02 \\
RIA-110 & Argila arenosa maciça & $\mathrm{L}$ & $-17,9$ & 7,01 & 17,61 \\
RIA-210 & Argila arenosa maciça & $\mathrm{L}$ & $-10,1$ & 10,6 & 8,17 \\
\hline & & & & & \\
& & & & &
\end{tabular}


ANEXO 2: Publicações, prêmios, participação em eventos 
Publicações vinculadas com o projeto de doutorado:

1. VILlaGRAN, Ximena S., BALBO, Andrea L., MADELLA, Marco, VILA, Assumpció, ESTEVEZ, Jordi. Stratigraphic and spatial variability in shell middens: microfacies identification at the ethnohistoric site Tunel VII (Tierra del Fuego, Argentina). Archaeological and Anthropological Sciences, v.3, p.357 378, 2011.

2. VILlAGRAN, Ximena S., BALBO, Andrea L., MADELlA, Marco, VILA, Assumpció, ESTEVEZ, Jordi. Experimental Micromorphology in Tierra del Fuego (Argentina): building a reference collection for the study of shell middens in cold climates. Journal of Archaeological Science, v.38, p.588 - 604, 2010.

3. GODINO, Ivan Briz, ALVAREZ, Myrian, BALBO, Andrea, ZURRO, Débora, MADELLA, Marco, VILLAGRAN, Ximena S., FRENCH, Charles. Towards high-resolution shell midden archaeology: experimental and ethno-archaeology in Tierra del Fuego (Argentina). Quaternary International, v.239, p.125 - 134, 2011.

4. GIANNINI, Paulo C. F., VILLAGRAN, Ximena S., FORNARI, M., NASCIMENTO, D. R., MENEZES, P. M. L., TANAKA, Ana Paula B., ASSUNCAO, D. C., DEBLASIS, P., AMARAL, P. G. C. Interações entre evolução sedimentar e ocupação humana pré-histórica na costa centro-sul de Santa Catarina. Boletim do Museu Paraense Emílio Goeldi. Ciências Humanas, v.5, p.105 - 128, 2010.

Publicações vinculadas com projetos paralelos ao doutorado

1. VILLAGRAN, Ximena S., KLOKLER, Daniela, PEIXOTO, Silvia, DEBLASIS, Paulo, GIANNINI, Paulo C. F. Building Coastal Landscapes: Zooarchaeology and Geoarchaeology of Brazilian Shell Mounds. The Journal of Island and Coastal Archaeology, v.6, p.211 - 234, 2011.

2. VILLAGRAN, Ximena S. With an Eye on the Southern Shores: Insights Into South American Coastal Archaeology. The Journal of Island and Coastal Archaeology, v.6, p.173 - 175, 2011.

3. VILLAGRAN, Ximena S., SCHAEFER, Carlos E.G.R. Geoarqueologia das primeiras ocupações humanas na Antartica. Vestígios. Revista latino-americana de arqueologia histórica, v.5, p.115 - 136, 2011.

4. FORANCELLI PACHECO, Mírian L.A., VILLAGRAN, Ximena S., MARTINS, Gilson R. Macroscopic and microbiological alterations of bird and small mammal bones buried in a Cerrado biome (south western Brazil). Journal of Archaeological Science, v.39, p.1394 - 1400, 2011.

5. KLOKLER, Daniela, VILlAGRAN, Ximena S., GIANNINI, Paulo Cesar Fonseca, PEIXOTO, Silvia, DEBLASIS, Paulo. Juntos na costa: zooarqueologia e geoarqueologia de sambaquis do litoral sul catarinense. Revista do Museu de Arqueologia e Etnologia, v.20, p.53 - 76, 2010. 
Prêmios

Young Micromorphologist's Publication Award 2012, International Union of Soil Sciences, Comission 1.1 Soil Morphology \& Micromorphology

Participação em eventos

1. Apresentação Oral no(a) 14th International Working Meeting on Soil Micromorphology, 2012. (Congresso). Mounded landscapes of the Brazilian coast: shell, sand and fish mounds from the macro- to the micro-scale.

2. Apresentação de Poster / Painel no(a) 14th International Working Meeting on Soil Micromorphology, 2012. (Congresso). The geoarchaeology of the first human settlements in Antartica.

3. Apresentação de Poster / Painel no(a) XIII Congresso da Associação Brasileira de Estudos do Quaternário - ABEQUA, 2011. (Congresso). A EVOLUÇÃO GEOLÓGICA DO LITORAL SUL DE SANTA CATARINA, VISTA ATRAVÉS DA MICROMORFOLOGIA DE SAMBAQUIS.

4. Apresentação Oral no(a) XVI Congresso da Sociedade de Arqueologia Brasileira / XVI World Congress of UISPP, 2011. (Congresso). A interpretação de estruturas de combustão e resíduos queimados em sítios concheiros do litoral catarinense (Brasil) e de Tierra del Fuego (Argentina).

5. Apresentação Oral no(a) II Semana de Arqueologia do MAE, 2011. (Congresso). Até o mínimo detalhe: microscopia de concheiros arqueológicos.

6. Apresentação Oral no(a) 75th Annual Meeting of the Society for American Archaeology, 2011. (Congresso). Optimal foraging or exceptional feasting: from environmental adaptation to social integration.

7. Apresentação Oral no(a) XVI Congresso da Sociedade de Arqueologia Brasileira / XVI World Congress of UISPP, 2011. (Congresso). Primeiros estudos micro-estratigráficos em "cerritos" - conjunto Pago Lindo (Tacuarembó), Uruguai.

8. Apresentação de Poster / Painel no(a) European Geosciences Union - General Assembly, 2010. (Congresso). An experimental approach for archaeological soil micromophology: building a model for site taphonomy in coastal shell middens of the Beagle Channel (Argentina).

9. Apresentação Oral no(a) $\mathbf{V}$ Reunion de Teoría Arqueológica en América del Sur, 2010. (Congresso). Un micro-mundo a orillas del Beagle: Aproximación micromorfológica para el estudio de concheros fueguinos.

10. Conferencista no(a) V Ciclo de Conversaciones en el Raval. Institución Milá y Fontanals (CSIC/ Barcelona), 2009. (Seminário). Arqueología de la costa de Brasil.

11. Apresentação Oral no(a) 74th Annual Meeting of the Society for American Archaeology, 2009. (Congresso). Building coastal landscapes: zooarchaeology and geoarchaeology as tools to understand ritual shell deposits.

12. Apresentação de Poster / Painel no(a) XV Congresso da Sociedade de Arqueologia Brasileira, 2009. (Congresso). Dinâmica espacial e assentamentos domésticos nos sambaquis da Ilha do Cabo Frio (Rio de Janeiro). 
13. Apresentação Oral no(a) XV Congresso da Sociedade de Arqueologia Brasileira, 2009. (Congresso). Evolução geológica e ocupação sambaquieira no litoral centro-sul de Santa Catarina: padrões estratigráficos e distribuição tempoespacial.

14. Apresentação Oral no(a) XV Congresso da Sociedade de Arqueologia Brasileira, 2009. (Congresso). Tafonomia microbiológica em carcaças enterradas em bioma de Cerrado.

\section{Organização de evento}

1. KLOKLER, D., VILLAGRAN, Ximena Suarez, GASPAR, M. D. Interpreting and detecting ritual in archaeological sites, 2011. Organized session at the 76th Conference of the Society for American Archaeology (SAA).

2. VILlaGRAN, Ximena Suarez, Peixoto, Silvia. Envisioning the shore: New insights into the occupation and anthropic configuration of coastal settings, 2009. Organized session at the 74th Conference of the Society for American Archaeology (SAA). 